\title{
Tectonics of the Indonesian Region
}

\author{
U.S. GEOLOGICAL SURVEY PROFESSIONAL PAPER 1078 \\ Prepared on behalf of the Ministry of Mines, Government \\ of Indonesia, and the Agency for Intermational Development, \\ U.S. Department of State, in cooperation with the Geological \\ Survey of Indonesia, the Australia Bureau of Mineral Resources, \\ Geology and Geophysics, and the Lamont-Doherty Geological \\ Observatory of Columbia University

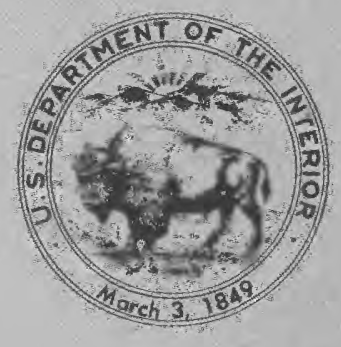




\section{Tectonics of the Indonesian Region}

By WARREN HAMILTON

\section{U.S. GEOLOGICAL SURVEY PROFESSIONAL PAPER 1078}

Prepared on behalf of the Ministry of Mines, Government of Indonesia, and the Agency for International Development, U.S. Department of State, in cooperation with the Geological Survey of Indonesia, the Australia Bureau of Mineral Resources, Geology and Geophysics, and the Lamont-Doherty Geological Observatory of Columbia University

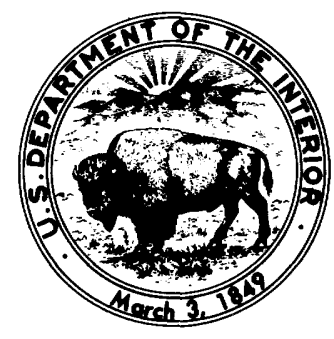




\title{
DEPARTMENT OF THE INTERIOR
}

MANUEL LUJAN, Jr., Secretary

\section{U.S. GEOLOGICAL SURVEY}

Dallas L. Peck, Director

\begin{abstract}
Any use of trade, product, or firm names in this publication is for descriptive purposes only and does not imply endorsement by the U.S. Government
\end{abstract}

First printing 1979

Second printing 1981

Third printing 1985

Fourth printing 1991

For sale by the Books and Open-File Reports Section, U.S. Geological Survey, Federal Center, Box 25425, Denver, CO 80225 


\section{CONTENTS}

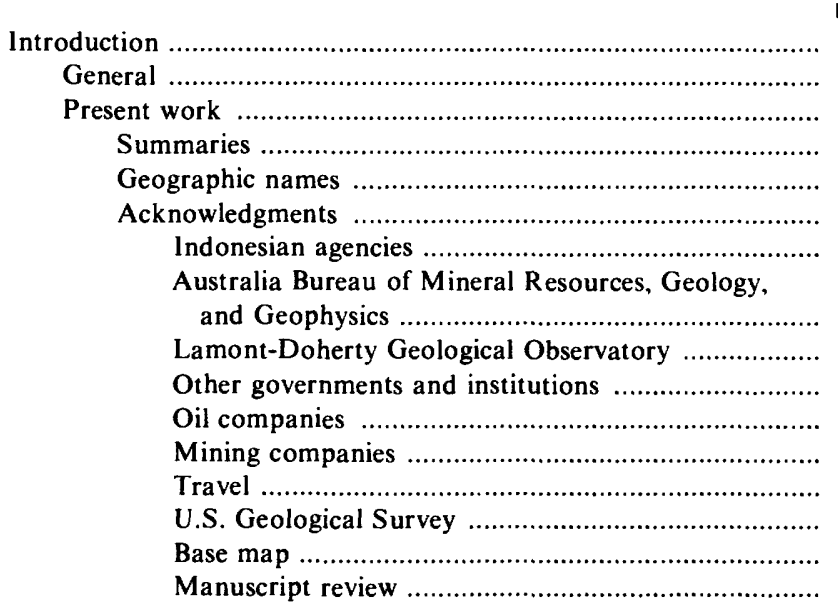

Plate tectonics ....

General

Earthquakes

Identification of ancient plate-tectonic features ...........

The "geosynclinal cycle"

Tectonic maps

Previous maps

Tectonic map of the Indonesian region ...............................

Introduction

Units

Contacts

Colors

Plate-tectonic emphasis

Environment of formation of sedimentary rocks ........

Isopachs of sedimentary rocks

Boundaries between lithosphere plates

Benioff zones

at plate boundaries .

Cenozoic biostratigraphy ........................................ 17

Modern subduction system of Java and Sumatra ........................ 18

Benioff seismic zone .......................................................... 18

Offshore tectonics ................................................................ 19

General features ......................................................... 19

Java Trench ….................................................................. 19

Outer-arc ridge .............................................................. 19

Melange of islands of outer-arc ridge ...................... 19

Deep-penetration reflection profiles .......................... 25

Outer-arc basin

Crustal structure

Formation of melange wedge

Trenches and subduction

Gravity surveys

Sumatra

Paleozoic and Mesozoic geology

Cenozoic geology .

Sedimentation

Oil and gas
Sumatra - Continued

Cenozoic geology - Continued

Magmatism

Rotation of Sumatra

Strike-slip faulting ............................................................. 37

Uplift of the Barisan Mountains ................................... 38

Relation between magmatism and tectonism ..................... 38

Offset between Sumatra and Malaya .............................. 38

The Tin Islands ........................................................................ 38

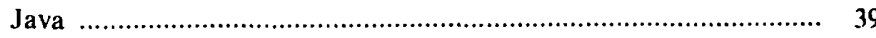

Upper Cretaceous or lower Paleogene melange ...................... 39

Paleogene strata ..................................................................... 39

Late Cenozoic volcanoes ......................................................... 41

Crustal composition .................................................... 41

Strontium isotopes ........................................................ 43

Neogene sedimentation and deformation ............................. 43

Strike-slip faulting .............................................................. 44

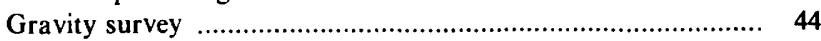

Indian Ocean ........................................................................ 44

Description .......................................................................... 44

Wharton Basin ......................................................... 44

Ninetyeast Ridge ....................................................... 51

Christmas Island ........................................................ 57

Australian continental margin ........................................ 58

Bengal abyssal fan ..................................................... 59

Gondwanaland and the Indian Ocean ..................................... 60

Separation of Australia from East Antarctica .................. 60

Mesozoic Gondwanaland ............................................. 60

History of the eastern Indian Ocean ............................... 64

Andaman-Nicobar Arc and Andaman Sea .................................. 64

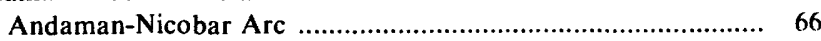

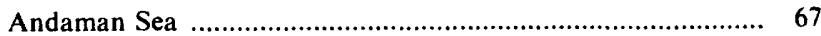

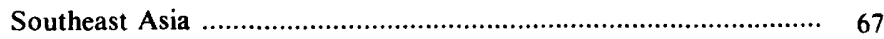

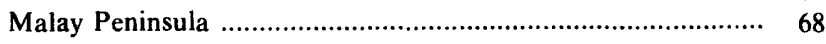

Basement rocks .......................................................... 68

Paleozoic and Mesozoic stratified rocks .......................... 68

Western Malay Peninsula ….................................... 68

Eastern Malay Peninsula ..................................... 70

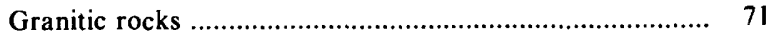

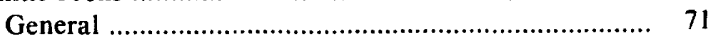

Age determinations .................................................. 71

Preferred age assignments ...................................... 72

Petrogenesis ....................................................... 72

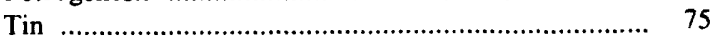

Paleomagnetism ........................................................... 75

Possible suture in medial Malaya .................................... $\quad 76$

Strike-slip faults .............................................................. 77

Cenozoic basalt ............................................................. 79

Western continental shelf and Mergui Terrace ....................... 79

Burma ……............................................................ 79

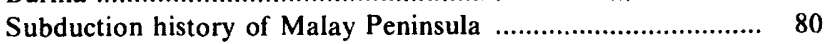

India and Southeast Asia ....................................................... 81

Rotation of Southeast Asia ................................................. 81

Indochina ................................................................... 83

Relationships of Paleozoic and Triassic terrains of

Sumatra, Malaya, and Indochina 
Borneo

Pre-Tertiary complexes

Western Sarawak

Southwest Borneo

Upper Cretaceous or lower Paleogene melange in southeastern Borneo

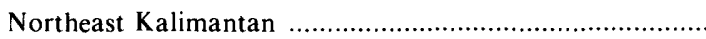

Cenozoic complexes of northwest Borneo

Eocene subduction complex

Paleogene of interior Borneo

Paleogene igneous rocks

Middle Tertiary outer-arc basin

Neogene igneous rocks of interior Borneo

Cenozoic complexes of Sabah

Tertiary melange

Oligocene to Quaternary magmatic-arc rocks ..................

Neogene strata of northeast Sabah and its continental shelf

Discussion

Cenozoic basins of east Kalimantan

Cenozoic strata of southeast Kalimantan ......

Cenozoic strata of east-central Kalimantan ......

Tarakan Basin, northeast Kalimantan

Java Sea

Basement geology

Tectonic correlations between Java and Borneo …................ 100

Cenozoic sediments ............................................................ 100

Cenozoic subduction and stability ........................................ 102

South China Sea and Gulf of Thailand ..................................... 102

Islands between Malaya and Borneo ..................................... 102

Cenozoic shelf basins ............................................................. 103

Malay Basin ......................................................... 103

Thai Basin .................................................................. 105

West Natuna Basin ................................................. 106

Northeastern basins ................................................... 108

Sarawak Basin .......................................................... 108

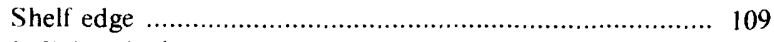

South China Basin ........................................................ 109

Foundered continent ................................................. 112

Northwest Borneo and Palawan Trenches ...................... 112

Tectonic correlations across the South China Sea ................. 112

Crustal structure ....................................................... 112

Upper Mesozoic belt, Borneo-Natuna-southern Vietnam .. 113

Paleogene of northwest Borneo ...................................... 113

Rotation of Borneo ...................................................... 113

Lack of correlation between Malaya and Borneo ............ 113

Formation of the South China Basin ……......................... 113

The Banda Arc ................................................................ 114

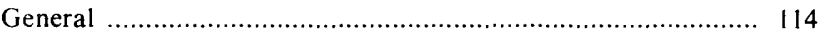

Topography ........................................................ $\quad 114$

Crustal relationships ..................................................... 116

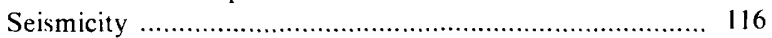

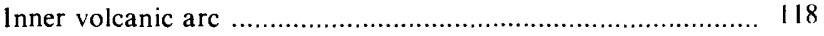

Outer-arc ridge ............................................................ 121

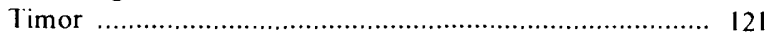

Published studies ................................................... 121

Melange …......................................................... 121

Upper Neogene materials and deformation ............... 130

Gravity ........................................................ 131

Interpretations by Audley-Charles ......................... 131

Raised reefs .................................................. 131

Biogeographic problem ........................................ 132

Mud volcanoes .................................................. 132
The Banda Arc - Continued

Outer-arc ridge - Continued

Small islands near Timor ............................................ 132

Roti ................................................................. 132

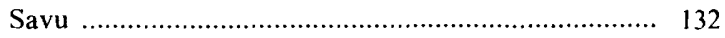

Northward thrusting near Savu ............................... 132

Islands east of Timor ............................................. 132

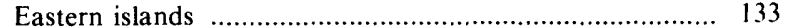

Seram and Buru .................................................... 133

Trench-the Timor and Seram Troughs .............................. 138

Seram Trough ........................................................... 138

Timor Trough ……...................................................... 138

Trench around eastern part of arc ……......................... 144

Outer-arc basin ................................................................. 144

Sumba continental fragment ................................................ 148

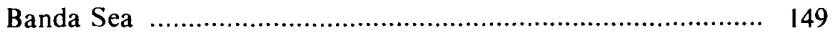

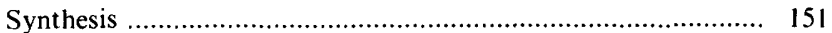

Subduction of continental shelf and basement ................. 151

Mechanics ............................................................... 154

Reversal of subduction polarity .................................... 156

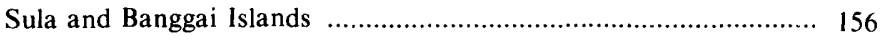

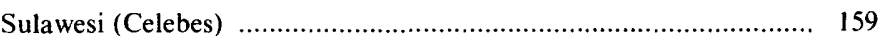

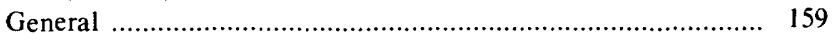

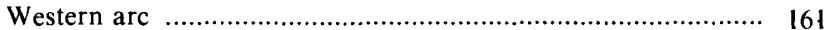

Cretaceous subduction complex ................................... 161

Paleogene shelf strata ................................................ 162

Neogene igneous and sedimentary rocks ......................... 162

$\begin{array}{lll}\text { Inactive island arc between the South Arm and Flores .... } & 164\end{array}$

Subduction complexes of the eastern arc …………............... 164

Western blueschist-and-melange belt ................................ 164

Belt of sedimentary and metasedimentary rocks ............. 167

Ophiolite and sedimentary rocks .................................... 167

Imbricated sedimentary terrain .................................... 169

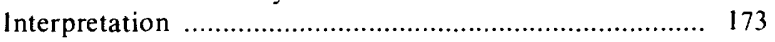

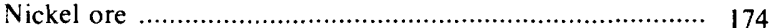

Boundary between eastern and western arcs ……….............. 175

Strike-slip faults .............................................................. 175

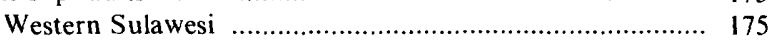

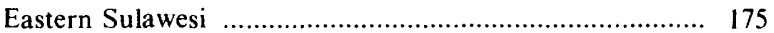

North Sulawesi Trench ....................................................... 181

Islands in Gulf of Tomini ................................................. 181

Sulawesi and regional tectonics ............................................ 181

Rotating plate: the North Sulawesi Trench,

Palu fault, and Northeast Sulawesi orocline ................ 181

Collision of continental fragments with Sulawesi .............. 181 Sula and Banggai lslands ...................................... 181 Southeast Sulawesi ................................................. 183

Rifting of Makassar Strait ....................................... 185

Subduction and magmatism ......................................... 188 Age of subduction ............................................. 188 Magmatic belts ................................................ 188

Separation of the arms of Sulawesi ................................ 188

Eastward migration of subduction system ......................... 189

Java, Borneo, and Sulawesi .................................. 189

Sumbawa and Flores .......................................... 189

Banda Arc .......................................................... 189

Paleogene history of Java, Borneo, and Sulawesi ............ 189

The northern Moluccas …........................................................ 190

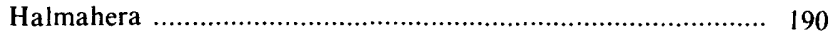

Melange ……...................................................... 190

Magmatic arc .......................................................... 190

Regional relationships ..................................................... 191 
The Northern Moluccas - Continued

Obi Islands

Waigeo

Arc systems between Sulawesi, Halmahera, and the

Philippines

Celebes Sea

Sangihe island arc ......................................

Sangihe Islands ........................................................ 194

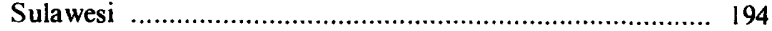

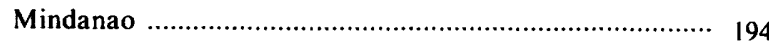

Tectonics ..................................................................... 194

Recent changes in subduction pattern .................................. 194

Molucca Sea melange wedge ................................................. 195

Bathymetry and geophysics .......................................... 195

Islands …....................................................................... 195

Outward thrusting ….................................................. 196

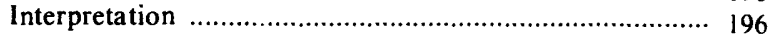

Philippine Trench system ................................................. 196

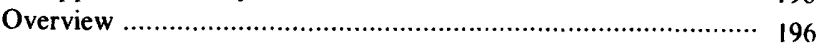

Island arcs between Borneo and the Philippines .......................... 197

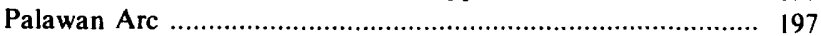

Paleozoic-Mesozoic continental fragment ....................... 197

Paleogene melange ....................................................... 197

Magmatic arc …...................................................... 199

Outer-arc basin ............................................................... 199

Palawan Trench ....................................................... 201

Relationship to Borneo and the Philippines ..................... 201

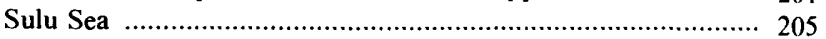

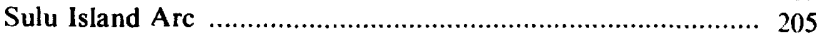

Sulu Islands and Ridge ............................................... 205

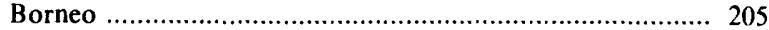

Zamboanga ............................................................. 206

Polarity reversal of Sulu Arc …................................. 206

Philippine Islands ................................................................. 206

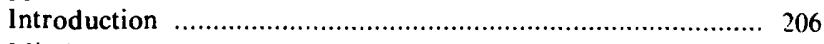

Mindanao ................................................................. 206

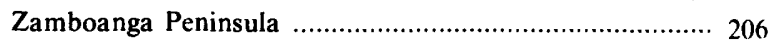

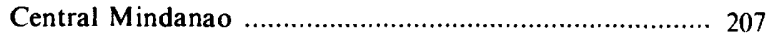

Agusan-Davao lowlands .................................................. 207

Pacific Cordillera ............................................................ 207

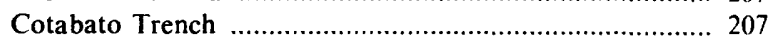

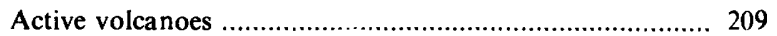

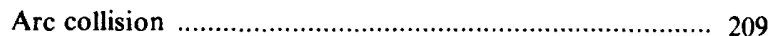

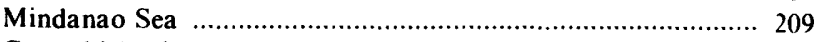

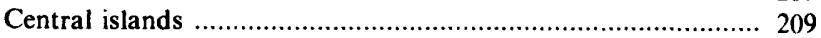

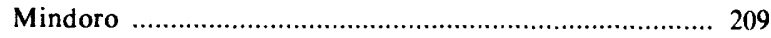

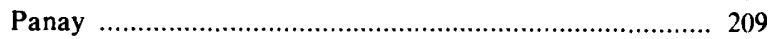

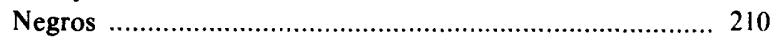

Negros Trench ............................................................. 210

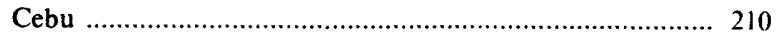

Masbate …...................................................... 210

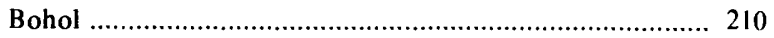

Camotes Islands ..................................................... 210

Leyte ......................................................................... 210

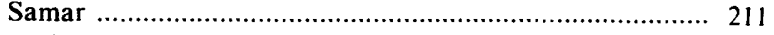

Active volcanoes and Benioff zones ................................ 213

Philippine Trench ................................................................ 213

Curvature of the islands ..................................................... 213

Manila Trench .............................................................. 213

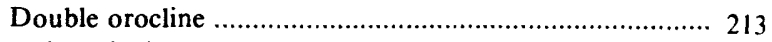

Strike-slip faulting ....................................................... 213

The Philippines as a composite of island arcs ......................... 216

Relationship to Taiwan ....................................................... 218
218

Northwest Australia .......................................................... 218

Precambrian time scale ............................................... 218

Precambrian basement rocks ....................................... 219

Kimberley Basin ................................................ 220

Victoria River Basin .................................................. 222

McArthur Basin ...................................................... 222

Arafura Basin ............................................................ 222

Problems of Precambrian geology …............................ 223

Lower Cambrian(?) plateau basalt ................................. 223

Paleozoic and Triassic strata ........................................... 223

Paleozoic deformation ...................................................... 223

Cretaceous strata ...................................................... 224

Northwest Australian shelf ................................................... 224

Browse Basin .......................................................... 224

Bonaparte Gulf Basin ........................................... 224

Northwestern source of pre-Cretaceous sediment .............. 225

Rifting history of the shelf ............................................ 225

Basin north of Melville Island ......................................... 225

Timor Trough ................................................................ 225

Modern sedimentation ................................................... 225

Northern Australian shelf ................................................. 225

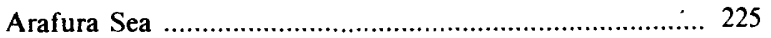

Gulf of Carpentaria ..................................................... 225

Northeast Australia ...................................................... 225

Crustal structure ............................................................ 226

Precambrian metamorphic rocks ................................... 226

Middle Paleozoic rocks .............................................. 226

Paleozoic granitic rocks ........................................... 226

Cape York Peninsula ............................................ 226

Torres Strait ........................... 227

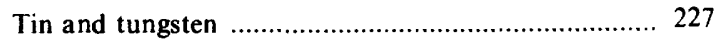

Petrogenesis ……............................................. 227

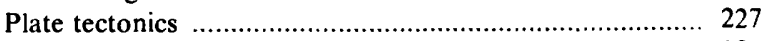

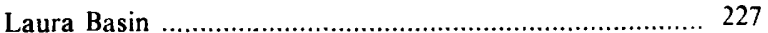

Carpentaria Basin ………………................................. 227

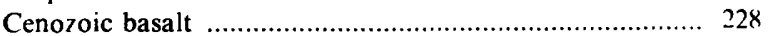

Phanerozoic continental drift …………………………...... 228

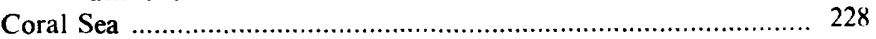

Coral Sea Plateau and Queensland Trough .......................... 228

Coral Sea Basin ............................................................. 229

Opening of the Coral Sea by rifting ..................................... 229

New Guinea ..................................................................... 230

Paleozoic and early Mesozoic tectonics ..................................... 23. 23

Paleozoic basement of Vogelkop ..................................... 233

Upper Paleozoic basement of southeast New Guinea ....... 2.34

Paleozoic shelf or platform strata .................................. 234

Early Mesozoic history .............................................. 235

Rifting of Malay-Sumatra subcontinent from

New Guinea ....................................... 235

Old metamorphic and plutonic terrains .......................... 237

Mesozoic volcanic and sedimentary terrains .................... 237

Mesozoic and Cenozoic evolution of southern New Guinea .... 238

Late Mesozoic and early Tertiary continental shelf ......... 238

Torres Strait and Gulf of Papua .................................. 239

Neogene foreland basin ............................................ 242

Neogene thrust belt ................................................... 242

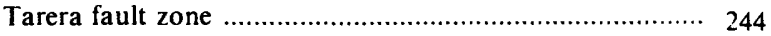

Conjectural offsets between Australia and New Guinea .... 245

Misool ..................................................................... 245

Cretaceous to early Miocene island arc and its collision

with New Guinea in Miocene time .................................... 249

Melange of northern medial New Guinea ......................... 249

Ophiolite of Papuan Peninsula ...................................... 251 
New Guinea - Continued

Cretaceous to early Miocene island arc and its collision with New Guinea in Miocene time - Continued Cretaceous, Paleogene, and lower Miocene volcanic arc .. 251 Islands north of Geelvink Bay Interpretation of the island arc ........................................ 253 Arrival of the Melanesian flora ...................................... 254

Neogene south-dipping subduction system of north New Guinea 254 Neogene volcanic and granitic rocks ............................... 254 Melange of Cyclops Mountains ....................................... 255 Modern seismicity ............................................................ 255

New Guinea Trench ..................................................... 256 Schouten Islands collision zone ...................................... 259

Other Neogene features of northern New Guinea .................. 259 Late Neogene sedimentation ......................................... 259 Sorong fault system ........................................................ 261 Regional significance of Sorong fault system ................... 262 Geelvink Bay and Ransiki fault .................................... 262 Markham-Ramu fault zone .......................................... 262 Faults south of Sepik lowlands ........................................ 263 lslands near northwest Vogelkop ..................................... 263

Rifting of Vogelkop from Australia ...................................... 263

Expansion of the Banda Arc ............................................... 263

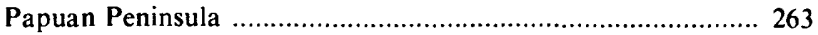

Port Moresby Trench ................................................ 265

Melange and ophiolite ......................................................... 265

Metamorphic melange .................................................. 266

Trobriand Trench …....................................................... 268

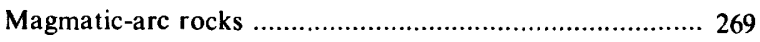

Papuan Plateau ................................................................ 269

History of the Papuan Peninsula .................................... 269

Arcs and basins of the Mariana system ........................................ 270

History north of the tectonic-map area .................................. 270

Mariana Trench ............................................................ 270

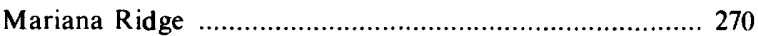

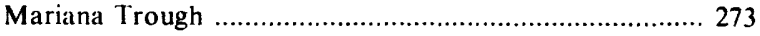

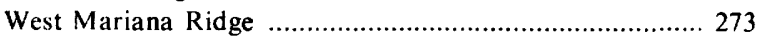

Parece Vela Basin ........................................................ 273

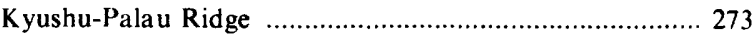

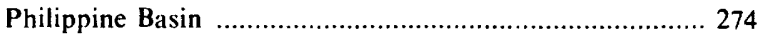

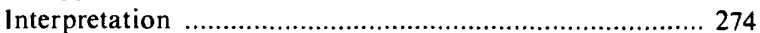

Arcs and basins of the Mariana system - Continued

Behavior of island arcs .................................................... 274

Southern components of the Mariana system ........................ 275

Mariana Trench and Mariana Ridge .............................. 275

Yap Trench and Ridge .............................................. 275

Parece Vela Basin .................................................... 277

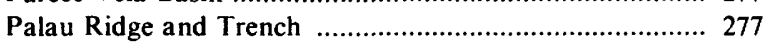

Philippine Basin ....................................................... 277

Region south of Palau Ridge .......................................... 277

Rotation of Philippine Sea plate ........................................... 278

The Caroline and Pacific plates .................................................. 279

Caroline plate ............................................................... 279

West Caroline Basin ................................................... 279

Eauripik Rise ......................................................... 279

East Caroline Basin ................................................... 280

Origin of the Caroline plate ........................................ 281

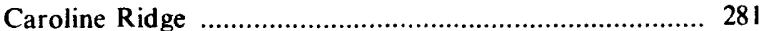

Mesozoic crust of the Pacific Ocean ....................................... 283

Mussau terrain .......................................................... 287

North boundary of the Caroline plate ................................. 287

Bismarck and Solomon arcs and seas ......................................... 288

Bismarck Sea region ...................................................... 288

New Britain lsland Arc .............................................. 288

Bismarck Island Arc ................................................ 291

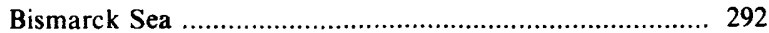

Solomon Sea region ........................................................ 293

Solomon Islands ..................................................... 293

Solomon Sea and Woodlark Basins ............................... 298

Woodlark and Pocklington Rises ................................ 298

New Britain - Trobriand collision zone ........................ 299

Fragmented island arcs ............................................. 300

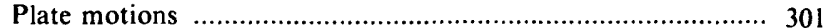

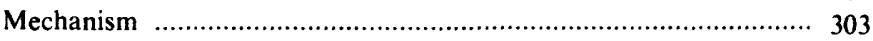

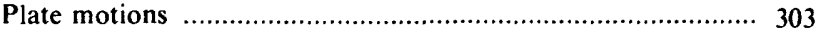

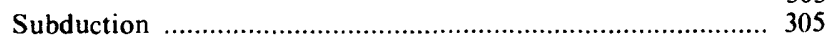

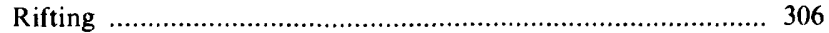

Arc magmagenesis ......................................................... 306

The future and the past ................................................. 307

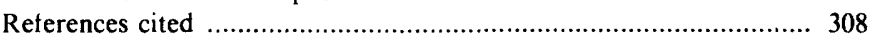

\section{ILLUSTRATIONS}

PI AIE 1. Tectonic map of the Indonesian region

FICI'R+ 1 -5. Maps:

1. Localities of the Indonesian region

In pocket

2. Lithosphere plates of the world

3. Location of earthquakes of magnitude 8.0 and greater in the world

4. Epicenters of major shallow earthquakes in the Indonesian region

5. Selected tectonic elements and location of seismic-reflection profiles

in the Indian Ocean between Java and northern Australia

6. Seismic-reflection profiles across the Java Trench ........

7. Photographs of melange and slope sediments. Nias lstand.

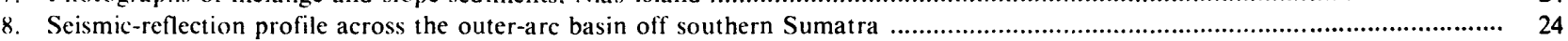

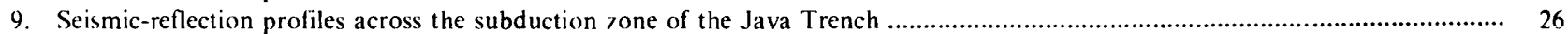

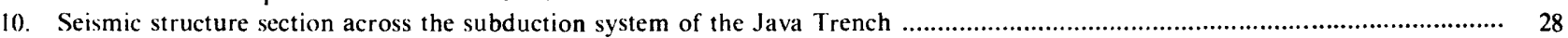

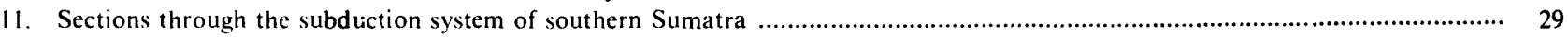

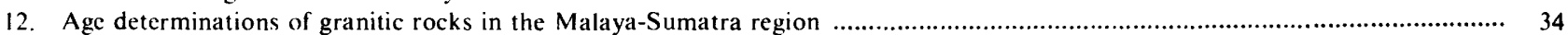

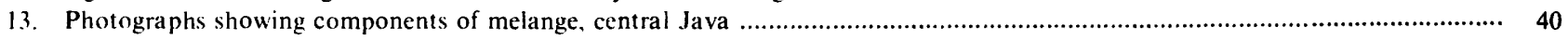

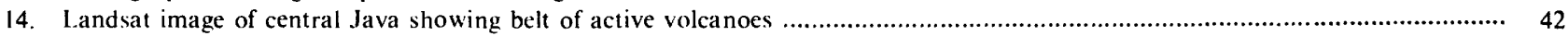

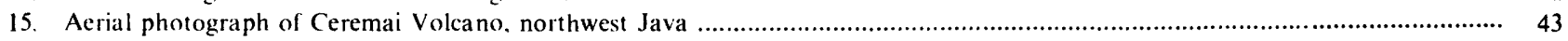


FIGURE 16. Aerial photograph of folded Neogene strata, north-central Java

17. Map of the eastern Indian Ocean showing location of seismic-reflection profiles …............................................................

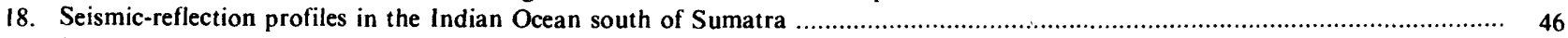

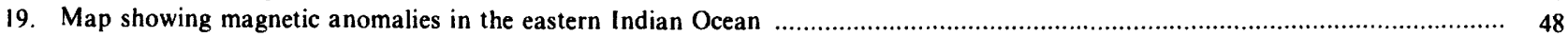

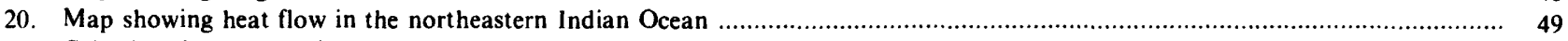

21 -26. Seismic reflection profiles:

21. Wharton Basin, Ninetyeast Ridge, and Andaman Sea

22. Wharton Basin and Ninetyeast Ridge

23. Ninetyeast Ridge

24. Indian Ocean west of northern Australia.

25. Indian Ocean northwest of northern Australia

26. Indian Ocean northwest of morthern Australia

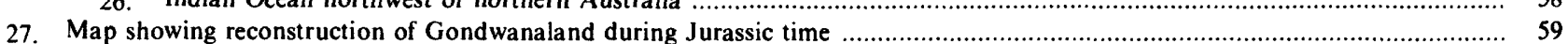

28. Schematic illustration of age and history of oceanic crust in the eastern Indian Ocean ....................................................... 61

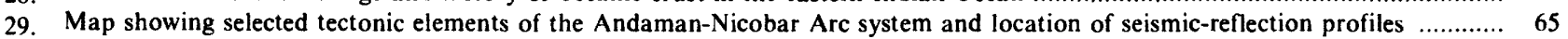

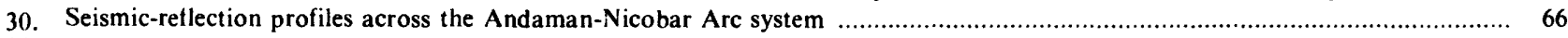

31. Map showing Mesozoic and selected Cenozoic tectonic elements of southeast Aisa and Indonesia ..........................................69

32. Graph showing strontium and rubidium abundances in granitic rocks of the Malay Peninsula ........................................... 74

33. Graph showing strontium contents and ages of granitic rocks in the Malay Peninsula .........................................................

34. Photographs showing components of possible melange in central Peninsular Malaysia …........................................................ 77

35. Landsat image of part of peninsular Thailand showing topographic lineaments ............................................................... 78

36. Seismic-reflection profile across the trench bounding southwest Burma …................................................................

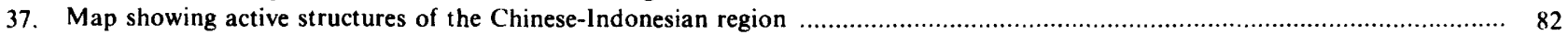

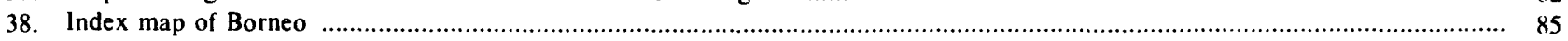

39 -43. Photographs:

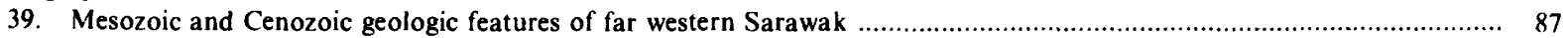

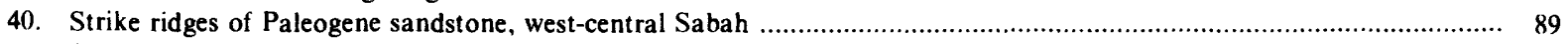

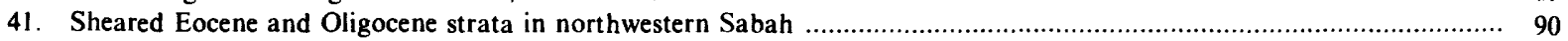

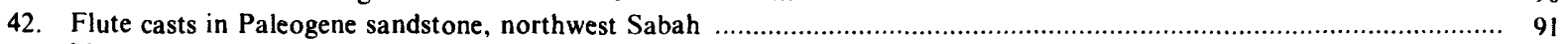

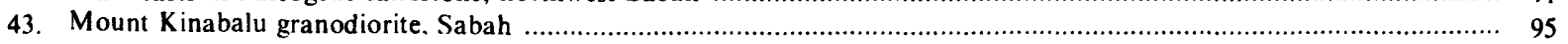

44. Radar image showing structure of the Makaham Delta region, east Borneo ...................................................................... 98

45 -47. Maps:

45. Geology and structure of the Makaham Delta region, east Borneo …............................................................. 99

46. Lithology and age of basement samples from the Java Sea region .................................................................. 101

47. Selected tectonic elements in the South China Sea and Gulf of Thailand, and location of seismic-reflection profiles ....... 103

48 -51. Seismic-reflection profiles:

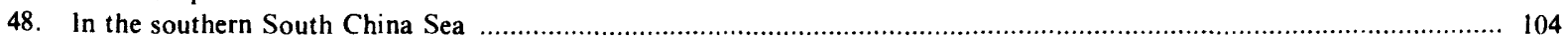

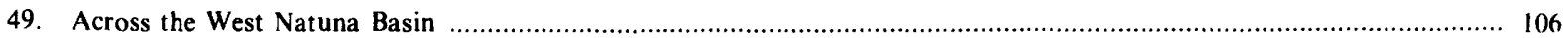

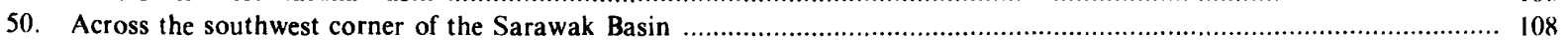

51. Across the Northwest Borneo and Palawan Trenches ................................................................................ 110

52. Map showing tectonic elements in the Makassar Strait, Banda Arc, and Timor Sea region, and location of seismic-reflection profiles ... 115

53. Map showing distribution of pre-Tertiary continental crust in eastern Indonesia and surrounding regions ............................. 117

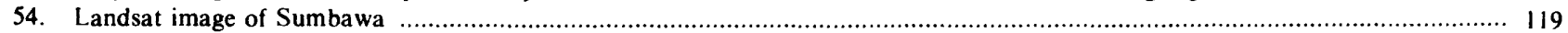

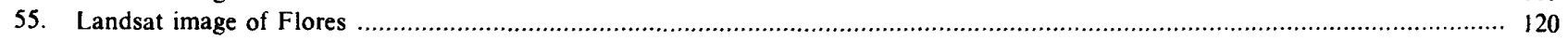

56. Seismic-reflection profile across the Banda Arc, Flores Sea, and Makassar Strait ....................................................... 122

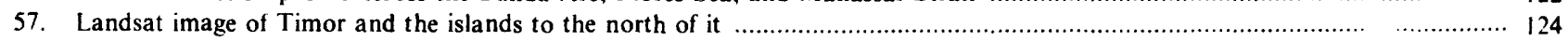

58 -65. Photographs:

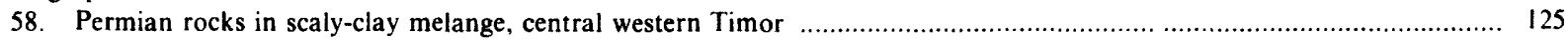

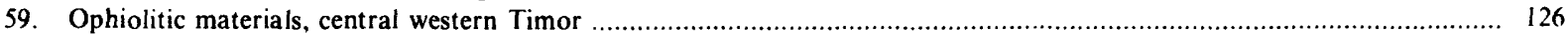

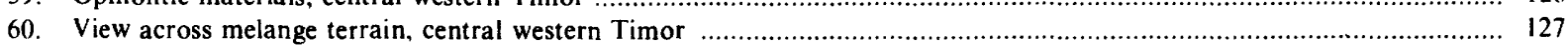

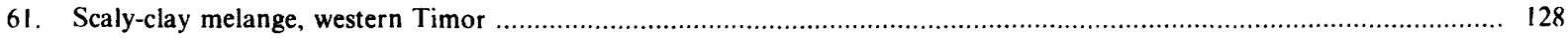

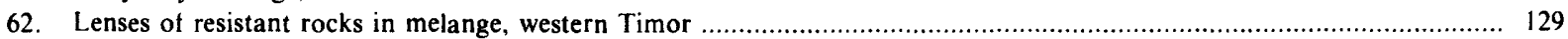

63. Disrupted Neogene sedimentary rocks, western Timor ........................................................................ 129

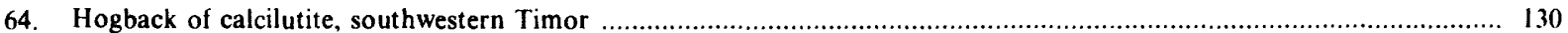

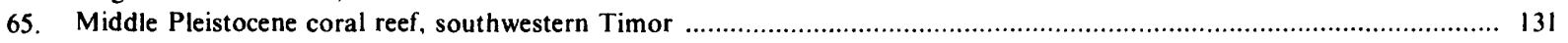

66. Landsat image of Seram ................................ 134

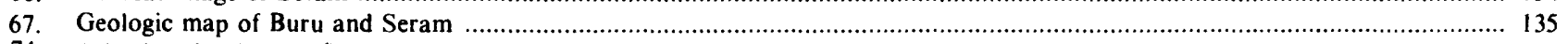

68 -74. Seismic-reflection profiles:

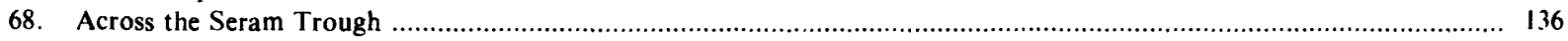

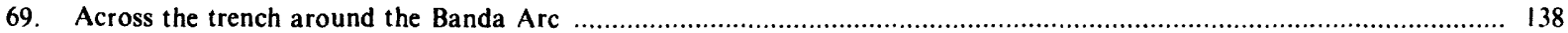

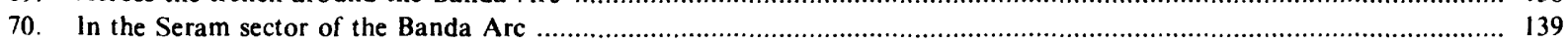

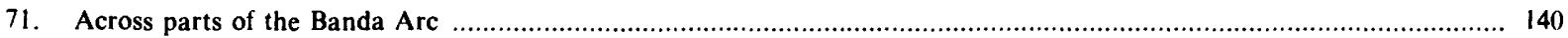

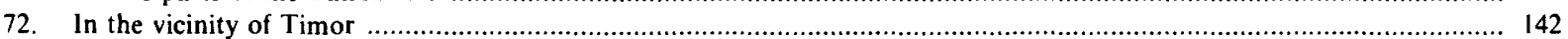

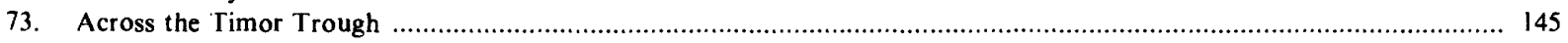


77. Palinspastic maps showing evolution of the Banda Sea region

78. Schematic cross section through the Timor sector of the Banda Arc

79. Map of selected tectonic elements in the Sula and Banggai Islands, Sulawesi, northern Moluccas and island-arc systems between the

Philippines and Sulawesi, Halmahera, and Borneo, and locations of seismic-reflection profiles

82. Photographs of sheared Cretaceous sedimentary rocks, southwestern Sulawesi

83. Photographs of Tertiary terrain of southwest Sulawesi

84. Landsat image of the Southeast Arm of Sulawesi

85. Geologic map of the Southeast Arm of Sulawesi

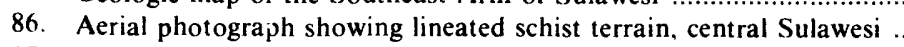

87. Aerial phtographs showing selected geo

88. Landsat image of East Arm of Sulawesi

89. Geologic map of East Arm of Sulawesi

90. Photograph of nickel ore, Soroaka, Sulawesi

91. Landsat image of north-central Sulawesi .

92 -95. Photographs:

92. Palu tault, west-central Sulawesi

93. Strike-slipvalleys, South Arm of Sulawesi

94. Neogene structure of central Sulawesi

95. Matano tault, central Sulawesi

96 -98. Seismic-reflection profiles:

96. In the Celebes Sea-Molucca Sea region

97. In the Celebes Sea-Molucca Sea region

98. In the Celebes Sea-Molucca Sea region

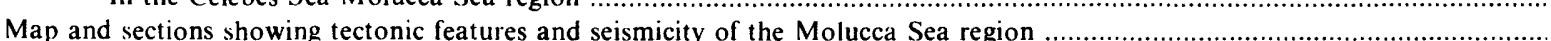

103 -105. Seismic-reflection profiles:

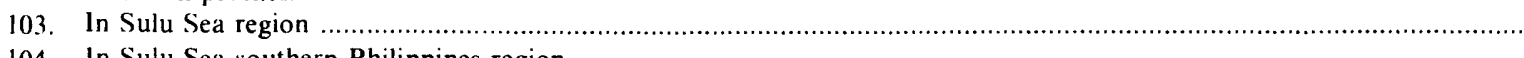

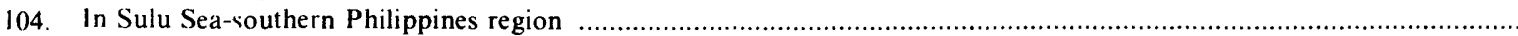

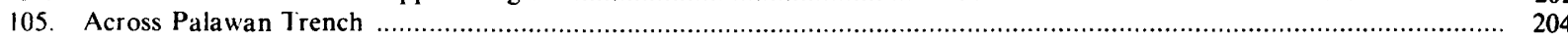

$106-108$. Landsat images:

106. Central Mindanao

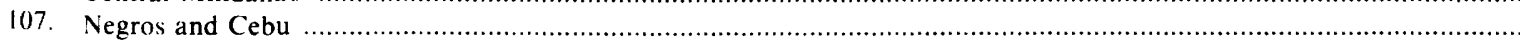

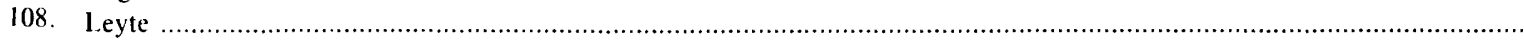

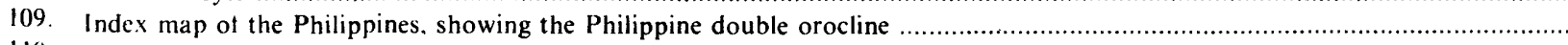

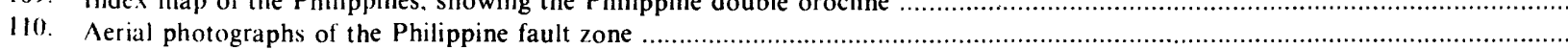

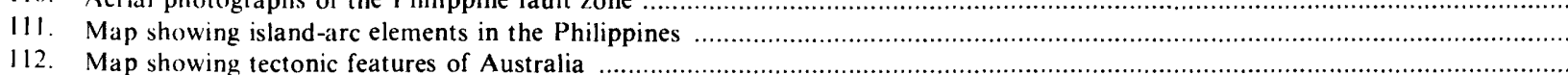

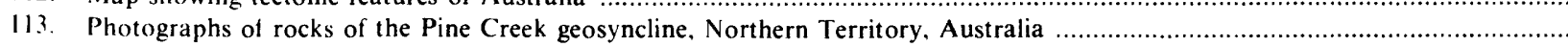

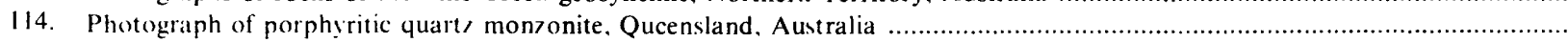

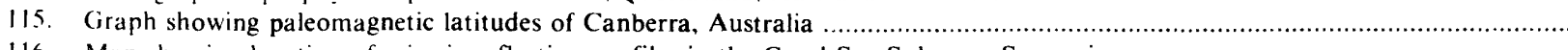

116. Map showing location of seismic-reflection profiles in the Coral Sea-Solomon Sea region

117. Seismic-reflection profiles. Coral Sea

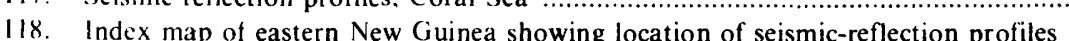

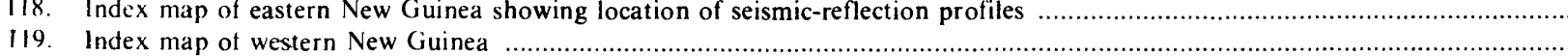

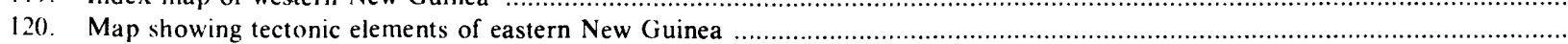

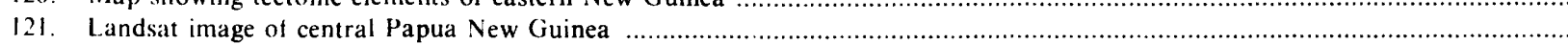

122. Map showing structural features of central Papua New Guinea

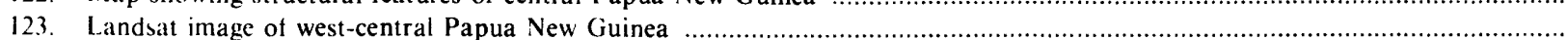

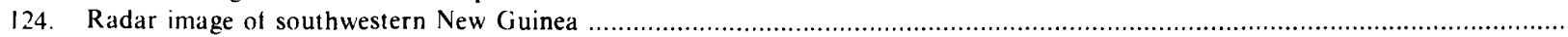

125. Map showing geologic structure of southwestern New Guinea

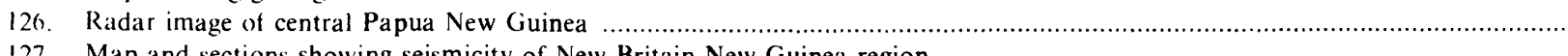

127. Map and sections showing seismicity of New Britain-New Guinea region

128. Seismic-reflection profiles, northeastern New Guinea

129. Seismic-reflection profiles across a possible trench, northeastern New Guinea

130. Landsat image of base of the Papuan Peninsula, New Guinea

131. Seismic-reflection profiles, Port Moresby Trench, southeastern Papua New Guinea

132. Seismic-reflection profiles, southwest Papua New Guinea 
Figure 133. Photographs showing melange and imbricated rocks of Port Moresby area, southeastern Papua New Guinea ........................ 268

134. Photograph showing undeformed volcanic rocks overlying melange, southeastern Papua New Guinea .................................... 269

135-137. Maps:

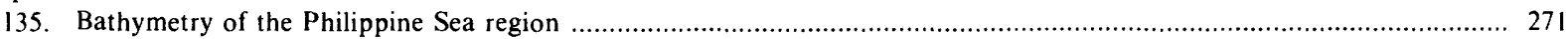

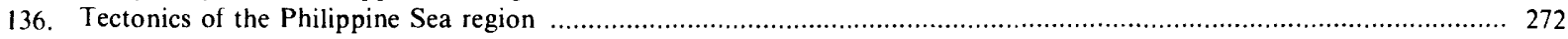

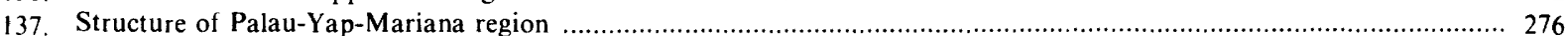

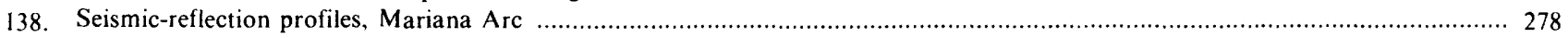

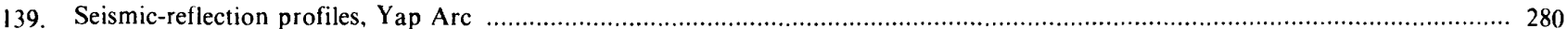

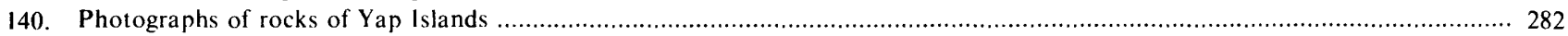

141. Seismic-reflection profile from Philippine Basin to West Caroline Basin .......................................................................284

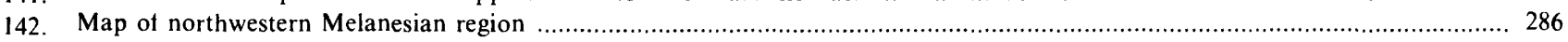

143. Seismic-reflection profile from West Caroline Basin to Ontong Java Plateau ..........................................................287

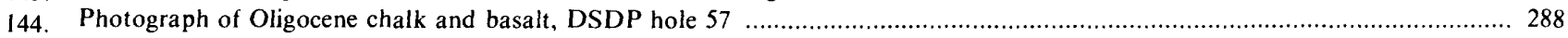

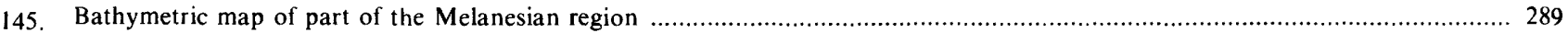

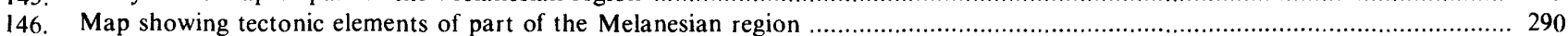

147. Seismic-reflection profiles from East Caroline Basin to Lyra Basin ............................................................................. 292

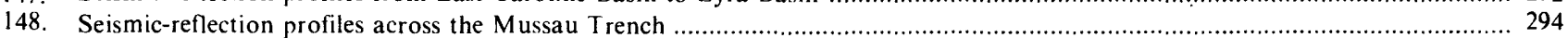

149. Maps showing seismicity of the New Guinea-Solomon Sea region .........................................................................296

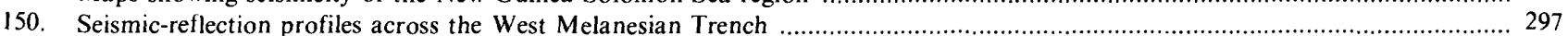

151. Seismic-reflection profile from southeastern Papua New Guinea to Ontoǹg Java Plateau .............................................. 298

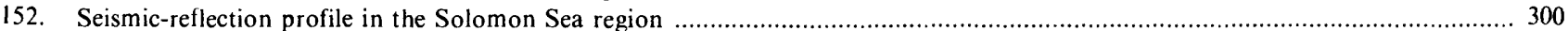

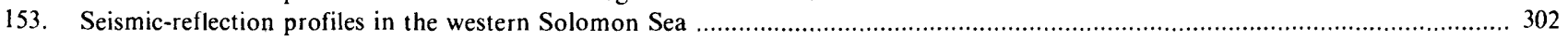

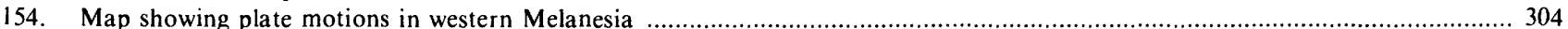





\title{
TECTONICS OF THE INDONESIAN REGION
}

\author{
By WarRen Hamilton
}

\section{INTRODUCTION GENERAL}

The tangled patterns of land and sea, and of deep-sea trenches, volcanic chains, and zones of mantle earthquakes, in the Indonesian region have long fascinated structural geologists and geophysicists. It was early recognized that processes that have gone to completion in mountain systems such as the Alps are displayed in earlier stages of evolution in Ind onesia. With the new concepts of plate tectonics to add to an increasing wealth of geologic and geophysical data, we can advance much farther toward an understanding of this complicated region.

We now see that the trenches, seismic Benioff zones, volcanic arcs, and other active tectonic features of the Indonesian region are responses to complex motions by large and small lithospheric plates. The convergence of three great plates dominates the system: Eurasia is one plate, much disrupted internally; the western Pacific floor, moving west-northwestward relative to Eurasia, is another; and the Indian Ocean floor and Australia, moving relatively northward, form the third. A number of small plates display complex behavior within the broad zone of interaction between the megaplates; the small plates grow behind migrating arcs, pivot, deform, subduct. The Mesozoic and Cenozoic history of plate motions can be read from the geologic complexes exposed on land or probed by offshore drilling and marine geophysics, and this history indicates complexly changing patterns of plate motions.

Indonesia represents an ideal level of complexity for analysis within the framework of available concepts of plate tectonics. Most of the active subduction, strike-slip, and spreading features that define the modern plate boundaries can be identified with reasonable confidence from their geologic and geophysical expressions. The patterns of these boundaries range from the simple to the exceedingly complex, and many new concepts are suggested by their analysis. Fossil plate-boundary systems can be identified, with widely varying levels of confidence, from the geologic record. Many of the tectonic elements are still separated by small ocean basins, and so can be kept distinct from one another. In much of interior Eurasia, by contrast, similar rock complexes have been crumpled together by nearly complete subduction of intervening ocean floors, and these squashed terrains represent a level of complexity that is far more difficult to analyze.

If the relative motions of the three megaplates now active in the region continue for another 30 or 50 million years into the future the landmasses of Indonesia and the Philippines will likely be squeezed between a colliding Eurasia and Australia, and the newly enlarged Eurasia will contain another broad and intricate terrain of mashed-together island arcs and continental fragments between internally stable subcontinental masses. Conversely, the sort of history deduced in this report for the Indonesian region is of a type that should be recorded in many of the ancient tectonic belts around the world.

\section{PRESENT WORK}

This report is the result of an eight -year study, supported in part by the Agency for International Development of the U.S. Department of State. This report describes the onshore and offshore geologic and geophysical data from Indonesia and surrounding regions, and interprets the data in terms of plate tectonics. The organization of the report is primarily geographic, but the order in which the provinces and sectors are discussed is chosen in part to permit the progressive development of concepts upon which subsequent sections can be based. Interpretations, broad and narrow, are presented in the text at whatever points the evidence displayed seems adequate to support them.

This report is a companion to the geologic and geophysical maps of the Folio of the Indonesian Region: a bathymetric map (U.S. Geological Survey, 1974; base also used for the other maps), a map of sedimentary basins (Hamilton, 1974a), an earthquake map (Hamilton, 1974b), and a tectonic map (Hamilton, 1978a; included here as pl. 1). The maps cover the region from long $90^{\circ}$ to $148^{\circ} \mathrm{E}$. and from lat $12^{\circ} \mathrm{N}$. to $16^{\circ} \mathrm{S}$., and are on a Mercator projection having an equatorial scale of $1: 5,000,000(50 \mathrm{~km}=1 \mathrm{~cm})$. The map area extends far beyond the political boundaries of Indonesia and includes northern Australia; most of Papua New Guinea; all of Malaysia; southern parts of Thailand, Burma, Kampuchea (Cambodia), and Vietnam; the southern half of the Philippines; and various small islands and groups of islands, as well as large offshore regions of shelves and ocean basins. The whole represents about 4 percent of the earth's surface. Many of the place names 
referred to in this text are shown on figure l; names of smaller islands and places are shown on the numerous index maps scattered through the text.

Much of the region of concern, including most of the active plate boundaries, is covered by water. An enormous quantity of geophysical data has been obtained in recent years from the offshore areas by both oceanographic institutions and oil-exploration companies. I have been able to incorporate much unpublished off shore data, as noted in the acknowledgments section, as well as the information in published reports. Particularly important unpublished material has been the extensive acoustic-reflection profiling made by many cruises by ships of the Lamont-Doherty Geological Observatory of Columbia University.

This report is intended to be comprehensive. Geologic and geophysical data and interpretations are presented for all lands and seas within the area of the maps of the Folio of the Indonesian Region (Hamilton, 1974a, 1974b; 1978a; U.S. Geological Survey, 1974), without regard to the political boundaries of Indonesia; and excursions are made far outside the map area where they appear revevant to an understanding of tectonic evolution within the area. The coverage is not, however, balanced. Regions such as the Banda Arc whose analysis leads to the development of tectonic principles are treated in far more detail than are others such as Indochina whose analysis does not.

The tectonic map (pl. 1; Hamilton, 1978a) was revised to accord with information obtained through mid-1976. References and other data received through middle 1977 were incorporated in this text, and limited additions were made as late as middle 1978.

Photographs not otherwise credited are by me.

\section{SUMMARIES}

The opening paragraphs after many first- and second-order headings in this report, and the opening sentences after many third-order headings, summarize the material which follows. These introductory statements can be scanned by the reader wanting an overview of the various topics.

\section{GEOGRAPHIC NAMES}

Place names in Indonesia represent variants of the same and different names in any of a babel of tongues, rendered phonetically into several conflicting European orthographies. Island and regional names may be completely different in European languages, the official Indonesian language, and the various languages actually used in the region in question. The official language, Bahasa Indonesia, is a Malay dialect, adopted after Indonesia became independent because that dialect was widely known in seaports, but it is not the primary language in any large part of the nation.
There are three distinct indigenous languages in use in Java, 15 in Sumatra, and hundreds more in the rest of Indonesia.

Dutch orthography was generally used for Indonesian names until about 1970 . Changes have been made since in governmental usage, but not necessarily individual usage, in the direction of English orthography. Among the letters likely to cause confusion are these:

$\begin{array}{ccc}\text { English } & \text { Indonesian, } & \text { Dutch } \\ & 1976 & \\ \mathrm{ch} & \mathrm{c} & \mathrm{tj} \\ \mathrm{j} & \mathrm{j} & \mathrm{dj} \\ \mathrm{s} & \mathrm{s} & \mathrm{c} \mathrm{or} \mathrm{s} \\ \mathrm{u} & \mathrm{u} & \mathrm{oe} \\ \mathrm{v} & \mathrm{w} & \mathrm{w} \\ \mathrm{y} \text { (initial in word } & \mathrm{y} & \mathrm{j} \\ \text { or syllable) } & & \mathrm{ij} \\ \mathrm{y} \text { (internal or } & \mathrm{i} & \mathrm{j} \\ \text { terminal) } & & \end{array}$

In this report, I use names likely to be most familiar to American and European readers and cast them in English orthography. Important variants are noted parenthetically with the major reference to the place in question. Thus, I use: Java, not Jawa or Djawa (all are phonetically the same); Vogelkop (Bird's Head), not Jazirah Doberai; Borneo, not Kalimantan; Sumatra, not Sumatera; and Geelvink Bay, not Teluk Sarera. Some Malay geographic terms (pulau, island; kepulauan, islands; sungai, river; danau, lake; and teluk, bay) are used on the tectonic map for features entirely within Indonesian jurisdiction but generally are not used in the text. On the other hand, I use Sulawesi, not Celebes, as the new Indonesian name is widely recognized; and I use new Indonesian names for cities wherever applicable.

Geographic names printed in blue or gray on plate 1 have been approved by the U.S. Board of Geographic Names, whereas the names in black for tectonic features include informal terms. Geographic names in the text include many that lack formal approval.

A number of international boundaries in this region are disputed. The boundaries shown on the tectonic map (pl. 1) and the text figures in this report are not authoritative.

\section{ACKNOWLEDGMENTS}

This book could not have been written without the generous cooperation of scores of academic, governmental, and industrial geologists and geophysicists. A large and indispensable part of the data reported here, or considered as background for the interpretations presented, has not been published previously. Published information about the Indonesian region describes primarily the onshore geology, although data are being released from both scientific and petroleum-exploration studies offshore. 
INDONESIAN AGENCIES

Individuals in several organizations within the Indonesian Ministry of Mines (Departemen Pertambangan) have been of much assistance during parts of this study. The Ministry is organized into an oil and gas department (Direktorat Jenderal Minyak dan Gas Bumi, "Migas") and a mines department (Direktorat Jenderal Pertambangan). The Geological Survey of Indonesia (GSI; Direktorat Geologi) is within the mines department. The oil and gas department includes both Perusahaan Pertambangan Minyak dan Gas Bumi Negara, "Pertamina," in charge of all production and exploration, and the research Indonesian Petroleum Institute (Lembaga Minyak dan Gas Bumi, "Lemigas").

This study of the tectonics of the Indonesian region was begun at the request of Johannas ${ }^{1}$, then Director of GSI and now at a higher position in the mines department, and John A. Katili, now Director General of the mines department. It was their expectation that the work would provide background data and concepts for both scientific work and economic exploration throughout Indonesia. Katili has followed the work with keen interest and has himself written a number of short papers on the plate tectonics of the Indonesian region. GSI provided office and library facilities during my visits to its headquarters in Bandung, as well as guides and logistic support for field trips as acknowledged subsequently here. Lemigas provided copies of several of its unpublished maps and reports on sedimentary basins in Indonesia. Pertamina authorized the release and publication of oil-company reflection profiles that illustrate this report.

AUSTRALIA BUREAU OF MINERAI, RESOURCES, GEOLOGY AND GEOPHYSICS

L. C. Noakes, present Director of BMR, most generously gave me seismic-reflection profiles for about $14,000 \mathrm{~km}$ of tracks in the western Bismarck Sea, western Solomon Sea, Gulf of Papua, and Timor Trough, thus making possible much of my interpretation of those regions. Some of those profiles illustrate this report. Many BMR scientists shared their ideas with me and provided manuscripts and geologic and geophysical maps prior to publication. I am indebted particularly to John Branson, John B. Connelly, Hugh L. Davies (and also to Davies in his subsequent position as Director of the Geological Survey of Papua New Guinea), David Denham, H. Fred Doutch, Ian B. Everingham, Douglas M. Finlayson, past-Director Norman H. Fisher, Douglas S. Hutchison, Douglas E. Mackenzie, R. W. Page, Kenneth A. Plumb, Ian D. Ripper, and R. J. Ryburn.

'Many Indonesians have only a single name.
LAMONT-DOHERTY GEOLOGICAL OBSERVATORY

Ten cruises of the Research Vessels Robert Conrad and Vema, of the Lamont-Doherty Geological Observatory of Columbia University, have zig-zagged through the Indonesian region, obtaining continuous seismic-reflection profiles for something like $70,000 \mathrm{~km}$ of tracks within the map area. The voluminous and superbly organized profiles for these traverses, and for others just outside the map area, were most generously given me by the late Maurice Ewing. Study of the profiles has added enormously to the tectonic interpretations, and segments of these Lamont-Doherty profiles constitute a large and important part of the illustrations in this report. Chief scientists on the Conrad and Vema cruises were at various times T. Aitken, George B. Carpenter, S. L. Eittreim, Robert Houtz, Marcus G. Langseth, William J. Ludwig, R. Meijer, and Charles C. Windisch. The cruises were supported by U.S. Navy contracts N00014-67-A-0108-0004 and Nonr 266(48), and by National Science Foundation grants GA-1299, GD-27250, G-22260, GP-884, GP-3332, and GA-728. Discussions with individual Lamont-Doherty scientists were also valuable. Roger $\mathrm{L}$. Larson and Walter C. Pitman, III, aided with their knowledge of the marine magnetic anomalies of the region.

\section{OTHER GOVERNMENTS AND INSTITUTIONS}

Geologists and geophysicists in agencies and institutions in other countries within the region of interest have given much unpublished information and have freely shared their concepts. I am indebted for such contacts to Robert W. Day, Cecil G. Murray, William G. Whitaker, and Ian Wilson, of the Geological Survey of Queensland; to K. A. W. Crook, Ian McDougall, M. W. McElhinny, and M. J. Rickard, of the Australian National University; to Hugh L. Davies, Director of the Geological Survey of Papua New Guinea; to Jumchet Charaljavanaphet and Kaset Pitakpraivan of the Royal Thai Department of Mineral Resources; to Jaafar bin Ahmad, Director Sooi Keong, Kwan Houng En, David A. K. Lee, Leong Khee Meng, and Lim Peng Siong, of the Geological Survey of Malaysia; to Guillermo R. Balce of the Philippine Bureau of Mines; and to Magnus S. Garson and Norman J. Snelling of the United Kingdom Institute of Geological Sciences. The multinational cooperative agency of the Economic Commission for Asia and the Far East (ECAFE) has its Industry and Natural Resources Division in Bangkok. Timothy A. Anderson, Yuri Borisovich Kazmin, C. Y. Li, and Leo W. Stach of that division were most helpful to me. (All but $\mathrm{Li}$ are now elsewhere.)

Allen Lowrie of the U.S. Naval Oceanographic Office (Navoceano) provided the computer printout maps of earthquake depths and locations that were incorporated in the earthquake map of the Indonesian region (Hamilton, 


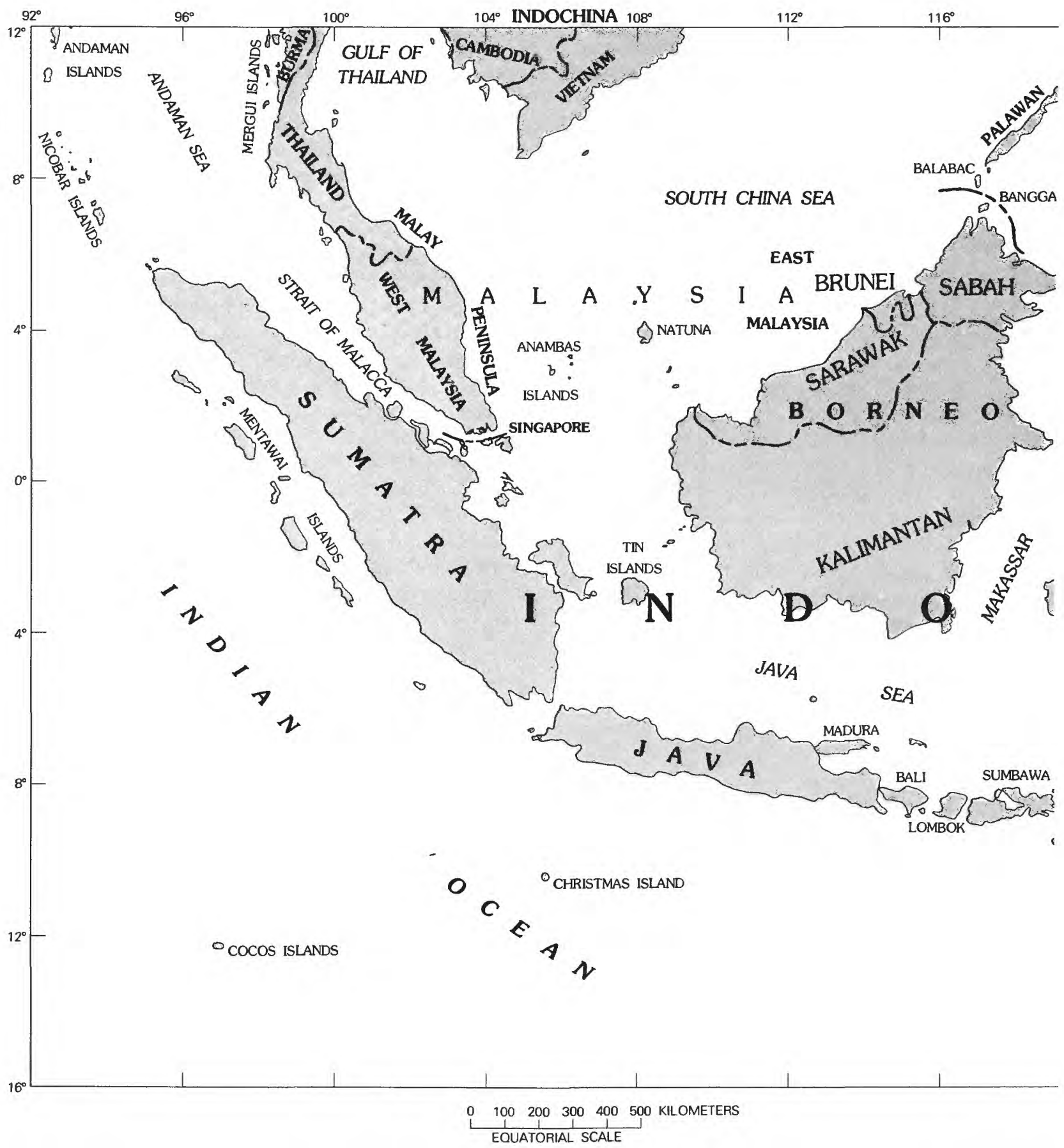

FIGURE 1.-Map of the Indonesian region showing some of the place names used in this report. Mercator projection.

1974b). Lowrie, Dewey R. Bracey, G. Leonard Johnson, and Peter R. Vogt gave information from Navoceano seismic-reflection profiling.

From the Scripps Institution of Oceanography came the contours for the bathymetric base map, as credited elsewhere here. Thomas A. Chase gave me the seismic-reflection profiling of Scripps cruise Circe II, across the northern part of the map area of the Indonesian region.

Dale L. Erlandson and Loren W. Kroenke, of the Hawaii Institute of Geophysics, provided copies of their unpublished Melanesian theses. Zvi Ben-Avraham and K. O. Emery of Woods Hole Oceanographic Institution kept me 


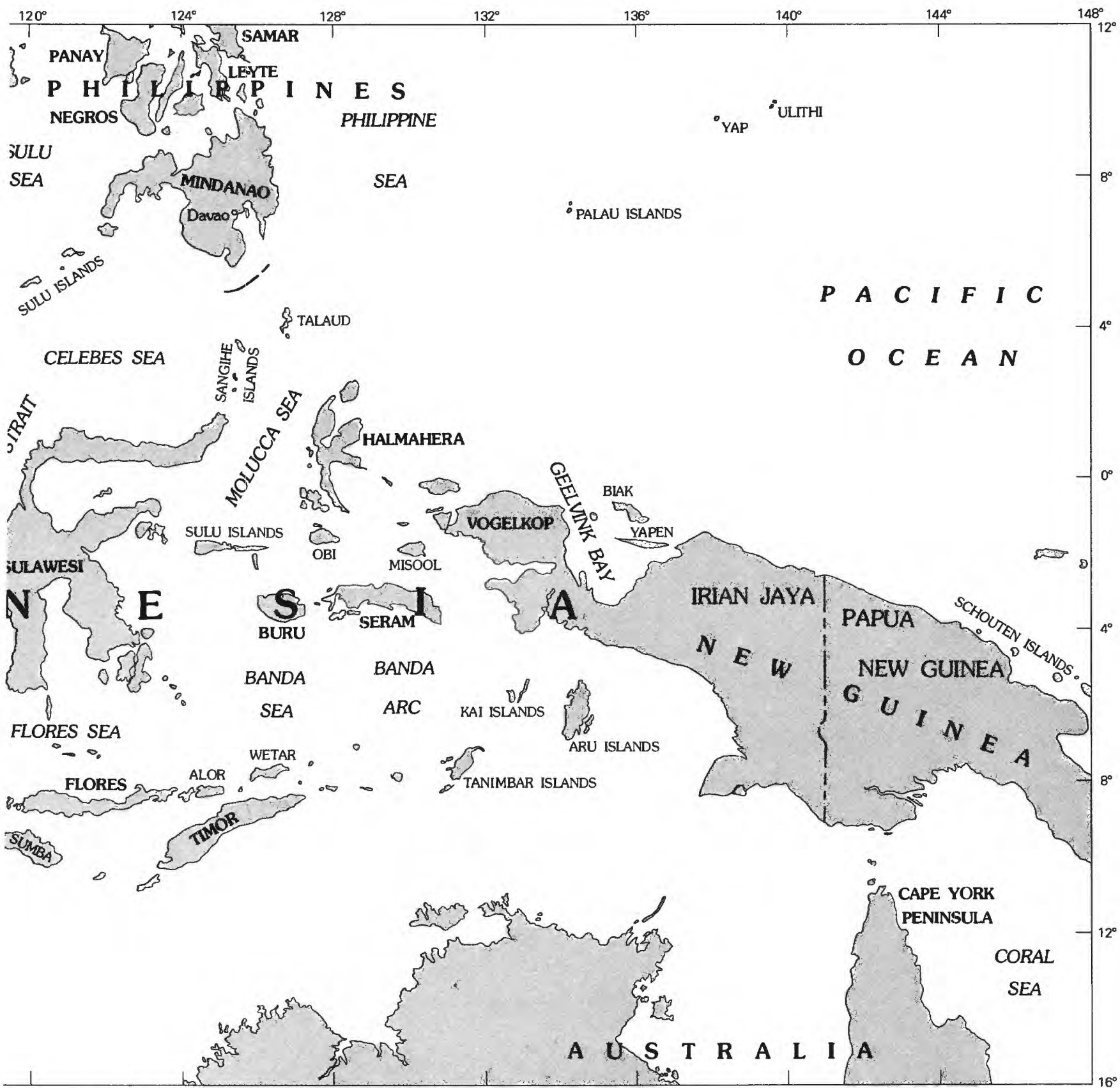

advised of their progress on then-unpublished studies on the $\mid$ Scores of geologists and geophysicists in many companies continental shelves of the South China Sea and Java Sea.

\section{OIL COMPANIES}

Most of the information presented here regarding the geology and geophysics of the continental shelves, and a substantial part regarding the deepwater continental margins, comes from oil companies active in exploration in the region. A large part of this data has not been published. have discussed their geology, shown me geophysical profiles and maps, provided information from wells, and given me basement-rock samples from wells. These data are incorporated in generalized form in this report, and in the maps of the Folio of the Indonesian Region. The companies vary widely in their treatment of their proprietary data, from very secretive to completely open. Commonly, I was permitted to incorporate the data I was given into generalized descriptions but not to cite them specifically-so many un- 
documented generalizations appear within this report. Often, data I received regarding one exploration concession would appear to conflict with those received from an adjacent concession, and likely I have erred in some of my attempts to reconcile such conflicts.

Most of the many geologists and geophysicists in the oil industry to whom I am indebted for discussions and information are listed here. I regret that in most cases they did not want to be quoted directly regarding the specific information I received from them and that the blanketing anonymity of this listing covers a number of men to whom my debt is very large. The company affiliations are those pertaining at the time I saw the men, many of whom have since moved to other organizations; some have retired, and some have died. The helpful companies and personnel:

AGIP Societa per Azioni: Franco di Cesare.

Amoco Production: Jonathon D. Stoen.

Amoseas Indonesia: C. E. Kirschner.

Atlantic Richfield Co. and Atlantic Richfield Indonesia: Larry M. Asbury, M. R. Clary, G. L. Fletcher, Peter V. Newman, M. H. Oakes, W. R. Scheidecker, I. D. Stephens, and Stuart Watson.

Australian Aquitaine Petroleum Pty., Ltd.: Robin Beiers, R. Laws, and S. Mulle.

British Petroleum Co. and BP Petroleum Development Ltd.: Geoffrey Bronstrom, David A. L. Jenkins, P. E. Kent, Michael F. Ridd, V. Paul St. John, and Robert Stonely.

Caltex Pacific Indonesia: Bactoel Chatab.

Chevron Exploration Co. and Chevron Overseas Petroleum: A. E. Dufford, William K. Gealey, Robert Lagaay, D. O. Oliver, Edwin S. Parker, and J. T. Shulenberg.

Cities Service Oil Co., Cities Service East Asia, and Indonesia Cities Service: Leslie R. Beddoes, Jr., Christopher S. Kenyon, Murray J. Wells, and John N. Wilson.

Constellation Group: Terry Griffith and Donald F. Todd. Continental Oil Co., Continental Oil Co. of Australia, and Continental Oil Co. of Indonesia: Alan Chatfield, George W. Dennis, Gregory K. Elias, Richard C. Harp, John Harrison, Paul K. Kopper, Leons Kovisars, John F. Mason, Ian Maycock, Ronald J. Marr, Peter G. Purcell, Robin Purcell, James L. Resor, S. L. Rieb, Gerald Turnern and John M. White, Jr.

Exxon Corp. and Esso Exploration: James D. Hedberg, William Kindschuh, Richard W. Murphy, Theodore A. Konigsmark, and Peter Vail.

Gulf and Western Indonesia: Edward A. Gribi, Jr. Gulf Oil Corp.: Frank Hooper and John S. Wonfor.

Mobil Oil Corp. and Mobil Oil Indonesia Inc.: Creighton A. Burk, Richard E. Sweet, and J. I. Walton.
Natomas and Independent Indonesian American Petroleum Co.: Charles B. Hauf and R. C. Slocum.

Oceanic Exploration Co.: C. J. Gudim.

Phillips Petroleum Co., Phillips Petroleum Co. Far East, and Phillips Petroleum Co. Indonesia: Don W. Dalrymple, Bailey Rascoe, Jr., Norman C. Tallis, J. J. Tanner, and A. A. Walker.

Shell International Petroleum Maatschapij N. V.: R. H. Beck, M. W. Hughes Clarke, Richard E. Farmer, Peter de Ruiter, and J. Schweighauser.

Stanvac Indonesia: M. P. Gillert.

Superior Oil Co.: R. L. Hillier and G. D. Mathews.

Tenneco Oil Co.: B. D. Carey, Jr., and T. W. Oppel.

Tesoro Petroleum Corp. and Tesoro Indonesia Petroleum Co.: John C. Michols and Monte N. Swetnam.

Texaco, Inc.: Martin Forrer.

Total Indonesie: Philippe Magnier and Hans Oesterle.

Trend Exploration: John J. Cloeter, C. J. Gudim, and John Redmond.

Union Carbide Petroleum Co. (since absorbed into Ashland Oil Co.): Eugene Borax and John E. Szatai.

Union Oil Co. of California, Union Oil Co. of Indonesia, Union Oil Co. of Thailand, and Unocal Corp.; Kenneth Bradley, Frederik E. Dekker, John Kowalski, Harold M. Lian, Daniel Munir, Doyle D. Paul, Richard D. Stewart, Quentin W. Van Camp, Henk Wories, and John O. Zehnder.

Virginia International Co.: Edgar W. Wellbaum.

Woodside-Burmah Oil and Burmah Oil Co. of Australia: Angelo A. Crostella, Peter Kaye, and Stephen Marchant.

\section{MINING COMPANIES}

I have had only limited contact with members of the mining industry, which generally has done relatively little regional mapping. P. T. International Nickel Indonesia (INCO), however, prepared a geologic map of the east arms of Sulawesi by compilation of previous mapping, new field reconnaissance, and air-photo interpretation, and a copy of this valuable map was given me by $\mathrm{B}$. N. Wahyu. Dennis Taylor gave me a photogeologic map and report on central Sumatra, made by Conzinc Riotinto Malaysia. Reconnaissance information on part of west-central Sulawesi was provided by Toru Ohtagaki of Nikko Exploration and Development Co., Ltd.

\section{TRAVEL}

This study was carried out primarily in Denver, Colo., but I was able to make seven trips to Indonesia and neighboring countries, including Thailand, East and West Malaysia, Singapore, the Philippines, Papua New Guinea, Australia, and Yap, with geologic field trips and the gathering of unpublished information from oil companies and govern- 
ment organizations as the major purposes of each trip. Four of these trips were supported financially by the U.S. Agency for International Development, and one was supported in part by the National Science Foundation. 1 also traveled extensively within the United States, obtaining unpublished information from both oil companies and research institutes.

Field trips within the Indonesian region mostly were organized and supported logistically by industrial and government groups. Union Oil Company of Indonesia provided a field trip in north Sumatra, led by Kenneth Bradley and Quentin W. Van Camp. Central Sulawesi was seen during an air and ground reconnaissance provided by International Nickel Indonesia, arranged by B. N. Wahyu and guided by Waheed Ahmad and B. Vishnu Pada. Southwestern Sulawesi and western Timor were seen on trips arranged by the Geological Survey of Indonesia (GSI), using vehicles belonging to that agency. On Sulawesi, my guides were Rab Sukamto, GSI, and Willis H. Nelson, U.S. Geological Survey. Guides on Timor were Soebardjio Tjokrosapoetra of GSI, and, again, Willis H. Nelson. Central Java was seen with GSI vehicles on a trip led by Sukendar Asikim, of the Institute of Technology in Bandung, and John A. Katili, now Director General of the Indonesian Department of Mines. The Geological Survey of Malaysia provided field excurisions in central Malaya, guided by Jaafar bin Ahmad and K. N. Murthy, and in northwest Sabah, led by Lim Peng Siang and Kwan Houng En. Hugh L. Davies of the Geological Survey of Papua New Guinea showed me geologic features near Port Moresby. I was able also to tour on my own parts of Sarawak and Malaya, and of Northern Territory and Queensland, Australia.

\section{U.S. GEOLOGICAL SURVEY}

The U.S. Agency for International Development supported a program of assistance by the U.S. Geological Survey (USGS) for the Geological Survey of Indonesia in Bandung. A number of USGS scientists worked in Indonesia within this assistance program. Discussions and field excursions with Keith B. Ketner, Willis H. Nelson, and the late Don E. Wolcott, among these USGS people, gave me valuable data and concepts that are incorporated in many places in this report. Paul W. Richards and the late Montis $\mathrm{R}$. Klepper helped with many matters in Bandung.

\section{BASE MAP}

The Bathymetric map of the Indonesian region, published both as a separate map (U.S. Geological Survey, 1974) and as the bathymetric base for the other maps of the Folio of the Indonesian Region, was compiled in cooperation with the Scripps Institution of Oceanography (SIO) of the University of California. The contours of the map are in meters, corrected for estimated sound velocities, with an interval of $1,000 \mathrm{~m}$, and a supplementary contour at $200 \mathrm{~m}$. Contours in the Banda Sea and Indian Ocean came from a compilation by Robert L. Fisher of SIO, subsequently published, with corrections, in the Geological-Geophysical Atlas of the Indian Ocean (Udintsev, 1975, p. 15, 23, 26, 27). Part of Fisher's contouring was also published, with corrections that were not incorporated in our Indonesian maps, by Sclater and Fisher (1974). The base-map bathymetry for the Pacific and northern Indonesian regions was taken from published maps by Chase and Menard (1969) and by Mammerickx, Chase, Smith, and Taylor (1974), all then of SIO, corrected-meter contours being interpolated between the uncorrected-fathom (Chase and Menard, 1969) and corrected-fathom (Mammerickx and others, 1974) contours of the originals. The bathymetry of the small part of the base map within the Coral Sea was taken from Gardner (1970, fig. $3)$.

\section{MANUSCRIPT REVIEW}

Many improvements in presentation and interpretation were made in this book through helpful comments on the manuscript by Richard W. Murphy of Esso Exploration; by John Branson, Douglas E. Mackenzie, and R. J. Ryburn of the Australia Bureau of Mineral Resources, Geology and Geophysics; and by my U.S. Geological Survey colleagues Ann C. Christiansen, Andrew Griscom, Keith B. Ketner, and Daniel R. Shawe.

\section{PLATE TECTONICS}

\section{GENERAI}

The explosion of data and concepts from marine geophysics during the late 1960 's resulted in the placing of continental drift into the broader context of plate tectonics. The independent approaches of geomagnetism, paleomagnetism, seismology, tectonic analysis of bathymetry and reflection profiling, deep-ocean drilling, and isotopic and paleontological dating have converged sharply upon a single explanation. The earth's crust is fragmented into seven very large lithospheric plates, each consisting of both oceanic and continental portions, and many small ones, all of which are moving relative to all others (fig. 2). Midocean ridges are formed where plates are separating; strike-slip faults occur where plates slide past one another; and inclined Benioff zones of mantle earthquakes mark the subduction of oceanic plates beneath either continental plates or other oceanic plates. The velocities of underflow into subduction zones reach at least $12 \mathrm{~cm} / \mathrm{yr}$, or $120 \mathrm{~km} / 10^{6} \mathrm{yr}$. Important early papers developing these concepts include those by Heirtzler and others (1968), Isacks, Oliver, and Sykes (1968), Le Pichon (1968), McKen- 


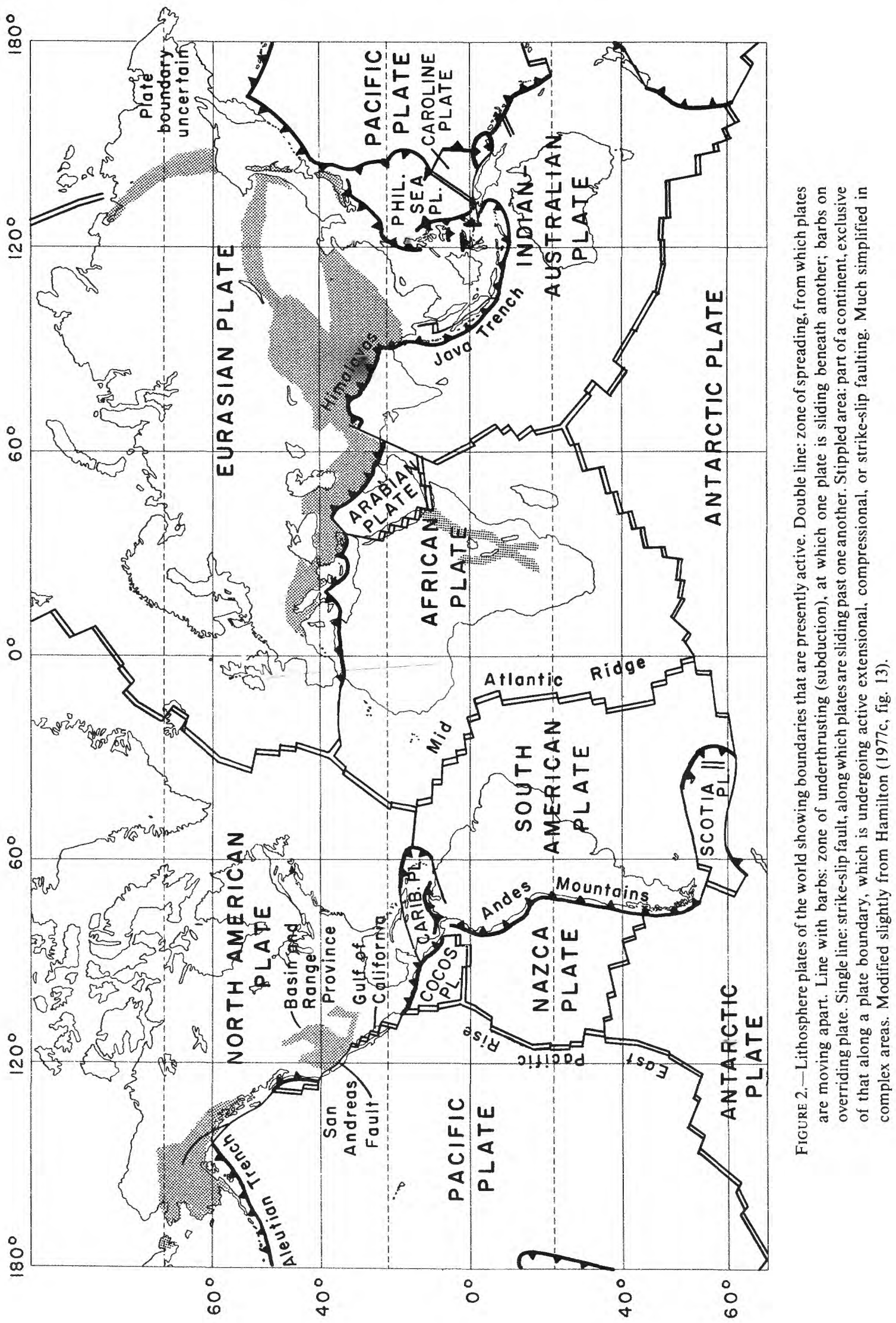


zie and Morgan (1969), McKenzie and Parker (1967), and W. J. Morgan (1968). Scores of subsequent papers have added data and refined concepts. The applications of plate tectonics to continental geology have been developed by Bird and Dewey (1970), Bott and Dean (1972), Burke, Dewey, and Kidd (1977), Coney (1970), Dewey and Bird (1970, 1971), Dickinson (1969, 1970, 1973, 1975), Ernst (1970), Hamilton (1969a, b; 1970b, 1978b), and many others. Applications of plate tectonics to Indonesia in particular have been made by Fitch (1970a, b), Fitch and Molnar (1970), and Hamilton (1974b) for seismology, by Hatherton and Dickinson (1969), and C. S. Hutchison (1975, 1976) for petrology of active volcanoes, and by Davies (1971a), Davies and Smith (1971), Hamilton (1970a, 1972, 1973, 1974a, 1977a, b, 1978a), Karig (1971a, b), Katili (1973a, b, 1974, 1975), and Sclater and Fisher (1974) for regional geology. Particularly important papers for an understanding of the tectonics of the zones at which oceanic lithospheric plates turn down beneath continental or island-arc plates include Grow (1973a), Montecchi (1976), and Seely, Vail, and Walton (1974).

The systematic relationship of the volcanoes, earthquakes, and active tectonic features of Indonesia to the deep submarine trenches was early recognized by Dutch geologists and geophysicists. We now see that these trenches mark the downturns of oceanic plates beneath other plates that can be either oceanic or continental and that the Benioff zones, dipping as deeply as $700 \mathrm{~km}$ into the mantle from these trenches, record the downward progress of the plates. Volcanic belts occur primarily above those parts of the Benioff zones that are between 100 and $200 \mathrm{~km}$ deep. The ratio of potassium to silicon in the magmas erupted above the Benioff zones varies systematically with depth to that zone (Hatherton and Dickinson, 1969; Dickinson, I973), although the ratio is somewhat higher for continental-margin magmatic arcs than for intraoceanic ones (Dickinson, 1975).

Other features of the belt between trench and magmatic arc are less obvious. Where voluminous sediments are available, either on the subducting plate or along the margin of the overriding plate, an outer-arc ridge and outer-arc basin are generally developed. No standardized nomenclature exists for these two features. Dickinson (1973, and other papers) has referred to them collectively as the "arc-trench gap." Von Huene, Nasu, and others (1978) refer to the basin as the "deep sea terrace." Seely, Vail, and Walton (1974), termed the ridge the "outer high." Karig (1973b and other papers), has termed the ridge the "mid-slope basement high", and Karig and Sharman (1975) called it the "trench-slope break"; these terms are appropriate for open-ocean island arcs, but not for arcs in the Indonesian region, where the feature in question is formed of low-density sediments, not basement, and where it can stand much higher topographically than does the volcanic arc behind it. The ridge is the top of a wedge, which can be $10 \mathrm{~km}$ thick, of contorted and imbricated sediments, melange, and crystalline rocks, whose thin front edge defines the topographic trench. Behind the ridge is a structural basin, which typically has a relief of many kilometers and may either be a bathymetric basin or else be filled with sediments and then be bathymetrically a platform or terrace.

\section{EARTHQUAKES}

Plate boundaries are broadly defined by zones of active seismicity (1sacks and others, 1968; and many other papers). Narrow zones follow oceanic spreading centers, strike-slip faults, and Benioff zones; broad zones occur in melange-wedge terrains above subducting plates, and in those parts of continents undergoing distributed extensional, strike-slip, and compressional deformation. Great earthquakes, magnitude greater than 8.0 , occur primarily along subducting plate boundaries, and otherwise mostly in continental strike-slip and compressional terrains (fig. 3). The Indonesian region accounts for a substantial proportion of these great earthquakes, as also of the world's severe, but less catastrophic, earthquakes (fig. 4) and of its lesser recorded events (Hamilton, 1974b). Within the Indonesian region, both major and minor events occur mostly in the Java-Banda subduction system, and in the complexes of strike-slip faults, compression, and subduction in the northern New Guinea, Molucca Sea, and Philippine regions.

\section{IDENIIHCAIION OF ANCIENT PIATE-TEC:TONIC:FEATLIRES}

The presently active structures and volcanoes of the Indonesian region are systematically related in space to the subduction trenches (identified by reflection profiling) and Benioff seismic zones (identified by seismicity). A large proportion of the now inactive structures and magmatic rocks of the region resemble those now forming, and it is the fundamental assumption of my work that these older features formed with similar systematic relationships to subduction and Benioff zones.

Half of the problem is to identify the relevant features in terrains of various geologic ages from descriptions in the literature. Only meager geologic information has been published for most of the onshore Indonesian region. Most geologic maps are based on widely spaced observations in poorly exposed and poorly understood terrains. Most of the field information within 1ndonesia predates 1939. (Publication was primarily in Dutch, which few Indonesian geologists can read; they are cut off from their own literature.) Logistics rather than data were the usual prime concern of the geologist involved, and petrography too often consisted only of casual descriptions of stream cobbles. Fieldwork since 1945 also has consisted primarily of hurried reconnaissance. 1dentification of geologic terrains from the literature must thus be made from inadequate data, and major errors are undoubtedly present in interpretations 
TECTONICS OF THE INDONESIAN REGION

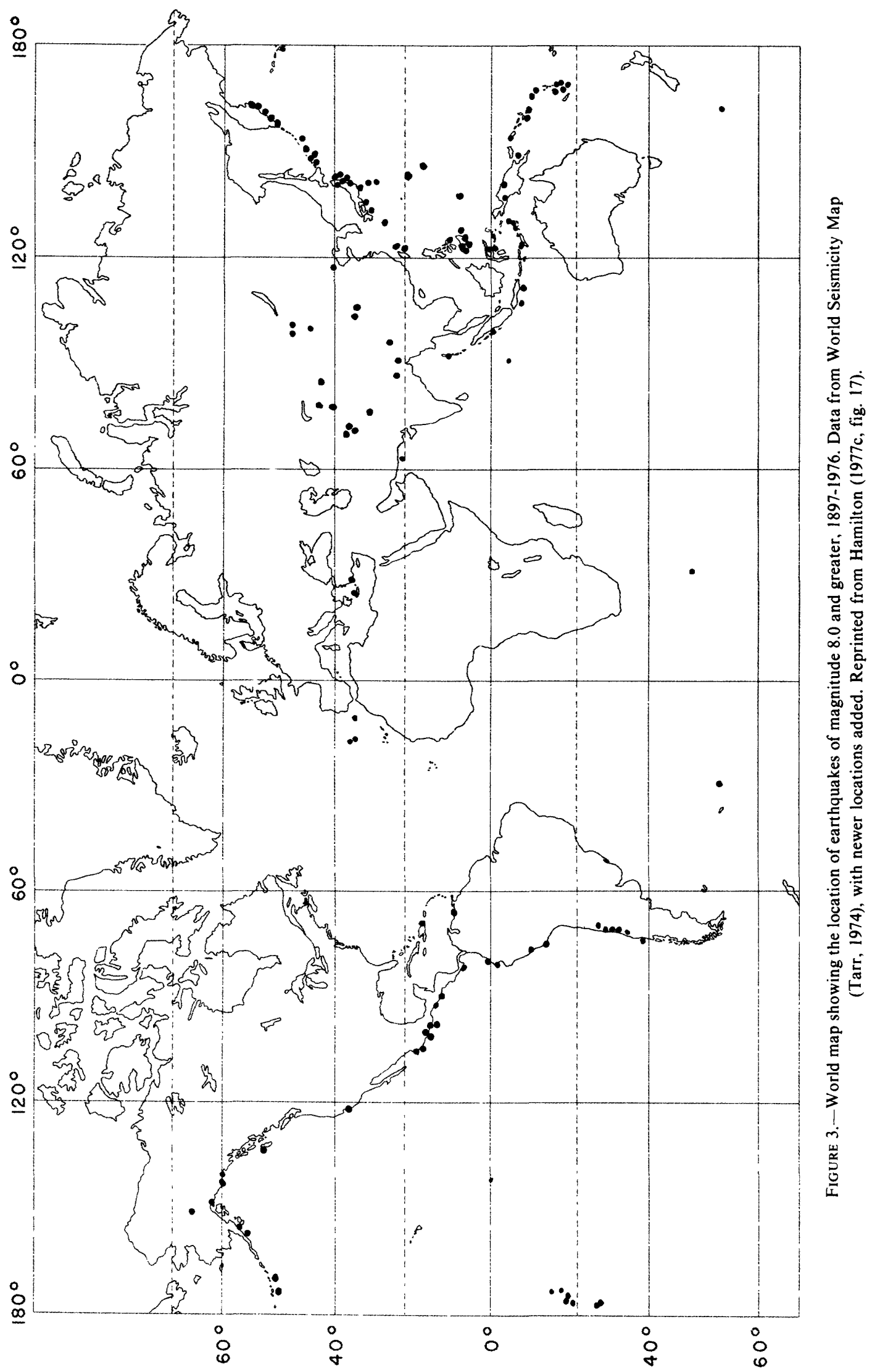


reached here. Careful fieldwork is much needed to solve the puzzles that remain in most aspects of Indonesian geology.

The second half of the problem is to determine the age of a terrain once it has been identified as to character. Vague lithologic correlations have often been carried far beyond reasonable limits in this region. Fitch $(1958$, p. 44$)$ provided an example of this when he explained why rocks in 16 areas had been assigned to one formation: "The rocks of the first two areas have been dated palaeontologically and those of the other areas have been assigned to the formation because of field association with rocks similar to those that have been so dated, or because of lithological similarity to rocks that have been dated from such associations." Worse yet, wholly undated rocks that compose vast regions have been assigned ages that are based on lithologic correlations with rocks dated only in places far distant, and such assumptions of age tend to change across national boundaries. Much work has incorporated the faulty assumption that degrees of alteration and deformation correlate with age and can be used as criteria to assign relative ages even to terrains separated widely.

Evaluating the evidence for both the identification and the dating of geologic terrains requires study of primary geologic reports. Secondary sources-national geologic maps, review papers, and compendia such as the valuable one by van Bemmelen (1949) — on the one hand do not repeat enough description for thorough analysis and on the other hand generally accept the traditional assumptions without adequate discussion. Only by reading the original reports can one be sure that he has seen all available descriptions and that he knows the basis, or lack of it, for conclusions that have become entrenched in the literature. Many valuable manuscript reports from Dutch work in progress before World War II are in the files of the Geological Survey of Indonesia in Bandung, and unless these are published soon, few will have survived attrition and decay.

The plate-tectonic elements that are generally recognizable in the literature of the Indonesian region are the calc-alkalic magmatic belts, formed above Benioff zones in either island arcs or active continental margins, and the subduction-zone melanges, formed in the great wedges above subducting plates on the landward sides of trenches.

Identifying the gross character of the magmatic belts seldom produces ambiguity, for even casual reconnaissance generally provides the critical minimum of information; but ages are often poorly known. An assemblage of dacite, quartz latite, and rhyolite, or of their plutonic equivalents granodiorite, quartz monzonite, and granite, or of both together, defines a suite formed upon or within crust that was then continental. Arc tholeiites dominate early phases of island-arc volcanism. An assemblage of mafic andesite, basalt (commonly the high-alumina type), and their volcaniclastic and intrusive equivalents, together with pelagic or fringing-carbonate sediments but without con- tinental clastic rocks, defines a suite formed in a more mature island arc.

A plate-tectonic element not generally recognizable in the pre-Miocene magmatic terrains of the Indonesian region is the cross-strike increase in the ratio of potassium to silicon known to characterize modern magmatic arcs. Such an increase can be documented in well-known old arcs, such as those of the California Mesozoic; but in the Indonesian region, adequate dating and petrologic data are not in general both available for pre-Miocene magmatic suites. The potassium gradient defines the direction of dip of the Benioff zone operative at the time the rocks were formed, but this valuable tool can as yet be applied only locally to the pre-Neogene history of the Indonesian region.

The second type of geologic terrain of major plate-tectonic significance that is generally recognizable in the Indonesian literature is subduction melange. Only a very little drilling has yet examined active subduction systems directly, and my early interpretation of what they should contain came from the characteristics of older complexes apparently formed in past subduction zones. When I started this Indonesian work, my model for the subduction complex was the Franciscan terrain (or "formation") of coastal California, the best known of fossil subduction melanges. The evidence which indicates that this latest Jurassic, Cretaceous, and early Paleogene chaos of crystalline and sedimentary rocks formed in large part within a subduction system has been given by Bailey and Blake (1970), Bailey, Blake, and Jones (1970), Dickinson (1970), Ernst (1970), Hamilton (1969b), Page (1970), and many others since. The Franciscan has been described by these authors; by Bailey, Irwin, and Jones (1964), Hsu (1968), Hsu and Ohrbom (1969), and Wood (1971), none of whom then recognized the subduction significance of the complex; and by Berkland (1972), Blake and Jones (1974), Coleman and Lanphere (1971), Cowan (1974), Loney, Himmelberg, and Coleman (1971), Maxwell (1974), O’Day and Kramer (1972), Page (1972), Suppe (1973), and others, all of whom did recognize its subduction character.

The Franciscan is a tectonic chaos formed primarily of abyssal clastic sediments and oceanic crustal and mantle rocks, exposed in a belt as wide as $75 \mathrm{~km}$. The complex consists of lenticular fragments, of all sizes from that of sand grains to coherent sheets many kilometers wide and tens of kilometers long, in a matrix of sheared scaly clay or its slaty or phyllitic equivalents. The fragments in most areas are dominated by deep-water graywacke, siltstone, and argillite. Fragments include in many areas also ophiolite (slabs of oceanic crust and mantle): abyssal pillow basalt bearing pelagic chert or limestone, and serpentine or peridotite. Also present in various areas are such high-pressure metamorphic rocks as glaucophane schist, jadeitic metagraywacke, and eclogite. Large areas of fragments and matrix alike display less conspicuous high-pressure metamorphism, often with 


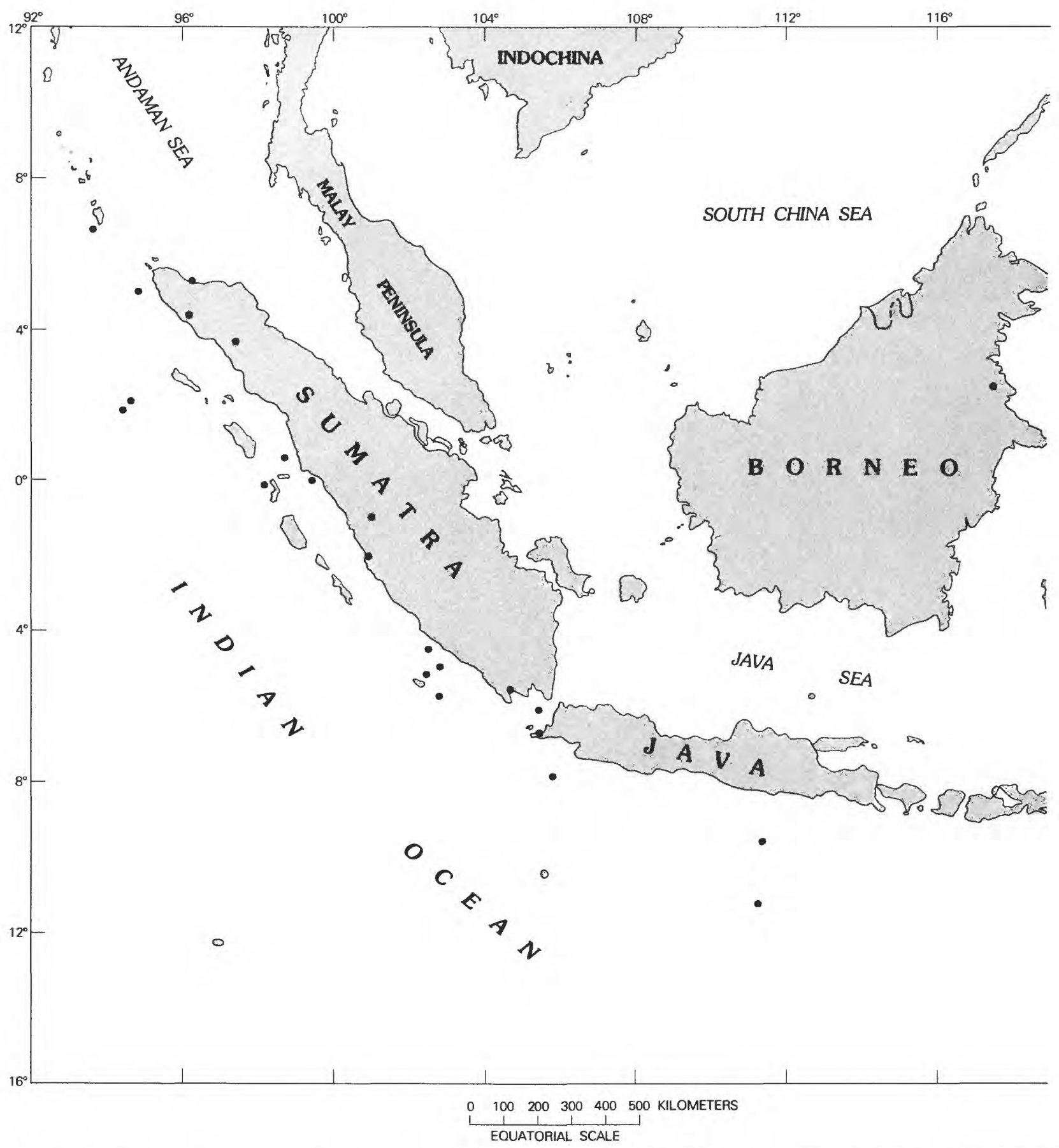

FIGURE 4. Epicenters of major shallow earthquakes in the Indonesian region, 1918-73. From a compilation by Kelleher and McCann (1976, fig. 6), from standard catalogs, of earthquakes of magnitude 7.0 or more.

little change in the gross appearance of the rocks, to prehnite-pumpellyite, glaucophane, or lawsonite-jadeite mineral assemblages. The Franciscan has a general eastward dip and formed at the same time as did sediments in an adjacent outer-arc basin and, further inland, a great magmatic arc (Dickinson, 1969, 1970; Hamilton, 1969a, b). The Franciscan forms an eastward-thickening wedge above oceanic crust and mantle that dip very gently eastward
(Griscom, 1973), whereas the internal structures of the Franciscan mostly dip steeply to moderately; this configuration is now known to be typical of subduction melanges elesewhere. (See for instance, Beck and Lehner (1974); Grow (1973a); Hamilton (1974a); Seely, Vail and Walton (1974); this report.) The abyssal sediments in the complex tend to become younger westward across it, apparently because they were in general scraped off against the front of the wedge, 


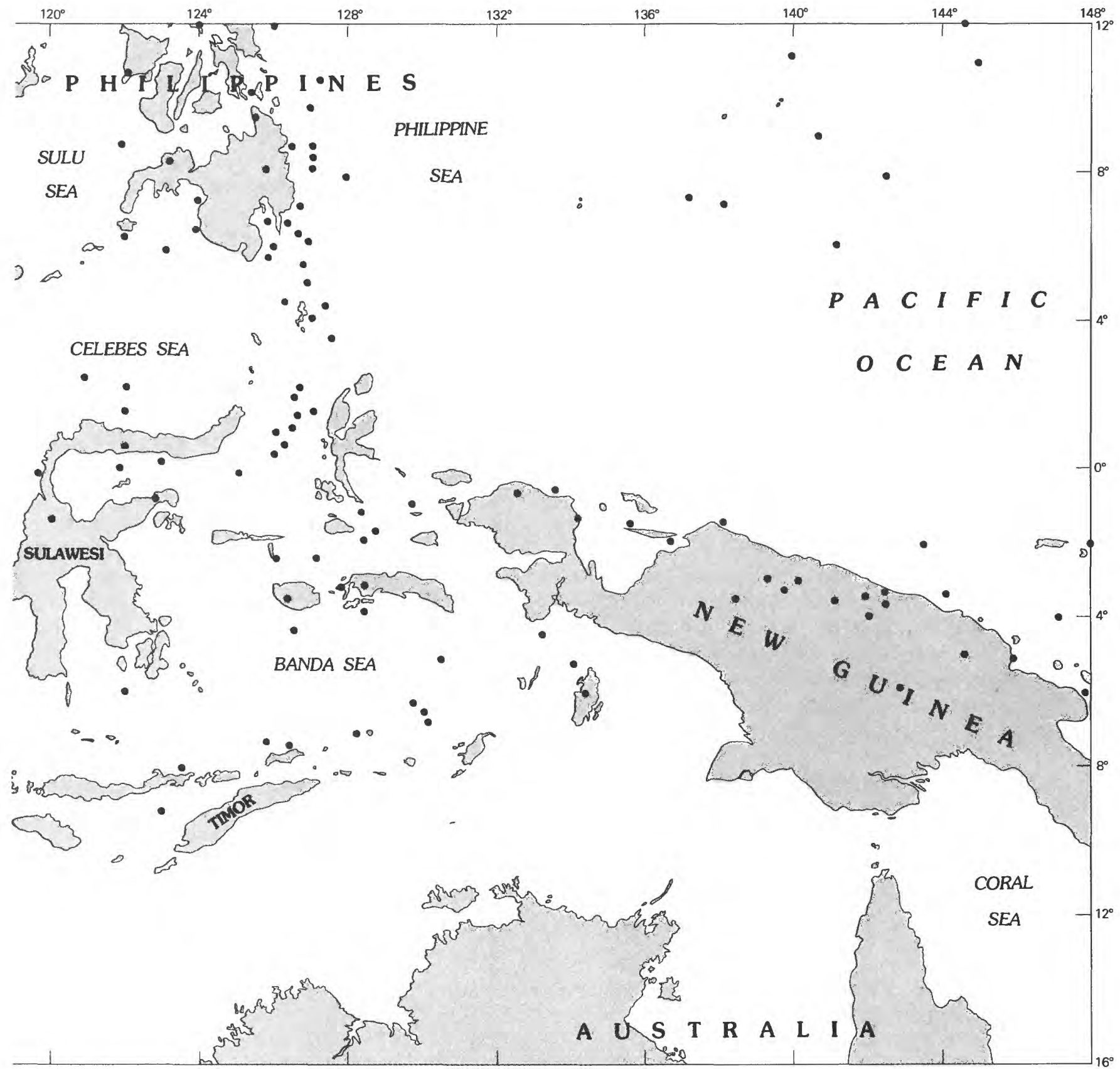

but shallower water strata imbricated into the complex are of varying ages, showing internal mobility of the entire wedge. The oldest (latest Jurassic) abyssal clastic sediments now within the melange were deposited directly on oceanic crust and pelagic sediments at a time when the continental margin was either stable or was subducting very slowly relative to sedimentation rates. Cretaceous abyssal sediments likely were deposited mostly in a trench, while rapid subduction was going on. All these features have analogs in modern subduction systems in Indonesia.

My early search of the literature of the Indonesian region for possible subduction melanges consisted in considerable part of looking for descriptions permitting a Franciscan analogy. I have accepted the presence of glaucophane schist as diagnostic of melange, for in well-documented orogenic belts around the world this appears to be its unique setting. I have accepted the presence of "alpine" serpentinite and peridotite, either alone or as complete ophiolite sequences, as in most cases indicating melange, but with the qualification that some ophiolite masses in the Indonesian region appear to be large upfaulted masses of ocean floor rather than components of melanges. (The term "serpentine" has occasionally been misapplied in the region to greenstones, so its designation is useful primarily where supported by 
petrographic description.) I have regarded the occurrence of pillow basalt (upper oceanic crust?) and of red radiolarian chert, red pelagic limestone, and red clay (abyssal pelagic sediments) as being highly suggestive of melange. Also suggestive is any field description that gives a picture of lenses of resistant rocks in a matrix of scaly clay or phyllite. Such images are conveyed in places by good descriptions in the Indonesian literature but more often must be inferred from such brief designations, unaccompanied by descriptions, as scaly clays, sheared landslides, submarine slumps, sheared conglomerates, and "slaty tuffs." All these criteria are present in the published descriptions of many of the individual terrains treated as subduction melanges on the tectonic map and in this book. Seldom do different reports of a single terrain yield conflicting conclusions: the criteria show through even very casual descriptions made by geologists with quite different viewpoints.

As my Indonesian survey progressed, my understanding of the character of melange wedges and of their relationship to subduction as determined by geophysical methods evolved greatly. Analogies can in fact now be run in the other direction: much can be told about the Franciscan and other ancient subduction melanges from the study of Indonesian and other modern complexes (Hamilton, 1978b).

Fossils within melange provide a minimum age of the subduction - the organisms could have lived at any time prior to that of subduction-but the youngest fossils need be very little older than the subduction. Fossils, however, are scarce in the abyssal materials that dominate the sedimentary components of most melanges, and are mostly of types-arenaceous foraminifera, radiolaria, shark teeth - that were not easily dated once found. (Radiolaria can now provide excellent dates.) A common assumption during the early Indonesian reconnaissance work was that degree of metamorphism correlates with geologic age. Where, for example, much-metamorphosed, little-metamorphosed, and unmetamorphosed materials are actually intershingled in melange, most old reconnaissance reports incorporated the assumption that two unconformities are present and that the unmetamorphosed sediments - the only ones likely to yield fossils - are wholly younger than the major deformation. In evaluating such possible situations, 1 have been guided by the field relationships as seen and reported by the field geologists. Where unmetamorphosed materials appear to be structurally concordant within melanges, I have in general assumed that they belong in the melanges and that any fossils present are no younger than the subduction. Probably I have erred in some interpretations of this sort, and the most likely errors will be in the direction of assigning ages that are too young to the melanges. A major complication is that sediments deposited unconformably on top of an active melange wedge become imbricated into it, and so such imbrication dates continuing subduction but not the time of major internal shearing recorded in the immediate vicinity.
The plate-tectonic model requires that calc-alkaline magmatic belts in general be related systematically to subduction zones of about the same age. This permits internal checks upon interpretations as they are developed. The other structural belts recognizable in active continental margin and island arc systems also have counterparts in fossil systems. It is not, however, commonly possible to identify these other belts from their characteristics as briefly mentioned in the reconnaissance literature of the Indonesian region, except insofar as the belts can also be related spatially to the magmatic zones and subduction complexes.

THE "CiEOSYNCILINAL, CYCLL"

Before the understanding that accompanied the concepts of plate tectonics, geology had no actualistic models for the interrelationships between sedimentation, magmatism, and orogeny. A complex rationale was constructed on the basis of observed sequences and had many variants, broadly grouped as the "geosynclinal cycle." One common variant was that the products of a long period of sedimentation in several adjacent troughs of different character, one of which (the "eugeosyncline") is the site of intermittent orogeny and magmatism, are inevitably deformed by climactic orogeny, at the end of which granites are formed. Such concepts had been losing credence for several decades because it was becoming increasingly obvious that neither active nor inactive modern continental margins nor island arcs could be explained in their terms. Now the concepts of plate tectonics have superseded those of the "geosynclinal cycle," which we see to be quite erroneous; we at last have actualistic models for "geosynclines," orogeny, and magmatism, with abundant analogs in the presently active parts of the world for the rocks and structures of old foldbelts.

There is no "geosynclinal cycle." Rather, a stable continental margin of "Atlantic" type (which is itself a product of continental rifting) will sooner or later become an active margin, either by the formation of a new subduction zone along it or by collision with an island arc or another continent that is bounded by an active subduction zone (Bird and Dewey, 1970; Coney, 1970; Dewey and Bird, 1970, 1971; Dickinson, 1970; Hamilton, 1970b). Orogeny probably is not periodic on a global scale: plate boundaries are forever changing, and subduction shifts from one site to another, but global motion continues, though at varying rates. No "eugeosyncline" exists in the sense of a filled trough; the rocks lumped by the term include the sediments of the previously stable outer continental shelf, slope, and rise, crumpled against the continental margin when it was activated subsequently; the products of tectonic accretion of various oceanic materials scraped off against the edge of the continent from the undersliding oceanic plate; and the volcanic products of arc magmatism formed above Benioff zones that either dipped inland from continental margins or else underlay island arcs that subsequently collided with the continent (Hamilton, 1969b). Most batholiths are the 
plutonic phase of arc volcanism (Dickinson, 1969, 1970; Hamilton, 1969a). Batholiths are generally causes, not products, of crustal metamorphism (Hamilton and Myers, 1967).

Tectonic maps published within the last 15 years have mostly been organized around the concept of the "geosynclinal cycle." This concept is the explicit foundation of Soviet tectonic maps. (Plate-tectonic concepts have still made little headway in the U.S.S.R., where most geologists continue to base their tectonic explanations upon fixist hypotheses.) Sphizharskiy (1966) used "region of geosynclinal regime" as a synonym for orogenic belt and assigned the lithotectonic units within each belt to such categories as "Third structural stage of the Second complex of geosynclinal structures." The primary classification of orogenic terrains around the Pacific Ocean made by Pushcharovskiy and Udintsev (1970) is into "Eugeosyncline" and "Miogeosyncline." The "geosynclinal cycle" is implicit in most other tectonic maps, which either provide separate explanations for each fold belt (King, 1969a) or give the color of the "climactic" orogeny or magmatism to whatever occurs within a foldbelt (Australia: Plumb and others, 1972; Canada: Stockwell, 1969).

\section{TECTONIC MAPS \\ PREVIOUS MAPS}

How, then, should the concept that magmatism and orogeny are controlled mostly by motions between lithospheric plates be incorporated in a regional tectonic map? Clearly, the map must emphasize those features that can most obviously be related to plate motions-but beyond that lie many choices of cartographic schemes. King (1969b) gave detailed descriptions of many of the systems devised for tectonic maps before plate tectonics was understood.

The 1:5,000,000-scale tectonic maps of North America (King, 1969a) and of Canada (Stockwell, 1969) were prepared with much collaboration by their authors and show basically the same units, contacts, and structures within Canada. The two maps, however, differ strikingly in their organization and in their use of patterns, colors, and symbols. On the Canadian map, all units belonging to a foldbelt share a basic color and capital letter. Eugeosynclinal, miogesynclinal, and foredeep assemblages are indicated by postscripts of $e, m$, and $f$, respectively. Ages of materials are indicated by number postscripts or superscripts. Igneous rock types are distinguished by patterns. Little-deformed cover is given the basic color of the underlying orogenic belt, white dots, and a postscript plus a number for age. Where several major episodes of deformation have affected a terrain, the basic color is that of the younger, but the color of the older is overprinted as dots, and the capital letters for both orogenies are printed together. These and other features of the map convey a great deal of information regarding environments of formation of materials and of subsequent history. Most details of the system can be quickly learned by the reader, so that he need not continually refer back to the map explanation. This map of Canada is by my prejudices the most successful tectonic map yet published.

The North American map (King, 1969a) also presents much information on environments of formation of rock assemblages and on complexities in their deformational evolution but is more difficult to read. Each foldbelt has its own explanation, and so much of the symbology is unique to each unit that the reader must continually refer to the explanation. Colors relate broadly to ages of rock assemblages, and some types of patterns and symbology carry through the map; but the key symbols for most units are numbers that relate only to the numerical order of boxes in the explanation for that particular foldbelt. The numbers variously represent basement rocks, sites of deposition of sedimentary rocks, and ages of stratigraphic assemblages.

Both the Canadian and North American maps emphasize the tectonic setting of formation of rock assemblages. Given in particular an expansion of designations for the widely differing terrains thrown into the "eugeosynclinal" wastebaskets of each map, either map system could be adapted easily to emphasize features of plate-tectonic significance. For reasons noted elsewhere, however, I do not regard the "foldbelt" as the proper fundamental framework around which tectonic maps should be built.

The tectonic map of Great Britain by Dunning (1966, scale $1: 1,584,000)$ conveys much information by using a separate symbol and color for each tectonic assemblage in the islands. Among such units are "Phyllitic nappes and allied rocks of Shetland" and "Silurian strata of shelf facies with conformably overlying Lower Old Red Sandstone folded by mid-Devonian movements." Such a system is practical only for a small area shown on a large scale.

Most other tectonic map systems emphasize the position of units within final orogenic settings, rather than within the settings in which they formed originally. Any such system is poorly suited to the depiction of the plate-tectonic history of a region. One such map - artistically very attractive-is that of Africa by Choubert and Faure-Muret (1968, scale $1: 5,000,000)$. Colors in terrains of crystalline or deformed rocks indicate age of the last major episode of orogeny or granitic intrusion, and many patterns and symbols give much easily understood structural and lithologic information but give little information regarding history or environments before such final orogeny. Posttectonic history is well depicted; age and thickness of undeformed sediments are shown by colors in reverse-layer tints and by additional symbols.

The 1:5,000,000-scale tectonic map of Australia and New Guinea by Plumb, Doutch, and Rickard (1972) assigns colors to orogenic terrains primarily to indicate age of deformation or metamorphism. Symbols give much information regarding age and composition of igneous rocks. Other symbols give a little information regarding the age, 
but not the lithology or the environment of formation, of sedimentary rocks in the orogenic belts. Relatively little deformed strata are broadly separated by two colors (essentially dividing Precambrian and Paleozoic materials from Mesozoic and Cenozoic ones) and are further depicted by selected internal contacts, contours on depth to basement, and structure symbols.

Soviet tectonic maps place a still greater emphasis on the final orogenic setting of units shown and suffer from the severe limitations imposed by the assumptions that sedimentation, magmatism, and orogeny proceed inevitably together through standard cycles and that crustal masses are fixed permanently in position. Beyond this, the many recent Soviet tectonic maps vary widely in approach and in rendition of geologic information. They range from detailed interpretations of the geology (for example, the tectonic map of the Soviet Union by Spizharskiy (1966)) to the highly schematic (as, the Eurasia map by Yanshin (1966), the Pacific map by Pushcharovskiy and Udintsev (1970), and the map of India by Eremenko and others (1968). All these maps use colors primarily as indicators of age of orogeny and use patterns, and tints of the basic colors, to show structural units.

The schemes used on these and other published tectonic maps do not appear to me to be well suited to depiction of plate-tectonic evolution of a region. Where an old orogenic belt is overprinted by a younger one, the older terrain is obscured by any scheme that colors both in accord with the age of the younger event. A rifted continental margin can be the site of quiet sedimentation for hundreds of millions of years; this history is submerged if the resulting shelf assemblage is given the color of deformation or magmatism that records totally unrelated events.

\section{IECIONIC MAP OF THE INDONESHAN REGION}

\section{INTRODUCTION}

The tectonic map of the Indonesian region (pl. 1; Hamilton, 1978a) is intended to depict the geology of the region as objectively as possible while emphasizing the features of greatest plate tectonic significance. Colors are used primarily to indicate age of rocks and not the age of their deformation, which can be inferred from the map from the age of intrusive rocks, or of overlying strata, or of adjacent sedimentary rocks of differently indicated tectonic environment. Some major structural boundaries are drawn across continental-shelf areas, but the submarine regions are given bathymetric coloring only, and their structure is indicated primarily by plate-boundary structures and by isopachs of sediments in their basins.

\section{UNITS}

The units separated on the tectonic map are lithotectonic assemblages. Rocks of similar environment and history in each region are mostly grouped into single units, and the intent of the age designations is generally to indicate the age span of rocks in each assemblage. For example, the Jurassic through lower Tertiary strata of southern New Guinea all formed on a continental shelf, to the north of which lay open ocean, so they are put in a single unit. The histories of the various parts of the region have been very different, and a complexly overlapping series of age units is used to cover the various rock assemblages. Thus, rocks of Eocene age are included in units designated variously Eocene, Tertiary, Paleogene, early Miocene through Jurassic, and Eocene through Late Cretaceous.

Where data from geologic mapping permit and where evolution through time is better indicated by so doing, I have separated out parts of single broad lithotectonic assemblages. I have done this particularly with Quaternary sedimentary and volcanic materials, for although these in most places represent a continuation of late Tertiary conditions, their separate depiction locates the present activity.

In some regions, broad age designations have been required to indicate brackets of uncertainty in the age of the materials, which perhaps actually span much shorter times. And in some other areas (as, in the Triassic to Cambrian unit of the Malay Peninsula), the broad brackets refer to known ages of rocks that may belong to quite different assemblages but for which field data are inadequate to allow consistent map separation.

\section{CONTACTS}

The contacts shown between lithotectonic units on the tectonic map are, insofar as data permit, mapped geologic contacts. I have not left any blank spaces on the map and have guessed at contacts in poorly known areas, but the lines drawn are as objective as the data permit. The map should accordingly serve the purpose of a regional geologic map. It represents a compilation from much more material than was used by Klompé (1954) for his geologic map of Indonesia. (That map was reissued with little change under the nominal authorship of the Indonesia Geological Survey (1965) and was incorporated without further change as the Indonesian portion of the 1971 U.N. ECAFE geologic map.) My map also represents a viewpoint very different from that of Klompé, and I have interpreted many ambiguities differently than did he.

\section{COLORS}

The Indonesian tectonic map depicts the ages of rocks by colors: browns for the Precambrian, blues for the Paleozoic, greens for the Mesozoic, yellows for the Cenozoic (but gray for the Quaternary). Rocks of all types - sedimentary, metamorphic, volcanic, granitic - of the same age are given the same basic color and are distinguished by different overprints.

\section{PLATE-TECTONIC EMPHASIS}

The most important and easily recognized geologic elements for plate-tectonic interpretation are the subduc- 
tion-zone complexes and the magmatic-arc rocks. These have accordingly been selected for emphasis.

The subduction melanges and the ophiolites within them are colored purple. As many areas of exposed melange are quite small, it is not cartographically feasible to give them both an age color and an obvious color indicator of their melange character. The ages of the melanges are indicated by the same letter symbols as are the ages of other rock units.

The arc granitic and volcanic rocks, and the associated metamorphic rocks, are given red-pattern overprints. The reddish hue added by these overprints on the basic geologic colors indicates the position of the magmatic arc in terranes of each geologic age, and the specific patterns indicate the rock types present.

\section{ENVIRONMENT OF FORMATION OF SEDIMENTARY ROCKS}

The present tectonic setting of sedimentary rocks may be grossly different from the setting within which they formed. The depositional environments are indicated by gray overprints on the tectonic map.

\section{ISOPACHS OF SEDIMENTARY ROCKS}

The map illustrates by one-kilometer isopachs the thickness of little-deformed sedimentary rocks in the various land, shelf, and deep-sea basins of the region. These isopachs are based on profiles and data supplied by the Lamont-Doherty Geological Observatory of Columbia University, by other institutions, and by many oil companies. Where these isopachs differ from those on the map of sedimentary basins in the Indonesian region (Hamilton, 1974a), the tectonic-map isopachs incorporate more and better data.

\section{BOUNDARIES BETWEEN LITHOSPHERE PLATES}

Active, inactive, and buried plate-bounding trenches are discriminated on the tectonic map. All the trenches shown (except for two short ones inferred near northwestern New Guinea, one trending southeast from the south end of the Philippine Trench, the other south of Biak) were identified on reflection profiles. The Sumatra-Java-Banda Arc trench, the Philippine (Mindanao) Trench, and the Mariana-Palau-Yap trench complex are among those that have been long known, but a number of the others have not been reported previously in the literature. These structures are described in this report and are illustrated by appropriate profiles. Where the tectonic map shows an active subduction-zone trace but the bathymetric base map shows no trench, the bathymetry generally is in error. The tectonic map incorporates newer information than did the previous maps of the folio (Hamilton, 1974a, 1974b) and differs from them in some areas.

The region of major uncertainty regarding the character even of active plate boundaries is that between Halmahera, Palau, and northern New Guinea. Bathymetric data from this region is poor, and I have seen relatively few reflection profiles within it. The patterns must be complex, and the structures must record both subduction and strike-slip components of large magnitude, but more detailed future data may lead to interpretations quite different from those shown.

\section{BENIOFF ZONES}

The zones of earthquakes dipping deep into the mantle from the trenches mark the descent of plates of oceanic lithosphere subducted beneath island arcs and active continental margins. Such descending plates are relatively cold and have been identified by their high seismic velocities (Barazangi and Isacks, 1971; Utsu, 1971). The precise geometry of the Benioff zones is in question (for example, Stoiber and Carr, 1971), as is the significance of the mechanisms of the deep earthquakes, but the existence of the zones themselves is unquestioned. Presumably shallow earthquakes occur near the top of the subducting plate and in the wedge above it, whereas deep earthquakes are within the relatively cool interior of the plate.

The Benioff zones define the positions of sinking lithosphere plates, and so are a critical part of the modern tectonic pattern. Most active Indonesian volcanism occurs in narrow belts above these zones, typically where a zone is about $125 \mathrm{~km}$ deep. Depth contours, with an interval of 100 $\mathrm{km}$, for the active Benioff zones are shown on the tectonic map. These contours are slightly modified from those on the earthquake map of the Indonesian region (Hamilton, 1974b). The contours represent much smoothing of data of variable quality and incorporate the assumption that Benioff zones are basically simple surfaces-although earthquakes likely vary much, in ways not yet proved, in both position and mechanism within and above the sinking slabs. (Compare Engdahl and others (1977); McGarr(1977); and Spence (1977).)

\section{SLIP DIRECTIONS AT PLATE BOUNDARIES}

First-motion studies of earthquakes at plate boundaries in the region have defined the general directions of relative motions between some of the lithospheric plates. Published first-motion solutions were compiled on the earthquake map of the Indonesian region (Hamilton, 1974b).

\section{CENOZOIC BIOSTRATIGRAPHY}

Correlations of Cenozoic strata in the Indonesian region with each other and with the series recognized elsewhere can be made only roughly.

The system of dating used most widely in the pre- 1960 literature is the letter scale based upon large calcareous benthonic foraminifers. The approximate correlations of the letter scale with the European series are given by Adams (1970) as:

$\mathrm{Th}=$ middle and upper Pliocene and Quaternary

$\mathrm{Tg}=$ high upper Miocene and lower Pliocene

$\mathrm{Tf}=$ middle Miocene and lower upper Miocene

$\mathrm{Te}_{5}=$ lower Miocene and lowest middle Miocene 
$\mathrm{Te}_{1-4}=$ upper Oligocene

$\mathrm{Td}=$ middle Oligocene

$\mathrm{T} c=$ lower Oligocene

$\mathrm{Tb}=$ upper Eocene

$\mathrm{Ta}=$ Paleocene through middle Eocene

This system has gross defects in both theory and practice, as Adams (1970) documented. The letter stages indicate fossil assemblages, not stratigraphy; the assemblages are seldom tied to stratigraphy, have no type sections, have not generally been related to other fossils, and have undefined ranges. Different assemblages represent different environments and cannot be related chronologically to one another. The diagnostic foraminifers neither appear nor disappear at series boundaries. Many fossil designations are erroneous.

An analogous and equally ambiguous letter-classification system is used in the older literature on the Philippines. Its approximate standard equivalents, given in part by Irving (1952), are:

Tertiary $\mathbf{Z}=$ upper Pliocene and Quaternary

Tertiary $\mathrm{Y}=$ high upper Miocene and most Pliocene Tertiary $\mathrm{X}=$ middle Miocene and lower upper Miocene Tertiary $\mathrm{W}=$ upper Oligocene and lower Miocene

Tertiary $\mathrm{V}=$ lower and middle Oligocene

Tertiary $U=$ Paleocene and Eocene

Other correlations in many of the older published reports are based upon mollusks, plants, or other fossils and are in general of poor accuracy and precision. Van Bemmelen (1949, p. 79-95) discussed the varying methods and criteria in use in the 1930's.

Modern work on correlation of marine Tertiary sections relies primarily upon pelagic foraminifers where they are available. A major problem in the Indonesian region is that these foraminifers are rare or absent in water shallower than $40 \mathrm{~m}$ (Brunei Shell Petroleum Co., Ltd., 1963) and hence are not present in thick sections of deltaic sediments that fill many of the shelf basins in the region. Foraminifera in some widespread, thick deltaic sections are only long-ranging benthonic arenaceous forms of little dating value. Pollen and spores are now used for dating such sections.

A number classification of the Cenozoic based upon pelagic foraminifers was developed by paleontologists of the Royal Dutch/Shell Group and recently has been used by other oil companies also. The first number in each symbol indicates broad divisions, from 1 to 4 , and the second number indicates subdivisions, totalling variously between 3 and 7, of those divisions; both numbers get larger upward in the section. The approximate correlations of the units so designated are given by Visser and Hermes (1962, Enclosure 7):

T41-T43 = Pliocene and Pleistocene

T31-T35 = middle Miocene to lower Pliocene

T21-T27 = Oligocene and lower Miocene

T11-T15 = Paleocene and Eocene
Shell Group paleontologists have since adopted another system, based on specific index pelagic foraminifers of very wide geographic range, wherein Neogene zones are numbered upward to N. 23 and Paleogene ones to P.22 (Haak and Postuma, 1975). Confusion reigns in the middle and upper Oligocene, most of which was previously misassigned to the Miocene and designated as N.1 to N.3, but now identified as P.19/20 to P.22.

Any discussion of the ages of Indonesian Cenozoic materials is thus beset with many ambiguities. In this report, I have generally used, without qualification, the standard series terms as given in the preceding lists, for only these terms will have obvious meaning for most readers. These assignments, however, certainly contain numerous errors, many of them important.

The term Neogene is used here as synonymous with late (or upper) Cenozoic and as including Miocene, Pliocene, and Quaternary time (or materials). The Paleogene is equivalent to the early (or lower) Cenozoic and includes Paleocene, Eocene, and Oligocene time (or materials). It should be noted that the use of Neogene is not standardized in the global literature; the term is used here as defined originally and as employed by many authorities (as, Berggren and van Couvering, 1974), although many other specialists exclude the Quaternary from the Neogene.

\section{MODERN SUBDUCTION SYSTEM OF JAVA AND SUMATRA}

The Indian Ocean floor is now sliding approximately northward beneath Java and Sumatra at a velocity probably near $6 \mathrm{~cm} / \mathrm{yr}$ (Le Pichon, 1968). The features of a subduction system-trench, outer-arc ridge, outer-arc basin, volcanic arc, and foreland basin-are developed here with particular clarity, and geophysical information regarding this subduction system is of high quality. The discussion of the tectonics of the Indonesian region is accordingly begun with an analysis of the off shore part of the subduction system of Java and Sumatra, for analogies with this system are important in interpretations of other parts of the region.

\section{BENIOFF SEISMIC ZONE}

From the Java-Sumatra Trench, the subducting Indian Ocean lithosphere can be tracked by the inclined Benioff seismic zone as sliding gently beneath a melange wedge for a distance of about $200 \mathrm{~km}$, beyond which the dip increases. The seismic zone below a depth of $100 \mathrm{~km}$ dips about $65^{\circ}$ northward beneath Java and the Java Sea, and extends down to a depth of about $650 \mathrm{~km}$ (pl. 1; Fitch, 1970a, 1972; Hamilton, 1974b; Santo, 1969). The zone reaches a depth of only about $200 \mathrm{~km}$ beneath Sumatra, where the dip below $100 \mathrm{~km}$ is about $30^{\circ}-40^{\circ}$; inclination is only about $25^{\circ}$ as measured in the northward subduction direction, Focal mechanisms were determined by Fitch (1970a, 1972; also Hamilton, 1974b) and Soedarmo (1973). 
The length of the curving seismic zone, measured down-dip from the trench, is about $800 \mathrm{~km}$ in the Java sector and only about $400 \mathrm{~km}$ in the Sumatra one; the length in the Sumatra sector is about $550 \mathrm{~km}$ as measured along the northward direction of subduction. In both sectors, the horizontal width of the seismic zone is about the same, 500 $\mathrm{km}$, when measured northward. Presumably the earthquakes are concentrated near the top of the subducting slab at shallow depth, and within its coolest and most brittle part of greater depth. Presumably also the dip and lower limit of the zone are functions of the minimum temperature of the slab, and hence of convergence rate and of age of the subducting lithosphere. (Compare with Farrar and Lowe, 1978.) These factors are considered further in the final section of this report.

\section{OFFSHORE TECTONICS}

GENERAL FEATLRES

The Java Trench is flanked on its landward side by an outer-arc ridge, and between that ridge and the main islands is the outer-arc basin, underlain by thick sediments (pl. 1; figs. 1, 5). The oceanic basement, with its thin veneer of pelagic sediments (off Java) or its variable cover of abyssal turbidites (off Sumatra), turns gently downward at the outer edge of the trench and is covered by a small wedge of clastic sediments in the bottom of the trench. The oceanic plate subducts beneath the continental slope at a very gentle dip. The continental slope and the outer-arc ridge at its top (which is exposed as islands off Sumatra) are the top of a wedge of imbricated sediments and melange. The thick sedimentary fill of the outer-arc basin laps onto the basement on the landward side but becomes increasingly deformed toward the outer-arc ridge on the seaward side. The thin melange wedge between the gentle continental slope and the subducting oceanic plate beneath is deforming by a combination of subductive underthrusting and gravitational overthrusting.

\section{JAVA TRENCH}

The floor of the Indian Ocean inflects gently downward at the outer edge of the Java-Sumatra Trench and typically descends only about $1,000 \mathrm{~m}$ across the $70-100-\mathrm{km}$ width of the trench. The depths of both the ocean floor and of the trench increase along the arcuate southeastward-to-eastward trend (pl. 1). The trench is only about $4,500 \mathrm{~m}$ deep off northern Sumatra (fig. 21), but is 6,000-7,000 $\mathrm{m}$ deep off Java (fig. 9). This depth range continues the trend from the Burma-Andaman-Nicobar sector: the trench is shallower than $3,000 \mathrm{~m}$ off Burma (fig. 36 ) and less than $4,000 \mathrm{~m}$ deep along the Andaman and Nicobar Islands (fig. $30 \mathrm{~B}, \mathrm{C}$ ). The changing depth of the trench correlates in part with the thickness of sediment on the ocean floor and in the trench. The oceanic basement surface deepens as the overlying sediment thickens and the trench floor shallows, so the effect must be in substantial part controlled isostatically. The Bengal abyssal fan is extremely thick off Burma, and it thins southward to a distal edge off central or southern Sumatra (Hamilton, 1974a; pl. 1). Sediments deposited within the trench cover the abyssal-fan sediments as they are carried into the trench by the subduction "conveyor belt." The reflectively layered sediments deposited within the trench also thin southeastward and apparently have been deposited as turbidites flowing longitudinally along the trench, mostly from sources in the Bay of Bengal; Bengal sediments may extend as far southeast in the trench as western Java. Anikouchine and Ling (1967) described intercalated micaceous-silt turbidites and hemipelagic lutites in the trench near lat $6^{\circ} \mathrm{S}$.

Along Java, only thin pelagic sediments are carried into the trench atop the Indian Ocean plate (fig. 6), and terrigenous sediments in the trench are thin. Most terrigenous sediments from Java are trapped closer to the island, in the outer-arc basin; if they reach the trench, they are quickly added to the melange wedge by tectonic accretion.

East of Java, thick ocean-floor sediments from Australia become involved in the subduction system, and water depths of ocean floor and trench again shallow as sediments thicken. This is discussed in the subsequent section on the Banda Arc.

\section{OITTR-ARC RIDGE}

The continental slope rising from the Java-Sumatra Trench is formed of sediments deformed complexly by subduction and gravitational processes, as is brought out later. The slope rises gradually but irregularly to the outer-arc ridge, whose crest lies between a third and half of the way between the trench and Java, Sumatra, and the other islands along the volcanic arc. The outer-arc ridge is a wholly submarine feature off Java and southernmost Sumatra, and its crest lies mostly 1,000-3,000 m below sea level. The ridge crest rises northwestward, however, and is shallower than $1,000 \mathrm{~m}$ along most of Sumatra. A number of islands, mostly standing a few hundred meters above sea level, top the ridge along Sumatra.

The continental slope and the ridge crest are underlain by a landward-thickening wedge of melange and imbricated sediments, whose origin is discussed in a later section. As the height of the ridge crest is greater off Sumatra than off Java, the thickness of the wedge is likely also greater off Sumatra. These parameters correlate broadly with the amount, great along most of Sumatra and negligible along Java, of terrigenous abyssal sediment on the undersliding plate. The scraping off of such terrigenous sediment is likely the major factor in the growth of the wedge.

\section{MELANGE OF ISLANDS OF OUTER-ARC RIDGE}

The rocks exposed on the islands of the Sumatra sector of the outer-arc ridge are mostly moderately to highly deformed sediments and sedimentary rocks, and subordinate 


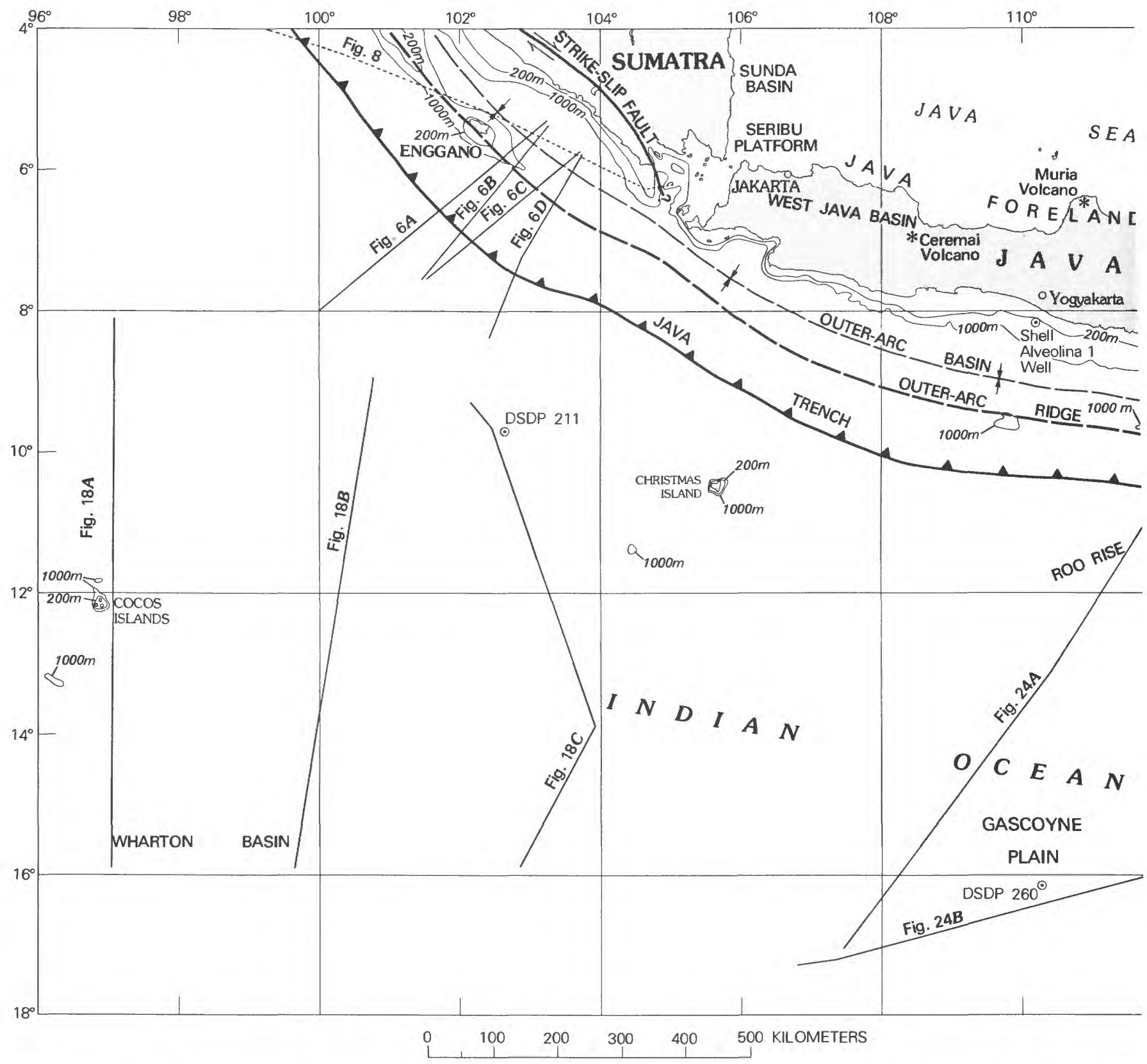

FigURE 5.-Selected tectonic elements of Java and of the Indian Ocean between Java and northern Australia. Locations of seismic-reflection profiles shown in figures $6,8,9,18,24,25$, and 26 are indicated, as are some place names referred to in text.

crystalline rocks. Published descriptions (van Bemmelen, 1949, p. 163-175; Terpstra, 1932; van der Veen, 1914) include many indicators of polymict melange: scaly clay, broken formations, serpentinite and peridotite, basalt and spilite, greenschist and low-grade metasedimentary rocks, and amphibolite, all jumbled together. Fossiliferous Eocene strata have been found in these complexes. Herman Burrough and Peter Power (oral commun., 1971) described to me melange, which they saw southwest of the midline of the island of Nias (fig. 12), consisting of lenses of crystalline rocks of all sizes up to hundreds of meters long enclosed in scaly clay. Northeastern Nias, by contrast, consists of strongly but coherently deformed strata of early Miocene age, overlain unconformably by middle Miocene and younger strata.

A detailed study of Nias, aimed at defining mechanisms of deformation in and atop subduction-melange wedges, has been made by G. F. Moore and D. E. Karig (1976, and written and oral communs., 1975-78). They have found that polymict melange and coherent sedimentary rocks occur together in steeply dipping zones, $2-3 \mathrm{~km}$ wide, in which blocks of sandstone and pebble conglomerate, derived from 


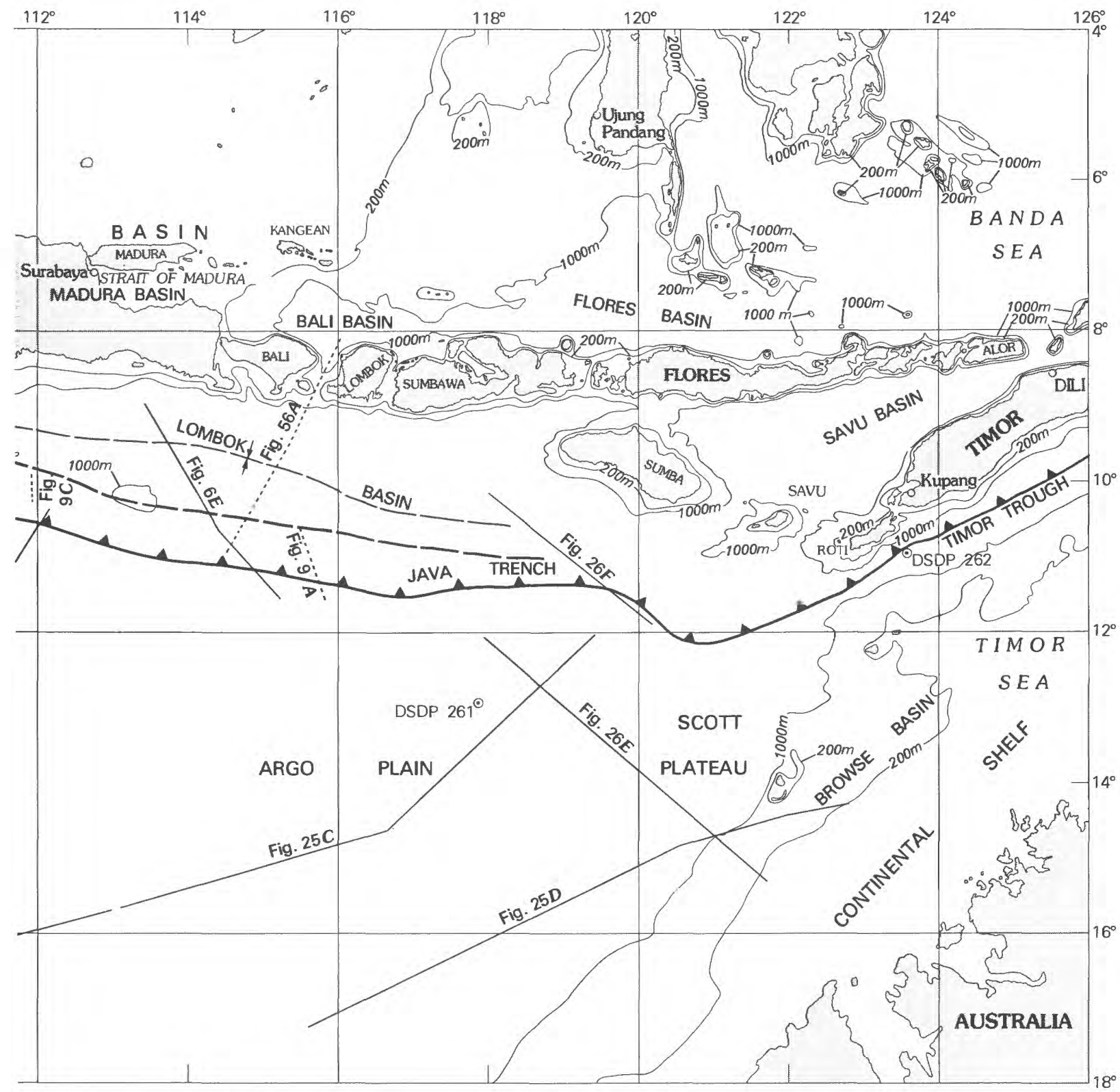

Sumatra, and lesser amounts of pillow basalt, chert, serpentinite, garnet amphibolite, and limestone lie in a matrix of pervasively sheared siltstone and mudstone (fig. $7 A, B$ ), such materials being intercalated with sheets of more coherent sedimentary rocks, otherwise similar to those whose disruption produced the melange. Between belts of these mixed materials are wider belts, $5-10 \mathrm{~km}$ across, of lower Miocene and younger marls and calcareous sandstones (fig. $7 \mathrm{C}$ ), intersheared with melange in their lower portions and deformed typically into thrust-broken synforms. These synformal assemblages are attributed by Moore and Karig to deformation of strata deposited in basins on top of the melange wedge and incorporated into it by continuing deformation. The youngest broken formations are Miocene. Bengal fan sediments are not involved in the exposed melange, so the fan did not reach this latitude until after Miocene time.

Figure 8 shows that sedimentary rocks, which appear to be equivalent to those of the outer-arc basin, yield coherent reflections as far oceanward as the crest of the outer-arc ridge off southern Sumatra. Disruption of these materials appears to increase both downward and oceanward, for the depth to the lowest recorded reflectors decreases oceanward, and the reflecting sediments of most of the slope from ridge to trench occur as small fills in topographically low areas between highs of acoustic basement.

Much sediment from Java and Sumatra is deposited in the outer-arc basin, the outer-arc ridge barring it from the trench. The smooth floor of the basin and its gentle longitudinal slopes between saddles and lows indicate that 

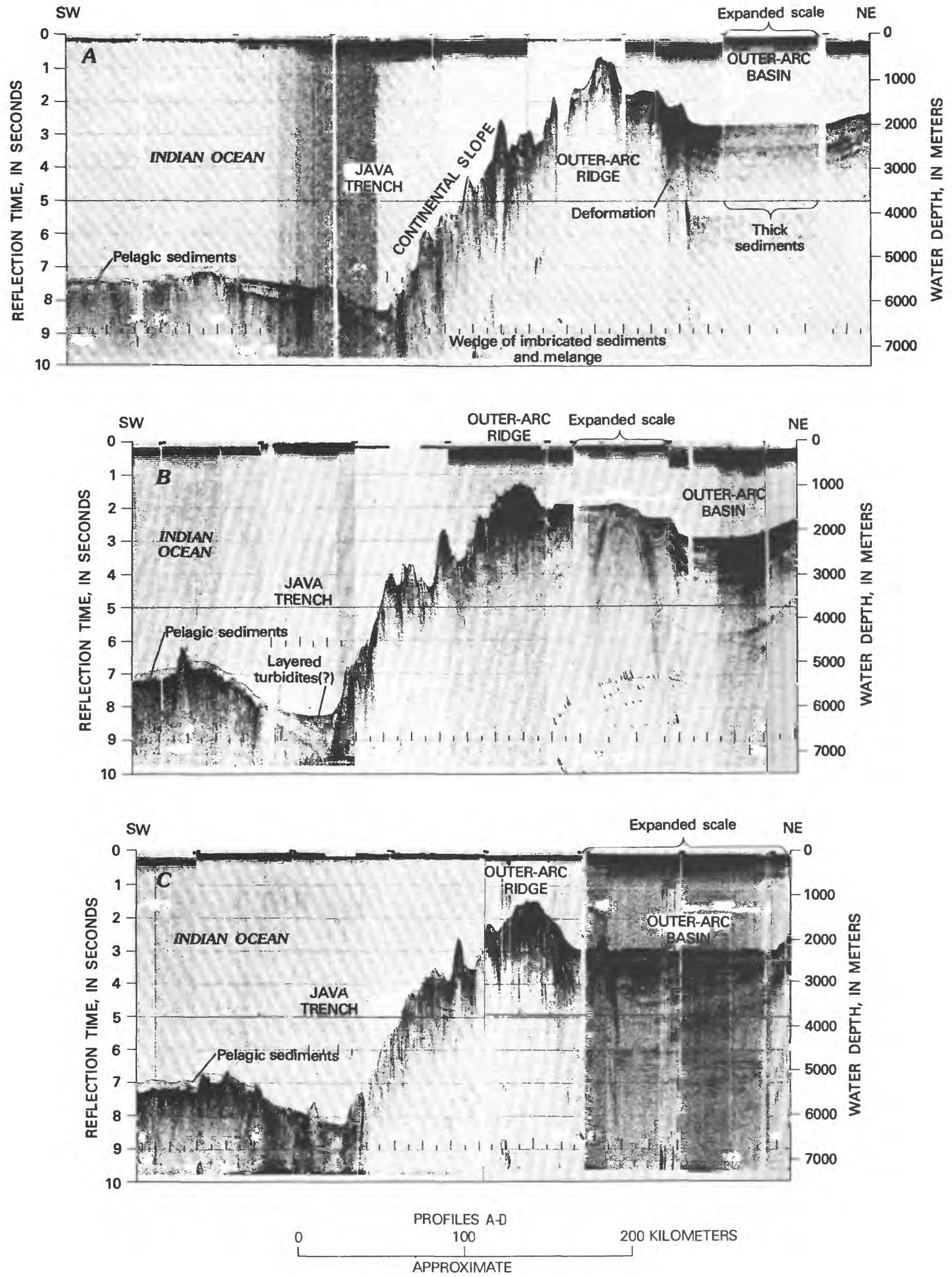

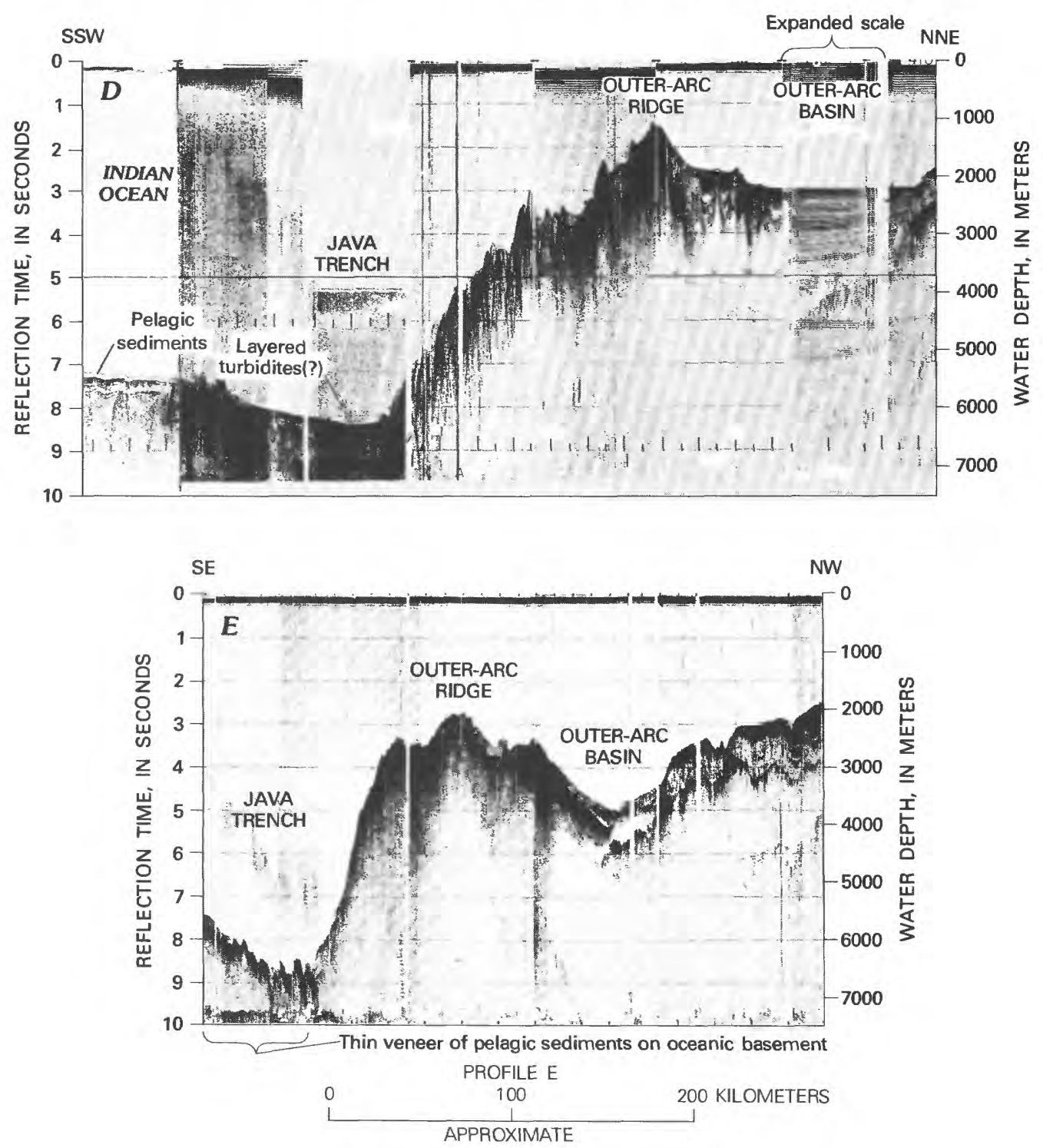

FIGURE 6 (above and facing page).-Seismic-reflection profiles across the Java Trench, outer-arc ridge, and outer-arc basin. Vertical exaggeration about $25 \mathrm{x}(A-D)$ and $33 \mathrm{x}(E)$; compare with true-scale profile figure 9A. $A-D$, Thin pelagic sediments on Indian Ocean floor turn downward at outer edge of trench and are covered by a thin wedge of layered turbidites(?) in bottom of trench; sediments show folding and(?) upthrusting on landward side of trench in $B$ and $D$. Continental slope is low-velocity acoustic basement and presumably consists mostly of melange; topographic irregularities may be due to thrust faulting. The thick sediments of the outer-arc basin lap onto the basement of the landward edge of the basin but are deformed increasingly toward the outer-arc ridge; the crest of the ridge appears to consist mostly of deformed sediments equivalent to those in the basin. Continental basement can be tracked oceanward only to the center of the basin. $E$, No sediments are visible in the trench. The continental slope and rise are acoustic basement (seen on fig. $9 A$ and $B$ to be imbricated sediments). The acoustically visible sediments of the outerarc basin are thin and thicken landward; the character of the strong reflector beneath the obvious sediments is not apparent. Location of profiles shown in figure 5. Profiles from Lamont-Doherty Geological Observatory, R. V. Robert Conrad cruise $14(A-D)$ and R. V. Vema cruise $24(E)$.

deposition likely is dominated by longitudinally flowing turbidites.

The profiles of figures 6 and 8 show that the basin sediments are deformed, first gently and then more severely toward the outer-arc ridge. Deeper reflections are missing near the ridge, but it appears probable on the profiles that the ridge is formed largely of deformed sediments equivalent to those in the basin. This interpretation accords with the 

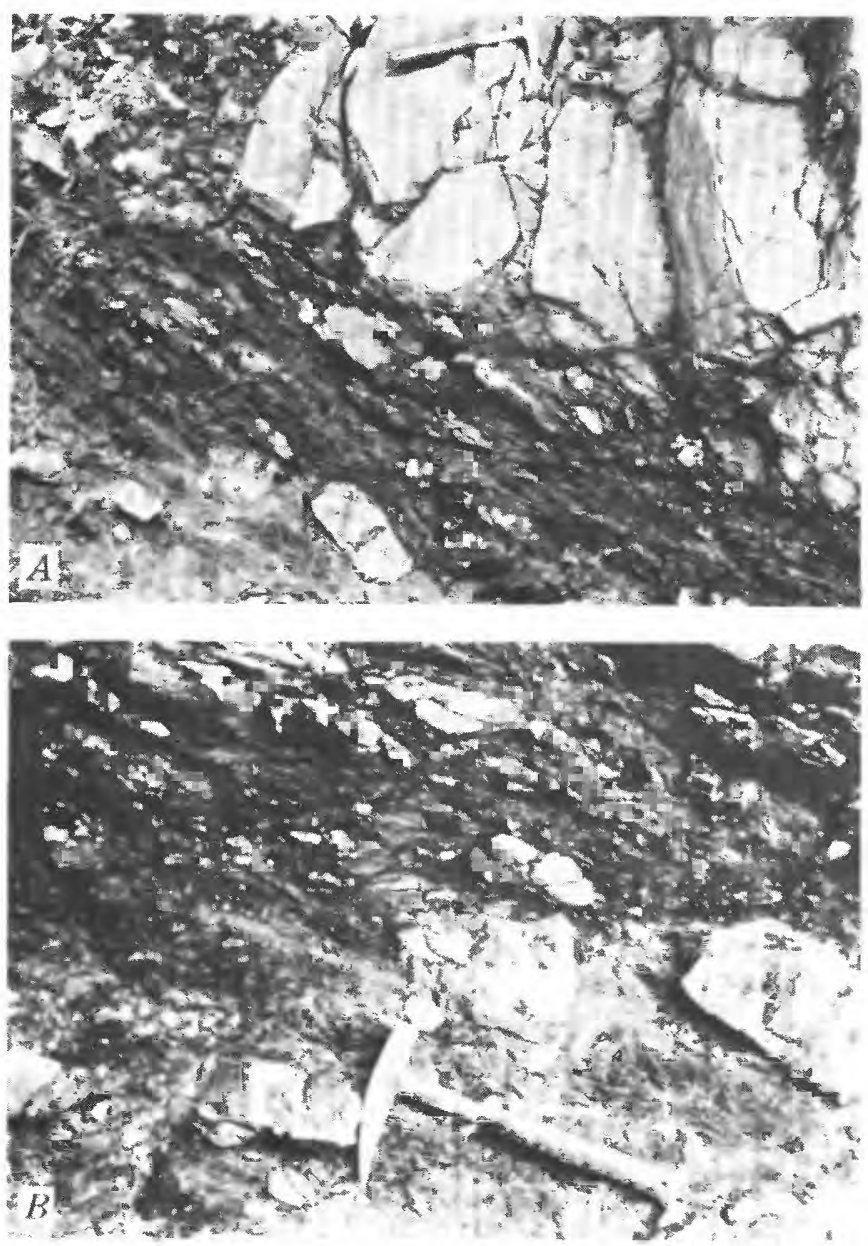

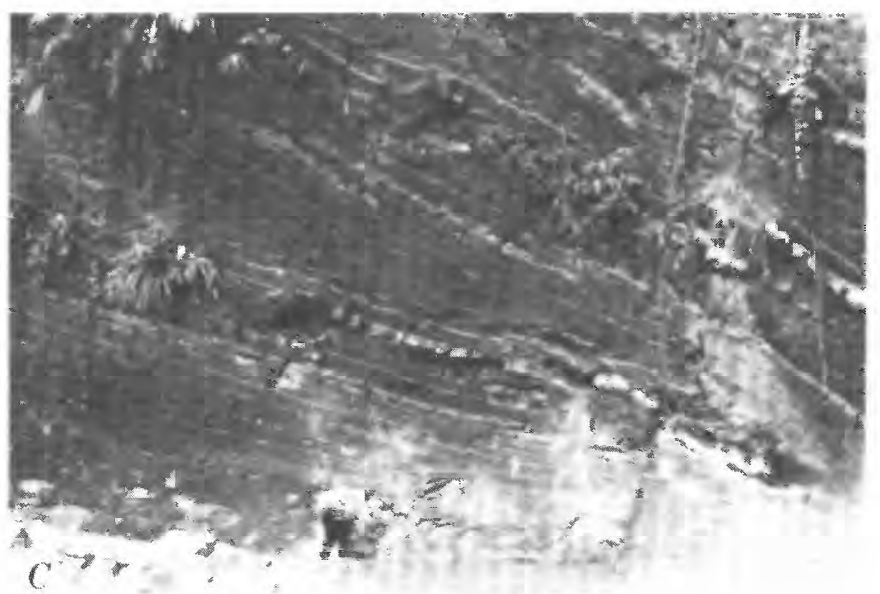

FIGURE 7.-Photographs of melange and slope sediments of Nias Island, by Gregory F. Moore. $A$ and $B$, Broken formation (melange), consisting of blocks and lenses of quartzose graywacke in a matrix of strongly sheared siltstone. Sparse foraminifers indicate a likely late Oligocene age. Eastern Nias, $4 \mathrm{~km}$ east of the Oyo River. $C$, Lower Miocene noncalcareous turbiditic siltstones with interbedded light-colored turbiditic calcarenites, deposited on top of the melange wedge and imbricated into it. Oyo River, eastern Nias.

FIGURE 8 (below).--Seismic-reflection profile across the outer-arc basin and ridge and the Java Trench, off southern Sumatra. Vertical exaggeration is about $33 x$, but because of the obliquity of the course to the strike of the tectonic elements the effective exaggeration is only about $15 \mathrm{x}$. The deformed strata of the basin side of the outer-arc ridge appear to be equivalent to strata in the basin. The materials of the trench side of the ridge are much disrupted. Location of profile shown in figure 5. Profile from Lamont-Doherty Geological Observatory, R. V. Vema cruise 29.

WNW

ESE

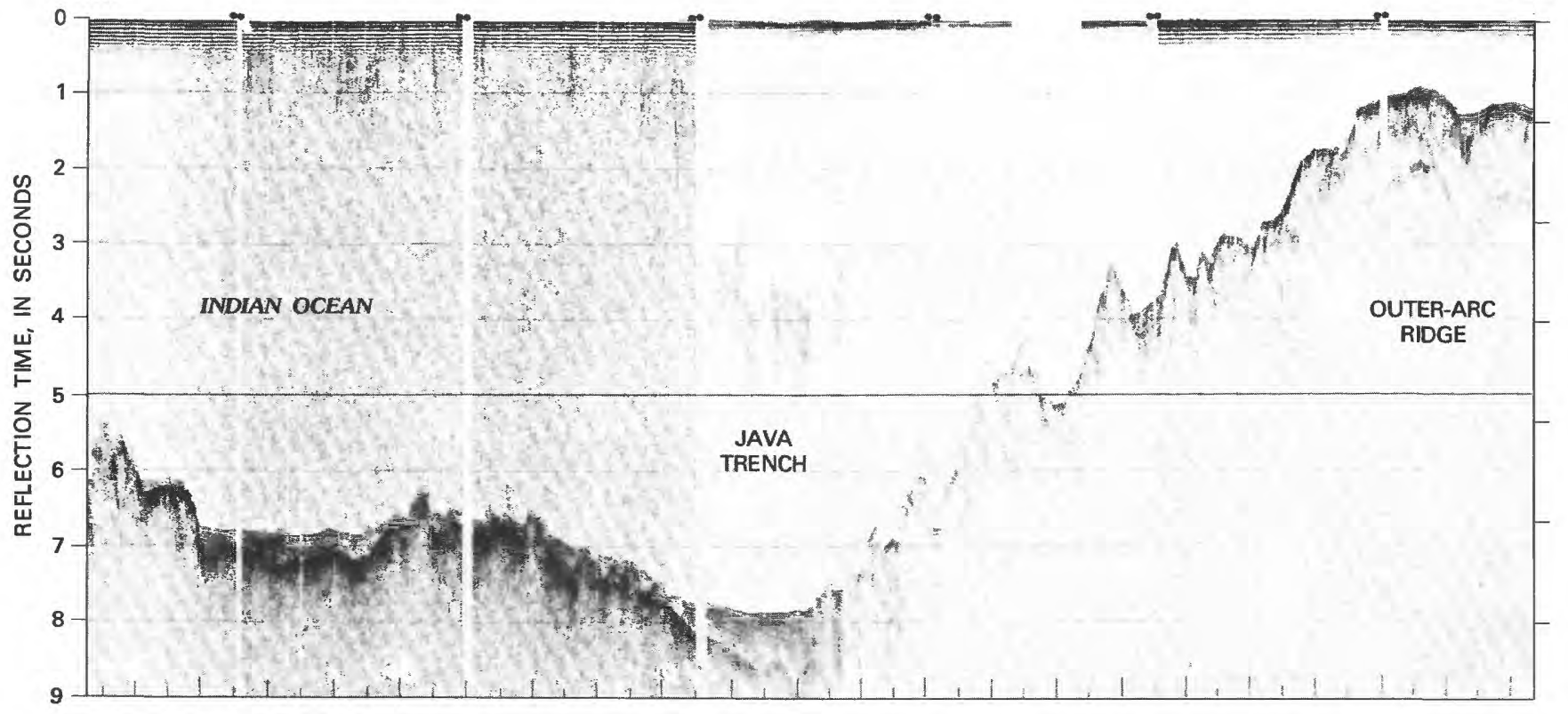

$0 \quad 100$

200 KILOMETERS

APPROXIMATE 
geology of the islands on the ridge, as just discussed, and with the deep-penetration seismic profiling reported next.

\section{DEEP-PENETRATION REFLECTION PROFILES}

The Shell seismic-reflection profiles of figure 9 illustrate the geometry of the subduction zone of the Java Trench and provide much insight into the subduction process. Beck and Lehner (1974) published parts of these profiles and made interpretations of them similar to those presented here. Bolliger and de Ruiter (1976) presented another profile across the subduction system.

The strongly reflecting oceanic basement can be tracked for $55 \mathrm{~km}$ in profile $A$, and for $40 \mathrm{~km}$ in profile $C$, under the material of the landward slope of the trench. The basement surface has a general dip of only $7^{\circ}$, and at its deepest visible points lies only 9 or $10 \mathrm{~km}$ beneath the sea floor of the outer-arc ridge. An imbrication of the basement is suggested by the upward step by about $1 \mathrm{~km}$ of the reflecting zone about $13 \mathrm{~km}$ inland from the bottom of the trench in $A$ and $B$ : to the right of this step, the reflector may be a slab of oceanic crust now more or less attached to the upper mass, present subduction occurring primarily between this slab and the lower reflector. The strong, subhorizontal reflector about $8 \mathrm{~km}$ below the sea floor near the north end of profile $A$ might be another such slab.

The oceanic crust - the top of the subducting lithospheric slab - thus appears to be sliding smoothly beneath the landward side of the Java Trench at a gentle inclination.

Above the gently dipping basement in profile $A$ is a thin, trenchward-thinning wedge of low-velocity, much-deformed sediments. The top of the wedge - the landward slope of the trench-slopes only $3^{\circ}-4^{\circ}$ toward the trench. The dominant dip of rocks within the wedge is about $30^{\circ} \mathrm{N}$. The lack of continuity of reflectors, and the abundance of spurious or ambiguous records in the profile, indicates structures to be complex in detail. Severe imbrication of sediments along shear planes dipping typically $30^{\circ}$ landward is inferred. The base of the imbricate wedge is decoupled at the top of the subducted oceanic crystalline plate, for the shear planes dip much more steeply than does that plate.

\section{OUTER-ARC: BASIN}

A broad structural and bathymetric basin lies between the outer-arc ridge and Sumatra and Java (figs. 6, 8). Water depths in the basin are typically $3,000-4,000 \mathrm{~m}$ off Java but only 200-2,000 m along most of Sumatra. Thick sediments lie beneath most of the basin and lap onto the acoustic basement on the landward side. The sediments are little deformed beneath the center and landward side of the basin but become increasingly deformed oceanward of the center, with structures apparently overturned away from the ridge, near the outer-arc ridge. The flat-lying sediments beneath the axis of the basin are at least $6 \mathrm{~km}$ thick in some sectors (Hamilton, 1974a; pl. 1).

The near-surface strata in the basin are deformed by, but become thin over, the structures on the inner slope of the outer-arc ridge, so these strata have been deposited during the period in which the ridge has been rising and its materials deformed. Along Sumatra and Java the deeper strata in the basin thicken seaward past its axis. (See, for example, Bolliger and de Ruiter, 1976, fig. 3.) The axis of the basin has been displaced landward as melange has been stuffed beneath the seaward strata. (Compare with Coulbourn and Moberly, 1977.) The deepest strata may have been prograd-

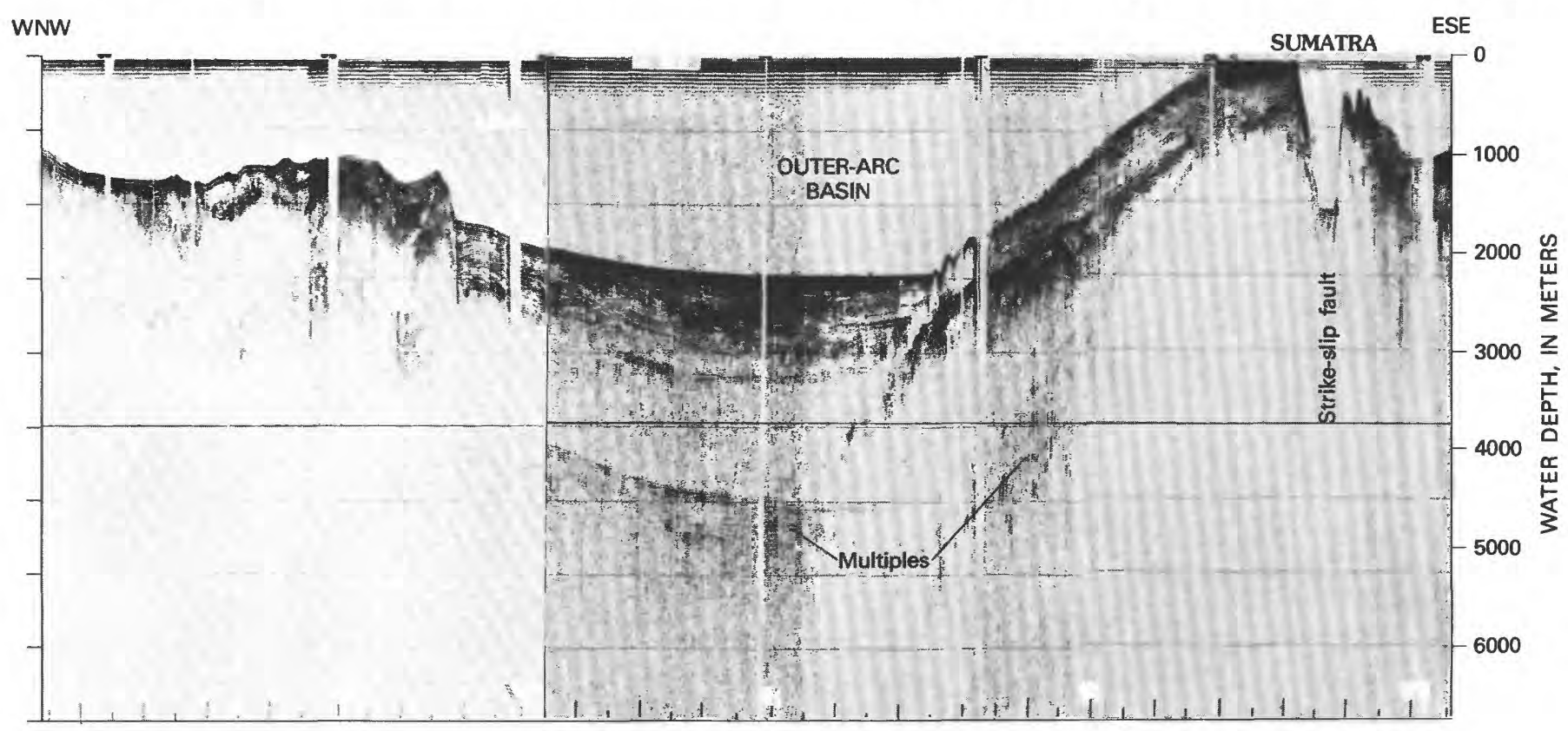




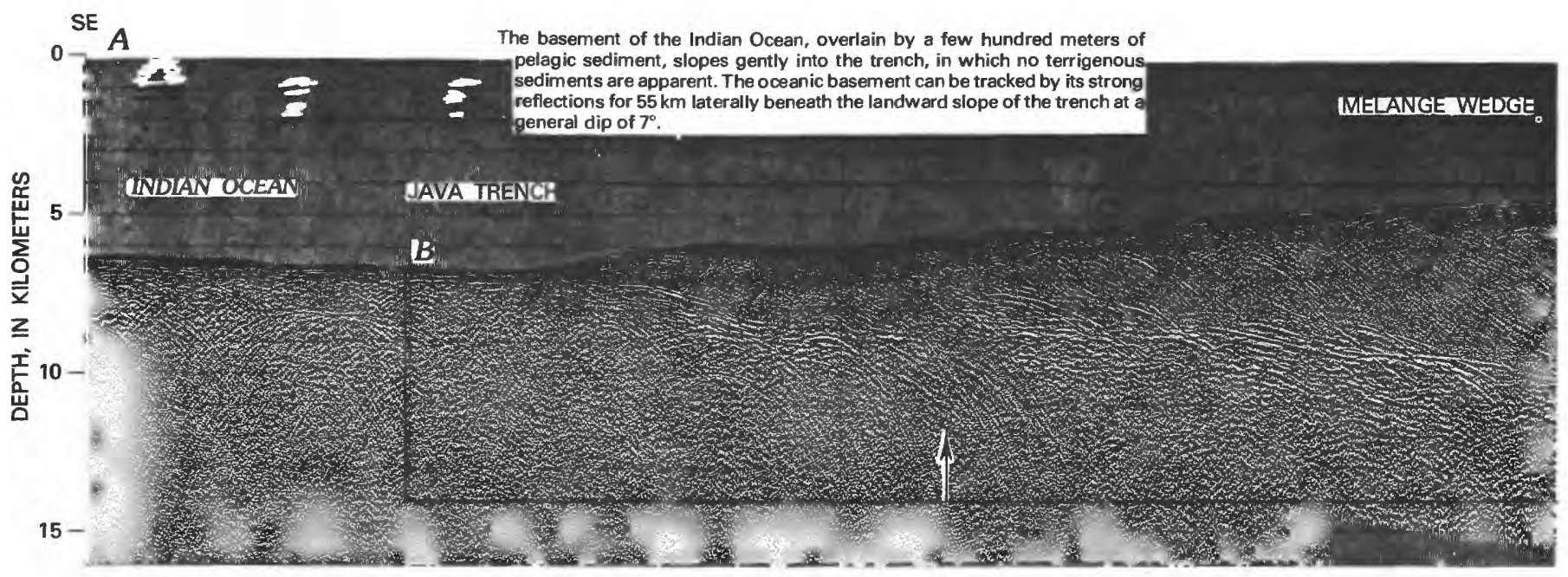

SE

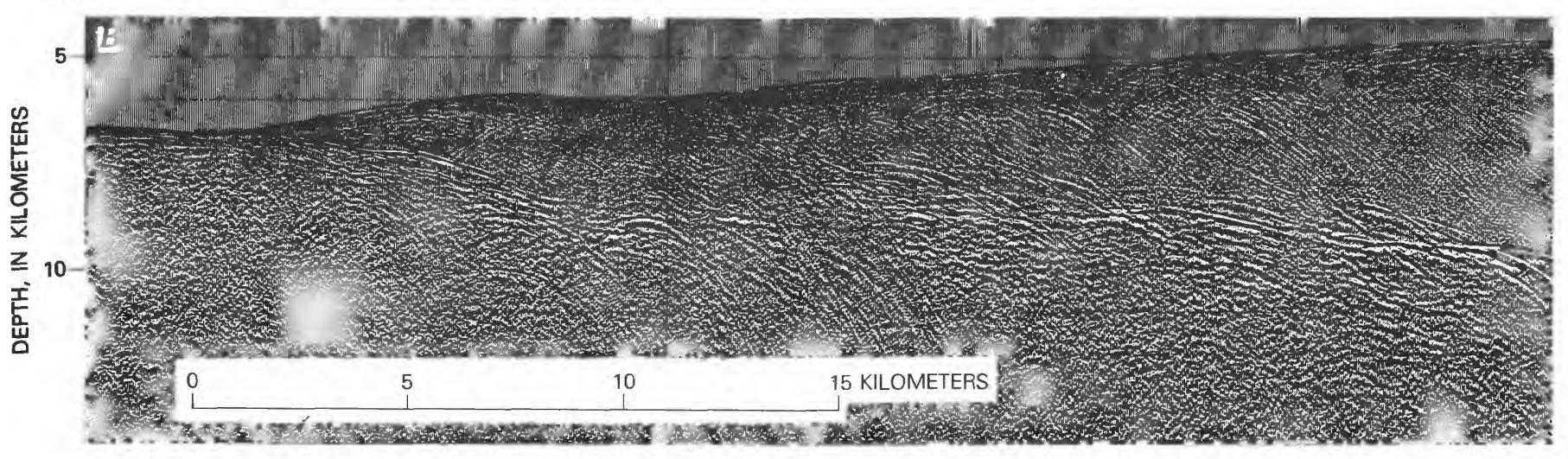

S

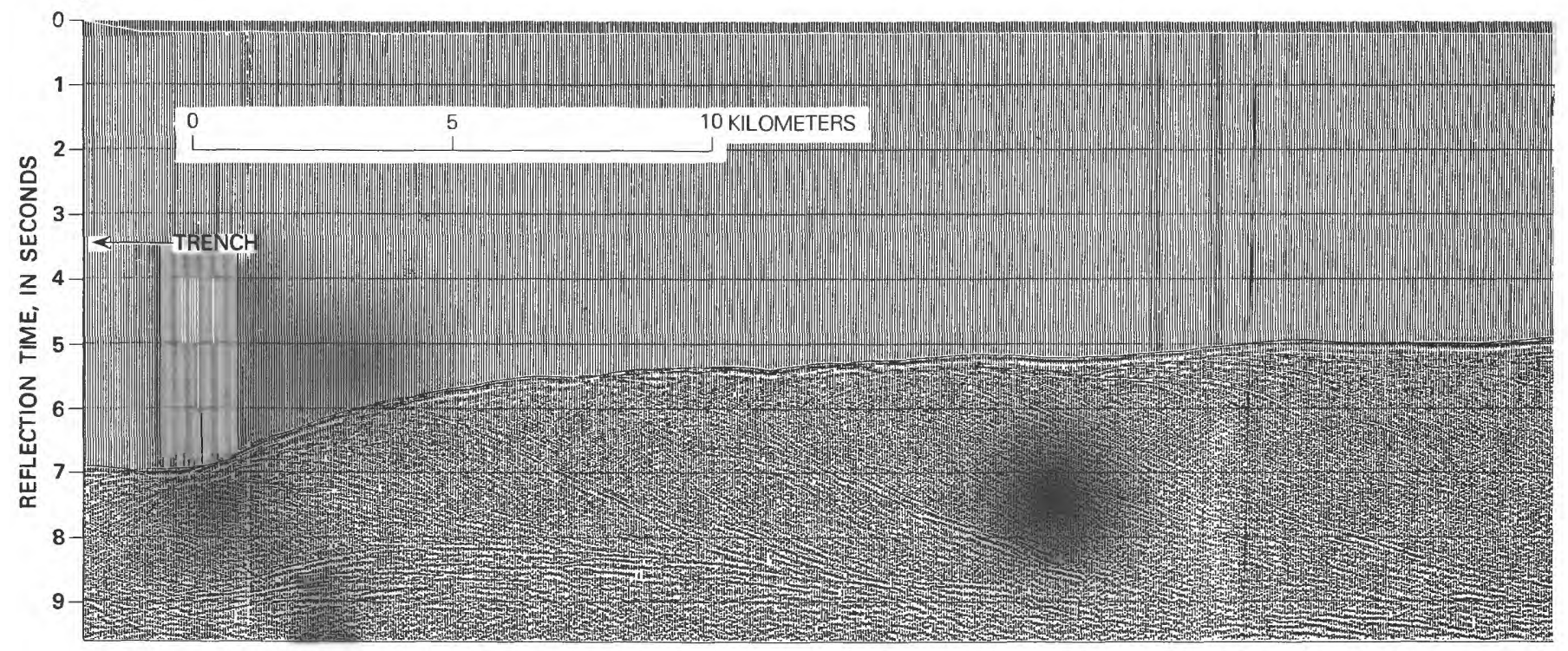

FIGURE 9.--Seismic-reflection profiles across the subduction zone of the Java Trench. Location of profiles shown in figure 5. Profiles computer stacked by common-depth-point method, provided by Shell Internationale Petroleum Maatschapij N. V., and in part published previously by Beck and Lehner (1974, figs. 20-23). Profile $A$ is rectified for depth on the basis of reflection velocities and has no 
NW

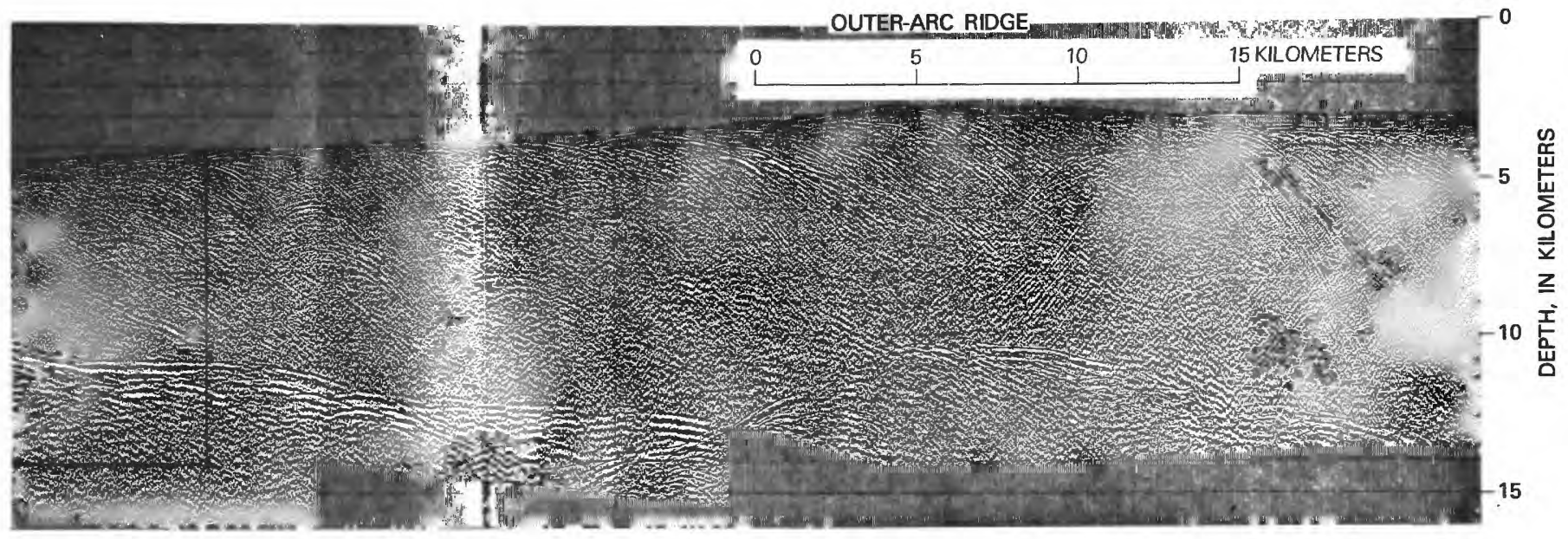

NW

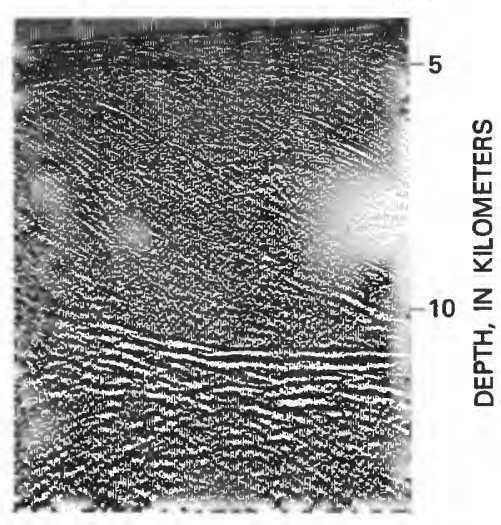
$A$ and $B$ : The offset (arrow), up on the north, of the basement reflector might be due to imbrication, the higher reflector representing an abandoned ophiolitic slab of oceanic crust, and the lower the present trajectory of the subducting plate. In the low-velocity melange above the basement reflector, spurious parabolic records confuse the interpretation, but the general incli- nation northward at $30^{\circ}$ or so of apparent events indicates dominant dips in that direction. The melange is imbricated at dips steeper than the dip of the subducting basement.

$\mathrm{N}$

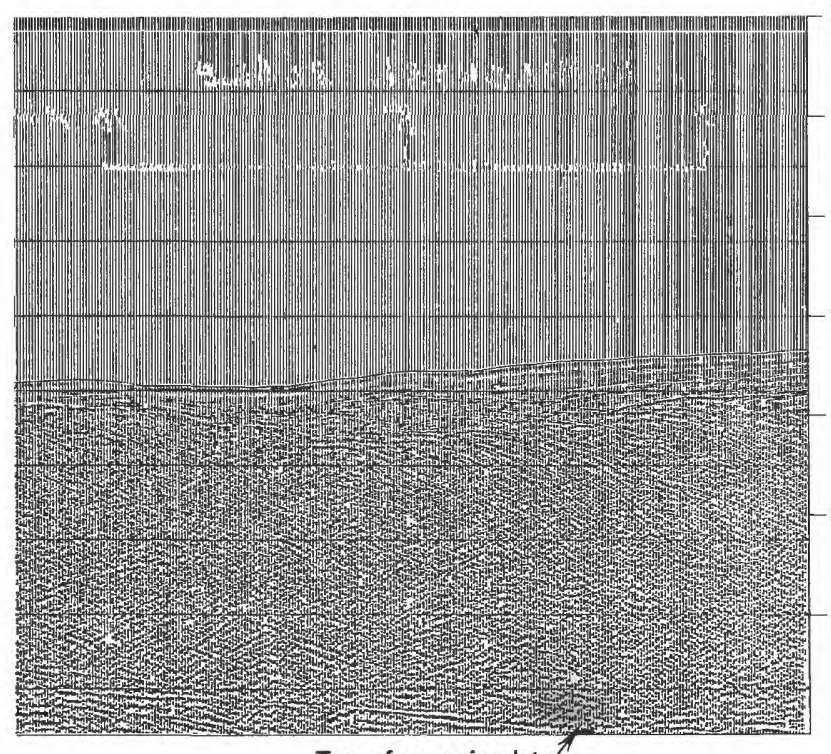

1000

2000

$\stackrel{w}{\stackrel{w}{\Sigma}}$

The strong reflecting zone (arrow) presumably includes the oceanic basement; velocity rectification for water depth would give the zone a genera (ante northward dip (as in A). Dips in the imbricate melange are markedly steeper than those of the subducting basement. The melange wedge is about $10 \mathrm{~km}$ thick at the north end of the profile, and seismic velocities of compressional waves increase downward within the wedge from about 2 to about $5 \mathrm{~km} / \mathrm{sec}$.

Top of oceanic plate

vertical exaggeration of either water or rock, but its reflections have not been migrated for true positions and dips. $B$ is an enlarged portion of the same record. Profile $C$ is not rectified, and its vertical scale is two-way reflection time. 

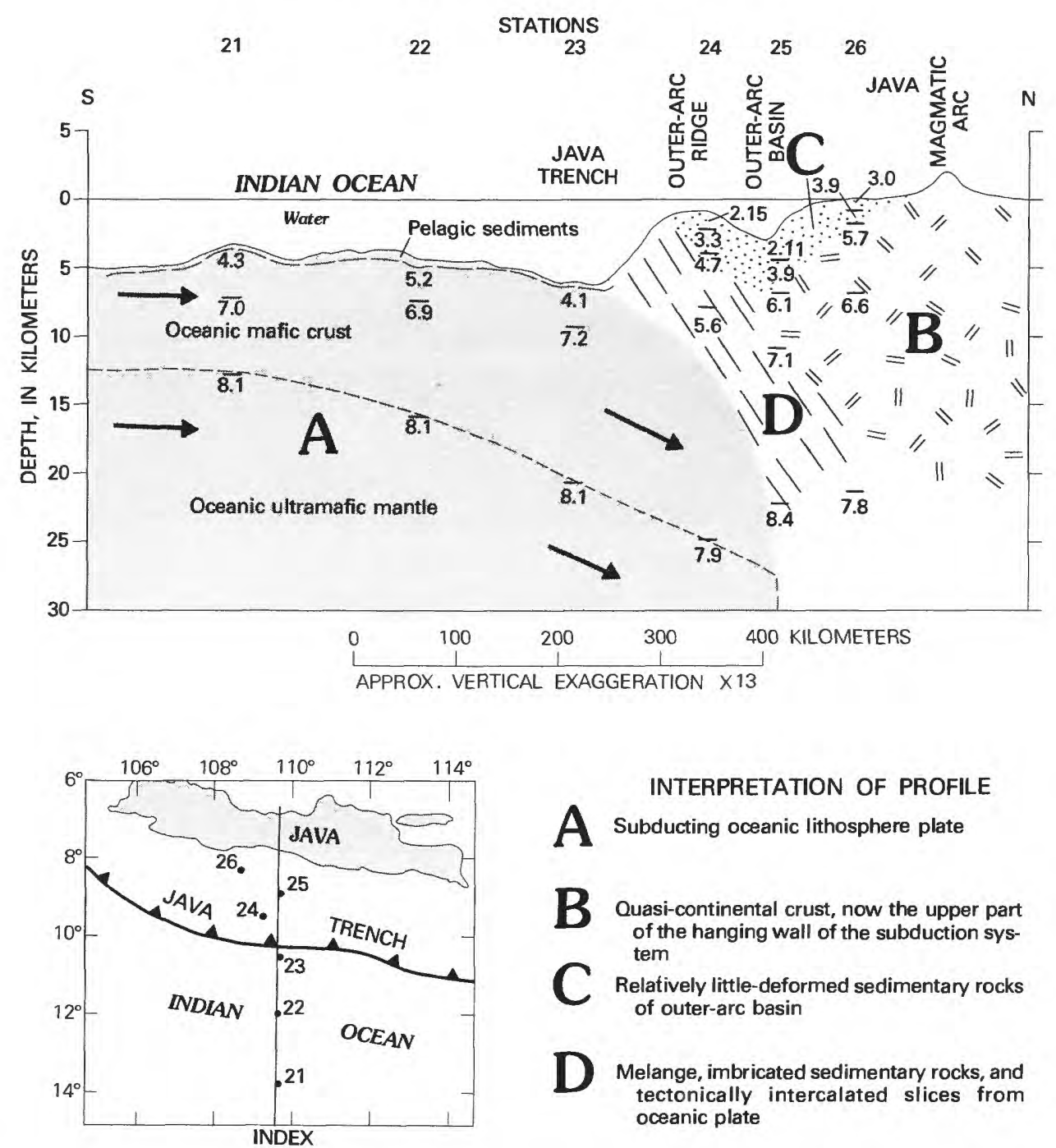

INTERPRETATION OF PROFILE

A Subducting oceanic lithosphere plate

B Quasi-continental crust, now the upper part of the hanging wall of the subduction system

Relatively little-deformed sedimentary rocks of outer-arc basin

Delange, imbricated sedimentary rocks, and tectonically intercalated slices from oceanic plate

Figure 10.- Seismic structure section across the subduction system of the Java Trench. Stations 21 to 26 mark two-ship seismic-refraction sections showing $P$-wave velocities in kilometers per second, as determined by R. W. Raitt (unpub. data, cited by Ben-Avraham, 1973, fig. 15).

ed seaward onto stable oceanic crust, before the present episode of subduction began.

Low geothermal gradients, mostly $2^{\circ}-3^{\circ} \mathrm{C} / 100 \mathrm{~m}$, have been found in wells drilled in the Sumatra-Java outer-arc basin (Kenyon and Beddoes, 1977). Temperatures at moderate depths in these wells are inadequate for maturation of liquid hydrocarbons. Such low gradients probably are characteristic of outer-arc basins generally, and these settings may not provide attractive petroleum-exploration targets. These low gradients may be the result of the stuffing beneath the outer-arc basins of relatively cold subduction melange and oceanic crust.

\section{CRISIAL STRUCIURE}

A seismic-refraction study by R. W. Raitt, as cited by Ben-Avraham (1973, fig. 15; also Curray and others, 1977), illustrates the seismic velocities of crustal and uppermost mantle elements across the Java Trench subduction system (fig. 10) The outer-arc basin is "filled by low-velocity sedimentary rocks, which also compose the upper part of the melange wedge beneath the crest of the outer-arc ridge. Velocities increase downward in the melange wedge, presumably because of the generally increasing compaction and metamorphism of sedimentary rocks and because of the increasing proportion of tectonically intercalated slices of oceanic crustal and mantle rocks.

\section{FORMATION OF MELANGE WEDGE}

The data of the preceding section lead to an understanding of the mechanism of the formation of subduction melange that differs markedly from that espoused in early plate-tectonic papers (including my own). The present concepts are illustrated by figure 11 . 

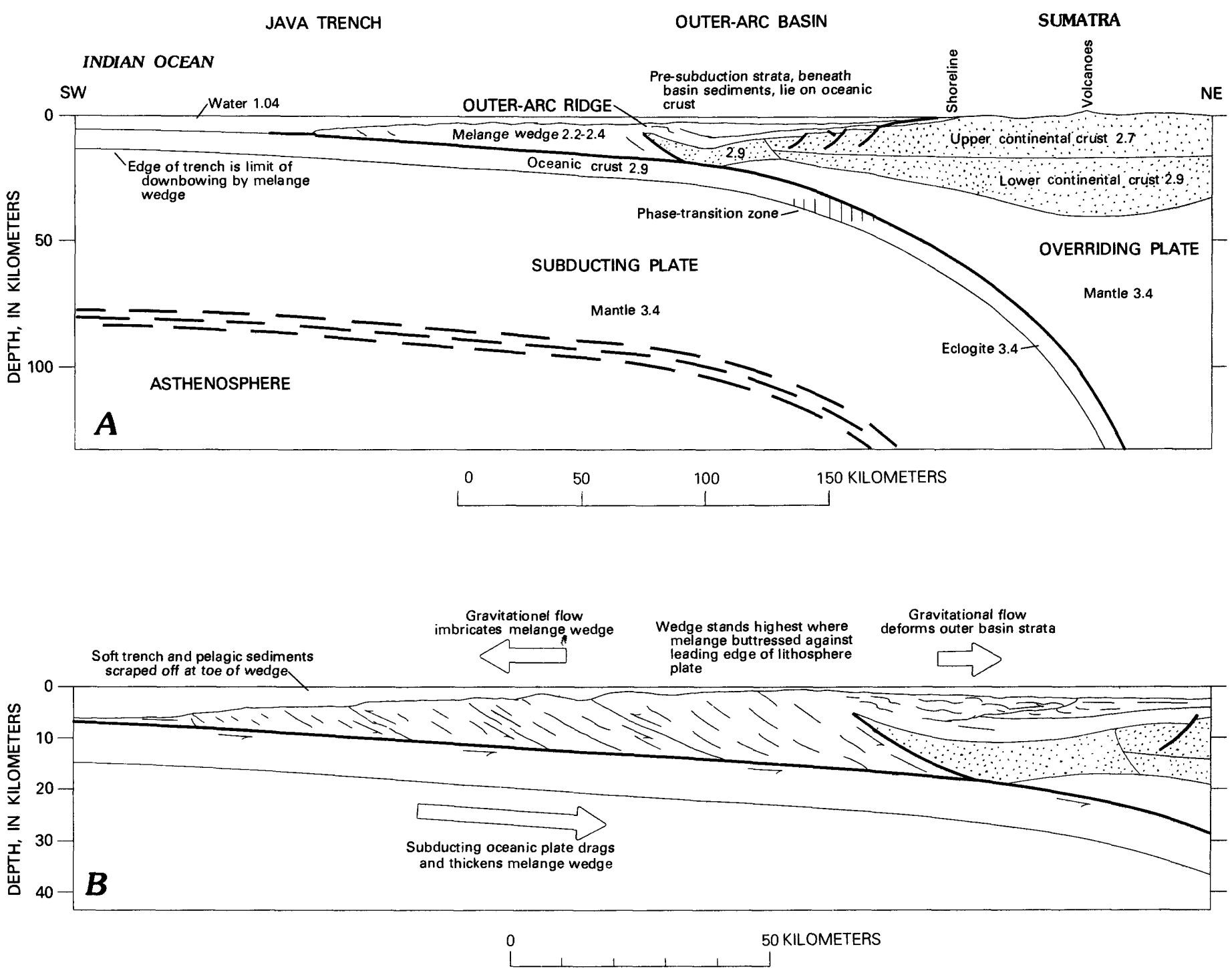

Figure 11.-Sections through the subduction system of southern Sumatra. $A$, Major tectonic components. Assumed densities are in grams per cubic centimeter. $B$, Mechanism of deformation of the melange wedge; other components as in $A$.

The thin wedge of deformed sediments beneath the landward slope of the Java Trench (fig. $9 A, B$ ) is imbricated at a dip that is markedly steeper than the gentle inclination of the subducting oceanic plate beneath. The oceanic plate is sliding rapidly beneath the overriding plate, and the gently dipping discontinuity at the top of the plate must be a narrow zone of intense shearing. The overlying wedge of deformed sediments is not, however, being deformed by laminar shear parallel to that zone of decoupling. Rather, it appears that the sediments are shearing, obliquely to this zone, in response to the couple represented by the landward subduction of the plate beneath and the trenchward gravitational movement of the deforming wedge above. Shear distribution within such a wedge was analyzed mathematically by Elliott $(1976 a, b)$.
A. W. Bally commented at the Geological Society of America Penrose Conference on Continental Margins, at Airlie, Va., in December 1972, on the geometric similarity of decoupled basement and imbricate sediments in the Java Trench system to those of the Cretaceous and very early Tertiary thrust belt of the Canadian Rocky Mountains (Bally and others, 1966), and the comparison is enlightening. Price and Mountjoy (1970) showed that the imbrication in the Canadian Rockies represents the spreading, relatively eastward, of a tectonic wedge of sediments whose top sloped gently eastward and whose base was a decollement zone above basement, dipping gently westward, which was not involved in the imbrication. Slopes of upper and lower surfaces of the wedge and the details of the imbrication were controlled gravitationally, regardless of whether the driving 
mechanism was subduction of the basement beneath the wedge, some sort of piston operating above the basement behind the wedge, or tectonic or magmatic thickening of the crust above the level of the basement behind the wedge. A similar gravitational control of imbrication in the melange wedge is inferred (fig. 11B).

A melange wedge obviously grows by the scraping off of packets of deformed sediments at its front. This can be seen on reflection profiles (and with particular clarity on fig. 105) and accounts for much of the deformation seen in exposures of the wedges. Early packets are rotated back to moderate dips as later ones are stuffed in beneath and in front of them. Rotation by this process is limited largely to the frontal few kilometers of the toe of the wedge, however, and stops when a dynamic-equilibrium dip of $30^{\circ}$ or so is attained. Simple rotation operating far back into the wedge to steadily increasing steep dips, and shearing high within the toe of the wedge parallel to its base, as postulated by Karig and Sharman (1975) and Moore and Karig (1976) among others, are inconsistent with the data. The complex deformation of strata deposited atop the wedge and the convexity of its upper slope show that much internal shearing takes place within the main body of the wedge mostly with moderate dips, and extends to its crest.

The great Alaska earthquake of 1964 was a melange-wedge event whose characteristics are known in some detail (Plafker, 1969). The wedge slipped southward, up its gently inclined base upon the undersliding Pacific lithosphere, along a length of about $800 \mathrm{~km}$ and a width of $250 \mathrm{~km}$. The slip plane did not reach the trench, however, but broke upward through the wedge to reach its continental-shelf top as a thrust fault with uplifts that reached at least $9 \mathrm{~m}$. The uplifted terrain was simultaneously narrowed by as much as $18 \mathrm{~m}$. Here was dramatic confirmation for the concept of continuing imbrication within a wedge.

I picture a wedge as a standing wave of constant internal motion but near-stable outer shape. The bottom of the wedge is dragged arcward by the undersliding oceanic plate, while the entire wedge spreads seaward gravitationally. The wedge is enlarged by offscraping of sediments at its toe and by imbrication into the wedge of sediments deposited on top of it, but the shape of its upper profile, like that of a continental ice sheet, is determined dynamically and changes little in the process of growth of the wedge. The continuing imbrication within the wedge as it spreads forward in equilibrium with backward pulling produces an intensity of deformation that trends to increase with age, for progressively younger materials have correspondingly less time in which to be folded and churned into the imbrication system. The most severe and pervasive deformation at any one time tends to occur near the toe of the wedge. The mixing process does not homogenize the materials of the entire wedge laterally but rather keeps the first-accreted materials largely segregated in the rear of the wedge.
The material within a melange wedge represents various depositional settings. Tectonic scrapings from the subducting oceanic slab provide abyssal pelagic sediments, slices of oceanic crust and mantle, and trench sediments. The Bengal abyssal fan must be an important ingredient in the outer part of the melange wedge off Sumatra. Strata deposited in local basins on top of the wedge are imbricated into it. A major part of the wedge off Sumatra and Java may be formed from stable-margin sediments of continental shelf, slope, and rise, deposited during periods when subduction was not operating and then crumpled by being carried back against the continent when subduction recurred.

The combination of imbrication and trenchward spreading of the wedge with underflow by the subducting slab provides a mechanism to carry offscraped masses of crustal and mantle rocks from the subducting slab, and possibly also metamorphic rocks formed at considerable depth in either wedge or slab, to the surface and to mix such materials by imbrication with other rocks that have never been buried deeply. The observed juxtapositions in many melanges of dense rocks such as glaucophane schist, formed at depths on the order of $25 \mathrm{~km}$, with sheared but unmetamorphosed sediments, may represent an extreme product of uplift and mixing by imbrication. Glaucophane may form only beneath the overriding crystalline plate, not out in the surficial melange wedge.

Surficial slumping presumably can occur where active shear zones in the imbricate system crop out, and slumped materials can be reincorporated into the melange as they are overridden by the thrusts. The total amount of shearing distributed within the melange can record thousands of kilometers of subduction, so extreme grinding, mixing, and recycling can be postulated.

The increasing severity of folding of outer-arc-basin sediments toward the crest of the outer-arc ridge, and the suggestion on reflection profiles (fig. 6) that this deformation is directed toward the basin, may indicate that gravitational spreading operates landward from the ridge also, producing disharmonic deformation of the outer part of the basin fill concurrently with sedimentation. The wedge spreads outward in both directions from its crest (fig. $11 B$ ).

$A$ buttress at the back of the wedge seems required to control the position of the crest of the outer-arc ridge. The outer edge of the overriding lithosphere plate is inferred to provide this buttress (fig. $11 A$ ). The deeper strata in the synclinal outer-arc basin off Sumatra are known to thicken oceanward past the axis of the basin and are thought to represent deposits of presubduction continental shelf and slope; figure $11 A$ suggests an explanation for them. Melange is piled up against the buttress and spreads over the top of it to deform the adjacent basin sediments.

Many recent papers interpret ancient melanges in subduction settings to record dominantly brecciation by submarine slumping in olist ostromes, rather than disruption by tectonic 
shearing within melange wedges. Such speculation is disproved as a general explanation by reflection profiles across modern trench systems, for olistostromes are rare whereas melange-wedge shearing is ubiquitous. The speculation is based typically upon evidence for soft-sediment deformation, which indeed is common but which is to be expected within melange wedges because of the rapid incorporation into them of unconsolidated trench sediments.

\section{TRENCHES AND SUBDUCTION}

The Java-Sumatra Trench system is characterized by a thick wedge of melange and imbricated sediment that forms a broad continental slope and outer-arc ridge and by a broad outer-arc basin between ridge and main islands. Both inner and outer slopes of the trench are gentle slopes.

Some of the other trenches in the Indonesian region-particularly those that bound open-ocean island arcs-are strikingly different. (They are described in succeeding sections.) Those trenches have steep inner and outer slopes and lie much closer to the magmatic arcs paired to them. The outer-arc ridge is either missing or is represented by a minor step on the continental slope; the outer-arc basin if present is represented by a small platform. Still other trench systems are intermediate in character between the extreme Java-Sumatra and open-ocean types. Karig and Sharman (1975) gave other examples of the several types.

The differences between the contrasted types are thought to be due primarily to the availability of sediments. The open-ocean type represents the tectonic end-member of the system. The Java-Sumatra type represents a complication of a similar tectonic pattern by isostatic depression of the landward edge of the oceanic plate under the load of the melange wedge.

The weight of the melange depresses the leading edge of the oceanic plate and results in the gentle landward slope of that plate from the outer edge of the trench to a zone beneath the outer-arc basin, where the plate inflects downward at a moderate angle. The axis of a topographic trench of Java-Sumatra type is thus displaced far seaward, about 200 $\mathrm{km}$, from the position of the fundamental downflex in the subducting oceanic plate. The Java-Sumatra type of trench is the depression between the spreading melange wedge and the minor downflex produced by the weighting by that wedge. The open-ocean type of trench by contrast records directly the fundamental downflex of the subducting plate. The slight outer rise that flanks the seaward side of the trench represents an elastic response to the downbowing (Caldwell and others, 1976; Parsons and Molnar, 1976).

\section{GRAVITY SURVEYS}

F. A. Vening Meinesz made spot gravity observations, using a multiple-pendulum instrument aboard a submerged submarine, throughout the Indonesian region. He reduced his observations using several "regional isostatic" schemes, of which the one he preferred assumed a radius of isostatic compensation of $174 \mathrm{~km}$ and an elastic oceanic crust, of uniform thickness of $30 \mathrm{~km}$ and density of $2.67 \mathrm{~g} / \mathrm{cm}^{3}$, floating in a mantle of density $3.27 \mathrm{~g} / \mathrm{cm}^{3}$. The resulting gravity map (Vening Meinesz, 1940, folding plate) has been widely reproduced (by, among others, van Bemmelen, 1949, fig. 90; Heiskanen and Vening Meinesz, 1958, map 10C-2; Kuenen, 1950, pl. B; Vening Meinesz, 1954, pl. 1). The map shows a gravity anomaly of extreme negative amplitude, with axial values to almost -250 milligals, to be centered on the outer-arc ridge of the Java Trench system and on the topographic crest of the Molucca Sea melange wedge. The authors just cited regarded this anomaly belt as indicative of extreme mass deficiencies that require that the Earth's crust here be pulled down into a deep root, far out of isostatic equilibrium. Vening Meinesz himself wrote many papers (for example, 1954) explaining the hypothetical root as pulled down by converging convection currents in a complex global shear pattern. The notion that the anomaly belts require extreme dynamic disequilibrium persists to the present time among many geologists and geophysicists unfamiliar with modern work in island-arc systems.

The Vening Meinesz belts of extremely negative "regional isostatic" gravity anomalies measure primarily the great difference between actual crustal configurations and the very unrealistic ones assumed in the reduction. Ewing and Worzel (1954, p. 170) recognized this long ago: "Since all of these assumptions of density distribution do. not fit the data, we can discard the isostatic anomalies." The crest of the outer-arc ridge - the axis of the anomaly belt-marks the top of a wedge, $10 \mathrm{~km}$ or so thick, of low-density imbricated sediments and melange. The magnitude of the anomaly correlates with the thickness of the melange wedge, not with conjectural dynamic disequilibrium.

Continuous gravity profiles have been obtained by research-vessel gravimeters along many traverses across the Indonesian trench systems. Work is in progress with these profiles by several investigators. The profiles of free-air anomalies show the strong positive correlation with local bathymetry, and those of Bouguer anomalies the strong negative correlation with regional bathymetry, that are forced by the methods of reduction, but both display negative anomalies superimposed on the melange wedges and indicative of their thickness and low density. Melange-wedge models comparable to those deduced here have been presented for Central America by Seely, Vail, and Walton (1974); for the Lesser Antilles by Westbrook, Bott, and Peacock (1973), and Westbrook (1975); and for the Aleutian Islands by Grow (1973a). (See Watts and Talwani, 1975, for a discussion of some details of Grow's analysis.) 


\section{SUMATRA}

The active structural elements of mainland Sumatra (Sumatera) trend northwestward (pl. 1) parallel to the offshore trench, outer-arc ridge, and outer-arc basin discussed previously. The Barisan Mountains, near the southwest coast, are a geanticline of old rocks surmounted by the volcanic rocks of the active magmatic arc. The range is about $100 \mathrm{~km}$ wide and has summit altitudes near $3,000 \mathrm{~m}$. Next northeast is the low-lying foreland basin. Farthest northeast, the Tin Islands (Bangka, Belitung, and others)-Strait of Malacca-Malay Peninsula region is the craton, partly submerged, of the present time.

This northwest structural and topographic grain is a Cenozoic phenomenon, not recorded in the broad distributions of pre-Tertiary rocks. The Paleozoic and Triassic strata of western Sumatra are of continental-shelf or platform facies and show no indication that a continental margin then existed near the present one. Continental rifting may have occurred between Triassic time and the inception of the Cenozoic pattern. The northwest-trending system may have been inaugurated as recently as the late Oligocene, the age of the oldest dated calc-alkalic volcanic rocks (as recorded by debris in sedimentary rocks) that clearly belong to the system. Cretaceous and Paleogene ages for granitic rocks have been determined radiometrically but in so few places that it is not yet known how the belts are oriented. The only subduction melange identifiable as belonging to the northwest-trending system is that of the offshore outer-arc ridge and is of middle Tertiary to Holocene age.

\section{PALEOZOIC AND MESOZOIC GEOLOGY}

The pre-Tertiary terrain of Sumatra crops out beneath the young volcanic and sedimentary rocks along much of the Barisan Mountains (pl. 1). These old rocks largely resemble those of the Malay Peninsula.

A western facies of upper Paleozoic and Triassic strata extends westward from about the meridian of long $100^{\circ} 30^{\prime}$ E. The rocks are evenly bedded limestone, shale, and sandstone, likely of platform type, and are metamorphosed only near intrusive masses (Brouwer, 1931; Zwierzijcki, 1922). Shallow-water Permian or Carboniferous fossils have been found at many localities and Triassic ones at a few. Fusulinids have been found as far northwest as lat $4^{\circ} 45^{\prime} \mathrm{N}$., long $96^{\circ} 25^{\prime} \mathrm{E}$., and corals probably of late Paleozoic age still closer to the northwest tip of the island (Tobler, 1923; Zwierzijcki, 1922). The contrasted eastern Sumatra facies consist of Upper Carboniferous, Permian, and Triassic shallow-marine limestones and shallow-marine and continental clastic strata, with which are intercalated abundant intermediate and silicic volcanic rocks and tuffs (Brouwer, 1931; Gobbett, 1973; Kastowo and Leo, Klompé and others, 1961; Krumbeck, 1914; Musper, 1928, 1930; Rosidi and others, 1976; Silitonga and Kastowo, 1975; Westerveld, 1941; Zwierzijcki, 1930, 1935). No ages older than Late Carboniferous have yet been proved in Sumatra.
The eastern facies has yielded a large and well-preserved latest Carboniferous or Permian flora, studied in detail by Jongmans and Gothan (1935). The plants represent a tropical Cathaysian assemblage that contains such characteristic Chinese genera as Gigantopteris and is unlike correlative assemblages in Australia, India, or Europe (Jongmans, 1937). Associated fusulinids include such Asiatic forms as Verbeekina and Sumatrina (Zwierzijcki, 1930). Although the subcontinent of China is bounded on the south by sutures marking post-Paleozoic continental collisions, it appears likely that land connected Sumatra and China in late Paleozoic time. The fully tropical land floras, marine faunas, and lithologic indicators of the Upper Carboniferous and Lower Permian of Sumatra and Malaya contrast strikingly with the glacial to temperate indicators in correlative rocks in India and Australia, and (as Jongmans, 1937, and Stauffer, 1974, emphasized) this negates speculation such as that by Ridd (1971b) that western Indonesia lay between India and Australia in late Paleozoic time. Paleoclimatic, paleobiogeographic, and facies and tectonic similarities are, however, consistent with the interpretation, made here in a subsequent section, that Sumatra and Malaya lay north of New Guinea, their eastern late Paleozoic and Triassic igneous terrain having been continuous with that along the east margin of Australia until separation by continental rifting occurred during the Triassic or Early Jurassic.

This interpretation of rifting predicts that a stable-edge continental shelf should have developed along what is now southwestern Sumatra from Jurassic time until the inception of subduction, perhaps in the Cretaceous, along this margin. Stratigraphic data are too meager to provide evidence either for or against this conjecture.

Subduction melange may be present in central Sumatra between the two major facies of upper Paleozoic and Triassic rocks. Kastowo and Leo (1973) reported "sheared serpentinite, $*^{* *}$ slightly sheared greenstone, $* * *$ breccia of similar greenstone blocks in a serpentinite matrix," beneath young volcanic rocks at about lat $0^{\circ} 10^{\prime} \mathrm{S}$., long $100^{\circ} 10^{\prime} \mathrm{E}$. Brouwer (1915a) and von Steiger (1922, p. 112-113) mentioned "conglomerate," near lat $0^{\circ} 20^{\prime} \mathrm{N}$., long $100^{\circ} 25^{\prime} \mathrm{E}$., that contains clasts of quartzite, graywacke, limestone, slate, schist, radiola rian chert, and some "hard-to-identify rocks;" such clasts could occur in polymict melange, but the published descriptions are inadequate to indicate whether the clasts are sedimentary rollstones or are fragments in a sheared matrix. These materials are in the same regional tectonic position as is the possible Paleozoic melange of Medial Malaya and are suggested on the tectonic map to be subduction melange (pl. 1)

The pre-Tertiary granitic rocks of Sumatra are dominantly silicic and potassic, and many contain tourmaline. (See for example: Brouwer, 1915c; de Haan, 1935; Kimpe, 1944; Tongeren, 1936.) Tin granites occur in the area between the equator and lat $0^{\circ} 30^{\prime} \mathrm{N}$., and two-mica leucogranites have 
been reported as far northwest as $3^{\circ} 50^{\prime} \mathrm{N}$., $97^{\circ} 20^{\prime} \mathrm{E}$. (Taverne, 1924). As many geologists have noted, these tin and two-mica granites resemble, and likely are correlative with, those of the Malay Peninsula, which now are known to range at least from Permian to Cretaceous in age. Volcanic rocks are abundant in the Carboniferous(?), Permian, and Triassic sections of the eastern facies in Sumatra, so granitic rocks of those ages are undoubtedly present in that region. The K-Ar age of hornblende and biotite in a granite near lat $0^{\circ} 36^{\prime} \mathrm{S}$., long $100^{\circ} 57^{\prime} \mathrm{E}$., is about 207 m.y. (J. D. Obradovich, as cited by Silitonga and Kastowo, 1975). In two areas in central Sumatra, unmetamorphosed Permian or Upper Carboniferous fusulinid-bearing limestone is in direct contact with granite, which thus is assumed to be older (Musper, 1930; Zwierzijcki, 1935).

Cretaceous volcanic and sedimentary rocks occur in the Gumai Mountains of southern Sumatra, near lat $3^{\circ} 45^{\prime} \mathrm{S}$., long $103^{\circ} 20^{\prime} \mathrm{E}$., (Musper, 1937). Highly contrasted rock types are present: abundantly fossiliferous shallow-water limestone, some of it reefoid; deeper water marl and limestone containing planktonic foraminifera; siliceous marl; shale or slate; red radiolarian chert; andesite and basalt. Both sedimentary and volcanic rocks of Cretaceous age, but not nearby Paleogene strata, are cut by small granitic intrusives, which thus are likely also Cretaceous. Van Bemmelen (1949, p. 661) summarized information on several other small occurrences of known and possible upper Mesozoic rocks in southern and central Sumatra.

Reconnaissance $\mathrm{K}-\mathrm{Ar}$ and $\mathrm{Rb}-\mathrm{Sr}$ age determinations suggest that the pre-Tertiary granitic rocks of Sumatra are dominantly of Cretaceous and Triassic age in the west, and Cretaceous, Triassic(?), and late Paleozoic age in the east (fig. 12). Late Paleozoic magmatism is also recorded by geologic data, as just noted, along the mountains that follow the Neogene magmatic axis of central and southeastern Sumatra but not of northwestern Sumatra. The regional contact between a western terrain that lacks or nearly lacks Paleozoic igneous rocks and an eastern one that contains them appears to trend southward through Malaya (as discussed in a subsequent section) and Sumatra to a truncation against the Indian Ocean. It is suggested in the section on New Guinea that this truncation.is due to early Mesozoic rifting of a Malay-Sumatra continental plate away from a New Guinea-Australia one.

The pre-Oligocene basement rocks of far northwestern Sumatra are very poorly known but may include Mesozoic or lower Paleogene melange. Such melange might be expected from the projection southward of Burmese tectonic belts. Schürmann (1929) stated that many large masses of serpentinite and gabbro crop out in this region, but he did not describe or map them, and the term "serpentine" was often wrongly applied to altered basalt by reconnaissance geologists. Zwierzijcki (1922) reported large masses of serpentine to be present west of long $96^{\circ} \mathrm{E}$. Van Bemmelen (1932, p. 81-83, 89-90) mentioned rocks (his Glansleigroep) near lat $4^{\circ} \mathrm{N}$. that might be in part melange: crumpled and sheared lustrous phyllite, graywake, quartzite, and limestone, and in one area repeated intercalations of upper Mesozoic(?) limestone, variably sheared basalt, and serpentinite. Van Bemmelen likened these rocks to the Bundner Schiefer of the Alps, much of which is now recognized as subduction melange. He did not describe the serpentinite, although subsequently he referred to the complex as "ophiolitic" (1949, p. 672). Inferring the presence of melange here entails problems. The limestone with the mafic rocks contains bryozoa and corals, which suggests a shallow-water setting rather than oceanic depths. If the rocks do include melange, then the regional relationships are not understood; shallow-water late Paleozoic fossils, including fusulinids, have been found at several localities still farther northwest (Tobler, 1923, p. 317-319; Zwierzijcki, 1922, p. 20-21). The possible melange is not separated on the tectonic map (pl. 1). Extensive north Sumatra field and laboratory studies by B. G. N. Page and a team of British and Indonesian geologists are underway and should greatly clarify the regional tectonics.

Adinegoro and Hartoyo (1975) and Adiwidjaja and de Coster (1973) gave some generalizations regarding basement rocks encountered in oil wells that penetrated the Neogene fill of the foreland basin of northeast Sumatra, but their references are not specific enough to make more than the obvious point that the basement rocks are similar to those exposed in the Malay Peninsula and in the mountains of Sumatra. On the basis of the distribution of poorly dated pre-Tertiary rocks in the Barisan Mountains and of unspecified basement-well data in the forekand basin, de Coster (1975, fig. 10) suggested that upper Mesozoic granitic, metamorphic, and sedimentary belts trend west-northwestward across southern Sumatra, oblique to the modern northwestward structural trends.

The presence of granites giving Cretaceous radiometric ages in widely separated areas along the mountains of Sumatra may indicate that a Cretaceous subduction system was approximately coincident with the modern one. Data from Sumatra on Cretaceous rocks are too sparse to test this inference. Subsequent sections of this report discuss the possible relationships of the granitic rocks of Sumatra to those of surrounding submerged and exposed regions.

\section{CENOZOIC GEOLOGY}

Cenozoic sedimentary rocks in Sumatra record regional subsidence and marine transgression during the middle Tertiary, and then uplift and deformation during the late Tertiary and Quaternary. The present three-part longitudinal division of Sumatra - an outer-arc basin, mostly offshore, in the southwest; the medial Barisan Mountains, a broad geanticline coincident with the volcanic belt; and the foreland basin in the northeast - may date only from the latter part of this cycle. (The outer-arc basin and the outer-arc ridge and trench between it and the deep Indian 


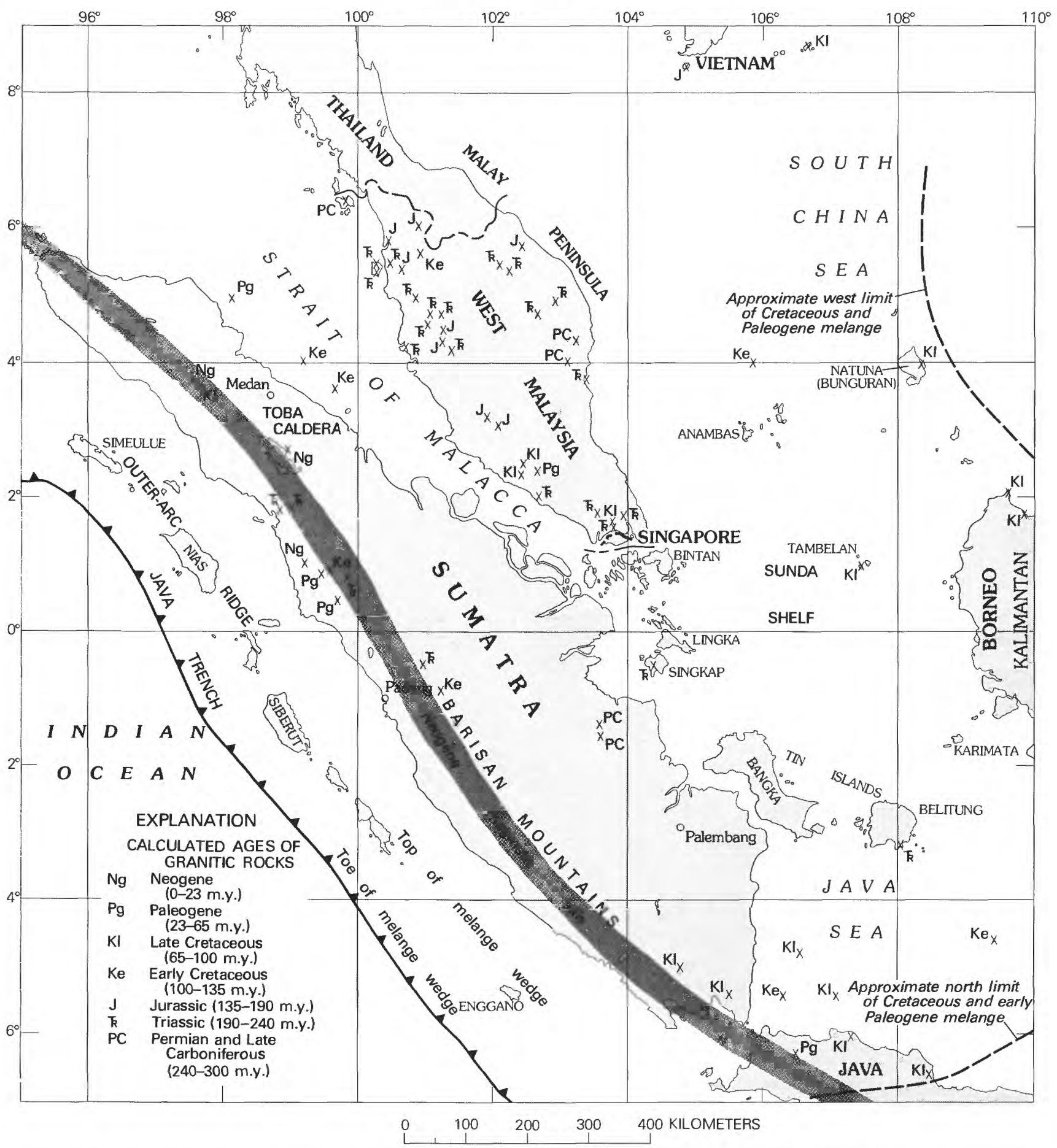

FIGURE 12.-Age determinations of granitic rocks in the Peninsular Malaysia-Sumatra region, as calculated from K-Ar and Rb-Sr analyses. Only a few of these determinations are concordant multimethod or multimineral ages: most represent only single mineral or whole-rock analyses, or widely discordant determinations by different methods or on different materials, or apparent-isochron ages of different specimens whose consanguinity is not established; age assignments may be much in error. Ages are shown as calculated by the original investigators and have not been recalculated for standard decay constants. Major sources of determinations: Norman J. Snelling and John D. Bignell (as cited by C. S. Hutchison in Gobbett and Hutchison, 1973, p. 216-238); Rodger E. Denison (written commun., 1972); and John D. Obradovich (oral commun., 1975; U.S. Geological Survey, 1975). Additional determinations as published by Edwards and McLaughlin (1965), Haile and Bignell (1971), Hilde and Engel (1967), Katili (1973a, b), Kirk (1968), Patmosoekismo and Yahya (1975), and Pupilli (1973); others supplied by Atlantic Richfield Indonesia, Independent Indonesian American Petroleum Co., and Japanese Overseas Mineral Resources Development Co. 
Ocean were described in prior sections of this report.) The Paleogene configuration of at least northwestern Sumatra may have been that of a stable continental shelf before late Oligocene time.

\section{SEDIMENTAIION}

Sedimentation began in Eocene or Oligocene time in medial and northeastern Sumatra in the low areas of the basin-and-ridge terrain of considerable topographic relief. The small basins were gradually filled, and then the highs were covered, as the broad foreland basin developed. The Cenozoic strata lap northeastward onto the craton in the Strait of Malacca but are increasingly deformed southwestward, and the older strata are strongly deformed at the structural margin of the present foreland basin along the Barisan Mountains. Summary accounts of the Cenozoic sedimentary geology of large areas are given by A. R. U. Adinegoro (1973), Adinegoro and Hartoyo (1975), van Bemmelen (1949, p. 112-126), Bouquigny and others (1971), de Coster (1975), Kamili and Naim (1973), Kamili and others (1977), Koesoemadinata (1969), Mertosono and Nayoan (1975), Pulunggono (1974), Wennekers (1958), Wongsosantiko (1977), and Zwierzijcki (1922).

The broad foreland basin of Sumatra northeast of the Barisan Mountains has a topographic surface of low to moderate relief, but its strata cover a basement surface of subbasins and ridges with as much as $5,000 \mathrm{~m}$ of local relief (pl. 1; Hamilton, 1974a). The complex basement irregularities represent in part the rough basin-and-ridge topography that was buried by sediments of the middle Cenozoic and in part the deformation superimposed upon both basement and fill during the late Cenozoic. The old topographic grain was dominantly north-northwestward, parallel to the structural grain of Malaya, and was not parallel to the Neogene northwest-trending system. The pre-Tertiary basement reaches the sea floor in the shallow Strait of Malacca. The continental clastic strata that inaugurated the depositional cycle are Oligocene in several fossiliferous localities but mostly are undated except as older than overlying marine sedimentary rocks, which are early Miocene in some sectors and late Oligocene in others. The continental sediments were deposited in the topographic subbasins, east of the Barisan Mountains, and over the site of the present mountains in northwestern Sumatra, where a stable continental shelf might thus have existed. Lower Miocene materials were deposited in increasingly more marine environments, with maximum transgression in the late early Miocene and early middle Miocene. The higher Neogene reverses the trend and becomes decreasingly marine upward.

Oligocene and low lower Miocene clastic strata, known primarily in the subsurface, fill troughs and small basins, bounded by faults and flexures, in southern and central Sumatra northeast of the mountains. These clastic materials were derived in part from the intervening basement highs and are typically sandstones at the edges of the troughs and shales at the centers. The higher lower Miocene and younger strata progressively covered the older troughs and ridges and record widespread marine transgression followed by regression and a progressive northeastward shift of the major sites of deposition. Basal continental sandstone gives way upward to finer grained deltaic and neritic sandstone that contains sparse brackish-water faunas. The sandstone is richly quartzose, and the deltas are prograded southward, so the material was derived mostly from the Malay Peninsula and Sunda Shelf. Above the sandstone is marine shale (Telisa shale). The age of the transition from sand to shale becomes younger northeastward across the strike, from late early Miocene to well within the middle Miocene. Abundant planktonic foraminifers in the shales record water depths that were generally shallow in the northeast and bathyal in the southwest. The regional basin thus both deepened and expanded northeastward with time. Reefs and carbonate banks that grew on the subsiding basement highs, first as fringing reefs and then as platforms, were gradually buried by shale. The early and middle Miocene marine transgression was followed by late middle Miocene and younger regression, during which the sediments deposited (Palembang facies) became increasing sandy and changed irregularly from shallow marine to continental. The clastic materials came from sources both to northeast and southwest. Tuffs and volcanic rocks are abundant in the far southwest throughout the regressive section, and the Quaternary across the basin is dominated by volcanic ash. The Barisan Mountains geanticline rose concurrently with the deposition of the regressive facies, and the depositional axis of the upper Neogene shifted correspondingly northeastward, away from the mountains, with time. In the subbasins, the transgressive and regressive materials are each typically about $1,000 \mathrm{~m}$ thick, and the intervening marine shale about $2,000 \mathrm{~m}$.

Middle Tertiary sedimentary rocks are exposed widely in the mountains of northwest Sumatra. It is not clear from published data whether the strata were deposited on a continental shelf, open to the Indian Ocean to the southwest, or in a basin whose axis lay near the present northeast side of the mountains; but certainly the modern mountain system had not begun to form. Above a locally derived conglomeratic basal unit generally lies a thick section of quartzose and micaceous sandstone, the lower part of which is continental and unfossiliferous and the upper part of which includes fossiliferous Oligocene shallow-marine strata. Next higher is a thick, dark marine shale, not dated by fossils except in its upper part, which contains high lower Miocene pelagic foraminifers. The mountains began to rise later in the Miocene, and the main locus of sedimentation migrated eastward.

In north Sumatra east of the mountains, Cenozoic deposition began similarly with continental conglomerate and quartzose sandstone (the upper part of which is Oligocene), above which are upper Oligocene or lower Miocene paludal, deltaic, and shelf strata, mostly clastic. 
The middle and upper Miocene strata record the maximum marine transgression; they are clays, marls, and tuffs bearing a rich marine fauna, intercala ted with sands near the Barisan Mountains but not on the cratonic side.

The clastic sediments of the transgressive sequence were derived primarily from the Malay Peninsula, whereas the regressive sediments of the upper Neogene came mostly from the rising Barisan Mountains. The regression probably was caused largely or entirely by increased sediment supply rather than by uplift of the region of deposition.

Superimposed on the broad pattern of middle and late Cenozoic transgression and regression has been a continuing control by basement structures. Throughout the period of deposition, the large, irregular foreland basin of central and south Sumatra was separated from both the smaller and more regular foreland basin of north Sumatra and the small basins of the western Java Sea, just east of the present Sumatra coast, by north-trending basement arches which were covered by marine strata only during the time of maximum Miocene transgression. The same interval saw the maximum deposition of strata across what is now the Barisan Mountains region of central and southern Sumatra. Within central and southern Sumatra, the subbasins present at the onset of sedimentation had typically northerly trends, whereas the younger Neogene structures have northwesterly strikes. Sedimentation smoothed out the old structural topography, and then the younger family of structures began to develop concurrently with further sedimentation, and so the young strata thin and arch, and their facies change, over the structural highs. Reverse faults are present in some areas, but no major overthrusts are known. The Tertiary strata dip northeastward into the foreland basin from the basement terrain of the Barisan Mountains, which is not thrust over them.

Some published papers have inferred short, major episodes of deformation within Miocene and Quaternary times, but such inferences depend at least in part upon circular arguments that assign ages on the bases of degree of deformation and of sedimentary facies within strata that otherwise are only poorly dated.

Strata of the landward edge of the otherwise offshore outer-arc basin are present discontinuously along the southwest coast of Sumatra. Some of the onlapping basin areas are exposed only as areas of alluvium, and others as seaward-dipping wedges of upper Neogene marl and continental and marine tuffaceous shale and sandstone whose deposition preceded much of the uplift of the Barisan geanticline. The lower Neogene of northern Sumatra is dominated by shallow-water limestone (A. R. U. Adinegoro, 1973). The lower Neogene of the west coast of central and southern Sumatra is more varied and is in part highly deformed, and formed synchronously with volcanic rocks in what are now the nearby mountains but were then volcanic islands (Westerveld, 1941, 1949).

\section{OIL AND GAS}

Many large and small oil and gas fields lie in the foreland basin of south and central Sumatra. Most of the fields are present either in the west side of the broad, deep basin west-southwest of Palembang in south Sumatra or above a northwest-trending basement high, between lat $0^{\circ} 40^{\prime}$ and $1^{\circ} 40^{\prime} \mathrm{N}$., in the shallow, eastern part of the foreland basin of central Sumatra. The giant Minas field is in the latter setting. Oil is produced from sandstones in both the transgressive lower Neogene (with source beds in paralic and continental shale) and the regressive upper Neogene (with marine shale source beds), mostly in anticlines that deform the basement as well as the strata above (Soeparjadi and others, 1975). Although reflection seismic exploration is now widely used, many of the fields were found before World War II by drilling surface anticlines, oil seeps, and the gravity highs that mark the basement highs. Many structures of favorable appearance are barren because they formed after the migration of oil updip through their sectors.

High geothermal gradients in clastic sections enhance the formation and migration of oil and gas. Central Sumatra has very high gradients, which reach $7^{\circ} \mathrm{C} / 100 \mathrm{~m}$ in the Minas field, where production comes from depths of less than a kilometer (Kenyon and Beddoes, 1977; Klemme, 1975). South Sumatra has more normal gradients, and less oil.

The giant Arun gas field of north Sumatra, $225 \mathrm{~km}$ northwest of Medan, contains condensate-rich natural gas in thick lower and middle Miocene reef limestones that formed on top of a north-trending basement ridge (Graves and Weegar, 1973). The reservoir rocks are capped by high middle Miocene and younger shale and sandstone. A number of small oil fields have been discovered near the coast of northeastern Sumatra, between lat $4^{\circ}$ and $5^{\circ} \mathrm{N}$., in a northwest-trending belt near the axis of maximum Neogene sedimentation. Geothermal gradients in the north Sumatra basins are mostly about $4^{\circ}$ or $5^{\circ} \mathrm{C} / 100 \mathrm{~m}$ (Kenyon and Beddoes, 1977).

\section{MAGMATISM}

The present pattern of subduction, magmatic arc, and foreland basin has existed at least since Oligocene time in Sumatra, for the Oligocene (and lower Miocene?) sandstones in and near the Barisan Mountains contain minor intercalations of volcanic rocks, tuff, and volcanic debris (van Bemmelen, 1932, and 1949, p. 112; Bouquigny and others, 1971; Musper, 1937; Zwierzijcki, 1922). The older Paleogene character of the system cannot yet be defined. Undated altered volcanic rocks in southern Sumatra include many assumed to be Paleogene (by Westerveld, 1941, for example), although these are not proved to be older than Neogene. Two granitic plutons in the mountains of central Sumatra, between the equator and lat $1^{\circ} \mathrm{N}$., were dated as presumably Eocene by one K-Ar determination of each (43 and 48 m.y.) made for the Japanese Overseas Mineral Resources Development Co. (Katili, 1973b). 
Neogene silicic and intermediate volcanic rocks form much of the mountain belt of southwestern Sumatra. The volcanic rocks become progressively less voluminous northwestward along the strike, and only Quaternary ones are present in the far northwest. The Neogene foreland-basin sediments of northeastern Sumatra contain correspondingly abundant volcaniclastic material in the southeast and central sectors but not in the northwest sector. Information on the many active volcanoes was assembled by Neumann van Padang (1951, p. 2-51), and that on other late Quaternary volcanoes by Westerveld (1952). Meager information on older volcanoes and volcanic rocks is scattered widely through the literature.

Andesite, dacite, and rhyodacite dominate the young volcanic rocks, but much rock as silicic as rhyolite is also present. On the tectonic map (pl. 1), areas of Quaternary volcanism, as recognized primarily by their display of obvious constructional volcanic topography, are separated in a general way from areas of older volcanic rocks. The fragmentary descriptions of the pre-Holocene rocks in the literature indicate that variably altered andesite and dacite are the characteristic rock types. Two very large fields of rhyodacitic welded tuff occur in Sumatra, one in the far southeast (Westerveld, 1942), the other in the northwest (van Bemmelen, 1939a). Eruption of the latter field, about 75,000 years ago (Ninkovich, Hays, and Abdel-Monen, 1971), formed the enormous Toba caldera, in which the moatlike lake is $500 \mathrm{~m}$ deep. Van Bemmelen (1933), Verstappen (1973), and Westerveld (1942) described other, smaller welded tuff plateaus, several of them marked by calderas. Presumably each ignimbrite field records the venting of a granodiorite batholith.

An analyzed specimen of silicic welded tuff from the Toba caldera complex has a ${ }^{87} \mathrm{Sr} /{ }^{86} \mathrm{Sr}$ ratio of about 0.714 , indicative of a large crustal contribution to its composition (Whitford, 1975). Andesite from Merapi volcano, at about lat $0^{\circ} 25^{\prime} \mathrm{S}$., long $100^{\circ} 30^{\prime} \mathrm{E}$., in the central Sumatran part of the main volcanic belt, has an average ratio of about 0.7046 , suggestive of a minor crustal component. Neogene volcanic rocks in the Padang area, near the southwest coast of central Sumatra, form a bimodal assemblage of silicic andesite on the one hand and rhyolite on the other, but both types show similar ranges of strontium-isotope ratios, from 0.7044 to 0.7066 , indicating variable contamination $(\mathrm{G}$. W. Leo, written commun., 1976).

\section{ROIIIION OF SIMAIRA}

India has rammed northward into Asia during Cenozoic time, producing enormous drag along the sides of the moving subcontinent. The effects of this movement include the great syntaxes of Pakistan in the west and Assam in the east, complicated by the clockwise swinging of Southeast Asia and western Indonesia westward toward the Indian Ocean. (See subsequent discussion and figure 37.) Sumatra may have rotated clockwise during Cenozoic time, from an initially more east-west orientation to its present southeast trend. Ninkovich (1976) reached the same conclusion from an interpretation of the Neogene volcanic history of Sumatra. The amount of subduction of Indian Ocean crust beneath Sumatra would have decreased northward during such rotation. The northwestward decrease in the volume and the age of inception of Neogene magmatism in Sumatra may be a manifestation of this phenomenon.

\section{SIRIKE-SILIP FAILIING}

A narrow strike-slip fault trough, displayed as a linked series of deep longitudinal valleys, runs the length of Sumatra along the northwest-trending axis of the mountains and the coextensive belt of active volcanism (Katili, 1970a, b; Katili and Hehuwat, 1967; Tjia and Posavec, 1972). The fault system has been the site of most major Sumatran earthquakes, which have been distributed throughout its length (van Bemmelen, 1949, p. 258). An 1892 earthquake in north Sumatra was accompanied by $2 \mathrm{~m}$ of right-lateral strike slip (Reid, 1913). Earthquakes in 1926 in central Sumatra and in 1932 or 1933 and 1952 in south Sumatra produced observed offsets of about $0.5 \mathrm{~m}$ each (Katili and Hehuwat, 1967). Modern stream courses, alluvium, and lahars are offset by the fault (Durham, 1940; Katili and Hehuwat, 1967; Posavec and others, 1973; Verstappen, 1973). The fault trough is a conspicuous structure through the young welded tuff sheet surrounding the Toba caldera, so the fault offset is rapid. J.A. Katili loaned me for study aerial photographs along a sector of the fault in central Sumatra, which show the active strand of the fault to be in part in the narrow valley floor, where its offsets are not apparent; where the active strand trends a short distance up the talus slopes of the valley sides, however, it produces consistent right-lateral offsets of gullies of about $50 \mathrm{~m}$. Two shutter ridges indicate recent offsets of about $500 \mathrm{~m}$. Verstappen (1973, photo 53) illustrated other strike-slip offsets.

Total offsets have yet to be shown unambiguously along the fault system. In each of several areas, Katili and Hehuwat (1967) suggested offsets of several tens of kilometers, on the basis of local rock assemblages. Offsets of Neogene volcanic and granitic rocks by as much as $130 \mathrm{~km}$ were inferred by Posavec, Taylor, van Leeuwen, and Spector (1973) on the basis of speculative interpretations of past spacings between eruptive centers. The Paleozoic sections northeast of the fault contain abundant volca nic rocks as far northwest as about long $100^{\circ} 30^{\prime} \mathrm{E}$., and a search for the northwest limit of similar volcanic sections on the other side of the fault might serve to define total offset.

The Sumatran rift bounds on the northeast a prism of crust and mantle whose other boundaries are the trench on the southwest and the subducting oceanic lithosphere plate at the bottom. The prism is moving northwestward relative 
to the craton of northeast Sumatra and Malaya. The rift is coextensive with the belt of active volcanism in Sumatra. It is an obvious inference from these relationships that the rift owes its position to lubrication by a discontinuous curtain of magma rising from the Benioff zone to the surface and that the motion of the prism resolves some of the obliquity of convergence of the major crustal plates.

The Sumatran rift goes to sea at the southeast end of Sumatra, and its offshore course is not obvious in the available bathymetry. The fault likely intersects the trench south of Java, but the mechanics and geometry of this intersection are not apparent. The rift trends to sea at the opposite end of Sumatra also. Peter, Weeks, and Burns (1966) inferred from their widely spaced bathymetric traverses that the fault swings to a northward strike and continues along the submarine volcanic arc east of the Andaman-Nicobar outer ridge.

D. E. Karig and Wallace Jensky (written commun., 1972) suggested that the Barisan Mountains are undergoing extension normal to the rift system and that this extension represents the usual oceanward migration of the frontal parts of arc systems.

The folds in the Neogene foreland basin of Sumatra tend to trend farther west of north than does the rift system, and, as Wilcox, Harding, and Seeley (1973) concluded, this pattern suggests that distributed shearing parallel to the rift affects the crust for a considerable distance to the northeast of the major faults.

\section{UPLIFI OF THE BARISAN MIOUNTAINS}

The mountainous region of western Sumatra is a geanticline that widely exposes pre-Tertiary rocks and is topped by Cenozoic volcanic rocks. The geanticline and the volcanic belt are almost coextensive and have a width generally near $100 \mathrm{~km}$. A possible explanation for the uplift is that the crust is inflated by Cenozoic intrusions along the magmatic belt. The proportion of Cenozoic volcanic rocks decreases greatly northwest along the mountain system, yet the height and width of the geanticline display no obvious change correlative with this decrease. Perhaps the crust must be heated greatly by many intrusions before silicic magma can reach the surface in large volume. Or perhaps the geanticline is a product of crustal compression, localized by the magmatic heating.

\section{REI_A IION BETWEEN M.ACIMATISM AND TECTONISM}

Downbowing of the sedimentary basins, sedimentation in them, and deformation of those sediments and of the basement beneath them have proceeded concurrently with the uplift and magmatism in the volcanic belt of Sumatra. The magmatism, which as just noted may be the primary cause of the uplift of the Barisan Mountains, may also be the primary cause of subsidence and deformation of the basins. The magmatism represents the transfer of an enormous amount of mass to high crustal sites. Downbowing due to the loading of the lithosphere by this mass may have produced the basins, and outward spreading of the thickened crust may have caused the deformation of those basins and their contents concurrently with sedimentation.

\section{OFFSE I BEIWEEN SUMATRA ANI MALAYA}

Various upper Paleozoic and Mesozoic rock assemblages shared by Sumatra and Peninsular Malaysia (Malaya) appear to be offset from their respective projected trends. A Cretaceous or Paleogene right-lateral fault, striking northwestward, might lie beneath the Sumatra foreland basin or the Strait of Malacca and have an offset of at least $300 \mathrm{~km}$; or a tight orocline may be present in the Sunda Shelf region. These matters are discussed at the end of the subsequent section on Southeast Asia.

\section{THE TIN ISLANDS}

The Tin Islands-Bangka (Banka), Belitung (Billiton), and smaller islands-east of southern Sumatra (fig. 12) consist of upper Paleozoic and Triassic rocks that represent the along-strike continuation of part of the terrain of eastern Malaya (pl. 1), and they contain similar tin granites. The bedded rocks are shale, sandstone, silicic volcanic rocks, a little limestone, and their contact-metamorphosed equivalents, and they have yielded Carboniferous(?), Permian, and Triassic fossils (van den Bold and van der Sluis, 1942; Bothé, 1928; Katili, 1967; Priem and others, 1975; Zwartkruis, 1962).

The granitic rocks intrusive into these varied materials are dominantly granodiorite, quartz monzonite, and granite but include locally more mafic types (Priem and others, 1975). All of the granites may be of Late Triassic age: a number of whole-rock and biotite samples from Belitung, Bangka, and islets just north of Bangka have an $\mathrm{Rb}$-Sr Late Triassic isochron age of about $210 \mathrm{~m}$.y. (using an ${ }^{87} \mathrm{Rb}$ decay rate of $1.42 \times 10^{-11} / \mathrm{yr}$; M.R. Jones and others, 1977; Priem and others 1975; also Edwards and McLaughlin, 1965). Initial ratios of ${ }^{87} \mathrm{Sr} /{ }^{86} \mathrm{Sr}$ were moderately high $(\cong 0.715$ ), indicating incorporation of silicic crust in the magmas. Biotite and hornblende $\mathrm{K}-\mathrm{Ar}$ age determinations from Bangka and Belitung cluster around 214 m.y. (Priem and others, 1975). Primary tin occurs in biotite quartz monzonite and in metasediments, but not in hornblendic granitic rocks (Adam, 1960; Aleva, 1960). The tin granites have high rare-earth contents and contain accessory fluorite, tourmaline, topaz, and scheelite (Kieft, 1952).

Galena in tin ores in two mines on Belitung has highly radiogenic lead (M.R. Jones and others, 1977; Bruce R. Doe and Maryse Delevaux, written commun., 1975). For a given value of ${ }^{206 \mathrm{~Pb}} /{ }^{204} \mathrm{~Pb}$, the ratios of ${ }^{206} \mathrm{~Pb} /{ }^{204} \mathrm{~Pb}$ and ${ }^{208} /{ }^{204} \mathrm{~Pb}$ are relatively $\mathrm{high}^{2}$, and like those typical of cratonic continental regions. This indicates that old Precambrian

\footnotetext{
$2{ }^{200} \mathrm{~Pb},{ }^{20} \mathrm{~Pb}$, and ${ }^{20 \times} \mathrm{Pb}$ are the daughter products of ${ }^{23 \times} \mathrm{U},{ }^{235} \mathrm{U}$, and ${ }^{232} \mathrm{Th}$, respectively, and ${ }^{204} \mathrm{~Pb}$ is nonradiogenic.
} 
continental basement likely underlies the island and that components from it have been incorporated in the ores and, presumably, in the granites (Bruce R. Doe and Maryse Delvaux, written commun., 1975).

The Tin Islands are the exposed parts of a peneplain, elsewhere submerged, that rises in the islands to altitudes of $30-50 \mathrm{~m}$ and is there eroded to broad, open valleys and low ridges (Verstappen, 1973). Valleys were incised during Pleistocene intervals of lowered sea level, then refilled with sediment. Tin is concentrated in residual placers, on or near the primary deposits, in these valley fills, both onshore and offshore (Aleva, 1973).

\section{JAVA}

The modern structural belts of onshore and offshore Sumatra trend southeastward and inflect abruptly to eastward trends between Sumatra and Java (or Jawa, or Djawa; fig. 7; pl. 1). The continuous offshore features - trench, outer-arc ridge, outer-arc basin-were discussed previously. Mainland Java (described in this section) has a magmatic belt continuous with that of Sumatra and similarly superimposed at least locally upon old rocks, so here too it is apparently coincident with a geanticline. Java has a northern foreland basin, beyond which is the submerged craton of the Java Sea.

Java presents many contrasts with Sumatra. The young volcanic rocks are markedly more mafic in average composition than are those of Sumatra. The late Cenozoic volcanoes rise mostly above Neogene marine strata, rather than above outcropping pre-Tertiary complexes. The basement rocks of Java that are exposed consist of melange of Late Cretaceous or very early Tertiary age. No indication of old continental crust exists.

\section{UPPER CRETACEOUS OR LOWER PALEOGENE MELANGE}

The only pre-Eocene complexes exposed in Java are melange terrains in the southwest and central parts of the island. Mesozoic crystalline and sedimentary rocks have been reached by oil wells in many places beneath Tertiary strata in northern Java and in the Java Sea to the north, but discussion of these is reserved for the section on the Java Sea.

Melange that involves Upper Cretaceous and Paleocene sediments is exposed in three small areas south of the midline of Java (pl. 1). Descriptions of the western of the two areas in central Java have been published by Harloff (1929a, b; 1933), Ketner and others (1976), Loth and Zwierzycki (1926), Tjia (1966), and others. I had the opportunity in 1971 to examine some of the facies of this melange during a field trip led by Sukendar Asikim and J. A. Katili.

The central area of melange in Java is exposed beneath a folded cover of shallow-water and continental sediments, dated poorly within the Eocene. The melange includes widely varied intersliced rock types: greenschist, possibly glaucophane schist, amphibolite, eclogite, serpentinite (fig.
$13 A$ ), peridotite, gabbro, pillow basalt (fig. $13 B$ ), red radiolarian chert and red pelagic limestone (fig. $13 C$ ), scaly clay with sheared lenses of more resistant graywacke and siltstone (fig. 13D), extremely sheared slate with resistant lenses (fig. 13E), pebbly mudstone (fig. 13F), quartz-pebble conglomerate, abundant crushed quartz porphyry, and others. Early Cretaceous foraminifers occur in limestone in the complex, muscovite schist yielded a potassium-argon age of $117 \mathrm{~m} . y$., and sheared quartz porphyry has a fission-track age of 65 m.y. (Ketner and others, 1976). Sukendar Asikim (oral commun., 1972) found Paleocene nannofossils in sheared shale of the melange. A large mass of polymict melange is thrust over coherently deformed sedimentary rocks (Ketner and others, 1976). The quartz porphyry, anomalous here in a melange terrain, may owe its presence to melting caused by subduction beneath the wedge of very young, hot Indian Ocean lithosphere. (See Marshak and Karig, 1977.)

The eastern of the melange areas in central Java, that of the Jivo (Djiwo, Jiwo) Hills, consists of varied greenschist, amphibolite, phyllite, slate, quartzite, limestone, radiolarian limestone, radiolarian chert, and serpentinite, all contorted and highly sheared ('t Hoen, 1930; A. C. D. Bothé, unpub. manuscript, ca. 1940, files of Geological Survey of Indonesia, Bandung). Overlying strata are middle and upper Eocene marls and limestones.

Melange likely occurs also in the southwest corner of Java, where J. Duyfjes (unpub. data, 1941 manuscript report in files of Geological Survey of Indonesia; also Baumann, de Genevraye, and others, 1973) found peridotite, gabbro and albite-epidote amphibolite derived from it, and basalt, all variably altered and sheared. Deformed upper Eocene and younger clastic rocks overlie these crystalline rocks.

\section{PALEOGENE STRATA}

Paleogene sedimentary rocks are exposed in small areas atop these melange terrains, and elsewhere near the south edge of the modern volcanic belt, in southwestern and south-central lava and are known in wells there also (U. Adinegoro, 1973; Baumann, de Genevraye, and others, 1973; van Bemmelen, 1949, p. 103-106; Condon and others, 1975; Effendi, 1974). Beneath low lower Miocene and upper Oligocene shelf limestone with reefs are lower upper Oligocene to upper or middle Eocene marl, and conglomerate, quartz sandstone, shale, and lignite that in part are continental and in part are intercalated with shallow-marine carbonate sediments. The general section is similar to that of the Java Sea continental shelf, described in a subsequent part of this report.

A stable continental shelf may have extended to the edge of the Indian Ocean during much of the Paleogene (fig. 46). Late Cretaceous and Paleocene subduction is recorded by melanges and igneous rocks in the region, and active subduction again from late Oligocene time onwards is 

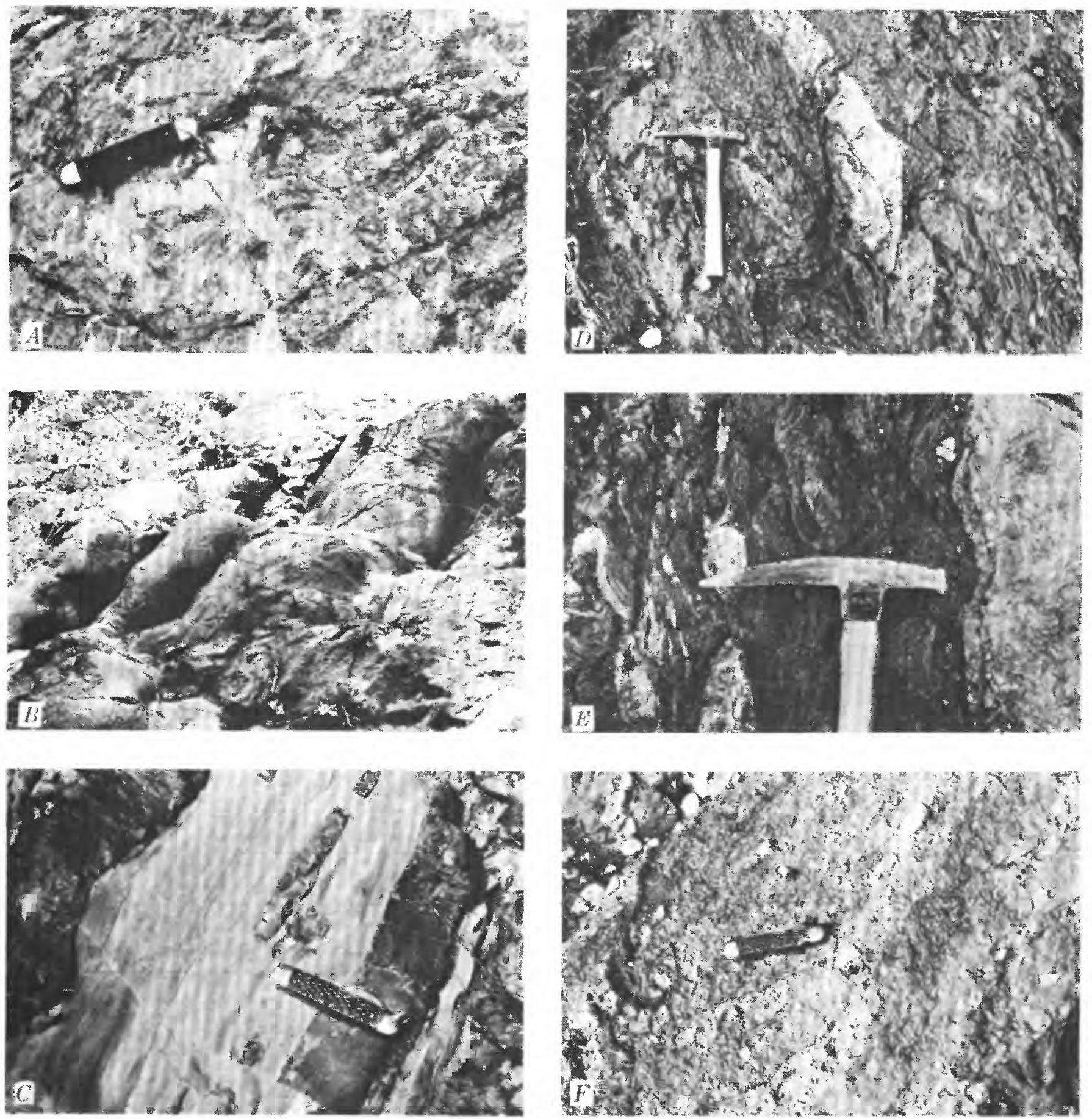

FigitRi 13.-Components of melange formed in very early Teriary time, in central Java near lat $7^{\circ} 30^{\prime} \mathrm{S}$, long $109^{\circ} 40^{\prime}$ E. $A$, Serpentinite. $B$, Pillow basalt, presumably abyssal tholeiite. Pillows are about $1 \mathrm{~m}$ long. $C$. Laminated pink pelagic limestone (light) nodules and layers of red chert (dark), presumably abyssal pelagic sediments. These are intercalated with pillow basalt. $D$, Soft, sheared scaly clay containing lenses of resistant sandstone and siltstone. $E$. Dark, slaty sheared shale containing lenses of hard sandstone. $F$, Pebbly mudstone, the pebbles being mostly angular fragments of sandstone.

indicated by voluminous calc-alkaline volcanic rocks; but the middle Eocene through middle Oligocene may have been an interval of tectonic quiet along this margin. (No proved lower Eocene strata occur in the region according to Adams,
1970.) Tuffs are known within the upper Eocene and lower Oligocene marls, but the eruptive sources are not likely to have been within Java. 
Such a structural and stratigraphic interpretation is counter to long-standing assumptions regarding Javanese geology. Many of the old Dutch reports emphasized that volcanic and volcaniclastic materials are widespread in the Paleogene. (See van Bemmelen, 1949, p. 103-106, for summary and references.) An arc of Eocene and Oligocene volcanic islands is widely assumed to have been present in medial or southern Java. The existence of a chain of active volcanoes within a terrain undergoing deposition first of a sheet of quartzose clastic sediments and then of another sheet of shelf carbonate is, however, difficult to visualize; I suspect, as have others, that the old age assignments for volcanic materials may be erroneous.

The only voluminous volcanic rocks assigned to the Paleogene by the early mappers are the "Old Andesites," a designation based merely on the appearance of the rocks. Shapely volcanic cones were assigned to the Quaternary, deeply eroded volcanic rocks to the Neogene, and altered or deformed rocks to the Paleogene. Only latest Paleogene volcanic materials appear to have yet been dated firmly by their presence within sections of fossiliferous sedimentary rocks. Volcaniclastic rocks as old as late Oligocene have been dated in the Shell Alveolina 1 well, south of Java near long $110^{\circ}$ E. (M. W. Hughes Clarke, written commun., 1975). Other upper Oligocene or lower Miocene volcanic rocks have been reported in, or nearby offshore from, southern Java by Baumann, de Genevraye, and others (1973), Bolliger and de Ruiter (1976), and Mulhadiyono (1973). Floods of volcanic debris appear in sediments from late early Miocene or middle Miocene age upwards.

Although a number of the early Dutch geologists reported that volcanic and volcaniclastic rocks occur in formations containing undoubted middle or upper Eocene and Oligocene large foraminifers, their conclusion is questionable. J. Duyfjes (unpub. 1941 manuscript report in files of Geological Survey of Indonesia) argued that Paleogene conglomerates studied by him in southwest Java, considered previously to have been derived from a contemporaneous volcanic terrain, were in fact polymict conglomerates derived from highlands of pre-Tertiary rocks that included many kinds of nonvolcanic rocks. Mapping by Effendi (1974) and his associates in southwest Java clearly separates nonvolcanic Paleogene and low lower Miocene sedimentary rocks from volcanigenic higher Neogene formations, in a region in which the early reconnaissance mappers confused the two as intercalated. The rocks are much deformed, and it is easy to see, by study of Effendi's relatively detailed map, how the early mappers overlooked faults, folds, and unconformities that juxtapose unlike units which were lumped together on the old maps. A volcanigenic unit in south-central Java mapped as "Eocene" by C. ter Haar is now known to contain lower Miocene pelagic foraminifers (Mulhadiyono, 1973). Reworking of large foraminifers as clasts into younger sandstones is another likely explanation for some of the old age assignments.
Sutan Assin and Tarunadjaja (1973) stated that K-Ar dating shows some unfossiliferous pre-middle Miocene volcanic rocks to be "Eocene/Oligocene" in age, but no data are available for evaluation. Detailed studies are obviously needed to resolve the ambiguities.

The significance of the Paleogene regime is discussed in the section on the Java Sea.

\section{LATE CENOZOIC VOLCANOES}

Most of the many active volcanoes of Java are stratovolcanoes arrayed along a medial zone (pl. 1; figs. 14, 15). Pyroxene andesite and high-alumina basalt are the dominant rock types of the main volcanic belt (Neumann van Padang, 1951; Nicholls and Whitford, 1976; Whitford and Nicholls, 1976). Dacite is quite subordinate, and large masses of silicic rocks such as those of Sumatra are absent. In the north part of Java, young but inactive volcanoes are dominantly of potassic alkalic rocks (Brouwer, 1928; Klompe, 1954). Ratios of potassium to silicon tend to correlate with height above the present Benioff zone (Hatherton and Dickinson, 1969; C. S. Hutchison, 1975, 1976; Whitford and Nicholls, 1976). Geologic maps illustrating relationships between eruptive products of active volcanoes include those by Condon, Pardyanto, and Ketner (1975) and Thaden, Sumadirdja, and Richards (1975).

The belt of active calc-alkalic volcanoes is superimposed upon older volcanic and volcaniclastic rocks, which are intercalated with Oligocene and Neogene sediments and are intruded by small plutonic masses of similar composition (Baumann, de Genevraye, and others, 1973; Baumann, Oesterle, and others, 1973; de Genevraye and Samuel, 1973; Mulhadiyono, 1973; Rutten, 1926). The main magmatic belt lay in about its present position during most of Miocene and Pliocene time, but during the late Oligocene and early Miocene it lay closer to what is now the south coast. The composition of upper Neogene sediments indicates that the volcanic rocks are in general more basic in the east than in the west (Rutten, 1926), although such a progression is not obvious in the active-volcano data of Whitford and Nicholls (1976).

The sediments of the deep-ocean floor south and southwest of Indonesia record two periods of particularly voluminous explosive volcanism in the Indonesian region-one in the early late Miocene, the other in the late Pliocene and Quaternary (Kennett and Thunell, 1975). Presumably these peaks correlate with peak magmatism in the arc.

\section{CRIISTAL COMPOSITION}

The relatively basic composition of the dominant volcanic rocks is taken to indicate that a silicic continental crust has not yet been built beneath the main volcanic axis of Java. This accords with the presence of melange of Late Cretaceous or very early Tertiary age in exposures within the magmatic belt. Java has a crust of continental thickness (fig. 10) which has, however, been built only recently by subduction-zone 
$111^{\circ} 00^{\prime}$

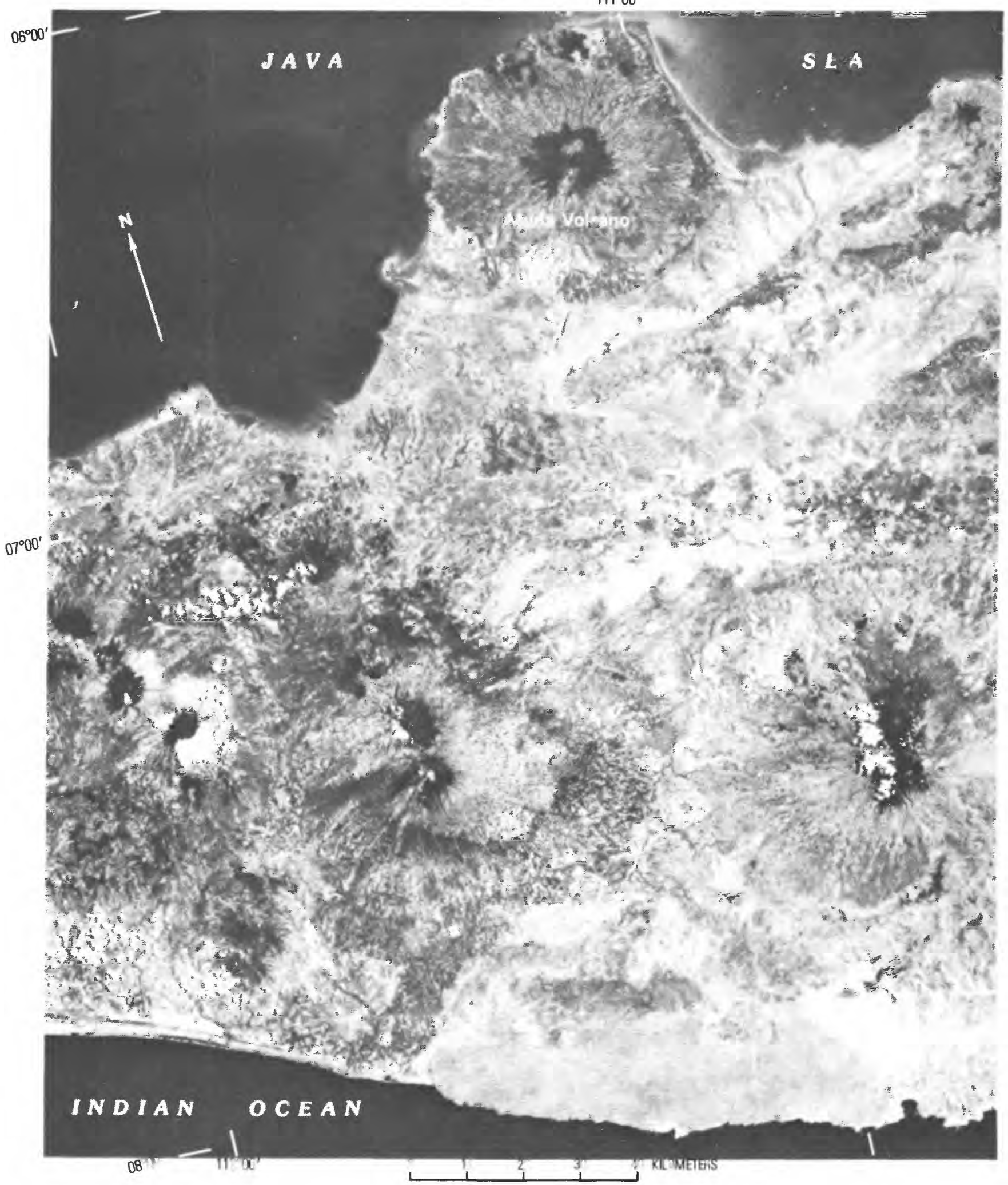

Figini 14. - Landsat image of central Java. The main belt of active volcanoes, trending east-southeast from about lat $7^{\circ} 15^{\prime} \mathrm{S}$. to $7^{\circ} 40^{\prime} \mathrm{S}$., is of calc-alkalic rocks, whereas large Muria (Muriah) volcano is of potassic alkalic lavas. Neogene strata fill the basin north of the main volcanic belt. NASA-ERTS pictures 1067-2145 and -2152, and 1103-2151, September and November 1972. 


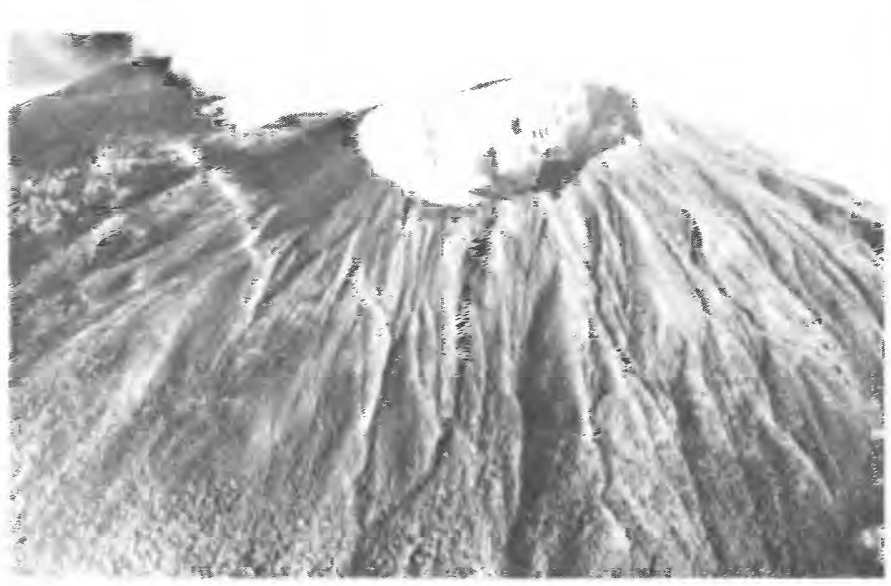

FIGLRE 15. - Aerial view southward at active andesitic Ceremai (Tjeremai, Cheremai) Volcano, northwest Java. Location approximately $6^{\circ} 55^{\prime} \mathrm{S}$. $108^{\circ} 25^{\prime}$ E.; summit altitude $3,080 \mathrm{~m}$. June 1976.

accretion plus arc magmatism, and which has yet to achieve a fully continental, silicic character. That the crust is likely thicker or more silicic in west Java than in the east is suggested by the more silicic character of the young volcanigenic sediments in the west than in the east and by the progression in strontium isotopic composition.

\section{SIRONIIIM ISOIOPES}

Within the narrow belt of normal calc-alkalic volcanism, the strontium-isotopic composition of young volcanic rocks tends to become less radiogenic eastward from west Java to east Java and Bali (Whitford, 1975). The ratio of ${ }^{87} \mathrm{Sr} /{ }^{86} \mathrm{Sr}$ is near 0.705 in the west, 0.704 in the east. This is suggestive of increasing contamination of mantle magma by the crustal material through which it rises, going westward along the arc. Strontium also tends to become more radiogenic northward across the strike of the arc in Java, a trend presumably related to the same (but not yet understood) factors as those which produce the parallel potassium enrichment.

\section{NEOGENE SEDIMENTATION AND DEFORMATION}

The foreland basin of northern Java and the nearby offshore area is the site of active deformation and sedimentation. Two deeply filled alined subbasins, West Java and Madura Basins, are separated by a basement high (pl. 1). The sedimentary rocks record a marine transgression during the Oligocene, bathyal marine conditions during the earlier part of the Miocene, and regression during the later Neogene, through decreasingly marine conditions to the present largely continental setting. The lower Neogene clastic sediments were derived in large part from old crystalline sources to the north but in part came from volcanic islands along the magmatic arc that fringed the basin on the south, and the sediments indicate shallow water in the north but bathyal depths and turbiditic deposition in the medial parts of the basin (Baumann, Oesterle, and others, 1973; Rutten, 1926; Weeda, 1958a). The higher Neogene is in regressive, shallower water facies; clastic materials came mostly from volcanoes to the south, and reef limestones characterize the northern areas. The age of the oldest abundant volcanic material becomes progressively younger northward (Rutten, 1926), and both progressive basining - the sedimentary axis migrating northward as folds developed in the south - and a northward shift of the magmatic axis during Miocene time seem indicated. Shallow-water shelf conditions prevailed in the northern parts of the subbasins, where lower or middle Oligocene limestone is overlain by upper Oligocene to middle Miocene limestone, marl, and clay, and by upper Miocene to Quaternary clay and marl (A. R. U. Adinegoro, 1973; Baumann, Oesterle, and others, 1973.)

In the West Java Basin, folding began in the Miocene in the south while sedimentation continued in the north, where northward-directed folds and thrusts were produced (Ringkasan, 1963). Deformation is less severe in the north-central Java region of thinner sedimentation (fig. 16). The southern part of the Madura Basin is deformed intensely, the medial part is synclinal and folded gently, and the northern part is deformed moderately (Weeda, 1958a). Dips in anticlines become progressively more gentle with decreasing age of the sediments, but even upper Quaternary materials are deformed (for example, Duyfjes, 1938); folds have grown during sedimentation, and no distinct brief episodes of folding have occurred. Shale rises into anticlines in the Strait of Madura (Sudiro, 1973). Oil fields in the West Java Basin are in sand reservoirs above basement highs (Patmosukismo and Yahya, 1974), whereas fields in the onshore western part of the Madura Basin are in quartz sandstones and calcarenites in small culminations on long, narrow anticlines (Soetanti and others, 1973). Bioherms

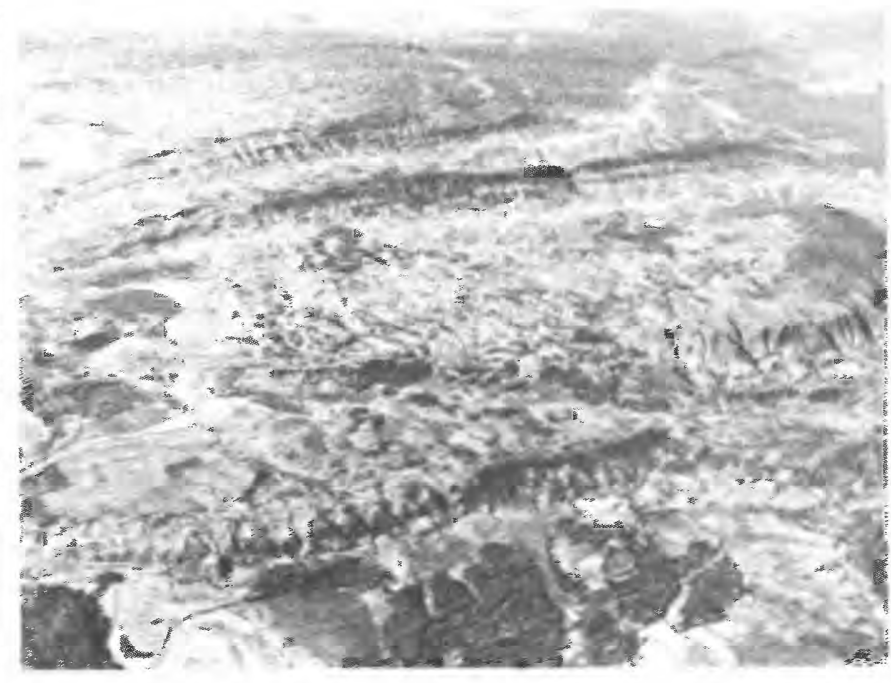

Figure 16.- Oblique aerial photograph northward over openly folded Neogene strata. North-central Java near long $109^{\circ} 15^{\prime} \mathbf{E}$. 
provide the likely exploration targets still farther east (Cree, 1972). Geothermal gradients are moderate, mostly about $4-5^{\circ} \mathrm{C} / 100 \mathrm{~m}$, in the West Java and Madura Basins (Kenyon and Beddoes, 1977).

Presumably much of the Neogene downbowing of the crust to produce the sedimentary basins of Java has been the result of depression by the weight of the volcanoes and plutons loaded atop the anticlinorial magmatic belt. The deformation of the sediments, which represents both an outward sliding of strata and a lateral compression of basement, also may be produced primarily by magmatism, partly by gravitational flow of the upper crust and its sedimentary cover in response to magmatic loading, and partly by spreading of the crust in the magmatic belt by intrusions within it. Compressional structures in Neogene materials tend to arc concentrically around, and to be directed outward from, large volcanic edifices, both active (Djuri, 1975) and much eroded (Kastowo, 1975). The marine regression of the late Neogene presumably was caused by the increased supply of volcanigenic sediments from the magmatic belt.

\section{STRIKE-SLIP FAILTS}

No evidence suggests that major strike-slip faulting has affected onshore Java. The lack of obvious major lineaments on satellite imagery (fig. 14) makes the presence of such faulting improbable. Strike-slip faults parallel to the east-west trend of the island are particularly unlikely, for that is nearly perpendicular to the approach direction of the Indian Ocean plate. Tjia (1968) speculated that a north-facing scarp, $22 \mathrm{~km}$ long, in west-central Java, marks a minor fault with dominantly left-lateral strike-slip offset.

\section{GRAVITY SLRVEY}

A reconnaissance Bouguer-anomaly gravity map of Java was compiled by Untung (1974). He used throughout a reduction density of $2.5 \mathrm{~g} / \mathrm{cm}^{3}$ - too high for the sedimentary basins, but too low for the volcanic terrains.

\section{INDIAN OCEAN} DESC:RIPTION

The deep Indian Ocean lies south and west of the Java-Sumatra Trench. Within the area of the tectonic map of the lndonesian region ( $\mathrm{pl} .1$ ), the water depth is mostly near $5,000 \mathrm{~m}$. Thick clastic sediments overlie the oceanic crust near Australia and also in the far northwest part of the map area west of the trench, but most of the ocean floor within the map area has only a thin cover of pelagic sediments (Ewing and others, 1969). The east flank of the submarine Ninetyeast Ridge extends into the west edge of the map area. A Paleogene volcanic island (Christmas), a coral island on a volcanic base (Cocos), and some volcanic seamounts rise from the ocean floor within the map area (fig. 17).

The Indian Ocean bathymetry shown on the maps of the Folio of the Indonesian Region (p. 1; Hamilton, 1974a, b, 1978a; U.S. Geological Survey, 1974) is based on 1968 contouring by Robert L. Fisher. Fisher subsequently revised the bathmetry of the region west of long $103^{\circ} \mathrm{E}$., and the improved version was published by Sclater and Fisher (1974, fig. 1) and by Udintsev (1975). The revised map is particularly better than the folio base map in depicting north-trending fracture zones in the western Wharton Basin.

\section{WHARTON BASIN}

The northeastern part of the Indian Ocean is the abyssal Wharton (or West Australian) Basin, which lies between the Ninetyeast Ridge on the west and Australia on the east and between the Java-Sumatra Trench on the north and the submarine ridges trending west-northwestward from southwestern Australia on the south. The north half of the basin is within the area of the tectonic map of the Indonesian region. Water depths exceed $6,000 \mathrm{~m}$ in the central part of the basin. The basin typically has a rough oceanic basement veneered thinly by pelagic sediments (fig. 18), although extensive abyssal turbidites, the east lobe of the Bengal abyssal fan (figs. 2l-23), come into the basin from the Ganges-Brahmaputra Delta region far to the northwest, and less extensive turbidites cover the eastern part of the basin near Australia (figs. 24-26). Reflection profiles along long tracks zig-zagging about the Wharton Basin and the western submerged margin of Australia are presented and discussed by Veevers, Heirtzler, and others (1974, p. 339-381).

The floor of the Wharton Basin is of Late Jurassic and Early Cretaceous age near Australia and of progressively younger Cretaceous and early Tertiary age westward and northward. The older part of the basin formed as India (and some other Asian subcontinent?) drifted northeastward away from Australia in the Late Jurassic and Early Cretaceous, and the younger part formed as a spreading ridge migrated northward during the Late Cretaceous and Paleogene.

Nine of the Deep Sea Drilling Project (DSDP) drillholes lie at abyssal depths in the Wharton Basin (von der Borch, Sclater, and others, 1973; Heirtzler and others, 1973; Luyendyk and Davies, 1973; Veevers and Heirtzler, 1973; Veevers, Heirtzler, and others, 1974). Most reached basalt. In hole 211 , south of southeast Sumatra (figs. 6, 7; lat $9^{\circ}$ $47^{\prime}$ S., long $102^{\circ} 42^{\prime}$ E.), Quaternary and upper Pliocene pelagic silicic ooze and minor ash overlie Pliocene turbidite silt and sand, and silicic ooze; beneath these is undated pelagic brown clay; at the base of the section is nannofossil ooze and clay of Maestrichtian and early Campanian (Late Cretaceous) age, and under that altered basalt. Hole 213 , closer to the Ninetyeast Ridge (fig. 20; lat $10^{\circ} 13^{\prime} \mathrm{S}$., long $\left.93^{\circ} 54^{\prime} \mathrm{E}\right)$, penetrated pelagic sediments, which are of late Paleocene age at their base, just above ferromanganese-oxide sediment and basalt. Hole 212 is in the middle of the basin $\left(19^{\circ} 12^{\prime} \mathrm{S} ., 99^{\circ} 18^{\prime} \mathrm{E}\right.$.); its sediment are pelagic clays

FIGURE 17 (facing page).-Location of seismic-reflection profiles shown in figures 21,22 , and 23 . 
INDIAN OCEAN

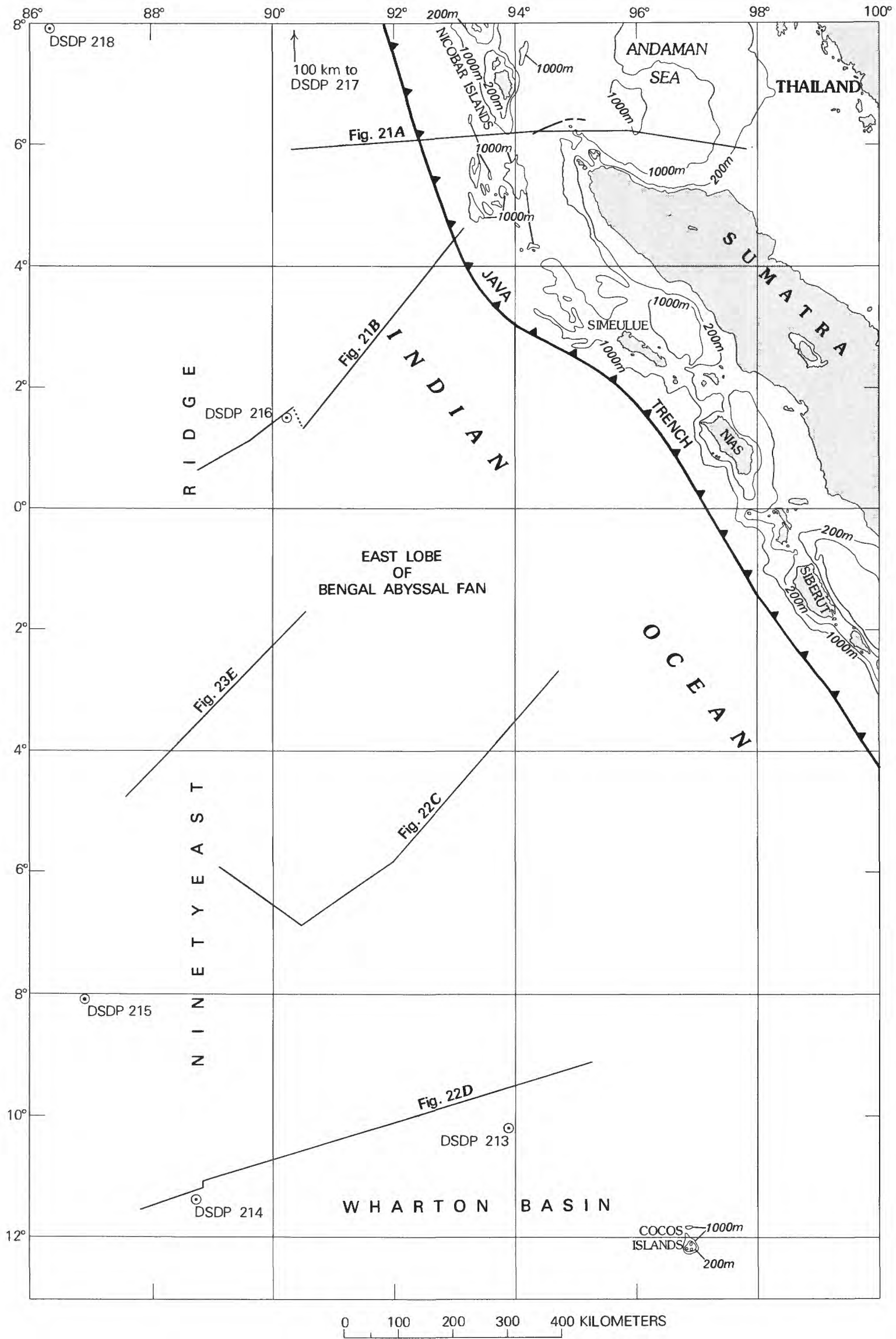



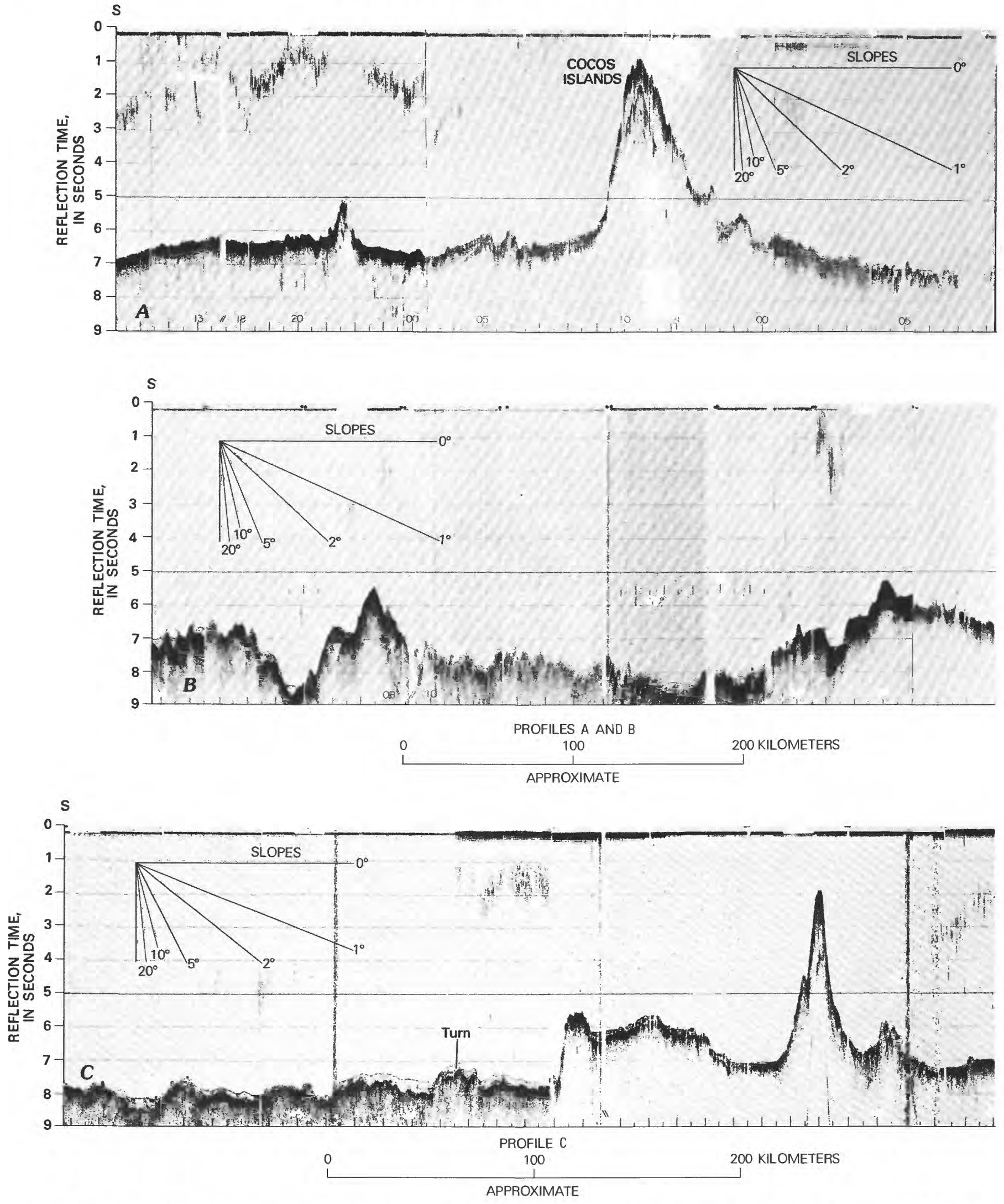

FIGURE 18 (facing page and above).-Seismic-reflection profiles in the Indian Ocean south of Sumatra. Thin pelagic sediments veneer the rough basement. The basal sediments in DSDP drillhole 211, which is near the north end of line $C$, are Campanian (high Upper Cretaceous). Paleocene. Location of profiles and DSDP drillholes shown on figure 5. Profiles from Lamont-Doherty Geological 

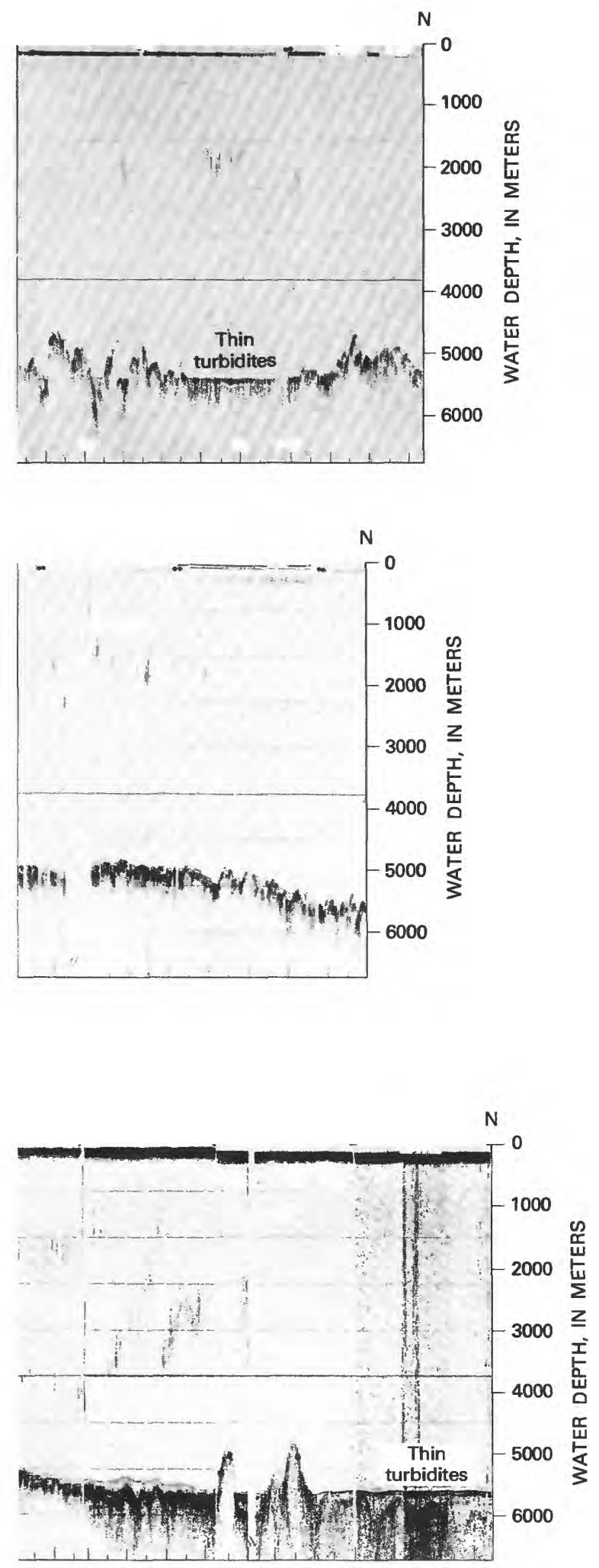

Observatory, R. V. Vema cruise $28(A$ and $B$ ) and R. V. Robert Conrad cruise $14(C)$. and redeposited calcareous ooze and chalk, and the basal strata above basalt are of approximately middle Cretaceous age. Three holes in the southern part of the basin $\left(256: 23^{\circ} 28^{\prime}\right.$ S., $100^{\circ} 47^{\prime}$ E.; $257 ; 30^{\circ} 59^{\prime}$ S., $108^{\circ} 21^{\prime}$ E.; $259: 29^{\circ} 37^{\prime}$ S., $112^{\circ} 42^{\prime}$ E.) yielded mostly clays, of which the lower parts yielded cold-water Early Cretaceous foraminifera, lying upon basalt. Holes 260 and 261 (pl. 1; fig. 5), on the abyssal plain off northwestern Australia, are at $16^{\circ} 09^{\prime} \mathrm{S} ., 110^{\circ} 18^{\prime} \mathrm{E}$., and $12^{\circ} 57^{\prime}$ S., $117^{\circ} 54^{\prime}$ E., respectively. Hole 260 cut turbidite-redeposited nannofossil, foraminiferal radiolarian, and clay oozes of Paleocene to Quaternary age, overlying Upper and Lower Cretaceous clays and oozes, and basaltic basement. At hole 261, Neogene pelagic clay and carbonate ooze overlie Upper Jurassic and Cretaceous claystone, which overlies basalt. Hole 263 , on the abyssal plain off western Australia at $23^{\circ} 20^{\prime} \mathrm{S}$., $110^{\circ} 58^{\prime} \mathrm{E}$., cut upper Neogene turbiditic calcareous oozes above middle Cretaceous clays; basement was not quite reached.

The DSDP holes show that sediments are largely lacking in two intervals, one in the Upper Cretaceous or lower Paleogene or both, and the other in the Oligocene. These hiatuses were attributed by Davis, Weser, Luyendyk, and Kidd (1975) to variations in water circulation and sediment supply owing to the opening of the southern oceans and to changing Antarctic climates.

The cores show explosive volcanism-presumably in the Java-Banda Arc to the north-to have been particularly voluminous during the late Pliocene and Quaternary (Kennett and Thunell, 1975). The oldest widespread volcanism recorded is early late Miocene - whether the lack of older tuff is due to paleodistance from the arc or to lack of volcanism is not obvious-and the intervening latest Miocene through middle Pliocene interval was one of more subdued volcanism.

The DSDP holes disprove the conjecture by Dietz and Holden (1971) that the Wharton Basin represents pre-Mesozoic oceanic crust. Their speculation was based upon their reconstruction of the Gondwana continents for late Paleozoic time, for they hypothesized that the Wharton Basin floor had then separated India and Australia. The initial rationale was based on a dubious fit of Africa against Antarctica.

The basement rocks of DSDP hole 211 consist of diabase intrusive into thin basaltic lava flows that are variably amphibolitized (Hekinian, 1973) and that have a whole-rock $\mathrm{K}$-Ar age of about 71 m.y. (Ian McDougall in von der Borch, Sclater, and others, 1973, p. 377-379). Hole 212 encountered pillow lavas altered to chlorite-quartz-pumpellyite metamorphic mineral assemblages indicative of a pressure of greater than 1 kilobar and a temperature of about $200^{\circ} \mathrm{C}$ (Hekinian, 1973). (Metamorphism of oceanic crust is a normal process accompanying the formation of the crust - Bonatti and others (1975), Cann (1974), and Spooner and Fyfe (1973) - but the pumpellyite produced here is unusual.) Hole 213 penetrated a series of pillow-basalt flows, 


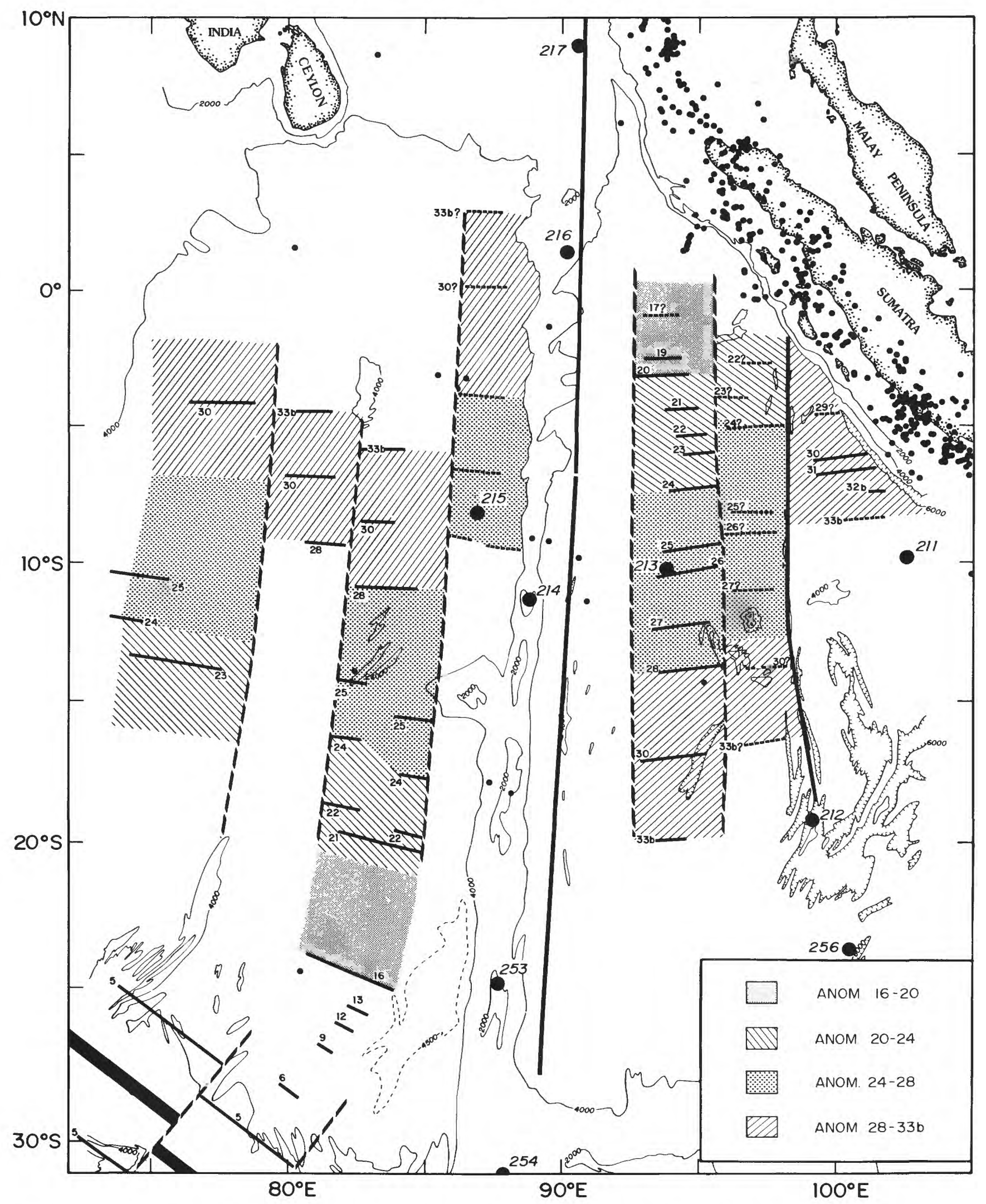

FIGURE 19.- Magnetic anomalies recognized in the eastern Indian Ocean by John G. Sclater. Anomalies (Anom.) 16, 20, 24, 28, and 33b are approximately 39, 46, 56, 64, and 71 m.y. old, respectively, according to Sclater and Fisher (1974, fig. 2). Localities of DSDP holes 211-217, 253, 254, and 256 are shown. Reprinted from Sclater and Fisher (1974, fig. 9), by permission of the authors and the Geological Society of America. 


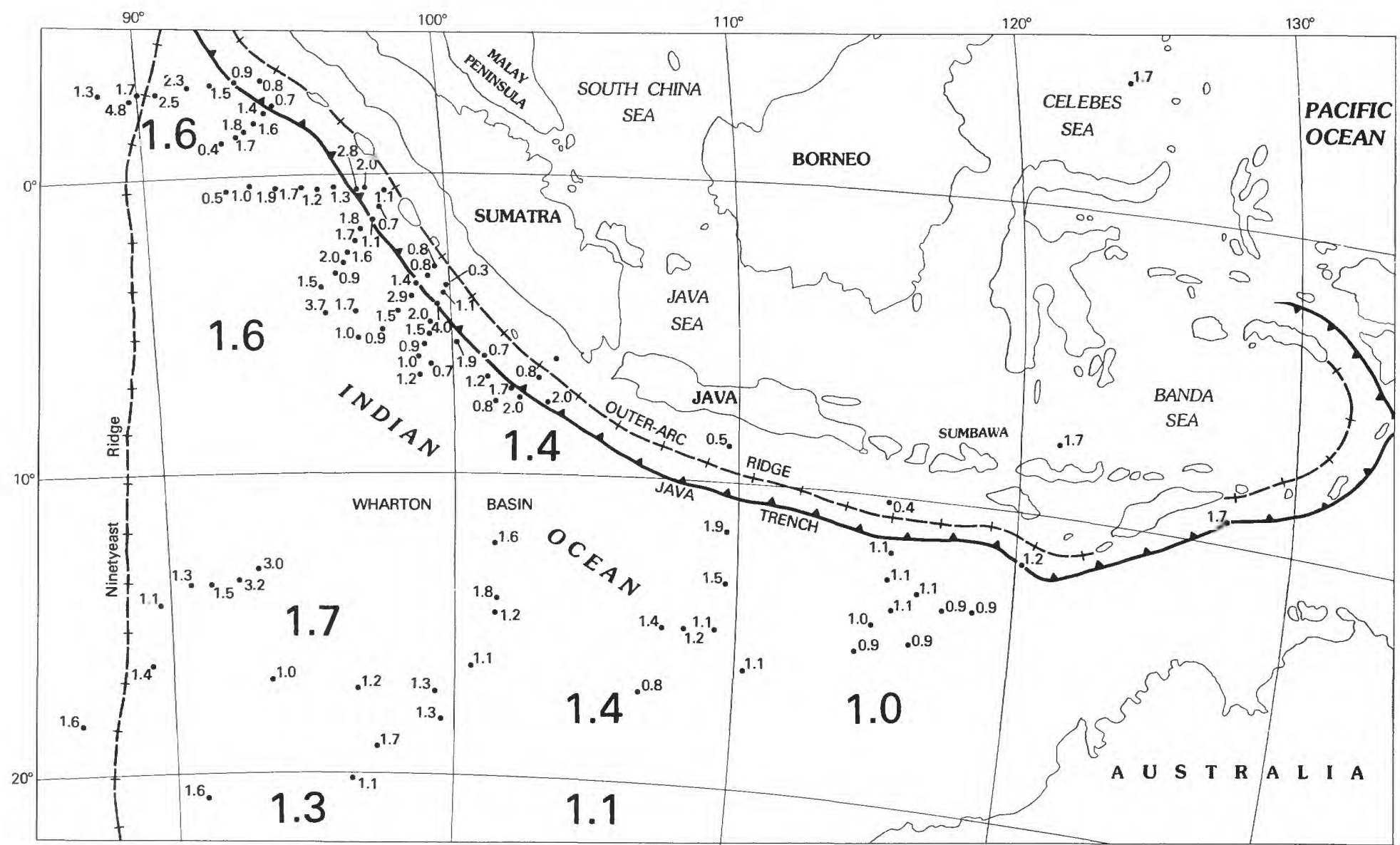

FIGURE 20.- Heat flow in shallow holes in sediments of the northeastern Indian Ocean, in microcalories per square centimeter per second. Large gray numbers in each $10^{\circ} \times 10^{\circ}$ square give mean heat flow on deep ocean floor seaward of axis of trench; in far south, other determinations within the squares but outside the figure area are included in the means. From a compilation by R. P. von Herzen, M. G. Langseth, J. G. Sclater, and G. B. Udintsev (in Udintsev, 1975, p. 107) of determinations in the American and European literature through 1970 and in the Soviet literature through 1972.

distinguished by contents of $\mathrm{K}_{2} \mathrm{O}(0.4-1$ percent by weight) that are high for ocean-floor basalts. The basalts of holes 259,260 , and 261 are of spreading-ridge, abyssal-tholeiite types, except that a flow or sill above the tholeiite basement in 261 is strongly fractionated and likely represents later intraplate magmatism (P. T. Robinson and D. J. Whitford, in Veevers, Heirtzler, and others, 1974, p. 551-559).

Northward motion of the Wharton Basin floor during Cenozoic time, and gradual subsidence after formation along spreading crests, is indicated by the character of the abyssal sediments (von der Borch, Sclater, and others, 1973), by the foraminifers within them (Viera Scheiberova, in Veevers, Heirtzler, and others, 1974, p. 697-741), and by paleomagnetic inclinations of basement basalts (R. D. Jarrard and J. G. Sclater, in von der Borch, Sclater, and others, 1973, p. 369-375; Pierce, 1976). Mismatches between Wharton Basin and Australian paleomagnetic latitudes suggest that the basin may have moved a little south relative to Australia since Paleocene time, along a strike-slip fault near the west edge of Australia (Pierce, 1976).

Holes 260,263, and 259, listed in order southward, lie near the base of the Australian continental slope, between lats $16^{\circ}$ and $30^{\circ} \mathrm{S}$.; all reached basalt beneath Lower Cretaceous sediments, whereas 261 , at $13^{\circ}$ S., encountered Upper Jurassic materials above basalt. The ocean floor near the continent south of $16^{\circ} \mathrm{S}$. is apparently about $30 \mathrm{~m} . \mathrm{y}$. younger than that near $13^{\circ} \mathrm{S}$.

The history of formation by sea-floor spreading of various parts of the Wharton Basin can be specified from magnetic-anomaly bands, as calibrated by the deep-sea drilling results (fig. 19; pl. 1). The oldest known part of the basin is the extreme northeast, between northwestern Australia and the Java Trench south of Sumbawa, where Late Jurassic (Oxfordian and Kimmeridgian) anomalies trend east-northeastward, become younger northwestward, and define a half-rate of spreading of about $4.4 \mathrm{~cm} / \mathrm{yr}$ 

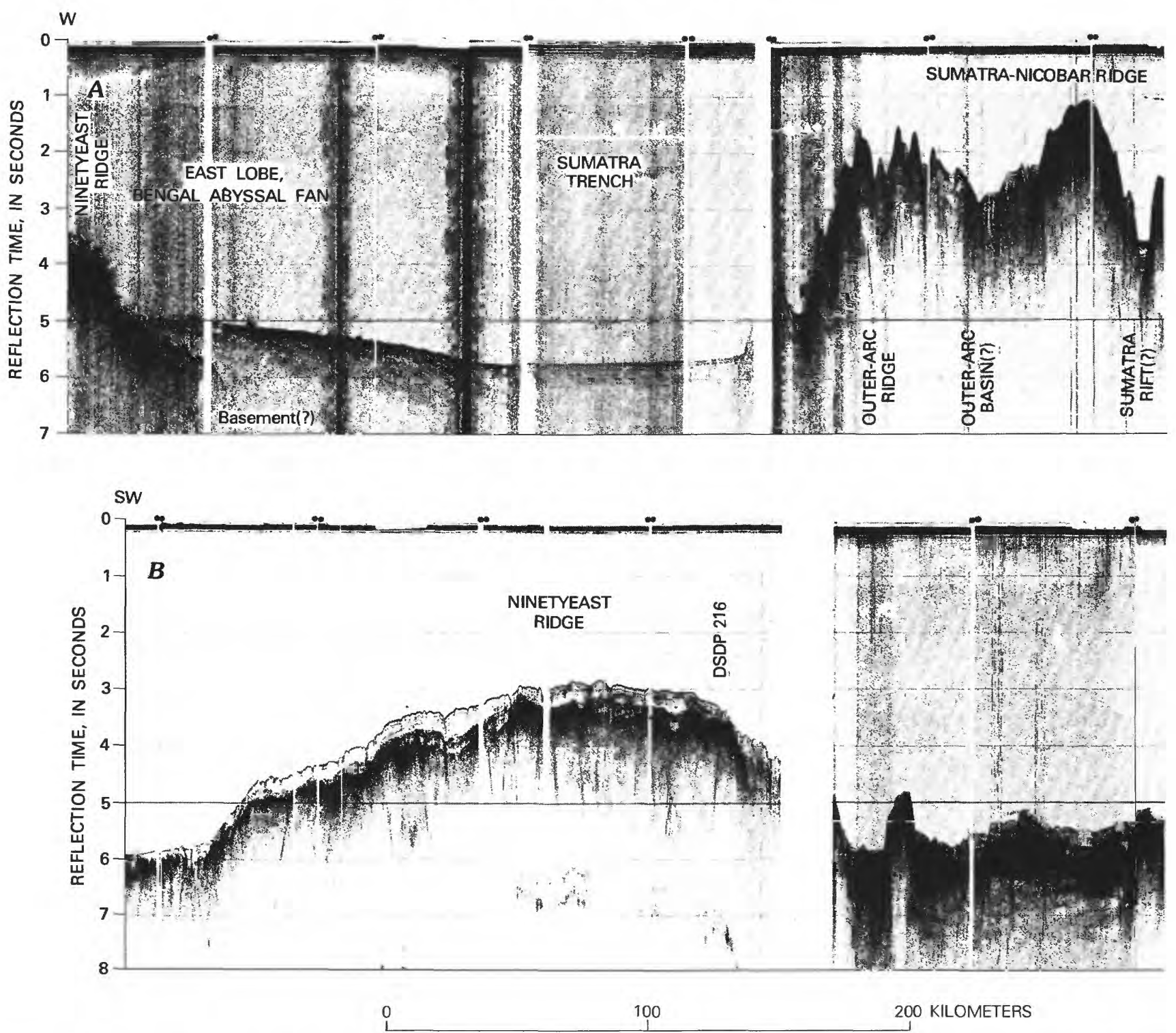

FIGURE 21.-Seismic-reflection profiles in the region of the Wharton Basin, Ninetyeast Ridge, and Andaman Sea. The Bengal abyssal fan, formed of turbidites mostly from the Ganges and Brahmaputra Rivers (which empty into the Bay of Bengal 1,500 km north of profile $A$ ), divides into lobes around the Ninetyeast Ridge. The fan thins southward; in this series of profiles, (figs. 21-23) the sediments are very thick in the north $(A)$, considerably thinner a little to the south $(B)$, and feather out southward, filling depressions in the rough basement topography (figs. 22C, 23E). Still farther south, no turbidites are present (fig. 22D). Ninetyeast Ridge follows a transform fault active primarily in Late Cretaceous and early Tertiary time; the ridge becomes younger northward. The voluminous fan sediments show a slight downward increase in dip inthe Sumatra Trench $(A, B)$; sedimentation has been concurrent with tilting as the oceanic plate has planed downward into the subduction zone. Location of profiles shown in figure 17. Profiles from Lamont-Doherty Geological Observatory, R. V. Robert Conrad cruise 14.

(Larson, 1975; also Falvey, 1972, and Heirtzler and others, 1973). The southern part of the basin, west of southwest Australia, is distinctly younger: Early Cretaceous anomaly bands trend north-northeastward, become younger northwestward, and record a half-rate of spreading of about $2.1 \mathrm{~cm} / \mathrm{yr}$ (Larson, 1977; Markl, 1974). Farther west in the south, ambiguous data suggest that the same Early Cretaceous anomalies may be present in inverted order, symmetrical about an extinct spreading axis trending northeastward through lat $30^{\circ} \mathrm{S}$., long $102^{\circ} \mathrm{E}$., (Markl, 1974)

There was thus a marked change in spreading direction and rate during middle Cretaceous time (Larson and others, 1978). The northwest half of the Wharton Basin is marked by east-trending anomaly bands that become younger northward, at least as far north as lat $2^{\circ} \mathrm{S}$., from Late 

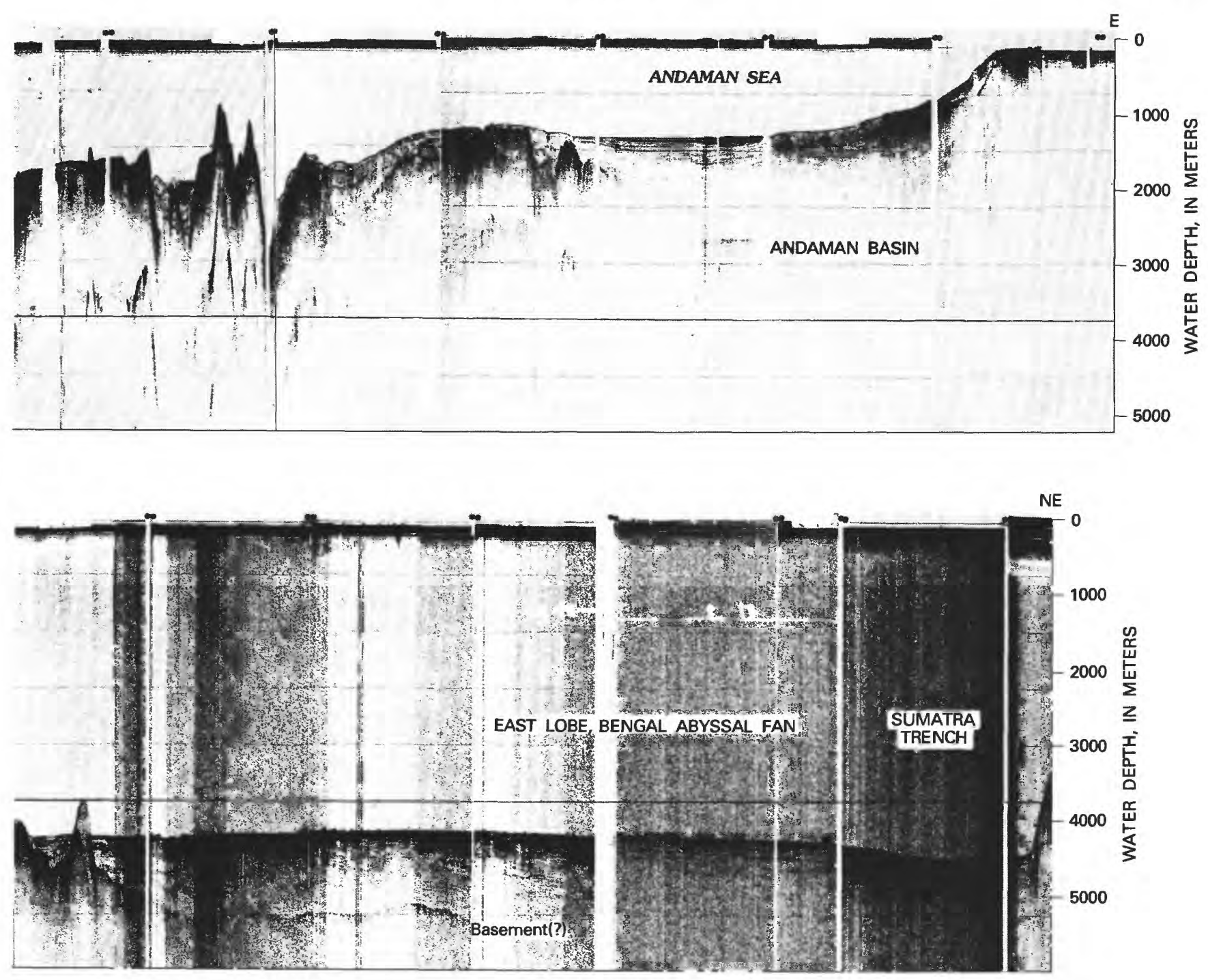

Cretaceous to early Tertiary (fig. 19; Sclater and Fisher, 1974). A major transform fault trends northward along the Investigator Ridge, near long $98^{\circ}$ E. (Larson and others, 1978; Sclater and Fisher, 1974). The anomalies in the northwest part of the basin record a half-rate of spreading of about $10 \mathrm{~cm} / \mathrm{yr}$ between about 71 and $55 \mathrm{~m} . \mathrm{y}$. ago but only about $4 \mathrm{~cm} / \mathrm{yr}$ between 55 and 44 m.y., and possibly until about $41 \mathrm{~m} . \mathrm{y}$. or later; the slowdown approximately correlates with the beginning of spreading of the ocean between Australia and Antarctica.

Seismic-refraction studies demonstrate the expected oceanic structure of the crust, which is typically about $8 \mathrm{~km}$ thick, beneath the basin (Curray and others, 1977; Francis and Raitt, 1967; Larson and others, 1978). Compressional velocities in the uppermost mantle may be 5 or 10 percent higher parallel to spreading directions (as defined by magnetic lineations) than perpendicular to them, presumably because of the crystallographic orientation of olivine in the flow direction (Shor and others, 1973).
The mean heat flow in the Wharton Basin increases northward and westward, from about 1.0 to about 1.6 microcal $/ \mathrm{cm}^{2} \mathrm{sec}$ (fig. 20), as expected from the varying age of the oceanic lithosphere. Heat flow is lower at stations on the melange wedge, between the Java Trench and the outer-arc ridge just north of it, because of the rapid tectonic accumulation of cold melange and of the presence beneath it of subducting cold oceanic crust.

Water depth in the basin shows a rough correlation with age of its oceanic crust, as expected from similar relationships elsewhere.

\section{NINETYEAST RIDGE}

The great submarine Ninetyeast Ridge trends slightly east of north, approximately along long $90^{\circ} \mathrm{E}$., nearly straight for $4,800 \mathrm{~km}$ from the north slope of the Indian-Antarctic Midocean Ridge to the Bay of Bengal, where it is buried beneath the thick sediments of the Bengal abyssal fan (Heezen and Tharp, 1965a; Laughton and others, 1970). The 


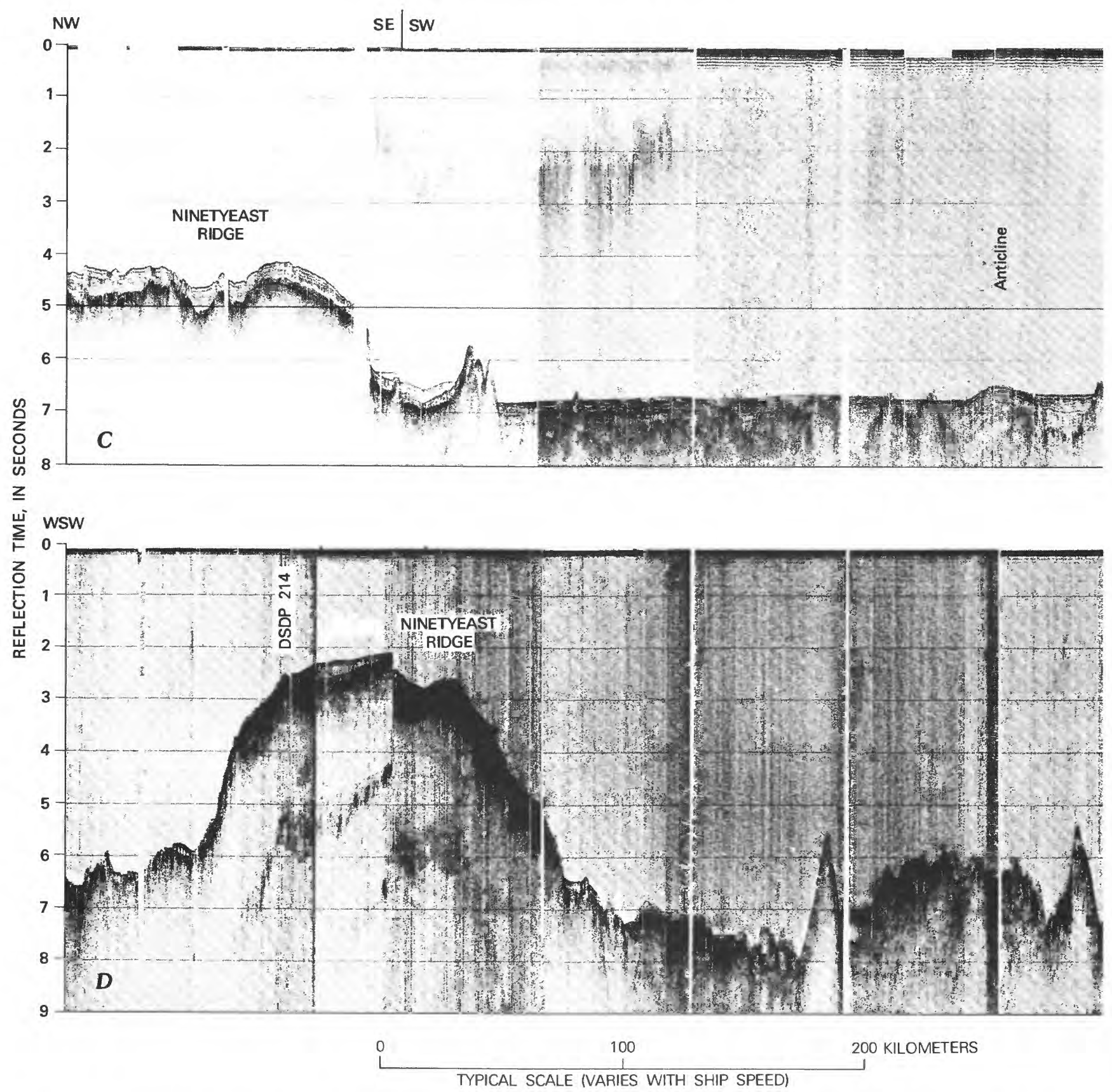

FIGURE 22,-Seismic-reflection profiles in the region of the Wharton Basin and Ninetyeast Ridge. The turbidites of the Bengal abyssal fan feather out southward, filling depressions in the rough basement topography ( $C$ and fig. 23E). Still farther south, no turbidites are present $(D)$. Ninetyeast Ridge follows a transform fault active primarily in Late Cretaceous and early Tertiary time; the ridge becomes younger northward. Location of profiles shown in figure 17. Profiles from Lamont-Doherty Geological Observatory, R. V. Vema cruises $24(D)$ and $29(C)$.

ridge is about $200 \mathrm{~km}$ wide, and most of it has crestal depths between 1,500 and $3,000 \mathrm{~m}$ and stands $2,000-4,000 \mathrm{~m}$ above the flanking basin floors (figs. 21, 22, 23). The ridge is now only moderately seismic, and its broad crest and scarps are mantled by pelagic sediments. Five holes of the Deep Sea Drilling Project (DSDP) have been located on the ridge (fig. 19; von der Borch, Sclater, and others 1973, Kemp and
Harris, 1975; Luyendyk and Davies, 1973). The basal sediments on the basaltic basement of the ridge become older northward: they are Oligocene in hole 254 (lat $30^{\circ} 58^{\prime} \mathrm{S}$., long $87^{\circ} 54^{\prime}$ E.), middle Eocene in $253\left(24^{\circ} 53^{\prime}\right.$ S., $87^{\circ} 22^{\prime}$ E.), Paleocene at 214 (fig. $20 ; 1^{\circ} 20^{\prime}$ S., $88^{\circ} 43^{\prime}$ E.), and late Maestrichtian (latest Cretaceous) at hole 216 (fig. 20; $1^{\circ} 27^{\prime}$ S., $90^{\circ} 13^{\prime}$ E.). Hole 217 (fig. $20 ; 8^{\circ} 56^{\prime}$ N., $90^{\circ} 32^{\prime}$ E.) 

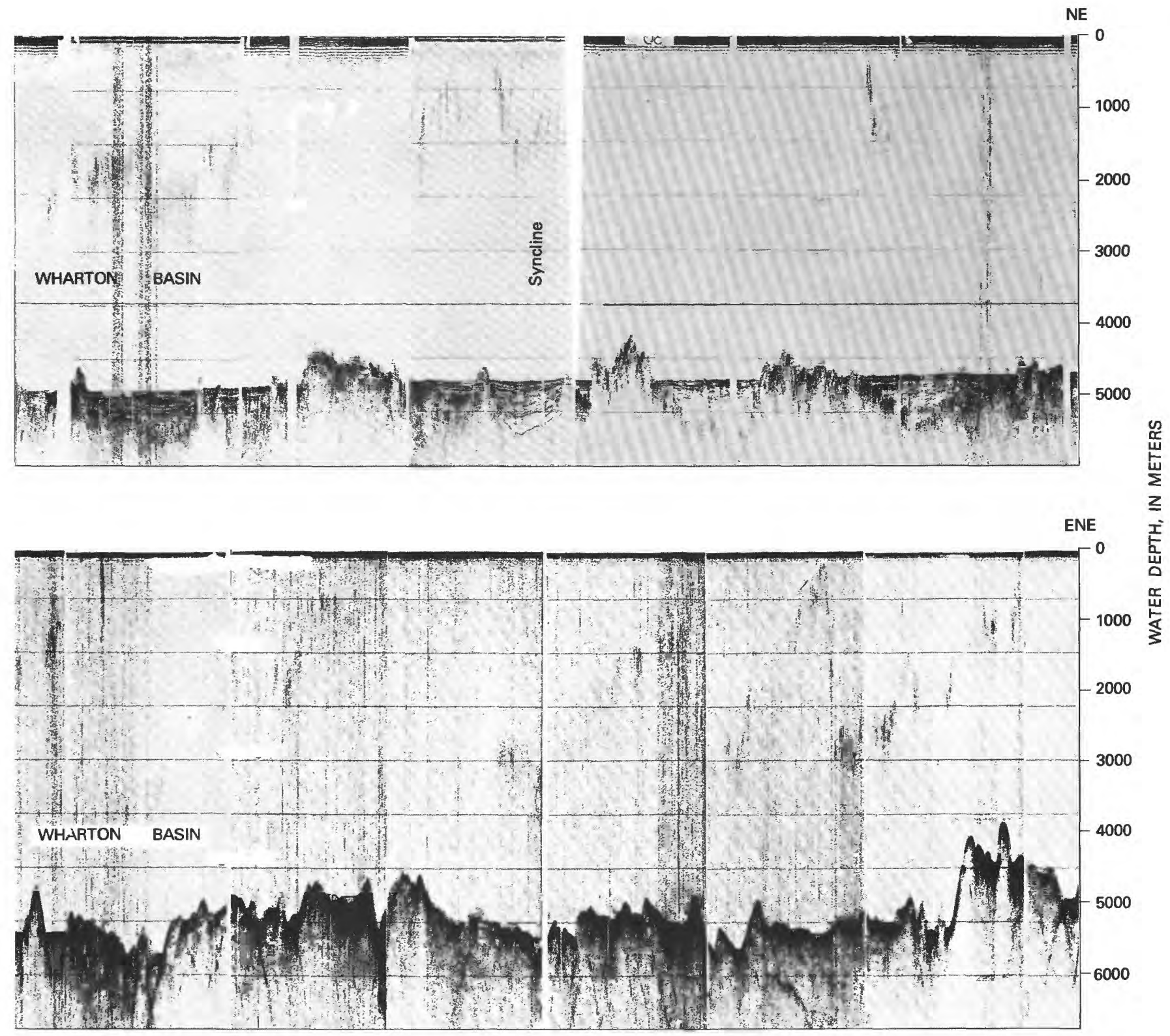

bottomed in beds of early Maestrichtian or late Campanian age without reaching basement. At all five sites, the basal sediments formed near sea level, and the ridge subsided with time to present depths (von der Borch, Sclater, and others, 1973; Luyendyk and Davies, 1973; Pimm and others, 1974). In hole 214, the Paleocene sediments are nonmarine volcaniclastic strata bearing temperate-climate pollen, and shallow-marine strata with temperate-water benthonic foraminifera, beneath Eocene strata deposited in deeper, warmer water, so long-distance northward plate motion is indicated (Kemp and Harris, 1975; Pimm and others, 1974). Paleomagnetic latitude for the basement rock in each of the DSDP holes is near $50^{\circ} \mathrm{S}$., also requiring great northward transport (Pierce, 1976).
The Paleogene pollen at holes 214 and 254 is similar to that of Australia and New Zealand (Kemp and Harris, 1975). The Late Cretaceous and Cenozoic wet, south-temperate continental flora is represented at these Ninetyeast Ridge sites by pollen from abundant podocarpaceous conifers, common araucarian conifers, and rare Nothofagus (southern beech, which might, however, have been wind-blown here). Other austral angiosperms are present in abundance, as well as more cosmopolitan plants. The sites of holes 214 and 254 were adjacent to Broken Ridge (fig. 28) when their plant-bearing materials were deposited and presumably were populated from that continental crustal mass. (Kemp and Harris speculated that, on the contrary, the floras crossed large oceanic gaps to reach islands on the Ninetyeast Ridge, but this possibility is inconsistent with modern 


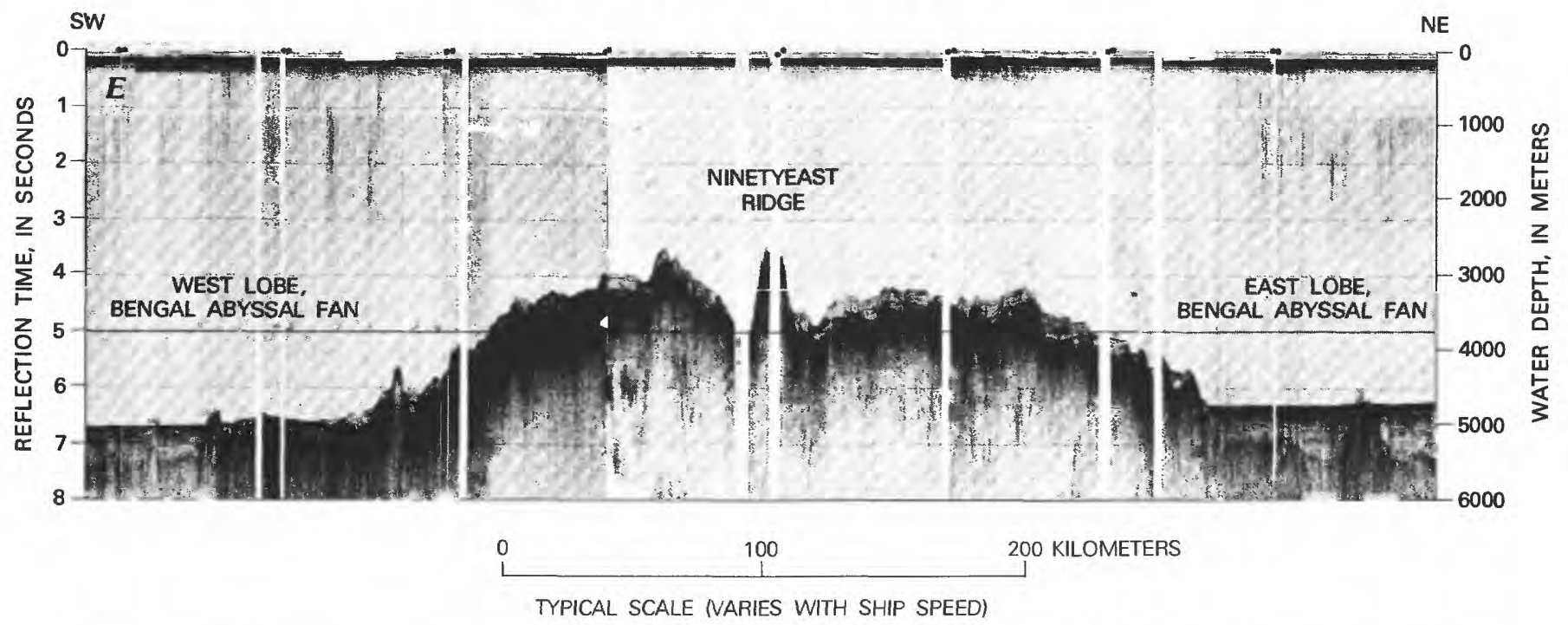

FIGURE 23.--Seismic-reflection profile in the region of the Ninetyeast Ridge. The turbidites of the Bengal abyssal fan fill depressions in the rough basement topography ( $E$ and fig. $22 C$ ). Ninetyeast Ridge follows a transform fault active primarily in Late Cretaceous and early Tertiary time; the ridge becomes younger northward. Location of profile shown in figure 17. Profile from Lamont-Doherty Geological Observatory, R. V. Robert Conrad cruise 14.
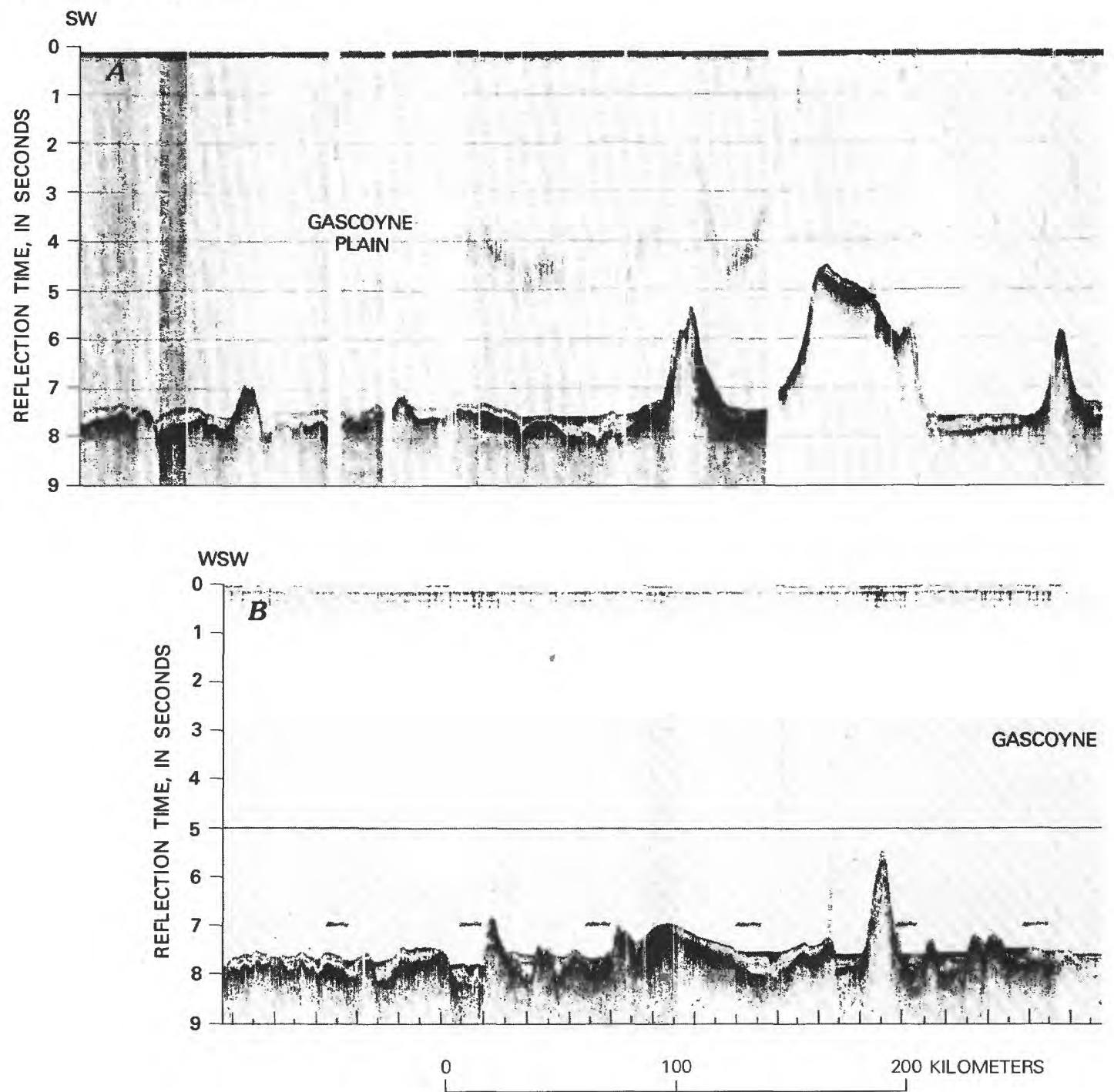
dispersal patterns and mechanisms of the conifers in question; see Preest, 1963.)

The volcanic basement rocks encountered in DSDP holes 214 and 216 are tholeiitic basalts and subordinate oceanic andesites that differ from ocean-floor basalts in having relatively high contents of iron, titanium, and potassium, high ratios of ferric to ferrous iron and of total iron to magnesium, and corresponding anomalies in minor elements. The rocks are shallow-chamber differentiates and resemble rocks of other aseismic oceanic ridges and of some islands on midocean ridges, rather than of either spreading ridges or island arcs (Hekinian, 1974; Thompson and others, 1973). The volcanic basement of the Ninetyeast Ridge apparently formed as a chain of elevated volcanoes appearing in sucession southward with time (Hekinian, 1973). Bowin (1973) concluded from gravity and seismic refraction data that the ridge must be supported by a root of density intermediate between normal oceanic crust and mantle, hence perhaps gabbro or partly serpentinized ultramafic rocks.

The southward decrease of basal-sediment ages on the Ninetyeast Ridge corresponds to the direction of age progression in the Indian Ocean to the west and contrasts with the northward decreasing of ages in the Wharton Basin to the east; therefore, the Ninetyeast Ridge must lie on the west side of a great transform fault between the Wharton

FIGURE 24.- Seismic-reflection profiles in the Indian Ocean west of northern Australia. The oceanic crust in this region is of Late Jurassic age adjacent to Australia and of decreasing Cretaceous age northwestward. DSDP hole 260 penetrated reflective-layered redeposited Paleocene to Quaternary pelagic oozes above acoustically transparent Cretaceous oozes above fresh basalt. The turbidites of the northwest Australian abyssal fans thin westward (fig. 25c) and near their distal ends lap around basement highs $(B)$; only pelagic sediments are present farther west $(A)$. Acoustically transparent pelagic sediments mantle the basement and lie disconformably beneath the turbidites ( $B$; fig. $25 C$ ). The oceanic crust is warped broadly upward south of the Java Trench $(A)$. Location of profiles shown in figure 5. Profiles from Lamont-Doherty Geological Observatory, R. V. Vema cruises $20(B)$ and $24(A)$.
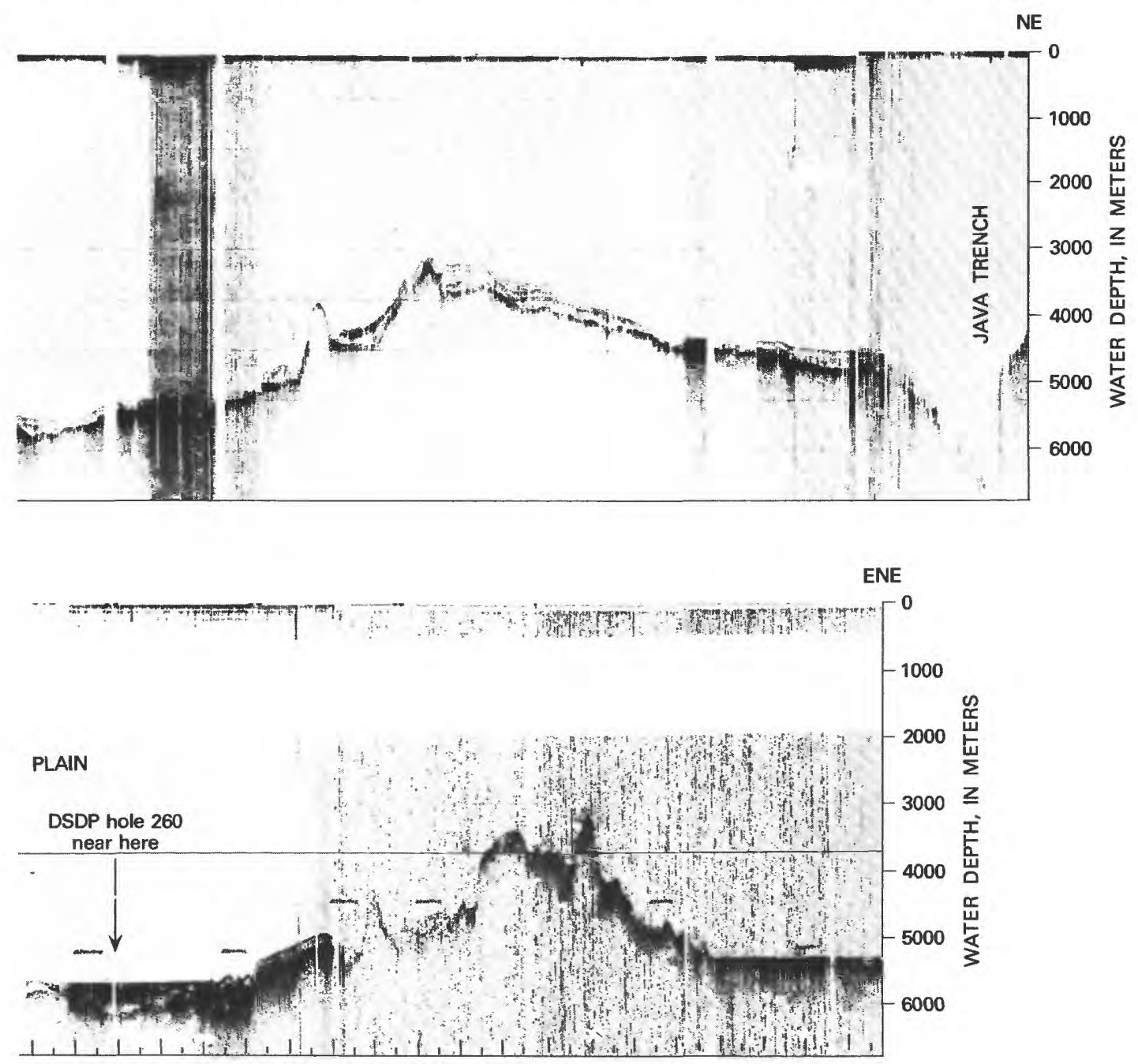

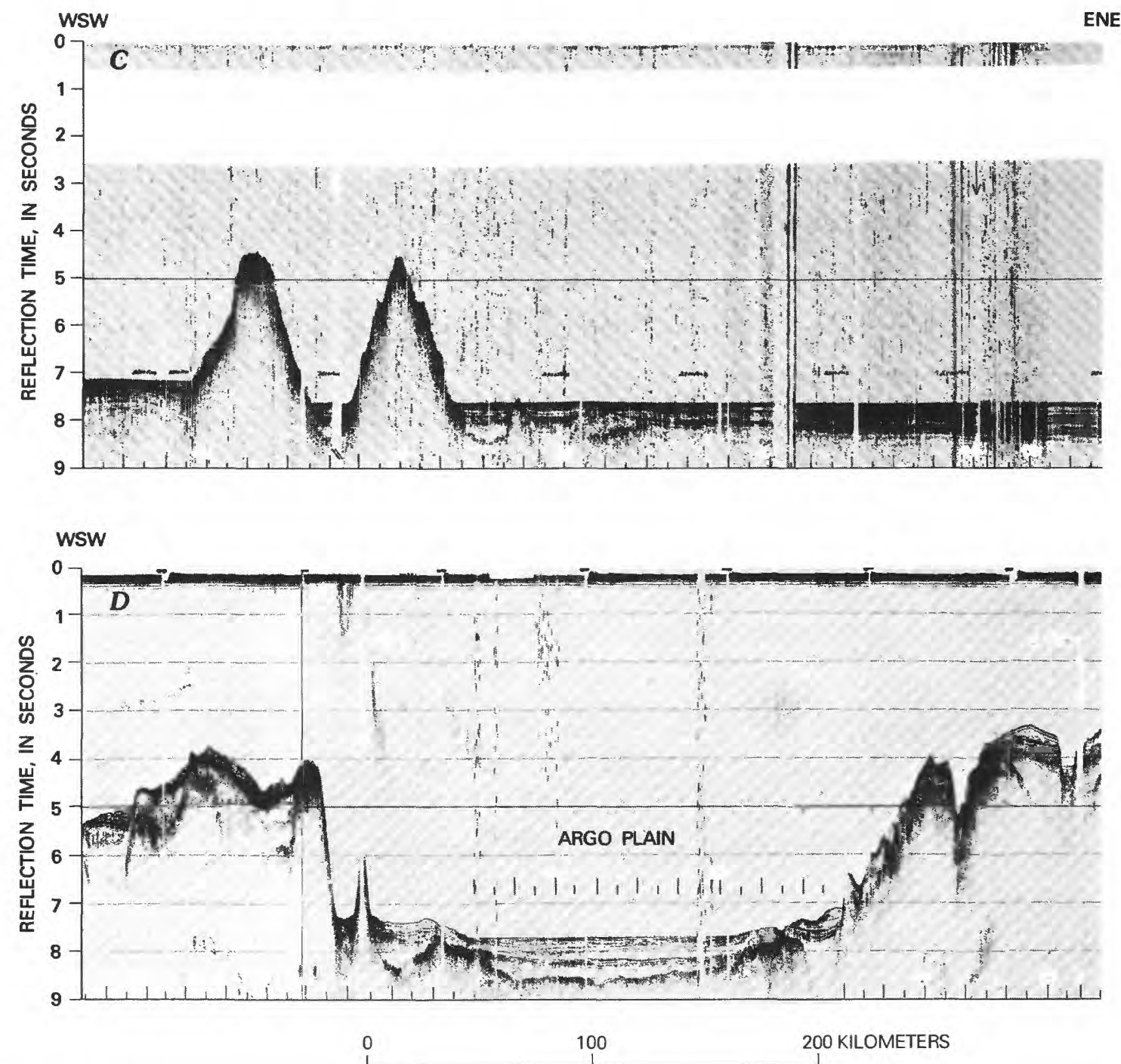

FIGURE 25.-Seismic-reflection profiles in the Indian Ocean northwest of northern Australia. The oceanic crust in this region is of Late Jurassic age adjacent to Australia and of decreasing Cretaceous age northwestward. DSDP hole 261 cut Neogene pelagic sediments over Cretaceous and Upper Jurassic abyssal claystones and then basalt. Acoustically transparent pelagic sediments mantle the basement and lie disconformably beneath the turbidites ( $C$ and fig. $24 B$ ). The oceanic crust is warped broadly upward south of the Java Trench; the warping postdates much of the abyssal turbidite sedimentation $(C)$. The steep-sided ridge at the west end of $D$ may be of continental crustal material, for it is part of a broad rise that shallows gradually southeastward to the Australian shelf. The thick sediments of the Australian shelf and continental slope show broad folding and probably also normal faulting $(D)$. The lowest continuous reflector beneath the Scott Plateau ( $D$ and fig. 26E) is likely of Albian (Early Cretaceous) age (Veevers, Falvey, and others, 1974), and the acoustic basement is the sub-Jurassic surface (Stagg, 1978). Location of profiles shown in figure 5. Profiles from Lamont-Doherty Geological Observatory, R. V. Robert Conrad cruise $14(D)$ and R. V. Vema cruise 20 (C).

Basin and the rest of the Indian Ocean (Sclater and Fisher, 1974). The rate of decrease of age with distance is, however, much less on the ridge than on the ocean floor to the west. DSDP holes 253 and 216, about 2,950 km apart on the ridge, have basal sediments differing in age by about 20 million years (middle Eocene and late Maestrichtian, respectively), whereas on the ocean floor to the west, magnetic anomalies 21 and $33 \mathrm{~b}$ are only about $1,550 \mathrm{~km}$ apart and also represent a time gap of about 20 million years, from approximately early Eocene to early Maestrichtian or Campanian (Sclater and Fisher, 1974). The distances are measured north-south, perpendicular to the magnetic lineations, in both cases. It appears likely that volcanism on one end or the other of the ridge crest continued long after the formation of the original crust beneath, and generation along a "leaky transform" can be inferred (Sclater and Fisher, 1974). The ridge apparently formed just on the Indian Ocean (north) side of the junction between the mid-Indian spreading ridge of the 

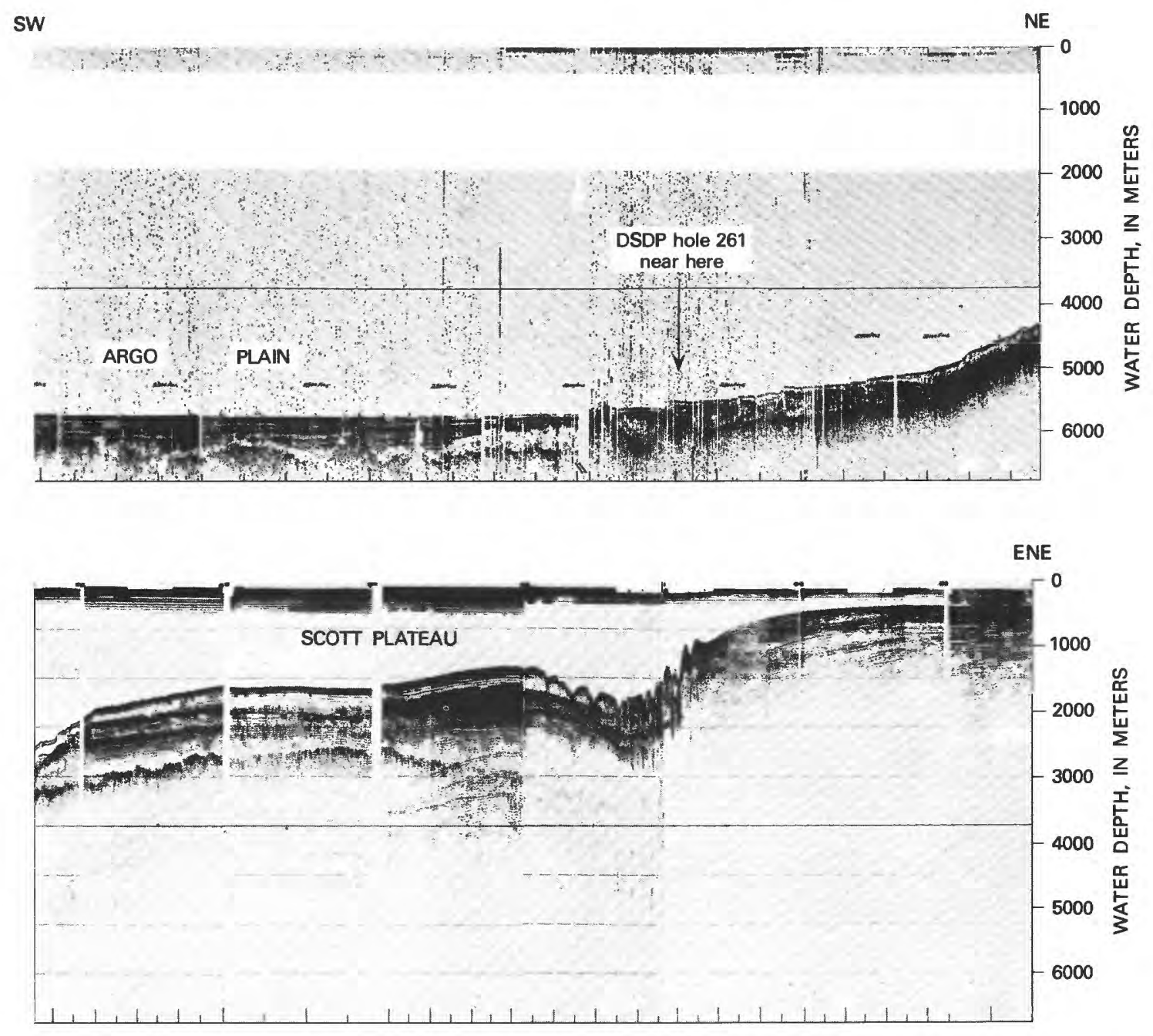

Late Cretaceous and early Paleogene, and west of the transform fault at the west side of the Wharton Basin (Luyendyk and Davies, 1973; Sclater and Fisher, 1974). The ridge subsided, as it moved northward with the Indian plate, at a rate compatible with the subsidence rate of normal oceanic crust formed at spreading ridges (Detrick and others, 1977). The north part of the ridge is still undergoing a little left-lateral faulting (Stein and Okal, 1978).

\section{CHRISTMAS ISLAND}

Christmas Island is the top of a long-extinct volcano located in the Wharton Basin $400 \mathrm{~km}$ south of the west end of Java (fig. 5). An undated volcanic basement is overlain by little-deformed upper Eocene, upper Oligocene, and lower Miocene algal limestones and volcanic rocks, and by Quaternary coral reefs (Adams and Belford, 1974; Ludbrook, 1965; Smith, 1926; Trueman, 1965). The volcanic rocks are mostly sodic in composition-alkali olivine basalt, trachybasalt, trachyandesite, and others - which is appropriate to the midocean position of the island. The oceanic crust on which the island stands is of very late Cretaceous age, approximately Campanian, as dated by nearby DSDP drillhole 211 and by the magnetic anomalies in the region.

A broad upward bulge of oceanic lithosphere bounds the Java Trench on the south and apparently is a quasi-elastic response to the downturning of the Indian Ocean plate beneath the continental plate to the north. Christmas Island is on the bulge, so the recent uplift of the island is a product of the convergence of oceanic and continental plates.

John D. Obradovich (written commun., 1978) determined the whole-rock, $\mathrm{K}$-Ar ages of three specimens of fresh basalt from Christmas Island to be Oligocene. The specimens were collected by Peter Barrett, of the British Phosphate Commission, from the western promontory of the island. Analytical data for the three specimens:

\begin{tabular}{ccccc}
\hline $\begin{array}{c}\text { Denver } \\
\text { K-Ar No. }\end{array}$ & $\begin{array}{c}\text { Percent } \\
\mathrm{K}\end{array}$ & $\begin{array}{c}\text { Moles } \\
{ }^{\circ} \mathrm{Ar} / \mathrm{g}^{*} \text { 10-11 }\end{array}$ & $\begin{array}{c}\text { Percent } \\
\text { radiogenic } \\
\text { argon }\end{array}$ & $\begin{array}{c}\text { Age, } \\
\text { million } \\
\text { years }\end{array}$ \\
\hline 3513 & 1.03 & 6.09 & 37.7 & $33.7 \pm 1.0$ \\
3507 & 1.35 & 8.18 & 17.2 & $34.7 \pm 1.7$ \\
3514 & 0.93 & 4.72 & 38.6 & $28.9 \pm 0.9$ \\
\hline
\end{tabular}




\section{AUSTRALIAN CONTINENTAL MARGIN}

The magnetic anomalies and DSDP drillholes of the Wharton Basin indicate that the ocean floor immediately west of Western Australia is of Late Jurassic and Early Cretaceous age and that it becomes younger northwestward (Heirtzler and others, 1973; Larson, 1975, 1977; Larson and others, 1978; Markl, 1974). The thick continental-shelf strata of northwestern Australia display on reflection profiles (figs. $25 D$ and $26 E$ ) broad warps and normal faults in a wide borderland of irregular topography that steps downward to the ocean floor (Stagg, 1978; Veevers, 1974; Veevers, Falvey, and others, 1974). This borderland is visualized as the product of tensional thinning and collapse of initially thicker, high-standing continental crust. The rifting away from Australia of India is inferred, as is discussed subsequently.

Several irregular submarine plateaus lie west of the Australian shelf, and of these the Scott Plateau is within the area of the maps of the Folio of the Indonesian Region. From an analysis of the velocity structure, as determined by sonobuoy, of the plateau as compared to that of the shelf, Veevers, Falvey, and others (1974) concluded that the lowest reflector beneath the plateau in profiles figs. $25 D$ and $26 E$ is of shallow-water Albian (high Lower Cretaceous) strata,

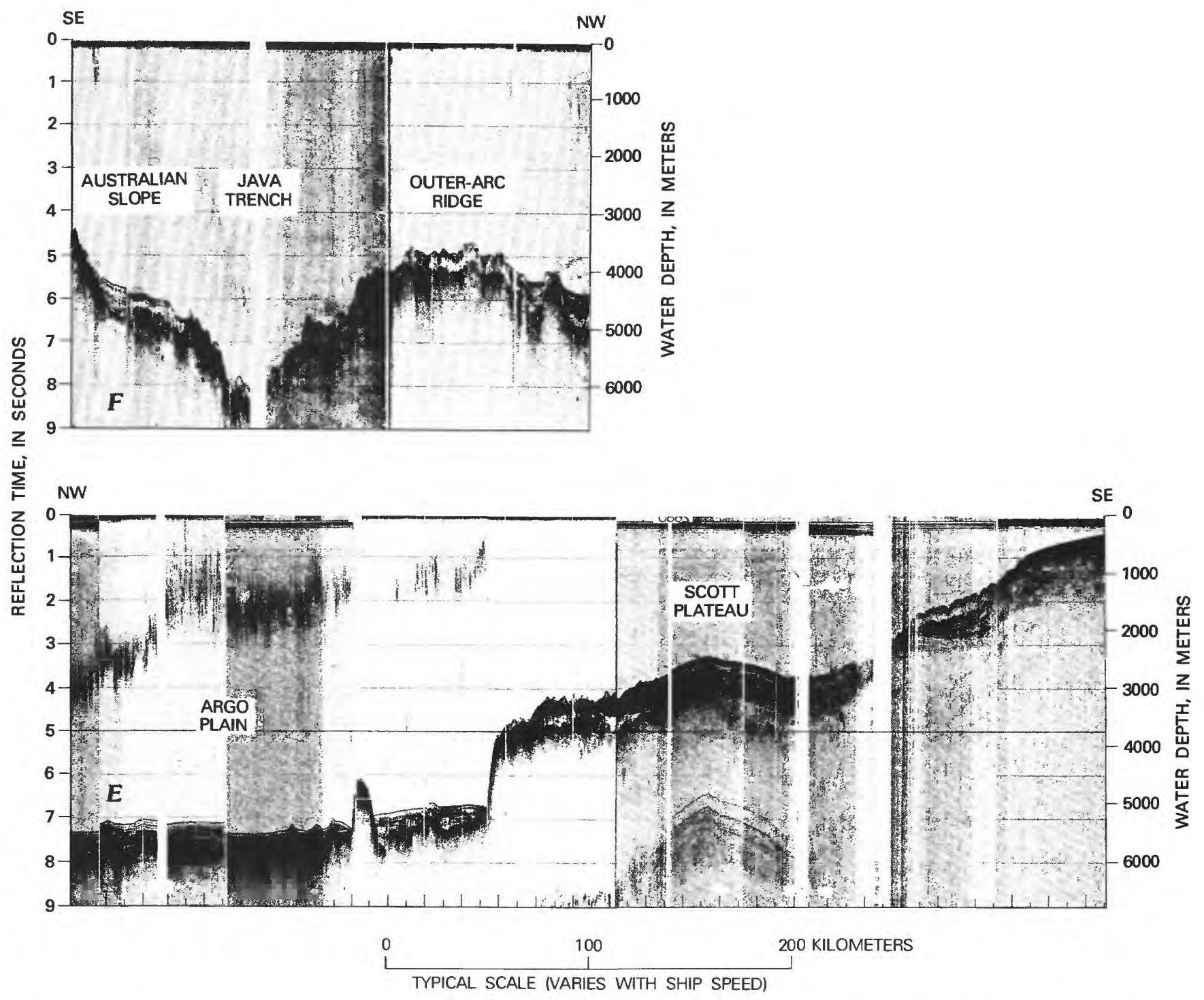

Figvire 26. - Seismic-reflection profiles in the Indian Ocean northwest of northern Australia. The oceanic crust in this region is of Late Jurassic age adjacent to Australia and of decreasing Cretaceous age northwestward. The thick sediments of the Australian shelf and continental slope show broad folding and probably also normal faulting ( $E$ and fig. $25 D$ ). The lowest reflector beneath the $S c o t t P l a t e a u$ $(E)$ is likely of Albian (Early Cretaceous) age (Veevers, Falvey, and others, 1974, and the acoustic basement is the sub-Jurassic surface (Stagg, 1978). The outer-arc ridge south of Sumba $(F)$ appears to consist of much-deformed Australian strata. Location of profiles shown in figure 5. Profiles from Lamont-Doherty Geological Observatory, R. V. Vema cruises $24(F)$ and $28(E)$. 
whereas the overlying Cenozoic materials are of deeper water origin. Subsidence since middle Cretaceous time of a small continental crustal mass is inferred. The Exmouth Plateau, a little farther south (lat $18^{\circ}$ to $22^{\circ} \mathrm{S}$., minimum water depth about $1,000 \mathrm{~m}$ ) is also continental and consists of folded and faulted pre-Jurassic strata beneath as much as 2,000 $\mathrm{m}$ of little-deformed Upper Jurassic and younger strata (Willcox and others, 1975). Still farther south, the Wallaby Plateau, Carnarvon Terrace, and Naturaliste Plateau also probably are all submerged continental crustal masses (Heezen and Tharp, 1973; Jongsma and Petkovic, 1977; Symonds and Cameron, 1977).

The abyssal turbidite apron of the Argo Plain, west of northern Australia, is thin even near the continent (fig. 24B), and the distal end of the apron is only about $600 \mathrm{~km}$ beyond the base of the continental slope (fig. 25C). Where drilled by DSDP its sediments are mostly redeposited pelagic materials. Even within a few hundred kilometers of the base of the continental slope, acoustically transparent pelagic sediments are visible bewteen the acoustic basement and the overlying turbidites. (Compare profiles $24 B$ and $26 E$.) Northwestern Australia has not been a source of voluminous clastic sediments at least since Jurassic time. The same conclusion is indicated by the long-stable cratonic character of the ancient Australian shield.

\section{BENGAL ABYSSAL FAN}

The Ganges and Brahmaputra Rivers are the main sources of sediment for the enormous Bengal abyssal fan, which divides into east and west lobes around the Ninetyeast Ridge and has its south limit at the same latitude on both sides (Curray and Moore, 1971, 1974; D. G. Moore, J. R. Curray, R. W. Raitt, and F. J. Emmel, in von der Borch, Sclater, and others, 1973, p. 403-412; Ewing and others, 1969). The turbidites of the fan thin southward and finally feather out as thin fillings of lows in the rough basement at a distance of

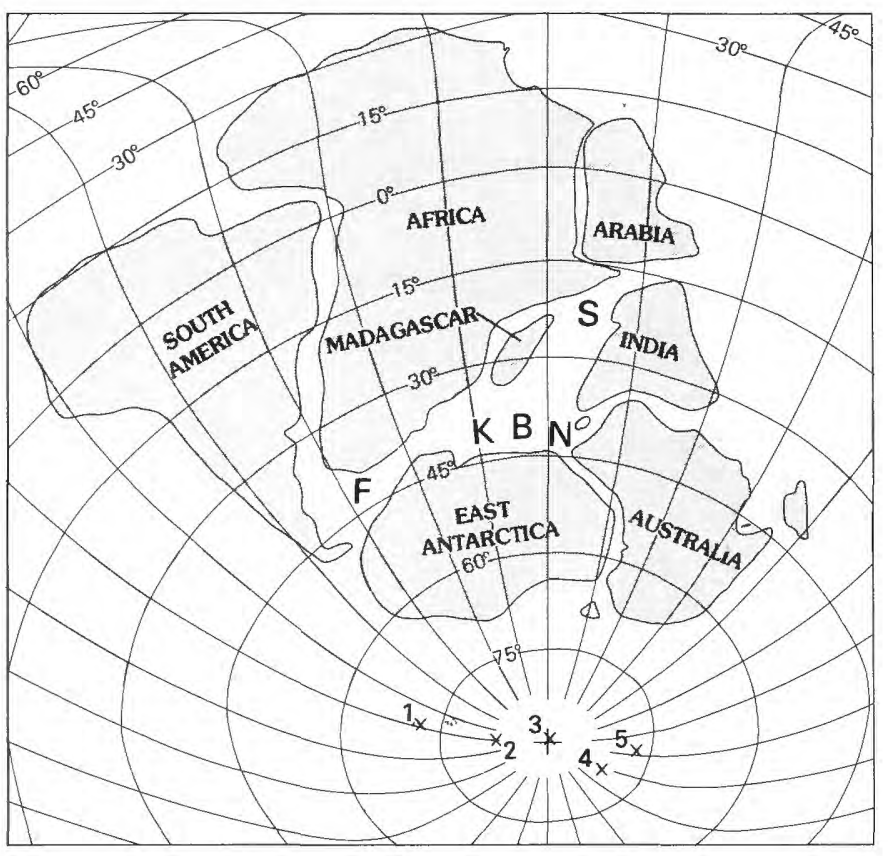

POSITIONS OF CONTINENTAL FRAGMENTS THAT ARE NOW MOSTLY UNDER WATER

EXPLANATION

$X$ Paleomagnetic pole position

1. Africa plus_______ Middle Triassic through_____66.
South America
Middle Jurassic.

1Relative to Africa

FIGURE 27.-Reconstruction of Gondwanaland during Early Jurassic time. The pole of the projection is placed arbitrarily at the Jurassic paleomagnetic pole for Australia; the longitude lines, 15 degrees apart, illustrate the elliptical equal-area projection. New Zealand and West Antarctica are omitted because of uncertainty as to their positions; northern continents are not shown. 
about $3,000 \mathrm{~km}$ south of their major source at the shelf edge of the Ganges-Brahmaputra Delta, where sediments are about $17 \mathrm{~km}$ thick. The east lobe of the fan has been fed through the gap between the Ninetyeast Ridge and the Andaman-Nicobar Trench. Detailed bathymetric studies (Curray and Moore, 1974) and DSDP hole 211 (von der Borch, Sclater, and others, 1973) show that except for turbidites coursing along the Sumatra-Java Trench itself, no sediment now gets through that gap, which has been narrowed by subduction beneath the island arc: Ninetyeast Ridge and arc will soon collide. DSDP hole 218 , in the west lobe of the fan at lat $8^{\circ} \mathrm{N}$. (fig. 17), penetrated $773 \mathrm{~m}$ into the turbidite sequence and ended in middle Miocene beds without reaching the base of the section (von der Borch, Sclater, and others, 1973). The drilled section consists mostly of silt, sandy silt, and clayey silt but includes interbeds of nannoplankton oozes. The older sediments of the east lobe of the fan are gently folded near the southern limit of the turbidites (fig. 22C).

\section{GONDWANALAND AND THE INDIAN OCEAN}

The Indian Ocean formed in late Mesozoic and Cenozoic time as the fragments of the large continent of Gondwanaland (fig. 27) separated, with new oceanic crust forming at the spreading centers between the dispersing pieces. The pattern of separation has been complex (fig. 28).

\section{SIEPARA IION OF AISIRAIII FROM EAST ANTARCIICA}

The ages of the magnetic anomalies arrayed almost symmetrically on opposite sides of the spreading-ridge axis midway between Australia and East Antarctica show that deep ocean began to form between these two diverging continents about 50 m.y. ago (Weissel and Hayes, 1971). The magnetic-anomaly ages of the oceanic crust are confirmed by holes 265, 266, and 267B of the Deep Sea Drilling Project (Hayes and Frakes, 1973). The continents are now about $3,000 \mathrm{~km}$ apart, so during the past $50 \mathrm{~m} . \mathrm{y}$. they have separated with an average relative velocity of about $6 \mathrm{~cm} / \mathrm{yr}$. The south magnetic pole recorded by the paleomagnetic orientations of Australian Tertiary rocks shows that Australia has migrated northward at least $2,000 \mathrm{~km}$. during the same period if the magnetic orientations are indicative of a geocentric dipole field (Wellman and others, 1969): Australia has moved northward faster than Antarctica has moved southward, and the spreading ridge has itself migrated northward at a velocity of half the difference. The ridgecrest is still spreading (Sykes, 1970; Weissel and Hayes, 1971).

Tensional thinning of the continental plate near the site of the subsequent rift between Australia and East Antarctica began at about the beginning of Cretaceous time. The structural and stratigraphic development of the southern margin of onshore and offshore Australia was summarized by Boeuf and Doust (1975); see also Brown, Campbell and Crook (1968), Griffiths (1971b), and Taylor (1971). Rift valleys received Lower Cretaceous nonmarine strata, then fluvio-deltaic Upper Cretaceous and Paleocene strata that show increasing marine components upward. Rifting was accelerated in the late Paleocene, and Eocene and younger strata were prograded seawards toward the developing oceanic basin.

Only a little ambiguity surrounds the relative positions of Australia and East Antarctica during Paleozoic and Mesozoic time. When the Cenozoic spreading of the intervening ocean, as indicated by the magnetic-anomaly method, is reversed and the ocean closed, the Paleozoic terrains of the two continents are juxtaposed appropriately (Laird and others, 1977; Veevers, 1976). The morphologic fit is good, although the fit shown places Australia a bit farther east, relative to Australia, than does the best fit based on morphology alone. (Compare with Smith and Hallam, 1970, and Sproll and Dietz, 1969.)

\section{MESOZOIC GONDWANALAND}

The relative position of South America against Africa during late Paleozoic and early Mesozoic time is established, and only a minor ambiguity remains regarding that of Australia against East Antarctica. Data now available appear to me to define also the position of India against Australia, although my preference is for a fit different than the one now accepted commonly. Great ambiguity however still clouds the relationship of the African-South American mass to the Indian-Australian-Antarctic mass. The spreading history of the past $75 \mathrm{~m}$.y. has been deciphered by the magnetic-anomaly method for much of the Indian

FIGURE 28.-Schematic illustration of age and history of oceanic crust in the eastern Indian Ocean. About 50 million years ago, Australia and Broken Ridge separated from East Antarctica and the Kerguelen Plateau, and since that time the Indian-Antarctic Ridge and Mid-Indian Ridge have been continuous. Between 50 and at least 75 million years ago, the ancestral Mid-Indian Ridge ended at Ninetyeast Ridge. along which spreading was transformed to a spreading ridge whose southern flank is the northern part of the Wharton Basin, the basement of which becomes younger northward; the northern Wharton oceanic plate has been subducted beneath Indonesia. In Late Jurassic and Cretaceous time, the Bay of Bengal and the southeastern part of the Wharton Basin opened as India and Australia drifted apart. Base is on Mercator projection, with submarine contours at 1,000 and 4,000 m; mostly from Heezen and Tharp (1965, fig. 5) and Sclater and Fisher (1974, fig. 9). 


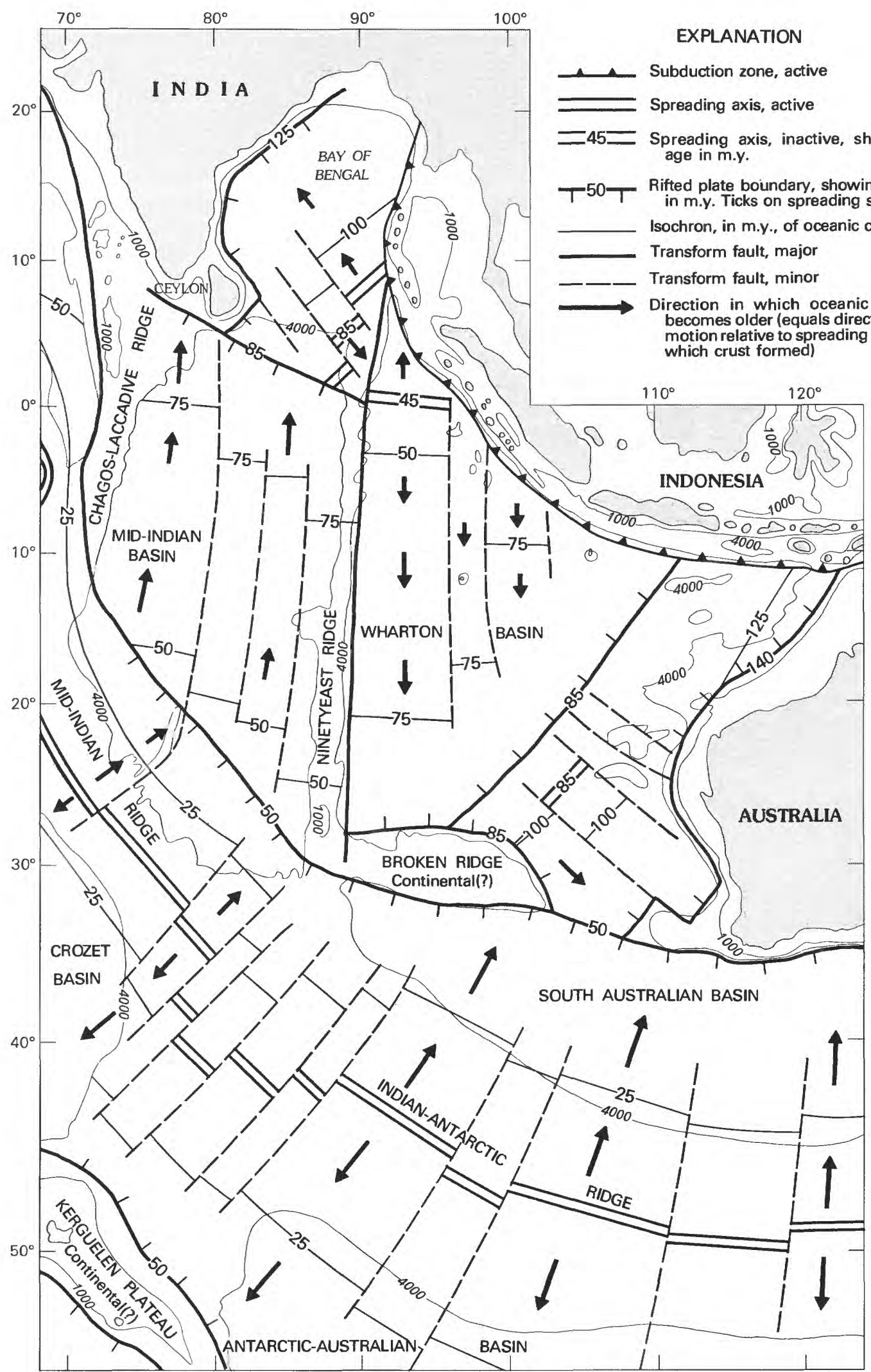


Ocean, but reversing all of this spreading leaves sizeable middle Late Cretaceous oceans between the landmasses of Africa, India, and Antarctica plus Australia (McKenzie and Sclater, 1971; Sclater and Fisher, 1974). Only locally can older motions be constrained, and continental margins cannot be matched convincingly.

Various configurations have been proposed for the Gondwanaland of early Mesozoic time. Most assemblies (including those by Barron and others, 1978; Craddock, 1977; De Wit, 1977; du Toit, 1937, fig. 7; Embleton and Schmidt, 1977; Embleton and Valencio, 1977; Ford, 1968; Griffiths and Burrett, 1973; Hamilton, 1963; Johnson and others, 1976; McElhinny, 1970; Smith and Hallam, 1970; Tarling, 1972; and Veevers and McElhinny, 1976) have placed the east side of India against East Antarctica, giving India no direct contact with Australia. Crawford (1974), Johnson, Powell, and Veevers (1976), Larson (1975, 1977), and Veevers, Powell, and Johnson (1975) added to such reconstructions the speculation that Tibet lay between India and Australia. These configurations, however, allow no space for the mostly submerged continental fragments now in the Indian Ocean (next paragraph), and they provide very poor paleolatitudinal relationships with which to explain paleoclimatic and biogeographic provinces of the late Paleozoic and early Mesozoic. The continent that was rifted from Australia in the Late Jurassic and Early Cretaceous (discussion following) could not have been Tibet, which was rimmed by the sea in Permian and Triassic time and which lacks Gondwana faunal and climatic characteristics.

Large and mostly submerged continental fragments - the Seychelles, Kerguelen(?), and Naturaliste Plateaus, and Broken Ridge-lie in the Indian Ocean and must be accounted for. The Seychelles Plateau, between Madagascar and India, has a continental crustal structure (Matthews and Davies, 1966), and its islands expose granites of latest Precambrian or Cambrian age (Baker, 1967). Broken Ridge, west of southern Australia, is shown by seismic-refraction data to have a crust of probable continental character (Francis and Raitt, 1967). Sea-floor magnetic spreading anomalies suggest that Broken Ridge separated from the Kerguelen Plateau, and thus that if one is continental both are (McKenzie and Sclater, 1971; also Heezen and Tharp, 1965b; Houtz and others, 1977, disagree). Both the Kerguelen Plateau and Broken Ridge have thick covers of sediments going back at least to the early Late Cretaceous (Ewing and others, 1969, 1972; Houtz and others, 1977; Kaharoeddin and others, 1973; Quilty, 1973). DSDP drilling shows Broken Ridge to have been continuously at shallow depths since at least middle Late Cretaceous time, and for one interval to have been above sea level (Luyendyk and Davies, 1973), which is highly suggestive of continental crust. Gravity and magnetic studies indicate the Naturaliste Plateau, on strike to the east of Broken Ridge, to be continental (Jongsma and Petkovic, 1977; Petkovic, 1975).
Of the two DSDP holes on the Naturaliste Plateau, one stopped in shallow-water Lower Cretaceous strata without reaching crystalline rocks, and the other penetrated andesitic to rhyolitic arc volcanic rocks beneath Upper Cretaceous chalk (Ford, 1975). Continental crystalline basement rocks were dredged from the plateau by Heezen and Tharp (1973). The very large Kerguelen Plateau has been near its present altitude throughout at least much of Cenozoic time, for middle Tertiary lignites contain fossil land plants. The Tertiary trees included podocarps and araucarians (Cookson, 1947), which are the characteristic conifers in the wet-temperate forests of the southern hemisphere continents that were joined in Cretaceous time and which probably cannot cross oceanic gaps (Preest, 1963). Alkalic basalts, trachytes, and their intrusive equivalents cover most of the Kerguelen islands, have potassium-argon ages of 1 to 30 m.y., and have compositions that could represent a purely oceanic island (Nougier, 1972a, b; Watkins and others, 1974), but ratios of ${ }^{87} \mathrm{Sr} /{ }^{86} \mathrm{Sr}$ of 0.704 to 0.706 (Hedge and others, 1973) that make contamination by silicic crust likely. Gravity anomalies indicate the Kerguelen Plateau to be in approximate isostatic equilibrium and thus to have a thick crust (Houtz and others, 1977). Seismic-refraction studies define the acoustic velocity, about $5 \mathrm{~km} / \mathrm{sec}$, of only the uppermost part of the crystalline crust beneath the strata capping the Kerguelen Plateau (Houtz and others, 1977), and hence do not prove whether that crust is of oceanic or continental character.

Placing the east side of India against western Australia permits a reconstruction (fig. 27) that provides appropriate space for the continental fragments within the Indian Ocean, accounts for better than do the other reconstructions noted for the paleoclimatologic and paleobiogeographic relationships of the late Paleozoic and early Mesozoic records, and is consistent with paleomagnetic pole positions. India and Australia show parallel northward progressions in their closely similar late Paleozoic and early Mesozoic lithologic and paleontological assemblages, from pure Gondwana (cold to temperate) in the south to marginal-Tethyan (subtropical or, in India, even tropical) in the north. The Indian paleoclimatology is quite incompatible with the conventional Indian-Antarctic juxtaposition. The excellent morphologic fit of eastern India and western Australia led Ahmad (1961), Ahmad and Ahmad (1977), Carey (1958), Crawford (1969), Shields (1977), Tarling (1972), and Veevers, Jones, and Talent (1971) to reassemble the continents with these edges together (although Crawford, Tarling, and Veevers subsequently accepted the dominant assumption that India belongs next to Antarctica instead). This join juxtaposes Precambrian terrains of compatible terrains and ages (Crawford, 1969). The fit is compatible with the patterns of Late Jurassic and Early Cretaceous magnetic anomalies and transform faults recognized by Larson $(1975,1977)$ and Markl (1974) west of Australia. India and Australia were not separated by deep 
water until Late Jurassic time in the north, and the Early Cretaceous in the south.

The continental-shelf record is now well known on the Australian side of the rift (Brown and others, 1968; Halse and Hayes, 1971; Jones and Pearson, 1972; Kaye and others, 1972; Veevers, 1974; Veevers and Cotterill, 1976, 1978; J. J. Veevers and M. H. Johnstone, in Veevers, Heirtzler, and others, 1974, p. 571-585; Warris, 1973). Permian-to-Jurassic sedimentation on the Australian shelf was dominantly nonmarine, although shallow-marine deposits are important; sedimentation was in part localized in grabens. Basins subparallel to the present shelf edge began to form along northwestern Australia in the Late Triassic; extensional faulting and thinning climaxed in the Jurassic in the north, but in the Early Cretaceous in the south. High Upper Jurassic and Lower Cretaceous strata are transgressive marine and deltaic deposits in the north; however, in the south Upper Jurassic and low Lower Cretaceous beds are nonmarine, and the main marine transgression does not appear until the higher Lower Cretaceous. On the northwest Australian shelf, clastic Triassic and Jurassic sediments, even near the edge of the present shelf, were derived largely from a continental source to the west, northwest, or north (Kaye, 1972). Continental and near-shore Upper Triassic and Jurassic strata were deposited near the present shelf edge at the same time that marine sediments filled basins between there and Australia. Not until the Upper Cretaceous does the modern shelf appear in the record, with deeper water sediments appearing generally northwestward of shallow-water ones (Kaye, 1972). The obvious general pattern is one of extensional faulting and tensional thinning of the crust through Late Triassic, Jurassic, and Early Cretaceous time, as India and Australia moved slowly apart, followed by complete rifting in the middle Cretaceous and rapid separation since (Kaye, 1972).

The east side of India has a narrow continental shelf. The geology of the narrow basins that extend onshore is described by Sastri, Sinha, Singh, and Murti (1973), Sastri, Raju, Sinha, and Venkatachala (1974), and Sastri, Raju, Sinha, Venkatachala and Banerji (1977), The known sedimentary record begins later than does that of western Australia: the initial rift may have developed within what is now the Australian side, the final rift developing subsequently farther west, leaving the partially filled older basins mostly with Australia. The Cauvery Basin, between lat $9^{\circ}$ and $12^{\circ}$ $\mathrm{N}$., at about long $80^{\circ} \mathrm{E}$., was initiated with Upper Jurassic deposition of clastic sediments derived from the east. This basin underlies the strait between Indian and Ceylon, the separation of which presumably represents incomplete rifting begun in the Late Jurassic. The Palar Basin, $13^{\circ}-14^{\circ}$ $\mathrm{N}$. and $80^{\circ}-81^{\circ}$ E., has a thick paralic Cretaceous section, and a thin continental Neogene one, above fluvioglacial(?) Lower Permian strata. The Godavari-Krishna Basin, $15^{\circ}-17^{\circ} \mathrm{N}$. and $80^{\circ}-83^{\circ} \mathrm{E}$., contains shallow-marine and paralic Lower Cretaceous strata, and continental Neogene sediments. The basins are in part fault bounded. As in the Australian basins, fault-basin deposition during the late Mesozoic was followed by blanket marine deposition in the Cenozoic.

The geometry and history of the rifting of the west Australian margin are strikingly similar to those of the modern East African rift system, and the submerged continental remnants west of Australia may have analogs in the inter-rift plateaus of East Africa (Veevers and Cotterill, 1976). The Godavari Basin of southeastern India, which extends northwest across the craton from an intersection with the coast at about lat $16^{\circ} \mathrm{N}$., received continental clastic sediments, probably concurrently with block faulting, from Early Permian until Early Cretaceous time (Pascoe, 1959). (See Ghosh and Mitra, 1970, for references to subsequent local studies.) This basin appears to be the "failed" arm of a rift-rift-rift triple junction whose "successful" arms produced the two straight margins each of eastern India and Western Australia. Veevers and Cotterill (1976) assumed a different prerifting position of India relative to Australia and hence reached different conclusions.

The reconstruction of figure 27 does not provide continuity between the Transantarctic Mountains of East Antarctica and the Cape Mountains of southernmost Africa. Such continuity has been widely assumed, from du Toit (1937, fig. 7) through Hamilton (1963) and Ford (1968) to Craddock (1977). Part of the rationale in favor of this continuity is based on the assumption that the latest Precambrian and early Paleozoic crystalline terrains of the two regions fit together, but terrains of this age are so widespread in Africa and Madagascar (Clifford, 1970; McCurry and Wright, 1978; Saggerson, 1973), Seychelles (Baker, 1967), Arabia (Greenwood and others, 1976), and the outer coast of East Antarctica (Craddock, 1970) that the assumption has little merit. The conventional Transantarctic Mountains-Cape Mountains juxtaposition also assumes that the upper Paleozoic and Mesozoic Gondwana clastic sedimentary sequences of the two regions-Beacon in Antarctica, Karroo in southern Africa-formed in continuity, whereas the reconstruction of figure 27 relates the Karroo instead to correlative sequences in the interior of Gondwanaland.

The reconstruction of figure 27 accounts for many paleobiogeographic features, such as the striking similarity in sedimentary facies and marine faunas of the platform Cambrian strata of Arabia and northern India (Wolfart and Kursten, 1974), not explained by the widely used restorations. The reconstruction utilizes the northern paleoposition of Madagascar against Africa (McElhinny and Brock, 1975; McElhinny and others, 1976), and the transform relationship between the south edge of Africa and the Falkland Plateau (Scrutton and others, 1975).

The reconstruction of figure 27 accords well with paleomagnetic data. The approximate positions of relative south poles that appear to be reasonably well established by 
consistent results from rock assemblages of about the age illustrated by the reconstruction are plotted on the figure. As there is little ambiguity regarding the relative positions of Africa and South America, the combined paleomagnetic pole for these assembled continents is used.

IIISIORY OH IHE FASIERN INI)IAN OCCAAN

An oceanic gap began to appear between India and Australia in the Late Jurassic in the north but not until the Early Cretaceous in the south. Late Jurassic counterclockwise rotation of India relative to Australia, about a southern pivot, is inferred from magnetic lineation patterns (Larson and others, 1978). After the beginning of Cretaceous time, India moved away from Australia in the direction that is now west-northwestward. The oceanic crust of the southeastern part of the Wharton Basin, and presumably also of the Bay of Bengal, formed in the widening Early Cretaceous gap. Plate motions changed again near the middle of Cretaceous time as north-south spreading took over after a period of clockwise rotation of India (Larson and others, 1978), and during Late Cretaceous and very early Tertiary time the northern Wharton Basin formed by spreading at a northward-migrating axis, whereas the Mid-Indian Basin was then growing by spreading at a southward-migrating one, the two axes being joined by the Ninetyeast Ridge transform fault. Then, about 50 m.y. ago, the Wharton axis was abandoned, Australia and East Antarctica began to separate, and spreading became continuous from the Mid-Indian Ridge to the Pacific via the new Indian-Antarctic Ridge. This evolution is illustrated by figure 28 , which was prepared before the additional data of Larson, Carpenter, and Diebold (1978) were available.

The Ninetyeast Ridge apparently lies just west of a great transform fault, active until about $50 \mathrm{~m} . \mathrm{y}$. ago, by which spreading on the ancestral Mid-Indian Ridge, west of the Ninetyeast, was stepped to spreading on the center that formed at least the north half of the Wharton Basin, east of the Ninetyeast (Sclater and Fisher, 1974). The eastern spreading center migrated relatively northward from Broken Ridge and Australia, and the northern Wharton Basin floor is part of the lithosphere formed to the south of this center. While the Ninetyeast Ridge was forming along an active transform fault, the Mid-Indian center migrated southward, and the since-vanished Wharton spreading center migrated northward. About 75 m.y. ago, the Wharton center east of the ridge was something like $1,500 \mathrm{~km}$ south of the projection of the Mid-Indian center west of the ridge; at some time near $60 \mathrm{~m}$.y. ago, the then-active Wharton axis lay perhaps $2,500 \mathrm{~km}$ to the north of the projection of the Mid-Indian axis. Since about $50 \mathrm{~m} . \mathrm{y}$. ago, the Ninetyeast Ridge has been a relatively inactive structure within the huge lithospheric plate of the northeastern Indian Ocean, India, and Australia.

Spreading of the ancient Wharton ridge before $50 \mathrm{~m} . \mathrm{y}$. ago, and since then of the Indian-Antarctic Ridge, has presumably been matched by subduction beneath Indonesia and Southeast Asia. Spreading on the Wharton axis likely stopped $50 \mathrm{~m} . \mathrm{y}$. ago when spreading began on the Indian-Antarctic system. The Wharton ridge and the oceanic plate that must have formed to the north of it, symmetrical to the present Wharton plate to the south, have vanished into the subduction zones. A small part of the plate formed at the north side of the Wharton spreading center might still be present, unrecognized but not yet subducted, in the northwest corner of the Wharton Basin. Figure 28 shows such a fossil spreading center at a position which is merely speculative.

India has been part of the subplate bounded on the east by Ninetyeast Ridge and on the southwest by the spreading Mid-Indian Ridge since middle Late Cretaceous time. Compensating subduction has occured north of India, apparently along the ophiolite-and-melange Indus Suture Zone of the Himalayas, where the Tethyan ocean floor vanished beneath Tibet until India collided with it (Gansser, 1966). The beginning of collision may be recorded by the facies change in northern India (for instance, Bhandari and others, 1973) between the continental-shelf strata of the Paleocene and Eocene and the deltaic and continental deposits, derived from the north, of the Oligocene and Neogene.

The Himalayas mark a plate boundary of continuing convergence. Argand (1924) long ago speculated that the uniquely high altitude (and, as we know now, the uniquely thick crust) of the Tibetan Plateau might be due to the sliding beneath it of the northern extension of India. The northern boundary of the lithospheric plate of Australia, the northeastern Indian Ocean, and India is defined by a continuous belt of thrusting, subduction, and strike-slip faulting. The mechanics of this system are discussed subsequently. (Also see figure 37.) No major seismic zone separates India and the spreading Mid-Indian Ridge, although occasional small earthquakes and the presence of deformed abyssal sediments near the southern limit of the Bengal abyssal fan may indicate that a subduction zone will eventually break through the Indian Ocean floor (Eittreim and Ewing, 1972; Sykes, 1970), and the northern part of the Ninetyeast Ridge is the site of moderate seismicity (Stein and Okal, 1978).

\section{ANDAMAN-NICOBAR ARG AND ANDAMAN SEA}

The northern subduction system continues northward from Sumatra as a trench and arcuate submarine ridges, which separate the Indian Ocean from the Andaman Sea (fig. 29). The Andaman and Nicobar Islands stand on the outer ridge. Marine-geophysical studies of the system have been reported by Lawver, Curray, and Moore (1975); Peter, Weeks, and Burns (1966); and Weeks, Harrison, and Peter (1967). Reflection profiles are given here in figures 21 and 30 . 


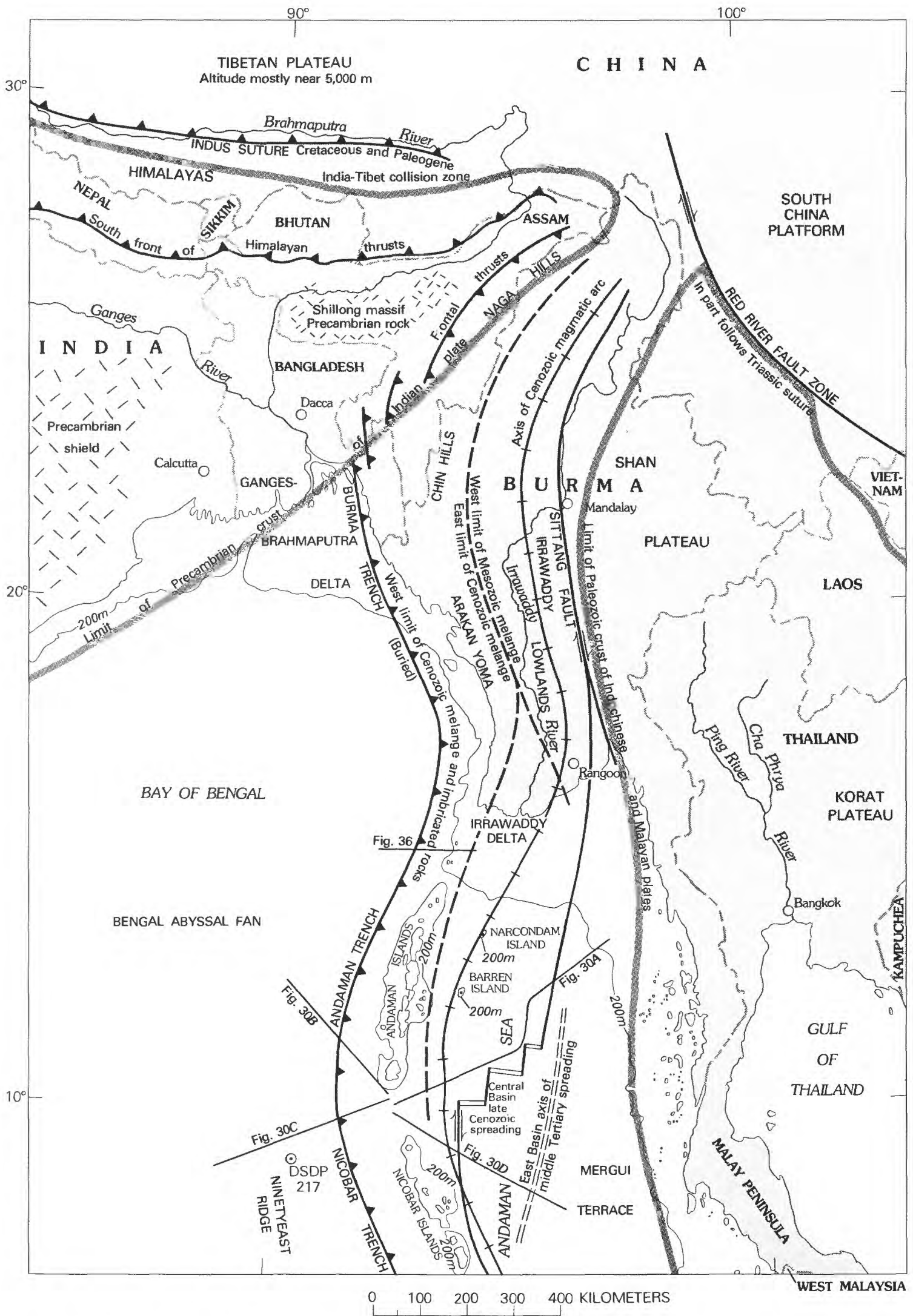

Figure 29. - Selected tectonic elements of the Andaman-Nicobar Arc system and surrounding regions, and location of seismic-reflection profiles shown in figures 30 and 36 . Modified from many sources, following interpretations developed here. See plate 1 for more detailed bathymetry south of lat $12^{\circ} \mathrm{N}$. 

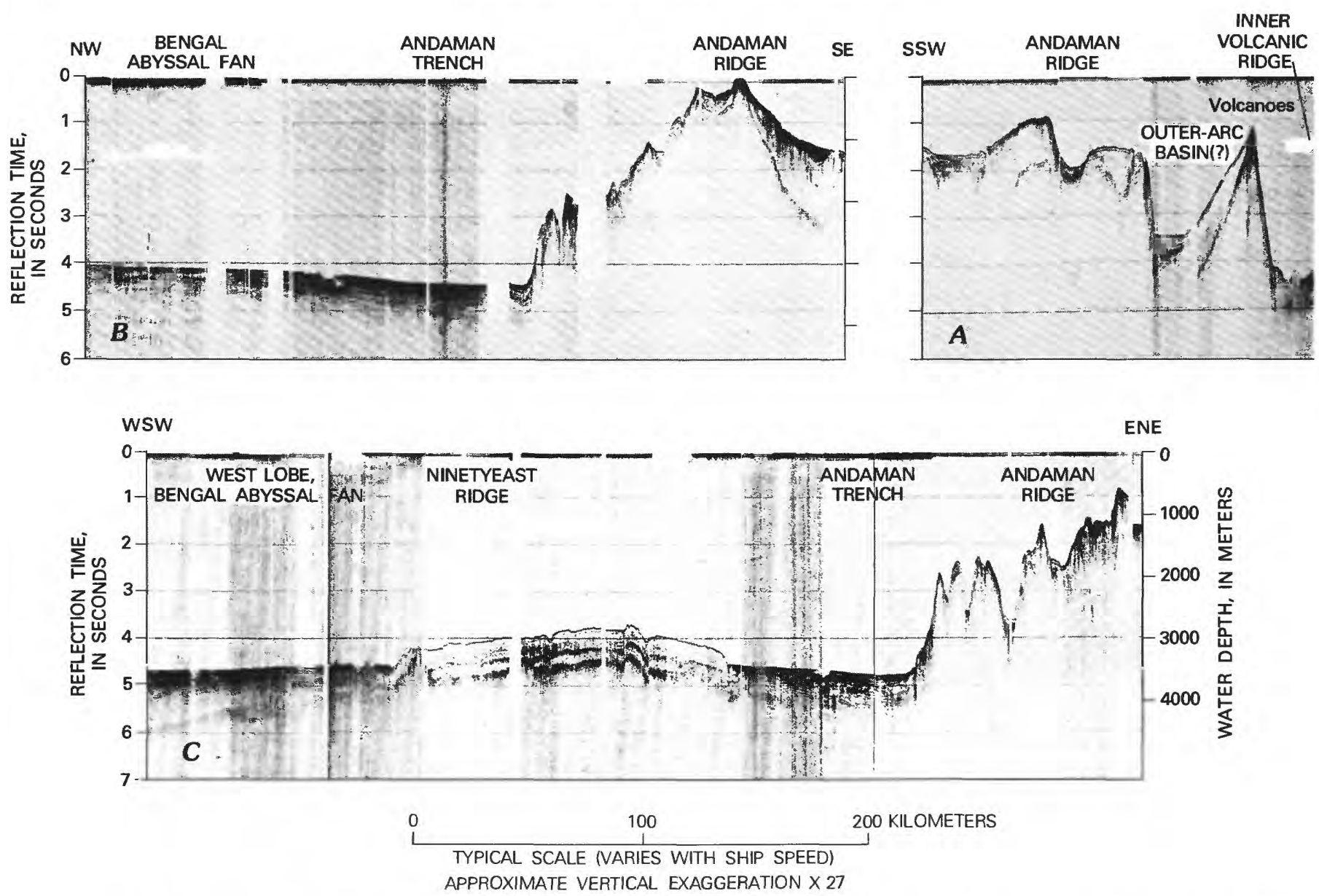

Figure 30.-Seismic-reflection profiles across the Andaman-Nicobar arc system. $A$, The strata of the abyssal plain of the Andaman Sea show increasing deformation with age; volcanic seamounts lie between that plain and the Andaman Ridge. $B$, The rest of the Andaman Ridge consists of middle Tertiary melange; the Andaman trench displays downward fanning of the turbidites of the Bengal abyssal fan. $C$, The Bengal abyssal fan is divided into two lobes by the Ninetyeast Ridge, which has a thick veneer of acoustically transparent pelagic sediments; the sediments in the Andaman trench show landward fanning of dips. DSDP hole 217 showed the basal strata above the basaltic basement of the Ninetyeast Ridge to be here of Late Cretaceous (Campanian) age. $D$, The Andaman Ridge has a bedrock of melange; the conical seamounts left of the Central Basin may be volcanoes. Location of profiles shown in Figure 29. Profiles from Lamont-Doherty Geological Observatory, R. V. Robert Conrad cruise 12.

\section{ANDAMAN-NICOBAR ARC}

The Andaman and Nicobar Islands (Bandyopadhyaya and others, 1973; Chatterji, 1964; Gee, 1926; Jacob, 1954; Karunakaran and others, 1964, 1968; Srinivasan and Sharma, 1973; Tipper, 1911) consist, like the islands on the same ridge off Sumatra, mostly of melange and imbricated materials. Polymict melange, serpentinite, peridotite, gabbro, basalt, spilite, Cretaceous red radiolarian chert, Paleocene shallow-water limestone, and Paleocene, Eocene, and Oligocene graywacke, siltstone, and shale are imbricated concordantly together. Much polymict melange has a serpentinite matrix. Neogene strata overlie these materials unconformably.

The volcanic inner arc continues northward from Sumatra through the Andaman-Nicobar sector as a discontinuous submarine ridge, from which rise volcanic seamounts and the andesitic volcanoes of small Barren and Narcondam Islands. The outer-arc basin, between inner volcanic and outer melange ridges, is poorly developed near lat $10^{\circ} \mathrm{N}$. (fig. $30 A, D$ ) but is conspicuous near $6^{\circ}$ and $12^{\circ} \mathrm{N}$. (Weeks and others, 1967, figs. 3 and 4; their "interdeep"). The right-lateral strike-slip fault system of Sumatra appears to continue far northward along the Andaman-Nicobar volcanic belt (pl. 1; figs. $21 \mathrm{~A}, 30 \mathrm{~A}$, and $30 \mathrm{D}$; Fitch, 1970b, 1972; Weeks and others, 1967).

West of the Andaman-Nicobar Trench, the Bengal abyssal turbidite fan, derived largely from the Ganges-Brahmaputra Delta region (and discussed in the Indian Ocean section of this report), is divided into two lobes by the Ninetyeast Ridge (fig. 30C). The sediments of the fan show an increasing dip downward beneath the Andaman Trench (fig. 30B. C), downtilting has accompanied sedimentation, presumably as 

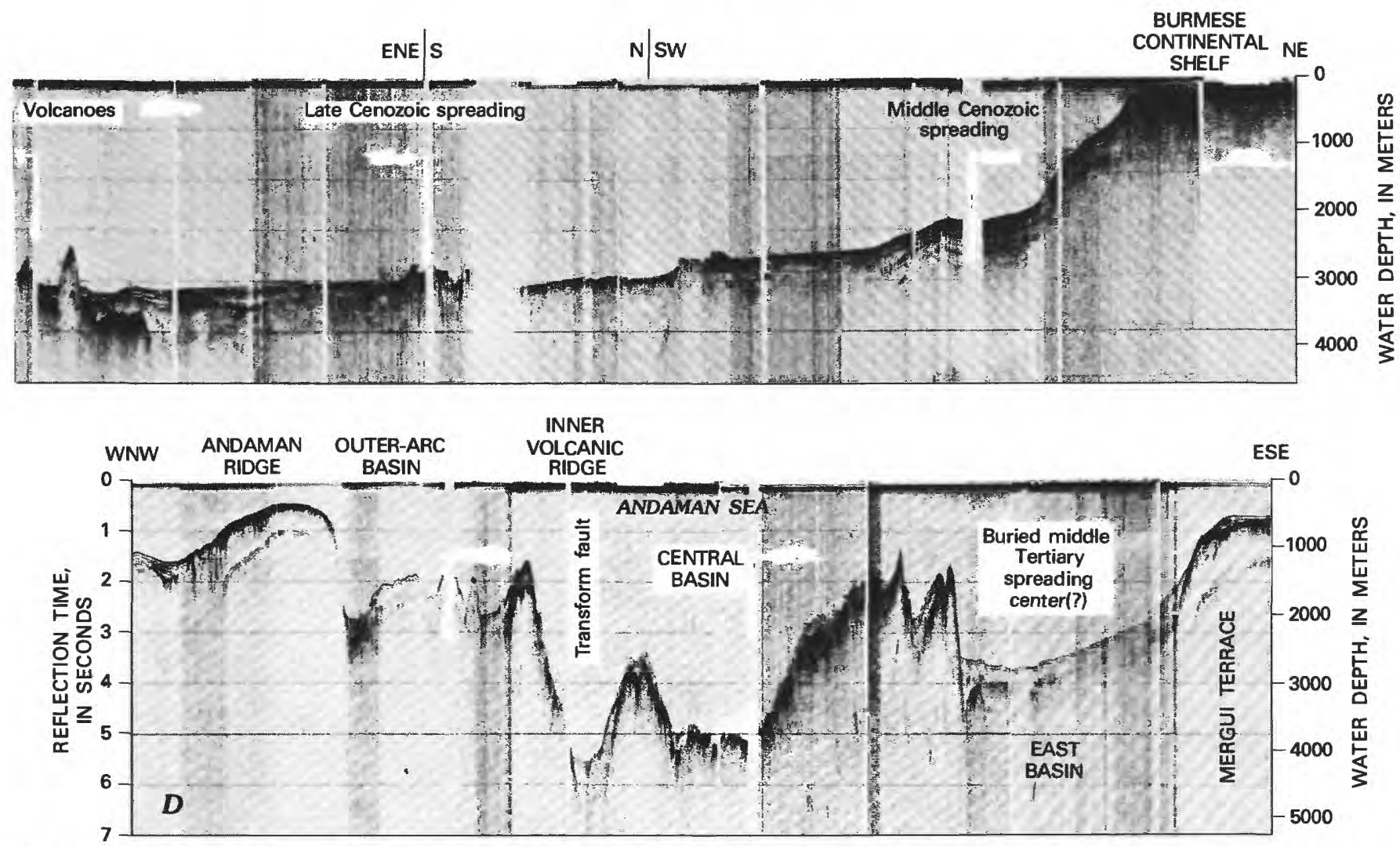

the Indian Ocean floor has flexed downward into the trench on its way along the subduction conveyor belt. Sedimentation is rapid relative to subduction, and the trench is a minor bathymetric feature.

The structural belts of the Andaman-Nicobar system continue northward and come ashore in Burma, as described in a subsequent section.

\section{ANDAMAN SEA}

The small but complex basin of the Andaman Sea is enclosed behind the Andaman-Nicobar Arc. Most of the eastern half of the basin is floored by the broad, continental Mergui Terrace, $600 \mathrm{~m}$ deep, discussed in a succeeding section of this report. Bounding the terrace on the west is the narrow East Basin (bathymetric), which trends north-northeastward, has a floor depth of about $2,500 \mathrm{~m}$, and is itself bounded, in its southern half, by an irregular ridge trending northeastward and rising to depths of about $1,500 \mathrm{~m}$ (fig. $30 \mathrm{D}$ ). Joining the East Basin in the north, and separated from it by the ridge in the south, is northeast-trending Central Basin (bathymetric), more than $3,000 \mathrm{~m}$ deep. Very thick sediments, within which deformation increases markedly with age (fig. $30 A, D$ ), flood the basins and mostly are the deep-sea fan of the Irrawaddy River.

Ridd (1971a) and Rodolfo (1969) deduced that the Andaman-Nicobar Arc likely had migrated away from the Malay Peninsula, opening the deep basins of the Andaman Sea in its wake, and this speculation appears to be confirmed by the results of detailed magnetic and seismic reflection and refraction studies by J. R. Curray and D. G. Moore (1974; written commun., 1975, 1977; also Lawver, Curray, and Moore, 1975). The Central Basin, south of the limit of thick Irrawaddy sediments, displays symmetrical magnetic spreading anomalies that increase in age outward to $3 \mathrm{~m} . y$. and indicate a whole-rate of spreading of about 4 $\mathrm{cm} / \mathrm{yr}$. The active spreading center (fig. 30), marked by some shallow seismicity, steps the right-lateral slip on the fault coming north along the Andaman-Nicobar Arc from Sumatra, to slip on an eastern north-trending fault that goes ashore in the eastern part of the central valley of Burma. From the history of deformation of sediments in the East Basin, as shown primarily on reflection records, Curray and Moore concluded that it formed by spreading in middle Tertiary time. The ridge between the basins is presumably foundered continental crust. These concepts are incorporated in the tectonic map (pl. 1).

The spreading in the Andaman Sea has an orientation such that it may represent oblique tensional fragmentation of the southeast Asian lithosphere plate as a drag effect of the northward-moving plate of India and the Bay of Bengal.

\section{SOUTHEAST ASIA}

The Malay Peninsula and the southern part of Indochina are included within the area of the tectonic map of the Indonesian region (pl. 1) and of the maps of the Folio of the 
Indonesian Region. The tectonic history recorded by the rocks and structures of these mainland Asian areas is dominated by late Paleozoic and Mesozoic deformation and magmatism. Major Mesozoic tectonic elements are shown schematically on figure 31 .

\section{MALAY PENINSULA}

The Malay Peninsula consists mostly of much-deformed Cambrian to Triassic sedimentary rocks, Permian and Triassic volcanic rocks, and Carboniferous or Permian to Cretaceous granitic rocks. Several broad provinces can be recognized in the sedimentary rocks, and a subduction suture zone may be present in medial Malaya (West Malaysia $^{3}$ ). The granitic rocks probably became in general younger westward across the structural strike of the peninsula.

New geologic maps have been published for both Malaya (Chung, 1973; Gobbett, 1972) and Thailand (Javanaphet, 1969). A number of geologists contributed broad summary papers, written from classical viewpoints, to the compendium edited by Gobbett and Hutchinson (1973). The Annual Reports of the Geological Survey of Malaysia for 1973, 1974 , and 1975, received after completion of the compilation of the tectonic map (pl. 1), contain geologic sketch maps of a number of small areas in Malaya; the maps and accompanying notes show minor errors in my map contacts.

\section{BASEMENT ROCKS}

Basement rocks, of Precambrian age in the far northwest and at least as old as early Paleozoic elsewhere, must underlie the platform-facies sediments (discussed next) of western Malaya at generally shallow depth. Such basement rocks have not yet been recognized in outcrop. In one area in west-central Malaya (Suntharalingam, 1968), however, unmetamorphosed limestones ranging from middle Devonian or older to middle Permian dip westward away from an unexposed contact with granitic rocks, which thus could be basement rather than part of a younger batholith.

A basement of middle Paleozoic or older age might be present beneath the dated rocks of eastern Malaya although the rationale is less compelling. Again, there are no proved basement rocks. MacDonald (1967) suggested that the Taku Schists and associated gneiss and sheared granite in northeastern Malaya (not separated on the tectonic map) may represent basement. Potassium-argon mica ages of these materials mostly cluster at about 70 and 215 m.y., but whole-rock $\mathrm{Rb}-\mathrm{Sr}$ analyses suggest that some may be of middle Paleozoic age (Bignell and Snelling, 1977).

\footnotetext{
${ }^{3}$ Malaysia Barat--West Malaysia - is the official name for that part of Malaysia that is within the Malay Peninsula (which includes also Singapore, southwest Thailand, and southernmost Burma). The names Malaya and Peninsular Malaysia are used here as synonymous with Malaysia Barat.
}

\section{PALEOZOIC AND MESOZOIC STRATIFIED ROCKS}

Paleozoic strata of the Malay Peninsula occur as contrasted eastern and western facies (pl. 1). West of the Main Range (which trends northward near the meridian of $102^{\circ}$ E.), Paleozoic strata are of nonvolcanic platform and basin facies, all likely deposited upon old continental crust, and all periods of the Paleozoic are represented by fossiliferous strata. Not until Mesozoic time did magmatism affect the western part of the peninsula. East of the Main Range, by contrast, only Carboniferous and Permian rocks are known to represent the Paleozoic, and volcanic and volcaniclastic rocks are widespread. The same contrast between nonvolcanic western and volcanic eastern facies of upper Paleozoic strata characterizes mainland Thailand (Daniel R. Shawe, written commun., 1977) and probably also Sumatra (as discussed previously in this report).

WESTERN MALAY PENINSULA

The lower Paleozoic is known in many areas in northwestern Malaya and in peninsular Thailand southeast of the Marui fault and is inferred to represent a continental-shelf environment. In Thailand and northwesternmost Malaya, it consists of Cambrian and lowest Ordovician deltaic sandstone, quartzite, and shale, about $2,000 \mathrm{~m}$ thick with the base not exposed, overlain by Ordovician, Silurian, and Lower Devonian limestone about $1,500 \mathrm{~m}$ thick (Jones, 1968; Ridd, 1971c). Southeast of these in northwestern Malaya, the Lower Devonian and Silurian are in black-shale facies (Mahang), presumably deposited in deeper water (Bradford, 1972; Burton, 1967, 1970a, b, 1972; Courtier, 1974; C. R. Jones, 1968, 1973); older rocks are not known. Still farther east, but west of the Main Range, a section of limestone, sandstone, shale, and possibly tuff is assumed to be correlative by Jones $(1968,1970 \mathrm{~b})$, although it has yielded no fossils. To the south, near lat $3^{\circ} 10^{\prime} \mathrm{N}$., fossiliferous Silurian limestone is present (Jones and othets, 1966). At lat $2^{\circ} 37^{\prime} \mathrm{N}$. in southwestern Malaya, one locality in a terrain of otherwise undated slate, phyllite, and quartzite yielded graptolite fragments assigned to the Lower Devonian by $\mathrm{E}$. H. Yin (as cited by bin Ngah, 1974).

Higher Devonian and Carboniferous rocks change northwestward from platform facies to turbidite facies. West of the central part of the Main Range in Malaya, Middle Devonian (and older?) to middle Permian shelf-facies dolomite and limestone, and subordinate dark shale, have a total thickness of about 1,700 m (Suntharalingam, 1968). The equivalent Middle Devonian to Lower Carboniferous, and possibly higher, section in northwestern Malaya and southeastern peninsular Thailand is of clastic sediments-nonsandy marine shale in the east, giving way westward or northwestward to mudstone, pebbly mudstone, siltstone, and graywacke (called variously Singa, Phuket, 


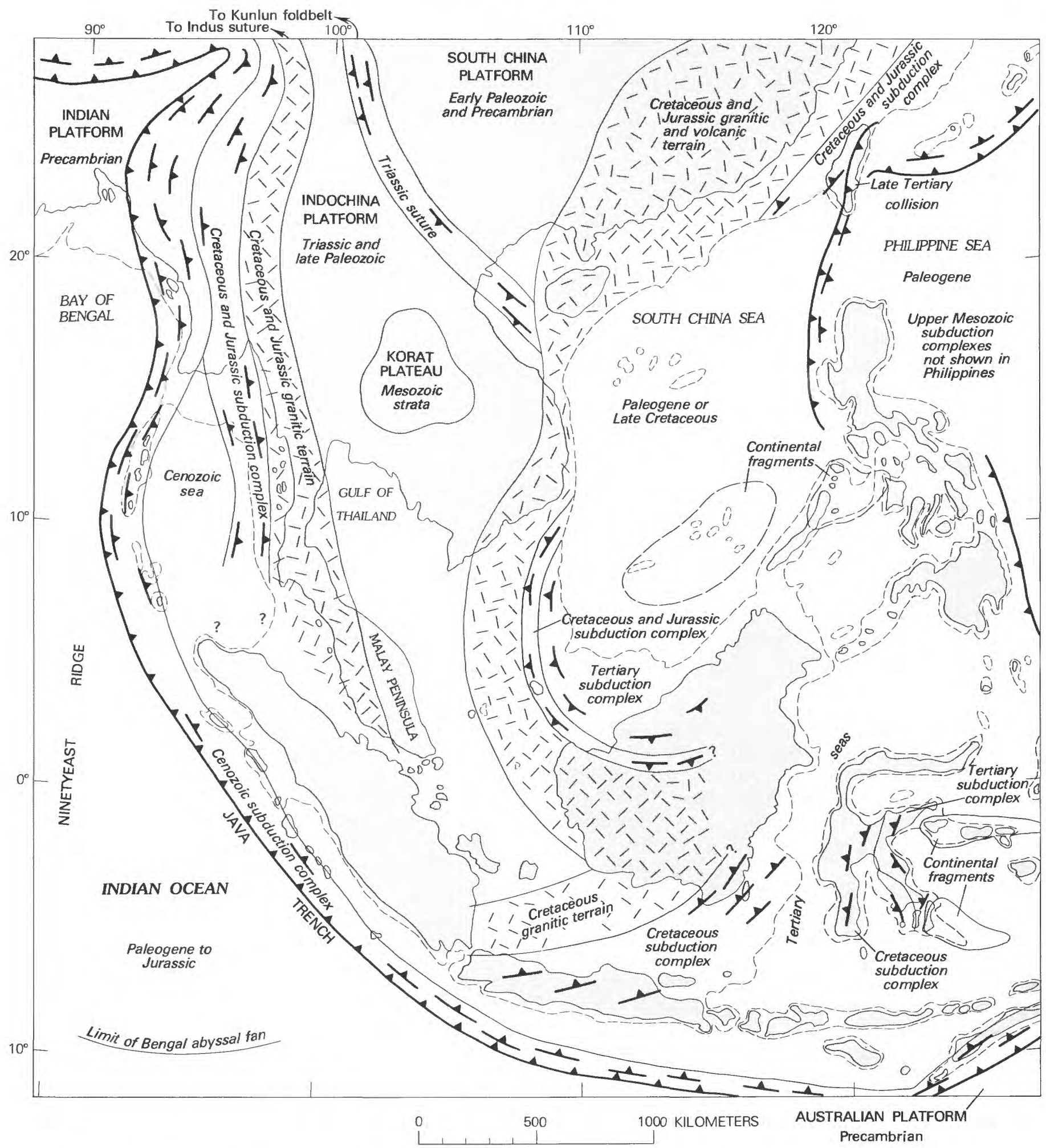

Figure 31_- Mesozoic and selected Cenozoic tectonic elements of southeast Asia and Indonesia. Positions and shapes of many elements were very different at the time they formed. Symbols within subduction complexes show dominant direction of thrusting; barbs on overriding side. Based on interpretations in this report south of $12^{\circ} \mathrm{N}$.; north of $12^{\circ} \mathrm{N}$., interpreted freely from many sources. 
Kanchanaburi, and Kempong Sena: Burton, 1972; D. J. Gobbett in Gobbett and Hutchison, 1973, p. 61-95; Hamada, 1969; Jones, 1968; Ridd, 197 Ic). The turbidite facies is on the order of 2,000 m thick in southeastern peninsular Thailand, where the older platform carbonates are exposed beneath it as far northwest as the Marui fault (Ridd, 1971c). The base of the turbidite facies has not been recognized northwest of the fault in Thailand (Garson and others, 1975; Ridd, 197lc; Young and Jantaranipa, 1970) or in southern peninsular Burma (where the turbidites are the Mergui Series: Rau, 1933). The turbidites, rich in quartz and other material of continental origin, came from a source to the west, where ocean is now present (Ridd, 1971c). Thin shallow-water basal Permian sandstone and shale overlie the thick turbidites in southwestern peninsular Thailand (Garson and others, 1975).

The Middle Devonian to lowest Permian clastic wedge, derived from the west and superimposed upon an older continental shelf or platform, may be the fill of a foreland basin. The succession within the wedge of a lower sequence of flysch overlain by shallow-water strata is suggestive that the wedge is such a fill. (See Eisbacher, 1974, and Van Houten, 1974, for summaries of the successions in a number of foreland basins elsewhere in the world.) Devonian uplift, of a character not yet defined, apparently affected a continental region that lay mostly west of the present western limit of continental crust. These conclusions accord with those of Ridd (1971c) and conflict with those of Burton (1974) and Garson, Young, and Mitchell (1975).

Overlying the varied Devonian to basal Permian strata throughout west-central and northwestern Malaya and peninsular Thailand and Burma is shallow-water, richly fossiliferous Lower to Upper Permian limestone (Chuping, Moulmein, and Rat Buri Limestones: Burton, 1972; Gobbett, 1968, 1973; Suntharalingam, 1968; Waterhouse, 1973). J. Bruce Waterhouse (oral commun., 1977) regarded the limestone as representing patch and barrier reefs, rather than a widespread continuous sheet. The rich tropical fauna in middle Permian limestone in peninsular Thailand near lat $14^{\circ} \mathrm{N}$. is suggestive of a near-equatorial position (Waterhouse and Piyasin, 1970). Dated Triassic rocks west of the Main Range occur in northwestern Malaya and adjacent Thailand, where they are Middle and Upper Triassic marine sandstone, shale, chert, and, in the west, limestone and conglomerate (C. K. Burton in Gobbett and Hutchison, 1973, p. 97-141; Courtier, 1974; Jones and others, 1966; Kobayashi and others, 1966). Jurassic and Cretaceous clastic sedimentary rocks are present also (Javanaphet, 1969) but have yet to be described in print.

The Paleozoic and Triassic rocks are much deformed and are intruded by many masses of granitic rocks. Regional metamorphism away from the generally narrow hornfels zones around granites is mostly negligible or of low grade. None of the granites of the western half of the peninsula is proved to be of Paleozoic age by field relations, and the presence of widespread Permian limestone suggests that no plutonism took place then, a conclusion which conflicts with ambiguous interpretations of rubidium-strontium data, as discussed subsequently. Major orogeny within the middle Paleozoic was postulated by Kimura and Jones (1966) and Koopmans (1965) and rejected by Burton (1972) and Yancey (1975). Although the field evidence cited for major unconformity within the exposed terrain was clearly misinterpreted, orogeny at this time farther west is recorded by the abrupt change in northwestern Malaya and peninsular Thailand from the platform conditions of the Early Devonian to the beginning of deposition of the great clastic wedge in Middle Devonian time. If deformation did occur in the exposed region within Paleozoic time, it was not accompanied by appreciable metamorphism in northwestern Malaya (Burton, 1970b; Kimura and Jones, 1966), and it did not affect the continuous Middle Devonian to middle Permian limestone section farther south (Suntharalingam, 1968).

No volcanic rocks are known with certainty to occur within the Paleozoic and Triassic sections of western Malaya. Jones (1970b) mapped metamorphosed, unfossiliferous quartzite, graywacke, siltstone, shale, limestone, and silicic tuff west of the central Main Range and assumed them all to be Paleozoic; he likely is correct for most of the sedimentary rocks, but the occurrence of the volcanic rocks in two large, compact masses permits the interpretation that they represent two synclinal downfolds of younger rocks. The large, irregular mass of "quartz porphyry" assumed by Savage (1937) to be intrusive into old sediments seems likely from his description to be rhyolite welded tuff; although it is itself much deformed, and is contact metamorphosed near granite, it is mapped as in contact with diverse sedimentary units, hence presumably lies unconformably upon the sediments. C.S. Hutchison (in Gobbett and Hutchison, 1973, p. 180-185) noted other occurrences of altered silicic volcanic rocks with undated sediments assumed to be of early Paleozoic age.

Carboniferous, Permian, and Triassic strata in Thailand north and northeast of the Malay Peninsula also occur as contrasted nonvolcanic facies in the west and volcanic-and-sedimentary facies in the east (Daniel $\mathbf{R}$. Shawe, written commun., 1977).

EASTERN MALAY PENINSULA

Malaya east of the Main Range was a generally low lying part of a continent, subjected to widespread silicic magmatism, during Carboniferous, Permian, and Triassic time. The region consists of sedimentary and volcanic rocks of Early Carboniferous to Late Triassic ages and of granitic rocks (pl. 1; bin Ahmad, 1976; Alexander 1968; Aw, 1974; C. K. Burton in Gobbett and Hutchison, 1973, p. 97-141; Chin, 1971; Chong, 1970; Fitch, 1952; Gobbett, 1968, 1972, and in Gobbett and Hutchison, 1973, p. 61-95; Grubb, 1968; Jones and others, 1966; Khoo, 1974; Kobayashi and others, 
1966; MacDonald, 1967; Rajah, 1970; Richardson, 1950; Tamura and others, 1975). The sedimentary rocks in the east half of the eastern region are mostly Carboniferous but include many of Permian age. Those in the west half of the eastern region are Permian and Triassic, the Permian rocks being dominant in the north and the Triassic ones in the south. Shale, argillite, and siltstone, slightly to moderately metamorphosed, are the most abundant clastic sedimentary rock types, but quartzose and feldspathic sandstones are widespread and conglomerate is locally plentiful. Limestone also is important in the upper Paleozoic sequences and is present locally in the Triassic. Fossils in both belts include both land plants and shallow-marine invertebrates. Deformation has been moderate to severe. The strata formed in diverse local environments and do not represent platform sheet deposits, but stratigraphy and structure are nowhere known in detail.

Silicic volcanic rocks-welded tuffs, tuffs, flows, and breccias, mostly of rhyolite, rhyodacite, and dacite-are abundant in many sectors of the western Permian and Triassic belt (C. S. Hutchison in Gobbett and Hutchison, 1973, p. 185-201). Similar volcanic rocks are present, but less widespread, in the eastern Carboniferous and Permian belt, where it is not known whether both of those ages or only one of them is represented by the volcanic rocks. Batholiths apparently formed concurrently with Carboniferous(?), Permian, and Triassic sedimentation and volcanism. The silicic character of the magmatic rocks indicates that the crust of eastern Malaya was fully continental by late Paleozoic time.

Jurassic(?) and Lower Cretaceous fluviatile, deltaic, and lacustrine clastic sedimentary rocks, among which red conglomerate and quartz sandstone are dominant, lie unconformably upon the Triassic and Paleozoic complexes of eastern Malaya (C. K. Burton, in Gobbett and Hutchison, 1973, p. 97-141; Chong, 1970; Koopmans, 1966, 1968; Rajah, 1970; Rishworth, 1974; Smiley, 1970). The sediments were derived from nearby mountains and deposited in intermontane basin environments, probably under a savannah climate. The strata are deformed by open folds. Silicic volcanic rocks and tuffs are interbedded locally, showing concurrent granitic magmatism in the region.

\section{GRANITIC ROCKS}

GENERAL

The late Paleozoic and Mesozoic batholiths in the Malay Peninsula typically form north-trending mountain ranges separated by regions of lower relief eroded from other rock types. The great Main Range batholith runs the length of the Malaysian sector of the peninsula just west of its midline, and smaller batholiths are scattered throughout the rest of the peninsula ( $\mathrm{pl}$. 1). The granitic rocks are on the average markedly silicic and potassic, and biotite quartz monzonite is the dominant rock type (C. S. Hutchison in Gobbett and Hutchison, 1973, p. 215-252). Biotite and two-mica granite, and hornblende-biotite granodiorite and quartz monzonite, are also common. The relatively mafic rocks occur mostly in a broad belt of small batholiths lying east of the Main Range but west of the easternmost batholiths of the peninsula (Burton, 1969; Hosking, 1969). Quartz diorite is present only in minor occurrences; no belt is dominated by that rock type, and trondhjemite (sodic leucogranite) has not been reported. Thus no obvious gradient exists in potassium-sodium-silicon ratios to indicate a simple genetic relationship to a single paleo-Benioff zone. It is not yet possible to search for less conspicuous compositional gradients in the granitic masses across the regional strike, because ages and compositions cannot be correlated adequately.

\section{AGE DETERMINATIONS}

An extensive program of determinations of apparent ages of Malayan granites from $\mathrm{K}-\mathrm{Ar}$ and $\mathrm{Rb}-\mathrm{Sr}$ data was carried out by J. D. Bignell and N. J. Snelling (1977; I am much indebted to them for providing a copy of the manuscript several years before publication). They placed primary. reliance upon whole-rock $\mathrm{R} b-\mathrm{Sr}$ data, plotted as ${ }^{87} \mathrm{Rb} /{ }^{86} \mathrm{Sr}$ against ${ }^{87} \mathrm{Sr} /{ }^{86} \mathrm{Sr}^{4}$. They assumed that any samples from a region that plot approximately along a single line away from an initial (magmatic) ratio of ${ }^{87} \mathrm{Sr} /{ }^{86} \mathrm{Sr}$ of about 0.708 are defining isochrons, and that the slope of the line thus indicates the age of all of the samples on the line. Ages so derived are summarized in figure 12 . As field and petrologic relationships between samples plotted on such possible isochrons, or between such samples and those on other possible isochrons, have not been determined, the method is open to much question. Separate-mineral $\mathrm{Rb}-\mathrm{Sr}$ and $\mathrm{K}-\mathrm{Ar}$ data yield ages generally compatible with these whole-rock determinations for eastern Malaya, but not for western Malaya.

The granites of eastern Malaya, east of the Main Range batholith, yield generally concordant $\mathrm{K}$-Ar mica ages, $\mathrm{Rb}-\mathrm{Sr}$ whole-rock ages, and in the several samples so analyzed, separate-mineral $\mathrm{Rb}-\mathrm{Sr}$ ages. The dates define three peaks, presumably major intrusive episodes, at about $250 \mathrm{~m} . \mathrm{y}$. (latest Permian?) and 220 and 200 m.y. (Late Triassic) ${ }^{5}$. These concordant ages are compatible with the geologic record: Permian and Triassic silicic volcanic rocks are widespread in eastern Malaya, and concurrent batholithic

4 ${ }^{87} \mathrm{Rb}$ is the radioactive isotope of rubidium, ${ }^{87} \mathrm{Sr}$ its strontium daughter product, and ${ }^{85} \mathrm{Sr}$ a nonradiogenic isotope comparable in relative abundance to ${ }^{87} \mathrm{Sr}$ but constituting only about 10 percent of total nonradiogenic strontium. On a plot of ${ }^{87} \mathrm{Rb} /{ }^{85} \mathrm{Sr}$ against ${ }^{87} \mathrm{Sr} /{ }^{m 8} \mathrm{Sr}$, isochrons depicting the increase of ${ }^{8} \mathrm{Sr}$ by decay of ${ }^{87} \mathrm{Rb}$ are straight lines originating at the initial ratio of ${ }^{82} \mathrm{Sr} /{ }^{86} \mathrm{Sr}$, which is the intercept at which ${ }^{87} \mathrm{Rb} /{ }^{3} \mathrm{Sr}=0$ (fig. $32 A$ ). The slope of the isochron defines its age, so materials of different initial ratios but the same age define parallel isochrons, whereas materials of the same initial ratio hut different age define isochrons that fan from that ratio. Ages cited in the present discussion are based on the ${ }^{87} \mathrm{Rb}$ beta decay rate of $1.42 \times 10-11 / 4 r$, adopted as standard by the Subcommission on Geochronology of the International Commission on Stratigraphy in 1976, but the isochrons of fig. $32 \mathrm{~A}$ are calculated with a decay constant of 1.47 .

${ }^{5}$ The widely used Geological Society of London (1962) time scale assumed, from very few data, that the beginnings of the Early, Middle, and Late Triassic and the Early Jurassic were at $224,215,205$, and $190 \mathrm{~m} . y$., repectively, but subsequent, fuller data show that the actual ages are likely closer to 245, 235, 225, and 190 m.y.; see Armstrong and Besancon (1970), Bignell and Snelling (1977), Lambert (1971), and Webb and McDougall (1967). 
magmatism is probable. (General relationships between silicic volcanism and plutonism have been discussed by Hamilton, 1969a, Hamilton and Myers, 1967, and others.)

The age determinations for granitic rocks of medial (Main Range) and western Malaya are far more ambiguous. The whole-rock-isochron $\mathrm{Rb}$-Sr method, based on an assumed initial ratio of ${ }^{87} \mathrm{Sr} /{ }^{86} \mathrm{Sr}$ of 0.708 , favored by Bignell and Snelling, yields a few Cretaceous ages, many Triassic ones (mostly 200-245 m.y.), a substantial number of latest Carboniferous and Early Permian ages (mostly 275-295 m.y.), and a few older ages back to 440 m.y. The K-Ar mica ages, which mostly represent a smaller selection from the same samples, by contrast define a broad peak from 130 to 210 m.y., earliest Cretaceous to Late Triassic, and a lesser 80-100 m.y. peak, Late Cretaceous. Similar conflicts between $\mathrm{K}-\mathrm{Ar}$ and whole-rock $\mathrm{Rb}-\mathrm{Sr}$ ages were found in less extensive dating studies in Malaya by Rodger E. Denison (written commun., 1972) and in peninsular Thailand by Burton and Bignell (1969). The whole-rock ages also conflict with the limited separate-mineral $\mathrm{Rb}-\mathrm{Sr}$ work done by Bignell and Snelling. The two specimens, S24 and S30, so studied, which were thought to fit late Paleozoic whole-rock isochrons when an initial ${ }^{87} \mathrm{Sr} /{ }^{86} \mathrm{Sr}$ of 0.708 was assumed, have biotite, potassium feldspar, plagioclase, and whole-rock $\mathrm{Rb}-\mathrm{Sr}$ isotopes that all plot together on an apparent isochron with a slope corresponding to $160 \mathrm{~m}$.y. and an initial-ratio intercept of about 0.72 . Biotite $\mathrm{K}-\mathrm{Ar}$ ages from the same two specimens are 125 and 135 m.y. Bignell and Snelling assumed that all of the various minerals were reset, in both $\mathrm{Sr}-\mathrm{Rb}$ and $\mathrm{K}-\mathrm{Ar}$ ratios, by a thermal event long after initial crystallization; such complete resetting in unmetamorphosed massive granites is difficult to visualize, and obviously these two granites at least may be of Jurassic age.

Discrepancies also mark some of the early Mesozoic age assignments. Sample S16 from the Main Range yields nearly concordant Late Triassic ages by all methods: 215 m.y. by the whole-rock $\mathrm{Rb}-\mathrm{Sr}$ method, 202 m.y. by a biotite-potassium feldspar-whole rock $\mathrm{Rb}$-Sr isochron, and 201 m.y. by biotite K-Ar. But samples S7, S11, S25, and S31, all regarded as 200 m.y. or older from the whole-rock method, each yield apparent isochrons from various minerals and the whole rocks with slopes equivalent to about 180 m.y.; K-Ar mica ages are about 160 m.y. for two of these samples, 67 m.y. for a third, undetermined for a fourth. Three other "early Mesozoic" samples yield highly erratic mineral $\mathrm{Rb}$-Sr data that do not define isochrons.

The presence of upper Paleozoic granites in medial and western Malaya, as advocated by Bignell and Snelling and accepted by C. S. Hutchison (in Gobbett and Hutchison, 1973) and other geologists now concerned with Malayan granites, is difficult to reconcile with the known occurrence in the region of platform and shallow-marine sedimentary rocks that span the entire Paleozoic from Cambrian to middle Permian and that are nowhere proved to include volcanic rocks. I suggest accordingly that in medial and western Malaya the inference of Paleozoic granitic-rock ages from whole-rock Rb-Sr methods is in error, that no granitic rocks there are older than Triassic, and that most of the granites are of Late Triassic and Jurassic age. More detailed field and isotopic study of some of the possibly old granites is obviously needed to resolve the matter.

\section{PREFERRED AGE ASSIGNMENTS}

Several small granites in southern Malaya yield approximately concordant $\mathrm{Rb}-\mathrm{Sr}$ and $\mathrm{K}$-Ar Cretaceous ages, and so are designated Cretaceous on the tectonic map (pl. 1).

The granites east of the Main Range are otherwise shown as of Permian through Jurassic age, a span that includes all of the other $\mathrm{K}-\mathrm{Ar}$ ages and most of the Rb-Srones, as well as the stratigraphic age of the voluminous Permian and Triassic volcanic rocks. Jurassic magmatism is suggested by some of the isotopic dates but not by available geologic information. Major magmatism was apparently over before the beginning of the Cretaceous, for the Lower Cretaceous (and Upper Jurassic?) strata of eastern Malaya are mostly nonvolcanic and little deformed. Neither volcanism nor plutonism is yet proved for the Carboniferous. Both the $\mathrm{K}-\mathrm{Ar}$ and $\mathrm{Rb}-\mathrm{Sr}$ ages suggest that the hornblende-biotite quartz monzonites and granodiorites of the west part of eastern Malaya are largely of Triassic age, whereas the biotite quartz monzonites of the east part are both Permian and Triassic.

The granitic rocks of Malaya in and west of the Main Range, and of southeastern peninsular Thailand, are shown on the tectonic map and figure 31 to be of Mesozoic age. This broad bracket accords with the geologic inference that the granites are largely or wholly younger than middle Permian. The bracket encloses nearly all of the K-Ar dates and $\mathrm{Rb}-\mathrm{Sr}$ mineral-isochron dates by Bignell and Snelling. Their Paleozoic ages, calculated by the assumed-isochron whole-rock $\mathrm{Rb}-\mathrm{Sr}$ method, are rejected for the reasons specified in the preceding section.

\section{PETROGENESIS}

The whole-rock Rb-Sr data of Bignell and Snelling (1977) apparently yield spurious ages for the granites of medial and western Malaya because the primary assumption of the whole-rock method is invalid here: the magmas did not come from a single source region of uniform abundance of $\mathrm{Rb}$ and Sr. The very factors that make the data unsuitable for dating, however, make them invaluable as constraints on petrogenetic theory.

Granites of Malayan type characteristically have high and erratic initial ratios of ${ }^{87} \mathrm{Sr} /{ }^{86} \mathrm{Sr}$. The Paleozoic granites of northeast Australia are of this type and had initial ratios between 0.715 and 0.76 (Cooper and others, 1975). It is suggested subsequently in this report that Australian and Malayan terrains were continuous, via New Guinea and Sumatra, before middle Mesozoic continental rifting. The 
granites of northwest Thailand, approximately on strike from those of western Malaya, have ages that are mostly Triassic but partly Cretaceous, according to both $\mathrm{Rb}-\mathrm{Sr}$ and $\mathrm{K}$-Ar methods (Besang and others, 1975). Initial ratios of ${ }^{87} \mathrm{Sr} /{ }^{86} \mathrm{Sr}$ in the Triassic granites were very high, about 0.725 . These results are compatible with my inferences about the Malayan data of Bignell and Snelling.

Many igneous rock suites in other parts of the world crystallized from magmas having variable initial ${ }^{87} \mathrm{Sr} /{ }^{86} \mathrm{Sr}$ ratios, and so were not derived from single-source magmas. The tholeiitic basalt flows of Jurassic age in one sector of the Transantarctic Mountains had initial ${ }^{87} \mathrm{Sr} /{ }^{86} \mathrm{Sr}$ ratios that scattered from 0.7094 to 0.7133 , and relationships between various $\mathrm{Rb}, \mathrm{Sr}$, and other isotopic and elemental abundances indicate that basaltic magmas of mantle origin here assimilated 20 to 40 percent by weight of Precambrian crustal rocks (Faure and others, 1974). Pliocene and Quaternary volcanic rocks in Idaho (Leeman and Manton, 1971), central Africa (Bell and Powell, 1969), and the Andes (James and others, 1976) yield apparent $\mathrm{Rb}-\mathrm{Sr}$ isochrons that point to spurious ages of 400 to $1,000 \mathrm{~m}$.y. Whole-rock specimens from single late Quaternary volcanoes in Sumatra and Java yield spurious isochrons with slopes equivalent to ages of about 100 m.y. (Whitford, 1975). Brooks, James, and Hart (1976) discussed the problem at length. Either two-stage origins or the mixing of materials from two contrasted sources can produce such results, and Leeman and Manton and also Bell and Powell interpreted the pseudo-isochrons as mixing lines due to the assimilation of Precambrian crustal rocks by magmas melted in the mantle.

Bell and Powell (1969) and Faure, Bowman, Elliot, and Jones (1974) applied a number of arithmetically based tests to their isotopic and chemical data to demonstrate the composite origins of their rocks. Present ratios of ${ }^{87} \mathrm{Sr} /{ }^{86} \mathrm{Sr}$ show positive, linear correlations with ratios of total $\mathrm{Rb}$ to $\mathrm{Sr}$. The plotting of any ratio involving two of the $\mathrm{Sr}$ and $\mathrm{Rb}$ isotopic or weight components against the absolute amount of any other component produces a hyperbolic pattern. Initial ${ }^{87} \mathrm{Sr} /{ }^{89} \mathrm{Sr}$ ratios correlate both with strontium concentrations and with major-oxide contents.

Figures 32 and 33 illustrate such relationships in the $\mathrm{Rb}$ and $\mathrm{Sr}$ data of Bignell and Snelling (1977). The ratio of radiogenic ${ }^{87} \mathrm{Sr}$ to nonradiogenic ${ }^{86} \mathrm{Sr}$ increases hyperbolically as total $\mathrm{Sr}$ decreases (fig. $32 B$ ) but increases directly with the ratio of total $\mathrm{Rb} / \mathrm{Sr}$, and the rocks yielding the calculated Paleozoic ages define a lower narrow zone than do those yielding Mesozoic ages (fig. $31 \mathrm{C}$ ). The apparent isochron age increases irregularly with total $\mathrm{Sr}$ (fig. 33). These correlations are in the directions that would be produced by decay of ${ }^{87} \mathrm{Rb}$ to ${ }^{86} \mathrm{Sr}$, but as only about $1-4$ percent of the total $\mathrm{Sr}$ in the rocks is ${ }^{87} \mathrm{Sr}$ produced by this decay within the last several hundred million years, the correlations cannot be explained by this effect. The granites are uncommonly high both in total $\mathrm{Rb}$ and in $\mathrm{Rb} / \mathrm{Sr}$ ratios. The $\mathrm{Sr}$ appears to be too radiogenic for total derivation from the same source as the $\mathrm{Rb}$, and the discrepancy tends to increase with increasing $\mathrm{Sr}$ and to decrease with increasing $\mathrm{Rb}$. A paradoxical conclusion is suggested: the $\mathrm{Sr}$ in the western Malayan granites came from sources that on the average were higher in $\mathrm{Rb}$ than were those which on the average yielded the $\mathrm{Rb}$ itself.

Inspection of figure $32 A$ shows that, if $255 \mathrm{~m}$.y. is regarded as the true old age limit of western Malayan granites, all but one of the samples of Bignell and Snelling plot above the 255-m.y. isochron when it is moved, parallel to itself, to an origin at ${ }^{87} \mathrm{Sr} /{ }^{86} \mathrm{Sr}=0.725$. As noted previously, two samples give a good isochron of whole rocks plus various minerals with age slopes of $160 \mathrm{~m} . \mathrm{y}$. and initial-ratio intercepts of about 0.720 . Several sets of concordant $\mathrm{K}-\mathrm{Ar}$ ages for various minerals point to similarly high initial ratios. Such high initial values are comparable to those in Precambrian crystalline rocks (Faure and Powell, 1972; Faure and others, 1974), whereas mantle strontium should have had a ratio of only about 0.703 in Mesozoic time.

The granitic rocks of medial and western Malaya thus may record either direct melting of lower continental crust or the assimilation of Precambrian crustal $\mathrm{Sr}$ in Mesozoic magmas derived ultimately from the mantle. (See Hamilton, $1969 \mathrm{~b}$, and Hamilton and Myers, 1967, for arguments that granitic magmas generally represent crust-mantle mixes.) California provides an analog for the contamination inferred: both $\mathrm{Sr}$ (Kistler and Peterman, 1972) and $\mathrm{Pb}$ (Doe and Delevaux, 1973; Zartman, 1974) in Mesozoic granitic rocks become more radiogenic southward as the crust into which they were intruded changes from a young subduction-accretion "eugeosyncline" through a continental shelf to an old continental platform (Hamilton, 1969b, 1978b). Western Malaya must have old continental crust, and the $\mathrm{Sr}$ in its young granites is relatively radiogenic. In eastern Malaya, where no geologic criteria require Precambrian continental crust to be present, the $\mathrm{Sr}$ is much less radiogenic.

A possible explanation for these features of $\mathrm{Rb}-\mathrm{Sr}$ geochemistry is that the granitic melts contained both mantle and crustal materials. The mantle-component melt retained $\mathrm{Rb}$ proportionately more than it did $\mathrm{Sr}$, which tended to stay behind, or to crystallize out during rise of the magma, with $\mathrm{Ca}$ and other refractory elements. The component of melt from the crust (which has an $\mathrm{Rb} /$ Srratio perhaps 10 times greater than did the mantle) represented selective melting of, and greater relative retention of $\mathrm{Sr}$ from, $\mathrm{Rb}$-rich minerals such as mica and potassic feldspar.

The presence throughout the Malay Peninsula of silicic and potassic granites that show no obvious cross-strike compositional variation to indicate the usual relationship to ancient Benioff zones might be explicable in terms of subduction of continental crust. The high altitude of the Tibetan Plateau has been explained by many geologists, from Argand (1924) on, as due to the doubling of the thickness of continental crust from compression or the 
TECTONICS OF THE INDONESIAN REGION

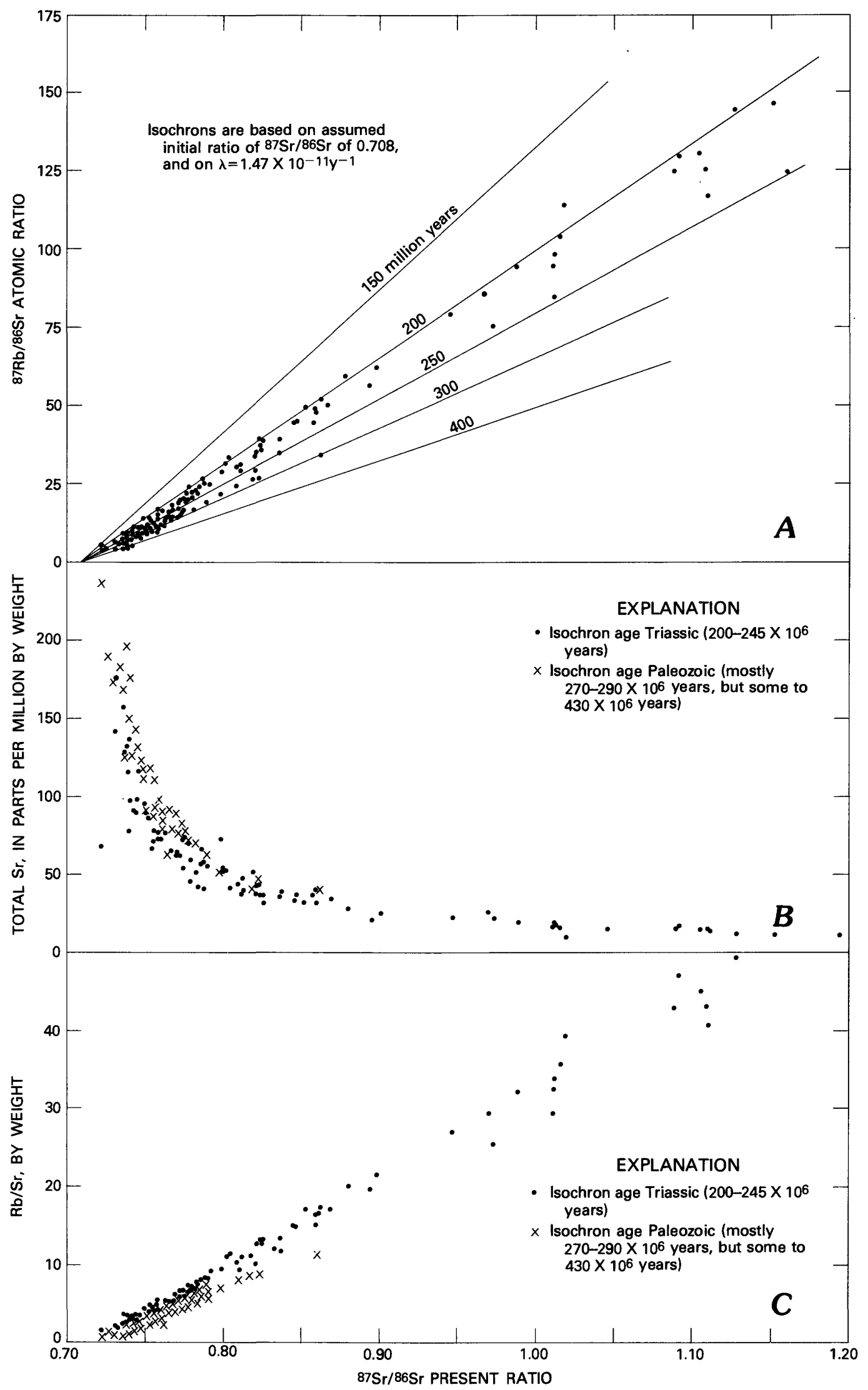




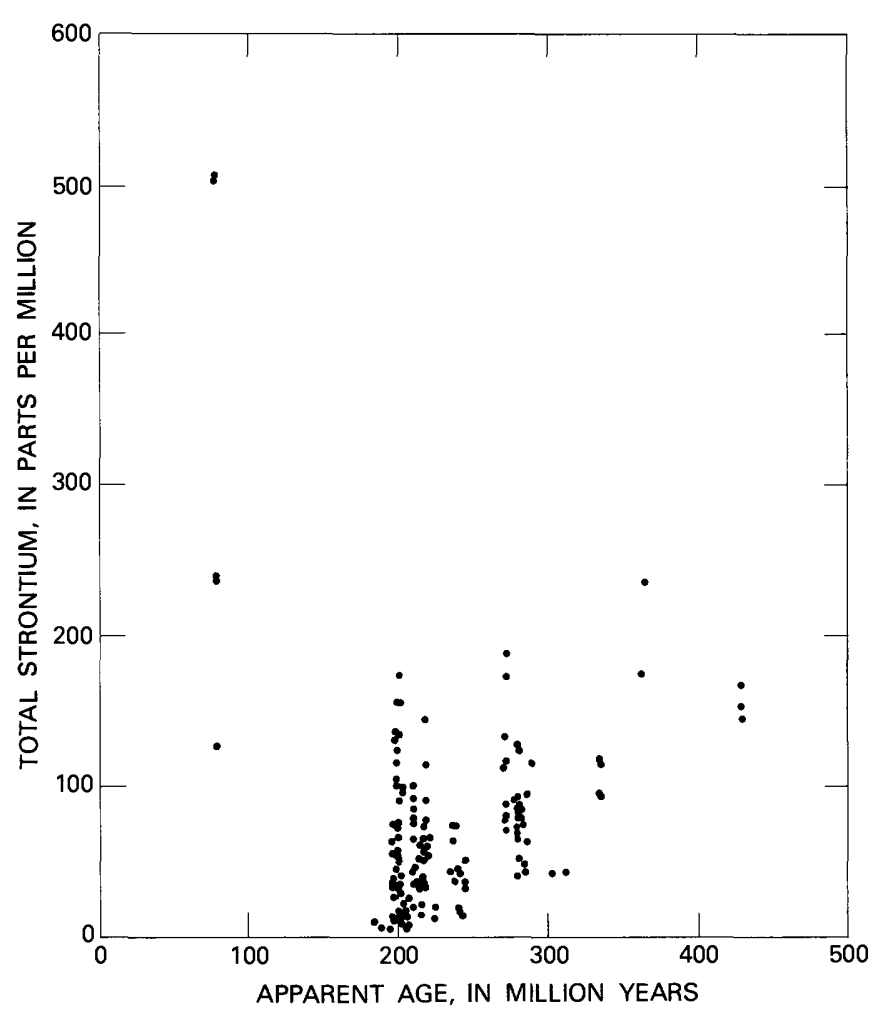

FIGURE 33. - Strontium contents of granitic rocks in medial and western Malaya, plotted against the ages of the rocks as inferred by Bignell and Snelling (1977) from the assumption of initial ratios of ${ }^{8 /} \mathrm{Sr} /{ }^{86} \mathrm{Sr}$ of 0.708 . There is a very irregular increase in calculated age with increase in total $\mathrm{Sr}$, except that the several specimens yielding the youngest age ( $80 \mathrm{~m} . \mathrm{y}$.) also have generally high contents of $\mathrm{Sr}$.

sliding beneath Tibet of the northern part of the Indian plate. Dewey and Burke (1973) argued on geological grounds, Bird, Toksöz, and Sleep (1975) on the basis of computer modeling, and Bird and Toksöz (1977) on the basis of attenuation of Rayleigh waves, that such doubling should lead to the direct melting of lower continental crust.

\section{TIN}

The widespread tin deposits of the Malay Peninsula are derived mostly from coarsely porphyritic two-mica granites bearing accessory tourmaline (Burton, 1969; Hosking, 1972). Primary tin occurs in various settings near the tops of granitic masses: in pegmatites; in pyrometasomatic deposits in wallrocks, particularly limestone; in hydrothermal replacements in granite; and in lodes and vein swarms
(Hosking, 1970, 1972). Most of the tin mined comes from placers, both onshore and offshore, derived by tropical weathering, residual concentration, and limited transportation from these primary deposits. Tin occurs in granites of similar petrologic type but of ages ranging apparently from Permian to Cretaceous, so either similar processes operated at different times, or else tin mineralization was superimposed on granites of diverse ages during a more limited period. The tin-bearing granites are generally rich in rubidium, fluorine, lithium, boron, and some other minor elements.

\section{PALEOMAGNETISM}

A reconnaissance paleomagnetic study of several small suites of oriented hand specimens of Malayan rocks of known and assumed late Paleozoic and Mesozoic ages reported by McElhinny, Haile, and Crawford (1974). They concluded that Malaya lay near lat $15^{\circ} \mathrm{N}$. throughout late Paleozoic and Mesozoic time and could not then have lain next to the east coast of India. (The Indian connection has been advocated by several geologists, but, as noted elsewhere in this work, it is invalidated by paleoclimatic and paleontological data.) Their conclusion, if correct, would also negate the suggestion made in this book that Sumatra lay adjacent to what is now medial New Guinea in the Permian and Triassic and was rifted away from it before the Middle Jurassic, so an analysis of the Malayan paleomagnetic data is appropriate here.

The paleomagnetic position of Australia, and hence of southern New Guinea, is reasonably well established for the late Paleozoic and Mesozoic (McElhinny and Luck, 1970a). The paleomagnetic latitude of medial New Guinea was near $10^{\circ} \mathrm{S}$. early in the Carboniferous, but then Australia and New Guinea moved rapidly southward and medial New Guinea lay near $40^{\circ} \mathrm{S}$. during the Permian and Mesozoic. The late Paleozoic paleolatitude of southwestern Sumatra must have been only a little lower if the interpretations made in this report are correct.

The suites of Malayan samples are small, and enough scatter occurs in the results so that precision of pole determinations is low. The orientations of stable magnetization are, nevertheless, broadly consistent, and the results cannot be dismissed. The oldest rocks studied in the paleomagnetic reconnaissance in Malaya are two small suites of sedimentary rocks - one from the probably Lower Carboniferous part of the moderately dipping Singa Formation in northwesternmost Malaya and the other from the

FIGURE 32.--Strontium and rubidium isotopic and elemental abundances and ratios in whole-rock analyses of granitic rocks of medial (Main Range) and western Malay Peninsula. All data from Bignell and Snelling(1977); several of their analyses are off the scales used here and are not plotted, but continue the trends illustrated, and the several analyses indicative of Cretaceous ages are omitted. The points falling below the $255 \mathrm{~m}$. $y$. isochron in $A$ - note that the ${ }^{87} \mathrm{Sr} /{ }^{86} \mathrm{Sr}$ ratio is here plotted on the horizontal axis-are assumed by Bignell and Snelling to indicate Paleozoic ages. Pre-Mesozoic ages are difficult to reconcile with the geology of the region, and the hyperbolic distribution in $B$ and linear array in $C$ are suggested in the text to be indicative of mixing of old crustal rocks in Mesozoic magmas to produce pseudo-isochrons. 
steep-dipping Lower Carboniferous or Devonian Bentong Group of central medial Malaya. Paleomagnetic orientations cluster to suggest a common magnetic latitude of about $10^{\circ}$. Accepting the polarity assumption of McElhinny, Haile, and Crawford (1974) that this latitude is north, and using their paleomagnetic north pole position of lat $57^{\circ}$ N., long $178^{\circ} \mathrm{W}$., the Triassic or Jurassic rift line I postulate to be present in Sumatra has a nearly east-west paleotrend and an early Carboniferous paleolatitude of about $5^{\circ} \mathrm{N}$. This is so close to the paleomagnetic position and orientation of Early Carboniferious medial New Guinea as to pose no problem to the reconstruction supported here.

Two other small suites of samples from Malaya were assumed by McElhinny, Haile, and Crawford (1974) to be of Permian and Triassic age. One suite is of rhyolite samples from southeasternmost Malaya, and the other of rhyolite and redbeds from west-central Malaya. The magnetic orientation of these rocks-paleomagnetic pole position about lat $55^{\circ} \mathrm{N}$., long $160^{\circ} \mathrm{E}$. - is similar to that of the Lower Carboniferous(?) sedimentary rocks. If the Permian or Triassic age is assigned correctly, then that orientation is incompatible with a New Guinea attachment, for by Permian time New Guinea lay far to the south. Assuming that the paleolatitude of the samples is south rather than north is not a viable alternative, for this would require that Malaya and Sumatra be rotated almost $180^{\circ}$, putting Sumatra farther from New Guinea than was. Malaya. The Permian or Triassic age assignments by McElhinny, Haile, and Crawford, however, were based on particularly ambiguous $\mathrm{Rb}$-Sr age determinations. I discussed in the preceding section the problems with the Malayan-granite assumed-isochron $\mathrm{Rb}$-Sr age determinations, which appear to be much older than true ages because of magmatic assimilation of radiogenic strontium. The suites reported on by McElhinny, Haile, and Crawford could well be Jurassic or Cretaceous, as apparently are nearby granites, in which case the pole position poses no problem. A reconnaissance paleomagnetic study of Jurassic redbeds in northeast Thailand yielded a similar paleomagnetic pole position of lat $69^{\circ} \mathrm{N}$., long $177^{\circ}$ E. (Haile and Tarling, 1975).

The apparently equatorial fauna of the middle Permian of northern peninsular Thailand (Waterhouse and Piyasin, 1970 ) is given a paleolatitude of $30^{\circ} \mathrm{N}$. by the pole of McElhinny, Haile, and Crawford (1974) or one of about $25^{\circ}$ S. by my reconstruction-a poor fit either way.

Another suite of samples studied paleomagnetically is of basalt flows from southernmost Malaya, dated only by a single whole-rock K-Ar determination of $62 \mathrm{~m}$.y. McElhinny, Haile, and Crawford (1974) assumed the suite to be of Cretaceous age, whereas field geologists have assigned it to the Tertiary, likely Neogene. Paleomagnetic latitude is $10^{\circ}$ or $20^{\circ}$, and the pole position is about lat $45^{\circ} \mathrm{N}$., long $35^{\circ} \mathrm{E}$. Malaya has moved something like $1,500 \mathrm{~km}$ southward during Cenozoic time, and its southern part has rotated about $45^{\circ}$ counterclockwise, if this pole approximately represents the north geographic pole.

As the ages of the rock suites analyzed paleomagnetically are mostly defined only within very wide limits, all derivative tectonic interpretations are of course speculative.

\section{POSSIBLE SUTURE IN MEDIAL MALAYA}

A belt of rocks trending northward through central Malaya, along the eastern foothills of the Main Range near the meridian of $102^{\circ} \mathrm{E}$., is inferred on the tectonic map (pl. 1) to consist of Paleozoic subduction melange. The brief descriptions of the terrain by bin Ahmad (1976; his Foothill Formation), Alexander (1968, p. 49-54, 76, 79, Bentong Group), Khoo (1974, Karak formation, and 1975), Richardson (1939, 1950, Arenaceous Series), and Willbourn (1934, p. 7) permit a melange interpretation. The rocks include interlensed and thoroughly sheared clastic sediments, carbonaceous chert, radiolarian chert, serpentinite, greenschist, amphibolite, "schistose conglomerate," and other types. The "intraformational breccia" in bin Ahmad's photograph (1976, pl. 1) appears to be melange. Scrivenor (1931, figs. 9 and 10) presented two rough sketches of outcrops, one showing lenses of quartzite enclosed in finer grained sediments, the other showing highly contorted masses of chert and shale. Sediments that are either within the complex or that lie unconformably upon it within the belt have yielded Silurian(?), Lower Devonian, and Lower Carboniferous fossils (Jones, 1970a; Jones and others, 1966). The rocks are intruded on the west by the Main Range batholith.

I spent two days in March 1972 looking at the belt in the area between and near Bentong and Raub, 45-70 km north-northeast of Kuala Lumpur. On one day. I was guided by Jaafar bin Ahmad and K. N. Murthy of the Geological Survey of Malaysia. Outcrops are widely separated and generally much weathered, and relationships between rock types are not generally apparent. Although most outcrops seen within the belt in question are of nondisrupted sedimentary rocks, some of the materials seen are quite suggestive of melange. Sheared serpentinite (fig. 34A) forms a sizeable mass about $12 \mathrm{~km}$ northwest of Raub. Several cuts about $30 \mathrm{~km}$ north of Bentong on the road to Raub expose saprolite-residual material produced by extreme weathering-which appears to be formed from lenses of sandstone in a matrix of sheared shale (fig. 34B). Other cuts in the saprolite in the same vicinity however expose coherent strata. Closer to the Main Range batholith, numerous cuts on the road from Raub to Fraser's Hill expose dark phyllite enclosing abundant small lenses of feldspathic quartzite. Similar phyllite containing quartzose lenses, of all sizes from $2 \times 5 \mathrm{~mm}$ to at least $0.2 \times 2 \mathrm{~m}$ (fig. $34 \mathrm{C}$ ), composes much of a septum in the batholith crossed by the Kuala Lumpur-Bentong road in the vicinity of milepost $181 / 4$ (about $30 \mathrm{~km}$ ) from 

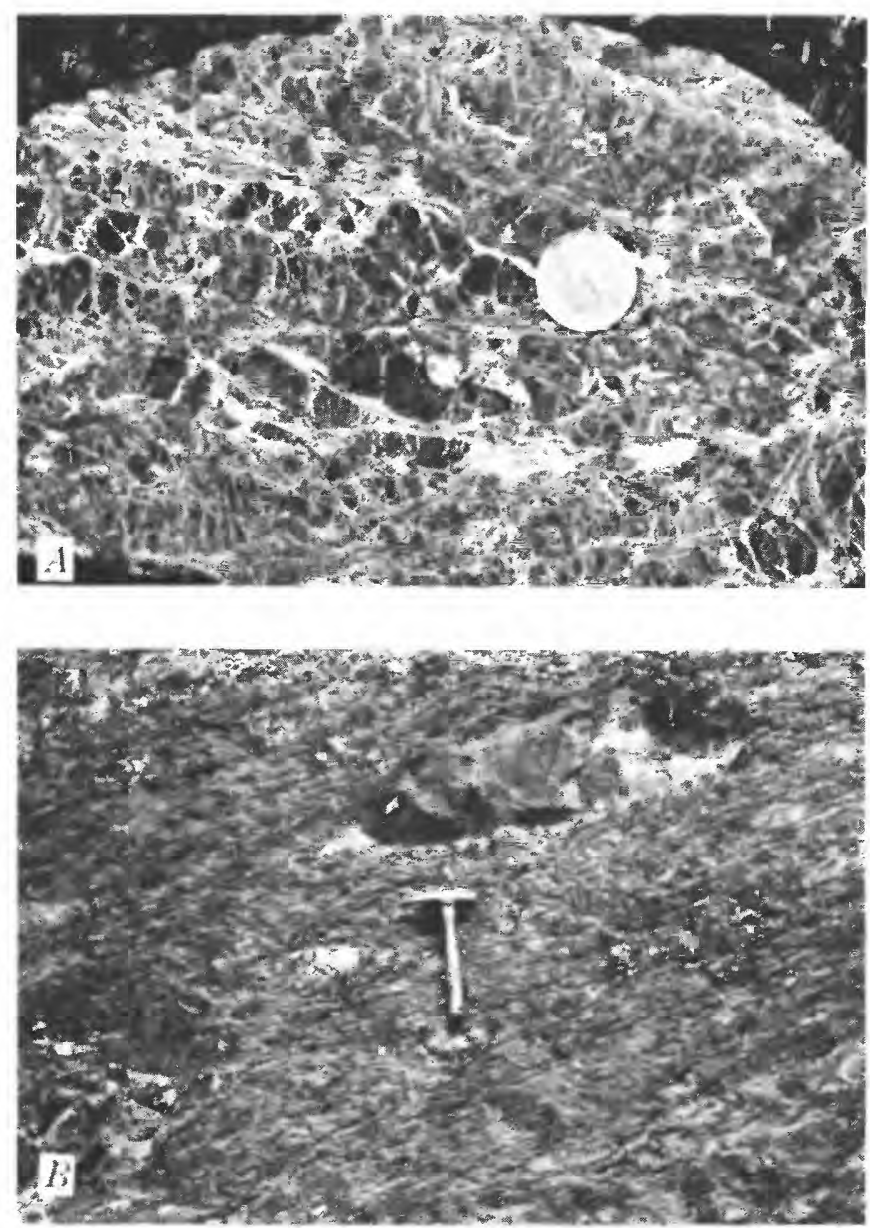

FIGURE 34.-Components of possible melange of Paleozoic or early Mesozoic age. on east side of Main Range in central Malaya. A, Sheared serpentinite, $12 \mathrm{~km}$ northwest of Raub. Photograph of a sawed surface on a specimen collected by K. N. Murthy. B, Saprolite displaying lenses (initially sandstone?) in a planar-structured matrix (initially sheared shale?). Roadcut, $30 \mathrm{~km}$ north-northwest of Bentong toward Raub. C, Quartzite lenses in dark phyllite, in a septum in the Main Range batholith. The lenses might have formed from quartz. veins deformed by shearing accompanying the intrusion of the batholith or from quartz sandstone deformed during either metamorphism or formation of broken formation. Hammer, to lower left of large quartzite lens, gives scale. Roadcut, milepost $181 / 4$ on road from Kuala Lumpur to Bentong.

Kuala Lumpur. As these phyllites are products of contact metamorphism by the nearby granitic rocks, it is not clear whether the formation of the lenses is a product of shearing accompanying the metamorphism or of an older shearing, as during subduction. Other outcrops seen in the eastern part of the belt display neither shearing nor metamorphism: they are siliceous platy shale in sharp contact with massive, altered basalt; pebbly mudstone; and dark calcareous siltstone containing abundant Carboniferous or Permian brachiopods. I conclude that melange may be present but that in this area the belt that includes the possible melange also includes

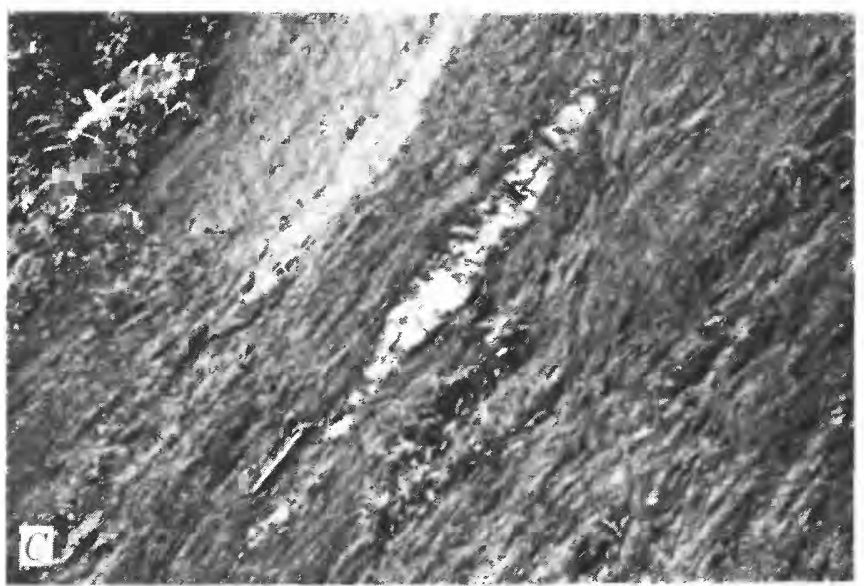

unrelated materials, and it cannot yet be specified whether or not the late Paleozoic fossils occur within the melange or in strata overlying it unconformably and folded down into it.

N. S. Haile (written commun., 1972) also examined part of the Bentong Group near Bentong and Raub and found that whereas some of the exposed rocks so mapped are disrupted, most are not. Haile believed that the Bentong represents two nonmelange formations - an older assemblage of chert, argillite, and sandstone, and a younger one of massive red sandstone and conglomerate.

If subduction melange is indeed present in this belt, then Malaya presumably is a composite of two subcontinents that collided after an intervening oceanic or marginal-sea plate disappeared beneath one side or the other. The suture might record only the opening and closing of a narrow rift, analogous to the Red Sea or Gulf of California, within Malaya. The melange(?) is older than the Triassic Main Range batholith and may or may not also be older than the upper Paleozoic strata within the belt. Although no igneous rocks of proved Paleozoic age occur in western Malaya, Hutchison (1973) speculated that various undated volcanic rocks there might be of early Paleozoic age and might be related to west-dipping subduction from the medial Malayan suture zone. Alternatively, the subduction,zone recorded by the possible melange may have dipped eastward, and perhaps the upper Paleozoic granitic and volcanic rocks of eastern Malaya are products of this subduction system.

\section{STRIKE-SIIP FAILITS}

Several conspicuous topographic lineaments trend northeast across peninsular Thailand, oblique to the regional northerly structural and topographic grain. One zone of these lineaments is shown on figure 35. Presumably the lineaments are strike-slip faults. Garson, Young, and Mitchell (1975) and Garson and Mitchell (1970) found the faults to truncate masses of granitic rocks and suggested that the faults are left-lateral structures by which the main belt of 

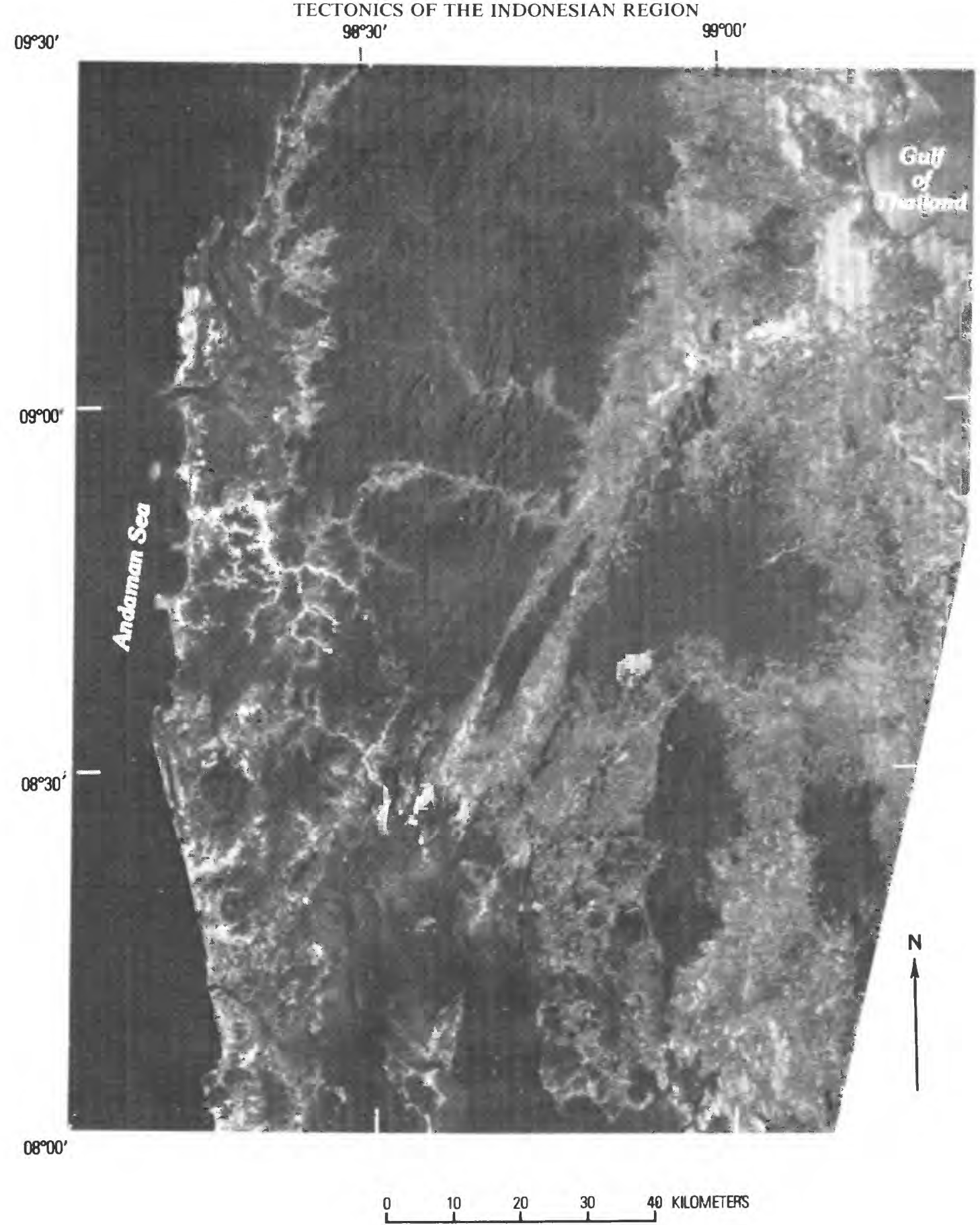

Figurr 35.- Landsat image of part of peninsular Thailand. The lineaments trending south-southwestward across the center of the picture define the Khlong Marui (or Phangnga) fault zone and probably are strike-slip faults. The broadly folded strata making the conspicuous ridges around lat $9^{\circ} 00^{\circ} \mathrm{N}$., long $98^{\circ} 40^{\prime} \mathrm{E}$., are platform Permian limestones. NASA-ERTS picture 1222-03143, March 1973.

tin granites is displaced 200 or $300 \mathrm{~km}$, from the east part of them. Offshore to the southwest, ${ }^{6}$ offsets on the faults have been concurrent with Neogene sedimentation, and the sense of vertical offsets varies along single faults, so they apparent-

"See Mergu Terrace discussion. ly are Neogene strike-slip structures. The faults, however, are now aseismic and presumably inactive.

A less likely interpretation is that the faults have had right-lateral offsets instead of left-lateral. The bathymetric basin between the south end of the Mergui Terrace and northern Sumatra might have formed in response to the 
pulling away of the terrace from Sumatra, along right-slip structures. Elsewhere in this report, however, that basin is ascribed to the northwestward shift of Sumatra.

Burton (1965) conjectured that a major northwest-trending left-lateral fault crosses northwestern Malaya, and he (1970b) presented a schematic map showing one area chopped into straight-sided rhombs by faults trending northwest and northeast. The postulated structures are not supported by geologic mapping, and their existence is doubtful. Other major strike-slip faults in various directions were inferred by Holcombe (1977) to be present, primarily on the basis of local exposures of sheared rocks.

CENOZOIC: BASALI

Alkalic olivine basalt, mostly potassic but including nephelinic sodic rocks, covers a small area near the east coast of central Malaya (Fitch, 1952). The rocks are little deformed but much eroded. A single whole-rock K-Ar age determination of $1.7 \mathrm{~m} . \mathrm{y}$. was cited by P. H. Stauffer (in Gobbett and Hutchison, 1973, p. 153).

\section{WESTERN CONTINENTAL SHELF AND MERGUI TERRACE}

The western shallow continental shelf of the Malay Peninsula has only a thin and discontinuous cover of Cenozoic sediments, but reflection profiling shows the broad and deeper Mergui Terrace farther west to contain filled fault-bounded basins (pl. 1; Paul and Lian, 1975). The sea floor of the terrace has low relief and a water depth near 600 $\mathrm{m}$. The high-velocity acoustic basement beneath the terrace is broken by numerous steep faults, mostly trending north-northeastward, which die out upwards into the Cenozoic sedimentary section and do not reach the surface. The faults face either way, and the largest of them bound half-grabens which contain locally more than $3,000 \mathrm{~m}$ of strata. Apparent directions of dip slip vary along several of the long, straight faults, which thus may have large strike-slip components (Paul and Lian, 1975). The Mergui Terrace strata have low to intermediate seismic velocities, suggesting that the oldest sediments are of middle Tertiary age. Two oil-exploration wells on the terrace indicate a stratigraphy analogous to that of the Sumatra foreland basin, with transgressive sand beneath lower Miocene deep-water shale. Pre-Tertiary strata are not displayed by reflection profiles. Exploration targets include possible reef limestones, capped by shales, on the horsts and the outer basement ridge, as well as the transgressive sands.

\section{BL RMA}

The geology of Burma, north of the area of the tectonic map of the Indonesian region, is critical for an understanding of relationships within the map area. The onshore continuation of the Andaman-Nicobar arc complex is present in Burma, and structural belts west of any exposed in the Malay Peninsula crop out in Burma (figs. 29, 31).
The Andaman-Nicobar Trench continues northward as a structural feature, though not a conspicuous bathymetric one, along the base of the continental slope of Burma on the east side of the Bay of Bengal (fig. 36). The trench is presently active, for even the youngest turbidites of the Bengal abyssal fan are deformed near the base of the continental slope. A Benioff zone of mantle earthquakes dips gently eastward beneath Burma from the trench to a depth of about $200 \mathrm{~km}$ (Santo, 1969).

The outer-arc ridge of the Sumatra-Andaman-Nicobar subduction system comes ashore in Burma as the Arakan, Chin, and Naga Ranges. The western part of the Irrawaddy lowlands - the Western Trough, in the nomenclature of Mitchell and McKerrow (1975) - appears to be the onshore extension of the outer-arc basin. A row of small anticlinal oil fields is present in the lowlands, trending along the Irrawaddy River.

The structural belts of Burma swing in broad, concentric arcs from north-northwestward in the south through northward to northeastward in the far north (figs. 29, 31); Burma Geological Department, 1961; U.N. Economic Commission for Asia and the Far East, 1971; Mitchell and McKerrow, 1975). The mountainous eastern highlands, including the Shan Plateau, consist of Paleozoic and Mesozoic sedimentary and crystalline terrains equivalent to those of the Malay Peninsula and Thailand. The west edge of these highlands displays, in the region near lat $17^{\circ} \mathrm{N}$, , a belt of upper Mesozoic melange containing, among many other components, serpentinite, eclogite, and fossiliferous Jurassic sedimentary rocks ( $\mathrm{Ba}$ Than Haq, Rangoon University of Arts and Sciences, oral commun., 1972). West of the mountains are the Irrawaddy (or central) lowlands, $200 \mathrm{~km}$ wide, and west of the lowlands is the mountainous region of the Arakan, Chin, and Naga Ranges, $50-150 \mathrm{~km}$ wide. The rocks of these western mountains, as described by Clegg (1941), Cotter (1938), and, particularly, Brunnschweiler (1966), display all the indicators of subduction melange: wildflysch, scaly clay, glaucophane schist and other metamorphic rocks, jadeite, serpentinite, gabbro, pillow basalt, radiolarian chert, and assorted sedimentary rocks, all sheared chaotically together. The melange involves fossiliferous Cretaceous and probably lower Eocene rocks in the east, and higher Eocene ones in the west. Steeply folded Eocene, Oligocene, and lower Neogene shallow marine and continental strata lie unconformably on the melange in the east (Clegg, 1938; Cotter, 1938). Similar Oligocene(?) and Neogene strata project through the fill of the Irrawaddy lowlands in broad folds farther east. Rhyolite, andesite, and basalt occur as intercalations in upper Paleogene(?) and Neogene strata exposed in the lowlands, and small Quaternary volcanoes of these materials are present also, although no volcanoes are presently active north of the Andaman Islands (Barber, 1936). To the west of the Arakan-Chin-Naga mountainous belt is the deep-water Bay of Bengal in the south, the very deeply filled Cenozoic basin 


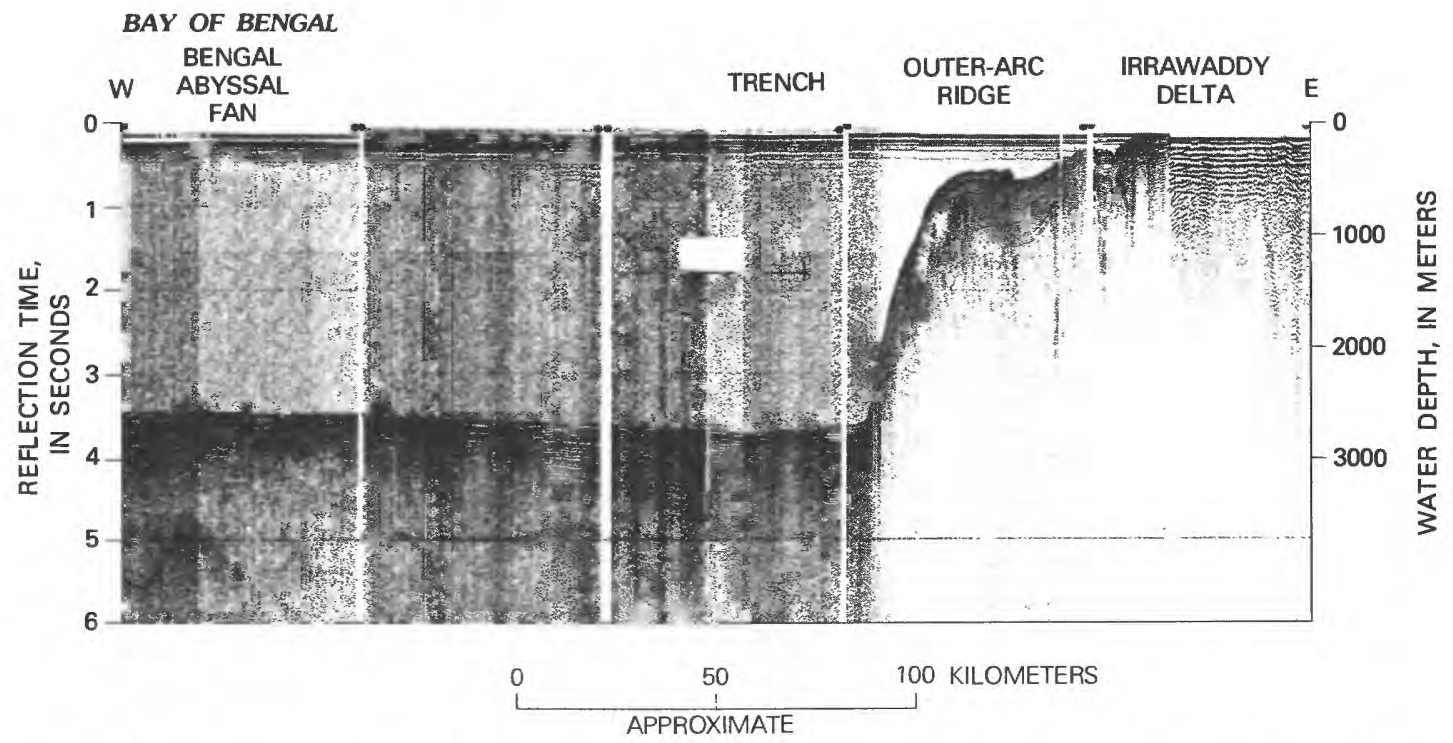

FIGURE 36.- Seismic-reflection profile across the trench bounding southwest Burma against the floor of the Bay of Bengal. The Bengal abyssal fan shows a general downward increase in dip, and deformation that increases landward, in the trench area. The trench is a tectonic feature but not a conspicuous bathymetric one, for it is overwhelmed by the Bengal turbidites. The outer-arc ridge is on the trend between the Andaman Islands and the Arakan Yoma ranges of western Burma, and its crest presumably consists of Paleogene subduction melange. The very thick sediments of the Irrawaddy Delta are ponded behind the ridge. Location shown on figure 29. Profile from Lamont-Doherty Geological Observatory, 'R. V. Robert Conrad cruise 12.

of the Ganges-Brahmaputra Delta in the center, and a basement high and shallow Cenozoic basin in the north; a broad belt of west-directed imbricate thrusts and overthrusts marks the boundary zone between the basins and the mountains to the east (Evans, 1964). Deformation decreases in intensity westward, and a row of small anticlinal gas fields is present in Bangladesh in the west. A Benioff zone of mantle earthquakes dips gently eastward from the tectonic front to a depth of about $150 \mathrm{~km}$ (Chandra, 1975).

Much of this Burmese geology can be explained by a plate-tectonic model wherein Southeast Asia grew relatively westward as the result of the tectonic accretion of subduction melange and of arc magmatism during Jurassic(?), Cretaceous, and Tertiary time (figs. 29, 31). The trench and the front of the melange wedge lay near the west edge of what is now the Shan Plateau in Jurassic (or Early Cretaceous?) time, in the eastern part of the Arakan-Chin-Naga terrain in the very late Cretaceous, or early Paleocene, Eocene, and in the western part of that terrain in the later Eocene. The process continued into late Cenozoic time, for the young volcanoes of the Irrawaddy lowlands likely formed above a Benioff zone. The corresponding Neogene subduction zone may be recorded by the thrust belt between the Bengal basins and the Arakan-Chin-Naga terrain; if so, the zone was smothered by the voluminous sediments of the Ganges and Brahmaputra Rivers, and no deep oceanic trench was present. The sedimentary fill of the Ganges-Brahmaputra Delta region is probably more than $10 \mathrm{~km}$ thick (Evans, 1964), and oceanic crust may lie directly beneath it. The upper Eocene and younger sedimentary rocks of the Irrawaddy lowlands may fill what was the outer-arc basin of Eocene time but that more recently may have been the site of extension behind the migrating Andaman-Nicobar Arc system. First-motion studies of earthquakes indicate continuing east-west compression (Rastogi and others, 1973).

\section{SUBDUCTION HISTORY OF MALAY PENINSULA}

Projection of these Burmese terrains southward permits interpretations regarding the late Mesozoic and Cenozoic evolution of the Malayan region. The Eocene melange of the Arakan-Chin-Naga belt projects directly along the submarine ridge to the Andaman Islands, which display melange of the same age, and the postulated sediment-smothered Neogene subduction zone west of the Arakan-Chin-Naga terrain has its analog in the south in the active Andaman-Nicobar-Sumatra Trench system. The Jurassic(?) and Cretaceous melange belts of Burma project southward along the outer part of the continental shelf and Mergui Terrace. The granites of western Malaya were interpreted in a previous section to be dominantly of Jurassic age and to a lesser extent of Cretaceous and possibly also Triassic ages; the Jurassic and Cretaceous granites may be products of the same subduction system as is the melange to the west. The paired belts of subduction and magmatism might have been continuous initially with those of the Java Sea and southern Borneo, although if so, extreme deformation, the geometry of which is not yet apparent, has disrupted them. 


\section{INDIA ANI SOUTHEAST ASIA}

The concept that India was an island continent during the Cretaceous and sailed northward into Asia in the early Tertiary has long been part of continental drift theory (for example, Argand, 1924). Some of the convincing geophysical evidence for this was noted in the previous section on the Indian Ocean. The concept also is consistent with the geology of the Himalayan region at the great Assam and Pakistan syntaxes at its east and west ends (fig. 37; Gannser, 1966) and with the paleoclimatic and paleontologic records of India (for example, Chowdhury, 1966).

The active right-lateral strike-slip Sittang fault trends northward near the east side of the Irrawaddy lowlands (fig. 29). The structure may be known best north of Mandalay in northeastern Burma, where the straight, continuous fault has been traced for a length of almost $200 \mathrm{~km}$ and is marked by shutter ridges, sag ponds, and fault-block valleys in a zone as wide as $1 \mathrm{~km}$ (Win Swe, 1972). The great Pan Laung fault zone, marked by a crush zone $1-3 \mathrm{~km}$ wide and separating quite different pre-Tertiary terrains, trends northward near the west side of the Shan Plateau of central Burma (Garson and others, 1976) and may be a major strike-slip fault. A large strike-slip fault was reported by Sein Myint, Hoke Maw, Tin Htut, and Tin Hlaing (1972) to trend northwestward in southeastern Burma but was not described by them except as a prominent linear feature on air photographs. These structures appear to be part of the strike-slip zone by which India moves northward past Southeast Asia.

The great arc from the west trends of Java through the northwest ones of Sumatra to the north trends of the Nicobars, Andamans, and Burma has the sense of a gigantic drag fold caused by the motion of India and the floor of the Indian Ocean west of the Ninetyeast Ridge northward past Southeast Asia (Gansser, 1966). The strongly developed subduction geology of the Late Cretaceous and early Tertiary of Burma may have been produced when the belts that now trend northward trended westward, perpendicular to the direction of relative advance of oceanic crust from the south rather than nearly parallel to it as is the case now. Continuing eastward subduction of the floor of the Bay of Bengal beneath Burma is however indicated by first-motion studies (Rastogi and others, 1973) and by the occurrence of intermediate-depth mantle earthquakes beneath Burma: the Burmese side is swinging in toward the Indian plate as the latter plows northward.

That the Bay of Bengal is a rhombochasm, opened as Southeast Asia rotated counterclockwise away from India about a northern pivot, was speculated by Burton (1970a, 1972) and Maung Thein (1973) on the basis of the triangular shape of the bay, and by Ridd $(1971 \mathrm{~b}, \mathrm{c})$ as a way of accounting for the missing western continental source of the middle Paleozoic clastic rocks of peninsular Thailand. No apparent similarities in terrains older than middle Tertiary in the two subcontinents, however, support such a postulate.
For example, the Upper Carboniferous or basal Permian continental glacial deposits of India contrast strikingly with the correlative tropical reef limestones of western Southeast Asia. The broad terrain of subduction melange exposed in Burma between the two subcontinents indicates consumption, not formation, of intervening oceanic crust. The strikingly different spreading histories of the Indian Ocean floor east and west of the Ninetyeast Ridge require that India and Southeast Asia have been in different crustal plates until recently. Stauffer and Gobbett (1972) showed that the rhombochasm conjecture is incompatible with contrasts between Indian and Southeast Asia in sedimentary facies, paleoclimates, and paleofloras. McElhinny, Haile, and Crawford (1974) showed that the concept does not accord with reconnaissance paleomagnetic data from the Malay Peninsula.

Land nevertheless lay west of the Malay Peninsula during Paleozoic time, for clastic sediments of the western part of the peninsula were derived at least in part from western sources. Crawford (1972) suggested that the subcontinent of Tibet is the missing landmass, having since been displaced northward and caught between the Indian subcontinent and the rest of Asia.

\section{ROTATION OF SOLTHEAST ASIA}

The island continent of India collided with the Tethyan margin of Eurasia in Eocene time, about $\mathbf{4 0}$ million years ago, and since then has continued to move northward at a velocity of about $5 \mathrm{~cm} / \mathrm{yr}, 50 \mathrm{~km} /$ million years, relative to the internally stable, northwestern part of Eurasia (Molnar and Tapponnier, 1975). The great Pakistan and Assam syntaxes, at west and east corners of the Indian plate, indicate northward motion of India relative to the Middle East to the west, and to Southeast Asia to the east (as Gansser, 1966, and others have recognized). The continuing convergence of India and Eurasia has been accommodated by continental underthrusting (which may have doubled the thickness of the continental plate beneath the Tibetan Plateau), by crustal compression, and by the eastward motion of China, obliquely out of the way of the advancing southern continent, along a complex series of strike-slip faults and other structures (fig. 37; Molnar and Tapponnier, 1975; Tapponnier and Molnar, 1977). Much less analogous westward motion is indicated northwest of India because of the buttressing effect of continental crust, far from an ocean, in that direction.

The continuous subduction zone trending south from the Assam syntaxis to Sumatra requires that the Southeast Asian and western Indonesian region have a westward component of motion relative to the Indian Ocean and to the ensimatic(?) Ganges-Brahmaputra Delta region. This westward component, integrated with the active tectonic pattern north of India, requires that Southeast Asia be rotating clockwise, pivoting near the Assam syntaxis. Motion patterns are interpreted schematically on figure 37. Presumably the angular velocity of this rotation decreases 


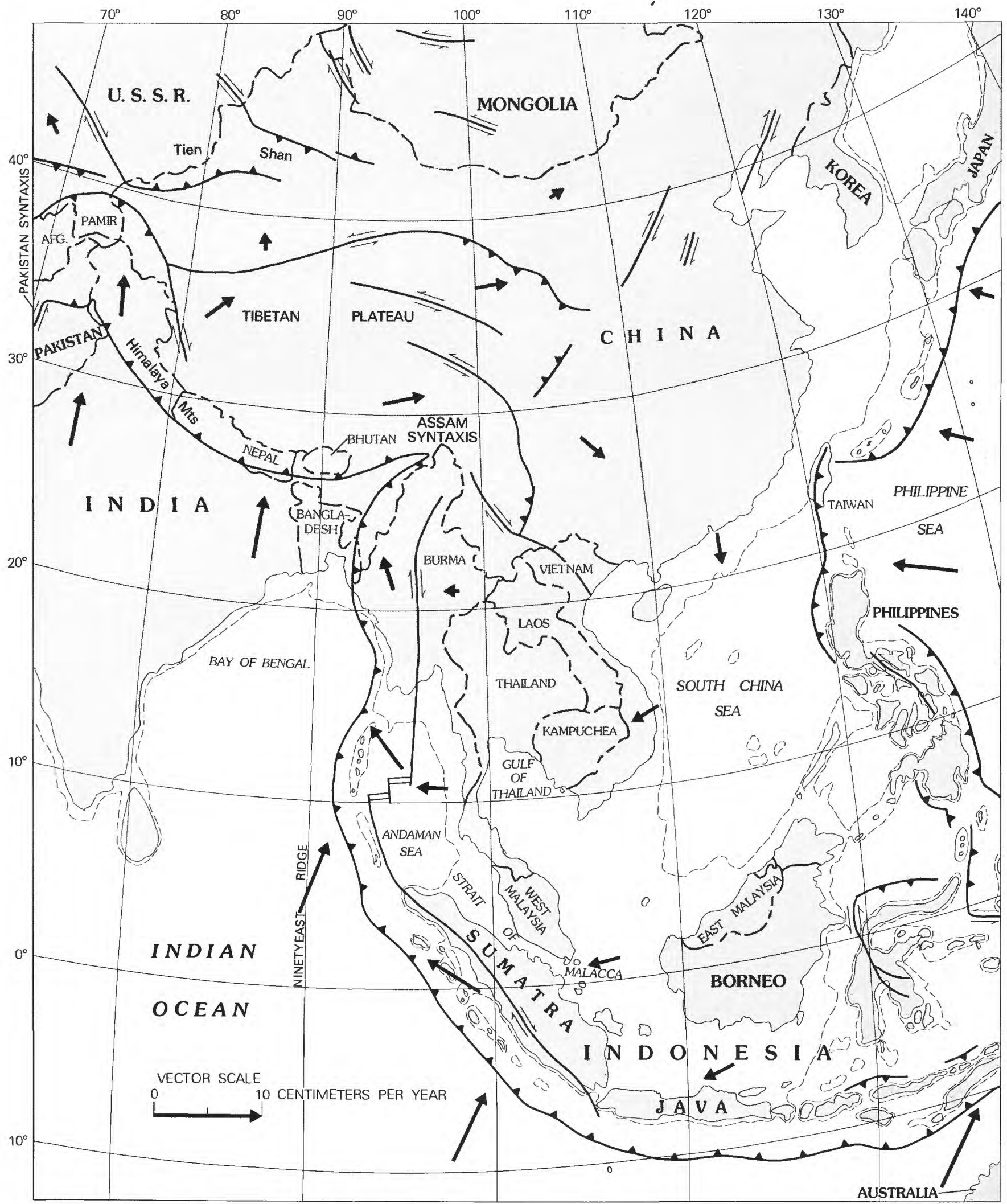


southward beyond the Andaman Sea, as Sumatra lags behind Burma. Burma, the Malay Peninsula, and Sumatra must have trended more easterly before Eocene time than they do now. Tapponnier and Molnar (1976) and Tapponnier and Molnar (1977) reached similar conclusions from a consideration of the mechanical effects on interior Asia of a colliding India. More complex motions, minimally constrained by geologic considerations, were postulated by Holcombe (1977).

\section{INDOCHINA}

Early work in the deformed terrains of Indochina incorporated the assumption that long-distance correlations of undated rocks could be based on degree of metamorphism and deformation. For the southern part of lndochina-which lies within the present map area-such assumptions were accepted by Fromaget (1941, 1952), Kudryavtsev, Agentov, Gatinskiy, and Mishina (1971), Postel'nikov (1964), Saurin (1935), and others. (See Workman 1972a and 1977 for recent summaries of the old

\section{EXPLANATION}

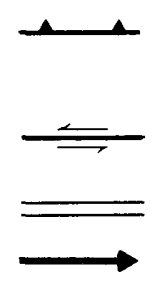

Trace of subduction zone (at sea) or front of thrust belt (on land)-Barbs on overriding side

Strike-slip fault-Arrows show direction of relative motion

Spreading axis (in Andaman Sea)

Direction and velocity of motion relative to northwestern EurasiaVectors are controlled by sea-floor spreading geometry for India and the Indian Ocean (Minster and others, 1974; Molnar and Tapponnier, 1975), but otherwise are schematic interpretations

200-meter bathymetric contour
French work.) This approach resulted in the assignment of the slightly metamorphosed clastic rocks of southeastern Vietnam to the Devonian and Early Carboniferous and of the granites that intrude them to the late Carboniferous. Fossils have, however, since been found; all well-dated fossils from this terrain are of Permian and Mesozoic ages (Fontaine, 1965; Saurin, 1962, p. 69), and fossiliferous Jurassic sediments are cut by granite (Fontaine and Saurin, 1965). The few K-Ar dates obtained for granites in the belt are Mesozoic, mostly Cretaceous (Faure and Fontaine, 1969; Fontaine and Saurin, 1965; Hilde and Engel, 1967). On the tectonic map (pl. 1), I have assigned the metasedimentary rocks to the Permian through Jurassic, the granites to the Jurassic and Cretaceous, and the silicic metavolcanic rocks also to the Jurassic and Cretaceous with the assumption that they are the extrusive equivalents of the granites.

This late Mesozoic orogenic terrain trends northeastward in southeastern Vietnam, and presumably belongs to the belt of Jurassic and Cretaceous deformation and granitic intrusion that trends northeastward also in southeastern China (fig. 31; Allen and Stephens, 1971; Jahn and others, 1976; Terman, 1973), Korea (Workman, 1972b), and Japan (Kawai and others, 1971). The melange terrain adjoining the magmatic belt on its Pacific side is exposed in Taiwan and Japan but elsewhere must lie offshore, on the continental shelf. The northeast-trending belts are printed across the obliquely truncated end of an older terrain of mostly Paleozoic and Triassic orogeny, which trends northwestward across northern Indochina (Fromaget, 1952; Gatinskiy and others, 1973; Nguen Dinh Kat, 1970; Postel'nikov, 1964; Staritskiy and others, 1973) and which apparently marks the suture along which Indochina collided with China in the Triassic after an intervening ocean floor disappeared beneath the Indochinese side. Some of the upper Paleozoic and Triassic granites of Southeast Asia, Sumatra, and eastern New Guinea and Australia may belong to the subduction system now exposed in northern Indochina.

On the tectonic map (pl. 1) I have shown a belt of melange and imbricated materials, deformed in Permian or Triassic time, to trend northward through southwestern Kampuchea (Cambodia). This interpretation is based primarily upon the descriptions of sheared complexes by Gubler (1935; his Pailin, Press, and Kchol complexes) and Gubler and Saurin (1962). Ultramafic rocks, spilites, radiolarites, clastic sediments bearing arenaceous foraminifera, and other rock types including shallow-water sediments are all sheared together and intercalated in steep-dipping chaotic array. The terrain includes fossiliferous sediments as young as Permian (Gubler, 1935) and intruded by undeformed granite that has a single biotite potassium-argon date of $180 \mathrm{~m}$.y. (P. Lacombe as cited by Faure and Fontaine, 1969). On strike 
farther north in Thailand, Daniel R. Shawe (written commun., 1977) interpreted ophiolite fragments and regional geologic relationships to record the collision of two subcontinental masses in Late Carboniferous or Early Permian time.

The extreme west edge of the Indochina Peninsula, just north of the area of the tectonic map, consists of Devonian to Triassic sedimentary rocks deformed with northwestward trends and intruded by Triassic (and younger?) granites (Hughes and Bateson, 1968). Tin occurs with Triassic granite, indicating likely continuity of petrologic and tectonic terrains with those of the Malay Peninsula.

The Triassic and older complexes are overlain with strong unconformity by little-deformed Upper Triassic, Jurassic, and Cretaceous strata of the Korat (or Khorat) Group in northeast Thailand (Borax and Stewart, 1965; LaMoreaux and others, 1958; Ward and Bunnag, 1964). These continental clastic sedimentary rocks, characteristically redbeds, are several kilometers thick and are preserved primarily in the broad basin of the Korat Plateau. The continental strata interfinger both eastward and westward into marine sections. In southwestern Kampuchea (Cambodia), within the area of the tectonic map of the Indonesian region, another large mass of little-deformed Korat strata is preserved (Gubler, 1935) in a basin that plunges southward beneath the Gulf of Thailand and there contains about $3,000 \mathrm{~m}$ of section (pl. 1). A reconnaissance paleomegnetic study of a mere nine samples suggests a paleomagnetic pole position for Jurassic redbeds to be near lat $69^{\circ} \mathrm{N}$., long $177^{\circ} \mathrm{E}$. (Haile and Tarling, 1975). If this pole represents the Jurassic paleogeographic pole position, then the region has rotated slightly clockwise but has undergone little change in latitude since Jurassic time. The confidence limits are however poor: $\alpha_{95}=26^{\circ}$.

\section{RELATIONSHIPS OF PALEOZOIC AND TRIASSIC TERRAINS OF SUMATRA, MALAYA, AND INDOCHINA}

The pre-Cenozoic rock assemblages of Sumatra, Malaya, and Indochina are similar, but their belts appear to be offset by strike-slip faults or by crustal extension.

Sumatra and Malaya share similar eastern and western facies of Paleozoic and Triassic strata, separated in each case by what may be subduction melange. In the mountainous belt of southwestern Sumatra, the facies boundary lies offset at least $300 \mathrm{~km}$ west from the projection along the strike from Malaya. A similar offset is indicated by the tin granites if those of the western tin belt of Malaya formed in line with those now present in central Sumatra. A large right-lateral strike slip fault of late Mesozoic or Paleogene age might trend northwestward beneath the Sumatra foreland basin or the Strait of Malacca. The northwest tip of Sumatra projects about $300 \mathrm{~km}$ northwest beyond the south-trending edge of the Malay-Malacca continental shelf, and this projection could be due to such a fault. Alternatively, a sharp bend may intervene between Malayan and Sumatran exposures. The likely old-melange complexes of northwestern Sumatra could have formed in the belts of Cretaceous and Jurassic melange exposed in Burma and present offshore on the continental shelf west of Malaya.

Another major offset may occur between the Malay and Indochina Peninsulas, beneath the Gulf of Thailand. The major facies boundary and melange(?) of medial Malaya trend northward into the gulf near the meridian of $101^{\circ} 30^{\prime}$ or $102^{\circ} \mathrm{E}$., whereas what may have initially been the continuation of the same boundary trends southward into the opposite side of the gulf from Kampuchea (Cambodia) along about $104^{\circ} 30^{\prime} \mathrm{E}$. An offset beneath the Gulf of Thailand of about $300 \mathrm{~km}$ could account for this. The thick sedimentation and echelon structures within the Gulf of Thailand are interpreted in the subsequent section on the South China Sea to represent oblique right-lateral extension, and the $300-\mathrm{km}$ offset may be a measure of the extension.

\section{BORNEO}

The basement terrain of western and interior Borneo $^{7}$ (fig. 38) consists of Paleozoic and Mesozoic, and possibly Paleogene, sedimentary, metamorphic, granitic, and volcanic rocks, and this region behaved more or less as a craton in middle and late Cenozoic time. Bounding this old terrain on the east, northwest, and north are younger additions to the continental crust: regions whose basement consists of subduction complexes of Late Cretaceous, Eocene, and middle Tertiary ages, respectively, overlain by younger sediments. The Indonesia Geological Survey (1970a, b) published compilations of available geologic mapping for the south half of Kalimantan; Wilford (1967) presented a geologic map of Sabah; and Liechti, Roe, and Haile (1960) compiled a map of both Sarawak and Sabah.

\section{PRE-TERTIARY COMPLEXES}

Variably deformed and metamorphosed Paleozoic and Mesozoic sedimentary and volcanic rocks, and Mesozoic granitic plutons, form the basement of western and interior Borneo, (pl. 1). These complexes have been studied in systematic reconnaissance in far-western Sarawak, but they are known only from very widely separated observations and traverses in the vastly larger region of Kalimantan. Subduction melange, largely or wholly of Cretaceous age, occurs in both northwestern and southeastern Borneo, on opposite sides of a broad terrain dominated by Cretaceous magmatic rocks. At least some of this intervening terrain was of silicic, continental character before Jurassic time. Problems outnumber certainties in interpretations of this region.

The island is Borneo to the Malaysıans and most of the rest of the world, but Kalimantan to the Indonesians, who use the term also for that part of the island which is Indonesian territory. In this report, "Borneo" is used to refer to the entire island, and "Kalimantan" to its large Indonesian portion alone. Western Malaysıan Borneo is the state of Sarawak (which encloses tiny independent Brunei), and northern Malaysian Borneo is the state of Sabah. 


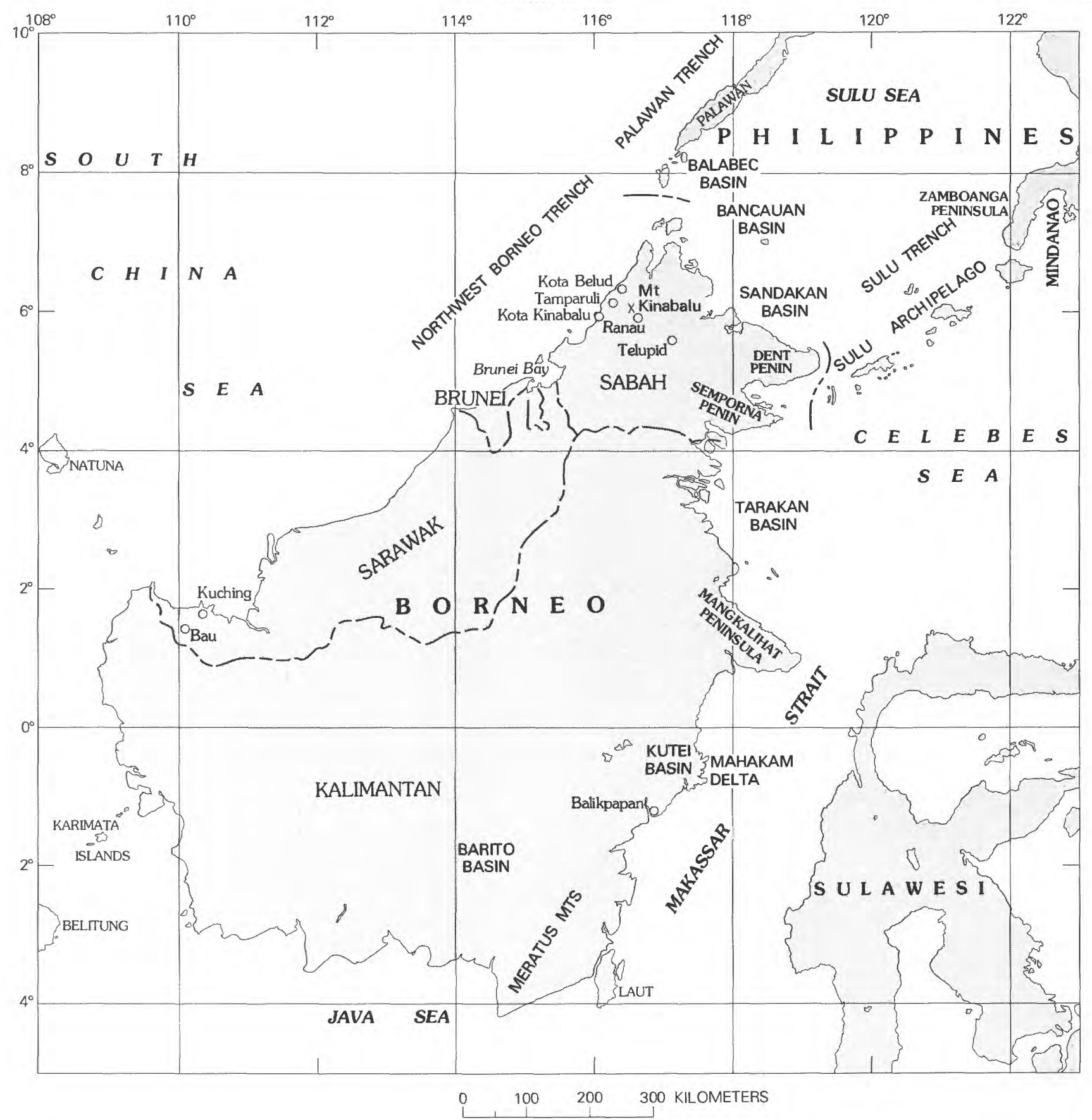

FigURE 38.--Index map of Borneo.

WESTERN SARAWAK

The pre-Upper Cretaceous rocks of the coastal part of far western Sarawak are interpreted as consisting of Jurassic or Lower Cretaceous polymict subduction melange. The material was described briefly by Allen (1954, p. 50-55, his "slatey conglomerate" and associated rocks) and Wilford (1955, p. 37-38, his Serabang Formation), and at length by Wolfenden and Haile (1963, p. 10-33, 57-62, and 94-97, also as the Serabang Formation). The complex is dominated by variably sheared shale, graywacke, and subgraywacke and is characterized by sheared lenses of greenstone, ultramafic rocks, graywacke, and other resistant rock types in an extremely sheared groundmass of clayey, slaty, or phyllitic aspect. The chemical composition of the greenstones resembles that of abyssal tholeiite. Tectonic lenses seen in outcrop reach lengths of many meters, and those inferred 
from map relationships reach lengths of many kilometers. The shales contain undated abyssal arenaceous foraminifera. Radiolaria of Jurassic or Cretaceous age occur in chert, which is common and is mostly white but partly red and manganiferous. The melange is intruded and contact-metamorphosed by quartz monzonite plutons from which Late Cretaceous $\mathrm{K}$-Ar ages have been obtained and is overlain by sandstone of very late Cretaceous or early Tertiary age. Melange of the same age may be present in the inland part of the broad terrain of melange and broken formations, farther east in Sarawak, assigned to the Paleogene on the tectonic map (pl. 1).

Far-western Sarawak south of this melange was continental before the melange formed and consists of much-deformed shale, sandstone, silicic and intermediate volcanic rocks, and subordinate limestone, metamorphosed near granitic intrusions (fig. 39 B, C, D; Bayliss, 1966; Cummings, 1961; Haile, 1954; Muller, 1968; Pimm, 1965; Wilford, 1955; Wilford and Kho, 1965; Wolfenden and Haile, 1963). Shallow-water marine invertebrates have been found in a number of localities-Lower Permian (and Upper Carboniferous?) in limestone, Upper Triassic in clastic rocks, including some intercalated with volcanic rocks, and Upper Jurassic and Lower and Upper Cretaceous in shale, sandstone, tuff, and limestone. Paleozoic clastic, volcanic, or granitic rocks have not yet been identified with certainty. Triassic(?) volcanic rocks in one area are dominantly basalt and andesite, and range to rhyodacite (Hon, 1975): perhaps an island arc is represented here. Conglomerates from continental crystalline sources are known in the Triassic and Cretaceous sections. One pluton of granodiorite is overlain by unmetamorphosed Upper Jurassic strata (Kirk, 1968; Wilford, 1955) and perhaps is correlative with Upper Triassic volcanic rocks. The other plutons are mostly of biotite quartz monzonite, cut strata dated with variable confidence as Jurassic and Early Cretaceous, and have yielded Cretaceous $\mathrm{K}-\mathrm{Ar}$ age determinations of about 75 m.y. for three plutons and 100 m.y. for one other (Kirk, 1968; Wolfenden and Haile, 1963). Rocks as young as Late Cretaceous are variably metamorphosed. High Upper Cretaceous and Paleogene continental strata overlying these older rocks are gently to severely deformed and contain intercalated intermediate and silicic volcanic rocks and small intrusions.

\section{SOITHWEST BORNEO}

A huge region in western Kalimantan consists mostly of deformed and variably metamorphosed clastic sedimentary rocks and silicic volcanic rocks, intruded by large and small granitic plutons. Published information consists mostly of sketchy reconnaissance, including that reported by van Bemmelen (1939b), Haile, McElhinny, and McDougall (1977), Molengraaff (1900), Sumartadipura (1976), Wing Easton (1904), and Zeijlmans van Emmichoven $(1938,1939)$. Biotite, hornblende, or both, from 16 specimens of granitic rocks from the region between the Equator and lat $2^{\circ} 10^{\prime} \mathrm{S}$., and between long $110^{\circ}$ and $111^{\circ} \mathrm{E}$., were dated by the $\mathrm{K}-\mathrm{Ar}$ method by Ian McDougall (Haile and others, 1977). Ages calculated for 14 of the samples are within the range 76-115 m.y.; the single-mineral determinations for the other two are 127 and 154 m.y. Two granite samples from near lat $1^{\circ} 15^{\prime} \mathrm{S}$., long $113^{\circ} 00^{\prime} \mathrm{E}$., have fission-track ages of about 77 m.y. (R. Wikarno, as cited by Sumartadipura, 1976). The southwest Borneo granites thus may be dominantly of Cretaceous age. Cretaceous ages also are indicated by $\mathrm{K}-\mathrm{Ar}$ analyses of many samples from islands and well cores to the south and west of Borneo, as described in other parts of this report. Haile (1973a) found abundant middle Cretaceous pollen in steep-dipping sandstone and shale (near lat $1^{\circ} 25^{\prime} \mathrm{S}$., long $110^{\circ} 25^{\prime} \mathrm{E}$.) in a section that includes massive volcanic rocks and is intruded by granitic plutons.

Presumably these igneous rocks are paired to the Cretaceous melange complexes that occur in both northwestern and southeastern Borneo. The granitic rocks exposed in western Kalimantan are in general more potassic in the south than in the north, suggesting that the bulk of these rocks formed in response to subduction from the north; but this exposed terrain represents only the north half of the width of the granite-dominated region known offshore to the southwest.

Karimata Island (west of southwestern Borneo, at about $1^{\circ} 30^{\prime} \mathrm{S}$.) consists of alkali granite, and subordinate granophyric granite and hornblende-biotite granodiorite, intrusive into hornfels and quartzite (Priem and others, 1975). The granitic rocks yielded an $\mathrm{Rb}-\mathrm{Sr}$ whole-rock assumed isochron suggesting an age of about $72 \mathrm{~m}$.y. Late Cretaceous, and an initial ${ }^{87} \mathrm{Sr} /{ }^{86} \mathrm{Sr}$ ratio of about 0.710 (Priem and others, 1975). A single K-Ar date for a nearby amphibolite is $78 \mathrm{~m} . \mathrm{y}$.

Paleomagnetic study. - The orientations of stable magnetization were determined by M. W. McElhinny (Haile and others, 1977) for 46 oriented hand specimens of dike rocks, lavas, tuffs, hornfelses, and granitic rocks from southwestern Borneo between lat $0^{\circ} 45^{\prime}$ and $2^{\circ} 20^{\prime}$ S., and long $110^{\circ}$ and $111^{\circ} \mathrm{E}$. Age determinations for biotite or hornblende, or both, in nine specimens of granitic rocks within the same region are mostly within the range 80 to 90 m.y. (Haile and others, 1977), so presumably the dominant magnetic orientation is that for Late Cretaceous time. The magnetic inclination for 39 of the specimens is on average horizontal, indicating a paleoposition on the magnetic equator, and the declination is northwest-southeast, indicating a paleomagnetic pole at about lat $41^{\circ} \mathrm{N}$., long $21^{\circ}$ E. Polarities are mixed. The Cretaceous terrain apparently has undergone a net rotation of about $45^{\circ}$ counterclockwise, or $135^{\circ}$ clockwise, in the last 80 million years but has had no net change in latitude. Another seven specimens yielded stable north-south paleomagnetic orientations and may be of younger, postrotation materials. 

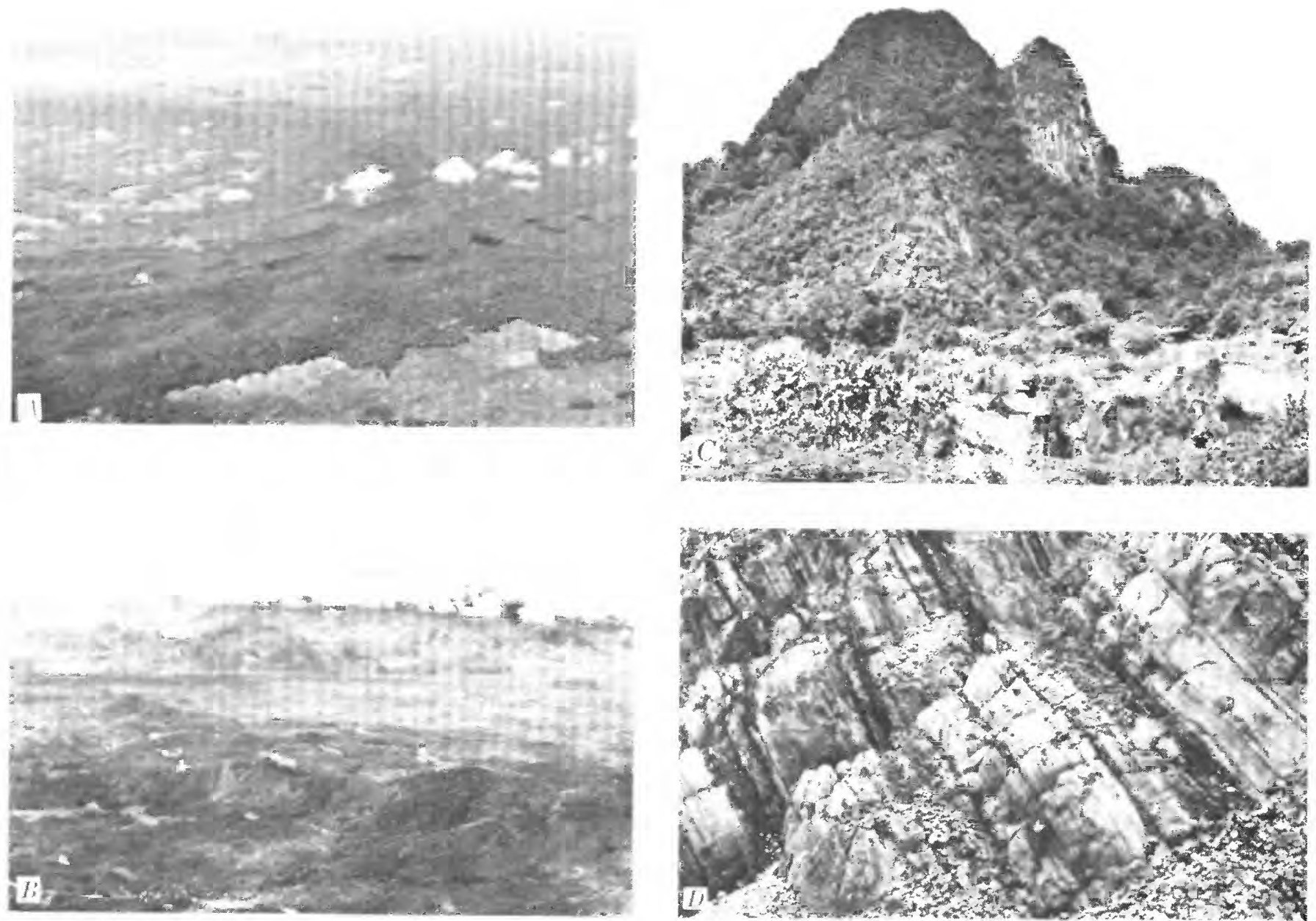

FIGi Rr 39. Mesozoic and Cenozoic geologic features of far western Sarawak. A. Aerial view southeastward from $65 \mathrm{~km}$ west of Kuching. over the southwest end of the Kayan syncline of middle Tertiary Plateau Sandstone. Schist (melange?) underlies the sandstone in the right foreground, and much-deformed Cretaceous and Jurassic sediments underlie the far side of the syncline and are in Kalimantan. See 1. iechti, Roe, and Haile(1960. map sheet III). B. Aerial view sout hward from $25 \mathrm{~km}$ west of Kuching. Middle Tertiary Plateau Sandstone hills in the foreground: Upper Jurassic limestone hills at Bau in the middle distance, surrounded by low ground eroded from Jurassic and Lower Cretaceous clastic strata and Upper Cretaceous and lower Tertiary intrusive granitic and hypabyssal rocks. C, View southward at Bukit Young (Young Hill), formed of nearly vertical Upper Jurassic shallow-water micritic limestone (Wolfenden, 1965), 30 km southwest of Kuching. The foreground pit is a gold mine, from which gold in low concentrations is obtained from guart/ose clay residuum derived from altered limestone. D. Saprolitized Upper Jurassic or L.ower Cretaceous feldspathic sandstone and siltstone. Eroded cut on Penrissen Road, $13 \mathrm{~km}$ south of Kuching.

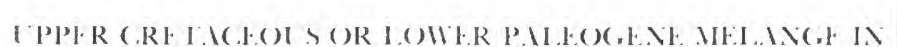
()IIHASIRKN BORNE()

Subduction melange involving Cretaceous sediments occurs in several areas in southeastern Kalimantan and is overlain by Eocene strata. The Meratus Mountains provide the largest outcrop area. This terrain consists of widely varied materials including polymict breccia, glaucophane schist, greenschist, peridotite, serpentinite, deep-ocean radiolarian sediments. and clastic and carbonate sediments bearing pelagic middle Cretaceous foraminifera, all chaotically intercalated at all scales from outcrop to regional in a steeply dipping complex (Koolhoven, 1936; Krol, 1920).
Biotite quartz monzonite and hornblende andesite also occur in the pre-Eocene complex of the Meratus Mountains (Krol, 1920). Whether the quartz monzonite and andesite - which likely formed above a Benioff zone - are components of the melange or intrude it is unclear; they may owe their presence to melting, anomalously close to the trench of the time, of young, hot lithosphere. (See Marshak and Karig, 1977.) Farther east, in Laut Island at the southeast corner of Borneo, the presence of peridotite, serpentinite, gabbro, and basalt beneath Paleogene strata (Gollner, 1924; Macke, 1924) suggests more melange to be present. 


\section{NORTHEAST KALIMANTAN}

The basement terrain of northeastern Kalimantan is inferred to include subduction melange formed in Cretaceous time. This terrain is known only from extremely sketchy reconnaissance, including that reported by Harting (1925), de Jongh (1915), Rutten (1925), Rutten (1947), and Ubaghs (1936). Oil companies, whose concern with the basement rocks has been minimal, have given me some additional information. The basement is overlain unconformably in its medial and eastern portions by gently to moderately deformed middle(?) Eocene and younger shallow-marine and continental strata and is bounded on the west, by contacts not yet described, against highly deformed Paleogene rocks, partly in melange. Low-grade metamorphosed clastic sediments, notably quartzose graywacke, probably dominate the basement terrain, which includes a number of rock types suggestive of the presence of melange: serpentinite, peridotite, diabase, basalt, spilite, greenstone, radiolarian chert, scaly clay. Several of the geologists who have seen the complex have likened it to the Danau Formation of western Kalimantan, which is certainly melange. The complex is shown on the tectonic map (pl. 1) to be a single terrain of Cretaceous melange, the age being inferred from the known age of melange beneath similar Paleogene strata in southeastern Borneo, but several terrains representing quite different tectonic settings are in fact likely to be present. Shallow-water Devonian or Silurian fossils occur in one area (Rutten, 1940). Dioritic to quartz monzonitic intrusives were reported by Harting (1925) and Rutten (1947). A single K-Ar age determination of about 190 m.y. was made for Atlantic Richfield Indonesia for a micaceous quartzite specimen collected near lat $3^{\circ} 15^{\prime} \mathrm{N}$., long $117^{\circ} 00^{\prime} \mathrm{E}$.

\section{CENOZOIC: COMPLEXES OF NORTHWEST BORNEO}

Nested crescentic belts that curve through the length of Sarawak and adjacent northwestern Kalimantan and southwestern Sabah (pl. 1) appear to have been formed mostly by the subduction of the South China Sea floor southeastward beneath Borneo. Voluminous melanges and broken formations were produced during the Eocene from abyssal clastic sediments, and the resulting great deformed wedge is overlain in northwestern Sarawak by middle Tertiary strata regarded as formed in an outer-arc basin when the subduction front had migrated to what is still the offshore region. Other components of the subduction system also appear to be present.

\section{EOCENE SUBDUCIION COMPLEX}

A terrain interpreted to have been imbricated by subduction mostly during Eocene time is exposed in a broad crescent that trends east-southeastward in central and eastern Sarawak and adjacent Kalimantan, then arcs to the north, narrowing gradually, in northwestern Sabah. This is the broadest area of subduction complex exposed onshore in the Indonesian region. The terrain is essentially that termed "eugeosynclinal" by Haile (1969) and Liechti, Roe, and Haile (1960). The inland part of this terrain may have formed by subduction during late Mesozoic time and be correlative with the melange exposed in far western Sarawak, but available data do not permit separating old and young terrains on the tectonic map (pl. 1).

The southeastern belt of the crescent, in southwestern Sarawak and central Kalimantan, displays all the criteria indicative of polymict subduction melange. Various labels, including Danau, Engkilili, and Lupar Formations, have been given to rocks of this belt by ter Bruggen (1935), Haile (1957), Kirk (1957), Liechti, Roe, and Haile (1960, p. 48-56), Molengraaff (1900, 1910, 1915a), Zeijlmans van Emmichoven and Ubaghs (1936), and others. Subsequently, Haile (1973b) and Tan (1975b), following my suggestions, referred to it as a subduction-zone complex. The belt is a tectonically interlensed chaos of crystalline and sedimentary rocks: glaucophane schist, greenschist, amphibolite, basalt, spilite, gabbro, serpentinite, extensive abyssal pelagic sediments (ferruginous siliceous shale, manganiferous radiolarian chert, and radiolarite), limestone, and crushed shale, sandstone, slate, and phyllite like those of the adjacent terrain to the northwest. Interlensing by shearing of these diverse rock types occurs at both outcrop and map scales. Sedimentary lenses in the sheared complex include rocks bearing Cenomanian (early Late Cretaceous) to early Eocene calcareous foraminifers, but most of the foraminifers present are undatable abyssal arenaceous types (Keij, 1965; Liechti and others, 1960, p. 51-55; W. V. Milroy, unpub. report as cited by N. H. Haile, written commun., 1972). Radiolaria of Early Cretaceous age have been identified by E. A. Pessagno, Jr. (oral commun., 1976) from chert collected from melange by N. K. Tan. Apparently subduction was underway here at least as late as late Eocene time and might have begun as early as the Early Cretaceous.

In western Sarawak and adjacent Kalimantan, the shallow-water sediments of the Paleogene basin of interior Borneo are thrust relatively northward over this melange, with much intershearing of the contrasted types near the faults (ter Bruggen, 1935; Zeijlmans van Emmichoven, 1935; Zeijlmans van Emmichoven and ter Bruggen, 1935). The Paleogene basin sediments are broadly folded where distant from the thrust zone, but near it they turn up abruptly to dips subparallel to those in the melange (Haile, 1957). The thrusting, subparallel to layering on both sides, may be another manifestation of the subduction that formed the melange. Major faults may also separate the Paleogene basin sediments from melange along the strike of the same contact in southwestern Sabah (Collenette, 1965).

The remainder of the probable Eocene subduction complex of northwestern Borneo consists primarily of imbricated clastic sediments deposited in water deeper than the lower stability limit of calcium carbonate. These rocks have been described (as the Rajang Group, Crocker Formation, and various other names lacking stratigraphic significance) 
in regional Malaysian Borneo memoirs by Collenette (1958, 1965), Haile (1957), Jacobson (1970), Kirk (1957), Liechti, Roe, and Haile (1960, p. 54-81), Wilford (1961), and Wolfenden (1960). Dutch geologists gave the rocks various other designations in Kalimantan, including Embaluh complex (Zeijlmans van Emmichoven, 1938) and phyllitic facies (ter Bruggen, 1935). The strike of the rocks arcs broadly, parallel to the crescent, the sandier units standing as ridges (fig. 40). Dips are steep in either direction but are more common toward interior Borneo than toward the South China Sea. The rocks are mostly poorly sorted quartzosesand turbidites and interbedded shales (Brondijk, 1963; Jacobson, 1970; Stauffer, 1967). Volcanic and continental-crystalline rocks dominate the pebbly component (ter Bruggen, 1935; Stauffer, 1967), and tuff may be widespread (McManus and Tate, 1976). Wildflysch and sheared lenses of sandstone in thoroughly sheared shale are widespread (ter Bruggen, 1935; Jacobson, 1970; Kirk, 1957; Liechti, 1967; Stauffer, 1967). Fossils consist mostly of abyssal pelagic foraminifers that are not diagnostic of age, but the rare calcareous pelagic foraminifers, and the occasional calcareous benthonic foraminifers redeposited in turbidites (ter Bruggen, 1935), define rough concentric belts of rocks of different ages-Paleocene and lower Eocene in the outer part of the crescent, next to the obvious melange of Danau type, middle Eocene in the medial part, and upper Eocene in the northwestern part (Keij, 1965). Stratigraphic tops in the steeply dipping turbidites tend to point toward the outside of the crescent (Stauffer, 1967): the rocks become younger northwestward but top southeastward, so their structure must be intricately imbricate. Rocks of the outer part of the crescent generally display conspicuous slaty cleavage, whereas those of the rest do not. A mass of pillow basalt and spilite occurs in the northwest part of the crescent (Kir, 1957, 1968).

In 1976, I had the opportunity to see this imbricated terrain of Eocene and Oligocene deep-water clastic sediments in the Kota Kinabalu-Kota Belud-Mount Kinabalu-Ranau region of northwestern Sabah, during a field trip led by Lim Peng Siang and Kwan Houng En of the Geological Survey of Malaysia. Deformational styles are illustrated by the photographs of figure 41, (Jacobson, 1970, illustrated similar features.) Most of the strata seen are coherent at outcrop scale, although near-bedding thrust faults, minor boudinage, and tight folds are abundant. Broken formations, consisting typically of lenses and blocks of sandstone in a matrix of sheared and generally scaly shale, are common throughout the region traversed. Such broken formations compose only a few percent of the outcrops seen, but presumably they are eroded selectively so that their true abundance is considerably greater.

Abyssal clastic sediments of Crocker-Rajang type are one of the components of the obvious melange of Danau type. The main mass of Crocker-Rajang sediments is variably sheared and is imbricated on a large scale, and it lies on the oceanic side of melange formed more or less concurrently with Crocker-Rajang sedimentation. I infer that the
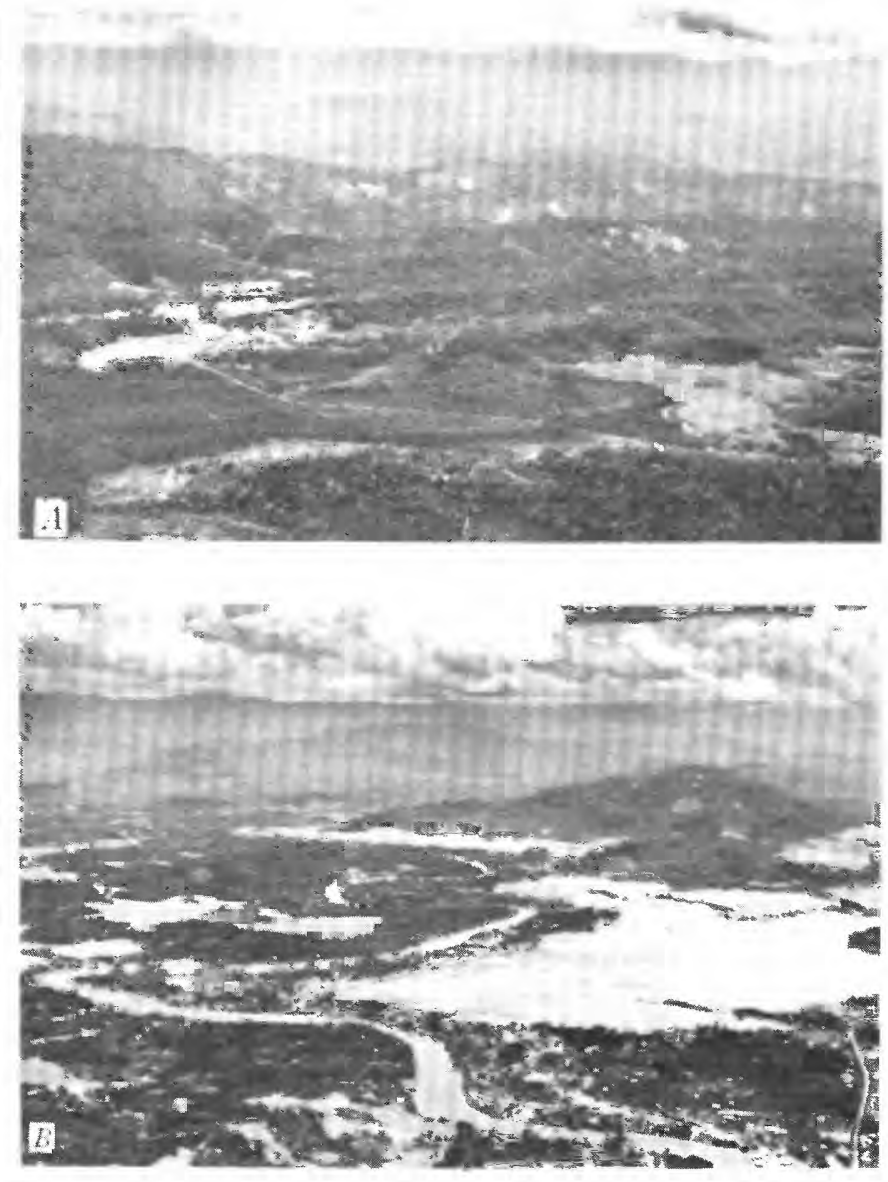

Figure 40.-Aerial views southeast over strike ridges of Paleogene sandstone in subduction-imbricated complex of west-central Sabah. Pictures taken about $20 \mathrm{~km}(A)$ and $40 \mathrm{~km}(B)$ south of Kota Kinabalu.

Crocker-Rajang terrain is also a subduction complex, formed before Oligocene time and hence either concurrently with Paleocene and Eocene sedimentation or within a short time after sedimentation. (The Oligocene time limit is provided by overlying sediments, discussed in a subsequent section.)

The volume of the Crocker-Rajang subduction complex increases eastward and northward around the crescentic terrain, and sedimentary structures show northward transport along the strike (fig. 42; Jacobson, 1970; Stauffer, 1967; Tan, 1975b). The sediment incorporated in the complex may have come largely from Southeast Asia and may have been deposited in a dominantly longitudinal fashion along the base of the Borneo continental slope. A voluminous supply of sediment was converted into a voluminous subduction complex. An analogy with present relationships between the huge abyssal fan of the Bay of Bengal and the active Andaman-Nicobar-Sumatra subduction system is suggested: the Bengal Fan sediments move radially, insofar as bathymetry permits, away from their Ganges-Brahmaputra source, but this motion is longitudinally southward along the Andaman-NicobarSumatra Trench and the ocean floor to the west of it. 

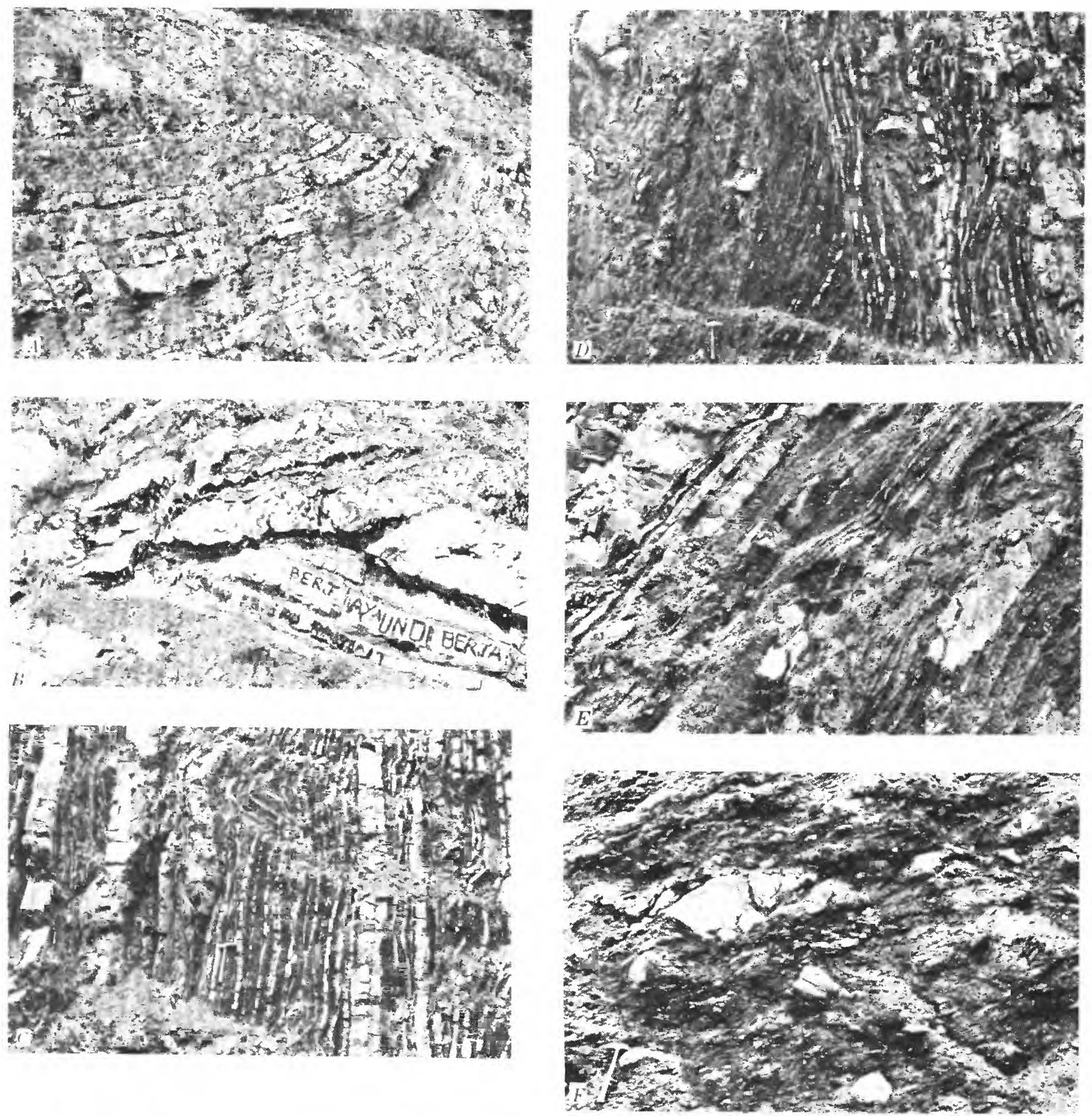

Figure 41.-Styles of deformation of deep-water Eocene and Oligocene clastic sediments in subduction-imbricated terrain of northwestern Sabah. Formation designations from Jacobson (1970) and Wilford (1967). A, South-trending, eastward-overturned recumbent syncline, sandstone and maroon shale of Crocker Formation; roadcut, $5 \mathrm{~m}$ high, $10 \mathrm{~km}$ south of summit of Mount Kinabalu. $B$, Thrust fault in sandstone and dark-gray shale of East Crocker Formation. Beds beneath the fault are coherent, whereas sandstones above it are variably boudinaged. Cut $4 \mathrm{~m}$ high, $8 \mathrm{~km}$ southeast of Tamparuli on Ranau road. $C$, Thin-bedded sandstone and dark-gray shale of Crocker Formation. The strata are disrupted by many shears almost parallet to bedding. Cut $24 \mathrm{~km}$ southeast of Ranau on Telupid road. $D$. Semicoherent strata, broken by near-bedding shears, on right, grading into broken formation, on left. Locality and lithology as for $C$. $E$, Coherent sandstone beds at upper left; variably sheared gray and maroon shale enclosing boudins of sandstone in rest of exposure. Cut $4 \mathrm{~m}$ high, $18 \mathrm{~km}$ southeast of Tampuruli on Ranau road, East Crocker Formation. F, G, and $H$, Broken formation; blocks and lenses of sandstone in dark-gray scaly clay and sheared shale, Trusmadi Formation. Roadcuts about $500 \mathrm{~m}$ south of Mount Kinabalu National Park Headquarters, $15 \mathrm{~km}$ west of Ranau. Knife in $H$ is $9 \mathrm{~cm}$ long. 

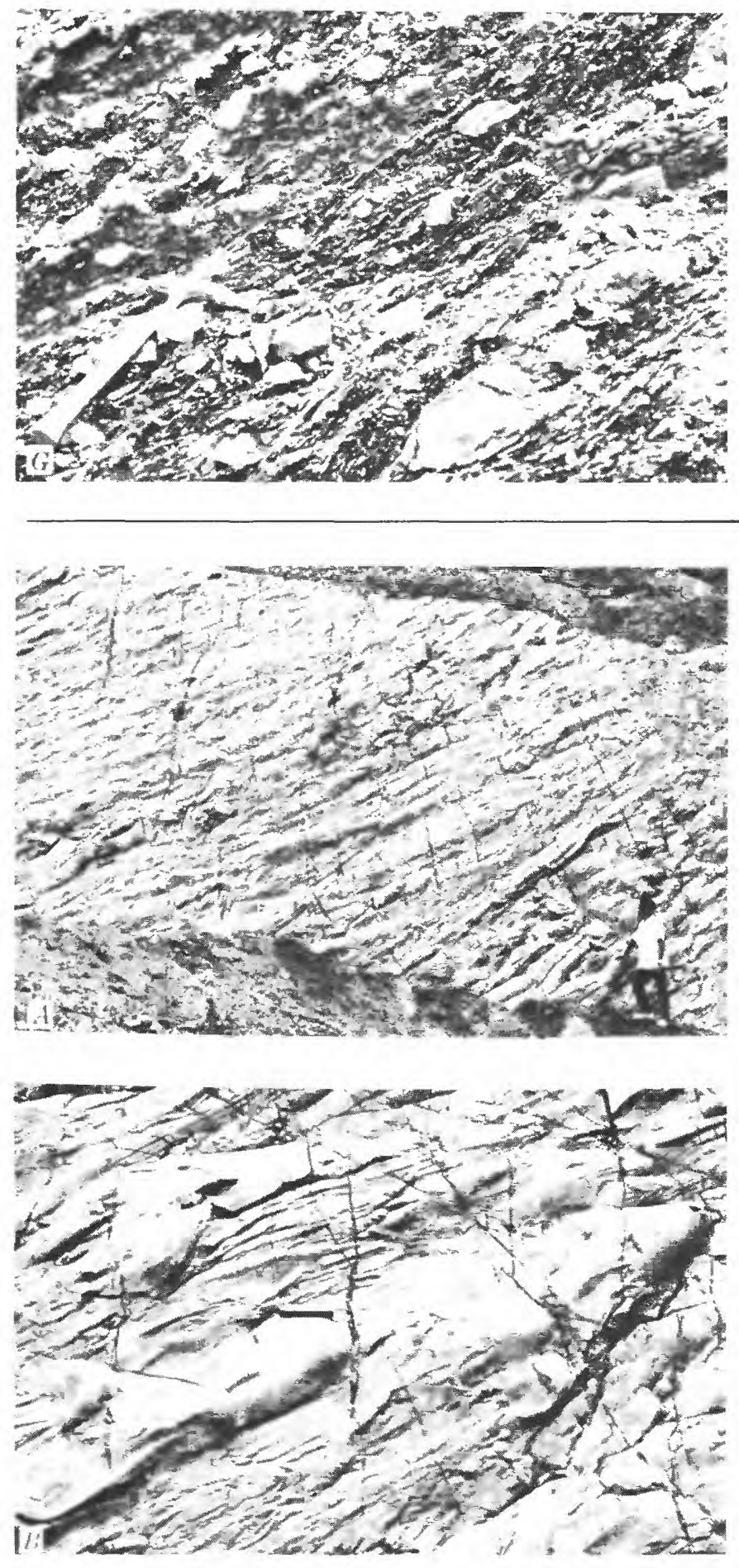

FIGURE 42.-Flute casts in sandstone of Paleogene Crocker Formation, on the underside of an overturned bed dipping $50^{\circ}$ northeast (toward the observer), northwest Sabah. Current moved from upper right to lower left. Rotation of the bedding about its strike back to horizontal indicates local current direction was from the north. The southeast strike here is, however, believed to have been rotated, oroclinally clockwise, from a north-northeast strike; if so, the initial current direction was from the southwest. Picture $B$ shows a detail (pocketknife left of center is $9 \mathrm{~cm}$ long) within the large outcrop of $A$. West side Kadamaian River, $8 \mathrm{~km}$ southwest of the summit of Mount Kinabalu.

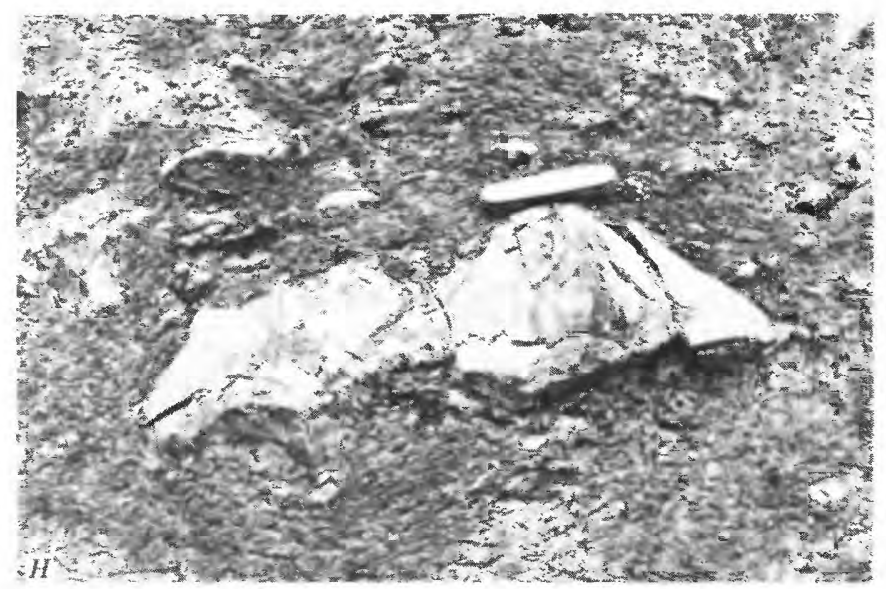

The entire Borneo subduction complex represents a wedge of melange and imbricated materials like that of the outer-arc ridge of the Java Trench system. The age of sediments decreases as the structural level descends, northwestward across the complex. Sedimentation and subduction imbrication apparently went on simultaneously during Paleocene(?) and Eocene time, sediments of each age increment being shingled against the base of the growing wedge soon after they were deposited. Much of the sediment may represent longitudinal filling of a trench. rather than the much broader deposit of an abyssal fan.

\section{PAIEOGENE OF INIERIOR BORNEO}

Paleogene strata define a thick basin sequence in an arcuate belt, about $150 \mathrm{~km}$ wide, that trends east-southeast from westernmost Sarawak and adjacent Kalimantan - the west tip of Borneo - to central Kalimantan, from which it swings through northeast in northeastern Kalimantan to north in south-central Sabah (pl. 1). The basin is superimposed on the pre-Eocene granitic-and-metamorphic basement terrain in the southwest and upon the complex inferred to include Cretaceous melange on the north; its arc is concentric and adjacent to the margin of the Paleogene subduction terrain of northwestern Borneo. The basin sediments are variably deformed, mostly gently (fig. $39 \mathrm{~A}$ ) to moderately, but severely in some large areas, especially near the Paleogene melange terrain to the northwest. They are preserved primarily in broad synclines between uplifts of basement rocks. The basin fill includes: the Silantek Formation of Liechti, Roe, and Haile (1960) and Tan (1975a); the Melawi Basin and the Plateau Sandstone of Zeijlmans van Emmichoven (1939) and other geologists working in northwestern Kalimantan and western Sarawak: the Upper Mahakam Basin of Beltz (1944) in central Kalimantan; part of the Danau Formation of Rutten (1947) in northeastern Kalimantan; and the Sapulut and Labang formations of Collenette (1965, p. 42-50) in Sabah. The sediments are dominantly clastic and represent variously shallow and intermediate-depth marine, estuarine, and. mostly in the upper part of the section, continental 
environments (Collenette, 1965; Haile, 1957; Leichti and others, 1960, p. 169-177; Ubaghs, 1936; Wolfenden and Haile, 1963; Zeijlmans van Emmichoven, 1938, 1939). Calcareous foraminifers date the strata as dominantly Eocene and as Paleocene, Oligocene, and possibly early Miocene in places. Collenette (1965) reported several small collections of Upper Cretaceous foraminifers, which, however, might have been reworked into Paleogene sediments, and Wolfenden and Haile (1963) listed possibly Upper Cretaceous pollen from several localities, including some in rocks adjacent to beds containing mollusks assigned to the Eocene. Volcanic rocks are abundant in some parts of the basin fill (ter Bruggen, 1935; Zeijlmans van Emmichovan, 1935), and parts of it may be correlative with the volcanic-and-granitic terrain, which has been assumed to underlie it, discussed previously. Dikes and stocks, with maximum dimensions of a few kilometers, of diorite, quartz diorite, and granodiorite intrude and contact-metamorphose Paleogene strata, some of which are volcanigenic, at least in southwestern Sarawak (Tan, 1975a). McManus and Tate (1976) speculated that much of the Paleogene sandstone of northwest Borneo is derived from volcanic sources.

The Paleogene strata may have been deposited in an outer-arc basin, for sedimentation was contemporaneous with and adjacent to the broad subduction complex of northwestern Borneo.

\section{PALFOGENE IGNEOUS ROCKS}

The analysis developed here suggests that a terrain of calc-alkalic Paleogene granitic and volcanic rocks formed above a Benioff zone that dipped under Borneo from the subduction complex in the northwest. Much of the igneous terrain of southwestern Kalimantan is in a position appropriate for such magmatism, but the dates available from this terrain indicate Cretaceous ages.

\section{MIDDLF, IERTIARY OITER-ARC: BASIN}

The crescentic belt of Eocene subduction complex exposed in northwest Borneo encloses on the northwest a concentric smaller crescent of uppermost Eocene to middle Miocene shale and sandstone (pl. 1). The latter sediments define a marine basin in which water depths decreased as sedimentation progressed: the rate of sedimentation exceeded that of subsidence until the basin was filled completely. History and setting of the basin are interpreted to indicate that it originated as an outer-arc basin. The basin fill is approximately equivalent to the "miogeosyncline" of Haile (1969) and Liechti, Roe, and Haile (1960). The basin sediments and structure have been described, as the Setap Shale. West Crocker Formation ${ }^{8}$, and other units, in the

\footnotetext{
"I have included much of the West Crocker Formation of Brondijk (1963), Liechti, Roe, and Haile (1960), and others in the basin section, rather than assigning it to the "eugeosyncline" to the east as has commonly been done, because it contains abundant calcareous foraminifers (and hence was deposited in water shallower than were the eastern rocks), because it apparently is not broken into melange, and because it is of Oligocene age. See Keij (1965).
}

reports of Haile (1962), Kirk (1957), Liechti, Roe, and Haile (1960), Wilford (1961), Wilson and Wong (1964), and Wolfenden (1960). Broader aspects of the sedimentation, structure, and paleontology have been discussed by Brondijk (1963), Haile (1969), Keij (1965), Liechti (1967), Liechti, Roe, and Haile (1960), Schaub and Jackson (1958), and Wilson (1968).

The basin sediment is mostly shale (some of it calcareous) and quartzose sandstone, although reef limestone is present locally. The proportion of sand increases toward interior Borneo in both lower and upper parts of the basin fill (Schaub and Jackson, 1958). The faunas and sedimentary characteristics of the basin fill show that water depths decreased during the period of sedimentation, from bathyal open sea, shallower than the carbonate compensation depth, early in the period, through shallow-marine to estuarine and deltaic (Brondijk, 1963; Schaub and Jackson, 1958). Turbidite dominates most of the Oligocene but is subordinate in the highest Oligocene or lower Miocene, and it is lacking in the higher Miocene (Brondijk, 1963 ; age assignments from Brunei Shell Petroleum Co., Ltd., 1963, Keij, 1965, and Liechti and others, 1960).

An offshore ridge - an outer arc ridge(?) - may have bounded the basin on the northwest side, for widespread slump breccias, with reworked Upper Cretaceous, Paleocene, and Eocene foraminifers, occur in Miocene strata around Brunei Bay (Liechti and others, 1960, p. 105, $155,294)$. These breccias include clasts of spilite, so the ridge may have consisted of Eocene or Oligocene melange.

Deformation of the basin fill decreases southwestward around the crescentic belt and also northwestward across the belt toward the South China Sea. In the southwest, deformation decreases from moderate, with open folds, in the south (Kirk, 1957; Wolfenden, 1960) to gentle in the north (Wilford, 1961). In the northeast, by contrast, deformation is severe across most of the onshore width of the belt (Wilford, 1961; Wilson and Wong, 1964); dips are mostly steep to the east, and although the beds apparently are in general right-side up, the terrain tends to become younger westward, so imbrication by thrust faults dipping steeply eastward is indicated. In the central coastal area, wide, gentle synclines are separated by relatively narrow and complicated anticlines into which the thick shales have risen (Liechti and others, 1960, p. 280; Schaub and Jackson, 1958). Quaternary sediments thin over anticlines and thicken in synclines, so the deformation is continuing (Schaub and Jackson, 1958). Mud volcanoes (Liechti and others, 1960, p. 146,283 ) record continuing rise of the shale cores. The Seria and Miri oil fields of coastal Brunei and adjacent Sarawak produce from the Neogene sands atop shale-cored anticlines, and the thick shale is the likely source from which the petroleum migrated (Schaub and Jackson, 1958). Geothermal gradients are moderately low, typically about $3^{\circ} \mathrm{C} / 100$ $\mathrm{m}$ (Kenyon and Beddoes, 1977). The offshore oil and gas 
fields of the Royal Dutch/Shell Group presumably include both stratigraphic traps and shale-cored anticlines.

Upper Miocene and younger clastic strata, mostly sands, are preserved in open synclines, with gentle to moderate dips, downfolded into the older and more deformed terrain.

\section{NEOGENE IGNEOUS ROCKS OF INTERIOR BORNEO}

Neogene andesite, dacite, and basalt form small volcanic fields lying unconformably upon the Eocene melange terrain of central Sarawak (Kirk, 1968) and upon various terrains in northwestern, north-central, and northeastern Kalimantan (Rutten, 1947, and Zeijlmans van Emmichoven, 1938). Several K-Ar age determinations made for Atlantic Richfield Indonesia on rocks from small volcanic piles in northeastern Kalimantan indicate ages of 1.5-12 m.y. Many small Miocene intrusions of intermediate composition are present in far-western Sarawak (Kirk, 1968). These magmatic rocks occur within a broad arcuate belt concentric to the middle Tertiary outer-arc basin of northwestern Borneo (pl. 1), and perhaps they are a byproduct of a subduction system whose early phase is recorded by the Eocene melange, whose middle phase is recorded by that outer-arc basin, and whose late phase is represented by the Northwest Borneo Trench.

\section{CENOZOIC COMPLEXES OF SABAH}

Cenozoic subduction is recorded in Sabah by lower and middle Tertiary melange and broken formations, by upper Oligocene and Neogene calc-alkalic volcanic rocks, and by what may be an outer-arc basin of Neogene strata. The whole terrain forms the middle part of an oroclinal(?) $\mathrm{Z}$ structure that provides continuity between the subduction complexes of northwest Borneo and of the Sulu Island Arc. Reconnaissance geologic maps have been published for all of Sabah, but the data contained in them, and the descriptions in the accompanying reports of rocks, structures, and relationships, are so fragmentary that major ambiguities remain in interpretations.

\section{TERTIARY MELANGE}

The northeastern half of Sabah consists mostly of melange and broken formations, in a broadly arcuate belt that swings from west-soutwestward strikes in the east, where the Sulu Arc comes ashore, to northwestward in the northwest (pl. 1). In the northwest, it swings abruptly but complexly to become the subduction terrain of the Northwest Borneo system. Strikes are erratic in detail, and dips are moderate to steep either landward or seaward. The Sabah complex involves materials of Late Jurassic or Cretaceous to early or middle Miocene ages and formed in part during the Miocene but likely mostly within the Paleogene.

The melanges are giant breccias, consisting of lenses of resistant or coherent rocks in highly sheared matrixes of scaly clay or phyllite or of more formless breccias. They have been described by Collenette $(1958,1965,1966)$, Haile and Wong (1965), Jacobson (1970), Kirk (1962), Koopmans
(1967), Lee (1968), Leong (197lb), Liechti (1967), Liechti, Roe, and Haile (1960, p. 81-106), Meng (1972), Newton-Smith (1967), Stephens (1956), and Wilson (1961, 1963) and have been interpreted as products of regional shearing or of submarine slumping. Photographs of melange and broken formations have been published by Jacobson (1970, pls. 7, 9, 48, and 49) and by Liechti, Roe, and Haile (1960, pls. 26, 27, and 33), and more are given here in figure 41 . The degree of internal dislocation and the dominant compositions of resistant lenses vary from place to place, and these properties, combined with assumptions regarding local structural relationships, have led to confusingly inconsistent designations for the complexes, as Brondijk (1964) rightly protested. The Chert-Spilite, Trusmadi, and Wariu Formations appear to be entirely of melange, and the Ayer, Crocker, Kudat, Kulapis, Labang, and other units include much melange.

One very abundant, polymict melange type, that of the Chert-Spilite and Wariu facies, is characterized by lenses of ophiolite. The largest of these are shown separately on the tectonic map (pl. 1). Smaller lenses and blocks occur on all scales down to that of the outcrop. The mafic and ultramafic rocks have been described by Collenette (1958), Hutchison and Dhonau (1969, 1971), Jacobson (1970), Johnston and Walls (1975), Kirk (1968), Koopmans (1967), Leong (1971a), Wilson (1963), and others. Unaltered remnants of the widespread ultramafic rocks are mostly harzburgite (enstatite peridotite), but the rocks are now largely serpentinite. Altered basalt, pillow basalt, fragmental basalt, and spilite are ubiquitous. Abyssal pelagic sediments, notably manganiferous radiolarian chert and cherty shale, occur primarily in contact with the basalt, and the Late Cretaceous and early Tertiary ages of the radiolaria (Kirk, 1962) provide minimum ages for the basalts, which presumably formed as oceanic crust. Dolerite and gabbro, variably hornblendized, are less common. In some areas in the east, the ophiolites include moderately to highly metamorphosed rocks and consist of greenschist, or of amphibolitic or pyroxene-granulitic gneisses, enclosing lenses of serpentinite. Single K-Ar age determinations of 100 and 140 m.y. were reported by Hutchison and Dhonau (1968) for two of these amphibolitic rocks, and Meng (1972) listed seven determinations scattered from 87 to 210 m.y. Glaucophane schist has been found in central Sabah (Johnston and Walls, 1975; Kirk, 1968). Graywacke and low-grade metagraywacke dominate the lenses of sedimentary rocks, although shale is preserved also in the least sheared parts of the terrain. Much of the sandstone includes a volcanic component (Johnston and Walls, 1975). Foraminifers in both matrix and lenses of resistant sediments are mostly abyssal arenaceous types, not useful for dating, but calcareous foraminifers have been found in many localities and are of Early Cretaceous to late Oligocene or early Miocene ages (Collenette, 1965; Kirk, 1962; Meng, 1972; Newton-Smith, 1967; Stephens, 1956). Eocene, Oligocene, and Miocene(?) foraminifers are com- 
monly in close proximity in the melange (Liechti and others, 1960, p. 101-104).

Melange containing fragments of high-pressure metamorphic rocks and of ophiolite was described from eastern Sabah by Haile and Wong (1965) as the "polymict boulder bed facies" of the Ayer Formation. This melange type consists of squeezed and slickensided lenses of many lithologies in a matrix of "mylonitic shale." The sheared lenses of resistant rocks in the scaly matrix reach lengths of at least $200 \mathrm{~m}$ and include glaucophane schist, eclogite, kyanite schist, corundum-pyrope amphibolite, spilite, red chert, metagabbro, and serpentinite, as well as resistant sedimentary rocks that have yielded Upper Cretaceous, Eocene, and Oligocene foraminifers. Fossiliferous lower or middle Miocene rocks may also be involved in the melange, although this is not made certain by the published descriptions. High Miocene and younger strata overlie the melange unconformably. High-pressure garnet pyroxenites among the exotic blocks may have formed at mantle depths on the order of $65 \mathrm{~km}$ (B. A. Morgan, 1974).

Other melange facies consist primarily of sedimentary rocks, occurring in part as large coherent masses of sandstone and shale and in part as broken formations of lenses of resistant rocks in scaly-clay matrixes (fig. 41; Collenette, 1958, 1965, 1966; Jacobson, 1970; Kirk, 1962; Lee, 1968; Liechti and others, 1960, p. 81-92; Wilson, 1961). The sandstones are quartzose, hence had a continental source, and fossils are mostly abyssal arenaceous foraminifers. Calcareous foraminifers, occurring mostly in exotic lenses of limestone (which slid into the trench as olistoliths from shallow water?), date many rocks as Late Cretaceous through early Miocene. Although sandstone is the most abundant lens-forming rock type in this facies of melange, serpentinite, spilite, chert, and limestone are common also.

Strata containing late Oligocene and early Miocene foraminifers have been found within the polymict Sabah melange in a number of areas across much of the width of the terrain (Collenette, 1965, 1966; Lee, 1968; Newton-Smith, 1967; Stephens, 1956). Middle Miocene rocks may be involved at least locally (Lee, 1968; Meng, 1972). Offshore farther north, however, little-deformed strata as old as early Miocene are present, and if they were deposited atop a melange wedge, then that melange must have formed within Paleogene time. A collision suture is inferred in the subsequent "Discussion" section to lie within the Sabah terrain.

Attitudes of layering shown on the reconnaissance geologic maps of western Sabah (Collenette, 1958, 1965; Fitch, 1958; Stephens, 1956) define a complex but abrupt swing from northwestward to south-southwestward trends. The Sabah and Northwest Borneo subduction complexes belong to a single continuous system. The axis of the sharp but irregular inflection between them trends approximately south-southeastward from the northwest coast, near long $116^{\circ} 25^{\prime} \mathrm{E}$., to the Indonesian border at about $117^{\circ} \mathrm{E}$.

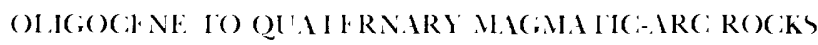

The inactive Sulu 1sland Arc system comes ashore in eastern Sabah, where arc magmatism is recorded by upper Oligocene to Quaternary volcanic rocks, mostly of intermediate compositions (pl. 1). The arc system is now dormant, for it has neither active volcanoes nor a present Benioff seismic zone, but the apparent youth of the trench along the northwest base of the island arc and of some of the volcanoes in the system shows that its deactivation was quite recent. The island-arc system of trench and composite ridge of melange and of volcanic rocks is described in a subsequent section of this report; the arc emerges in the northeast as the Zamboanga Peninsula of western Mindanao, and in the southwest as the Semporna Peninsula of southeastern Sabah. In the Semporna Peninsula, the volcanic arc is shown most conspicuously by large Pliocene and Quaternary volcanoes of intermediate calc-alkalic rocks-two-pyroxene andesite, hornblende andesite, and dacite (Kirk, 1962, 1968). Upper Oligocene and Miocene sections both on this peninsula and on Dent Peninsula to the north contain locally voluminous andesite and dacite, particularly as tuffaceous sediments (Haile and Wong, 1965; Kirk, 1962), and, although now much deformed, apparently were deposited upon preexisting polymict melange. Farther west, in west-central Sabah, late Tertiary stocks of biotite and hornblende quartz monzonite and granodiorite were intruded into broken formations and melange (fig. 43; Jacobson, 1970). Whether or not some of the "spilite" and "basalt" of the reconnaissance mappers are volcanic rocks of arc type, rather than an oceanic-crust component of melange (as much of it apparently is), is not made clear by the meager published descriptions of the rocks. No igneous rocks of magmatic-arc type older than late Oligocene have been recognized in Sabah.

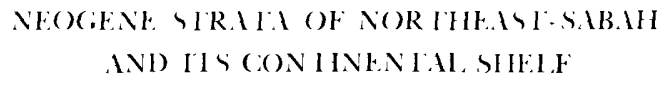

Coherent but much-deformed, thick middle Tertiary strata in northeastern Sabah may represent an outer-arc basin. The strata occur in a belt superimposed on the northeast half of the broader belt of middle Tertiary melange of Sabah. Melange involving ophiolite occurs both north of the belt and (as uplifts?) within it, and the northern exposures may represent the outer-arc ridge of the time. The possible outer-arc basin strata include much of the Miocene and Kulapis Formation of Fitch (1958), though even his Miocene includes polymict breccia according to Lee (1968), and of the Ayer, Kulapis, and Labang of Haile and Wong (1965), the Kudat of Liechti, Roe, and Haile (1960), and the Crocker of Wilson (1961). The rocks are dominantly clastic, and include deep- and shallow-marine and brackish-water 

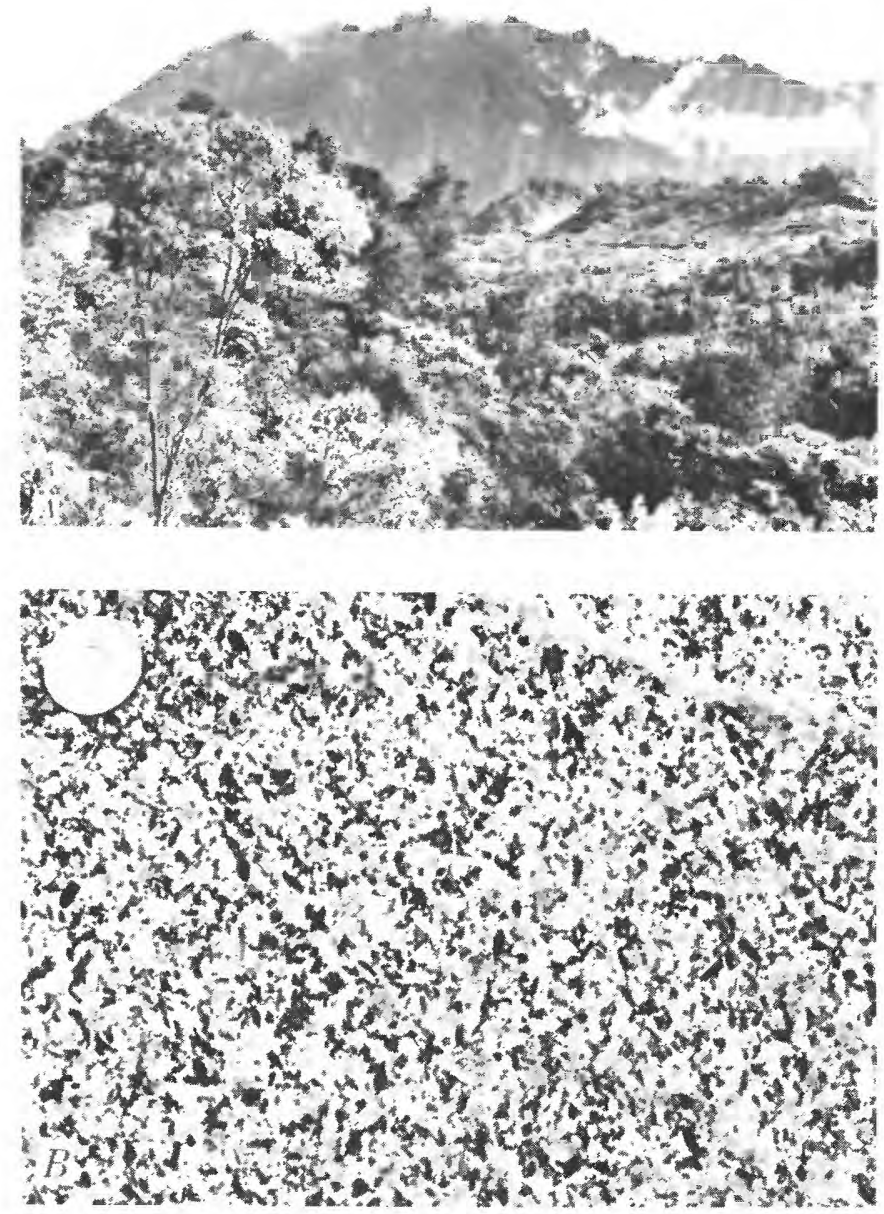

Figure 43.-Mount (Gunung) Kinabalu, northwest Sabah. A, View north-northwest toward the mountain, whose summit of $4,100 \mathrm{~m}$ is the highest in southeast Asia. The mountain is formed of quartz monzonite about 10 m.y. old, intrusive into Paleogene clastic sedimentary rocks, which form most of the lower ground. $B$, Hornblende quartz monzonite, the typical rock type of the main stock. The coin is $1.9 \mathrm{~cm}$ in diameter.

materials. At least in the east, the water of the depositional basin became generally shallower with time (Haile and Wong, 1965; their Ayer Formation), so gradual filling of a basin is indicated. The strata are mostly dated only as belonging to Indonesian Tertiary "Te," late Oligocene or early Miocene. Similar dates apply to the young fossils in strata intercalated in the melange of northeastern Sabah.

Upper Miocene and younger strata onshore occur in irregular basins and in coastal regions and were deposited in terrestrial and shallow-marine environments (Fitch, 1958; Haile and Wong, 1965; Wilson, 1961). Sands and shales are dominant, and coal and reef limestone are among other rock types present. Volcanigenic sediments are widespread in the east, as discussed previously. Deformation of the older of these materials consists of gentle to moderate folding.
The continental shelf between the northeast coast of Sabah and the deep Sulu Sea contains several small basins filled by Miocene, Pliocene, and Quaternary sediments, prograded northward from Borneo (pl. 1; Beddoes, 1976; Bell and Jessop, 1974). The thick shale of the lower part of the fill, which is at least $7 \mathrm{~km}$ thick, of the deep Sandakan Basin has risen into the overlying northeastward-prograded strata in shale-cored anticlines and diapiric structures. Small Bancauan Basin contains broadly deformed lower and middle Miocene strata beneath flat Pliocene and Quaternary sediments. The older part of the little-deformed high lower Miocene and younger fill of small Balabec Basin, south of southwestern Palawan, ends abruptly in the southeast against a northeast-trending fault that uplifts basement rocks. The position of the three basins suggests that together they may be the wholly filled outer-arc basin of the inactive Sulu Arc system. Geothermal gradients in the basins are moderately low, $2^{\circ}-3.5^{\circ} \mathrm{C} / 100 \mathrm{~m}$ (Kenyon and Beddoes, 1977).

\section{DISCIUSSION}

The Tertiary complexes of Sabah form the central part of a $\mathrm{Z}$ structure that provides tectonic continuity between the Northwest Borneo and the Sulu Arc systems (pl. 1), but many uncertainties are present in the interpretation of the evolution of the region. The subduction complexes exposed onshore in northwest Borneo were formed during Paleocene(?) and Eocene time, and so likely was most of the similar material, on strike around the western bend of the $Z$, in northeastern Sabah. The middle Tertiary strata of Sarawak, on the northwest, inner side of the crescent defined by the Northwest Borneo subduction complex, trend offshore northward onto the continental shelf, and strata of similar type reappear on trend, as projected concentrically to the western bend of the $Z$, in northern Sabah. In eastern Sabah, unlike Sarawak, polymict melange involves strata as young as early Miocene; yet offshore from northeastern Sabah, where analogy with Sarawak would suggest increasing deformation of young materials, lower Miocene strata are little deformed. Pliocene and early Quaternary subduction southward beneath eastern Sabah, from a trench hidden in the present offshore region, is indicated by the andesitic stratovolcanoes present there and by the physical continuity with the recently inactivated Sulu Island Arc, which has a young but dormant trench along its northwest base.

The western bend of the Sabah $\mathrm{Z}$ is too abrupt to have analogs in modern, active arc systems, so it likely is an orocline, produced by bending of a previously straighter terrain. The complexities within this bend-the irregularities shown by distribution of rock types and of attitudes of layering - tend to increase southward along its axis consistent with compressive buckling in such an orocline. (See reconnaissance maps by Collenette, 1958, 1965; Fitch, 1958; and Stephens, 1956.) A speculative interpretation, compati- 
ble with the contrasts between the geology of Sarawak, western and eastern Sabah, and the Sulu Arc, can proceed from this inference. During Eocene time, the northeast Sabah terrain extended on strike out to sea from northern Borneo, as Palawan does now, with subduction southeastward beneath the continuous terrain. In the Oligocene, polarity of the offshore part of the system, including what is now the Sulu Island Arc, reversed, and the arc migrated southeastward above a northwest-dipping subduction zone, colliding with the mainland progressively from west to east. The polymict melange of eastern Sabah, which involves lower Miocene rocks, may mark a collision suture, along which the southward-migrating arc collided with a simultaneously active south-dipping subduction system that had developed beneath the mainland in this sector and to which the middle Tertiary andesites of the Semporna Peninsula belong. Continuing convergence of Sulu Sea and Borneo plates produced a new subduction system dipping south beneath Sabah as enlarged by the collision and southeastward beneath the Sulu Arc, and at least the Pliocene and Quaternary andesites of eastern Sabah belong to this late pattern. (Beddoes, 1976, made somewhat similar suggestions.)

The ophiolite fragments now in the Sabah melange are too young to have formed part of the western Pacific plate, so likely formed in marginal-sea environments, perhaps behind migrating arcs of which parts are now in the Philippines, Sulawesi, or northern New Guinea. These oceanic basement rocks probably were covered by terrigenous clastic sediments - now the quartzose and feldspathic sands in the melange-in what may have been a stable continental slope-continental rise-abyssal plain configuration, north of Sabah in the latest Cretaceous and Paleogene. Other quartzose sediments now in Sabah melange were swept into the arc from the South China Sea or from the trench along the arc.

The relationships between Sabah and the inactive Palawan and Sulu Island Arc systems are discussed after the description of those arcs in a subsequent section of this report.

\section{CENOZOIC BASINS OF EAST KALIMANTAN}

Beyond the reach of the events coupled with the subduction beneath northern and northwestern Borneo, basins developed in eastern Kalimantan in response to other forces. Among these basins, the Kutei was apparently inaugurated by the rifting away from Borneo of Sulawesi.

\section{CENOZOIC STRATA OF SOUTHEAST KALIMANTAN}

Stable-shelf and epicontinental conditions prevailed over southeastern Borneo during the early and middle Tertiary, but during the late Tertiary and Quaternary the Barito Basin and Meratus Mountains have developed (A.R.U. Adinegoro, 1973; Pelton, 1975; Sumartadipura, 1976; Weeda, 1958b; and unpub. data provided by oil companies and by Lemigas, the Indonesian Petroleum Institute). In the Barito Basin-Meratus Mountains region, continental sands and conglomerates give way upward to brackish-water, and then to marine, shales, marls, sands, and lignites. The oldest strata firmly dated are middle Eocene and are low in the marine section. The coarse clastic materials thin and disappear southeastward, so apparently came from interior Borneo. Oligocene and lower Miocene shelf limestone was deposited over much of southeastern Kalimantan and contains barrier, patch, and pinnacle reefs that are oil-exploration targets. The Meratus Mountains apparently existed in the early Tertiary only as a relative high that received thinner sediments than did flanking areas.

The Barito Basin and Meratus Mountains came into existence only after the deposition of the lower Miocene limestone. The later Neogene strata of the broad, asymmetric basin thin westward and lap onto the platform of south-central Borneo and are at their thickest in the east, near the Meratus Mountains, which are bounded against the basin by steep folds and east-dipping reverse faults. The middle Miocene and younger sediments are of mixed shallow-marine, deltaic, and continental facies. Broad swamps in the Barito Basin attest to continuing subsidence and sedimentation, but the main period of basin development and sedimentation was within the Miocene. Only one small oil field, atop an asymmetric anticline, has been located in the basin, near its east edge. The Barito Basin is largely an onshore feature, and its base rises southwestward under the Java Sea (pl. 1). Two small, narrow Neogene basins, largely offshore, lie along the east side of the Meratus Mountains. Barito Basin geothermal gradients are moderate, typically $3^{\circ}$ or $4^{\circ} \mathrm{C} / 100 \mathrm{~m}$ (Kenyon and Beddoes, 1977).

Offshore from southeastern Borneo, the Oligocene-lower Miocene shelf limestone has been traced eastward to the edge of the shelf, and southward far into the Java Sea, in reflection profiles and oil wells. A thin Eocene section of conglomerate, quartz sandstone, and shale is generally also present, and the transition from clastic to carbonate rocks is within the upper Eocene in the east. The Eocene to lower Miocene section thickens abruptly near the east edge of the shelf. Middle Miocene and younger strata are dominantly marine, are mixed carbonate and clastic types, and also are thicker at the eastern shelf edge.

Pyroxene and hornblende andesite and dacite occur in a small area at the south end of Laut Island at the southeast corner of Borneo and apparently are of post-Eocene age (Macke, 1924).

CENOZOIC: STRATA OF EAST-CENTRAL KALIMANTAN

Sedimentary facies of the Kutei (or Kutai) Basin region of onshore and offshore east-central Borneo are interpreted to record the two-stage rifting apart of Sulawesi and Borneo during middle and late Tertiary time. (The descriptive basis for the following discussion is provided by Billman and 
Kartaadiputra, 1975; Fletcher and Soeparjadi, 1976; Gerard and Oesterle, 1973; Gwinn and others, 1975; Magnier and others, 1975; de Matharel and others, 1977; Samuel and Muchsin, 1976; Schwartz and others, 1973; Weeda, 1958b; and unpublished data given by oil companies and by Lemigas.)

The Eocene consists of relatively coarse continental and transgressive-marine clastic sedimentary rocks in the western Kutei Basin, as in onshore and offshore southeastern Borneo. The Oligocene and lower Miocene are represented by shelf limestone in and east of southeastern Borneo; by a thicker section of marine clays, sandy shales, and silicic volcanic rocks in the outcrop belt in the western Kutei; and by a very thick shale section in the subsurface of the Mahakam Delta region near the present coast. The Kutei Basin was inaugurated by Oligocene time.

The higher Miocene and younger strata of the onshore and nearshore parts of the Kutei Basin are regressive clastic sediments that display in their facies the eastward progradation of the Mahakam Delta. For example, in the subsurface at the north edge of the present delta, where wells have probed nearly $4,000 \mathrm{~m}$, the deep section is of middle Miocene distal delta-front sediments; the middle section is of later Miocene proximal delta-front materials; and the upper section is of Pliocene and Quaternary delta-plain deposits. As is typical of deltaic complexes, stratigraphic zonation is made difficult by the rarity of planktonic foraminifers. The depositional axis of eastward-prograded delta sediments is progressively farther east in progressively younger strata, and the thickest Pliocene and Quaternary sediments are offshore. The total Cenozoic section is thickest near the present coast, where it reaches a maximum of 8 or $10 \mathrm{~km}$ (pl. 1). Despite the thickness of low-density sediments, Bouguer gravity anomalies are positive in the offshore part of the basin, so oceanic crust presumably underlies this region. The basement risies to the east of the Borneo coast, but the sediments remain thick across both the narrow continental shelf and the deep-water Makassar Strait (fig. 56). Reefs are present along the shelf edge and in the underlying upper Neogene.

The young strata of the offshore Mahakam Delta are prograded eastward and obviously were derived from Borneo. Two company geologists have told me that reflection profiles suggest older Nogene beds of the outer part of the shelf to be prograded westward; other geologists dispute this. The section in question has not been drilled but appears to be of approximately middle Miocene age. If a westward-prograded section indeed occurs here, then presumably it was derived from Sulawesi, before the Makassar Strait was opened by late Neogene rifting; extension during Oligocene to middle(?) Miocene time produced the Kutei Basin and resulted in complete sundering of the continental crust near the present coastline. This rifting is discussed further following the description in a subsequent section of the geology of Sulawesi.
The sedimentary fill of the Kutei Basin is much deformed by folds subparallel to the coast. The intensity of folding and the age of the youngest materials involved both decrease eastward (fig. 44). Folds both onshore and offshore typically are steep, narrow anticlines separated by flat synclines. Dips tend to increase with age of strata within the anticlines: the folds have grown concurrently with Neogene sedimentation. The thick middle Tertiary clays have risen into the anticlines, and much of the folding likely represents a response to loading of the poorly consolidated shale section by the prograding delta of the upper Neogene. (Compare with Bruce, 1973, and Chapman, 1974.) Many of the folds are asymmetric and broken by minor thrust faults, which commonly are directed eastward but locally are directed westward, and decollement sliding of the upper Neogene toward the continental slope can be inferred. Normal faults, dropped down on the seaward side, and crestal-foundering faults are also common.

The various small to large oil fields discovered onshore and offshore in the Mahakam Delta region are on culminations on some of the youngest, and least compressed, anticlines (fig. 45). Each field has numerous reservoirs in meandering channel sands in the upper Neogene (primarily upper Miocene) regressive deltaic section, at depths ranging from 900 to $3,000 \mathrm{~m}$. Source beds presumably are the thick middle Tertiary shales. The largest field, Attaka, is on an anticline with areal and vertical closures of $70 \mathrm{~km}^{2}$ and 200 $\mathrm{m}$, respectively, and in some of the sands as much as 70 percent of the closure is occupied by oil and gas columns (Schwartz and others, 1973). Geothermal gradients are low, typically about $3^{\circ} \mathrm{C} / 100 \mathrm{~m}$ (Kenyon and Beddoes, 1977).

The Kutei Basin is bounded on the north by the Mangkalihat Peninsula. In the sector between about lat $1^{\circ}$ and $2^{\circ}$ N., flat-lying Paleogene coarse clastic sediments overlie older deformed clastic rocks in the far west, but Paleogene shales and varied sands are thicker than $5,000 \mathrm{~m}$, are intercalated with tuffs high in the section, and are moderately deformed closer to the peninsula. The eastern part of the peninsula has a thin Paleogene section of interbedded clastic and carbonate strata. The Neogene Kutei section thins rapidly northward to end against the Mangkalihat Peninsula, and the entire Neogene of the eastern part of the peninsula is in thin, shallow-marine facies (Rutten, 1917).

\section{TARAKAN BASIN, NORTHEAST KALIMANTAN}

Another Neogene basin, Tarakan, lies along the coast of northeasternmost Kalimantan, north of the Mangkalihat Peninsula, and extends into south-central Sabah (Beltz, 1944; Collenette, 1965, de Johngh, 1915; Masatani, 1967; and unpub. data from oil-industry sources). The basin fill represents the overlapping deltas of several major river systems. Middle Tertiary sediments are moderately deformed, upper Tertiary and Quaternary ones less so; sedimentation and folding are still going on. The small Tarakan and 


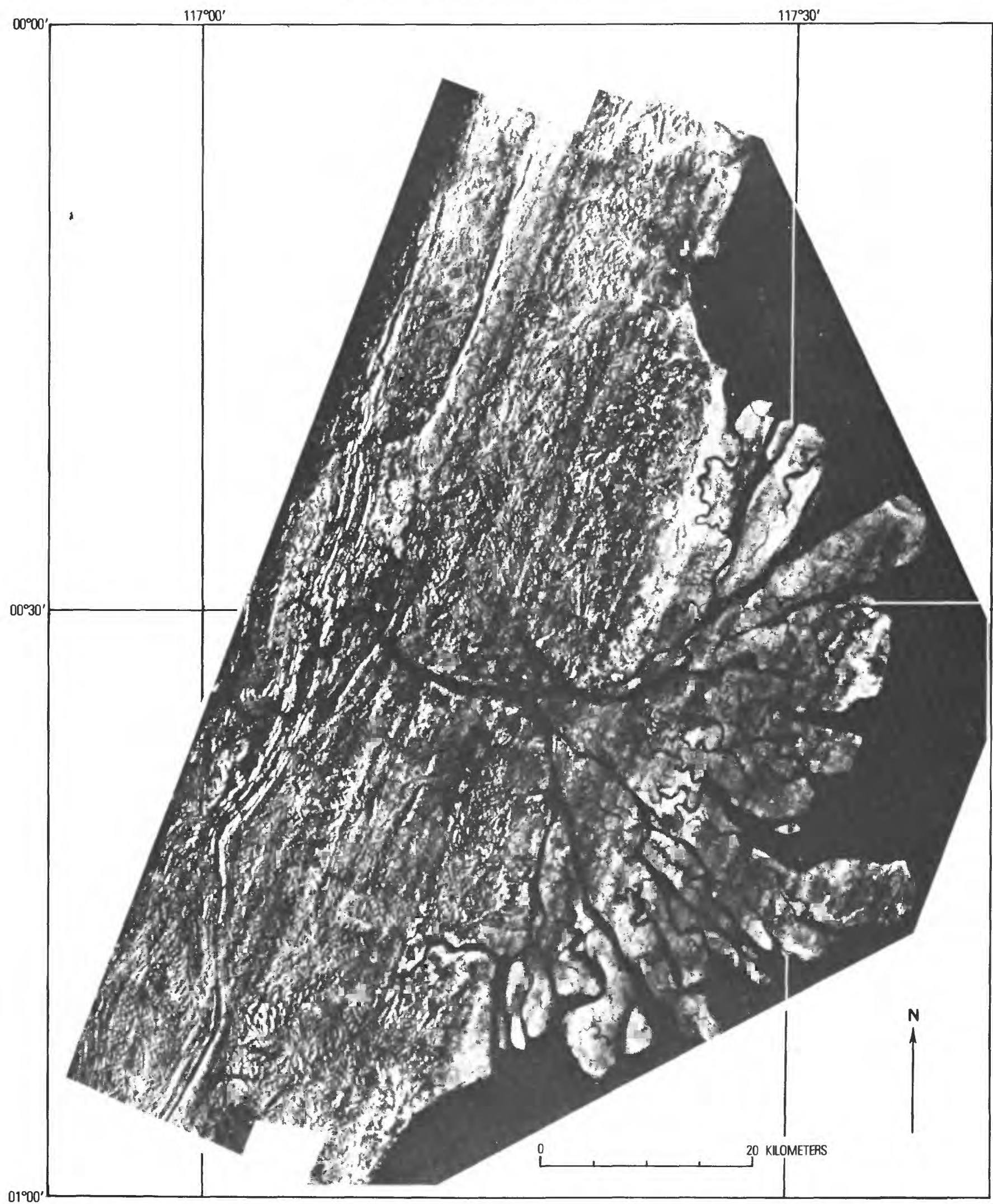

FIGURE 44.-Side-looking radar imagery showing structure of the Mahakam Delta region, east Borneo. Imagery by Westinghouse, mosaicked by Hunting Surveys, Ltd.; provided by Total Indonesie. Geology is shown in figure 45 . 


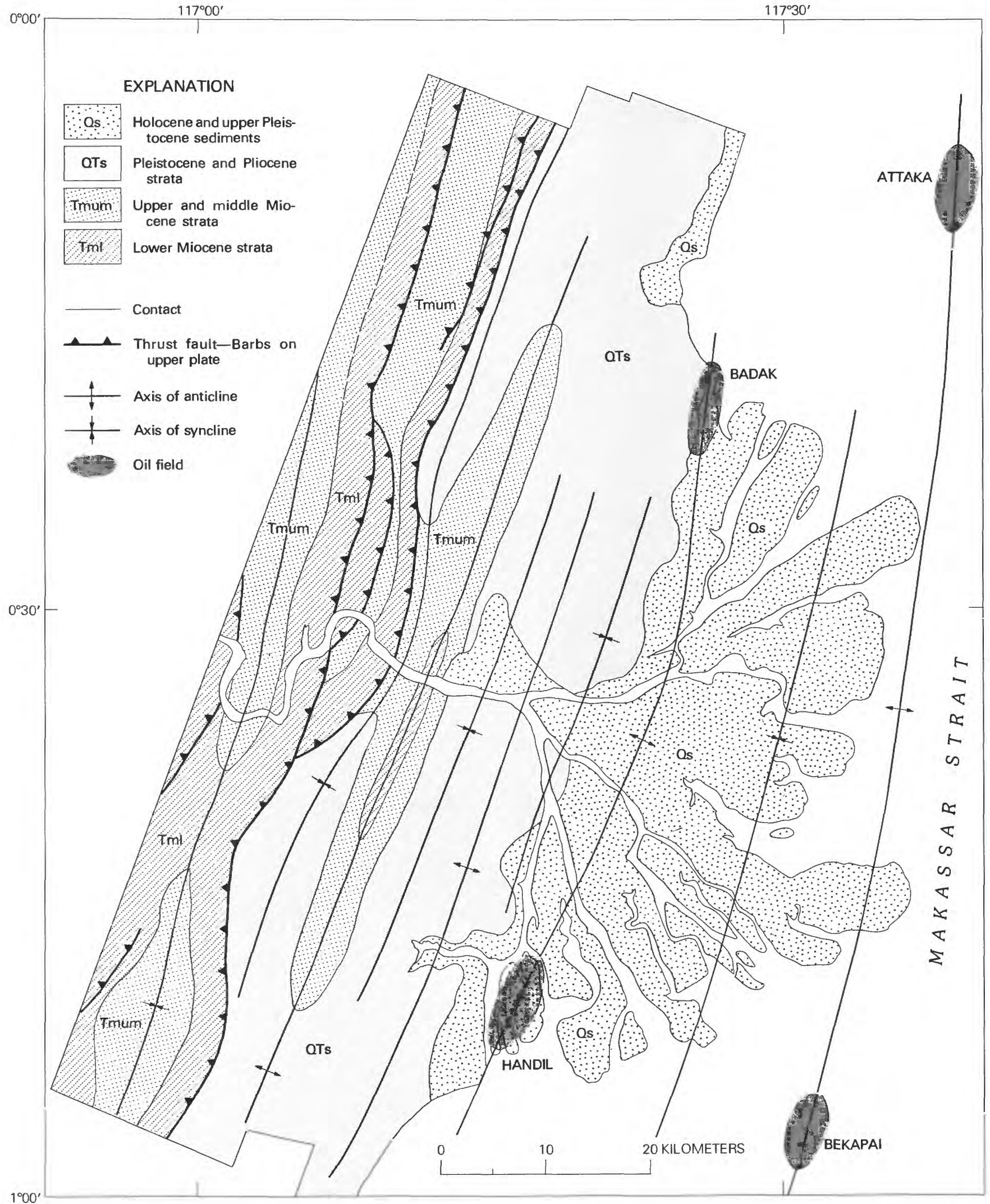

FIGURE 45.-Geologic sketch map showing structure of the Mahakam Delta region, east Borneo. Geology interpreted by Hamilton, on a 1:100,000-scale print of the radar imagery (fig. 44), to best fit the geologic units as identified by Shell geologists prior to 1963 and released as the 1:1,000,000-scale Geologic Map of East Kalimantan, 1971, by the Indonesian Petroleum Institute (Lemigas). Fold axes offshore and beneath delta from Magnier, Oki, and Kartaadiputra (1975). 
Bunju oil fields are on faulted anticlines, trending north-northwest, in the center of the basin.

\section{JAVA SEA}

The continental-shelf Java Sea, $350 \mathrm{~km}$ wide, separates the Tin Islands (Bangka, Belitung, and others) and Borneo on the north from Java on the south. Extensive petroleum exploration has in the past several years provided much information regarding the geology of the shelf. Some of the information has been published by Cree (1972), Fletcher and Soeparjadi (1976), Najoan (1973), Pulunggono (1974), Sudiro and others (1973), and Todd and Pulunggono (1971), and more has been made available to me by the companies active in the region. The results of a marine-geophysical reconnaissance were summarized by Ben-Avraham (1973), Ben-Avraham and Emery (1973), and Emery, Uchupi, and others (1972).

\section{BASEMENT GEOLOGY}

Many oil-exploration wells have reached basement beneath Eocene, Oligocene, or Miocene strata in the Java Sea, particularly in its south half (fig. 46). North of western Java, low-grade metasedimentary rocks (slate, phyllite, quartzite, marble) are dominant; middle-grade metasedimentary rocks are present also. Large and small masses of granitic rocks - quartz monzonite more abundant than granodiorite, and gneiss, quartz diorite, and diorite occurring locally - are widespread, as are mafic to silicic volcanic rocks. North of eastern Java, slaty metasediments, some of them extremely sheared, are dominant and are of either terrigenous or volcaniclastic origins; basic to silicic volcanic rocks, and in the northwest granitic rocks, are also present. Many K-Ar age determinations have been made on granitic, volcanic, and metasedimentary rock samples and mostly indicate Paleocene and Cretaceous ages of 58-115 m.y., although other determinations scatter back to 140 m.y. (fig. 46). Unmetamorphosed high Lower Cretaceous limestone and clastic sediments unconformably underlie Eocene strata in one sector north of western Java.

Magnetic anomalies in the northeast part of the Java Sea trend southwestward or west-southwestward, indicating that the general basement strike shown by the melange of Cretaceous or very early Tertiary age of the Meratus Mountains of Borneo prevails over a large region to the south.

\section{TECTONIC CORRELATIONS BETWEEN JAVA AND BORNEO}

The melange terrains of Late Cretaceous and very early Tertiary age in central Java and southeastern Borneo likely belong to a belt that trends northeastward beneath the sedimentary cover of the Java Sea (pl. 1). West of this belt, the widespread silicic igneous rocks show that the crust was of continental character by Cretaceous time (fig. 46). The Late Cretaceous and Paleocene $\mathrm{K}-\mathrm{Ar}$ age determinations in this terrain in the Java Sea suggest that the silicic magmatism records the same subduction system as does the melange of Late Cretaceous or very early Tertiary age farther east. Within and east of the projected belt of melange, the basement rocks found may be mostly melange components, the silicic magmatic rocks present having formed after further outgrowth of the continental margin or having been incorporated in it tectonically.

These considerations, plus others regarding Sulawesi (discussed subsequently), are interpreted to indicate that during Late Cretaceous and early Tertiary time an active subduction zone bounded the Java-Java Sea-Borneo continental mass on the southeast and trended in what is now an east-northeasterly direction. Accretion of melange against this continental mass caused southeastward growth of the continent and migration of the trench. Only in the middle and late Cenozoic did the subduction system migrate on eastward, opening the Banda Sea and producing the modern arc which trends eastward rather than northeastward from Java.

\section{CENOZOIC SEDIMENTS}

Sedimentary cover is thin over most of the shelf, except in the far south in the foreland basin along northern Java (as discussed in the previous section on Java). The basement surface of the shelf has considerable relief, being blocked into basins by warps and normal faults that typically trend north-northeastward near Sumatra in the far west and northeastward elsewhere (pl. 1). Much of the structural relief of the basins north of western and central Java predates the deposition of sediments there, whereas most of the relief near southeastern Borneo postdates most of the sedimentation. Between these two areas, broad folds and low-angle unconformities attest to deformation concurrent with basin filling. The old basins were filled gradually by sedimentation that began in the middle Eocene in the far east but in the Oligocene in most of the area. Upper Oligocene and lower Miocene strata lap progressively higher onto the flanks of the old highs and cover some of them, but not until middle Miocene time were the last of them covered. A major zone of faults trends westward, from south of Kangean Island to northern Madura Strait; associated folds strike southeastward into the faults from the north, suggesting left-lateral strike slip.

Clastic sediments were derived from the north and northwest, and from the basement highs. The basal sediments are Eocene and lower Oligocene continental and paralic clastics, rich in quartz sand, except that no sand reached the Madura-Kangean region in the far southeast, where the strata are shale, mudstone, and a little limestone. Above these basal clastic strata, carbonate sediments dominate the eastern sections and clastic the western; carbonate deposition extended far to the west during the late Oligocene and early Miocene, with the formation of massive shallow-water lime-mud limestone (Berai, Batu Raja, and Kajung Limestones) containing abundant bioherms and 


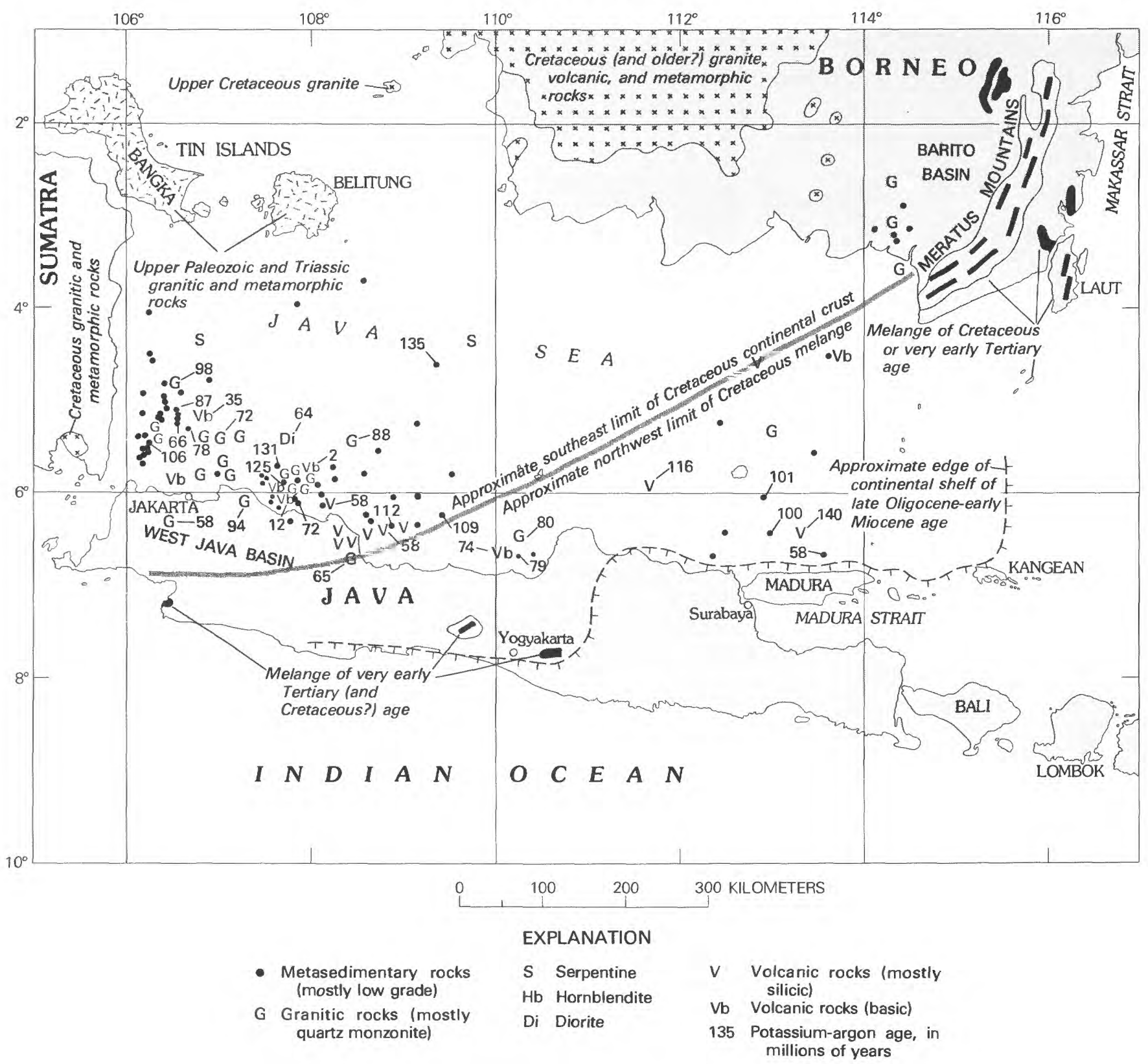

FIGURE 46. - Lithology and potassium-argon age of basement samples in oil-exploration wells in northwest Java, the Java Sea, and the Barito Basin. Data provided by Atlantic Richfield Indonesia, Continental Oil Co., Indonesia Cities Service, Independent Indonesian American Petroleum Co., and Union Carbide Petroleum Co. Four wells in onshore Java are from Patmosukismo and Yahya (1975). The oldest sediments overlying the basement rocks are of Eocene age in Borneo and variously of middle Eocene to middle Miocene ages in the Java Sea. Neogene volcanic rocks are present locally north of western Java near $107^{\circ} 55^{\prime}$ E. Unpatterned land areas are Cenozoic sedimentary and volcanic rocks.

reefs, and again during part of the middle Miocene, whereas clastic strata were deposited over the entire shelf in the early middle Miocene. The upper Oligocene-lower Miocene shelf limestone ends in the southeast at an abrupt paleo-shelf edge, trending eastward north of Madura and perhaps northward near Kangeàn (fig. 46; Soeparjadi and others, 1975). Shale was deposited in the deeper water southeast of the line of middle Tertiary reefs that formed along this edge, and the shelf edge was prograded southward with time.

A number of oil fields are being developed on variably faulted anticlines in the West Java Basin north of Java (Scheidecker and Taiclet, 1977), and in the Sunda Basin just east of southeastern Sumatra. Reservoir rocks are upper Oligocene and lower Miocene sandstone and reef limestone, 
at depths of only $800-2,500 \mathrm{~m}$. Reservoir targets north of eastern Java are reef limestones, oil there being generated from plant debris in underlying Oligocene shale (Russell and others, 1977).

Geothermal gradients in the sediments of the Cenozoic basins of the Java Sea tend to increase westward (Kenyon and Beddoes, 1977), in accord with the change in basement complexes from melange in the east to igneous terrains in the west. Gradients are about $1^{\circ}-2^{\circ} \mathrm{C} / 100 \mathrm{~m}$ north of Sumbawa; $3^{\circ}-5^{\circ} \mathrm{C} / 100 \mathrm{~m}$ north of east Java; $4^{\circ}-5^{\circ} \mathrm{C} / 100 \mathrm{~m}$ north of central Java, and $5^{\circ}-7^{\circ} \mathrm{C} / 100 \mathrm{~m}$ near the north coast of west Java and $4^{\circ}-5^{\circ} \mathrm{C} / 100 \mathrm{~m}$ farther north of west Java.

\section{CENOZOIC SUBDUCTION AND STABILITY}

The modern volcanic arc of medial Java has been active since late Oligocene time. Middle Eocene through middle Oligocene strata are, however, in transgressive and continental-shelf sedimentary facies. Most of the Dutch geologists believed that Eocene and Oligocene volcanic islands stood upon this shelf in medial or southern Java, but arguments against this belief were given in the previous section on Java; furthermore, the contrary interpretation was made (consistent with the information just summarized here on the Java Sea) that a stable continental shelf extended to the edge of the open Indian Ocean during middle Eocene through middle Oligocene time. The approximate location of the edge of this shelf is shown in figure 46 .

The magnetic-anomaly patterns of the Indian Ocean, described in the prior section on that ocean, require that rapid consumption of oceanic crust has continued between Asia and the Indian Ocean during Paleogene as well as during Late Cretaceous and Neogene time. Subduction during Cretaceous and Neogene time is accounted for in the geologic record of Java and the Java Sea and was northward beneath the subcontinent of western Indonesia. If my inference is correct that little or no corresponding subduction took place during the Paleogene, then Paleogene crustal consumption must have occurred in some other subduction system between the Indian Ocean and mainland Asia.

The Eocene and Oligocene subduction shown by the geologic record of northwestern Borneo (as described in the section on that island) is of an age and location appropriate to have accounted for the major crustal convergence in these longitudes. Java and the Indian Ocean may have gradually locked together during the early Paleogene as a south-dipping subduction system developed under northwest Borneo. During Neogene time, the situation was reversed, and Borneo became locked to the South China Sea floor as the Indian Ocean plate was again subducted rapidly beneath Java. If this synopsis is correct, however, it is in no way obvious how the relative motions of other components in the region were accommodated during the Paleogene excursion.

A contrary explanation could be suggested by applying to Java the rationale developed by DeLong and Fox (1977) for the Paleogene history of the Aleutian Island Arc. In Paleogene time, the young, northward-migrating spreading center of the eastern Indian Ocean may have been subducted beneath Java. As the overriding Indonesian plate climbed up the slope of the approaching ridge, shoaling and emergence resulted, and arc magmatism decreased or ceased as the young, hot lithosphere was subducted.

\section{SOUTH CHINA SEA AND GULF OF THAILAND}

The broad, shallow continental shelf of the southern part of the South China Sea and the Gulf of Thailand lies between the Malay Peninsula on the west, Indochina on the north, and Borneo on the southeast (fig. 47). To the northeast of the shelf, and within the area of the tectonic map of the Indonesian region, is part of the deep-ocean basin (South China Basin) of the South China Sea. The profiles of figure 48 give an overview of the shelf and the nearby part of the ocean basin.

\section{ISLANDS BETWEEN MALAYA AND BORNEO}

Neogene sediments are thin or lacking in the large shelf region bounded by western Borneo on the east, the Tin Islands (Bangka, Belitung, and others) and far southeastern Malaya on the south and southwest, and the Anambas and Natuna (Bunguran) Islands on the north (pl. 1). Important information regarding projections (discussed in a subsequent section) of pre-Neogene terrains across the shelf is given by the geology of the islands between about lats $2^{\circ}$ and $4^{\circ} \mathrm{N}$.

The Natuna Islands, trending northwest from the north tip of western Borneo, appear to be analogous geologically to westernmost Sarawak and adjacent Kalimantan. The youngest consolidated rocks are gently dipping Paleogene(?) and Miocene continental sandstones and shales, lithologically similar to the Paleogene of the basin in interior Kalimantan. These may underlie the thick middle and upper Cenozoic fill of the continental shelf basin east of Natuna Island (fig. $48 \mathrm{~B}$ ). Probably the youngest major basement rock is two-mica, tourmaline-bearing quartz monzonite, from which single Cretaceous $\mathrm{K}-\mathrm{Ar}$ and $\mathrm{Rb}-\mathrm{Sr}$ ages were reported by Haile (1970), Haile and Bignell (1971), and Katili (1973b, citing AGIP Società per Azioni). Rocks that are at least in part older than the quartz monzonite include deformed shale, meta-arkose, chert, and variably sheared and amphibolitized serpentinite, gabbro, diabase, and diorite. The mafic rock types-an ophiolite assemblage?- suggest melange to be present.

The small Tambelan Islands, west of the extreme west tip of Borneo, consist of deformed and altered intermediate and mafic volcanic rocks and younger(?) biotite quartz monzonite and granite porphyry (Haile, 1970). One K-Ar age and one $\mathrm{Rb}$-Sr determination suggest the quartz monzonite to be of Late Cretaceous age (Haile, 1970; Haile and Bignell, 1971).

The Anambas Islands, in the region about lat $3^{\circ} \mathrm{N}$. , long $106^{\circ}$ E., consist mostly of granitic rocks but include also andesite, diabase, shale, greenschist, and amphibolite 


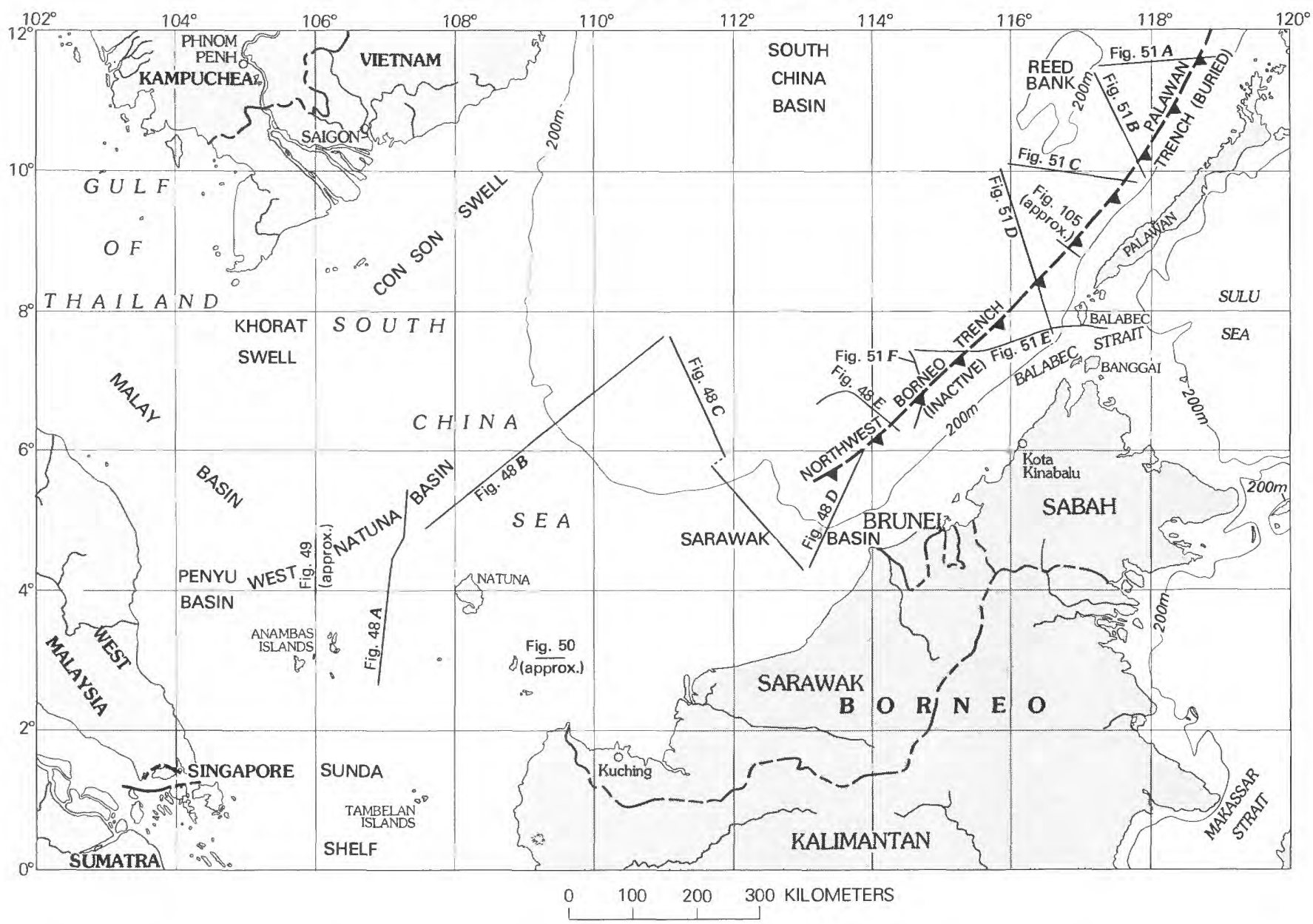

FIGURE 47.-Selected tectonic elements in the South China Sea and Gulf of Thailand areas and location of seismic-reflection profiles shown on figures $48-51$ and 105 .

(Bothé, 1928). One granite sample yielded a K-Ar age of about 85 m.y., Late Cretaceous (AGIP Società per Azioni, as cited by Katili, 1973b).

Lithologies and $\mathrm{K}-\mathrm{Ar}$ age determinations for basement rocks in four offshore wells, north of the Anambas Islands and northwest of Natuna, were reported by Pupilli (1973). Biotite-hornblende quartz monzonite or granodiorite, near the Anambas group at about lat $4^{\circ} 00^{\prime}$ N., long $105^{\circ} 49^{\prime} \mathrm{E}$., yielded an age determination of 110 m.y., Early Cretaceous. Much-altered andesite was cored near $4^{\circ} 28^{\prime} \mathrm{N}$., $105^{\circ} 14^{\prime} \mathrm{E}$., and near $5^{\circ} 10^{\prime} \mathrm{N}$., $106^{\circ} 48^{\prime} \mathrm{E}$., and the samples have apparent (but dubious) K-Ar ages of 169 and 92 m.y., respectively. An amphibolite, apparent age $171 \mathrm{~m} . \mathrm{y}$., was drilled near $5^{\circ} 07^{\prime}$ N., $106^{\circ} 21^{\prime} \mathrm{E}$.

\section{CENOZOIC SHELF BASINS}

Large, complex basins, filled deeply by Cenozoic sediments, underlie much of the flat, shallow continental shelf (pl. 1). A western composite-basin system is broadly axial to the Gulf of Thailand, extending south to about the latitude of Natuna Island. An eastern composite-basin system forms a broad arc that trends southwest and west from northern Borneo to east of Natuna, thence northwest and north approximately parallel to the edge of the continental shelf. The two basin systems were broadly outlined by Ben-Avraham (1973), Haile (1973a), and Parke, Emery, Szyankiewicz, and Reynolds (1971). Dash and others (1972) published shallow-penetration reflection profiles near Natuna Island. The following statements however, are based largely on unpublished data given me by oil geologists.

The western basin system consists of the small west-trending Penyu and West Natuna Basins in the south, the large Malay ${ }^{9}$ Basin trending northwest in the center, and the north-trending Thai Basin in the north.

\section{MALAY BASIN}

The basement surface beneath the Malay Basin steepens inward, and the thickness of sedimentary fill in the center is

\footnotetext{
' On my sedimentary basins map (Hamilton, 1974a), this basin was labelled the Gulf of Thailand Basin. Industry usage, however, favors the name Malay Basin for the one in question and applies the name Thai Basin, or Gulf of Thailand Basin, to the northern basin in the system; that usage will be followed here.
} 

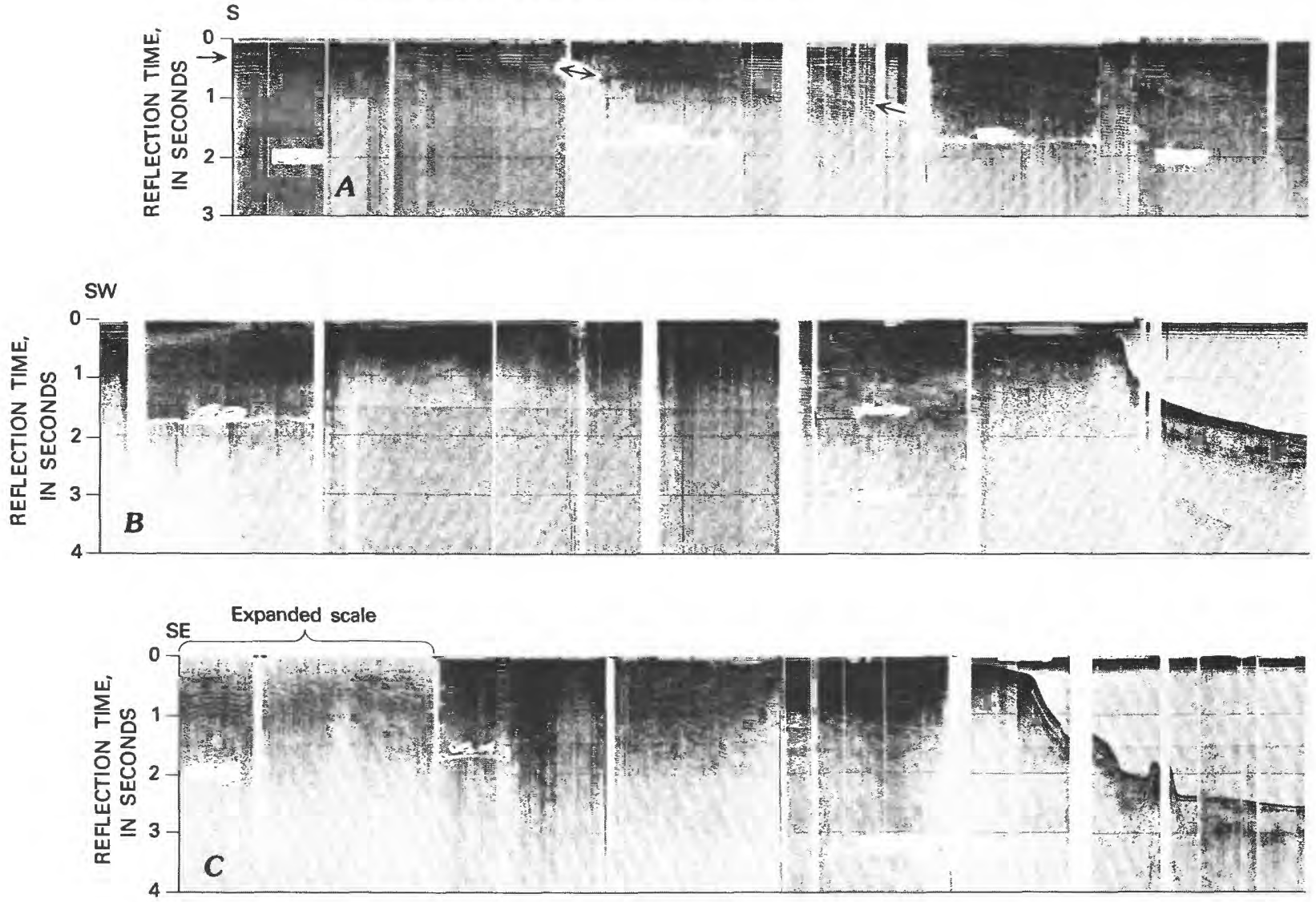

PROFLLS A, B, AND C

$\stackrel{100}{\stackrel{1}{0}} \stackrel{200 \text { KILOMETERS }}{\text { APPROXIMATE }}$

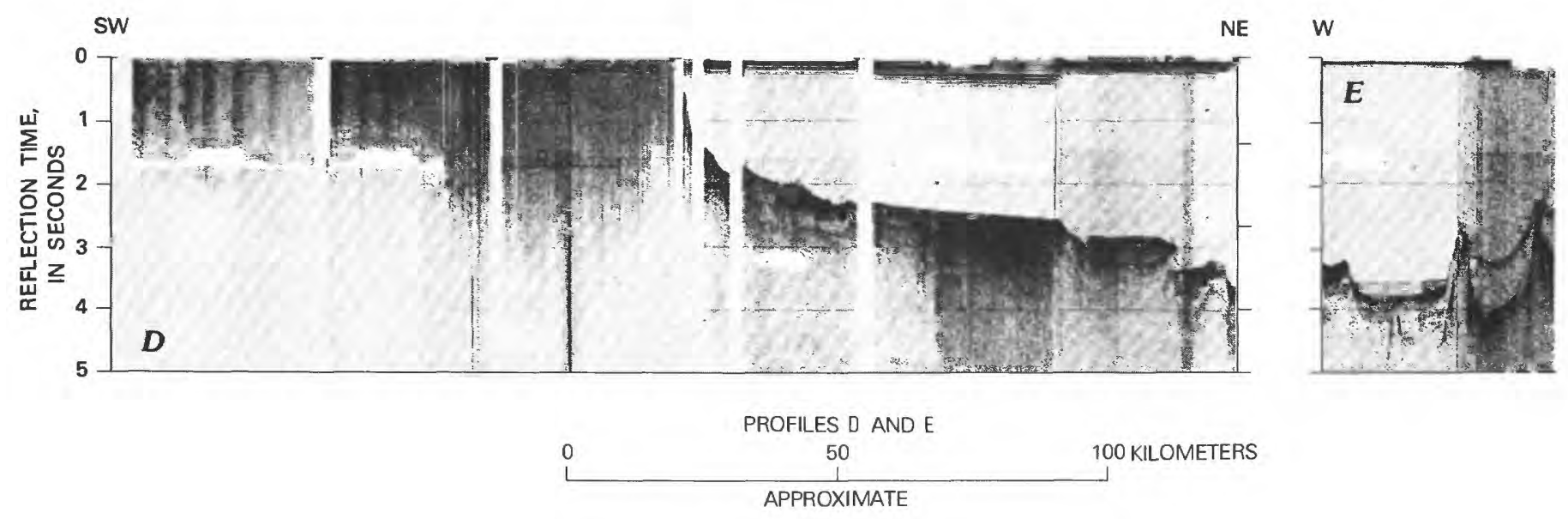

about $10 \mathrm{~km}$. Younger sediments overlap greatly onto the basement and stratigraphic units thicken into the basin, so the basin has broadened and subsided throughout its evolution. The upper part of the section consists of upper Neogene deltaic, estuarine, and lagoonal sands, silts, muds, and lignites, which have a maximum thickness of a few thousand meters. Beneath this is a very thick shale section whose upper part is approximately middle Miocene and whose basal age is unknown but presumably is Paleogene. Long, narrow anticlines trend west-northwestward in the deeply filled part of the basin and have grown concurrently with the late Neogene sedimentation so that the young strata thin over them. The underlying shales have risen into the cores of the anticlines but do not pierce the young clastic 
N
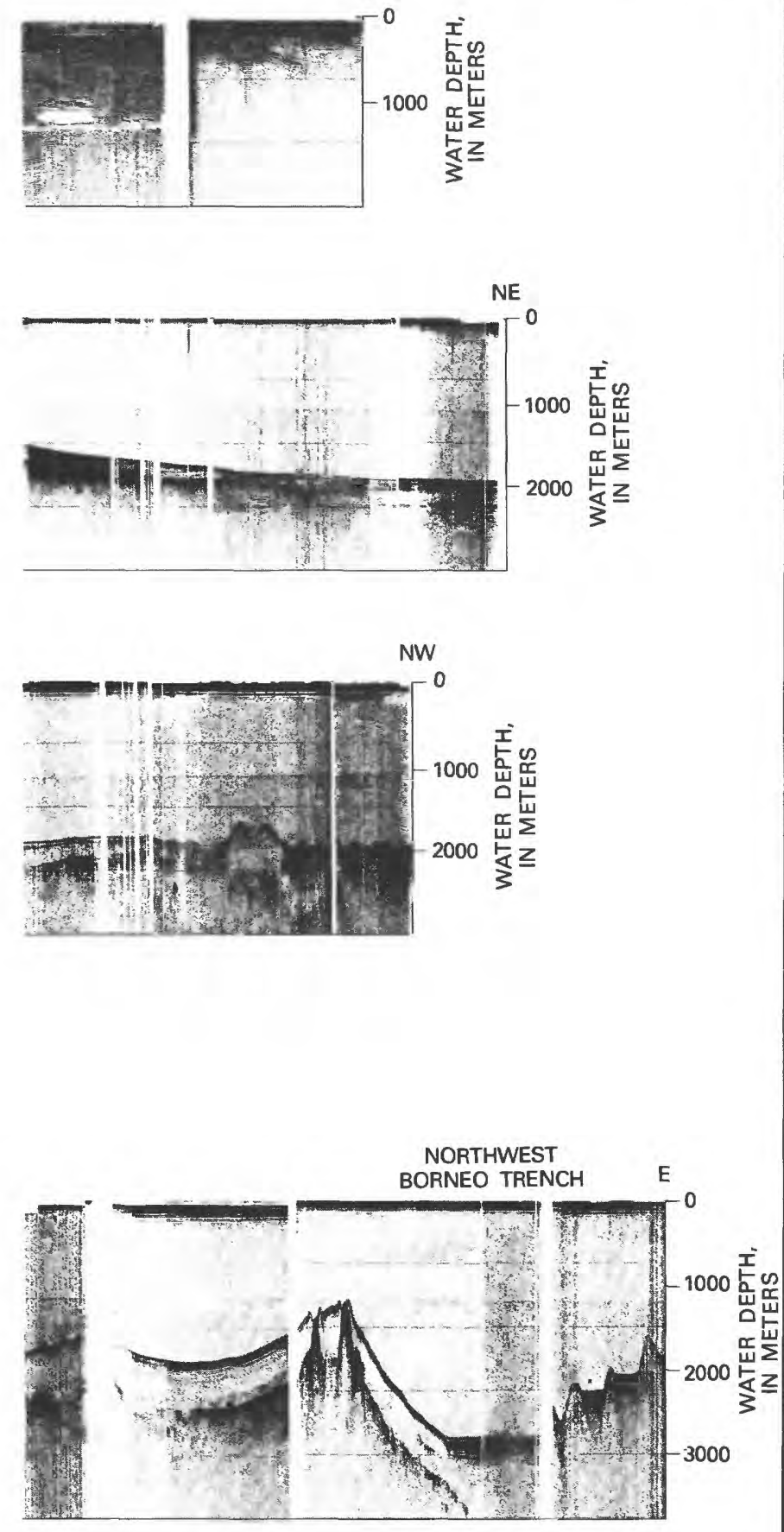

strata. The anticlines die out upward and do not affect the sea floor, so the structures may have been inactivated by lithification of their shale cores. A number of these anticlines have been drilled, to depths between 1,500 and $3,000 \mathrm{~m}$, in the search for oil and gas, drilling generally being stopped high in the shale cores.

The anticlines in the Malay Basin are obvious petroleum exploration targets, for the capping clastic strata provide possible reservoir rocks and the underlying shales are likely petroleum source rocks. Large units of clean quartz sand, such as would provide major reservoirs, are, however, uncommon in the capping clastic rocks. High pressures and temperatures characterize the shale cores of the anticlines and make natural gas more likely than oil beneath the varied capping strata. Geothermal gradients are typically within the range $4^{\circ}-6^{\circ} \mathrm{C} / 100 \mathrm{~m}$ (Kenyon and Beddoes, 1977). Possible stratigraphic traps, peripheral to the anticlines or elsewhere, are being investigated. The Pulai oil field is being developed on an anticline in the southeast part of the basin.

The great basement depth of the central part of the Malay Basin and the apparent lack of basement involvement in the anticlines suggest that tensional thinning of the continental crust dominated its formation and still operates. The main basin trends northwest, but the individual shale-cored anticlines tend to trend west-northwest and to be arrayed in echelon. This oblique orientation of the structures suggests that right-lateral shear, oriented northwestwards, has played a part in their formation, and oblique right-lateral extension is inferred. The rise of little-lithified mud cores presumably dominated the growth of the anticlines.

\section{THAI BASIN}

The deep, narrow, north-trending Thai Basin has a thick fill of middle and upper Cenozoic sands, silts, muds, and lignites, mostly continental and deltaic but in part estuarine and lagoonal (Achalabhuti, 1974; Paul and Lian, 1975). The section has been drilled to depths in excess of $3,000 \mathrm{~m}$, the deeper wells having reached the Oligocene, but that is only perhaps half way to basement in the deeper part of the basin. The section is of mixed clastic sediments throughout; the thick shale section, and correspondingly the shale-cored anticlines, of the Malay Basin have no analogs here. Pelagic foraminifers are all but lacking throughout the drilled section, and biostratigraphic zonation is by the imprecise

FIGURE 48 (above and facing page).--Seismic-reflection profiles in the southern South China Sea. $A$, The conspicuous unconformity (marked by arrows) separates poorly consolidated upper Cenozoic sediments from Paleogene or Mesozoic layered rocks. The angular discordance disappears to the north as older middle(?) and upper Cenozoic sediments lap on. An anticline near the north end of the profile dies out upward in the section, hence grew concurrently with deposition of all but the highest strata. $B$, Deformed rocks are probably present at shallow depth near the southwest end of the profile. The overlying shelf sediments are prograded to the northeast, with dips increasing downward, to the shelf edge. Abyssal-fan sediments are thick and show a possible unconformity high in the section. $C$, The shelf sediments are prograded outward toward the northwest to the shelf edge. The nonreflecting core (white) in the anticline 50 $\mathrm{km}$ from the southeast end of the profile is perhaps of shale. The reflective abyssal turbidites at the northwest end lap on to acoustically transparent pelagic sediments draped on a rough basement. $D$. The anticline at the shelf edge may be draped over the outer-arc ridge of the extinct Northwest Borneo Trench system. The syncline behind the anticline may be a wholly filled outer-arc basin. $E$, Acoustically transparent pelagic sediments about $700 \mathrm{~m}$ thick cover the deep-sea basement and plane down with that basement beneath the layered turbidites of the inactive trench. Location of profiles shown on figure 47. Profiles from Lamont-Doherty Geological Observatory, R. V. Robert Conrad cruise 12. 

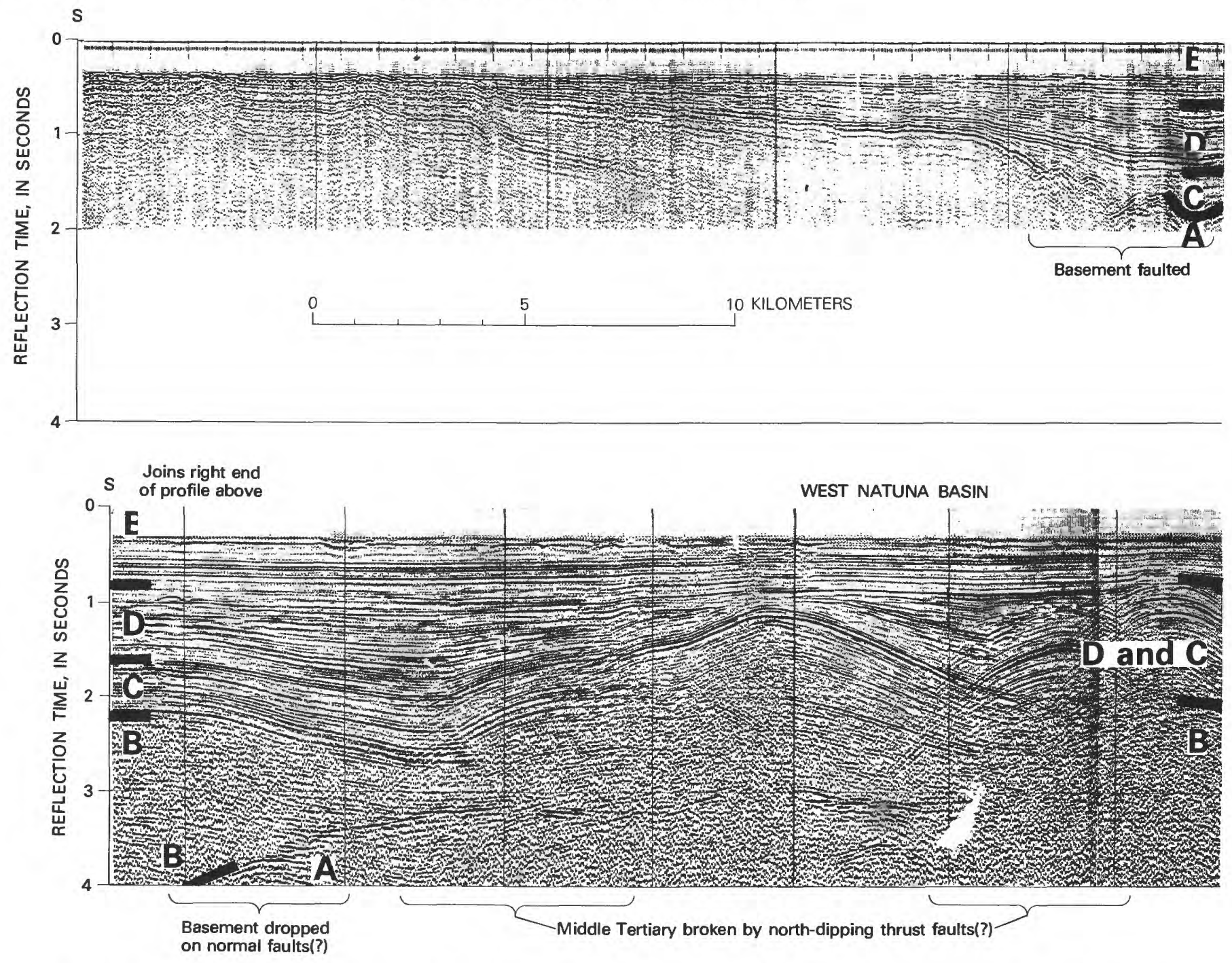

FIGURE 49.--Seismic-reflection profile across the West Natuna Basin, approximately along the meridian of $106^{\circ}$ E. Sea floor, not shown, is shallower than $200 \mathrm{~m}$ (1/4 second) throughout. Dips are not migrated. Stratigraphic units: A, economic basement; B, Paleogene fine-grained sediments; C, Oligocene fluvial and continental sandstone and shale; D, lower and middle Miocene brackish-water and tidal-flat sediments, including some coal; E, upper Miocene to Quaternary shallow-marine mud and sand. Profile provided by the Continental Oil Co.

methods of palynology. The upper Miocene to Quateruary strata are flat, have a maximum thickness of about $1,000 \mathrm{~m}$, and lie with marked unconformity on the more lithified middle Miocene and older strata. Broad folds and half-grabens grew concurrently with sedimentation through middle Miocene time but have since been more or less inactive. Older strata slumped into the deepening basin on gravity faults that do not reach the basement. Considerable natural gas and some oil have been discovered in thin sand reservoirs, but the commercial potential is uncertain. High temperatures preclude the presence of oil at great depth; Paul and Lian (1975) reported that temperatures are typically about $120^{\circ} \mathrm{C}$ at $2,500 \mathrm{~m}$ and reach $175^{\circ} \mathrm{C}$, the general upper temperature limit for liquid petroleum, at about $3,200 \mathrm{~m}$.
Basement is generally shallow beneath the surface of the shelf east and west of the narrow Thai Basin, but the basement is broken by Miocene faults into horsts, grabens, and half-grabens, filled and completely buried by as much as several thousand meters of Neogene clastic sediments (Paul and Lian, 1975). The small basin trending northward along the east coast of peninsular Thailand near long $99^{\circ} 30^{\prime} \mathrm{E}$. is filled by openly folded deltaic Pliocene strata.

\section{WEST NATUNA BASIN}

The West Natuna Basin (fig. 49) forms the southern part of the western basin complex and is quite different from the Malay Basin. Structural trends are in general east-northeastward. The dated section consists of Oligocene 


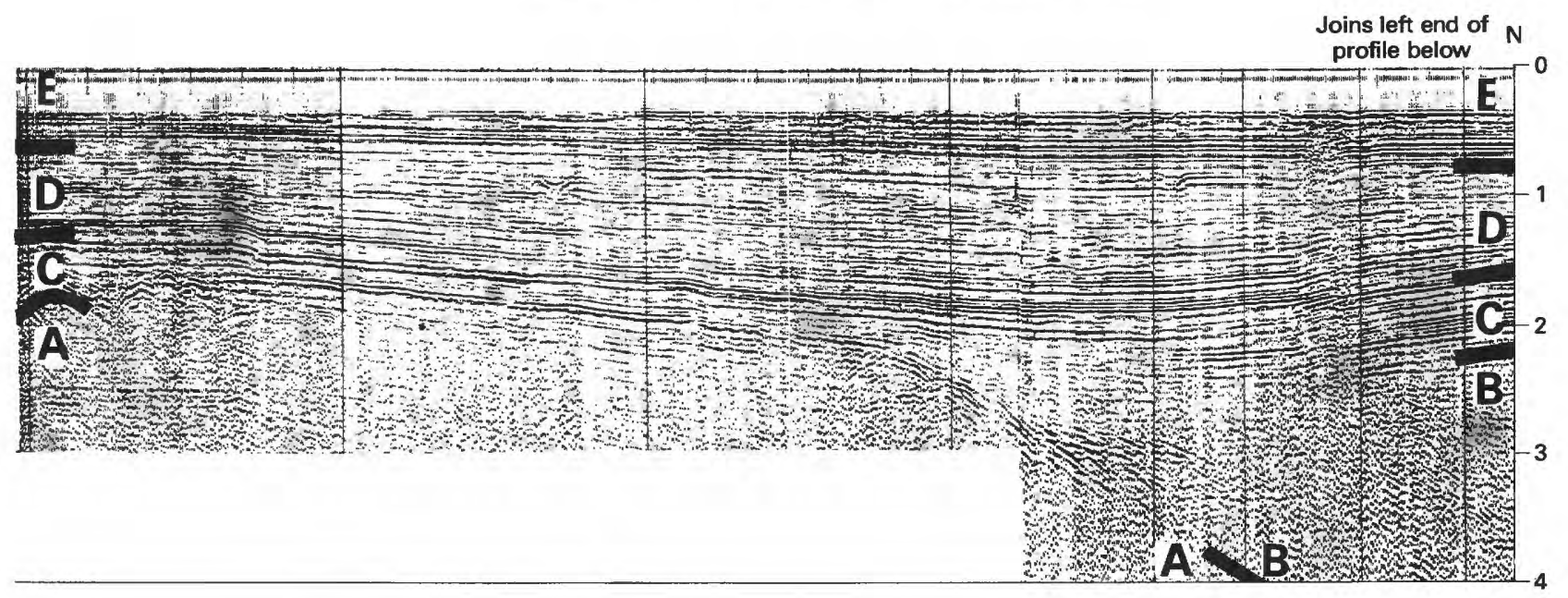

N

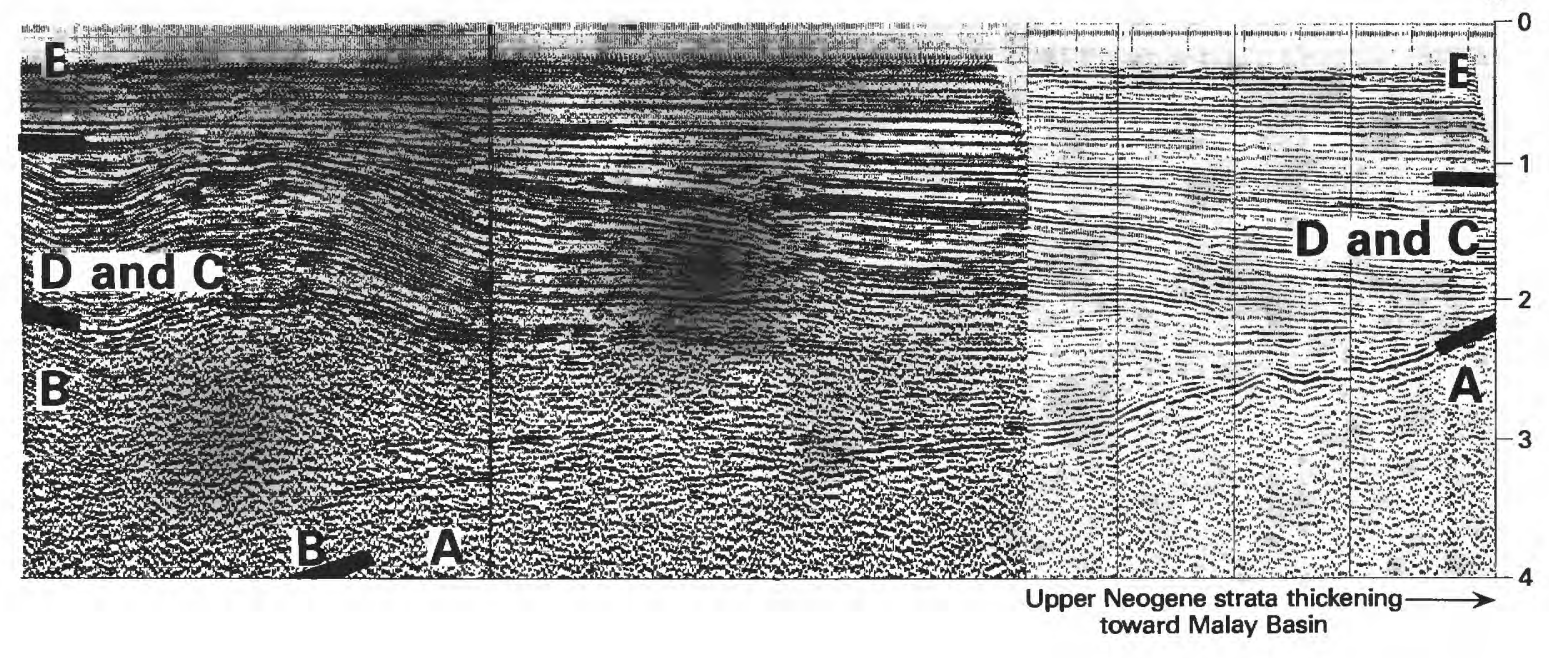

continental sandstone and shale, Miocene continental, brackish-water, and tidal-flat strata, and upper Miocene, Pliocene, and Quaternary shallow-marine mud, silt, sand, and coal. No open-marine strata are present, and dating of the sediments is by palynology. Units thicken into the basin; as the basin has broadened with time, successively younger units lap farther onto the basement, which consists at least in part of slightly to moderately deformed layered rocks of presumed Cretaceous or Paleogene age. The anticlinorial uplift that separates the West Natuna Basin from the east-trending, southeast end of the Malay Basin probably involves basement rocks, although these have not been reached by drilling, and the uplifted sediments are deformed by southward-directed reverse faults and asymmetric folds. The deformation proceeded concurrently with Miocene sedimentation, for Miocene strata lap onto or thin over the anticlines and are progressively less deformed upward by them. The deformation effectively ends at an unconformity in strata dated only approximately as late Miocene or early or middle Pliocene, although strata above this unconformity thicken markedly into the southeast end of the Malay Basin. The sedimentary axis of the basin, south of the complex welt of basement highs, is marked by a broad anticline: the basin was produced by downdropping of the basement, but the thick section filling the basin was later compressed and its top arched upward. The anticlinorial welt developed from an older ridge between the West Natuna and Malay Basins. Oil has been found in the West Natuna Basin. Geothermal gradients are mostly within the range. $3.5^{\circ}-5.5^{\circ} \mathrm{C} / 100 \mathrm{~m}$ (Kenyon and Beddues, 1977).

Obliquely compressive left-lateral shear, oriented east-northeast, can be inferred from the structural pattern in the West Natuna Basin. Individual structures are either parallel to the east-northeast trend of the basin or else strike more nearly east-west. Here, unlike the Malay Basin, the basement is involved, and reverse faults and asymmetric folds have been produced. 


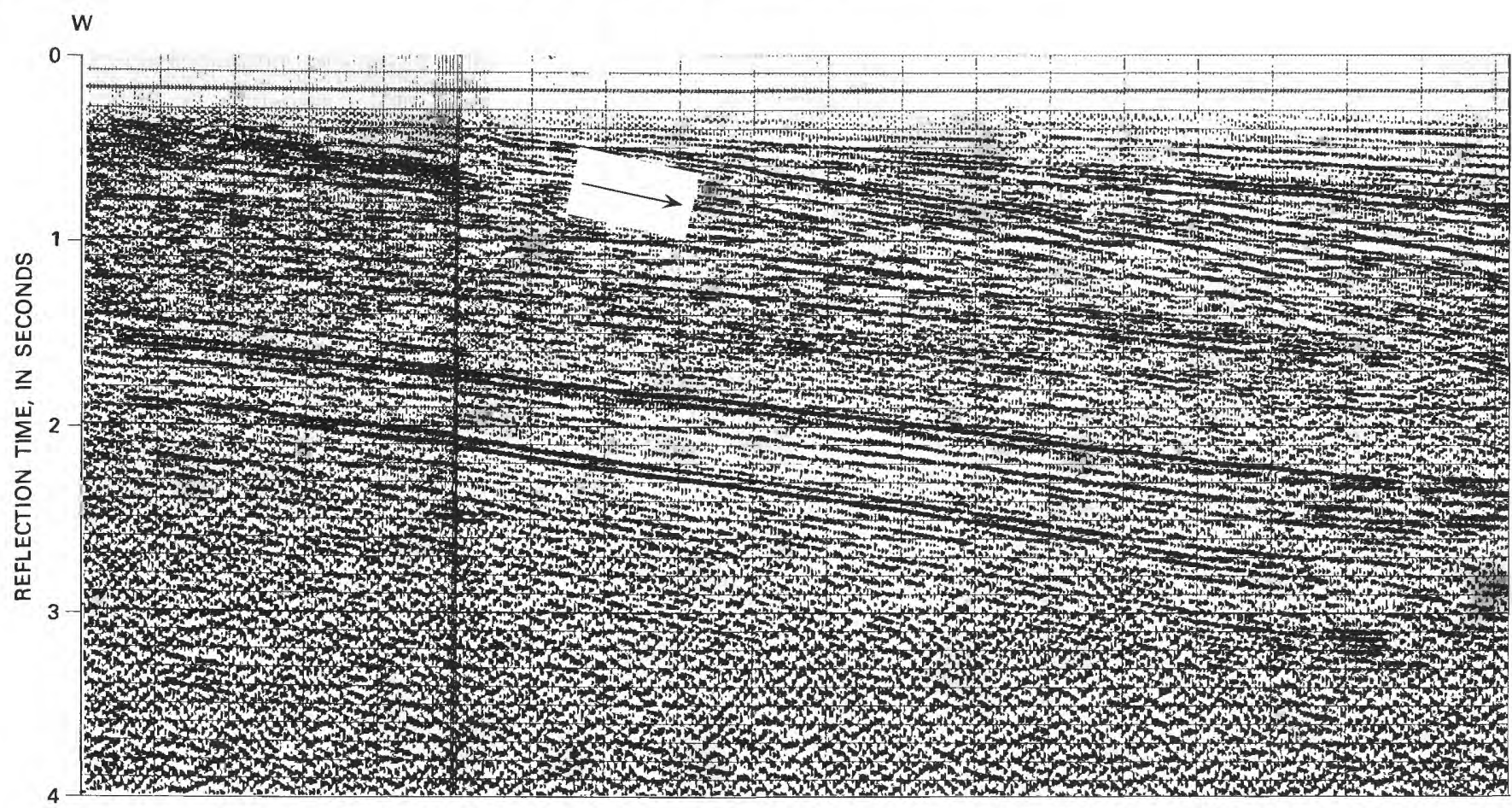

0 5 10 KILOMETERS

Figure 50.-Seismic-reflection profile across the southwest corner of the Sarawak Basin, south of Natuna Island near $3^{\circ} \mathrm{N}$. A great unconformity (between arrows) appears nearly straight, hence actually steepens markedly downward. The pre-Oligocene strata beneath the unconformity dip more gently than does the unconformity. Basal strata above the unconformity are almost parallel to it, but higher beds lap upward to the left. Inferred history: the pre-unconformity strata were tilted downward to the west, beveled by erosion, and covered by subhorizontal early post-unconformity beds; subsequent Oligocene and younger deposition has been synchronous with tilting downward to the east. Profile provided by the Continental Oil Co.

\section{NORTHEASTERN BASINS}

The complex Neogene continental-shelf basin east of the Korat and Con Son Swells consist of linked subbasins of north to northeast trends (pl. 1). The subbasins are in general half-grabens, bounded by normal faults mostly on their east sides.

\section{S.IRAWAK BASIN}

The large continental-shelf Sarawak (or Brunei-Saigon) Basin forms a broad crescent off the northwest coast of Borneo (pl. 1; Pupilli, 1973; H. Doust, unpub. report, 1977). The stratigraphic section consists largely of interbedded sand, silt, and clay, marine and nonmarine facies interfingering complexly. Near the coast, strata as old as late Eocene are only moderately deformed, whereas near the shelf edge sediments as young as upper Miocene or Pliocene lie directly on highly deformed strata.

Within about $100 \mathrm{~km}$ of the Borneo coast, the lower part of the section is mostly shale, dominantly marine in the northeast but of coastal-plain environments in the southwest, of late Eocene to early Miocene age, to at least $5,000 \mathrm{~m}$ thick; the thin overlying section, which thickens gradually offshore, is dominantly deltaic. The shales have risen diapirically to produce complexly faulted anticlines, growing concurrently with Neogene sedimentation, in which reverse faulting is more commonly directed toward than away from the coast. Strike of the anticlines changes from southwest to northwest at about long $112^{\circ} 30^{\prime} \mathrm{E}$., these trends being parallel to the south margins of the basin. (The southwest margin trends approximately northwest from the coast, not nearly west as shown on plate 1 , as far as $111^{\circ} \mathrm{E}$.) Intensity of deformation decreases seaward.

Some of the anticlines contain oil, derived from underlying nonmarine shales. One commercial field (Temana: $3^{\circ} 15^{\prime}$ N., $112^{\circ} 45^{\prime}$ E.), and many minor oil accumulations, have been found in the southwest. Reservoir rocks are discontinuous, regressive Oligocene and lower Miocene sands; over much of the basin, diagenesis has closed the analogous strata. Other oil has been found in the northeast, offshore from Brunei and Sabah, in younger deltaic strata.

The thick middle Tertiary shale comes ashore in the Brunei region as the uppermost Eocene to lower Miocene bathyal shale, interpreted in a previous section to be the product of filling of an outer-arc basin, a setting inferred for the offshore basin also.

Northeast from Brunei, the top of the shale becomes younger toward the shelf edge and is of late Miocene or early Pliocene age on the outer shelf. The overlying varied strata 


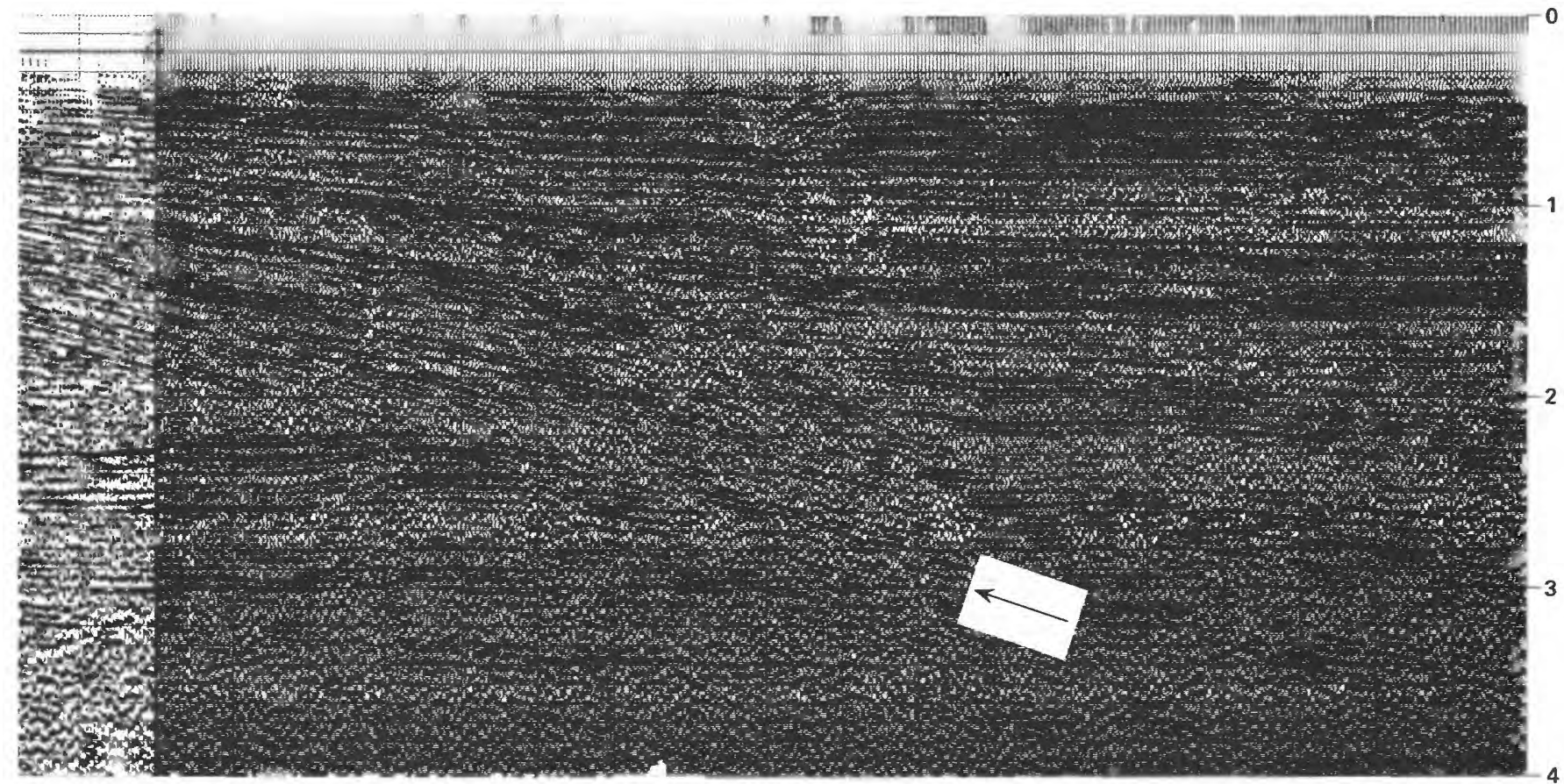

are late Miocene and younger onshore but only Pliocene and Quaternary farther out, where they are typically 2,000-4,000 $m$ thick. On the outer half of the shelf in the northeast, the young shallow-water clastic sediments form great foreset units a kilometer or so thick, prograded seaward over the deeper-water shales.

Off Sarawak, more than $100 \mathrm{~km}$ from the present coast in the sector from $111^{\circ}$ to $113^{\circ} \mathrm{E}$., widespread platform and pinnacle reefs grew from late early Miocene to early Pliocene time and were buried subsequently by deltaic upper Cenozoic strata, thickening and prograded seaward. The carbonates are now limestone and dolomite, to $1,500 \mathrm{~m}$ thick, with moderate to great secondary porosity and contain much commercial gas, the source of which has not been identified.

The diapiric anticlines trend subparallel to the Borneo coast and to the shelf edge about as far east as long $116^{\circ} 00^{\prime} \mathrm{E}$. Between about $116^{\circ} 30^{\prime} \mathrm{E}$. and the coast of northernmost Borneo, however, the diapirs trend approximately west-northwest, almost perpendicular to the coast and the shelf edge. In both cases, these trends follow those of Tertiary basement rocks as projected offshore. The west-northwest trends in the northeast part of the basin follow the projected trend of the Miocene melange of Sabah, and this may indicate that the melange continues on strike well out onto the shelf, at a high angle to the strike of older structures to the southwest. Several of the diapiric anticlines of the offshore region in the sector trending west-northwest have associated high-amplitude, short-wavelength magnetic anomalies that require the presence within the diapirs of crystalline rocks high above the basement. The polymict melange of the acoustic basement may rise in the diapirs with the overlying shales.

A subbasin trends northwestward at the southwest corner of the Sarawak Basin, east and southeast of Natuna Island, and is separated from the main basin by the basement high. A remarkable unconformity is recorded on reflection profiles in this subbasin (fig. 50). The strata above the unconformity are Oligocene and younger clastic sediments, deposited in an open-marine environment. The beds beneath the unconformity have not been drilled but are presumed to be older Paleogene continental clastic sediments like those of Natuna and Borneo. Geothermal gradients are high, about $4.5^{\circ}-6.5^{\circ} \mathrm{C} / 100 \mathrm{~m}$ (Kenyon and Beddoes, 1977).

\section{SHEL ED)}

Upper Neogene sediments are prograded outward, with dips increasing downward, to the edge of the continental shelf on the South China Sea (figs. $48 B, C$ ). (Parke, Emery, Szymankiewicz, and Reynolds, 1971, inferred that a basement anticline lies along the shelf edge; this hypothetical feature does not appear on the Lamont-Doherty profiles of figure 48 except for the buried outer-arc ridge that flanks the Northwest Borneo Trench.) Whether or not the outer part of the shelf is built over oceanic crust is unknown. The sediments thin rapidly seaward beyond the shelf edge, and the basement rises to near the sea floor not far beyond the foot of the continental slope.

\section{SOUTH CHINA BASIN}

The deep part of the South China Sea, the South China Basin, lies north of the eastern part of the broad continental shelf between Indochina and Borneo, and northwest of the 

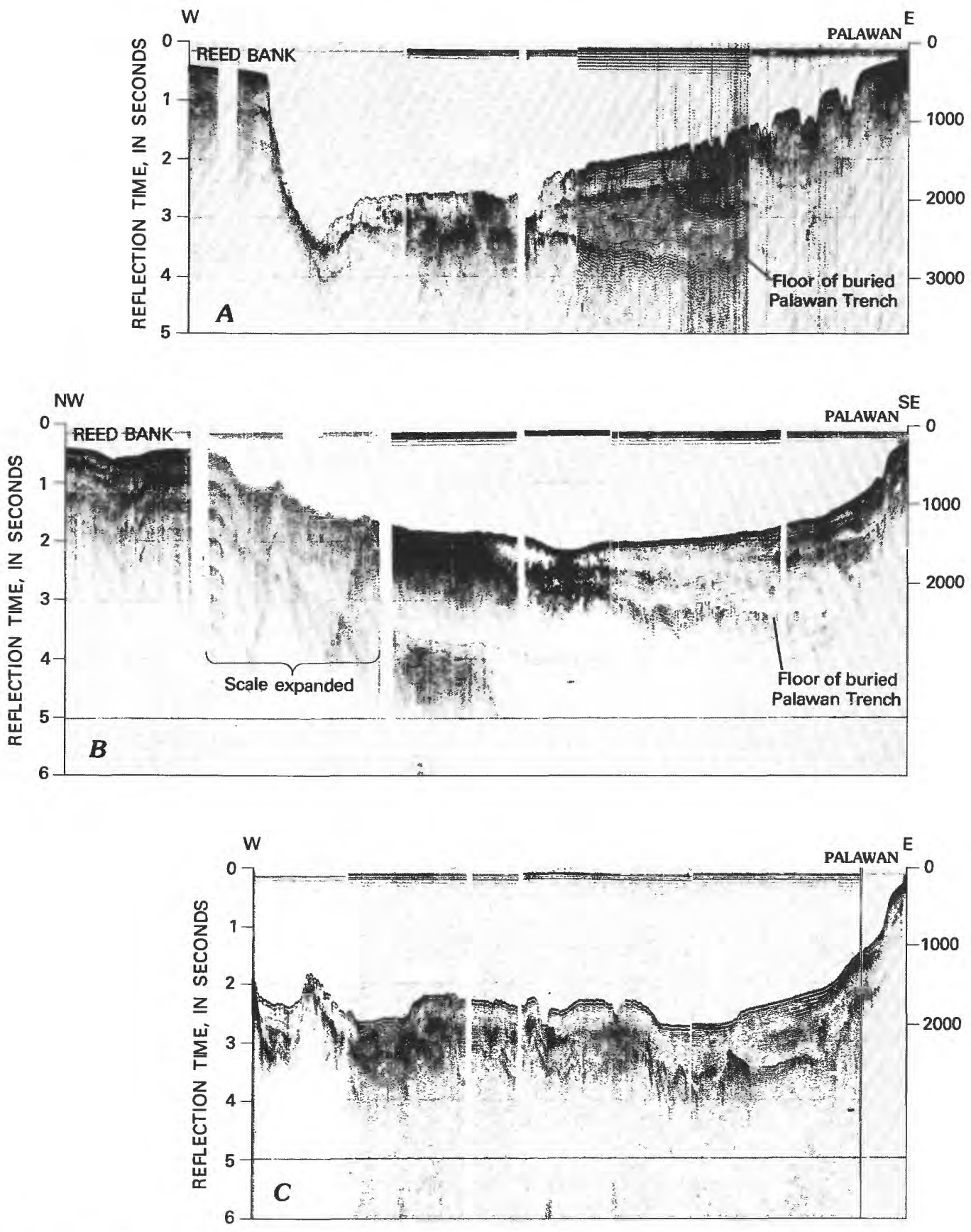

FIGURE 51.-Seismic-reflection profiles across the Northwest Borneo and Palawan Trenches. $A$ and $B$ show the inactive, partly buried Palawan Trench, with southeast-sloping floor, to be present beneath the northwest-sloping sediments of the continental slope. (See also fig. 105.) The trench is not visible on profiles $C$ and $D$. The Northwest Borneo Trench $(E$ and $F)$ is still a conspicuous bathymetric feature and contains only thin ponded turbidites. The older turbidites show the characteristic downward fanning of trench structures. The rough basement hills of the South China Sea $(E$ and $F)$ are covered by about $500 \mathrm{~m}$ of acoustically transparent pelagic sediment, which follows the conveyor-belt basement beneath the layered clastic fill of the trench. $F$ shows a ridge, presumably of melange, behind which thick clastic sediments are dammed. Location of profiles shown on figure 47. Profiles from Lamont-Doherty Geological Observatory, R. V. Robert Conrad cruises 12 (profiles $E$ and $F$ ) and 14 (profiles $A-D$ ).

Palawan Trench. The basin has north-trending east and west sides (the deep-water margins of Luzon and southern Taiwan in the east, and the edge of the continental shelf near $110^{\circ} \mathrm{E}$. in the west) and northeast-trending north and south sides (the continental margins of southern China, and of
Palawan and northern Borneo, respectively). Only a relatively small, medial portion of the basin, mostly north of the area of plate 1 , is as deep as $4,000 \mathrm{~m}$. This deep portion is largely floored by an abyssal plain, whose sediments are as thick as $\mathbf{3} \mathrm{km}$ east of southern Vietnam but are thin near 

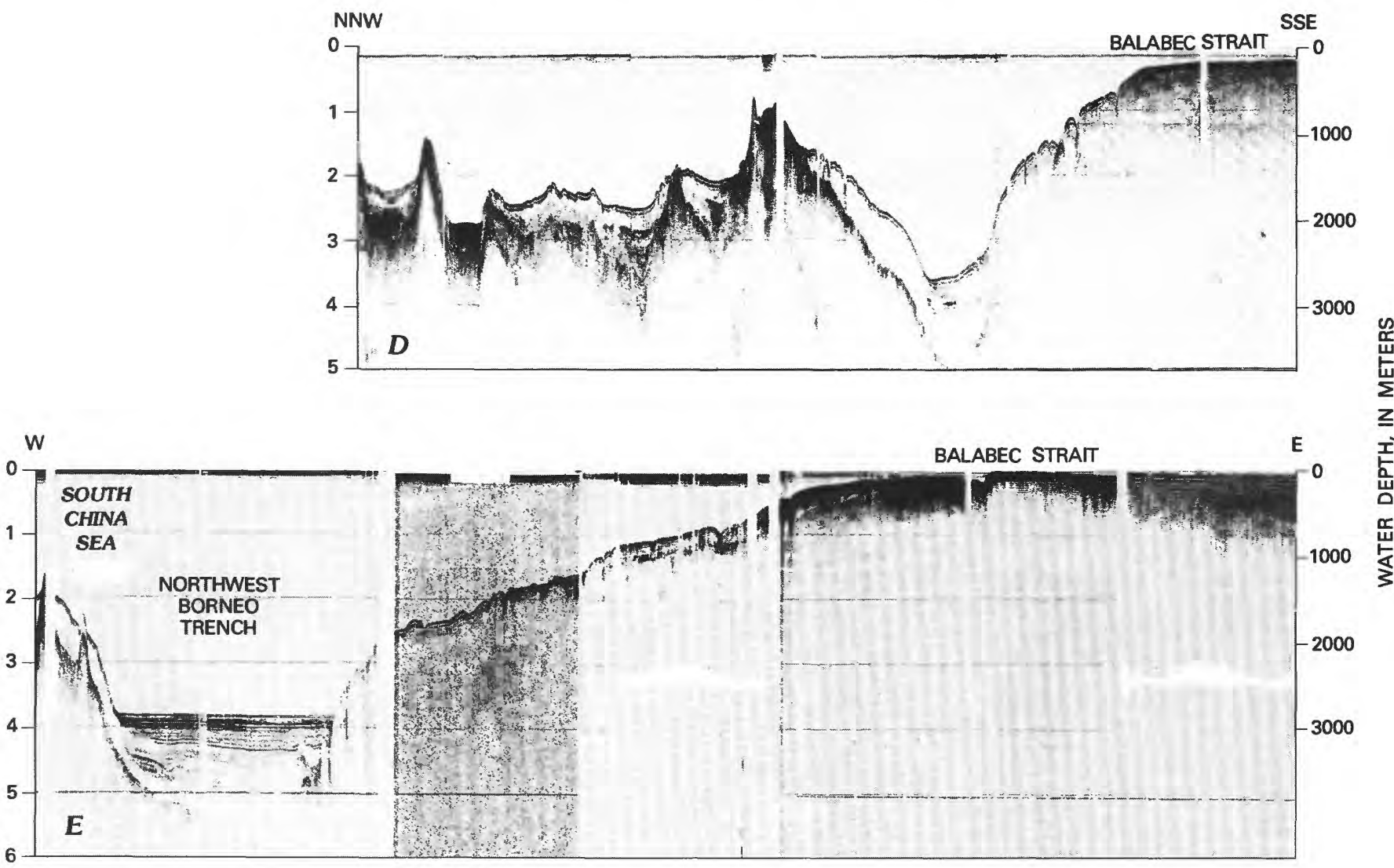

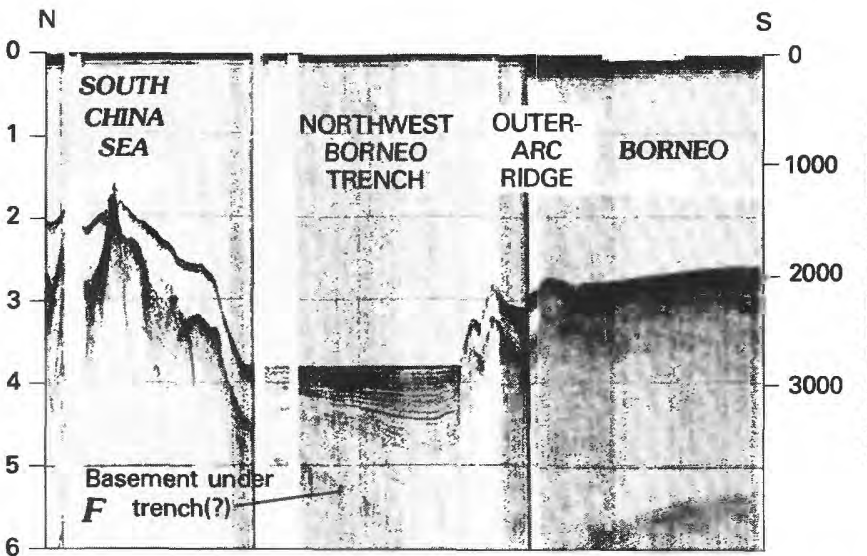

Palawan. The Palawan continental slope is covered by some hundreds of meters of little-deformed sediments (figs. $51 \mathrm{~A}$, $B)$, which are seen on profiles just north of the map area to be continuous with the abyssal-plain section. Within the area of the tectonic map, most of the sea floor north of the shelf and the trench displays highly irregular topography-ridges, plateaus, and seamounts, capped by broad coral shoals and reefs (which make this the Dangerous Ground of mariners), separated by depressions mostly less than $2,000 \mathrm{~m}$ deep (figs. $48 E, 51)$. This region is interpreted in the next paragraph to be a foundered continental fragment. The largest bank in this terrain within the map area is shallower than $200 \mathrm{~m}$ over an extent of $60 \times 150 \mathrm{~km}$ and lies west of northern Palawan. The deeper area of irregular topography is characterized by an irregular basement surface from which rise many seamounts. A mantle of acoustically transparent-hence presumably pelagic - sediment is draped over most of the basement (fig. $48 C, E$; figs. $51 D, E, F$ ). Strongly layered turbidites are now being deposited over some of these pelagic sediments and are filling in the hollows between them (fig. 48C, fig. $51 E$ ). (Emery and Ben-Avraham, 1972, and Parke, Emery, Szymankiewicz, and Reynolds, 1971, interpreted similar records elsewhere in the South China Basin to indicate that the irregular configuration of basement and 
pelagic cover was due to widespread deformation before the covering and ponded turbidites were deposited, but this seems unlikely.)

\section{FOINDERED CONIINENT}

The irregular shoals, submarine plateaus, and small intermediate-depth basins of the southeastern part of the South China Sea are interpreted on the tectonic map to represent a foundered mass of continental crust. (Richard W. Murphy, written commun., 1975, has expressed similar conclusions.) This terrain is mostly shallower than $2,000 \mathrm{~m}$ over an area about $400 \mathrm{~km}$ wide and $900 \mathrm{~km}$ long, trending northeastward to the northwest of the Northwest Borneo and Palawan Trenches. The high parts of the terrain are capped by thick reef limestone. The bathymetric features are appropriate to a continental borderland fragmented and thinned by tension. Although 1 know of no seismic-refraction data bearing on the crustal structure of this terrain, the rather featureless magnetic-anomaly profiles across it (Ben-Avraham and Uyeda, 1973, figs. 2 and 4) provide evidence for continental, rather than oceanic or volcanic, structure. The small continental mass exposed on northern Palawan and adjacent islands presumably is another fragment of the same terrain; this Palawan terrain has an exposed basement of highly deformed Permian and other sedimentary and volcanic rocks, intruded by Cretaceous granitic rocks, as described subsequently in this report. The lower Tertiary strata of Palawan contain abundant arkose derived from a granitic source. Perhaps the foundered continent of the South China Sea, rather than mainland Southeast Asia, Borneo, and the shelf region between them, provided the source region for some of this sandstone.

\section{NORTHWEST BORNEO AND PALAWAN TRENCHES}

Inactive subduction-zone trenches lie along the base of the continental slope west of northern Borneo and Palawan (figs. 51E, 105). The Northwest Borneo Trench is still a conspicuous bathymetric feature and indeed would likely be interpreted as active from its reflection profiles were the onshore region not now almost aseismic (Hamilton, 1974b; Tarr, 1974) and devoid of active volcanoes. Acoustically transparent pelagic sediments veneer the oceanic basement that planes beneath the downward-fanning turbidite fill of the trench.

The Northwest Borneo Trench may mark the final phase of activity of the Cenozoic subduction system of northwestern Borneo. The Eocene melange terrain and Oligocene and Miocene outer-arc basin belong to this system, and so perhaps do the Neogene calc-alkalic igneous rocks of western and southern Sarawak and northwestern Kalimantan. The northwestward growth of Borneo by subduction accretion of oceanic materials began in early Eocene time and added about $200 \mathrm{~km}$ to the width of the continent in the north and $500 \mathrm{~km}$ in the south before the system stopped in late Cenozoic time.
An inactive trench, largely buried by postsubduction strata, lies along the northwest base of the Palawan continental slope (fig. 51). The internal structure of the trench and the melange wedge behind it are made clear by the deep-penetration reflection profile of figure 105. Undeformed Pliocene and Quaternary strata are prograded across the wedge and trench. Basal to upper Miocene strata were deposited atop the melange wedge (the melange character of which has been confirmed by drilling); the older of these Miocene rocks are much deformed and cannot be separated from the melange everywhere on the profile, whereas the younger lap westward onto more extensive areas of the melange wedge. Subduction apparently continued well into Miocene time, and sediments deposited on top of the melange concurrently with subduction were deformed by motion within the wedge, while severe deformation was going on near the toe of the wedge. This is discussed further in the section on Palawan.

\section{TECTONIC CORRELATIONS ACROSS THE SOUTH CHINA SEA}

The geology of the lands bordering the continental shelf of the South China Sea is known only from reconnaissance, and only small islands provide data regarding the bedrock geology of the shelf area. Structural trends appear to form a broad arc from Malaya to southwestern Borneo, curving from southward in northeastern Malaya through southeastward in southeastern Malaya, southeastward to eastward in the Tin Islands, and thence eastward in southwestern Borneo. Tectonic continuity around this apparent arc has accordingly long been assumed, for example by van Bemmelen (1949, fig. 378), Pimm (1967), and Westerveld (1949), although in this section it is concluded that no continuity exists between the Tin Islands and Borneo.

\section{CRISTAL SIRUCIIURF}

Continental crustal complexes project into the shelf from the adjoining landmasses. Presumably continental crust underlies most of the shelf area, except for whatever part of the shelf has been prograded over melange and oceanic crust between northwestern Borneo and Indochina. The presence within the shelf of basins filled deeply by sediments, of which at least the upper several kilometers formed in shallow-marine and brackish-water environments, requires long-continuing subsidence of the top of the crystalline crust. This in turn must have been compensated either by a steady decrease in thickness of that crystalline crust or by a steady increase in density of the crust or upper mantle or both. (Seismic-refraction data would cast light on the problem.) If the crust did decrease in thickness, then tensional extension may have occurred; this would necessarily have altered the relative positions of terrains exposed in surrounding landmasses. The apparent offset of Paleozoic terrains across the Gulf of Thailand, from western 
Indochina to the Malay Peninsula, may be due to such extension.

ITPPER MESOZOIC; BELT, BORNEO-NATUNA-SOUTHERN VIETNAM

The Paleogene basin of interior Borneo curves from southward through southwestward to west-northwestward in its course from central Sabah through interior Kaliman$\tan$ to the northern part of western Borneo. The basin sediments apparently are present also in the Natuna Islands, so the curvature is continued at least that far, and the regional trend in the Natuna region should be approximately north-northwestward. Natuna Island likely contains subduction melange that is older than quartz monzonite of Late Cretaceous(?) age, and this melange may correlate with that of Jurassic or Early Cretaceous age at the western tip of Sarawak. This upper Mesozoic melange-and-granite terrain could be a product of the same subduction system as that recorded by the northeast-trending magmatic belt of coastal southern Vietnam. The north part of western Borneo, the Natuna Islands, and southeastern Vietnam may belong to a continuous upper Mesozoic terrain, which converges northward, around its curving trend, with the edge of the continental shelf. At lat $12^{\circ} \mathrm{N}$.- - the north margin of the tectonic map - the continental shelf is only about $50 \mathrm{~km}$ wide, and there is no room for any sizable structural belt, except perhaps for upper Mesozoic melange, on the shelf.

\section{PALEO(;ENE OF NORTHWEST BORNEO}

The broad Eocene crescentic belt of melange and imbricated strata, and the concentric smaller crescent of mid-Tertiary outer-arc basin fill along its northwest side, have no counterparts on the Asian mainland. Projection of their trends, considered with those defined by the NatunaVietnam terrains, is interpreted to indicate that the inland limit of the Eocene subduction complex continues to curve clockwise to the north of western Sarawak and that this limit reaches the edge of the continental shelf obliquely in the region of lat $9^{\circ} \mathrm{N}$., long $109^{\circ} \mathrm{E}$. As noted previously, this is also the northwestern limit of the sedimentary basin represented by the middle Tertiary and younger sediments of northwest Borneo.

\section{ROIATION OF BORNEO}

The broad arc defined by the terrains of Southeast Asia and Borneo may be an orocline, produced by the counterclockwise rotation of Borneo as it advanced over the lithosphere of the then-larger South China Sea. The broadly curving Eocene subduction system ended midway between Borneo and Indochina and records the subduction of oceanic lithosphere beneath northwestern Borneo. The Borneo end of the Southeast Asian subcontinent may have advanced over the South China Sea, whereas the Indochinese end did not. If the Cretaceous trends were initially straight, then southwest Borneo has rotated about $45^{\circ}$ counterclockwise relative to southernmost Malaya and $135^{\circ}$ relative to Indochina; northern Borneo has rotated almost $90^{\circ}$ more.

As noted in a previous section, the dominant paleomagnetic declination of probable Upper Cretaceous crystalline rocks in southwest Borneo is northwest-southeast, suggesting a net rotation of about $45^{\circ}$ counterclockwise within the last 80 million years. (See Haile and others, 1977.) The same paleomagnetic orientation characterizes a small suite of vaguely dated, post-Triassic basalts from southernmost Malaya (McElhinny, Haile, and Crawford, 1974). Haile, McElhinny, and McDougall (1977) assumed that Borneo and Malayan suites are of the same age and have not moved relative to one another. If they are correct, then Borneo and Malaya may have pivoted together, propeller fashion, subducting Bay of Bengal crust west of Malaya but South China Sea crust north of Borneo.

\section{I.ACK OF (ORRELATION BETWEEN MALAYA AND BORNEO}

Near physical continuity, as well as much similarity in rock types and ages, occurs along the trend of the Paleozoic and Triassic terrain of eastern Malaya and the Tin Islands. This terrain projects eastward from the Tin Islands toward the south edge of the crystalline terrain of southwestern Kalimantan or toward the basement buried beneath the fill of the western part of the Barito Basin. Placer tin deposits are abundant in the terrain in Malaya and the Tin Islands and yet are unknown in Borneo, and dated granites of southwestern Borneo are younger than most of those of Malaya and the Tin Islands; so if the Malayan terrain does reach Borneo, it likely does so only beneath the Barito cover. The exposed crystalline complexes of western Borneo might be continuous with others in Indochina and Thailand but are unlikely to be continuous with those of Malaya.

\section{FORMATION OF THE SOUTH CHINA BASIN}

The 4,000-m depth of the deepest part of the South China Basin is taken to indicate the crustal structure there to be oceanic. This depth and the relative thinness of the abyssal-plain sediments suggest that this oceanic crust is no older than Late Cretaceous and perhaps is entirely Tertiary. An origin of the basin by spreading behind a migrating arc, or by sea-floor spreading behind the migrating continental plates now within the basin, is inferred.

Ben-Avraham and Uyeda (1973) suggested that Borneo slid southward away from southern China and Hainan in middle Mesozoic time, opening the parallelogram of the deep South China Basin in the process. This speculation is difficult to reconcile with the known geology of Borneo but cannot yet be dismissed. The conjecture would account for the lack of tin granites in Borneo if the hypothetical Borneo plate is bounded on the west by a great right-lateral strike-slip fault that trends irregularly southward from the southwest corner of the South China Basin, passing west of the Natuna Islands but east of the Tin Islands. 
The large areas of shoals and irregular topography of shallow to intermediate depth in the basin of the South China Sea suggest the presence of continental fragments. Any such fragments presumably were rifted from the larger continental mass whose migration opened the sea. One small continental mass is exposed in northern Palawan, where it may be in effect a very large clast in a melange, swept up during early Tertiary subduction of the South China Sea beneath Palawan.

D. E. Karig (written commun., 1972) suggested that the deep basin of the South China Sea opened behind an eastward-migrating Philippine island-arc system. It is not obvious how the geology of Borneo could be fitted into such an interpretation.

\section{THE BANDA ARC}

\section{GENERAL}

\section{TOPOGRAPHY}

The presently active subduction system of parallel trench, outer-arc ridge and basin, and magmatic arc trends eastward for almost $2,000 \mathrm{~km}$ from Java and thence curves sharply counterclockwise, in a U-turn whose outside diameter is only $700 \mathrm{~km}$, to a westward trend in the north (pl. 1). This great system is the Banda Arc, and it encloses the deep Banda Sea (fig. 52).

The arc is marked by two concentric ridges, from which rise many islands. The inner ridge is formed of upper Cenozoic calc-alkalic volcanic rocks: large islands of the south limb, from Bali eastward through Sumbawa and Flores to Wetar; the small Damar Islands in the southern part of the eastern curve: and volcanoes, most of which are submarine only, in the northern part of the curve and on the northern limb. The outer ridge is formed mostly of Tertiary subduction melange and imbricated complexes: Savu, Roti, Timor, and Leti on the south; Babar and the Tanimbar, Kai, and Watubela island groups around the great bend; and Seram and Buru on the north. In the sector from long $118^{\circ}$ to $122^{\circ} \mathrm{E}$., the outer ridge is complicated by the presence of Sumba, apparently part of a small detached continental mass.

Between the two ridges is the outer-arc basin. In the western part of the south limb, the basin continues the eastward trend of the same feature south of Java and is about $4,000 \mathrm{~m}$ deep. At about long $118^{\circ} \mathrm{E}$., the basin splits into two less distinct parts, one passing north of Sumba and the other south. The troughs merge east of Sumba in broad, deep Savu Basin, beyond which the outer-arc basin is continuous around the rest of the arc. The basin is shallow and narrow north and east of eastern Timor. From there to Seram, around the main curve of the arc, the outer-arc basin has a crescentic shape in plan, and in the broadest part of the crescent, the Weber Basin in the center of the bend, it has a depth of more than $7,000 \mathrm{~m}$. On the north limb of the arc,

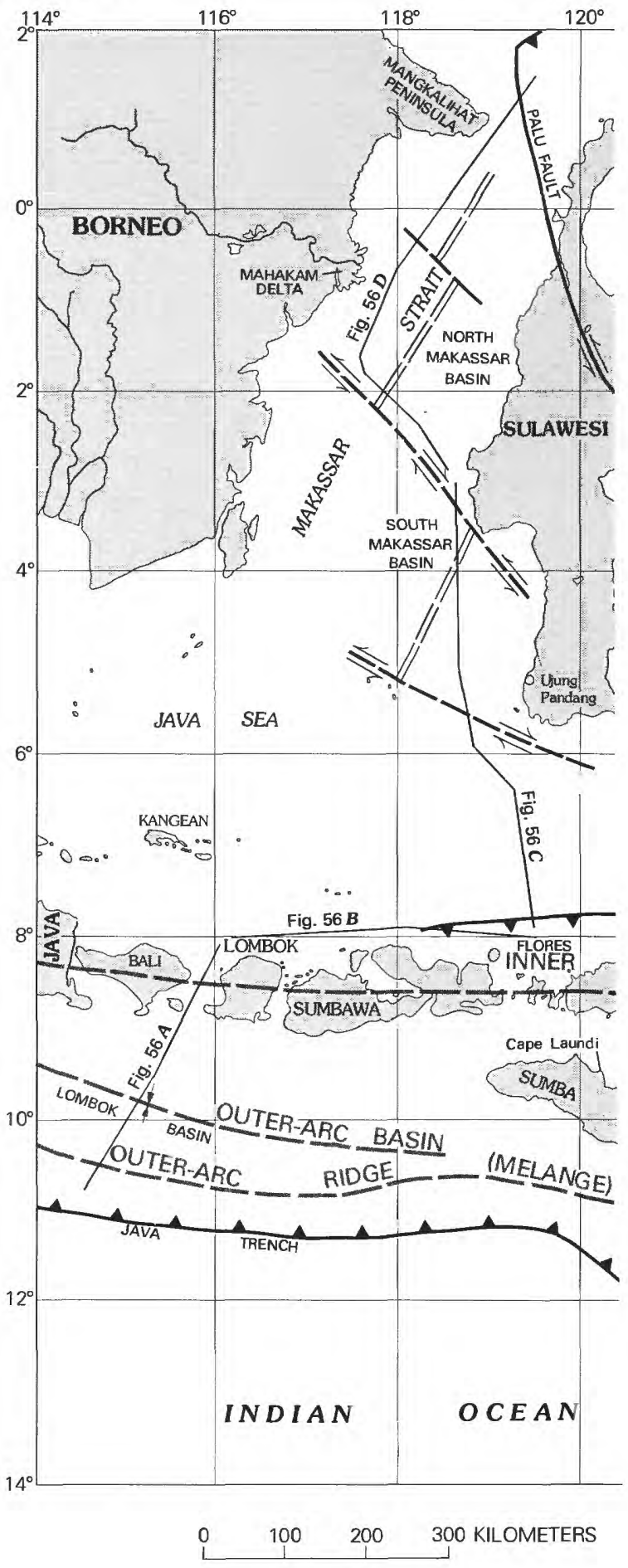

along the south side of Seranı and Buru, the basin is again narrow.

Outside the outer-arc ridge is the modern trench. This is deeper than $6,000 \mathrm{~m}$ south of Bali and Sumbawa, where the arc fronts on the thinly sedimented Indian Ocean along the west part of the southern limb, and deeper than $5,000 \mathrm{~m}$ at 
THE BANDA ARC

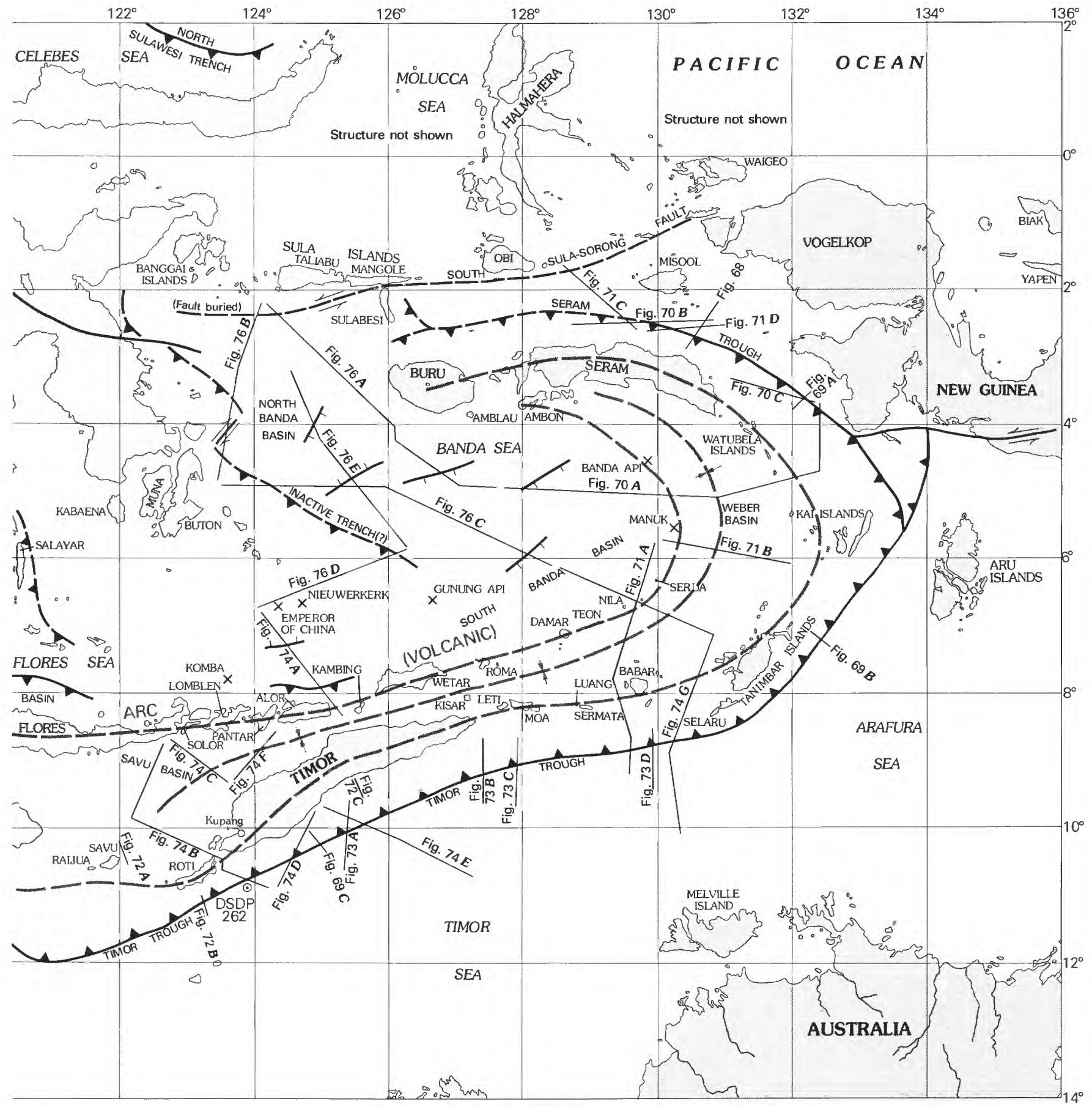

EXPLANATION

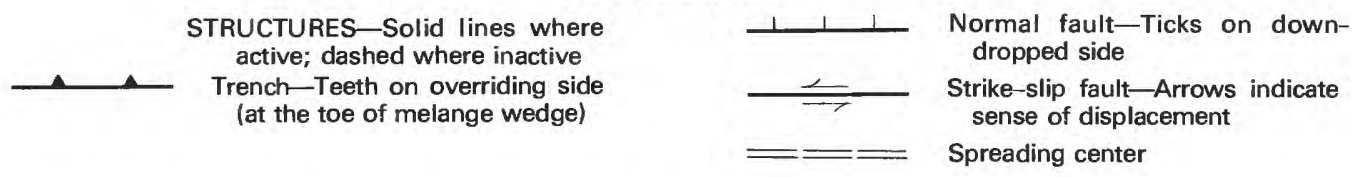

Figure 52 (facing page and above).-Tectonic elements in the Makassar Strait-Banda Sea-Timor Sea region and location of seismic-reflection profiles shown in figures $56,68,69,70,71,72,73,74$, and 76 . Trenches marked by teeth on overriding sides (at the toes of melange wedges); normal faults, by ticks on downdropped sides; strike-slip faults, by arrows indicating sense of displacement; spreading centers, by double lines. All structures solid where active and dashed where inactive. 
the west end of the northern limb near Buru. The trench is only about 1,500-3,000 $\mathrm{m}$ deep, however, around the great bend, and in the eastern part of the south limb, where thick sediments lie beneath the trench and beyond the trench is the continental shelf of Australia and New Guinea.

\section{CRISTAL RELA IIONSHIPS}

The Banda Arc is remarkable in that, although the crust on the inside is almost entirely oceanic, the crust on the outside is continental around all the tightly curving eastern part of the arc. We see here in progress a collision of an island arc with a continental margin. The tight arc of the collision zone poses major tectonic problems.

The crust of the Banda Sea, inside the inner volcanic arc, is oceanic (Curray and others, 1977; Purdy and Detrick, 1978; Purdy and others, 1977; Raitt, 1967, and as cited by Chamalaun and others, 1976). The small Flores Sea, north of Flores and eastern Sumbawa, is similarly deep and also oceanic (Curray and others, 1977). At the west end of the south limb of the Banda Arc, however, the bathymetric Bali Basin, along the north side of volcanic Bali, Lombok, and western Sumbawa, is relatively narrow and only 1,000-2,000 $\mathrm{m}$ deep. Sediments in foreland-basin position and $2,000-5$,$000 \mathrm{~m}$ thick underlie this relatively shallow basin (pl. 1). Isostatic considerations suggest that the crust beneath the Bali Basin is of a type transitional in thickness or density between oceanic and continental materials, and this accords with the suggestion made previously that the crust in this region was formed largely of subduction melange in the Late Cretaceous and very early Tertiary Java-Java Sea-east Borneo system. Crust beneath the outer-arc basin is oceanic (Purdy and others, 1977).

The crystalline crust beneath and south of the trench along the south limb of the arc west of long $122^{\circ} \mathrm{E}$. is the oceanic basement of the Indian Ocean. The submerged transitional margin of the Australian continent trends northeastward obliquely into the trench, between about long $122^{\circ}$ and $124^{\circ}$ E., and various criteria (including seismic structure and magnetic anomalies: Bowin and others, 1977; Shor and Jacobson, 1977) indicate that from there around the arc to Seram the crust beneath the trench and most of the outer-arc ridge is continental. This evidence is presented subsequently.

The present distribution of pre-Tertiary continental crust in eastern Indonesia and surrounding regions is indicated on figure 53. Continental crust is here defined as crust that reached continental thickness as a result of either tectonic accretion in subduction systems (which applies in general to the Cretaceous and Paleogene terrains) or by silicic magmatism (the Precambrian and Paleozoic terrains) in the time noted. Volcanic island arcs on oceanic crust are excluded; were these included, then part of northern mainland New Guinea would be designated as Cretaceous and Paleogene island-arc crust. The tectonic features indicated are some of those responsible for the present distribution of the continental terrains and are discussed at length in subsequent sections of this report.

\section{SEISMICITY}

The Banda Arc is characterized by a spoon-shaped Benioff zone that dips inward from the south, east, and probably north to depths that exceed $600 \mathrm{~km}$ beneath the western Banda Sea (pl. 1; Hamilton, 1974b). The active volcanoes of the inner volcanic arc stand typically about 125 $\mathrm{km}$ above the seismic zone. The zone dips as steeply as $75^{\circ}$ in the depth range of $200-600 \mathrm{~km}$ north of Flores on the south limb, but the dip decreases eastward, and the westward plunge of the axis of the spoon, approximately along lat $5^{\circ} 30^{\prime} \mathrm{S}$, is only about $40^{\circ}$ in the depth range of $100-600 \mathrm{~km}$. The north side of the spoon is poorly defined north of about $4^{\circ} 45^{\prime}$ or $5^{\circ} 00^{\prime} \mathrm{S}$. because of the near absence there of earthquakes deeper than $100 \mathrm{~km}$, and this side of the spoon may now be inactive. On the south limb and around the east end of the Banda Arc, the $100-\mathrm{km}$ contour is $150-300 \mathrm{~km}$ arcward of the trench: the dip of the subducting plate is very gentle near the trench but increases gradually to moderate beneath the inner volcanic arc and moderate to steep beneath the Banda Sea.

Cardwell and Isacks (1978) made first-motion determinations for many Banda Arc earthquakes at various depths. They found shallow earthquakes to show complex patterns of strike-slip, normal, and thrust motions; earthquakes near $100 \mathrm{~km}$ to be mostly thrust events; and earthquakes deeper than $200 \mathrm{~km}$ to represent mostly normal faulting.

Cardwell and Isacks (1978) also refined hypocentral locations in the Banda Arc, and analyzed their data in terms of the conjecture that the arc represents two distinct subduction systems which meet at the base of the $U$ in a triple junction between two trenches and a left-slip transform fault that strikes in from the east, in such a way that continuity of the various components of the arc system is achieved fortuitously at the surface. They then discussed the topology of the southern of the hypothetical two subducting plates, but not of the northern one nor of the interaction between them. Cardwell and Isacks $(1978$, p. 2826, 2834) rejected the interpretation, made here and previously by me, that the subducted sheet may be essentially a single sheet, U-shaped in plan, because this is "difficult to imagine" if the deformation of the subducted lithosphere "is assumed to be done without significant strains ... along a trench with fixed outline." Their assumption, which they make no attempt to justify, if correct would indeed preclude the single-sheet alternative, which requires that trenches migrate and subducting sheets deform. The distinction bears importantly on the mechanism of subduction.

An active left-slip fault system does strike westward, approximately along lat $4^{\circ} \mathrm{S}$., across the continental shelf from western New Guinea to the trench (pl. 1), and there is an irregularity of the trench at this latitude, as discussed in the New Guinea section of this report. Available geologic data do not demonstrate the amount or rate of slip along the fault system, but the similarity of stratigraphic assemblages 


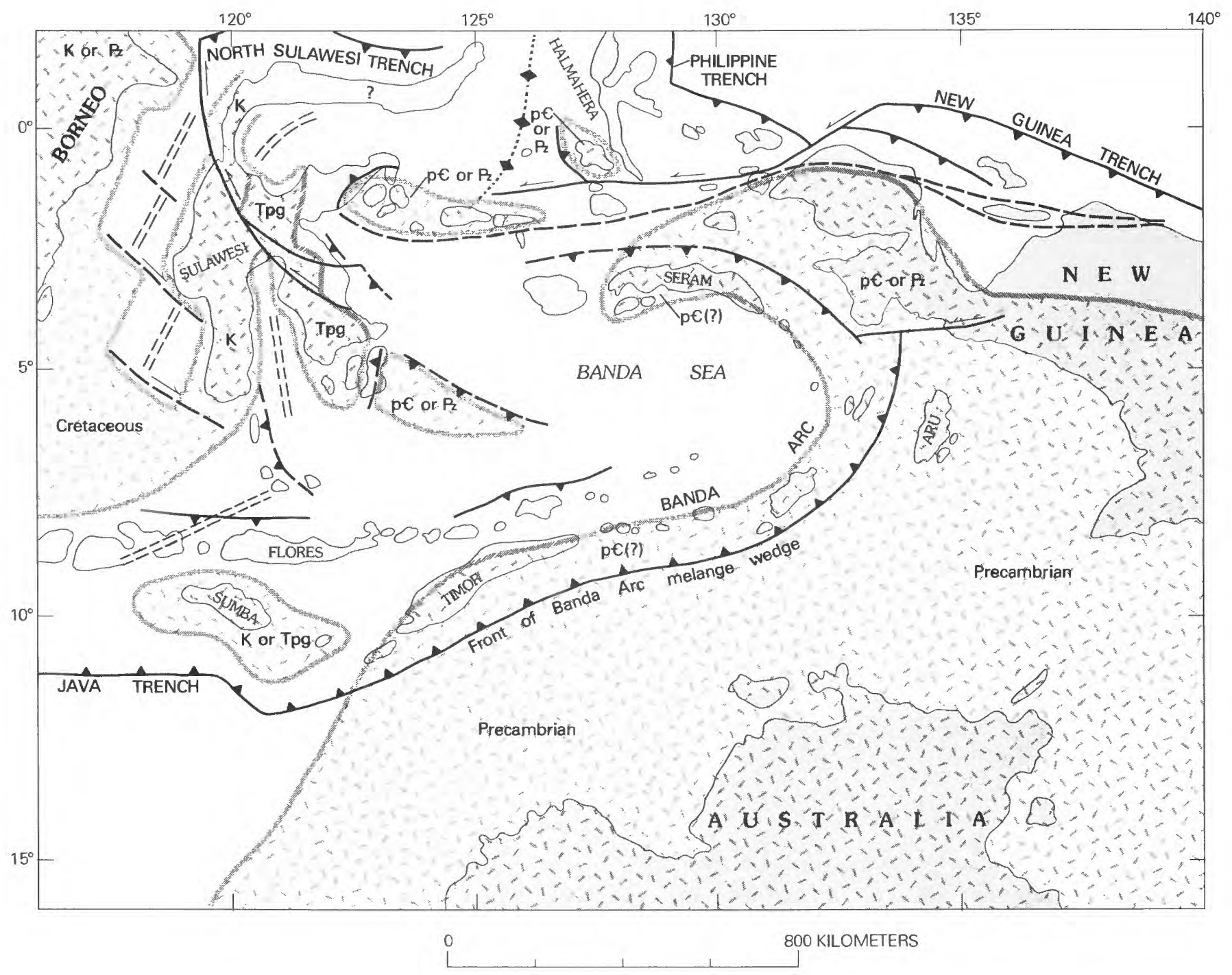

EXPLANATION
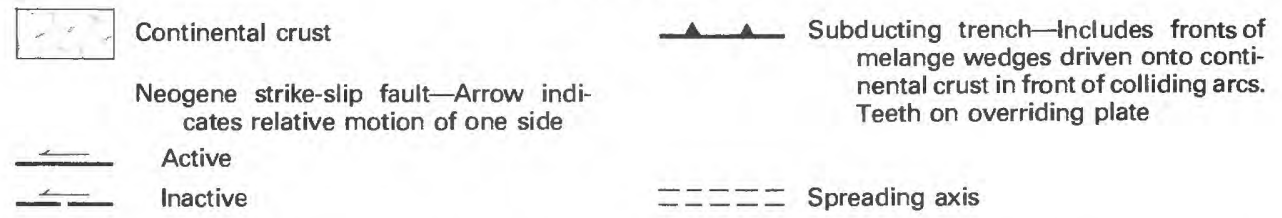

FIGURE 53.- Distribution of pre-Tertiary continental crust in eastern Indonesia and surrounding regions. Time of consolidation of crust of continental thickness by tectonic accretion related to subduction zones, or by silicic magmatism, is specified: p $\boldsymbol{\epsilon}, \mathrm{Precambrian} ; \mathrm{Pz}$, Paleozoic; K, Cretaceous; Tpg, Paleogene. The dotted doubly barbed subduction zone between Halmahera and Sulawesi marks the subcrop of the collision of the Halmahera and Sangihe zones. See figure $77 \mathrm{~A}$ for additional information.

on opposite sides of it likely precludes a slip of much more than the $200 \mathrm{~km}$ by which the edge of the continent appears to be offset. The fault system is an important flaw, but is not a boundary between grossly disjunct lithosphere plates. It is unclear how Cardwell and Isacks visualized even a major transform fault here as permitting the independent motion of descending slabs which they inferred.
The Benioff zone of Banda Arc earthquakes strikes eastward from Java with generally steep dip, and swings northward to define a plunge of $40^{\circ}$ westward along the axis of the U. North of this, earthquakes appreciably deeper than $100 \mathrm{~km}$ are sparse, and ambiguity clouds the drawing of contours. I (Hamilton, 1974b; pl. 1) opted for maximum continuity, maintaining concentricity with the surface struc- 
tures, to define a west-plunging synform. Cardwell and Isacks (1978, figs. 3 and 5) worked from better data, but distorted their contouring to fit their assumption that there could be no continuity past the axis of the U. The data require more continuity than they showed, but less than I did. They miscontoured the deep events in the critical region north of lat $5^{\circ} 30^{\prime} \mathrm{S}$. to avoid swinging any contours to the west of north. The event at $550 \mathrm{~km}$ at about lat $5^{\circ} \mathrm{S}$., $125^{\circ} \mathrm{E}$., is contoured as $600 \mathrm{~km}$. The three events along $125^{\circ} 40^{\prime} \mathrm{E}$. between $4^{\circ} 35^{\prime}$ and $5^{\circ} 10^{\prime} \mathrm{S}$., are in the approximate depth range $400-420 \mathrm{~km}$; yet Cardwell and Isacks showed the top of the envelope containing them as at about $470 \mathrm{~km}$. Trends west of north are indicated also by the horizontality of the deepest earthquake zones as projected into north-northwest sections (Cardwell and Isacks, 1978, fig. 4C and D). North of the axis of the Banda Arc, the belt of young volcanoes curves to a northwest trend between long $130^{\circ}$ and $128^{\circ} \mathrm{E}$., and two $100-\mathrm{km}$ earthquakes occur appropriately in this belt and define the same trend (Cardwell and Isacks, 1978, figs. 2 and $4 G$ ). The volcanic ridge and $100-\mathrm{km}$ seismic contour both appear to be continuous with those around the axis of the $\mathrm{U}$ and hence with those of the south limb of the arc; yet Cardwell and Isacks drew instead an east-trending 100-km contour beneath the north limb, sharply across the volcanic arc, and permitted no connection with the axis and south limb. Seismic sections across the arc, coming into the axis on one radius and going out on the symmetrical radius, would have been more informative in demonstrating continuity or discontinuity than are the sections presented by Cardwell and Isacks, which do not cross their assumed major plate break.

I thus continue to infer general continuity of subducted lithosphere around the Banda Arc (as also around the similar Caribbean and Scotia Arcs). Such continuity is interpreted elswhere in this report as one type of evidence suggesting that subduction is dominated by gravitational sinking of downgoing lithosphere, rather than by plate-injection mechanism such as Cardwell and Isacks implicitly assumed.

\section{INNER VOLCANIC ARC.}

The islands of the inner volcanic arc consist of upper Cenozoic volcanic rocks, mostly calc-alkalic, intercalated with volcanigenic and carbonate sediments. The western part of the south arm of the arcuate system, from Bali east to central Flores, exposes, like Java, lower or middle Miocene strata as well as younger rocks, whereas from central Flores east the oldest dated rocks are late Miocene (van Bemmelen, 1949, p. 485-506; Sudradjat, 1975). The westernmost islands of Bali, Lombok, and Sumbawa carry the young structural and volcanic belts of Java eastward along strike. The northern parts of these islands contain the many young and active volcanoes, whereas the rocks older than late Miocene occur only near the southern coasts (fig. 54). The submarine ridge narrows between Sumbawa and Flores, and Flores and the small islands - including Solor, Lomblen, and Pantar - to the east of it bear their active volcanoes mostly along the south side of the ridge (fig. 55). In the next sector east, that of the islands of Alor, Wetar, and Roma, north and northeast of central and eastern Timor, there are no active volcanoes, yet an active volcano is now present about $150 \mathrm{~km}$ to the north, rising from the deep Banda Sea. The volcanic rocks of inactive Atauro (or Kambing) Island, between Alor and Wetar, are of Pliocene age, about 3.0-3.3 m.y. (Abbott and Chamalaun, 1976).

The volcanic rocks of these islands are dominantly of mafic and intermediate calc-alkalic compositions-andesite, basalt, and dacite (Abbott and Chamalaun, 1976; van Bemmelen, 1949, p. 485-506; Brouwer, 1942; Ehrat, 1928; Matrais and others, 1972; Neumann van Padang, 1951, p. 159-212; Whitford and others, 1977). Small plutons of similar compositions are present also. The rocks of the young volcanoes display the usual increase in the ratio of potassium to silicon with increasing distance to the Benioff zone beneath (Hatherton and Dickinson, 1969); Hutchison, 1976). Thus, at Lomblen the southern volcanoes are of basalt and pyroxene andesite, the northern volcanoes include potassic trachybasalt and trachyandesite, and the island of Komba (or Batu Tara) still farther north is of leucitic rocks (Brouwer, 1940). Leucitic rocks also occur in northernmost Sumbawa (Brouwer, 1943). The volcanic rocks of the main volcanic belt contain radiogenic strontium, ratios of ${ }^{87} \mathrm{Sr} /{ }^{86} \mathrm{Sr}$ being $0.7045-0.7095$, likely indicating a contribution to the magmas by subducted sediments (Margaritz and others, 1978; Whitford and others, 1977).

Small islands, formed by active volcanoes, rise from the tightly curving eastern part of the inner ridge of the Banda Arc. These islands - in order counterclockwise, Damar, Teon, Nila, Serua, Manuk, and Banda Api-all consist mostly of pyroxene andesite (van Bemmelen, 1949, p. 471; Neumann van Padang, 1951, p. 217-225). The ridge is otherwise marked by seamounts (figs. $70 A, 71 A$ and $B, 74 G$ ), which appear to be volcanoes.

No presently active volcanoes are known on the north limb of the Banda Arc to the west of Banda Api, which is 100 $\mathrm{km}$ south of central Seram. Available bathymetry suggests that the inner-arc ridge continues westward from Banda Api for $400 \mathrm{~km}$, south of western Seram and Buru, but no islands stand on this ridge. The two seamounts at the left end of the profile of figure $76 \mathrm{~A}$, south of Buru, may be volcanoes. Pliocene or Quaternary volcanic rocks do form several small islands close to the southeast corner of Buru and the southwest corner of Seram, standing on the edge of the ridge that includes the large islands (van Bemmelen, 1949, p. 453; Kuenen, 1949; Verbeek, 1905). Amblau, off southeastern Buru, consists of andesite. Ambon and its neighbors, off southwestern Seram, consist of andesite, basalt, dacite, and rhyolite, and Ambon has an exposed continental-crystalline basement complex about which more is written subsequently. 


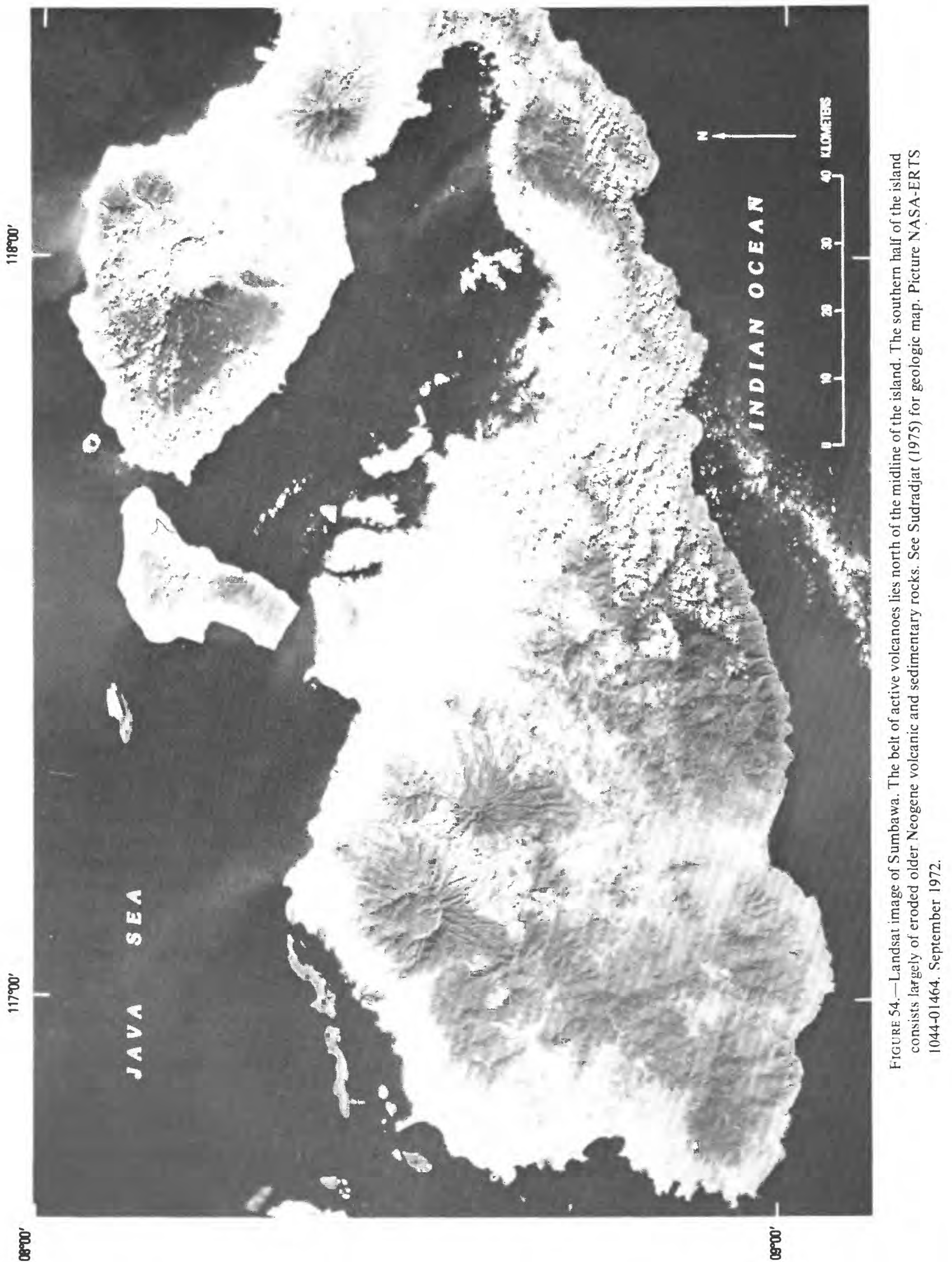




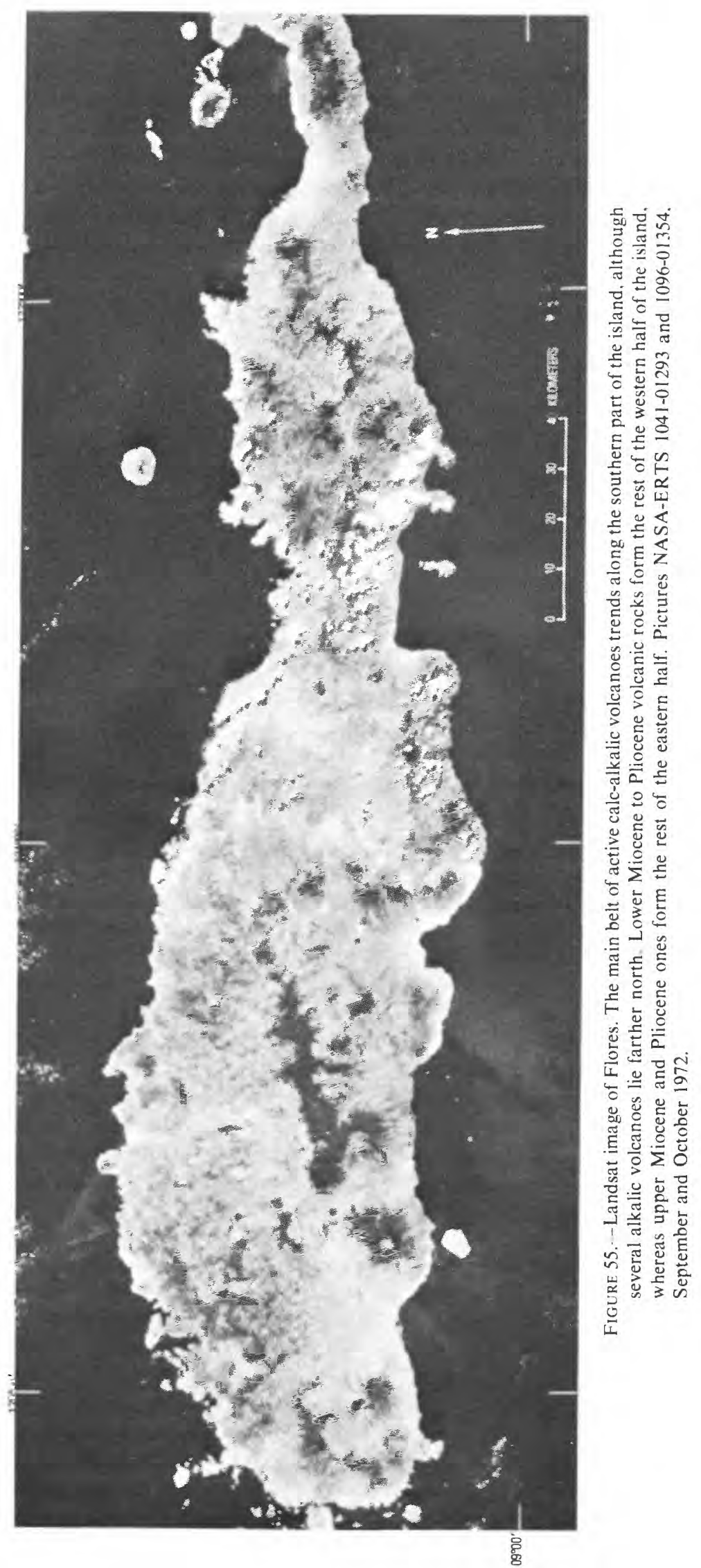


A trench, with geometry indicating southward subduction, is present in the Flores Sea at the north base of the Flores-Sumbawa volcanic ridge (fig. $56 C$; I have seen the trench also in an excellent oil-company reflection profile farther east). This trench is not matched by a south-dipping Benioff zone; on the contrary, the mantle seismic zone in this sector dips north and obviously belongs, like the Flores volcanoes, to the Java Trench system (pl. 1; Hamilton, 1974b). Presumably we see here an incipient arc reversal.

\section{OUTER-ARC RIDGE}

The outer ridge of the Banda Arc forms many islands-large Timor on the southern limb, and Buru and Seram on the northern limb, plus many smaller islands around the curving east end of the arc. All these islands, except for the young coral islets (and not including the continental fragment of Sumba, west of Timor), are interpreted to consist of Tertiary subduction melange and imbricated complexes, formed in large part from the voluminous sediments of the continental margin of New Guinea and Australia. Most of the islands display highly upraised young coral reefs, attesting to rapid uplift that has presumably resulted from the buoying effect of the light sediments stuffed underneath the arc. Magnetic anomalies indicate that continental crust probably extends to the oceanward, inner side of the ridge (Bowin and others, 1977). The islands are described here in order counterclockwise around the arc, from Timor to Buru.

\section{TIMOR}

The large island of Timor is a tectonic chaos (fig. 57). Widely different rocks-deep- and shallow-water sediments of all ages from Permian to Quaternary, metamorphic rocks including high-pressure types, ophiolites, continental crystalline rocks, and others-are jumbled together in melange and imbricated terrain. This chaos is a product of the collision of the Banda Arc with the Australian shelf. One might anticipate from this that a general progression southward across the complex should record the progressive sweeping-up of open-ocean sediments and crust, deep-water Australian-margin strata, and shelf strata, but any such progression across the island is at best exceedingly irregular. Seismic reflection profiles, discussed subsequently, demonstrate that Australian continental-shelf strata are now sliding northward beneath the incoherent, sheared complex that crops out as Timor.

\section{PUBLISHED STUDIES}

Many reconnaissance accounts give field and petrographic information about Timor. Practically all emphasize the chaotic structure of much of the island, although this structure has been explained with varying combinations of tectonic and gravitational thrusting, normal faulting, submarine slumping, and landsliding. (See, for example, Audley-Charles, 1965c, 1968; Audley-Charles and Carter, 1972; Brouwer, 1942; Brunnschweiler, 1978; Crostella and
Powell, 1976; Gageonnet and Lemoine, 1958; Grunau, 1953, 1957; Lemoine, 1959; Marks, 1961; de Roever, 1940a; van West, 1941; de Waard, 1955.) Geologic reports from western 10 Timor present mostly studies of small areas by geologists who did not attempt regional syntheses. It is possible from such reports to obtain a fair picture of local structural relationships, although the reports are confusingly organized around nomenclature systems in which each pseudostratigraphic name is based upon some one criterion among age of material in melange, rock types dominant in melange, degree of shearing, inferred age of deformation, and topographic expression. Thus, the Sonnebait series of Brouwer (1942), de Waard (1955), and others is mostly polymict melange-scaly clay enclosing less sheared relics of sedimentary and crystalline rocks of any age from Permian to Miocene; their Fatu limestone is limestone of any age or type that forms a hill. The general distribution of rock complexes in western Timor is shown by the reconnaissance map by van Es (1926). The three units shown in gray on his map (Perm en Mesozoicum, Flyschfacies van den Trias, and Ofoe-serie) are in general polymict melange, within which he separated out some of the larger masses of limestone and crystalline rocks. In eastern Timor, by contrast, broad reconnaissance has yielded broad speculation. Grunau (1953, 1957), Gageonnet and Lemoine (1958), and M. G. Audley-Charles and his associates A. J. Barber, D. J. Carter, and J. S. Milsom (as discussed subsequently) developed increasingly complex rationales wherein some rock assemblages were regarded as autochthonous up-bulged parts of the little-deformed Australian continental shelf and others as nearly flat allochthonous masses that were thrust or slid over these, across the entire width of Timor, from a now-vanished northern source land. These papers describe concepts and assumptions more than rocks and structures.

\section{MELANGE}

Geologic maps show that the widely varying components of the tectonic chaos are intercalated concordantly in moderately to steeply dipping complexes. In the central region of western Timor, de Roever (1940a) mapped an area in which rocks dip in general moderately northeastward and consist of, in order northeastward: variably coherent Permian and Triassic terrigenous clastic sediments; a melange, several kilometers thick, formed of intersheared slices of schist, ophiolite, pink Cretaceous pelagic limestone and radiolarite, and Permian and Triassic volcanic-island and fringing-reef complexes; and varied intersheared schists and ophiolite fragments. Van West (1941) mapped nearby steeply dipping, northeast-trending melange, consisting of randomly intercalated sheared lenses of undated terrigenous clastic rocks, Cretaceous pelagic sediments, and Triassic, Eocene, and lower Miocene shallow-water limestones, all

10 The term "Western Timor" is here applied to the half of the island which was administered by the Netherlands, and "eastern Timor" to the half that was administered by Portugal, prior to the absorption of both by Indonesia. 

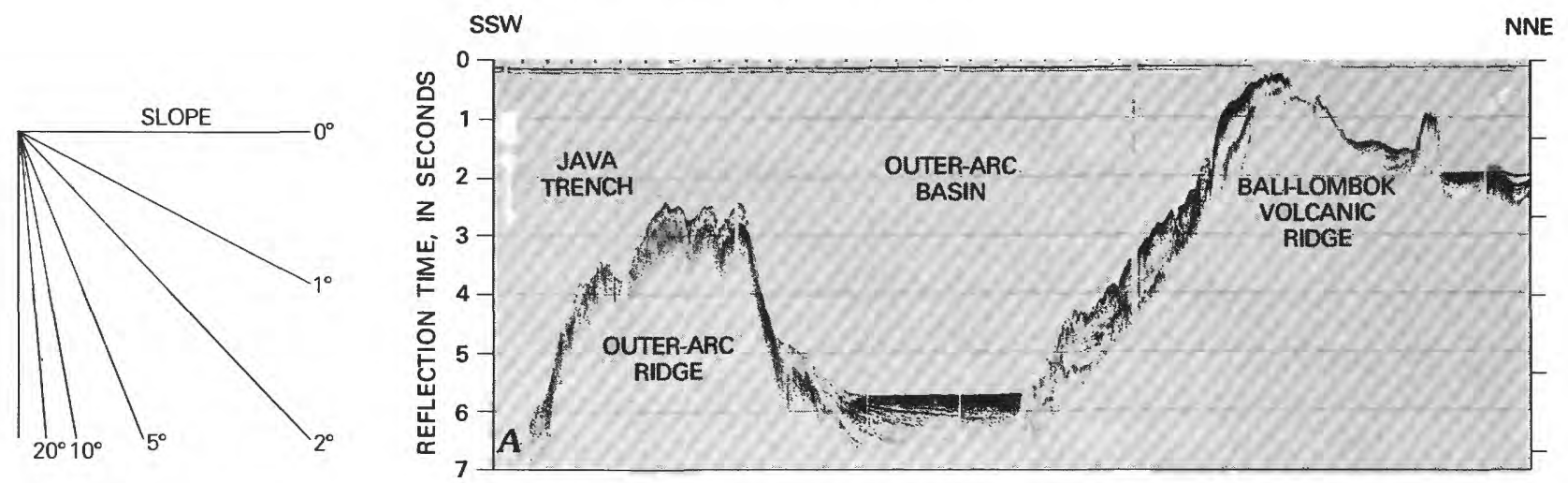

$\mathbf{S}$

N

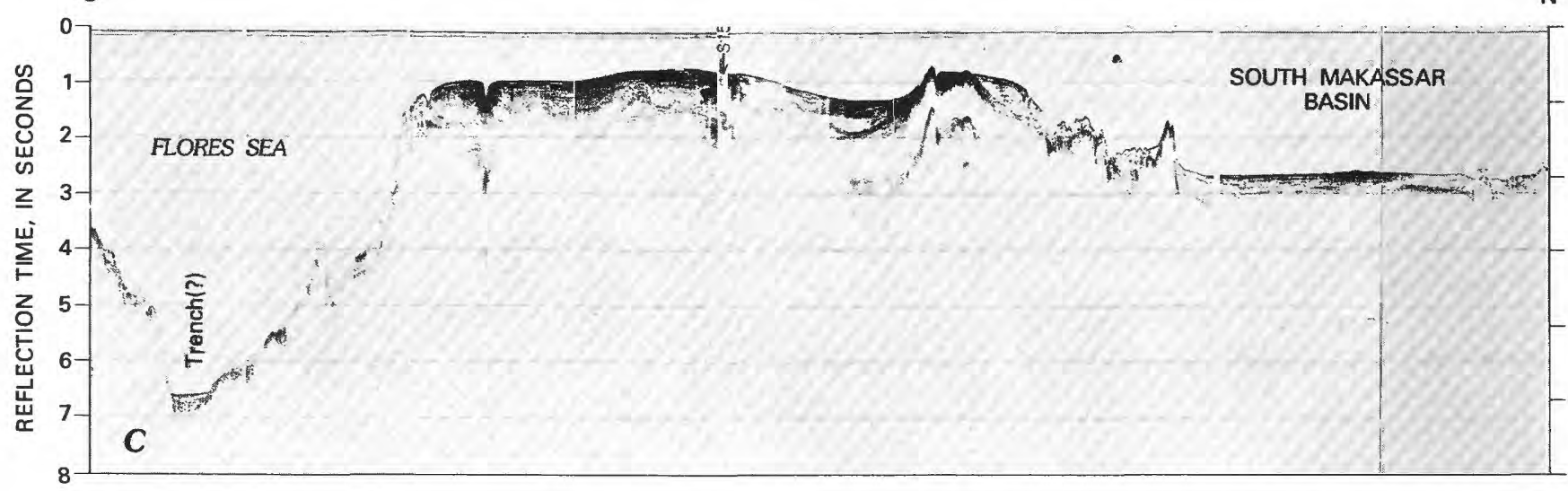

Figure 56. - Seismic-reflection profile across the Banda Arc, Flores Sea, and Makassar Strait. A, The crest and north flank of the outer-arc ridge are mantled by pelagic sediments, whereas the south flank is not; this may record increasing intensity of deformation within the melange wedge southward toward the Java Trench. Strata within the outer-arc basin display basinal downfolding which decreases upward. $A$ and $B$, The volcanic ridge is made irregular by volcanoes, fault blocks, and folds which affect the sedimentary cover. $C$, There is little sediment on the narrow floor (a trench?) of the Flores Sea, in contrast to the thick strata on the platform between that sea and the South Makassar Basin, The north margin of the platform is broken by faults. $D$, The young sediments of Makassar Strait are moderately deformed near the Sulawesi coast (south end of profile). The Mahakam Delta displays both structural and erosional relief. Location of profile shown in figure 52. Profile from Lamont-Doherty Geological Observatory. R. V. Robert Conrad cruise 11.

lying between larger lenses of schist and ophiolite. Tappenbeck (1940) found farther west a southeast-dipping imbricated pile of metamorphic rocks, shallow-water clastic Triassic sediments, ophiolite, abyssal chert, Cretaceous graywacke, Permian and Triassic limestones and diabase, and Eocene shallow-water carbonates. In northeastern western Timor, Simons (1940) mapped a strongly sheared jumble of similarly varied sediments and ophiolite. Gageonnet and Lemoine (1958) described and illustrated similar examples of tectonically intercalated sheets of diverse rocks in eastern Timor. In a south-central Timor belt of rocks, $5 \mathrm{~km}$ wide and dipping gently north, for example, they (1958, p. 68 and fig. 8 ) recognized, in order northward, micaceous sandstone and shale; boudinaged, folded, and scaly-sheared limestone; very sheared shale containing blocks of igneous rocks, nummulitic (Paleogene) limestone; and, thrust over all the rest, with contact exposed, crystalline rocks. A well in eastern Timor was drilled through intersheared and brecciated Upper Triassic to Eocene strata to a depth of $1,355 \mathrm{~m}$ before being abandoned (Brunnschweiler, 1978).

The dominant "background" material of Timor is sheared, soft scaly clay. This is the Bobonaro Scaly Clay of Audley-Charles (1965c, 1968), most of the Sonnebait series of Brouwer (1942) and others, and much of the flysch of Gageonnet and Lemoine (1958). Lenses of all sizes from tens of kilometers long down to single mineral grains occur in this matrix. Internally coherent lenses large enough to show at reconnaissance mapping scales are depicted on the various geologic maps, whereas small lenses of similar rocks are left in the "background" units. The small lenses include all the types specified for the large lenses in the preceding paragraph. Pelagic foraminifers in the clay are of Miocene to Quaternary ages, as discussed in sequence.

Abyssal pelagic sediments, formed in midoceanic environments, occur in the complexes on Timor. The rocks most distinctive of such environments are the unlithified, lime-free red clays that contain manganese nodules and 

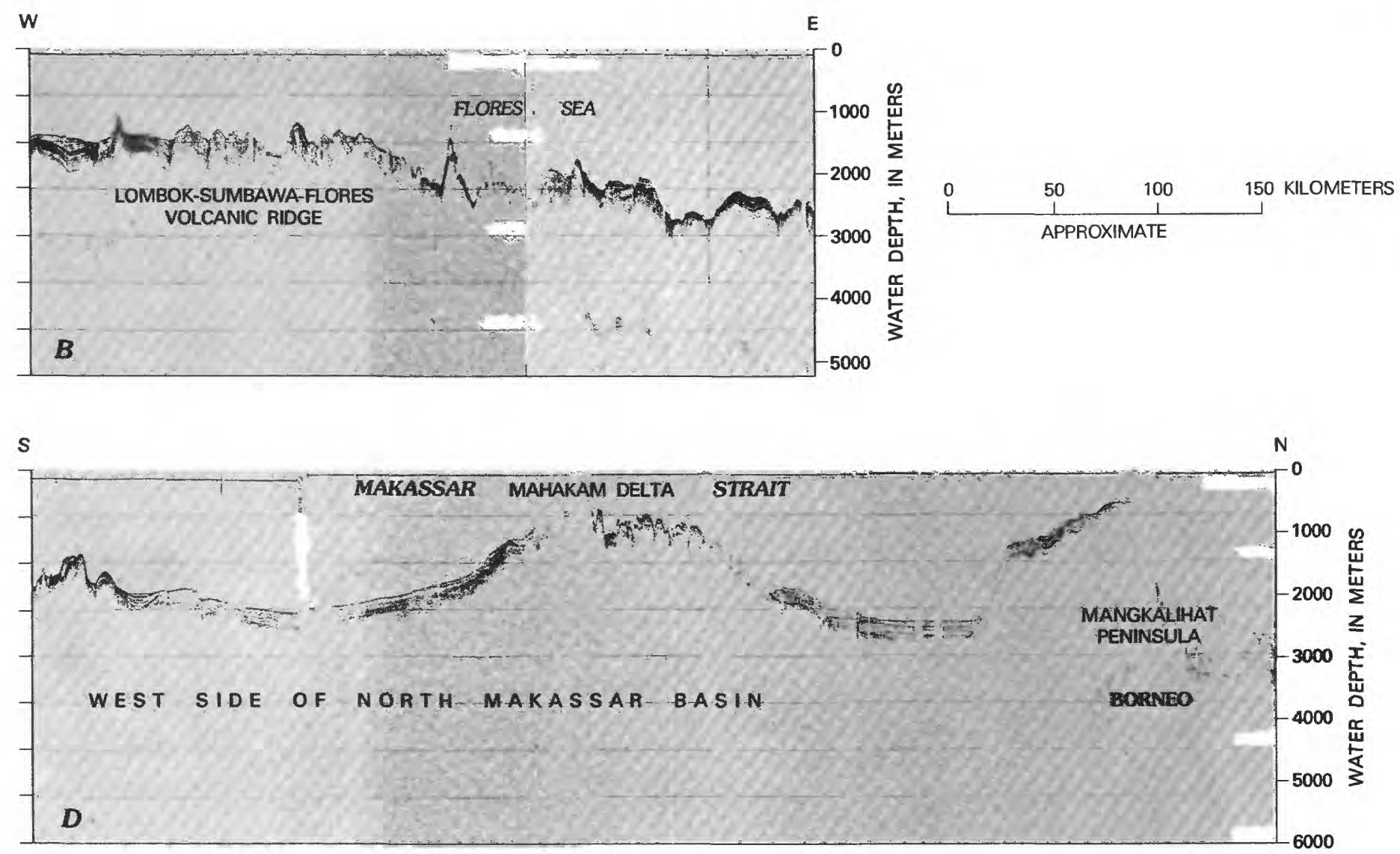

Upper Cretaceous shark teeth (de Beaufort, 1922; Molengraaff, 1915a; Molengraaff and de Beaufort, 1921). The shark teeth precisely resemble those of modern deep oceanic deposits in having lost by solution all but their enamel sheaths. The manganese nodules structurally and chemically resemble those now forming on the deep ocean floor (Audley-Charles, 1965a; El Wakeel and Riley, 1961; Molengraaff and de Beaufort, 1921; Price, 1967). Other Upper Cretaceous pelagic sediments found in many places in Timor include calcilutite, radiolarite, and radiolarian shale (for example: Audley-Charles, 1968; Brouwer, 1942; de Roever, 1940e; Tappenbeck, 1940; van West, 1941). These various deep-water materials occur mostly as large and small isolated masses in melange, but many are still in direct contact with pillow-basalt masses that presumably represent oceanic crust.

Many of the Permian, Mesozoic, and lower Tertiary rocks of Timor are in shallow-water facies like those of the continental shelf of northwestern Australia. The similarity in facies and faunas has been commented on by Audley-Charles (1965b, 1968), Teichert (1970), Veevers (1969b), Waterhouse (1972), and others. The shelf section of Australia deflects downward at the shelf edge, disappears beneath the Timor Trough and the wedge of imbricated rocks and melange, and reappears as allochthonous fragments of all sizes within the wedge in Timor.
The oldest fossiliferous rocks of Timor are Permian, in contrasted clastic and limestone facies. Fossils and lithologies of the clastic Permian are strikingly like those of the nonglacial parts of the Permian of northwestern Australia (for example, Veevers, 1969b), and agreement is widespread that the Timor clastic rocks were derived from the greater Australian landmass. Paleomagnetic orientations accord with this inference (Chamalaun, 1977a). Limestone, however, is rare in the onshore Australian Permian, and the fossils in the Timor limestones clearly indicate warmer water than was general within Australia. The contrast led Audley-Charles (1975, 1977), Barber and others (1977), Carter and others (1976), and Gerth (1926) to speculate that the limestones had formed far to the north and had been transported to Timor and there juxtaposed with the Australian-facies rocks.

The contrast has been much overstated in the course of such speculation. The Upper Permian of the northwestern Australian offshore shelf, $150-250 \mathrm{~km}$ from the southwest tip of Timor, includes abundant limestone (Laws and Kraus, 1974). The Timor limestone fauna is subtropical, not tropical; it contains fusulinids and rugose corals, for example, but not reef limestones nor the extremely diverse assemblages to be expected of the tropics. The limestone faunas show their closest taxonomic affinities to the faunas of northern India (where glacial and temperate Permian rocks 


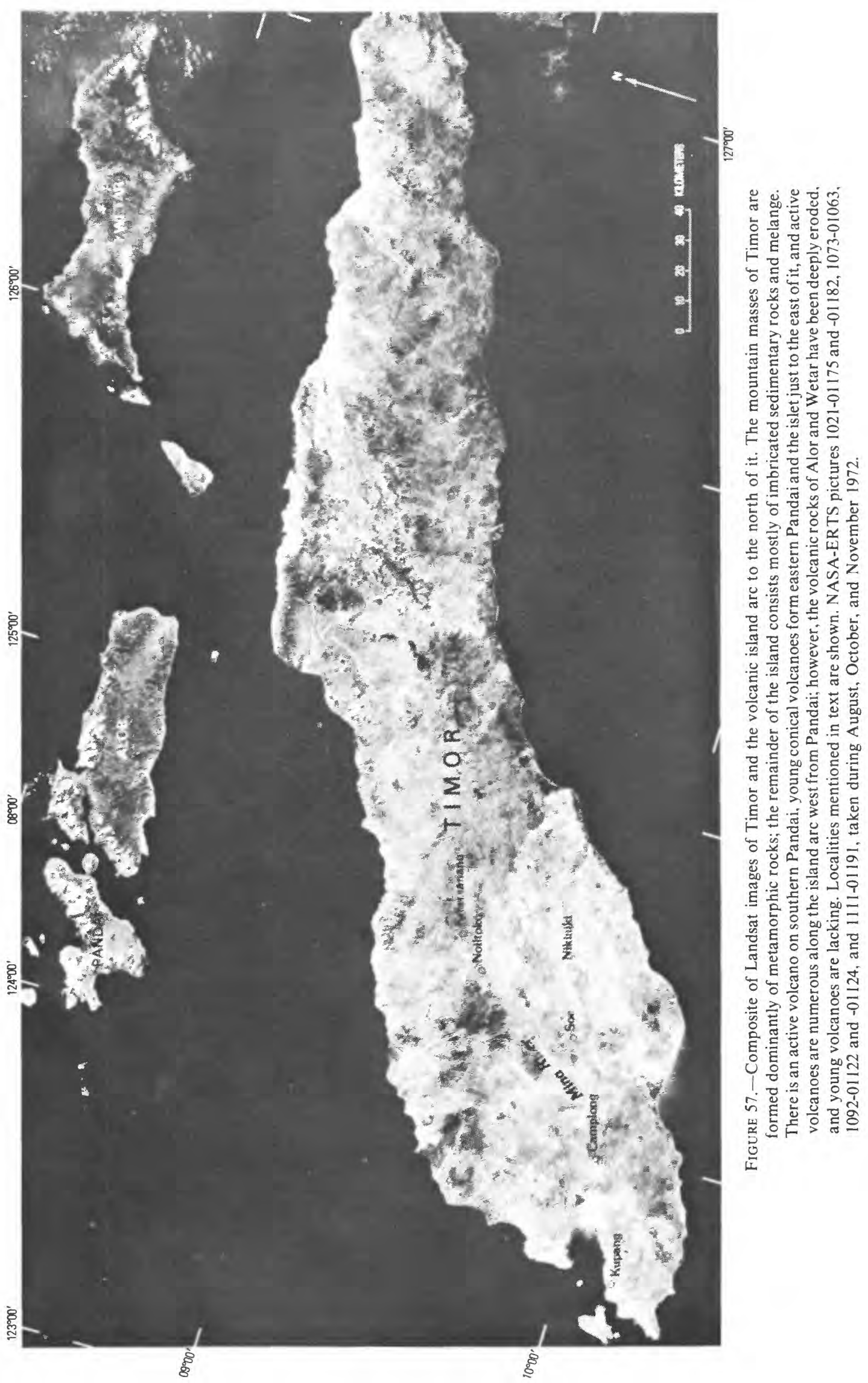


are also present lower in the section) and of northwestern Australia, despite the facies contrast (Teichert, 1972; Waterhouse, 1972). Paleontologists Patrick J. Coleman, J. M. Dickins, V. J. Gupta, Bruce Runnegar, George A. Thomas, and J. Bruce Waterhouse have all confirmed these relationships to me in correspondence during 1976 and 1977. According to Grady (1975) and Grady and Berry (1977), clastic Triassic strata with Australian faunà lie with depositional contact upon the warm-water Permian limestone, which is intercalated with colder water Permian clastic strata, in central Timor and were mismapped by Audley-Charles (1968). Paleomagnetic latitude of the clastic Permian is the same as that of red shale interbedded with the carbonate Permian (Chamalaun, 1977a, b).

I infer that the Timor limestones were deposited on the warm north margin of Gondwanaland, Timor and north India having been then close together, and that the limestone formed on the warm side of the critical winter water-temperature isotherm that separated carbonate from noncarbonate terrains and subtropical faunas from temperate ones. Paleomagnetic latitudes indicate warming of Australia in the appropriate direction. Both clastic and carbonate facies of Timor could have been deposited upon Australian basement.

The red, pink, and white Permian limestone and associated marl are widespread components of the Timor melange, both as small exotic blocks (fig. 58) and as large allochthonous masses as long as many kilometers. (Audley-Charles, 1968, classed the limestone and associated basalt as producing about 70 percent of the exotic blocks in eastern Timor; from my own limited observations in western Timor, I suspect that he was misled by the conspicuousness of the resistant limestone blocks on the ground and that softer marls and clastic sediments of diverse ages actually bulk much more than the limestone as exotic blocks.) The limestone has yielded rich assemblages of shallow-water echinoderms, corals, fusulinids, brachiopods, and other invertebrates. (See Gerth, 1926; and Wanner, 1941, and many earlier papers; fig. $58 \boldsymbol{B}$.) This strongly colored limestone is quite unlike the common gray shelf and platform limestones of the Paleozoic elsewhere, and sedimentological study is needed to constrain its environment of deposition; analogs with some of the Tethyan Mesozoic might be fruitful. (Compare Bernoulli and Jenkyns, 1974.)

Volcanic rocks interbedded with the Permian limestones have been reported by Audley-Charles (1968), Brouwer (1942), Grady and Berry (1977), de Waard (1955), and others. Pillow basalt is common (fig. 58). The volcanic rocks, as described from part of western Timor by de Roever (1940b, 1941, 1942), are dominated by olivine-clinopyroxene basalt but include much trachybasalt and trachyte and a little quartz syenite and other rock types, all variably albitized. Such a petrologic assemblage is suggestive of formation either in a midocean island or in a tensional
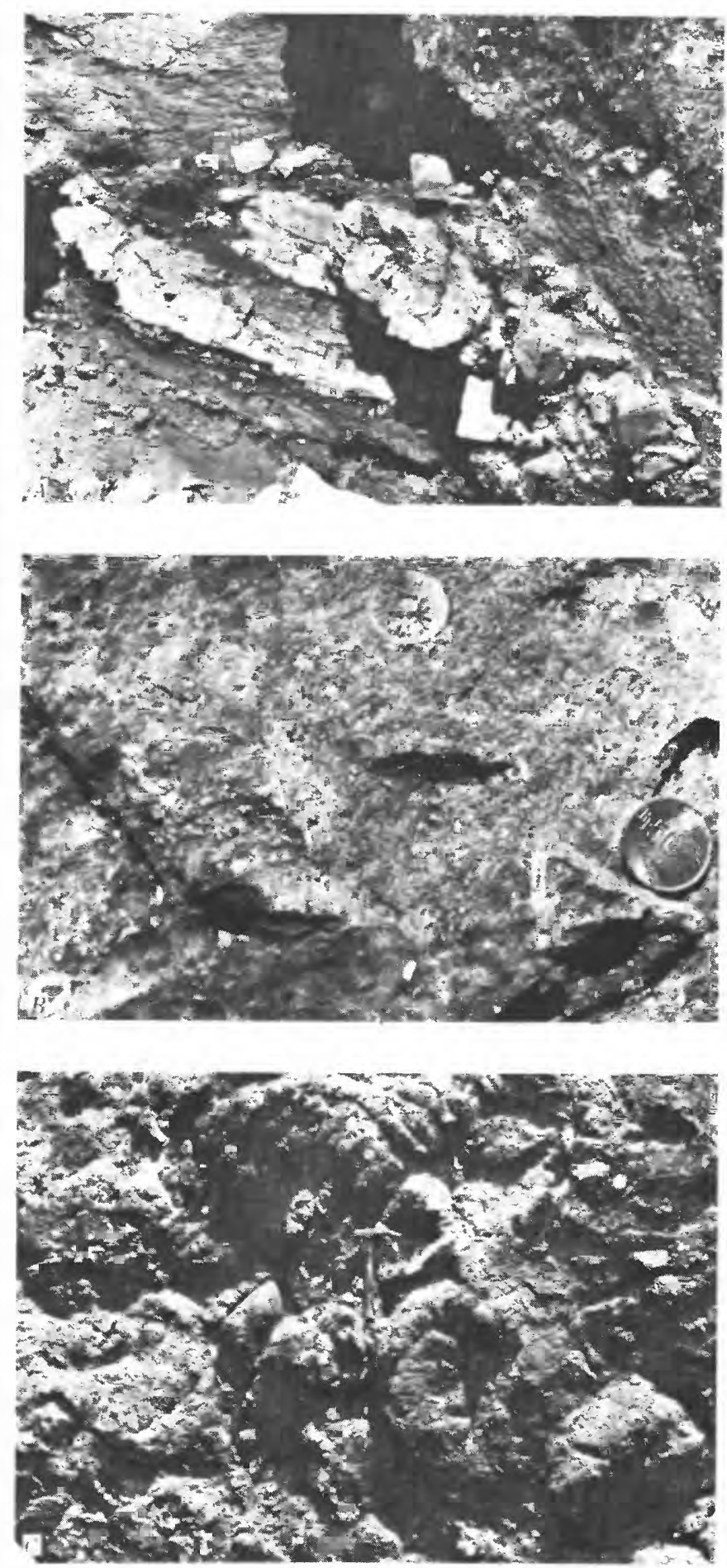

Figure 58.- Permian(?) rocks in scaly-clay melange, about $2 \mathrm{~km}$ south of Nikiniki, central western Timor. $A$, Lens of hard white and red limestone, tailing off into breccia at lower right. Scaly clay encloses the lens; its foliation is exposed by fresh erosion at upper left and beneath lens, but the clay has developed its characteristic puffed, hydrated weathered surface at upper right. The area pictured is about $2 \mathrm{~m}$ high. $B$. Pink limestone, richly fossiliferous with coralline and crinoidal debris. The coin is about $2 \mathrm{~cm}$ in diameter. $C$, Pillow basalt, altered to greenstone. Part of an exotic block about $5 \mathrm{~m}$ in diameter. 


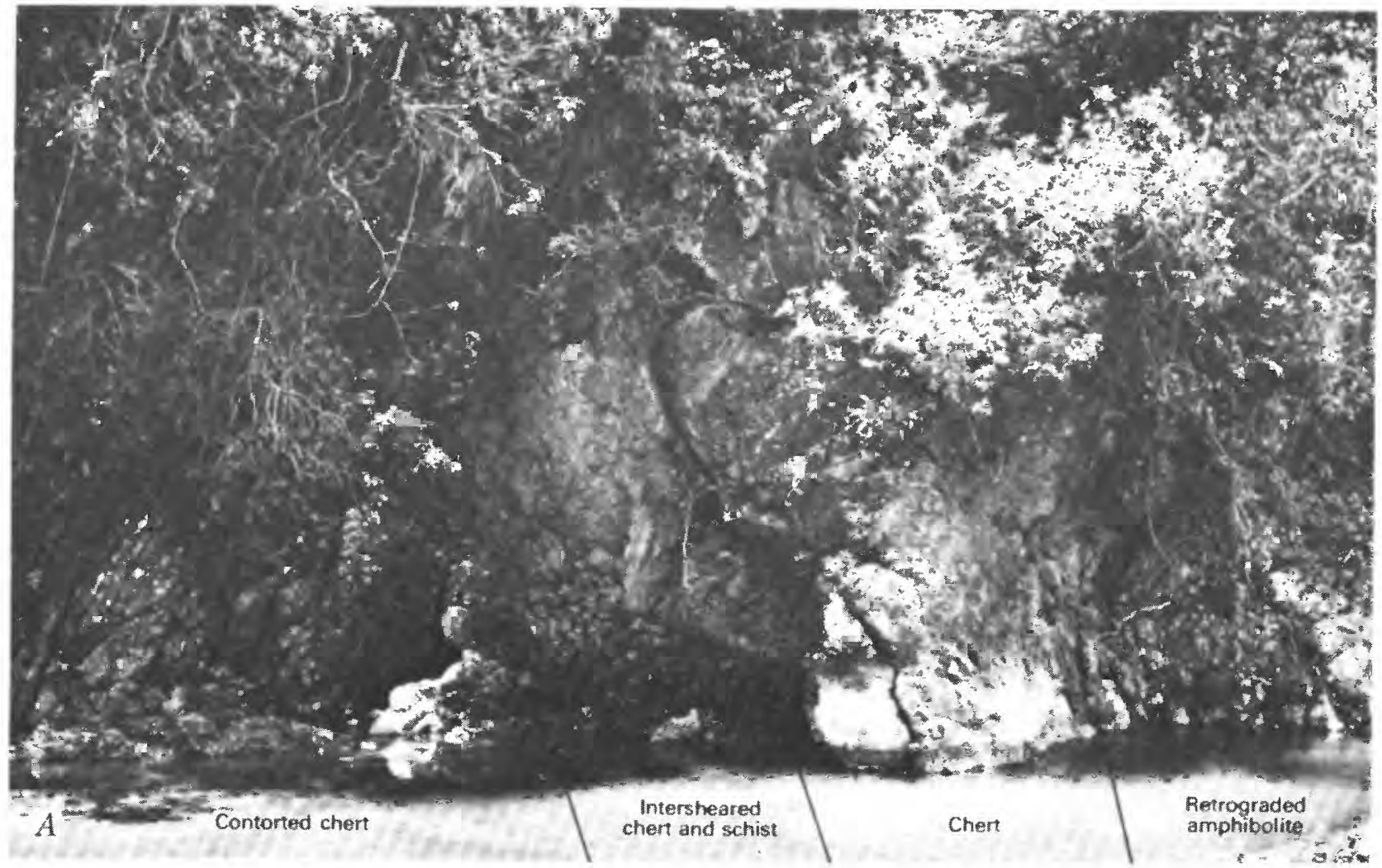

FIGURE 59 (above and facing page). - Metamorphosed ophiolitic materials in a sheet several kilometers thick, about $3 \mathrm{~km}$ south of Noiltoko, central western Timor. $A$, Sheared contact zone between chert and retrograded amphibolite. This is assumed to be the metamorphosed upper part of an ophiolite sequence, across the contact between basaltic oceanic crust and abyssal pelagic chert. The pictured area is about $10 \mathrm{~m}$ wide. $B$, Mafic phyllonite, produced by retrograde shearing of fine-grained amphibolite.

continental setting. It is possible that basaltic islands, carried northward on the oceanic plate formerly north of Australia, were scraped off where that plate slid beneath the Banda Sea plate. This explanation, however, requires the presence of ocean floor at least as old as Permian on the subducted plate, and this seems unlikely since continental masses did not rift away from Australia and New Guinea until Jurassic time. Also, the ubiquitous clasts of shallow-water Permian limestone throughout the Timor melange are difficult to explain in these terms. More likely, in view of the Gondwana affinity of the fossils in the limestone, the basalt records early extension of continental crust within what became subsequently the zone of rifts outlining western Australia.

Reconnaissance study suggests that the paleomagnetic latitude and orientation of the largest terrain of Permian strata in eastern Timor is approximately that to be expected if the rocks had been deposited on the northwest edge of the Australian plate, and had been rotated subsequently about horizontal axes but not about vertical ones (Chamalaun, 1977a, b). This led Chamalaun (1977b) and Chamalaun and Grady (1978) to speculate that the rocks are the autochthonous, folded outer edge of the Australian con- tinental shelf; but this speculation is disproved by the structural geology. That the rotation has been primarily about horizontal, rather than vertical, axes is to be expected in a setting of imbrication, and is not evidence for lack of thrusting.

Widely varied metamorphic rocks occur in large and small outcrop masses scattered over much of Timor. A. J. Barber and M. G. Audley-Charles (1976, and written commun., 1974) studied thin sections from both Audley-Charles' collection and the old Dutch collections of these rocks. Lowand high-grade metasediments, including quartzose types, and mafic rocks-greenschist, epidote amphibolite, and amphibolite - are widespread. Rocks suggestive of continental crustal types - cordierite gneiss, garnetiferous meta-anorthosite, andalusite-biotite-muscovite schist, biotite gneiss, and others - are present in various areas north of the midline of western Timor, and some of these rocks may be retrograded granulites such as are common in the Precambrian shield of Australia. Ophiolite is present as metamorphosed mafic (fig. 59) and ultramafic rocks. Glaucophane was recognized in only one specimen, from western medial Timor. Barber and Audley-Charles conclud- 


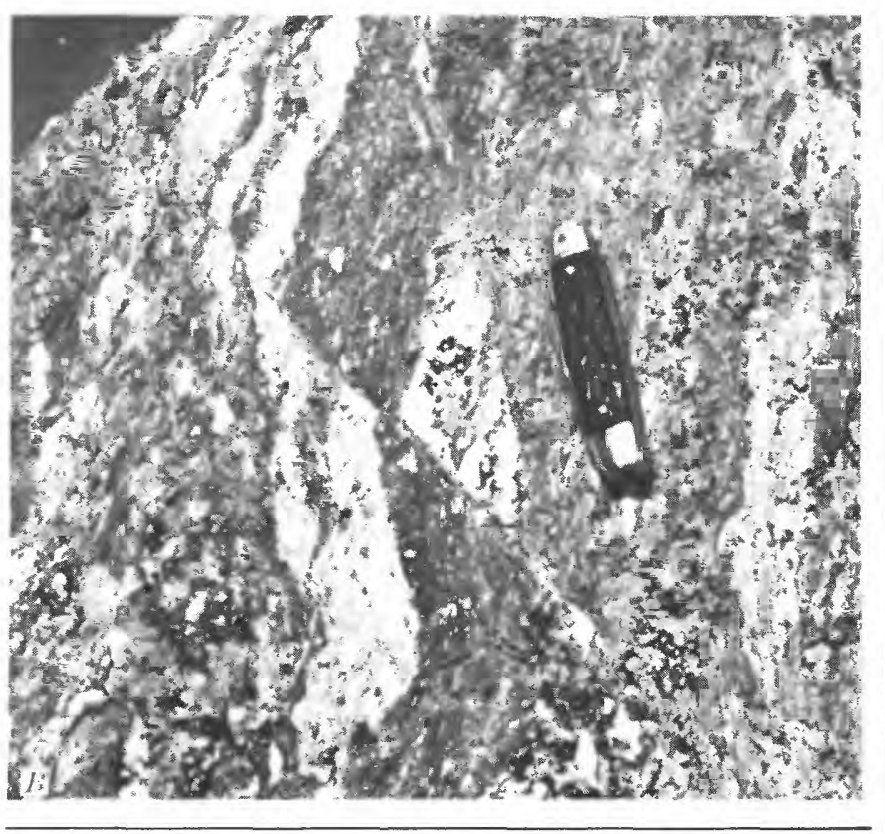

ed that both continental and oceanic-crustal sources are represented in these materials. Slates and metamorphosed silicic sedimentary rocks were regarded by Barber and Audley-Charles as representing both pelagic and clastic strata.

R. F. Berry and A. E. Grady (Berry and Grady, 1977; Grady and Berry, 1977; oral and written communs., 1977) studied the metamorphic rocks that extend for about $10 \mathrm{~km}$ southward from the north coast of Timor between long $125^{\circ} 31^{\prime}$ and $126^{\circ} 00^{\prime}$ E. Pelitic and quartzose schists, and locally calcareous and mafic rocks, show a metamorphic progression northward and eastward from chlorite through biotite, hornblende, garnet, oligoclase, staurolite, clinopyroxene, and sillimanite-potassium feldspar zones. Hornblende and biotite in amphibolite have $\mathrm{K}-\mathrm{Ar}$ ages of 5-16 m.y. The high-grade eastern rocks are in contact with ophiolite masses-serpentinite, peridotite, and gabbro-and map patterns and dips indicate the complex to be antiformal, metamorphism increasing upward toward the ophiolitic rocks. I infer (Berry and Grady did not) that

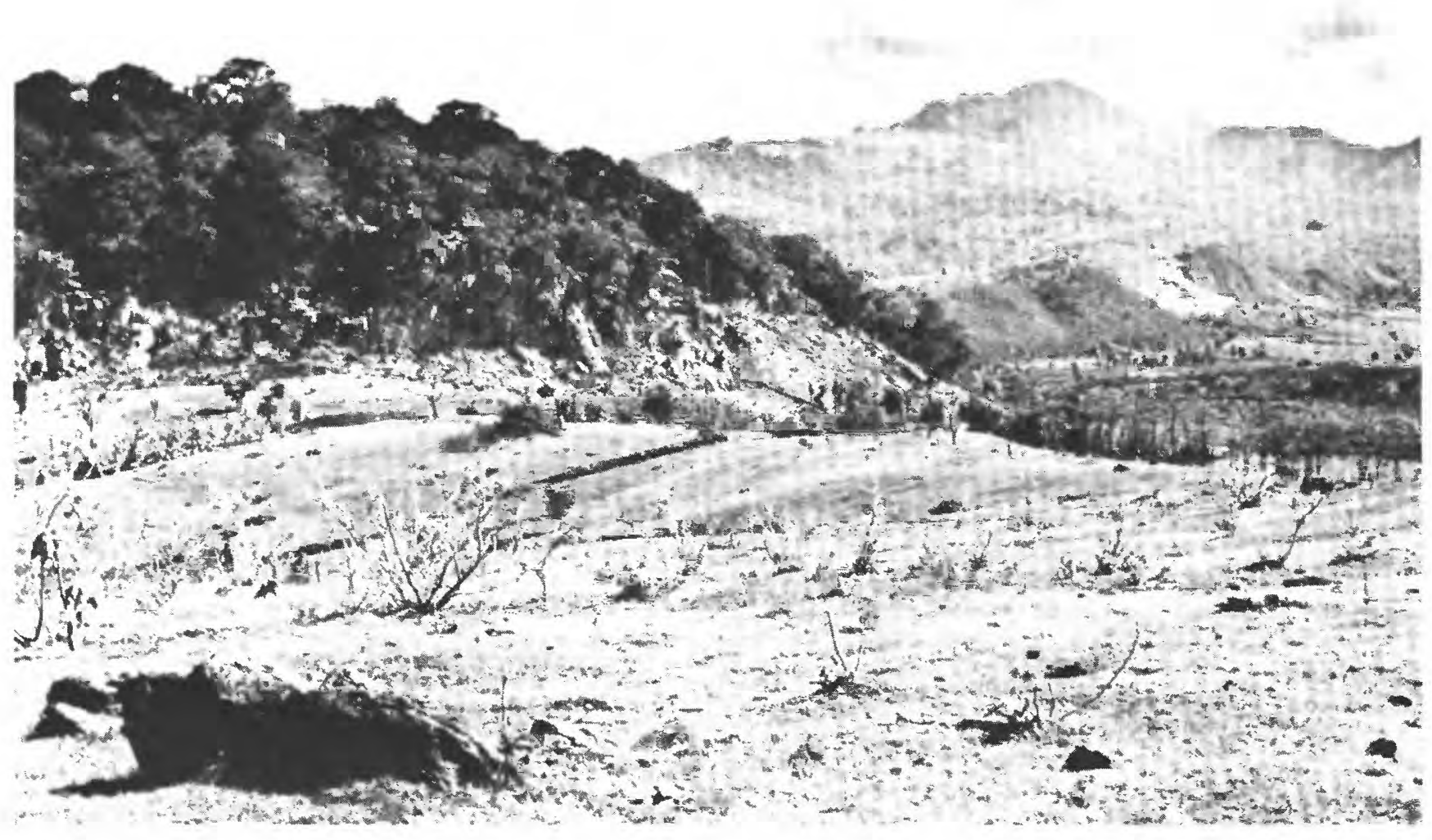

FIGURE 60. - View north-northeast across melange terrain from about $5 \mathrm{~km}$ southwest of Kefamananu, western Timor. The rugged parts of the hills are of resistant rocks: Permian and Triassic limestone, the wooded hill on the left, the small knob on the center skyline, the high peak on the skyline, and the block in the left foreground; amphibolite and greenschist, the skyline at the right edge of the picture; and middle Tertiary marl and limestone, the south-dipping sheet that forms the low ridge in the right middle distance. All these are intercalated in, and separated from each other by, scaly-clay melange, which forms the gentler slopes. Resistant blocks and lenses of sandstone, limestone, serpentinite, greenstone, and other types weather out of the melange and litter the foreground surface. Rocks of this area were described by de Bruyne (1941). 
metamorphism was produced beneath overthrust hot, young Banda Sea oceanic lithosphere. (Compare Brookfield, 1977, and Woodcock and Robertson, 1977.) The metamorphic complex in part is faulted against much-deformed Permian(?) and Mesozoic(?) shale and sandstone on the south, and in part grades into them via decreasing metamorphism.

I examined much melange in central and southwestern Timor on a field trip led by Subardjio Tjokrosaputro and his associates of the Geological Survey of Ind onesia (who made a reconnaissance study of most of western Timor) and by Willis H. Nelson of the U.S. Geological Survey. My sample was that along the rough main road through Timor, from Kupang to Kefamananu via Camplong (Tjamplong) and Soe, with excursions into the hinterland south of Nikiniki and southwest of Kefamananu. The entire region seen, barring small alluvial plains and small plateaus capped by raised Quaternary reefs, is of melange and of large and small masses of resistant rocks within it. A typical landscape is shown by figure 60 . Low, rolling ground is formed on scaly-clay melange, the surface being strewn with resistant blocks weathered out of it, and large and small hills and

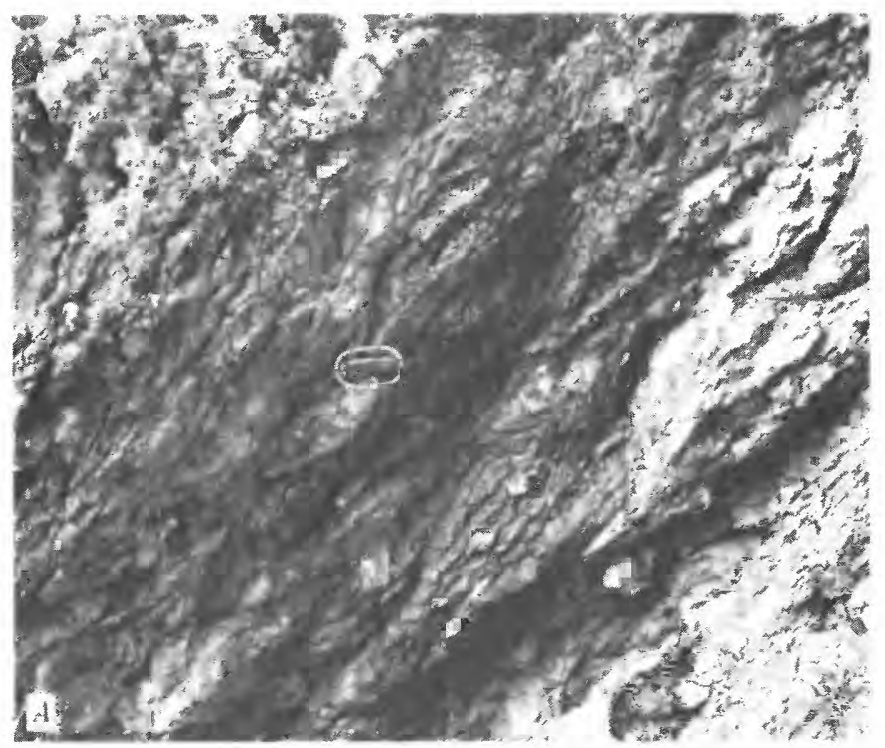

FIGURE 61. - Scaly-clay melange, western Timor. The dominant material is foliated clay, in glossy, slickensided scales, which encloses granules, shear-formed lenses, and chunks of resistant rocks. $A$, The lenses are mostly of sandstone, but a chunk of greenstone (marked gs) is at top center. The foliation dips steeply left, and is displayed in the partly puffed surface of a freshly slumped cut; the older surface in the upper left is of fully puffed, hydrated clay, in which the structure is not visible. Cut $1.5 \mathrm{~m}$ wide; pocket knife at center of picture. Gully near kilometer post 93 on road from Kupang and Camplong to Soe, $B$, Gently dipping swelling scaly clay containing lenses and brecciated fragments of white and pink Permian(?) limestone, exposed in fresh slump in creek bank about $2 \mathrm{~km}$ south of Nikiniki. $C$, Shear-polished scaly clay. Such material can be broken down into smaller and smaller chips along successive shear surfaces. This piece is about $6 \mathrm{~cm}$ long. Specimen collected by Willis $\mathrm{H}$. Nelson from roadcut near Besian River, between Camplong and Soe, and photographed by Lowell Kohnitz. ridges are formed of larger masses and sheets of hard rocks within the complex. The clay-rich areas tend to support only grass and open scrub or woodland, whereas other rock types are frequently heavily forested.

The dominant material throughout the region I saw is scaly-clay melange. Most of the clay hydrates and swells to puffy lumps, several centimeters in diameter, on weathered surfaces; no internal structure of the melange is apparent on such surfaces. Much fresh clay is exposed in gullies, however, particularly in the scars of fresh slumps where banks are undercut. Representative exposures are shown in figure 61. Lenses of resistant rocks within the melange are shaped and polished (fig. 62) or brecciated (figs. 58 $A, 63 A$ ) by shearing. The strong, pervasive foliation in the clay has steep to moderate dips more commonly than gentle ones, where I saw it.
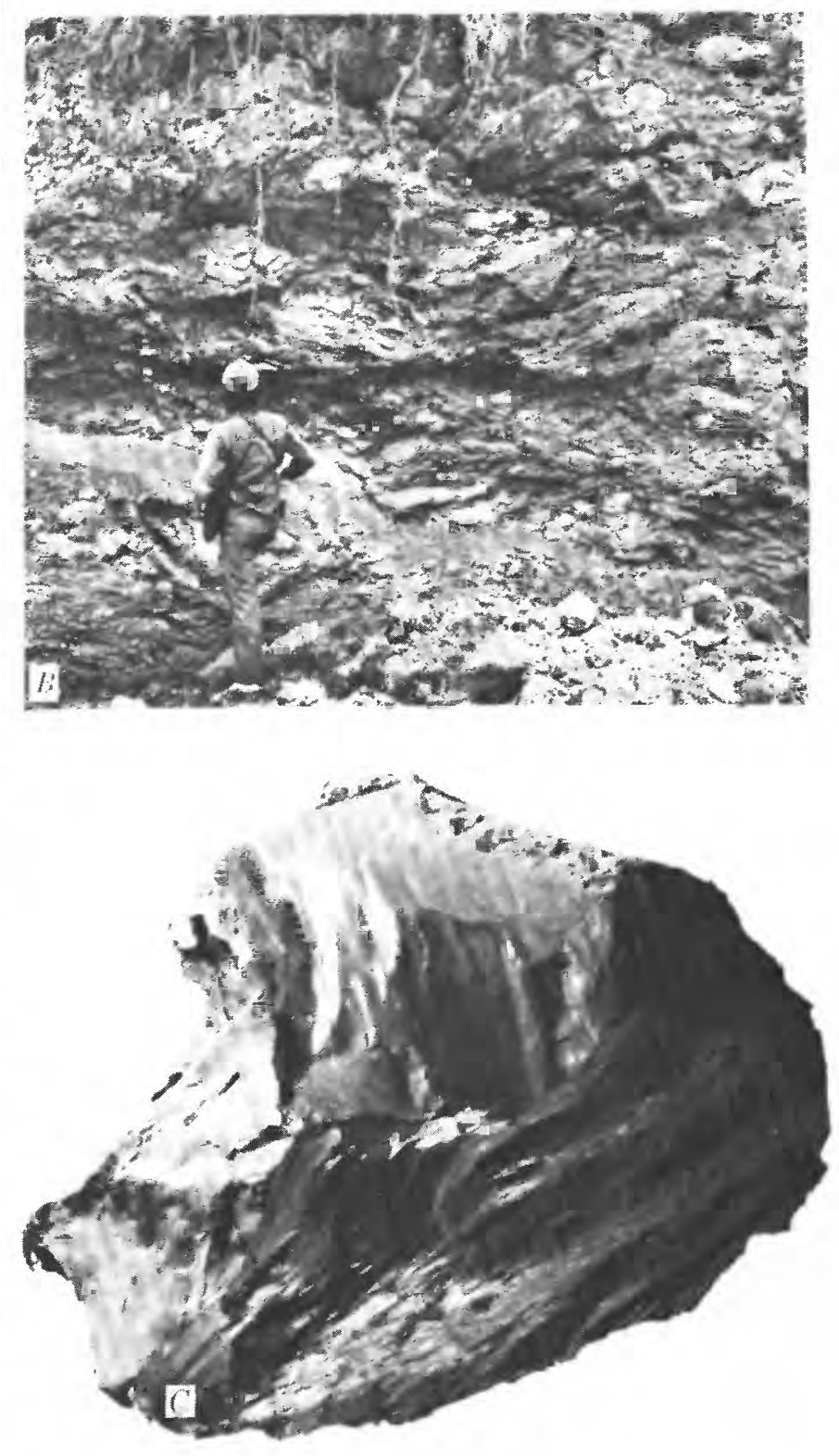

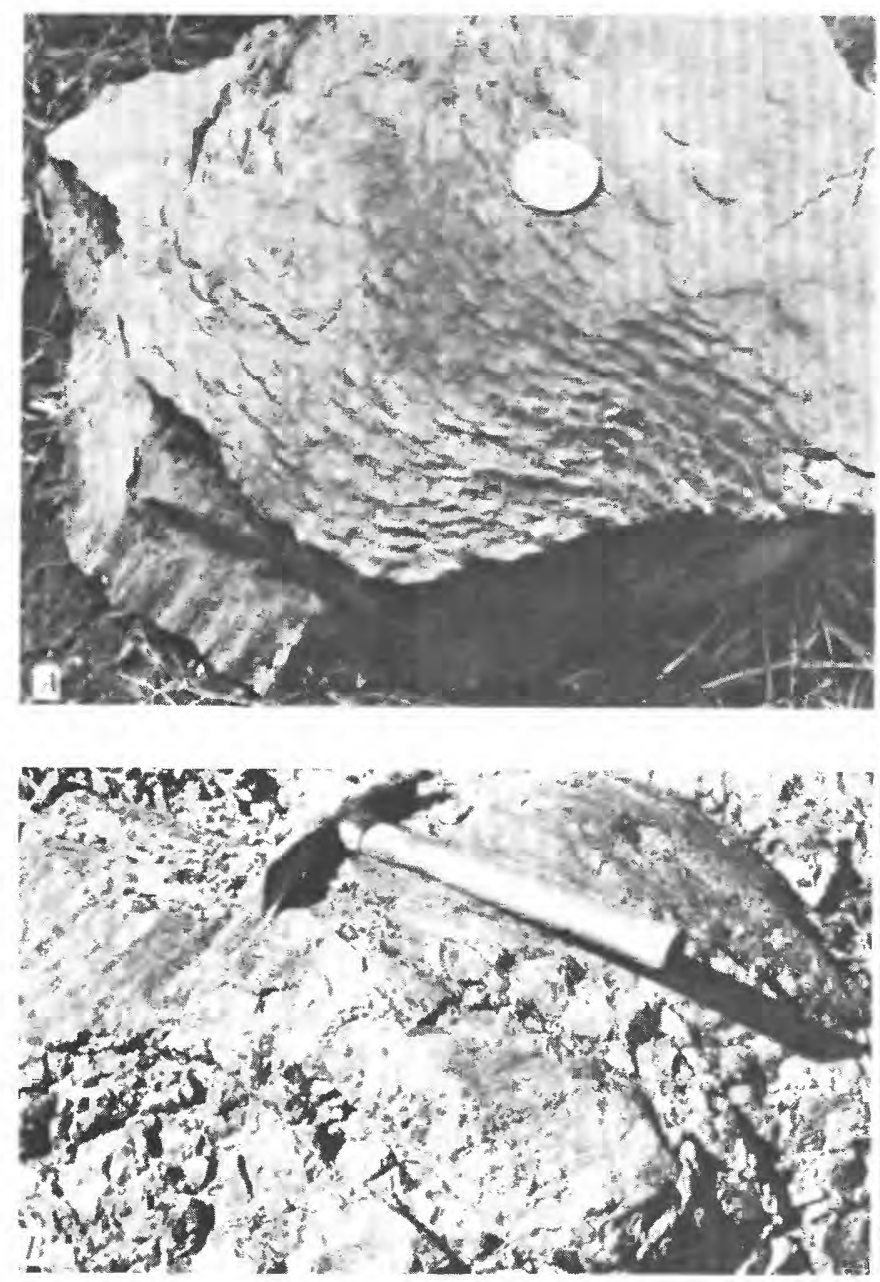

FIGURE 62.-Lenses of resistant rocks shaped by shearing within scaly-clay melange, western Timor. $A$, Fragment of a lens of marl. The shear-polished surface is offset by numerous tiny crescentic faults which are parallel to a radial prismatic structure (visible at lower left) developed in the outer $3 \mathrm{~cm}$ of the lens. Coin is about $2 \mathrm{~cm}$ in diameter. Locality about $30 \mathrm{~km}$ east of Kupang, by road to Camplong. $B$, Shear-polished surface of lens of micaceous sandstone. Slickensides trend in various directions, showing that block rotated within melange as shearing progressed. Locality about $5 \mathrm{~km}$ southwest of Kefamananu. $C$, Lens of micaceous sandstone enclosed concordantly in scaly clay dipping moderately south (right). Same locality as $B$.

Where exposures are good, many masses of partly disrupted swelling-clay sediments, with or without interbedded marl (figs. $63 A, B$ ), are seen. A traverse of a kilometer along a steep gully, with particularly good exposures, south of Nikiniki revealed that about a third of the complex there consists of such partially disrupted material, which grades back and forth, with increasing shearing, into fully developed scaly-clay melange that encloses abundant exotic lenses and blocks of Permian(?) limestone and pillow basalt (fig. 58 ; fig. $61 \mathrm{~B}$ ). The partly disrupted strata have the same pink and gray colors and the same swelling-clay weathered surfaces as does the scaly-clay melange and obviously represent its parental material.
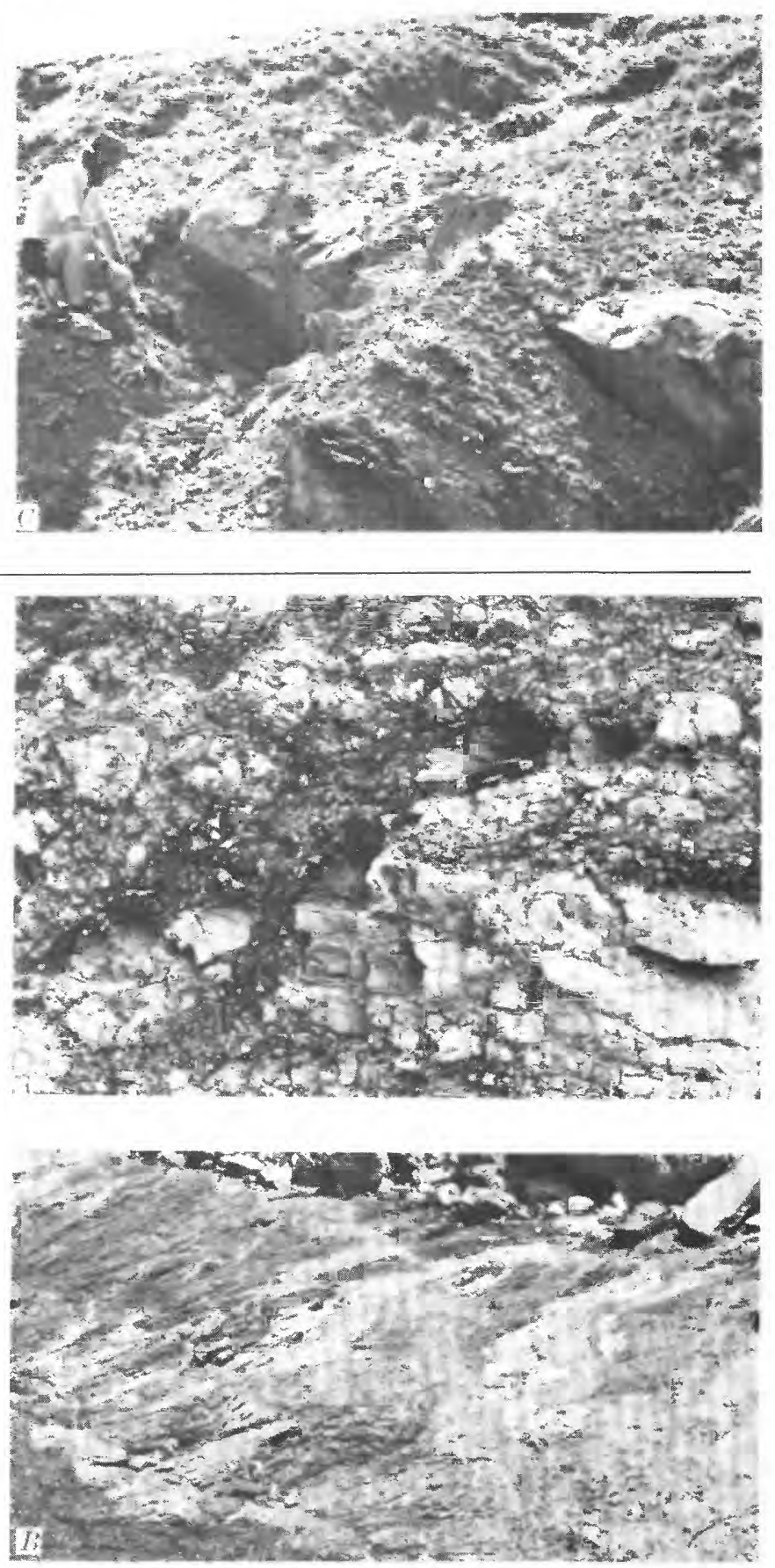

Figure 63.-Disrupted Neogene(?) sedimentary rocks, representing a stage in shearing less than that which produces scaly-clay melange, in a gully about $2 \mathrm{~km}$ south of Nikiniki, western Timor. A, Dark-pink swelling clay, which has flowed around shattered fragments of light-gray marl. $B$, Swirled lenses of variably disrupted white and pink swelling clay. The pictured area is about $4 \mathrm{~m}$ long.

The scaly-clay matrix of the melange is apparently derived mostly from volcanic ash. The clay swells where hydrated - that is, on all exposures but the freshest of cuts and slumps (figs. 61, 63). Audley-Charles (1965c) referred to 
the clay as "bentonitic" and as dominated by montmorillonite. This volcanic-ash clay could not have been derived from subducted Australian continental-shelf strata, for the latter are dominantly clastic sediments formed of the weathering products of older rocks in the Mesozoic sequence and nontuffaceous carbonates in the Cenozoic. The deepocean sediments probed by DSDP holes west of Australia are not adequately tuffaceous to be the parent materials. A source in the late Cenozoic volcanoes of the Banda Arc is likely. Microfossils within the clay-representing both microclasts within the melange and fossils present within the parent clay - are of widely varying ages and include abundant pelagic foraminifers that mostly are late Miocene (Audley-Charles, 1965c, 1968). Pliocene and Pleistocene foraminifera also are abundant (Brunnschweiler, 1978; T. Rothwell, as cited by Gribi, 1973; the fossil list of Audley-Charles, 1968, p. 48, includes the Pleistocene index species Globorotalia truncatulinoides). Either the clay represents a broad Neogene time span, or else most of its fossils were reworked into the clay within Quaternary time.

\section{UPPER NEOGENE MATERIALS AND DEFORMATION}

Upper middle Miocene to lower Pleistocene marine strata, typically about $2,000 \mathrm{~m}$ thick, form a discontinuous belt in medial Timor (pl. 1) and remnants farther south. Despite their youth, these strata share in the later part of the imbrication of the melange complex, and so provide valuable information regarding deformation mechanisms. The most detailed descriptions available for these rocks and their structure are those made in western Timor by Christopher S. Kenyon (Ph.D. thesis, Imperial College of Science and Technology, London; and oral communs., 1974), to whom I am indebted for much of this information. Published accounts include those by Audley-Charles (1968) and de Bruyne (1941). The sequence is dominated by marl, calcilutite, and shale, variably tuffaceous in the Miocene and Pliocene but ash-free in the Quaternary. The high middle Miocene was deposited in something like $2,000 \mathrm{~m}$ of water, and water depths become progressively shallower during deposition of the rest of the sequence.

In the northern part of the main belt in medial Timor, the young strata lie unconformably upon melange, are bounded at their north margin by warps and faults along which the northern mountains are raised, and are covered by coarse clastic upper Quaternary debris from those mountains. Deformation of the upper Neogene strata increases southward, from open folds to tighter folds and to complete disruption by thrust faulting in the southern mountains. The deformation of the large sheet of these rocks exposed at the Mina River (fig. 64) (one of several places where I was able to examine briefly the upper Neogene) is particularly informative. The sheet is about $2 \mathrm{~km}$ thick and many kilometers long, dips moderately to steeply southward, and is intercalated tectonically in polymict melange in which the shear

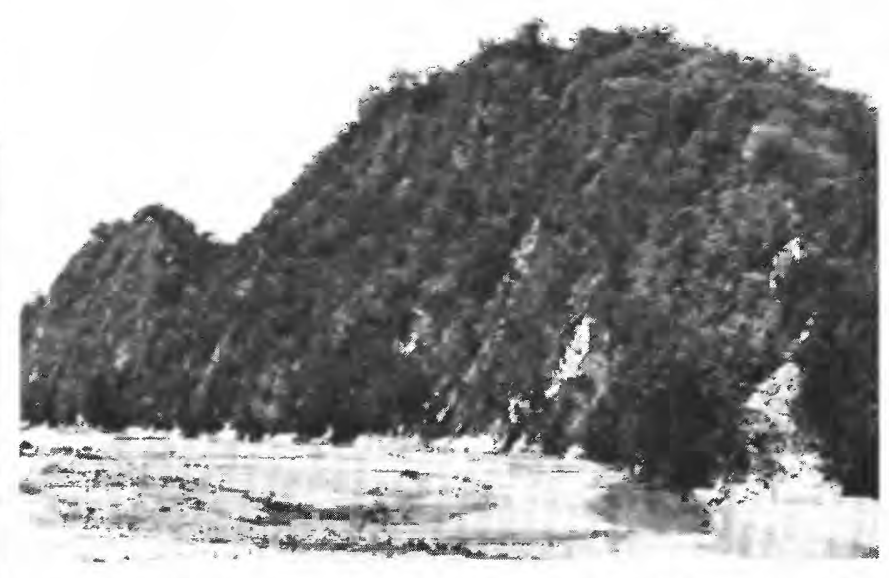

FIGURE 64.-Hogback of steep-dipping calcilutite within upper middle Miocene to upper Pliocene sequence which forms a large sheet intercalated in scaly clay polymict melange. View westward across Noil (River) Mina to Fatu (Hill) Antoni, which rises about $50 \mathrm{~m}$ above the river, southwestern Timor.

foliation is parallel to the bedding in the nearby Neogene mass. Although the Neogene is coherent internally, it becomes increasingly sheared within $10 \mathrm{~m}$ of its upper contact - well exposed in roadcuts and river bluffs on the south side of the Mina River near kilometer post 76 on the road from Kupang to Soe-with the tectonically overlying melange. The lower part of the Neogene sheet is well exposed in a long roadcut at $\mathrm{km} 87$, on the north side of the Mina valley, where upper Miocene marl and tuff are intersheared as a thoroughly disrupted broken formation.

My interpretation of such stratigraphic and structural relationships is that the coherent upper Neogene strata were deposited on the melange wedge of the active arc system, perhaps in a slope basin like that of figure $72 B$, after much of the melange had been formed by processes related to subduction. The position of the crest of the ridge at the time is not known, but the tuffaceous component of the Neogene part of the sequence presumably came from the volcanic arc nearby to the north. Internal imbrication of the melange wedge (a process deduced from other evidence as operating in the outer-arc ridge along Java and Sumatra) continued during and after this deposition, with increasing severity southward toward the trench, and imbrication of the upper Neogene resulted. The coherent upper Neogene was deposited on top of the melange wedge but has since been incorporated tectonically into the wedge. (Analogous explanations may account for the presence of imbricated slices of young, coherent strata within polymict melange terrains in other parts of the world, as in the Upper Jurassic to Eocene Franciscan complex of California.) But if the dominant swelling-clay parent material for the melange is of the same age as the coherent calcareous strata, then different sites of sedimentation and some more complicated process of tectonic juxtaposition are needed. 
A chain of small basins of moderately deformed upper Neogene strata (upper Pliocene and younger clastic sediments where drilled off central Timor) occurs just offshore along the south coast of Timor (fig. $72 \mathrm{~B}$; Crostella and Powell, 1976, fig. 8). Submarine basalt of island-arc-tholeiite type and late(?) Miocene age crops out along the north coast of western Timor near Uikusi (or Oecusse; Abbott and Chamalaun, 1976).

\section{GRAVITY}

Chamalaun, Lockwood, and White (1976) combined the results of a detailed gravity traverse across Timor, near long $125^{\circ} 40^{\prime} \mathrm{E}$., with reconnaissance gravity data obtained previously by others. Bouguer anomalies increase northward. Bouguer values (using a reduction density of 2.6 $\mathrm{g} / \mathrm{cm}^{3}$ ) are slightly negative ( 0 to -40 mgals) along the south coast, increase irregularly and slightly to about zero along the midline of the island, and then increase, more regularly and with steepening gradient, to +80 to +120 mgals along the north coast, where the gradient reaches $6 \mathrm{mgals} / \mathrm{km}$. Chamalaun and his colleagues modeled the north-coast gradient and concluded that a reverse contact, oceanic crust lying above continental crust on a contact dipping moderately northward, was required.

\section{INTERPRETATIONS BY AUDLEY-CHARLES}

A reconnaissance field and photogeologic study of eastern Timor was reported by Audley-Charles (1968) and, with lesser unpublished work in western Timor, formed the main basis for a long series of speculative papers by him (Audley-Charles, 1965a, b, c; 1966a, b; 1968; 1972; 1973; 1974a, b; 1977) and his associates (Audley-Charles and Carter, 1972, 1974; Audley-Charles, Carter, and Barber, 1975; Audley-Charles, Carter, and Milsom, 1972; Audley-Charles and Hooijer, 1973; Audley-Charles and Milsom, 1974; Barber and Audley-Charles, 1976; Barber, Audley-Charles, and Carter, 1977; and Carter, Audley-Charles, and Barber, 1976). The papers of the 1960's were based on a stabilist rationale that denied the possibility of horizontal motions of continental or oceanic plates. Timor was assumed to be the upbowed outer edge of the Australian continental shelf, and the Permian to Paleogene sedimentary rocks of Australian-shelf facies were assumed to be the exposed autochthonous top of a shelf-edge anticline. Chaotic melange, and masses of sedimentary and crystalline rocks of non-Australian facies, were assumed to compose a thin, discontinuous veneer atop the arch and to be olistostromes and gravity-slide sheets from a high Miocene uplift of what had been previously, and subsequently was again, deep ocean to the north. Crostella and Powell (1976, p. 154-155) stated that structures conjectured by Audley-Charles to be broad, simple, and autochthonous "have been found in the field to be chaotically folded and faulted, virtually reduced to one limb - or at best strongly asymmetric, with the southern flank sub-vertical and many associated minor reverse faults developed ${ }^{* * *}$ all pre-Upper
Miocene sediments outcropping on Timor and the adjacent islands are allochthonous." Brunnschweiler (1978), Grady (1975), and Grady and Berry (1977) documented major errors in Audley-Charles' mapping and field interpretations.

Reports of the 1970's by Audley-Charles and associates gradually added limited plate-tectonic conjectures involving the collision of the Banda Island Arc with the Australian continental shelf and postulating geometrically impossible patterns of subduction systems and transform faults. These interpretations have been unconstrained by seismological or marine-geophysical data. The recent papers still viewed the chaotic and exotic materials of Timor as a thin veneer emplaced gravitationally from the north but saw their source as a ridge of debris scraped up in front of the advancing arc; they recognized that the Australian-facies rocks of Timor have been thrust southward in an imbricate pile. Audley-Charles and his associates in the mid-1970's regarded the Savu and Weber Basins, between the inner volcanic ridge and the outer Timor-Tanimbar-Seram ridge, as marking the emergence of the north-dipping subduction zone of the Banda system. (Crostella and Powell, 1976, concur.) This speculation is disproved by reflection profiles, presented in a subsequent section of this report (figs. 70, 71, 74), across the trough and by the $50-100-\mathrm{km}$ depths of earthquakes beneath the basins (Fitch and Hamilton, 1974; Hamilton, 1974b). The notion that melange forms only a thin veneer atop Timor is disproved by many geologic and geophysical data, as summarized in this report.

\section{RAISED REEFS}

Middle Pleistocene reefs of algae and corals lie unconformably upon the upper Neogene strata and older complexes and are raised, without appreciable internal deformation, to altitudes of as much as $800 \mathrm{~m}$ in various parts of Timor (fig. 65 ; dating provided by C.S. Kenyon, oral commun., 1976).

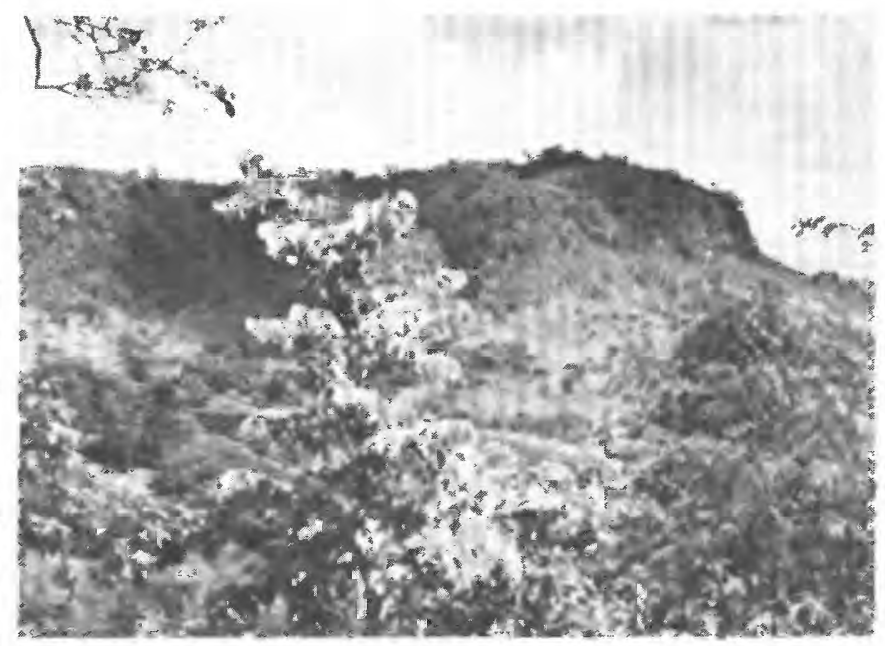

Figure 65.-Middle Pleistocene coral reef, raised to an altitude of about $500 \mathrm{~m}$, northeast of Camplong (Tjamplong), interior southwestern Timor. Melange, dominated by scaly clay, forms the gentler slopes above which the bluff-forming reef limestone rises about $50 \mathrm{~m}$. 
Along the north coast of eastern Timor, coral reefs dated by the ${ }^{230} \mathrm{Th}-234 \mathrm{U}$ method as about 120,000 years old are raised mostly about $60 \mathrm{~m}$ above sea level, so uplift rates there average about $0.5 \mathrm{~mm} / \mathrm{yr}$ (Chappell and Veeh, 1978).

\section{BIOGEOGRAPHIC PROBLEM}

A fossil anthracothere, a Tertiary relative of the hippopotamus, of South Asian type was reported from central Timor by von Koenigswald (1967). Although it was inferred to be of late Eocene age by von Koenigswald, it could in fact be considerably younger (D. A. Hooijer, written commun., 1973). Had the ancestors of this beast arrived overwater and had evolution then proceeded in isolation in an island setting, the anthracothere would be expected to be a pygmy form (as is the case with the Pleistocene stegodont proboscidians of Flores and Timor: Audley-Charles and Hooijer, 1973), which it is not. The material containing the fossil likely was part of the Asian continent when the animal lived, although the rock is now a component of the tectonic chaos of Timor. Migration of the island-arc system outward from Borneo and Sulawesi, as is advocated here on other grounds, perhaps accounts for the presence of this fossil in Timor.

MUD VOLCANOES

Mud volcanoes are common in parts of Timor (Brouwer, 1922). Presumably these are mostly products of the rapid tectonic burial of wet sediments within the melange wedge.

\section{SMALL ISI ANDS NEAR TIMOR}

The small islands rising from the outer-arc ridge near Timor all contain rock types similar to those of Timor and presumably also consist of imbricated complexes and melange.

\section{ROTI}

West of Timor, Roti (or Rotti) is known to contain fossiliferous Permian, Triassic, Jurassic, Cretaceous, and Eocene sediments, all analogous to correlative materials on Timor (Brouwer, 1922). As on Timor, Permian limestone occurs with alkalic basalt. Triassic and Jurassic strata are mostly shallow-water fossiliferous terrigenous shale and sandstone and subordinate marl and limestone. The Upper Cretaceous includes chert, white and red limestone, and granule conglomerate derived from continental sources. Jurassic and Cretaceous abyssal sediments, including red shale, red limestone, red radiolarian chert, and manganese nodules, also are present. Eocene nummulitic limestone is intercalated tectonically with older rocks. Neogene foraminiferal limestones are less deformed but have moderate to steep dips. Young reef limestones are raised to about $450 \mathrm{~m}$ above sea level. Mud volcanoes occur on Roti, as on Timor and other islands of the outer Banda Arc.
SAVU

The outer-arc ridge trends southwestward through Timor and Roti, then swings to the west-northwest through small Savu (Sawoe, Sawu) Island, which lies at about long $122^{\circ} \mathrm{E}$. From there, the ridge trends slightly south of west, passing south of the continental ridge of Sumba (discussed in a succeeding section) to merge with the outer-arc ridge bounding the Java Trench on the north. Savu has a basement complex of "strongly folded," north-dipping "green permian rocks" containing Permian corals, limestone bearing Upper Triassic mollusks, and undated sandstone and radiolarite, according to van Bemmelen (1949, p. 533). Analogy with nearby Roti and Timor suggests that the old rocks occur as allochthonous masses within melange and an imbricated complex. A section of $500 \mathrm{~m}$ of little-deformed lower and middle Pliocene calcilutite is exposed on northern Savu and is overlain offshore by about $1,000 \mathrm{~m}$ more of strata that probably are mostly sandstone and shale (Crostella and Powell, 1976).

Raijua (or Raidjua, or Renjuva) Island, on the outer-arc ridge just west of Savu, is still within the negative-anomaly belt: a negative regional-isostatic anomaly was determined by Vening Meinesz (1954) midway between Raijua and Sumba to the northwest. The oldest dated rocks of Raijua are Paleogene (Eocene?) marls containing quartz grains and large shallow-water foraminifers (Verbeek, 1908b; summary given by van Bemmelen, 1949, p. 533). The presence of undated "red limestone fragments" suggests analogy with the melange terrains of Savu, Roti, and Timor.

\section{NORTHWARD THRUSTING NEAR SAVU}

An excellent reflection profile (fig. $72 C$ ) just east of Savu shows young, broadly arched strata to be overthrust from the south by a northward-imbricated mass of sedimentary rocks. Crostella and Powell (1976) showed this thrust to cross northernmost Savu to the west of the profile and to trend generally eastward east of the profile to project to the north of Roti and western Timor (where, however, northward thrusting is not suggested by the profiles of figure 74). They regarded the imbricated mass as "a gravity slide (olistostrome)," an interpretation not easily reconciled with the moderate south dip of its base. My own inference is that the northward thrusting represents surficial back-thrusting within the zone of tectonic transition between little-deformed strata of the outer-arc basin (and the Sumba minicontinent?) and the melange and imbricated materials of the outer-arc ridge, within which the dominant structure is south-directed thrusting.

\section{ISIAANDS EAST OF TIMOR}

The small islands that trend east from north of the east tip of Timor resemble Timor. Kisar exposes biotite and hornblende schist and metagabbro (van Bemmelen, 1949, p. 472; Kuenen, 1942). Leti has widespread melange in the 
north: tectonically interjumbled blocks and masses of serpentinite, varied metamorphic rocks (glaucophane and crossite schist, hornblende schist, biotite schist, greenschist, quartzite), crystalline limestone, granodiorite and diorite, basalt, fossiliferous Permian and Triassic limestone, Cretaceous calcareous sandstone, middle Teritary lepidocycline limestone, and abyssal pelagic sediments (Brouwer, 1915b; Molengraaff, 1915b). The south part of Leti is dominated by graywacke, sandstone, sandy shale, shale, arkose, quartz sandstone, and a little limestone, which have yielded Permian invertebrates in many localities; these rocks are steeply dipping, much sheared parallel to bedding, and include much scaly clay. The island of Moa contains much ophiolite: peridotite, calcic gabbro veined by trondhjemite, basalt, and red radiolarian chert (Brouwer, 1918a, b). Luang has shallow-water Permian sediments, and Sermata greenschists (Brouwer, 1921a).

\section{EASTERN ISILANDS}

The eastern part of the outer ridge of the Banda Arc forms the $180^{\circ}$ bend that connects the northern and southern limbs. The islands that rise from this sector of the ridge all appear to be formed of lower Neogene melange, overlain by upper Neogene sediments. They are mentioned here in order counterclockwise around the bend.

Babar exposes coherent and broken-formation sediments and polymict melange that includes basalt, serpentine, red chert, and fossiliferous shallow-water Permian, Triassic, and Jurassic strata (van Bemmelen, 1949, p. 475; Wiryosujono, 1977).

The Tanimbar Islands consist of much-deformed Eocene to upper Miocene or Pliocene shallow-water limestone and marl, Jurassic and Triassic clastic sedimentary rocks, Cretaceous limestone bearing pelagic foraminifers, Jurassic sandstone, and varied undated clastic sediments and crystalline rocks (van Bemmelen, 1949, p. 153, 473-474; Brouwer, 1923a; Heim, 1939, 1942). Sediments of contrasted types and ages are in structurally concordant imbricate intercalations, generally dipping westward. Clay strewn with chaotically varied exotic blocks is widespread. Even upper Miocene or Pliocene limestone and marl are tightly folded, crushed, and sheared (Heim, 1939), hence likely are involved in the melange in the east, whereas across strike in the west, Quaternary and Pliocene(?) limestone lies unconformably upon the melange. The Kai Islands contain much-deformed Eocene to Miocene sediments, mostly of shallow-water origin (van Bemmelen, 1949, p. 466-467; Brouwer, 1923b; Heim, 1939). The small Watubela and other islands between the Kai group and Seram display variously serpentinite, varied schists and gneisses, and undated sedimentary rocks (Brouwer, 1923b; Heim, 1939).

Heim (1942) reported about 50 areas in the Tanimbar and Kai Islands in which blocks of widely varied crystalline and sedimentary rocks were strewn chaotically in clay matrixes.
Some of these localities are active mud volcanoes, and Heim inferred that all the others represent extinct mud volcanoes, although likely scaly-clay melange accounts for many of his localities. The active mud volcanoes indicate that thrusting is going on very rapidly here and that it involves wet sediments. The thrusting is presumably part of the process of formation of subduction melange by underthrusting.

\section{SERAM AND BI'RI}

The large islands of Seram (or Seran, or Ceram) and Buru (Boeroe) on the north limb of the outer ridge of the Banda Arc display the products of imbrication and disruption of continental-shelf strata of New Guinea facies and of deep-water sedimentary rocks and ophiolite slices. Crystalline basement rocks probably of continental type occur both as slices in these complexes and as two possible minicontinental masses. Both islands are high and mountainous; altitudes reach $3,000 \mathrm{~m}$ above sea level in central Seram (fig. 66), and only slightly less on Buru.

Seram is shown by seismic reflection profiling (illustrated and discussed subsequently) to be the top of an allochthonous wedge of deformed rocks above southward-subducting continental-shelf strata of New Guinea. Seram displays the internal structure of the crest of that wedge. A northern belt, forming the north half of the island in the west and all of it in the east (fig. 67), consists of imbricated rocks and melange dominated by unmetamorphosed sedimentary rocks in shallow-water facies (van Bemmelen, 1949, p. 79, 442-451; Germeraad, 1946; Rutten, 1919, 1920; van der Sluis, 1950; Valk, 1945). Abundant rock types in this northern belt include Upper Triassic or Jurassic graywacke, sandstone, shale, slate, and radiolarite; coralline Upper Jurassic limestone; pelagic Cretaceous limestone and marl; Paleogene and lower Miocene orbitoidal limestone; and Paleogene and Miocene deeper water clastic rocks and pelagic limestone. Fossils are abundant, and fossils and host rocks of the Jurassic, Cretaceous, and shallow-water Paleogene resemble those of Misool and the nearby New Guinea continental shelf, described in a later section. Within this northern belt in Seram, rocks tend to represent deeper water environments in the south than in the north, and the southern part of the belt consists primarily of clastic rocks. The strata are highly deformed and are chaotically juxtaposed by thrusting. The northern part of the belt contains in central Seram a large coherent mass of shallow-water rocks, mostly limestone, extending from Upper Cretaceous to lower Miocene, but elsewhere in the terrain breccias, strongly sheared rocks, broken formations, and melange are widespread (E. A. Gribi, Jr., 1973, and written and oral communs., 1972). The common melange has a matrix of scaly clay, and clasts and intersheared lenses of all sizes of shale, graywacke, and limestone, including middle Tertiary rocks, and some variably metamorphosed rocks. Dips are steep to moderate 


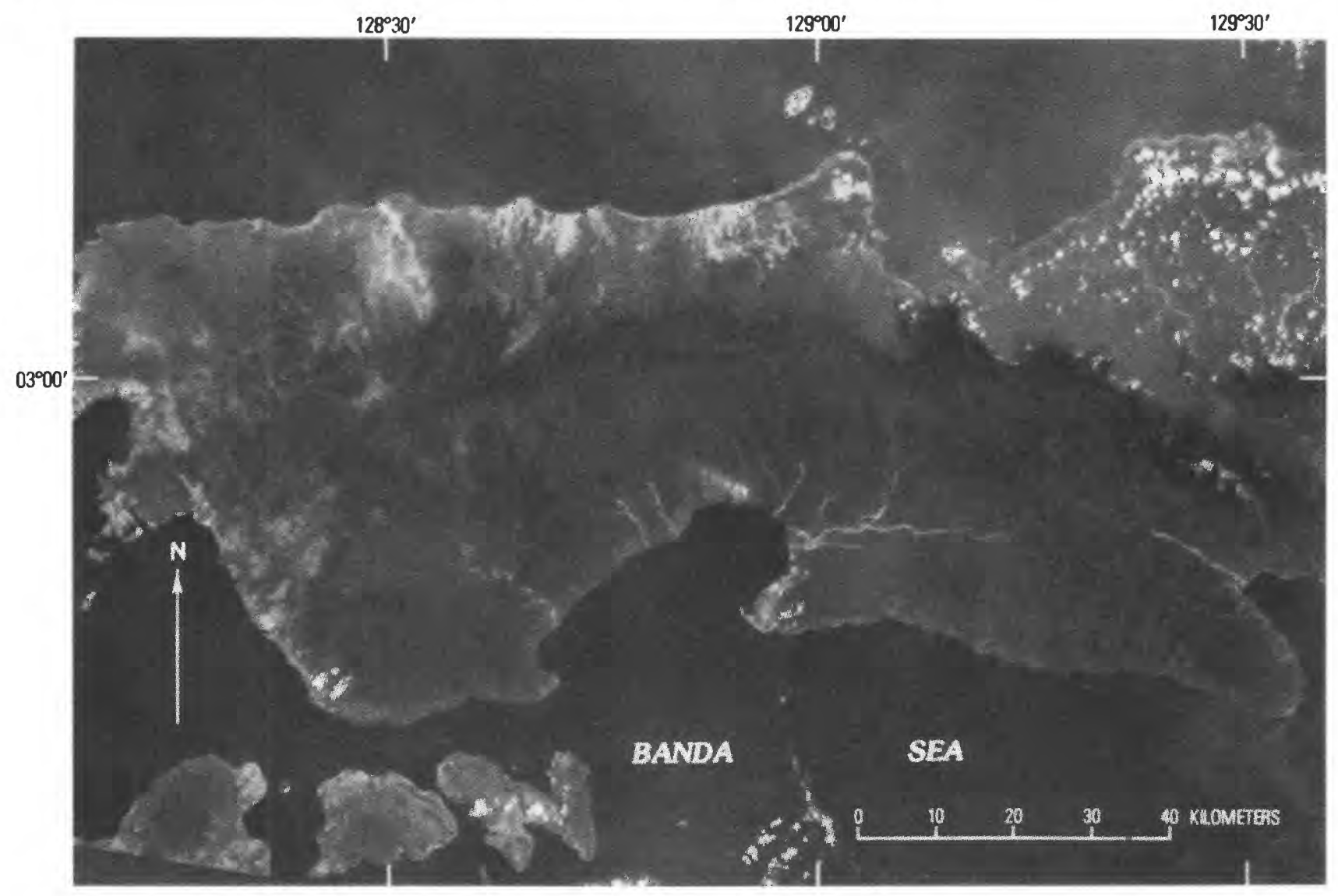

FIGURE 66.--Landsat image of central and western Seram. See fig. 67 for geologic map. NASA-ERTS picture 1073-01045, October 1972.

and are mostly southward. Imbricated sheets of sedimentary rocks are more common, and polymict scaly-clay melange is less common on Seram than on Timor, according to Subardjio Tjokrosaputro (oral commun., 1976), who has worked extensively on both.

Slivers of likely continental basement rocks of granulite and amphibolite facies are intersliced with the sedimentary rocks in this northern belt in both central and eastern Seram (fig. 67; Germeraad, 1946; van der Sluis, 1950; Valk, 1945). The crystalline rocks are dominantly biotite-quartz-feldspar gneisses bearing potassic feldspar or plagioclase, or both. Common accessories are cordierite, brown or green hornblende, pale-colored pyroxene, garnet, and spinel. There is also much amphibolite. These rocks are much sheared, some to mylonite, and variably retrograded.

The southern belt of imbricated rocks and melange is dominated by phyllite metamorphosed from quartzose clastic sediments (Germeraad,1946; Valk, 1945). The contact between northern and southern zones (represented on figure 67 by a line) is a broad zone of intermixing and gradation. Throughout the southern belt, large and small slices of ophiolite, represented by greenschist, amphibolite, basalt, gabbro, serpentinite, peridotite, and radiolarite are abundant. Glaucophane schist also is present in the south (Subardjio Tjokrosaputro, oral commun., 1976).
Southwestern Seram and nearby Ambon contain numerous masses of crystalline rocks of continental type, like those intersliced with the sediments of the northern belt. Gneissic and granitic rocks, including cordierite biotite quartz monzonite, occur in the southern tip of southwestern peninsular Seram (fig. 67; Schroeder van der Kolk, 1902a; Valk, 1945). In a larger region in far-western Seram, crystalline rocks of continental type-granulite- and amphibolite-facies gneisses with abundant biotite and potassic feldspar or sodic plagioclase, and various combinations of cordierite, sillimanite, kyanite, andalusite, garnet, and hornblende - are interspersed with ultramafic rocks and low-grade metasediments (fig. 67; Valk, 1945). Ambon also contains cordierite-biotite quartz monzonite and other granitic rocks, adjacent to peridotite and serpentinite, which in turn are adjacent to fossiliferous shallow-water Triassic or upper Paleozoic quartz sandstone that is moderately to steeply dipping (van Bemmelen, 1949, p. 456; Verbeek, 1905). In each case, relationships of the granitic rocks to flanking rocks are undefined, but nowhere has contact metamorphism been recognized.

The Neogene(?) volcanic rocks of Ambon are andesite, dacite, and rhyolite; range from 60 to 80 percent in $\mathrm{SiO}_{2}$ content and from 1 to more than 5 percent $\mathrm{K}_{2} \mathrm{O}$; and contain 


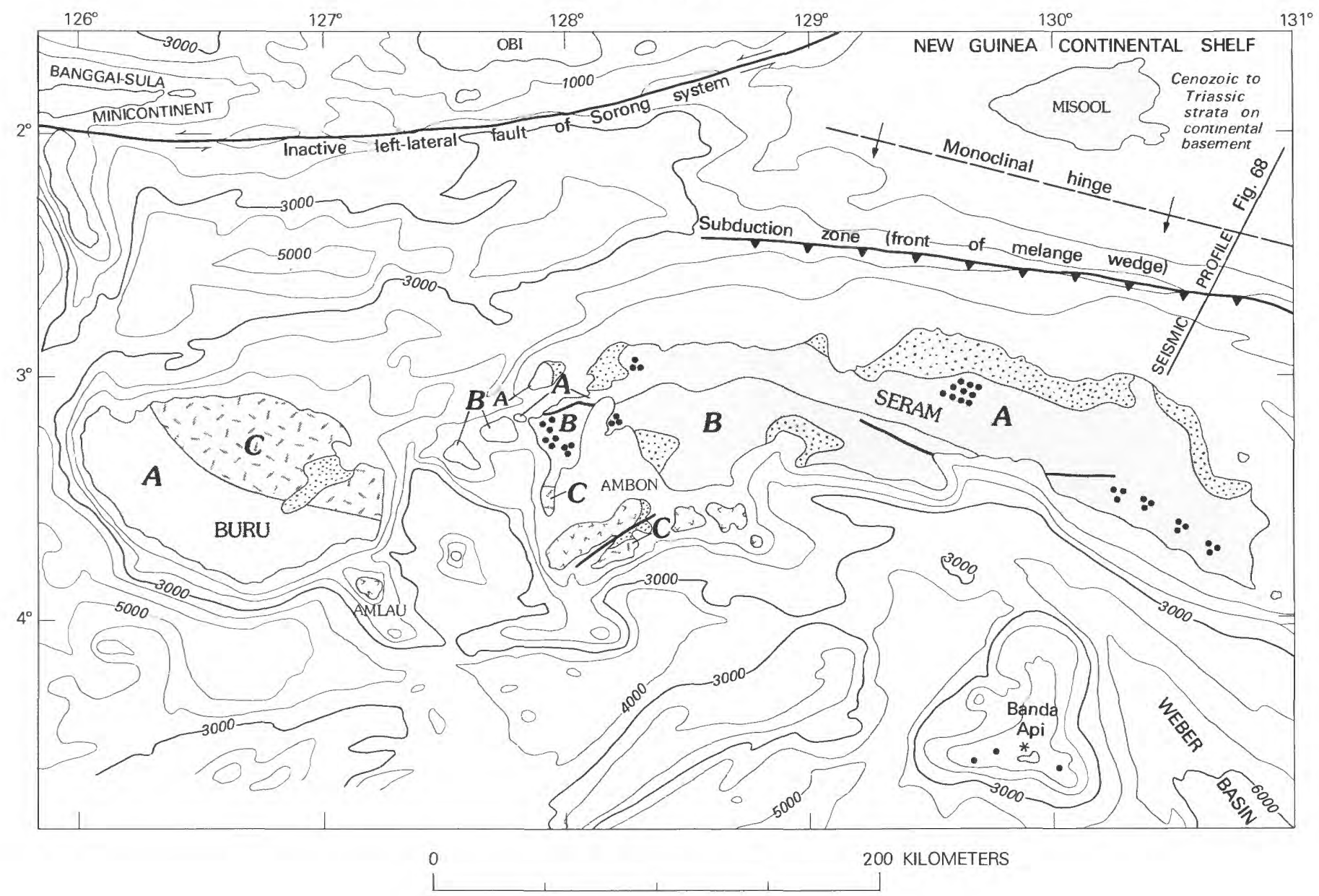

EXPLANATION
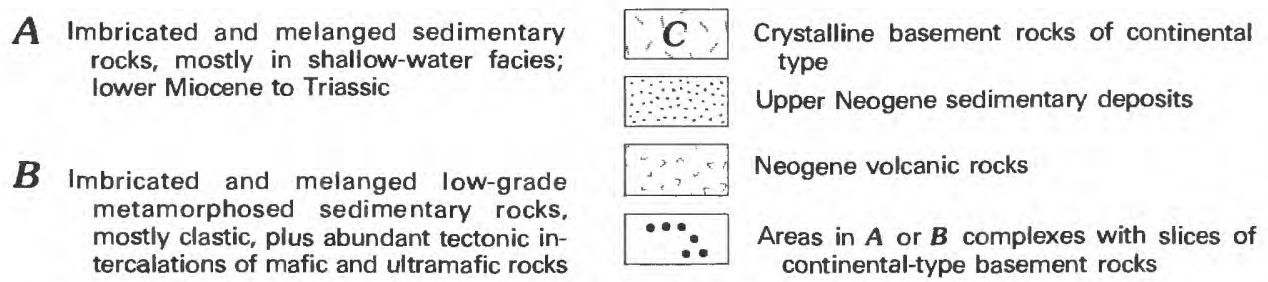

FIGURE 67.-Geologic map of Buru and Seram. Geology compiled and interpreted from sources cited in text. Bathymetry, shown by 1,000-m contours, from a compilation by Robert L. Fisher, Scripps Institution of Oceanography.

xenocrysts of cordierite (Kuenen, 1949). Both the bulk composition and the xenocrysts of the volcanic rocks suggest that a continental basement may underlie them. Both oxygen and strontium isotopes indicate a major contribution by continental material, either as subducted terrigenous sediments or as underlying crust, to the magmas; the ratio of ${ }^{87} \mathrm{Sr} /{ }^{86} \mathrm{Sr}$ reaches at least 0.7175 (Magaritz and others, 1978).

Southwestern Seram and Ambon may represent a fragment of old continental crust, or a tectonic hash of slices of continental crust in a subduction-produced complex, or the product of Neogene(?) metamorphism of terrigenous strata by a hot overthrust sheet of young oceanic crust and mantle.
The last-mentioned option was suggested for a similar terrain in northern Timor.

Buru displays rock complexes similar to those of Seram, but in different geographic order. The southwest half of Buru consists of chaotically juxtaposed sedimentary rocks (fig. 67): Triassic and Jurassic sandstone, shale, and shallow-water limestone; Upper Jurassic tuff; Cretaceous cherty and pelagic limestone; and Paleogene and(?) lower Miocene shallow-water limestone (van Bemmelen, 1949, p. 450-455; Rutten, 1927, p. 741-747; Wanner, 1918). This southern terrain of Buru likely represents the imbrication and disruption of strata derived from the New Guinea 

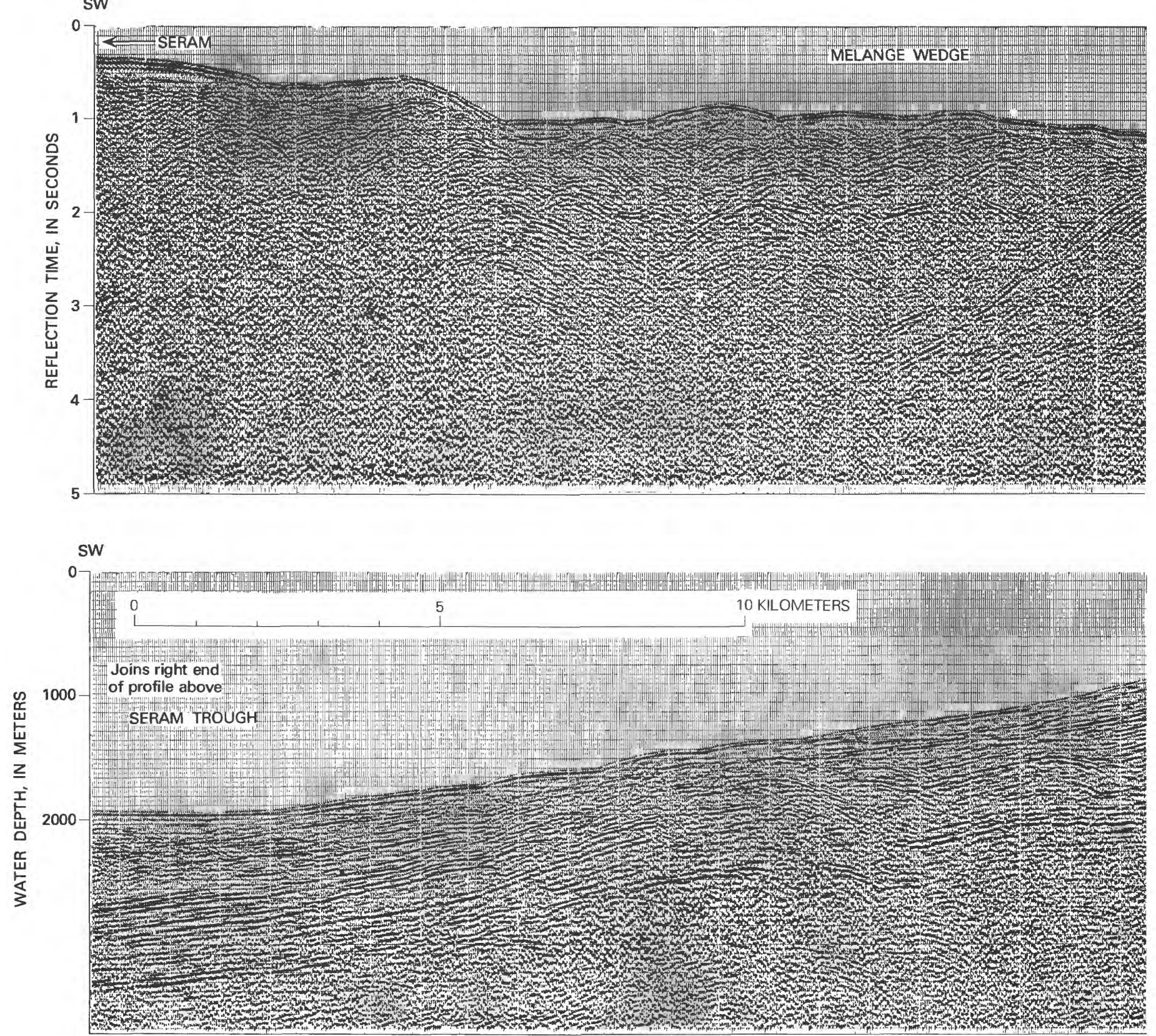

FIGURE 68.--Seismic-reflection profile across the Seram Trough, illustrating subduction of continental-shelf strata beneath the melange wedge of Seram. Approximate compressional velocities: melange wedge, about $7 \mathrm{~km}$ southwest of edge of Seram Trough, velocity decreases upward from about 4 to about $2 \mathrm{~km} / \mathrm{sec}$; sedimentary wedge beneath Seram Trough (to 4-sec depth beneath southwest edge of trough), velocity very low; continental-shelf strata, velocity decreasing upward from about 5 to about $3.5 \mathrm{~km} / \mathrm{sec}$ under continental slope and trough, undetermined under melange wedge. Location of profile shown in figure 52. Profile by Western Geophysical for Phillips Petroleum Company Indonesia; 12-fold stacking by common depth point method.

continental shelf. Northeastern Buru consists of crystalline rocks, which although poorly known include phyllite, chlorite schist, mica schist with or without garnet, amphibolite, biotite gneiss bearing orthoclase, and biotite granite (Schroeder van der Kolk, 1902b; Wanner, 1918). The granite likely indicates a continental basement.
The geology of Seram can be accounted for largely by subduction of the New Guinea continental shelf, with resulting imbrication of the shelf strata and their continental basement with the deeper water strata and their oceanic basement which initially lay relatively farther south or west. The crystalline rocks of southwestern Seram may indicate 


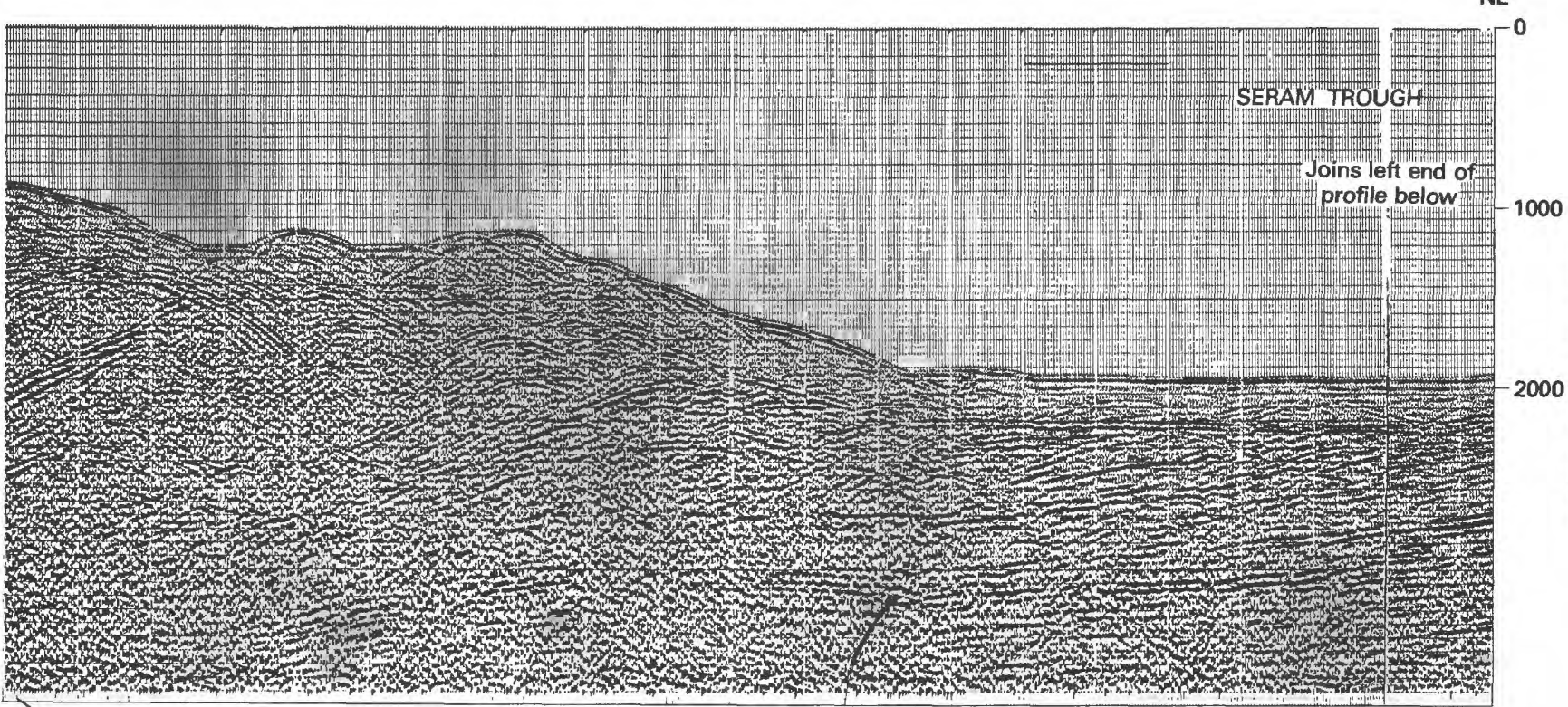

Subducting shelf strata

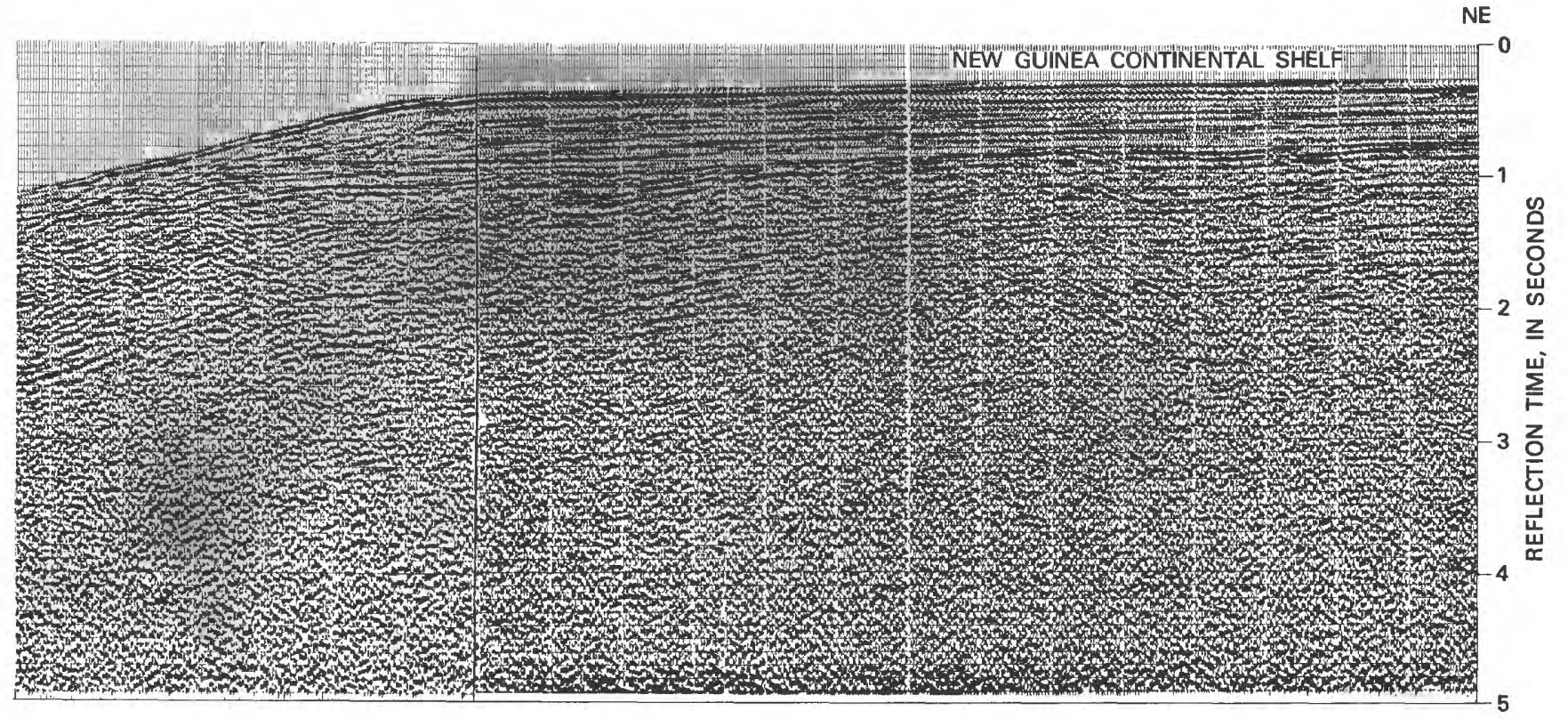

that a continental fragment was incorporated into the tectonic system.

Buru presents more complex problems, for it now faces deep ocean on both sides. Buru and the continental fragment of southwestern Seram may have been torn from northwestern New Guinea by strike-slip faults, carried westward in the Banda Sea region when New Guinea lay south of its present latitude, and swept up by the Banda Arc as the arc migrated eastward in middle Tertiary time.

The coastal basins of northern and northeastern Seram are filled by lower Pliocene and younger strata, mostly thinner than $2 \mathrm{~km}$, which are strongly unconformable on the older terrain (Gribi, 1973; Zillman and Paten, 1975). The Pliocene is typically in bathyal facies, whereas the Pleistocene is neritic. The total section is about $3 \mathrm{~km}$ thick in north-central Seram. A little oil is produced in northeastern Seram from stratigraphic traps formed by bar and shoreline sands.

The Bouguer gravity anomalies of Seram are symmetrical to those of Timor (Milsom, 1977). Low negative values near the north coast of the island give way gradually to a zero value north of the midline, then more abruptly to positive anomalies, which generally are +100 mgals near the south coast. 
TRENCH-THE TIMOR AND SERAM TROUGHS

The trace of the subduction system follows a trench - the Timor, Aru, and Seram Troughs - around the outside of the Banda Arc. This trench, only 1,500-3,500 m deep, is far shallower than are parts of the outer-arc basin farther inside the arc system. Shallow-water continental-shelf strata, and under them continental crust (Shor and others, 1977), are being overridden by and incorporated into the melange wedge of the outer-arc ridge.

\section{SERAM TROUGH}

Subduction of New Guinea continental-shelf strata beneath Seram is shown by excellent reflection profiles (figs. $68,69 A$ ). The moderate- and high-velocity shallow-water Cenozoic and Mesozoic strata of the New Guinea continental shelf inflect downward at the edge of the shelf; this inflection is inferred to be a hinge that is migrating landward. The shelf strata are disrupted by faults and slumps on their journey down the continental slope (fig. 68). At the base of the slope and in the Seram Trough, the strata are covered by a southward-thickening prism of low-velocity deep-water sediments and then are overridden by the melange wedge of Seram. The smoothly subducting shelf strata can be traced on the profiles for horizontal distances of $19 \mathrm{~km}$ (fig. 68) and $20 \mathrm{~km}$ (fig. 69A). The wedge displays internal reflections in its northern part in fig. 68 , showing it to be in general imbricated with moderate south dips that are markedly discordant to the gentle dip of the subducted shelf section beneath. (Hyperbolic patterns in the wedge typically represent reflections from point sources, not anticlines.) The southern part of the wedge in figure 68 , and all of it in figure $69 \mathrm{~A}$, lacks internal reflections and presumably is more chaotic in structure. At least the upper part of the wedge consists of very low-velocity materials and hence likely is dominated by disrupted, poorly consolidated trench sediments. A similar profile across the Seram Trough was presented by Usna (1977).

The Lamont-Doherty reflection profiles across the Seram Trough (fig. 70 ) provide further information. In profile $B$, which crosses the profile of figure 68 , the low-velocity sediments of the trough are almost transparent acoustically, in contrast to the opaque shelf strata. The low-velocity sediments appear to be humped up on the Seram side to form the visible upper part of the melange wedge; apparently as the consolidated shelf strata are smoothly subducted, the unconsolidated trench sediments are shoveled up at the front of the wedge. On profile $C$ also it appears that the upper front part of the wedge consists of rumpled sediments, although here trench and shelf strata cannot be distinguished in the thick section beneath the trough.

Southward subduction at the Seram Trough is illustrated also on profiles $C$ and $D$ of figure 71 .
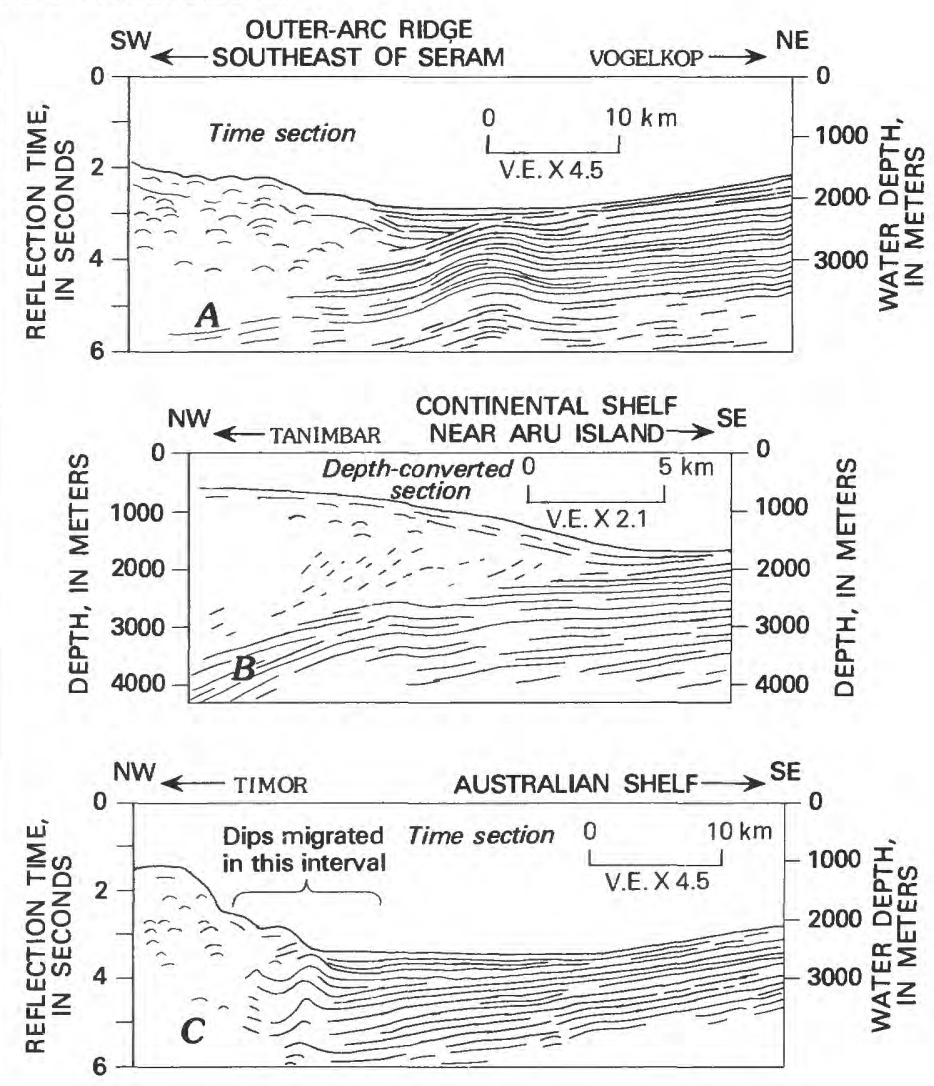

FIGURE 69.-Seismic-reflection profiles across the trench around the Banda Arc. In each profile, confinental-shelf strata, overlying continental crust (not visible), are overridden by the melange and imbricated materials of the outer-arc ridge (Seram-Tanimbar-Timor). As the overriding progresses, the small prism of trench-filling turbidites is deformed first, and then the shelf strata in general order progressively downward. The many diffraction events in the overriding wedge suggest complex and incoherent internal structure. Location of profiles shown in figure 52. Traced from the multichannel-processed R. V. Gulfrex lines published by Montecchi (1976, figs. 2, 3, and 4).

\section{TIMOR TROUGH}

The Timor Trough, the part of the trench of the Banda Arc system that is south of Timor and nearby parts of the outer-arc ridge, has a flat floor 1,800-3,400 m deep and 3-20 $\mathrm{km}$ wide. The flat floor is the top of a small northward-thickening prism of sediments deposited in the dihedral angle between the northward-tilted strata of the Australian continental shelf and the southward-sloping top of the outer-arc wedge of strongly deformed materials. Reflection profiles show the shelf strata to dip gently beneath the strongly deformed materials. Excellent multichannel reflection profiles south of Roti and Timor were presented by Beck and Lehner (1974, fig. 24), Crostella and Powell (1976, figs. 5 and 10), and Montecchi (1976, figs. 3 and 10-13). Three of these profiles are presented here in 

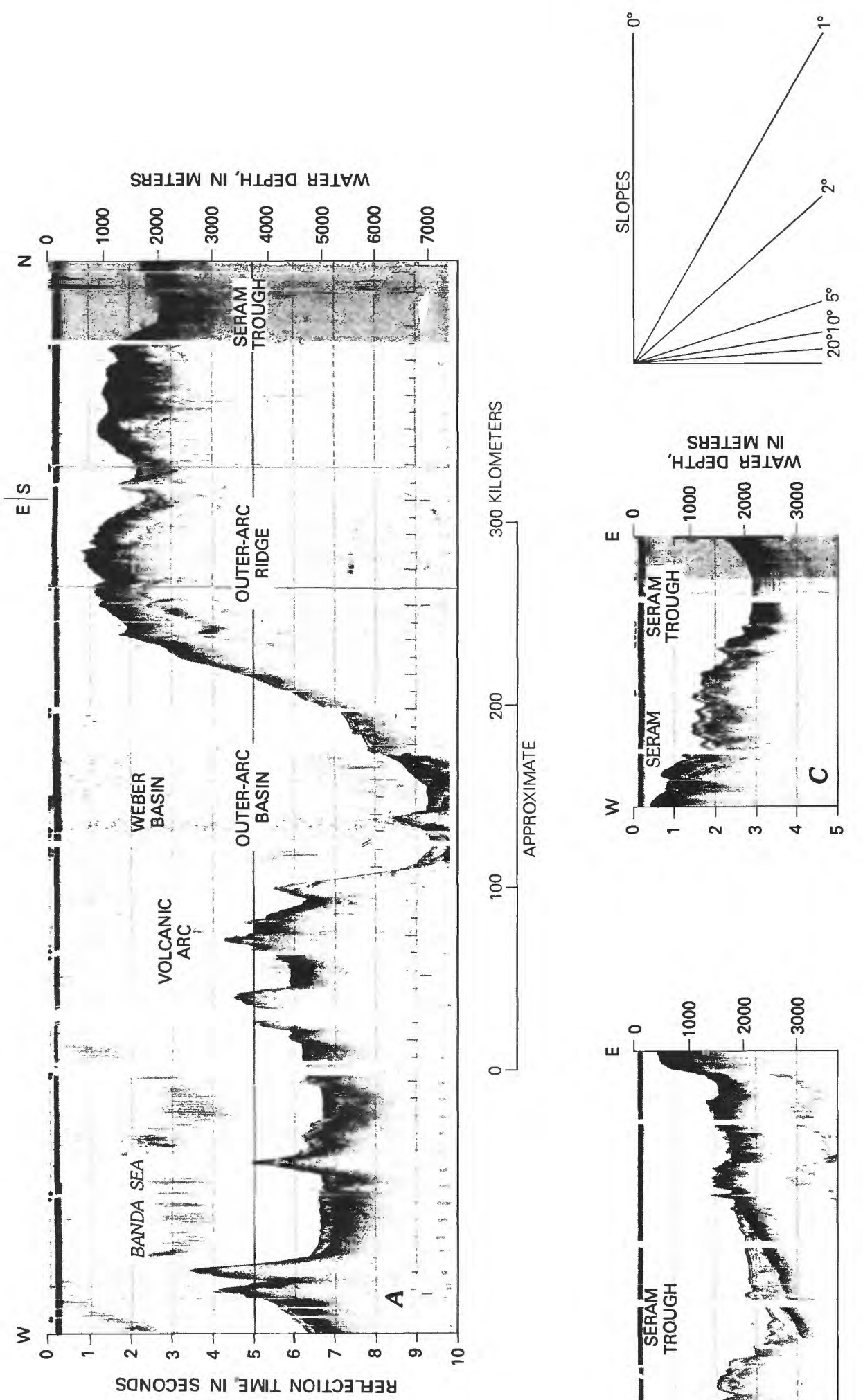

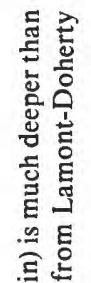
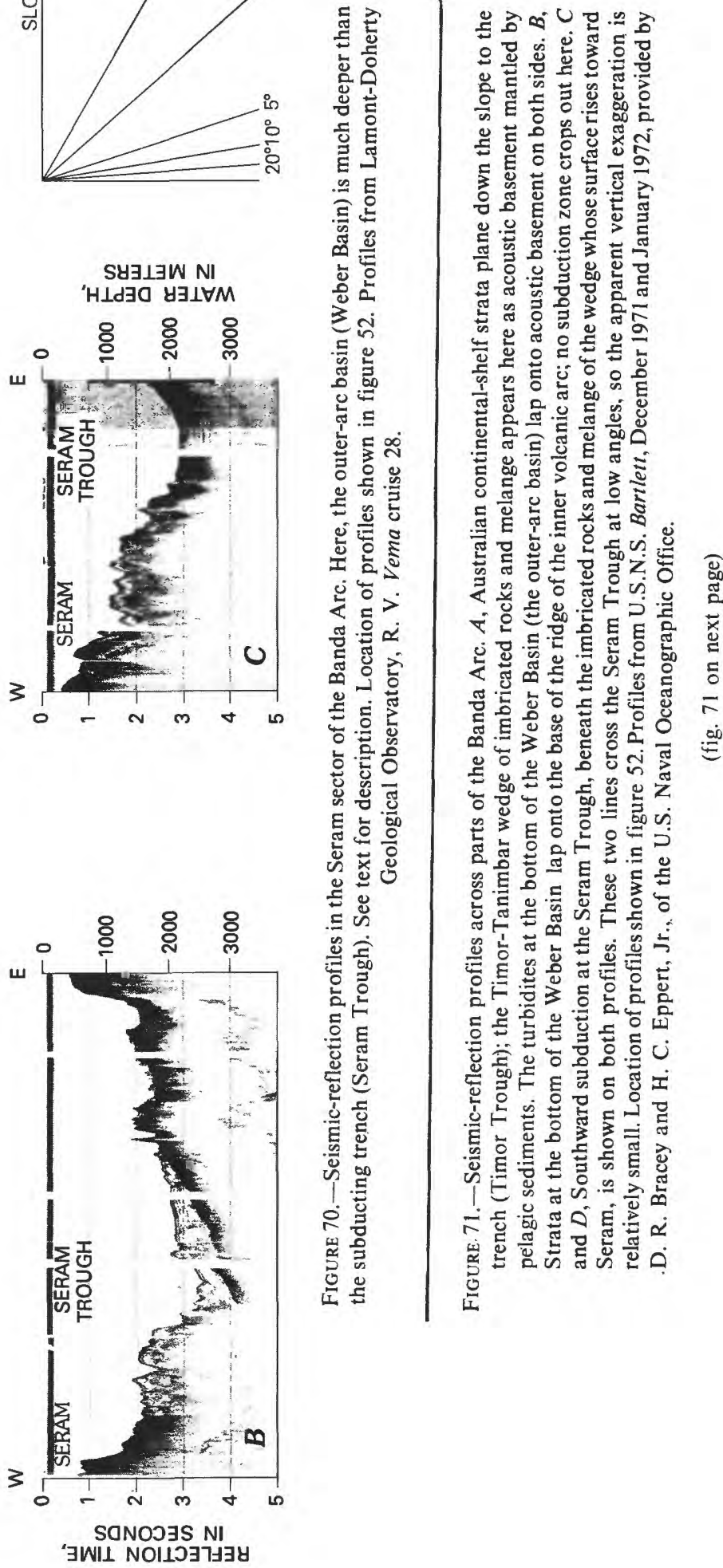

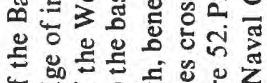

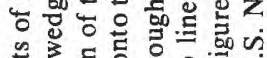

壳

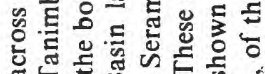

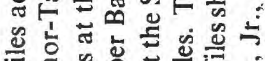

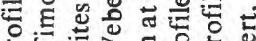

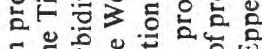

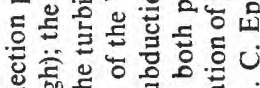

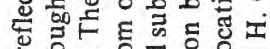

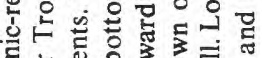

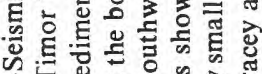
1 E क्ष

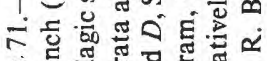

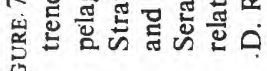

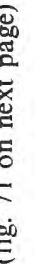



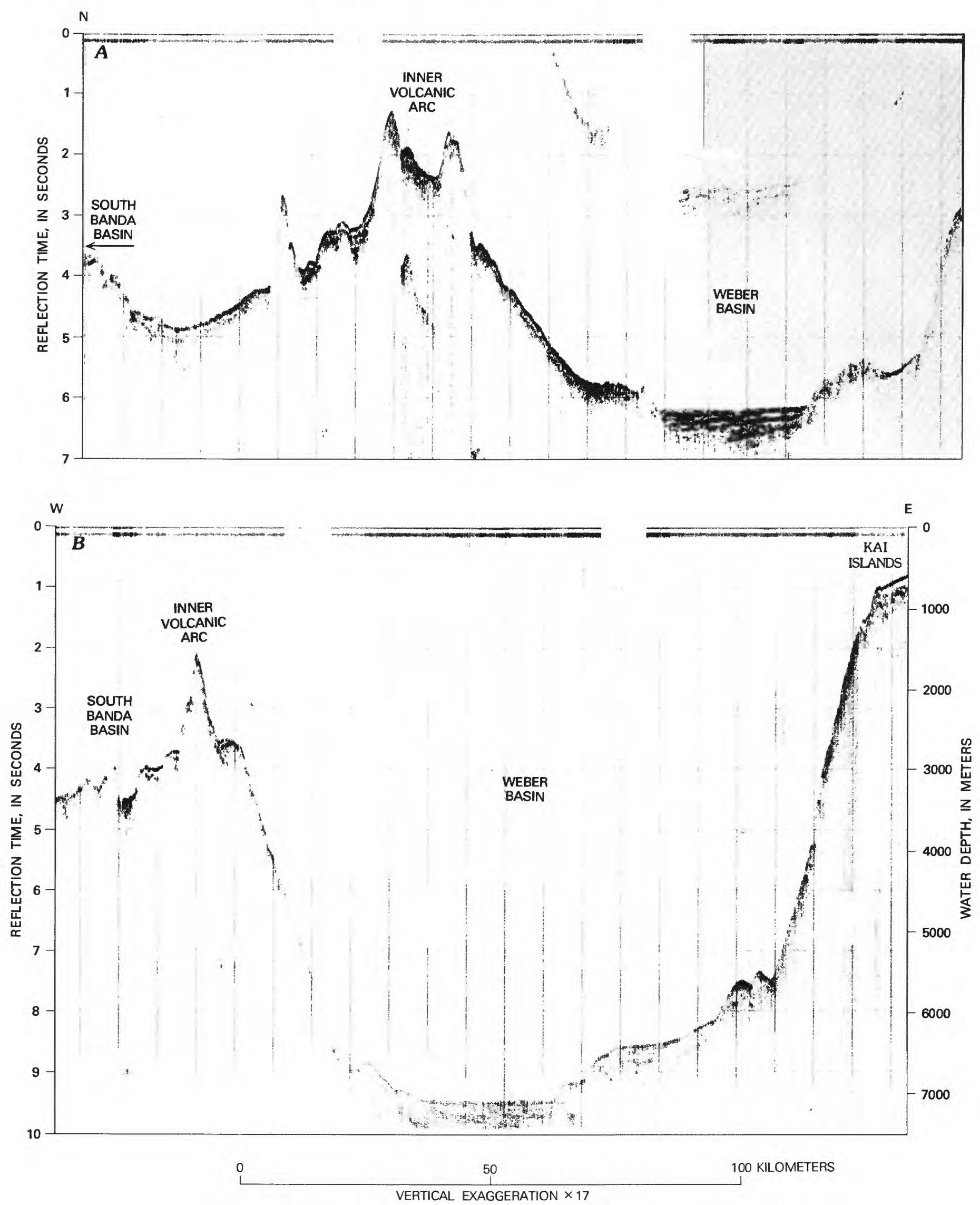

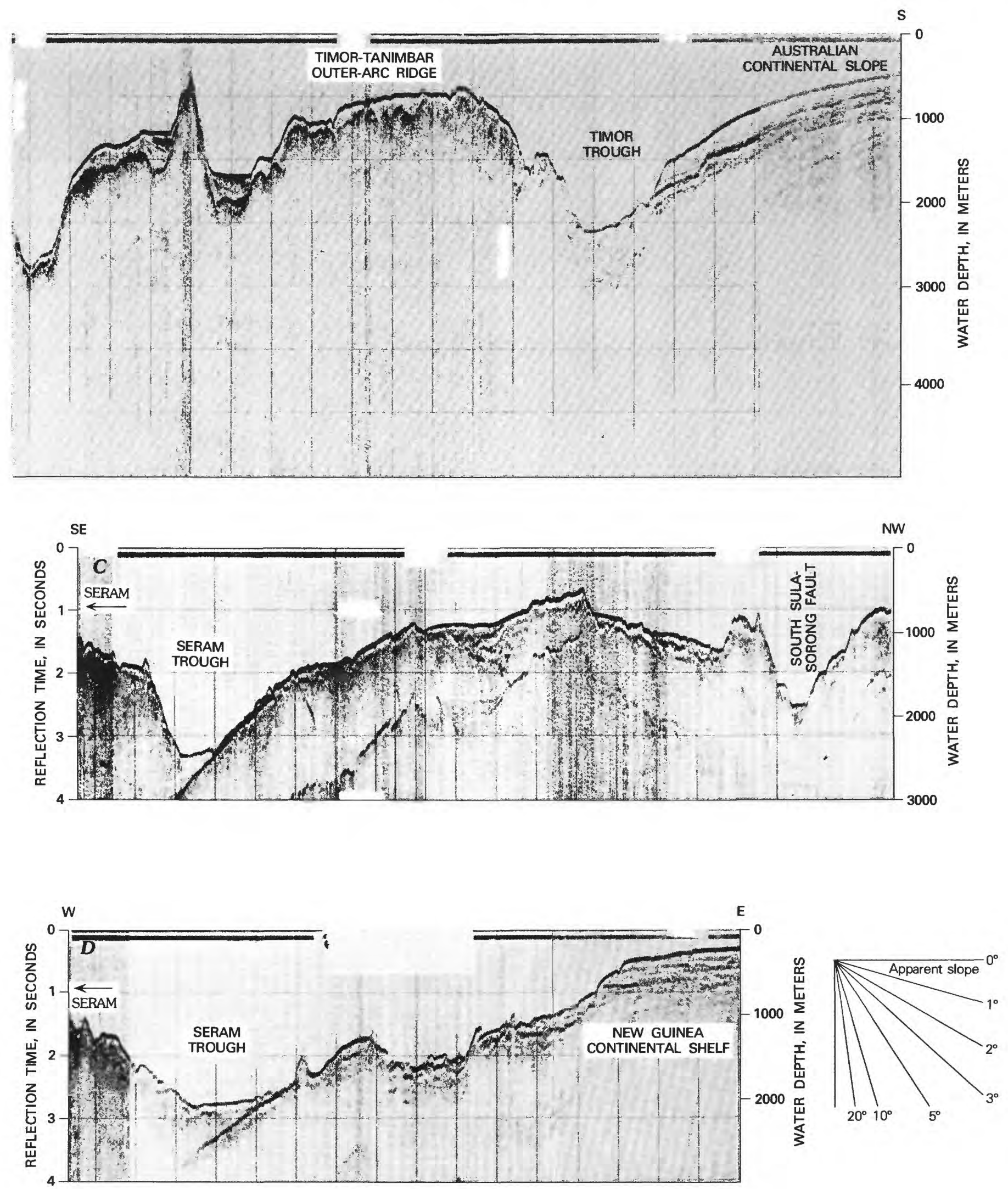

Figure 71.-Caption is on page 139. 
142

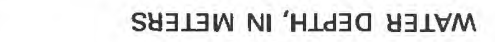

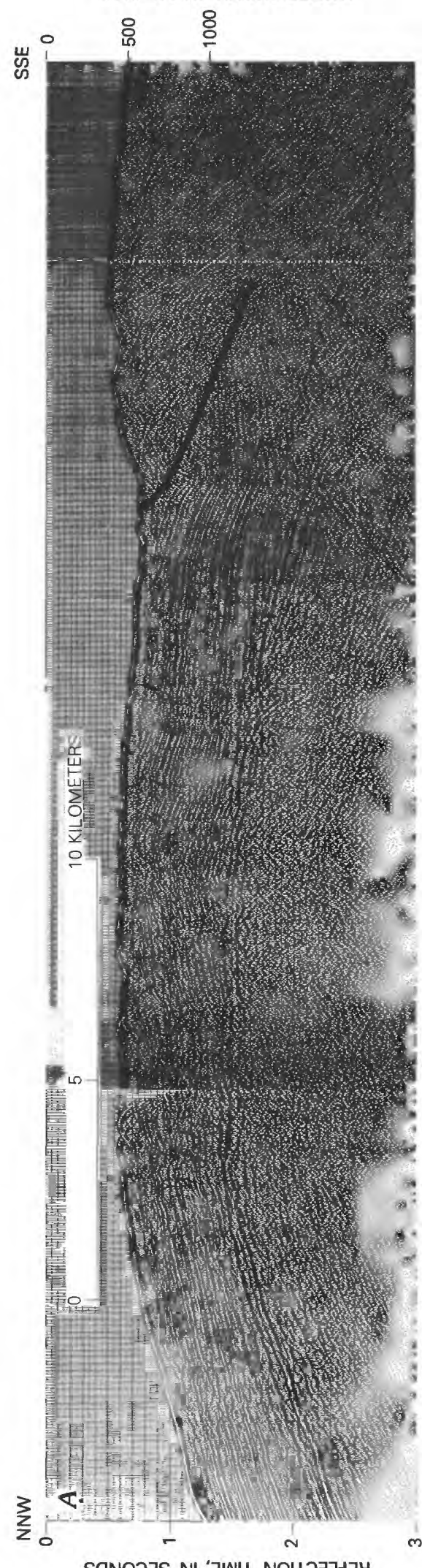

TECTONICS OF THE INDONESIAN REGION

SY $\exists \perp \exists W N^{\prime}$ ' $H \perp d \exists O \quad Y \exists \perp \forall M$

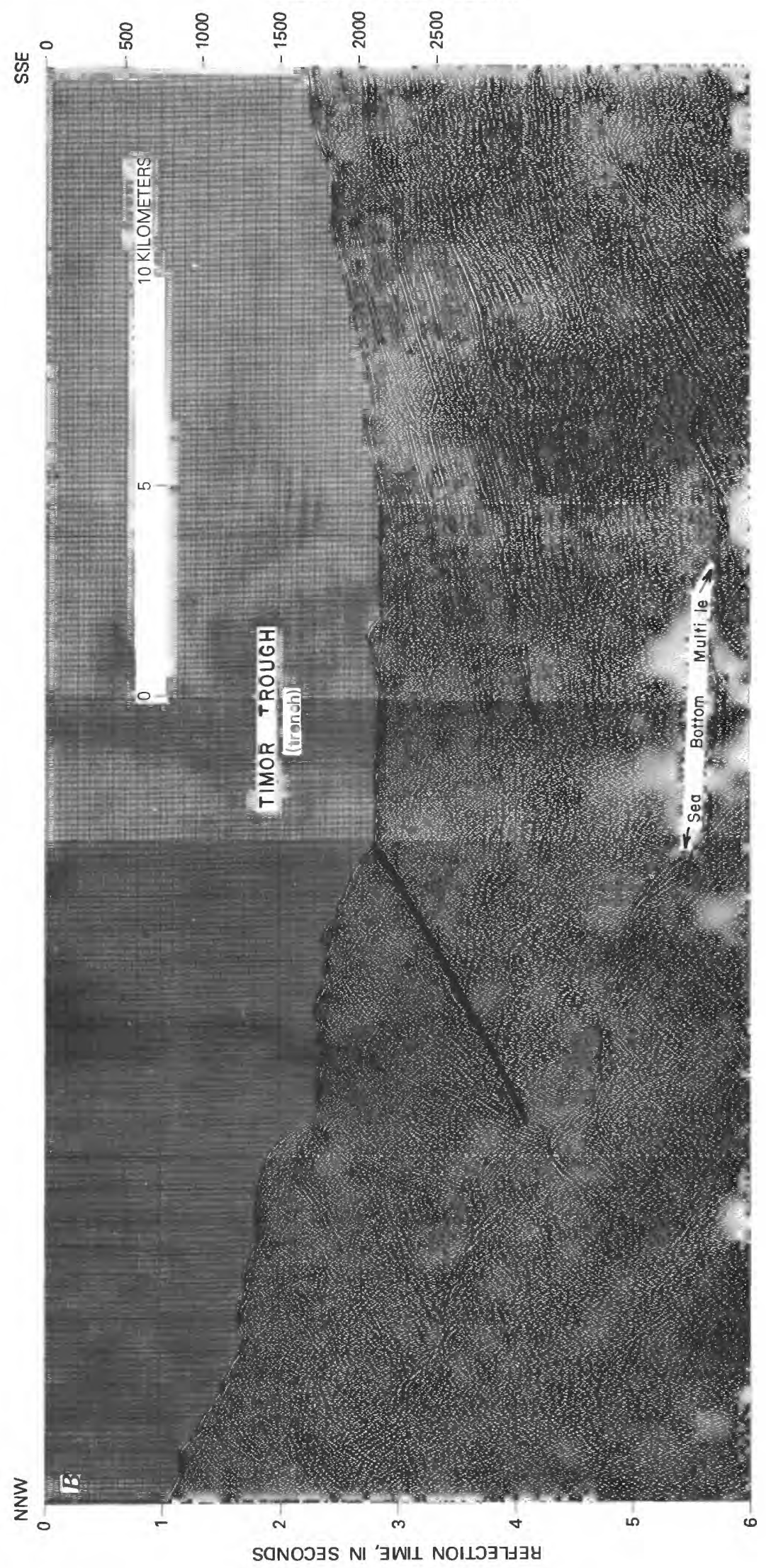




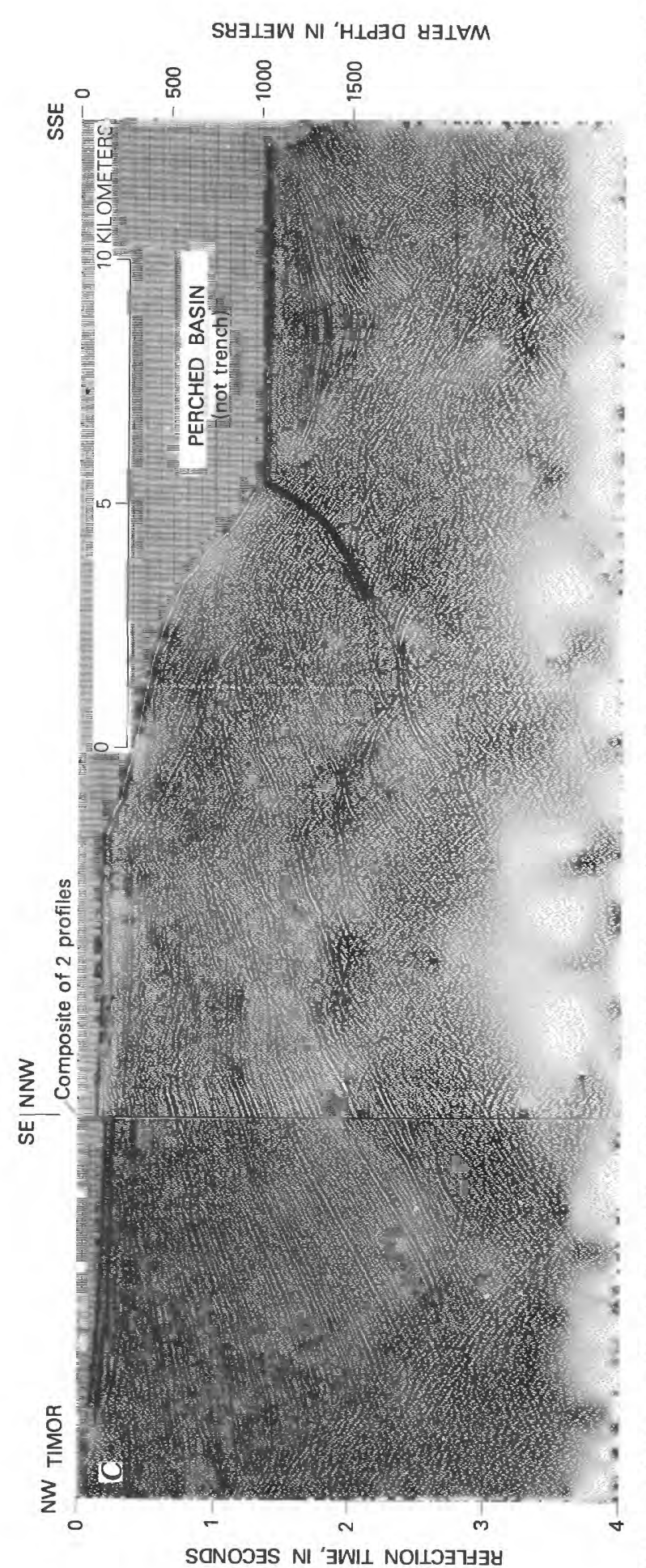

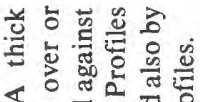

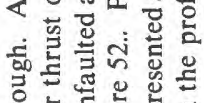

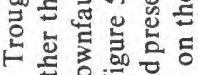

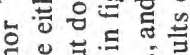

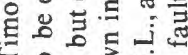

올

热识

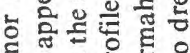

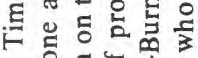

돈 현현

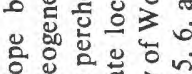

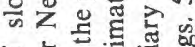

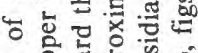

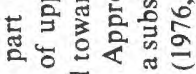

总焉运这

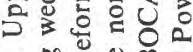

ن.

능

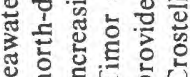

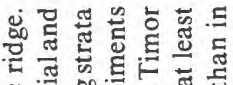

5.0

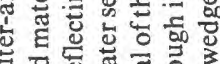

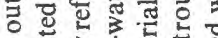

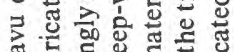

की है 옹 क्ष

>

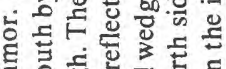

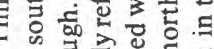

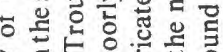

릉 응

든 $\underline{0}$ 의

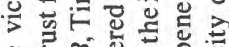

ક

ㄷํ웜

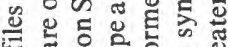

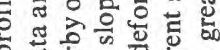

픈

क क 대을

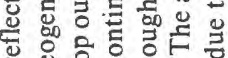

它

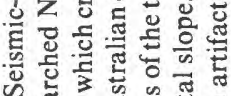

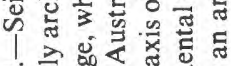

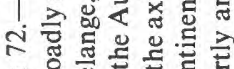

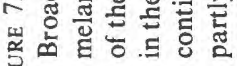

焉 
figures 72 and $69 C$. A series of profiles crossing the trough every $60 \mathrm{~km}$ was made for the Australia Bureau of Mineral Resources, Geology and Geophysics (Garnet, 1975; Watt, 1976); four of these, which presently are available only as single-channel monitor records, are illustrated on figure 73. The strongly reflecting Australian shelf strata dip gently beneath the toe of the outer-arc wedge, which is seen to be imbricated coherently in some profiles but which appears to be quite incoherent in others. The materials of the Timor Ridge are everywhere allochthonous with regard to the subducted shelf strata beneath the wedge.

That the strongly reflecting strata beneath the tectonic wedge are shallow-water continental-shelf strata is demonstrated by hole 262 of the Deep Sea Drilling Project (Veevers and Heirtzler, 1973; Veevers and others, 1974, p. 193-278) and by reflection profiling. Hole 262 was drilled in the axis of the Timor Trough, south of the west end of Timor in water 2,300 m deep (figs. 52 and $74 B$ ). The hole penetrated a prism, $400 \mathrm{~m}$ thick, of flat Quaternary and upper Pliocene planktonic ooze, and then $28 \mathrm{~m}$, to the bottom of the hole, of upper Pliocene shallow-water foraminiferal dolomitic mud and dolomitic shell calcerenite. On the Australian side of the trough, the shallow-water Neogene section of the Australian shelf can be seen in reflection records to turn downwards at the shelf edge and to plane gently down the continental slope, broken by many slumps and faults in some sectors but not in others (Veevers, 1971a; Australia Bureau of Mineral Resources, Geology and Geophysics, Gravity, Magnetic, and Seismic Profile Maps C51-12, C52-5, -6, -7, -8, and -9, and D51-1, -2, and -6 , all published in 1969). Veevers (1971a) found that a regional shallow-water unconformity, dated by drilling on the shelf as between middle Miocene and lower Pliocene strata, could be followed down the slope to a present water depth of more than $700 \mathrm{~m}$. Several other stratigraphic features formed on the shelf can also be traced down the continental slope into the Timor Trough (Branson, 1975).

A seismic-refraction study by $\mathbf{R}$. W. Raitt (as cited by Chamalaun and others, 1976) shows that the sedimentary rocks beneath the Timor Trough at about lat $9^{\circ} 10^{\prime} \mathrm{S}$., long $128^{\circ} 40^{\prime} \mathrm{E}$., are about $4 \mathrm{~km}$ thick and that the underlying crystalline crust is continental, having a compressional seismic velocity of about $6.03 \mathrm{~km} / \mathrm{sec}$.

The poorly consolidated strata deposited in the trough apparently provide most of the material for the thin edge of the tectonized wedge in at least some sectors. Montecchi (1976) gave interval-velocity data for a reflection profile south of central Timor that show the thin southern part of the wedge there to be of low-velocity materials ( $V p$ about 1.5 to $2.5 \mathrm{~km} / \mathrm{sec}$ ), as is the section of deep-water ponded sediments beneath the narrow flat floor of the adjacent trough, in contrast to the continental-shelf strata of higher velocity $(V p>3.5 \mathrm{~km} / \mathrm{sec})$ beneath both trough and wedge.

The present south boundary of the Timor Trough is a hingeline in the Australian continental shelf. It is reasoned elsewhere in this report that this hingeline marks the outer limit of downbowing caused by the weight of the tectonic wedge whose top is the outer-arc ridge. The hingeline must have migrated southward as the wedge has been enlarged. The subsidence of the shelf strata now at the axis of the trough amounts to about $2 \mathrm{~km}$ since the late Pliocene (as demonstrated by DSDP drillhole 262); this represents in part downbowing under the weight of the enlarging wedge and in part northward conveyor-belt motion of the Australian shelf as it inflected through the shelf-margin hinge.

Lamont-Doherty reflection profiles (fig. 74) provide more limited information. The thick Australian shelf section planes gently down the convex slope into the Timor Trough $(B, D, E, G)$. The upper part of the deformed wedge of Timor is formed of rumpled sediments $(B, D)$, which as at Seram appear to represent the upper part of the section in the trench: again, the competent, lithified shelf section is subducted gently, and the overlying soft sediments are scraped off at the front of the wedge. On profile $B$, coherent reflections across the Timor-Roti outer-arc ridge show much of the exterior part of the ridge to be a much-faulted anticline, presumably crumpled atop a melange wedge.

\section{TRENCH AROUND EASTERN PART OF ARC}

The same geometry of continental-shelf strata passing arcward beneath a wedge of strongly deformed materials characterizes the horseshoe curve around the eastern part of the Banda Arc. One reflection profile (Montecchi, 1976, fig. 4; fig. $69 B$ of this report) shows strongly reflecting shelf strata to dip gently for at least $15 \mathrm{~km}$ northwestward beneath the wedge of low-velocity deformed rocks east of Tanimbar. Profiles $69 A$, and $B$, $70 A$ and $C, 71 A, 73 D$, and $74 G$, show the simple monoclinal character of the Australian-New Guinea side of the trough, in contrast to the structurally complex, or acoustic-basement, character of the arc side.

\section{OUTER-ARC BASIN}

The outer-arc basin system of the Banda Arc is much less regular than is that of the Java-Sumatra region to the west. The crescentic Savu and Weber Basins, respectively west and east of Timor, are separated by a narrow saddle in the Timor sector itself. On the north limb of the arc, the basin system loses its identity behind Buru and western Seram.

The Savu Basin has a flat turbidite floor at about $3,000 \mathrm{~m}$ (fig. $74 A, D, E$ ). The very thick underlying strata define a broad syncline that has subsided concurrently with sedimentation, so that units thin toward both sides. The youngest strata show moderate deformation on the Timor flank of the basin in profiles $A$ and $E$, but only tilting in $D$. Profile $E$ also shows considerable deformation at the north edge of the basin, at the foot of the volcanic ridge. 

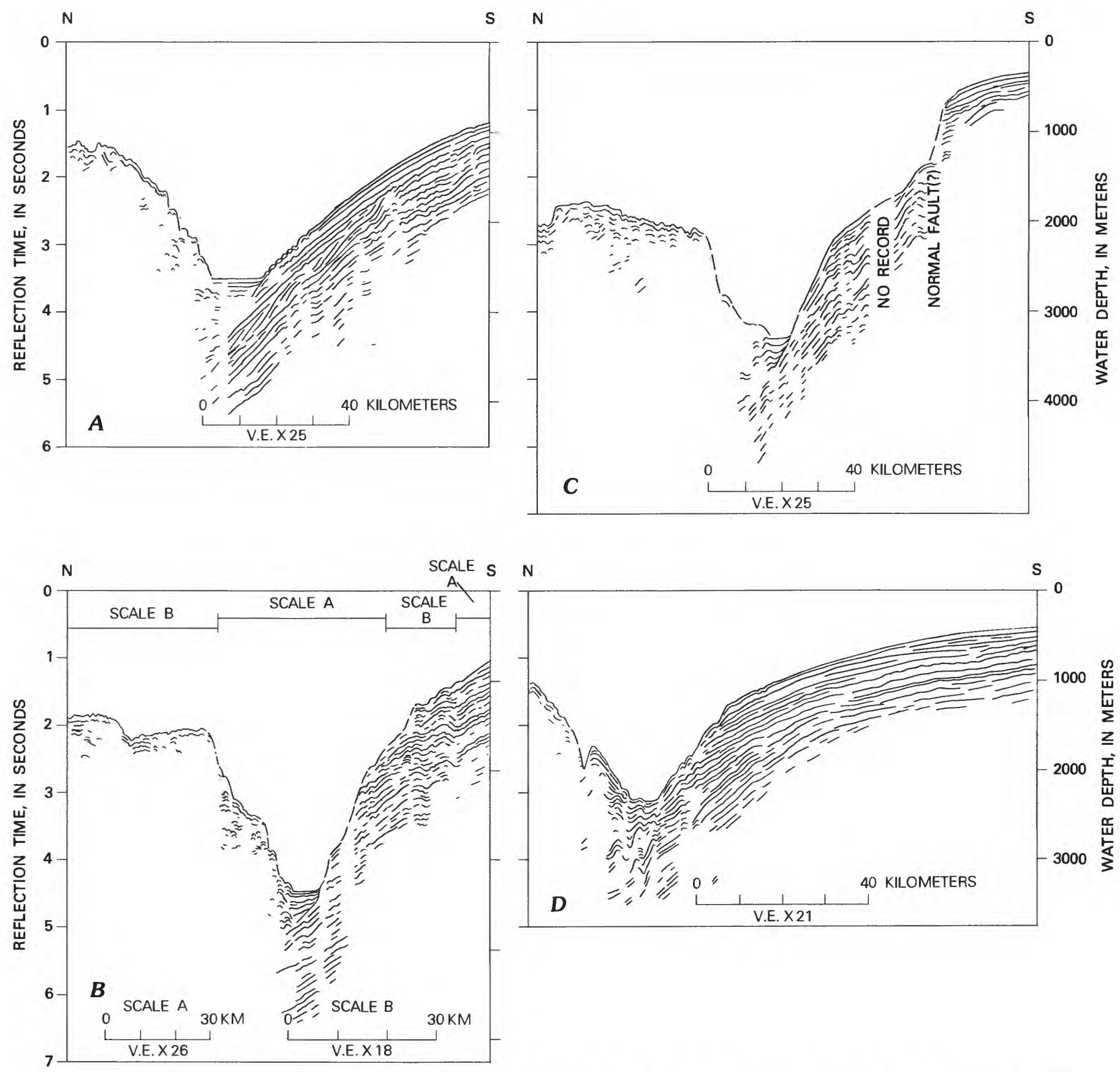

FIGURE 73.-Seismic-reflection profiles across the Timor Trough. The wedge of melange and imbricated rocks whose surface rises north toward Timor and the rest of the outer-arc ridge is thrust over depressed Australian continental-shelf strata at the trench. Location of profiles shown in figure 52. Traced from single-channel monitor records made by Compagnie Generale de Geophysique for the Australia Bureau of Mineral Resources, Geology and Geophysics (BMR; the survey was described by Watt, 1976) and provided by Director L. C. Noakes of BMR.

The Weber Basin (figs. $70 A, 71 A, B, 74 G$ ), inside the unique horseshoe bend of the Banda Arc, is bathymetrically by far the deepest outer arc basin in the Indonesian region. Water depths exceed 7,000 m near the axis of the great curve of the arc. Most of the basin lacks a flat floor, and little sediment is visible in reflection profiles. Sedimentary aprons, apparently thin, cover the lower slopes of the flanking ridges. In the Tanimbar sector, acoustically transparent sediments mantle the inner part of the outer-arc ridge, and sediments are ponded in a small midslope basin (fig. 74G). Normal oceanic crust underlies the basin (Purdy and others, 1977).

The reflection profiles disprove conjecture, as that by Audley-Charles and Milsom (1974) and Crostella and 

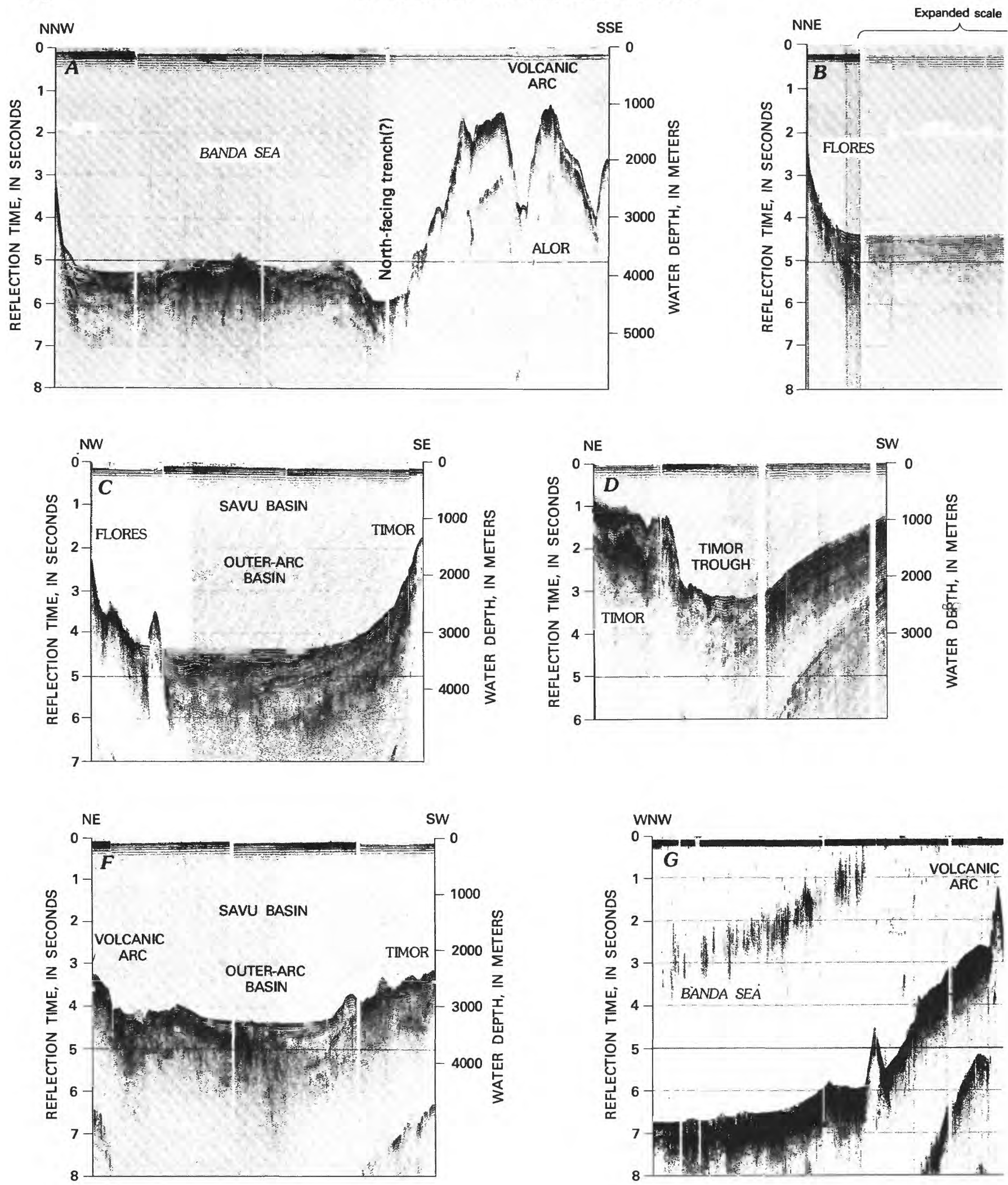

FIGURE 74.- Seismic-reflection profiles across the Banda Arc system in the Timor sector. The Australian shelf section is being overridden by the melange wedge of the outer-arc ridge at the Timor Trough, as described in text. The outer-arc basin is much deeper than this trench. Location of profiles shown in figure 52. Profiles from Lamont-Doherty Geological Observatory, R. V. Robert Conrad cruise 14( $A-F)$ and R. V. Vema cruise $28(G)$. 
THE BANDA ARC
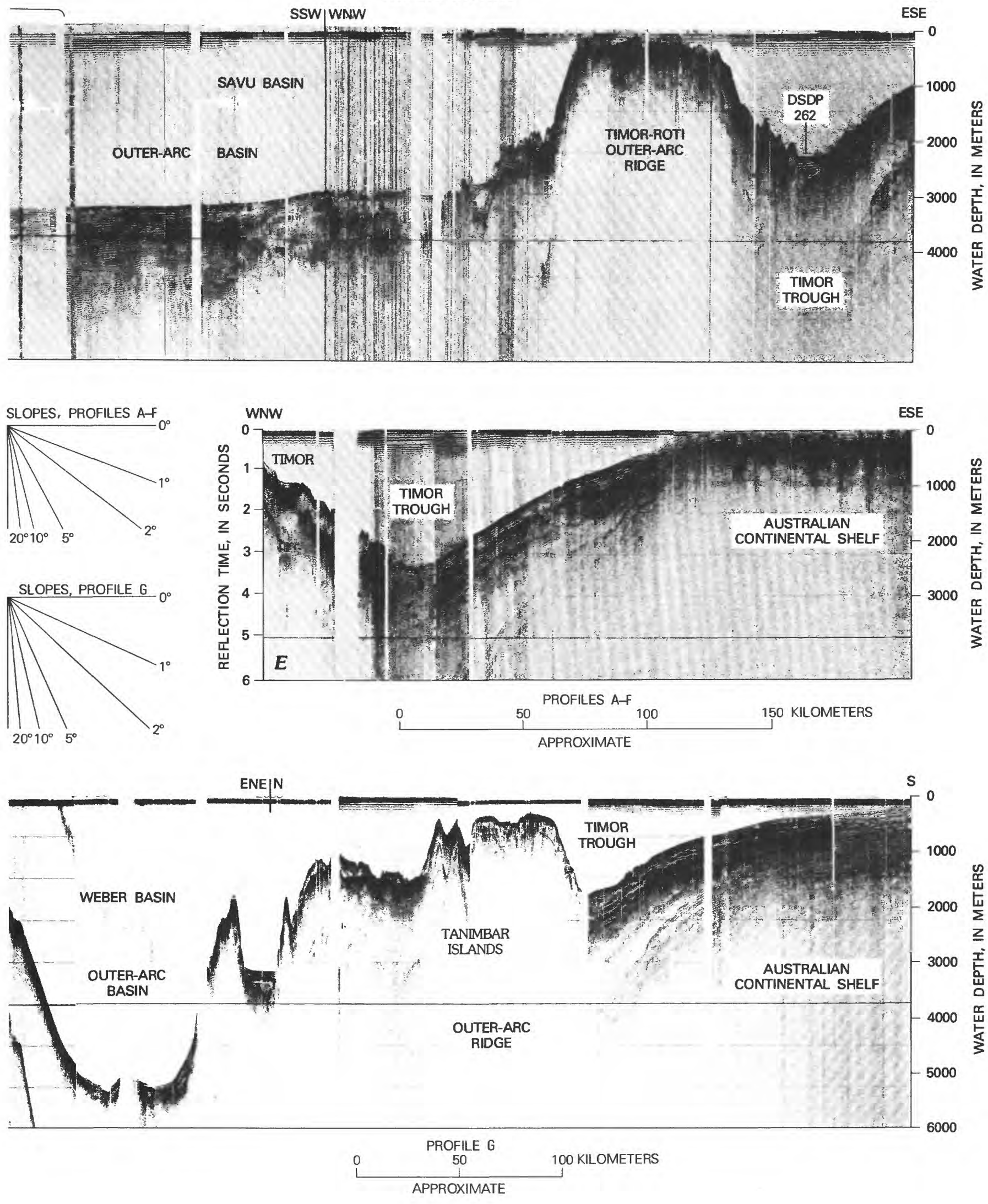
Powell (1976), that the Weber Basin and other sectors of the outer-arc basin comprise a subducting trench.

\section{SUMBA CONTINENTAL FRAGMENT}

The regularity of the subparallel elements of the Java-Banda subduction system - inner volcanic arc, outer-arc basin, outer-arc melange ridge, trench - is broken in the sector between long $118^{\circ}$ and $121^{\circ}$ or $122^{\circ} \mathrm{E}$., where the broad ridge on which stands the large island of Sumba (or Soemba) trends southeastward across the strike belt that elsewhere is occupied by the outer-arc basin. The aberrant ridge appears to be a small fragment of continental crust (fig. 53), quite unlike Timor and the other islands along the outer-arc ridge, caught up in the subduction system. Whereas the outer-arc ridge, both to east and west, is coincident with a negative regional-isostatic gravity anomaly of very large amplitude - indicative of the presence of a thick wedge of melange and imbricated sediments - this anomaly must be relatively narrow and pass south of Sumba, if indeed it is present at all at this longitude (Vening Meinesz, 1954).

The major public source of information about Sumba is the summary by van Bemmelen (1949, p. 155-159, 507-510), which combines data from unpublished reports, including a 1941 Caltex report and geologic map by J. H. Kinser and B. E. Dieperink, with material from the meager published literature. A little newer information was given by Meiser, Pfeiffer, Purbohadiwidjojo, and Sukardi (1965) and Pfeiffer and Meiser (1968). Tertiary foraminifers and correlations were presented by Caudri (1934).

Only the gently deformed Neogene strata covering most of the island have been studied systematically. The total Neogene section is typically about $1,000 \mathrm{~m}$ thick. At the base, on the moderate-relief unconformity developed upon older rocks, is a thin transgressive shale (and locally a lower Miocene conglomerate); above that is a lower or middle Miocene reef limestone approximately $200 \mathrm{~m}$ thick. Next is a thicker section of upper Miocene and Pliocene chalk, marl, and abundant waterlaid tuff, which lies directly upon igneous and Paleogene rocks in the southeast part of the island. The upper Neogene tuff presumably came from centers in the volcanic arc to the north of Sumba, although sources in southern Sumba are possible. Broad elevated Quaternary coral-reef terraces, trenched by canyons but otherwise little eroded, stand at altitudes of as much as $600 \mathrm{~m}$ along the west, north, and east coast (fig. 75).

Proved Paleogene strata occur only near the south coast and are poorly known. The oldest dated Tertiary strata are middle(?) Eocene shale, lignite, calcareous sandstone, foraminiferal marl, and limestone containing a rich large-foraminifer fauna; the environments are shallow marine and nonmarine, without reefs. The higher Eocene and Oligocene are mostly limestone and marly limestone and include reefs. Graywacke, arkose, calcareous sandstone, and conglomerate may be older than any of these; they contain globigerinids and could be either Cretaceous or Paleogene.

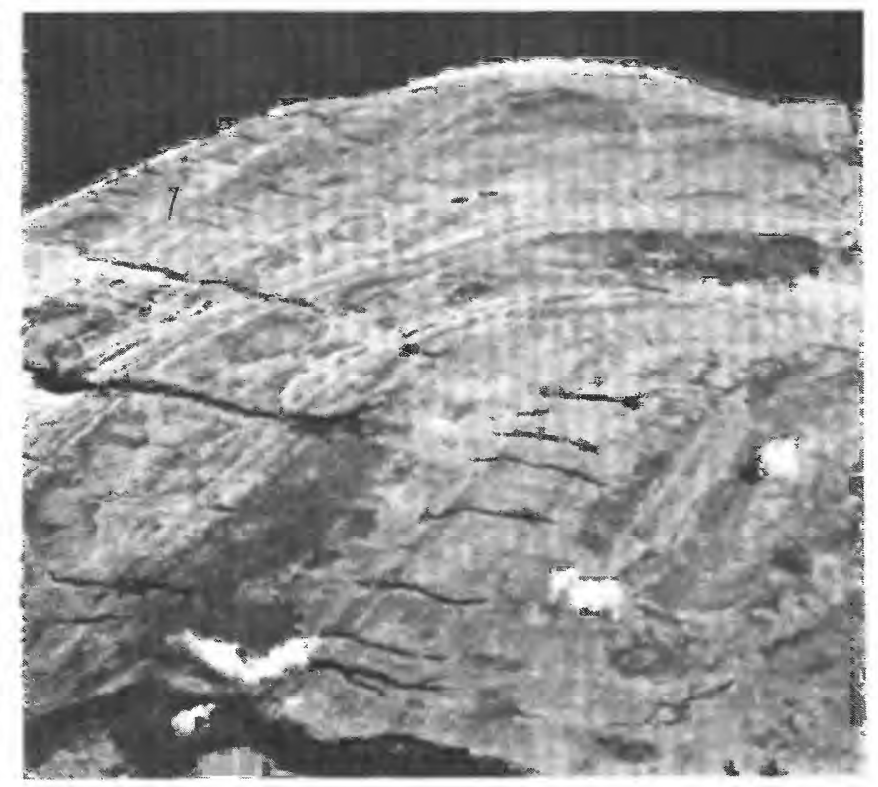

FIGURE 75.-Aerial view northeastward over Quaternary marine terraces of northern Sumba. The materials are mostly coral limestones but include marl, sand, and gravel. Tanjung (Cape) Laundi in the distance is about $9 \mathrm{~km}$ from the Langulung River at bottom left. Altitude of the highest terrace on the right is about $450 \mathrm{~m}$.

A Jurassic(?) ammonoid and Jurassic or Cretaceous pelecypod fragments were reported from one locality by Roggeveen (1929). The Paleogene and older rocks are much deformed.

Volcanic, hypabyssal, and plutonic igneous rocks are widespread in the medial and southern parts of Sumba and at least in part are of pre-Miocene age. The igneous rocks range from mafic to felsic, and the porphyries and plutonic rocks approximate mafic granodiorite in typical composition, to judge from Roggeveen's (1932) fragmentary descriptions. The fossiliferous middle to upper Paleogene strata of Sumba are spatially associated with the igneous rocks but whether older, younger, or correlative with them is not defined by published work. Argillite, semislate, quartzite, and hornfels apparently are older than the igneous rocks; but, again, whether these low-grade metamorphic rocks are older than or correlative with the Paleogene strata is unclear.

These ambiguities are resolved arbitrarily on the tectonic map (pl. 1) by the designation of the pre-Miocene complexes as a Paleogene volcanic-and-sedimentary terrain. This does not account for the possibly Jurassic locality and may be much in error.

Sumba has been little deformed since the Oligocene. The lithologies of the dated Paleogene strata resemble those of the Java Sea region-southeastern Borneo, southwestern Sulawesi, and the submerged platform of the Java Sea-rather than those known in the outer-arc ridge in or east of Timor, or in the Australian continental shelf. The large Paleogene foraminifers resemble those farther west in Indonesia (Caudri, 1934). The fragmentary descriptions of 
Paleogene rocks and structures support no inference that Tertiary subduction melange is present. Sumba may mark a continental fragment, despite its present position between subducting deep-ocean trench and volcanic arc, torn from what is now the southeastern edge of the continental shelf of the Java Sea when the subduction system began to migrate eastward, opening the Banda Sea behind it, in middle Tertiary time. The pre-Tertiary rocks of Sumba (not separated on pl. 1) would in this context have formed as part of the Cretaceous basement (mostly melange) of the Java Sea, and the igneous rocks might be late Paleogene and Neogene. Alternatively, Sumba might be a continental fragment, like the others strewn along the western margin of Australia, torn from Australia as India was rifted away from it during late Mesozoic time and subsequently swept against the Java Trench subduction system.

\section{BANDA SEA}

Enclosed within the inner volcanic arc of the Banda Arc is the South Banda Basin of the Banda Sea. The basin likely opened behind the migrating Banda Arc in late Cenozoic time; but only a partial explanation of the features of the basin floor can be made from available data.

The South Banda Basin has an irregular, high-relief floor. The topography appears to be mostly structural but partly volcanic (figs. $70,74,76$ ). The most widespread depth interval is 4,000-5,000 m; broad ragged-bottom areas lie within the general range $3,000-4,000 \mathrm{~m}$, ridges rise above $2,000 \mathrm{~m}$ and locally are capped by shoals, and deeps reach $6,000 \mathrm{~m}$. A middle Tertiary age can be inferred from these depths. (Compare with Sclater, 1972.) The general topographic grain is east-northeastward, according to the bathymetric compilation by R. L. Fisher (used for the base map of pl. 1, and of the maps of the Folio of the Indonesian region). The profiles accompanying this report are not generally close enough together to permit drawing continuous structures between them.

Reflectively layered sediments-turbidites and volcaniclastic aprons(?)-fill some of the local topographic-low areas and lap onto seamounts and ridges but can nowhere be seen to be thick on the low-energy profiles. The older strata north of Alor (fig. 74A) are faulted and tilted in a manner suggesting extension; basement is not visible here. Pelagic sediments, acoustically nearly transparent on the profiles, mantle irregular topography and are typically about $200 \mathrm{~m}$ thick ( 0.2 seconds reflection time) in the western part of the basin; they are thinner in the eastern part (figs. $70 A, 74 G, 76 C, E$ ). The acoustic basement is likely all of Neogene age and is younger in the east than in the west.

The northeast foot of the ridge extending southeast from the Southeast Arm of Sulawesi is marked by topographic depressions (fig. $76 B, C, D$ ), which are inferred (fig. 52 , and pl. 1) to mark traces of inactive southwest-dipping subduction zones, connected by a transform fault. The ridge in the center of the profile of figure $76 B$ has the reflection appearance of the top of a melange wedge. This ridge lacks pelagic-sedimentary cover, so recent inactivation of subduction here is postulated. This accords with the evidence onshore on the Southeast Arm, discussed in a subsequent section, for subduction there continuing into Neogene time.

The contact between the inner volcanic-arc ridge at Alor and the south edge of the South Banda Basin may be a south-dipping subduction system. The layered sediments of the Banda Sea floor tip abruptly downward at the north edge of the trough here and dip beneath subhorizontal trough deposits (fig. 74A). This is the geometry to be expected for a subduction-zone trench. As the overall geometry of the components of the south limb of the Banda Arc, described previously, is obviously that of a subduction system dipping northward from the Timor Trough, this sector of the arc may now be undergoing a reversal in its subduction polarity, so future subduction will be of the Banda Sea floor from the north of the arc rather than of the Australian shelf from the south.

Lofting, Crostella, and Halse (1975) speculated that the major convergence between the Australian and eastern Indonesian regions is taken up on a south-dipping subduction system trending east-northeastward from the Flores Basin to the east end of the South Banda Basin. This conjecture is disproved both by reflection profiles and by depths of earthquakes in the region concerned, although an incipient trench exists in the Flores-Sumbawa sector (fig. $56 C)$.

As is discussed subsequently in this report, a great left-lateral strike-slip fault, the South Sula-Sorong, is inferred to lie along the south base of the ridge of the Sula Islands. Sediments thickly cover the presumed fault trace where it is crossed by the profiles of figures $76 A$ and $B$.

The active volcanic island of Gunung Api rises from the South Banda Basin at about lat $6^{\circ} 38^{\prime} \mathrm{S}$., long $126^{\circ} 39^{\prime} \mathrm{E}$., and consists of moderately alkalic, two-pyroxene andesite (Neumann van Padang, 1951, p. 216-217). Neumann van Padang (1951, p. 213-216) reported the presence of two active submarine volcanoes to the west of Gunung Api, at the same latitude: Emperor of China at long $124^{\circ} 13^{\prime} \mathrm{E}$., and Niewerkerk at $124^{\circ} 42^{\prime}$ E. All three are marked on the tectonic map (pl. 1) as active volcanoes. According to Peter Jezek (written and oral communs., 1978), however, evidence for the supposed submarine eruptions is extremely dubious, and Emperor of China and Niewerkerk probably do not exist, as least as active volcanoes. Volcanic seamounts, partly buried by sediments, do appear to be present in this region (fig. $76 D$, left end).

Unpublished measurements of heat flow in the Banda Sea indicate values mostly less than $1.5 \mathrm{microcal} / \mathrm{cm}^{2} \mathrm{sec}$ (Bowin and others, 1977). This is compatible with an early or middle Tertiary age for a marginal basin. (Compare with Sclater, 1972; but Bowin and others, 1977, made the contrary assumption that the Banda Sea floor is of Jurassic age.) 

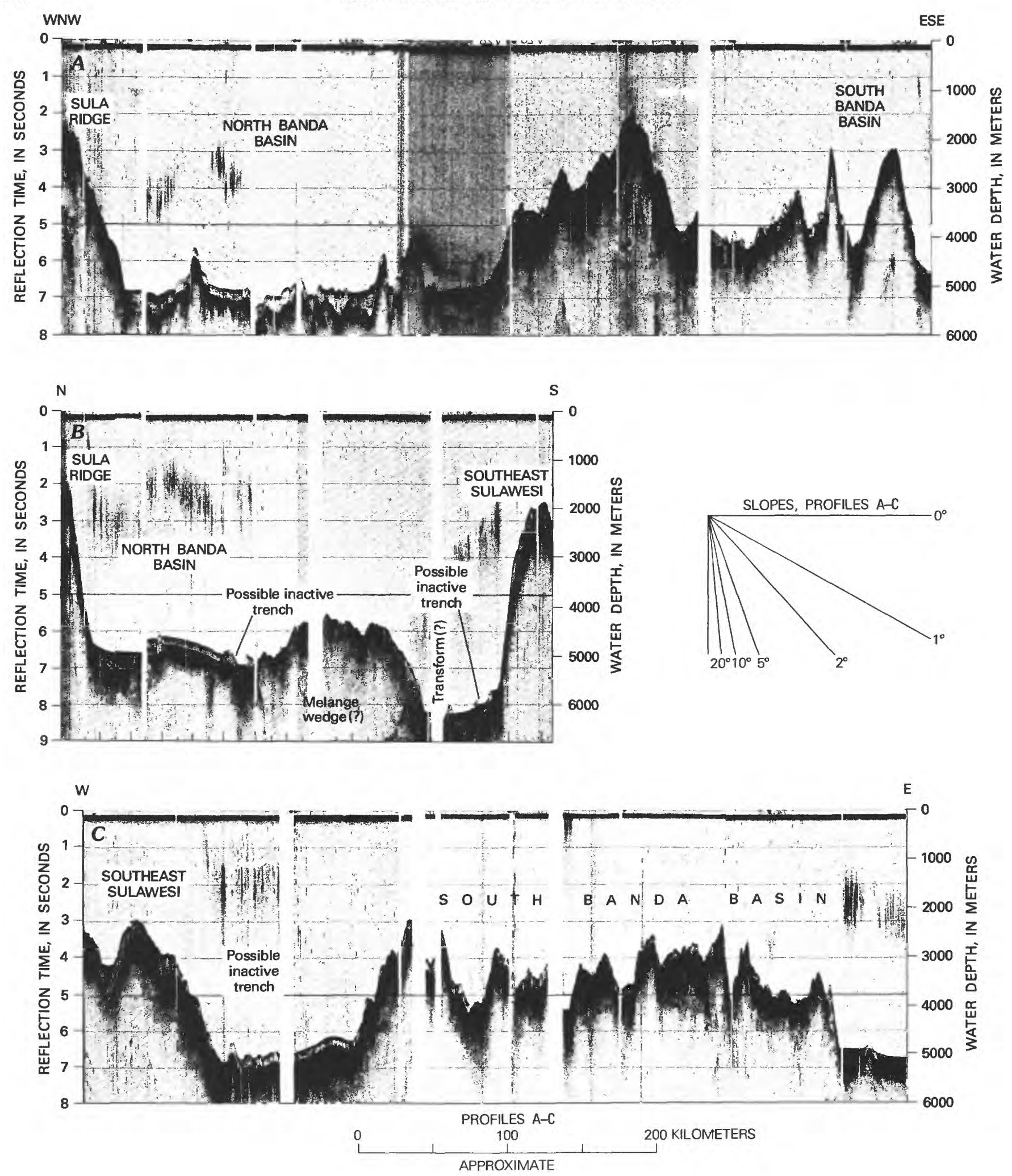

FIGURE 76 (above and facing page).--Seismic-reflection profiles across the western Banda Sea. See text for discussion. Location of profiles shown in figure 52. Profiles from Lamont-Doherty Geologieal Observatory, R. V. Robert Conrad cruise 11 and R. V. Vema cruise 28. 

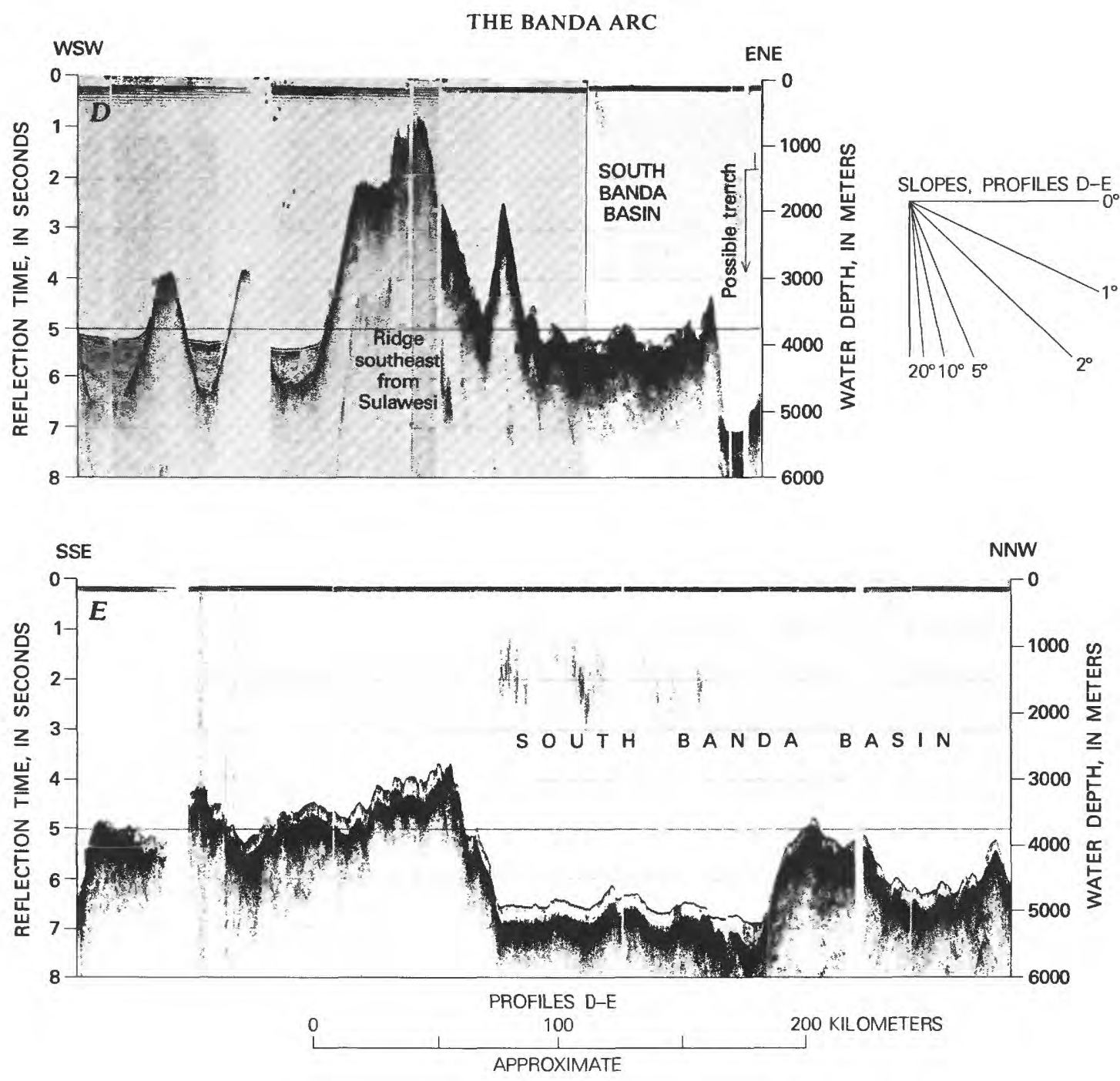

SYNTHESIS

The subduction-imbricated complexes of the islands of the outer-arc ridge are formed mostly of continental-shelf sediments in a matrix of sheared tuffaceous arc sediments but include voluminous intercalated materials of other origins. Ophiolite fragments are common, and abyssal pelagic sediments are present. Metamorphic rocks include indicators for subduction (glaucophane schist) and probably also for continental environments (potassic granulite). The Banda Arc, from Timor to Seram, represents the ramping onto continental crust of material pushed in front of an advancing island arc. The subcrop of the primary plate boundary, beneath the surficial debris wedge, is approximately along the inner edge of the outer-arc ridge.

\section{SUBDUCIIION OF CONTINENTAL SHELF AND BASEMENT}

The outer-arc ridge is the top of a wedge of melange and imbricated rocks, and the part exposed in the islands formed mostly within late Neogene time. Subduction is in progress now at the trench at the toe of the wedge. The dominant components of the wedge as exposed on the islands are shallow-water sedimentary rocks, similar in facies and paleontology to those of the New Guinea and Australian continental shelves. (See van Bemmelen, 1949, p. 69-71, 153, and 154, and Mollan and others 1970.) Such sediments can be traced in reflection profiles from the present shelf into the trench and beneath the wedge.

The island melange contains shelf-facies strata as young as early Miocene on Timor, and late Miocene or Pliocene at the east end of the arc, and deeper water sediments as young as early Pleistocene. Sediments of latest Miocene and younger age overlie the melange unconformably yet are themselves deformed into it, indicating that the exposed melange formed both before and during the late Neogene. Deep-water sediments in the melange reach younger ages than do shallow-water ones because the shelf sediments were conveyed down the continental slope and were covered by trench sediments before being subducted, and because strata deposited on top of the melange wedge were incorporated into the wedge tectonically. 


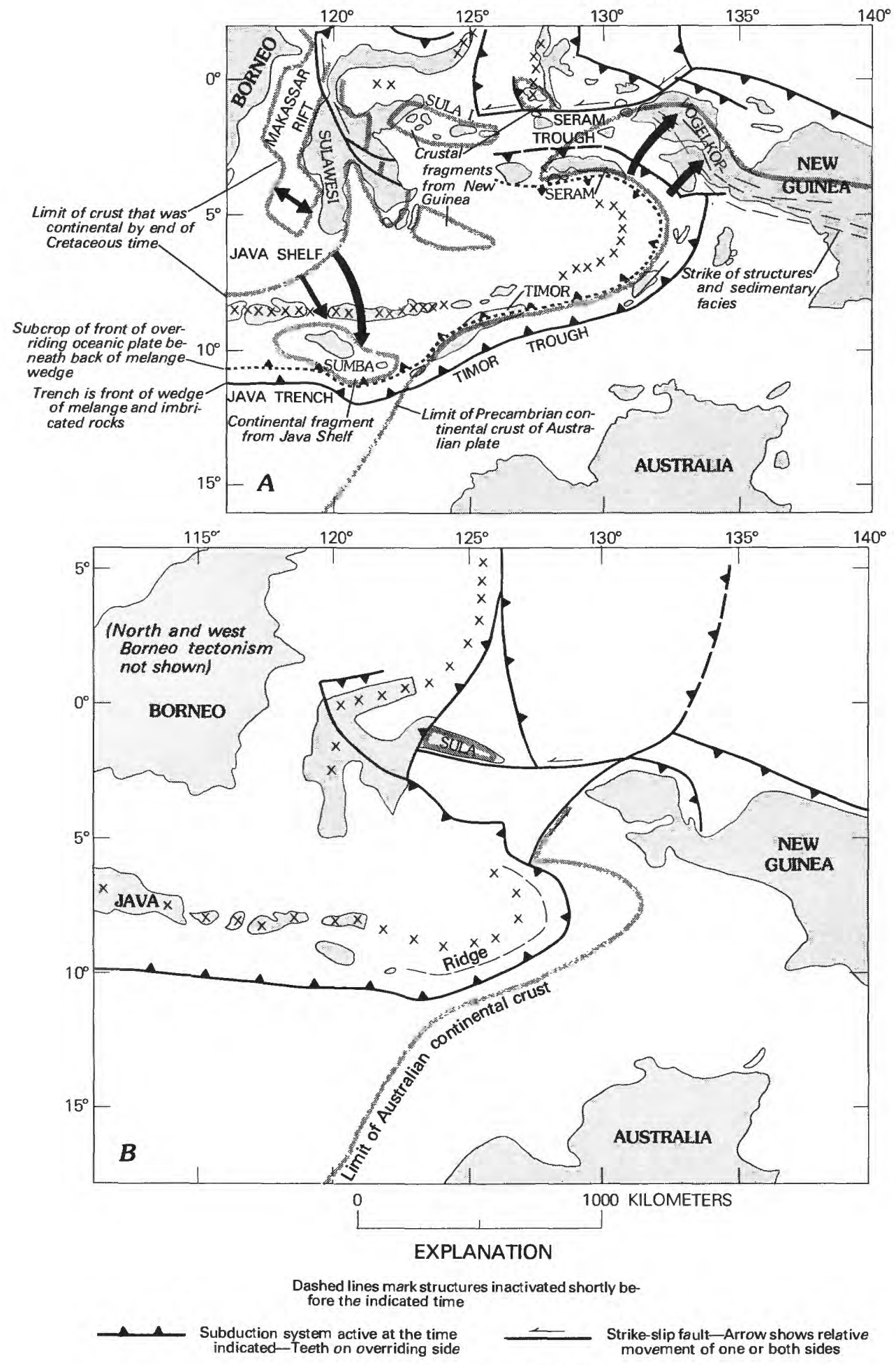

$x \times x$ Axis of active volcanic arc

NOTE: Present land areas shown for reference on palinspastic maps, though shoreline positions in fact varied greatly. Lonmaps, though shoreline positions
gitudes are relative to Greenwich

FIGURE 77. - Palinspastic maps showing Neogene evolution of the Banda Sea region. The interpretations account for as many as possible of the features discussed throughout this report, but actual configurations were likely more complex. $A$, Present configuration. Gray arrows indicate some Tertiary rifts and rotations which are accounted for in the other maps. See figure 53 for additional information $B$, Conliguration about Miocene-Pliocene boundary time, 5 m.y. ago. $C$, Configuration in middle Miocene time, about 10 m.y. ago. $D$, Configuration in early Miocene time, about 20 m.y. ago. 
THE BANDA ARC

153
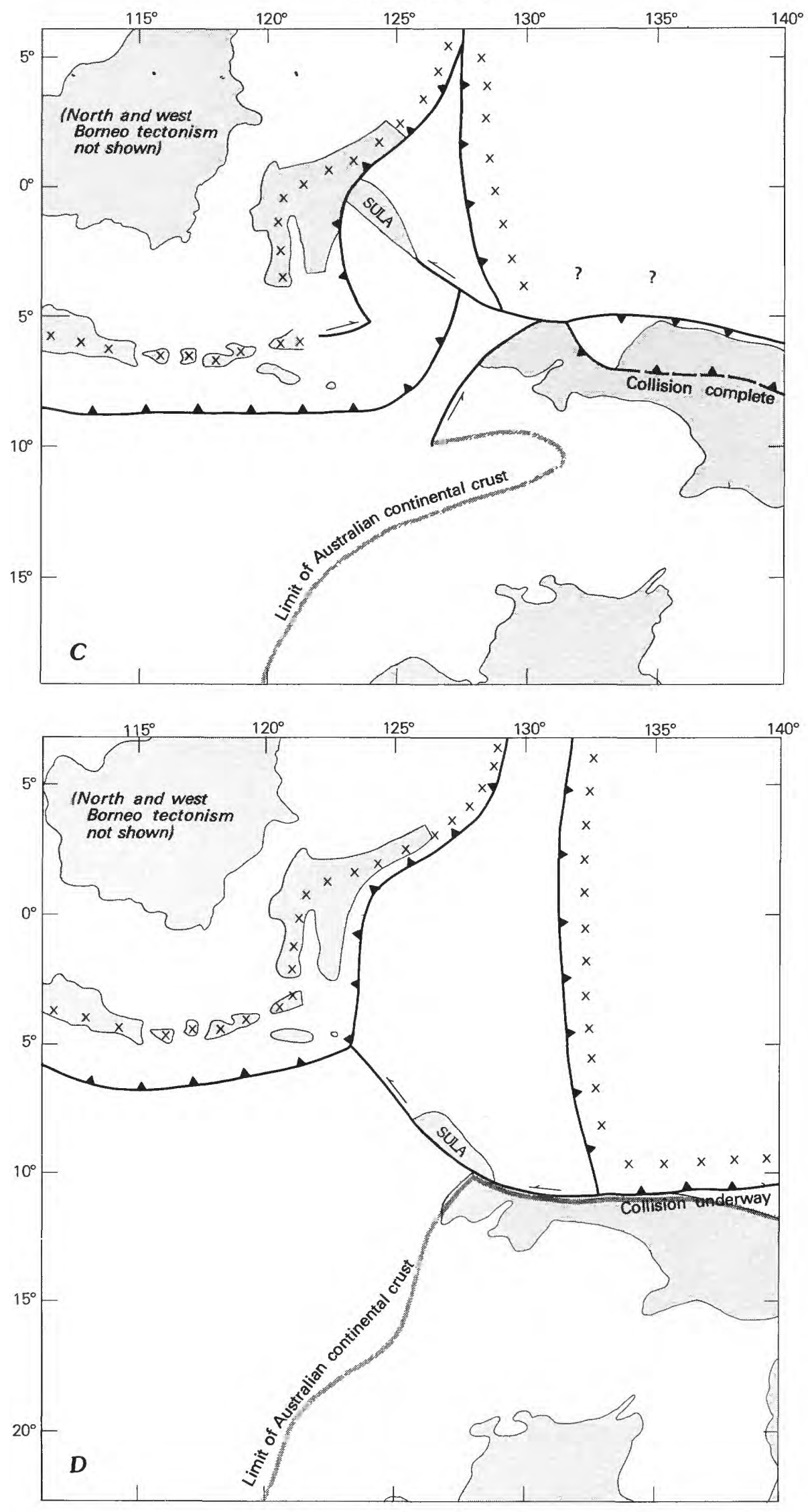
Continental basement rocks may be present in the melange of Seram and Timor. The granulite-facies gneisses invite analogy with the granulites of the older Precambrian of the Australian shield, although Tertiary metamorphism beneath hot ophiolite may account for them instead. Gravity data indicate that continental crust likely continues seaward, at shallow depth beneath the melange wedge, to the inner side of the outer-arc ridge (fig. 53), where it tips more steeply downward for at least a short distance beneath oceanic crust. The dense lower part of the continental crust may be undergoing subduction beneath the leading edge of the overriding oceanic plate, but the light upper continental crust likely does not pass far beyond this boundary.

The outer-arc basin of the Java-Sumatra sector was deduced in a previous section to have been formed by the raising of the front of the overriding plate as melange from the subducting plate was stuffed beneath it, producing an elastic downbowing of the adjacent part of the plate beneath the basin. In the Java-Sumatra case, oceanic crust is being subducted, and the leading edge of the overriding plate also consists of oceanic crust, in front of and attached to the main continental plate. The outer-arc basin from Timor around to Seram - the Savu Basin, Weber Basin, and so on-includes sectors far deeper bathymetrically than any part of the Java-Sumatra outer-arc basin. The Weber Basin reaches water depths greater than $7,000 \mathrm{~m}$, yet is not a trench. An elastic-downbowing origin for the Banda outer-arc basin is inferred also; but here, the overriding plate is entirely oceanic, and its front is buoyed high by, and depresses, light continental crust, so the leading edge of the overriding plate is raised almost to sea level and the elastically downbowed outer-arc-basin belt behind this is greatly depressed. The deepest part of the Weber Basin is at the axis of the Banda Arc, where the depression of the lithospheric beam is a response to raising to the north, east, and south. Walcott $(1970,1976)$ discussed the flexural behavior of lithosphere plates.

The inferred geometric evolution of the Banda Arc is illustrated schematically by figure 77 , and a cross section through it is given on figure 78 .

\section{MECHANIC'S}

The subduction zone of the Banda Arc is presently active as far counterclockwise around the arc as eastern Seram, as shown by deep earthquakes and active volcanoes. The western part of the north limb-western Seram and Buru-lacks these indicators and may recently have become inactive as a subduction zone, although it still has abundant shallow earthquakes, and subduction appears in the Seram reflection profiles to be active. The Banda subduction zone is spoon shaped. Around the arc from Timor to Seram, sediments that formed on the continental shelf of Australia and New Guinea have been incorporated into the melange wedge. The continental slope from the present edge of the Australia-New Guinea shelf down to the floor of the trench is a monocline produced by the downflexing of the preexisting continental shelf. The flexure at the top of the monocline is concentric in plan to the elements of the Banda Arc, and the monocline - the continental slope-is $50-100 \mathrm{~km}$ wide in front of the advancing tectonic wedge, The materials of the downdip projection of that monocline have been converted to melange and imbricated terrain such as that exposed in the islands of the outer-arc ridge. The width of the belt of original shelf that has been covered by the wedge or actually subducted beneath the oceanic plate must be greater than the present distance of $100-150 \mathrm{~km}$ between the trench floor and the melange exposed on the islands of the outer-arc ridge.

Apparently the shelf-edge flexure, the trench, and the outer-arc ridge of the Banda Arc are migrating concentrically outward into the continental plate of Australia and New Guinea. Shallow-water upper Pliocene sediments underlie the trench, so the trench has advanced the full width of the continental slope, $50-100 \mathrm{~km}$, in the last 3 million years, indicating a rate of advance of the subduction system of about $3 \mathrm{~cm} / \mathrm{yr}$.

The geology of Australia, New Guinea, and the intervening shelf (discussed in subsequent sections) provides further constraints on analysis of the mechanics of the Banda Arc. No major post-Paleozoic crustal break, such as a great strike-slip fault, separates Australia from New Guinea, for the Paleozoic orogenic terrain of eastern Australia continues northward across the shelf and southern New Guinea and into medial New Guinea (pl. 1). Geologic relationships indicate that Vogelkop (Jazirah Doberai)-the large northwestward projection of New Guinea, west of long $135^{\circ} \mathrm{E}$. - might have rotated clockwise as much as $90^{\circ}$ relative to the rest of New Guinea but cannot have rotated counterclockwise. Vogelkop may be rotating away from the advancing Banda Arc, but it is not rotating toward it. The distance between the north and south limbs of the Banda Arc is increasing, and the South Banda Basin is broadening from north to south.

The South Banda Basin may also bc lengthening from east to west, and possibly at a greater velocity than it is broadening. The youngest melange exposed on the outer-arc ridge probably is that of the Tanimbar and Kai Islands, on the outer edge of the ridge near its east end; thus, subduction is most rapid there. These islands have abundant mud volcanoes, further suggestive of very rapid subduction of wet sediments. The basement floor of the South Banda Basin appears from the thinness of its sediments to be of Neogene age. The apparent east-northeast grain of the tectonic topography of the basin, if parallel to isochrons of basin-floor formation, may indicate that the expansion has been asymmetric, the arc having unrolled to a relatively stable eastward strike along the south rim but having dragged the north rim along with it.

A great earthquake, which may have released more energy than any other in the world since 1964, was produced beneath the Java Trench, southwest of Sumba, on August 19, 1977. Slip occurred on a normal fault striking west, parallel to the trench, and dipping about $45^{\circ}$; the area of the 
THE BANDA ARC

\begin{tabular}{|c|c|c|c|c|c|c|}
\hline $\begin{array}{l}\text { NNW } \\
7^{\circ} \mathrm{S} . \\
123^{\circ} \mathrm{E} . \\
5 \\
0\end{array}$ & BANDA SEA & $\begin{array}{c}\text { VOLCANIC } \\
\text { (INNER) } \\
\text { ARC } \\
\text { SOLOR }\end{array}$ & $\begin{array}{l}\text { OUTER-ARC } \\
\text { BASIN } \\
\text { SAVU BASIN }\end{array}$ & $\begin{array}{c}\begin{array}{c}\text { OUTER-ARC } \\
\text { RIDGE }\end{array} \\
\text { WESTERN TIMOR } \\
\end{array}$ & $\begin{array}{c}\text { TRENCH } \\
\text { TIMOR } \\
\text { TROUGH } \\
\end{array}$ & $\begin{array}{c}\text { AUSTRALIAN } \\
\text { CONTINENTAL } \\
\text { SHELF } \\
\end{array}$ \\
\hline 5 & & BATH & ETRIC PROFILE & /ERTICAL EXAGGER & $2.5 \times)$ & \\
\hline
\end{tabular}

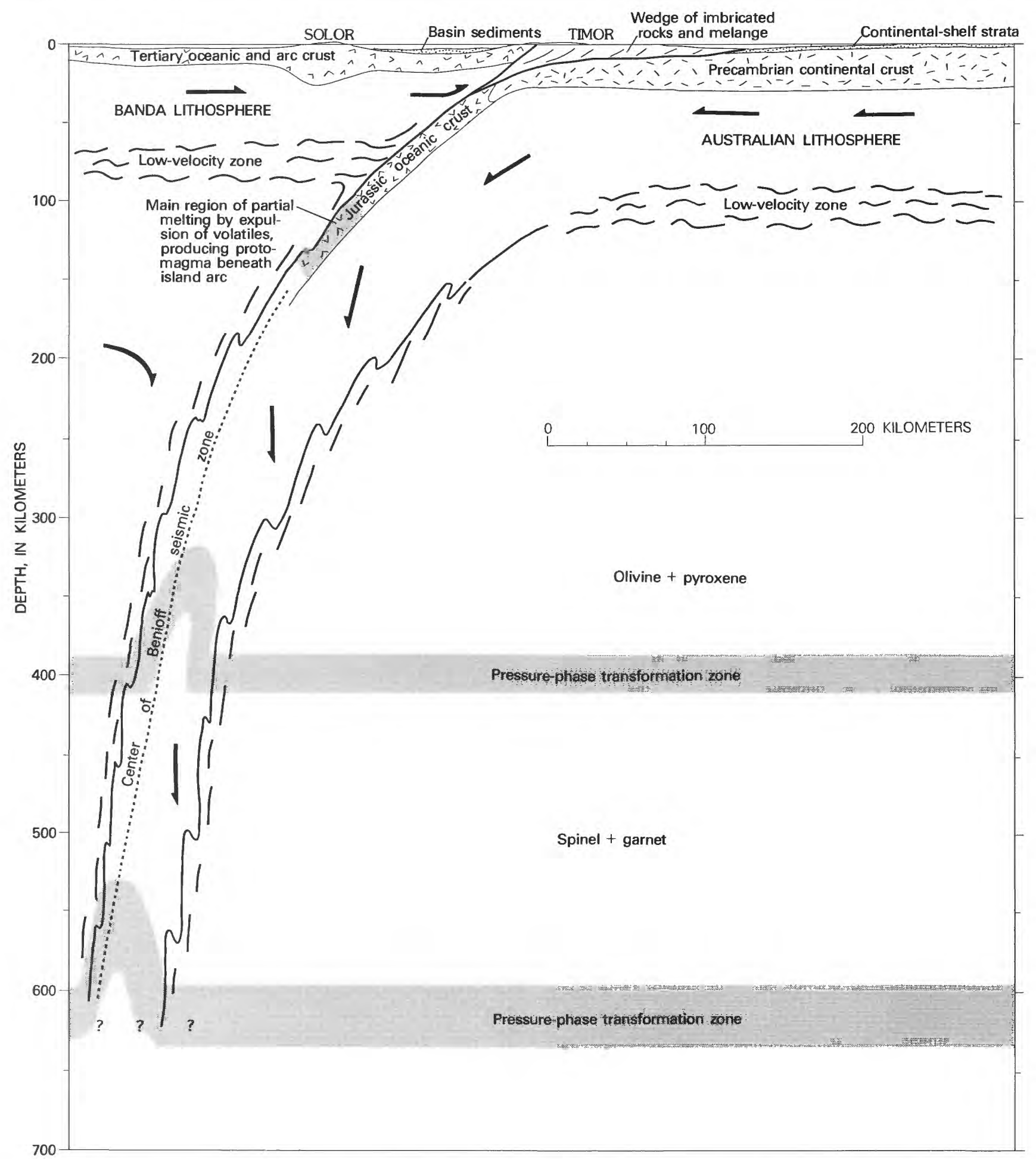

Figure 78.-Schematic cross section through the Timor sector of the Banda Arc. Arrows indicate directions of relative motions but no vector scale is implied. Curvature of the earth's surface is not shown. 
fault surface ruptured was about $16,000 \mathrm{~km}^{2}$ (Stewart, 1978). Fracture completely through the lithosphere due to decoupling of the descending slab, pulled gravitationally away from the oceanic lithosphere, was inferred by Stewart (1978).

\section{REVERSAL OF SUBDUCTION POLARITY}

Incipient subduction southward beneath two sectors of the south limb of the Banda Arc is indicated by reflection profiles, as noted previously. This reversal in subduction direction, from northward beneath the south side of the arc system to southward beneath the north side, is presumably a byproduct of the collision of the south-facing arc with the Australian continent, the density of which is too low to permit continuing subduction.

One of the reversing sectors is that of Timor, approximately between long $124^{\circ}$ and $128^{\circ} \mathrm{E}$. No volcanoes are active along the inner volcanic arc of most of this sector, and the now-inactive volcanic islands-Alor, Kambing, Wetar, Roma - are characterized by reef-limestone terraces uplifted to $500-800 \mathrm{~m}$ above sea level (Abbott and Chamalaun, 1976; van Bemmelen, 1949, p. 471, 485-487). Such uplift, uncommon for island-arc volcanic islands, is characteristic of outer-arc ridges, where it appears to be due primarily to buoying up by low-density subduction melange stuffed beneath the ridge. The southward subduction indicated by the geometry of the trench along the north base of the extinct volcanic ridge similarly may have produced buoyancy here.

This same Timor sector is marked also by a break in the Benioff seismic zone. The Benioff zone of the Banda Arc is reasonably well defined east of long $128^{\circ} \mathrm{E}$. and north of lat $7^{\circ} 20^{\prime} \mathrm{S}$. and has a spoon snape, concentric to the Banda Arc and plunging to a depth of more than $600 \mathrm{~km}$ (pl. 1: Hamilton, 1974b). The deep part of this zone continues across the Timor sector, but the part shallower than about $350 \mathrm{~km}$ is not represented by earthquakes between long $124^{\circ}$ and $126^{\circ} 30^{\prime} \mathrm{E}$.

The new southward subduction system beneath the Timor sector is not yet recorded, presumably because of its youth, by either a south-dipping Benioff zone or by appropriately positioned active volcanoes.

The other sector apparently undergoing incipient reversal is that of the Flores Sea, west of the zone of actual contact between Australia and the Banda Arc. In this sector, both active volcanoes and Benioff zone attest to the continuing effect of northward subduction from the south side of the arc system, so reversal if actually underway here has begun more recently than that in the Timor sector.

In the Timor sector, another unusual feature is that Timor and Leti, atop the outer-arc ridge, converge with the extinct volcanic-arc ridge to the north, and the intervening basin is narrow and shallow. Brouwer (1919) suggested that outer and inner ridges are here moving together. Such motion could be explained by the subduction of part of the outer-arc basin beneath either the volcanic or outer-arc ridges. 1 have seen no evidence for such hypothetical subduction in reflection profiles; perhaps such subduction, now inactive and its trench buried, will be displayed by future deep-penetration profiles that can see through the young sediments on opposite sides of the basin.

\section{SULA AND BANGGAI ISLANDS}

The Sula and Banggai Islands stand on a narrow ridge that trends eastward from Sulawesi (fig. 79). The islands are the emergent parts of a small fragment of continental crust, for they consist of Paleozoic potassic, silicic granitic rocks beneath a little-deformed cover of Mesozoic continental-shelf sedimentary rocks. Klompé (1956) and Stille (1945) are among those who have puzzled over these anomalous islands, which Stille $(1945$, p. 73$)$ termed the Sula Spur (Sulasporn). A little reconnaissance information on the islands was published by van Bemmelen (1949, p. 380-392), Brouwer (1921 b, 1926), Koolhoven (1930), and Wichmann (1914), and a more detailed study of Taliabu, Mangole, and Sulabesi islands was made by the late Don E. Wolcott of the U.S. Geological Survey (written communs., 1972, 1973) and geologists of the Geological Survey of Indonesia (Sukamto, 1975a, b, c). Data from all these sources are summarized in this section.

The Banggai and Sula Islands expose widely a basement complex of granitic and metamorphic rocks of continental types. The granitic rocks are dominantly white or pink biotite granite, quartz monzonite, and granodiorite but include also quartz diorite, diorite, and tourmaline-muscovite granite. The metamorphic rocks are slate, phyllite, greenschist, biotite and muscovite schists, quartzite, and amphibolite; garnet, sillimanite, kyanite, andalusite, and calc-silicate minerals are among the accessory components. Strontium-rubidium age of feldspar in a Sula granite is $235 \pm 10$ m.y. and in a Banggai granite is $245 \pm 25$ m.y., by the assumed-initial-ratio method. Potassium-argon age of muscovite from a Banggai schist is $305 \pm 6$ m.y., and the K-Ar age of a pegmatite from the same locality is about 418 m.y. (R. E. Denison, then of Mobil Oil Corp., written commun., 1973; also Hehuwat, 1975, and Sukamto, 1975b). Apparently the basement rocks are of middle or late Paleozoic or Triassic age.

Overlying this basement is a gently deformed cover of pre-Jurassic(?), Jurassic, Cretaceous(?), and middle Tertiary strata, mostly in shallow-water facies. Best known are fossiliferous Jurassic black shale and limestone. Undated quartz sandstone occurs beneath the dated Jurassic. A basal conglomerate lies on the basement in western Taliabu, and undated, rapidly deposited clastic sediments lie between basement and Jurassic on Mangole, according to Wolcott. Overlying the Jurassic strata are Cretaceous(?) clastic sediments and marls and lower Miocene limestone and quartz sandstone.

Rhyolite in the Sula Islands is older than the Jurassic strata; it was thought by Wolcott to be younger than the basement complex. Two whole-rock $\mathrm{Rb} / \mathrm{Sr}$ age deter- 


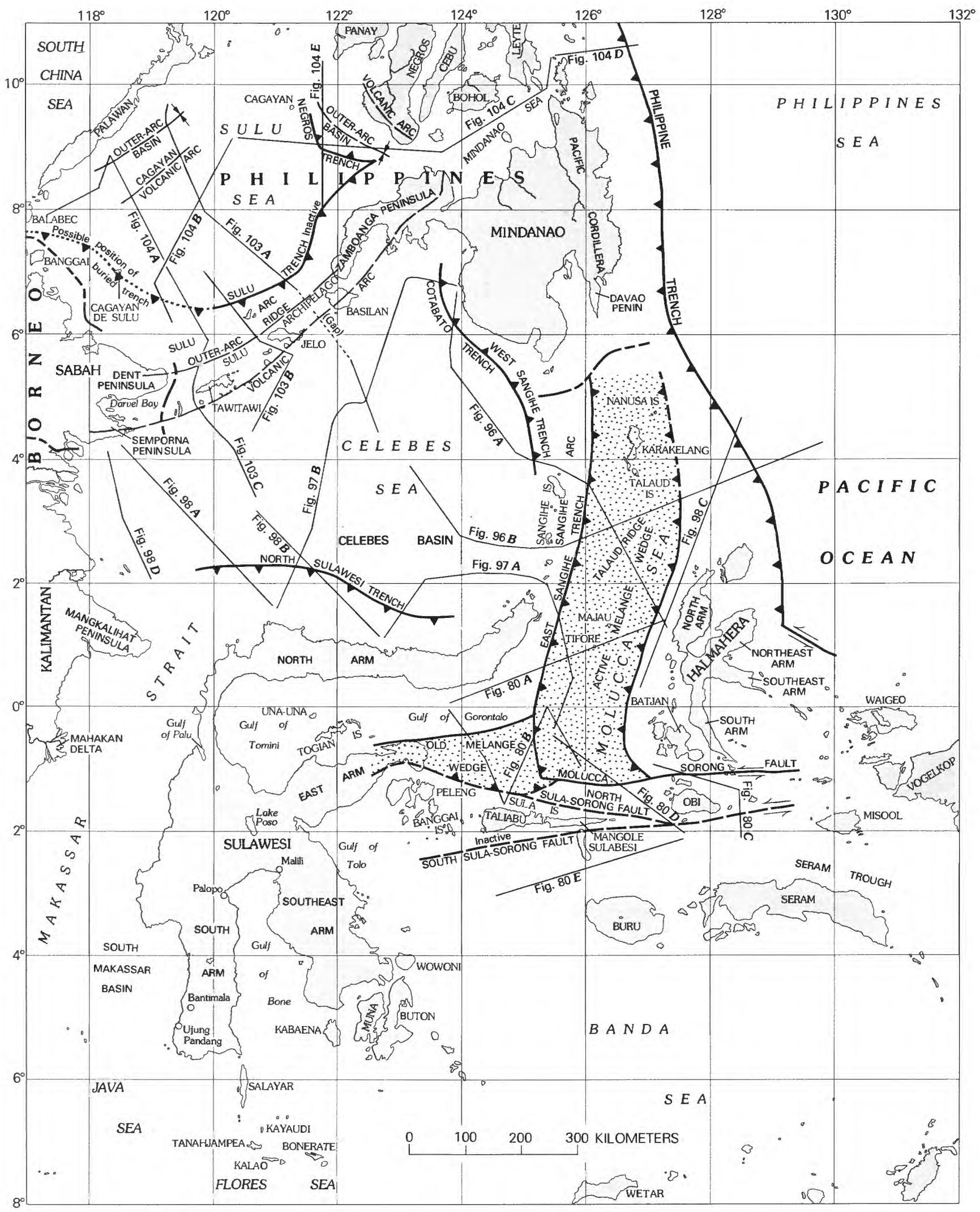

FigURE 79.--Selected tectonic elements in the Sula and Banggai Islands, Sulawesi, northern Moluccas, and island-arc systems between the Philippines and Sulawesi, Halmahera, and Borneo. Locations of seismic-reflection profiles shown in figures $80,96,97,98,99,103$, and 104 are indicated. 

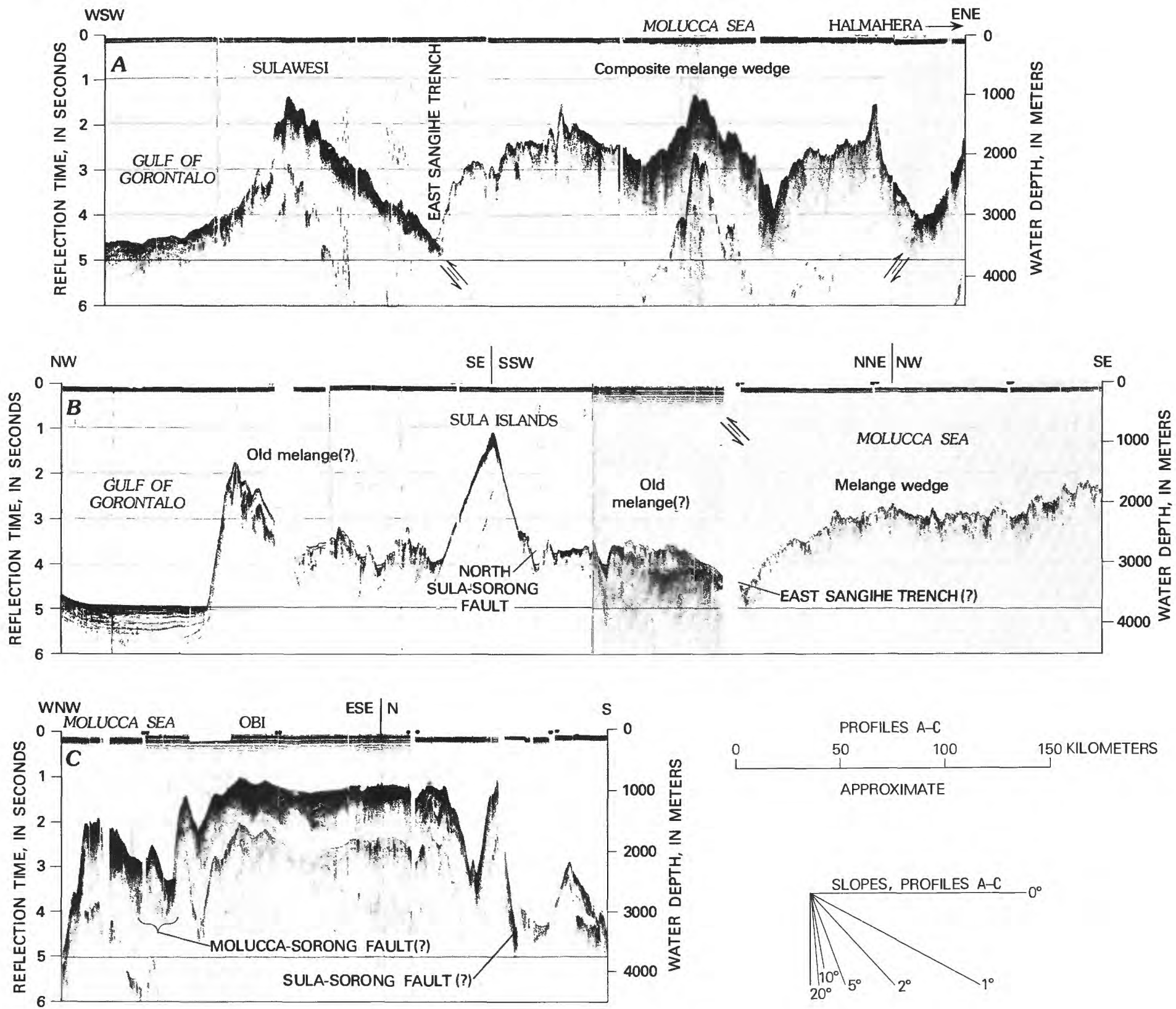

FIGURE 80.-Seismic-reflection profiles in the Sula Islands-Sulawesi-Halmahera region. The Molucca Sea melange wedge appears in profiles $A, B$, and $D . A$, The Molucca Sea melange wedge appears to be riding west ward up onto the slope of the North Arm of Sulawesi. $B$, The Sula Islands are a fragment of Paleozoic continental crust. $C$ and $D$, The troughs on both sides of the Obi Ridge may contain strands of the Sorong left-lateral strike-slip fault system. $E$, The rough, tectonic topography between the Sula Islands and Buru (the northwest end of the Banda Arc) is not understood. Location of profiles shown in fig. 79. Profiles from Lamont-Doherty Geological Observatory, $\mathbf{R}$. V. Vema cruise $28(A$ and $B$ ) and R. V. Robert Conrad cruise $14(C, D$, and $E)$.

minations, on rhyolite specimens from Sula and from Banggai, yielded calculated ages of $210 \pm 25$ m.y. and $330 \pm 90$ m.y., respectively (R. E. Denison, written commun., 1973), so it appears likely that the rhyolites are cogenetic with some of the basement granites.

Strong east-trending submarine topographic alinements, including the straight sides of the narrow Sula Ridge (fig. 80 ), connect the Sula Islands with the strike-slip Sorong fault system of northern New Guinea, as Krause (1965, fig. 6) emphasized. The various tectonic belts of Vogelkop-the large projection of New Guinea northwestward from the meridian of $135^{\circ}$ E.- trend northwestward to an oblique truncation against this fault system. The rocks along the south side of the fault in Vogelkop are middle Paleozoic granitic and metasedimentary rocks, overlain by Permian, Carboniferous, Mesozoic, and lower and middle Tertiary 

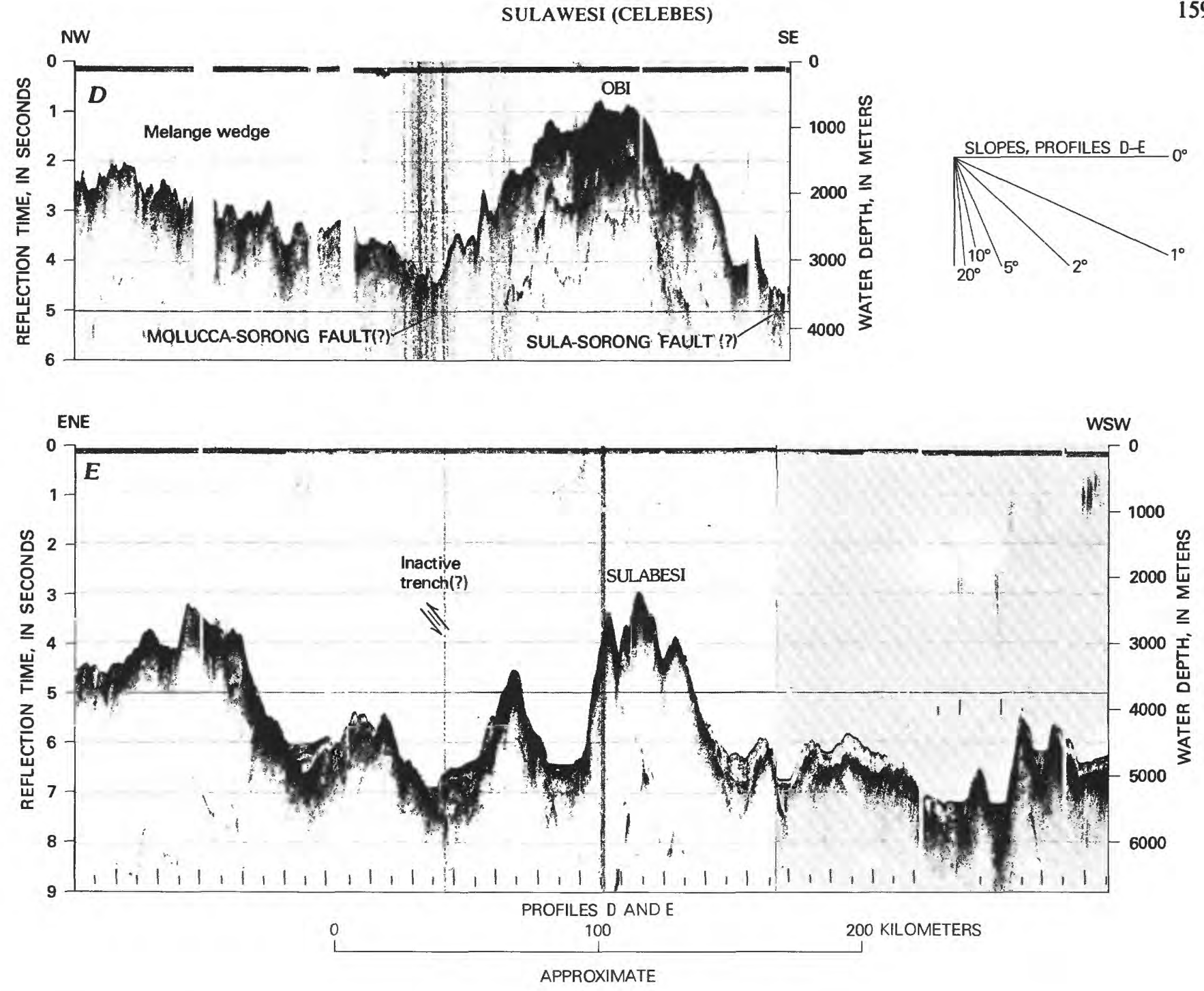

continental-shelf strata. It is an obvious inference (and one made also by Gribi, 1973, and Hermes, 1974) that the Sula-Banggai Ridge is a sliver of continental crust, torn from Vogelkop and transported westward about $1,000 \mathrm{~km}$ along a strand of the Sorong fault system.

It is inferred elsewhere in this report that the Malaya-Sumatra-Tin Islands subcontinent was rifted in early Mesozoic time from Australia and New Guinea. The upper Paleozoic granitic and volcanic rocks that lie along the Pacific sides of both of these subcontinents are of about the same age as apparently are the Sula basement rocks, so the Sula terrain might once have been within the same magmatic belt. If so, its course to its possible intermediate position in Vogelkop is not apparent.

The straight south side of the west-trending ridge of the Sula and Banggai Islands is presumably a major left-lateral fault. Trending southward from the east end of this ridge is narrow Sulabesi Island, which was examined by D. E. Wolcott (oral commun., 1972) and his Indonesian associates. Most of the island consists of shale and quartzose turbidite, which in part appear coherent and in part are sheared apart so that lenses and contorted fragments of sandstone lie in sheared shale. On the tectonic map (pl. 1), this material is suggested to be subduction melange. Young coral reefs unconformably overlying this material are uplifted as high as $400 \mathrm{~m}$ in the south part of the island but have been submerged below sea level in the north part.

\section{SULAWESI (CELEBES)}

\section{GENERAL}

The four diverging arms of Sulawesi record a complex geologic history whose analysis casts light on the tectonic processes of active plate boundaries. (The four arms of Sulawesi are named, in order clockwise from the southwest, the South, North, East, and Southeast Arms.) In the western arc of the island-the South and North Arms and the western part of central Sulawesi-Cretaceous subduction complexes are overlain by sediments perhaps deposited in an outer-arc basin. Above these are upper Paleogene continen- 


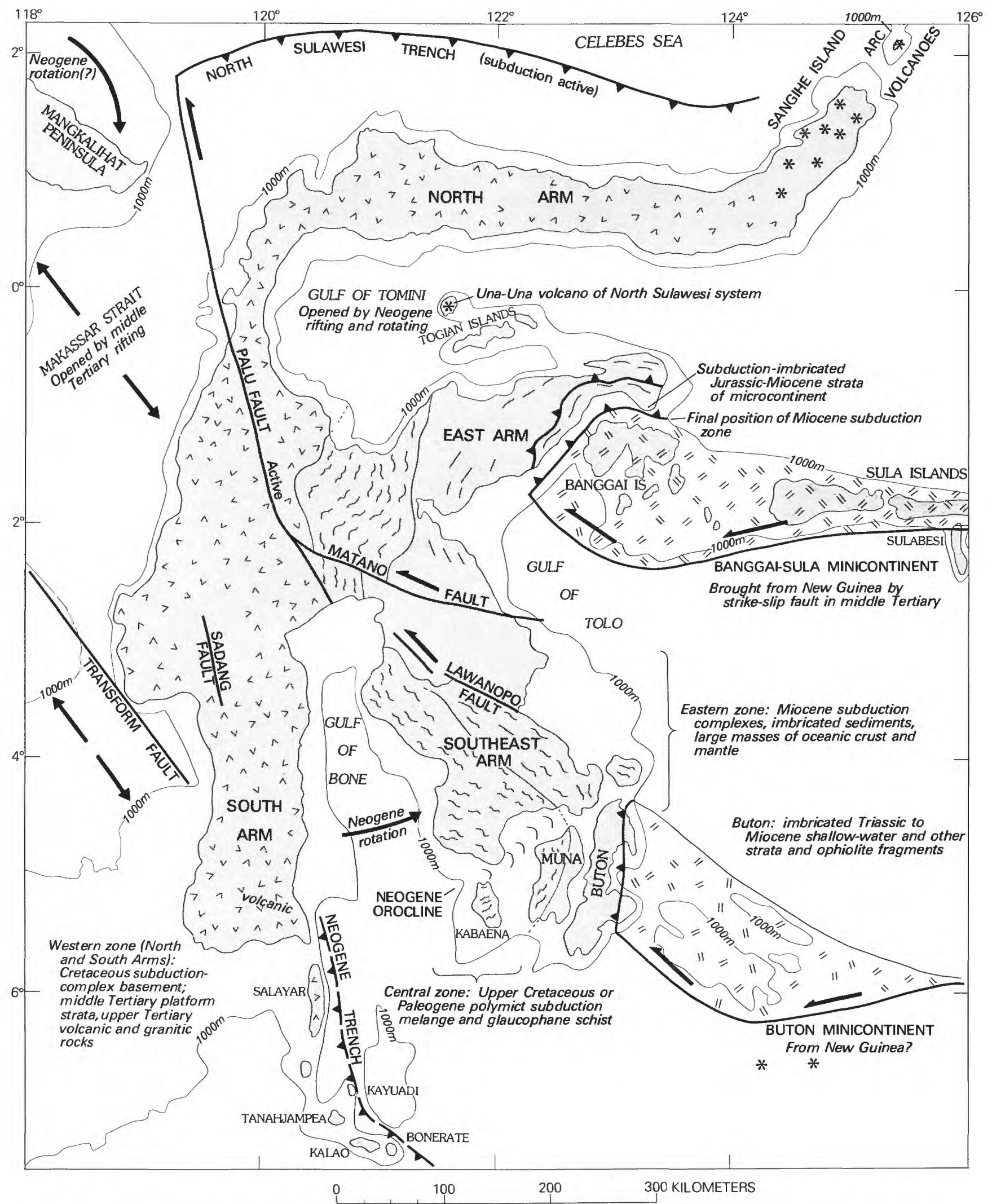

FIGURE 81.-Some major structural elements of Sulawesi. Gray arrows illustrate local relative motions of several of the components. Upper Neogene deposits are omitted. Only the 1,000-m bathymetric contour is shown. 
tal-shelf strata. These in turn are overlain by Neogene sedimentary and volcanic rocks and are intruded by Neogene granitic rocks (fig. 81). The eastern arc - the East and Southeast Arms and the eastern part of central Sulawesi-consists of fragments of ophiolites and of subduction complexes, the latter likely becoming in general younger eastward to a limiting age of approximately late Miocene. This broad succession in the western and eastern arcs is interpreted to record the eastward migration of a subduction system during Cenozoic time and of the magmatic arc (and perhaps also of the outer-arc basin) related to it, by tectonic accretion of material through subduction processes. Apparently superimposed on this broad pattern are the effects of the rifting of Sulawesi away from Borneo, of the separation and distortion of the arms, and of the progressive lengthening of the young subduction zone along the north side of the North Arm.

The distribution of rock assemblages shown on the tectonic map for west-central Sulawesi and the South Arm is taken primarily from Sukamto's (1975a) 1:1,000,000-scale compilation of published geologic mapping and of reconnaissance mostly by geologists of the Geological Survey of Indonesia. The delineation of units in the East and Southeast Arms is adapted from many published reports and also from an unpublished 1971 photogeologic map provided by International Nickel Indonesia. My interpretation of units in both eastern and western arcs of the island diverges markedly from these sources in various instances.

\section{WESTERN ARC}

CRETACEOI'S SI BIDUCIOION COMPLEX

The two small windows eroded into the basement complex of the southwest part of the South Arm both expose ultramafic and metamorphic rocks ('t Hoen and Ziegler, 1917; von Steiger, 1915; Sukamto, 1973b, 1975a, b); D. E. Wolcott, written comuns., 1971, 1973). The larger (Bantimala) of the two exposures is the better known. Its metamorphic rocks strike northwestward and include glaucophane schist and eclogite but are dominantly greenschist, hornblende-mica schist, and chloritic phyllite; quartzite is present locally. The K-Ar age of muscovite in a garnet schist is 111 m.y., Early Cretaceous (J. D. Obradovich, written commun., 1974). The ultramafic rocks and high-pressure metamorphic rocks are inferred to show that the basement complex formed in an environment of subduction.

The melange of the two areas of exposure in the northeast part of the South Arm consists of chaotically intercalated and broken feldspathic sandstone and siltstone, sheared shale, red chert and red limestone, ultramafic rocks, variably altered gabbro, amphibolite, glaucophane-lawsonite schist, greenschist, and other materials (Abendanon, 1916-18, v. 1, p. 33-34, 62-134; Djuri and Sudjatmiko, 1974; Gisolf, 1917;
K. B. Ketner, oral commun., 1972). The small mass of melange faulted up along the Sadang fault farther west consists of broken feldspathic sandstone and siltstone, red chert and limestone, and ultramafic rocks (K. B. Ketner, oral commun., 1972). Abendanon (1916-18, v. 2, p. 875-881) reported serpentinite, harzburgite, and radiolarite-rocks likely to have come from melange - to be minor components of gravels in streams entering the central part of the Palu Valley, at the base of the North Arm.

The schist in the Bantimala area is overlain by red, radiolarian chert (fig. $82 A$ ) interbedded with lenses of schist-pebble conglomerate, and the chert is overlain concordantly by siliceous shale. Radiolaria in the chert and low in the shale are of late Albian (latest Early Cretaceous) age
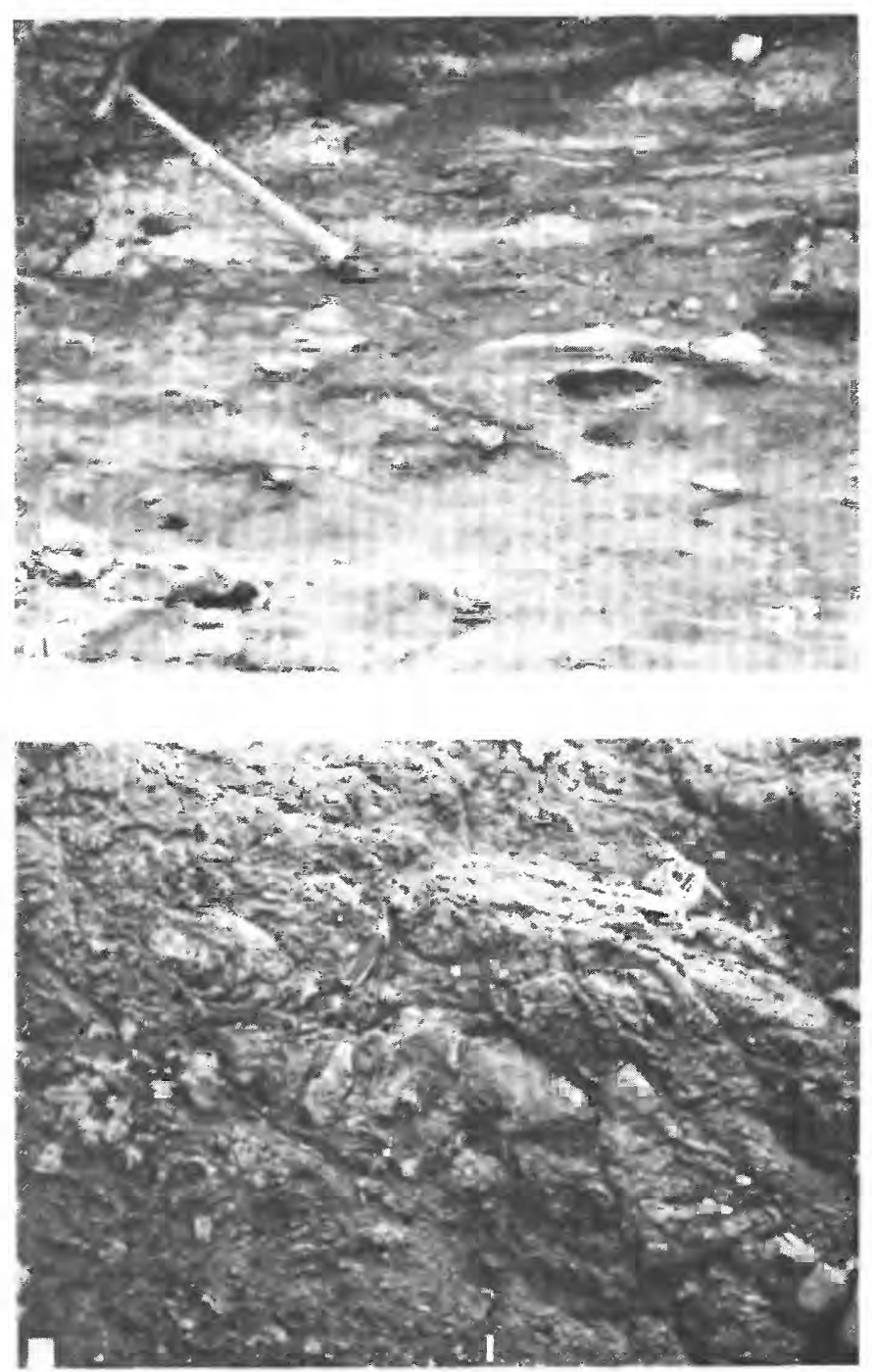

FIGURE 82.-Sheared Cretaceous sedimentary rocks in the southwest part of the South Arm of Sulawesi, near Bantimala, about $50 \mathrm{~km}$ northeast of Ujung Pandang (Makassar). $A$, Sheared radiolarian chert. $B$. Lenses of limestone in sheared shale. Photographs by Don E. Wolcott. 
according to Emile A. Pessagno, Jr." unmetamorphosed but are locally much sheared (fig. 82A). As their stratigraphic age is only slightly younger than the $\mathrm{K}$-Ar age of the underlying schist, the sediments may have been deposited on top of the growing middle Cretaceous melange wedge and may have been deformed by its continuing internal imbrication.

A thick section of mostly clastic rocks-shale, turbiditic siltstone and graywacke, and minor limestone-overlies the chert and shale, but detailed relationships are unknown. Some of these rocks also are sheared (fig. $82 \mathrm{~B}$ ). A pillow basalt in this section has a K-Ar age of $58.5 \mathrm{~m}$.y., probably Paleocene (J. D. Obradovich, written commun., 1974; Sukamto, 1975b).

\section{PALEOGENE SHELF STRATA}

Overlying the turbiditic facies of the lower Paleogene is an upper Paleogene and lower Miocene shelf section, deformed only moderately, which was deposited as a regional sheet in the South Arm and west-central Sulawesi (Sukamto, 1975a). In the southern part of the South Arm, quartzose sandstone, shale, and coal are overlain by upper Eocene to lower Miocene shallow-water platform limestone (fig. 83; 't Hoen and Ziegler, 1917; von Steiger, 1915; D. E. Wolcott, written commun., 1971, 1973). Offshore to the west of the southern part of the South Arm, lower Eocene redbeds, quartz sandstone, conglomerate, and coal are overlain by middle Eocene and younger marine strata. South of the South Arm, the middle Eocene through Miocene is bathyal shale and subordinate limestone. In the north-central part of the South Arm, red marine Eocene shale, marly shale, and quartz sandstone underlie thick Oligocene and lower Miocene limestone (Djuri and Sudjatmiko, 1974; Waterschoot van der Gracht, 1915; K. B. Ketner, oral commun., 1972). Eocene and Oligocene limestone is the oldest rock exposed in the west-coast basin (Lariang Basin) of central Sulawesi (Beltz, 1944). Oil geologists have told me that the upper Oligocene and lower Miocene section of this basin much resembles that beneath the Mahakam Delta of east Borneo; the two areas would have been close together before later Miocene opening of Makassar Strait. Widespread slate, phyllite, graywacke, and limestone in the south part of the North Arm, froin the equator to $1^{\circ} \mathrm{S}$., are of Eocene age in the four localitios in which they are- dated by fossils (Sukamto, 1973a; D. E. Wolcott, written commun., 1971).

The shallow-water continental-shelf strata of the lower Paleogene continue into the offshore region about the South

\footnotetext{
11 Pessagno (written commun., 1976) identified and dated radiolaria in two samples collected by Willis H. Nelson and Don E. Wolcott near lat $4^{\circ} 50^{\prime}$ S., long $119^{\circ} 45^{\prime}$ E. Sample GG-4, of manganiferous, ferruginous chert, contains Pseudodictyomitra pentacolaensis Pessagno, Novixitus n. sp., Alievium sp. cf. A. antiguum Pessagno, Archaeodictyomitra simplex Pessagno, Kozurium sp., and Archaeodictyomitra sp. aff. A. sliteri Pessagno. This assemblage, considered independently, is likely late Albian but could be of early Cenomanian (earliest Late Cretaceous) age; the former option is, however. required by its position beneath the other sample. Sample GG-2, of siliceous shale about $50 \mathrm{~m}$ directly above the chert sample, contains Pseudodictyomitra pentacolaensis Pessagno, Pseudodictyomitra sp., Xitus plenus Pessagno, and Zifondium lassenensis Pessagno, a late Albian assemblage. Dating is primarily by correlation with well-dated assemblages in California.
}

Arm, whereas the upper Paleogene of the two settings is different. Apparently the South Arm was distinct by about late Eocene time. As is discussed subsequently, it is thought that deep-water Makassar Strait opened by Tertiary rifting of what was in early Eocene time a single continental mass that included Borneo, the South Arm, and west-central Sulawesi, and that the quartzose lower Paleogene strata of Sulawesi were derived from Borneo.

\section{NEOGENE IGNEOUS AND SEDIMENTARY ROCKS}

The stable-platform conditions of Eocene to early Miocene time in the South Arm and west-central Sulawesi came to an abrupt end, and rocks of late early Miocene and younger age mostly record magmatism and volcaniclastic sedimentation, in what is now the onshore region, and deep-water sedimentation offshore. The Neogene magmatism appears to be paired to westward subduction that is recorded in the geology of the East and Southeast Arms.

The high lower Miocene to Quaternary stratified rocks of the South Arm are mostly welded tuffs, waterlaid tuffs, lava flows, volcaniclastic sediments, turbidites, and marls (Abendanon, 1916-18, v. 1; Djuri and Sudjatmiko, 1974; 't Hoen and Ziegler, 1917; von Steiger, 1915; Sukamto, 1973b, 1975a, b; K. B. Ketner and D. E. Wolcott, written communs., 1971). The volcanic rocks are basalt, andesite, dacite, rhyolite, and abundant alkalic rocks, including many bearing leucite. A geochronological reconnaissance study of South Arm volcanic rocks by J. D. Obradovich (in U.S. Geological Survey, 1975, p. 163) indicates that volcanism began with basaltic lavas about $18 \mathrm{~m} . \mathrm{y}$. ago and that andesitic magmatism began about 9 m.y. ago; dacite was erupted 4 to $5 \mathrm{~m}$.y. ago. A large cone of Quaternary andesite stands at the south end of the South Arm, and little-deformed but considerably eroded rhyolite welded tuff lies unconformably upon deformed older Neogene alkalic and calc-alkalic volcanic and sedimentary rocks in the northwest part of the arm. The youngest magmatism apparently was of calc-alkalic, not alkalic, character, but available data do not permit further specification of the age of the alkalic volcanism.

Several terrains of calc-alkalic and alkalic volcanic rocks in the South Arm have been assigned to the Paleogene (Sukamto, 1975a) or Oligocene (Djuri and Sudjatmiko, 1974). So far as I am aware, these are not dated except as older than middle Miocene, and in a case or two as younger than Eocene. As nearby fossiliferous Eocene and Oligocene strata are platform clastic and carbonate rocks, I am dubious of the old age assignments for these volcanic rocks.

West-central Sulawesi and the south part of the North Arm contain batholiths and stocks that intrude variously Neogene (and older?) volcanic rocks, little-metamorphosed Paleogene shelf strata, and undated low-, middle-, and high-grade metamorphic rocks (Abendanon, 1916-18, v. 1, v. 2; Brouwer, 1934; Egeler, 1947; Nikko Exploration and 

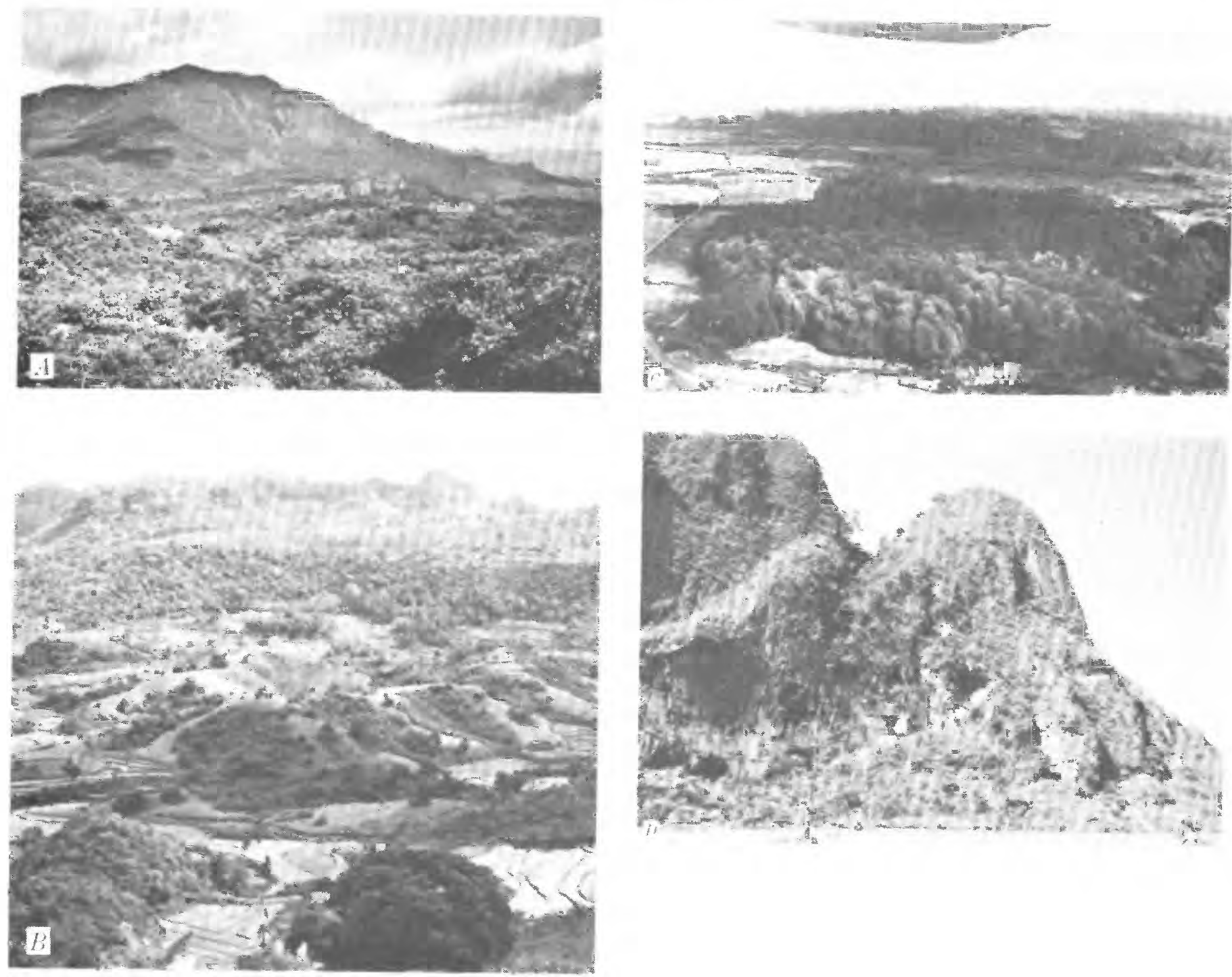

Figure 83.-Tertiary terrain of southwestern Sulawesi. A, Middle Tertiary limestone (bluffs, middle distance) is overlain by Neogene volcaniclastic rocks (peak). View southward from a point about $70 \mathrm{~km}$ northeast of Ujung Pandang. $B$, West-dipping section of Paleogene strata. Sparsely wooded foreground area is formed of shale and turbiditic siltstone; wooded ridge in middle distance is of shale and quartzose sandstone, with coal beds; and the turreted skyline ridge is of limestone. View southwestward from about $50 \mathrm{~km}$ northeast of Ujung Pandang. C, Tower karst developed from flat-lying middle Tertiary limestone southwest of Bantimala. $D$, Cave-riddled karst towers, middle Tertiary limestone, west of Bantimala. Photographs $A$ and $B$ by D. E. Wolcott.

Development Co., Ltd., 1971, 1972; Sukamto, 1973a, 1975a; D. E. Wolcott, written commun., 1971). Fresh biotite or hornblende-biotite granodiorite and quartz monzonite are the dominant granitic rocks, quartz diorite is common, and small intrusions of variably altered and more mafic rocks are present also. The metamorphic rocks include slate, phyllite, chlorite schist, biotite schist and gneiss, amphibolite, and granitic gneiss; whether pre-Tertiary rocks are present is not known, and the Paleogene designation on the tectonic map is uncertain. The Neogene volcanic rocks are the extrusive equivalents of the granitic rocks and presumably in part also form their roofs.
Twenty-three samples of intermediate and silicic volcanic, hypabyssal, and plutonic rocks and metamorphic rocks from the South Arm, west-central Sulawesi, and the south end of the North Arm have been dated by the K-Ar method (J. D. Obradovich in U.S. Geological Survey, 1975, p. 163; J. D. Obradovich, written commun., 1974; N. D. Coggleshall, Gulf Research and Development Corp., written commun., 1972; Nikko Exploration and Development Co., Ltd., 1971; Sukamto, 1975a, b). These dates scatter only from 1.6 to 31 m.y., and most of them, including the reliable ages on the granitic and metamorphic rocks, are within the range 5-14 
m.y. The magmatism thus occured at least mostly within middle and late Miocene time.

The rest of the North Arm is formed mostly of volcanic, volcaniclastic, and granitic rocks (Ahlburg, 1913; Bucking, 1904a; Koperberg, 1929; Ratman, 1976). Constructional volcanic forms are preserved in the east part of the arm, near the still-active northeast tip: the active zone apparently has shortened northeastward with time. (In another section, this is ascribed to the oroclinal folding of the North Arm as subduction from the east, on the Sangihe system, gave way progressively to subduction from the north, on the North Sulawesi system.) Otherwise, dated sedimentary rocks intercalated in volcanic sections are Miocene or younger. The northeasternmost reported Paleogene fossils are in sedimentary rocks south of the equator, near the base of the North Arm (Ahlburg, 1913; Brouwer, 1934, p. 59, 206). The volcanic rocks are mostly andesite and dacite, although leucitic rocks have been found, and the widespread granitic rocks of the western part of the arm are typically hornblende-biotite granodiorite and quartz monzonite (Bucking, 1904a; Koperberg, 1929). Two clusters of porphyry-copper quartz-diorite plutons of late Miocene age are intrusive into older Miocene intermediate and silicic volcanic rocks farther east in the North Arm (Dow, 1976). The nonvolcaniclastic sediments in the volcanic sections of most of the arm are pelagic carbonates, clays, and radiolarites, variably tuffaceous (Koperberg, 1929, pt. 1, p. 21-30, 249), and an island-arc setting is inferred, similar to that of the present Sangihe Arc.

Active volcanoes on Sulawesi are now confined to the northeast tip of the North Arm, where many vents on numerous cones have erupted within historic time (Effendi, 1976; Koperberg, 1929; Neumann van Padang, 1951, p. 227-244). (The active volcanic island of Una-Una, between North and East Arms, is described in another section.) The rocks are dominantly andesitic. The volcanic chain here represents the south end of the Sangihe Island Arc. A Benioff seismic zone dips westward deep into the mantle beneath the Celebes (Sulawesi) Sea, but, as discussed in a subsequent section, the overriding Sangihe plate here has collided with the westward-advancing Halmahera plate as the intervening Molucca Sea plate has been subducted at both sides. Alkalic volcanic rocks - trachyandesite and trachyte - occur at the west side of the volcanic terrain at the northeast tip of the North Arm (Effendi, 1976), as is appropriate to formation above a west-dipping subduction system.

INACITIVE ISLAND ARC: BETWEEN THE SOUTH ARM AND FLORES

Salayar (Selayar) and the islets just south of it consist of volcanic rocks and of Neogene sedimentary rocks (Verbeek, $1908 \mathrm{a}, \mathrm{b}$ ). The small islands farther southeast (Kayuadi, Tanahjampea, Kalao, and Bonerate, 120-170 km north of Flores) consist of undated andesite, basalt, and highly alkalic volcanic and intrusive rocks, plus raised reef limestone (Hetzel, 1930a). I have seen an oil-company reflection profile showing that thick strata east of Salayar tip westward toward the deep, narrow trough at the base of that long, straight island. Presumably this trough is a trench that was recently inactivated. The volcanic rocks of Salayar and the ridge to the southeast of it, and also the large, inactive volcano in the southeast corner of the South Arm of Sulawesi, are inferred to belong to the inactive subduction system.

\section{SUBDUCTION COMPLEXES OF THE EASTERN ARC}

The rocks and structures of east-central Sulawesi and of the East and Southeast Arms define a broad, asymmetric arc of ophiolite, melange, and imbricated sedimentary and metamorphic rocks (fig. 81), interpreted as the products of west-dipping subduction during Late Cretaceous(?), Paleogene(?), and Neogene time. Several quasiconcentric arcuate belts can be broadly delineated within these subduction-produced complexes. The western belt, presumably the oldest, is characterized by glaucophane schist and polymict melange. Next to this is a discontinuous belt dominated by sedimentary and low-grade metasedimentary rocks. Next is a terrain of large masses of ophiolite and subordinate ones of sedimentary rocks. Last, on the east, occur increasingly abundant sedimentary rocks, intercalated tectonically with ophiolite in the west but lapping onto one or two continental fragments in the east. The structural grain of the Southeast Arm is east-southeasterly, oblique to the general south-southeast trend of the arm (figs. 81, 84). This east-southeasterly grain is recorded by both the structures within the bedrock terrains and by the young uplifts, basins, and faults by which they are deformed.

\section{WESTERN BLIESCHIST-AND-MELANGE BELI}

Glaucophane schist is abundant in the western part of the eastern arc in central Sulawesi, the southwestern and southern parts of the Southeast Arm, and in Kabaena Island (fig. 85; Abendanon, 1916-18, v. 2; Bothé, 1927; Brouwer, 1934, 1947; Dieckmann and Julius, 1925; Hetzel, 1927; de Roever, 1947, 1950, 1953, 1956; Willems, 1937; Wunderlin, 1914). The blueschist-facies rocks contain glaucophane, crossite, lawsonite, jadeite, and aegerine. Rocks of lower grade, but likely still indicative of relatively high ratios of pressure to temperature, contain such minerals as prehnite and pumpellyite. These high-pressure rocks are juxtaposed chaotically with metamorphic rocks of quite different facies (amphibolite, epidote amphibolite, greenschist, phyllite), with unmetamorphosed to metamorphosed pelagic chert and limestone, and with ophiolite masses. As de Roever (1953) emphasized, these conjunctions of rocks representing such different pressure-temperature fields require large offsets on the bounding faults. Tectonic intercalation of contrasted types occurs on both large (Hetzel, 1927; de Roever, 1953) and small scales, and descriptions in the 


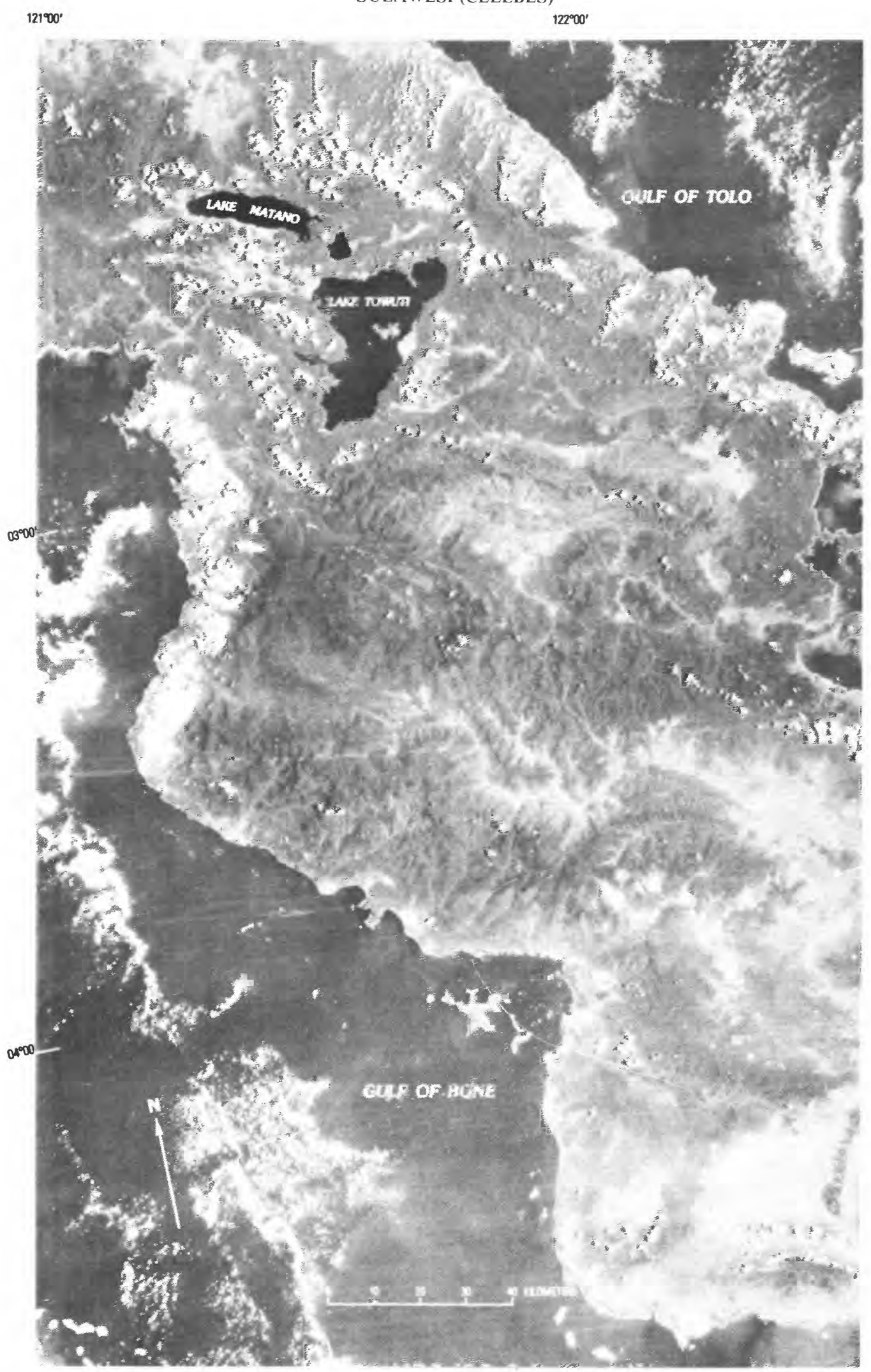

FIGURE 84.- Landsat image of the Southeast Arm of Sulawesi. The overall trend of the peninsula is south-southeastward, but the dominant structural grain is east-southeast. See figure 85 for geologic map. NASA-ERTS pictures 1096-01340 and -01343, October 1972. 


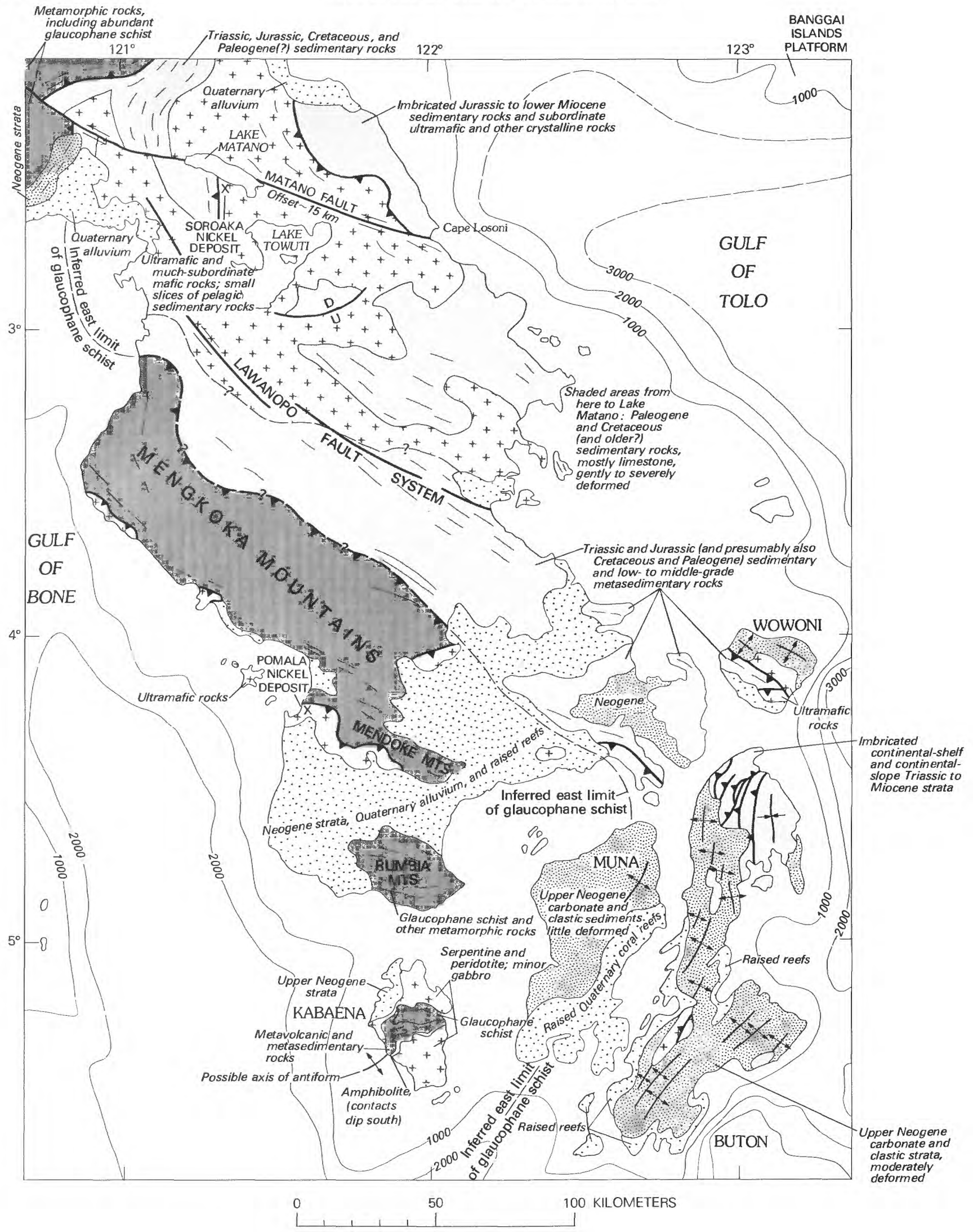


literature indicate that polymict melange is probably very widespread. Thus Brouwer (1934) referred (I translate freely) to "strongly squeezed schists of a breccious aspect" (p. 69), a "tectonic mixed zone" (p. 92), "phyllitic conglomerate" and "very strong***folding and scale formation" (p. 93), and "strongly mylonitized conglomeratic phyllite" (p. 107). The blueschist-and-melange terrain has yielded no dated fossils, although radiolaria are widely present in the cherts, and is dated directly only as older than the middle or upper Miocene and younger strata that overlie it north of Lake Poso (van der Vlerk and Dozy, 1934, p. 195-197). Topography developed on this terrain in central Sulawesi is strongly lineated (figs. 86,91 ), and severe imbrication within it is obvious. The oldest dated strata of the shallow-marine and continental section that locally overlies these complexes are of middle or late Miocene age in the southeast part of the South Arm, but the strata contain reworked late Oligocene or early Miocene shallow-water foraminifers that likely came from other beds overlying the highly deformed and metamorphosed complex (P. Baumann and J. Sigal, written commun., 1971).

\section{BEI, I OF SEDIMENTARY AND METASEIDIMENTARY ROCKS}

This next belt forms a broad but poorly known band trending northwestward across the Southeast Arm (fig. 85), and a narrower and discontinuous band trending irregularly northward across the east part of central Sulawesi to the Gulf of Tomini (Bothe, 1927; Brouwer, 1934, p. 87-102; 1947; Dieckmann and Julius, 1925; de Roever, 1947, 1950).

\section{EXPLANATION}

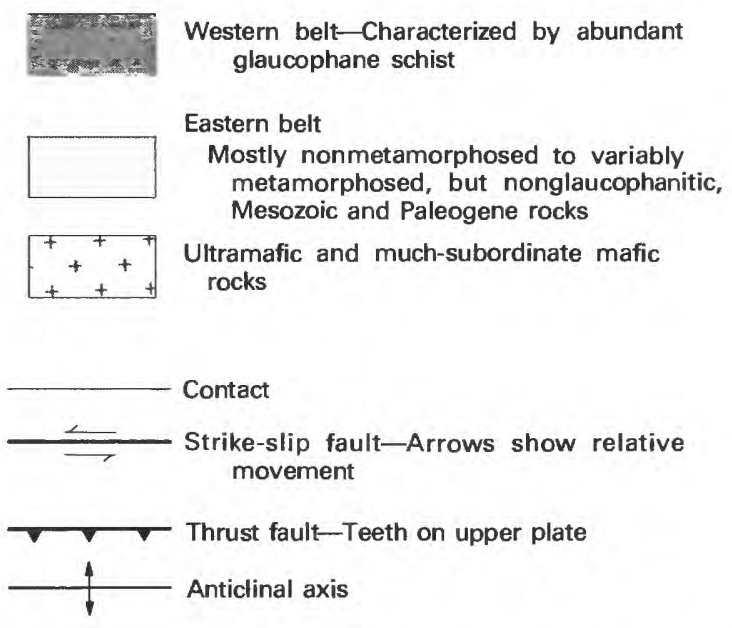

The sedimentary rocks represent both pelagic and terrigenous-clastic sedimentation: red and gray chert, limestone, and shale; quartzose and micaceous sandstones. Triassic and Jurassic cephalopods and clams and Cretaceous, or possibly Tertiary, pelagic foraminifers have been found in a few places. Also abundant are low-grade metasedimentary rocks, including schist, phyllite, slate, and quartzite and piedmontite-bearing metachert. Blueschist is unknown, but rocks bearing pumpellyite and prehnite have been reported. Nothing is known about the stratigraphy of the rocks, which are highly deformed, much sheared, and intercalated tectonically with ophiolite fragments and with metamorphic rocks including amphibolite. The juxtaposition of such unrelated rock types indicates that polymict melange probably is widespread. Silver, Joyodiwirya, and McCaffrey (1978) described melange, which they inferred from a reconnaissance gravity survey to be very voluminot's despite its minimal exposures. A large irregular area of tower karst in the Southeast Arm, centered at about lat $3^{\circ} 20^{\prime} \mathrm{S}$., long $121^{\circ} 15^{\prime}$ E. (unpub. International Nickel Indonesia photogeologic map), shows the presence of a large mass of limestone, but whether this is within or atop the complex is unknown.

\section{OPHIOI.ITE AND SEDIMENTARY ROCKS}

Most of the East Arm and of the northeast part of the Southeast Arm consists of a broad expanse of ophiolite interspersed with smaller masses of Mesozoic and Tertiary sedimentary rocks (figs. 81, 85). Ultramafic rocks are dominant and are mostly peridotite (harzburgite and Iherzolite), plus a little dunite and pyroxenite, and their variably crushed, brecciated, sheared, and serpentinized derivatives (Abendanon, 1916-18, v. 2, p. 536-537; Kündig, 1956; de Roever, 1947; Soeria Atmadja and others, 1974). The compositions of the primary minerals indicate crystallization of much of the peridotite under upper-mantle conditions rather than near the surface (International Nickel Indonesia, 1972). Some of the ultramafic rocks however are high-level cumulates; at Soroaka (on the south side of Lake Matano), I was shown by International Nickel geologists pegmatitic pyroxenite and olivine-ilmenite rock, types known from the upper cumulate parts of the ultramafic phases of ophiolites elsewhere. Gabbro, diabase, basalt, spilite, amphibolite, and greenschist are widely associated with the ultramafic rocks and are of major volume in the

FIGURE 85.-Geologic map of the Southeast Arm of Sulawesi and neighboring islands. A western belt (dark shading) is characterized by abundant glaucophane schist, and an eastern belt consists mostly of nonmetamorphosed to variably metamorphosed, but nonglaucophanitic, Mesozoic and Paleogene sedimentary rocks (light shading) and ultramafic and much-subordinate mafic rocks (cross pattern). The contact between the belts defines curves in the northwestern and southeastern parts of the area which may be oroclines. Modified freely from published reports (mostly in the pre-1940 Dutch literature) and from a 1971 photogeologic map by geologists of International Nickel Indonesia; most of the region is very poorly known. Reconnaissance bathymetric contours, interval $1,000 \mathrm{~m}$, are from a 1968 compilation by Robert L. Fisher of the Scripps Institution of Oceanography. 


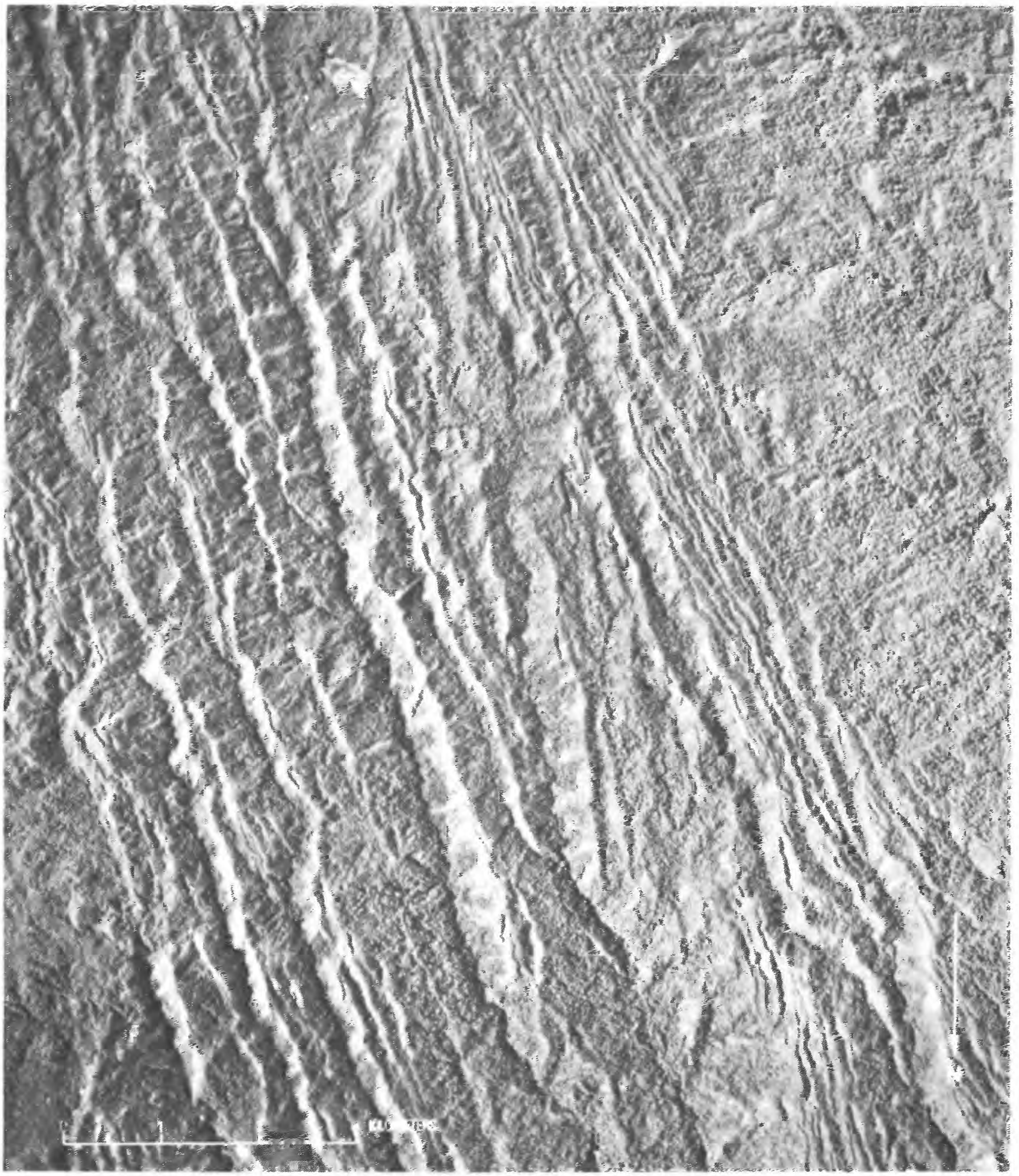

Figi'RE 86. - Vertical aerial photograph of strongly lineated terrain of glaucophane schist and Mesozoic sedimentary rocks, Pompangeo Mountains. (east-northeast of Lake Poso, which is shown in fig. 79). central Sulawesi. Severe imbrication is made obvious by the oblique truncations of the ridges eroded along bedding and foliation. Neogene sedimentary rocks cover the deformed complex in the southwest (upper right). The center of the area illustrated is near lat $1^{\circ} 45^{\prime} \mathrm{S}$., long $120^{\circ} 55^{\prime} \mathrm{E}$. Photograph provided by International Nickel Indonesia. 
East Arm but of generally minor volume in the Southeast Arm. Presumably these ultramafic and mafic complexes represent large masses of oceanic mantle and crust, although their size and the relative scarcity of mafic rocks in the Southeast Arm pose problems.

Abundant small masses of Mesozoic and Tertiary sedimentary rocks are intercalated tectonically with the ultramafic and mafic rocks (Abendanon, 1916-18, v. 2; Brouwer, 1934, 1947; Dieckmann and Julius, 1925; von Loczy, 1934; van der Vlerk and Dozy, 1934). The sedimentary rocks have in many localities yielded Triassic, Jurassic, Cretaceous, and lower or middle Miocene fossils. Dated Mesozoic rocks are limestones, whereas some Miocene rocks contain detrital quartz; there is much undated sandstone and shale. Much of the limestone, marl, chert, and siliceous shale is red and radiolarian, and abyssal pelagic deposition can be inferred. Described contacts between sedimentary and crystalline rocks are faulted. I examined several of the contacts between ultramafic rocks and small slices of gray limestone, red radiolarian chert, and red siliceous shale exposed in cuts along the road between Malili and Soroaka; they showed much shearing.

Large masses of Mesozoic and Tertiary sedimentary rocks also occur within the ophiolite-dominated terrain. The large mass of limestone and subordinate chert at the southwest side of Lake Matano(fig. 85) is moderately to steeply folded, considerably contorted on a small scale, and locally sheared (Koolhoven, 1932). The rocks likely are abyssal pelagic sediments. The lower part of the section consists of interbedded gray limestone, brownish-red limestone containing radiolaria, marl, and manganiferous red radiolarian chert; a little red clay is present at the base. The upper part of the section consists of gray and brownish-gray limestone. The limestone mass is bounded against the peridotite to the east by a west-dipping zone of highly sheared serpentinite. Within the southern part of the mass are zones, dipping mostly south, of mylonitized serpentinite melange enclosing clasts of amphibolite, garnet amphibolite, quartzite, and piedmontite quartzite; presumably the peridotite and other rocks to the south are thrust over the mass, although this geometry has not been demonstrated. As Koolhoven concluded, the surrounding ultramafic rocks may represent the oceanic basement upon which the section was deposited at abyssal depths, although the expected oceanic crustal section of basalt, diabase, and gabbro has not been recognized around the mass and hence has been removed by faulting. The only fossils dated from the strata are pelagic Upper Cretaceous foraminifers (van Bemmelen, 1949, p. 414).

The mass of sedimentary rocks southeast of Lake Towuti (fig. 85) consists of Mesozoic and Tertiary limestone and calcareous shale and sandstone (fig. 87 A, D; Brouwer, 1934, p. 72-76; van der Vlerk and Dozy, 1934, p. 185). The stratigraphy of the mass is unknown, but Triassic or Jurassic belemnites have been found in red manganiferous limestone, Upper Cretaceous foraminifers in cherty pink limestone, and Tertiary foraminifers in quartz-sandy limestone. Perhaps the Mesozoic part of the section consists of abyssal pelagic sediments and resembles the section at Lake Matano, whereas the Tertiary part is a continental-rise section deposited over the pelagic strata. The limestone of the northern part of the mass dips gently southward above mafic and, dominantly, ultramafic rocks (fig. 87 A; unpub., 1971, photogeologic map by International Nickel Indonesia [IN$\mathrm{CO}]$ ). Elsewhere around the mass, tectonic intercalations of sedimentary and ultramafic rocks (including "breccious serpentine*** mylonites") and subordinate mafic rocks are present, dips are mostly moderate, and small-scale deformation is conspicuous (Brouwer, 1934, p. 72).

The much larger mass of sedimentary rocks, extending inland from the east coast southeast of Lake Towuti, includes much limestone, for broad areas of tower karst are present (unpub. INCO photogeologic mapping).

\section{IMBRICAATED SEDIMENTARY IERRAIN}

The proportion of sedimentary rock intersliced with ultramafic and mafic rocks increases toward the Gulf of Tolo in both the East and Southeast Arms, and sedimentary rock dominates the imbricated terrain of the easternmost exposed belt of Sulawesi. Much of the sedimentary rock is of shallow-water origin.

In the coastal region of both arms near the west end of the Gulf of Tolo, Triassic to Miocene rocks are imbricated with each other and with crystalline rocks (Brouwer, 1934; von Lóczy, 1934; van der Vlerk and Dozy, 1934). Pelagic sediments dominate the western part of this belt: red and gray limestone, marl, and chert, mostly undated but including Triassic to Upper Cretaceous fossils. Shallow-water coralline Triassic limestone is also known. The Tertiary includes Eocene clastic sediments and Oligocene to lower or middle Miocene carbonate strata, both types including many redeposited shallow-water fossils.

FigurE 87 (overleaf).--Aerial views of geologic features of north part of Southeast Arm of Sulawesi. A, Contact, possibly thrust fault, between Mesozoic or Tertiary limestone (TMzl) and dominantly ultramafic rocks (um); view east, $15 \mathrm{~km}$ east of central Lake Towuti. $B$, Ultramafic rocks (um) thrust over Mesozoic or Tertiary clastic and carbonate strata (TMzl); view north, $20 \mathrm{~km}$ west of Cape Losoni. In $A$ and $B$, note differences in topographic texture and vegetation between the sedimentary and ultramafic rocks. $C$, Intersliced ultramafic and sedimentary rocks form lineated topography in foreground, and imbricated Mesozoic and Miocene strata form the distant upfaulted ridge. The Matano fault zone trends through the valley but is not apparent in the picture. View north to Cape Losoni. D, Karst developed on Mesozoic or Tertiary limestone, $10 \mathrm{~km}$ east of southern Lake Towuti; distant ridges mostly ultramafic rocks; view south. Geologic interpretations by geologists of International Nickel Indonesia; photographs by Hamilton. Places named are located in figure 85 . 

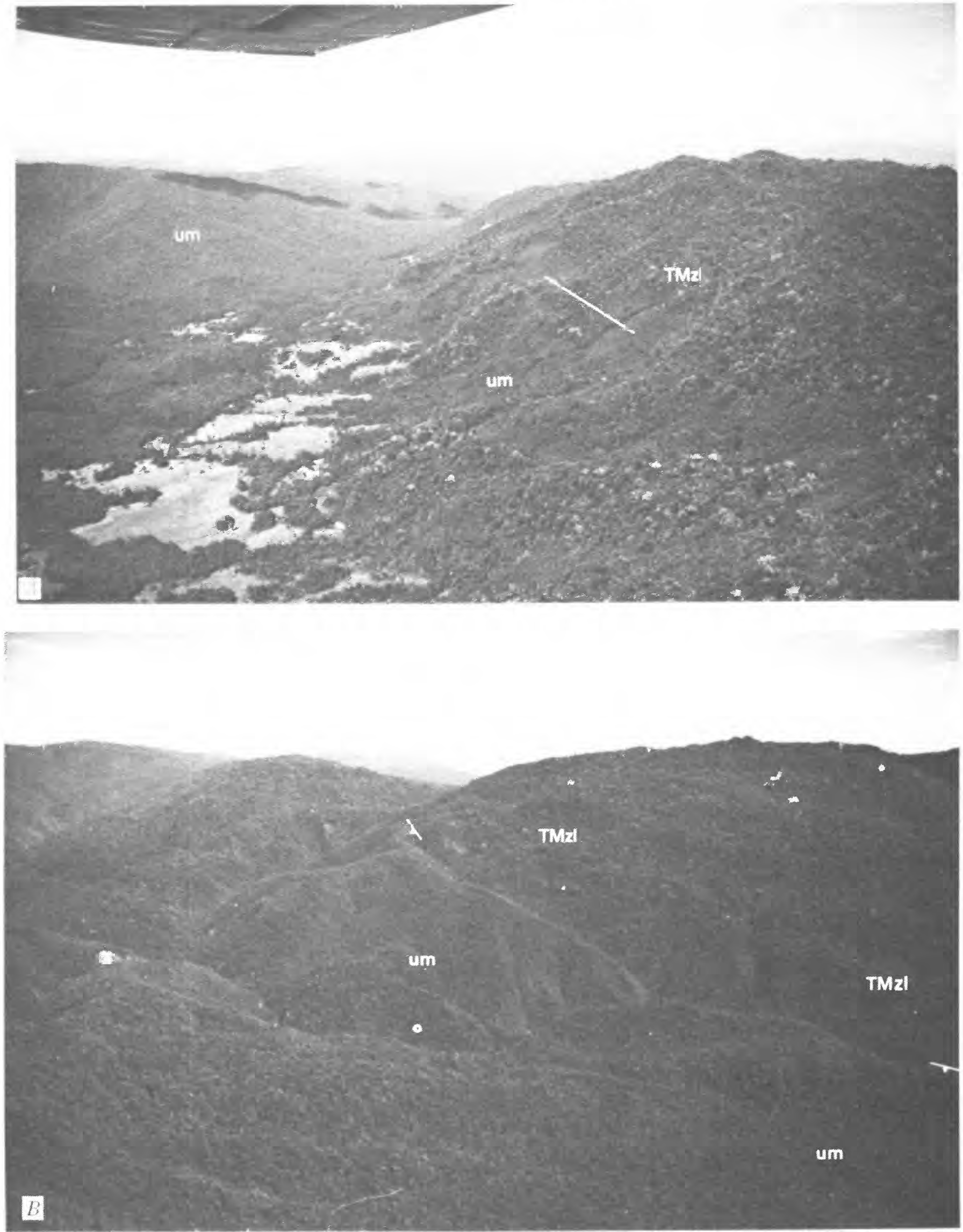

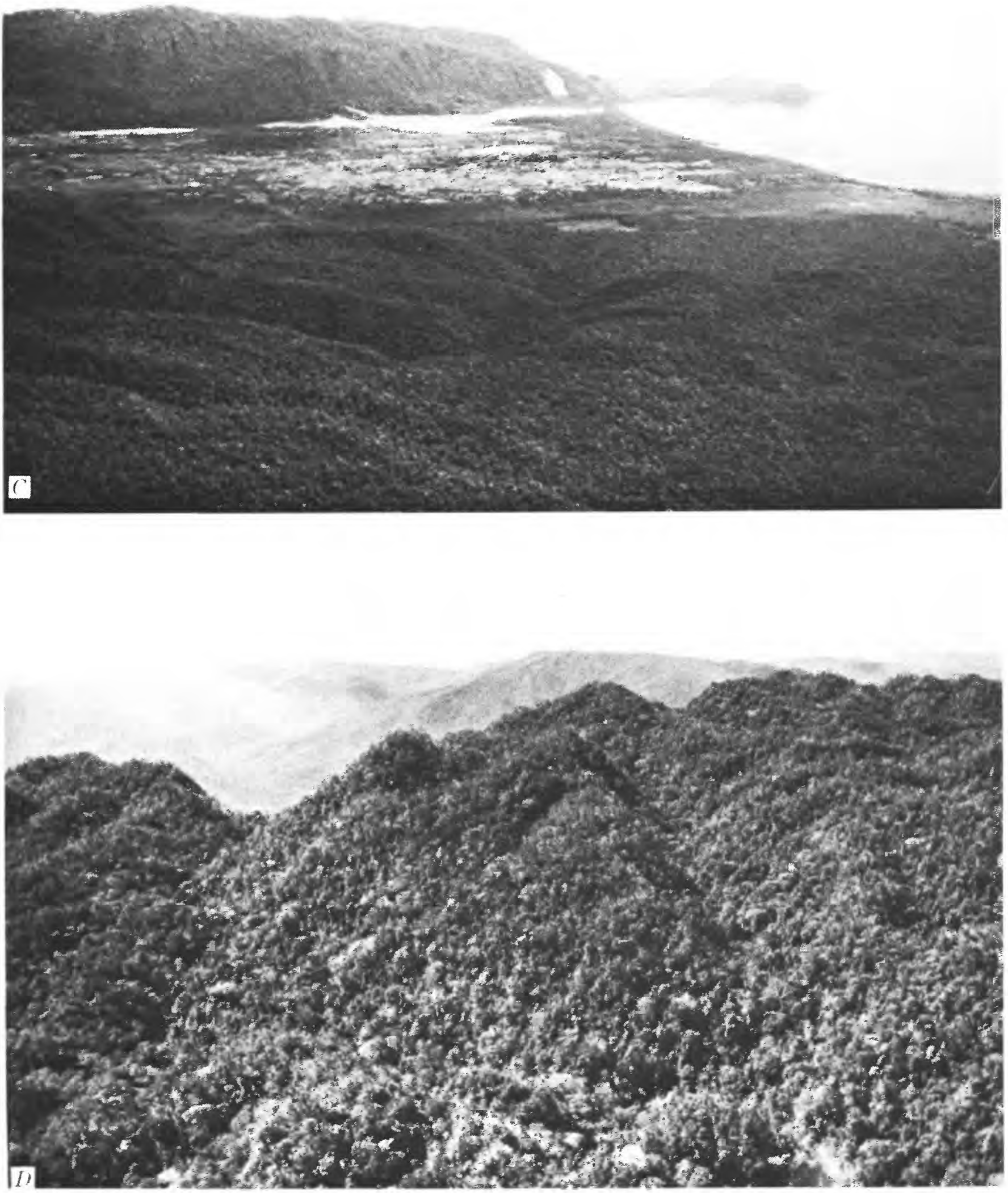
The east part of the East Arm consists of large masses of ophiolite, with subordinate tectonic intercalations of Mesozoic sedimentary rocks, on the northwest, and of a northwest-dipping imbricated complex of Mesozoic, Paleogene, and Miocene strata, on the southeast (figs. 88, 89; Koolhoven, 1930; unpub. 1941 report by R. H. Hopper as cited by van Bemmelen, 1949, p. 66-67, 149-150, 394-395; and, particularly, the sophisticated report by Kundig, 1956). The components of the imbricated complex tend to become younger and to represent shallower water environments of sedimentation, toward the south coast, a short distance beyond which is Peleng Island and the other islands of the Banggai and Sula groups, with their Paleozoic crystalline basement and Mesozoic and Cenozoic platform cover. The southeastern part of the imbricated terrain is dominated by Eocene, Oligocene, and lower Miocene shallow-water limestone and quartz sandstone. Correlative strata in the medial part of the imbricate complex are deeper-water marls and clastic rocks. The northwestern part of the imbricated terrain is a more complicated hash of Mesozoic and
Cenozoic deep-and shallow-water sedimentary rocks and of ophiolite fragments. The deformation occurred progressively, beginning in middle or late Miocene time: lower Miocene strata are fully involved in the imbrication, upper Miocene clastic sediments derived from the thrust belt are folded and locally broken by thrust faults, and Pliocene clastic rocks are moderately deformed. Post-deformation Quaternary(?) reef limestones are uplifted as high as $400 \mathrm{~m}$ above sea level.

The island of Buton (Boeton, Butung), off the southeast end of the Southeast Arm, displays a similar imbricated terrain that includes shallow-water strata and ophiolite slices (fig. 85; van Bemmelen, 1949, p. 421-4221; Bothé, 1927; Hetzel, 1937; unpub. 1971 INCO photogeologic map). The crystalline rocks are variably crushed amphibolite, greenschist, serpentinite, harzburgite, and gabbro. Sedimentary rocks include fossiliferous Triassic strata (shallow-water shale, marl, limestone, quartzose and micaceous sandstones, and conglomerate), Jurassic marl and limestone containing ammonites and belemnites, cherty Cretaceous limestone containing pelagic foraminifers, and

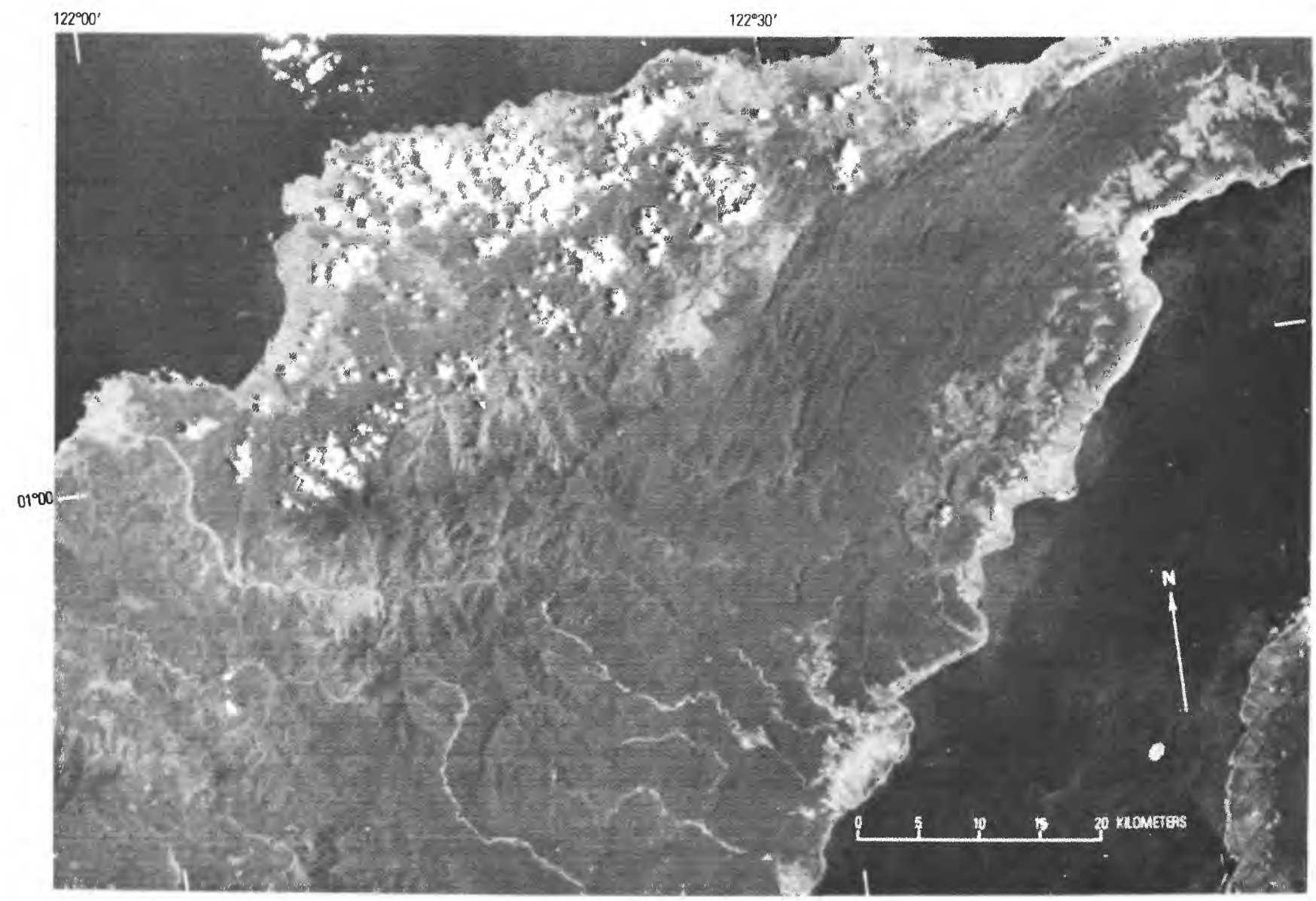

FIGURE 88.- Landsat image of northeast part of East Arm of Sulawesi. See figure 89 for geologic map. The geology is interpreted to record the collision in late Miocene and Pliocene time of the Banggai Islands minicontinental fragment with the northwest-dipping subduction system of Sulawesi. Picture NASA-ERTS 1096-01334, October 1972. 


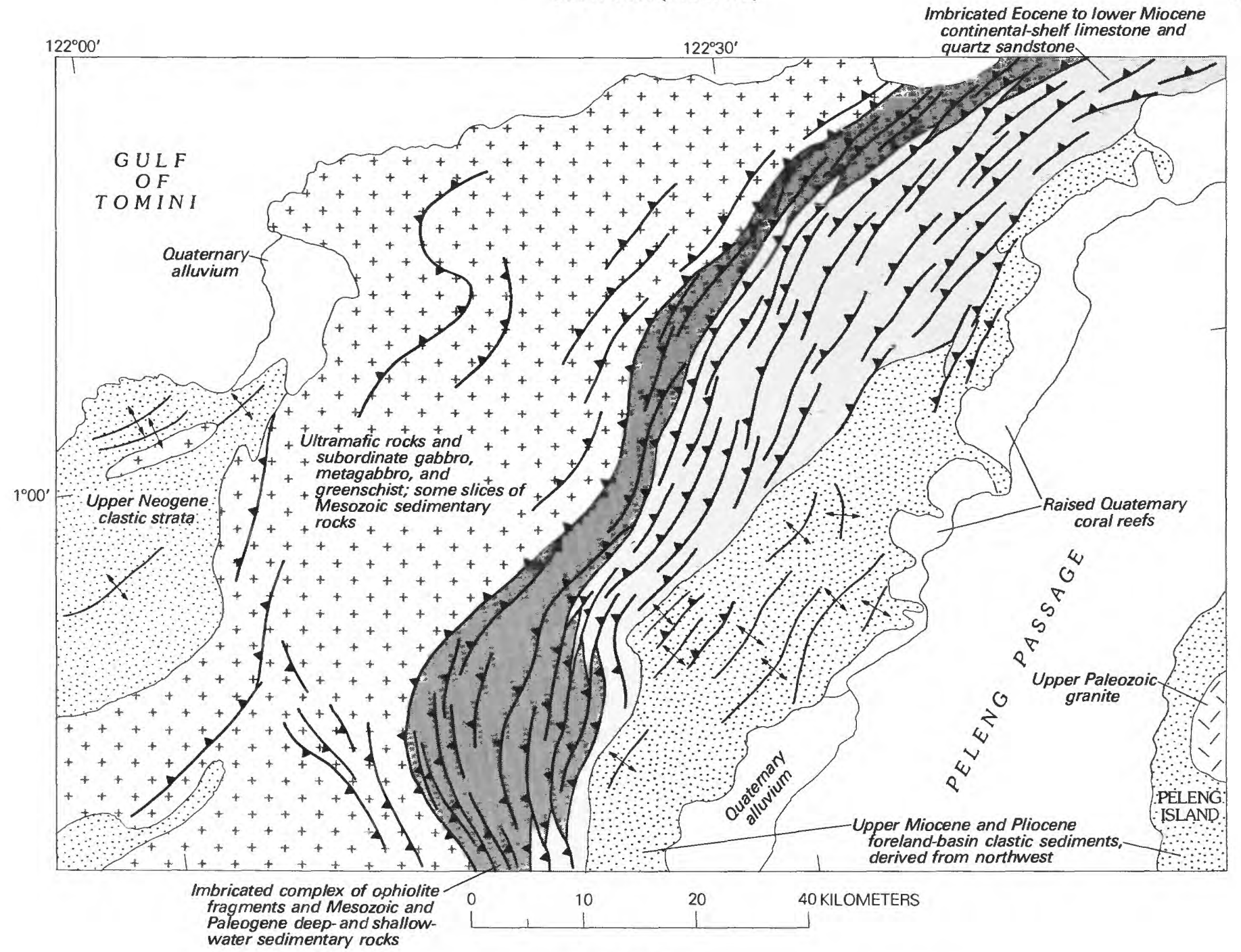

EXPLANATION

Contact Thrust fault-Teeth on upper plate

FIGURE 89.-Geologic map of area illustrated by figure 88. Modified from Kundig (1956, 1:500,000-scale geologic map); minor modifications from an unpublished 1971 photogeologic map by International Nickel Indonesia and from the imagery of figure 88.

upper Oligocene or lower Miocene shallow-water limestone. Middle(?) and upper Miocene carbonates and mudstones overlie the imbricate complex unconformably west of Buton but thicken eastward, with increasing deformation by folds that grew concurrently with sedimentation, to Buton, where they are imbricated, with east-directed structures, with the older rocks. Deformation of Mesozoic and Cenozoic strata decreases offshore, east of Buton. Pliocene or Quaternary coral reefs are raised as high as $700 \mathrm{~m}$ above sea level on Buton and $400 \mathrm{~m}$ on the island of Muna to the west (van Bemmelen, 1949, p. 421; Bothe, 1927).

\section{INTERPRETATION}

The East and Southeast Arms of Sulawesi are regarded as displaying the products of Tertiary subduction westward beneath them and of the collision of one or two continental fragments with that subduction system in Miocene time.

The western belt of this eastern. Sulawesi terrain consists of imbricated sheets and melange and includes glaucophane schist, abyssal pelagic sediments, and ophiolite fragments. The subduction recorded here cannot be dated from evidence yet available within the belt, but Late Cretaceous or Paleogene age can be inferred from the position of the terrain between dated Cretaceous and middle Tertiary subduction complexes. The next belt east, of imbricated sedimentary and metasedimentary rocks, includes both pelagic and terrigenous sedimentary rocks that are at least as young as Cretaceous; a subduction-mixed assemblage of open-ocean and of trench or outer-arc-basin sediments may be represented. 
The next broad belt is of ophiolite and subordinate sedimentary rocks, the latter likely representing primarily deep-water pelagic sedimentation. Presumably we see here a broadly raised region of oceanic lithosphere, crumpled by deformation related to the subduction process. An analogy with better known structural relationships of the Solomon Islands and the oceanic Ontong Java Plateau to the northeast of them (as described briefly in a subsequent section) can be suggested. There, oceanic crust, carrying a thick blanket of pelagic Cretaceous and Cenozoic sediments, has been imbricated and raised by subduction to form large fault blocks and anticlines both above and below sea level in the northeastern part of the Solomon Islands. In the case of Sulawesi, similar imbrication was followed by much more subduction, which ended when a continental fragment collided with the resulting complexes.

The sediment-dominated eastern imbricate complexes of Sulawesi appear to again record westward subduction, in this case directly beneath the ophiolite-dominated terrain. The simplest case to interpret is that of the east part of the East Arm, where the shelf-facies Mesozoic and Tertiary lie atop the Paleozoic basement of the continental Banggai and Sula Islands and are imbricated with northwest dips beneath the ophiolitic terrain: a Banggai-Sula continental fragment collided with the Sulawesi subduction system. The collision occurred within Miocene time, for lower Miocene strata are fully involved in the imbrication, and upper Miocene clastic rocks were derived from the thrust belt but are themselves considerably deformed. The deeper-water terrigenous Mesozoic and Paleogene strata farther west and northwest in the imbricate belt represent the sedimentary apron flanking the continental fragment, now rumpled together with open-ocean sediments and ophiolite slices. The interpretation is made elsewhere that the Banggai-Sula fragment was torn from northwestern New Guinea and carried westward along a strand of the Sorong left-lateral strike-slip fault system.

Buton also displays shallow-water strata, including quart7ose and micaceous sandstones of presumed continental derivation, in its imbricate complex; so this complex also may record the collision of a continental fragment with the Sulawesi subduction system. No old continental basement rocks are exposed on Buton, but they may be present in the subsurface. Buton and the submarine banks southeast of it (fig. 85) may comprise a continental fragment, carried westward to Sulawesi from New Guinea on a strike-slip fault older than that bounding the Banggai-Sula mass farther north.

Other sedimentary rocks of the easternmost exposed arc of Sulawesi around the west end of the Gulf of Tolo provide a mixture of deep-water and shallow-water, and pelagic and terrigenous, Mesozoic and Miocene materials. These can be accounted for in a subduction model as representing variously open-ocean sediments, trench or basin deposits on the Sulawesi side, and continent-flanking deposits on the east side.

\section{NICKEI, ORE}

The residual materials produced by tropical weathering of ultramafic rocks are potential nickel-ore deposits over huge areas in central Sulawesi and its East and Southeast Arms. Two large deposits are now under development, one by International Nickel Indonesia (INCO) at Soroaka on the south side of Lake Matano, the other by an Indonesian government operation at Pomala on the west coast of the Southeast Arm (fig. 85; information supplied by INCO geologists Waheed Ahmad and B. Vishnu Pada). Unweathered ultramafic rocks contain one to several tenths of a percent of nickel, and this is concentrated by weathering to values that average as high as 2 percent nickel as silicates in enormous volumes of material. The weathered material on the ultramafic rocks typically consists of an upper yellow laterite, a lower maroon laterite, and a basal zone of interspersed fresh rock and residual material that carries most of the nickel (fig. 90). Grades are similar in deposits formed from fresh peridotite (as at Soroaka) and from serpentinite (as at Pomala), but the peridotite is much more economical to process because the nickel-bearing weathered material can be removed by tumbling; with serpentinite, the unweathered rock itself crumbles when this is attempted, so much more material must be processed further to obtain the

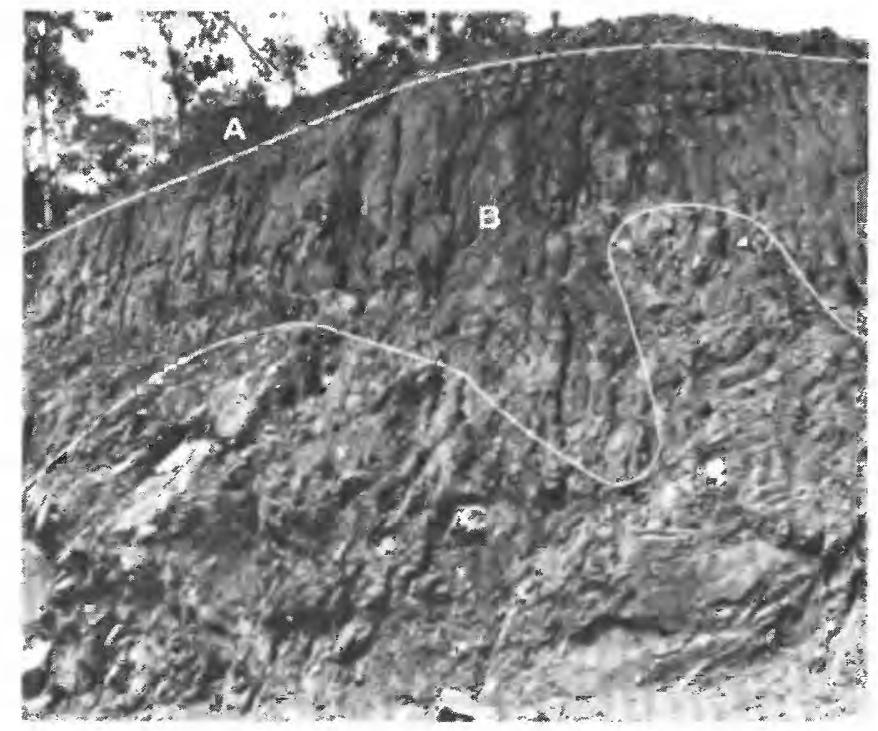

FIGURE 90.--Nickel ore produced by weathering of peridotite (harzburgite), Soroaka, central Sulawesi. A. Yellow laterite and soil; very low nickel content. B, Dark-maroon laterite; contains about 1 percent nickel and very high iron; can be concentrated as ferronickel alloy, but processing not presently economic. C, Mineable zone of blocks of fresh harzburgite with yellow rinds and interstitial saprolite; contains about 2 percent nickel, mostly in the weathered material, which is removed by tumbling the blocks and is processed to metal containing 75 percent nickel. Cut is $8 \mathrm{~m}$ high. 
nickel. The Soroaka deposit is expected to supply about 45,000 metric tons of nickel per year, all or most of it to Japan, by 1980 .

\section{BOUNDARY BETWEEN EASTERN AND WESTERN ARCS}

The blueschist-and-melange Late Cretaceous or Paleogene terrain of the eastern arc of Sulawesi is in contact with the Neogene granitic-and-volcanic terrain of the western arc along an irregular line trending generally northward across central Sulawesi near the meridian of $129^{\circ} 20^{\prime}$ E. (fig. 81). Granitic rocks, and metamorphic rocks bearing either biotite or potassic feldspar, occur west of the zone, whereas blueschists occur east of it (Brouwer, 1934, 1947; Egeler, 1947). Brouwer (1947) interpreted part of the boundary as a mylonite zone, but his descriptions suggest that he may instead have seen eastern-arc melange; dips are steep to the west. In the northeast part of the South Arm, west of the projection southward of the central Sulawesi boundary, post-Oligocene granitic rocks intrude pre-late(?) Eocene melange.

\section{STRIKE-SLIP FAULTS}

WESTERN SULAWESI

The active left-lateral Palu fault trends north-northwest across west-central Sulawesi (fig. 81) and apparently is the west boundary of a lithosphere plate that is overriding the Celebes (Sulawesi) Sea floor to the north. The Sadang fault, parallel to and west of the Palu, may be another of the same family.

The Palu fault is marked by a continuous rift valley, which has a flat floor $5 \mathrm{~km}$ or so wide in its northern Palu Valley-Gulf of Palu sector (for which the fault is named) but which is narrow throughout the rest of its length (fig. 91). The valley walls rise $1,500-2,500 \mathrm{~m}$ above the floor. Katili (1970a) recognized the left-lateral character of the fault, which he termed the Palu-Koro fault. Abendanon (1916-18, v. 2, p. 916-917) termed the structure the Fossa Sarasina and puzzled over the odd juxtapositions it produced that could not be explained by vertical offsets. Tjia and Zakaria (1974) noted physiographic evidence for left-lateral faulting along the northern part of the fault.

I studied aerial photographs of the fault northward from lat $2^{\circ} \mathrm{S}$. to the northwest coast. Left-lateral offsets on old and young strands of the fault are spectacularly shown over a zone several kilometers wide between $1^{\circ} 40^{\prime}$ and $2^{\circ} 00^{\prime} \mathrm{S}$. Most of this sector is illustrated by fig. 92 . At present the most active strand is near the valley floor, and it crosses at a low angle from one side to the other. In one part, all side drainage have been displaced $500-1,000 \mathrm{~m}$ in left-lateral fashion. (Katili, 1970a, referred to some of these offsets.) About $4 \mathrm{~km}$ to the east of this locality, an older strand has disarranged topography on a large scale; offset drainage cannot be neatly matched, but a number of kilometers of displacement appears required. In another part, the most active strand is marked by two left-lateral shutter ridges, one $2 \mathrm{~km}$ long and the other $4 \mathrm{~km}$. At the latitude of this shutter-ridge sector, another, older strand, higher up the valley wall and $3 \mathrm{~km}$ to the east, has offset a major canyon by $3 \mathrm{~km}$; and midway between these strands, another fault has produced stream offsets of about $300 \mathrm{~m}$. Each of these strands in the fault zone is marked by a straight, narrow trough that cuts directly across erosional topography. The fault system is obviously moving at high velocity now, and its total offset is likely much greater than the minimumof $7 \mathrm{~km}$ indicated by topographic displacements in the shutter-ridge sector, Geologic mapping along the fault zone is not good enough to permit suggestions regarding offsets of bedrock geologic units.

North of about lat $1^{\circ} 40^{\prime} \mathrm{S}$., the rift valley of the Palu fault broadens and becomes a flat-floored trough bounded on both sides by fault blocks. Lateral offsets are not generally conspicuous on aerial photographs in this sector. At least one strand of the fault at the south end of the braod valley underwent surface offset during a severe earthquake in 1909 (A bendanon, 1916-18, v. 2, p. 888-891).

The continental slope at the north edge of Sulawesi is bounded by the North Sulawesi Trench (discussed subsequently), which extends westward to the edge of the continental slope of northeast Borneo. The Palu fault is suggested on the tectonic map and on figure 81 to project north-northwestward along strike from its rift valley on Sulawesi and to connect with the west end of this trench. The trench may mark the boundary of a small Sulawesi plate which is overriding the floor of the Celebes Sea, and the Palu fault may bound this plate, on the west side, against Borneo and southwest Sulawesi.

A possible major straight fault zone (Sadang) trends north-northwestward farther west, obliquely across the South Arm (fig. 81). Faults of this zone bound mountain masses in the south part of the arm and produce the straight valley of the Sadang and Masupu Rivers in the north part. The fault zone may now be active, for landslides dam the rivers along its course in the valley $(K$. B. Ketner, oral commun., 1972). If this is indeed a through-going fault zone, then presumably it is a left-slip structure. Faults trending northward in the southern part of the South Arm perhaps also are dominantly of strike-slip character.

The mountains of the northeast corner of the South Arm are cut by two straight, south-trending systems of alined valleys (figs. 93, 94A), subparallel to the Sadang fault to the west and the Palu fault to the northeast. The straightness of these valley systems suggests a control by strike-slip faulting.

\section{EASTERN SILAWESI}

The active left-lateral Matano fault trends west-northwestward across central Sulawesi and passes through Lake Matano (fig. 85). The apparent offset of 


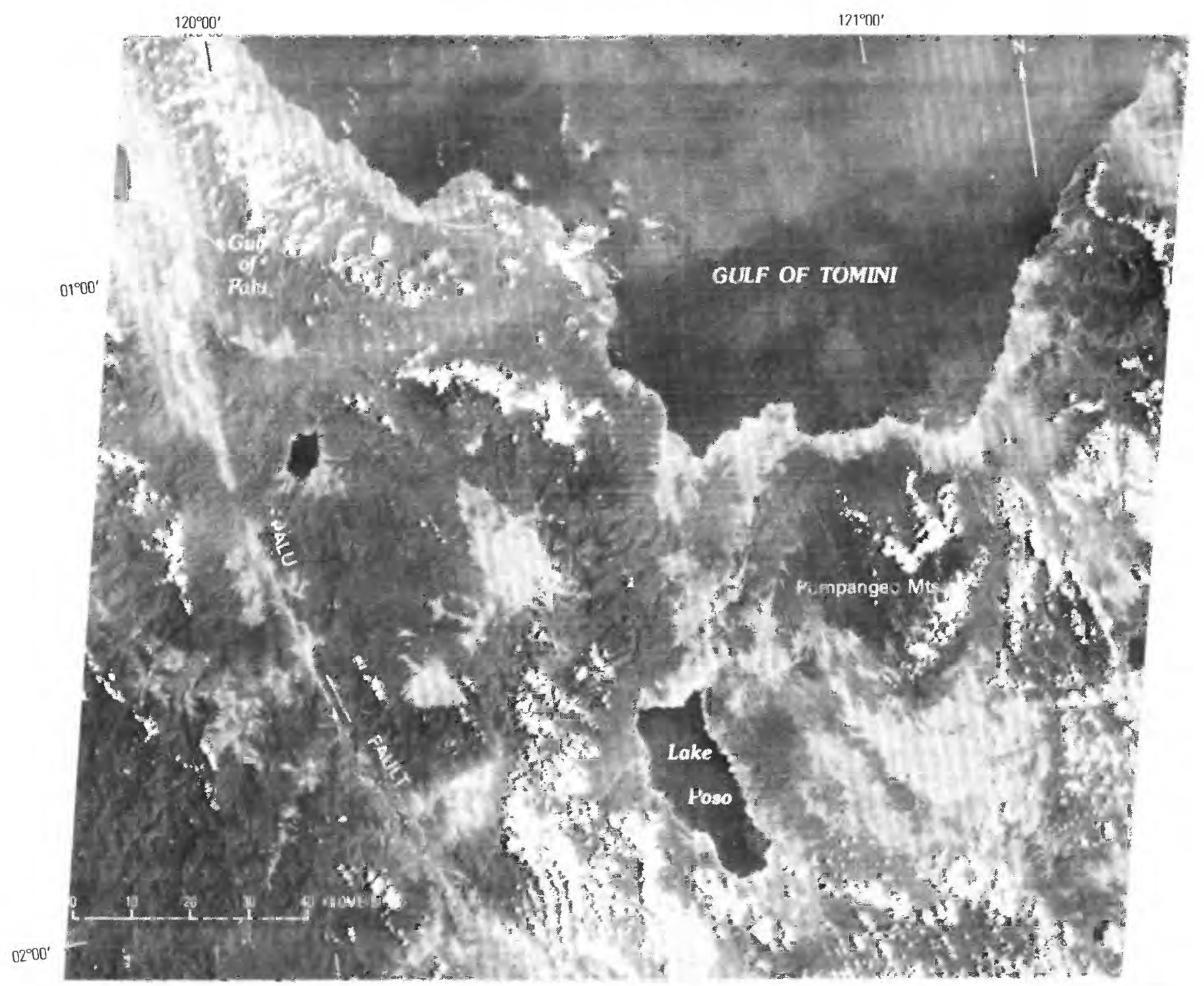

FIGi'Rr 91. - Landsat image of north-central Sulawesi. The highlands west of about long $120^{\circ} 30^{\prime} \mathrm{E}$. consist of granitic rocks, high-temperature metamorphic rocks, and deformed sedimentary rocks. all of Tertiary age. The highlands to the east are formed mostly of subduction-imbricated complexes; the strongly lineated terrain east and northeast of Lake Poso (see also fig. 86) is characterized by glaucophane schist. Picture NASA-ERTS 1097-01392, October 1972.

contacts between major geologic units is about $15 \mathrm{~km}$, as illustrated by figure 85 ; but some of the relevant contacts are very uncertainly located on this map. The fault is marked by a conspicuous rift where it crosses hilly terrain (fig. 95). This rift disrupts drainage patterns, and it is apparent in several sectors, on vertical aerial photographs shown me by geologists of International Nickel Indonesia (INCO), that stream courses are offset in a left-slip sense. The rift swings northwestward to the west of Lake Matano, which lies within the rift zone and is almost $600 \mathrm{~m}$ deep. Waheed Ahmad of INCO (written commun., 1975) believes that two geologic contacts near the lake are each offset $20 \mathrm{~km}$ by the fault.

The Matano fault zone is more active seismically than appears to be the case on the earthquake map of the Indonesian region (Hamilton, 1974b), because seven earthquakes along or near the fault were inadvertently omitted from the map. These events compose an array trending

Figu'RE 92.-Aerial photographs along the Palu fault in the Koro River valley, west-central Sulawesi. The active strand of the fault, marked by arrows, offsets gullies and canyons in a left-lateral sense and produces shutter ridges. The two panels overlap slightly. Scale and coordinates are approximate only. Photographs taken by Lockwood Survey Corp. for Kokusai Aerial Surveys Co., October 1970. 1970 . 
SULAWESI (CELEBES)

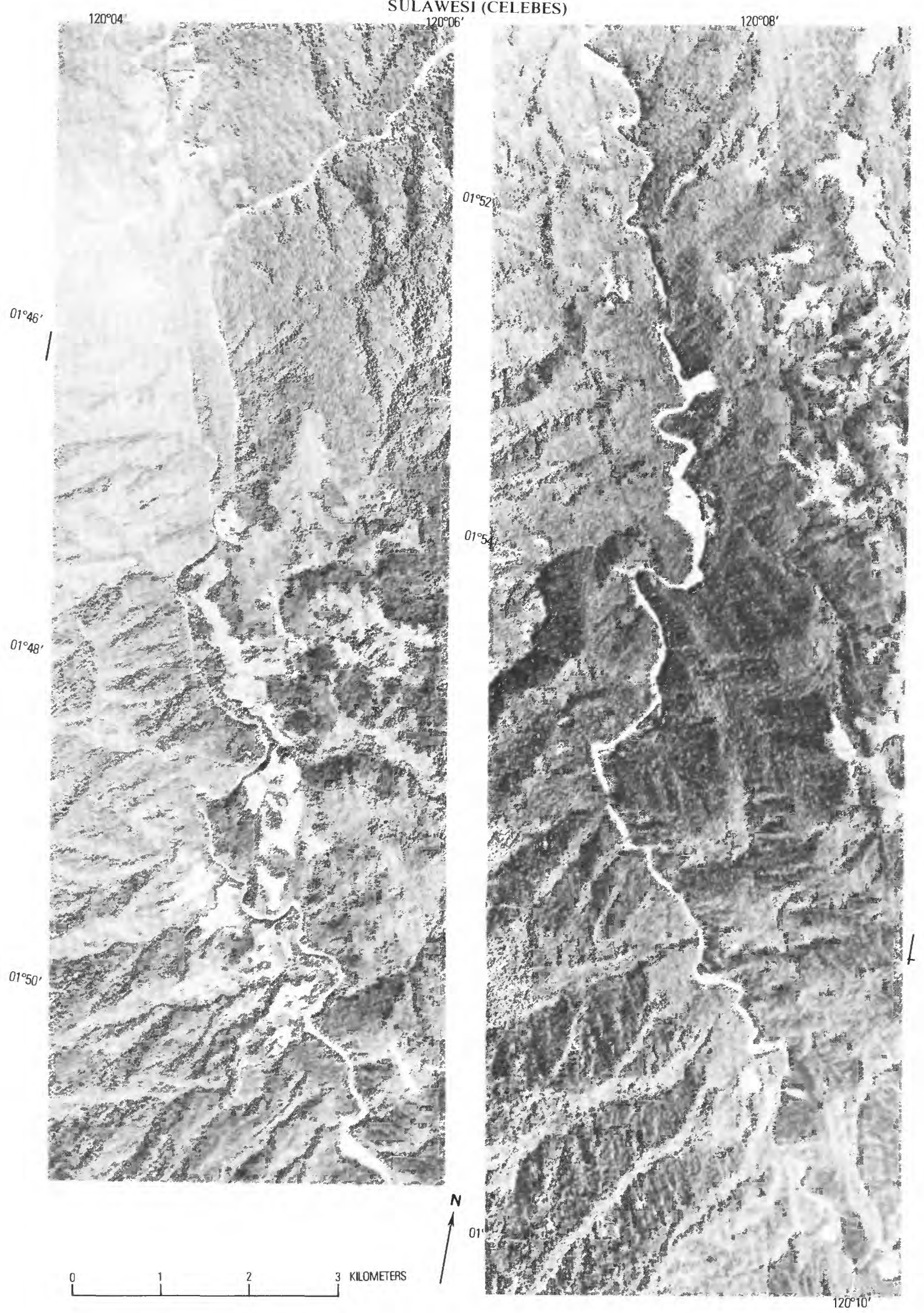



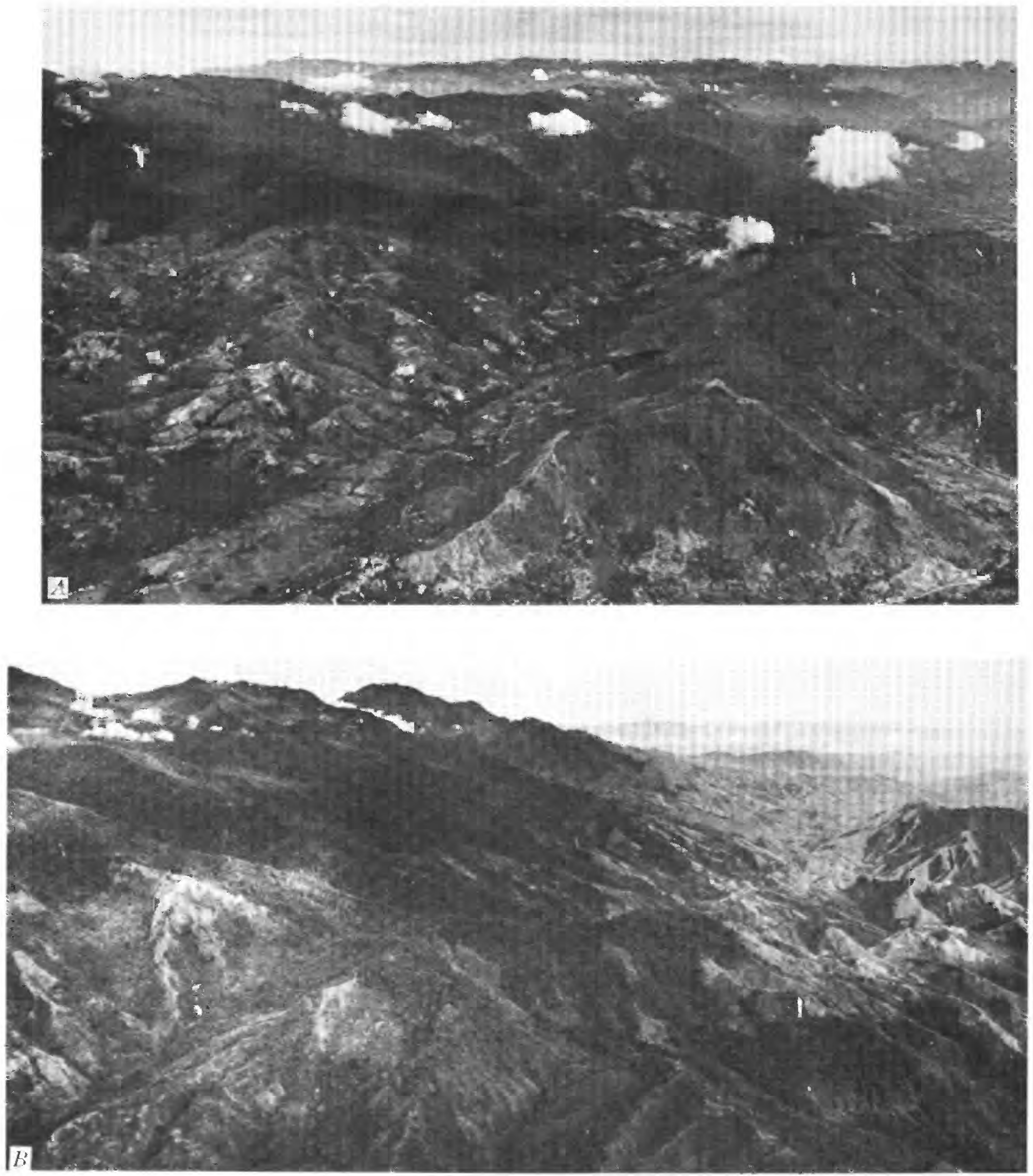

FigilRF 93.-Straight valleys along possible strike-slip faults in mountains in northeast corner of South Arm of Sulawesi. $A$. Northwest from above the town of Palopo, across south-trending valley; the same valley lies behind the foreground ridge of figure $94 A$, and the pictured areas overlap. $B$, Northwest over part of longitudinal rift valley, $70 \mathrm{~km}$ long, trending $\mathrm{N}$. $10^{\circ} \mathrm{W}$., from about lat $3^{\circ} 31^{\prime} \mathrm{S}$., long $120^{\circ} 11^{\prime} \mathrm{E}$. The peaks on the left are more than $3,000 \mathrm{~m}$ high. 

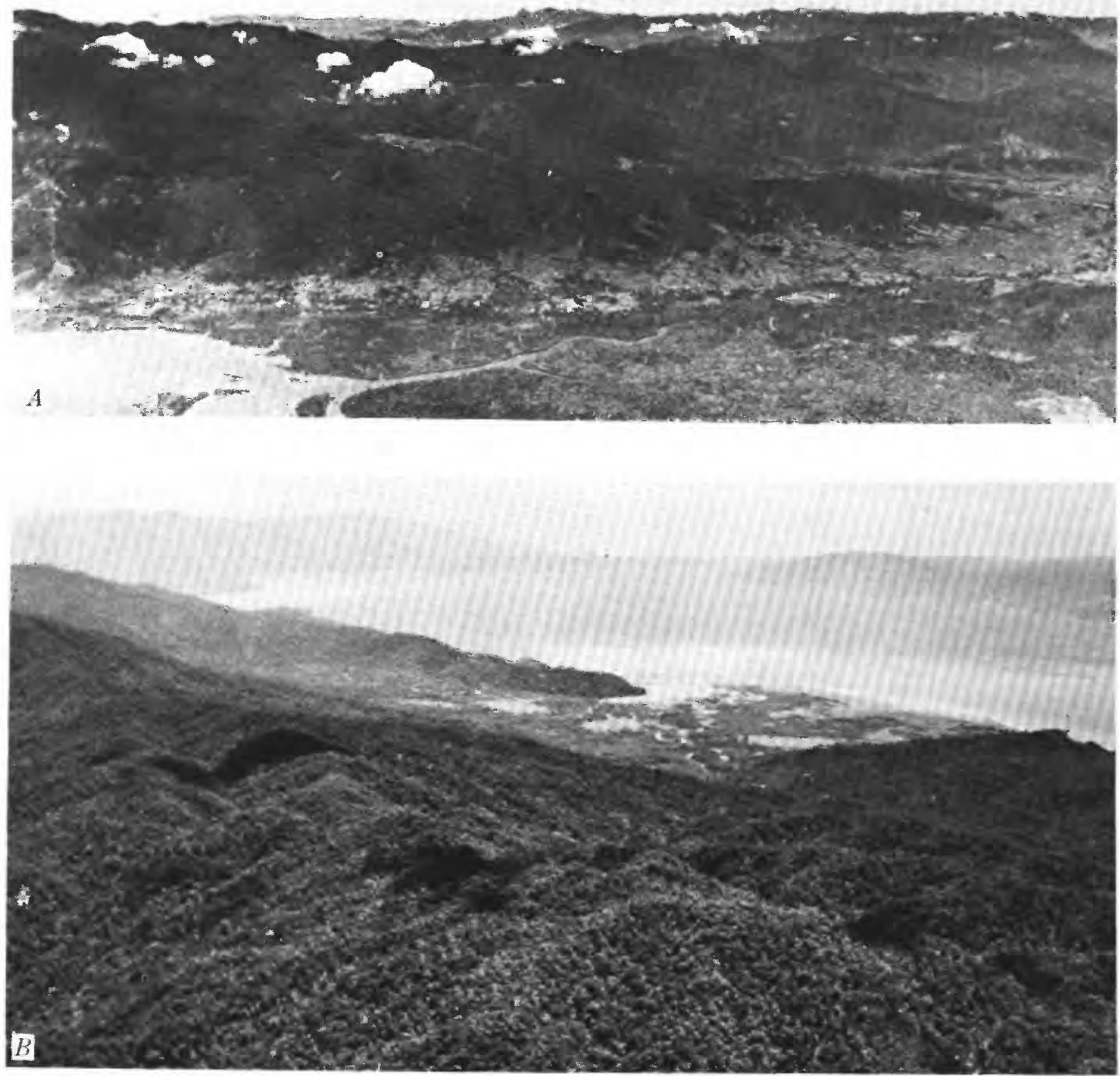

FIGURE 94.-Neogene structures of central Sulawesi. $A$. View west-northwestward over fault blocks at the northeast corner of the South Arm. The town of Palopo is on the coast just to the left of the area shown. B, View northward across Lake Poso. The flanking mountains are of metamorphic rocks, among which glaucophane schist is common. The moderate slopes toward the lake suggest that synclinal downfolding has been more important than normal faulting in forming the basin. The lake is at least $440 \mathrm{~m}$ deep.

west-northwestward, extending from about long $122^{\circ} 20^{\prime} \mathrm{E}$. to $121^{\circ} 35^{\prime}$ E., across the east coast of Sulawesi.

Conspicuous straight valleys trend northwestward across the central part of the Southeast Arm and are thought by INCO geologists to belong to a left-lateral fault zone, the
Lawanopo fault system (fig. 85; named for the Lawanopo Plain, crossed by the faults). The straight valleys do not form a continuous line as viewed on either Landsat images (fig. 84) or aerial photographs, and as they are parallel to the structural grain of the region, no offset of geologic units can 

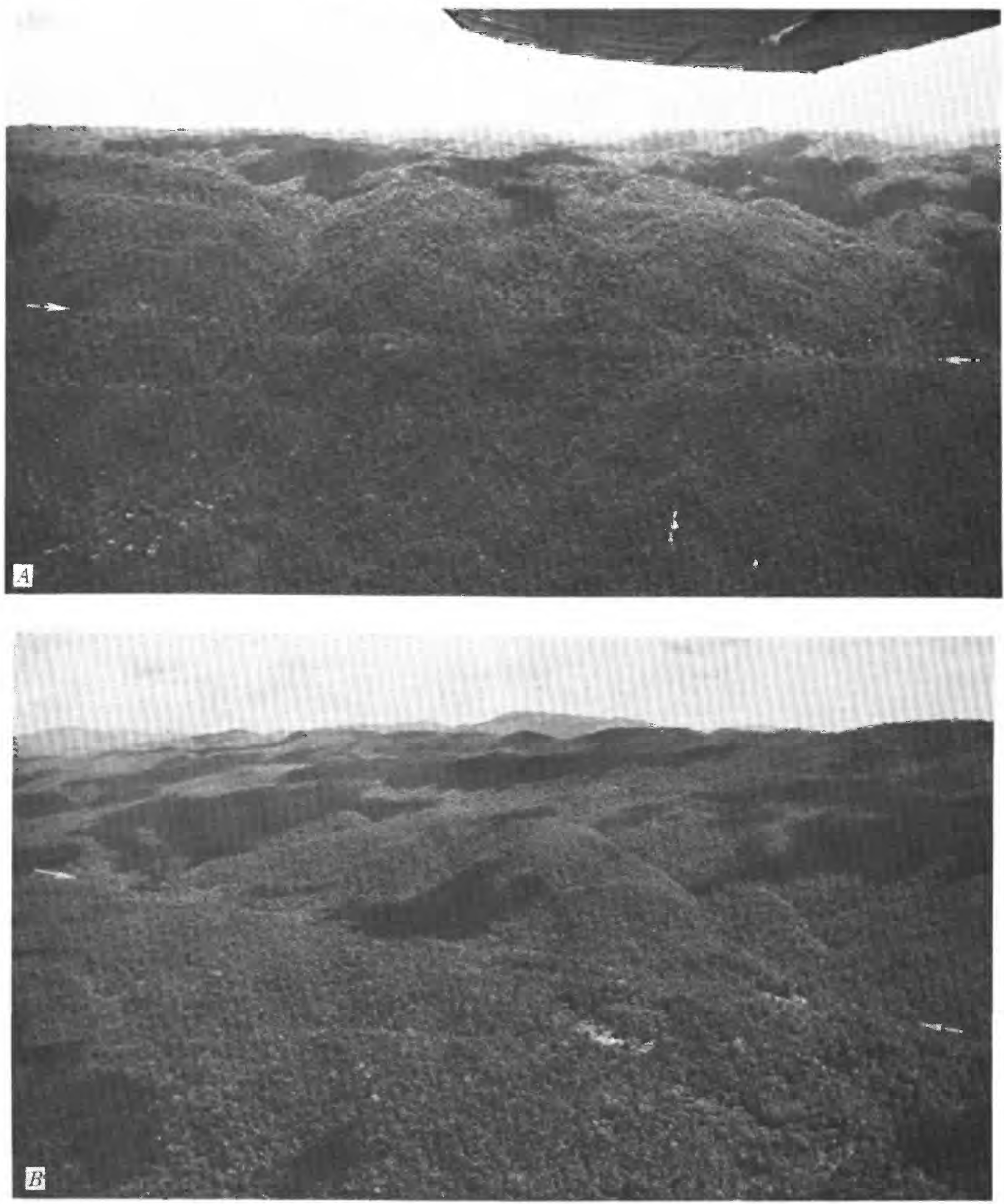

FIGURE 95. - Aerial views across the Matano fault, marked by arrows. The fault is an active left-lateral structure. $A$, View northeastward, about $25 \mathrm{~km}$ west of Lake Matano. B, View northward, about $2 \mathrm{~km}$ east of Lake Matano. 
be demonstrated from the meager data available. The Lawanopo zone might be produced by strike-slip faults (presumably left lateral), or it may represent valleys eroded along the least resistant parts of the old terrain. Farther south in the Southeast Arm, straight valleys trend northwestward along the south flank of the Mendoke Mountains. The valleys are parallel to the regional structural grain and do not define an obvious continuous line across the peninsula; left-lateral faulting is a possible cause and has been inferred by INCO geologists. The Lawanopo fault(?) system projects northwestward to the head of the Gulf of Bone, and the Mendoke valley system projects along the straight northwest-trending part of the coast that bounds the wide and deep southern part of the gulf. Left-lateral offsets on these two possible fault systems would have operated to open the gulf. As such opening is inferred on other grounds, it is possible that the systems are indeed important left-lateral fault zones of Neogene age, now inactive in contrast to the active Matano fault.

\section{NORTH SULAWESI TRENCH}

A trench lies along the base of the continental slope along the north side of Sulawesi (fig. 79) and is shown by Lamont-Doherty reflection profiles (figs. 97 $A, B, 98 A ; B$ ). The thick turbidites flooring the Celebes Sea turn downward at the north side of this trench and receive a veneer of other sediments before disappearing southward beneath the acoustic basement of the continental slope. A small outer-arc basin is developed behind a low outer-arc ridge midway up the continental slope (figs. 97 $A, 98 B$ ).

\section{ISLANDS IN GILF OF TOMINI}

The Togian islands lie in the Gulf of Tomini between the North and East Arms of Sulawesi (fig. 81). Una-Una, the northwestern island of the group, is an active volcano whose lavas include andesite(?) and mafic rhyodacite (Neumann van Padang, 1951, p. 225-227). The other islands consist of Neogene sedimentary rocks and "young volcanic rocks" (van Bemmelen, 1949, p. 394). The one chemical analysis available of an Una-Una rock (62 percent $\mathrm{SiO}_{2}, 3.2$ percent $\mathrm{K}_{2} \mathrm{O}$ : Neumann van Padang, 1951, p. 226) suggests formation above a deep part of a Benioff zone. Whether the Benioff zone dips southward from the North Sulawesi Trench or is a dying zone dipping northwestward from eastern Sulawesi is uncertain. (Compare pl. 1, Hamilton, 1974b, and Sukamto, 1975b.)

\section{SULAWESI AND REGIONAL TECTONICS}

Sulawesi holds many vital clues to the evolution of the eastern Indonesian region. The subject matter presented thus far on Sulawesi, Borneo, and the Java-Banda Arc system makes it appropriate to discuss here some of the broad relationships of Sulawesi with other tectonic elements of Indonesia.
ROTATING; PLATE: THE NOR IH SLLAWESI TRENCH, PALU FAILT, AND NORTHEAST SILAWESI OROCILINE

Northeastern Sulawesi appears to be rotating clockwise past southwestern Sulawesi and Borneo, as a small plate bounded on the southwest by an arcuate system of left-lateral faults, and overriding the Celebes Sea floor in the north by subduction at the North Sulawesi Trench. The Palu and Matano faults are both active left-lateral structures, and it is assumed on the tectonic map (pl. 1) that they curve together and are part of a single fault system, although the connection is not yet proved. It was noted in prior sections that other active or inactive strike-slip structures may trend southward in the northeast part of the South Arm, and east-southeastward across the Southeast Arm, and be part of the same broadly splaying system. Inadequate seismic data suggest that a Benioff seismic zone dips southward from the North Sulawesi Trench, and active Una-Una volcano, between North and East Arms of Sulawesi, may be a product of this subduction system.

The North Sulawesi Trench ends at the east where the northeast tip of the North Arm of Sulawesi swings from an easterly trend to a northerly one. Active Sangihe Arc volcanism extends southward to this same bend, but volcanoes that became extinct in Quaternary time continue westward some distance from this bend. Presumably these recently extinct volcanoes, like the currently active ones, formed above the Sangihe Benioff zone, but the right-angle bend of the North Arm here makes subduction with the present geometry difficult to visualize. The sharp bend near the northeast end of the North Arm may be an orocline that has progressed eastward with time. This, if correct, requires that the North Sulawesi Trench has progressively lengthened eastward, and with it the east-trending segment of the North Arm, while at the same time the Sangihe Trench, and with it the north-trending segment at the end of the North Arm, shortened northward. As the oroclinial axis progressed eastward along the arm, subduction west of the orocline flipped from westward beneath the east side to southward beneath the north side. Collision with the Halmahera Arc, discussed subsequently, greatly complicates the pattern.

COILISION OF CONIINENIAI FRAGMENIS WITH SILAWESI SULA AND BANGGAI ISLANDS

The Sula and Banggai Islands stand on a narrow ridge of continental crust, apparently torn from northwestern New Guinea and carried westward along a left-lateral fault of the Sorong system (figs. $77,53,81$ ). Northwestern New Guinea shares with the Sula and Banggai Islands a similar continental basement. The shallow-water Triassic, Jurassic, and Cretaceous strata of the two terrains are lithologically and paleontologically quite similar (van Bemmelen, 1949, p. 66-67). The collision between the Sula-Banggai fragment and Sulawesi is recorded in the geology of the eastern part of the East Arm (fig. 89). The northwest-dipping imbricate complex there involves shallow-water Paleogene and lower 

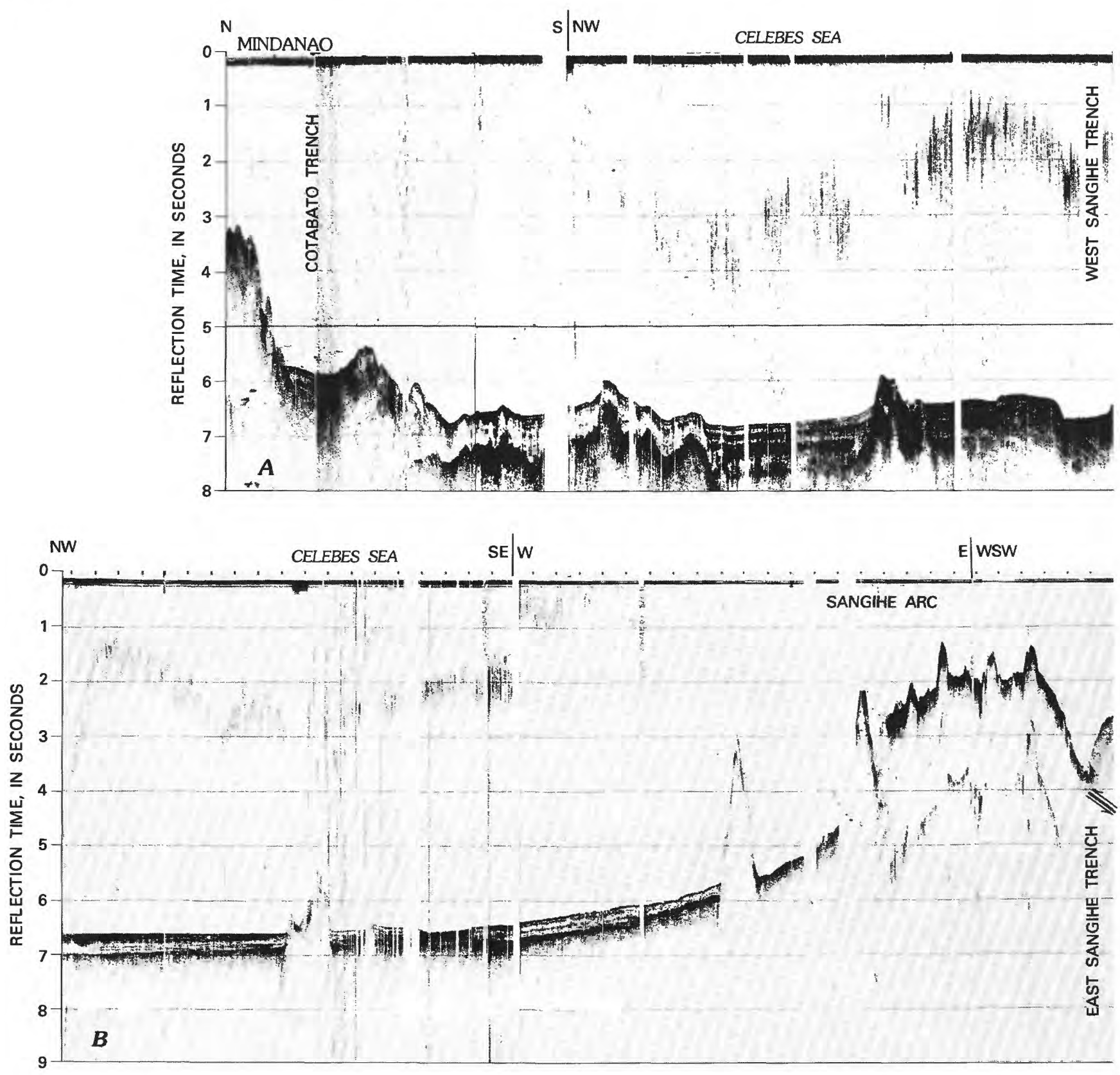

$100 \quad 200$ KILOMETERS

TYPICAL SCALE (VARIES WITH SHIP SPEED)

FIGURE 96.-Seismic reflection profiles in the Celebes Sea-Molucca Sea region. Notice the roughness and lack of sedimentary cover on acoustic-basement young melange of the Talaud Ridge. A, The Sangihe Arc formed above a subduction zone dipping west from its east side, but the trace of this zone was overridden by melange spreading above the collision zone between Sangihe and Halmahera Arcs. Subduction recently flipped to the West Sangihe Trench in the north, reversing the original polarity of the Sangihe Arc. The Cotabato Trench is continuous with the West Sangihe Trench. The basement of the northern Celebes Sea, near the Cotabato Trench, is mantled by acoustically transparent pelagic sediments, but layered turbidites take their place closer to the Sangihe Arc. $B$, The east base of the Sangihe Arc system is here also being overridden by the Talaud wedge of collision melange, but in this sector there has not yet been a flipping of subduction to the west side of the Sangihe Arc. The ridges north of Halmahera may have formed as part of the Halmahera system but have been captured by the Philippine subduction system after arc reversal; these ridges are mantled by pelagic sediments. Location of profiles shown in figure 79. Profiles from Lamont-Doherty Geological Observatory, R. V. Vema cruises $24(B)$ and $28(A)$. 

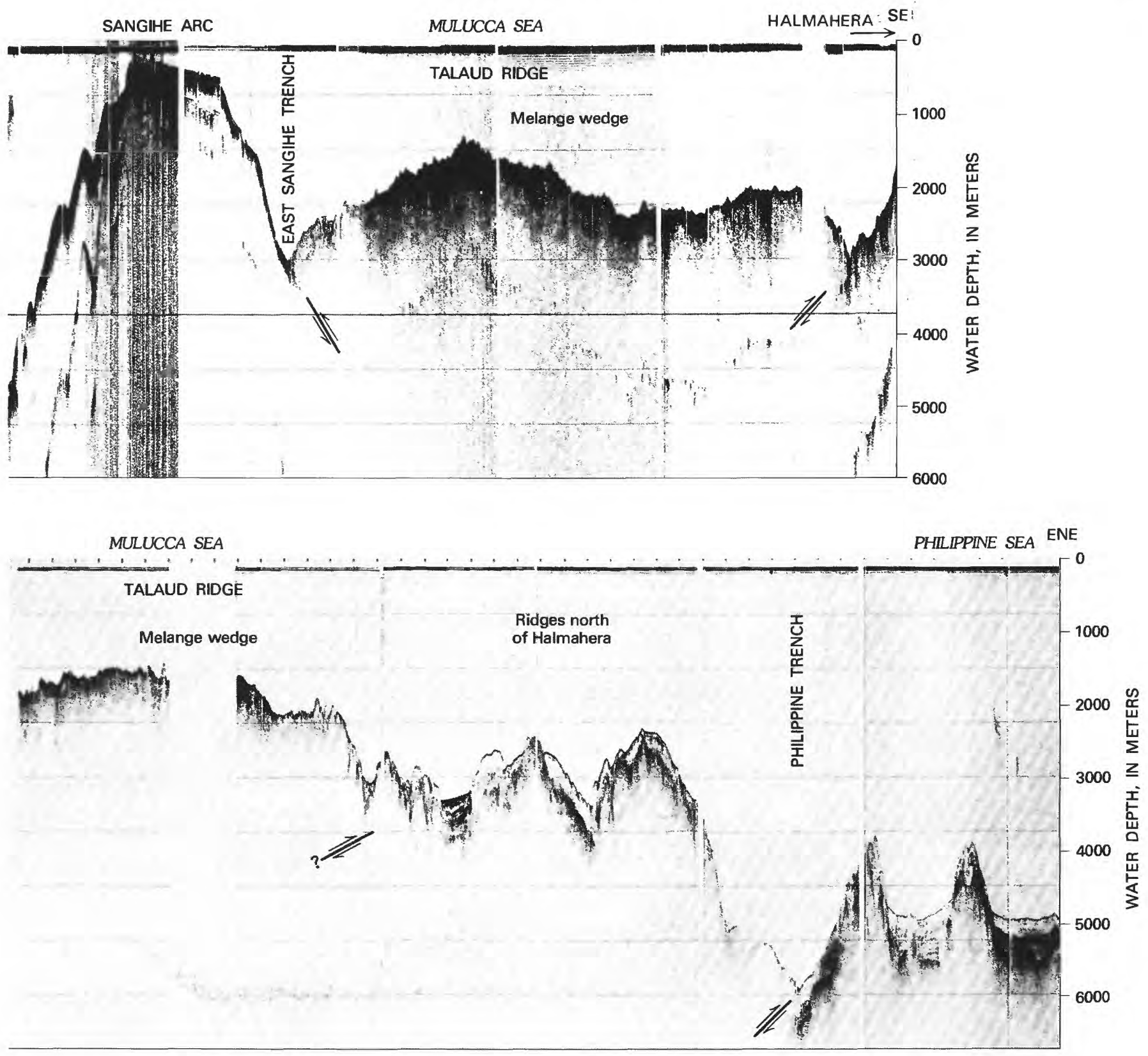

Miocene limestone near the coast and deeper-water Paleogene marl northwest across the strike. These lower Tertiary strata are inferred to represent the shallow and deep portions, respectively, of the continental shelf developed on the minicontinent. The imbrication of shelf materials is thought to represent the ramping of the front of the Sulawesi melange wedge onto the Sula-Banggai fragment as that fragment hit the northwest-dipping subduction system in late Miocene time. Clastic sediments were then shed southeastward from the rising thrust belt, forming a foreland basin whose fill lapped onto the Sula-Banggai continental basement (fig. 89). The early part of the fill was broken by thrusts and folds, showing that it formed synchronously with the advance of the wedge of melange and imbricated strata. This collision geology is very similar to that of medial New Guinea, discussed subsequently in this report.

\section{SOUTHEAST SULAWESI}

The middle Tertiary(?) melange of the east part of the Southeast Arm and adjacent Buton contains shallow-water Triassic, Jurassic, Cretaceous, and, probably, Oligocene sediments, and some of the Mesozoic clastic rocks are quartzose and micaceous. A continental-shelf origin for these materials would account for their character, and a New 

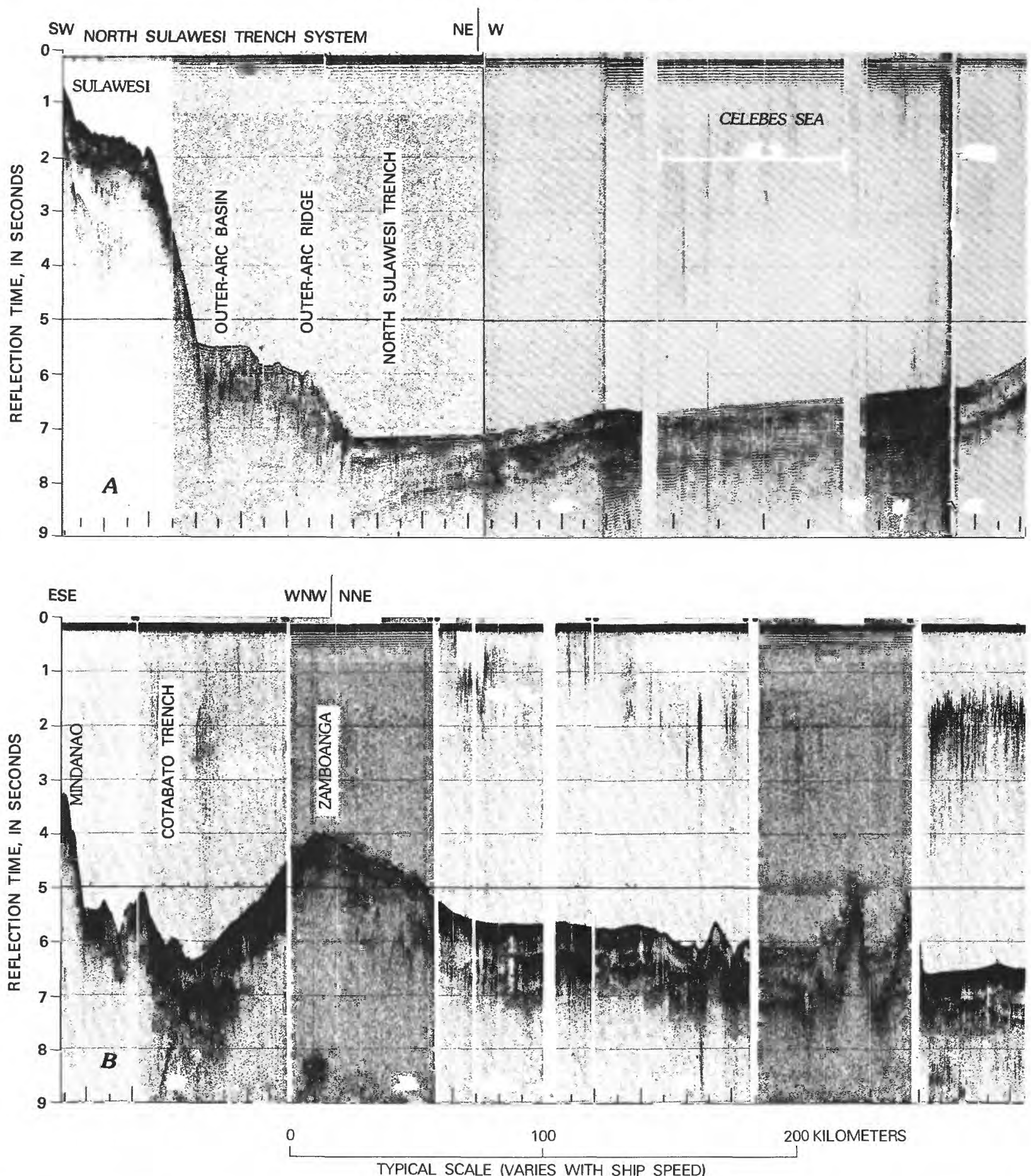

Figure 97.--Seismic-reflection profiles in the Celebes Sea-Molucca Sea region. A, The complete profile of the Sangihe Arc appears to be present, with outer-arc ridge, outer-arc basin, and volcanic seamounts, formed above a west-dipping Benioff zone. Melange is presently riding westward onto the arc at the East Sangihe Trench, however. Thick turbidites floor the Celebes Sea. B, The rough basement of the Celebes Sea is mostly covered by thick turbidites, although volca nic seamounts with veneers of pelagic sediments project through them. In the north near Zamboanga, the turbidites are moderately deformed, and in the south they dip beneath the thin ponded strata flooring the North Sulawesi Trench. Location of profiles shown on figure 79. Profiles from Lamont-Doherty Geological Observatory, R. V. Robert Conrad cruise $14(C)$ and R. V. Vema cruise $28(D)$. 

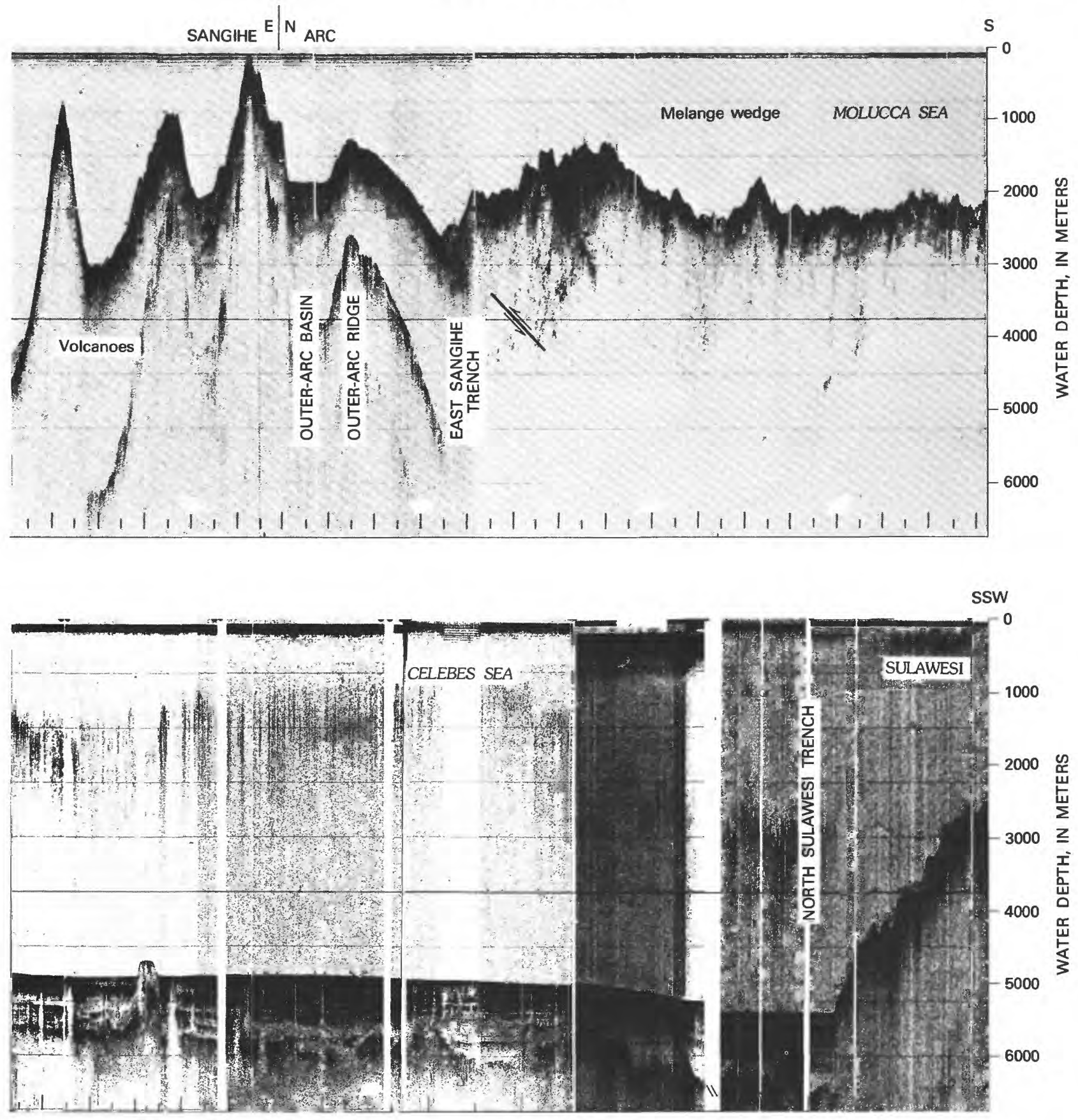

Guinea source is more likely than a northwestern Australian one because of the warm-water nature of the Mesozoic strata. A submerged platform extends about $200 \mathrm{~km}$ east-southeastward from Buton. It is $125 \mathrm{~km}$ wide and rises to shoals and reefs (Hetzel, 1930b), although much of it is deeper than $1,000 \mathrm{~m}$. This platform might be another small continental fragment from New Guinea.
RIF IING OF MAKASSAR STRAIT

Eastern and southeastern sections of Borneo share Cretaceous and early Paleogene features with Sulawesi suggestive that until middle Paleogene time Sulawesi was a part of Borneo, oceanic Makassar Strait having opened subsequently as Sulawesi drifted relatively southeastward away from Borneo. Southeastern Borneo, the shelf to the east of it, and the South Arm of Sulawesi all have basements 

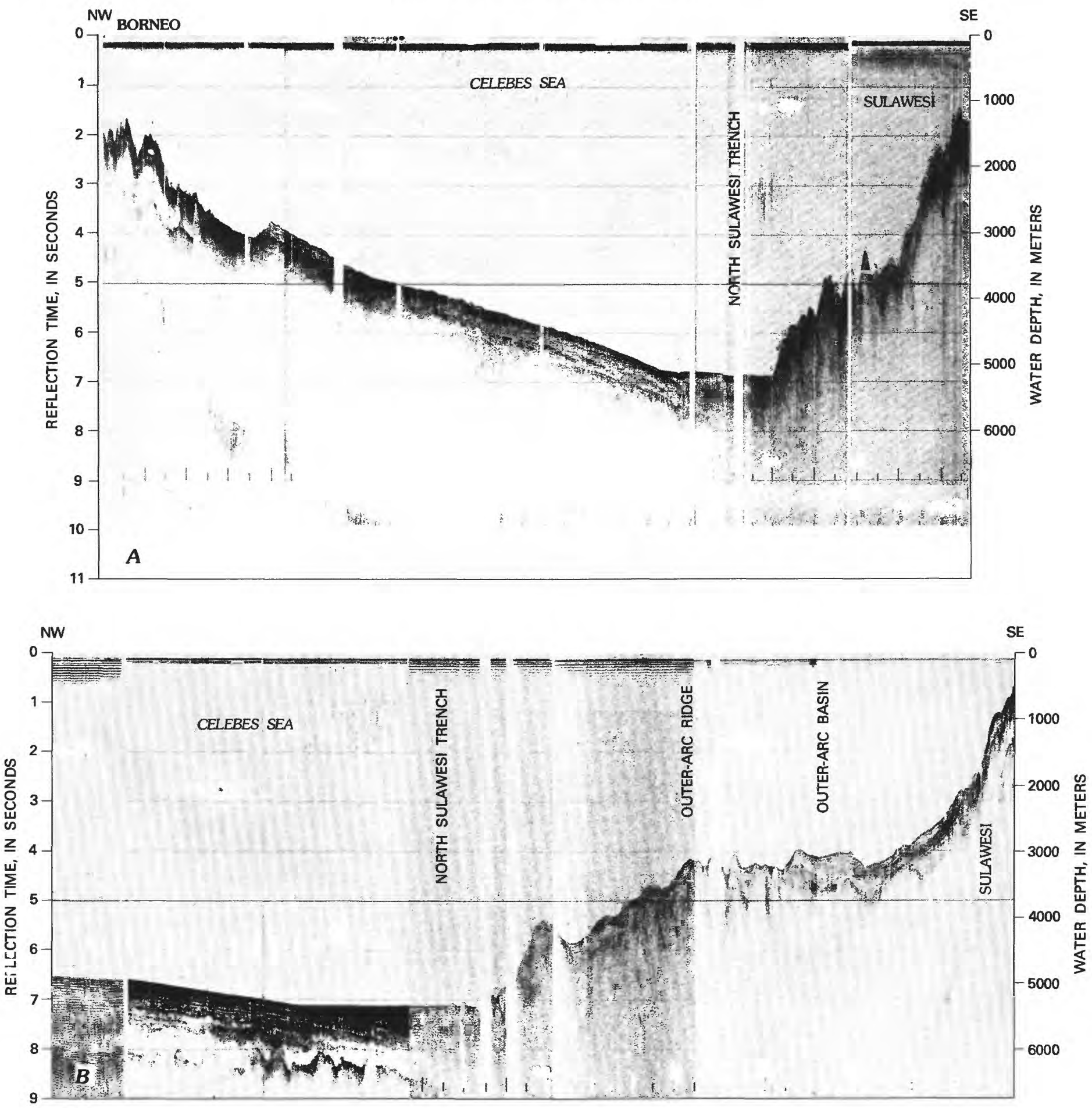

Figure 98. - Seismic-reflection profiles in the Celebes Sea-Molucca Sea region, $A$ and $B$. The turbidites flooring the Celebes Sea are covered by ponded trench turbidites before they are subducted at the North Sulawesi Trench. $C$, The deep and steep-sided Philippine Trench may have formed by reversal of polarity of subduction to westward beneath Halmahera after collision of Halmahera and Sangihe Arcs. The part of the Molucca Sea basement near the center of the profile has a mantle of sediments, whereas that on the left does not and is presumably younger. $D$, The Borneo continental slope is formed of sediments broken by normal faults and cut by canyons. No basement is visible. Location of profiles shown in figure 79. Profiles from Lamont-Doherty Geological Observatory, R. V. Robert Conrad cruise I4 ( B) and R. V. Vema cruises $20(C)$ and $28(A$ and $D)$. 

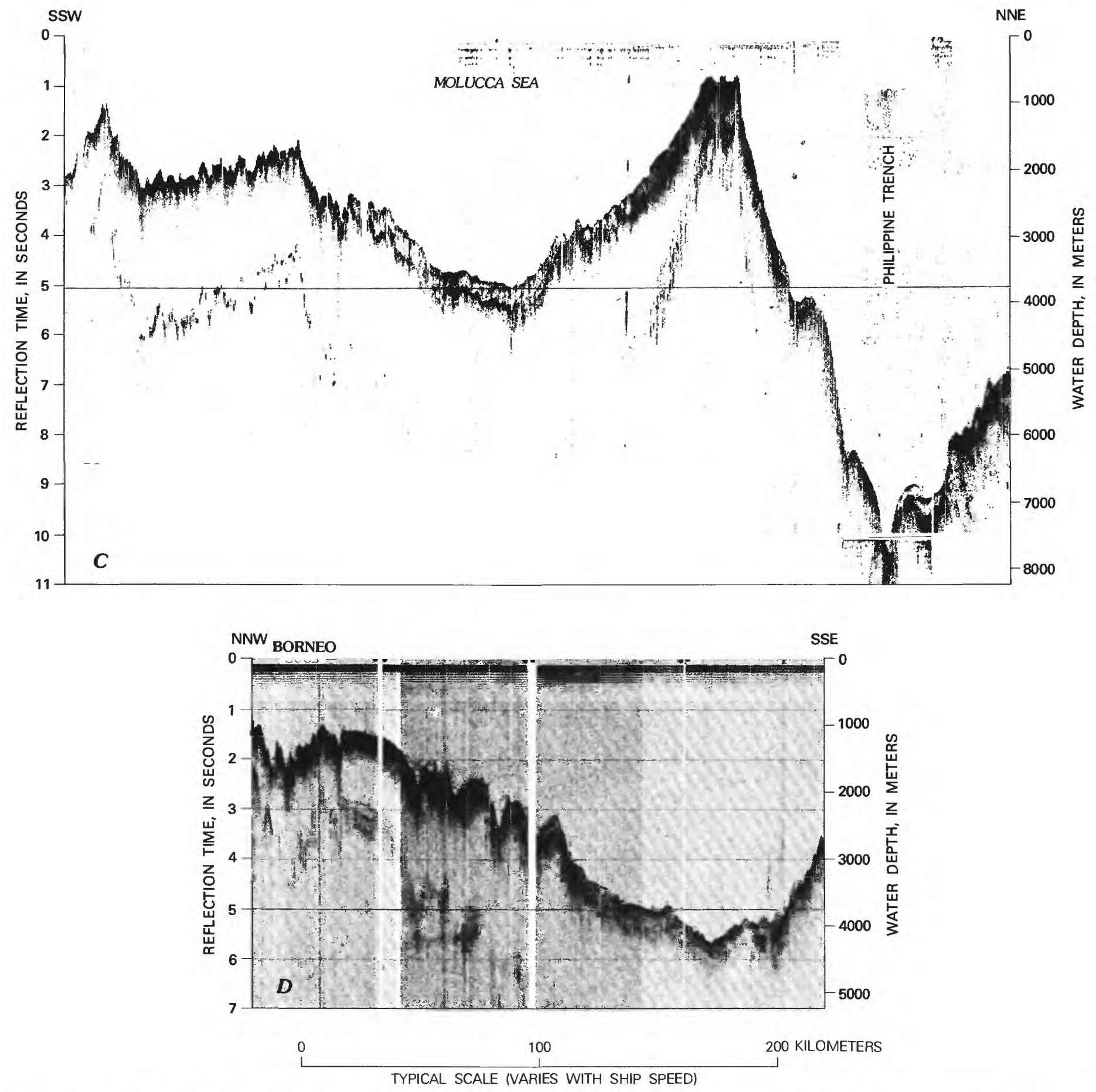

of Cretaceous subduction complexes overlain by similar lower Paleogene shelf strata. In both Borneo and Sulawesi, quartzose Eocene clastic strata and coal are overlain by a thick sheet of limestone, of late Eocene, Oligocene, and early Miocene age, which gives way northward to mostly clastic rocks. If Sulawesi has moved southeastward away from Borneo, the westward bulge of central Sulawesi having slid along the southeast-trending edge of the continental shelf off southeastern Borneo, then the limestone sheets and underlying continental strata on both islands were initially continuous. Rifting may have begun in Paleogene time; the eastward thickening of Oligocene and lower Miocene strata on the continental shelf of eastern Borneo might record the tensional thinning of the continental crust as rifting 
progressed, before the complete sundering of the crust in Miocene time. Clastic sediments of approximately middle Miocene age beneath the outer part of the Borneo continental shelf off the Mahakam Delta may be prograded westward and if so presumably were derived from Sulawesi, whereas all higher strata are prograded eastward and obviously were derived from Borneo. The sediments of the Borneo continental slope of northern Makassar Strait display much normal faulting, mostly downdropped on the deep-water side (fig. $98 D$ ). The old subduction complexes of Sulawesi apparently were continuous with those of the Java Sea and Java before the opening of Makassar Strait.

\section{SI BDICIION ANI) MAGMATISM}

The pairing of belts of subduction complexes and of arc-type magmatic rocks indicates that west ward subduction beneath Sulawesi occurred primarily during Cretaceous and Neogene times and that little if any activity occurred during the Paleogene.

\section{AGF OF SUBDUCTION}

The oldest rocks seen in southeastern Borneo and the South, Southeast, and East Arms of Sulawesi all belong to subduction complexes of Cretaceous age and possibly in part of very early Tertiary age, insofar as they can be dated. The melange of the Meratus Mountains in southeastern Borneo involves middle Cretaceous sedimentary rocks and is overlain unconformably by upper(?) Eocene strata. The South Arm subduction complex both contains and is overlain by middle Cretaceous rocks. The glaucophanitic terrain-the western belt-of the East and Southeast Arms of Sulawesi is overlain by middle or upper Miocene strata. The medial belt of the East and Southeast Arms, of sedimentary and metasedimentary rocks, involves Cretaceous sedimentary rocks. Lower or middle Miocene strata are intercalated tectonically with other sedimentary rocks and ophiolite slices in various areas in the eastern belt; the major deformation is probably older than late Miocene in the south and Pliocene in the north but may be entirely Neogene.

\section{MAGMATIC BELAS}

The granitic and volcanic rocks of the basement of the Java Sea are mostly of Cretaceous age (fig. 46) and so are the dated igneous rocks of southern Borneo west of the Barito Basin. In the exposed crystalline terrain of southwestern Borneo, the granitic rocks are suggested by reconnaissance data to be in general more potassic in the south than in the north, so if the contrasted rocks are of similar age, then formation above a Benioff zone dipping south from the subduction complexes of northwestern Borneo is perhaps indicated. This would leave the Barito Basin basement granites and the Java Sea Cretaceous igneous rocks as possibly paired to Benioff zones dipping northwestward and westward from the subduction complexes of southeastern Borneo and the western parts of Sulawesi.
From late Eocene into early Miocene time, the Java Sea-southeastern Borneo-western Sulawesi region was largely a shallow sea undergoing stable-shelf sedimentation. Presumably no major subduction operated beneath this region from eastern Sulawesi during this period. In east-central Borneo silicic volcanic rocks and tuffs are interbedded with Oligocene and lower Miocene strata in the western part of the Kutei Basin and to the west of the Mangkalihat Peninsula, but these volcanic rocks likely were erupted above a Benioff zone dipping southeastward from northwest Borneo.

The high lower Miocene through Pliocene rocks of the South and North Arms of Sulawesi are dominantly magmatic-granitic rocks, and calc-alkalic and alkalic volcanic and volcaniclastic rocks. These magmatic rocks form a belt $50-200 \mathrm{~km}$ wide, coextensive with the western arc of Sulawesi. As westward-dipping subduction was underway in the east part of the eastern arc of Sulawesi in middle Miocene and, at least in the north, younger time, pairing of magmatic and subduction belts is indicated. Changing dips of the paleo-Benioff zone, perhaps accompanying changing velocities of rifting of Sulawesi from Borneo or of the arms of Sulawesi from one another (following section), could account for the varying compositions of the magmatic rocks. Magmatism continued into Quaternary time in far southwest Sulawesi, but there it appears related to the recently inactivated trench along Salayar, rather than to subduction from east of the East and Southeast Arms.

\section{SEPARATION OF THE ARMS OF SUILAWESI}

The subduction recorded by the geology of the eastern part of the eastern arc of Sulawesi presumably was paired genetically with the magmatism recorded by the Neogene volcanic and granitic rocks of the western arc. The eastern and western arcs are now joined by land across central Sulawesi but otherwise are separated by the Gulf of Bone, in the south, and the Gulf of Tomini, in the north, which may be products of extension. Each gulf is deeper than 2,000 m over much of its extent, has a sedimentary fill more than 5,000 m thick (pl. 1; Hamilton, 1974a), and likely has an oceanic basement in its deeper portion. A $3,000-\mathrm{m}$ well, drilled on the shallow shelf near the head of the Gulf of Bone, bottomed in middle Miocene clastic strata, so the entire sedimentary fill in the gulf, and hence the age of separation of the Southeast and South Arms, may be Neogene. Part of this separation may have accompanied left-lateral motion on the faults that trend west-northwestward across the Southeast Arm.

Oceanward migration of the eastern arc, in the form of an outer-arc ridge, away from the inner-arc magmatic ridge, is inferred. Several other island arcs in the western Pacific display strong evidence for separation of ridges. (See subsequent discussion of the Philippine Sea-Mariana Arc complexes.) The preexisting crust-melange-was thinned tensionally near the head of each gulf, and wholly rifted 
across the deeper parts, according to this interpretation. 1sland arcs generally are convex toward the direction of their advance, whereas the eastern arc of Sulawesi is broadly concave in this direction. The concavity, however, is centered on the central Sulawesi sector in which the ridges have remained locked together. Southward from this join, the Southeast Arm trends are toward the east.

\section{EASIWARI MIGRAIYON OH SLBDLICIION SYSIEM}

A subduction system appears to have migrated eastward, from a position along the southeast margin of a Java- Java Sea-Borneo continent to that of the present Banda Arc, during Late Cretaceous and Cenozoic time.

\section{JAVA, BORNEO, AND SULAWESI}

The eastward migration of a subduction system during Late Cretaceous and Cenozoic time is recorded by the geology of central Java, the southeastern part of the Java Sea, southeastern Borneo, and Sulawesi. The migration is shown by the eastward growth of melange terrains, by the position of the Neogene magmatic arc to the east of the Cretaceous one, and by the rifting of the eastern arc of Sulawesi from the western arc and of Sulawesi from Borneo. Presumably both melange accretion and rifting resulted in intermittent abandonment of descending plates of oceanic lithosphere as new hinges developed farther east. The distribution of magmatic rocks was inferred in a prior section to indicate that subduction occurred largely within Late Cretaceous and Neogene time, with little if any activity during the Paleogene.

\section{SLMBAWA AND FLORES}

Clockwise rotation of eastern Sumbawa and western Flores some $45^{\circ}$ from Sulawesi and the continental shelf of the Java Sea is inferred from geologic and crustal relationships. The islands of the presently active inner magmatic arc extending east from Java expose rocks as old as early and middle Miocene only as far east as central Flores, beyond which the volcanic ridge is narrower and the oldest rocks seen are late Miocene or Pliocene. The Flores Sea, between Flores and eastern Sumbawa on the south, the Java Sea shelf on the northwest, and Sulawesi on the north, is very deep, hence oceanic in crustal structure, and bears little sediment (fig. 56C), hence likely is young. The broad Neogene magmatic terrain of the South Arm of Sulawesi projects southward toward a truncation by the north edge of the Flores Sea. The sector of the magmatic arc containing eastern Sumbawa and western Flores may have broken away from the western arc of Sulawesi, with which it was continuous previously, in the late Miocene and opened the Flores Sea (fig. 77). Farther east, the subsequent volcanic arc was built upon oceanic crust, whereas in the Java-Sumbawa-western Flores sector the new magmatic arc was superimposed on the old. The narrow and relatively shallow Bali Basin, north of Bali, Lombok, and western Sumbawa, may record tensional thinning, but not complete rifting, of the pre-Miocene crust.

BANDA ARC:

The modern Java Trench subduction system began operating at least as early as late Oligocene time, yet no magmatic evidence is apparent for subduction beneath Sulawesi during the Paleogene and early Miocene. As a number of island arcs elsewhere are known to have migrated during their development - this is discussed at length subsequently, particularly regarding the Mariana system-one explanation possible for the gap in magmatis $m$ is that the arc form migrated eastward away from Sulawesi, opening the Banda Sea behind it, to become what is now the Banda Arc (fig. 77).

No drill holes yet date the floor of the Banda Sea. The Banda Sea has locally thick turbidites (fig. 74A), but its pelagic sediments thin eastward away from Sulawesi (fig. $76 A, C, E$ ) and could be entirely Neogene. Formation behind an eastward-migrating arc is inferred. If, alternatively, the Banda Sea was enclosed behind a newly inaugurated Banda Arc, then the oceanic crust so enclosed was not a piece of the old Indian Ocean floor, but belonged to some younger plate. Further, no abyssal plain of sediments exists that could have been derived from Australia or New Guinea before formation of the arc.

Melange is now being formed in the outer-arc ridge of the Banda Arc, and upper Neogene melange is exposed on the islands. Much of the material composing the ridge may, nevertheless, have moved with the migrating ridge from an initial site on the margin of the Asian continent as it once existed at Sulawesi. Paleogene strata bearing an Asian anthracothere on Timor, discussed previously, provide a notable example. Continuing imbrication in the wedge of rocks above the subducting oceanic and, most recently, continental Australian plates has mixed young and old components.

Neogene subduction may have been rejuvenated beneath Sulawesi after the primary arc migrated away from it. Subduction continuing into Pliocene time is indicated by the voluminous magmatic rocks of Sulawesi. Even as the Banda Arc migrated away from Sulawesi, creating the Banda Sea behind it, the western part of the Banda Sea may have been subducted beneath Sulawesi. This situation is analogous to that of the Philippine Sea, which is being created as the Mariana Arc migrates eastward, yet simultaneously is being consumed on the west at the Mindanao Trench.

PAIEO(FFE IHSIORY OF JAYA, BORNEO, INH SLI AWISI

In the various components of the arc system occur many subduction melanges that could, in the lack of definitive dating, be of early Tertiary age; but only in central Java (where Eocene strata overlie a melange that contains probably Paleocene nannofossils) does it appear that a Paleogene date can actually be specified. Correspondingly, 
no tightly dated Paleogene magmatic rocks, of the types likely to have formed above a Benioff zone, predate the late Oligocene. A few isolated early Tertiary $\mathrm{K} / \mathrm{Ar}$ age determinations have come from the region: two of $58 \mathrm{~m} . \mathrm{y}$. for basement samples north of Java (fig. 46), one of 31 m.y. for a granodiorite at the base of the North Arm of Sulawesi. Otherwise, the magmatic rocks appear to be of Cretaceous and Neogene ages. If the lack or scarcity of subduction and arc-magmatic complexes representing most of the Paleogene is real, and not merely an illustration of lack of knowledge, then little subduction may have occurred within the Java-Sulawesi-Banda system during early Tertiary time. The northern part of the Indian Ocean is, nevertheless, shown by the magnetic anomalies of the spreading oceanic ridges to have been moving rapidly northward during this period.

Very early in Tertiary time, subduction may have slowed or stopped on the Java-Sulawesi-Banda system, the plate to the north of that arc then moving northward with the Indian Ocean plate. Evidence for subduction southward beneath northwest Borneo during the Paleogene was given in a prior section, and this subduction fills the time gap missing in the southern system. During the early Tertiary, the major consumption of oceanic crust between converging Asian and Indian Ocean plates may have been accommodated, within the longitudes of Borneo, by subduction southward under Borneo. In the late Oligocene, the major subduction again became northward under the subcontinent from its southern side.

This rationale can be fitted to the complexities of eastern Indonesia, where small plates with rapidly changing boundaries and configurations have converged or swirled past one another as Australia and New Guinea have moved northward. Problems of a different sort complicate the rationale to the west of Borneo. The Northwest Borneo Paleogene subduction system does not continue around the southwest end of the South China Sea to emerge in eastern Indochina; nor does it continue across the Malay Peninsula, Sumatra, or the Tin Islands. It was inferred for these reasons in a prior section that Borneo pivoted counterclockwise during Paleogene time, the subduction of the South China Sea beneath it decreasing to zero near the west tip of Borneo. A complementary change in north-dipping subduction beneath Sumatra and Java may have accompanied this, that subduction rate being near zero in the east but increasing westward to accommodate the full amount of convergence between Indian Ocean and Asian plates west of Borneo.

\section{THE NORTHERN MOLUCCAS}

The northern Moluccas-the Indonesian islands of Halmahera, Obi, Waigeo, and their neighbors-occupy a particularly cha otic tectonic setting. Their region is bounded on the south by the strands of the Sorong fault system trending westward from New Guinea to Sulawesi; on the west by the northern Molucca Sea; on the northeast by the south end of the Philippine Trench; and on the east probably by a northwest-trending member of the Sorong system. The geology of the islands is very poorly known.

\section{HALMAHERA}

The four-armed island of Halmahera resembles larger Sulawesi in more than its irregular shape, for Halmahera also has a western magmatic arc and an eastern terrain dominated by apparent subduction melange. The magmatic arc forms most of the North Arm ${ }^{12}$ of Halmahera and the islands west of the South Arm (fig. 79). According to the interpretation of trimetrogon aerial photography by Verstappen (1960), the two eastern arms are deeply dissected undulating uplands; the North Arm contains young volcanoes within a complex graben; and the South Arm is an east-tilted fault block.

\section{MEI.ANGE}

The Northeast and Southeast Arms of Halmahera are shown on the tectonic map ( $\mathrm{pl} .1$ ) as consisting of a subduction complex because of the imbrication of appropriate rock types. (My information on the structure comes primarily from Rab Sukamto, oral commun., 1976, who led a Geological Survey of Indonesia field party there; published data, limited to rock-type information and local attitudes, comes from widely spaced landings and traverses reported by Brouwer, 1923c, and Wanner, 1913.) Ophiolite (serpentinite, peridotite, gabbro, norite, basalt, red radiolarian chert), pelagic sediments (marl, limestone, and chert, bearing radiolaria, sponge spicules, and Cretaceous? and Paleogene foraminifers), and shallow-water Miocene strata are imbricated together. Melange is presumably present, although Sukamto saw no outcrops of it. Young coral reefs are raised high above sea level in some sectors.

The tiny islands about $30 \mathrm{~km}$ west of the north tip of Halmahera are inferred on the tectonic map to consist of Tertiary melange because of the brief, ambiguous description by Gogarten $(1918 \mathrm{a}$, p. 275,$276 ; 1918$ b, p. 277) of a complex of intersheared "crystalline breccia," limestone and other sediments, and "conglomerate" containing "iron ore blocks" and volcanic clasts.

\section{MACDATIC:ARC:}

The North Arm, west-central Halmahera, and the islands west of the South Arm consist of Tertiary and Quaternary basalt, andesite, and dacite (Brouwer, 1921c, 1923d; Bücking, 1904b; Gogarten, 1918b; Neumann van Padang, 1951, p. 251-271; Verbeek, 1908a, b). The active and recently extinct volcanoes within this terrain form a narrower belt that trends southwestward across the North Arm, thence curves southward through the offshore islands.

Batjan (or Bacan) - the large island west of the South Arm-contains also granitic and quartz dioritic gneisses and contact-metamorphic schists (Brouwer, 1923d; Bücking,

\footnotetext{
12The arms are termed, in order clockwise from the northwest, the North. Northeast, Southeast,
} and South Arms. 
1904b). Perhaps these represent intrusive centers within the magmatic arc. Because of the proximity of Batjan to strike-slip faults of the Sorong system, however, it is also possible that the silicic rocks are part of a continental fragment torn from New Guinea. The silicic rocks are undated, and their assignment to the Paleozoic on the tectonic map reflects only the assumption that they have been conveyed here from northwestern New Guinea.*

\section{REGION.AL REL.ATIONSHIPS}

The active volca nic arc of Halmahera is related spatially to a Benioff zone dipping eastward from the west side of the northern Molucca Sea (fig. 99; Hatherton and Dickinson, 1969), yet the Caroline plate is now being subducted westward at the Philippine Trench east of northern Halmahera. Melange of the modern Halmahera system lies beneath the Molucca Sea, west of the volcanic belt. The symmetry of Halmahera itself, with Paleogene(?) melange in the east and Tertiary arc volcanic rocks in the west, is suggestive of paired belts belonging to a west-dipping subduction system. These matters and others are integrated in a subsequent section into a complex interpretation of flipping polarities of colliding subduction systems.

The Southeast Arm of Halmahera connects along strike to Waigeo by a ridge, mostly submarine, which presumably is, like the islands, formed mostly of Paleogene(?) melange.

\section{OBI ISLANDS}

Published geologic information on the island of Obi, south of Halmahera, consists mostly of notes on rock types and fossils by Brouwer (1924a) and Wanner (1913). Ultramafic rocks-serpentinite, harzburgite, Iherzolite, wehrlite - are abundant and presumably occur in subduction melange. Gabbro, diabase, basalt, greenstone, radiolarite, red jasper, quartzite, schist, brown and black slates, black shale (some containing Jurassic ammonites), and Cretaceous(?) globigerinid marl are other materials present that could be in melange. Neogene sands and marls are folded only gently and must lie uncomformably upon these materials, and raised Quaternary reefs stand above parts of the coast. Paleogene nummulitic limestone and middle Tertiary lepidocycline limestone are of unknown association but must have formed in shallow water. Undated hornblende andesite, dacite, tuff, diorite, sheared quartz diorite, and quartz monzonite porphyry indicate magmatic-arc activity at some time. Brouwer (1924a) reported serpentinite to be thrust over andesite at a well-exposed locality, so either some of these magmatic-arc rocks are in melange, or, if they intrude and overlie melange, deformation also followed their crystallization. The flat-topped ridge extending east from Obi bears little-deformed strata (fig. $80 \mathrm{C}$ ).

The small islands near Obi contain ultramafic, gabbroic, and basaltic rocks, and sheared "tuffs" and "conglomeratic

"Note added in 1981: Recent fieldwork by geologists of the Geological Survey of Indonesia indicates instead that the island is a fragment of a Tertiary island arc. rocks" (Brouwer, 1924a; Kuenen, 1942), suggesting melange to be present.

Obi is assumed on the tectonic map to consist of Tertiary melange and Tertiary magmatic-arc volcanic rocks. No interpretation of relative ages of these contrasted materials is intended. Obi is bounded on both north and south by east-west submarine topographic lineations that presumably are strands of the Sorong fault system (fig. 80), so the original sites of formation of the rocks now juxtaposed could be far distant from their present location. Some of the rock types noted, particularly quartz monzonite, are suggestive of the presence of a continental fragment, presumably of northwestern New Guinea derivation, within the melange terrain.

\section{WAIGEO}

The island of Waigeo (or Waigeu), north of the northwest tip of New Guinea, contains much west-trending, steep-dipping melange. This is shown clearly by the descriptions by Brouwer (1924b, p. 84) and Verbeek (1908a, figs. 213, 217-219) of excellent north-coast outcrops, where the melange consists of chaotically intercalated, brecciated, and sheared serpentinite, peridotite, gabbro, diabase, schist, red and brown chert, silicic ironstone, sandstone, globigerinid marl, limestone bearing Paleogene foraminifers, and shallow-water Oligocene limestone. Ultramafic rocks dominate the northern part of the island (Verstappen, 1960). The basement of the rest of the island includes both similar breccias and variably altered andesite and dacite, the relationship of which to the melange is not known (Brouwer, 1924b). Unconformably overlying these materials are gently deformed upper Neogene strata (Brouwer, 1924b; Verstappen, 1960). Nickeliferous laterite developed on the ultramafic rocks has been explored by Pacific Nikkel Indonesia, a subsidiary of United States Steel, and found to include extensive deposits of commercial or near-commercial grade (Reynolds and others, 1973).

Gag, a small island $50 \mathrm{~km}$ west of Waigeo, consists of exposed oceanic crust and mantle. The rocks include peridotite (harzburgite) and sheeted diabase dikes, the latter of oceanic-tholeiite composition (Ryburn, 1977). A single $\mathrm{K}-\mathrm{Ar}$ age of amphibole from a quartz-bearing dike is $148 \pm 8$ m.y.

\section{ARC SYSTEMS BETWEEN SULAWESI, HALMAHERA, AND THE PHILIPPINES}

Reflection profiling, geologic data, and seismicity in the northern Molucca Sea region combine to yield a picture of complex changes in subduction patterns, the subduction systems themselves being variously collided, imbricated, and reversed in polarity. Roeder (1977) and Silver and Moore (1978) also have analyzed some of these relationships.

\section{CELEBES SEA}

The abyssal plain of the Celebes (Sulawesi) Sea lies at a depth of 5,000-5,500 m, and its thick turbidites (fig. 96-98) 


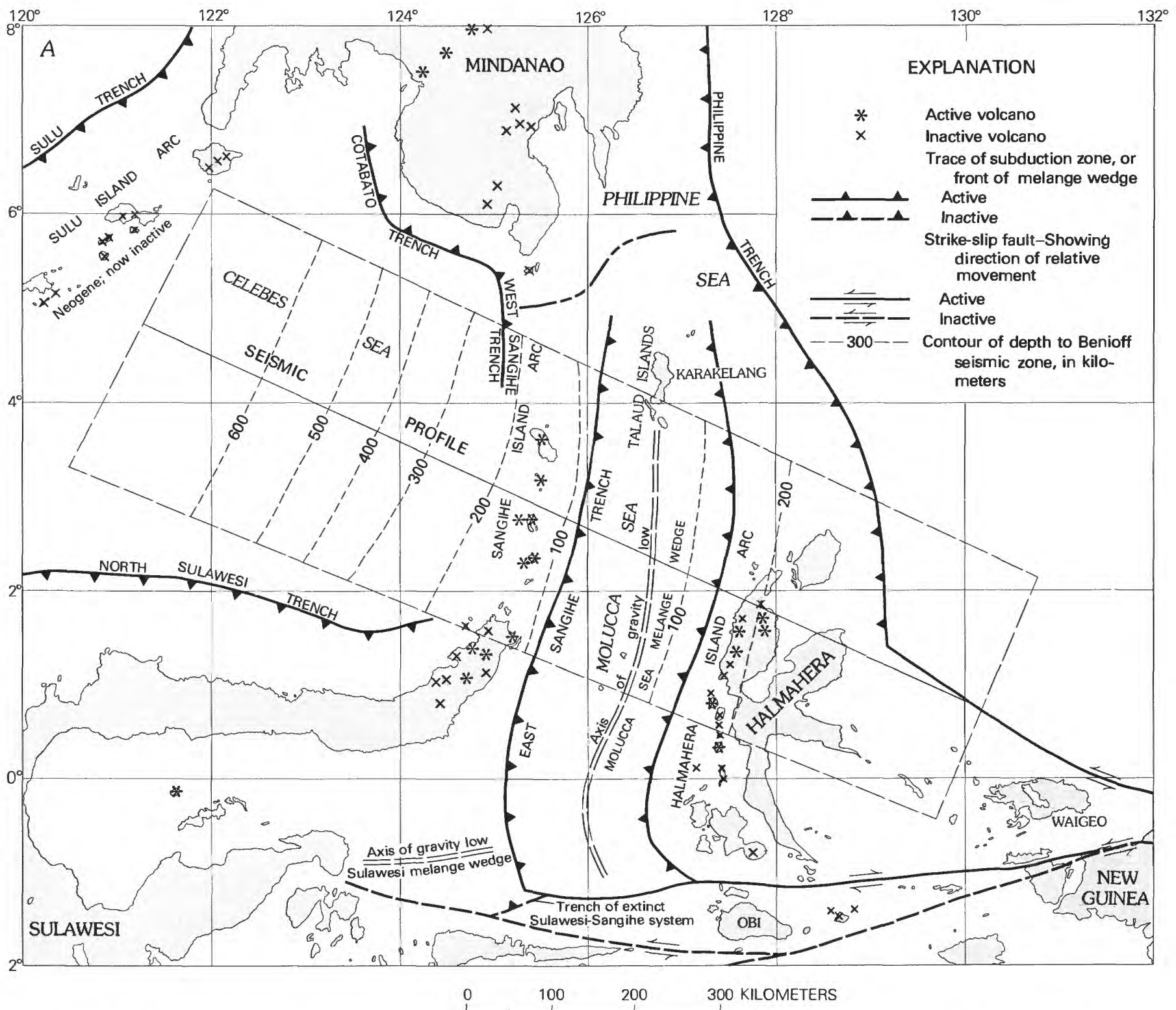

FIGURE 99.-Tectonic features and seismicity of the arc collision in the Molucca Sea region. $A$, Map, showing traces of subduction zones, major strike-slip faults, volcanoes, contours on Benioff seismic zones, and position of seismic profile. $B$, Seismic profile, showing 1959-1966 earthquakes within the area outlined in $A$, projected to the indicated plane; redrawn from Hatherton and Dickinson (1969, fig. 5). $C$, Tectonic section along the same line. Horizontal and vertical scales are equal.

likely were derived mostly from Borneo. The sediments thin eastward as the sea floor rises toward the Sangihe Ridge, the basement rising faster than does the sea floor. Part of the rise toward Sangihe Arc appears on profiles $96 B$ and $97 A$ to be a sedimentary apron derived from the arc. Crustal structure of the Celebes Basin is oceanic (Murauchi and others, 1973). Heat-flow measurements in the deep part of the sea range from 1.1 to $1.9 \mathrm{microcal} / \mathrm{cm}^{2} \mathrm{sec}$ but are mostly about 1.5 (Sclater and others, 1976). Both heat flow and depth are appropriate for an early Tertiary or Late Cretaceous age of formation of the oceanic crust (Sclater and others, 1976). A submarine volcano erupted in 1955 in the east-central part of the sea, near lat $3^{\circ} 58^{\prime}$ N., long $124^{\circ} 10^{\prime}$ E., according to Hantke (1976).

\section{SEISMICITY-COLLISION OF ISLAND ARCS}

Two active Benioff seismic zones of mantle earthquakes intersect beneath the western Molucca Sea (fig. 99; pl. 1; 

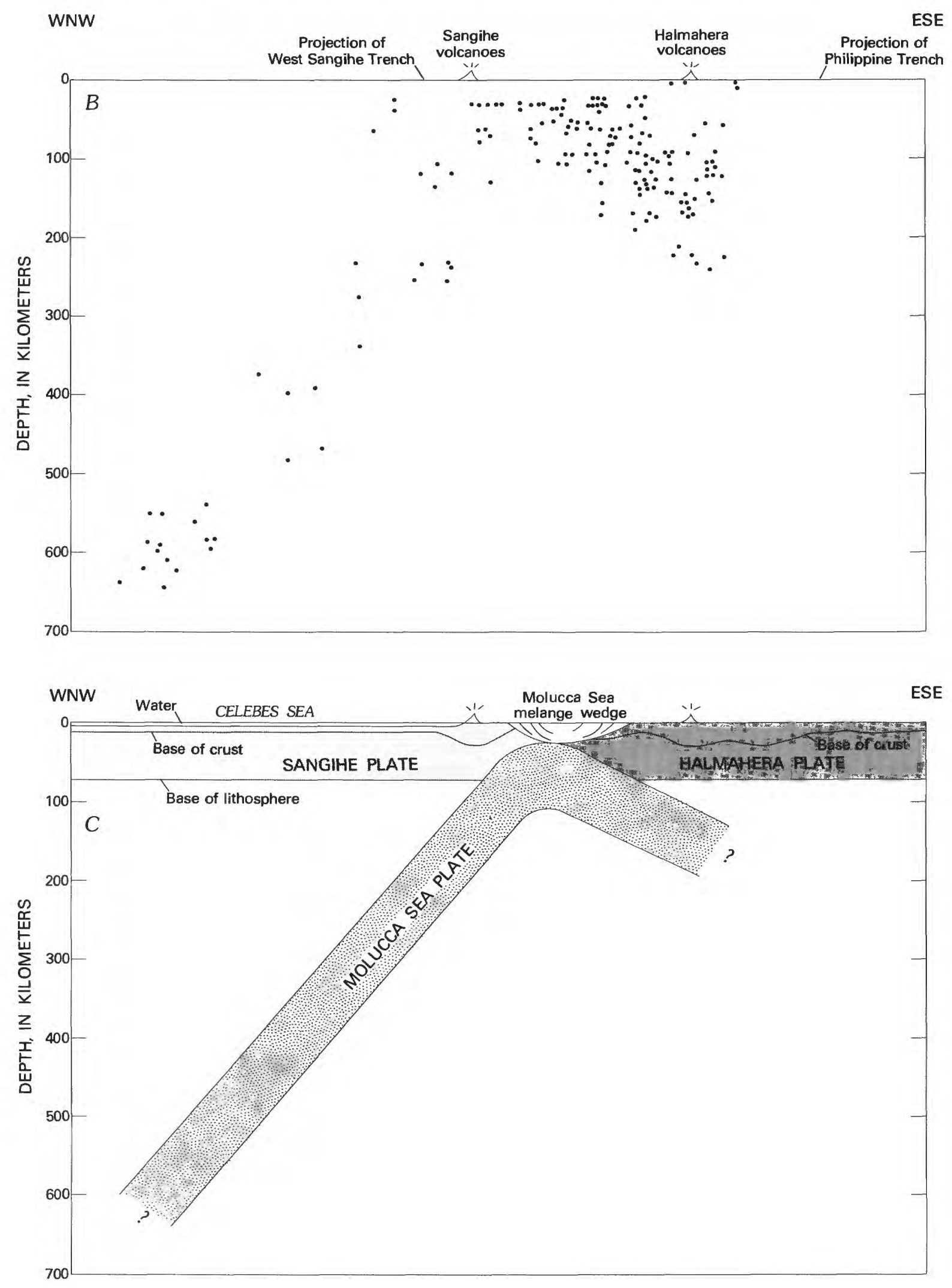
Fitch, 1970a; Hamilton, 1974b; Hatherton and Dickinson, 1969) and indicate the collision of two island arcs. One zone dips moderately west beneath the Sangihe Island Arc and the Celebes Sea, and the other dips more gently east beneath Halmahera. Each zone is accompanied by appropriate active island-arc volcanoes. Although the Philippine Trench is a great topographic feature that extends southward to Halmahera, and although sediments in the trench show severe deformation on reflection profiles, no apparent Benioff zone dips westward from it south of Mindanao, at least not to a depth much greater than $100 \mathrm{~km}$.

\section{SANGIHE ISLAND ARC:}

The Sangihe (or Sangi, or Sangir) Island Arc trends northward from the northeast tip of Sulawesi to south-central Mindanao. As this arc is continuous with the late Neogene arc of Sulawesi and has a youthful appearance, I assume that the Sangihe sector also was inaugurated early in middle Miocene time. The active volcanoes of the Sangihe Arc are clearly related to the west-dipping Benioff zone beneath it, but the arc displays complexities indicating that drastic changes are underway. Reflection profiles show that no west-dipping subduction zone now reaches the surface east of the arc.

\section{SANGIHE ISI ANISS}

The small islands standing on the Sangihe Ridge are young volcanoes, a number of which have erupted within historic time (Brouwer, 1921c; Bücking, 1904b; Neumann van Padang, 1951, p. 245-254, and 1953, p. 2). Two-pyroxene andesite is the dominant rock type. Basalt, augite andesite, hornblende andesite, and dacite are subordinate. The rocks have compositions appropriate to their height above the west-dipping Benioff zone beneath the ridge (Hatherton and Dickinson, 1969).

\section{STIAIIESI}

The northeast tip of the North Arm of Sulawesi is the emergent south end of the Sangihe volcanic arc. The interpretation was made in a previous section that all of the North Arm was previously part of this arc but that oroclinal folding consequent upon subduction along the North Sulawesi Trench has lengthened the east-trending part of the arm at the expense of the northeast-trending part.

\section{MINDANAO}

The Sangihe Ridge projects onshore northward as the peninsula and eastern ranges of south-central Mindanao. This terrain consists of Neogene volcanic and sedimentary rocks. It includes both young, but not historically active. volcanic cones, and older volcanic rocks that in part are considerably deformed and altered ( Ranneft and others, 1960). Andesite and basalt are the common rock types.

\section{IECIONIC:S}

The Sangihe system displays in figure $97 A$, a reflection profile across the south end of the chain, what might at first be taken to be a complete east-facing island arc. In order eastward appear volcanic seamounts and possible outer-arc basin, outer-arc ridge, and trench. The profile, however, shows no hint that the Sangihe Ridge is overrding the Molucca Sea floor at that trench and on the contrary suggests that the trench marks the trace of a thrust by which the Molucca Sea floor is riding relatively westward up onto the ridge. Richard W. Murphy pointed out to me this relationship in 1972. A similar relationship is shown both farther south (fig. $80 A$ ) and north (fig. 96 A, B). Silver and Moore (1978) documented this westward thrusting with new reflection profiles. The Celebes Sea west of the Sangihe Arc is almost twice as deep as the trench at the east side of the arc, which in turn is much deeper than the unique northern Molucca Sea. The Sangihe Ridge lacks an apparent outer-arc ridge-and-basin pair in profiles figure $96 A$ and $B$, and the sharp seamounts on and west of the ridge appear to be volcanic.

Near the center of the Sangihe Arc, topographic trenches lie on both sides of the ridge (fig. $96 \mathrm{~A}$ ). The eastern trench again is interpreted to mark the trace of an east-dipping thrust zone. At the west base of the Sangihe Ridge, the turbidites of the Celebes Sea floor are warped downward into the West Sangihe Trench. Another profile across the north part of the Sangihe Ridge (R. V. Robert Conrad, cruise 11; the profile is too faint to reproduce well), just south of Mindanao, also shows a topographic trench along the west base of the ridge, although it does not display the downward fanning of sedimentary fill that characterizes many subduction trenches. Still farther north, two profiles across the southwest margin of central Mindanao (figs. $96 \mathrm{~A}$ and $97: B$ ) show a trough, which also lacks apparent downward fanning of fill, at the base of the continental slope.

\section{RECENT CHANGES IN SUBDUCTION PATTERN}

The west-dipping Sangihe Benioff zone, the active andesitic volcanoes of the Sangihe Arc related to that Benioff zone, and the island-arc belts displayed in the profile of figure $97 A$ show the Sangihe Arc to be the product of a long-lasting west-dipping subduction zone. The seismic relationships and reflection profiles just described, and other features discussed subsequently, however, indicate that the system is undergoing collision and polarity reversal.

The melange wedge beneath the Molucca Sea is riding relatively westward up onto the eastern base of the Sangihe Arc and has covered the trace of the west-dipping Sangihe subduction zone (fig. 99). This is a surficial effect of the collision, underway beneath the wedge, of the converging Sangihe (Celebes Sea) and Halmahera plates.

A deeper-seated effect of the same collision is the polarity reversal of the northern Sangihe Arc. The geometry of the West Sangihe Trench indicates that subduction is now eastward beneath the north part of the Sangihe Arc, even though this arc obviously formed above a subduction system dipping westward. The Sangihe Arc has been joined to the 
Halmahera Arc, and a new subduction zone is breaking through on the west side of the aggregate mass.

\section{MOLLCC:A SEA MELANGE WEDGE}

The northern Molucca Sea, between the Sangihe and Halmahera-Mindanao ridge systems, is floored by young subduction melange, scraped up in front of the converging Sangihe and Halmahera Arcs and now covering their collision zone.

\section{BATIMMFIRY AND GHOPIISICS}

The northern Molucca Sea is relatively shallow. Just east of the Sangihe Ridge and Trench complex, the sea floor is typically about $2,300 \mathrm{~m}$ deep, and it rises gradually eastward to the medial Talaud Ridge, which is no deeper than about $800 \mathrm{~m}$ and emerges to form the Talaud and other islands. The floor of the sea is almost uniquely rough within the Indonesian region. Coherent reflections are shown in few places on profiles across it; mostly, it is acoustic basement on low-energy profiles (figs. 80, 96, 97, 98). That basement, however, likely is of low-velocity material, for it is not acoustically opaque: on profiles $A$ and $B$ of figure 96 and $A$ of figure 97 and profile $A$ of figure 80 , the Sangihe Ridge basement apparently can be seen through the Molucca Sea basement. A topographic basin lies between the Talaud Ridge on the west and Halmahera on the east (fig. 96 $A, B$ ).

A broad negative gravity anomaly of extremely large amplitude marks the northern Molucca Sea (Vening Meinesz, 1954, pl. 1; Ben-Avraham, 1973; Silver and Moore, 1978). The north-trending axis of the anomaly lies between the Talaud Ridge crest on the west and Halmahera and the ridge to the north of it on the east. In the south, the anomaly is coincident with the topographic basin west of Halmahera. Free-air anomalies reach -250 milligals along the gravity trough. Large-amplitude negative anomalies in the Indonesian region are centered along the melange wedges of active subduction systems, and the amplitude of the northern Molucca Sea negative gravity anomaly is matched only by the anomaly of the outer-arc basin inside the easternmost part of the Banda Arc.

\section{ISI..INISS}

The rock types reported from the islands that rise from the broad submarine Talaud Ridge of the northern Molucca Sea are interpreted to indicate that the islands consist largely of subduction melange. The largest islands are those of the Talaud group, which extend from lat $3^{\circ} 45^{\prime}$ to $4^{\circ} 33^{\prime} \mathrm{N}$., and from long $126^{\circ} 36^{\prime}$ to $126^{\circ} 55^{\prime}$ E. Sukamto (1976) described and illustrated polymict melange, on Karakelang, in which lenses of basalt and serpentinite are scattered in a scaly-clay matrix (fig. 100). The dominant dip is eastward. Ultramafic rocks (harzburgite, serpentinite, and much-subordinate dunite), mafic rocks (olivine gabbro, calcic feldspathic gabbro, troctolite (olivine-plagıoclase rock), alkalic gabbro,hornblende gabbro, basalt, and trachybasalt) and red-brown radiolarian chert are abundant (Roothaan,

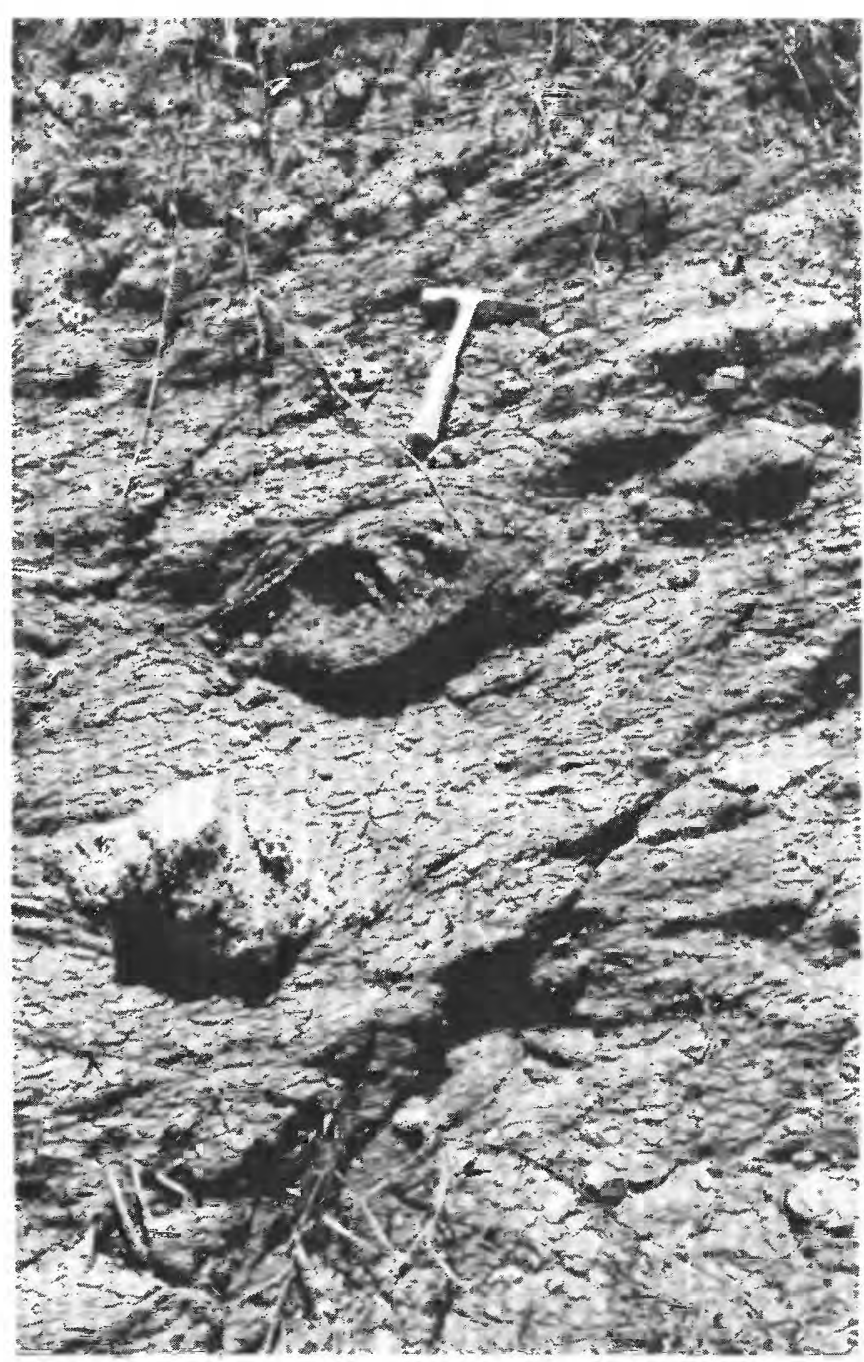

FigURE 100. Polymict melange from Karakelang Island, Talaud Islands. Molucca Sea. A block of basalt (lower left) and two lenses of red shale (below and right of hammer) lie in a matrix of scaly clay. Photograph by Rab Sukamto, Geological Survey of Indonesia; see Sukamto (1976).

1928). Gently folded, undated marl and sandstone are present also. Raised reefs cap all of these rocks. The small Nanusa Islands, northeast of the Talaud Islands in the area from lat $4^{\circ} 42^{\prime}$ to $4^{\circ} 47^{\prime} \mathrm{N}$. and from long $127^{\circ} 03^{\prime}$ to $127^{\circ} 08^{\prime}$ E. display raised reefs lying unconformably upon undated marl and sandstone (Roothaan, 1928). Small Majau (or Mayau) Island, farther south at $1^{\circ} 19^{\prime} \mathrm{N}$. and $126^{\circ} 23^{\prime} \mathrm{E}$. contains fresh and altered diabase overlain by raised reefs (Verbeek, 1908b, p. 153-255). Still farther south, tiny Tifore (or Tofure, or Gureda) Island at $0^{\circ} 58^{\prime}$ N., $126^{\circ} 08^{\prime} \mathrm{E}$., displays altered diabase and folded red marly and sandy limestone whose clastic grains include quartz, mica, hornblende, pyroxene, and Paleogene(?) foraminifers (Verbeek, 1908b, p. 152, 154). 


\section{OITWARD THRI'SIING;}

The Molucca Sea melange wedge is thrust onto the island-arc aprons on both sides. The westward thrusting onto the base of the Sangihe Ridge was noted previously. Reflection profiles also show eastward thrusting at the east side of the Molucca Sea: the east side of the melange wedge is ramped eastward onto the base of the Halmahera Arc. (Silver and Moore, 1978). This latter information negates my previous interpretation - as, Hamilton (1974b) - that the shallow trench at the west base of the Halmahera Arc represents the trace of a subduction zone dipping eastward beneath Halmahera and also negates part of the analysis by Roeder (1977) based on my earlier interpretation.

\section{IN IERPRETATION}

A wedge of melange, about $150 \mathrm{~km}$ wide and perhaps 20 $\mathrm{km}$ thick, lies above the junction of the Sangihe and Halmahera subduction systems (fig. 99C). The wedge is thrust symmetrically onto the flanks of both Sangihe and Halmahera Arcs, so it is uncoupled from both of the converging lithosphere plates, which slid beneath the floating wedge as they overrode the narrow antiformal remnant of the intervening oceanic plate (Silver and Moore, 1978). The relatively constant width of the complex, and the reversals in subduction polarity now underway, suggest that overriding of one advancing plate by the other does not occur. Convergence continuing after contact between the leading edges of the overriding plates may shift promptly to new subduction zones broken through on either side of the new aggregate of two island arcs.

The geometry of arc collision is strong evidence that the intervening Molucca Sea lithospheric plate sank vertically beneath the advancing Sangihe and Halmahera Arcs, as the doubly subducting plate could not have been injected, with a sizable horizontal component of motion, under both arcs simultaneously. The gentler dip of the Halmahera Benioff zone than of the Sangihe one is in these terms explained as caused by more rapid advance of the Halmahera Arc over the Molucca Sea plate than of the Sangihe Arc.

The voluminous sediments within the Molucca Sea (Talaud Ridge) melange wedge have no apparent adequate source within the small landmasses now nearby and may have been derived mostly from New Guinea when the Halmahera Arc lay far east of its present position. As the oceanic plate on which the sediments were deposited was subducted at both sides, its sedimentary cover was scraped off against both Sangihe and Halmahera Arcs. The melange wedges ultimately collided, and their material was combined into a large, two-sided wedge.

The Talaud Ridge comes ashore in the north as the Davao Peninsula of southeastern Mindanao. This peninsula is interpreted in a succeeding section to consist of melange that contains rocks at least as young as Eocene. The melange of the peninsula and of the rest of the Pacific Cordillera of eastern Mindanao farther north may have formed between converging arc systems. This is discussed further in the section describing the Philippines.

\section{PHILIPPINE TRENCH SYSTEM}

The very deep Philippine (or Mindanao) Trench bounds Mindanao on the east, and continues southward to the latitude of central Halmahera. The trench is $6,000-9,000 \mathrm{~m}$ deep and is narrow and almost devoid of sedimentary fill north of Halmahera (figs. $96 \mathrm{~B}$ and $98 \mathrm{C}$ ). The ocean floor to the east is $4,500-5,500 \mathrm{~m}$ deep and displays a considerable cover of pelagic sediments upon a moderately rough basement from which rise volcanic seamounts. A Benioff seismic zone dips westward far into the mantle beneath Mindanao from the northern (Mindanao) part of the Philippine Trench, but no obvious Benioff zone occurs in the south where, on the contrary, seismicity indicates subduction eastward beneath Halmahera (fig. 99B). The Philippine Trench is inferred to be a very young feature south of Mindanao, as is brought out in the following section.

An irregular ridge lies between the Philippine Trench and the floor of the northern Molucca Sea. Volcanic seamounts are not obvious on the profiles across the ridge, although their presence might be expected here. Figure $98 \mathrm{C}$ shows two notches on the slope from this ridge to the Philippine Trench; the upper could be an outer-arc ridge related to the Philippine Trench subduction system. On this same profile, the broad basin bounding the ridge system on the west is marked by a synclinal sedimentary cover, and the profile might be interpreted to show that the ridge is uptilted Molucca Sea floor. The other profile (fig. 96B) shows two highs, presumably parallel ridges, both mostly mantled by sediments. The western of the ridges is separated from the rough Molucca Sea floor by a shallow trench, in which the profile suggests sediments to fan downward to the west; a subduction-zone interpretation of this geometry would have the Molucca Sea floor riding relatively eastward onto the ridge.

\section{OVERVIEW}

The Molucca Sea region-including Mindanao, northern Sulawesi, Halmahera, and the arc systems linking them together-records complex and rapidly changing subduction patterns. Throughout the development of this terrain, subduction has continued of oceanic plates that were moving relatively westward toward Asia and that were bounded on the south by left-lateral faults. The following synopsis integrates data and interpretations from these and many other sections of this report.

During early Neogene time, a subduction system dipped westward beneath Sulawesi, the Sangihe Arc, and central Mindanao. The voluminous melanges of the eastern arms of Sulawesi and of the Molucca Sea record largely the sweeping off of sediments of New Guinea origin from the subducting oceanic plate, and the magmatic rocks of the western arms of Sulawesi, the Sangihe Ridge, and parts of Mindanao formed above the Benioff zone of the time. An east-dipping 
Halmahera subduction system converged with the Sangihe arc as the intervening oceanic lithosphere disappeared beneath them (fig. 99). The Sulawesi sector of the western subduction system became inactivated as it was rotated into unfavorable orientations, and the Halmahera system took up the difference. The two systems then collided in the north, welding central Mindanao (a product of the Sulawesi-Sangihe system) and the Pacific Cordillera (part of the Halmahera system) into an enlarged Mindanao. The collision has progressed southward with time. The northern part of the Sangihe Ridge now belongs to the Halmahera plate, the central part is in process of capture, and the southern part has not yet collided with the Halmahera subduction system.

The Philippine Trench developed along Mindanao after the collision of the two arcs there: relative motion continued as before between Philippine Islands and Philippine Sea plates, but all of the motion was thereafter taken up on the new west-dipping zone. The Philippine Trench broke through southward as far as central Halmahera only very recently; the trench is well developed, but no obvious deep Benioff zone marks the trajectory of lithosphere sinking westward from the trench. Perhaps the Halmahera and southernmost Sangihe subduction systems will in the near future become extinct, and the new Philippine system will become, if it is not already, the dominant subduction boundary in these latitudes.

\section{ISLAND ARCS BETWEEN BORNEO AND THE PHILIPPINES}

Two island-arc systems bridge northeastward from Borneo to the main Philippine Islands. The Tertiary Palawan Arc, in the west, faces northwest, separates the South China Sea from the Sulu Sea, and connects the north tip of Borneo with Panay and Mindoro (fig. 109). The Sulu Arc, in the east, also faces northwest, had only recently been deactivated along much of its length, separates the Sulu and Celebes (Sulawesi) Seas, and comes ashore as eastern Sabah in the southwest and as the Zamboanga Peninsula of Mindanao in the northeast (fig. 79).

\section{PALAWAN ARC}

The Palawan submarine ridge between Borneo and the Philippines has a minimum width of $100 \mathrm{~km}$ at the $1,000-\mathrm{m}$ isobath. Palawan (fig. 101) and the other islands of the ridge consist of ophiolite and Tertiary melange, overlain unconformably by little- to moderately deformed lower Miocene and younger strata. The north part of the ridge contains a Paleozoic-Mesozoic continental fragment, which can be pictured as a large clast in the melange.

\section{PALEOZOIC-MESOZOIC CONTINENTAL FRAGMENT}

Paleozoic and Mesozoic continental crustal rocks compose the northern part of the Palawan Ridge (Hashimoto and Sato, 1973; Tamesis and others, 1973; G. R. Balcé, oral commun., 1976). Slightly metamorphosed quartzose clastic sediments dominate the terrain as exposed on Palawan, but limestone, some of it containing middle and Upper Permian fusulinids and other fossils and Upper Triassic invertebrates, is present also. Two plutons of biotite quartz monzonite cut and more highly metamorphose the older rocks. Pebbles of quartz monzonite occur in Upper Jurassic conglomerate in southern Mindoro, presumably bracketing the age of plutons as Early of Middle Jurassic. The islet of Carabao, northeast of Palawan and $10 \mathrm{~km}$ north of the northwest tip of Panay, exposes Permian fusulinid limestones lying on undated graywacke (C. A. Reyes, M. V. Reyes, and E. P. Ordonez, written commun., 1972). Melange is exposed a short distance east, in western Panay, and ophiolite is faulted against the Paleozoic terrain on the south in Palawan. A trench that became inactive at the end of Miocene time lies at the foot of the continental slope west of the Paleozoic terrain; thus, middle Tertiary melange must bound the Paleozoic rocks on that side. The Paleozoic complex appears to be a continental fragment within melange and is overlain by shallow-water Eocene arkose, chert, and limestone (Kintanar, 1966).

The Paleozoic and Mesozoic assemblages resembles that of the upper Mesozoic magmatic-arc terrain along the southeast side of mainland Asia. The Palawan continental fragment may be the piece apparently missing from the mainland in the vicinity of lat $16^{\circ} \mathrm{N}$. (fig. 31), rifted away in Late Cretaceous or Paleogene time. Large shoal areas lie west of Palawan in the South China Sea, and as noted previously these may be other continental fragments related to the same rifting but not subsequently swept against subduction complexes.

\section{PALEOGENE MELANGE}

The basement of the southern two-thirds of the Palawan submarine ridge, as exposed on Balabec (Balabac) Island (John, 1963) and southern Palawan (Casasola, 1956; Irving, 1950, p. 285-288; Kintanar, 1966; Philippines Bureau of Mines, 1964, Sheet NC-50; de los Santos, 1959; unpub. data provided by oil companies) is interpreted to be melange and imbricated materials, mostly ophiolite and Paleogene clastic sediments. Ophiolite is represented by a large mass on central Palawan and by innumerable lenses and blocks elsewhere, of serpentinite, peridotite (mostly harzburgite) and other ultramafic rocks, gabbro, diabase, quartz diorite, pillow basalt, spilite, variably ferruginous and manganiferous radiolarite and chert, amphibolite, hornblende schist, and greenschist. The clastic sediments are much-deformed mudstone, shale, siltstone, slate, phyllite, graphitic schist, arkose, quartzose sandstone, and quartzite. Scaly clay and broken formations are widespread. The dominant sandstone type is arkose containing abundant quartz and potassic feldspar, so a continental source terrain is indicated. All these materials are interlensed tectonically and are much sheared, boudinaged, and brecciated. Arenaceous for- 


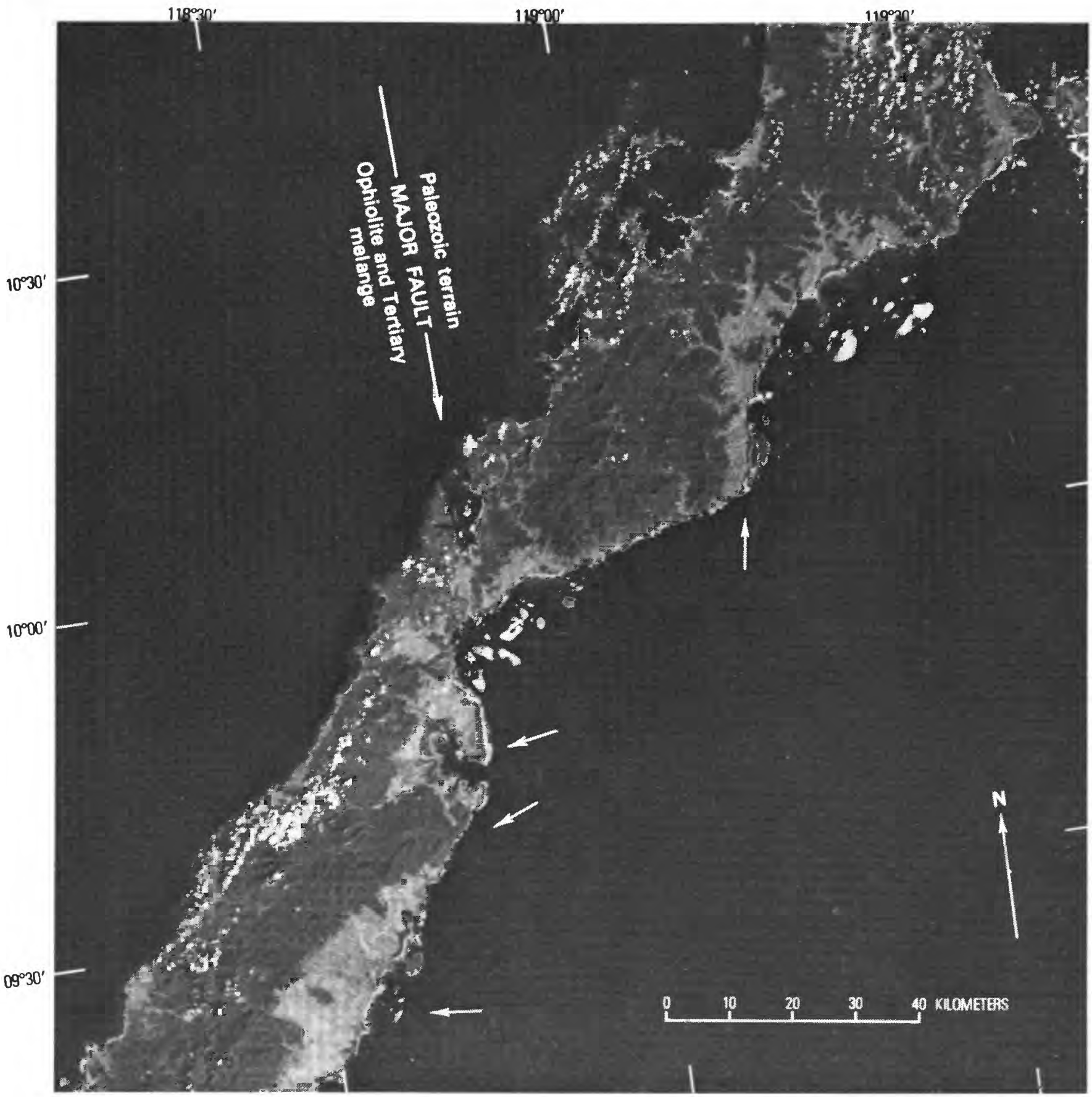

FIGL'RE 101.- Landsat image of Palawan. Most of the northern five-eighths of the island appears in the picture. The major fault separates the Paleozoic-Mesozoic minicontinent of northern Palawan from the ophiolite and Tertiary melange of the rest. The small arrows point along topographic lineaments which appear to mark other major faults, although no such structures are shown on the published reconnaissance geologic maps. NASA-ERTS picture 1154-01533, December 1972.

minifers, suggesting Paleogene ages, are the common fossils in the unmetamorphosed clastic rocks. Limestones present locally contain calcareous foraminifers, some of which were dated by Samaniego (1964) as Paleogene, but strata as young as Miocene may be deformed severely. Upper Neogene strata lie unconformably upon the complex onshore, whereas offshore to the northwest strata as old as early Miocene are little deformed.

Banggai (or Banggi, or Banguey) Island, which stands on the continental shelf just north of the north tip of Borneo, 
appears to belong tectonically to the Balabec and Palawan terrain to the north, rather than to northern Borneo. Like both regions, Banggai and neighboring islands consist mostly of melange of Paleogene or Miocene age, but the general northward to northeastward strikes and eastward dips on Banggai and its neighbors indicate likely continuity with Palawan, rather than with the northwest-trending melange terrain of nearby northern Borneo. Wilson (1961) described much ophiolite (figs. 102A, B, this report) and a variety of highly sheared sediments from Banggai and the nearby islet of Malawali.Fossiliferous Eocene limestone (fig. $102 C$ ) is enclosed in serpentinite, and fossiliferous middle(?) Miocene shale is intercalated tectonically in highly sheared sediments.

\section{MAGMATIS:ARC}

No rocks yet described from the islands of the Palawan ridge require the presence there of a Paleogene magmatic arc paired to a subduction-zone arc, although the islands expose, at one latitude or another, samples across most of the width of the ridge. Basalt, spilite, and gabbro are abundant, but their general association with ultramafic rocks and the apparent lack of andesite indicate ophiolitic, oceanic-crust assemblages. Some quartz diorite is present in several sectors, but at least that on Banggai Island (Wilson, 1961 ) is part of an ophiolitic suite within melange.

The magmatic arc may be represented by the discontinuous submarine ridge that trends southwestward across the Sulu Sea, subparallel to the Palawan Ridge, 150-200 km southeast of Palawan Island (figs. 79, 103, 104). Shoals and reefs, including Cagayan and other islands, rise from the ridge, which is separated from the Palawan ridge by a basin about 2,000 $\mathrm{m}$ deep. Cagayan de Sulu (a different island than Cagayan: fig. 79) and some of the neighboring islets near the south end of the ridge consist of variably dissected cones of basaltic volcanic rocks. Reflection profiles (fig. 103 $A$; Murphy, 1975, fig. 19) show the Cagayan Ridge to have a bedrock shape suggestive of conical volcanoes. The crustal structure of the ridge is appropriate for its being a volcanic island arc (Murauchi and others, 1973). A core sample of acoustic basement on the ridge at lat $7^{\circ} 55^{\prime} \mathrm{N}$., long $119^{\circ} 03^{\prime}$ E., is of volca niclastic rocks (D. E. Karig, written commun., 1973). The basin to the northwest of the ridge is filled deeply by little-deformed sediments, dammed behind the ridge.

FIGURE 102.-Photographs of components of Tertiary melange on Banggai Island and nearby Malawali Island, by R. A. M. Wilson (1961, pls. 8, 17, and 18; published by permission of the Geological Survey of Malaysia). $A$, Pillow basalt and interstitial chert, Kuala Bitara, Banggai Island. $B$, Photomicrograph of crushed dunite, north coast of Malawali Island. Crystals of unaltered olivine display mortar structure and are separated by bands of mylonitized olivine and serpentine. Plane polarized light. $C$, Photomicrograph of Eocene foraminiferal limestone, from a tectonic lens enclosed in ultramafic rocks, northeastern Banggai Island. A large nummulite appears in the center of the field; the rock also includes lepidocyclines and globigerinids (not illustrated here). Plane polarized light.
OITER-ARC: BASIN

If the Cagayan Ridge is indeed the magmatic arc paired to the melange of the Palawan ridge, then the intervening basin (Murauchi and others, 1973; fig. 103A) likely is the
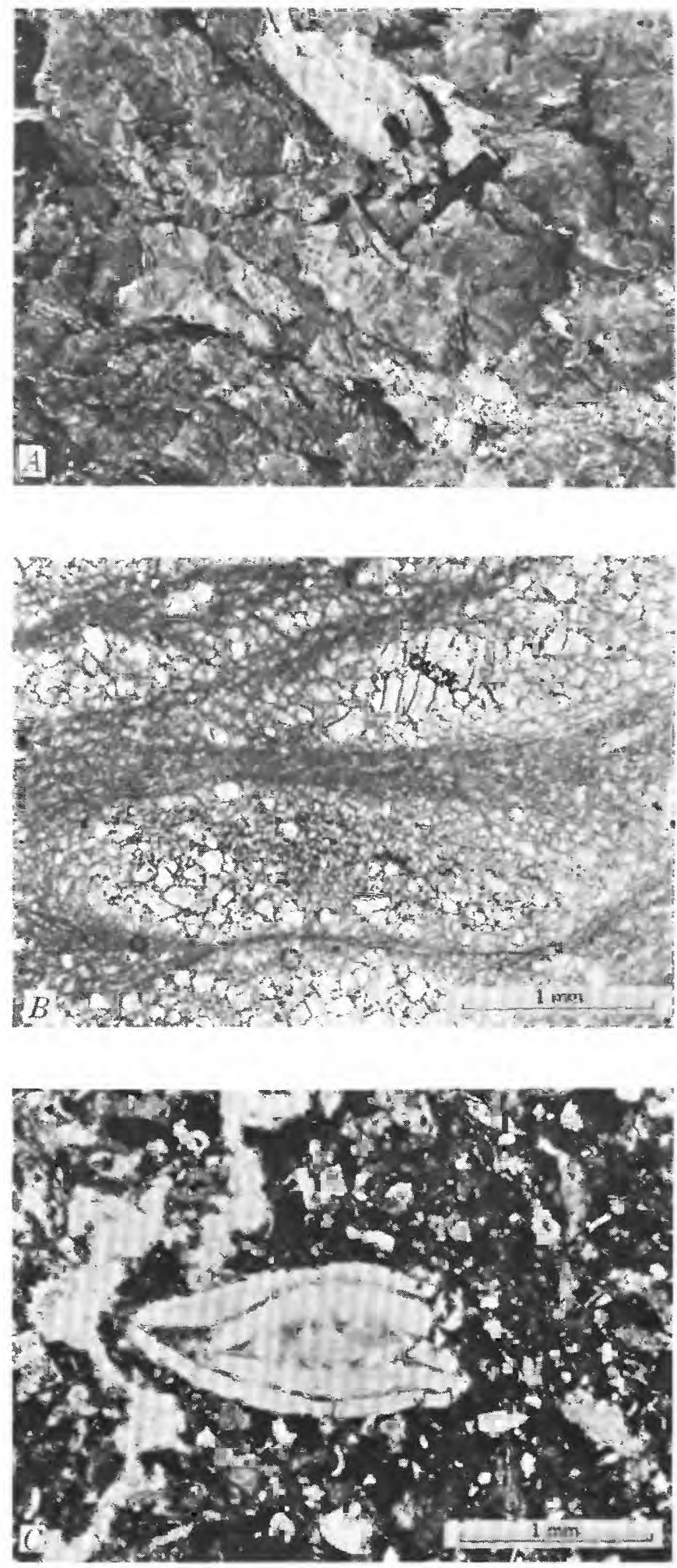

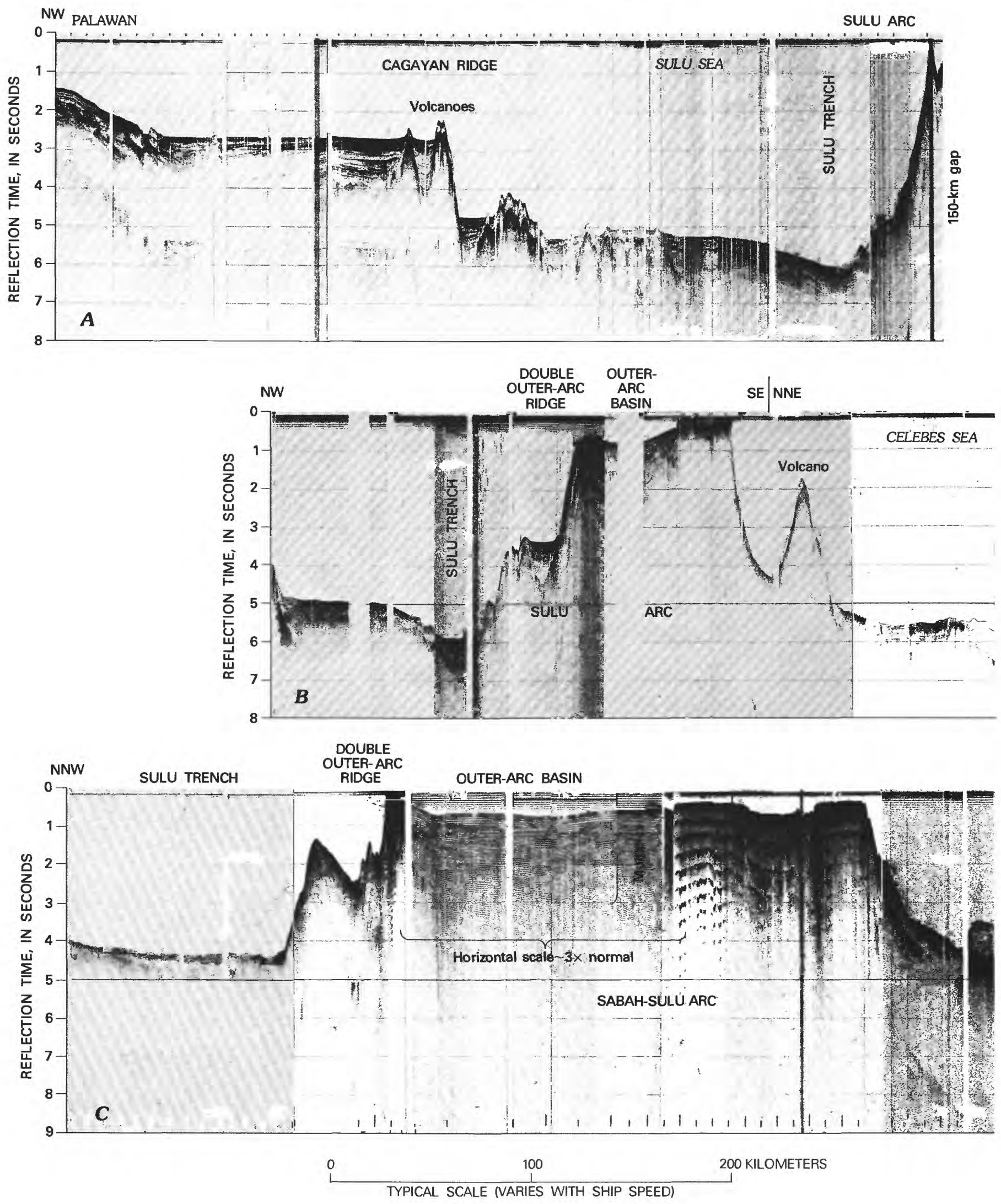

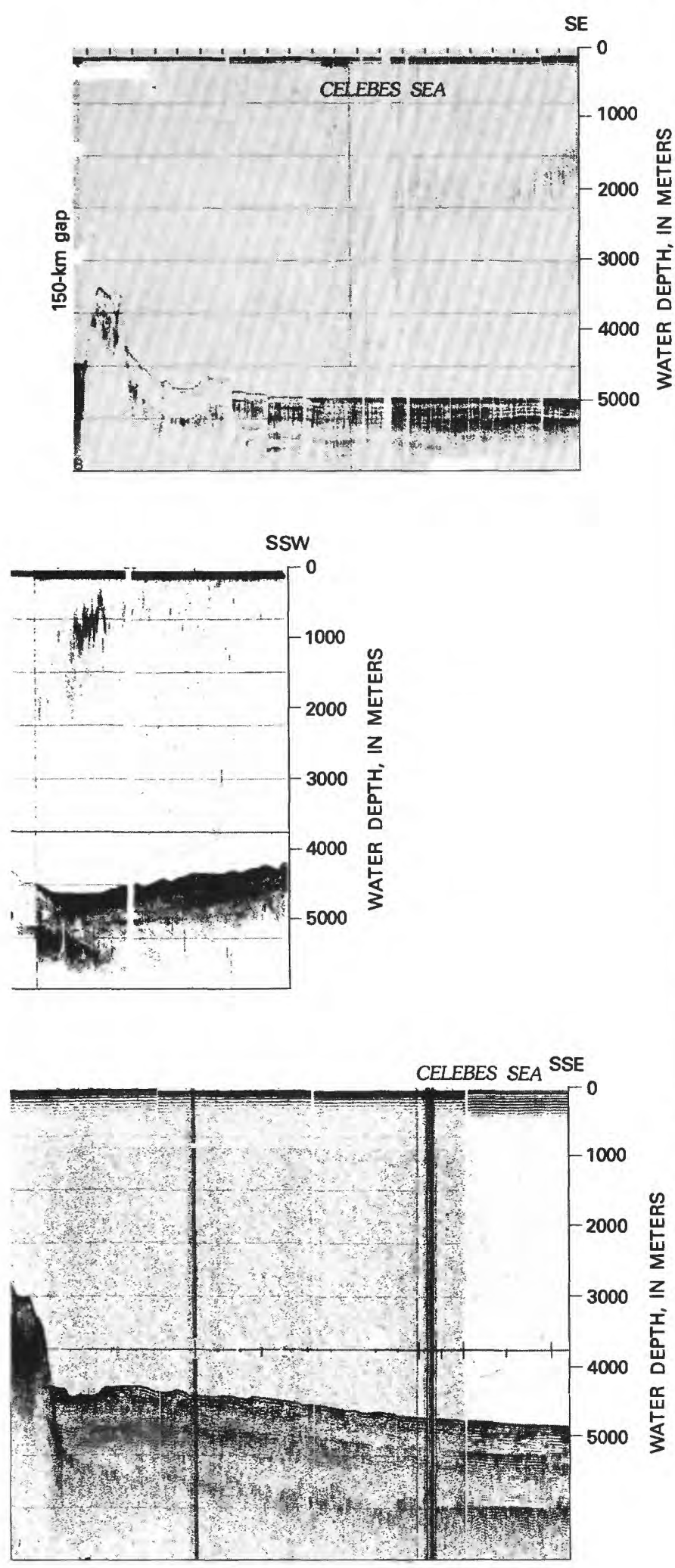

Paleogene outer-arc basin, filled to the rim with sediments since the subduction system became inactive.

\section{PALAWAN TRENCH}

A trench and a melange wedge, at which subduction stopped near the end of Miocene time, lie along the northwest side of Palawan (fig. 105; fig. 51 A, B; Murphy, 1975, figs. 22 and 23). Pliocene and Quaternary strata of the continental slope are prograded across the wedge and trench and are undeformed. The deep-penetration profile of figure 105 shows with particular clarity the mechanics of formation of a melange wedge by scraping off of trench sediments at the toe of the wedge; the slow imbrication into the wedge of strata deposited on top of it can be inferred. (See descriptive caption for the figure.)

\section{RELATIONSHIP TO BORNEO AND THE PHILIPPINES}

The Palawan and Northwest Borneo subduction complexes share quartzose sandstone, general northeasterly strikes, and various elements of deformationai style, and the fossil Miocene Northwest Borneo and Palawan Trenches that bound them are alined. The two Paleogene terrains could, nevertheless, not have formed in their present relative positions (as Kintanar, 1966, Wilson, 1961, and others have assumed), because, as was discussed in the section on Borneo, the Northwest Borneo Paleogene terrain swings abruptly eastward in western Sabah. Northernmost Borneo has easterly strikes, whereas Banggai and the other islands immediately north of it have north-northeast strikes toward Palawan (Stephens, 1956; Wilson, 1961).

It was suggested in the section on Borneo that the Sabah terrain includes an Eocene subduction complex that formed as the seaward extension along strike of the Northwest Borneo subduction complex; that the subduction polarity of the offshore extension reversed in Oligocene time; and that the arc system migrated southeastward, colliding with

FIGURE 103 (left and facing page).-Seismic-reflection profiles in the region of the Sulu and Celebes Seas. $A$, The deeply filled sedimentary basin on the left may be the outer-arc basin of the Palawan system, its sediments dammed behind the Cagayan Ridge volcanic arc. The thick turbidites of the Sulu Sea floor turn down at the Sulu Trench, where they are covered by only a thin wedge of ponded trench sediments. $B$, Profile across the inactive Sulu Arc shows trench, an apparent double outer-arc ridge, an outer-arc basin, and a probable volcano. $C$, Profile across the broad southern part of the Sulu Arc. The landward slope on the left is irferred to be the trench, although little of its internal structure is visible. A thickly filled outer-arc basin is on the left side of the ridge. The geology of the bedrock (right) part of the broad ridge is known from its onshore exposures in northwestern Borneo. Profiles $A, B$, and $C$ all show the thick turbidites of the floor of the Celebes Sea, southeast of the Sulu Arc. Location of profiles shown in figure 79. Profiles from Lamont-Doherty Geological Observatory, R. V. Robert Contad cruise 14 (C) and R. V. Vema cruises $24(A)$ and $28(B)$. 

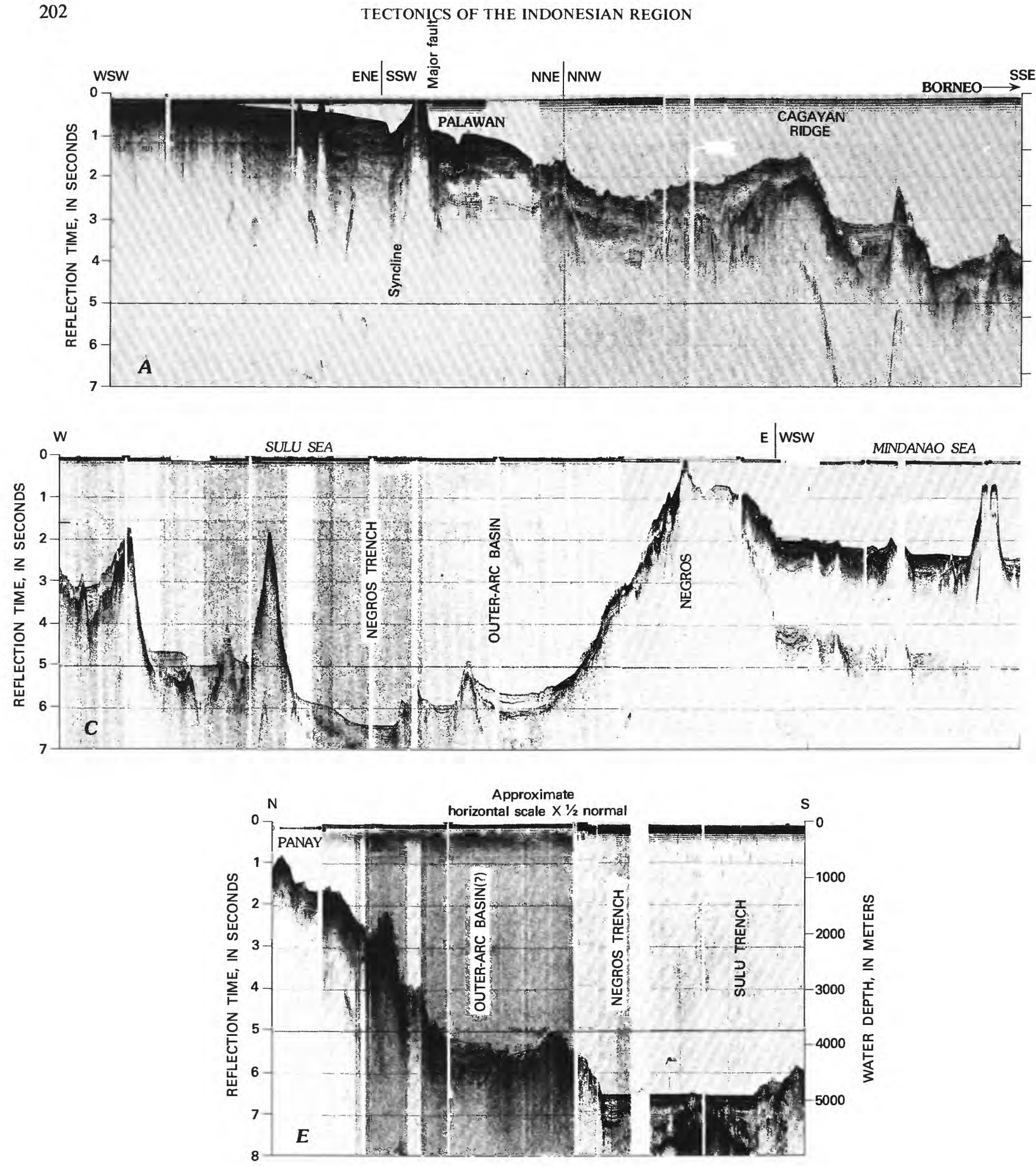
Approximate
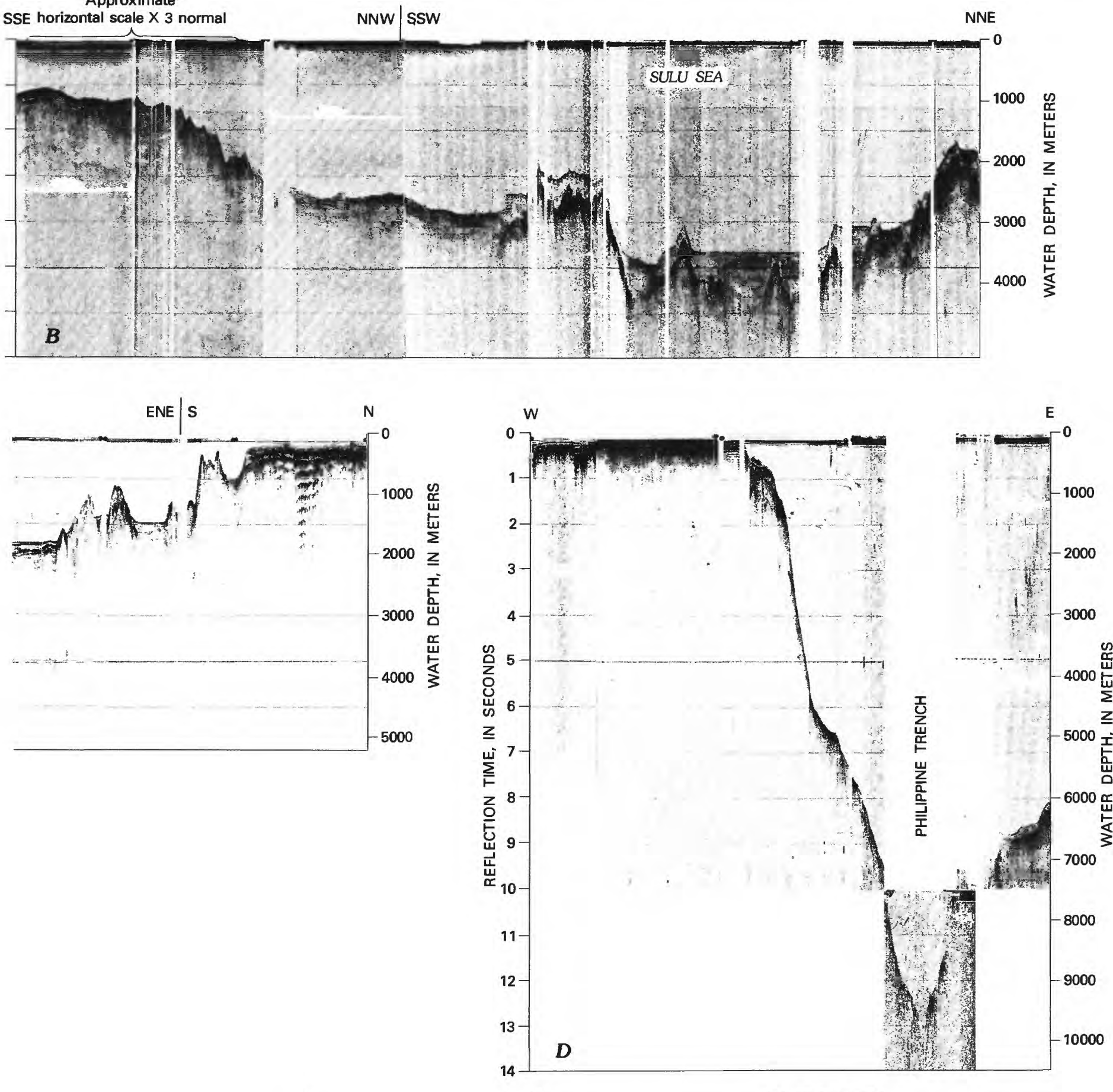

0

100

200 KILOMETERS

TYPICAL SCALE (VARIES WITH SHIP SPEED)

Figure 104,-Seismic-reflection profiles in the region of the Sulu Sea and the southern Philippines. A, Continental margin of northeast Borneo and southeast Palawan. The thick sediments above acoustic basement are much deformed. $B, C$, and $D$, A continuous profile from northern Borneo across the Sulu and Mindanao Seas and the Philippine (Mindanao) Trench. The Sulu Trench might be buried by the thick sediments left of center in $B$. Possible volcanic seamounts are partly buried by sediments (turbidites beneath acoustically transparent pelagics) on the right side of $B$ and the left side of $C$. The extremely deep Philippine (Mindanao) Trench displays no sedimentary fill, but a true floor could well be present yet masked by side echoes. $E$, The Negros and Sulu Trenches have almost collided by subduction of the intervening ocean floor. The trench sediments on the arc side of the Sulu Trench are much deformed. Location of profiles shown in figure 79. Profiles from Lamont-Doherty Geological Observatory, R. V. Robert Conrad cruises $12(B-D)$ and $14(A)$ and R. V. Verna cruise 28(E). 


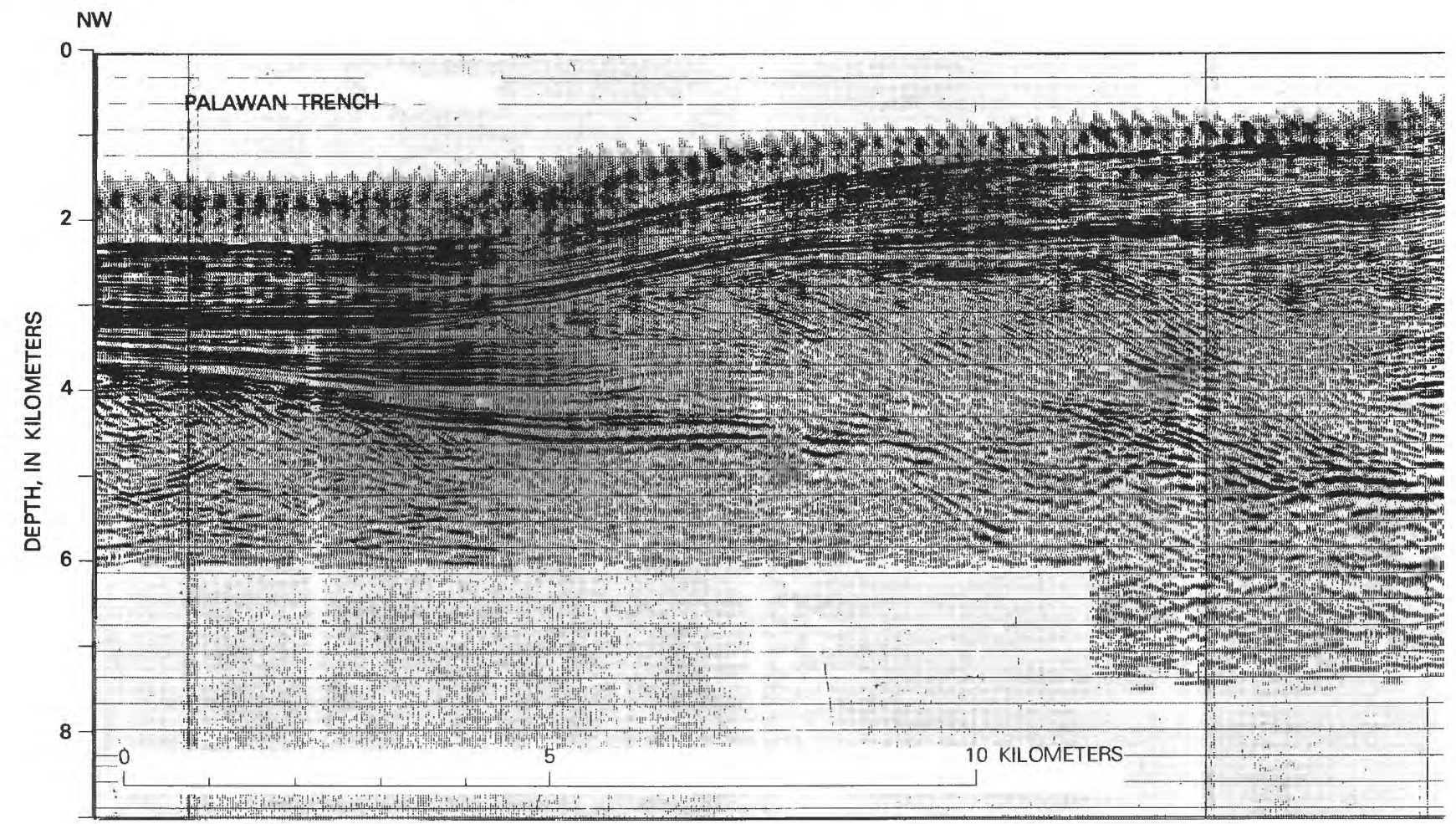

FIGURE 105.-Seismic-reflection profile across the buried Palawan Trench and melange wedge, southwest of Palawan. Undeformed Pliocene and Quaternary strata, about $1 \mathrm{~km}$ thick, are prograded across trench and wedge. Pre-Pliocene trench sediments (left) were scraped off against the underside of the toe of the melange wedge; the top sediments were scraped off first, and the basal sediments survived as coherent layers for 3 or $4 \mathrm{~km}$ from the landward edge of the trench, beyond which everything above the gently subducting oceanic plate was imbricated with moderate dips. A basin of basal to upper Miocene strata rests on the southeast half of the illustrated part of the wedge and was deposited concurrently with subduction and internal imbrication of the wedge, because the basin strata are progressively more deformed downward. Ages of strata, and presence of melange, are confirmed by drilling. Approximate location of profile shown in figure 47. The precise location of the profile was released by Chevron after completion of that map; the line trends southeast from a north west end at $8^{\circ} 45^{\prime} \mathrm{N}$. $116^{\circ} 44^{\prime} \mathrm{E}$. Migrated and depthconverted profile provided by Chevron Overseas Petroleum and Texaco Overseas Petroleum.

northern Borneo progressively from west to east. The Sulu Arc (discussed next) represents that part of this migrated arc that did not collide with Borneo. The Sulu Arc was complicated by a second polarity reversal, this one middle Neogene, back to southeastward subduction under the arc from the northwest. That part of the Sulu Arc which is now Zamboanga Peninsula of Mindanao may have collided with the Philippines while in the westward-subduction phase, but it too reverted to eastward-subduction polarity.

Where was Palawan in Eocene time? It may have been the continuation of the Sabah-Sulu-Zamboanga Arc system, the southern end of the Palawan Ridge having been attached to what is now the northeast end of Zamboanga, where the quartzose arc system of northwest Borneo, Sabah, and the Sulu Islands now terminates. When, on what structures, and with what relationship to other complexes, was Palawan brought into juxtaposition with Borneo? - the answers are not yet obvious.

The tectonic province of the Palawan Ridge, with its quartzose sediments of Asian or Borneo source, extends only as far into the Philippines as Mindoro and the northwest tip of Panay. The remainder of the Philippines to the east and north consists of materials of oceanic island-arc types, as is discussed later in this report. The north part of the Palawan Ridge broadens eastward and is separated from Panay Island only by a narrow basin, typically about 1,000 $m$ deep. The far northwest tip of Panay consists of quartzose metasediments, unlike anything farther east in the Philippines except for Zamboanga (discussion in Sulu Island Arc section); these Panay materials could belong either to the Paleozoic continental fragment or to the Tertiary melange of the Palawan Ridge. The presence of Permian limestone and older sandstone on tiny Carabao Island, $10 \mathrm{~km}$ north of this tip of Panay, was mentioned previously. The basement of the rest of western Panay consists of Oligocene or lower Miocene melange (as discussed in a subsequent section), which apparently lacks quartzose sediments, hence is unlikely to belong to the Palawan system. It may be part of the arc system of the Negros Trench.

Mindoro Island (northwest of Panay, $25 \mathrm{~km}$ north of the boundary of the maps of the Folio of the Indonesian Region) is the emergent northeast end of the Palawan Ridge. The 


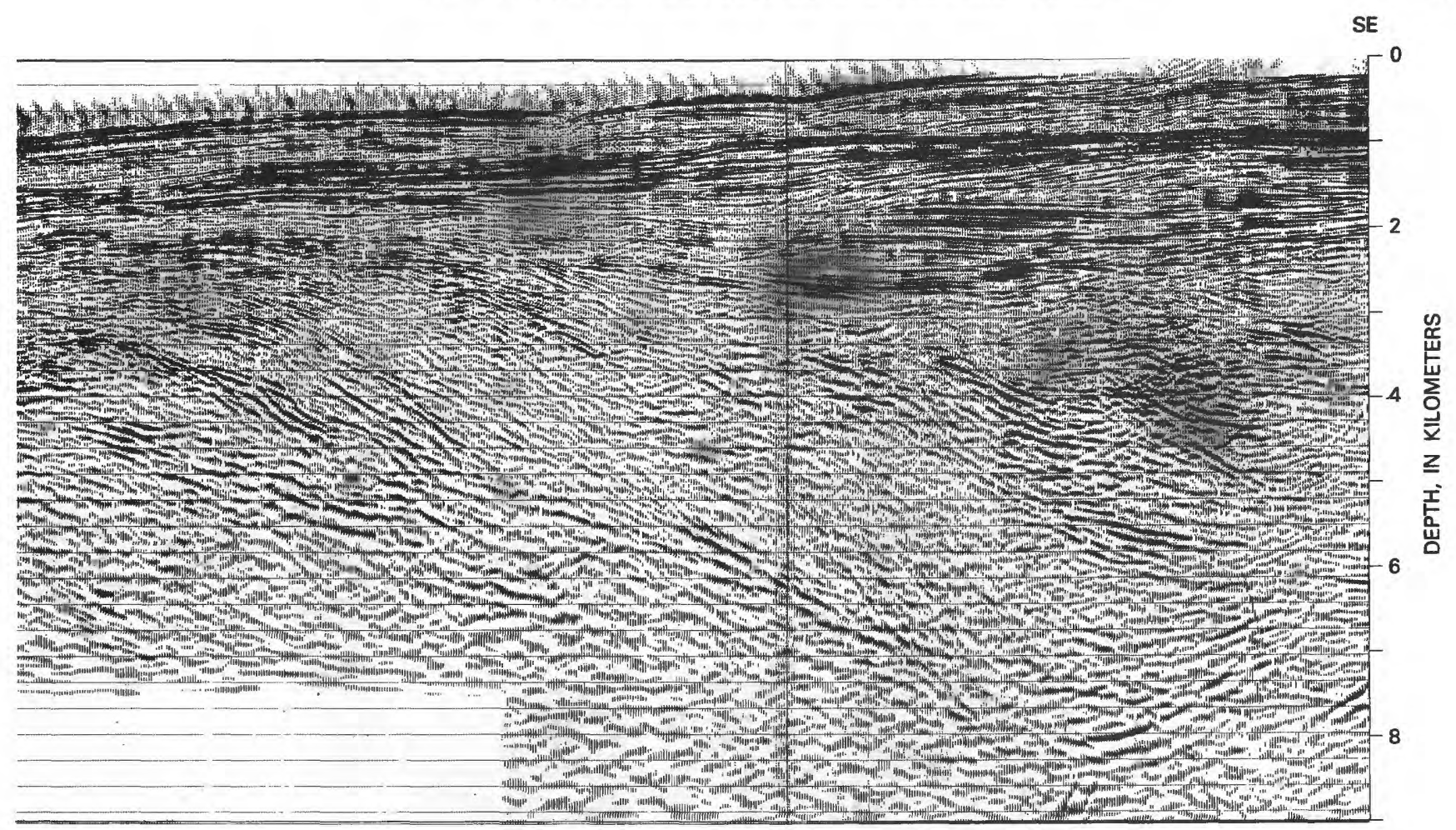

basement, melange that includes richly quartzose sediments, is the northeasternmost exposure of materials of Borneo type in the Philippines.

\section{SULU SEA}

Between the Palawan and Sulu Arcs is the Sulu Sea. This sea has an abyssal plain at a depth of 3,000-4,500 m, underlain in the shallower southwestern part by thick, reflecting sediments (figs. 103, 104) that presumably are largely turbidites derived from Borneo. The crust beneath the abyssal plain is oceanic (Murauchi and others, 1973). Eight heat-flow determinations in the deep part of the sea showed fluxes ranging between 0.6 and $2.6 \mathrm{microcal} / \mathrm{cm}^{2}$ sec, with a median value of 2.1 (Nagasaka and others, 1970; Sclater and others, 1976). These relatively high values, and the water depth, are appropriate for a middle Tertiary age of the basin (Sclater and others, 1976). An origin of the basin by spreading behind a Tertiary arc is inferred.

\section{SULU ISLAND ARC}

The recently inactivated Sulu ${ }^{13}$ Island Arc forms a straight ridge, $75-125 \mathrm{~km}$ wide at the $500-\mathrm{m}$ isobath, trending northeastward from the northeast tip of Borneo to Mindanao. The arc system faces northwestward. A trench (figs. 103, 104; also Murphy, 1975, figs. 20, 21) lies at the northwest base of the ridge. The basement of the northwest part of the ridge consists of melange, and that of the southeast part of andesite and related rocks. The paired

\footnotetext{
${ }^{13}$ The Sulu islands are not to be confused with the Sula islands, which lie east of Sulawesi.
}

melange and magmatic-arc belts come ashore as eastern Sabah in the southwest, and as Zamboanga Peninsula in the northeast.

\section{SUIUU ISL.ANDS AND RIDG ;E}

Only very meager informatin on the geology of the Sulu Islands has been published (Philippines Bureau of Mines, 1964, sheets NB-50 and 51; Taylor, 1951). Bedrock islands on the southeast part of the ridge are of volcanic rocks, and most are conical volcanoes. Some of these volcanoes are quite young in aspect and presumably are of Quaternary age, and ambiguous accounts suggest that one may still be active. Bedrock islands northwest of the volcanic islands consist of serpentinite and metamorphic rocks, overlain by upper Neogene sediments. This northwestern terrain presumably belongs to middle Tertiary melange, for this is clearly the character of the northwest part of the Sulu Ridge where broadly exposed and better studied in Mindanao and Borneo.

The submarine ridge on which the islands stand is smoothed by sedimentation, and sediments are particularly thick and conspicuous in the south (fig. 103C). An outer-arc basin appears to be present along the northwest half of the ridge (fig. $103 B, C$ ). The crustal structure of the ridge is that of an island arc (Murauchi and others, 1973).

\section{BORNEO}

The Sulu Island Arc system comes ashore in the southwest in eastern Sabah, the geology of which was described in prior sections. The magmatic arc is there represented by the rocks 
of the Semporna Peninsula: Miocene andesite, dacite, and tuff, volcaniclastic and other sediments, and large Pliocene and Pleistocene volcanoes of andesite and dacite. Middle Tertiary (and older?) subduction melange forms the bedrock of the rest of Sabah - the Darvel Bay and Dent Peninsula regions - north of the volcanic terrain.

\section{ZAMBOANGA}

Large Zamboanga Peninsula (Philippine Bureau of Mines, 1964, sheets NB-51 and NC-51; Ranneft and others, 1960; Santos-Y ñigo, 1953), extending southwestward from central Mindanao, is the emergent northeast part of the Sulu Ridge and Island-Arc system. The narrow part of the peninsula, west of $122^{\circ} 40^{\prime} \mathrm{E}$., represents the northwest half of the ridge and has a melange basement of serpentinite, gabbro, greenschist, quartzose sandstone, slate, and marble. This melange is intruded by diorite and overlain by Miocene and younger andesite and sedimentary rocks. The eastern part of the peninsula consists largely of Neogene andesite, the younger part of which stands as extinct volcanic cones.

\section{POLARITY REVERSAI, OF SILU ARC}

The dormant Sulu Island Arc faces northwestward over a trench at its northwest side, so when last active it should have been closing, not opening, the Sulu Sea. It, however, appears likely that during an earlier part of its activity the arc faced southeastward, consuming the floor of the Celebes Sea while opening the Sulu Sea behind it.

Probable melange crops out on islands near the southeast edge of the island-arc ridge, and it may have formed when the arc faced southeastward and subsequently have been intruded and covered by magmatic rocks when the arc reversed polarity and subduction began from the northwest side. In Sabah, where the island-arc ridge comes ashore, middle Tertiary melange is matched by upper Oligocene and younger calc-alkalic igneous rocks farther south, but much of the melange may be older than this, perhaps formed mostly in front of a southward-migrating arc that ramped onto Borneo. If some of the melange is older than late Oligocene, then there was a reversal in subduction to the north side of the arc, limited consumption of the southern Sulu Sea floor, and formation of the late Oligocene and Neogene volcanoes of southeastern Sabah.

\section{PHILIPPINE ISLANDS}

\section{INTRODUCTION}

The Philippine archipelago presents a jumble of the subduction complexes, magmatic rocks, and volcaniclastic sediments of different island-arc systems. The Palawan and Sulu Island Arcs trend in from the southwest and the Sangihe and Halmahera Arcs from the south, and all four continue into the main mass of the southern Philippines as important components of its geology. The Philippine Trench system along the east side of the southern Philippines formerly extended along the northern part also; however, subduction in the north recently reversed to the west side to the new Manila Trench system,and products of these two systems dominate the central and northern islands. Complex histories of convergence, rifting, strike-slip faulting, and oroclinal folding of the materials of these and other systems, and of the abandonment of old systems and initiation of new ones, are needed to account for the swirled, truncated, and superimposed patterns.

Mountainous areas are dominated by crystalline rocks, and lowlands by sediments. Facies relationships are poorly understood, and many paleontologic correlations are grossly in error, as Sheldon (1973) emphasized. Many of the crystalline highlands consist of the volcanic and intrusive correlatives of the volcaniclastic strata in the nearby lowlands, and Kintanar (1966) pointed out that much confusion in the literature has resulted from the erroneous assumption that the highland rocks are commonly the basement complexes upon which the sediments were deposited. Most of the meager published literature represents only casual reconnaissance. Hard-rock geology is particularly neglected, and the conclusions developed here are based on very inadequate data. Reconnaissance mapping by the Philippines Bureau of Mines resulted in the publication in 1964 of 1:1,000,000-scale geologic maps of the entire archipelago. Almost nothing has been published by Bureau geologists on the regional mapping aside from the maps themselves, and because many of the units designated are overlapping "wastebaskets" whose descriptions incorporate more assumption than knowledge, interpretation contains many ambiguites. Major errors in large parts of the 1:1,000,000-scale geologic maps have been demonstrated by subsequent work.

The south half of the Philippines is within the area of the tectonic map of the Indonesian region. The geology of this half is presented in the following several sections, where local interpretations regarding the tectonic significance of rock assemblages are made. The succeeding sections then attempt a broader synthesis. (See figure 109 for a general index map of the Philippines.)

\section{MINDANAO}

The regions of Mindanao are described here in order generally from west to east. The major published reference on the geology of the island is the report by Ranneft, Hopkins, Froelich, and Gwinn (1960). An illustration of the lack of knowledge of Philippine geology is given by the gross inconsistencies among the geologic maps of Zamboanga by the Philippines Bureau of Mines (1964, sheet NB-51), by Ranneft, Hopkins, Froelich, and Gwinn (1960, fig. 3), and by Santos-Y ñigo (1953, folded plate).

\section{ZAMBOANGA PENINSULA}

The peninsula of Zamboanga projects southwestward from west-central Mindanao and is the onshore continuation of the Sulu Island Arc, formed above a subduction system that dipped southeastward during at least its 
Neogene activity. The inactive trench that bounds the Sulu Ridge on the northwest continues along the northwest side of the Zamboanga Peninsula. The northwest part of the peninsula has a basement likely of melange, whereas the southeast part consists of magmaticarc volcanic and volcaniclastic rocks. The presumed melange includes chlorite and hornblende schists, metasandstone (some of it quartzose), phyllite, slate, marble, Cretaceous foraminiferal limestone, volcanic rocks, and large and small lenses of serpentinized peridotite (Ranneft and others, 1960; Santos-Yñigo, 1953; G. R. Balcé, oral commun., 1973). Lying along the east side of this melange are lower Miocene (and upper Oligocene?) volcanic rocks and volcaniclastic sediments and locally limestone and coal, which are much deformed, slightly metamorphosed, and intruded by andesite (Ranneft and others, 1960). The eastern part of the peninsula consists of upper Cenozoic lava flows, tuffs, and volcaniclastic sediments (Ranneft and others, 1960).

\section{(ENTRAL MINDANAO}

Between the base of the Zamboanga Peninsula, at about long $124^{\circ} \mathrm{E}$., and the Agusan-Davao lowlands is the broad and confusing region of central Mindanao (fig. 106). The northern part of this region has a basement that includes sheared serpentinite, altered diabase, chlorite schist, phyllite, slate, and clastic sediments (Merchant, 1951; Ranneft and others, 1960). Merchant (1951) wrote of "ashy shale, sandstone conglomerate" in one area and steeply dipping "conglomerate with serpentinite and schist cobbles" in another. These diverse materials, inferred on the tectonic map to be melange, are overlain by upper Neogene plateau-forming basalts from which rise stratovolcanoes of basalt, andesite, and dacite (Ranneft and others, 1960). Volcanic rocks of the southern part of central Mindanao include deformed and variably altered andesite, basalt, dacite, and their intrusive equivalents, of Miocene and older age (Martin, 1976; Ranneft and others, 1960); these are arc-type magmatic rocks, analogous to the younger, little-altered volcanic rocks which overlie them. Upper Neogene shallow-marine clastic and carbonate sediments also lie upon the older rocks. The Cotabato Basin of the southwest part of central Mindanao is filled by upper Oligocene to Quaternary marine and continental clastic, volcaniclastic, and carbonate strata, and has yielded no significant hydrocarbon shows to exploratory drilling (Martin, 1976).

\section{AGUSAN-DAVAO LOWLANDS}

A lowland basin curves southward through eastern Mindanao, between the Central and Pacific Cordillera, and goes to sea in the south as Davao Gulf. The basin is filled thickly by Eocene carbonates overlain unconformably by Neogene fine- to medium-grained basic volcaniclastic rocks and subordinate carbonates (Martin, 1976; Ranneft and others, 1960). The dominant dip of the sediments is eastward, toward the major faults along which the Pacific Cordillera is raised (Ranneft and others, 1960).

\section{PACIFIC: CORDILLERA}

The Pacific Cordillera forms a belt $50 \mathrm{~km}$ or so wide along the east side of Mindanao. Paleogene subduction complexes and later Tertiary magmatic arc rocks and related sediments appear to be represented.

Ophiolite is widespread on the Davao Peninsula at the south end of eastern Mindanao and includes peridotite, serpentinite, gabbro, amphibolite, diabase, basalt, manganiferous jasper, chert, and splintery red ferruginous shale (Melendres and Comsti, 1951). Limestone containing Eocene foraminifers is associated with these materials, so presumably a subduction melange of Eocene or younger age is present. Low-grade metamorphosed clastic sediments with minor Eocene limestone occur a little farther north (Merchant, 1951) and perhaps belong to the same complex. Toward the north end of the island, clastic sediments containing "tongues" and "squeezed-in *** blocks" of serpentinite (Oca and Gonzales, 1947) may also be melange.

Melange forms much of the basement of the small islands near the northeast tip of Mindanao. The complex consists of intersheared peridotite, serpentinite; metamorphic rocks, graywacke, siltstone, and chert (Wright and others, 1958). The metamorphic rocks are dominated by garnet amphibolite but include tremolite amphibolite, metadiabase, metabasalt, biotite schist, and talc schist. The sedimentary rocks are highly sheared and variably phyllonitic. "Chaotic conglomerate"-melange?-is dominated by clasts of ultramafic rocks but includes many clasts of metamorphic rocks and some of fossiliferous Eocene limestone; the melange is not older than Eocene.

In other parts of the Pacific Cordillera, Miocene and Pliocene andesite, basalt, pyroclastic and intrusive rocks, continental and marine volcaniclastic sediments, and limestone are widespread (Kintanar, 1966; Oca and Gonzales, 1947; Ranneft and others, 1960; Santos-Y ñigo and others, 1956).

\section{COTABATO TRENCH}

A trench lies along the southwest side of central Mindanao and continues southward to become the West Sangihe Trench, which bounds the northern part of the Sangihe Ridge on its west side. Subduction is directed relatively eastward, beneath Mindanao and the northern Sangihe Ridge. A Benioff zone of mantle earthquakes probably dips eastward from the Cotabato Trench to a depth of about 150 $\mathrm{km}$ ( $\mathrm{Hsu}, 1971$, fig. 36j). A thrust-mechanism earthquake of $\mathrm{Ms}=7.8$ occured in the melange wedge of this trench system in 1976, and a still greater earthquake, Ms $=8.0$, occurred there in 1918 (Gordon S. Stewart and Stephen N. Cohn, written commun., 1978). 


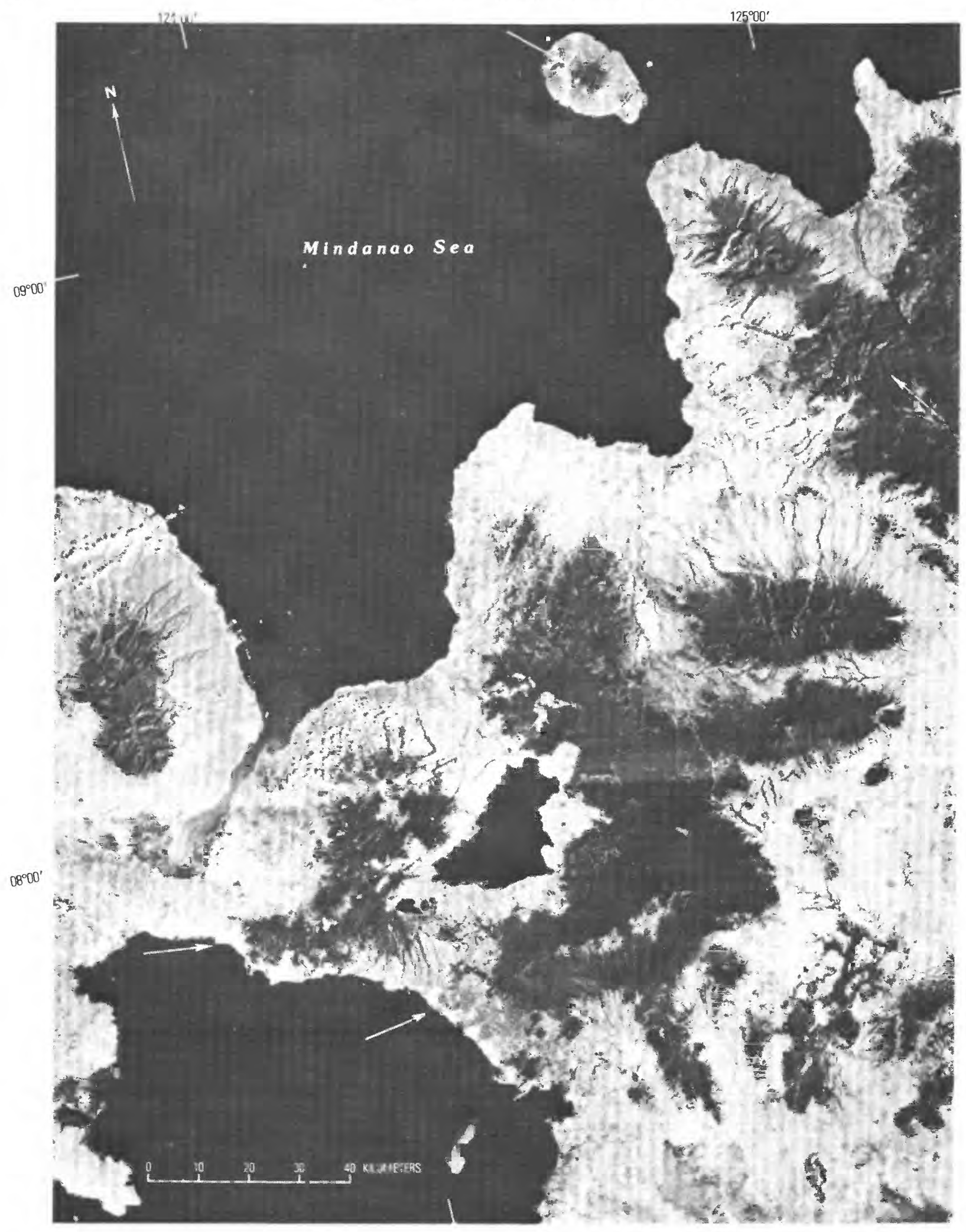

FIGURE 106.-Landsat image of the northwestern part of central Mindanao. Arrows point along vent lines of late Quaternary volcanoes. NASA-ERTS pictures 1168-01304 and -01311, January 1973. 
ICIIIE VOI.CANOES

At least six active or fuming volcanoes are present on Mindanao, and two more on adjacent islands (Neumann van Padang, 1953, p. 1-11). All are west of the Agusan-Davao lowlands. Their distribution is irregular: several arcuate lines might be drawn to pass near most of them, but no single narrow zone can enclose all of them. The volcano of Catarman Island, in the Mindanao Sea just north of central Mindanao, is of two-pyroxene andesite, hence likely formed at a relatively shallow height above a Benioff zone-too shallow for the Philippine Trench subduction system to be responsible for its magmatism. One volcano in south-central Mindanao, west of the head of Davao Gulf, is of "biotite-hornblende andesite," a designation suggesting a relatively potassic composition and hence a greater height above a causative Benioff zone. Compositional information useful in inferring depths to Benioff zones is not available for the other active volcanoes.

\section{ARC: COLLISION}

As is discussed in both previous and succeeding sections, the west-facing Halmahera Island Arc and the east-facing Sangihe Island Arc are in the process of colliding in the Molucca Sea region, south of Mindanao. The zone of collision projects northward into eastern Mindanao. The melange terrains of the Pacific Cordillera of Mindanao may belong to these collided arcs, rather than to the Philippine Trench system. The still-active west-dipping Benioff seismic zone of the Sangihe Arc appears to continue northward beneath southern Mindanao, even though collision is complete, and near-surface subduction must have ceased, at that latitude. The active and inactive but young volcanoes in the zone treinding northward through Mindanao west of the Agusan-Davao lowlands may belong in part to the Sangihe system.

\section{MINDANAO SEA}

The deeper part of the Mindanao Sea, north of central Mindanao, displays seamounts whose shapes look mostly volcanic. They are partly buried by sediments that lap onto them or are ponded between them and presumably are largely volcaniclastic (fig. $104 F$ ). The shallow eastern part of the sea, north of eastern Mindanao, has a thin veneer of little-deformed sediments, but its deeper structure is not apparent on the profile of figure $104 C$.

\section{CENTRAL, ISLANDS}

The larger of the many islands of the central part of the Philippine archipelago, north of the latitude of Mindanao but mostly within the area of the tectonic map of the Indonesian region, are described here from west to east.
MINDORO

Mindoro lies just north of the boundary of the tectonic map of the Indonesian region, northeast of Palawan and northwest of Panay. (See fig. 109 for location.) Middle and upper Tertiary carbonate and clastic sediments (Corby, 1951 , p. 84-85) overlie older rocks that include calcareous mudstone and carbonaceous sandstone intercalated with serpentinite, gabbro, and diorite (Irving, 1950), and also slate, phyllite, schist, and hornblende gneiss (Teves, 1953). The sandstones are richly quartzose (Kintanar, 1966). Jurassic ammonites and other invertebrates occur in clastic sediments (Hashimoto and Sato, 1968; Sato, 1975) which, according to G. R. Balcé (oral commun., 1973), overlie undated quartzose metaclastic rocks. Slightly metamorphosed Paleogene clastic and volcanic rocks are also present (Hashimoto and Sato, 1968).

A steeply dipping Neogene conglomerate in southeastern coastal Mindoro consists of subrounded unsorted blocks, to $50 \mathrm{~cm}$ across, of sandstone, slate, mudstone, phyllite, radiolarian chert, limestone, altered basalt, greenschist, piedmontite schist, quartzose schist, and granitic rocks (Andal, 1966; Koike and others, 1968). The limestone clasts came from Permian fusulinid-bearing reefs (Koike and others, 1968)

The fusulinid limestone, Jurassic strata, and pre-Jurassic metasedimentary rocks presumably represent more of the continental fragment exposed on northern Palawan and its neighbors. The piedmontite schist (metamorphosed abyssal sediment?) is a rock type that could be derived from polymict subduction melange, and many of the other rock types could have come from such material also.

PANAY

The western ranges of triangular Panay Island consist of a subduction complex, described by Santos-Ỹ̃igo (1949a; his Paniciuan formation and basement rocks). Much of the complex is composed of polymict melange, in which a scaly-clay matrix contains blocks, to more than $15 \mathrm{~m}$ in diameter, of variegated cherts, various schists including glaucophane schist, serpentinite, gabbro, volcanic and metavolcanic rocks, and Tertiary clastic sediments and limestone. Larger masses, coherent at outcrop scale, are dominated by ophiolite-serpentinite, diabase, pillow basalt, altered basalt, manganiferous chert. Lower Miocene limestone is steeply dipping and overthrust by serpentinite; if the thrusting is due to subduction, then the melange is at least as young as Miocene.

The northeast corner of Panay consists of basaltic and andesitic lavas, agglomerates, and volcaniclastic sediments (Capistrano and Magpantay, 1958). The oldest dated sediments, middle(?) and late Miocene, are older than some of the volcanic rocks but of unknown relationship to others.

The Iloilo Basin lies between the western ranges and the eastern volcanic terrain at the southeast corner of Panay. 
Shelf sedimentation in the late Oligocene and early Miocene was succeeded by deeper water sedimentation, with water at least $1,000 \mathrm{~m}$ deep during much of the Miocene; the basin shoaled again beginning in the middle Pliocene (Bandy, 1962; Martin, 1976). The clastic sediments were derived from andesitic sources (Ohara, 1969) and intertongue with volcanic rocks that have been widely mistaken for basement, according to Kintanar (1966). Oil shows and minor gas accumulations, but no commercial hydrocarbons, have been found by drilling down to middle Miocene reef limestones (Martin, 1976).

Tiny Carabao Island, just north of the northwest tip of Panay at lat $12^{\circ} 04^{\prime} \mathrm{N}$., long $121^{\circ} 56^{\prime} \mathrm{E}$., has an outcrop of Permian limestone and conglomerate, the latter including cobbles of fossiliferous Carboniferous rocks (Andal, 1966; G. R. Balcé, oral commun., 1973). Mica-quartz schist and marble (L. Santos-Y ñigo, as cited by Irving, 1950) are present in the northwest tip of Panay and may be part of the Paleozoic basement of the north Palawan-Mindoro continental fragment.

\section{NEGROS}

Upper(?) Cretaceous sandstone, shale, spilite, and pillow basalt crop out in the southwest part of the island (fig. 107; G.R. Balcé, oral commun., 1973). Otherwise, poorly known Negros consists mostly of andesitic volcanic rocks and their intrusive equivalents and of derivative volcaniclastic sedimentary rocks including volcanic conglomerate and sandstone, mudstone, and tuffaceous mudstone. Three or four stratovolcanoes on the island are presently active (Neumann van Padang, 1953, p. 11-15); other Quaternary and upper Neogene volcanic materials (Melendres and Barnes, 1957) occur, along with older but undated altered, crushed volcanic rocks and quartz diorite (Kinkel and others, 1955). The sedimentary rocks include such probable indicators of shallow water as coal and large foraminifers and go back at least to the middle Miocene (Melendres and Barnes, 1957).

\section{NEGROS TRENCH}

A trench lies along the southwest margin of Negros (fig. $104 F, H)$. A deep-water outer-arc basin is separated from the trench by a deep outer-arc ridge. The upper Tertiary and Quaternary volcanic rocks of southwest Negros perhaps belong to this arc system. The melange of southwest Panay may be the onshore continuation of an older part of the same arc. A Benioff zone dips moderately eastward from the trench and may also be present beneath Panay (Hsu, 1971, figs. $35 \mathrm{~h}$ and $36 \mathrm{i})$. The Negros Trench almost intersects the Sulu Trench in the profile of figure $104 \mathrm{H}$, and bathymetry suggests that the two trenches do intersect a short distance to the east of this profile, between northern Zamboanga and southeastern Negros.

\section{CEBU}

Old rocks crop out in north-central Cebu Island (fig. 107) and include tightly folded and slightly metamorphosed conglomerate, sandstone, shale, andesite, and basalt (Barnes and others, 1956; Corby, 1951; Irving, 1950), and limestone, some of which contains Eocene (Grey, 1956) and Upper Cretaceous (Corby, 1951; G. R. Balce, oral commun., 1973) foraminifers. Lower Cretaceous orbitoidal limestone forms clasts in younger conglomerate (Balce, oral commun., 1973). A quartz-porphyry intrusion in central Cebu has a K-Ar age of 59 m.y. (Gervasio, 1973). The largest copper deposit in the Philippines, that of the Atlas mine, is associated with this pluton (Bryner, 1969). Irving (1950, p. 295) stated that serpentinite is present on the island but did not describe it; as the other rock types reported are not suggestive of the presence of melange, none is indicated there on the tectonic map. Presumably the old volcanic and intrusive rocks belong to a magmatic arc, active during Cretaceous or early Paleogene time. Miocene limestone and coal-bearing clastic sediments are much deformed, whereas upper Neogene limestone, marl, and tuff are but gently dipping (Barnes and others, 1956; Corby, 1951; Sheldon, 1973).

\section{MASBATE}

The old rocks of Masbate are red and gray slate and interlaminated siltstone and graywacke, intruded by quartz diorite, gabbro, and diorite; volcanic rocks intercalated structurally or stratigraphically with middle Tertiary limestone; and undated, little-altered volcanic rocks and volcaniclastic sediments (Corby, 1951, p. 158-161; Ferguson, 1911). Relationships among these assemblages are not known. Moderately deformed upper Neogene carbonate and clastic strata overlie these rocks.

\section{BOHOL}

Serpentinite and volcanic rocks (Corby, 1951) and fossiliferous Eocene limestone (Grey, 1956) are among the components of the oldest terrain on poorly known Bohol Island and may occur in a subduction melange. The oldest rocks of north-central Bohol consist of andesite, basalt, and clastic strata (Santos-Yñigo, 1949b). Upper Neogene clastic sediments and limestone overlie these materials (Corby, 1951).

\section{CAMOTES ISLANDS}

The small Camotes Islands, between Cebu, Bohol, and Leyte, consist of Neogene sedimentary rocks according to the geological map of the Philippines Bureau of Mines (1964, sheet NC-51), and they are so shown on the tectonic map. Corby (1951) stated that "basalt and peridotite" and "highly distorted beds" are present, so the island may have a melange basement; but their (1951, pl. 7) geologic map indicates "volcanics" as the oldest rocks present.

\section{LEYTE}

The basement terrain of Leyte includes serpentinite, peridotite, metagabbro, greenstone, basalt, and chlorite schist (Irving, 1950; G. R. Balcé, oral commun., 1973), rock 


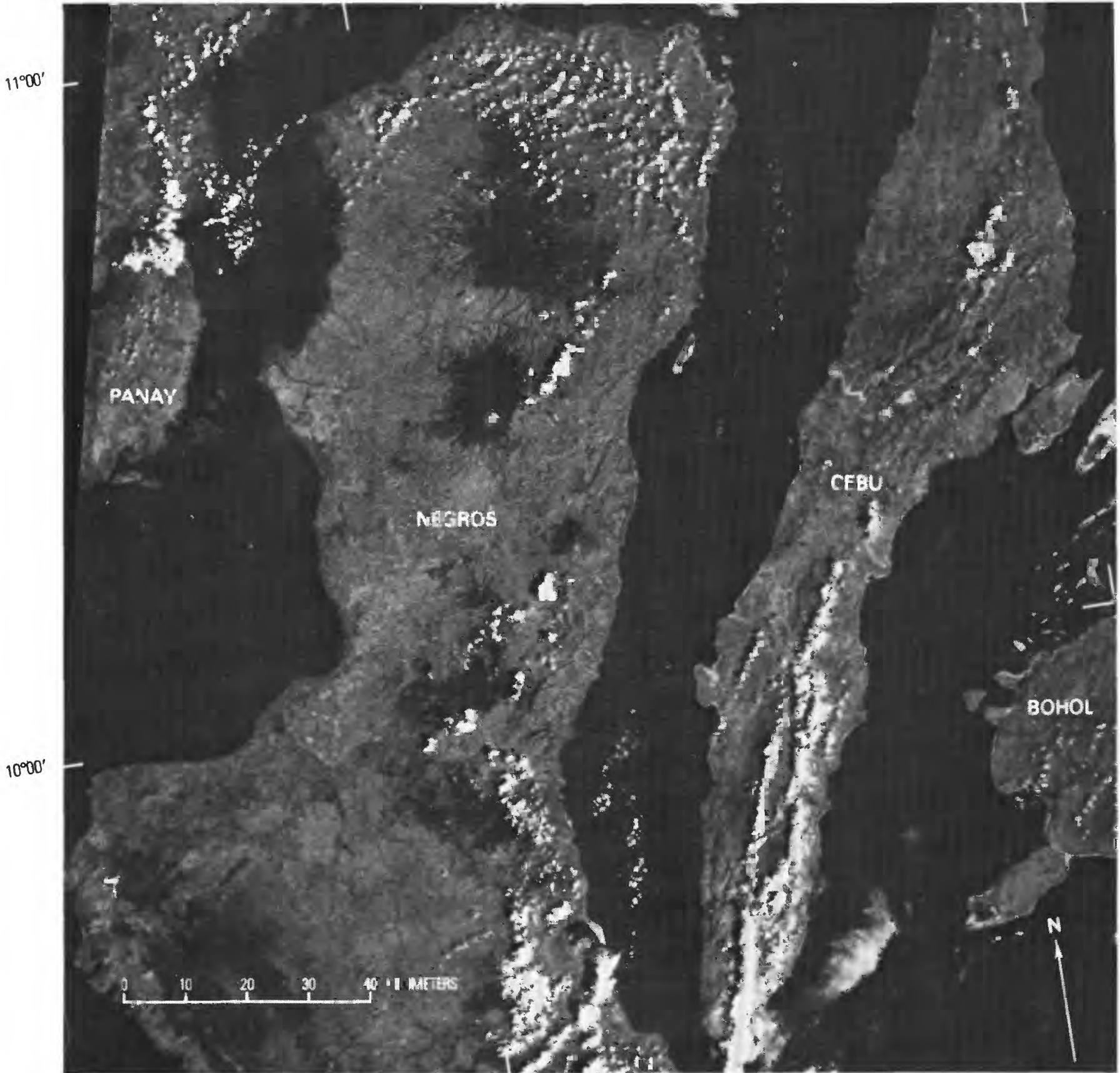

FIGr'RE 107.-Landsat image of Negros and Cebu. The highlands of southwestern Negros expose Cretaceous(?) and other old rocks; two large active stratovolcanoes dominate the northern part of the island. The old rocks of Cebu form the strongly ridged north-central terrain, and the island consists otherwise of Neogene strata. Picture NASA-ERTS 1187-01361, January 1973.

types suggestive of the presence of subduction melange. Otherwise, the island consists of Neogene volcanic rocks and volcaniclastic and carbonate sediments (fig. 108; Corby, 1951). Several stratovolcanoes are in a solfatara stage (Neumann van Padang, 1953). The active strike-slip Philippine fault zone across Leyte is discussed subsequently.

\section{SAMAR}

The easternmost of the central islands, Samar, consists of Neogene sedimentary rocks and a basement that likely is a melange terrain. Rock types in this basement complex include lower Upper Cretaceous abyssal mudstone enclosing 

$125^{\circ} 00^{\prime}$

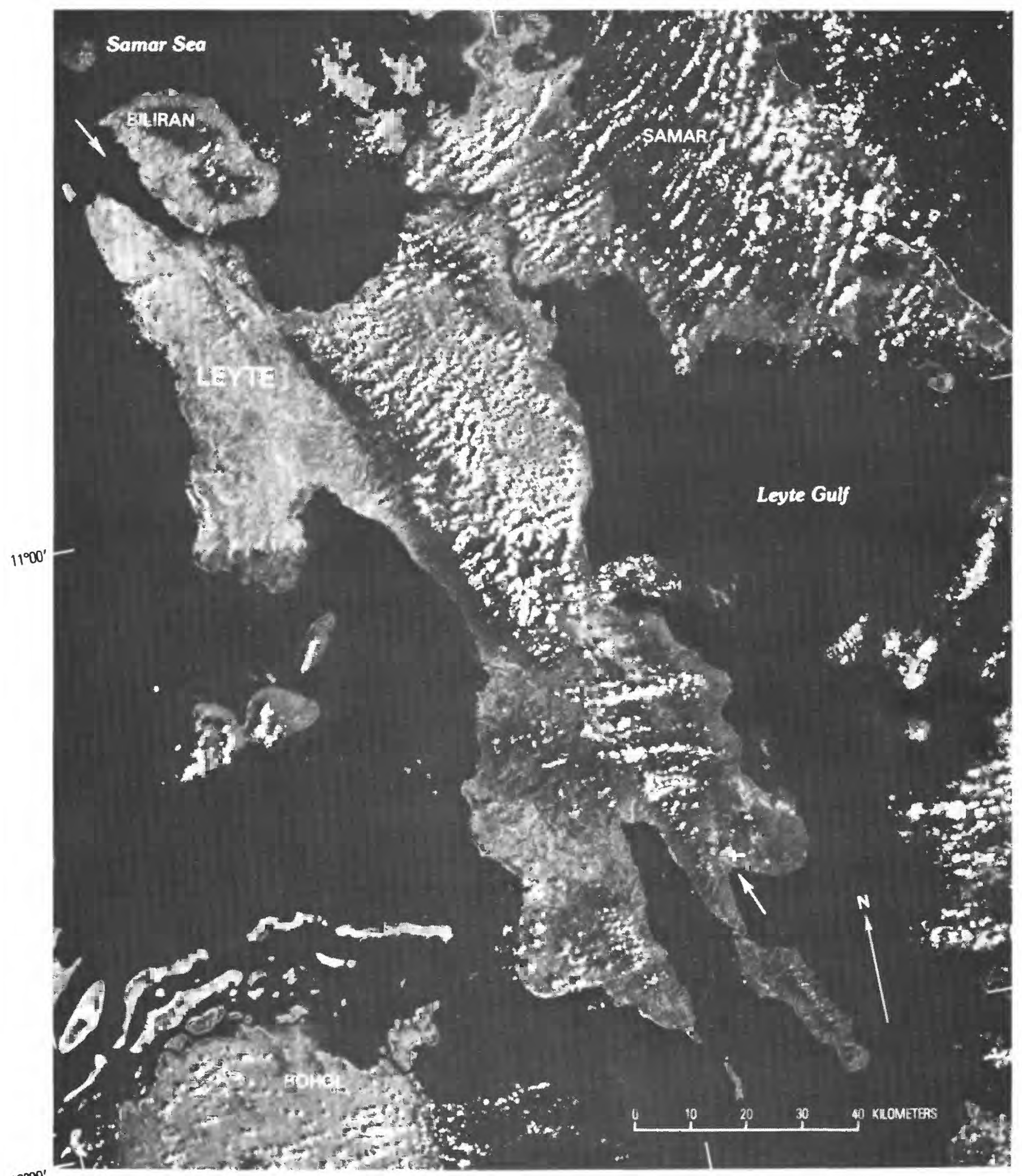


manganese nodules, pelagic red and gray limestone. jasper, abundant spilite, gabbro, serpentinite, greenschist, and garnet schist (Irving, 1950; G. R. Balcé, oral commun., 1973).

\section{ACIIVE VOLCANOES ANI) BENIOFF ZONES}

The very young or active volcanoes of Leyte are in a northwest line, on strike with the volcanic chain of southeastern Luzon and parallel to the Philippine Trench to the east. The rocks of this volcanic chain are identified by Neumann van Padang (1953) as andesite, hornblende andesite, hypersthene-augite andesite, and basalt. Formation above the Benioff zone dipping westward from the Philippine Trench is inferred.

A fuming stratovolcano is present on southeastern Negros, and three more active or fuming volcanoes are in northeastern Negros (Neumann van Padang, 1953). The rocks are andesites and basalts. These volcanoes are much too far west to likely belong to the subduction system of the Philippine Trench, and at least the volcano of southeastern Negros may be associated instead with the Negros Trench system.

\section{PHILIPPINE TRENC:H}

The narrow Philippine (Mindanao) Trench reaches depths of $10,000 \mathrm{~m}$. It is almost that deep where crossed by the profile of figure $104 \mathrm{D}$ northeast of Mindanao, and it is 6,000-8,000 $\mathrm{m}$ deep between Mindanao and Halmahera (figs. $96 B, 98 C, 135$ ). No sediments are visible in the trench in the profiles, in which, however, the apparent sharp-V bottom may be only an illusion produced by the recording of side echoes from the trench walls.

The Philippine Trench appears to mark the trace of an active Benioff zone of mantle earthquakes in the sector between lat $5^{\circ}$ and $14^{\circ} \mathrm{N}$. (pl. 1; Fitch and Molnar, 1970; Hamilton, 1974b; Hatherton and Dickinson, 1969). Earthquakes shallower than $50 \mathrm{~km}$ are concentrated on the landward slope of the trench, and those between 50 and 200 $\mathrm{km}$ are centered beneath the east coasts of Mindanao and Leyte. If a Benioff zone is associated with the Philippine Trench from $5^{\circ} \mathrm{N}$., near the south end of Mindanao, south to the end of the bathymetric trench at $1^{\circ} \mathrm{N}$. off Halmahera, it does not extend very deep. In that latitude sector, deep mantle earthquakes, as emphasized in a prior section, belong to two Benioff zones, one dipping east and the other west

FIGURE 108 (facing page).- Landsat image of Leyte and neighboring islands. The Philippine fault zone (Allen, 1962) is marked by arrows. The fault zone is almost superimposed on the belt of modern volcanoes, which occur on Biliran and the islet northwest of it, on Leyte opposite the south end of Biliran, along the medial highlands of Leyte, and at the ends of the two peninsulas on opposite sides of the fault zone in southeastern Leyte. NASA-ERTS pictures 1168-1302 and 1186-1300 and -1302. from an intersection in the western Molucca Sea, 200-400 $\mathrm{km}$ to the west of the Philippine Trench (fig. 99).

\section{CIRVATIRE OF THE ISLANDS} MANILA TRENCII

The Philippines are bounded on the west side by the active Manila Trench, from about lat $13^{\circ}$ to $16^{\circ} \mathrm{N}$. (Hayes and Ludwig, 1967; Ludwig and others, 1967). The trench is about $5,000 \mathrm{~m}$ deep, and it is separated from Luzon by an outer-arc ridge and a sediment-filled outer-arc basin. Volcanic rocks of appropriate compositions-tholeiitic in the west, calc-alkalic in the middle, and high-potassium in the east (Ragland and others, 1976)-have been erupted above the Benioff zone of mantle earthquakes that dips eastward from the trench (Hsu, 1971, fig. 35g). Murphy (1973) reasoned from the geology of Luzon and Taiwan that the Manila Trench represents a late Neogene reversal in the subduction polarity of the northern Philippines. Before the reversal, Luzon and Taiwan were bounded on the east by an active trench that was a continuous part of the Philippine (Mindanao)-Ryukyu system. This is discussed in the subsequent section on the relationship of the Philippines to Taiwan.

\section{DOLBIE OROCILINE}

The present activity of the Philippine Trench dies out northward along the east side of the Philippines in the sector in which the Manila Trench appears on the west side. The southern Philippines are moving relatively eastward over the Philippine subduction system as the northern islands are moving relatively westward over the Manila system. Some structure must serve as a left-lateral transform to accommodate the resulting stretching and disruption within the islands, yet no fault crosses the archipelago as a simple transform. Two arcs, however, are displayed by the structural trends of the eastern and northern islands and may be paired oroclines that fulfill the transform function by bending rather than faulting (figure 109). The trends swing from northward in Mindanao through northwestward in Leyte, Masbate, and Samar to west-northwestward in southern Luzon, where they swing abruptly back to northward again. Rutland and Walter (1974) also recognized this relationship.

\section{STRIKE-SI.IP FAIILIING;}

An active left-lateral strike-slip fault zone (figs. 108, 110) was found by Allen (1962) to trend northwestward across Leyte (within the area of pl. 1) and Masbate (largely north of the map area) and was named by him the Philippine fault zone. Total offset is unknown, but stream terraces and young gravels are offset in a consistent left-lateral sense. On strike to the northwest, a fault across the Tayabos Isthmus of southeastern Luzon, between Lamon Bay and Ragay Gulf 
FIGURE 109.- Selected tectonic elements of the Philippine-Taiwan region. The broad $S$ defined by the Pacific cordilleran system (dark,shading) of the Philippines may be a double orocline. The northern Philippines are moving relatively westward over the Manila Trench, and the southern islands are moving relatively eastward over the Philippine Trench; the double orocline transforms the motion between them. The Pacific cordilleran system is related to the subduction system of the Philippine Trench, which is now extinct off the northern islands. The lithosphere plate overriding the South China Sea at the Manila Trench subduction system collided with the Asian continental shelf in Pliocene time, forming Taiwan; see text.

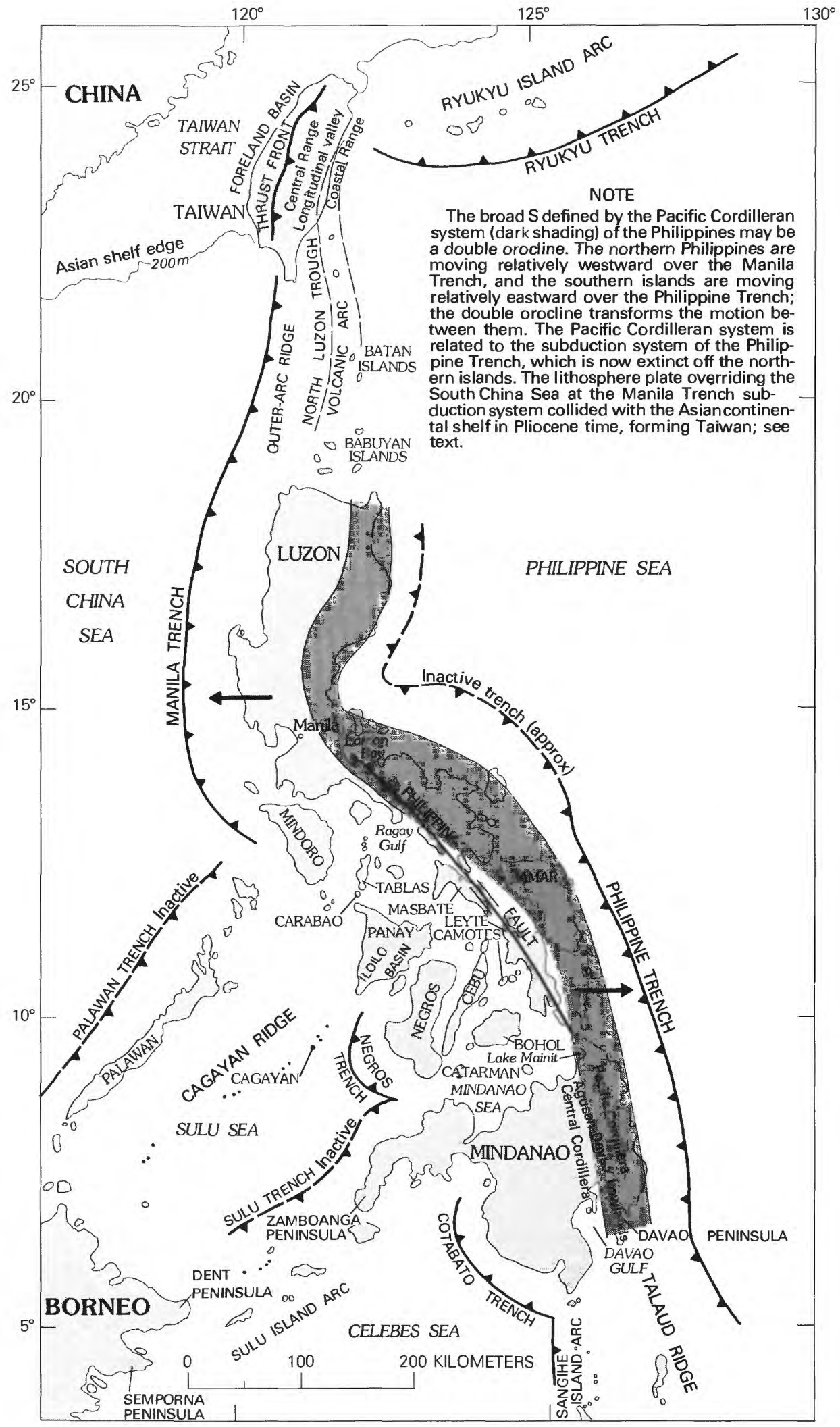




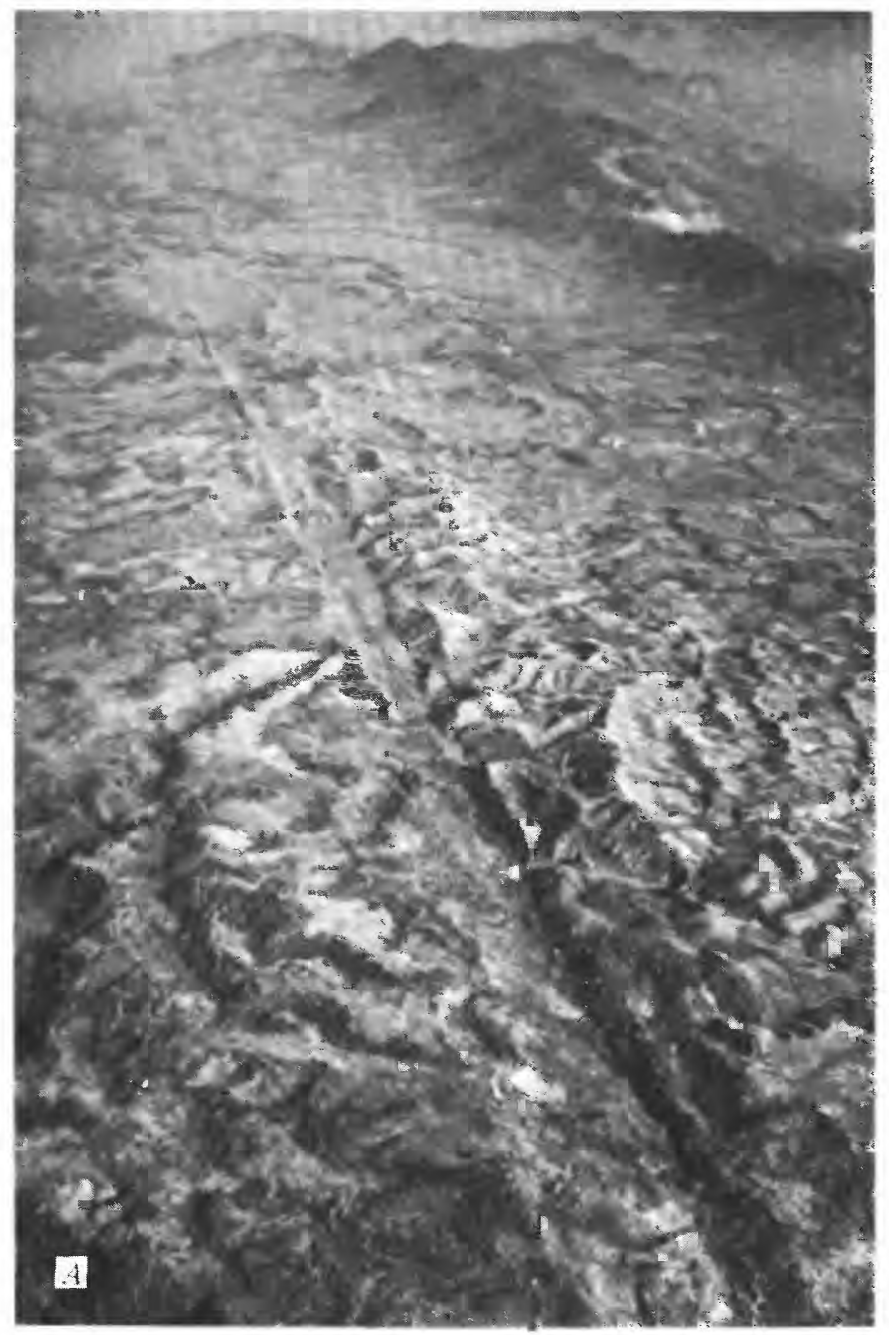

Figcre 110.-Aerial photographs of the Philippine fault zone in northwestern Leyte by Clarence R. Allen (Allen, 1962, figs. 3 and 5; published by permission). The zone of parallel left-lateral strike-slip faults trends northwestward and produces a narrow topographic trough in $A$ (view northward) and $B$ (view west ward) and benches and troughs along a mountain front in $C$ (view southeastward).

(fig. 109), slipped 2-3 m left laterally during an earthquake in 1973 (Morante and Allen, 1973). Allen (1962) inferred that the fault continued farther northwest into the main mass of northern Luzon, although Rutland (1967) disputed this projection. Large earthquakes are common along the fault system (Rowlett and Kelleher, 1976).

Allen suggested that the fault also continues southeastward from Leyte, crossing Mindanao along or near the east side of the Agusan-Davao lowlands. Ranneft, Hopkins, Froelich, and Gwinn (1960) mapped faults with appropriate trends in that sector. In September 1973, I studied vertical aerial photographs, in the files of the Philippines Bureau of Mines in Manila, along this trend. I recognized no strike-slip faulting and regard as unlikely the presence of the supposed structure in Mindanao. At the
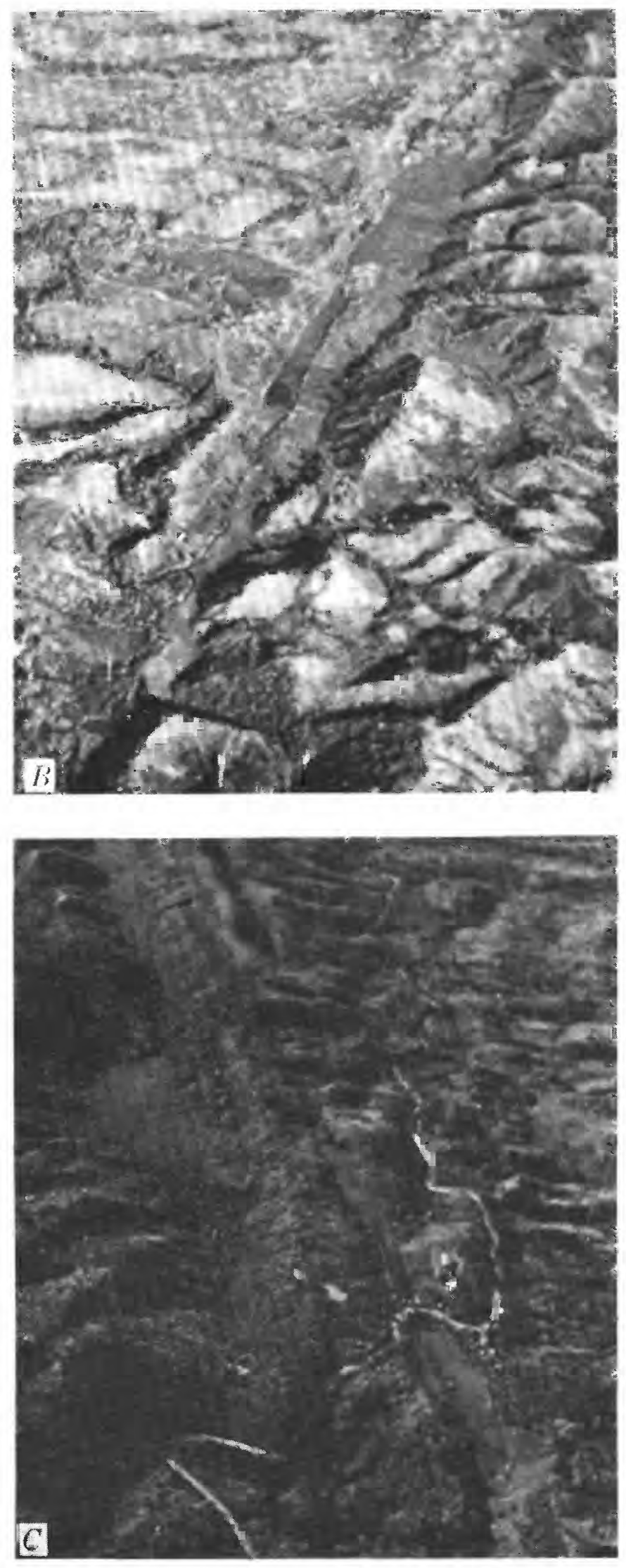
north end of the island, a rather straight normal fault, west side up, trends west of north and dams Lake Mainit on the west; the fault scarp dies out to both north and south, and no fault line is visible on strike in either direction. The straightness of the west coast of northeastern Mindanao, north of lat $9^{\circ} \mathrm{N}$., might be taken as evidence for strike-slip faulting, but no apparent fault comes ashore in the flat ground on strike to the south-southeast, nor is there any apparent through fault farther south-southeast. A major strike-slip fault should produce a continuous system of rift valleys, and lateral offsets of drainage features (as do the strike-slip faults of Sulawesi and of Sumatra, described elsewhere in this report); neither feature was seen in Mindanao. Short faults, as much as $20 \mathrm{~km}$ long, are present, with appropriate trend in the general region through which the fault has been postulated to pass; these neither connect nor offset drainage lines.

The strike-slip faulting in the central Philippines might represent shearing within the double orocline, geometrically analogous to bedding-plane slip within an anticline (fig. 109).

\section{THE PHILIPPINES AS A COMPOSITE OF ISLAND ARCS}

The Philippine Islands consist of rocks formed in many different island arcs of various ages and orientations, now confusingly juxtaposed and superposed. The dominant components of the islands are melanges formed in subduction zones, and calc-alkalic igneous rocks and volcaniclastic sediments formed above Benioff zones dipping into the mantle from those subduction zones. The most obviously recognizable of the various arcs have been described separately in prior sections. This section attempts to identify other arcs within the Philippines and to outline the history that follows from the analysis. Much of the interpretation is summarized in figure 111.

The most obvious of the distinct arcs now amalgamated in the Philippines are the Palawan and Sulu Arcs, which trend northeastward into the central and southern Philippines, respectively. These arcs are isolated by small ocean basins along much of their length and display a typical arc zonation that can be traced into the main Philippines. Each arc has a dormant trench on its northwest side, a northwest belt of melange, a medial outer-arc basin, and a southeastern volcanic arc.

The Palawan Arc can be identified within the main Philippine lslands by the continuation of its enclosed Paleozoic continental fragment into Mindoro and by the presence in extreme northwestern Panay of richly quartzose sediments such as characterize Palawan.The Palawan system has been inactive since Miocene time-its trench is buried by undeformed Pliocene and Quaternary strata, its outer-arc basin is full of sediments, and its volcanic island arc now consists of seamounts and atolls. Its exposed melanges include sediments at least as young as Paleocene and are overlain by strata at least as old as Miocene. The Palawan
Arc formed by the subduction of the South China Sea during the Paleogene and Miocene.

The Sulu Arc formed in late Cenozoic time. Its melanges as exposed in northeast Borneo are of Miocene age, and subduction must have continued into the Quaternary because volcanoes in the magmatic arc are little eroded. The arc, with its quartzose sediments from Borneo, comes ashore on Mindanao as Zamboanga Peninsula, and now ends at the southwest side of the Mindanao sea. The Sulu Arc most recently formed by migration relatively northwestward over the floor of the Sulu Sea. The arc is now dormant and has neither a Benioff zone nor active volcanoes.

Negros and most of Panay belong to the arc whose active manifestations are earthquakes, the Negros Trench, and the volcanoes of Negros Island. The bathymetric trench curves from westward to northward and projects onto the continental shelf just west of the north-trending melange belt of western Panay, which belt is assumed accordingly to belong to the arc. The Iloilo Basin of medial Panay may be the outer-arc basin of the system, and the volcanic rocks of eastern Panay may belong to the magmatic arc. Melange, basin, and volcanic belt of Panay probably all date primarily from the Miocene. Activity on the northern part of the arc may have ended with collision with the Palawan Arc. In the southeast, the Negros Trench intersects the Sulu Trench, indicating another arc-arc collision, the suture of which trends toward the Mindanao Sea. The intersection of Sulu and Negros Arcs may represent the oroclinal bending of a previously continuous arc, the north part of which folded southward to collide in $\mathrm{Y}$ fashion with the south part.

The complexities in Mindanao east of the remnants of the Sulu-Zamboanga A.rc system were discussed in part in the prior section on the island arcs of the Molucca Sea region. The east-facing Sangihe Arc and west-facing Halmahera Arc are in the process of colliding in the southern Molucca Sea region, and the collision is complete in the north, where the products come ashore in southern Mindanao on both sides of Davao Gulf. The Sangihe Arc likely had a short life span, having originated only in early Miocene time. The West Sangihe-Cotabato Trench has formed on the west side of the northern part of the collision aggregate and now extends from the northern part of the Sangihe Arc along the southwest side of Mindanao. The active volcanoes of southwest Mindanao may belong in part to this new subduction system and in part to magmatism continuing from the Sangihe subduction system; surface subduction has ceased on the northern part of the latter, but seismicity from its Benioff zone continues.

The melange wedge of the medial Talaud Ridge of the Molucca Sea comes ashore in southeastern Mindanao, where the exposed melange contains materials at least as old as Eocene. It is tempting to project the Halmahera Arc northward along the Pacific Cordillera of eastern Mindanao, but it is not yet possible to discriminate between products of Philippine and Halmahera systems there. Active volcanoes characterize the Philippine Trench subduction 


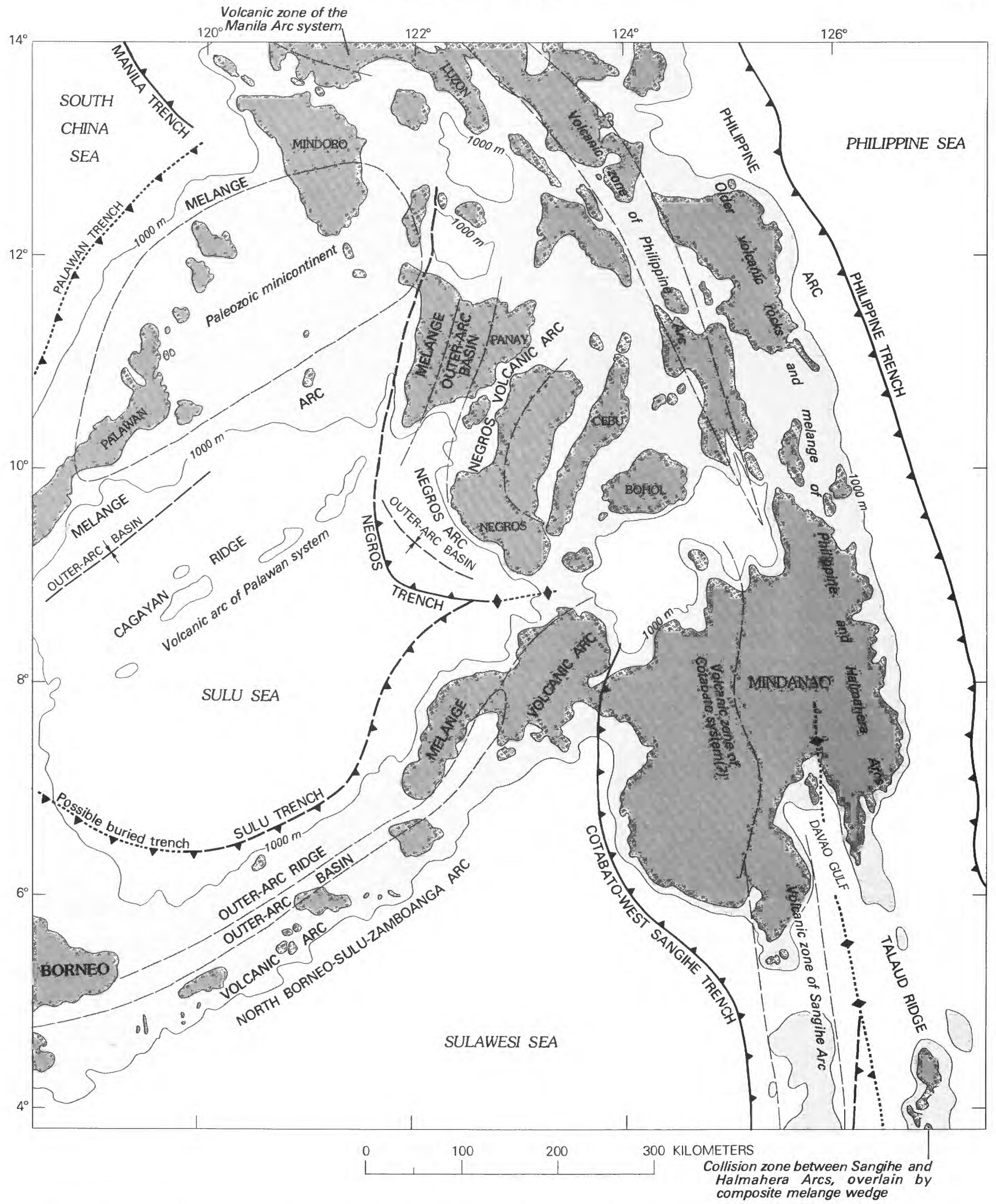

FIGURE i 11.-Island-arc elements in the central and southern Philippines. Trenches are shown by heavy lines with barbs on overriding plates: solid where subduction is now active, dashed where inactive, and dotted where trench is inactive and buried by sediments. Dotted line with barbs on both sides indicates zone of collision between opposed arcs. 
system in Leyte and southeastern Luzon but not yet in Mindanao, so the Philippine system may be quite young in the latitudes of Mindanao. Similarly, it is not yet possible to say how far north the remnants of the fossil Sangihe arc system extend in the Philippines. Relationships between these components must be complex.

These arcs whose products are now jumbled together in the Philippines formed by migrations in various directions relative to the surrounding ocean basins, and their shapes and relative positions have changed greatly. The bending of the main Philippine trend into a double orocline in response to the oppositely directed subduction of the Manila and Philippine Trenches has been discussed. The Sulu Arc (at least in its late stage) and the Palawan Arc migrated relatively northwestward. The Palawan Arc ends obliquely against a collision zone with the Panay-Negros Arc; the termination may record in part a middle Tertiary removal of the northeastward continuation of the Palawan Arc by rifting or strike-slip faulting. The Sulu-Zamboanga Arc now ends at the Mindanao Sea, perhaps in a closed orocline doubling back into the Negros-Panay Arc; Cebu and Bohol also may once have been within this arc. The Philippine Trench system has been printed across the amalgamated mass of various other arcs.

These interpretations give clues as to the past configurations of the island arcs now jumbled in the Philippines. Only when many more geologic data have come from the islands will it become possible to construct palinspastic maps incorporating some degree of reliability.

\section{RELATIONSHIP TO TAIWAN}

A west-directed subduction system trends northward from Luzon to Taiwan (fig. 109) and is marked by an east-dipping Benioff zone (Hsu, 1971, figs. 3, 35). In the intervening oceanic area are present, from west to east, trench, outer-arc ridge, outer-arc basin (North Luzon Trough), and volcanic island arc (Babuyan and Batan island groups). The melange wedge comes ashore in the longitudinal valley of eastern Taiwan as a belt of polymict subduction melange of late Pliocene age, and the outer-arc basin comes ashore in the eastern Coastal Range of easternmost Taiwan as a section of Miocene andesitic volcanic and plutonic rocks, overlain by Pliocene turbidites and conglomerate, tectonically above the melange (Biq, 1971, 1972a, 1974; Chai, 1972; Karig, 1973a; Murphy, 1973). The Taiwan geology records the collision of a west-facing island arc with China in Pliocene time, and that island arc probably had reversed its polarity from a previous east-directed orientation that existed when the arc belonged to the Philippine Trench system (Karig, 1973a; Murphy, 1973). The collision produced the Central Range highlands in medial Taiwan, west-directed thrust faulting of Neogene shelf strata of the western foothills, and a foreland basin in the western coastal plain and the Taiwan Strait (Biq, 1972b; Chai, 1972). Large, destructive earthquakes are still common in the collision zone (Rowlett and Kelleher, 1976).

\section{AUSTRALIA}

The western part of Australia is an old Precambrian craton, and the eastern part represents primarily a Paleozoic orogenic system. Recent summaries of Australian geology include the stratigraphic book by Brown, Campbell, and Crook (1968), the tectonic map by Plumb, Doutch, and Rickard (1972), the paleogeographic synthesis by Veevers and Evans (1975), and the Western Australian summary by the Western Australia Geological Survey (1975). Geologic maps have been published recently for Western Australia (Western Australia Geological Survey, 1974), Northern Territory (D'Addario, Wilford, and others, 1976), Queensland (Whitaker and Grimes, 1975), and all of Australia (Palfreyman and others, 1976). A gravity map (Bouguer anomalies onshore, free-air anomalies offshore) was published by the Australia Bureau of Mineral Resources, Geology and Geophysics (1976a; see also Anfiloff and others, 1976). Regional aspects of the gravity field were discussed by Dooley (1976), Mathur (1976), Symonds and Willcox (1976), and Wellman (1976a, b).

The present discussion is concerned primarily with that part of Australia that lies north of lat $16^{\circ} \mathrm{S}$., within the area of the tectonic map of the Indonesian region (pl. 1), but all of mainland Australia is shown in figure 112.

\section{NORTHWEST AUSTRALIA}

Northern Australia west of the Gulf of Carpentaria-the northern parts of Western Australia and Northern Territory - has been a generally cratonic region for about 1,800 m.y. The exposed rocks are mostly Precambrian strata, 800-1,800 m.y. old, deformed only gently over broad areas. These strata are preserved in a number of basins, between which older Precambrian basement rocks are exposed. In three major basins middle Proterozoic strata are widely preserved - the Kimberley, Victoria River, and McArthur Basins, in order from west to east (fig. 112). Upper Proterozoic strata fill the Arafura Basin in the northeast. Phanerozoic rocks, also mostly sedimentary, veneer parts of the Precambrian terrain of the continentalinterior and occur as fillings of thicker basins near the edge of the continent. Paleozoic strata thickly fill the Bonaparte Gulf Basin in the northwest and cover the shallow Daly River Basin in the southeastern part of the tectonic-map area.

\section{PREC:AMBRIAN TIME SCAALE}

No internationally accepted time scale and terminology exists for the Precambrian. Thus, the Archean is about 3,000 m.y. and older in South Africa (South Africa Geological Survey, 1970), 2,400 m.y. and older in Canada (Stockwell and others, 1970), and 1,950 m.y. and older in the Ukraine (Semenenko and others, 1968). All the rest of the Precambrian is called Proterozoic in Canada, where its lower, middle, and upper units are separated at about 1,600 and 850 m.y. and are given era names (Stockwell and others, 1970). In the Ukraine, the most nearly equivalent terms are lower 
Proterozoic, upper Proterozoic, and Riphean, which are separated by time boundaries near 1,700 and 1,150 m.y. (Semenenko and others, 1968). Post-Archean rocks in South Africa are assigned to a large array of local systems. Present usage within the U. S. Geological Survey is of a purely temporal classification that drops names altogether and uses letter designations: Precambrian W, older than 2,500 m.y.; $\mathrm{X}, 2,500-1,600$; Y, 1,600-800; and $\mathrm{Z}$, younger than $800 \mathrm{~m}$.y.

These and other schemes of subdivision of the Precambrian have been devised to separate major stratigraphic and tectonic units within specific regions. Major time units are typically defined as ending with regionally important orogeny or magmatism. It is, however, now obvious that no worldwide Precambrian orogenic events occurred to permit the development of an internationally acceptable time scale based on orogenic periodicity.

Age determinations of Precambrian metamorphic and granitic rocks in Australia cluster within seven intervals (Compston and Arriens, 1968): 3,050-2,900 m.y., 2,750-2, $600,1,900-1,700,1,550-1,500,1,400-1,350,1,100-950$, and 700-650 m.y. Of two of the time scales that have evolved from this array, one is now in use by the Australia Bureau of Mineral Resources, Geology and Geophysics (BMR: Dun and others, 1966), the other by the Geological Survey of Western Australia (GSWA: Horwitz, 1967; A. F. Trendall, in Western Australia Geological Survey, 1975, p. 25-32). Both scales use the basic terms Archean and Lower, Middle, and Upper Proterozoic (or period or system names equivalent to the Proterozoic subdivisions) but differ on the ages of the boundaries. The BMR uses boundaries at 2,300, 1,800 , and 1,400 m.y., respectively, wheras the GSWA places the boundaries at $2,440,1,960$, and 900 m.y. Of the many period or system names used in the recent Australian literature, probably the most common are Nullaginian=Lower Proterozoic, Carpentarian=Middle Proterozoic of BMR, and Adelaidean=Upper Proterozoic of BMR (Brown and others, 1968).

The Precambrian rocks of northern Australia, within the area of the tectonic map of the Indonesian region, span at least 2,000 m.y. of Precambrian time. In order to depict these rocks with maximum clarity, I have used a classification system whose boundaries separate the major lithotectonic assemblages within this area. I have used the terms Archean and early, middle, and late ${ }^{13}$ Proterozoic for these assemblages because these names are easily understood, even though ambiguous internationally. I have avoided an emphasis on local system names, as these are recognized by few geologists outside Australia. In the classification that I have chosen, Archean rocks are older than 2,500 m.y.; lower Proterozoic rocks are between 2,500 and 1,800 m.y. old; middle Proterozoic rocks, 1,800-1,000; and upper Proterozoic rocks are younger than 1,000 m.y. The Proterozoic subdivisions are compromises between the

\footnotetext{
13 I do not capitalize these relative-age terms.
}

BMR and GSWA classifications, and the Archean-Proterozoic boundary is a bit older than that in either of these classifications because it here serves best to divide rocks near that boundary in age.

\section{PRECAMBRIAN BASEMENT ROCKS}

Varied metasedimentary, metavolcanic, and intrusive rocks form complexly deformed terrains, exposed between the basins of younger Precambrian sedimentary rocks and in uplifts within those basins. The crystalline basement rocks of northwestern Australia are mostly of early Proterozoic age. It is not yet obvious how the various areas of basement rocks are related in broad patterns, and no attempt is made here to assign the basement rocks to tectonic settings.

Archean granitic and high-grade metamorphic rocks crop out in a small area as the complex of Rum Jungle, near lat $13^{\circ} \mathrm{S}$., long $131^{\circ} \mathrm{E}$. The isotopic metamorphic age of these rocks is about 2,550 m.y. (Richards, Berry, and others, 1966). High-grade metamorphic rocks in several other small areas probably include Archean assemblages (Pontifex and Mendum, 1972; Sweet and others, 1974; Walpole and others, 1968). These areas are too small to show in figure 112. Large terrains of Archean rocks do crop out in southwest Australia.

The basement rocks exposed in the Halls Creek Mobile Zone bounding the Kimberley Basin on the southeast are low- to high-grade metasedimentary and metavolcanic rocks, intruded by mafic sheets and by granites and silicic porphyries and overlain by silicic volcanic rocks (Dow and Gemuts, 1969; Plumb and Veevers, 1971; Thom, 1975). The age of metamorphism and of the granitic rocks is about 1,800-2,100 m.y., early Proterozoic (Gellatly, 1971; Thom, 1975). A single $\mathrm{Sr}-\mathrm{R}$ b determination on a pegmatite suggests a possible older event at 2,700 m.y. (Gellatly, 1971), but Plumb and Gemuts (1976) regarded all rocks as younger than 2,200 m.y.

The triangular Pine Creek Geosyncline of exposed lower Proterozoic rocks north of the Daly River Basin and west of the McArthur Basin consists of much-deformed sedimentary rocks (Sweet, 1977; Sweet and others, 1974; Walpole and others, 1968; fig. 112). Deformation, initial thicknesses of sediments, and the water depths in which the sediments were deposited are all greatest in a northwest-trending mobile belt in the southwest half of the terrain. The northeast part of this mobile belt and the platform facies to which it gives way northeastward consist mostly of arkose, quartzose graywacke, siltstone, chert, and dolomite; the sands were, transported mostly in southwesterly directions. The southwest part of the mobile belt consists mostly of turbiditic graywacke and siltstone (fig. 113 $\mathrm{A}$ ) deposited largely in eastward directions. The western assemblage is overlain by higher lower Proterozoic platform sandstone. Slight metamorphism, and locally intense shearing, accompanied the tight folding (fig. $113 B$ ) of the trough sediments about 
northwest-trending axes; the platform sediments to the northeast were deformed more openly. Mapping (for example, Malone, 1962) indicates that structural continuity was generally preserved across the deformed terrain, and shows no ultramafic or other exotic rocks from which the presence of a suture might be inferred. The sedimentary rocks are intercalated with silicic volcanic rocks in some areas and are cut and contact-metamorphosed by a number of stocks and small batholiths which are about 1,800 m.y. old. Quartz monzonite (fig. 113C) is the dominant granitic rock type, true granite is common, and granodiorite and quartz diorite are uncommon.

The terrain west of the Victoria River Basin, oversimplified as lower Proterozoic on plate 1, consists of several rock assemblages (C. M. Morgan, 1972; Pontifex and Mendum, 1972; Sweet, 1977; Sweet and others, 1974; Walpole and others, 1968). These are Archean metasedimentary rocks; the western platform facies, moderately deformed, of the lower Proterozoic Pine Creek Geosyncline (discussed in the preceding paragraph); a batholith of quartz monzonite, granodiorite, and quartz diorite, variably fresh, altered, and metamorphosed, at least as old as early middle Proterozoic; and a thick sequence of middle(?) Proterozoic sandstone, siltstone, and grit.

The granitic and metamorphic basement beneath the eastern strata of the McArthur Basin is exposed in small areas at the west side of the northern part of the Gulf of Carpentaria. The metamorphic rocks include granulites-cordierite gneisses with or without garnet or hypersthene (Wilson, 1969). Age determinations by K-Ar and $\mathrm{Rb}-\mathrm{Sr}$ methods suggest that the granitic rocks in the terrain are about 1,800 m.y. old (McDougall and others, 1965 ), and the basement is assigned accordingly to the lower Proterozoic on the tectonic map.

\section{KIMBERLEY BASIN}

The exposed rocks of the Kimberley basin, or Kimberley Block, are mostly little deformed middle and high lower Proterozoic clastic sediments (Gellatly and Sofoulis, 1969; Plumb and Gemuts, 1976; Plumb and Veevers, 1971; Thom, 1975; Williams and Sofoulis, 1971). The total section is on the order of 5,000 m thick and is dominated by thick-bedded quartz sandstone; feldspathic, micaceous, and ferruginous sandstones, quartz-pebble conglomerate, siltstone, and shale are also important. Tholeiitic basalt flows with an aggregate thickness of 300-600 m occur in the middle of the section, and sills of tholeiitic diabase are common in the sandstones lower in the section. The igneous rocks are dated isotopically as about $1,800 \mathrm{~m}$.y. old (Thom, 1975). The rocks are warped into broad domes and open basins. Dips are mostly less than $10^{\circ}$, and the axes of folds are almost horizontal. Normal faults of small displacement occur in some areas. The intensity of deformation of the strata is moderately severe near the southeast margin of the Kimberley Basin, where open folds with moderate dips, and many faults, are present, and in the continuation of this belt

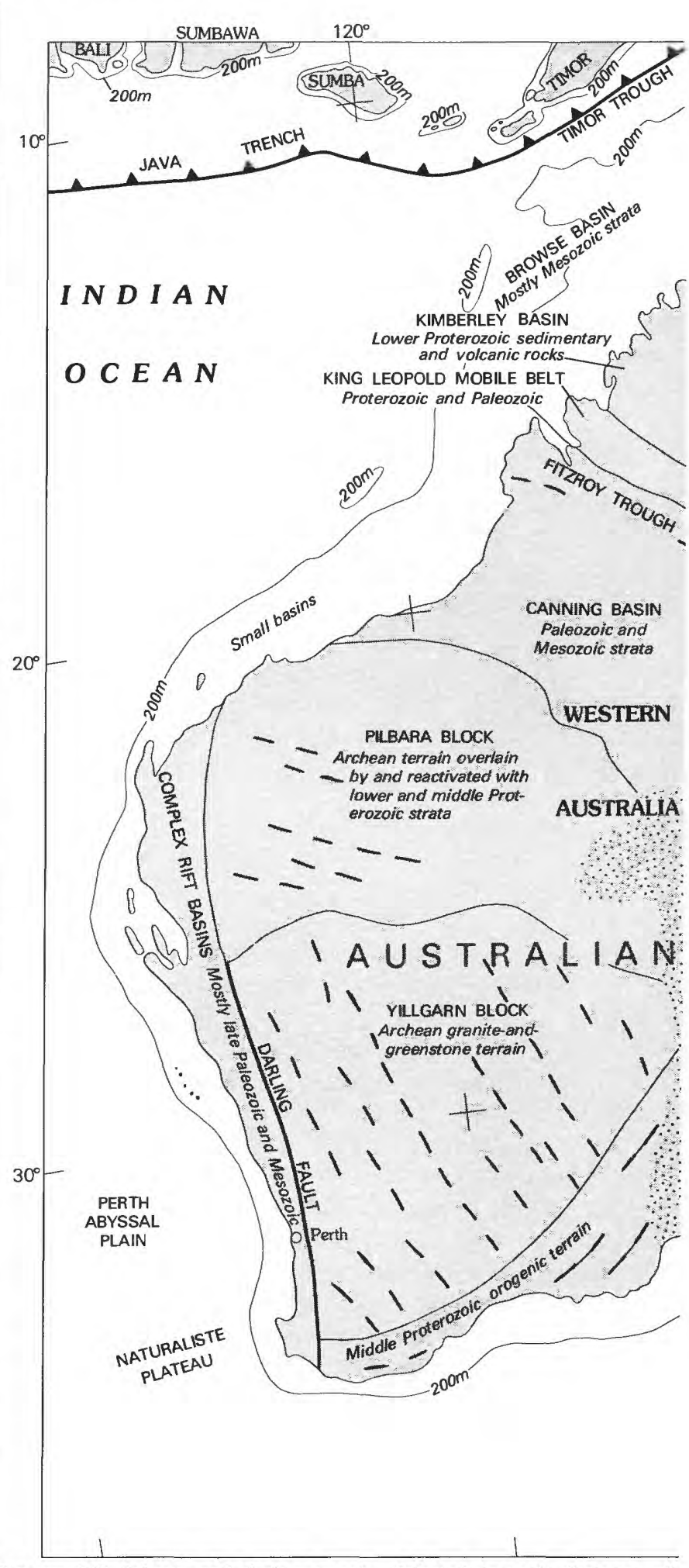

Figure 112 (above and facing page).-Selected tectonic features of Australia. The complex Tasman orogenic zone records the welding to the continent of various terrains by subduction-related accretionary and magmatic processes; the ages of granitic rocks are emphasized here. Structural trends indicated by short heavy lines. Areas covered completely by Permian and younger strata, generally thin and little deformed, are stippled. Modified freely from Palfreyman and others (1976) and other sources. 


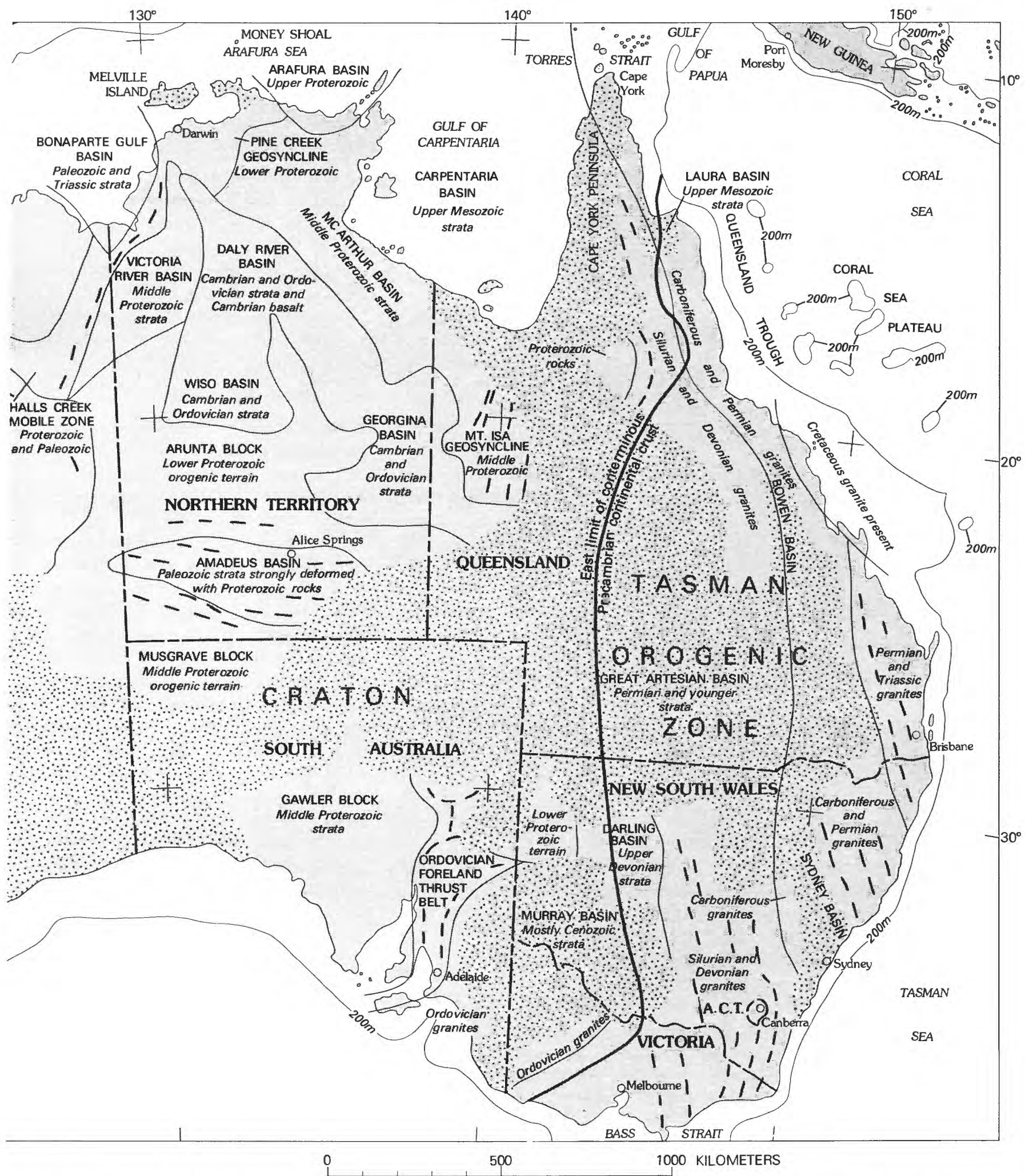

to the north (Sweet and others, 1974). Basement rocks appear locally beneath the basin strata or are faulted against them, along the southeast edge of the basin, and deformation and metamorphism probably overlapped the deposition of the older part of the basin sections.
Crossbedding and facies changes show that the general source of the sands was to the northwest (Gellatly and Sofoulis, 1969; Williams and Sofoulis, 1971). Only a narrow continental shelf now lies in that direction. 

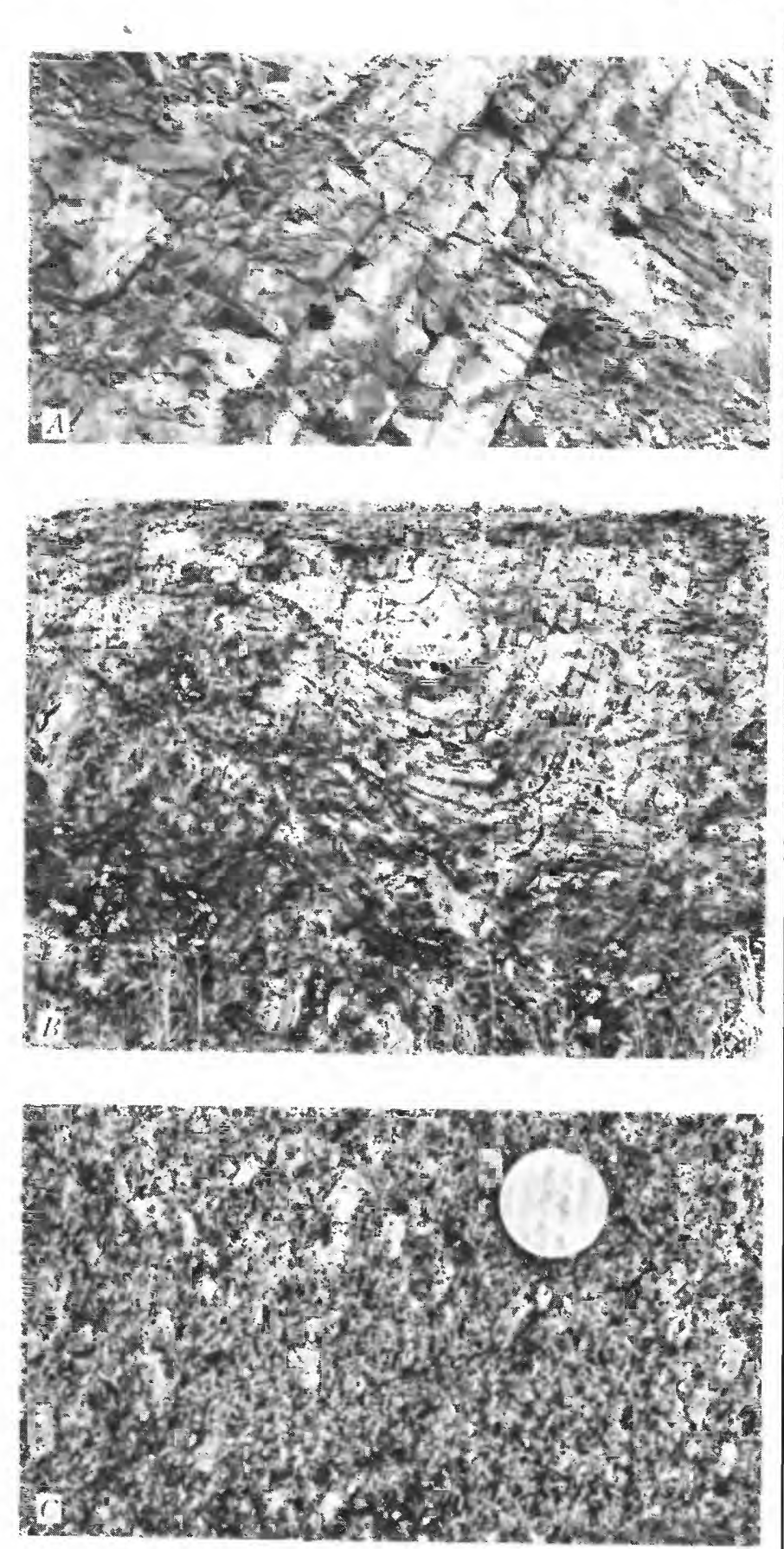

Figl're 113.- Rocks of the lower Proterozoic Pine Creek Geosyncline, south of Darwin. Northern Territory, Australia. A, Quartzose graywacke. Unstable minerals altered to matrix material, but metamorphism and cleavage not otherwise apparent. About $7 \mathrm{~m}$ of section is pictured. Noltenios Formation of Malone (1962), location about $13^{\circ} 11^{\prime}$ S., $131^{\circ} 06^{\circ}$ E. B, Folded siltstone and graywacke. A crumpled anticline lies to the left of the obvious syncline. Acacia Gap Tongue of Malone (1962). Cut is about $4 \mathrm{~m}$ high. Location about $13^{\circ} 02^{\prime}$ S., $131^{\circ} 07^{\circ}$ E. C. Porphyritic quartz monzonite, unsheared and little altered, of early Proterozoic age. The coin is $28 \mathrm{~mm}$ in diameter. Location about $13^{\circ} 32^{\prime} \mathrm{S}$., $131^{\circ} 17^{\prime} \mathrm{E}$.
The Kimberley Basin is bounded on the south by the King Leopold Mobile Belt (fig. 112), in which the middle Proterozoic strata are folded tightly into structures that trend west-northwestward and are overturned northeastward and in which the underlying lower Proterozoic plutonic basement is widely exposed (Gellatly and Sofoulits, 1975). Paleozoic strata are folded into the belt.

IIC:TORIA RIVER BASIN

The cratonic strata preserved in the broad Victoria River Basin are shallow-marine sandstone, siltstone, shale, dolomite, and minor limestone (C. M. Morgan, 1972; Pontifex and Mendum, 1972; Sweet, 1977; Sweet and others, 1974; Walpole and others, 1968). Maximum thickness is perhaps $1,500 \mathrm{~m}$, and the rocks are little deformed. The older strata, at least, are of middle Proterozoic age.

\section{MA ARIHITR BASIN}

The little-deformed middle Proterozoic shallow-water sediments of the McArthur Basin cover a broad region west of the Gulf of Carpentaria (Brown and others, 1968, p. 11-14; McDougall and others, 1965; Walpole and others, 1968). The lower part of the section is dominated by quartzose and feldspathic sandstones, and the upper part by finer grained clastic rocks and dolomite. The strata had a maximum initial thickness of perhaps $8,000 \mathrm{~m}$ in a trough trending northward near long $135^{\circ} \mathrm{E}$; they are considerably thinner, in both initial and present thickness, to the west of this and very much thinner to the east (Brown and others, 1968). Clastic sediments were derived from both the east and the west. Age determinations on glauconite indicate deposition to have been largely within the interval from 1,200 to 1,600 m.y. ago (McDougall and others, 1965). Silicic and intermediate volcanic and pyroclastic rocks occur sporadically at the base of the section. Intermediate and basic volcanic rocks are interbedded with the clastic rocks of the lower half of the section. Diabase sills cut strata high in the section and are probably at least 1,280 m.y. old (McDougall and others, 1965). Gentle folding has produced dips generally flatter than $10^{\circ}$.

\section{AR.AFI RA BASIN}

The upper Proterozoic strata of the Arafura Basin crop out in a broad arc of rocks dipping gently northward beneath the Arafura Sea. The beds are terrigenous shelf sediments - ripple-marked quartz sandstone, and greenish and purplish shale (Brown and others, 1968, p. 34). The $\mathrm{Rb}-\mathrm{Sr}$ and $\mathrm{K}-\mathrm{Ar}$ age of glauconite from sandstone high in the section is about 800 m.y. (McDougall and others, 1965). The Arafura Basin strata are about $3,000 \mathrm{~m}$ thick at the north edge of their outcrop arc, continue to thicken northward offshore (Plumb and others, 1972), and lie with marked unconformity upon the gently folded rocks of the McArthur Basin. 


\section{PROBLEMS OF PRECAMBRIAN GEOLOGY}

Northwestern Australia has been a craton for about 1,800 million years. Precambrian sedimentary rocks and subordinate basalts younger than 1,800 m.y. are little deformed over large regions. These strata are preserved in broad structural basins, and it is not yet clear what relationship, if any, these basins have to the basins in which the strata accumulated nor are the regional settings of sedimentation yet apparent.

The extent to which plate tectonics controlled Australian deformation and magmatism within Precambrian time is still uncertain. Paleomagnetic orientations show motion of Australia relative to both other continents and to the Earth's magnetic field during Precambrian time (Facer, 1974) but not relative motion between Precambrian cratons within Austrália (McElhinny and McWilliams, 1977). A scheme such as that outlined by Burke and Dewey (1973a) and Sutton and Watson (1974) appears very plausible. Until about 2,500 or $2,700 \mathrm{~m} . y$. ago, the lithosphere was thin, hot, and mobile, and there were no large cratons or internally stable continental masses. From then until 2,000 or 1,800 m.y. ago, the lithospere became progressively more rigid, and in an increasing number of regions motions of coherent plates dominated deformation. Since 2,000 or 1,800 m.y. ago, plate tectonics has operated everywhere, though in a manner changing with time. Davidson (1973) interpreted central Australian geology in terms of collision of two continents about 1,100 m.y. ago. But many investigators still dissent, and Rutland (1973) and McElhinny and McWilliams (1977) argued that plate tectonics did not affect Australia until Phanerozoic time.

\section{LOWER CAMBRIAN(?) PLATEAU BASALI}

Basalt as thick as $1,000 \mathrm{~m}$ occurs between Precambrian and Middle Cambrian strata over a broad region in north Australia. Within the area of the tectonic map of the Indonesian region, the basalt occurs primarily at the base of the Paleozoic section of the Daly River Basin, lying with slight unconformity beneath Middle Cambrian and younger sedimentary rocks (Pontifex and Mendum, 1972; Walpole and others, 1968). Most of the basalt is silica-saturated tholeiite, similar to the tholeiite of the Columbia River Plateau of the northwestern United States, and it occurs mostly as subaerial lava flows; olivine basalt is much subordinate (Bultitude, 1976; Dunn and Brown, 1969). The rocks are presumed to be of Early Cambrian age but could be wholly or partly very late Precambrian. Unfossiliferous quartzose sandstone, chert, conglomerate, and limestone are intercalated with the basalt (Sweet and others, 1974).

Continental tholeiites appear in many regions - as, in the Triassic and Jurassic of the eastern United States and Morocco, the Jurassic and Early Cretaceous of the Gondwana continents, and the very early Tertiary of the lands around Baffin Bay and the Arctic and subarctic Atlantic - to accompany tensional disruption of continents as they begin to rift apart. No application for such a concept to the Australian Cambrian tholeiite is obvious.

\section{PALEOZOIC: AND TRIASSIC: STRATA}

In northwestern Australia within the area of the tectonic map of the Indonesian region, a thin lower Paleozoic section is preserved in the broad Daly River Basin, and a thicker section, spanning the Paleozoic and extending into the Lower Triassic, is present in the Bonaparte Gulf Basin. The latter basin is mostly offshore and is described in the section on the continental shelf. Another marine Paleozoic basin, the Canning River Basin, trends westward to the west coast just south of the area of plate 1 (see fig. 112), and middle Paleozoic sedimentary rocks there show that water then deepened westward (Veevers, 1971b). Paleozoic strata became decreasingly marine farther south in Western Australia, presumably because India and Australia were then parts of a single continent. Thinning of the crust-premonitory rifting of India from Australia-may have begun about the beginning of Devonian time, producing a seaway extending southward between them from the Tethyan ocean to the north. (See Warris, 1973.)

The Kimberley Basin, or Kimberley Block, of little-deformed Proterozoic strata is bounded on the south by the west-northwest-trending King Leopold Mobile Belt and Fitzroy Trough (fig. 112). The latter contains a thick Paleozoic section deformed by west-trending compressional folds. Smith (1968) proposed that the echelon folds formed in response to right-lateral shear, directed west-northwestward, in the basement, and Rixon (1978) showed with model studies that this likely is correct.

Middle Cambrian to Lower Ordovician platform strata in the broad Daly River Basin are exposed poorly in a region of low relief (Pontiflex and Mendum, 1972; Walpole and others, 1968). The section is only a few hundred meters thick. The basal formation is of cherty limestone, with subordinate intercalations of sandstone and siltstone. The rest of the section consists of variably silicified limestone, dolomite, marl, ferruginous sandstone, and siltstone.

\section{PALEOZOIC: DEFORMATION}

The pattern of deformation in the Halls Creek mobile zone bounding the Kimberley Basin on the southeast suggests that major left-lateral strike-slip faulting, trending north-northeast, was there superimposed in early Paleozoic time on the products of Precambrian events (Plumb and Gemuts, 1976). Tensional thinning of the continental crust may have been the cause of formation of the Bonaparte Gulf Basin in middle Paleozoic time, as noted previously. A very different type of infracontinental plate deformation is shown in central Australia, south of the area of the tectonic map, 
where the entire continental crust and upper mantle appear to have been involved in upthrusts and downwarps at about the beginning of Cambrian time, and again during the Late Devonian or Early Carboniferous (Duff and Langworthy, 1974; Forman and Shaw, 1973).

\section{CRETACEOUS STRATA}

Thin subhorizontal, clastic Cretaceous strata of shallow-marine and continental origin are widespread in the northern part of the Northern Territory (Skwarko, 1966, 1973a). The larger preserved areas of these strata are shown on plate 1 , but numerous small, irregular patches are omitted. The rocks carry pelecypod faunas similar to those of Cretaceous rocks in India, South Africa, South America, and New Zealand.

\section{NORTHWEST AUSTRALIAN SHELF}

Much drilling and geophysical work has been done on the continental shelf of northwest Australia in recent years. This section of this report treats that part of the northwestern Australian shelf west of the meridian of $132^{\circ} \mathrm{E}$. The shelf formed as a result of the rifting apart of Australia and India within late Mesozoic time. During the earlier Mesozoic, tensional thinning of the crust produced basins that were filled by clastic sediments derived primarily from the Indian side. Upper Cretaceous and Cenozoic strata, prograded across older complexes, form the shelf assemblage.

\section{BROWSE BASIN}

The deeply filled Browse Basin trends northeastward in medial position along the shelf, offshore from the Kimberley Block (Allen and others, 1978; Halse and Hayes, 1971; Kaye, 1972; Martison and others, 1972; Powell, 1976; Williams and others, 1973). At the southeast side of the basin, Upper Carboniferous and Permian marine and nonmarine clastic strata lap onto Precambrian rocks, and Jurassic and younger strata lap further onto the basement. Jurassic and Cretaceous clastic strata thicken greatly northwest ward into the basin and are on the order of 5,000 m thick in the axial region, where the age of still older strata is unknown. The Jurassic and Cretaceous thin again on the northwest side of the basin, where thick Upper Triassic rocks have been reached beneath them by drilling. The axis of maximum Cretaceous sedimentation is offset northwestward from that of the Jurassic. Tertiary strata are dominantly carbonates and form a northwest-thickening wedge, deposited across the basin as the entire shelf subsided about a hinge near the present coastline.

\section{BONAPARTE GULF BASIN}

The U-shaped, northwest-plunging Bonaparte Gulf Basin lies mostly on the continental shelf, although its southeast end is exposed onshore. The onshore basin fill is divided into three main sequences by minor unconformities. The lower sequence consists of about $1,000 \mathrm{~m}$ of Middle Cambrian to Lower Ordovician strata, mostly quartzose sandstone but including glauconitic sandstone, shale, and dolomite (Kaulback and Veevers, 1969; Plumb and Veevers, 1971). The middle sequence consists of Upper Devonian and Carboniferous strata, 3,500 m thick in outcrop in the south (Veevers, 1969a; Veevers and Roberts, 1968). Paralic conglomerate and quartz sandstone in the southeast give way upward to carbonates and subordinate clastics and give way northwestward to shallow-marine quartz sandstone and lagoonal and reef limestones, beyond which in turn are deeper water shale and siltstone. The upper sequence consists of about $2,000 \mathrm{~m}$ of Upper Carboniferous, Permian, and Lower Triassic paralic and continental clastic strata (Veevers and Roberts, 1968). The lower and middle Paleozoic sequences are gently folded and broken by numerous faults in the southwest part of the basin, but elsewhere very gentle dips characterize all three sequences (Plumb and Veevers, 1971).

The Bonaparte Gulf Basin continues far offshore to the northwest, the Permian and Mesozoic part of its fill thickening greatly (Edgerley and Crist, 1974; Kraus and Laws, 1974; Laws and Kraus, 1974). Extensive pre-Upper Devonian evaporites have risen as salt domes into higher strata in the southwest part of the offshore basin. Following Carboniferous faulting and major uplift of the flanking Kimberley Blocks, $6,000 \mathrm{~m}$ of Upper Carboniferous and Permian deltaic sandstone, shale, and minor limestone were deposited in the basin. The depositional axis of these strata is more or less coincident with the structural axis of the basin, and the sands came primarily from the nearby Kimberley and Sturt Blocks. Major regression of the sea during the Early Permian, correlative with the deposition of glacial strata, was followed by transgression, another regression in the Late Permian, renewed transgression in the Early Triassic, and long-continuing regression during the rest of the Triassic and the Early and Middle Jurassic. Lower Triassic shale and siltstone are overlain by marine Lower and Middle Triassic marine sandstone and shale giving way upward to fluvial sandstone, and above these are Upper Triassic and Lower Jurassic redbeds.

The Bonaparte Gulf Basin presumably formed in response to southwest-northeast extension of the continent, most active during Devonian and Carboniferous time (Laws and Kraus, 1974; Warris, 1973). This direction of extension was later inactivated, and beginning in the Middle Jurassic, extension was oriented northwest-southeast and the modern continental margin began to develop. 
NORTHWESTERN SOURCE OF PRE-CRETACEOUS SEDIMENT

Many wells have been drilled into pre-Cretaceous strata along the sector of the shelf that trends northeast between long $116^{\circ}$ and $125^{\circ}$ E. The Upper Permian, Triassic, and Jurassic strata encountered are clastic sedimentary rocks, derived primarily from sources to the west, northwest, or north - the direction of the present deep ocean (Kaye, 1972). On the northwest rim of the Browse Basin, Lower, Middle, and Upper Jurassic rocks are in nearshore marine facies and were derived from the west. Two wells on the Australian shelf edge south of western Timor encountered Triassic deltaic sediments that had been transported from the northwest or north. Near the center of the shelf at about lat $17^{\circ} \mathrm{S}$., Upper Permian sands were derived from the west or northwest. A number of wells across the shelf in the sector between about lat $19^{\circ}$ and $20^{\circ} \mathrm{S}$. show thick Upper Triassic clastics, which are fluvial and deltaic in the northwest and marine in the southeast. Throughout Late Carboniferous through Early Jurassic time, the open ocean lay somewhere to the northeast, not to the northwest (Warris, 1973). Not until the Late Cretaceous did deep-water sediments prevail and form a wedge prograding northwestward toward the present shelf edge (Allen and others, 1978; Kaye, 1972; Martison and others, 1972).

\section{RIFIING HISTORY OF THE SHELF}

A history of continental rifting is obvious in these relationships (Allen and others, 1978; Kaye, 1972; Powell, 1976; Veevers, 1974; Warris, 1973) and in the Late Jurassic and Early Cretaceous age of the oceanic crust along the western margin of Australia. (See discussion in section on Indian Ocean.) A departed continent, which I presume as India, was continuous with Australia through early Mesozoic time. Tensional thinning of what is now the Australian shelf probably began in the Carboniferous and was severe during the Late Triassic, when very thick sediments were deposited in a marine trough; but the landmass to the northwest continued to shed detritus into the thinning zone in the Early Jurassic. By the Late Jurassic, detritus was coming from an uplift along the present shelf edge, but this uplift subsided during Cretaceous time; by the Late Cretaceous the modern shelf pattern of sediments prograding across the shelf had been established.

\section{BASIN NORTH OF MELVILLE ISLAND}

The northeast-trending basin centered at about lat $9^{\circ} 30^{\prime}$ S., $130^{\circ} 30^{\circ} \mathrm{E}$., is filled primarily by Cretaceous clastic sedimentary rocks, which change from nonmarine in the thin southwestern section to increasingly marine toward the basin (Balke and others, 1973). An oil-exploration well, drilled on Money Shoals about $200 \mathrm{~km}$ northeast of Melville Island on the southeast flank of the basin, penetrated thin Jurassic sedimentary rocks beneath the Cretaceous, then thin Silurian clastic strata, and reached Precambrian(?) quartzite. Seismic-reflection profiles from this region were presented by Jongsma (1974).

\section{TIMOR TROUGH}

The Australian continental-shelf strata inflect downward at the shelf edge and dip into the Timor Trough and beneath the subduction wedge of Timor and the rest of the outer-arc ridge. This region was discussed in the section on the Banda Arc.

\section{MODERN SEDIMENTATION}

Sedimentation since the early Pliocene has been primarily by outbuilding of the subsiding shelf edge by foraminiferal calcarenite and by the building of coral banks upon structural highs (Veevers, 1971a; H. A. Jones, 1973). The character of young sediments on the shelf shows that nearly all of the shelf was exposed above sea level during Pleistocene glacial intervals (van Andel and Veevers, 1967; Jongsma, 1974; H. A. Jones, 1973).

\section{NORTHERN AUSTRALIAN SHELF}

Phanerozoic strata are thin beneath the shallow Arafura Sea and Gulf of Carpentaria, between Australia and New Guinea, and Australian bedrock geology can be projected across the shelf.

\section{ARAFURA SEA}

Jurassic and younger strata are thinner than 2,000 $\mathrm{m}$ over most of the Arafura Sea, although in the southwest they thicken moderately into the shelf basins off northwestern Australia (Jongsma, 1974). Pre-Jurassic, high-velocity strata are very thick in the area of the offshore Arafura Basin, where crystalline basement rocks may be as deep as $10,000 \mathrm{~m}$, and presumably most of this section is Proterozoic (Nicol, 1970). The pre-Jurassic strata continue thick northward across much of the Arafura Sea, thence thin markedly westward toward the Aru Islands near the edge of the present shelf.

\section{GULF OF CARPENTARIA}

The broad Gulf of Carpentaria is underlain by a shallow basin filled with Jurassic and younger strata, mostly clastic, which reach a thickness of $2,000 \mathrm{~m}$ only in the center of the basin (Doutch, 1976; Newton, 1964; Wise, 1975). Flat-lying Paleozoic strata might also be present in the basin.

\section{NORTHEAST AUSTRALIA}

The Cape York Peninsula of northeastern Queensland projects into the area of the tectonic map of the Indonesian region, separating the Gulf of Carpentaria from the Coral Sea. The west half of the peninsula exposes only little-deformed Cretaceous and Cenozoic strata, but the east half and the extreme north tip expose a terrain dominated by Paleozoic and Precambrian metamorphic rocks and Paleozoic granitic rocks. 
CRI'SIAL SIRICITLRE.

The Mohorovicic discontinuity lies at a depth of about 30 $\mathrm{km}$ beneath the coast on both sides of Cape York Peninsula and deepens to about $45 \mathrm{~km}$ beneath the south-central part of the peninsula (Finlayson, 1968). The crust is only about 28 $\mathrm{km}$ thick beneath Torres Strait, and it thickens again in southern Papua New Guinea.

\section{PRECAMBRLN MFIAMORPHIC: ROCKS}

The pregranitic rocks of Cape York Peninsula are dominantly metasedimentary and increase eastward in metamorphic grade from chlorite and biotite zones in the west to andalusite and sillimanite zones in the east, in the region of Paleozoic batholiths (Wilmott and others, 1973). The most common rocks are phyllite, mica schist, and quartzite; greenstone, greenschist, amphibolite, marble, iron-rich rocks, and varied gneisses are subordinate. The initial sedimentary rocks probably were deposited on a shallow-water continental shelf or platform. Structural trends are generally northward, and the deformation and metamorphism of the rocks is due primarily to intrusion by plutons. Dating by various methods-K-Ar and both whole-rock and mineral Rb-Sr-suggests that the metamorphism recorded in the rocks is mostly of middle Paleozoic age, and partly late Paleozoic, but that the original sedimentary rocks were at least as old as early Proterozoic and were intruded extensively by diabase about 1,800 m.y. ago (Cooper and others, 1975).

\section{MIDDI.F P.IL.EO/OIC: ROCKS}

The pre-granitic rocks of southeastern Cape York Peninsula, east of $144^{\circ}$ E., consist of middle Paleozoic stratified rocks in very different eastern and western facies (Amos, 1968; de Keyser and Lucas, 1968). In the west is a shelf section of Silurian and(?) Lower Devonian shallow-marine limestone, chert, sandstone, and siltstone. In the east is a varied deep-water "eugeosynclinal" assemblage, Middle and Upper Devonian and(?) Lower Carboniferous, dominated by turbiditic sandstones and siltstones and containing abundant submarine volcanic rocks. The deep-water sandstones include much arkose, and local conglomerates contain granitic cobbles, indicating a continental source. The submarine volcanic rocks include "basalt," keratophyre, and quartz keratophyre - an altered arc assemblage-plus associated radiolarian jasper, chert, and siliceous shale. The eastern facies is intruded by many small upper Paleozoic granites, but away from contacts it is generally metamorphosed only at low grade.

\section{PALEOZOIC: GRANITIG ROC:S}

Southeastern Queensland, south of the limit of the tectonic map of the Indonesian region, displays abundant Paleozoic and Mesozoic granitic rocks in a belt whose total cross-strike width is about $700 \mathrm{~km}$. The granitic rocks become generally younger eastward across the belt and range from Late Silurian and Devonian in the west to Triassic in the east (fig. 112; Richards, White, and others, 1966; Webb and McDougall, 1968). The boundaries between the overlapping age provinces trend northward or north-northwestward, oblique to the northwest-trending coastline and continental-shelf edge. Aberrant to the general age trend, Cretaceous granites occur in a small region between lat $20^{\circ}$ and $22^{\circ} \mathrm{S}$., within what are otherwise belts of Carboniferous, Permian, and Triassic granites. Silicic volcanic rocks, presumably comagmatic with the granites, are also widespread in the Paleozoic terrain (Branch, 1969).

CAPE YORK PENINSULA

A great Paleozoic batholithic complex is exposed in the Cape York Peninsula, within the area of the Indonesian folio maps, trending northward between the general limits of long $143^{\circ}$ and $144^{\circ}$ E. (Cooper and others, 1975; Wilmott and others, 1973). Two-mica quartz monzonite is dominant, but other important rock types include biocite quartz monzonite and hornblende-biotite granodiorite and quartz diorite. Age determinations (K-Ar mineral ages, in part concordant pairs, and mineral- and whole-rock-isochron $\mathrm{Rb}-\mathrm{Sr}$ ages) show that most of the granitic rocks within this terrain are of Devonian and possibly Late Silurian age (Cooper and others, 1975). These old granitic rocks form north-trending plutons and are responsible for most of the metamorphism of the enclosing Precambrian metasedimentary rocks. In the north, high-level, crosscutting granites of Permian age are present within the batholithic belt (fig. 114; Cooper and others, 1975). Silicic welded tuffs and other extrusive equivalents of the late Paleozoic plutons are widespread (W. R. Morgan, 1974; Wilmott and others, 1973). Upper Paleozoic granitic rocks also occur as small plutons within the middle Paleozoic sedimentary terrain of southeastern Cape York Peninsula (Amos, 1968; de Keyser and Lucas, 1968).

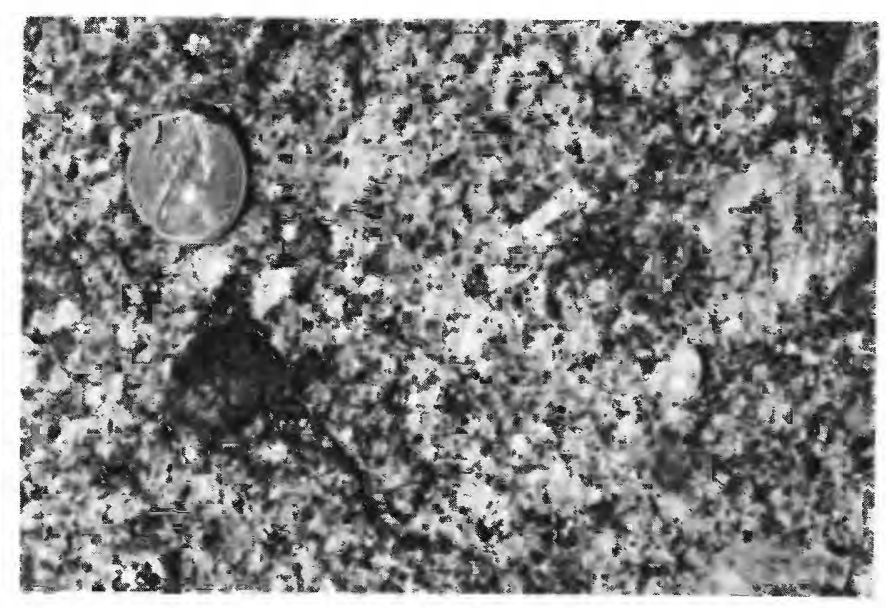

FIGtre 114. - Coarsely porphyritic biotite quartz monzonite of Permian age. A small xenolith of metasandstone lies beneath the coin, which is $28 \mathrm{~mm}$ in diameter. East coast of Cape York Peninsula, lat $16^{\circ} 39^{\prime} \mathrm{S}$. 
Presumably the old granitic rocks are younger than the middle Paleozoic shelf strata a short distance to the east, and a change at about the beginning of Devonian time from a passive to an active continental margin is recorded, although ambiguities in dating in both terrains are such that they could overlap in age, so that a more complex interpretation would be required. The "eugeosynclinal" Devonian and(?) Lower Carboniferous sedimentary and island-arc volcanic rocks farther east are equivalent in age to much of the main batholithic complex, so likely formed along and near the active margin.

\section{TORRES STRAIT}

Narrow Torres Strait separates Cape York, northeastern Australia, from New Guinea. Crystalline basement crops out in many islands and is shallower than $1,000 \mathrm{~m}$ below sea level across most of the strait. The bedrock ridge and tectonic province of Cape York Peninsula continue northward beneath a discontinuous veneer of upper Mesozoic and Cenozoic strata to New Guinea (Oppel, 1970; Stach, 1964; Vind and Harwood, 1965). The pre-Tertiary rocks of the islands of Torres Strait are Carboniferous and Permian granite and comagmatic lava, tuff, and welded tuff (Richards and Wilmott, 1970; Wilmott and others, 1973). Biotite quartz monzonite is the dominant granitic rock type.

TIN AND TUNGSTEN

Small deposits of tin, tungsten, and other metals are present in the high-level upper Paleozoic granites and quartz monzonites and their wallrocks (Blake, 1972; Wilmott and others, 1973). The tin granites contain fluorite, topaz, and tourmaline, and may have formed in a magmatic belt continuous with that of the similar and correlative tin granites of eastern Malay Peninsula, as is discussed subsequently.

\section{PETROGENESIS}

Initial ${ }^{87} \mathrm{Sr} /{ }^{86} \mathrm{Sr}$ ratios in the Paleozoic granitic rocks of Cape York Peninsula were high and ranged from 0.715 in granodiorite through $0.72-0.74$ in two-mica quartz monzonite to 0.76 in leucocratic quartz monzonite, and a high contribution of material from crustal rocks to the final magmas is clearly indicated (Cooper, and others, 1975).

It was inferred in the prior section on the petrologically similar granites of the Malay Peninsula that whole-rock $\mathrm{Rb} / \mathrm{Sr}$ "age" determinations there were in part grossly in error because initial isotopic ratios were much more erratic and more radiogenic than was assumed by the investigators. The isotopic composition of these Australian granites provides support for the Malay argument, for any whole-rock, assumed-initial-ratio $\mathrm{Rb} / \mathrm{Sr}$ age program carried out on the Australian rocks would yield apparent ages far older than the true ages.

Comparison with experimental-petrologic results indicates that the two-mica granites crystallized at depths greater than about $12 \mathrm{~km}$, the low pressure stability limit of muscovite, in the presence of quartz, at granite solidus temperatures. These are the deep equivalents of "mesozonal" arc batholiths.

\section{PLATE TECTONICS}

The geology of the Paleozoic and Triassic orogenic terrain of eastern Australia is amenable to explanation primarily in terms of convergent plate tectonics, wherein subduction of oceanic plates beneath the eastern margin of Australia, with resultant arc magmatism, and tectonic accretion of oceanic terrains, were the dominant processes. Day, Murray, and Whitaker (1979), Griffiths (1971b), Harrington (1974), Leitch (1974), Oversby (1971), Packham (1973), Scheibner (1973), and Solomon and Griffiths (1972) have made such interpretations. That both "eugeosynclinal" terrains and granitic rocks become generally younger eastward is easily explained in these terms. Paleozoic granitic rocks of Cape York Peninsula and Torres Strait presumably formed above Benioff zones that dipped westward beneath Australia.

Rifting away of the eastern part of the Paleozoic continent of Australia has also occurred. The Tasman Sea (between Australia and New Zealand) opened within Late Cretaceous time, as dated by the magnetic-anomaly method, when the continental strip of New Zealand plus now-submerged Lord Howe Rise pulled away (Hayes and Ringis, 1973). The oblique truncation of the belts of upper Paleozoic and Triassic granitic rocks against the continental margin in Queensland presumably is one of the products of this rifting. Concurrently or subsequently, the northwestern part of the new Tasman Sea plate may have been itself subducted beneath eastern Australia (Hayes and Ringis, 1973).

Older rifting events likely also occurred during Paleozoic time, although, if so, the oceanic lithosphere thus formed has long since been subducted beneath Australia or other plates. In particular, the lack of broad early and middle Paleozoic orogenic terrains in northeastern Australia (in contrast to their great breadth in southeastern Australia) and the presence of Precambrian rocks close to the present continental margin are suggestive of removal by rifting in the north.

\section{LAIRA BASIN}

Upper Jurassic and Lower Cretaceous strata as thick as 2,000 $\mathrm{m}$ occur in the Laura Basin on the east slope of north Queensland (de Keyser and Lucas, 1968). The Upper Jurassic is dominated by fluviatile and lacustrine quartz sandstone, with some conglomerate and shale, derived from highlands to the east. The Lower Cretaceous is mostly shale and quartz sandstone, much of it marine. Pinchin (1974) interpreted ambiguous seismic-reflection profiles to indicate about $8 \mathrm{~km}$ of gently dipping Permian and Carboniferous strata to lie beneath the flat Mesozoic beds.

\section{CARPENTARIA BASIN}

The Cretaceous and Cenozoic strata of the shallow Carpentaria Basin are mostly offshore, hidden by the waters 
of the Gulf of Carpentaria, but the thin edge of the basin fill covers most of the western part of the Cape York Peninsula. The exposed Cretaceous strata are marine and nonmarine sandstones and shales (Brown and others, 1968, p. 270, 274). Thin upper Tertiary and Quaternary marine and nonmarine clastics cover much of the southwestern part of the peninsula.

\section{CENOZOIC: BASALT}

Upper Cenozoic nonorogenic basalt covers two areas in eastern Queensland within the boundaries of the tectonic map of the Indonesian region. The basalt occurs as horizontal flows, erupted over topography similar to that of the present, and is mostly alkalic olivine basalt transitional to olivine tholeiite (W. R. Morgan, 1968). Some of the basalt is rich in analcite, and one occurrence of olivine nephelinite is known. Basaltic lavas and pyroclastics crop out on a number of small islands in the eastern part of Torres Strait; some represent volcanoes young enough to remain as well-preserved cones (Wilmott and others, 1973).

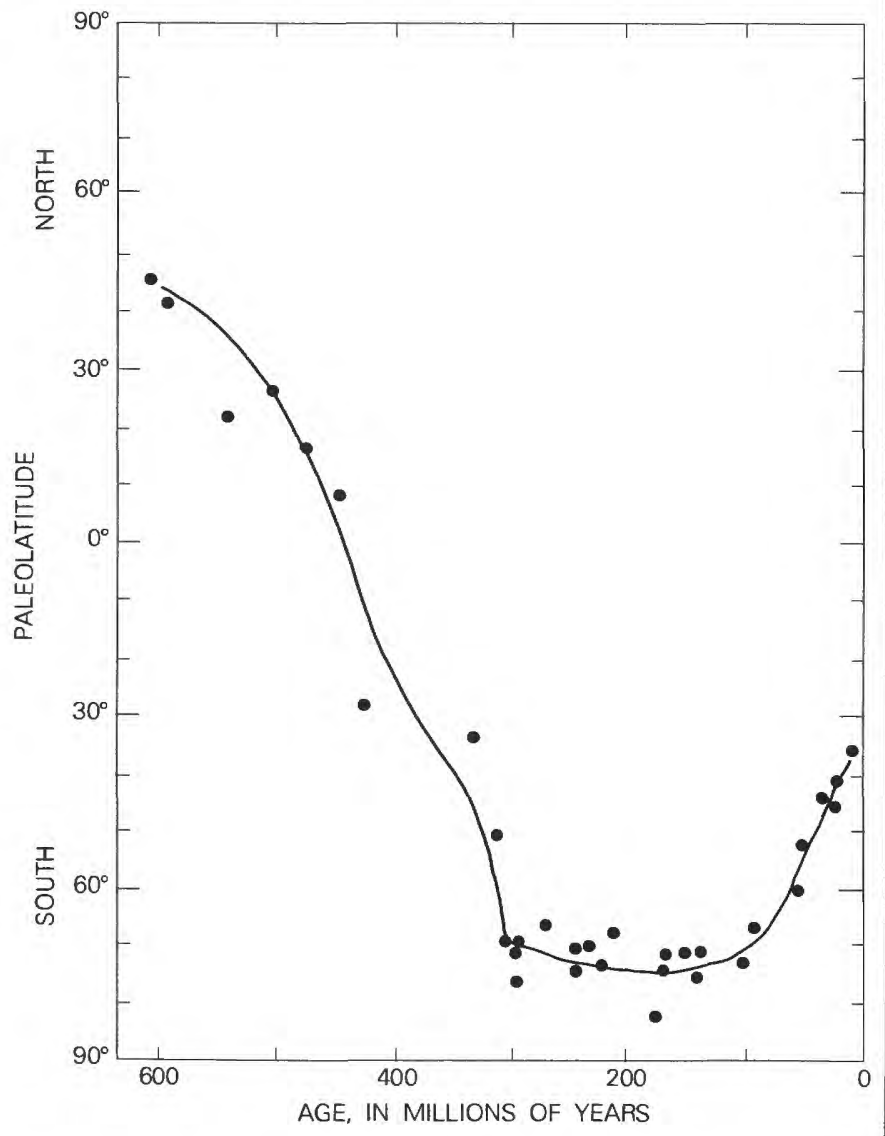

FIGURE 115.-Phanerozoic paleomagnetic latitudes of Canberra, Australia. Present latitude of Canberra is about $35^{\circ} \mathrm{S}$. Dots indicate data points; curve is fitted roughly to them. Replotted from McElhinny and Luck (1970a, fig. 6); additions from Embleton (1973) and Luck (1972)

\section{PHANEROZOIC CONTINENTAL DRIFT}

Paleomagnetic orientations of Australian rocks show that Australia moved about $110^{\circ}$ southward during early and middle Paleozoic time (fig. 115; Embleton, 1973; McElhinny and Embleton, 1974; McElhinny and Luck, 1970a). Australia then stayed more or less fixed in latitude until about the middle of Cretaceous time, since which time it has moved rapidly but irregularly northward (McElhinny, Embleton, and Wellman, 1974). Correspondingly, the early and middle Paleozoic paleoclimatic record of Australia indicates dominantly tropical conditions. Climates became markedly colder, progressively from south to north, during the Carboniferous. Cold conditions characterized the Permian, and cool ones the Mesozoic. The early Tertiary was a time of rapid warming.

\section{CORAL SEA}

The northwest corner of the Coral Sea lies within the area of the tectonic map of the Indonesian region, between the Papuan Peninsula of New Guinea and the northeast coast of Australia. The southwest part of the sea covers the foundered continental Coral Sea Plateau (fig. 116), and the deeper part of the sea is oceanic in crustal structure.

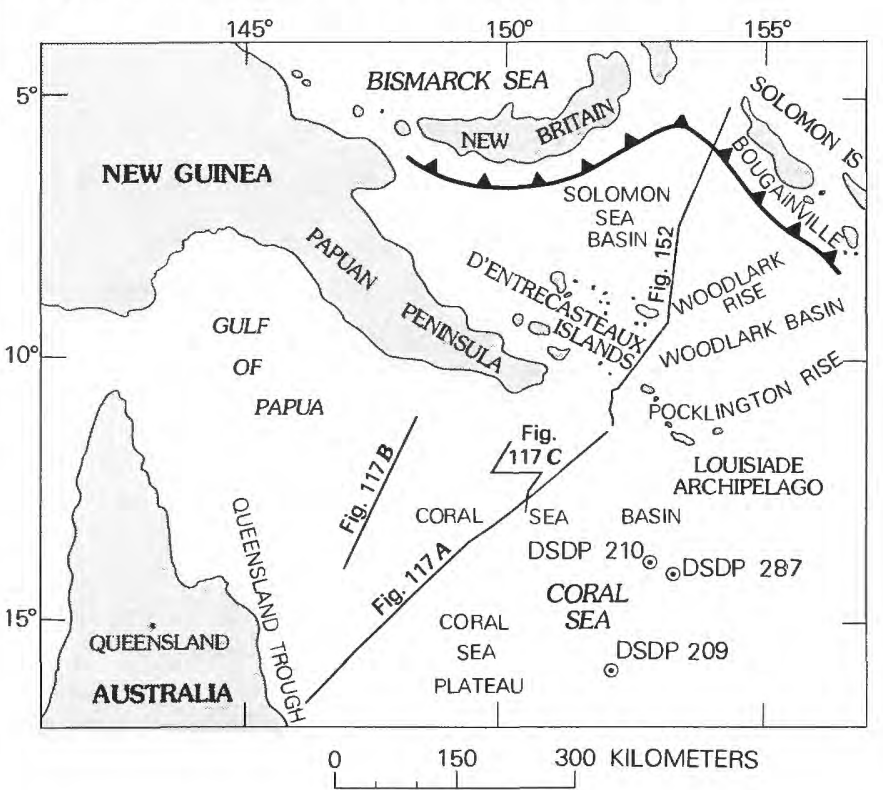

FIGURE 116.--Location of seismic-reflection profiles (figs. 117, 152) and Deep Sea Drilling Project (DSDP) holes in the Coral Sea-Solomon Sea region. Bathymetry of most of this region is shown in fig. 145 .

\section{CORAL SEA PLATEAU AND QUEENSLAND TROUGH}

The submarine Coral Sea (or Queensland) Plateau lies east of northwestern Australia and has a depth mostly near $1,500 \mathrm{~m}$ (fig. $117 \mathrm{~B}, \mathrm{C}$; fig. 145). The plateau has a continental crustal structure and is separated from Australia by the 
Queensland Trough, a graben, the shallow part of which is also underlain by continental crust (Ewing, Hawkins, and Ludwig, 1970). The rough basement surface of the plateau is covered by Eocene and younger sediments less than $2 \mathrm{~km}$ thick (Mutter, 1975b, 1977; Pinchin and Hudspeth, 1975). Hole 209 of the Deep Sea Drilling Project (DSDP), drilled in $1,400 \mathrm{~m}$ of water at the northeast edge of the plateau at lat $15^{\circ} 56^{\prime} \mathrm{S}$., long $152^{\circ} 11^{\prime} \mathrm{E}$., penetrated about $150 \mathrm{~m}$ of pelagic carbonate ooze of late Oligocene and younger age overlying $200 \mathrm{~m}$ of interlayered pelagic and terrigenous beds of middle and late Eocene age; basement was not reached (Burns and Andrews, 1972, Burns, Andrews, and others, 1973). The Coral Sea Plateau has gradually subsided within Cenozoic time to its present depth from an early Cenozoic position near sea level (Burns and Andrews, 1972, Burns, Andrews, and others, 1973; Ewing, Houtz, and Ludwig, 1970; Mutter, 1975b, 1977; Pinchin and Hudspeth, 1975). The Queensland Trough is underlain by $0.5-3 \mathrm{~km}$ of sediments, and the thickness beneath the dated Eocene-Oligocene unconformity is great enough so that the upper Mesozoic is likely present here as well as the lower Paleogene (Pinchin and Hudspeth, 1975; Taylor and Falvey, 1977).

The Coral Sea Plateau is the foundered margin of the Australian continent. Projection northward, from south of $20^{\circ} \mathrm{S}$., of structural trends in eastern Queensland suggests that Cretaceous granitic rocks, recording subduction of the Tasman Sea floor, may underlie part of the plateau. Crustal extension is indicated to produce the Queensland Trough. This graben deepens northward to oceanic depths, where the crust is oceanic and rifting of the continental crust has been complete. The subsidence of the plateau may be due to thinning of the lower continental crust by hot creep toward the suboceanic upper mantle. (Compare with Bott, 1971, and Bott and Dean, 1972.)

\section{CORAL SEA BASIN}

The Coral Sea Basin has a normal oceanic crustal structure, and the shallow depth of its northwestern part $(2,000-4,000 \mathrm{~m})$ is due mostly to the presence of thick young sediments there (Ewing, Hawkins, and Ludwig, 1970). The thick sediments of the deep basin (fig. 117) consist of acoustically transparent pelagic sediments, lying upon basement, beneath intercalated pelagic and turbiditic sediments (Burns and Andrews, 1972; Burns, Andrews, and others, 1973; Ewing, Houtz, and Ludwig, 1970). The turbidites are channeled to the basin by integrated submarine-valley systems draining both the New Guinea and Queensland coasts (Winterer, 1970). Two DSDP holes were drilled near the axis of the basin (fig. 116), Hole 287, in 4,600 $m$ of water at $13^{\circ} 55^{\prime} \mathrm{S}$., $153^{\circ} 16^{\prime} \mathrm{E}$., reached olivine basalt beneath $240 \mathrm{~m}$ of early Eocene and younger clays and calcareous pelagic sediments, plus intercalated silt-clay turbidites in the upper Pliocene and Quaternary (Andrews, Packham, and others, 1975). The basalt is of high-alumina, very low alkali type, even more primitive in its trace and minor elements than is most spreading-ridge basalt (D. B. Stoeser in Andrews, Packham, and others, 1975, p. 401-414). Hole 210 , drilled in $4,600 \mathrm{~m}$ of water at $13^{\circ} 46^{\prime} \mathrm{S}$., $152^{\circ} 54^{\prime} \mathrm{E}$., penetrated about $550 \mathrm{~m}$ of intercalated pelagic and turbiditic Neogene and upper Oligocene sediments, and then about $150 \mathrm{~m}$ of middle Eocene pelagic carbonate sediments, and did not reach basement (Burns and Andrews, 1972; Burns, Andrews, and others, 1973).

Heat flow is moderately high, mostly between 1 and 2 $\mu \mathrm{cal} / \mathrm{cm}^{2} \mathrm{sec}$, in both the Coral Sea Basin and the northern part of the Coral Sea Plateau (Macdonald and others, 1973).

The structure of the Coral Sea Basin was discussed by $\mathrm{C}$. W. Landmesser, J. E. Andrews, and G. H. Packham (in Andrews, Packham, and others, 1975, p. 647-662).

\section{OPENING OF THE CORAL SEA BY RIFTING}

New Zealand, its flanking submarine plateaus, and submarine Lord Howe Rise and Norfolk Island Ridge trending northwest from it, are variably foundered continental fragments that apparently split away from Australia in Late Cretaceous time (Griffiths, 1971a; Hayes and Ringis, 1973; Jones and Roots, 1974; van der Linden, 1970; Shor and others, 1971; Weissel and Hayes, 1977). The Tasman Sea, between Australia and New Zealand, is dated by the magnetic-anomaly method as having opened during the interval from 60 to 82 m.y. ago (Hayes and Ringis, 1973; Weissel and Hayes, 1977). Concurrently or subsequently, the northwestern part of the new oceanic plate may (Hayes and Ringis, 1973) or may not (Weissel and Hayes, 1977) have been subducted beneath Australia.

The northwestern Coral Sea might have been opened by the Late Cretaceous and early Paleogene counterclockwise rotation of the Papuan Peninsula away from northeastern Queensland (Brown and others, 1975; Carey, 1958; Davies and Smith, 1971; G. H. Packham and J. E. Andrews, in Andrews, Packham, and others, 1975, p. 691-705; Taylor and Falvey, 1977). The opposed continental slopes have appropriately similar shapes, and meager magnetic data permit the inference that oceanic-crust magnetic anomalies fan from an apex in the northwest part of the sea (Gardner ${ }^{14}$, 1970). I regard the possibility of rifting of the peninsula from the mainland, however, as unlikely.

The interpretation is developed in the New Guinea section of this report that the Papuan Peninsula formed by the advance southward, past the main mass of New Guinea to the west, of a Tertiary island arc. The peninsula is bounded on the south by a fossil trench; the terrains of the peninsula project northwestward into belts of melange and other accretionary complexes of northern medial New Guinea, not into the old-continental rocks of southern New Guinea. The quartzose metasedimentary rocks in parts of the peninsula

\footnotetext{
${ }^{14}$ Gardner speculated that all of New Guinea had rotated about $45^{\circ}$ relative to Australia, without internal deformation-but the crustal consumption required in the west between the two landmasses by this conjecture is wholly incompatible with the geology of the intervening platform region.
} 

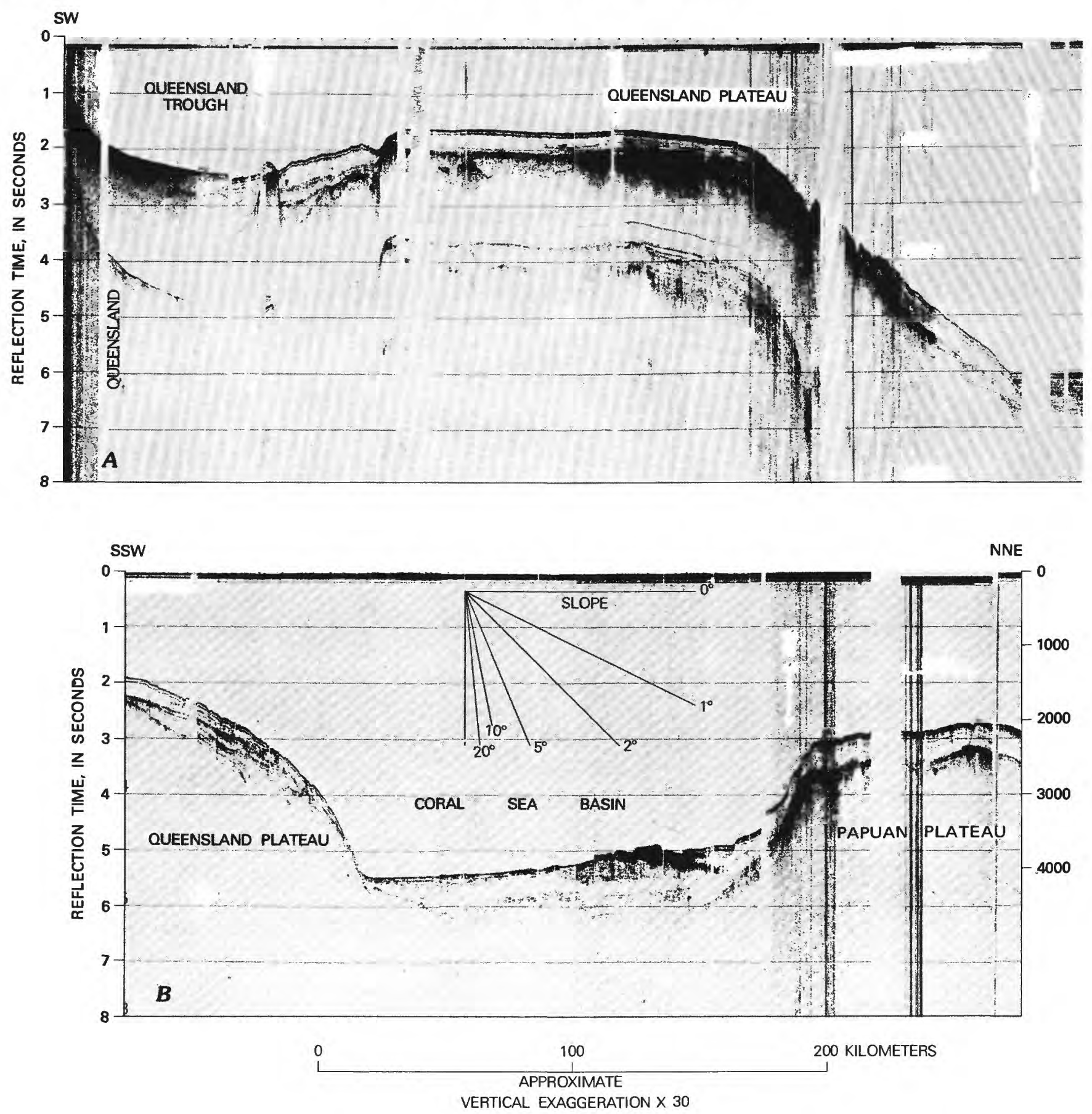

FIGURE 117. - Seismic-reflection profiles in the Coral Sea region. Thick sediments mantle the lower south slope of the Pocklington Rise and Papuan Peninsula, and also of the Coral Sea Basin and Plateau. There is no suggestion of any active or buried trench on either side of the basin in these shallow-penetration profiles. Location of profiles shown in fig. 116. Profiles from Lamont-Doherty Geological Observatory, R. V. Vema cruise 24.

may indeed have been derived ultimately from a continent, presumably Australia, but their occurrence indicates to me that the premetamorphic sediments were deposited on deep ocean floor of Cretaceous to Eocene age and were swept up into a melange wedge in front of the advancing Tertiary arc.

\section{NEW GUINEA}

Southern New Guinea is the northern part of the Australian landmass, separated from Australia only by an epicontinental sea. Southwestern New Guinea was cratonic 

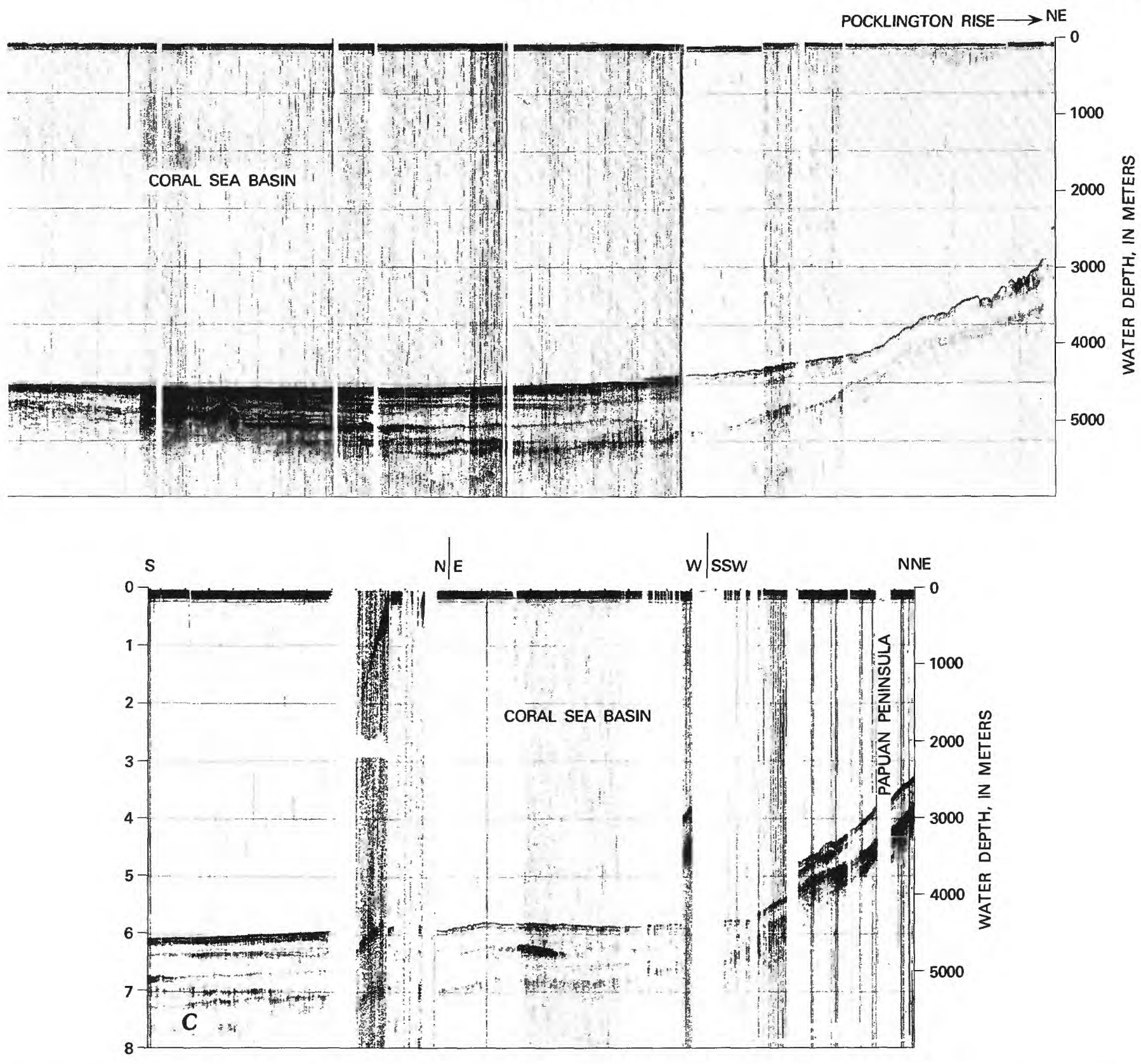

during Paleozoic time. The Paleozoic orogenic terrain of eastern Australia continues northward into central New Guinea and initially continued farther north along the Pacific side of a continental mass, probably now Sumatra and the Malay Peninsula, that was rifted away in middle Mesozoic time. During the late Mesozoic and early Tertiary, the northern edge of the Australian-New Guinea landmass was a stable continental shelf. Australia and New Guinea were detached from Antarctica in the Eocene and have since been moving northward, but until Miocene time the northern continental margin was a stable shelf. Then, an island arc, which had been migrating southward during Cretaceous and early Tertiary time, collided with the continent, producing melanges and obducted ophiolites between continent and tectonically accreted arc. The continent continued to move northward, but late Cenezoic subduction has been southward beneath the continent as enlarged by the addition of the island arc: the polarity of subduction reversed. The eastern part of the arc, not blocked by continental crust, continued to move southward, forming the Papuan Peninsula. These and other topics are discussed in this section.

The geological map of Papua New Guinea (Bain and others, 1972) summarizes the great amount of government and oil-company reconnaissance, much of it otherwise unpublished, done there since World War II. The smaller 


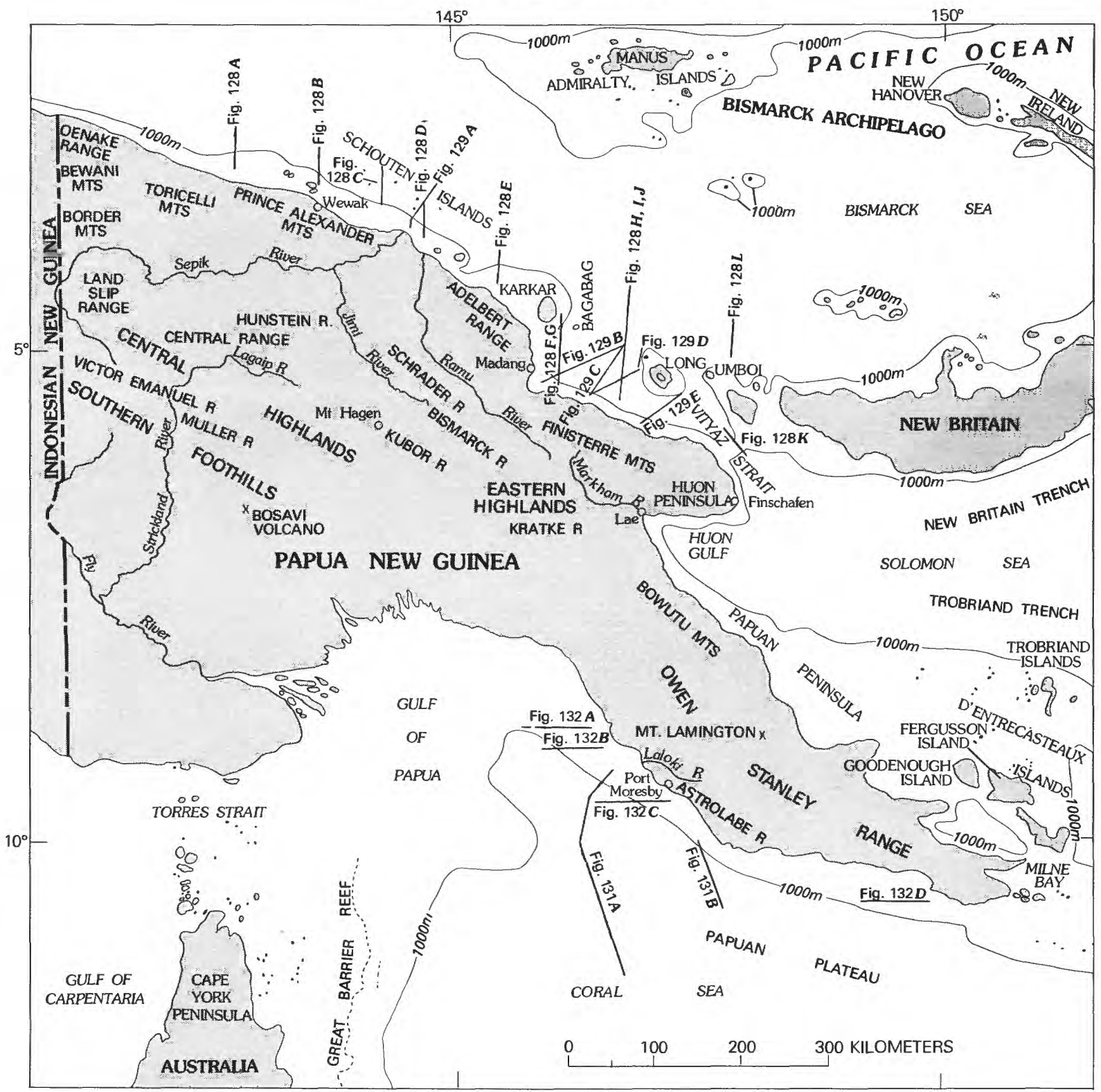

FIGU'RE 118.--Geographic features of eastern New Guinea and neighboring regions showing location of seismic-reflection profiles in figures $117,128,129,131$, and 132 .

scale map by D'Addario, Wilford, and others (1976) gives additional tectonic information. Dow (1977) summarized the geology of eastern New Guinea. Skwarko (1976) described briefly all rock units that have been named by Australian geologists. Modern work in Indonesian New Guinea (Irian Jaya) has been much less extensive; Visser and Hermes (1962) summarized the findings of the Royal Dutch/Shell Group. The older Dutch work was summarized by van Bemmelen (1949) and Zwierzijcki $(1928,1932)$. A gravity map (Bouguer anomalies over land, and free-air anomalies offshore) for Papua New Guinea and much of Melanesia to the east was published by the Australia Bureau of Mineral Resources, Geology, and Geophysics (1976b). A Bouguer-anomaly map of Indonesian New Guinea was presented by Visser and Hermes (1962).

"New Guinea" in this report refers to the entire island. Papua New Guinea here refers to the eastern half of the island, now an independent nation of that name but until recently the Australian-mandated territories of New Guinea in the north and Papua in the south; the term is not used here to include New Britain and other islands within the new nation. Geographic features of New Guinea and nearby regions are named on figures 118 and 119 . The western half of the island is referred to here as Indonesian New Guinea, 


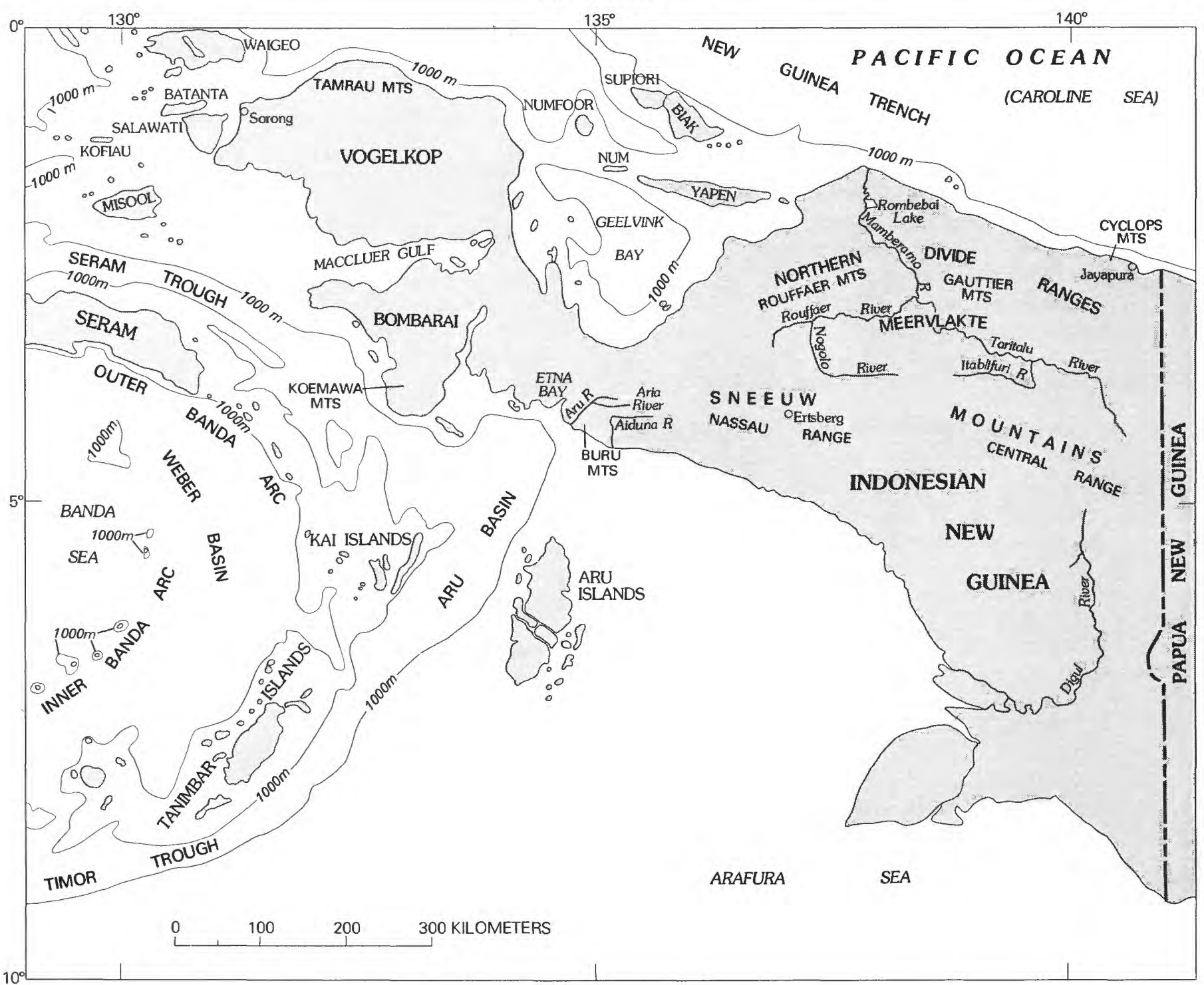

FIGURE 119.-Geographic features of western New Guinea and neighboring regions.

although it is presently termed Irian Jaya (Prosperous Irian) by the Indonesian government and was until recently termed by them Irian Barat (West Irian).

The concepts presented here regarding northern New Guinea and also the Papuan Peninsula were developed in part after completion of the tectonic map (pl. 1), and some inconsistencies exist between text and figures on the one hand and that map on the other.

\section{PALEOZOIC AND EARY MESOZOIC TECTONICS}

New Guinea south of its great medial belt of Cenozoic melange and exotic rock terrains has a continental crust of Precambrian and Paleozoic age. The upper Paleozoic igneous terrain of eastern Australia continues northward to medial eastern New Guinea. A middle Paleozoic orogenic complex is exposed in northern Vogelkop. In between, Paleozoic rocks are sediments in shelf and platform facies, and Precambrian basement rocks have been reached by drilling (Wise, 1975) but are not exposed. The landmass (now Sumatra and part of Southeast Asia?), which in Paleozoic time was continuous to the north, was rifted away from medial New Guinea in the early Mesozoic.

\section{PALEOZOIC: BASEMENT OF VOGELKOP}

The basement rocks of northern Vogelkop (Birds Head, or Jazirah Doberai, far northwestern New Guinea) south of the Sorong fault zone are of Paleozoic age (d'Audretsch and others, 1966; Robinson and Ratman, 1977, 1978; Ryburn, 1977; Visser and Hermes, 1962). Low-grade metasedimentary rocks-slate, quartzite, graywacke - are dominant in 
the west, where they have yielded Silurian graptolites in one area and are overlain by Upper Carboniferous or Lower Permian and younger strata. Rocks of higher metamorphic grade, up to kyanite schist, are common in the east, where Devonian ostracodes were found at one locality. Many small plutons of potassic, silicic granitic rocks cut the eastern metamorphic rocks, and have Late Permian and Early Triassic K-Ar mineral ages (R. J. Ryburn, 1977, and written commun., 1978; the plutons are erroneously shown as of Devonian and Carboniferous age on pl. 1). The basement complex is truncated on the north by the Sorong fault zone, but one long mass (presumably a fault slice; not shown on pl. 1) of granite like that south of the fault zone occurs on the north side of the fault zone, offset an apparent $50 \mathrm{~km}$ or so by left slip (Ryburn, 1977).

Shift of the Paleozoic and Triassic terrain of Vogelkop from an initial site far to the east, north of the similar complex in central eastern New Guinea, must be considered, although known strike-slip faults south of Vogelkop appear to be far too minor to accomplish such transport.

The Wandamen Peninsula, jutting northward into the southwest part of Geelvink Bay (Teluk Sarera) at long $134^{\circ} 30^{\prime} \mathrm{E}$., consists largely of gneisses, metamorphosed at amphibolite facies from sedimentary rocks, from mafic igneous rocks and eclogites, and from granitic rocks (Ryburn, 1977; also Visser and Hermes, 1962). Muscovite and biotite $\mathrm{K}-\mathrm{Ar}$ ages are only 3-4 m.y., so uplift has been great and rapid (Ryburn, 1977). The metamorphic rocks are depicted on pl. 1 as of Paleozoic age, but may instead belong to the belt of Tertiary melange and related complexes of medial New Guinea.

\section{IPPER PALEOZOIC: BASEMENT OF SOCTHEAST NEW GUINEA}

The eastern Australian terrain of metamorphic rocks and of upper Paleozoic, and possibly Triassic, granitic and volcanic rocks can be traced in the subsurface and in occasional outcrops and islands across Torres Strait and through the south half of New Guinea between long $142^{\circ}$ and $145^{\circ}$ E. (pl. 1; fig. 120). This terrain is the basement complex upon which the shelf deposits of the later Mesozoic and Paleogene were deposited. The dominant structural trend of the buried New Guinea basement rocks south of about lat $6^{\circ} 30^{\prime} \mathrm{S}$., and between about long $141^{\circ}$ and $143^{\circ} \mathrm{E}$., is shown by aeromagnetic surveys to be north-northeastward (O'Brien and others, 1961).

Carboniferous and Permian granitic rocks and silicic welded tuffs form the basement ridge that connects Cape York, northeast Queensland, with New Guinea, and are exposed on the islands of Torres Strait and also in the small basement exposure where this ridge comes ashore in southernmost New Guinea (pl. 1; Richards and Wilmott, 1970; Wilmott, 1972; Wilmott and others, 1973). Granite at that southern mainland exposure has a $\mathrm{K}-\mathrm{Ar}$ age of about 300 m.y. (Richards and Wilmott, 1970). A number of oil-exploration wells have reached alaskite, granite, quartz monzonite, and silicic volcanic rocks beneath the Jurassic and younger sedimentary rocks of the lowlands between the south coast of New Guinea and lat $7^{\circ} \mathrm{S}$. and between long $141^{\circ} 30^{\circ}$ and $143^{\circ} 30^{\prime}$ E. (Conybeare and Jessop, 1972; O'Brien and others, 1961). The K-Ar age of one of these oil-well granites is $236 \mathrm{~m}$.y. (Harding, 1969). A small uplift at $5^{\circ} 25^{\prime}$ S., $142^{\circ} 05^{\prime}$ E., exposes granitic rocks underlying Jurassic sandstone. A single $\mathrm{K}-\mathrm{Ar}$ age determination of biotite from this granite is $222 \mathrm{~m} . \mathrm{y}$., Triassic (Page, 1976). The larger Kubor Range basement uplift, around $6^{\circ} \mathrm{S}$., $144^{\circ} 30^{\prime} \mathrm{E}$., exposes a small batholith of hornblende-biotite granodiorite and quartz diorite. The pluton is overlain unconformably by Upper Triassic arkose and younger strata (Rickwood, 1955; Bain and Mackenzie, 1974, 1975; Bain and others, 1975; Skwarko and others, 1976). Many K-Ar age determinations of mineral separates from the granitic rocks peak at 220-225 m.y. and range from 215 to 245 m.y. (Page, 1976). Two biotite samples from granodiorite and three muscovite samples from pegmatites give almost identical $\mathrm{Rb} / \mathrm{Sr}$ ages of about $238 \mathrm{~m}$.y. (Page, 197615). The batholith is intruded into schist, phyllite, marble, metasandstone, and metavolcanic rocks. Muscovites from three schist samples define an a pparent Rb-Sr isochron of 239 m.y. (Page, 1976).

\section{PALEOZOIC: SHELF OR PIATFORM STRATA}

The proved Paleozoic rocks of New Guinea are in shelf or platform sedimentary facies except for the orogenic complexes, just described, in the southeast and the far northwest, and for that of the Border Mountains, discussed subsequently. Paleozoic strata are exposed extensively in the southern half of the medial mountains (Sneeuw Mountains) of Indonesian New Guinea, between long $135^{\circ}$ and $140^{\circ} \mathrm{E}$., partly in anticlines and partly in south-directed thrust sheets. Detailed stratigraphic studies have not been reported, but rocks present include Silurian limestone, Devonian limestone and sandstone, and Carboniferous(?) and Permian limestone and continental and marine sandstone and shale (F. G. Keyser as cited by van Bemmelen, 1949, p. 62; Visser and Hermes, 1962).

The western part of the Paleozoic orogenic complex of Vogelkop is overlain unconformably by Permian and(?) Upper Carboniferous strata both in outcrops in the mountains and in wells (Visser and Hermes, 1962). The strata are marine and continental quartz-rich sandstones and sandy, silty, and calcareous shales. Fossils-silicified tree trunks, land plants, thin coals, brachiopods, crinoids, tetracorals, and fusulinids - are indicators of warmer climates than are those of correlative Australia. The Permian floras include both Gondwana and Cathaysian assemblages; the tectonic significance of this is discussed subsequently.

\footnotetext{
${ }^{15}$ Page (1976) used a decay constant for ${ }^{\times 7} \mathrm{Rb}$ of $1.39 \times 10^{-11} \mathrm{yr}^{-1}$. The ages cited in this report from his work are recalculated for a decay constant of $1.42 \times 10^{-11} \mathrm{yr}^{-1}$ and so are about 2 percent younger than those he calculated.
} 


\section{EARI.Y MESOZOIC: HISTORY}

The Middle Jurassic through Paleogene strata of southern New Guinea clearly were deposited on a continental shelf, over which water deepened northward to a shelf edge in what is now the medial part of the island. No such pattern can be detected in the strata of possible Triassic and Early Jurassic ages, which (with the exception of the Mesozoic volcanic and sedimentary belt discussed subsequently) are on the contrary in facies suggestive of deposition on a continental-interior platform rather than near the edge of a continent. I infer that during the early Mesozoic southern New Guinea lay within a continental mass between Australia on the south and some other subcontinent on the north.

Upper Triassic strata occur in the Kubor Range anticline region of medial Papua New Guinea south of the melange belt, and other certainly dated Triassic strata lie within the belt of melange and complex strike-slip(?) faulting farther north. (See Skwarko and others, 1976.) In Indonesian New Guinea south of the melange belt, and in southeastern Vogelkop, a largely clastic section, much of it in continental redbed facies, consists of shale, quartzose sandstone, conglomerate, dolomitic shale, and dolomite; is $500 \mathrm{~m}$ or so thick; lies between Lower(?) Permian and Middle Jurassic strata; and is presumed to be Triassic, although it has yielded no diagnostic fossils (d'Audretsch and others, 1966; Visser and Hermes, 1962). Thick marine Upper Triassic rocks are present on the island of Misool, west of Vogelkop, as noted in a subsequent section.

\section{RIFTING OF MALAY-SUMATRA SUBCONTINENT FROM NEW GUINEA}

The belt of upper Paleozoic and Triassic(?) granitic rocks of northeast Australia continues northward as a basement high into the southern medial highlands of New Guinea, where it ends against the east-west belt of middle Tertiary melange of the northern part of the highlands (fig. 120). It is an obvious inference that the truncation of this magmatic terrain represents a rifting of the continent, the terrain having been initially continuous along the east margin of a contiguous continental mass to the north which has since been removed. Middle Jurassic and younger strata were deposited in water that deepened northward toward medial New Guinea (Skwarko, 1973b), hence they likely postdate any rifting. Rocks as young as Early Jurassic do not show clear evidence for a continental margin in medial New Guinea; so the rifting may have occurred within Jurassic time, although a Triassic age is possible also.

The missing landmass is likely now in Asia, forming one of the subcontinents whose aggregation during Phanerozoic time has produced Eurasia (Burke and others, 1977; Burrett, 1974; Dewey, 1977; Hamilton, 1970b; Ziegler and others, 1977). The landmass should have upper Paleozoic volcanic and granitic rocks, including tin granites, on one side and an old platform on the other, if it is to match northeast Australia. The Indochina-Malay Peninsula-Sumatra plate is the obvious candidate for selection as the missing subcontinent. Paleolatitude considerations, based on paleomagnetic orientations and the paleoclimates of Australia, are in general appropriate for this selection. The missing landmass should have had largely tropical climates and faunas, resembling those of Australia, from Cambrian through Devonian time; Southeast Asia did. In the Permian, by contrast, Australia lay in high and middle-high latitudes, much closer to the South Pole than now, and had cold-climate faunas and floras; New Guinea was in warm-temperate latitudes; and the missing landmass to the north must have been subtropical to tropical.

The Permian land floras of the world fall into four broad taxonomic and paleoclimatic categories. The south-temperate Gondwana (Glossopteris) flora characterizes Australia, East Antarctica, India, Africa, and South America. A morphologically similar but taxonomically very different north-temperate flora is found in Siberia. Paleoclimatically between these are tropical, subtropical, and warm-desert floras, which fall taxonomically into two groups, one (Euramerican) in Europe and North America, the other (Cathaysian) in Southeast Asia, China, Korea, and Japan. The Permian floras from New Guinea include several collections of Gondwana assemblages. and one that is Cathaysian and much like the Permian flora of Sumatra (Jongmans, 1940; Lacey, 1975; Visser and Hermes, 1962). The Sumatra collections in turn bridge to the fully tropical Cathaysian assemblages of China itself. The New Guinea floras thus indicate a paleogeographic position within the fluctuating zone between temperate and subtropical floras and also land continuity with Sumatra. The Permian (and Late Carboniferous?) marine invertebrates of New Guinea (Visser and Hermes, 1962) are similarly indicative of a middle-latitude position, for they have sparse contents of such warm-water indicators as fusulinids and tetracorals.

If the missing landmass has been identified correctly, then eastern Malaya, the Tin Islands, and southeast Sumatra , with their upper Paleozoic granites, lay near its Pacific side; and western Malaya and central Sumatra, cratonic during the late Paleozoic, lay in its interior. The shallow-water upper Mesozoic sedimentary rocks of far southern Sumatra, and undated but similar strata beneath the Cenozoic cover of the western Java Sea shelf, could be part of the continental shelf that developed along the rifted edge.

Land continuity from the Malay Peninsula and Indochina northward to China seems required by the similarity of the late Paleozoic land floras of both regions. Indochina is separated from southern China by the suture zone of the Red River, along which those two subcontinents are interpreted to have collided in Late Triassic time, following late Paleozoic and Triassic subduction of the intervening oceanic plate beneath the Indochinese side. The land connection of the late Paleozoic may have lain in the direction now west of the Malay Peninsula, and the Tarim and Tibetan continental 


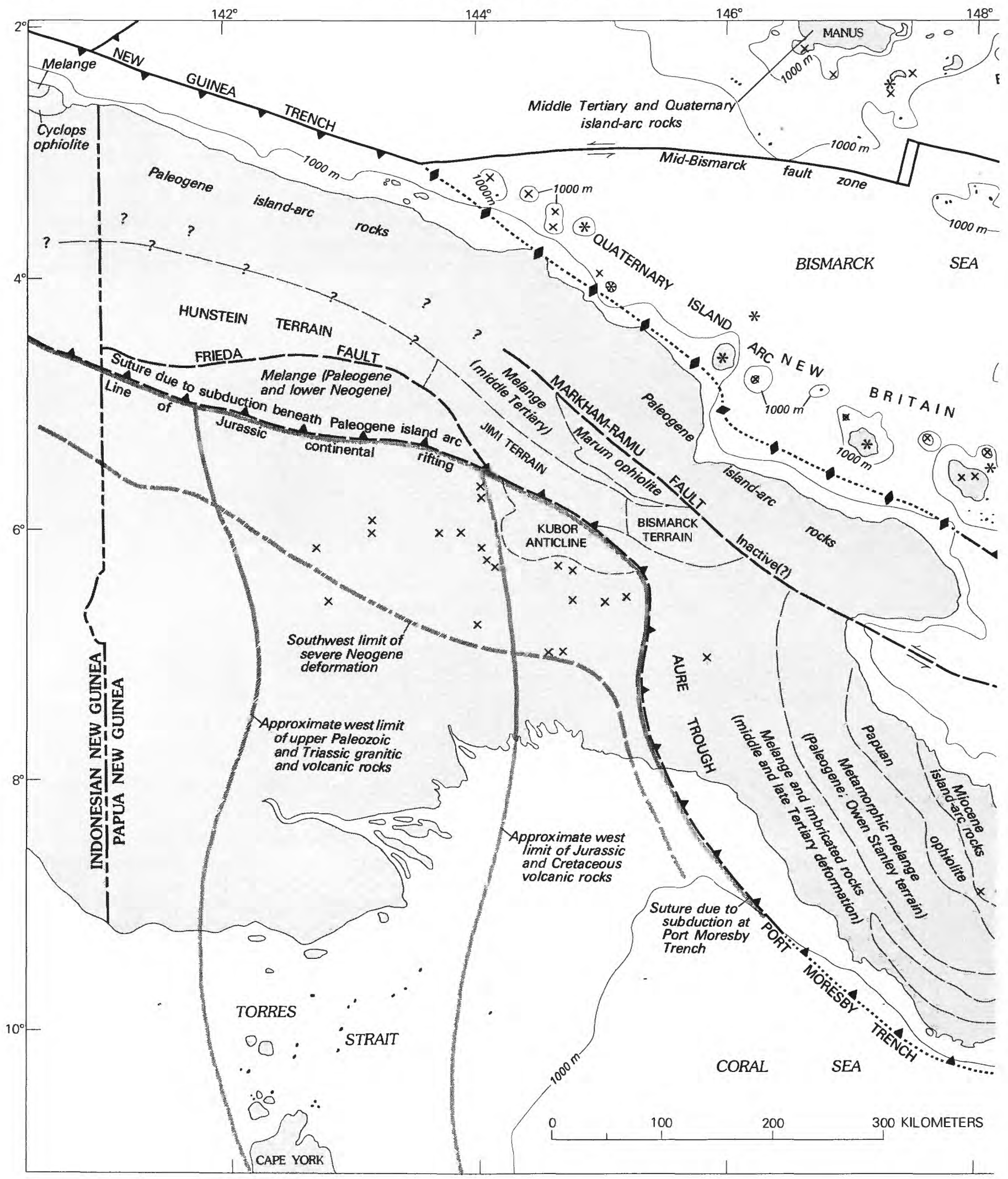

FIGURE 120.-Tectonic elements of eastern New Guinea and surrounding regions. *, active volcano; $x$, volcano active within late Quaternary time. Cenozoic magmatic-arc rocks are not otherwise identified here within New Guinea south of the Paleogene island-arc terrains. Interpretations illustrated are developed in the text. Geologic base and 1,000-m bathymetric contour from D'Addario, Dow, and Swoboda, (1976). 


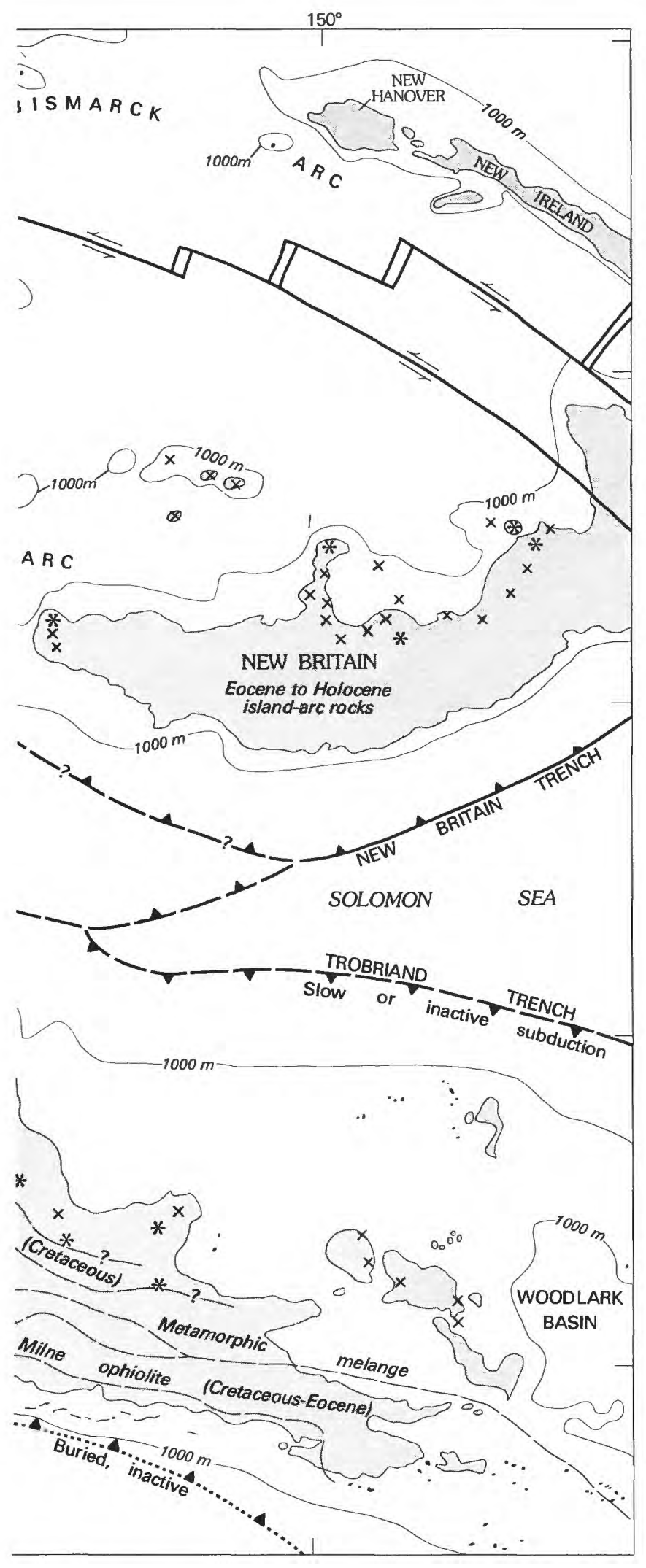

plates may then have been adjacent to Sumatra, the Malay Peninsula, and Burma.

\section{OLD METAMORPHIC: AND PLUTONIC: TERRAINS}

Metamorphic and plutonic rocks of possible continental-crustal types occur in poorly known terrains in Papua New Guinea, between Paleogene melange complexes on the south and the Upper Cretaceous and Paleogene island-arc complexes to the north. (These other materials are discussed subsequently.)

Granitic rocks in the Border Mountains (fig. 118; lat $3^{\circ} 40^{\prime}$ S., long $141^{\circ}$ E.), north of the Sepik River, yielded seven K-Ar age determinations within the range 242-257 m.y., approximately Late Permian (D. S. Hutchison, 1975; Norvick, 1975). These granites are within the southern part of the region assigned to the Upper Cretaceous and Paleogene island-arc complex of northern New Guinea on the tectonic map (pl. I-information noted too late for incorporation in the map), and they lie north of much Paleogene subduction melange. The granites intrude quartzose and micaceous metamorphic rocks of unknown age.

Metamorphosed sedimentary and igneous rocks, including such continental rock types as quartzite, arkose, granite gneiss, and andalusite schist, occur southwest of the Markham-Ramu Valley in the vicinity of $6^{\circ} 15^{\prime} \mathrm{S}, 145^{\circ} 45^{\prime} \mathrm{E}$. (Bismarck terrain of fig. 120; Tingey and Grainger, 1976). The larger intrusive masses, and probably the major metamorphism, are of Miocene age, but scattered K-Ar and $\mathrm{Rb}$ - $\mathrm{Sr}$ determinations indicate that some of the intrusive rocks are of Jurassic and Cretaceous ages (Page, 1976).

These complexes may have been transported from initial positions in the upper Paleozoic and Mesozoic orogenic terrain of eastern Australia and its continuation into New Guinea.

\section{MESO\%OIC: VOI CANIC AND SEDIMENTARY TERRAINS}

Late Triassic, Jurassic, and Early Cretaceous arc magmatism is recorded in several regions of central New Guinea. This may represent subduction of oceanic lithosphere westward beneath the Australian-New Guinea continent. Ambiguity is introduced by the lack of knowledge of continuity of the terrains, and it is not clear whether the terrains formed near or far from their present sites in New Guinea.

The most extensive exposures of these Mesozoic volcanic rocks occur in a lenticular block, $200 \times 40 \mathrm{~km}$, that trends west-northwestward to the north of the Kubor Range uplift of Paleozoic crystalline rocks (Bain and Mackenzie, 1975; Bain and others, 1975; Dow and Dekker, 1964; Dow and others, 1972; Skwarko, 1967, 1973b). The Jimi River flows within much of the lenticular block, which is here referred to as the Jimi terrain (fig. 120). Middle Triassic through Lower Jurassic dark shale, graywacke, and siltstone, containing 
sparse to locally abundant marine invertebrates including shallow-water forms, occur in a section with widespread basaltic and intermediate agglomerate, flows including pillow lavas, tuff, and tuffaceous clastic sediments. These are overlain by dark Upper Jurassic shale. The rocks are broadly folded and moderately faulted.

Lower Cretaceous volcanic rocks overlie lithologically and faunally similar Upper Jurassic shale in the Kubor Range anticline, just south of the Jimi terrain (fig. 120; Bain and Mackenzie, 1974, 1975; Bain and others, 1975; Edwards and Glaessner, 1953; Findlay, 1974). Here, the Lower Cretaceous Kondaku Tuff consists of tuffaceous and volcanilithic sandstone, shale, and siltstone, and minor agglomerate and lava; fossils include both land plants and marine invertebrates. Upper Cretaceous shale, siltstone, and sandstone locally contain interbeds of tuff and volcanilithic graywacke. Altered intermediate volcanic rocks (Kana Volcanics) beneath the Jurassic shale might be correlative with the Upper Triassic volcanic rocks of the Jimi terrain (as Bain and his associates assumed) but in part record late Paleozoic magmatism related to the Kubor batholith.

Interpretations are much complicated by the ambiguity of the tectonic relationship between the Kubor Range anticline on the south and the long Jimi block on the north. John Branson, D. E. Mackenzie, and R. J. Ryburn (written communs., 1978) inferred broad tectonic continuity, and minor disruption by younger structures; but those structures are of types that could record major dislocations by subduction and strike-slip faulting. The Kubor and Jimi masses are separated along most of their length by the broad shear zone of the Bismarck fault zone (Bain and Mackenzie, 1975; Bain and others, 1975; Dow and others, 1972). In the east, the masses diverge, and among the intervening rock assemblages is polymict melange-Oligocene(?) sediments intersheared with serpentinite (part of the Omaura Greywacke of Bain and Mackenzie, 1974). The Jimi and Kubor masses diverge in the west also, and between their projections is another terrain, $50 \mathrm{~km}$ wide, that includes much polymict Paleogene melange (April Ultramafics and much of the Salumei Formation-and, farther west, all of the Salumei Metamorphics and blueschist Gufug Gneiss-- of Dow, Smit, Bain, and Ryburn, 1972). Shear zone and melange indicate that the Jimi and Kubor masses are not now in the same relative positions in which they formed but do not constrain the amount or direction of net or total motion between them. The presence of abundant volcanic detritus in dark Jurassic shale in the Gulf of Papua region (encountered in oil wells east of the highlands of Paleozoic crystalline rocks), the presence of Cretaceous volcanic and granitic rocks in eastern Queensland (east of the structural belts exposed on shore in far northern Queensland), and the lack of known Mesozoic volcanic rocks farther west in southern New Guinea are taken to suggest that the Mesozoic volcanic rocks in at least the Kubor anticline belong to eastern Australian tectonic and magmatic belts (fig. 120).
Sandstone, siltstone, and mudstone, derived in substantial part from silicic and intermediate plutonic and volcanic rocks and subsequently metamorphosed to greenschist facies, form much of the Owen Stanley Range of the Papuan Peninsula, southwest of the great ophiolite sheet, between long $146^{\circ} 15^{\prime}$ and $149^{\circ} 15^{\prime} \mathrm{E}$. (fig. 120; Dow and others, 1974; Davies and Smith, 1971; Macnab, 1969; Pieters, 1974). A source terrain in a continental volcanic arc is suggested by the composition of these sediments, which have yielded Cretaceous fossils in several localities and which perhaps were deposited east of the north Queensland-Torres Strait region in late Mesozoic time and subsequently swung away from the mainland as the northwestern Coral Sea opened (Davies and Smith, 1971; also subsequent sections of this report, and the earlier section on the Coral Sea). The main metamorphism was post-Cretaceous and possibly as young as Miocene (Dow and others, 1974; Page, 1976). Polymict melange and glaucophane schist are present along both sides of this variably metamorphosed terrain (Davies and Smith, 1971; Macnab, 1969; Pieters, 1974; this report), and the terrain is inferred (pl. 1) to be part of the melange complex.

\section{MESOZOIC AND CENOZOIC EVOLUTION OF SOUTHERN NEW GUINEA}

Following the Triassic or Early Jurassic rifting away of the continental mass that earlier lay to the north of southern New Guinea, a stable continental shelf developed in New Guinea. The outer edge of the shelf trended in the direction now east-southeastward, approximately along the present midline of the island, to a corner at about the present meridian of $145^{\circ} 30^{\prime}$ E., along which, at least by early Tertiary time, the shelf edge trended southward to become the east margin of Australia. New Guinea and the deep ocean floor to the north of it moved rapidly northward during the early Tertiary. Concurrently, an island arc, with a north-dipping subduction zone, converged with New Guinea during the Late Cretaceous and early Tertiary, and the Caroline Sea floor opened north of the arc. The collision of this arc with New Guinea in Miocene time initiated the rise of the medial mountains of New Guinea and sedimentation in the foreland basin to the south of them. The polarity of subduction reversed, and late Tertiary subduction was southward beneath the New Guinea subcontinent as enlarged by the addition to it of the island arc and related materials. Volcanic and granitic rocks formed in southern New Guinea above this new south-dipping subduction system.

\section{LATE MESOZOIC AND EARLY TERTIARY CONTINENTAL SHELF}

Between long $134^{\circ}$ and $144^{\circ} \mathrm{E}$., the south half of the great medial mountain chain of New Guinea consists largely of sedimentary rocks of Middle Jurassic to middle Miocene age deposited on a north-facing continental shelf but now raised high and much deformed. The north half of the medial mountains exposes much Tertiary melange, in which deeper 
water equivalents of the shelf strata were jumbled with ophiolite slices, and with metamorphic rocks including blueschists, during early and middle Tertiary time. The Paleozoic crystalline terrain, extending northward into New Guinea from eastern Australia, stood as a relatively high area during the Jurassic and Early Cretaceous, and the region to the east of it had a history different from that to the north and west, as is discussed in a subsequent section.

The Middle Jurassic and younger sea transgressed broadly across southern New Guinea from the north. Jurassic deposits west of the highlands of Paleozoic rocks are mostly continental and estuarine Upper Jurassic sedimentary rocks in the south, but the section thickens and becomes increasingly marine northwestward and northward (Harrison, 1969; O'Brien and others, 1961). The marine facies in western Papua New Guinea is of dark shale, slate, siltstone, arkose, and quartz sandstone, nearshore quartz sandstone being dominant in the south and deeper water shale and siltstone in the north; the oldest fossils are late Middle Jurassic (H. L. Davies, 1971 b and written commun., 1972; Dow and others, 1972). In Indonesian New Guinea, Middle and Upper Jurassic sandstones give way northward to ammonite-bearing shales, and the facies boundary swings northward with the structural trends into Vogelkop (Hermes, 1968; Visser and Hermes, 1962).

By the end of the Middle Jurassic, an east-west seaway thus lay across southern New Guinea west of the Paleozoic orogenic belt. This seaway might indicate either the tensional thinning of the continent during early stages of rifting away of the East Asian continent presumed to have earlier lain to the north, or the presence of a continental shelf after such rifting was completed.

The Cretaceous and lower Paleogene continue the general Jurassic pattern of clastic sedimentation, reflecting a shelf edge near medial New Guinea, and the formation of a northward-thickening clastic wedge. Varied shallow-water clastic sediments give way northward to deeper water materials (Davies, 1971b; Findlay, 1974; Harrison, 1969; Hermes, 1968; Jenkins, 1974; Jenkins and Martin, 1969). The shallow-water rocks include quartzose and glauconitic sandstones, siltstone, and minor shale. The deeper water strata include siltstone, shale, and, particularly high in the Upper Cretaceous, calcareous mudstone. Shallow platform seas transgressed far southward onto Australia during parts of the Cretaceous, but much of southern New Guinea and what is now the sea to the south of it was emergent during the late Late Cretaceous and early Paleogene. The Lower Cretaceous (and higher? strata) contains much andesitic tuffaceous sediment, and some lava flows and breccias, near the Kubor Range, as discussed previously.

The rest of the Paleogene plus much of the Miocene section is typically shallow-water limestone in the south and deeper water carbonate and clastic sediments in the north (Bain and others, 1972; Bär and others, 1961; Davies, 1971 b; Findlay, 1974; Harrison, 1969; Jenkins and Martin, 1969;
O'Brien and others, 1961; Visser and Hermes, 1962). The upward transition from clastic to limestone sedimentation occurs low in the Paleocene in the west, but well up in the Eocene in the east. Paleogene strata are not generally preserved south of the eastern highlands, where the Miocene mostly lies directly on the Cretaceous or Paleocene. The facies trends in the Paleogene and Miocene follow the sinuosity of the structural trends northwestward into Vogelkop (Hermes, 1968).

The clastic shelf sediments of the late Mesozoic and early Paleogene presumably were deposited in markedly colder water than were the carbonate strata of the later Paleogene. The dominant control of the temperature contrast likely was the decreasing latitude of Australia and New Guinea during the Cenozoic.

\section{TORRES SIRAIT AND GIULF OF PAPUA}

The Paleozoic crystalline terrain, extending northward into New Guinea from eastern Australia, still stands as a basement high and was a higher and more continuous upland during the Jurassic and Early Cretaceous, when the highlands lost altitude in the north and gave way to islands fringed by Jurassic reefs (Harrison, 1969). Lower Jurassic to Lower Cretaceous marine strata thicken, and show increasing water depths, eastward from the highlands (Conybeare and Jessop, 1972). Shallow-water quartz sandstones along the highlands may have formed as barrier bars. Farther east, dark Jurassic shales contain much volcanic detritus. The Jurassic and Lower Cretaceous strata are broadly folded, and a wedge of Upper Cretaceous to lower Eocene argillaceous limestone deposited across them thickens eastward toward the Coral Sea (Tallis, 1975).

The deep ocean floor of the northwestern Coral Sea probably formed during Cretaceous and early Paleogene time, and the Gulf of Papua was enclosed subsequently by the wrapping around the corner of the continent of an island arc, as discussed in other sections of this report. The thick Cenozoic sediments (Papuan Basin, or Aure Trough) beneath the continental shelf at the northwest apex of the Coral Sea presumably overlie oceanic crust. The stratigraphic development of this region, relatively well known from oil-exploration work, has been discussed by Brown, Pieters, and Robinson (1975), Fjelstul, Tallis, and Erickson (1969), Harrison (1969), Jenkins and Martin (1969), Laws (1971), O’Brien, Gray, and Gillespie (1961), Oppel (1970), and Tallis (1975). Upper Cretaceous and Paleogene strata were deposited transgressively across broadly deformed older materials on the developing eastern Australian shelf. A lower Miocene barrier reef formed along the mainland edge of the shelf; much deeper water east of the reef is shown clearly by facies changes. Later Neogene clastic sediments, derived from the north, buried the reefs, which grew concurrently with subsidence and are more than $1 \mathrm{~km}$ thick, and which are now petroleum-exploration targets. On the east side of the Gulf of Papua, the older Miocene is 


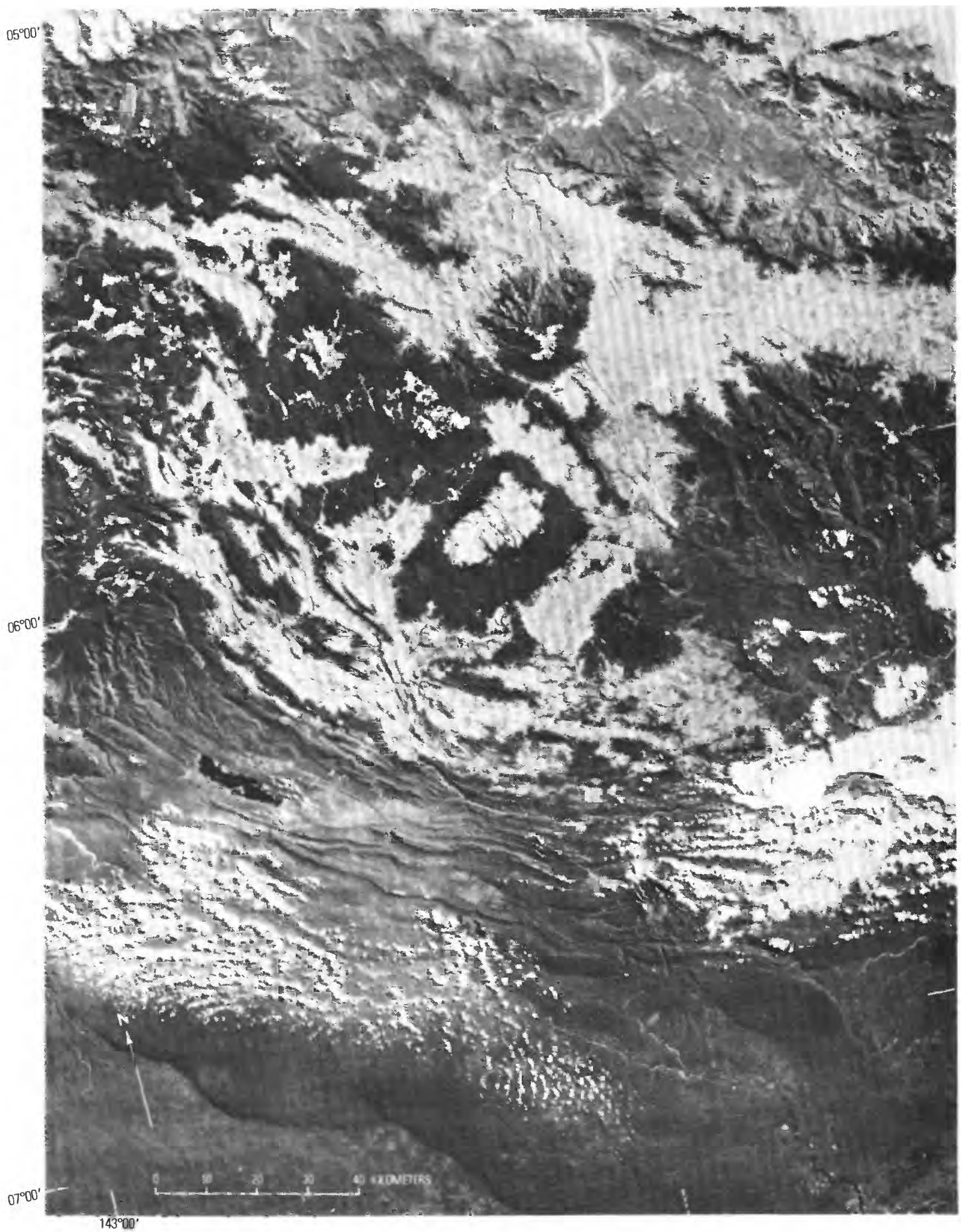

Figure 121.- Landsat image across the structural belts of central Papua New Guinea. NASA-ERTS pictures 1026-00023 and 1026-00030, August 1972 


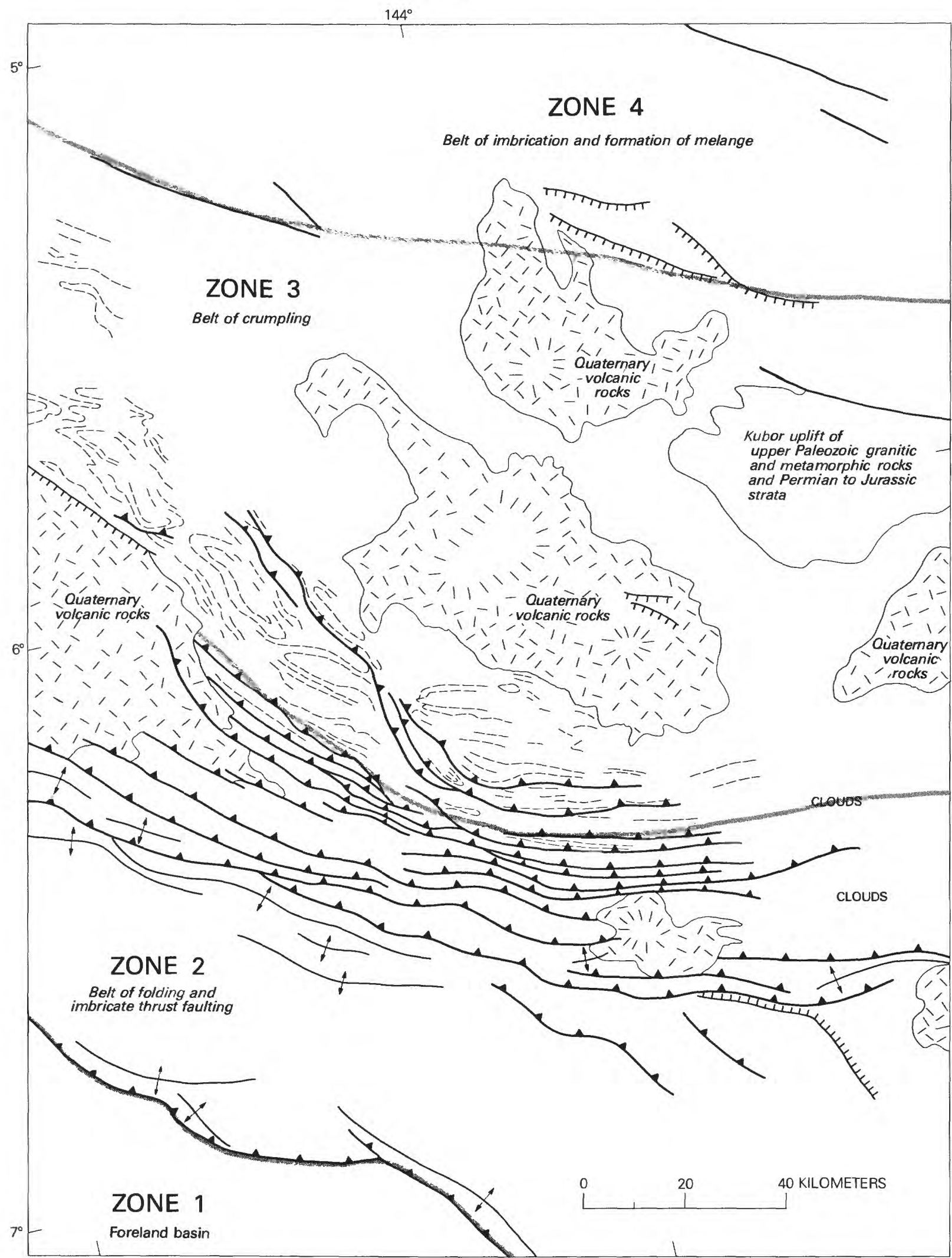

FIGURE 122-Geologic and structural features of central Papua New Guinea. Zones (described more fully in text): 1, foreland basin; 2, belt of folding and imbricate thrust faulting; 3 , belt of crumpling; 4, belt of melange and imbricated rocks. Contacts and structures from Bain and others (1972) and from interpretation of figure 121. 
dominated by mudstone, whereas the younger is composed mostly of graywacke derived from an andesitic and basaltic volcanic arc to the northeast. Pliocene and Quaternary clastic sediments prograded the continental shelf across these varied materials.

\section{NEOGFNF FORELAND BASIN}

The medial mountains of New Guinea formed during late Cenozoic time as the older continental-shelf strata and the melange complexes to the north of them were joined, thrust southward, and raised high above sea level. As the mountains rose, a foreland basin developed along their southern flank, and thick clastic sediments eroded from the mountains were deposited in continental and shallow-marine environments on top of the continental-shelf strata of the older Tertiary. (Foreland basins of similar depositional and structural history characteristically form in front of advancing thrust belts; see, for example, Price and Mountjoy, 1970, and Van Houten, 1974.) The foreland basin began to develop in early Miocene time in western Indonesian New Guinea (Visser and Hermes, 1962), but not until the late middle Miocene in central Papua New Guinea (Dow, 1977). The clastic sediments of the basin were derived primarily from the older shelf strata upraised in the mountains. With time the north edge of the basin became deformed and incorporated into the mountains, while the south edge concurrently transgressed farther onto the old continental platform, and the facies boundary between the clastic sediments of the foreland basin and carbonate strata of the continental platform to the south migrated southward. In southern Papua New Guinea near long $145^{\circ}$ E., the axis of the foreland basin as defined by upper Miocene clastic sediments lay entirely within what is now the foothillsthrust belt; the axis for the Pliocene lay at about the edge of the thrust belt, and the present axis is well out from the mountains (O'Brien and others, 1961).

The rise of the medial mountains is attributed to the collision of a southward-migrating island arc with the Australian-New Guinea continent and to continued convergent tectonics. The greater age of initiation of foreland-basin sedimentation in the west than in the east suggests that the collision occurred earlier in the west than in the east - that the breaking wave of the colliding island arc rolled eastward along the coast with time.

\section{NEOGENE THRUST BELI}

The great medial mountain chain of New Guinea is about $150 \mathrm{~km}$ wide, has crestal altitudes that commonly exceed $4,000 \mathrm{~m}$ and locally exceed $5,000 \mathrm{~m}$, and is compensated isostatically by thick crust (St. John, 1970). The mountains were raised during late Cenozoic time. In the north, deformation was penetrative and low-grade metamorphism widespread. In the south, the strata of the continental shelf broke and moved southward over the old continental basement in imbricate sheets (figs. 121, 122, 123). The structure of the south half of the medial mountains is dominated by late Cenozoic thrust faults, along which the Mesozoic and Paleogene platform and shelf strata have ridden southward. The foreland basin developed along the south edge of the thrust belt concurrently with deformation and received clastic sediments from the new highlands. As the thrust belt expanded southward with time, the older and more northerly foreland-basin strata were incorporated into it.

The structures are known best in Papua New Guinea (Bain and others, 1972; Brown and others, 1975; Findlay, 1974; Jenkins, 1974; Jenkins and Martin, 1969; O'Brien and others, 1961) and in the Gulf of Papua into which the belt goes to sea in the southeast (Fjelstul and others, 1969; Mutter, 1975a; Tallis, 1975). Deformation increases gradually northward across the lowlands toward the mountains. Gentle warps give way to sharp, asymmetric, thrust-broken anticlines, separated by open synclines, and this terrain gives way in turn to one of imbricate thrust faults. Overturning and thrusting are directed southward. Mudstone diapirs rise into offshore anticlines. The character of the deformation is strongly influenced by the stratigraphy: the competent Paleogene and Miocene limestones tend to form large sheets, whereas the incompetent Neogene clastics are deformed complexly. Structures high in the tectonic pile are strongly disharmonic on those beneath. The crystalline basement is not involved in the thrusting in the southern part of the mountains, and the basement surface slopes gradually northward beneath the tectonically thickened wedge of imbricated strata.

Such features are illustrated by figures 121 and 122 . In zone 1, the foreland basin, the basement, and the pre-upper Miocene continental-shelf strata deepen northward beneath clastic sediments that were derived from the thrust belt; Quaternary alluvium forms the surface. In zone 2, the belt of folding and imbricate thrust faulting, rocks at the surface are mostly middle Tertiary shallow-water continental-shelf carbonate and clastic strata and upper Tertiary foreland-basin clastic strata. The basement continues to deepen northward and is not involved in deformation. In zone 3 , the belt of crumpling, rocks at the surface are mostly upper Mesozoic and lower and middle Tertiary clastic strata deposited on the outer continental shelf and, in the far north, on the continental slope and rise, the rocks from which are highly disrupted and slightly metamorphosed. The crystalline basement was involved in regional compression and is raised in the Kubor uplift. Zone 4 is the belt of imbrication and formation of melange in front of a middle Tertiary island arc, whose arrival initiated the compression of zones 2 and 3 ; the zone contains chaotically disrupted rocks like those of northern zone 3 and also tectonic lenses of ophiolite and of glaucophane schist and other metamorphic rocks. The Cretaceous to middle Tertiary volcanic island arc itself lies to the north of zone 4 . Numerous masses of upper Tertiary 


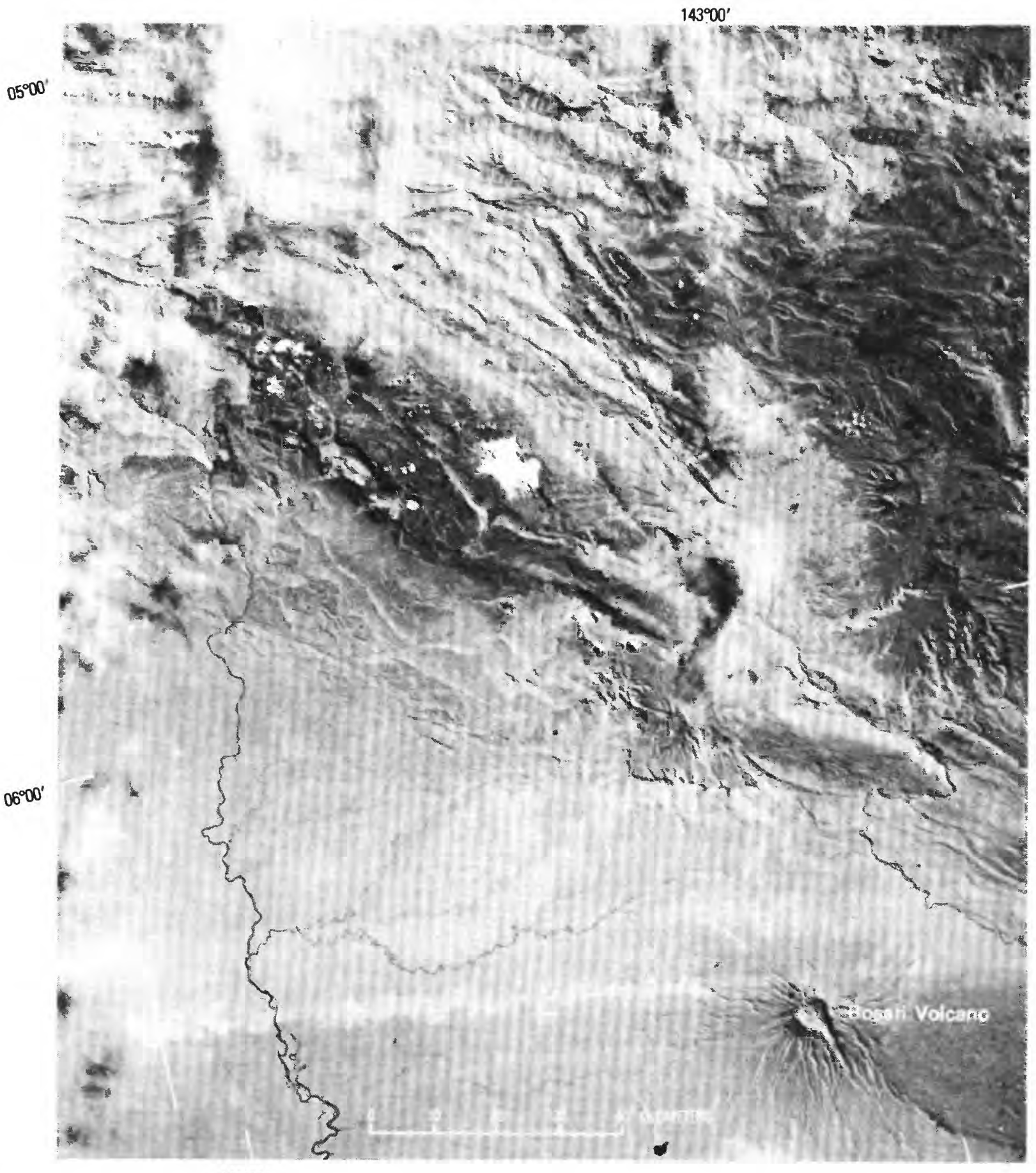

$142^{\circ} 00^{\prime}$

FIGURE 123, - Landsat image of the foreland basin (lower left) and the terrain of folded and imbricated strata, mostly Tertiary, of west-central Papua New Guinea. This view overlaps that of figure 121 from the west. NASA-ERTS pictures 1027-00081 and 1027-00084, August 1972.

volcanic and granitic rocks occur in the area of zone 4 and northern zone 3 but are not indicated on figure 122; these, and the Quaternary volcanic rocks that are shown, formed above a postcollision Benioff zone that dipped southward beneath the continent, as enlarged by the middle Tertiary tectonic addition of the island-arc complex.

Similar deformation continues westward through Indonesian New Guinea (Dozy, 1939; Visser and Hermes, 1962). 
The southern foothills belt of deformed strata is narrower than in Papua New Guinea. In the south is a zone of open anticlines, stepping to the left (individual folds trend more northwestward than does their chain), showing the influence of left-lateral shear on the system. A sharp, narrow anticline of middle Tertiary limestone, breached in part by thrusting, separates these folds from the more highly deformed terrain to the north. The Tertiary limestone is relatively thin in this sector and gives way northward to shales, and the structures developed contrast correspondingly with those of Papua New Guinea. In the east the widespread, thick limestone produces large thrust sheets and rootless folds; in the west the shale-dominated section crumples.

Thrusting decreases in Vogelkop, where deformation is mostly limited to open folding in the foothills south of the exposed Paleozoic crystalline core. As the thrust faults elsewhere along the length of New Guinea represent the southward shuffling of a northward-thickening wedge of continental-shelf strata that is missing in Vogelkop, the lack of a shearable prism of strata is presumably responsible for the difference in structural style. It is, however, possible that a prism of shelf strata, deformed by imbricate thrust faults, has been eroded away from atop the exposed Paleozoic basement terrain.

Thrusting is assumed by some geologists (as, by Findlay, 1974, and O'Brien and others, 1961) to have stopped at about the end of Pliocene time, but this assumption incorporates the circular argument that undeformed strata are Quaternary, whereas deformed ones, not otherwise separable, are Pliocene. Better data have been provided in one area in western Papua New Guinea by Williams, McDougall, and Powell (1972): lower Pleistocene pyroclastic deposits are involved in thrusting, whereas overlying upper Pleistocene materials as old as 750,000 years apparently are not. Here, most of the faulting was older than the lower Pleistocene rocks, but sliding continued after their deposition and may have ceased before late Pleistocene time. D. E. Mackenzie (written commun., 1978) has found rocks younger than 200,000 years to be folded and faulted. It appears likely on figure 121 that structures at the south edge of the deformed belt are still growing.

Bally, Gordy, and Stewart (1966) and Price and Mountjoy (1970) presented masterful analyses of geophysical and geologic data from the analogous belt of late Mesozoic and early Tertiary thrust faulting in the Canadian Rocky Mountains. They showed that such thrusting represents the cratonward spreading by gravity-driven laminar flow of a pile of sediments, away from an interior orogenic terrain of thickening of the rocks above the basement and of rise of the basement itself. The thrusting was inaugurated in a cratonward-thinning wedge of sediments (a miogeocline in the terminology of Dietz, 1964) and resulted in the thickening and shortening of the wedge. The top of the wedge sloped downward toward the craton, providing the gravity drive for the system, but the bottom of the wedge and most of the thrust surfaces sloped upward toward the craton. The conjecture by Mudge (1970) that this thrusting represents simple downhill sliding is disproved by the geometry of the belt, as the papers just cited and also Price (1971) emphasized. The cratonward sliding thickened the pile of sediments atop the basement and depressed the basement so that a foreland basin formed, in which accumulated clastic sediments eroded from the thrust belt. The sliding wedge continued to expand forward, and old foreland-basin strata were incorporated into it as the axis of the foreland basin migrated cratonward in front of the wedge.

The model appears to be applicable to New Guinea, where the driving mechanism for the thrust belt is inferred to have been provided by the island arc that collided with the continent in Miocene time. As the arc crumpled the New Guinea continental-slope sediments in front of it and then ramped up against the continental shelf, the sediments were thickened and the top of the pile raised high above sea level. The strata to the south responded by sliding southward away from the rising welt. The sliding of the base of the pile was upward to the south: thrusting occurred upward onto the craton because the top of the pile had a slope downward toward the craton, and the entire mass behaved in a manner analogous to a continental ice sheet. Compression and sliding are still continuing.

The basement complex beneath the imbricated strata is exposed in medial New Guinea, notably in the large Kubor anticline (figs. 120, 122.) The structural relief of the top of the basement, from the top of the anticline to the floor beneath the thrust belt to the south, is about $10 \mathrm{~km}$, and this led Findlay (1974), Jenkins (1974), and A. G. Smith (1976) to conclude that the imbricate thrusting and disharmonic folding were produced by the gravitational southward sliding of the sedimentary pile downslope and to the pushing of other strata in front of the sliding mass. Although such sliding is indeed likely to have added to the deformation south of the Kubor uplift, it cannot be the entire cause of the thrusting and disharmonic folding that characterize the foothill belt, for that belt runs the length of New Guinea, whereas uplifts of Kubor size do not. The Kubor anticline seems best regarded as another product of the upper crustal compression that is the basic cause of the thrusting and of the other deformation of medial New Guinea.

Both normal and strike-slip faulting also affect the medial mountains in southwestern Indonesian New Guinea. Some of the normal faults were noted by Dow (1968). Strike-slip faulting and its relation to local normal faulting are discussed next.

\section{TARERA FAULT ZONE}

A zone of important left-lateral strike-slip faults trends westward across southwestern New Guinea, south of Geelvink Bay (Teluk Sarera). The zone was recognized onshore by Royal Dutch/Shell geologists, who termed it the Tarera-Aiduna fault zone (Visser and Hermes, 1962). The zone has been traced offshore to the west by geophysical 
methods by Phillips Petroleum Co. Indonesia, whose geologists refer to it as the Adi-Tarera fault zone. I am indebted to A. A. Walker and others of that company for information on the offshore zone and for the radar picture reproduced here as figure 124 .

The conspicuous and apparently active Aria River fault trends westward across the north part of the pictured area (fig. 124). This fault is marked by straight, narrow troughs and welts in the west part of the picture and by a straight, steep fault scarp, downdropped to the north, in the east part. The narrow welts along the fault southeast of Etna Bay may be rumpled from the modern alluvium. The straightness of the fault is evidence for strike-slip character. Although no offset features can be recognized in the picture, the structural geometry at the east end of the fault indicates it to be a left-lateral fault, the north side having moved relatively westward. Eastward, the fault ends at a structural corner from which a normal fault, downdropped to the northwest, trends northeastward. The strike-slip fault apparently bears a transform relationship to the extension recorded by the normal fault. The crustal plate north of the Aria River fault and west of the normal fault is moving westward away from the plate south and east of those faults, and the broad, alluviated Aria River flats are forming in the subsiding zone of crustal extension. The extension permitted by this geometry can be a large fraction of the $15-\mathrm{km}$ width of the flats, as measured in the direction of plate motion. This interpretation predicts that the normal fault may end farther northeast at another corner, from which another left-lateral fault trends eastward, but no data are available from the relevant region to test this prediction.

An inactive strand, here called the Aiduna River fault, of the Tarera fault zone is inferred with little confidence to be present within the area of the radar picture (fig. 124). Just east of the pictured area, this fault juxtaposes west-trending upper Paleozoic strata, on the north, against varied northwest-trending Cretaceous and Tertiary strata for a considerable distance according to Visser and Hermes (1962, pl. 1, sheet 2), who drew the fault as extending far to the east-northeast through poorly known mountains. Along the Buru Mountains in and south of the southwest part of the pictured area, the position of the inferred fault is marked by a steep gravity slope of at least 30 milligals (Visser and Hermes, 1962, pl. 1, sheet 2), showing that young basin fill thickens abruptly on the downdropped south side of the structure.

Offshore to the west, the fault zone produces a broad belt of confusing reflection records. Contrasts in fold patterns and in reflection stratigraphy on opposite sides of the zone are interpreted by Phillips geologists to suggest that the fault zone has undergone about $50 \mathrm{~km}$ of offset since about the middle of Pliocene time. The fault projects farther west to approximately bound the bathymetric Aru Basin on the north; crustal shifts, segmentation of the subducting plate, or rifting behind a rotating Vogelkop might be inferred to explain the basin.

If the Tarera fault system does have large displacement, then it must continue farther east in medial New Guinea, through mountainous country whose topography and geology are poorly known. Perhaps the fault system is related to some of the great faults inferred by Australian geologists (Bain and others, 1972) to trend eastward across the northern part of medial Papua New Guinea.

\section{CONJECTIURAL OFFSETS BETWEEN AUSTRALIA AND NEW GIIINEA}

Audley-Charles, Carter, and Barber (1975), Carey (1958, 1970), and Rod (1966) are among those who have speculated that southern New Guinea and northern Australia were in relative positions quite different early in Mesozoic time than they are now and that they moved together by some complex series of strike-slip, divergent, and convergent motions on otherwise unknown structures. Such conjectures are incompatible with the continuity of the upper Paleozoic granitic and volcanic terrain, and its flanking and overlying Mesozoic sedimentary assemblages, northward through eastern Queensland, Torres Strait, and southern New Guinea to medial New Guinea.

\section{MISOOL}

The island of Misool (or Misol) stands at the southwest edge of the continental shelf of Vogelkop, just northeast of the Seram Trench. Misool exposes Mesozoic and Cenozoic strata, mostly in shelf facies, in the north-dipping limb of an eastward-plunging anticlinorium (van Bemmelen, 1949, p. 69-71, 153, 154; Froidevaux, 1975; Hermes, 1974; Vogler, 1941; Wanner, 1910). Middle Triassic shale and sandstone, about 2,000 $\mathrm{m}$ thick, were deformed before the deposition of thin Upper Triassic marl, shale, and reef limestone. A small area along the southwest coast, at the lowest part of the section, exposes phyllite, which may be either metamorphosed Triassic rocks or pre-Triassic basement. The Jurassic section, transgressive across the Triassic, begins with coarse quartzose sandstone and conglomerate, which give way upward to shallow-marine calcareous shale and limestone, rich in belemnites and ammonites, with coal interbeds; above these in turn is deeper water fossiliferous limestone and calcareous shale. The total Jurassic thickness is about $600 \mathrm{~m}$. The Lower Cretaceous consists of hard limestone, containing nodules and layers of red chert, about $400 \mathrm{~m}$ thick, whereas the Upper Cretaceous is represented by $450 \mathrm{~m}$ of shallow-water siltstone, sandstone, calcareous shale, and calcarenite. The lower Eocene has a basal coarse sandstone, which contains silicified wood, but is mostly calcareous shale, whereas the upper Eocene and, where present, the Oligocene, are mostly finely crystalline, massive, fossiliferous shallow-water limestone, in part dolomitic. The Paleogene section is about $1,500 \mathrm{~m}$ thick. The Miocene strata of Misool overlap successively older rocks westward, 


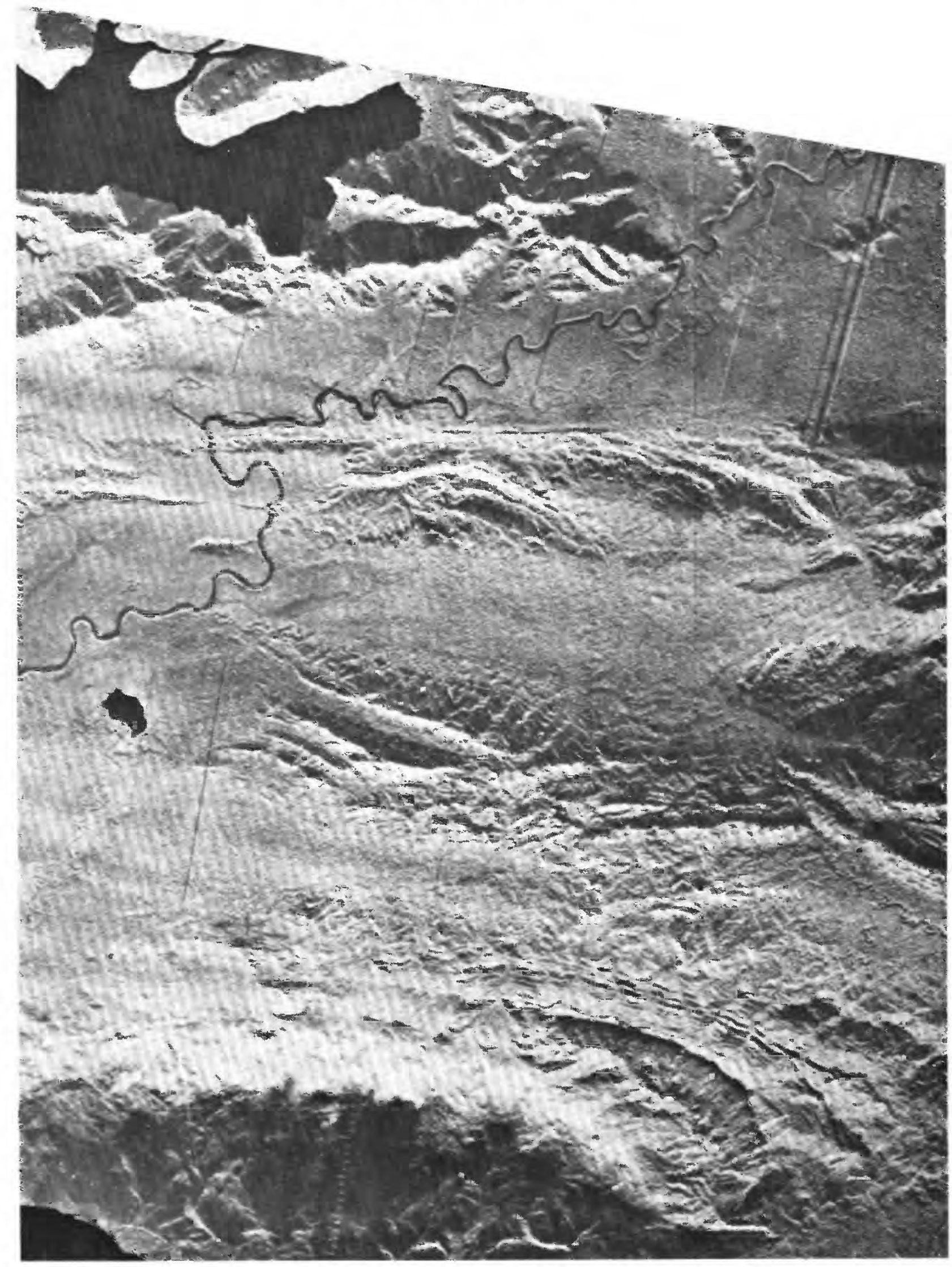


FIGURE 124.- Side-looking radar image showing geologic structure of part of the Tarera fault zone and other features, southwest New Guinea. Prepared by Raytheon Co. and provided by Phillips Petroleum Co. Indonesia. NOTE.-The picture is a mosaic of strips scanned alternately from the north-northeast and the south-southwest, and the apparent direction of topographic shading reverses accordingly. See figure 125 for location and interpretation.

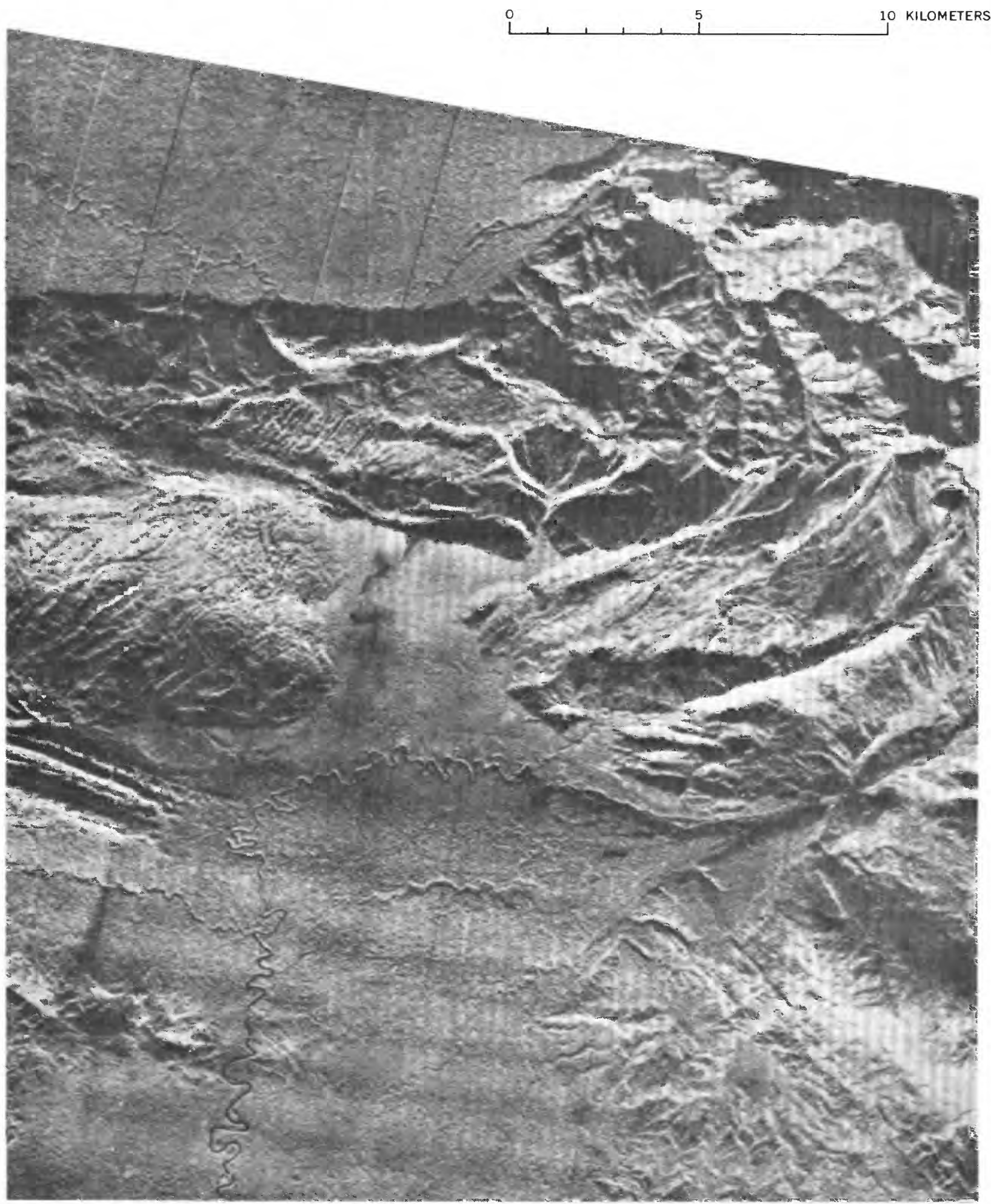




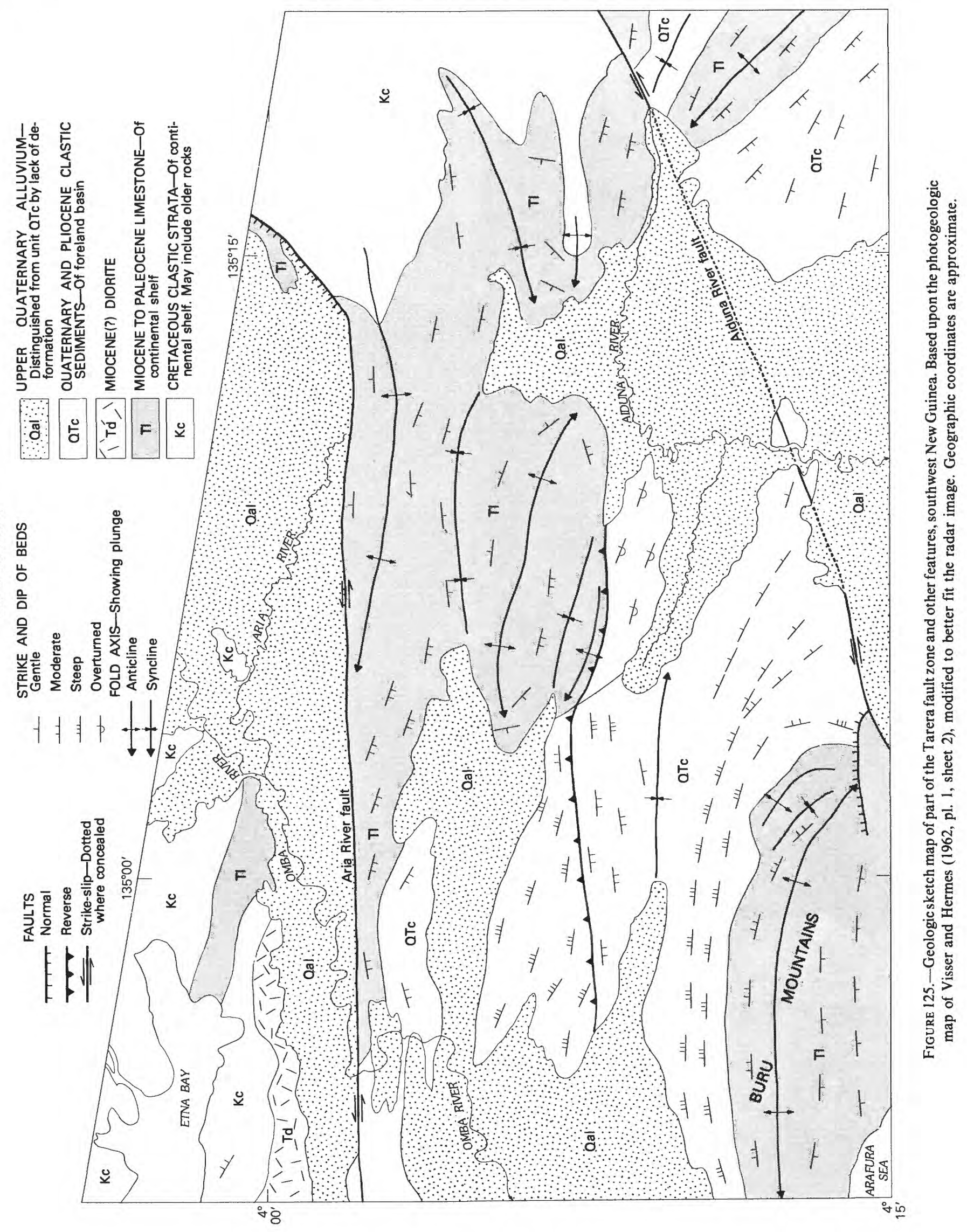


and upper Miocene lies on the Cretaceous in the far west. The lower Miocene consists of less than $600 \mathrm{~m}$ of soft, sandy limestone and interbedded platy limestone, and the upper Miocene is mostly hard, massive, fossiliferous coralline limestone, which thins westward from 700 to $100 \mathrm{~m}$. Pliocene siltstone grades upward to sandstone and is overlain by high Pliocene and Quaternary reef limestone.

Integration of stratigraphic data from Misool with that from wells and outcrop areas in the surrounding regions indicates that the clastic materials in the Mesozoic of Misool came mostly from the north, rather than from the south as was generally the case farther east in New Guinea, and that northwestern New Guinea was not wholly covered by the sea until about late Eocene time (Froidevaux, 1975). Pliocene clastic sediments also were derived from the north.

Deformation decreases northward. Southern Misool and the islands to the south display steep to moderate folds and a steep thrust fault, directed northward, involving Paleogene and Mesozoic strata (Froidevaux, 1975). Dips are gentle in northern Misool.

Van Bemmelen (1949, p. 69) emphasized that the upper part of the Jurassic of Misool resembles in facies and faunas that of Seram and Buru, whereas the lower part of the Jurassic resembles that of the Sula Islands. The first similarity is explained in this report as due to the imbrication of New Guinea shelf sediments into the subduction melange of Seram and Buru. The second similarity is interpreted as due to the transport far to the west, along left-lateral faults, of a small continental mass that in Mesozoic time was part of Vogelkop. The Paleogene and Miocene strata of Misool also are matched by similar rocks within the melange of Seram.

CRETACEOUS TO EARLY MIOCENE ISLAND ARC AND ITS COLLISION WITH NEW GUINEA IN MIOCENE TIME

The Cretaceous, Paleogene, and early Miocene complexes of the north half of New Guinea are, in order northward, a broad belt that includes much subduction melange; large masses of ophiolite, of which at least the only well-studied example dips and tops northward; and a belt of island-arc volcanic rocks. These are interpreted to belong to a south-facing island arc that migrated southward as New Guinea and Australia moved northward, the intervening ocean disappearing beneath the arc until it collided with New Guinea in Miocene time.

\section{MELANGE OF NOR THERN MEDIAL NEW GUINEA}

A belt, $50 \mathrm{~km}$ or so wide, of Cretaceous and Paleogene subduction melange runs the length of the medial mountains of New Guinea, forming generally their north slopes (figs. 120,126 ). The belt is bounded on the south mostly by the deformed shelf sediments of the crest and south slopes of the mountains, and on the north it disappears beneath the upper Tertiary and Quaternary fill of elongate basins.

The melange belt between long $145^{\circ} 30^{\prime}$ and $144^{\circ} \mathrm{E}$. was mapped by Bain and Mackenzie (1975; their Asai Shale and
Wulamer Beds) and Dow and Dekker (1964). Sedimentary rocks within the sheared and variably metamorphosed melange range in age from Late Cretaceous to early Miocene. An ophiolite mass (Marum Basic Belt, and part of the Kumbruf Volcanics, of Bain and Mackenzie, 1975), $100 \times 20 \mathrm{~km}$, lies within the belt (fig. 120) and is shown by gravity anomalies to dip northward (Milsom, 1975).

The melange belt in western Papua New Guinea, from $144^{\circ}$ to $141^{\circ} \mathrm{E}$., was examined in reconnaissance by Davies (1971b), Dow, Smit, Bain, and Ryburn (1972; their Salumei Formation, Salumei Metamorphics, Gufug Gneiss, and April Ultramafics), and Paterson and Perry (1964). South of the melange, Jurassic, Cretaceous, and Paleogene strata in shelf facies give way northward to progressively deeper water facies and become progressively more deformed, and the south border of the melange is drawn on the tectonic map approximately where the shearing of these rocks becomes severe. The southernmost $10 \mathrm{~km}$ or so of the melange belt as so designated consists of highly deformed terrigenous clastic sediments, metamorphosed at very low grade in their northern part. The rest of the belt, which has a total width generally near $50 \mathrm{~km}$, includes much polymict melange. Present are intersheared ultramafic rocks, high-pressure metamorphic rocks, slate, marble, and sedimentary rocks including Eocene limestone. The high-pressure metamorphic rocks include a mass $50 \mathrm{~km}$ long and several kilometers wide, the Gufug Gneiss, of coarse glaucophane schist and eclogite, and numerous smaller masses of greenschist and of lawsonite-glaucophane and glaucophane-epidote schist and phyllite. Ultramafic rocks form one mass $60 \mathrm{~km}$ long and are ubiquitous elsewhere as small, sheared lenses.

Higher temperature metamorphic rocks occur north of the blueschist terrain and south of the Sepik and Markham-Ramu lowlands in Papua New Guinea (Hunstein, Jimi, and Bismarck terrains on figure 120). The Jimi terrain is dominated by Mesozoic rocks, and Mesozoic materials occur within the Bismarck terrain; both were discussed in a prior section on Mesozoic complexes. The largest region of exposures of these northern metamorphic rocks is the Hunstein terrain of figure 120 , in the low ranges south of the Sepik lowlands between long $141^{\circ} 00^{\prime}$ and $143^{\circ} 30^{\prime} \mathrm{E}$. The rocks here are mostly in greenschist facies, but amphibolite-facies rocks are common, particularly in the west, and metamorphosed mafic and intermediate intrusive rocks are also present (Dow and others, 1972: their Hunstein Complex, Ambunti Metamorphics, and Chambri Diorite; also Paterson and Perry, 1964). Slate, phyllite, and sericite schist are dominant in the east, whereas biotite and muscovite schists are abundant in the west, where many rocks contain hornblende, garnet, kyanite, staurolite, sillimanite, or diopside. As Dow, Smit, Bain, and Ryburn (1972) emphasized, the high-temperature and low-pressure character of much of this metamorphism contrasts markedly with the low-temperature, high-pressure metamorphism to 


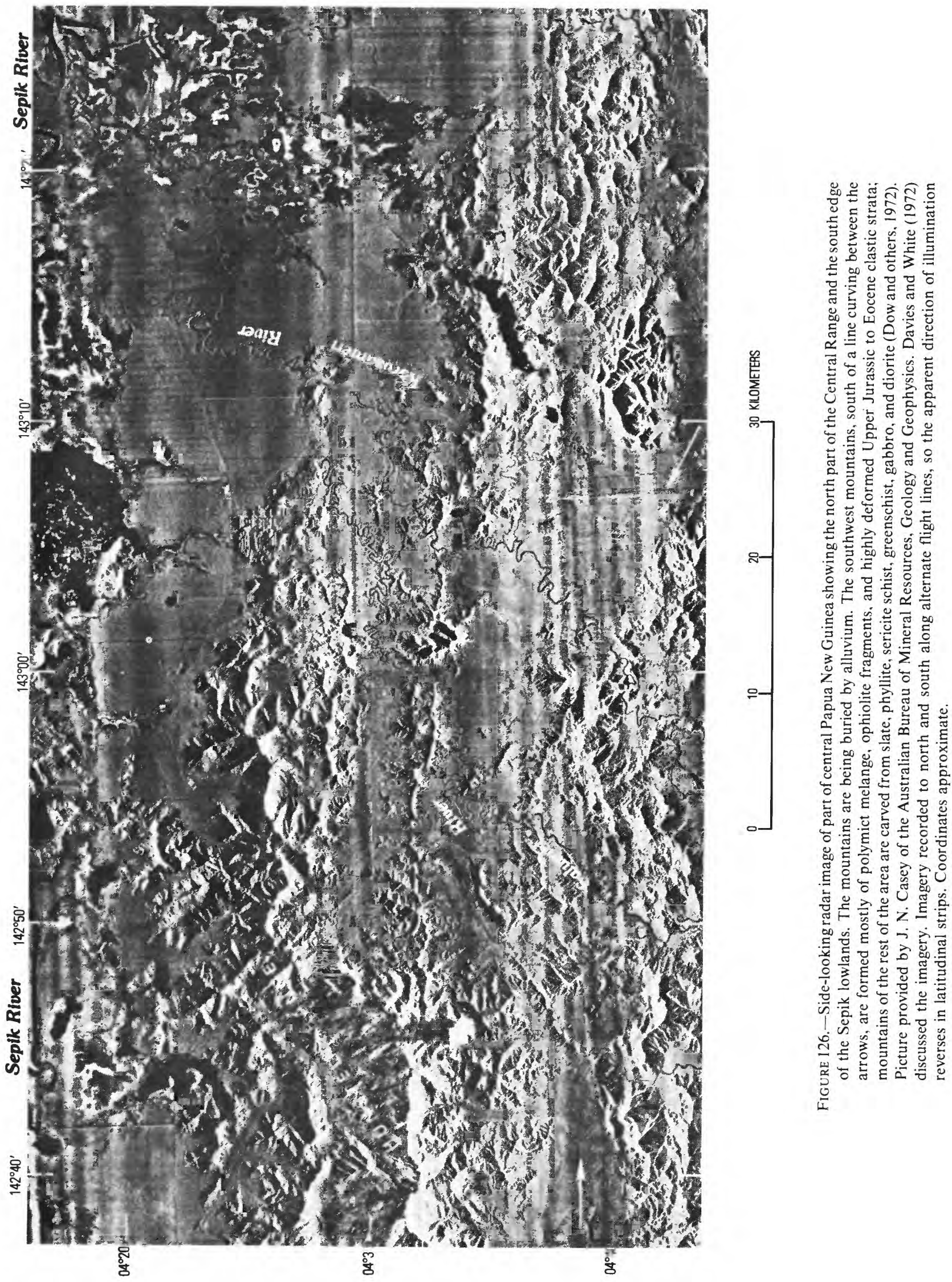


the south. The rocks are dated in the field only as older than lower Miocene strata. Reconnaissance $\mathrm{K}-\mathrm{Ar}$ and $\mathrm{Rb}-\mathrm{Sr}$ dating of both metamorphic and plutonic rocks in this terrain indicates only early Miocene and late Oligocene ages of 20-27 m.y. (Page, 1976). Perhaps this northern metamorphic terrain has been transported from the Owen Stanley terrain, which is truncated by major left-lateral faults farther east (fig. 120); perhaps the terrain is part of the magmatically heated island-arc terrain; or perhaps the terrain was heated by hot, young oceanic lithosphere thrust over it. (Compare Brookfield, 1977, and Woodcock and Robertson, 1977.) The high-temperature metamorphic terrain is included with melange on plate 1.

The Indonesian sector of the melange belt, from long $141^{\circ}$ E. to Geelvink Bay (Teluk Sarera) at $136^{\circ}$ E., is known only from extremely sketchy reconnaissance. Here also, ophiolite slices and probable melange form a belt $50 \mathrm{~km}$ or so wide, lying between the crest of the medial highlands and the broad lowlands, in this case the Meervlakte (Lake Flat) to the north. The northern part of the belt is dominated by ophiolite, the medial part by metamorphic rocks, and the southern part by highly deformed sedimentary rocks. A very large ophiolite sheet, its top to the north, may be present west and south of the western Meervlakte, where Visser and Hermes (1962) show extensive gabbro and peridotite. The metamorphic rocks are dominantly greenschists, derived partly from sedimentary rocks (Bär and others, 1961; Visser and Hermes, 1962), but glaucophane schist is present also (Verhofstad, 1966). South of the metamorphic rocks are highly deformed marine clastic sediments, of continental derivation and of Jurassic to at least Paleocene age (Visser and Hermes, 1962; van der Wegen, 1966). The deformation in these last-noted materials decreases southward, and the southern contact of melange is drawn arbitrarily within them on the tectonic map.

The metamorphic rocks of Wandamen Peninsula, in southwestern Geelvink Bay (Teluk Sarera) at $134^{\circ} 30^{\prime} \mathrm{E}$., described in the prior section on the Paleozoic basement complex of Vogelkop, may belong to the Tertiary melange terrain.

OPHIOLITE OF PAPIIAN PENINSULA

An enormous ophiolite sheet-a large slab of oceanic crust and mantle-is thrust southwestward onto eastern New Guinea (Davies, 1971a, 1976; Davies and Smith, 1971). The sheet is $400 \mathrm{~km}$ long (of which 250 are within the area of the tectonic map of the Indonesian region) and $40 \mathrm{~km}$ wide and forms a crescentic belt concave to the northeast. The sheet dips gently to moderately northeastward (Finlayson, Drummond, and others, 1976, 1977; Milsom, 1973; St. John, 1970) and has a maximum thickness of about $15 \mathrm{~km}$ (Finlayson, Muirhead, and others, 1976). The top $4 \mathrm{~km}$ consists of massive and pillow-lava low-potassium basalt, plus minor dacite. The next $4 \mathrm{~km}$ is of low-potassium gabbro, of which the upper $1 \mathrm{~km}$ is diabasic, and the rest is granular and includes much cumulate gabbro. Below the gabbro are 8 $\mathrm{km}$ of ultramafic rocks. The thin upper part of the ultramafic mass consists of cumulate peridotite, no more than $500 \mathrm{~m}$ thick, which contrasts strikingly with the thick lower part, of metamorphic-textured peridotite (harzburgite) and subordinate dunite and enstatite pyroxenite. The rocks are variably altered. Much of the basalt is now spilite or low-grade greenstone, and the ultramafic rocks are partially serpentinized. Upper Cretaceous pelagic foraminifers occur in marl with pillow lava at the east end of the complex. Two gabbros have K-Ar ages of 147 and 150 m.y., and one basalt has a K-Ar pyroxene age of $116 \mathrm{~m} . \mathrm{y}$.

The rock types, succession, and thicknesses indicate the ophiolite to be a huge slice of oceanic crust and mantle (Davies, 1971a). The basalt and gabbro are the crust, the ultramafic rocks the mantle. The basalt, gabbro, and cumulate ultramafics formed at an oceanic spreading center in Late Jurassic or Early Cretaceous time. The metamorphosed ultramafic rocks are old mantle, such as formed the bulk of the lithospheric plate on which the new crust formed. These metamorphosed ultramafic rocks have little-varying, highly magnesian mineral compositions, in accord with the concept that they are refractory mantle residues left after melting and migration of more fusible components, whereas the same minerals in the younger cumulate ultramafites show greater ranges and less magnesian compositions (England and Davies, 1973).

A broad belt of subduction melange lies beneath and southwest of the ophiolite thrust sheet. The explanation is developed in a subsequent section that the ophiolite sheet is the basement beneath an island arc that collided with New Guinea in Miocene time and that the melange formed by subduction in front of the advancing arc. The ophiolite sheet is intruded by Eocene quartz diorite and overlain by Eocene andesite, and rocks metamorphosed beneath the hot thrust sheet have an Eocene metamorphic age (Davies, 1976). The island arc of which the ophiolite forms the basement was thus active in Eocene time.

CRETACEOUS, PALEOGENE, ANI IOWER MIOCINE VOLC.INIC:ARC:

The exposures of the broad melange belt are in most sectors bounded on the north by the fill of the wide Meervlakte, Sepik, and other lowlands, or in part of the Sepik sector by terrains of high-temperature, low-pressure metamorphic rocks extending to those lowlands (fig. 120). Between these basins and the north coast is another mountainous belt, $100 \mathrm{~km}$ or so wide, known as the Northern Divide Ranges (or Van Rees Mountains) in Indonesian New Guinea, and as the Adelbert, Finisterre, Torricelli, and other ranges in Papua New Guinea (fig. 118). These northern mountains, described in this section from east to west, consist of deformed upper Miocene and younger sediments overlying Cretaceous, Paleogene, and lower Miocene complexes that are regarded as products of the magmatic part of the island arc of which the melange to the 
south is another manifestation. Detailed field and petrologic studies of these rocks are needed to permit more thorough interpretation.

The Adelbert Range and Finisterre Mountains, in northeastern New Guinea between long $145^{\circ}$ and $148^{\circ} \mathrm{E}$. (fig. 118), expose Eocene pelagic and hemipelagic sediments overlain by Oligocene and lower Miocene mafic and intermediate breccias, volcaniclastic sediments, and subordinate submarine lavas (Jaques, 1976a; Jaques and Robinson, 1975; Robinson, 1974; Robinson and Jaques, 1974a, b). The igneous rocks are mostly potassic basalt and low-silica andesite. Dips are dominantly northeastward. The volcanic rocks are overlain with strong unconformity by little-deformed middle or upper Miocene and younger strata, dominantly limestones, and locally by mafic volcanic rocks. Late Quaternary uplift has exceeded $600 \mathrm{~m}$ along parts of the north coast (Chappell, 1974). South of the Finisterre Mountains, the northeastern part of the great ophiolite sheet of eastern Papua New Guinea is intruded by stocks of quartz diorite, of which a number of samples have $\mathrm{K}-\mathrm{Ar}$ ages of 50-55 m.y., and is overlain by Eocene andesite (Davies, 1976). The quartz diorite and andesite presumably belong to the magmatic arc. The middle Tertiary rocks and history of the Adelbert-Finisterre terrain resemble those of the northern part of New Britain, which now lies in echelon to the northeast but which might in early Miocene time have lain farther east on strike in the same arc system. Upper Oligocene and lower Miocene basalt, andesite, and dacite near the north coast of the Papuan Peninsula in the area about $149^{\circ} 45^{\prime} \mathrm{E}$. (Smith and Davies, 1976) may belong to the same or a different arc.

The pre-middle Miocene rocks of northwestern Papua New Guinea, in the Oenake Range and the Bewani, Torricelli, and Prince Alexander Mountains, north of the Sepik lowlands between $141^{\circ} \mathrm{E}$ and $144^{\circ} \mathrm{E}$. (fig. 118), also belong in large part to the magmatic-arc terrain (D. S. Hutchison, 1975; also Robin Beiers, written commun., 1969; Harrison, 1969; Hutchison and Norvick, 1975a,b; Marchant, 1969; and Norvick, 1975). Crystalline rocks dominate the higher parts of the ranges and include variably altered mafic and intermediate lava, pillow lava, breccia, and tuff, comagmatic plutonic rocks, and greenstone, greenschist, and amphibolite. The older of the dated volcanic rocks are Paleocene and Eocene, are dominantly basaltic, and contain minor intercalated limestone that is of deep-water origin in the older sections but includes shallow-water material in younger sections (D. S. Hutchison, 1975). The younger volcanic rocks are of late Oligocene and early Miocene age, include much andesite and some dacite and rhyolite, and contain intercalations of shallow-water limestone. These assemblages thus record typical petrologic and bathymetric development of an island arc. Foraminifers of possible Late Cretaceous age have been found in one area, and reworked Upper Cretaceous foraminifers occur in younger sediments (D. S. Hutchison, 1975). The plutonic rocks are dominated by gabbro, diabase, and diorite but include subordinate granodiorite, monzonite, and quartz monzonite, and rare ultramafic rocks. Reliable K-Ar age determinations for the plutonic rocks are mostly Late Cretaceous and late Eocene to early Miocene (D. S. Hutchison, 1975). Volcanic and plutonic rocks are low in alkalies and moderate to high in alumina and are chemically intermediate between tholeiitic and calc-alkalic arc rocks (D. S. Hutchison, 1975). In the Prince Alexander Mountains, much-sheared and more silicic plutonic and metamorphic rocks are present (D. S. Hutchison, 1975). Variably mylonitized granodiorite, diorite, diabase, amphibolite, and quartz-biotite schist are common and have $\mathrm{K}-\mathrm{Ar}$ ages mostly near $100 \mathrm{~m} . \mathrm{y}$. These rocks are intruded by andesite dikes and more silicic porphyries, which have K-Ar ages of about 20-25 m.y. Gabbro and cumulate ultramafic rocks dominate one area; clinopyroxene is the dominant mineral in the ultramafic rocks, which thus likely belong to arc rather than oceanic-mantle magmatism. Variably metamorphosed metasedimentary and metavolcanic rocks in the southern part of the arc terrain are mostly undated, but Late Cretaceous and Eocene foraminifers have been found locally in associated limestone (D. S. Hutchison, 1975). A belt of polymict melange about $20 \mathrm{~km}$ trends along the northern part of the several ranges (Dow, 1977). Middle Miocene and younger nonvolcanic sediments overlie these various comrlexes unconformably.

Within Indonesian New Guinea, all the Upper Cretaceous to lower Miocene rocks north of the melange-and-ophiolite terrain are assigned to the volcanic-arc complex on the tectonic map. The inadequate basis for this assignment lies in the brief descriptions by van Dun (1962), Visser and Hermes (1962), and Zwierzijcki (1924). The most abundant rocks are basic and variably altered (but otherwise undescribed) volcanic rocks and volcanigenic clastic sediments. Basic intrusives, pelagic silicic and carbonate strata, and (in the Oligocene and lower Miocene only) shallow-water limestone are also common. The sedimentary rocks are dated by foraminifers in many places as of Late Cretaceous, Paleogene, and early (and middle?) Miocene ages. The volcaniclastic sedimentary rocks are dominantly turbiditic sandstone, siltstone, and shale. Also present in small areas within the terrain are schists and ultramafic rocks; the latter might be cumulates formed within the magmatic arc or else be part of the oceanic crust and mantle upon which the magmatic arc was formed. The shallow-water limestones high in the piles may record the time late in the history of the arc when islands were common and fringed by reefs. The upper part of the Miocene is generally missing in this region, and the upper Neogene sediments are nonvolcanic and are interpreted in a subsequent section as postdating the collision of island arc and New Guinea. Much more information is needed on the petrology of the volcanic rocks and on the relationships between the various rock 
assemblages before such interpretations can be made with any confidence.

The Tamrau Mountains of far northern Vogelkop, north of the Sorong fault zone, and of northeastern Vogelkop between the Ransiki fault and Geelvink Bay, include widespread intermediate lavas, pyroclastic rocks, and porphyries (d'Audretsch and others, 1966; Robinson and Ratman, 1977, 1978; Valk, 1962). Andesite is dominant and some basalt, dacite, and rhyodacite occur. Intercalated shale and limestone include upper Oligocene or lower Miocene fossiliferous strata (Valk, 1962). The volcanic section is overlain by upper Neogene strata and is assumed by d'Audretsch, Kluiving, and Oudemans, (1966) and Visser and Hermes (1962) to correlate with Paleogene andesites farther east in northern Indonesian New Guinea. Presumably the volcanic rocks belong to the Paleogene island arc. Granite of likely Permian or Triassic age and melange of post-Jurassic age also occur north of the Sorong, so geologic relationships must be complex.

\section{ISLANDS NORTII OF GEELVINK BAY}

Deep, triangular Geelvink Bay (Teluk Sarera) is closed on the north by the platform upon which stand Yapen (Japen), Biak, Supiori (Soepiori), and several smaller islands. The islands, whose geology was described briefly by Visser and Hermes (1962), are inferred to be fragments of the Paleogene volcanic arc that is exposed widely in northern New Guinea. Geelvink Bay may be closed by crustal masses dragged across to the north of it along faults of the Sorong system.

Long, narrow Yapen Island consists mostly of mafic rocks (greenschist, gabbro, porphyritic basalt and andesite, breccia, tuff) and possibly serpentinite and peridotite (Visser and Hermes, 1962). Volcaniclastic graywacke and clay intercalated with the volcanic rocks have yielded lower Miocene fossils, partly from shallow-water environments; poorly dated Miocene limestone overlies(?) the section. Dips are mostly moderate to steep. An assignment to the Paleogene and lower Miocene volcanic-arc assemblage of northern New Guinea is suggested on the tectonic map. The similarity of the rock types and apparent stratigraphy to those of the Jayapura (or Djajapura; previously Sukarnapura, and before that Hollandia) region, on the north coast near $141^{\circ}$ E., was emphasized by Visser and Hermes (1962, p. 111). The island appears to be a large sliver within the left-lateral Sorong fault system, and it might have been torn from an initial position closer to Jayapura and transported westward $600 \mathrm{~km}$ or so. Pliocene and Quaternary limestone, marl and volcanigenic sediments are little deformed.

Biak and Supiori Islands expose crystalline rocks in only one small area each, and these are mentioned vaguely as basalt, tuff, schist, and serpentinite by Visser and Hermes (1962). Otherwise, the islands expose moderately deformed upper Oligocene or Miocene limestone and marl, and gently dipping Pliocene and Quaternary marl and reef limestone. It is not clear from the fragmentary published descriptions whether the crystalline rocks belong to a volcanic-arc assemblage or an ophiolitic complex. The arc designation is suggested on the tectonic map and, like nearby Yapen, Biak and Supiori might have been torn from farther east in northern New Guinea and transported to their present sites along faults of the Sorong system.

\section{INIERPREITATION OF THE ISI AND ARC:}

The pre-middle-Miocene rocks of northern New Guinea form three great belts. On the south is the belt of subduction melange. The southern part of this melange represents the crumpled terrigenous clastic sediments of the upper Mesozoic and Paleogene continental slope of New Guinea, and the rest is polymict melange containing many exotic elements. In the middle is a belt containing small to enormous masses of ophiolite. Farthest north is another broad belt, formed largely of submarine mafic and intermediate volcanic rocks and their intrusive and volcanigenic-sedimentary equivalents. These three belts are regarded as parts of an island arc that migrated southward during the Late Cretaceous and Paleogene and collided with the previously stable northern margin of New Guinea during Miocene time. Such an explanation was proposed by Davies and Smith (1971) for the Papuan peninsula and by me (Hamilton, 1970a) for all of the island and has been adopted by many others since.

Of the ophiolite masses, only the great sheet of the Papuan Peninsula has been studied in any detail. It dips northeastward, is right side up, overlies a thick mass of subduction melange, and lies south of, but in unseen relationship to, and also beneath, volcanic rocks of island-arc type. Presumably the ophiolite is a slab of oceanic crust and mantle, generated at a spreading center, which formed the hanging wall of an island-arc system whose subduction zone is recorded by the melange to the south and whose magmatic arc is the belt above and to the north.

This explanation appears to fit the geology of the rest of northern New Guinea also. The magmatic arc in the north has an age of Late Cretaceous, Paleogene, and early Miocene. The subduction melange in the south incorporates sediments of various ages from Jurassic to early Miocene, but the older sediments are New Guinea shelf-and-slope strata that predate subduction. The island arc was itself likely a composite of the products of several subduction systems.

The shelf edge of the late Mesozoic, Paleogene, and early Miocene north margin of the Australia-New Guinea continent lay along what is now the medial mountain system of New Guinea. Open water then lay to the north, for the shelf sediments show increasing water depths northward, and little of their clastic component was derived from the north. New Guinea had a northern margin comparable to that of the eastern United States now, with a stable continental shelf, continental slope, and deep ocean floor beyond it. That deep ocean floor was, however, being subducted beneath the south-facing island arc, and the ocean narrowed until the arc collided with the continent. The deep-water 
strata north of New Guinea were incorporated in the melange at the front of the arc, and as the arc ramped up onto the continental slope, the strata of the upper slope and shelf were highly deformed. The medial mountains of New Guinea began to form at this time, as the old shelf sediments were crumpled, raised, and thrust southward. A basin formed to the south of the mountains and received clastic sediments from the new mountains. The collision of the Banda Arc with Australia and New Guinea, described in prior sections, represents an earlier stage of a similar process.

The collision occurred within early and middle Miocene time. In Papua New Guinea, lower and middle Miocene rocks are in shelf facies south of the suture zone, lower Miocene rocks are involved in the melange, and island-arc volcanism in the north continued into the early Miocene: the collision occurred not earlier than the late early Miocene. Calc-alkalic magmatic rocks were erupted through the old shelf terrains in both eastern and western Papua New Guinea as early as the middle Miocene (Page and McDougall, 1972), so a Benioff zone likely then dipped southward beneath the continent, suggesting that the collision was completed and the polarity of subduction reversed by the middle Miocene, and that a new subduction zone formed quickly, dipping southward beneath the continent as enlarged by the addition of the island arc. In western Indonesian New Guinea, foreland-basin clastic sediments appear first in the lower Miocene, so the collision occurred there before it did in the east, where such sediments appear in the middle Miocene. An oblique collision is inferred, the island arc "beaching" at about the beginning of the Miocene in the west but perhaps 10 million years later in the east.

The concept of an island arc migrating southward during Late Cretaceous and early Tertiary time and then colliding with New Guinea predicts that the ocean floor to the north of New Guinea should have formed behind the arc. As is discussed subsequently, this prediction is consistent with the results of two drillholes of the Deep Sea Drilling Project north of New Guinea, which encountered Oligocene and younger sediments resting on basalt presumed to be oceanic basement.

IRRHAI, OF IIIF, MELANESIAN FI,ORA

One of the major biogeographic puzzles of Australia, the source of its tropical Melanesian flora, may be explicable in terms of the middle Tertiary collision of the island arc with New Guinea. The modern Australian flora has evolved from three major stocks (Good, 1957, 1963; also Schuster, 1976). Two of these-a wet-temperate assemblage characterized by southern beech (Nothofagus) and podocarpaceous and araucarian conifers, resembling the flora of southern South America and New Zealand, and a dry-temperate assemblage related to that of southern Africa-arrived long ago, likely both within Cretaceous time, and have evolved together in profound isolation from the rest of the world. The third major stock, the tropical Melanesian flora, derived long ago from the Asian tropics, cannot have been long in contact with the two temperate Australian floras, because a profound taxonomic contrast exists between the temperate and Melanesian assemblages.

The Melanesian flora may have been carried to the Australia-New Guinea continent aboard the island arc that collided with it in Miocene time. The flora of this arc must have been tropical and derived from Asia. The flora evolved in the isolation of the migrating arc and was highly endemic when it reached New Guinea in the Miocene; it has not been ashore on Australia and New Guinea long enough to have evolved variants capable of populating nontropical environments.

NEOGENE SOITH-DIPPING SUBDUCTION SYSTEM OF NORTH NEW GUINEA

The middle Miocene through early Pleistocene geology of New Guinea is dominated by features explicable in terms of a subduction system dipping gently southward under the island from a trace near the north coast. A north-facing subduction melange is exposed on shore in one short sector and presumably belongs to this system, but the surface trace of subduction is otherwise offshore. The young calc-alkalic and alkalic intrusive and extrusive rocks of the Papuan Peninsula define by their cross-strike compositional variations a south-dipping Benioff zone (although the volcanoes of the mainland do not). The volcanoes are now almost inactive, and the present seismic Benioff zone is only feebly active, so the system is presently giving way to some other tectonic pattern. An active trench is now present along the north margin of New Guinea only west of long $143^{\circ} 40^{\prime}$ E., although a buried trench probably is present in the east; these trenches are discussed in subsequent sections.

NEOGENE VOICANIC: AND GRANITIC: ROCKS

Neogene volcanic and granitic rocks are widespread in the medial two-thirds of mainland Papua New Guinea. Pleistocene volcanism was intense both within and east of the area of the tectonic map of the Indonesian region, but volcanoes within the area are now almost extinct.

Middle and upper Miocene, Pliocene, and Pleistocene granitic rocks form numerous stocks and small batholiths in a belt that extends the length of Papua New Guinea and is mostly about $100-200 \mathrm{~km}$ from the north coast (Bain and others, 1972; Page, 1976; Page and McDougall, 1972). The rocks range from gabbro to granodiorite. Middle Miocene to Pliocene andesite, basalt, and dacite are widespread in the same belt (Page and McDougall, 1970; Plane, 1967). Small upper Miocene, Pliocene, and Pleistocene granites in western Papua New Guinea and adjacent Indonesian New Guinea, $225-275 \mathrm{~km}$ from the north coast, include porphyry copper plutons (Bamford, 1972; Grant and Nielsen, 1975; Page, 1975, 1976; Page and McDougall, 1972).

Very little mapping has been done in the terrain on strike farther west in Indonesian New Guinea, where quartz monzonite and other granitic rocks are known to intrude Paleogene strata in the analogous belt southeast of Geelvink Bay; the extent of these Neogene granites cannot be inferred from published data. A quartz-dioritic copper porphyry, 3 m.y. old, produced the Ertsberg (Gunung Bijih) 
copper-magnetite deposit (Dozy, 1939; Flint and others, 1976). This deposit is estimated from extensive drilling to contain about 33,000,000 metric tons of ore with an average copper content of 2.5 percent (Anonymous, 1973; Flint, 1972; Flint and others, 1976).

Young volcanoes - large stratovolcanoes, lava fields, and small cones-occur within the area of the tectonic map (pl. 1) in mainland Papua New Guinea primarily between lat $5^{\circ}-7^{\circ}$ S. and long $142^{\circ} 30^{\prime}-145^{\circ}$ E. (fig. 120; Johnson and others, 1973; Mackenzie, 1970, 1976; Mackenzie and Chappell, 1972). The rocks are alkaline basalts, trachybasalts, and andesites, and are high to very high in potassium $\left(\mathrm{K}_{2} \mathrm{O}=1-2\right.$ percent at $\mathrm{SiO}_{2}=48$ percent, and $2-3$ percent at 57 percent: Mackenzie, 1976). There is no distinct gradient in $\mathrm{K} / \mathrm{Si}$ ratios across the province to define depth and dip of a related south-dipping Benioff zone-indeed, rocks in the north average a little less potassic than those in the south-but rocks this high in potassium in subduction-zone settings occur typically above Benioff zones $180-300 \mathrm{~km}$ deep, and show at best erratic correlations between compositions and hypocentral depths (Dickinson, 1970, 1975; Hatherton and Dickinson, 1969). Older rocks in each volcano tend to be more mafic than younger ones (Mackenzie, 1976). Ratios of ${ }^{87} \mathrm{Sr} /{ }^{86} \mathrm{Sr}$ range from 0.7037 to 0.7045 : crustal contamination of the magmas was limited (Page and Johnson, 1974). Craters are preserved on some of the cones (fig. 123), and several volcanoes have fumaroles and hot springs.

Most Australian petrologists and seismologists presently (1978) concerned with New Guinea tectonics reject the interpretation that south-dipping subduction operates now beneath New Guinea, or has operated during late Miocene through Pleistocene time. (See, for example, Arculus and Johnson, 1978, Jaques and Robinson, 1977, Johnson, 1976b, Johnson, Mackenzie, and Smith, 1978, and Mackenzie, 1978.) I believe on the contrary that such subduction is indicated both by the modern seismicity and by the character of the trench along the north margin of New Guinea west of long $143^{\circ} 40^{\prime} \mathrm{E}$., and that such subduction is required by Neogene plate-motion patterns.

Pliocene and Quaternary volcanoes are also numerous in eastern Papuan Peninsula (fig. 120), and several are still active (Davies, 1973a; Johnson and others, 1973; Morgan, 1966; Smith, 1970; Smith and Davies, 1976). Of these volcanoes, the products of only one, Mount Lamington, extend west into the area of the tectonic map of the Indonesian region ( $\mathrm{pl}$. 1); these are moderately potassic, intermediate rocks. Similar rocks characterize the other northern volcanoes of far eastern Papua New Guinea. The volcanoes farther south are of highly potassic rocks. The ratio of potassium to silicon in the northern volcanoes is appropriate for formation above a Benioff zone about 200 $\mathrm{km}$ deep, whereas a greater depth is indicated by the composition of the southern volcanoes. A trench, discussed in the subsequent section on the Solomon Sea, lies at the base of the continental slope to the north of the peninsula.
Rocks and islets south of the head of the Gulf of Papua, in the region between lat $9^{\circ}-10^{\circ} \mathrm{S}$. and long $143^{\circ}-144^{\circ} \mathrm{E}$., consist of mafic, potassic volcanic rocks of late Cenozoic age (Wilmott and others, 1973).

\section{MELANGE OF CYCIIOPS MOUNTAINS}

Crystalline rocks exposed in the Cyclops (or Cycloop) Mountains, along the north coast of central New Guinea between long $140^{\circ}-141^{\circ} \mathrm{E}$. (figs. 118, 120), appear to record south-dipping subduction. Maps of the complex were given by Baker (1955) and Zwierzijcki (1924), and the rocks were described by Baker and by Gisolf (1924). The crystalline rocks crop out in an arc, concave to the north, of broadly concentric belts of schist, ophiolite, and intermixed schist and small masses of ophiolite (listed in order southward).

The main ophiolite sheet apparently has its top to the south, and this is the basis for the interpretation that the entire complex records subduction that dipped southward. The main ophiolite has a northern ultramafic part, on average about $8 \mathrm{~km}$ wide, of serpentinite and altered peridotite (harzburgite). South of this at the west end of the arc are, first, several kilometers of altered gabbro, and next another several kilometers of altered augite-labradorite diabase. Primary mineralogy of the gabbro was labradorite plus diallage, with or without hypersthene and olivine. Similar altered gabbro and diabase occur intermixed (as melange?) with masses of schist and of ultramafic rocks around the rest of the southern perimeter of the main ultramafic belt, to judge by the sketchy published data.

The schists of the Cyclops Mountains melange are dominantly albite-epidote greenschists, many of which contain a bluish-green amphibole ("blue actinolite": Gisolf, 1924; a "member of actinolite-glaucophane series": Baker, 1955). Schists bearing glaucophane (pleochroic from light yellow to blue to violet), garnet, or kyanite are also present.

Polymict breccia occurs at the northwest end of the Cyclops Mountains, with fragments of various igneous, pyroclastic, and clastic rocks, and, at one locality, Miocene or Pliocene fossils (Visser and Hermes, 1962). If this material is a subduction melange, rather than a sedimentary breccia, then the subduction was at least as young as Miocene.

South-dipping subduction occurred along northern New Guinea during late Cenozoic time. The Cyclops Mountains are inferred to present a sample of the resultant subduction complex.

\section{MODERN SEISMICITY}

The north margin of New Guinea is marked by the New Guinea Trench, with southward-subduction polarity, as far east as long $143^{\circ} 40^{\prime} \mathrm{E}$. East of $149^{\circ} \mathrm{E}$., along the same east-southeast trend, the Solomon Sea floor is being subducted northward beneath New Britain from the New Britain Trench. No trench, with either sense of subduction polarity, connects these trenches. Patterns of seismicity and volcanism are interpreted to indicate that an island arc continuous westward from New Britain has here collided recently with New Guinea, as intervening ocean floor was 
subducted steeply northward beneath the arc and gently southward beneath New Guinea.

Sharply defined fault zones are not apparent within the confusing array of northern New Guinea earthquakes. Most of the earthquakes, nevertheless, fit a broad pattern of increasing depth southward from near the north coast, between about long $138^{\circ}$ and $148^{\circ}$ E. (Denham, 1969; Jaques and Robinson, 1977; fig. 127), and these may define a Benioff zone marking a subduction system that is being inactivated as other structures take up the continuing convergence of Australian and Pacific plates. Earthquakes reflect dominantly thrust faulting on planes striking parallel to the coast (Johnson and Molnar, 1972; Ripper, 1975a, b, 1976). Farther north, the deep limit of earthquakes appears to indicate another, steeper Benioff zone, this one dipping northward beneath the Schouten Islands, continuing the New Britain seismic zone westward.

The present mantle-earthquake zone displays little activity deeper than $150 \mathrm{~km}$ and apparently does not extend as far south as the Quaternary volcanoes; the seismic system presumably was more active, and extended deeper and farther to the south, during Pleistocene time than it does now. The north-dipping subduction system is reflected by the continuous chain of active volcanoes from New Britain west-northwestward through Long, Karkar, and the Schouten Islands.

These relationships are taken to indicate that a south-dipping New Guinea subduction system has collided with a north-dipping Schouten-New Britain system. Neither the Schouten nor the north New Guinea Benioff zone is now tied to an actively subducting trench. No trench now exists between the Schouten Islands and New Guinea, although a southward-subduction fossil trench is possible there, buried deeply by young sediment; several profiles (figs. $128 E$ and $129 \mathrm{~A}$ ) suggest that a trench may be forming on the north side of the Schouten Arc, in which case polarity reversal is indicated, at the new margin of the continent as enlarged by the collision. Continuing convergence is apparently taken up in part by deformation within northern New Guinea, a region of intense seismicity (fig. 4; Hamilton, 1974b); perhaps megaplate convergence previously accommodated at Schouten and north New Guinea trenches is now absorbed at plate boundaries, notably the West Melanesian Trench, farther north. Available seismic-reflection profiles from north of New Guinea are discussed, and some are illustrated, in subsequent sections.
In 1970 a major earthquake of Richter magnitude 7.0 had its epicenter near lat $4^{\circ} 55^{\prime} \mathrm{S}$., long $145^{\circ} 35^{\prime} \mathrm{E}$.; focal depth was about $40 \mathrm{~km}$. This earthquake and its closely monitored aftershocks appear to define a zone of motion in the lower crust and upper mantle, at a depth of $25-60 \mathrm{~km}$, that trends west-southwestward from Karkar Island to about $100 \mathrm{~km}$ inland from the north coast of New Guinea. The zone of motion is marked both by left-lateral strike-slip motion trending west-southwest and by thrusting on planes striking subparallel to the coast (Everingham, 1975b; Ripper, 1976). The 1970 seismic zone trends at a large angle to the through-going west-northwest surface geologic grain, hence may represent uncoupling in the lower crust. Perhaps it is a byproduct of the arc collision.

Johnson (1976b) developed an explanation for the magmatic features here ascribed to the collision of opposed subduction systems that rejects subduction southward beneath New Guinea and explains the modern Schouten Islands volcanism as a relic feature of the island arc that collided with New Guinea in Miocene time. I see no analog elsewhere in the world for activity continuing so long after the cessation of subduction.

\section{NEW GIINEA IRENCH}

The New Guinea Trench, site of subduction southward beneath New Guinea, lies at the north base of the New Guinea continental slope between at least long $135^{\circ}$ and $143^{\circ} 40^{\prime}$ E. Nine seismic-reflection profiles across the Papua New Guinea sector $\left(141^{\circ}-143^{\circ} 40^{\prime} \mathrm{E}\right.$.) of this trench are included in the Bismarck Sea series made by Compagnie Generale de Geophysique for the Australia Bureau of Mineral Resources, Geology and Geophysics (BMR), and a representative two of these $\mathrm{BMR}$ profiles are illustrated here (figs. $128 A, B$ ). Six-channel recordings were made, but $I$ have seen only single-channel-monitor records from these; multichannel processing of the profiles presumably would better reveal the usual subducted plate and melange-wedge features. I have also seen four oil-company multichannel-processed lines in the Indonesian sector to the west, between $135^{\circ}$ and $139^{\circ} \mathrm{E}$., which show the features expected for active southward subduction. The best of these latter profiles shows clearly an imbricated melange wedge over basement subducting at a shallow dip. The trench displays acoustically transparent pelagic sediments tipping down, with the basement beneath them, under a prism of

FIGURE 127.-Seismicity of the New Britain-northeastern New Guinea region. The seismic cross sections, replotted from Johnson, Mackenzie, and Smith (1971, figs. 2 and 3), show foci for earthquakes of magnitude 4.5 and greater and recorded by 10 or more stations, from April 1958 to June 1969, projected to the lettered vertical planes within the sectors separated by dashed lines on the map. The Benioff zone that in the east dips moderately to steeply northward beneath New Britain appears to be subducted in the west beneath the zone that dips gently to moderately southward beneath New Guinea. See text for discussion. Volcanoes plotted from Fisher (1957) and Bain, Davies, Ryburn, Smith, Cameron, Tingey, and Moffat (1972). 

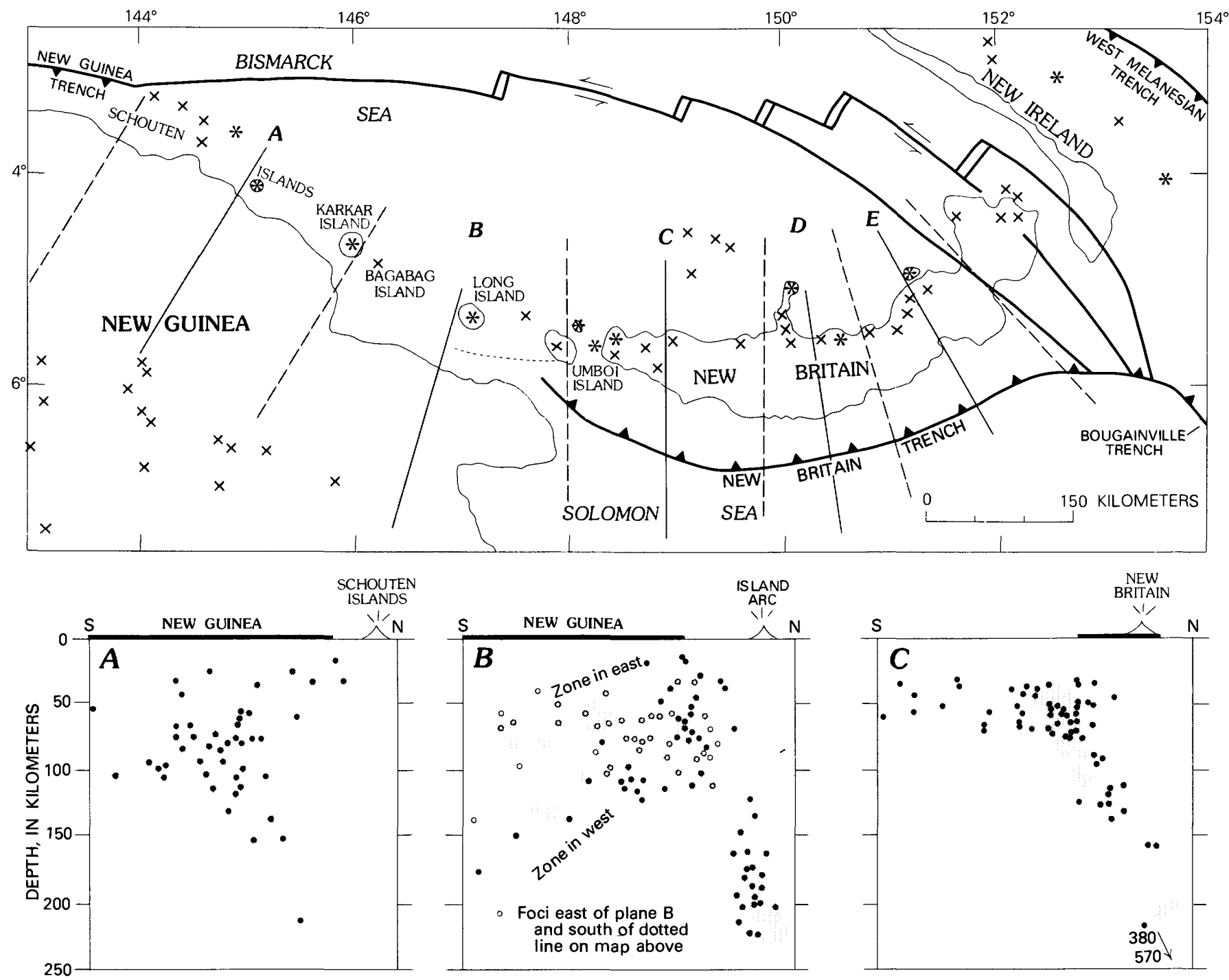

\section{EXPLANATION}

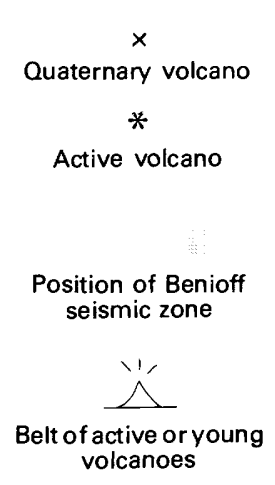

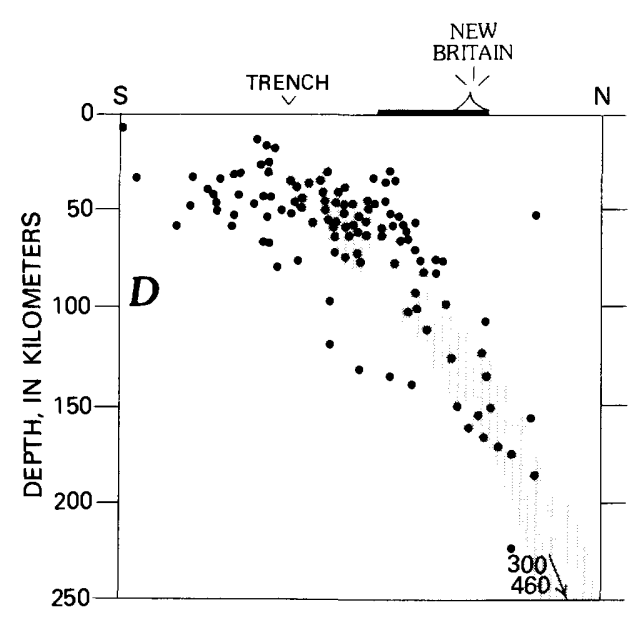

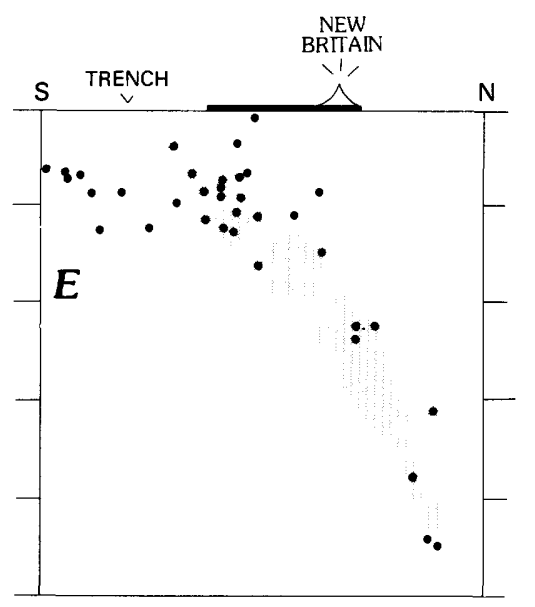



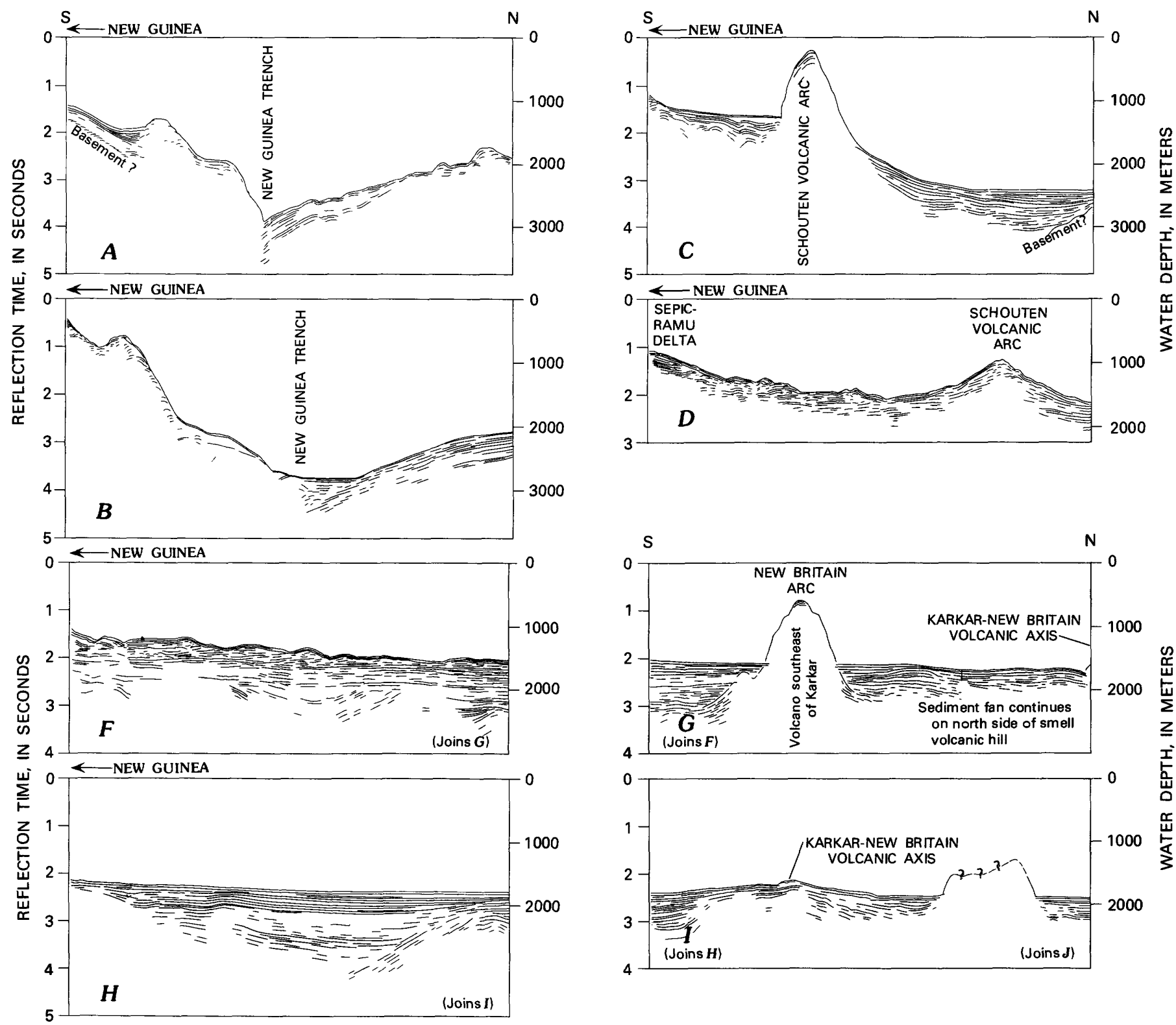

FIGURE 128 (above and facing page).-Seismic-reflection profiles across the north margin of eastern New Guinea. Locations shown in figure 118. Traced from single-channel monitor lines of multichannel survey made by Compagnie Generale de Geophysique for the Australia Bureau of Mineral Resources, Geology and Geophysics (BMR). The survey was described by Tilbury (1975). The original profiles were provided by David Denham and Director L. C. Noakes of BMR.

layered turbidites in the trench; the strata become increasingly deformed downward and landward.

The New Guinea Trench thus extends both east and west of the intersection with the West Melanesian Trench at about $141^{\circ} \mathrm{E}$., so that intersection is a trench-trench-trench triple junction and plate-convergence vectors must be very different across the sectors of the New Guinea Trench east and west of that junction. Plate boundaries and possible plate motions in this region are discussed and illustrated (figs. 146, 154) subsequently.
The obviously active part of the New Guinea Trench is last seen to the east on the profile along $143^{\circ} 40^{\prime}$ E. (fig. $128 B$ ). The next BMR profile, along $143^{\circ} 50^{\prime} \mathrm{E}$., and profiles at $10^{\prime}$ intervals farther east (profiles $C, D$, and $E$ of figure 128), show no apparent trench along the projection of the active trench between the Schouten Islands and the New Guinea mainland. The active trench thus ends at the intersection with the mid-Bismarck Sea fault system. The North Bismarck plate is moving rapidly westward with respect to both New Guinea and the South Bismarck plate (figs. 146, 154). 

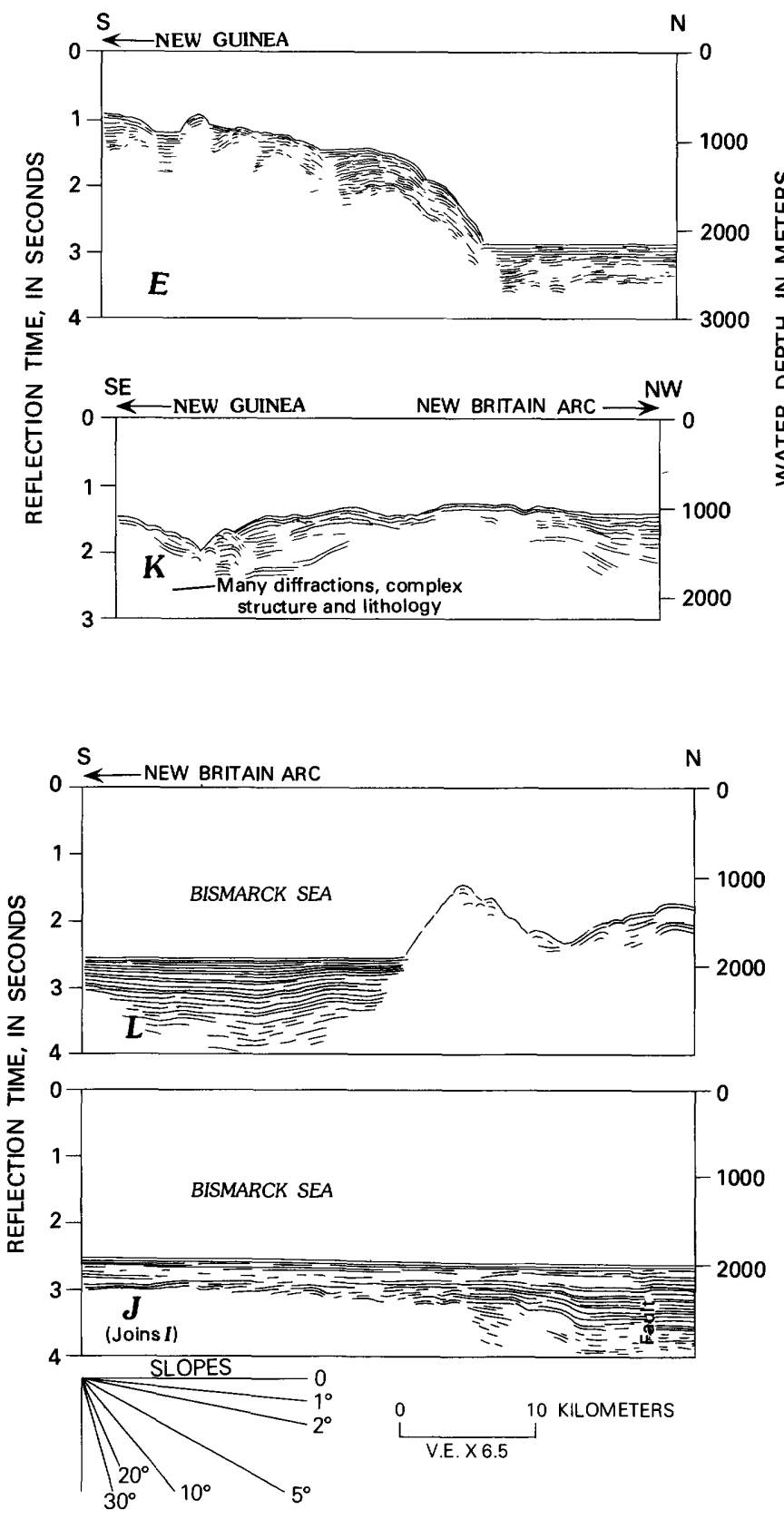

Deeper penetration reflection profiles (fig. 129) do, however, show a possible continuation of the New Guinea Trench, in the narrow space between the New Guinea mainland and the Schouten-New Britain volcanic arc, buried beneath $2,000 \mathrm{~m}$ or so of continental-rise strata.

\section{SCHIOUIEN ISLANDS COLI.ISION \%ONE}

Patterns of seismicity and volcanology were inferred in a preceding section to indicate that New Guinea and the Schouten-New Britain Island Arc have collided as the oceanic crust initially between them was subducted southward beneath New Guinea and northward beneath the Schouten Islands and New Britain. Profiles $C$ through $J$ of figure 128 are representative of the BMR profiles across the inferred collision zone. Water depths are less than $2,000 \mathrm{~m}$ across this zone. Underlying strata are much deformed, the degree of deformation increasing downward, but within the limits of resolution of these profiles $(0.5$ to $1.5 \mathrm{sec}$ of reflection time, corresponding to sediment thicknesses of less than $2 \mathrm{~km}$ ), no buried or exposed trench is apparent with either northward or southward subduction polarity. A buried trench may, nevertheless, be present at slightly greater depth (fig. 129). Sedimentation rates here must be very great because of the proximity of the Sepik, Ramu, and other rivers, and large-scale slumping of sediments down the continental slope occurs near the Sepik-Ramu delta (fig. 128D). The New Britain Trench emerges eastward from the complex zone (figs. 146, 153). Considerable plate convergence is inferred from plate geometry to be occurring now (fig. 154), resulting in crustal compression distributed across both this offshore zone and northern mainland New Guinea. The collision is discussed further in the section on the Solomon Sea.

\section{OTHER NEOGENE FEATURES OF NORTHERN NEW GUINEA}

\section{LATE NEOGENE SEDIMENTATION}

The Upper Cretaceous to lower Miocene island-arc complexes of the northern ranges of New Guinea rise as elongate mountain masses from a flood of upper Neogene clastic sediments. The crystalline island-arc rocks underlie the higher and more rugged parts of the ranges, whereas the lower flanks expose both the volcanigenic sediments of the old arc and the deformed portion of the nonvolcanic upper Neogene. Reconnaissance geologic mapping and photointerpretation (Marchant, 1969; Visser and Hermes, 1962) until recently incorporated the erroneous assumption that the crystalline rocks formed the basement for the volcanigenic sediments, whereas the two are now known to be in substantial part coeval. Further, the old volcanigenic sediments have been lumped with the young nonvolcanic ones in much field work, so many ambiguities cloud interpretations of most published reports. (Harrison, 1969, provides a notable exception.)

The Sepik and Ramu Basins (pl. 1) of Papua New Guinea are filled by thick middle Miocene to Holocene sediments, mostly clastic (Bain and Mackenzie, 1975; Beiers, 1969; Harrison, 1969; van Oyen, 1972). The fossils and sediments of both basins show great fluctuations in water depths before the inauguration of paralic, and then continental-fluvial, conditions in Quaternary time. Basin subsidence continues to be particularly active in the region of the vast Sepik swamps. Deformation-moderate basinward tilting-of the sediments of the Sepik Basin is largely limited to the older strata a long its north side. Pliocene strata are steeply folded, and Pleistocene sediments are locally folded, in the Ramu Basin. Gravity anomalies suggest that Ramu Basin strata may have been deposited directly on oceanic crust (Milsom, 1975). 

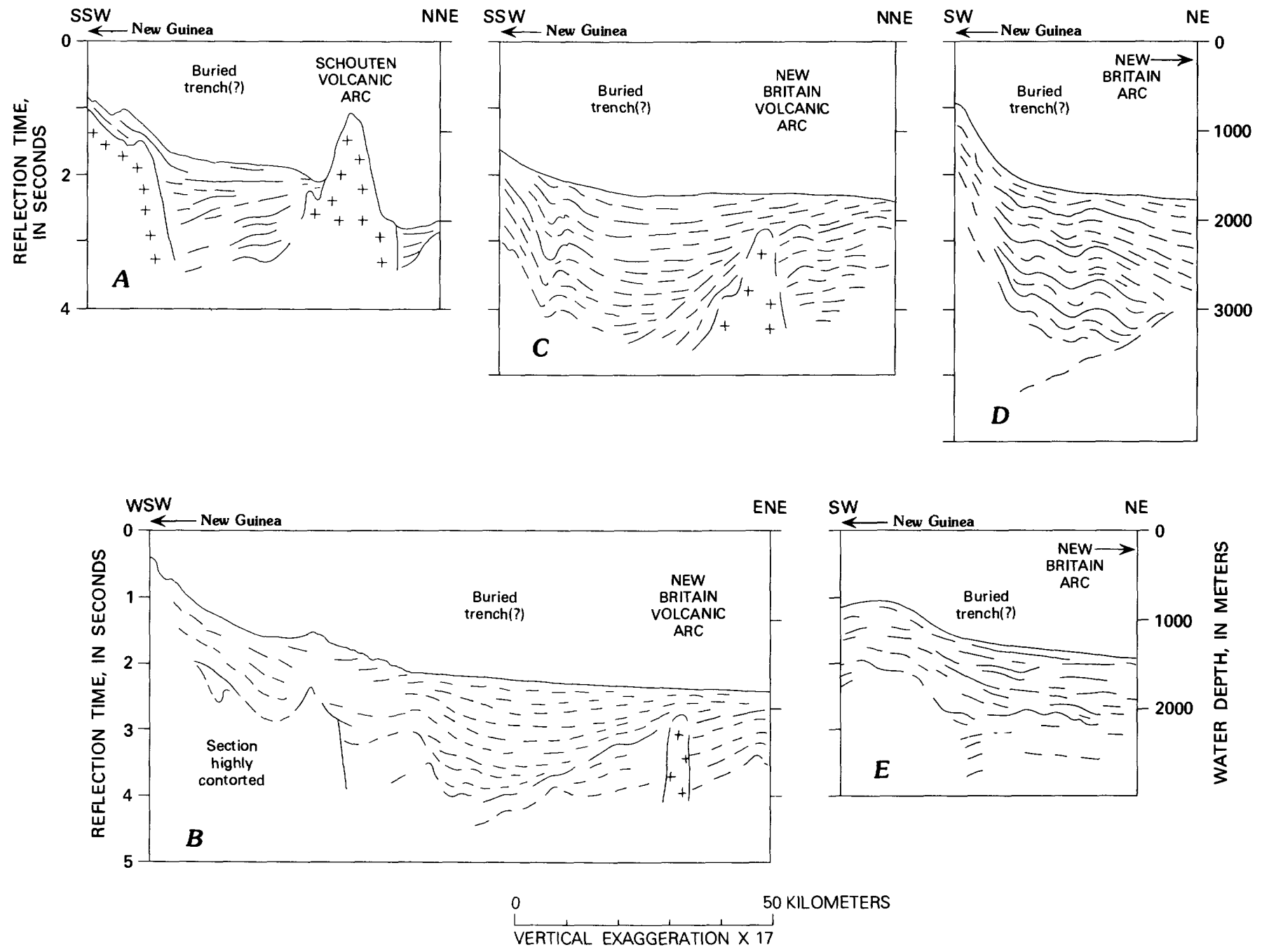

FigURE 129.-Seismic-reflection profiles across a possible buried trench between northeastern New Guinea and the Schouten-New Britain Island Arc. In each profile, a fossil trench, showing symmetry for subduction southward beneath New Guinea, appears to be present beneath continental-rise sediments $1-2$ seconds (I to 2 or $3 \mathrm{~km}$ ) thick. Locations shown in figure 118. Traced, omitting conjectural faults, from sketches of single-channel monitor lines in an untitled 1973(?) report by the Exploration Division, Gulf Research and Development Co., on a Gulfrex geophysical reconnaissance survey of Papua New Guinea, in the library of the Geological Survey of Papua New Guinea, Port Moresby.

In Indonesian New Guinea, the vast Meervlakte swampy lowlands, between central and northern ranges, are the present site of major subsidence and fluvial sedimentation. The Quaternary sediments of these lowlands lap onto the basement rocks of the central range to the south, whereas gently deformed thick Pliocene bathyal clastic sediments, overlain by paralic and continental Quaternary ones, emerge from beneath the young sediments to form the south half of the northern ranges on the north side of the basin (Visser and Hermes, 1962). The axis of major sedimentation has apparently shifted southward during Pliocene and Pleistocene time here, as in Papua New Guinea. The north half of the northern ranges exposes widespread uppermost Miocene to Holocene strata, mostly clastic, showing variable marine depths prior to recent shoaling (Visser and
Hermes, 1962). These strata are younger than the volcanic island arc. The setting of the older Neogene sedimentary rocks of the north half of the northern ranges is not made clear by the brief descriptions by Visser and Hermes (1962; their high lower Miocene and middle Miocene Makats Formation), but as these rocks contain many clasts of basic igneous rocks and as they are separated from the higher Neogene by a time gap representing most of the upper Miocene, they may belong to the island-arc complex. Both Neogene assemblages are strongly deformed in the north half of the northern mountains.

The Salawati Basin lies on the south side of the Sorong fault system west of northwestern New Guinea (Redmond and Koesoemadinata, 1976; Trend Exploration Technical Staff, 1973; Vincelette and Soeparjadi, 1976). The basin 
began to develop only within Miocene time; Paleocene through Oligocene strata are shelf and reef carbonates, whereas Neogene sediments thicken northwestward to at least $6,000 \mathrm{~m}$. Miocene pinnacle reefs formed along the irregular shelf edge between the carbonate shelf to the southeast and the limestone-and-shale basin to the northwest. Growth of the pinnacle reefs kept pace with subsidence, and the reefs are $300-800 \mathrm{~m}$ thick and are capped by higher Miocene and younger strata. A number of the reefs contain oil, and because of their height and very high porosity and permeability, they are very valuable, despite their small areas. The clastic sediments of the Salawati Basin were derived from the north. Those of the Quaternary came from a mafic "eugeosynclinal" terrain like that now adjacent to the basin on the north side of the Sorong fault, whereas the sediments of the Miocene and at least much of the Pliocene came from a sedimentary terrain that has since been displaced far to the west along the Sorong fault system (Hermes, 1974).

\section{SORONG FAULT SYSTEM}

A great left-lateral strike-slip fault system is generally assumed to trend westward near the north coast of western New Guinea, and is so shown on pl. 1. This fault system was drawn across northern Vogelkop by d'Audretsch, Kluiving, and Oudemans (1966) and by Visser and Hermes (1962), who named it the Sorong fault system. Clear evidence for strike-slip faulting within the system has not been published. The type strand of the fault system apparently is a belt of pre-Pliocene subduction melange, misidentified as a strike-slip fault, and the entire fault system within Vogelkop may be a suture zone. (See also Robinson and Ratman, 1977, 1978; they recognized the suture character of the zone, but thought it might also have left-lateral slip.)

The type strand of the Sorong fault system probably does not exist. Visser and Hermes mapped a fault zone $10 \mathrm{~km}$ wide as extending east-northeast from the town of Sorong, on the west coast of far northwestern New Guinea at about lat $0^{\circ} 52^{\prime} \mathrm{S}$., long $131^{\circ} 15^{\prime} \mathrm{E}$, at least to $131^{\circ} 50^{\prime} \mathrm{E}$., and they also mapped it as present to the west in northeastern Salawati. Their descriptions, however, make it clear that this zone is one of polymict melange, for it consists of chunks, lenses, and slabs, of all sizes up to $10 \mathrm{~km}$, of varied mafic and ultramafic rocks, Jurassic to Miocene deep- and shallow-water sedimentary rocks, and some granite and hornfels, in an extremely sheared matrix. Tjia (1973) recognized this as a polymict melange terrain, but like Visser and Hermes he assumed the shearing to be a product of strike-slip faulting. I have studied both vertical aerial photographs and radar imagery across the zone; the melange forms a ruggedly mountainous area, with none of the combed topography that would be present were this indeed a broad strike-slip zone. As Visser and Hermes (1962, Encl. I), and other oil geologists since, realized, gently deformed Pliocene strata unconformably cover the west end of this zone and are not broken by any active strike-slip faults.
Farther north, the northern bulge of Vogelkop is broken by a through-going, east-trending valley system, approximately along $0^{\circ} 45^{\prime} \mathrm{S}$., which Visser ard Hermes (1962, Encl. 1) and d'Audretsch, Kluiving, and Oudemans (1966, Encl. V) inferred to contain the "Sorong" strike-slip fault. If a strike-slip fault is here, it must be of pre-Pliocene age, for uncut Pliocene strata block its east end (d'Audretsch and others, 1966, Encl. V); or else it bends to the southeast and may even have been sharply bent oroclinally, turning to the south-southeast west of Geelvink Bay, where d'Audretsch, Kluiving, and Oudemans (1966) and Robinson and Ratman (1977, 1978) mapped the major Ransiki fault (described subsequently).

The geological reconnaissance by Visser and Hermes (1962) and d'Audretsch, Kluiving, and Oudemans (1966) indicates that this northern Vogelkop valley system, its projection westward between the islands of Salawati and Batanta, and the melange belt east of Sorong, truncate on a regional scale the geological belts swinging northwestward from central New Guinea. A granitic-and-metamorphic terrain like that truncated in Vogelkop reappears, on the north side of strong topographic lineaments continuous from the Salawati-Batanta gap, in the Sula Islands far to the west. A major strike-slip fault, now inactive, may lie in the north Vogelkop-Batanta depression; but see figure 77 . The Sorong melange cannot yet be placed confidently in a tectonic context relative to either the strike-slip faulting or Neogene subduction. I use the name Sorong fault system in this report because it is well established in the literature, but with the qualification that at least its type strand was misidentified.

A narrow submarine ridge, on which stands long Yapen (Japen) Island, closes deep Geelvink Bay (Teluk Sarera) on the north. It was noted in a previous section that Yapen may have been shifted about $600 \mathrm{~km}$ westward. The Sorong fault system is drawn on the tectonic map (pl. 1) as projecting east-southeastward from its Vogelkop fault-line valley and as bifurcating: branches pass north and south of Yapen and reunite east of it. Yapen is marked by a strong positive gravity anomaly that does not extend east onto the New Guinea mainland (Visser and Hermes, 1962). Two lines of very straight valleys cut completely across Yapen, trending east-southeastward, and may mark other Sorong strands. On the northern mainland, just east of Geelvink Bay on strike from Yapen, a young fault is seen on radar imagery to trend eastward along the straight northern edge of the low hills west of Rombebai Lake ( $1^{\circ} 50^{\prime} \mathrm{S}$., $137^{\circ} 55^{\prime} \mathrm{E}$.), but the fault does not project on strike east of the lake, where upper Neogene strata are unbroken. The geologic map of Visser and Hermes (1962, Encl. 1-I1I) suggests that the fault could curve southeastward from the lake, perhaps gaining an important thrust component. Rombebai Lake is in the east part of a zone, $10 \mathrm{~km}$ wide, of rapid subsidence, whose west part is marked by aberrant parallel rivers flowing westward; this zone perhaps is one of oblique extension. The north edge 
of this zone is suggested on pl. 1 to be the major strand of the Sorong fault, but its projection eastward into the confusing plate boundaries offshore is speculative; on land it is drawn through swamps in which I know of no evidence for its presence.

Wellman (1971) stated that an active fault can be recognized on aerial photographs in various sectors farther east near the north coast of New Guinea, but he provided no descriptions or illustrations. He wrote that the sense of motion cannot be determined on the photographs - and as active strike-slip faults normally display very obvious evidence for their sense of slip, there may not in fact be an active onshore fault.

\section{REGIONAL SIGNHFICANCE OF SORONG; FALILI SYSTEM}

The various tectonic belts of New Guinea trend west-northwestward along the main mass of the island to Geelvink Bay and the neck of Vogelkop, where they swing abruptly northwestward and are apparently truncated against the Sorong fault system in northern Vogelkop. None of the truncated complexes south of the fault can be recognized north of the fault within Vogelkop or the nearby islands (Hermes, 1974) except as large and small slices near the fault zone (Ryburn, 1977). It was argued in a previous section that the Sula Islands Ridge represents much of the missing material. The Sula Islands have a continental, granitic-and-metamorphic basement of middle or late Paleozoic or Triassic age, lithologically similar to the middle or upper Paleozoic crystalline complex truncated by the fault in Vogelkop. Jurassic, Cretaceous, and lower Miocene rocks of the Sula Islands are shelf-facies sedimentary rocks and could also have ridden westward on the continental basement as it slid westward on faults of the Sorong system, before or after the rotation of Vogelkop. (See fig. 77.)

The previously noted character of Neogene clastic sediments in the Salawati Basin indicates that "eugeosynclinal" rocks did not lie directly north of the basin across the fault until within Pliocene, or even early Pleistocene time (Hermes, 1974).

Any presently active strands of the Sorong fault system must serve as transforms to the south ends of the subduction zones of the Sangihe, Halmahera, and Philippine Trench systems. The details shown on the tectonic map (pl. 1) are inferred from bathymetric alinements, earthquake distributions, and the presence of faults as seen on seismic-reflection profiles. The pattern must be complex, and future detailed work is likely to necessitate considerable revision of this interpretation.

\section{GEELVINK BAY AND RANSIKI FAI'LI}

Triangular Geelvink Bay (Teluk Sarera) is enclosed between Vogelkop on the southwest, the main mass of Indonesian New Guinea on the southeast, and Yapen Island on the north. The bay is mostly between 1,500 and $2,000 \mathrm{~m}$ deep and has a generally flat floor (Visser and Hermes, 1962, p. 160). Thick sediments underlie the bay. No published data demonstrate whether the crust beneath the bay is oceanic or continental. A deep gravity low, marking a thickly filled upper Neogene basin, trends southwestward along the southeast shore of the bay (Visser and Hermes, 1962, Encl. 4).

The Ransiki fault zone trends southeastward from, and may or may not be continuous with, the Sorong fault zone in northwestern Vogelkop, goes to sea in Geelvink Bay, and can be traced far to the south-southeast, subparallel to the coast of the bay, by gravity anomalies (d'Audretsch and others, 1966, p. 103). The fault juxtaposes unlike terrains and is followed by topographic troughs, so it likely is either a major inactive strike-slip structure or a suture (Robinson and Ratman, 1977, 1978). The fault does not continue through the neck between Vogelkop and the main part of New Guinea, so if it is indeed a major strike-slip structure then it may have been bent oroclinally $50^{\circ}$ or so as Vogelkop rotated clockwise in Neogene time (as discussed subsequently). I infer that the fault trends eastward from the south end of Geelvink Bay, through or near the Meervlakte lowlands north of the medial mountains of New Guinea. The fault can in this context be either an old member of the Sorong system, inactivated as a result of oroclinal folding, or else be continuous with the medial New Guinea suture. The deeper part of Geelvink Bay may be a small oceanic area, closed in on the south by the oroclinal bending of Vogelkop, and on the north by the translation of the Yapen Ridge across it.

\section{MARKHAM-RAMU FAULIT \%ONE}

The straight valley of the Markham and Ramu Rivers in eastern Papua New Guinea, trending southeastward from long $145^{\circ}$ E. to Huon Gulf, separates and truncates different lithotectonic assemblages and may mark a major left-lateral fault system (figs. 118, 120; Bain and Mackenzie, 1975; Bain and others, 1972; Robinson and Jaques, 1974b; Tingey and Grainger, 1976). Marum, Bismarck, Owen Stanley, and Papuan ophiolite terrains are all truncated by the fault (fig. 120). Pleistocene sediments are broken by faults, but neither Holocene offsets nor throughgoing faults have been recognized; the fault is not apparent on the satellite imagery of figure 130. Offshore to the southeast, the fault zone may trend along a great submarine canyon in the center of Huon Gulf (von der Borch, 1972).

The Markham-Ramu fault must continue on to the northwest beyond $145^{\circ} \mathrm{E}$. if it is indeed a major regional structure. Jaques and Robinson (1975) inferred from magnetic-anomaly patterns that the fault does continue beneath the fill of the Ramu Basin. No master fault was recognized on the projection of this line farther northwest or west-northwest by Hutchison and Norvick (1975a, b), but D. S. Hutchison (1975) emphasized that many steep shear zones, typically with subhorizontal slickensides, trend westward to west-northwestward in northwestern Papua New Guinea. The Markham-Ramu fault may swing 
westward near $144^{\circ} \mathrm{E}$., lie buried beneath the alluvium of the Sepik and Meervlakte lowlands, and emerge as the Ransiki fault at Geelvink Bay.

\section{FAULTS SOUTH OF SEPIK LOWLANIS}

Other left-lateral strike-slip faults may trend west-northwestward across the northern part of medial Papua New Guinea, south of the broad Sepik lowlands, where Australian geologists (compilation by Bain and others, 1972) have mapped major faults of undefined character. Among these, the Frieda fault and an unnamed fault trending eastward from it strike eastward from the Indonesian border, at long $141^{\circ} 00^{\prime} \mathrm{E}$., to $143^{\circ} 30^{\prime} \mathrm{E}$., and generally mark the contact between melange and allied rocks to the south and greenschist and high-temperature, low-pressure metamorphic rocks to the north. The latter rocks include the Hunstein Complex, Ambunti Metamorphics, and Chambri Diorite of Dow and others (1972), described in a previous section; the present position of these rocks may be aberrant. This particular fault system is lost in Quaternary materials east of $143^{\circ} 30^{\prime} \mathrm{E}$., and no pre-Neogene rocks appear north of it; its projection as far as $144^{\circ} 30^{\prime}$ E. marks the northern limit, and apparent hidden truncation, of the northwest-striking Jimi terrain (also discussed previously) of sedimentary, volcanic, metamorphic, and plutonic rocks of continental types. Perhaps offset along the Frieda fault system has shifted Ambunti and related terrains $300 \mathrm{~km}$ or so westward from a position initially on strike from the Jimi terrain. The Frieda fault thus may be part of a system of great left-lateral faults that have yet to be mapped through eastern Indonesian New Guinea but that emerge farther west as the inactive Ransiki and active Tarera fault zones. The connecting faults might trend westward generally along the valleys of the Nogolo and Hablifuri Rivers, near lat $3^{\circ} 40^{\prime} \mathrm{S}$. between long $137^{\circ} 30^{\prime}$ and $139^{\circ} 30^{\prime} \mathrm{E}$.

\section{ISLANDS NEAR NORTHWEST VOGELKOP}

Triangular Salawati and narrow Batanta islands lie just west of the northwest tip of Vogelkop (Brouwer, 1924b; Verstappen, 1960; Visser and Hermes, 1962). Batanta and northern Salawati consist of middle Tertiary sediments and breccias that are described as sedimentary but likely are melange, whereas southern Salawati exposes folded Pliocene and Quaternary strata. Upper Neogene strata thicken greatly to the northwest of Salawati toward the Sorong fault, major strands of which may pass on both sides of Batanta (pl. 1). The island of Waigeo (or Waigeu) lies north of the Sorong fault system and the northwest tip of Vogelkop. The descriptions by both Brouwer (1924b) and Verbeek (1908b) show polymict melange to be widespread, as was discussed previously, beneath little-deformed upper Neogene strata.

\section{RIFTING OF VOGELKOP FROM AUSTRALIA}

The various upper Mesozoic and Cenozoic tectonic and sedimentary-facies belts of the main mass of Indonesian New Guinea trend westward to about long $135^{\circ} \mathrm{E}$., where they swing abruptly to the north-northwest in central Vogelkop (Jazirah Doberai, or Kepala Burung). In northern Vogelkop, the belts swing back toward the west-northwest and are truncated against faults of the Sorong system. The quartzose Jurassic and Cretaceous clastic sedimentary rocks of Vogelkop came in part from a continental source to the south, a direction in which now lie the deep eastern Banda Sea and its flanking island-arc complexes.

Hermes (1968, and in Visser and Hermes, 1962, p. 205-207) concluded from these relationships that the two inflections in Vogelkop are oroclines, produced by the folding into a " $\mathrm{Z}$ " of belts that initially continued westward or southwestward from those of the rest of New Guinea, and thus that Vogelkop and its continental shelf have been torn away from a position adjacent to what is now the shelf edge of northwestern Australia. Major additional evidence has since been provided by reflection profiling of the continental shelf southwest of Vogelkop and would make the rifting Neogene: Paleogene and Miocene strata are consistently thin and show no indication that a shelf edge lay nearby to the west of them when they formed, whereas Pliocene and Quaternary strata thicken rapidly toward the present shelf edge. Rotation is illustrated in figure 77 , and was espoused also by Hamilton $(1975,1977)$ and Robinson and Ratman $(1977,1978)$.

\section{EXPANSION OF THE BANDA ARC}

Vogelkop apparently has moved clockwise away from Australia in late Neogene time, and the gap between them is now filled by the U-shaped Banda Arc, which is ramping onto the continental shelves on both Vogelkop and Australian sides. It follows that the Banda Arc is expanding eastward into a region previously occupied by continental crust and that room for it is being made in part by subduction but in larger part by the rotation of Vogelkop away from the advancing arc. The velocity of retreat of Vogelkop is a little less than the velocity of advance of the arc.

\section{PAPUAN PENINSULA}

The Paleogene island arc that collided with mainland New Guinea west of long $145^{\circ} \mathrm{E}$. met no obstruction east of this limit of the old continent and instead continued to migrate southward, closing progressively southward against the east side of the New Guinea continent and projecting southeastward as the Papuan Peninsula (figs. 120, 130). A buried trench, inactivated in about Pliocene time, lies along the southwest edge of the peninsula. The onshore geology can be explained in terms of subduction-accretion in front of a migrating arc, followed by a polarity reversal to subduction beneath the north side of the peninsula quite late in 


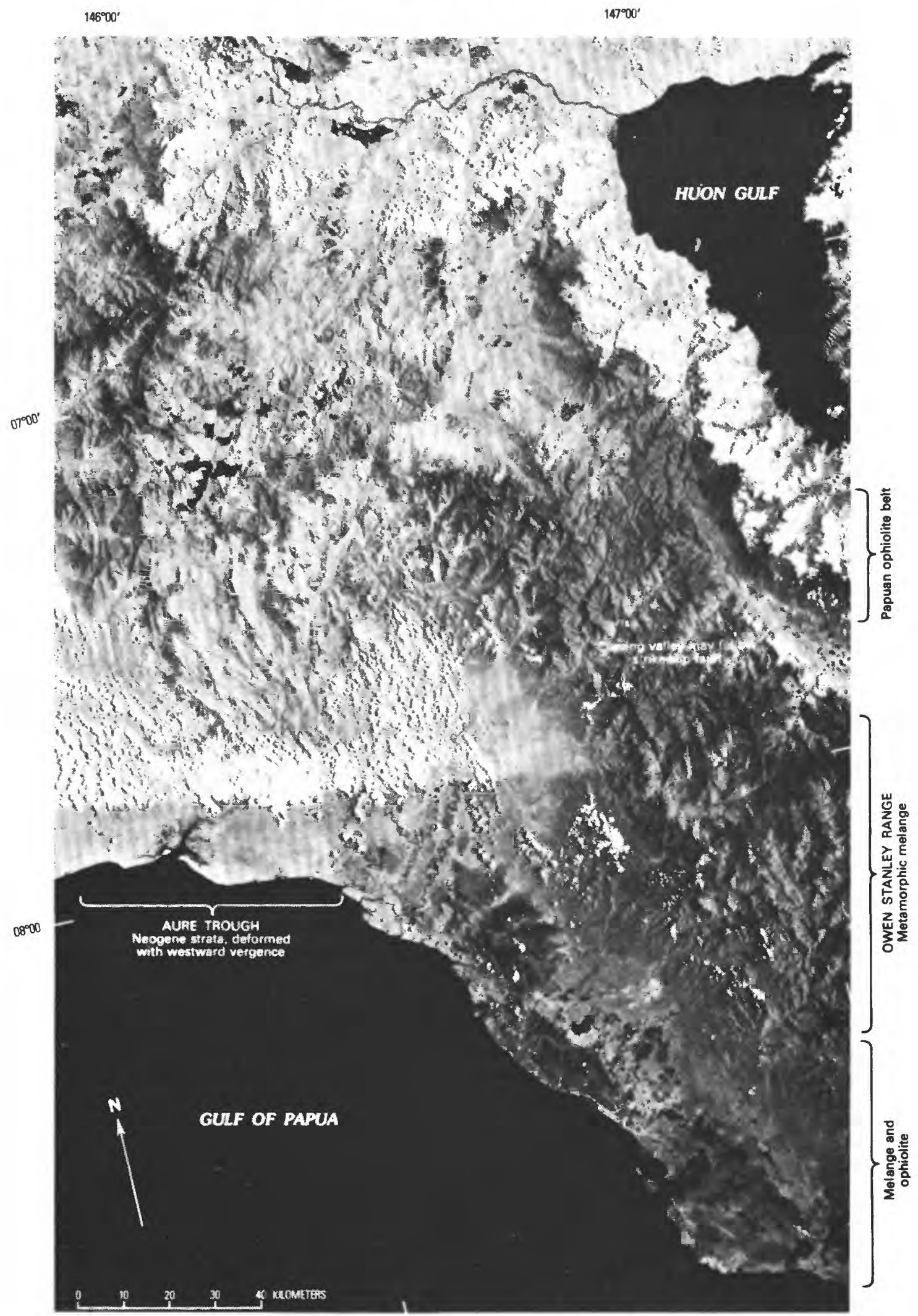

Figure 130.--Landsat image of the base of the Papuan Peninsula. NASA-ERTS pictures 1077-23514 and 1095-23523, October 1972. 
Cenozoic time. (When the various tectonic and magmatic terrains of the peninsula are known better, this synopsis may prove to be oversimplified, and additional complexities may be indicated.) The peninsula diverges southeastward from mainland New Guinea at long $147^{\circ}$ E., and it bounds the deep Coral Sea Basin on the north as continuous land almost to $151^{\circ} \mathrm{E}$. and beyond that as a submarine ridge past $156^{\circ} \mathrm{E}$. The general structural and facies strike, east-southeastward across the main mass of southern New Guinea, swings abruptly to the south at $145^{\circ} \mathrm{E}$., the structural base of the peninsula, and swings gradually back to the southeast between $146^{\circ}$ and $148^{\circ} \mathrm{E}$. The medial and northeast parts of the peninsula have rocks with apparent analogs on strike in mainland New Guinea, but the southwestern part mostly does not, despite the continuity into it of the belt of late Neogene folds and faults.

\section{PORT MORESBY TRENCH}

A probable fossil trench, now overlapped by thick, prograded strata, lies along the southwest side of at least the western part of the Papuan Peninsula (fig. 131; pl. 1) and is here termed the Port Moresby Trench. This inactive structure is shown by a series of Gulf Oil Co. Gulfrex reflection profiles, two of which are illustrated by figure 131, between long $146^{\circ} 20^{\prime}$ and $148^{\circ} 20^{\prime} \mathrm{E}$. The Gulfrex magnetic profiles and also those of Mutter (1975a) show that total magnetic intensity decreases northward across the continental slope and that short-wavelength magnetic anomalies are lacking there, so the basement presumably continues to descend northward beyond the limit to which it can be followed on the reflection profiles. The same conclusion is indicated by free-air and Bouguer gravity-anomaly profiles (Mutter, 1975a). (The anonymous Gulf interpreter who prepared the sketches copied in figure 131 did not recognize the fossil trench and assumed the continental slope to be underlain by northward-rising basement in normal-fault contact with deep-water strata; I omitted his hypothetical faults from my drawings.) "Stacked" multichannel reflection records have been released by Phillips Australian Oil Co. Mutter (1975a) cited these profiles, which I have not seen, as showing the continental slope to be underlain by strongly deformed strata, overturned and thrust southward. Onshore geology indicates that subduction on this system probably ceased about $5 \mathrm{~m}$.y. ago. A high-velocity slab dips gently northeast from the trench (Finlayson and others, 1977) and presumably is the fossil subducted slab of Coral Sea lithosphere.

A geophysical survey of the Gulf of Papua was made by the Compagnie Generale de Geophysique for the Australia Bureau of Mineral Resources, Geology and Geophysics (BMR), and included east-west reflection profiles about 20 $\mathrm{km}$ apart, from lat $8^{\circ} 00^{\prime}$ to $11^{\circ} 30^{\prime} \mathrm{S}$., across the submerged southwest margin of the Papuan Peninsula. These lines were given me, in single-channel-monitor form, by Director L. C. Noakes of BMR; a representative four of the profiles are illustrated in figure 132, and others were sketched by Mutter (1975a). These records lack the penetration needed to show the fossil Port Moresby Trench and associated melange wedge, but compressive deformation, including southwestdirected thrust faults and asymmetric folds, is abundantly displayed, and apparently is continuing, in the continentalslope strata.

\section{MELANGE IND OPHIOLITE}

Unmetamorphosed melange, broken and imbricated strata, and ophiolite fragments are exposed widely in the southwestern part of the peninsula. In a coastal belt, 10-20 $\mathrm{km}$ wide in the sector between $147^{\circ}$ and $148^{\circ} \mathrm{E}$., Upper Cretaceous (Senonian) through upper Eocene deep-water argillite, shale, siltstone, chert, and limestone are disrupted chaotically and are intercalated with shallow-water Paleocene and Eocene strata and with large and small masses of gabbro, diabase, and basalt (fig. 133; Brown, 1974, 1975; Davies and Smith, 1971; Glaessner, 1952, 1960; Macnab, 1969; O'Brien and others, 1961; Pieters, 1974; Yates and de Ferranti, 1967). Deformation was directed southwestward. The northeast part of the unmetamorphosed melange terrain in this sector is dominated by tuffaceous sandstone, quartzose sandstone in which plagioclase is the major feldspar, and siltstone; fossils range in age from Late Cretaceous to early Miocene. Dips are mostly steep to moderate to the northeast. Middle Miocene and younger strata lie unconformably on this northeastern terrain.

The belt of polymict, unmetamorphosed melange and broken formations swings northward at the base of the peninsula, approximately along $146^{\circ} \mathrm{E}$., where much of it was mapped as the Omaura Greywacke, some of which has enclosures of ultramafic and other exotic rock types, by Bain and Mackenzie (1974) and Dow, Smit, and Page (1974). It is dominated by Oligocene volcaniclastic rocks. A photograph of Miocene polymict melange in the "Aure Beds" was given by Down (1977, fig. 21; his "slumped polymictic conglomerate").

Eastward from $148^{\circ}$ E. to the end of the peninsula, sedimentary rocks are much less abundant and are deep-water pelagic types, and the melange belt is dominated by basalt (Davies and Smith, 1971, 1974). The mafic rocks are low-potassium, oceanic-tholeiite types where they have been studied, hence likely represent oceanic crust. Intercalated fossiliferous strata are of Late Cretaceous and Eocene ages. Middle Eocene ridge-type tholeiitic basalt is the dominant volcanic material (Milsom and Smith, 1975). A large sheet of basalt, diabase, and gabbro between about $147^{\circ}$ and $148^{\circ}$ E. is regarded by Yates and de Ferranti (1967) as an Oligocene intrusive mass, although an origin as Cretaceous oceanic crust, on which were deposited some of the flanking Cretaceous and Paleogene rocks now deformed with it, seems to me more likely from the relationships they mapped and described briefly. This sheet and the broad 


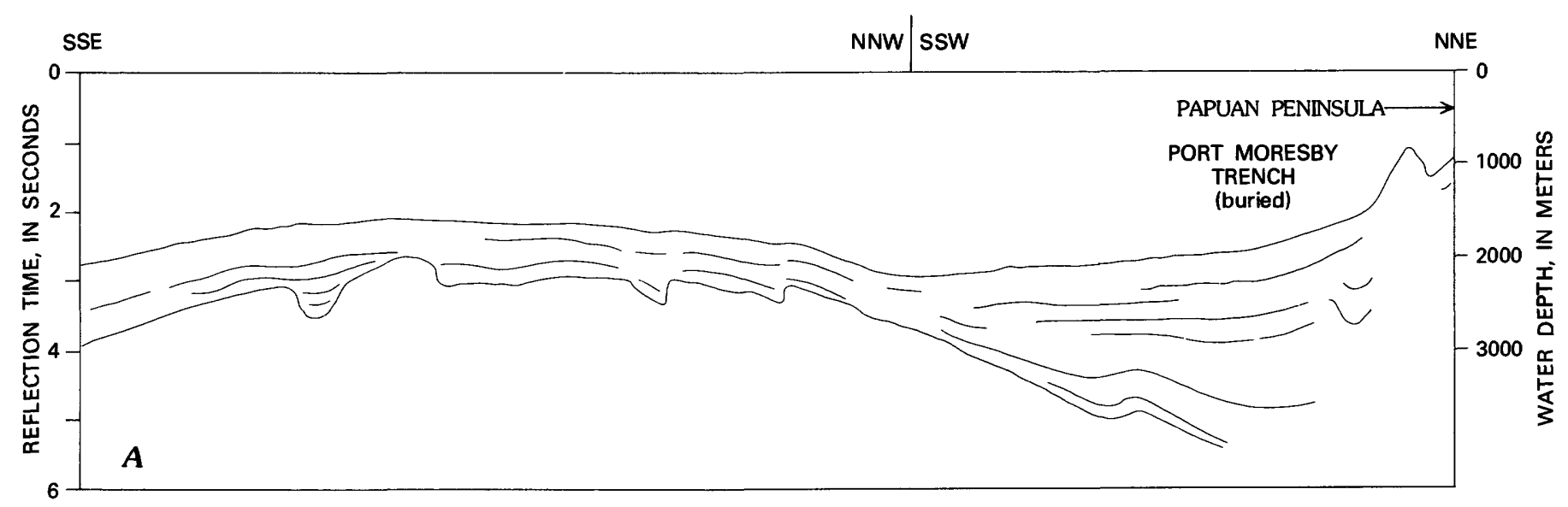

$\underbrace{50}_{\text {APPROXIMATE VERTICAL EXAGGERATION X } 17} 100$ KILOMETERS

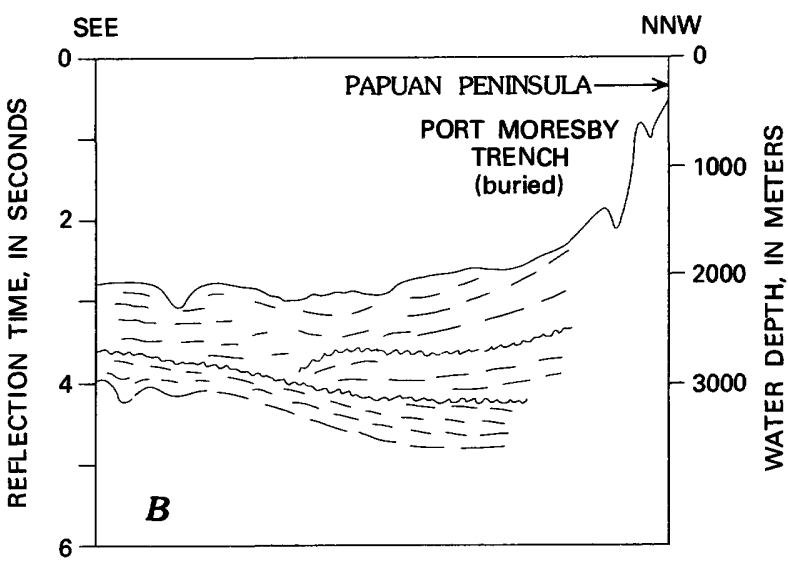

Figure 131.--Seismic-reflection profiles across the fossil Port Moresby Trench, along the southwest side of the Papuan Peninsula. Locations shown in figure 118. Redrawn from line drawings of single-channel-monitor profiles Au-72-73-73A $(A)$ and PNG-2 $(B)$ in an untitled report, circa 1973, by the Exploration Division, Gulf Research and Development Co., Pittsburgh, on a Gulfrex geophysical reconnaissance survey in the Papua New Guinea-Solomon Islands region, filed in the library of the Geological Survey of Papua New Guinea, Port Moresby.

terrain of abyssal basalt to the east of it are outlined as the Milne ophiolite (a name derived from Milne Bay, at the east end of the peninsula) in figure 120 .

\section{MIL:TMMORPHIC; MFLANGE}

The nonmetamorphosed terrain of melange and imbricated rocks merges on the northeast with progressively more metamorphosed rocks, which form the Owen Stanley terrain, $50 \mathrm{~km}$ or so wide, extending to the lower, southwest side of the Papuan ophiolite belt (fig. 120; Davies and Smith, 1971; Dow and Davies, 1964; Dow and others, 1974;
Macnab, 1969). Lawsonite schist forms a continuous strip a few kilometers wide along the base of the ophiolite sheet, and lawsonite-glaucophane gneiss and garnet schist occur in places within this high-pressure metamorphic strip. Glaucophane schist also occurs locally at the southwest side of the metamorphic terrain. Otherwise, the metamorphic rocks are mostly of greenschist facies, with garnet-bearing schist and pumpellyite-bearing rocks present in places. Graphite-quartz-feldspar-mica schist is the most common rock type, so a quartzose sedimentary assemblage was present before metamorphism. Mafic (metavolcanic?)

FIGURE 132.-Seismic-reflection profiles across the southwest margin of the Papuan Peninsula. Thrust faults likely reach the surface in profiles $A, B$, and $C$. Strata thin over anticlines and thicken into synclines, and dips increase downward: compressive deformation and sedimentation have progressed concurrently within the interval probed. Deeper-penetration profiles (fig. 131) indicate a fossil trench and melange wedge to lie at levels deeper than those illustrated here. Locations of profiles shown on figure 118. Line drawings of reflectors in single-channel-monitor profiles of records made for the Australia Bureau of Mineral Resources, Geology and Geophysics, by the Compagnie Generale de Geophysique. 

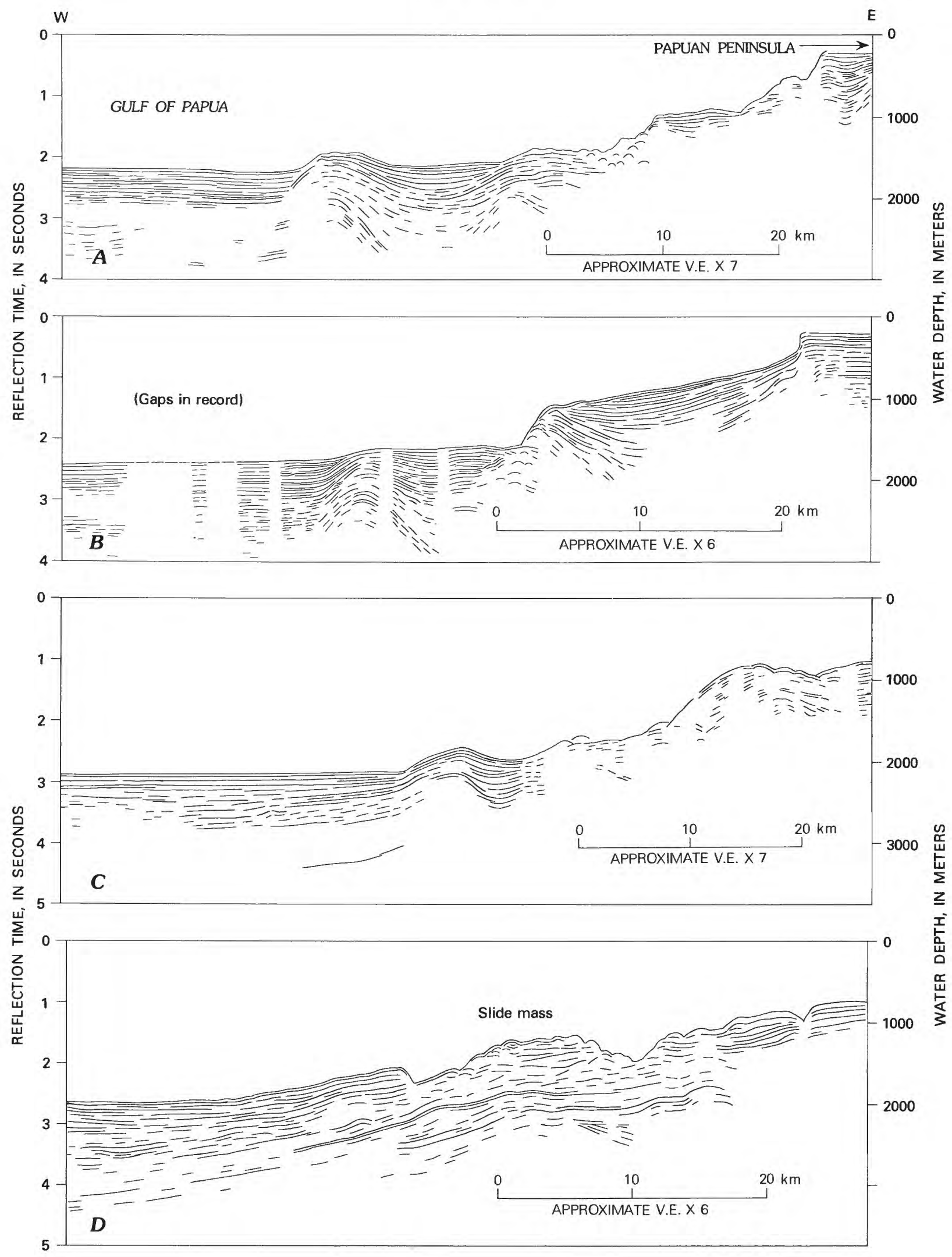

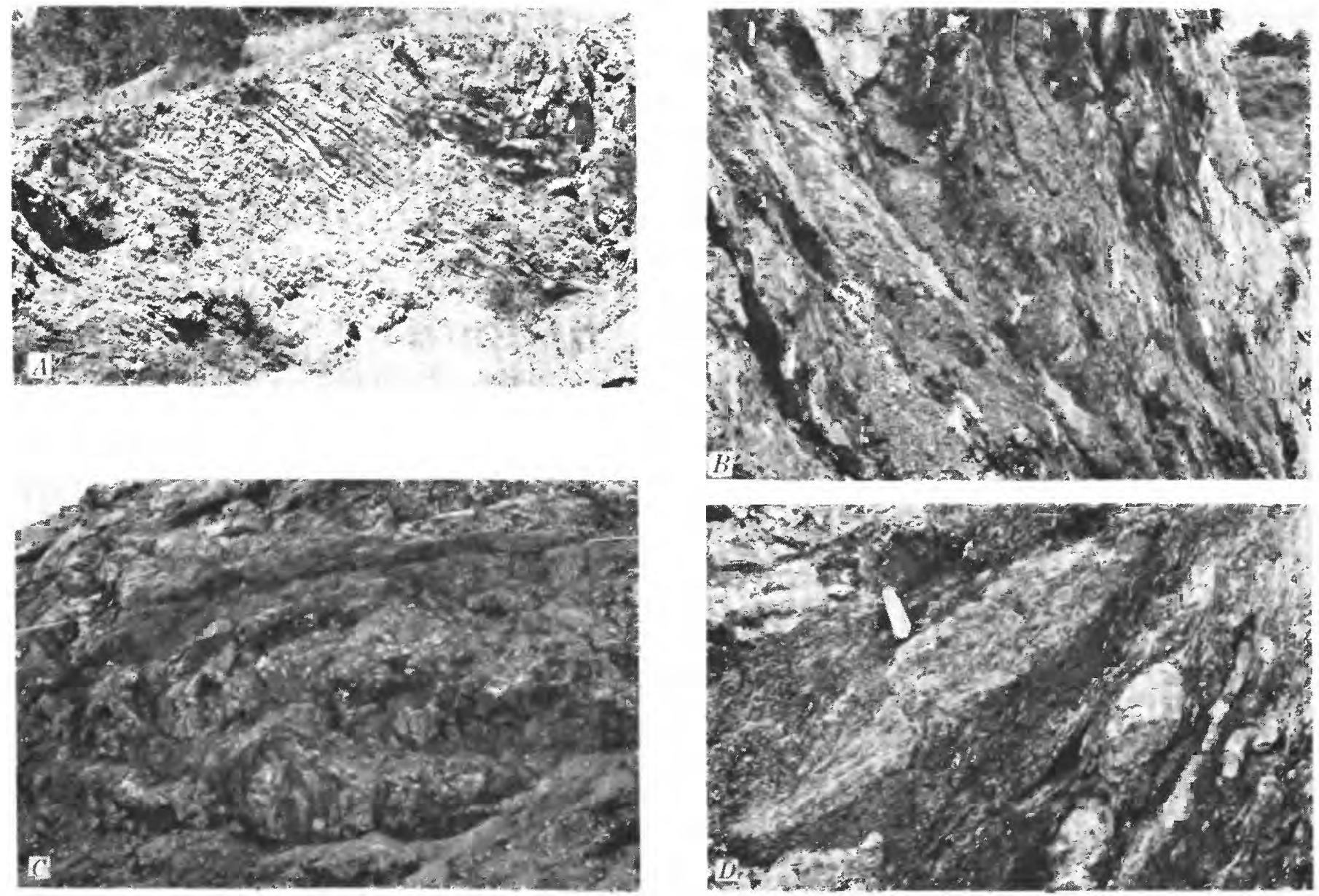

Figure 133. - Melange and imbricated rocks of Port Moresby area, Papuan Peninsula, Papua New Guinea. A, Eocene limestone. Coherent strata through the center of the exposure; disharmonic folding at the upper right; chaotically disrupted rocks at lower left. Quarry wall about $6 \mathrm{~m}$ high, $6 \mathrm{~km}$ northwest of Port Moresby, $9^{\circ} 27^{\prime} \mathrm{S} ., 147^{\circ} 8^{\prime} \mathrm{E}$. B, Sheared deep-water Eocene argillite. Strongly foliated scaly clay, dipping steeply right. encloses lenses of less-sheared sedimentary rock. Nearby melange is polymict. enclosing large and small masses of basalt and diabase. Center of exposure is about $4 \mathrm{~m}$ high; quarry, $10 \mathrm{~km}$ northeast of Port Moresby, $9^{\circ} 25^{\prime} \mathrm{S}$., $147^{\circ} 13^{\prime}$ E. $C$, Melange. Gabbro (above lines at sides of picture) lies structurally upon scaly clay enclosing disrupted lenses of pillow basalt. Argillite lenses at this locality are of both Late Cretaceous and Eocene ages. Quarry cut about $10 \mathrm{~m}$ high, $13 \mathrm{~km}$ east-northeast of Port Moresby, $9^{\circ} 25^{\prime} \mathrm{S}$., $147^{\circ} 15^{\prime}$ E. $D$, Melange. Lenses of basalt are separated by strongly foliated scaly clay. The large lens partly visible at upper left, from the knife upwards and left, is of gabbro. Same locality as $C$.

schists and marble are subordinate in the west but abundant in the east. Slate, phyllite, and unmetamorphosed sedimentary rocks, including deep-water Cretaceous limestone, are intercalated tectonically with the metamorphic rocks and become more abundant southwestward across the strike.

The premetamorphic character of the rocks in the metamorphic terrain changes southeast ward along the strike in the same way as does that in the nonmetamorphosed terrain. The eastern part of the metamorphic belt consists mostly of abyssal-tholeiite basalt and subordinate pelagic limestone, variably unmetamorphosed or metamorphosed in prehnite-pumpellyite, greenschist, or blueschist facies (Smith and Davies, 1976). The limestones have yielded foraminifers of Late Cretaceous (Senonian and
Maestrichtian), Eocene, and late Oligocene or early Miocene ages. Still farther east, the southern D'Entrecasteaux Islands (figs. 118, 120) also contain melange-intersliced glaucophane schist, greenschist, gabbro, and peridotite (Davies, 1973b; Davies and Ives, 1965; Davies and Smith, 1971). Silicic metamorphic rocks of the D'Entrecasteaux Islands, described in the subsequent section on the Solomon Sea region, likely record metamorphism beneath overthrust, hot oceanic lithosphere.

\section{TROBRIAND TRENCH}

A trench displaying southward-subduction asymmetry lies at the north base of the peninsular plateau (fig. 120). Little seismicity is associated with this feature, which thus 
presumably represents subduction that is either slow or recently inactivated, although the active volcanoes of the eastern part of the Papuan Peninsula and the D'Entrecasteaux Islands likely belong to the same subduction system. The trench is described in the subsequent section on the Solomon Sea.

\section{MAGMATIC-ARC: ROC:KS}

Igneous rocks of island-arc types are distributed widely in the Papuan Peninsula and are interpreted to record a modern period of subduction southward beneath the peninsula, preceded by subduction northward beneath it from the opposite side.

The belt of presently active volcanoes trending eastward between lat $9^{\circ}$ and $10^{\circ} \mathrm{S}$. and between long $148^{\circ}$ and $151^{\circ} \mathrm{E}$. (fig. 120) clearly belongs to the same south-dipping subduction system as does the Trobriand Trench. The northern of these volcanoes consist of moderately potassic calc-alkalic rocks (andesite and subordinate basalt, dacite, and rhyodacite), whereas the southern volcanoes consist of highly potassic mafic rocks (basalt, trachyandesite, absarokite, shoshonite, and banakite). The petrology of these rocks was discussed by Smith and Davies (1976), who emphasized that the trends are those to be expected above a southward-dipping subduction system; they were unaware that the Trobriand Trench exists to the north and were puzzled by the lack of a Benioff seismic zone beneath the volcanoes. The volcanism began here in Pliocene time, by which time southward subduction was thus operating.

The older Tertiary magmatic-arc rocks cannot be assigned subduction polarities from available petrologic data, which are inadequate to define cross-strike chemical trends within assemblages of known, limited ages. The broad distribution and age of the rocks, however, make their general relation to northeastward subduction probable. The volcanic axis trends southward, approximately along $146^{\circ} 15^{\prime} \mathrm{E}$., at the west end of the peninsula (between lat $6^{\circ} 45^{\prime}$ and $8^{\circ} \mathrm{S}$.), then curves southeastward, subparallel to the coast and $25 \mathrm{~km}$ or so inland from it. Very thick upper Oligocene through Pliocene volcaniclastic sediments were shed westward from the south-trending part of the arc and accumulated in the Aure Trough in water whose depth increased west ward from a shelf break (along which grew early Miocene reefs) near $146^{\circ}$ E. (Brown and others, 1975; Dow and others, 1974; O'Brien and others, 1961; Tallis, 1975). West-directed folding and thrusting of the strata of the eastern flank of the trough began not later than middle Miocene time, and the depositional axes of the thick marine middle and upper Miocene and marine-and-continental Pliocene clastic and andesitic-volcanigenic sediments were displaced successively westward in front of the advancing imbricated wedge (O'Brien and others, 1961). A middle Miocene granodiorite batholith, $70 \mathrm{~km}$ long, and numerous smaller Miocene masses, intruded into the northern part of the Owen Stanley schist terrain, presumably belong to the same system (Dow and others, 1974; Page, 1976). Volcanic rocks of Miocene and Pliocene age are voluminous as far southeast as about $147^{\circ} 15^{\prime} \mathrm{E}$., beyond which they are less widespread and are little deformed (fig. 134); but dikes and small stocks of mafic and intermediate igneous rocks are abundant (Bain and others, 1972; Brown, 1974, 1975; Pieters, 1974; Yates and de Ferranti, 1967). Dominant compositions throughout are andesite and basalt.

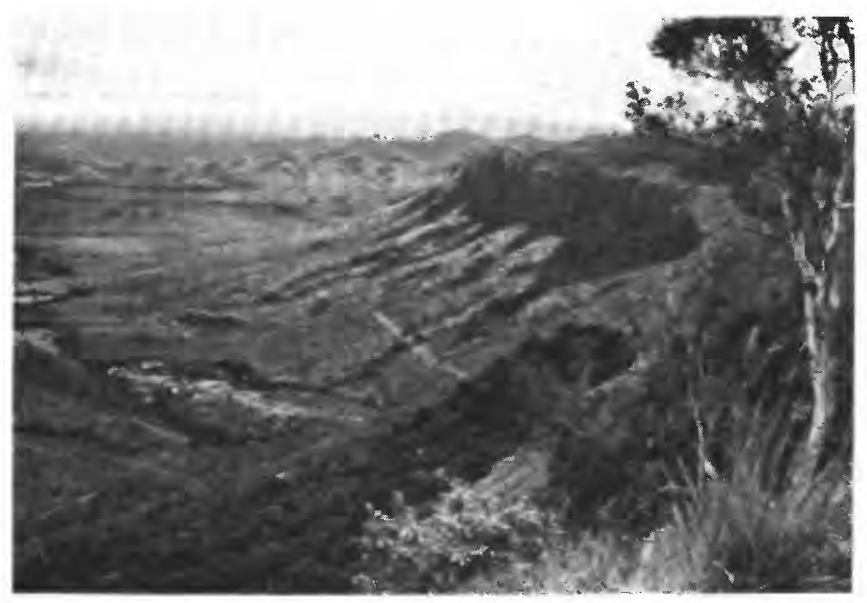

Figure 134.-View northwest across the Laloki River, from a point $20 \mathrm{~km}$ northeast of Port Moresby. Papua New Guinea. Little-deformed upper Miocene or Pliocene agglomerate of basaltic-andesite composition caps the ridge in the right foreground and middle distance and unconformably overlies melange and imbricated Upper Cretaceous and Paleogene rocks which crop out in most of the rest of the scene. The Owen Stanley Range, of metamorphosed Cretaceous and Paleogene rocks, forms the skyline.

\section{PAPIIAN PIAATEAU}

The submarine Papuan Plateau lies at a depth of about 2,000 m along the southwest side of the Papuan Peninsula, between the fossil Port Moresby Trench and the deep basins of the Gulf of Papua and the Coral Sea (figs. 117B, 131). The plateau is covered by $1,000 \mathrm{~m}$ or so of little-deformed strata of Tertiary age and likely is a fragment of continental crust (Taylor and Falvey, 1977).

\section{HISIORY OF THE PAPUIAN PENINSILA}

The Papuan Peninsula moved southwestward, overriding the oceanic crust of the Coral Sea and Gulf of Papua, during late Tertiary time. The tight syntaxis of structural trends, from east-southeast in central New Guinea to south at the base of the peninsula, is one product of this migration.

This appears explicable in terms of the continuing southward migration of the Paleogene arc that collided with northward-migrating New Guinea in Miocene time (although a more complex series of events may be indicated when age and structural relationships become known in more detail). Before the collision, the continent existed only to the west of what is now long $145^{\circ} 20^{\prime} \mathrm{E}$. Continental-slope 
and continental-shelf strata were ramped southward onto that continent by the colliding arc, and subduction subsequently flipped to southward beneath the continent as augmented by the addition of the arc. To the east of the end of the continent, however, the arc met no such resistance and continued to migrate southward, sweeping before it the strata on the floor of the subducting Coral Sea and pivoting to form the syntaxis at the corner of the old continent. Around that corner, the arc slid westward to first define, and then close, the Aure Trough, successively from north to south. Only within late Miocene or Pliocene time did subduction northward from the Port Moresby Trench cease, and subduction southward from the Trobriand Trench begin. The Port Moresby Trench has since been buried deeply by Pliocene and Quaternary sediments. Southward migration of the peninsula may have stopped when it collided with submerged, continental Papuan Plateau.

If this is correct, then the Papuan Peninsula did not exist as an appendage of New Guinea until Miocene time. The peninsula did not merely swing away from northeastern Australia in Late Cretaceous and Eocene time, as many (including, until recently, myself) have inferred. Whatever continental material was removed from Australia to form the Coral Sea is now farther east, in the New Zealand-Lord Howe-New Caledonia continental-ridge complex, or else is now in such complexes as those of northern New Guinea. The D'Entrecasteaux terrain northeast of the Papuan Peninsula, the Papuan Plateau south of the peninsula, and the Hunstein, Jimi, and Bismarck terrains of the New Guinea mainland (fig. 120) might include pieces of Australia.

\section{ARCS AND BASINS OF THE MARIANA SYSTEM}

The island arcs of the west-central Pacific extend southward into the area of the tectonic map of the Indonesian region as the festooned Palau, Yap, and Mariana Ridges and Trenches (figs. 135, 136). These appear to record various stages in the evolution of the Mariana Arc system as its frontal part has migrated toward the Pacific, becoming increasingly convex in the process.

\section{HISTORY NORTH OF THE TECTONIC-MAP AREA}

The migration of the frontal part of the Mariana Island-Arc system is suggested by evidence, first assembled by D. E. Karig, from north of the area of the tectonic map of the Indonesian region. This migration behavior is critical to an interpretation of the sectors within the map area.

The West Mariana Ridge, Mariana Trench, and intervening Mariana Trough and Mariana Ridge curve eastward from their abrupt terminus at the Yap Trench within the tectonic-map area (pl. 1) and swing northward in broad eccentric arcs, convex to the east. In the region between lat $12^{\circ}$ and $23^{\circ} \mathrm{N}$., the Mariana system consists of, from east to west, the Mariana Trench, the frontal-arc volcanic Mariana Ridge, the Mariana Trough, the West Mariana Ridge, the Parece Vela (or West Mariana) Basin, the Kyushu-Palau
Ridge, and the Philippine (or West Philippine) Basin (Karig, 1971b). The presently active Benioff zone dips westward from the Mariana Trench to depths as great as $680 \mathrm{~km}$, and first-motion studies of earthquakes indicate that the Pacific plate is sliding relatively westward beneath the arc and the Philippine Sea behind it and that offset along the west-trending, south end of the arc is nearly strike slip (Katsumata and Sykes, 1969).

\section{MARIANA TRENCH}

The Mariana Trench, bounding the arcs and marginal seas of the Mariana system against the old lithosphere of the main Pacific plate, is mostly $8,000-10,000 \mathrm{~m}$ deep and $75-100$ $\mathrm{km}$ wide. The ocean floor to the east has a general depth of almost $6,000 \mathrm{~m}$ and is dotted with seamounts. Shallow parts of the trench occur in places where seamounts or groups of seamounts lie close to the east side of the Mariana Ridge (as, near lat $16^{\circ}, 20^{\circ}$, and $26^{\circ}$ N.). Presumably at these places seamounts are colliding with ridge as subduction proceeds, and perhaps they will be scraped off the downsliding plate and added to the ridge. Much of the material of the Mariana Ridge might represent past additions of seamounts.

Ocean-floor tholeiitic basalt, vesicular seamount potassic trachybasalt, and volcaniclastic breccias containing Upper Cretaceous and Eocene foraminifers have been dredged from the seaward slope of the trench (Dietrich and others, 1978). The landward slope has yielded the apparent components of melange: clastic sedimentary materials, and variably sheared and altered ultramafic and mafic pieces of ophiolite assemblages (Dietrich and others, 1978).

\section{MARIANA RIDGF}

The active volcanoes of the Mariana Island-Arc system stand as seamounts, and as two islands, along the western side of the Mariana Ridge (Karig, 197lb). Other islands on the west side of this ridge display upper Eocene and younger volcanic and volcaniclastic rocks, derived from the west, and shallow-water carbonates. No islands stand on the eastern part of the ridge. The ridge has a steeply faulted west side. The east side is mostly covered by sediments, and slopes relatively steeply in its upper part but then flattens to a bench, beneath which are landward-thickening strata, at a water depth of about $2,000 \mathrm{~m}$. On this bench, which is equivalent to the outer-arc basins of the Indonesian arcs, sediments lap eastward onto the basement, and the youngest strata spill down the lower slope to the Mariana Trench. The platform disappears in the south, where the arc system swings around to the west. A sediment apron that extends down the deeper slopes toward the Mariana Trench was drilled by Deep Sea Drilling Project (DSDP) hole 60 (fig. 135) at a water depth of $3,700 \mathrm{~m}$. The $350 \mathrm{~m}$ of section penetrated consists of lower (?) and middle Miocene volcanic ash and volcanic sand, deposited in deep water (B. C. Heezen and others, in Fischer and others, 1971, p. 587-629).

The paleomagnetic pole position recorded in Miocene volcanic rocks of Guam, atop the southern, southwest-tren- 


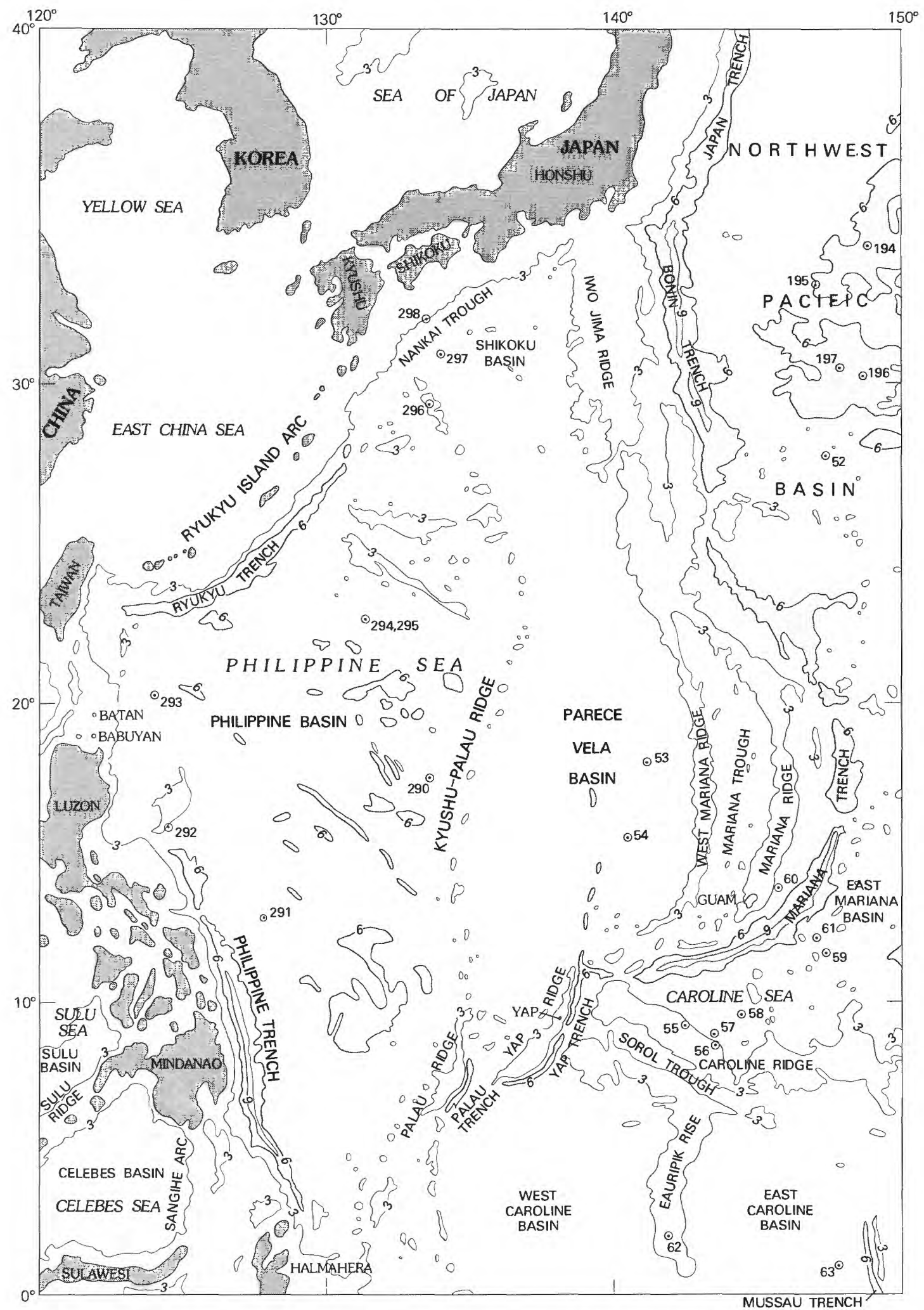

FIGURE 135.-Bathymetric map of the Philippine Sea and surrounding regions. Contour interval $3 \mathrm{~km}$; land areas stippled, and areas deeper than $6 \mathrm{~km}$ shaded. Generalized from Chase, Menard, and Mammerickx (1971). Numbers mark drillholes of the Deep Sea Drilling Project (DSDP). 


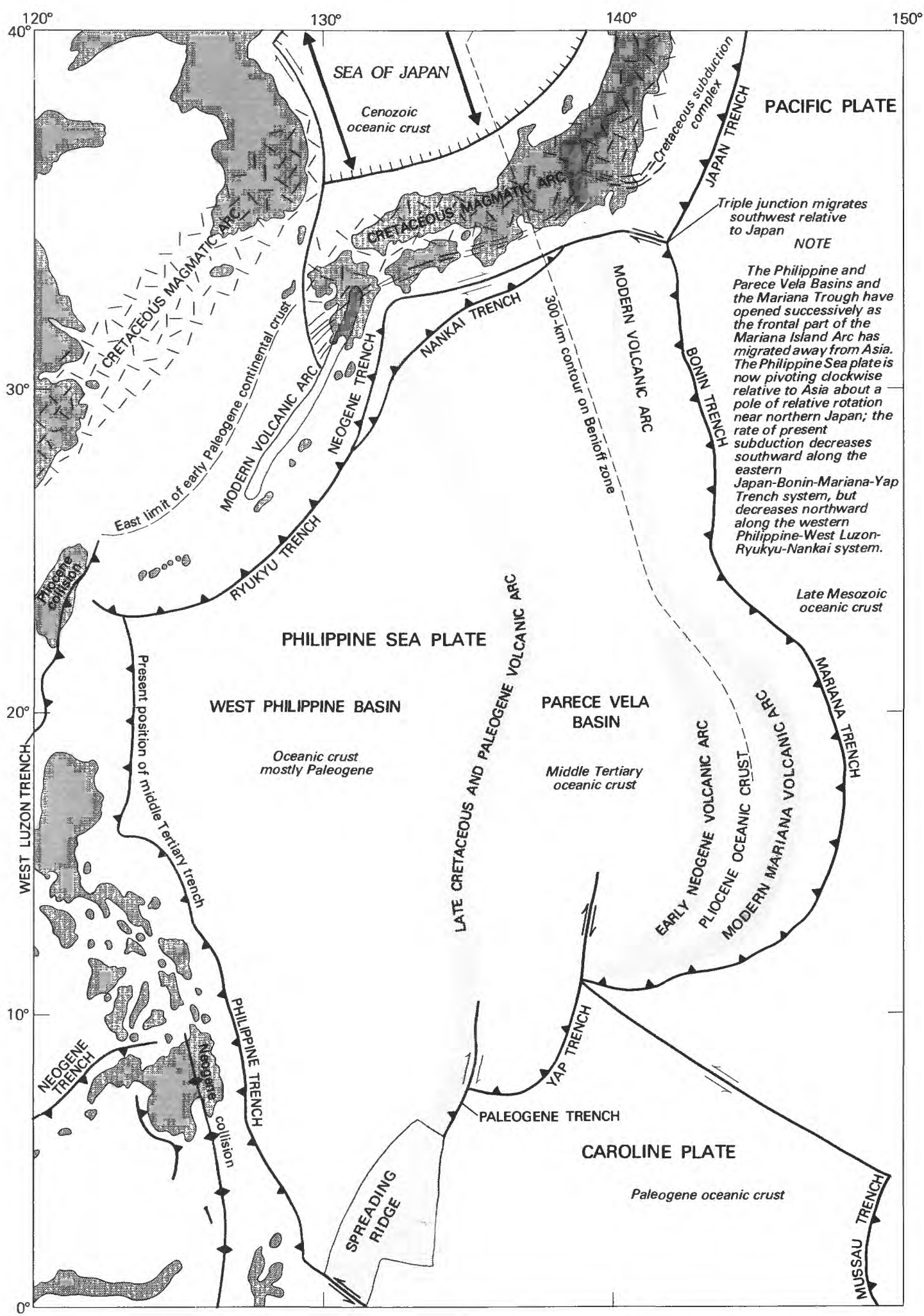

FIGURE 136.-Tectonic elements of the Philippine Sea and surrounding regions. Active subduction zones and strike-slip faults shown by black lines; inactive Tertiary ones shown by dark gray. Interpreted from many sources, including those cited in text. 
ding part of the ridge, suggests that this sector has rotated about $50^{\circ}-60^{\circ}$ clockwise in late Neogene time (Larson and others, 1975). This accords with the concept, developed subsequently, that the ridge has migrated and become more curved with time.

The derivation of some of the magmatic material erupted in island arcs by melting of oceanic sediments subducted on downgoing lithosphere plates has often been inferred. Lead and strontium isotopes in volcanic rocks of the Mariana lslands preclude the possibility that more than a minute fraction of the erupted magma represents recycled sedimentary material (Matsuda and others, 1977; Meijer, 1976), but strontium in rocks on islands closer to Japan on the ridge may record such contamination (Matsuda and others, 1977). MARIANA TROUGH

The crescentic Mariana Trough narrows northward and southward from a maximum width of about $200 \mathrm{~km}$ (Karig, 1971b; Karig and others, 1978). The average depth of this basin is about $4 \mathrm{~km}, 2 \mathrm{~km}$ less than that of the Pacific Ocean floor east of the Mariana Trench. Ridges and troughs trend northerly across the basin. A maximum of a few hundred meters of Quaternary volcaniclastic muds, derived from the Mariana Ridge, lies in the troughs in the basement, which thus apparently formed within Pliocene time (Karig, 1971b). Very young, olivine pillow basalt has been dredged from the steep flanks of the axial high within the basin, and greenstone has come from a trough across the high (Karig, 1971b). The basalt is of abyssal-tholeiite type in its rare-earth-element patterns, its ratios of $\mathrm{K} / \mathrm{Rb}, \mathrm{K} / \mathrm{Cs}$, $\mathrm{K} / \mathrm{Ba}$, and its low ratio of ${ }^{87} \mathrm{Sr}$ to ${ }^{86} \mathrm{Sr}$, although it has higher contents of $\mathrm{K}, \mathrm{Rb}, \mathrm{Cs}, \mathrm{Sr}, \mathrm{Ba}$, and rare-earth elements than does typical spreading-ridge basalt (Hart and others, 1972). Heat flow is high along the axial ridge and low along its flanks (R. N. Anderson, 1975). Upper mantle shear-wave velocities are very low, indicating high temperatures and partial melting (Seekins and Teng, 1977). An origin of the basin by Pliocene spreading behind an eastward-migrating Mariana Ridge is inferred (R. N. Anderson, 1975; Hart and others, 1972; Karig, 1971 b; Karig and others, 1978).

\section{WEST MARIANA RIDGE}

The West Mariana Ridge has a prominent east scarp, and a faulted west side that is like that of the Mariana Ridge except draped by a greater quantity of sediment (Karig, $197 \mathrm{lb}$ ). The ridge is locally broad but is mostly narrow and irregular. Seamounts in a line $20-40 \mathrm{~km}$ west of the ridge crest appear to be island-arc volcanoes and to be the source of the sediment apron extending westward from the ridge. Fore-reef limestone of late Miocene or Pliocene age was dredged from the crest of the east scarp at a depth of $1,500 \mathrm{~m}$, showing subsidence of the ridge by that amount in very late Cenozoic time (Karig, 1971b). DSDP hole 451 (not shown on fig. 135) on the ridge penetrated $900 \mathrm{~m}$ of upper Miocene calc-alkalic volcaniclastic rocks beneath $36 \mathrm{~m}$ of Pliocene and Quaternary foraminiferal and nannofossil oozes (Kroenke and Scott, 1978).
PARECE VELA BASIN

West of the West Mariana Ridge, between it and the Kyushu-Palau Ridge, is the Parece Vela (West Mariana) Basin. This basin is similar to the inter-arc Mariana Trough, although it is a little deeper-mostly 4,500-5,000 $\mathrm{m}$-and is about $800 \mathrm{~km}$ wide in its broadest sector(Karig, 197lb). The basin is broken by high-relief ridges and troughs in its central part. A sediment apron extends westward into the eastern part of the basin from the West Mariana Ridge and where drilled in DSDP hole 53 (fig. 135) consists of high upper Miocene and younger pelagic sediments, low upper Miocene to lower Miocene volcanic ash, and basal Miocene or high Oligocene pelagic limestone; the base of the section was not reached. DSDP hole 450 (near hole 53; not shown on fig. 135) penetrated $90 \mathrm{~m}$ of Pleistocene to middle Miocene pelagic clay and $240 \mathrm{~m}$ of underlying, undated basaltic tuff, and bottomed in intrusive basalt (Kroenke and Scott, 1978). Hole 54 in the same sediment apron reached acoustic-basement basalt beneath middle Miocene basaltic and andesitic tuff (Heezen and others in Fischer and others, 1971, p. 344-387). The basement basalt is high-alumina abyssal tholeiite of spreading-ridge type (Ridley and others, 1974). In the west part of the basin, west of the ridge-and-trough terrain, pelagic sediments thicken westward to a maximum of about 300 m near the Kyushu-Palau Ridge (Karig, 1971 b). DSDP hole 449 (at the west side of the basin; not shown on fig. 135) penetrated $111 \mathrm{~m}$ of upper Oligocene to Pleistocene pelagic clays resting on plagioclase-olivine phenocrystic-basalt basement (Kroenke and Scott, 1978). The axial ridge may mark a symmetrical spreading center that became extinct about the beginning of the Miocene (D. E. Karig in Karig, Ingle, and others, 1975, p. 859; Kroenke and Scott, 1978; Watts and Weissel, 1975). Dredge hauls from troughs in the axial zone yielded variably altered pillow basalt and porphyritic basalt, sheared gabbro, and serpentinized spinel lherzolite (Dietrich and others, 1978). The lithosphere beneath the Parece Vela Basin, above the mantle low-velocity zone, is only about $30 \mathrm{~km}$ thick (Seekins and Teng, 1977).

$$
\text { KYUSHU-PALAU RIDGE }
$$

The Kyushu-Palau Ridge is a Late Cretaceous and Paleogene island arc. DSDP hole 448 (on the central part of the ridge; not shown on fig. 135) penetrated upper Oligocene and lower Miocene nannofossil ooze and chalk, upper and middle Oligocene submarine tuffs, and $600 \mathrm{~m}$ of middle Oligocene highly vesicular basalt, high-alumina basalt, andesite, volcaniclastic breccia, dikes, and sills (Kroenke and Scott, 1978). Thick ash and volcaniclastic sediments were cut by hole 296, near the north end of the ridge, and contain Oligocene foraminifers in their central part (lngle and Karig, 1973; Karig, Ingle, and others, 1975). Lapilli tuff at the bottom of hole 296 has an Eocene ${ }^{40} \mathrm{Ar}-{ }^{39} \mathrm{Ar}$ age of about 48 m.y. (Ozima and others, 1977). In hole 296, and in hole 297 northeast of the north end of the ridge, more distant volcanism is indicated by fine-grained ash intercalated with Miocene pelagic sediments; Pliocene and Quaternary 
materials are pelagic (Karig, Ingle, and others, 1975).

The apron of clastic sediments along the west side of the Kyushu-Palau Ridge has a thicker pelagic cover than does the apron along the West Mariana Ridge and hence is older (Karig, 1971b). DSDP hole 290 (fig. 135) in the apron reached volcanic conglomerate beneath middle and upper Eocene and Pliocene pelagic sediments (Ingle and Karig, 1973; Karig, Ingle, and others, 1975). Reworked Upper Cretaceous foraminifers in the cores show that Cretaceous rocks are present in the ridge. Nearby hole 447 (not shown on fig. 135) at the distal edge of the apron penetrated $113 \mathrm{~m}$ of basement pillow basalts and flows beneath middle Oligocene and younger pelagic sediments (Kroenke and Scott, 1978).

\section{PHILIPPINE BASIN}

The broadest component of the Mariana system is the Philippine Basin, which is about $6,000 \mathrm{~m}$ deep. DSDP holes 291, 292, and 294 in the basin all reached basalt beneath Eocene sediments, whereas hole 293 bottomed in an undated basaltic breccia (Karig, Ingle, and others, 1975). The ages of basalt, determined by the ${ }^{40} \mathrm{Ar}-{ }^{39} \mathrm{Ar}$ method, in holes 292 , 293, and 294 are 50, 42, and $49 \mathrm{~m}$. y., respectively (Ozima and others, 1978). The lithosphere, above the mantle low-velocity layer, is only about $30 \mathrm{~km}$ thick (Seekins and Teng, 1977). Magnetic anomalies trend west-northwest across the basin and presumably record Paleogene sea-floor spreading within it, although the anomalies cannot yet be assigned ages or fitted to a symmetrical pattern (Louden, 1976; Shih, 1976; Watts and others, 1977). How spreading in a north-northeast direction can be accommodated in the regional pattern is unclear. The DSDP holes appear to invalidate the speculation by Ben-Avraham, Bowin and Segawa (1972) and Uyeda and Ben-Avraham (1972) that the basin floor formed by Mesozoic spreading. Changing paleomagretic inclinations in sediments in the DSDP holes suggest that the Philippine Basin has moved about $20^{\circ}$ northward, at an average velocity of about $5 \mathrm{~cm} / \mathrm{yr}$, during the past $40 \mathrm{~m} . \mathrm{y}$. (Louden, 1977).

\section{INTERPRECTATION}

These relationships were integrated by Ingle and Karig (1973), Karig (197la, b, 1972, and in Karig, Ingle, and others, 1975, p. 857-879), and Karig and Moore (1975) into an explanation of the Mariana Arc system in terms of the intermittent eastward migration of the frontal part of the system, each time leaving the back part behind and opening a new tensional basin between migrating and abandoned strips. The large and complex Philippine Basin to the west of the Kyushu-Palau Ridge apparently formed in Paleogene time, perhaps by similar spreading behind several migrating arcs, and the data contain "hints of arc polarity reversals, collisions, and other reorganizations of tectonic elements" (D.E. Karig, in Karig, Ingle, and others, 1975, p. 857). The following discussion pertains to the simpler evolution of the system from the Kyushu-Palau Ridge eastward and is based on the papers, noted above, by Karig and his associates.
(Bracey and Ogden, 1972, speculated on other details of the history.)

Three times in the history of the arc, the frontal ridge split longitudinally, the back side being abandoned in place and the front side migrating eastward, and new ocean floor formed in the growing gap. Both the Kyushu-Palau and West Mariana Ridges represent the western parts of former volcanic-arc ridges. The frontal parts - the basement bench and the trench-that formed with each of these ridges are lacking, so the subduction systems did not die as new ones broke through the crust farther east. The oceanic basins between the remnant ridges become older westward (fig. 136). The Mariana Trough is of Pliocene age; the Parece Vela Basin was forming by late Oligocene time, and at least its western part becomes older westward; and the Philippine Basin is early Paleogene. The West Mariana Ridge is the west part of the volcanic arc of Miocene age, and the Kyushu-Palau Ridge is the west part of the volcanic arc of the Late Cretaceous and Paleogene. Eocene to Miocene volcaniclastic rocks derived from the west occur now in the modern frontal-arc Mariana Ridge, so in each case the ridge split longitudinally, its east part migrating away while its west part remained behind. Each successive arc position was more convex toward the Pacific than the one before, and the ridges that define the successive positions converge northward and southward. The belt of active volcanism has migrated with the moving part of the arc. Periods of rapid migration appear to be correlative with periods of most intense volcanism along the arcs. Le Pichon, Francheteau, and Sharman (1975) showed that the opening of the Mariana Trough could be accounted for geometrically by the rigid-plate migration of the Mariana Ridge northward and counterclockwise away from the West Mariana Ridge, without change in curvature of the Mariana Arc, although Karig, Anderson, and Bibee (1978) have regarded this possibility as incompatible with the observed fracture-zone directions and known geology, and argued for opening by rotation about a pivot at the north end of the trough.

The geometry of the arcs (fig. 136) suggests a further complication. The Yap Trench appears to festoon southward past the north end of the Palau Trench, and the Mariana Trench similarly festoons southward past the end of the Yap Trench. It appears that in each case the migrating arc has not only moved away from the arc behind but has ballooned or slid southward past it. The lengths of the migrating arcs may increase not only to compensate for their increasing convexity toward the Pacific but also to accommodate the festooning.

\section{BEHAVIOR OF ISLAND ARCS}

Island arcs may characteristically migrate oceanward, opening marginal seas behind them. Such behavior is deduced for the Banda Arc in this report. Farther east, the geophysical and marine-geologic features of the Tonga-Kermadec Island Arc also appear to require migration (Burns 
and Andrews, 1972, Hawkins, 1974, 1976; Karig, 1970, 1972; Lawver and others, 1976; Sclater and others, 1972). Similar interpretations can be made for other arcs in the western Pacific (Karig, 1971a; Sclater, 1972; Sleep and Toksöz, 1971).

Island arcs apparently tend to migrate out over the plates that are sliding beneath them; but the mechanism is not clear. Documented, simple magnetic-anomaly spreading patterns are of limited, irregular extent in the marginal seas behind the arcs, so the mechanism is not likely to be regular, symmetrical spreading of midocean-ridge type. The authors cited in the preceding paragraph favored some sort of upwelling of basalt, melted in the mantle and somehow related to the Benioff zone beneath, as a driving process for the spreading. Andrews and Sleep (1974), Moberly (1973), and Sleep and Toksöz (1971) suggested that mantle beneath the arc is dragged down by the downgoing slab beneath it, creating an eddy above the slab with rising flow, and hence extension behind the arc.

Another possible mechanism was suggested by Frank (1968) and advocated by De Fazio (1974) and Scholz and Page (1970). A spherical lithosphere plate bent down at a trench must either conserve its surface area by buckling at the hinge or else reduce its area by thickening. Because of the thinness of the plate, buckling is favored except where such a constraint as an adjacent continent complicates the pattern. In the simplest case, the downbuckled edge forms hingeline scallops, which migrate into the oceanic plate as subduction proceeds. Curvature of the arc becomes greater with time, resulting in extension behind or at the trench. If a tear fault is present so that one end of the downgoing slab is free, the hingeline may be nearly straight, as in the Tonga-Kermadec Arc, which is bounded on the north by the complex transform system that steps Pacific motion to the west. In these terms, an arc is not driven out over the plate being subducted beneath it; rather, the trench form-the hingeline - migrates into the oceanic plate. New oceanic crust is formed behind whatever part of the island-arc system migrates oceanward with the hingeline.

\section{SOUTHERN COMPONENTS OF THE MARIANA SYSTEM}

The elements-Mariana Trench, Mariana Ridge, Mariana Trough, and West Mariana Ridge-of the eastern part of the Mariana system converge as they swing toward the southwest in eccentric arcs. (fig. 137). Southwest of Guam, in the region of southwesterly to westerly trends, the two ridges and intervening trough lose their identity in a narrowing composite ridge of jumbled topography. The Mariana Trench and this composite Mariana Ridge end with west-northwestward trend at a right-angle junction against the Yap Trench. The latter trench and the Yap Ridge that rises from its west side trend north-northeastward for about $400 \mathrm{~km}$ past the intersection. In the south, Yap Ridge and Trench in turn curve westward and meet the Palau Ridge and Trench at another right angle. The Palau Trench continues only a short distance north of the junction, but the ridge continues, as the Kyushu-Palau Ridge, northward to Japan. Southward, the Palau Ridge and Trench trend into a region of complex and poorly known topography.

\section{MARIANA IRENCH AND MARIANA RIDGE}

The Mariana Trench swings westward to the south of Guam and is 8,000-11,500 $\mathrm{m}$ deep (fig. 138), thus including the greatest known depth in the world's oceans. Slopes of $15^{\circ}-20^{\circ}$ are maintained for heights of several kilometers on the landward side of the trench (Fisher, 1975). Curving with the trench on the north are the Mariana and West Mariana Ridges. Motion between the Pacific plate and the Mariana Ridge in this west-trending sector is right-lateral strike-slip (Katsumata and Sykes, 1969).

\section{YAP TRENCH AND RIDGE}

The steep-sided Yap Trench is 6,000-8,000 $\mathrm{m}$ deep, and its axis is only $25-40 \mathrm{~km}$ from the east edge of the top of the Yap Ridge, which is mostly near sea level and stands above it in the Yap Islands. Two profiles (fig. 139) show the trench to be narrow-bottomed, with little or no sedimentary floor. (See also Fisher, 1975.) Thin sediments fill the topographic lows upon the rough ridge. Seismicity is generally low, although an earthquake with a Richter magnitude of about 8 occurred south of Yap in 1911.

The basement rocks of the Yap Ridge crop out on islands only on Yap and its nearly touching neighbors of Map, Rumong, and Gagil Tomil. Exposures are poor in the laterized interiors of the islands but are locally good along headlands and beaches. The bedrock consists of metamorphosed oceanic crust and mantle, a Miocene slump breccia derived from these materials, and Neogene basaltic or andesitic agglomerate. Although I spent a few days on the islands in 1972, this account is taken primarily from the reports cited in this section.

The metamorphic rocks are dominated by chloritealbite-actinolite greenschist (fig. 140A), which forms the northwest half of the islands, and by hornblende greenschist and andesine-hornblende amphibolite, which crop out over a smaller area in the northeast. Some of these metamorphic rocks have the general composition of ocean-floor basalts: they are low in $\mathrm{SiO}_{2}(46-49$ percent by weight in nine analyses) and $\mathrm{K}_{2} \mathrm{O}$ (mostly 0.09-0.20 percent), high in $\mathrm{MgO}$ (7-16 percent), and variable in $\mathrm{Al}_{2} \mathrm{O}_{3}$ (11-18 percent; Shiraki, 1971). The one greenschist sample analyzed by Matsuda, Zashu, and Ozima (1977) has primitive strontium: ${ }^{87} \mathrm{Sr} /{ }^{86} \mathrm{Sr}$ is only 0.7029 . Massive and brecciated serpentinite and minor partly serpentinized peridotite occur in the hornblendic rocks as many small lenses and as occasional lenses as large as $\mathbf{1 ~ k m}$ long and several hundred meters wide (Johnson and others, 1960). Ultramafic rocks and melabasalts are represented also by voluminous actinolite-rich schists (Hawkins and Batiza, 1978). The greenschist is broken by crosscutting shears (fig. 140 A), and both the hornblendic rocks (fig. 140D) and the nonhorn- 
blendic greenschists (Johnson and others, 1960, photo 20) include some that were breccias before metamorphism. This basement complex is inferred to be formed of oceanic crust plus shreds of oceanic upper mantle, dismembered by subduction processes.

Miocene sedimentary breccia, and subordinate sandstone and siltstone, derived primarily from hornblende and actinolite schist and amphibolite, underlie much of the northeastern part of the Yap Islands and composes the Map Formation of Johnson, Alvis, and Hetzler (1960) and Tayama (1935). Some of the breccia can be seen to form lenses within bedded strata (fig. 140 B), and large, continuous exposures of breccia indicate larger lenses to reach thicknesses of at least tens of meters. The breccias are internally massive and consist of angular, blocky fragments, to at least $4 \mathrm{~m}$ in diameter, of hornblende schist and amphibolite in a matrix of variably comminuted material of the same composition (fig. 140C). Hawkins and Batiza
(1978) recognized also abundant clasts of hornblende diorite and gabbro, serpentinite, pyroxenite, and diopsidic marble. The sands and silts are poorly consolidated and display abundant soft-sediment deformation-slumping, truncation of units, gouge. Dips are mostly moderate. The sand and silt contain large, shallow-water middle(?) Miocene foraminifers (Cole and others, 1960): whatever the water depth of deposition of the breccias, islands or reefs were nearby. The breccias appear to have been dumped by mass-movement processes into a setting that was otherwise receiving medium-grained clastic sediments. Stream erosion could not have been involved, for the clasts do not show fluvial rounding. Slumping from submarine scarps can perhaps be inferred, and possibly subduction was then operating.

Unmetamorphosed volcanic rocks, deeply weathered and poorly exposed, underlie much of the east-central and far southwestern parts of the Yap Islands. Some of these rocks

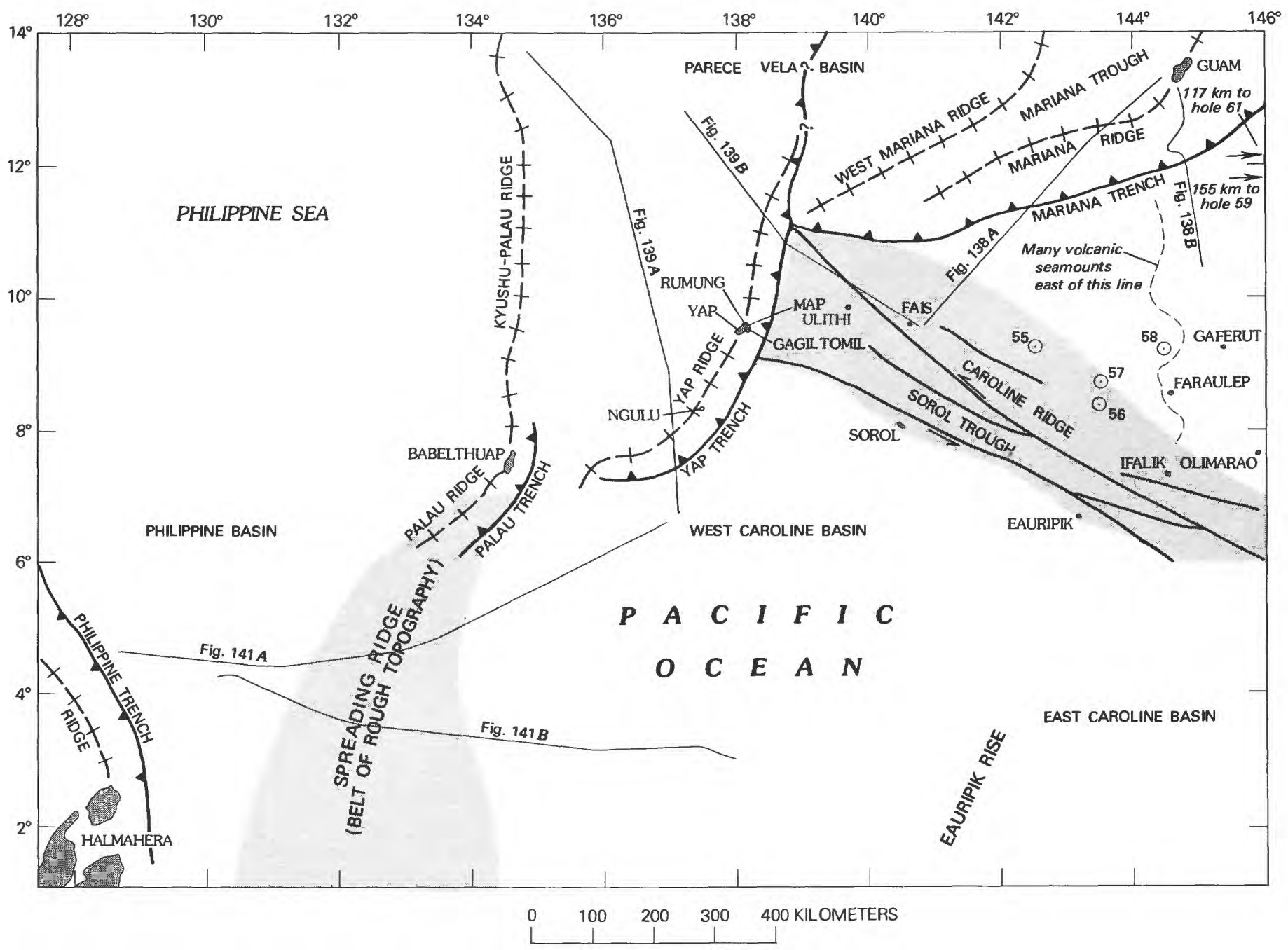

FIGURE 137.- Structural elements from the Philippine Basin to the Palau-Yap-southern Mariana region, showing location of reflection profiles of figures 138, 139, and 141 and of Deep Sea Drilling Project drillholes 55-58. That part of the Caroline Ridge which is complexly faulted and upwarped oceanic crust is shaded, as is the belt of rough topography extending southward from the Palau Ridge and Trench. 
are Neogene magmatic-arc parts of the Yap Island-Arc system: they overlie the middle(?) Miocene breccias as well as metamorphic rocks, have gentle dips, and include two-pyroxene andesite (Johnson and others, 1960). Other mafic volcanic rocks have steep dips, may underlie the breccia, and perhaps, like the metabasalts, represent oceanic crust. These contrasted volcanic rocks were lumped, with deeply weathered terrains possibly derived from schist or breccia, as the Tomil Volcanics by Johnson, Alvis, and Hetzler (1960) and Tayama (1935).

Three sites at depths of 1,500 to $4,600 \mathrm{~m}$ on the west wall of the Yap Trench were dredged by Hawkins and Batiza (1978). Amphibolite, calc-silicate rocks metamorphosed under amphibolite-facies conditions, chlorite-actinolite greenschist, altered feldspathic basalt, diabase, and alkalic basalt altered under prehnite-laumontite-facies conditions were retrieved. No melange was recognized. Oceanic crust and, in the case of the alkalic basalt, an oceanic seamount appear to be represented.

\section{PARECE VELA BASIN}

Between the Yap and Kyushu-Palau Ridges is the southwestern part of the Parece Vela Basin (in the nomenclature of Karig, 1971b; called the West Mariana Basin on pl. 1). The basin has a rough floor at a depth mostly near 4,000-5,000 m, and sediments are concentrated in the topographic lows (fig. $139 A, B$ ).

\section{PALAU RIDGE AND TRENCH}

The short Palau Trench has a depth mostly near $7,000 \mathrm{~m}$, and its axis is only about $25 \mathrm{~km}$ from the east side of the shallow platform of the Palau Ridge. Slopes of $10^{\circ}-15^{\circ}$ characterize the sides of the trench (Fisher, 1975). The islands standing on the Palau Ridge (fig. 137) expose only reefs and young limestones, except for the large island of Babelthuap, in the Palau group, which displays mostly moderately deformed Paleogene island-arc volcanic rocks (U.S. Army, 1956). The volcanic rocks are mostly basaltic, andesitic, and dacitic breccias. Both hornblende and two-pyroxene andesites are present. The potassium content of the rocks is relatively low-the $\mathrm{K}_{2} \mathrm{O}$ content at 55 percent $\mathrm{SiO}_{2}$ is only about 0.5 percent, to judge by the nine chemical analyses in the report cited - so formation at a height of only about $80 \mathrm{~km}$ above a Paleogene Benioff zone is suggested by the empirical relationships between composition and Benioff zones in active arcs (Hatherton and Dickinson, 1969 , fig. 6). Ratios of ${ }^{87} \mathrm{Sr} /{ }^{86} \mathrm{Sr}$ are low, about 0.703 (Matsuda and others, 1977). Upper Eocene fossils have been found in one volcanic unit, and all volcanic rocks are older than middle Miocene limestone.

\section{PHILIPPINE BASIN}

Between the Philippine Trench and the Kyushu-Palau Ridge lies the Philippine Basin (West Philippine Basin of Karig, 197lb), which narrows southward to end northeast of
Halmahera (fig. 135). The part of the basin within the area of the tectonic map of the Indonesian region has a heat flow near $1.7 \mathrm{microcal} / \mathrm{cm}^{2} \mathrm{sec}$ (Sclater and others, 1976), is mostly between 4,500 and $6,000 \mathrm{~m}$ deep, and has a veneer of a few hundred meters of pelagic sediments over a moderately rough acoustic basement (fig. 141). These sediments are markedly thicker than those of the Parece Vela Basin (fig. $139 A, B)$, on the east side of the Kyushu-Palau Ridge: here in the south, as farther north (previous discussion), the basement of the Philippine Basin appears to be older than that of the Parece Vela Basin. Presumably here too, both basins formed by spreading behind migrating arcs, the Philippine Basin in early Paleogene time, and the Parece Vela Basin in the middle Tertiary.

\section{REGION SOUTH OF PALAU RIDGE}

A belt of high-relief bottom topography trends southward and southwestward from the south end of the Palau Ridge. The bathymetry shown on the Indonesian folio maps, including $\mathrm{pl} .1$, is very inaccurate in this region; somewhat better bathymetry was compiled by Bracey (1975) and Mammerickx (1978). Seismicity is low. Two reflection profiles (fig. 141) across this terrain near lat $4^{\circ} \mathrm{N}$. leave its tectonic character in doubt. Although the Palau Trench projects toward these profiles, it does not obviously cross them: none of the topographic lows looks like a subduction-zone trench, fossil or active. Each profile does contain a particularly deep trough, its apparent $\mathrm{V}$ bottom at a depth of about $5,500 \mathrm{~m}$, near the center of the high-relief region at about long $133^{\circ} \mathrm{E}$., but these depressions are flanked on both sides by equally high and rugged terrain.

J. K. Weissel and R. N. Anderson (written commun., 1978) inferred that this trough marks a center of slow spreading. From an expanded print of part of the seismic-reflection profile reproduced here as fig. $141 B$, they found that thickness of pelagic sediments increases in linear, symmetrical fashion outward from the medial trough, from about $100 \mathrm{~m}$ at the trough axis to $300-350 \mathrm{~m}$ at a distance of $100 \mathrm{~km}$ on each side. They deduced from the sediment thicknesses that the medial $250 \mathrm{~km}$ of the ridge formed within the approximate time interval 5 or 6 to 10 or $12 \mathrm{~m} . y$. ago, and thus at a half-spreading rate of about $2 \mathrm{~cm} / \mathrm{yr}$, and that since 5 or $6 \mathrm{~m} . \mathrm{y}$. it has spread much more slowly if at all. Ridge depths, interpreted by Weissel and Anderson in terms of the usual correlation between age and subsidence, suggest that the same terrain formed instead between about 5 and $20 \mathrm{~m} . y$. ago, hence at a half-spreading rate of only about $0.6 \mathrm{~cm} / \mathrm{yr}$. The Caroline plate apparently is scissoring relative to the Philippine Sea plate, with Neogene subduction, beneath Palau and Yap, increasing northward from a pivot whose final position-it might have migrated northward with time-was near lat $5^{\circ}$ or $6^{\circ} \mathrm{N}$., and Neogene spreading increasing southward from that pivot. 

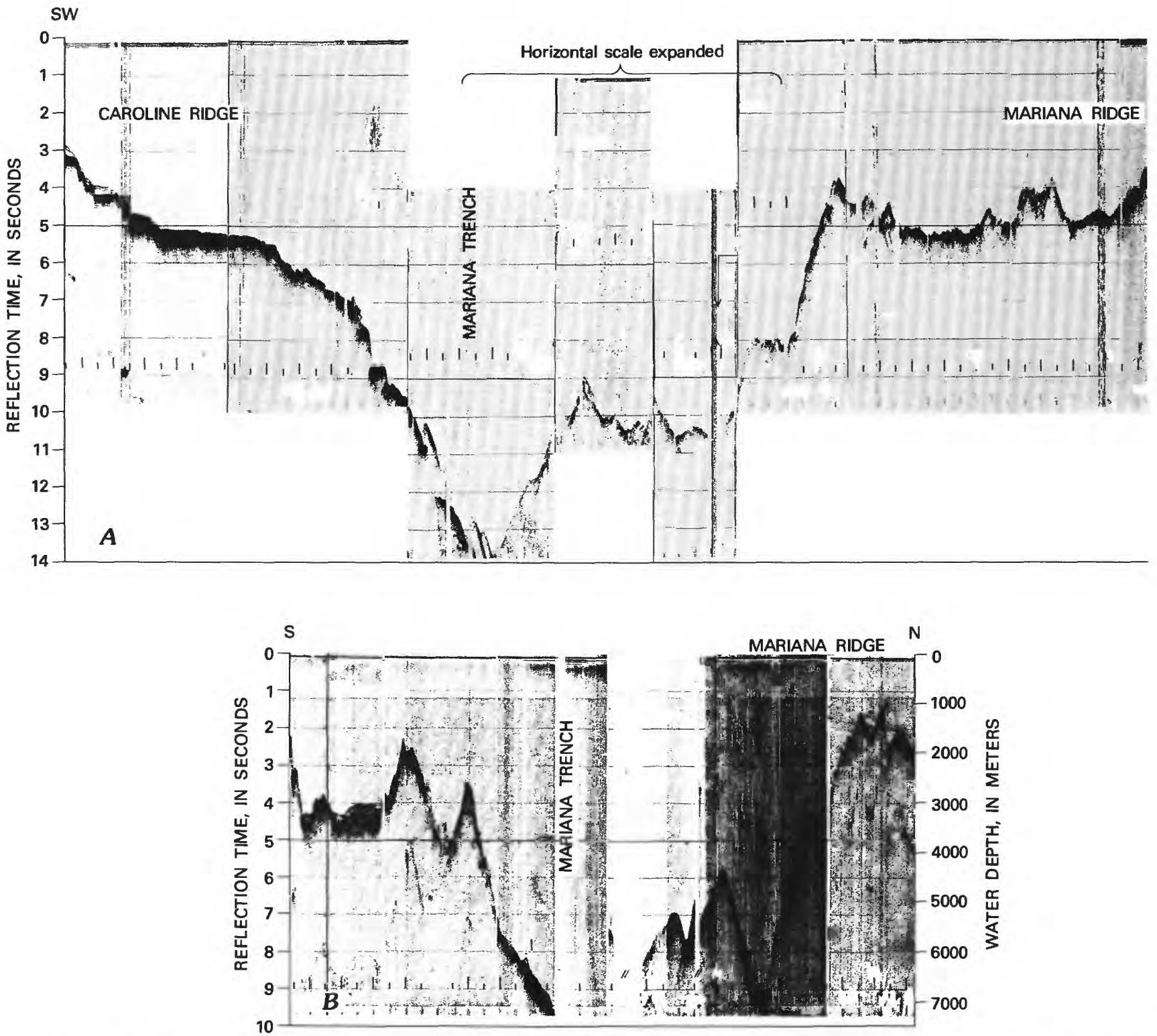

FIGURE 138 (above and facing page).--Seismic-reflection profiles across the south end of the Mariana Island Arc. Pelagic sediments as thick as $200 \mathrm{~m}$ are visible on the Caroline Ridge $(A)$, but obvious sediment on the Mariana Ridge and in the Parece Vela Basin is limited to ponded (turbiditic?) materials in small basins. No sediments or floor are apparent in the Mariana Trench, but it is possible that side-slope echoes mask the reflections from the actual trench bottom. Location of profiles shown on figure 137. Profiles from Lamont-Doherty Geological Observatory, R. V. Vema cruise 28.

ROTATION OF PHILIPPINE SEA PLATE

Earthquakes are virtually lacking within the Philippine Sea region, between the western belt of subduction zones of the Philippine, Ryukyu, and other trenches and the eastern belt of the Mariana, Bonin, and Japan Trenches (Tarr, 1974). Although the Philippine Sea has had a very complex Cenozoic history, it appears to be now behaving as a single, internally coherent lithospheric plate.

Few earthquakes occur in the eastern belt south of the Yap system: if subduction or spreading is now underway here, its velocity must be low. Likely, then, the velocity of relative motion is near zero south of Yap (fig. 136). A complementary change occurs in the western belt of trenches. Subduction must be exceedingly rapid in the south, where the westward translation of the Pacific past New Guinea is taken up by plate convergence in the PhilippineSangihe-Halmahera group of subduction zones. At the north end of the western system, by contrast, subduction is likely quite slow at the Nankai Trough, for major and rapid motion here cannot be transformed across the Iwo 

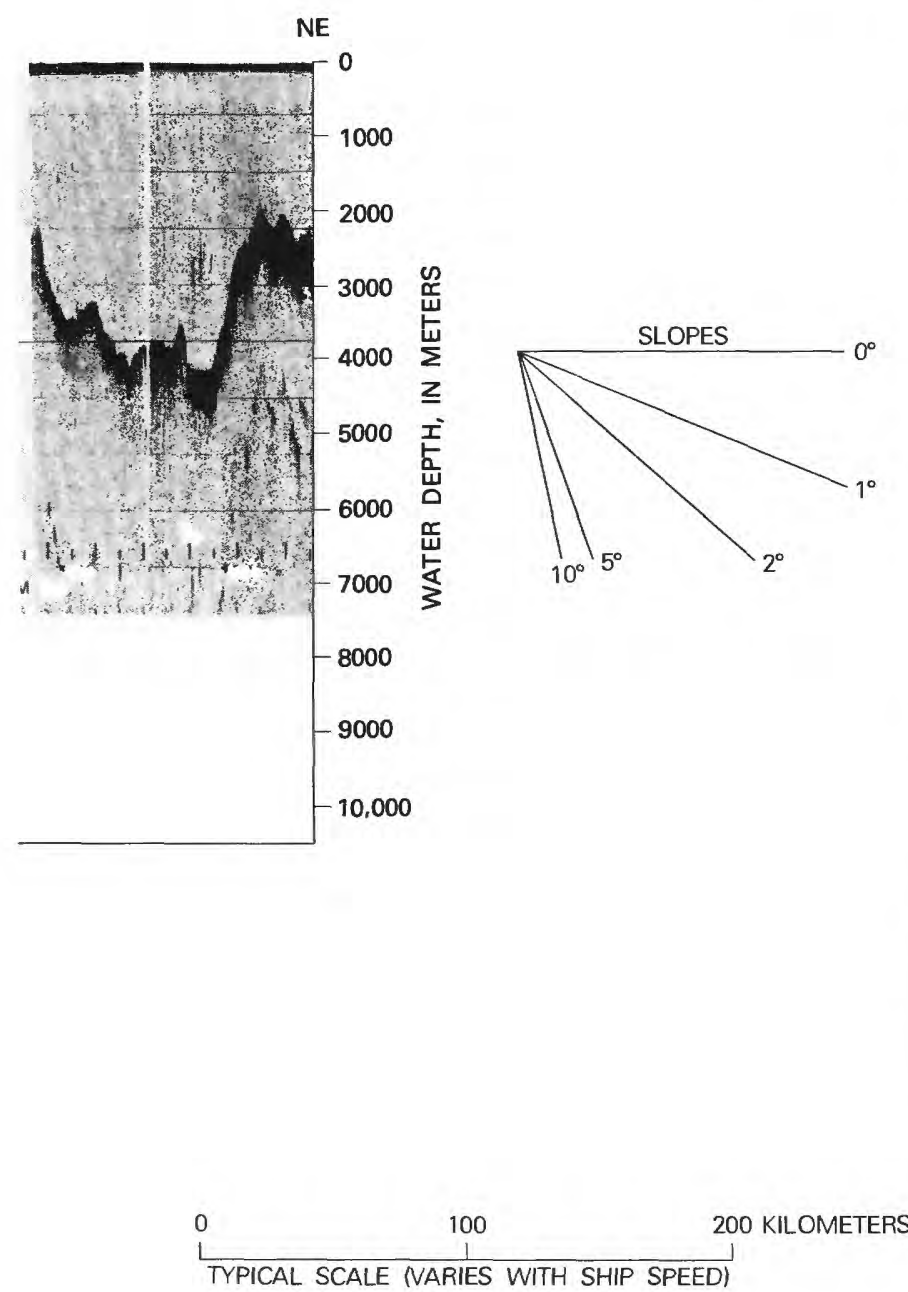

Jima Ridge to the Japan and Bonin Trenches (fig. 135).

It appears that the Philippine Sea plate is pivoting clockwise relative to Asia, about a pole of relative rotation located near northern Japan. The southern part of the plate is coupled or nearly coupled to the Caroline plate, but the northern part is separated from the main Pacific plate by a zone of rapid subduction. Conversely, the southern part of the Philippine Sea plate is converging rapidly with the large, composite plate that includes eastern Asia and the South China and Celebes Seas, but the northern part of the Philippine Sea plate is converging only slowly with Japan. Seno (1977) reached this same conclusion on the basis of earthquake first-motion slip vectors.

A complication which cannot yet be analyzed quantitatively is the motion of the Caroline plate, bounded on the north by left-lateral faults of the Sorol system and on the east by the Mussau Trench. (These structures are discussed subsequently.) The generally low seismicity of these structures suggests that there is little relative motion now occurring between Caroline and Pacific plates; but perhaps the seismic record is too short to define what are in fact quite active zones.

\section{THE CAROLINE AND PACIFIC PLATES}

A large region of Tertiary oceanic crust lies between the Mariana and Yap Island Arcs on the north and New Guinea and its neighbor complexes on the south, and between the Palau Ridge on the west and the Mussau Trench on the east. This region is here termed the Caroline plate (figs. 135, 136). It apparently formed by sea-floor spreading during middle Tertiary time, although the pattern of that spreading is in doubt. Subsequent to the preparation of the bathymetric base map for the folio of the Indonesian region (including pl. 1), better bathymetric maps of part of the Caroline plate sector, incorporating further data, were published by Bracey (1975), Erlandson (1975), Mammerickx (1978), and Erlandson, Orwig, Kiilsgaard, Mussells, and Kroenke (1976).

\section{Caroline plate}

The Caroline plate consists of the East and West Caroline Basins, the broad Eauripik Rise between them, the west part of the Caroline Ridge against which these other three features end in the north, and a small region between the Caroline Ridge and the Mariana Trench.

WESI CAROI.INE BASIN

The West Caroline Basin (fig. 142) has a low-relief basement surface overlain by a few hundred meters of pelagic sediments (fig. 143A). The tracing of reflectors within the sediments from DSDP hole 62 , on the Eauripik Rise to the east, indicates the sediments to be of Oligocene and younger age (fig. 143 $\mathrm{A}$; Den and others, 1971). The level of acoustic basement varies within the lower part of the sedimentary section, so sea-floor volcanism and intrusion apparently proceeded concurrently with Oligocene sedimentation. The high heat flow of the West Caroline Basin and Eauripik Rise - of nine determinations, only one is below 2 microcal $/ \mathrm{cm}^{2} \mathrm{sec}$-is appropriate for a middle Tertiary basement age (compare with Sclater and others, 1976).

$$
\text { EAL'RIPIK RISE }
$$

The Eauripik (or Eauripik-New Guinea) Rise trends southward between the East and West Caroline Basins (figs. $142,143 A$ ). From the basin floors at depths of about $4,500 \mathrm{~m}$, the flanks of the rise arch gently upward, with slopes of generally less than 1 degree, to a broad crest at about 2,500 $\mathrm{m}$ (Chase and Menard, 1969, maps 2201, 2202N; Mammerickx, 1978). The crust beneath the rise is oceanic. The thickness of the upper (basaltic?) part of the crust is similar to that beneath the flanking basins, but the lower (gabbroic?) crust is much thicker: the Mohorovicic discontinuity is only about $6 \mathrm{~km}$ beneath the sea floor under the basins but is at least $15 \mathrm{~km}$ beneath the crest of the rise (Den and others, 1971). Magmatic thickening of the lower crust, or serpentinization of what had previously been anhydrous upper mantle, might be the cause of the topographic rise.

The rise is mantled by $500-600 \mathrm{~m}$ of pelagic sediments (fig. 143A; Den and others, 1971; Kroenke and others, 1971), which were penetrated by DSDP hole 62 (figs. 142, 145). The 

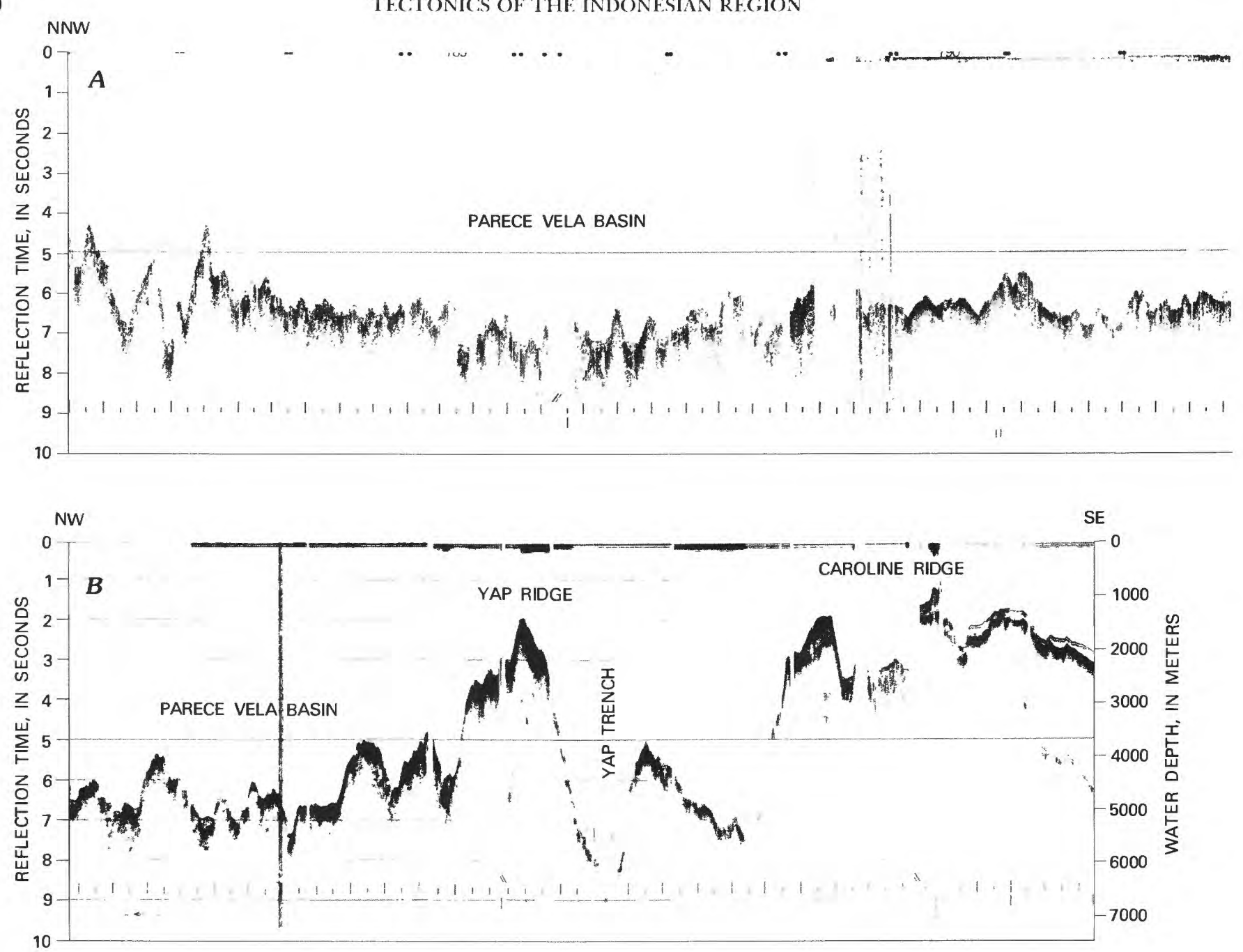

FigURE 139 (above and facing page). - Seismic-reflection profiles across the Yap Island Arc. Pelagic sediments as thick as $200 \mathrm{~m}$ are visible on the floor of the West Caroline Basin $(A)$ and on the Caroline Ridge $(B)$, but obvious sediment on the Yap Ridge and in the Parece Vela Basin behind it is limited to ponded (turbiditic?) materials in small basins. No sediments or floor are apparent in the Yap Trench, but it is possible that side-slope echoes mask the reflections from the actual trench bottom. Location of profiles shown on figure 137. Profiles from Lamont-Doherty Geological Observatory, R. V. Vema cruises $20(A)$ and $28(B)$.

hole cut $580 \mathrm{~m}$ of upper Oligocene through Quaternary calcareous pelagic sediments chalk and chalk ooze, rich in nannofossils, foraminifers and radiolaria (Winterer and others, 1971, p. 49-322). The hole bottomed in much-altered vesicular olivine basalt (R. Moberly, Jr., and G. R. Heath, in Winterer and others, 1971, p. 1011-1025), which may be intrusive into the chalk above because the latter is dolomitized at the contact. Reflection profiles in the vicinity are interpreted by Kroenke, Moberly, Winterer, and Heath (1971, p. 1165) to indicate that this basalt is one of a number of intrusive masses that rise into the lower part of the section and that about $100 \mathrm{~m}$ of sediments older than those drilled lie above older basaltic basement nearby. Extrapolation of sedimentation rates downward from the drilled section suggests that this older basement might be of early Oligocene age.

\section{F.ASI C.AROI.INE BASIN}

The upper Oligocene and younger pelagic cover continues smoothly down the east flank of the Eauripik Rise and across the East Caroline Basin (fig. 143B, C). DSDP hole 63 (figs. 142, 145) penetrated $560 \mathrm{~m}$ of lower or middle Oligocene and younger pelagic sediments and bottomed in basalt (Winterer and others, 1971, p. 323-471). Oligocene and Miocene sediments are chalk and chalk ooze, whereas Pliocene and Quaternary layers are marl ooze and calcareous clay. The basalt is chilled at the top and is overlain unconformably by unaltered sediment, which contains basalt shards, but the basalt itself contains xenoliths of lower or middle Oligocene chalk.

Reflection profiling shows that sediments below the lower middle Miocene double in thickness between the crest of the Eauripik Ridge and the bottom of the East Caroline Basin. 

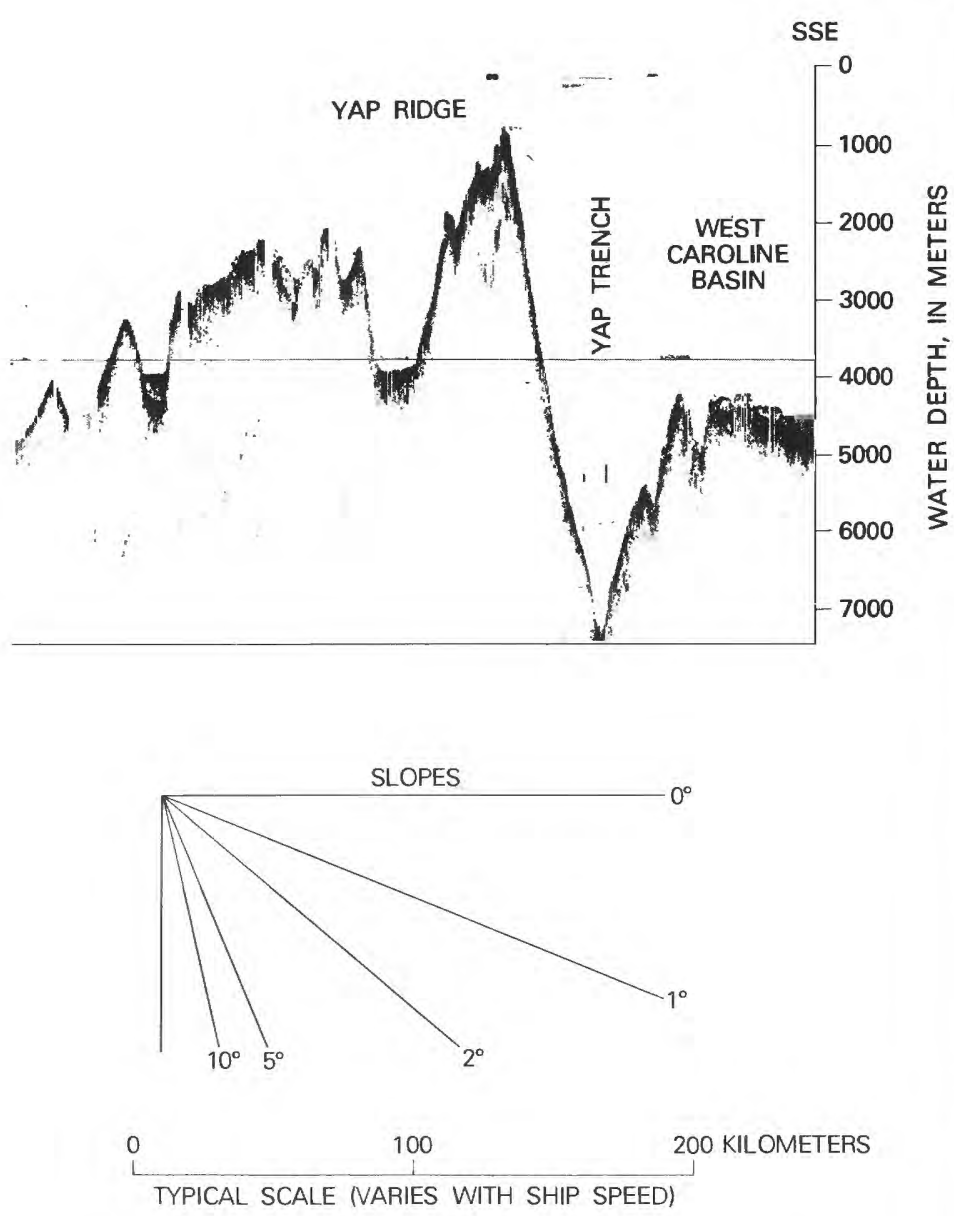

Sediments younger than the lower middle Miocene by contrast halve in thickness, presumably because of increased solution of carbonate in the deeper water (Kroenke and others, 1971, p. 1165-1166).

\section{ORIGIN OF THE CAROLINE PLATE}

The oceanic crust of the Caroline plate apparently formed during early Tertiary time. Erlandson, Orwig, Kiilsgaard, Mussells, and Kroenke (1976), integrating bathymetric, reflection-profiling, and DSDP data, proposed that the Eauripik Rise is an extinct spreading center, offset by contemporaneous transform faults striking north-northeastward. Magnetic lineations in the East and West Caroline Basins however trend close to east-west. Mammerickx (1978) suggested that the youngest spreading recorded in the plate was in a northwest-southeast direction and formed the Eauripik Rise by a series of northeast-trending spreading centers stepped to the left by northwest-striking transform faults, but that the rest of the plate formed by earlier north-south spreading.

Bracey (1975), working primarily with magnetic profiles made along north-south tracks $1^{\circ}$ apart across most of the basin, thought that magnetic anomalies could be correlated between some of the tracks to indicate general east-west magnetic trends. The anomalies lack the clear-cut profile characteristics of the anomalies associated elsewhere with midocean ridges, but Bracey inferred that the anomalies, nevertheless, could be correlated with the standard sequence of middle and late Cenozoic anomalies, using the DSDP basement dating for control. He concluded that the anomalies become progressively younger northward across the plate, that most of the plate formed between about 42 and $20 \mathrm{~m} . y$. ago, and that the plate formed south of a migrating spreading center whose northern products were consumed at a trench at the south side of the Caroline Ridge. (As noted in the next section, the identification of that trench is dubious.) Inspection of Bracey's (1975) observed and calculated-model anomalies shows that if they do represent a spreading-ridge system, they can be fitted just as well to the standard sequence, and more closely to the DSDP constraint, if in fact they become younger southward rather than northward. Of Bracey's magnetic profiles, only numbers 4 through 7 are distinctive enough in in appearance to provide any basis for correlation and in these, as good a tie to the model (and a better tie for the most distinctive profile, number 7) is achieved if the model is reversed, about a pivot between anomalies 11 and 12. Also, as Erlandson and his associates emphasized, bathymetric data do not suggest the presence of the north-south transform faults required by Bracey's model.

Another interpretation was made by Mammerickx (1978) and by J. K. Weissel and R. N. Anderson (written commun., 1978). Troughs (not shown by the bathymetry of pl. l, though indicated there in part by dashed-fault lines) trend east-northeastward across the north part of the West Caroline Basin (West Caroline Trough) and, less regularly, across the central part of the East Caroline Basin (Kiilsgaard Trough). Mammerickx, Weissel, and Anderson suggested these troughs to be inactive spreading centers, at which the crust of the basins formed symmetrically during middle Tertiary time. The West Caroline and Kiilsgaard Troughs are not, however, centered on ridges or rises.

\section{CAROLINE RIDGE}

The East and West Caroline Basins and the Eauripik Rise end northward against the Caroline Ridge, which trends west-northwestward. The term Caroline Ridge covers two distinct terrains that are topographically but not structurally continuous. The west part of the ridge is a deformed terrain that trends west-northwestward, broken by great longitudinal faults; it is shaded in figure 137. The east part of the ridge is an eastward-elongated region of abundant seamounts and atolls, and its irregular surface may be the result primarily of volcanism rather than faulting. The present discussion is concerned with the western terrain. This part of the Caroline Ridge has a crestal surface mostly between 2,000 and $3,000 \mathrm{~m}$ below sea level but is broken by narrow troughs that trend west-northwestward and locally are more than 5,000 m deep (Bracey and Andrews, 1974; Chase and Menard, 1969, map 2202N; Mammerickx, 1978); 
it displays moderate seismicity. A few atolls and shoals top some of the irregular seamounts.

Four DSDP holes were drilled on and near the north side of the Caroline Ridge (fig. 137), in an area in which pelagic sediments lie upon basalt that has a generally smooth, flat surface, much displaced by step faults (Andrews, 1971; B.C. Heezen and A.G. Fischer in Fischer and others, 1971, p. 1301-1305; Kroenke and others, 1971). Water depths at the drill sites range from 2,500 to $4,500 \mathrm{~m}$, and each drillhole penetrated between 130 and $340 \mathrm{~m}$ of middle and upper Tertiary calcareous oozes. Hole 55 bottomed in uppermost Oligocene chalk, approximately halfway to acoustic basement (Heezen and others in Fischer and others, 1971, p. 389-447). Hole 56 also bottomed in upper Oligocene chalk, just above a seismically opaque unit that was not reached but which might be basement (Heezen and others in Fischer and others, 1971, p. 449-492). In hole 57, unaltered upper Oligocene sediments rest on fresh, coarsely porphyritic, diabasic olivine basalt (fig. 144; Heezen and others in Fischer and others, 1971, p. 493-537). At site 58, on the ocean floor north of the ridge and west of a region of abundant seamounts, lower Miocene or upper Oligocene sediments overlie diabasic basalt (Heezen and others in Fischer and others, 1971, p. 539-556).

The basalt cored in hole 57 resembles island basalt, not ocean floor basalt, in its petrochemistry (Ridley and others, 1974). The basalt has relatively high $\mathrm{Ti}, \mathrm{P}$, and $\mathrm{Fe} / \mathrm{Mg}$, low $\mathrm{Ni}$ and $\mathrm{Mg}$, and strongly fractionated rare-earth elements. It has a whole-rock $\mathrm{K}-\mathrm{Ar}$ age of about $23 \mathrm{~m} . \mathrm{y}$., latest Oligocene. The Caroline Ridge appears to be a volcanic edifice atop oceanic crust of an age that cannot yet be defined.

The west-northwest-trending part of the Caroline Ridge appears to be a much-faulted mass of oceanic crust that is either of Oligocene age or underwent extensive volcanism during Oligocene time. The straightness of the narrow troughs cutting the ridge is suggestive of strike-slip faulting; but normal faulting dominates the north slope (Andrews,
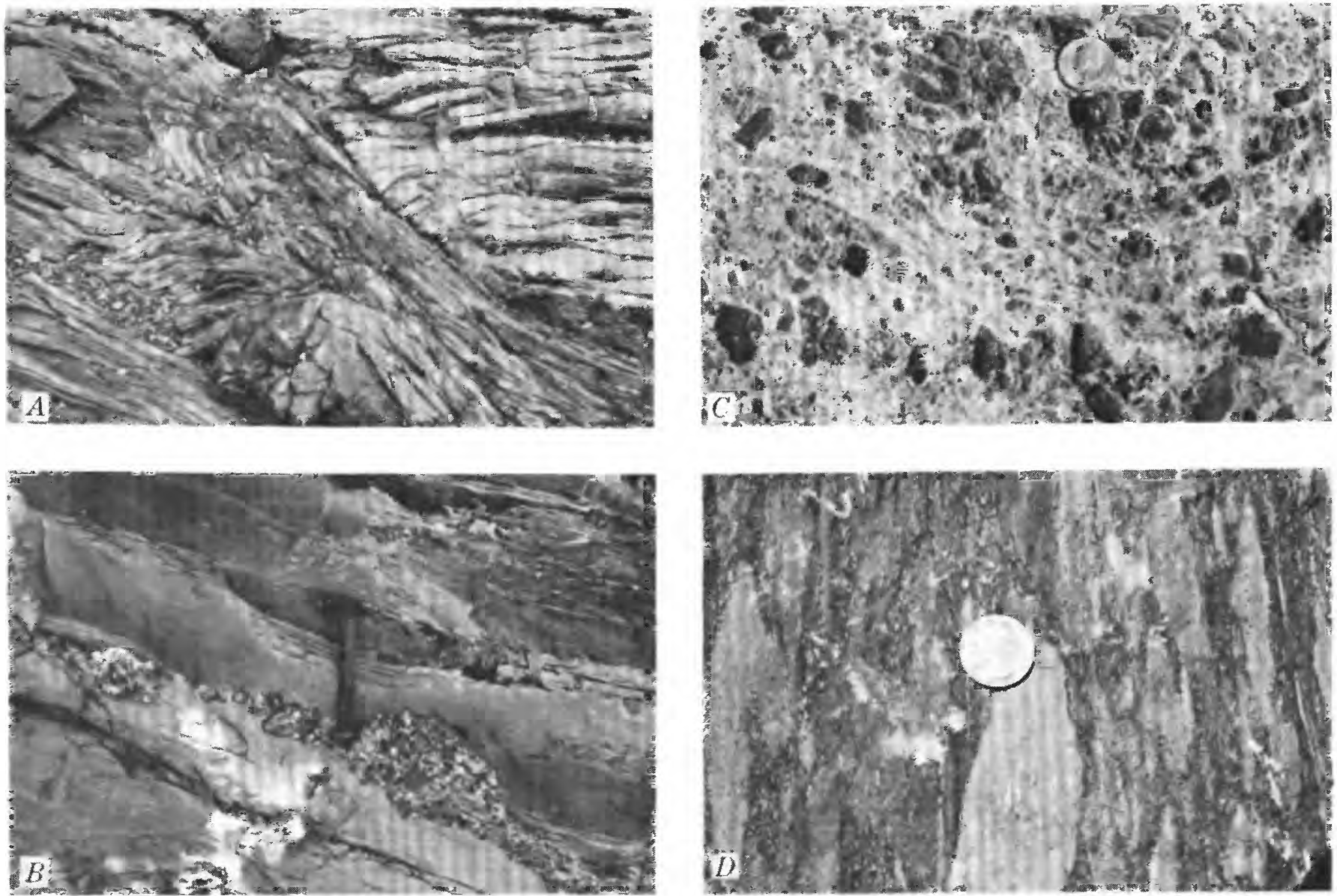

FIGLRE 140. - Rocks of Yap Islands. A, Greenschist (metabasalt), cut by shear planes in several directions, west coast of Yap north of Tafnith village. $B$. Sedimentary breccia of Miocene age, consisting of hornblende-schist breccia interlensed with turbiditic, sheared, and slumped sandstone and siltstone derived largely from similar schist. East coast of Map, north of Ueloi village. $C$, Sedimentary breccia of hornblende schist in a large lens, near $B$. D, Metamorphosed breccia, now hornblende greenschist, which is itself a block in unmetamorphosed sedimentary breccia like that of $B$ and $C$. East Coast of Map, Wacholab village. 
1971). That the faulting is now active is indicated both by the seismicity of the ridge (Katsumata and Sykes, 1969) and by the deformation of young sediments seen on reflection profiles (Andrews, 1971). A small triangular region of deep ocean floor north of the western part of the ridge, and west of the province of abundant seamounts, is floored by Oligocene basalt where reached by DSDP hole 58 , suggesting a basement age much younger than the Mesozoic crust of the ocean floor farther east; but the heat flow at three stations in this triangle is only $0.6-0.9 \mathrm{microcal} / \mathrm{cm}^{2} \mathrm{sec}$, suggesting a Mesozoic crustal age (compare with Sclater and others, 1976).

The longitudinal Sorol Trough atop the western part of the Caroline Ridge is bounded by high fault scarps and has rough internal topography (Bracey and Andrews, 1974). Markedly less sediment mantles the low areas than the outer flanks of the ridge, so extension of the ridge within late Cenozoic time can be inferred. Bracey and Andrews (1974) speculated that this extension might indicate the separation of the parts of an island arc, analogous to the separation of the components of the Mariana Arc described previously, and suggested that the Caroline Ridge might be an extinct island arc. They hypothesized that a minor trough on the south flank of the ridge might be its fossil subduction trench. The trough so identified (as shown on their minimal-penetration reflection profiles) bears little similarity to any of the known trenches in the Indonesian region; the trough is on the flank, not at the base, of the ridge and is not continuous along it; the ridge itself lacks arc characteristics. The speculation probably is invalid.

Vogt (1973) suggested that the Caroline Ridge serves as a strengthening girder in the Pacific lithosphere and that the right-angle intersection between Yap and Mariana Trenches is a syntaxis produced by the driving of this girder into the Philippine Sea plate. This speculation appears to be consistent neither with the eastward migration of the Mariana Island Arc, nor with the continuation of the Yap Trench northward past the west end of the Mariana Trench. Perhaps the position of the west end of the Caroline Ridge has, however, controlled the southern limit of the festoon migration of the Mariana Arc system. Vogt, Lowrie, Bracey, and Hey (1976) elaborated on this possibility.

My own speculation is that the western Caroline Ridge is the product of a "leaky transform": that it marks a major plate boundary, primarily the left-lateral Sorol strike-slip fault system, complicated by oblique rifting and resultant tension-produced magmatism. This transform is inferred to step convergence from the north end of the Mussau Trench (discussed subsequently) to the south end of the Mariana Trench. J. K. Weissel and R. N. Anderson (written commun., 1978) reached the same conclusion.

\section{MESOZOIC CRUST OF THE PACIFIC OCEAN}

Lithosphere formed in Early Cretaceous and Late Jurassic time lies to the east and northeast of the Caroline plate and to the east of most of the Mariana Island Arc (Fischer and others, 1971; Douglas and Moulade, 1972; Heezen, MacGregor, and others, 1972, 1973; Larson and Moberly, 1973). This lithosphere formed by spreading from several centers whose patterns are known only in part (Hilde and others, 1977; Larson and Chase, 1972; Larson and Moberly, 1973) but which certainly were quite different from the Late Cretaceous and younger pattern of spreading from the East Pacific Rise (Pitman and others, 1968; and many subsequent papers by many authors). These several Early Cretaceous plates probably were welded together in about the middle of Cretaceous time, since which time they have been part of the main Pacific plate, moving northwestward relative to Asia and the Americas. The absolute northward component of this motion during Late Cretaceous and Cenozoic time has been about 3,500 or $4,500 \mathrm{~km}$ (Heezen, MacGregor, and others, 1973; Larson and Chase, 1972; Winterer, 1973).

To the east of the middle Tertiary crust of the Caroline plate, the Early Cretaceous crust of the western Pacific floors the narrow Lyra Basin and the broad plateau to the east of it (figs. 142, 143, 145, 148). The submarine plateau has been referred to variously as Ontong Java, Kapingamarangi, and Solomon Rise or Plateau; but the name Ontong Java has priority, and the broad, flat feature is better termed a plateau than a rise (Kroenke, 1972), so the name Ontong Java Plateau is used here. The basin and plateau are mantled by about 1,000-1,500 m of pelagic sediments (figs. 143, 144; Furumoto and others, 1976; Kroenke, 1972). The plateau strata have been penetrated completely by one DSDP hole and partially by two others. Hole 289 (figs. 142, 145) reached extrusive basalt beneath $1,260 \mathrm{~m}$ of pelagic sediments of early Aptian (middle Early Cretaceous) and younger age, dominantly calcareous (Andrews, Packham, and others, 1975). Nearby hole 288 also reached Aptian strata but did not get to basement (Andrews, Packham, and others, 1975), and hole 64 penetrated only to the middle Eocene, about $150 \mathrm{~m}$ above the seismic-reflection basement (Winterer and others, 1971, p. 473-606). Small faults disrupt the strata on the homoclinal slope between Ontong Java Plateau and Lyra Basin (fig. 143D: Kroenke and others, 1971). The crust beneath the plateau is of high-velocity, oceanic type, but the Mohorovicic discontinuity is about $35-40 \mathrm{~km}$ deep (Furumoto and others, 1973, 1976) and perhaps there represents the lower limit of hydrated, serpentinized ultramafic rocks rather than a boundary between mafic and ultramafic rocks. (Compare with Clague and Straley, 1977.)

No apparent break is shown by the reflection profile of figure $143 C$ and $D$ between the bottom of the Lyra Basin and the top of the Ontong Java Plateau to suggest that a plate boundary lies within this sector. The major contact between the Oligocene crust of the East Caroline Basin and the Cretaceous crust of the Ontong Java Plateau probably is the Mussau Trench.

The oceanic basement and covering sediments of the Ontong Java Plateau plane down in another homocline, at the southwest side of the plateau, into a trench along the 

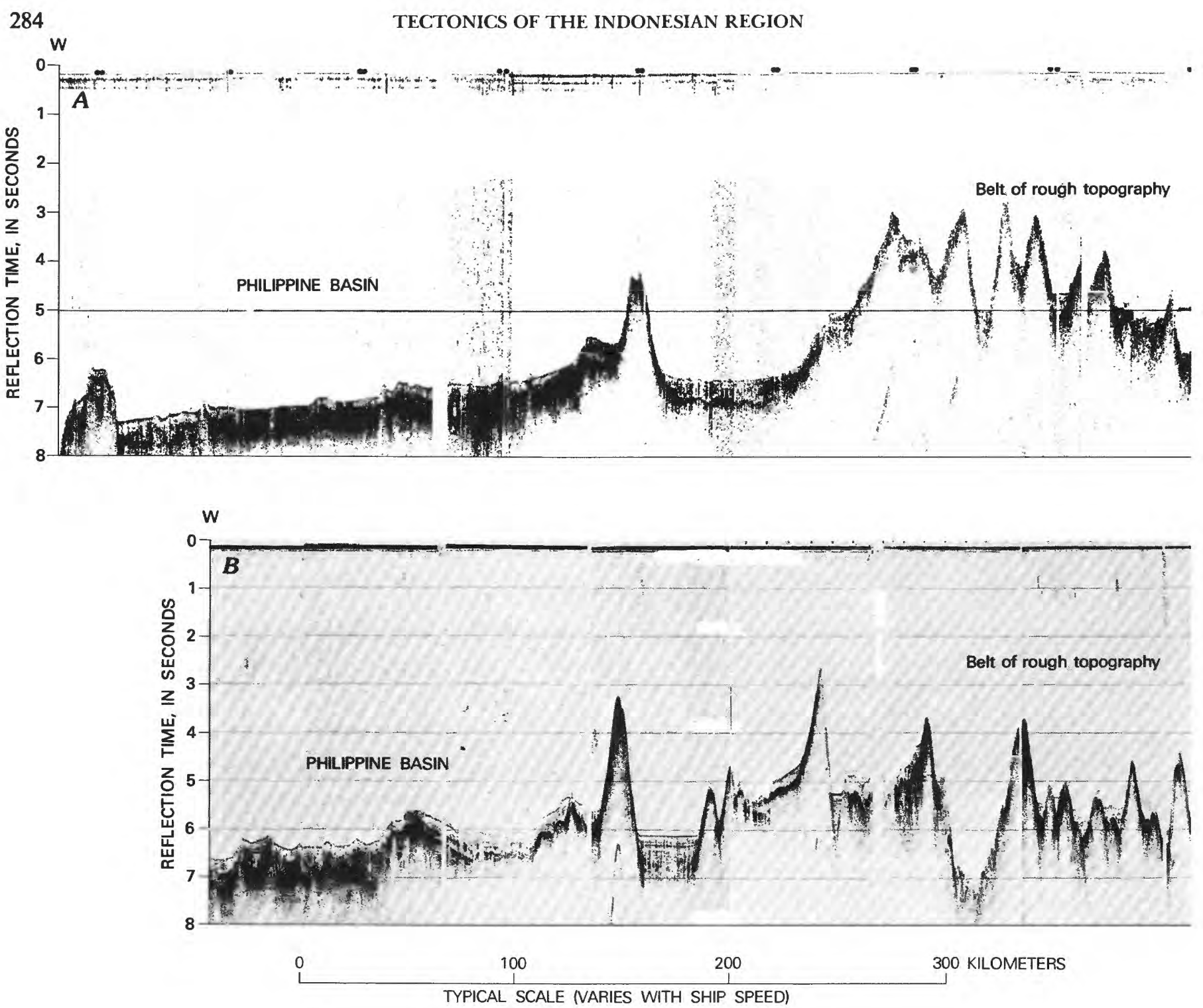

FIgure 141.-Seismic-reflection profiles from the Philippine Basin to the West Caroline Basin, across the belt of rough topography that belt obvious sediment is limited to depressions. The high-relief terrain likely includes a spreading ridge. Location of profiles shown on

northeast side of the Solomon Islands (figs. 146, 151), and are imbricated by southwest-dipping thrust faults and raised to form Malaita (southeast of Santa Isabel Island, fig. 145) and the islands of the northeastern chain within the complex Solomon group (Kroenke, 1972). The Cretaceous and Paleogene strata of Malaita, on this northeastern ridge, represent much the same deep-water pelagic section as that cut by the DSDP holes on the Ontong Java Plateau: the island is an upraised part of the plateau (van Deventer and Postuma, 1973; Hughes and Turner, 1977; Kroenke, 1972; G. H. Packham and J. E. Andrews in Andrews, Packham, and others, 1975, p. 691-705). Modern subduction beneath the Solomon Islands is northeastward from a trench at the southwest side, but earlier subduction was southwestward from the trench on the northeast side. The polarity of the arc reversed during Tertiary time (Karig, 1972), perhaps as a result of the difficulty of subducting the thick crust of the Ontong Java Plateau (Hughes and Turner, 1977; G. H. Packham and J. E. Andrews in Andrews, Packham, and others, 1975, p. 691-705).

It was suggested in the section of this report on Sulawesi that the medial part of the east arc of that island-a terrain of enormous masses of ophiolite and of pelagic carbonate sediments - represents an analog for this Solomon Islands terrain of oceanic crust and mantle raised by arching and imbrication at a subduction zone.

Cretaceous or older oceanic crust also underlies the seamount-studded abyssal Pacific floor northeast of the Caroline Ridge, as demonstrated by DSDP holes 59 and 61 (fig. 137). Hole 59 did not reach basement but penetrated a 

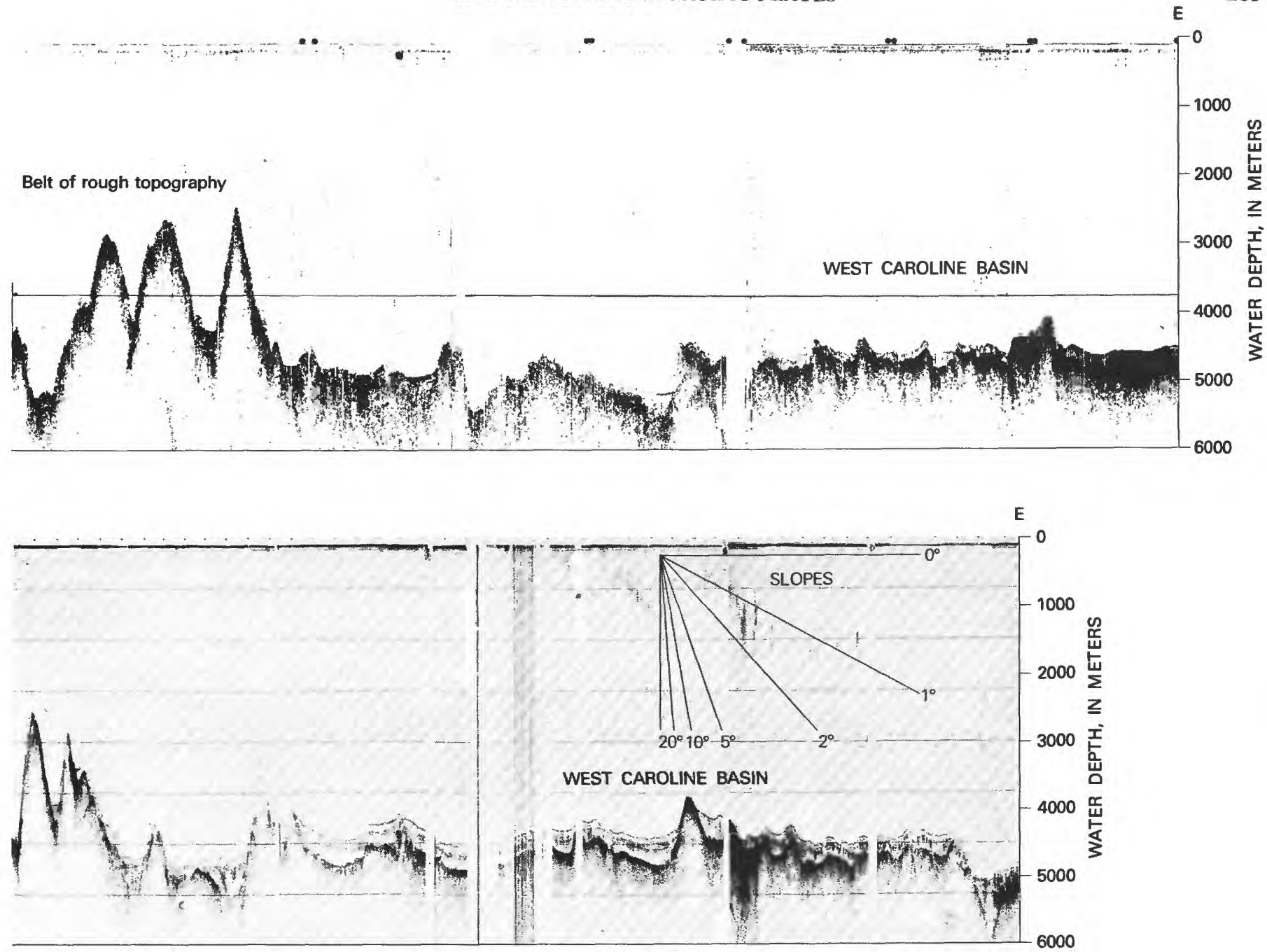

extends southward from the Palau Ridge and Trench. The broad basins display a mantle of pelagic sediments, but within the high-relief figure 137. Profiles from Lamont-Doherty Geological Observatory, R. V. Vema cruises $20(A)$ and $24(B)$.

total of 1,135 m of Neogene brown clay, Eocene and Paleocene clay and minor chalk, and poorly dated Cretaceous cherty brown clay and ash (B. C. Heezen and others, in Fischer and others, 1971, p. 557-585). Hole 61 bottomed in amygdaloidal basalt beneath middle Upper Cretaceous mudstone, and ambiguous reflections suggest that more sediments may underlie the basalt (Winterer and others, 1971, p. 27-47). Other drillholes east of the Mariana Arc farther north also reached Cretaceous sedimentaryrocks (Douglas and Moulade, 1972; Heezen, MacGregor, and others, 1972).

The numerous seamounts, many topped by reefs or atolls, rising from the eastern part of the Caroline Ridge and from the sea floor to the east and northeast of it are presumably of volcanic origin. Remnants of a large volcano form many small islands enclosed within Truk Lagoon, atop one of the largest of the volcanic undersea mountains, centered at about lat $7^{\circ} 30^{\prime} \mathrm{N}$., long $151^{\circ} 45^{\prime} \mathrm{E}$. The rocks of the Truk islands are alkalic olivine basalts, trachytes, and other rocks of oceanic, alkalic types; fossiliferous lower Miocene limestone occurs as fragments in a volcanic breccia (Stark and Hay, 1963).

A major plate boundary also may separate the Ontong Java Plateau from the main Pacific Plate, although such a boundary has yet to be identified. The paleomagnetic latitude of the middle Cretaceous basement basalt and the overlying Cretaceous and Cenozoic strata of the plateau decreased about $15^{\circ}$ during a short period in the middle Cretaceous, then decreased slowly a further $15^{\circ}-20^{\circ}$ to reach the present latitude about 30 m.y. ago (S. R. Hammond, L. 


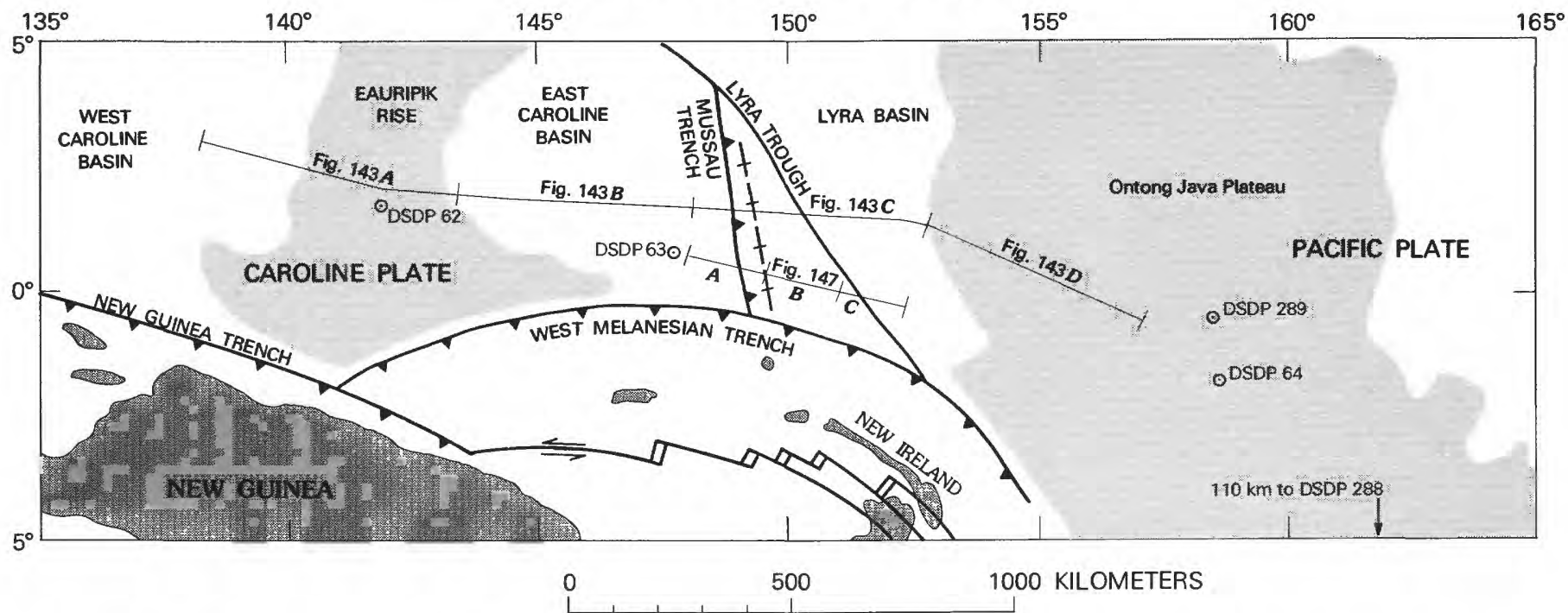

Figure 142.-Map of the northwestern Melanesian region, showing location of seismic-reflection profiles in figures 143 and 147 and of Deep Sea Drilling Project (DSDP) sites. Parts of the Eauripik Rise and Ontong Java Plateau shallower than $4,000 \mathrm{~m}$ are marked by light shading.

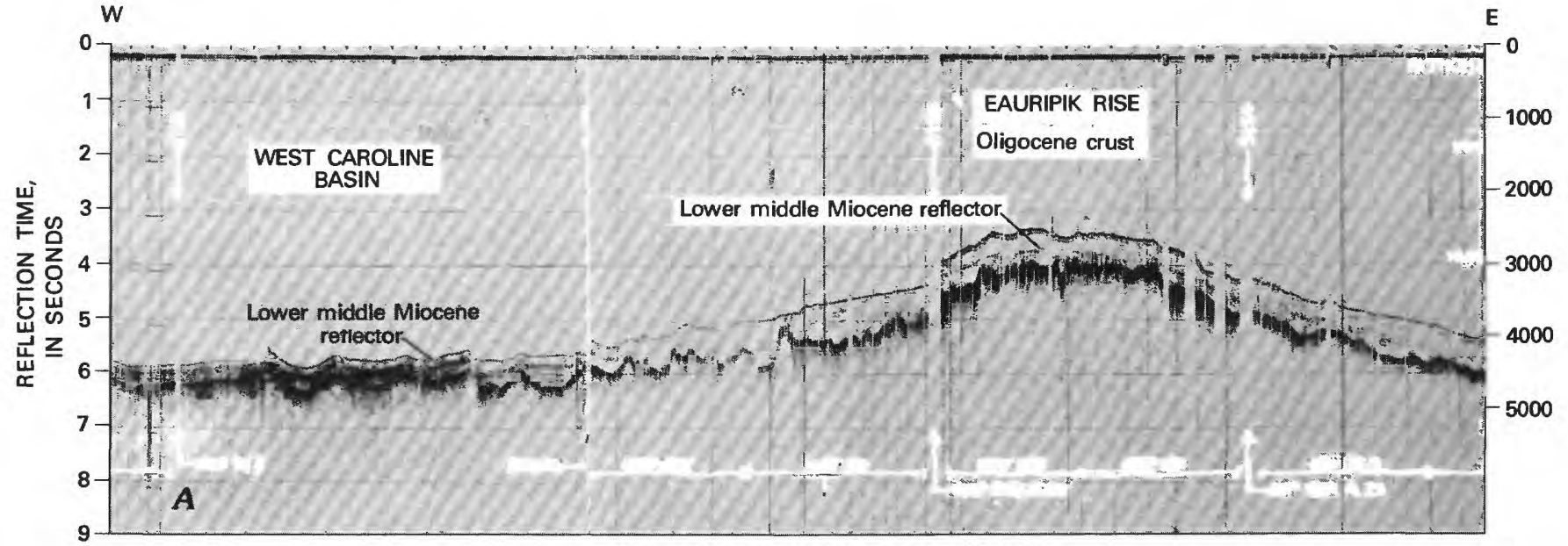

Note: The lower middle Miocene reflector was identified by Den and others (1971)

w

E

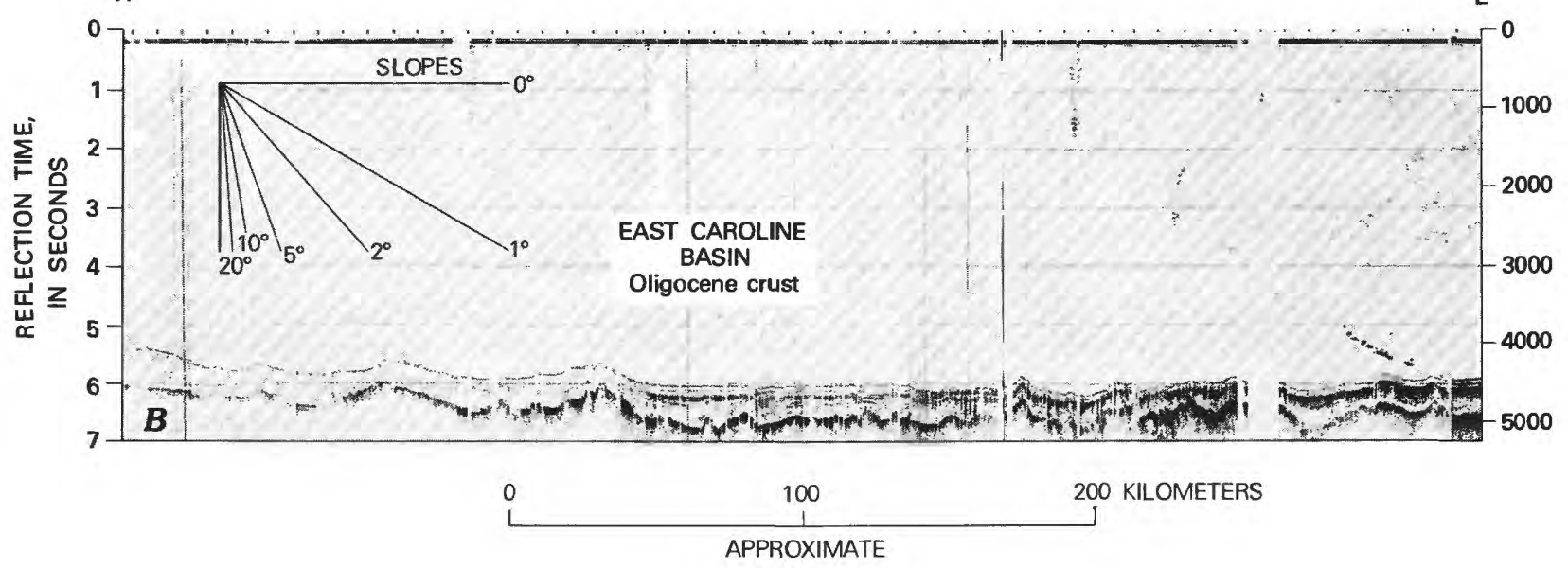


W. Kroenke, and F. Theyer, in Andrews, Packham, and others, 1975, p. 415-418). If the paleomagnetic orientations are indicative of paleogeographic latitudes, then these orientations, which are incompatible with coupling to the main Pacific mass, require another plate boundary.

\section{MUSSAU TERRAIN}

The boundary between the Paleogene crust of the Caroline plate and the Early Cretaceous crust of the Pacific plate lies within the northwest-narrowing Mussau terrain of complex tectonic and volcanic topography that trends northwestward between the approximate meridians of $149^{\circ}$ and $152^{\circ} \mathrm{E}$. (figs. 145-148). The west edge of this terrain is the Mussau Trench, recording eastward subduction.

The Mussau Trench is as deep as $7,000 \mathrm{~m}$. (The character of this trench was recognized also by Erlandson, 1975.) The floor of the East Caroline Basin is broadly arched in the usual elastic-beam fashion seaward of the trench. The trench contains only a narrow wedge of sedimentary fill and may be the product of subduction that is still active despite the paucity of earthquakes along the structure. Dredgings from R. V. Vityaz of the steep east side of the trench yielded basalt, diabase, greenstone, and volcanigenic sedimentary rocks from depths of 4,000-6,500 m (Udintsev and others, 1974).
The sharp crest of steep-sided Mussau Ridge lies subparallel to, and only $13-30 \mathrm{~km}$ east of, the Mussau Trench 2,500-6,000 $\mathrm{m}$ below. The ridge appears to be a volcanic arc and presumably formed paired to the nearby trench, and a steeply dipping Benioff zone is indicated.

Trending northwest near the east side of the complex terrain is the Lyra Trough, nearly $6,000 \mathrm{~m}$ deep. A broad wedge of sediment exceeding $1,000 \mathrm{~m}$ in thickness lies in the trough, which thus presumably is an inactive structure. The straightness of the trough as contoured by Erlandson (1975, fig. 3) permits the suggestion that it is of strike-slip or oblique-slip character. (Erlandson's bathymetry is incorporated in generalized form in figure 145 of this report.) Alternatively, the trough might be a trench, long inactive, formed during Cretaceous or early Tertiary time in response to westward subduction. East of the Lyra Trough is a tract characterized by apparent extensional faulting. West of the trough is a broad, asymmetric ridge.

\section{NORTH BOUNDARY OF THE CAROLINE PLATE}

The Caroline and Pacific plates are in contact along the Mussau terrain of structures in the east, but the contact cannot yet be defined so clearly in the north. The Mussau terrain ends in the north at about $4^{\circ} 30^{\prime} \mathrm{N}$., against the

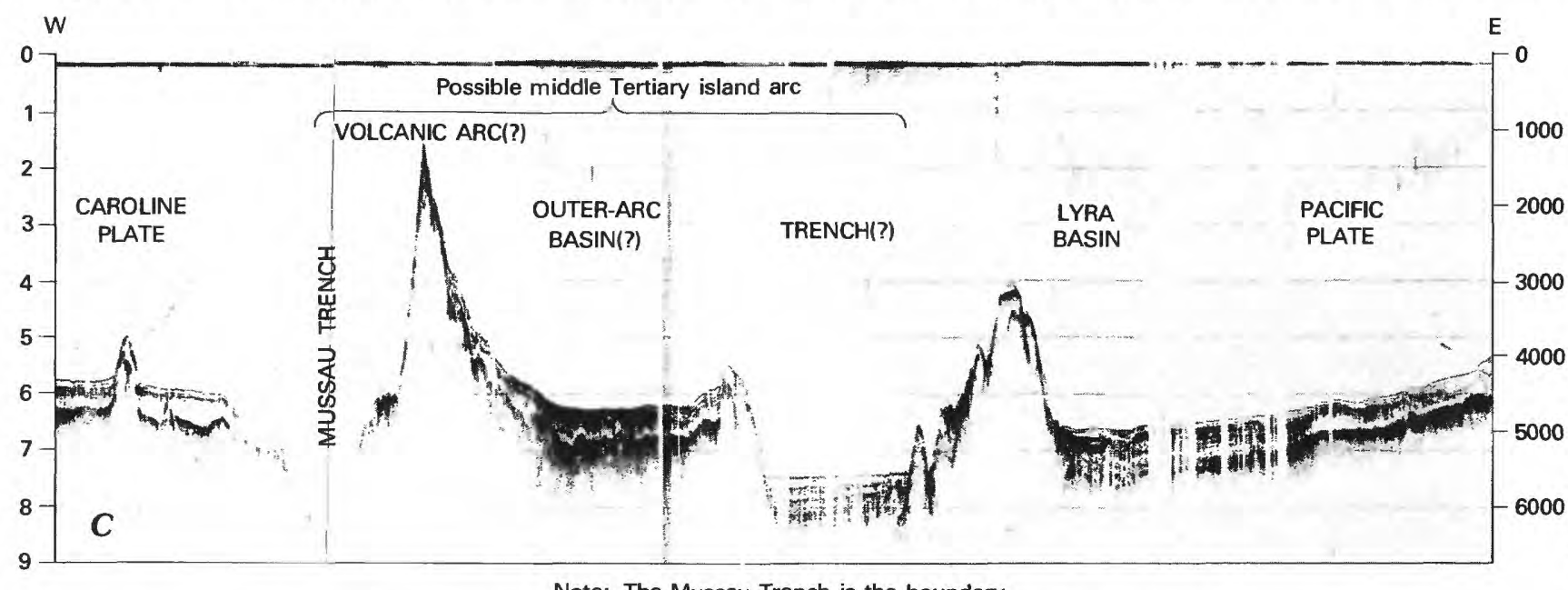

Note: The Mussau Trench is the boundary between the Caroline and Pacific plates

w

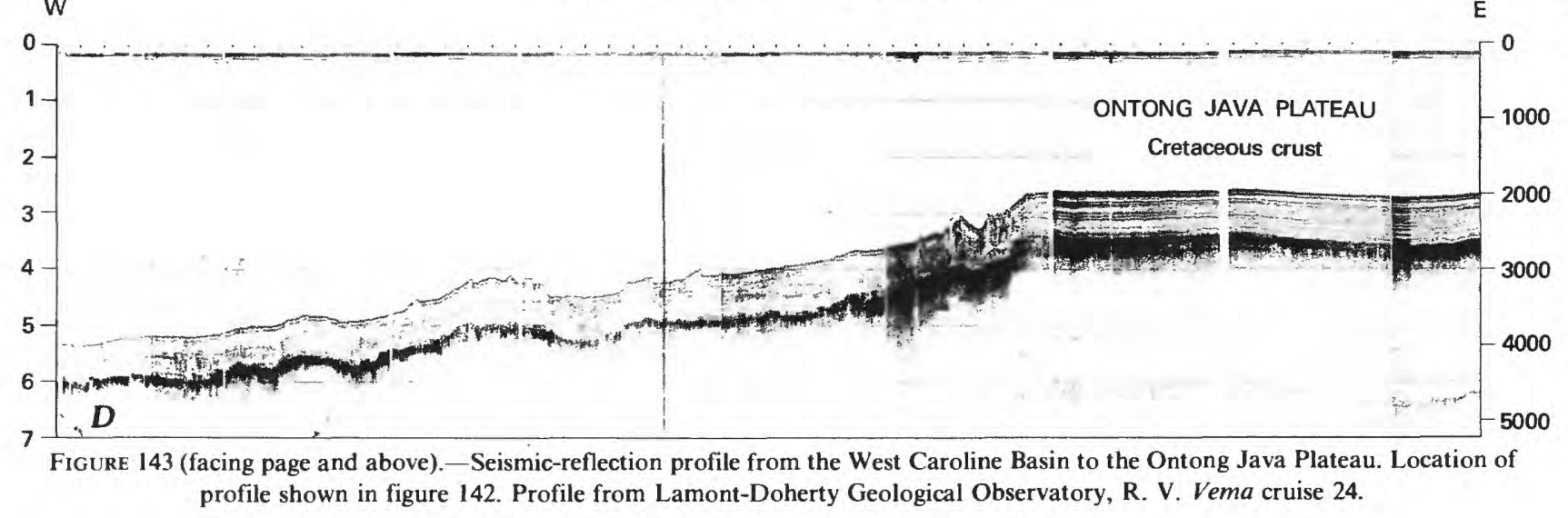


southeast end of the Caroline Ridge, which in turn trends west-northwestward to end at the intersection of the Yap and Mariana Trenches (figs. 135-137; Chase and others, 1971). As noted previously, the strongly lineated topography of the Caroline Ridge is suggestive of strike-slip faulting (Sorol fault system) trending west-northwestward, and the much-faulted basement of the ridge either formed during Oligocene time or else was covered by Oligocene basalt. The ridge itself may not mark the main plate boundary, for the triangular region of deep-ocean floor to the north of it

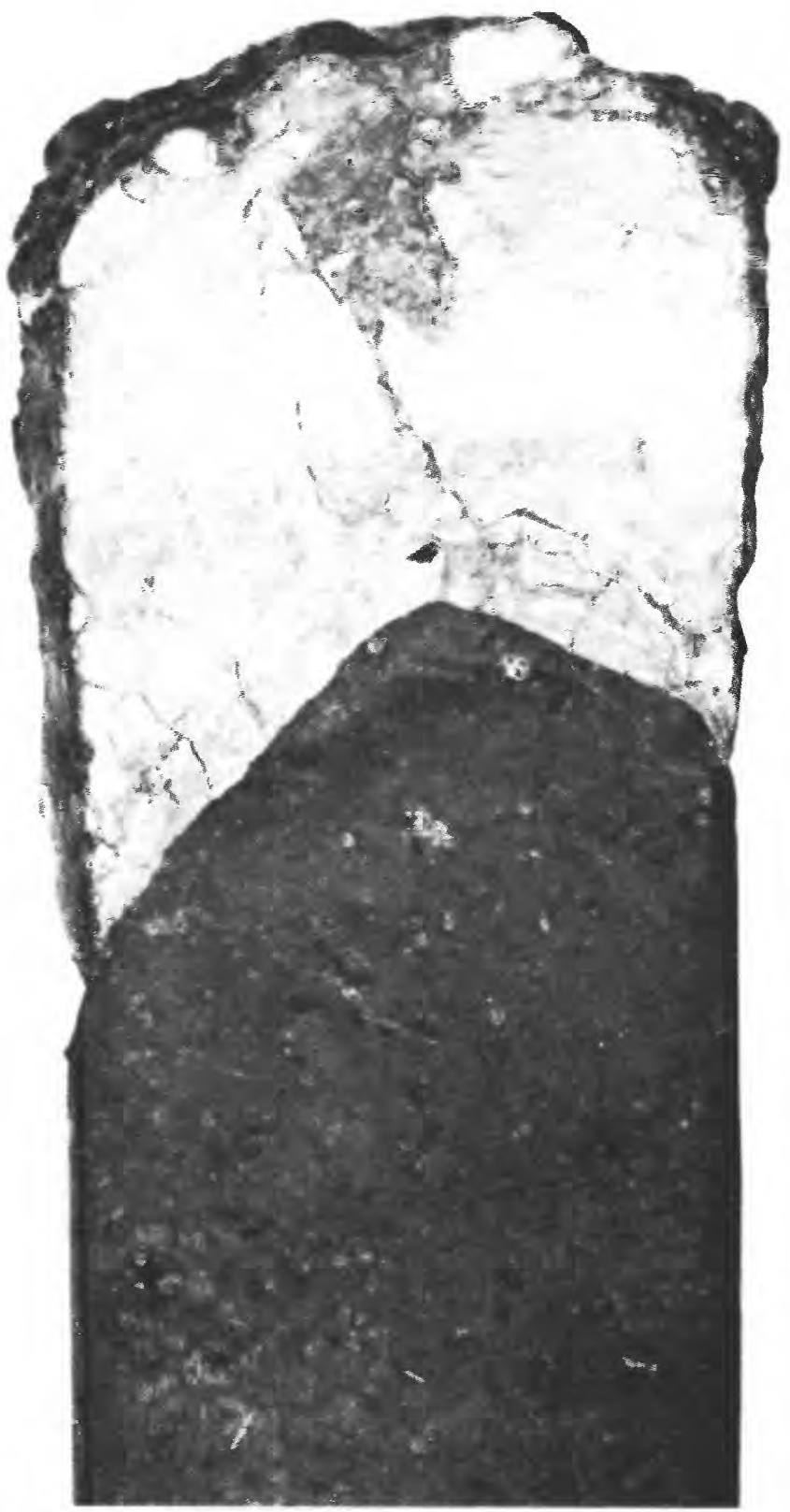

FIGURE 144.-Depositional contact between unaltered upper Oligocene chalk ooze and fresh diabasic olivine basalt. Drill core, $6.5 \mathrm{~cm}$ in diameter, from beneath $335 \mathrm{~m}$ of sediment on the north side of the Caroline Ridge in DSDP hole 57 (fig. 137). Photograph provided by A. C. Pimm, Deep Sea Drilling Project, National Science Foundation. (between the ridge on the south, the Mariana Trench on the north, and the terrain of abundant seamounts on the east) may also have Tertiary basement. Perhaps the seamounts (including those topped by the atolls of Olimarao, Faraulep, and Gaferut; fig. 137) bounding this triangular region on the east represent the northward continuation of components of the Mussau Arc system, offset $500 \mathrm{~km}$ or so left laterally along Caroline Ridge strike-slip faults. However, no preserved topography is suggestive, within the limits of present bathymetric knowledge as summarized by Chase, Menard, and Mammerickx (1971), of the presence of fossil subduction trenches flanking the seamounts in question.

\section{BISMARCK AND SOLOMON ARCS AND SEAS}

North and east of eastern New Guinea is a maze of small oceanic basins and active and extinct island arcs (figs. 145, 146). The complexities are many, and not all of the tectonic elements can yet be interpreted without ambiguity. Part of the region to be considered here lies within the area of the folio maps of the Indonesian region, but much lies to the east of it and is included because understanding of the eastern region is required for comprehension of the map area itself.

\section{BISMARCK SEA REGION}

Between New Guinea on the south and the Caroline and Pacific plates on the north lie the two small lithosphere plates of the Bismarck Sea, separated from each other by an arcuate zone of dominantly strike-slip faulting. The southern plate is separated from New Guinea and the Solomon Sea Basin, and the northern plate from the Caroline and Pacific plates, in part by subduction zones.

A detailed survey of the Bismarck Sea by seismicreflection, magnetometer, and gravimeter profiling was made in 1970 for the Australia Bureau of Mineral Resources, Geology and Geophysics (BMR), and preliminary accounts of the findings were given by Connelly $(1974,1976)$ and Willcox (1976). David Denham and Director L. C. Noakes of BMR generously gave me single-channel monitor records of reflection lines between long $141^{\circ} 00^{\prime}$ and $148^{\circ} 30^{\prime} \mathrm{E}$., and drawings made from some of these appear here in figure 117. Multichannel reflection data were recorded but have not yet been processed.

\section{NEW BRITAIN ISLAND ARC:}

The active New Britain (or South Bismarck) volcanic island arc, convex to the south and $1,050 \mathrm{~km}$ long, lies to the north of eastern New Guinea and bounds the South Bismarck plate on the south. The western islands - Schouten, Karkar, Bagbag, and Long Islands - are alined parallel to the north coast of New Guinea, from which they are separated by a narrow channel mostly $1-2 \mathrm{~km}$ deep. Arc and mainland diverge eastward, and a trench 6-8 km deep curves along the south side of New Britain. A Benioff zone dips northward beneath the arc from the trench to a depth of about $600 \mathrm{~km}$ (figs. 127, 149; Curtis, 1973a; Ripper, 1975a) and is very steep in the west but moderately dipping in 
the east. First-motion studies indicate that the Solomon Sea plate is being subducted northward beneath the arc (fig. 146; Johnson and Molnar, 1972; Ripper, 1975a, b, 1976). Many volcanoes along the arc are active (Fisher, 1957; Johnson and others, 1972). Large New Britain, easternmost of the islands, exposes widespread lower and middle Tertiary volcanic rocks as well as Quaternary ones, whereas the small islands of the rest of the arc are Quaternary volcanoes.

The modern volcanoes of New Britain stand near the north coast, and the central and southern regions display

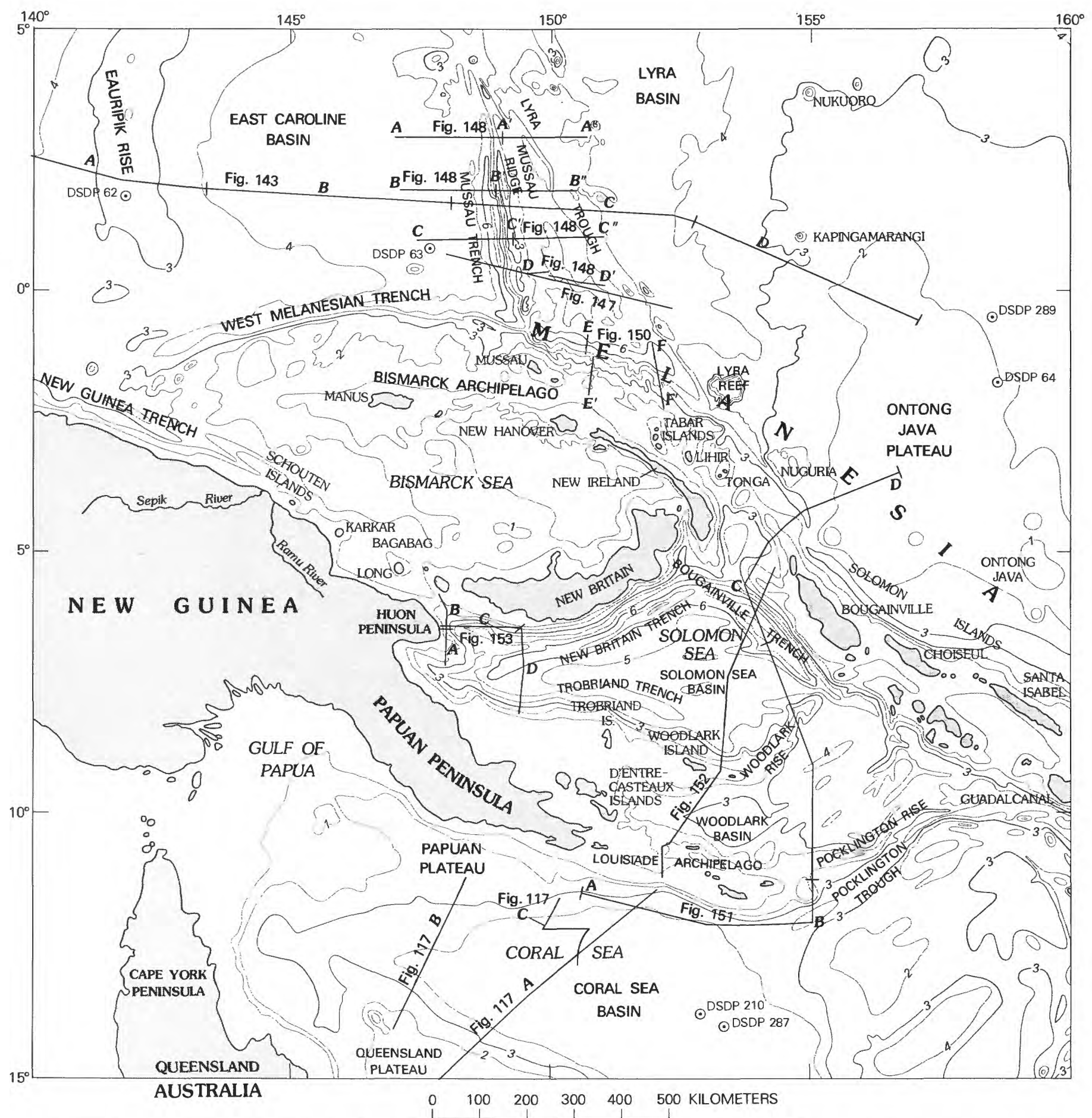

Figure 145. - Bathymetry of part of the Melanesian region. Contours, interval $1 \mathrm{~km}$, from Chase, Karig, Newhouse, Taylor, and Menard (1968), Chase, Menard, and Mammerickx (1968, sheet 6), Erlandson (1975, fig. 3), and Mammerickx, Chase, Smith, and Taylor (1974, sheet 11). 
mostly lower and middle Tertiary island-arc rocks. The oldest rocks exposed on New Britain are altered and much-deformed Eocene volcanic and volcaniclastic-sedimentary rocks, dominantly andesitic (Bain and others, 1972; Davies, 1973b; Ryburn, 1971, 1975, 1976). Rare limestone lenses contain shallow-water upper
Eocene foraminifers (Binnekamp, 1973). Upper Oligocene and lower Miocene volcanic and volcaniclastic rocks are of similar magmatic character but are much less deformed. These old assemblages are intruded by many small mafic and intermediate plutons, which are of late Oligocene and Miocene ages where dated (Page and Ryburn, 1977). The

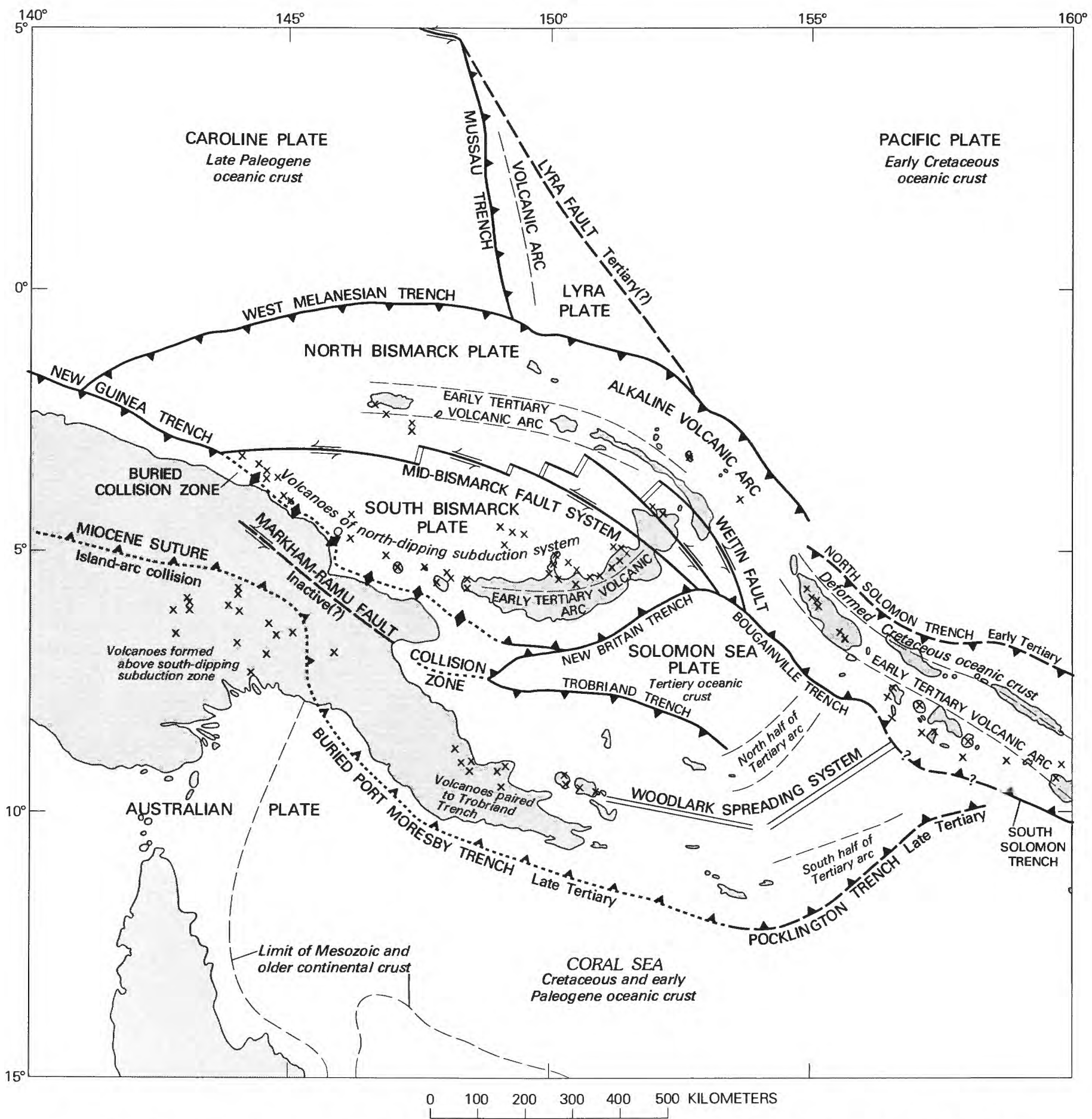

FIGURE 146.- Tectonic elements of part of the Melanesian region. Subduction zones (barbs on overriding plates): solid line, active zone; dashed line, inactive or uncertain zone; dotted line, trace buried by sediments. X, volcano active in late Quaternary time. 
ratio of potassium to silicon in the plutonic rocks increases southward at least in northeastern New Britain, so the island arc recorded by the middle Tertiary magmatic rocks may have stood above a Benioff zone that dipped southward from a trench to the north, whereas the modern Benioff zone dips northward from a trench south of the island (Davies, 1973b). The high lower Miocene, middle Miocene, and low upper Miocene are present as nonvolcanic, little-deformed, shallow-water limestone (Binnekamp, 1973; Davies, 1973b; Ryburn, 1971, 1976). Upper Miocene to Holocene rocks are mostly the volcanic products of the modern volcanic arc and include basalt, andesite, dacite, their volcaniclastic products, and limestone. Reefs are uplifted as much as $500 \mathrm{~m}$ above sea level along the south coast, whereas the north coast is stable or subsiding (Ryburn, 1971). The Quaternary stratovolcanoes, many of them presently active, consist mostly of two-pyroxene low-silica andesite, basalt, and dacite (Bain and others, 1972; Blake and Ewart, 1974; Heming, 1974, 1977; Johnson and Blake, 1972; Ryburn, $1971,1975,1976)$. The ratio of potassium to silicon in the young volcanic rocks increases northward across New Britain and the volcanic islands nearby to the north, as is appropriate to the position above a north-dipping Benioff zone, to where that zone is about $200 \mathrm{~km}$ deep; correlations are irregular or even negative above greater depths (Blake and Ewart, 1974 Johnson, 1970a, 1976a; Johnson and others, 1973). Rocks showing a wide range in silica content and potassium-silicon ratio all have primitive ratios of ${ }^{87} \mathrm{Sr}$ to ${ }^{86} \mathrm{Sr}$, providing no evidence for contamination by old continental crust (Page and Johnson, 1974; Peterman and others, 1970; Peterman and Heming, 1974).

The young volcanoes that form the rest of the New Britain Island Arc to the west are dominated by high-alumina, primitive-strontium, two-pyroxene basalt and andesite; more silicic rocks are rare (Johnson and others, 1972; Page and Johnson, 1974). The Schouten Islands, at the west end of the chain, lack basalt (Johnson, 1975). No pre-Quaternary rocks are exposed within the arc west of New Britain.

The crust beneath both New Britain and New Ireland (part of the Bismarck Arc, described next) is $20-40 \mathrm{~km}$ thick (Finlayson and Cull, 1973a, b; Finlayson and others, 1972; Furumoto and others, 1973; Wiebenga, 1973) and presumably has been built by Cenozoic island-arc magmatism from mantle sources and by subduction accretion. Bouguer gravity anomalies are positive throughout both islands and typically are near +100 milligals (Harrison, 1971).

A strike-slip fault system trends northwestward across eastern New Britain, between $151^{\circ}$ and $152^{\circ}$ E., and offsets the crustal welt and Paleogene terrain of the island about 40 km (fig. 146; also Bain and others, 1972). Unlike the nearby parallel fault system across the south end of New Ireland, this one is not obvious in the modern seismicity, but the two systems likely share a similar transform relationship to the Bismarck Sea spreading system, discussed subsequently.
BISMARCK ISLAND ARC

The North Bismarck plate bears on its north side the semicircular Bismarck (or West Melanesian, or North Bismarck, or Admiralty) Island Arc, which swings from central New Guinea to the Solomon Islands (fig. 145). The western half of the arc, whose largest island is Manus, lies within the area of the folio maps of the Indonesian region. New Ireland is the largest island of the eastern part of the arc.

Manus has a basement of middle Eocene to lower Miocene andesite and subordinate arc-type basalt, occurring as much-altered flow, breccia and pyroclastic rocks, intruded by middle Miocene copper-bearing granodiorite and allied rocks (Jaques, 1976b; Jaques and Webb, 1975). Flanking and overlying the igneous rocks is shallow water lower and middle Miocene limestone, overlain in turn by middle Miocene to Pleistocene basaltic and andesitic lava flows, tuffs, and volcaniclastic sediments, generally little altered (Jaques, 1976b; Kicinski and Belford, 1956). The small islands $20-60 \mathrm{~km}$ southeast of Manus are upper Quaternary cones and caldera-rim segments of quartz-normative tholeiite, olivine- and hypersthene-normative basalt, rhyodacite, and rhyolite and include one active volcano (Jaques, 1976b; Johnson and Davies, 1972; Johnson and Smith, 1974; Johnson, Smith, and Taylor, 1978). The silicic rocks are sufficiently radiogenic $\left({ }^{87} \mathrm{Sr} /{ }^{86} \mathrm{Sr}\right.$ about 0.7044$)$ to suggest that their magmas include a small crustal component (Page and Johnson, 1974).

Long, southeast-trending New Ireland (fig. 145) was part of the volcanic belt of an island arc in the Oligocene and was near such a belt in the late Miocene and Pliocene, but it lacks Quaternary volcanoes. The oldest rocks exposed are lower to upper Oligocene high-alumina andesitic agglomerates, tuffs, and volcaniclastic sediments, intruded by many mafic and intermediate stocks and sheets (Hohnen, 1970; Ryburn, 1971). Large foraminifers are abundant in limestone lenses in the Oligocene (French, 1966); thus, the arc included islands during Oligocene time. Shallow-water high lower Miocene to Pliocene limestone is widespread, thick, and little deformed and shows gradual subsidence of the island before more recent rapid uplift (Hohnen, 1970). Upper Miocene and Pliocene andesitic and dacitic waterlaid volcaniclastic and ashfall strata are known in central New Ireland (Hohnen, 1970; Ryburn, 1971). The island has been broadly tilted, down to the northeast, during Quaternary time, and a narrow strip along all of the northeast coast also has been uplifted (Hohnen, 1970; Ryburn, 1971). The major strike-slip Weitin fault (fig. 146) trends northwestward across the southeast end of the island and is marked by rift valleys and by geomorphic evidence for probable left-lateral offsets (French, 1966; Hohnen, 1970). A Benioff zone of mantle earthquakes, continuous with that of the Solomon Islands, dips northeastward under the south end of New Ireland, and the Weitin fault system projects northwestward as a zone of shallow, left-lateral strike-slip seismicity (Connelly, 1974; Denham, 1969; Ripper, 1975a, b). 


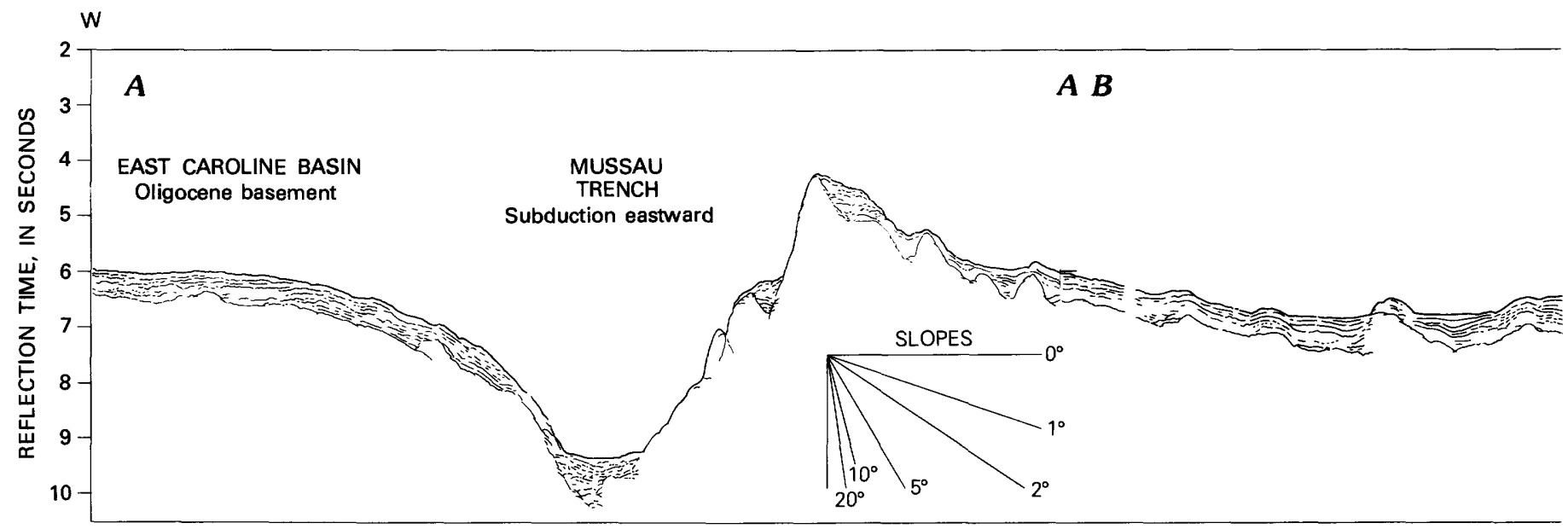

FIGURE 147.-Line drawing of reflectors in seismic-reflection profile from the East Caroline Basin across the Mussau Trench and Lyra (1971, p. 1185-1189) of

The young and slightly active (solfataric) volcanoes in a row to the northeast of New Ireland (fig. 146) are mostly low-silica highly alkalic basalts, rich in both sodium and potassium, and include trachyte, phonolite, and nephelinite (Ellis, 1975; Fisher, 1957). The rocks contain phenocrysts of plagioclase and clinopyroxene, plus variously olivine, hornblende, biotite, leucite, sodalite, analcite, zeolite, anorthoclase, Fe-Ti oxide, and apatite (R.W. Johnson and others, 1973, 1976). Ratios of ${ }^{87} \mathrm{Sr} /{ }^{86} \mathrm{Sr}$ are low, about 0.704 , indicating derivation from isotopically primitive sources (Page and Johnson, 1974). Exposed rocks are mostly of Pleistocene age, but middle Miocene limestone overlies undated volcanic rocks on one island, and Oligocene limestone is present on another (R. W. Johnson and others, 1976). Derivation above a nearly vertical subducted slab was inferred by Johnson, Wallace, and Ellis (1976).

The West Melanesian Trench swings around the north side of the magmatic arc and records subduction under the arc (figs. 145, 146, 150). A well-developed outer-arc ridge and basin occur between trench and magmatic arc along at least some of the system. Kogan (1976, figs. 10-12) presented three small-scale, extreme-exaggeration bathymetric profiles and also Bouguer and free-air gravity profiles across the trench near long $150^{\circ}$ E. De Broin, Aubertin, and Ravenne (1977, fig. 4c) gave a seismic-reflection profile near $152^{\circ} \mathrm{E}$. I have also seen an oil-company profile, near the west end of the trench, indicative of southward subduction.

New Ireland and the young volcanic islands to the northeast of it may have formed above a Benioff zone that dipped northeastward but that has recently been inactivated. (This is discussed briefly in the subsequent section on the Solomon Islands.) The line drawing by Furumoto, Webb, Odegard, and Hussong (1976, fig. 11) of a poor reflection profile suggests that a trench, with westward-subduction geometry, lies at the east base of southern New Ireland, between New Ireland and the row of volcanic islands extending northwest from Bougainville, so the plate history here may be quite complex.

\section{BISMARCK SEA}

A narrow belt of intense shallow seismicity trends northwestward across southern New Ireland, thence swings westward across the center of the Bismarck Sea to the north coast of central New Guinea (Connelly, 1974, 1976; Curtis, 1973a; Denham, 1969, 1973; Hamilton, 1974b). Available first-motion analyses indicate the belt to be dominated by left-lateral strike-slip faulting with west to northwest strike (Connelly, 1976; Curtis, 1973b; Johnson and Molnar, 1972; Ripper, 1975a, b, 1976). A median sediment-free area is centered on the midsea seismic zone (Connelly, 1974; Willcox, 1976). The sediment-free zone is as much as $60 \mathrm{~km}$ wide and has low relief in the east but is a rugged zone only about $40 \mathrm{~km}$ wide in the west. The seismic zone must mark a major plate boundary. This has been inferred variously to be a simple, curving strike-slip fault (Curtis, 1973b; Krause, 1973), a system of alternate spreading axes and transform faults recording northwestward or northward spreading (Connelly, 1976; Willcox, 1976), and two distinct strike-slip faults (Johnson and Molnar, 1972).

The known strike-slip faulting of New Ireland on the seismic belt, the zig-zag pattern of seismicity across the Bismarck Sea, and the first-motion solutions all can be accounted for by a fast-moving arcuate strike-slip system with offsets along short orthogonal spreading centers (fig. 146). The pole of relative rotation between the North and South Bismarck plates derived from this geometry lies near Cape York Peninsula, northeastern Australia.

Connelly (1976) and Willcox (1976) stated that magnetic anomalies near the mid-Bismarck seismic belt have dominant easterly trends and that much of the seismic belt is 


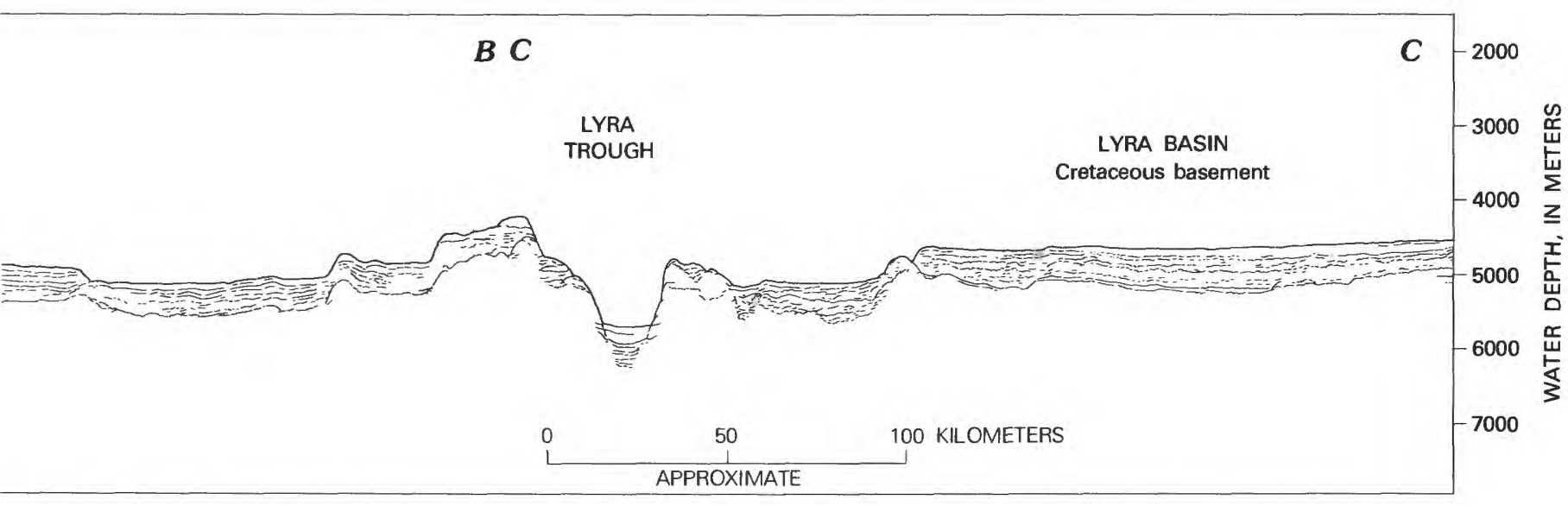

Trough to the Lyra Basin. Location of profile shown on figure 142. Redrawn from drawings by Kroenke, Moberly, Winterer, and Heath Glomar Challenger profiles:

followed irregularly by a negative-anomaly zone about $40-80$ $\mathrm{km}$ wide, and they inferred that spreading associated with the seismic belt is oriented nearly north-south. This interpretation is dubious. The magnetic-anomaly map on which the analysis was based was computer contoured from spot values taken each $9 \mathrm{~km}$ along north-south tracks about 37 $\mathrm{km}$ apart; this gridding strongly biased the contouring toward east-west anomalies, and short anomalies trending north-northeast and separated by west-northwest transforms (as predicted by figure 146) could not have been discriminated. Further, as the geographic ( $3^{\circ} \mathrm{S}$.) and magnetic latitudes of this area are equatorial, induced and geomagnetic fields are subhorizontal, and so likely is the remanent field of oceanic crust not substantially shifted in latitude since crystallization; detailed analysis, not yet reported, is needed to discriminate areas of reversed and normal remanence. Willcox (1976) suggested that the alternative solutions-right-lateral faults trending near north-for the first-motion studies give the correct sense of strike-slip faulting and that this north-northwest trend is the direction of active spreading; but this is incompatible with transform-fault geometry, for the zig-zag pattern of the seismic belt would then require compression, not extension, along the sectors trending westward.

\section{SOLOMON SEA REGION}

Between the New Britain Arc on the north and the Coral Sea on the south, another complex region includes the small, young oceanic plates of the Solomon Sea and Woodlark Basins, the Solomon Island Arc (the subduction polarity of which reversed during Tertiary time), and the Woodlark and Pocklington Rises (which may be the split halves of a middle Tertiary island arc). Figures 151-153 give reflection profiles across the region. Marine and land gravity surveys in the region were reported by Laudon (1968) and Rose, Woollard, and Malahoff (1968). De Broin, Aubertin, and Ravenne (1977), Coleman and Packham (1976), and Recy, Dubois, Daniel, Dupont, and Launay (1977) summarized aspects of the tectonics of the region.

\section{SOI.OMON ISL.ANDS}

The southeastward trend of New Ireland is continued as the active island arc of the Solomon Islands (fig. 146). A Benioff zone of mantle earthquakes dips northeastward beneath the Solomons (fig. 149; Curtis, 1973a; Denham, 1969) from a deep trench (Johnson and others, 1974) along their southwest side. Seismicity is more intense in the northern and southern sectors than in the central one, where a trench is lacking. Deep-earthquake distribution in the northern sector suggests the presence of a detached lithosphere slab deep beneath this arc. (See Curtis, 1973a, fig. 6, profiles 10,11 , and 12.) First-motion solutions indicate northeastward subduction (fig. 149; Curtis, 1973b; Everingham, 1975a; Johnson and Molnar, 1972; Ripper, 1975a, b, 1976). Active basalt and andesite volcanoes occur along the southwest side of the island-arc ridge (Coleman, 1970). The medial part of the ridge where exposed consists of greenstone, amphibolite, altered basalt, and deep-water sediment, intruded and covered by upper Eocene and Oligocene basaltic and andesitic rocks (Blake and Miezitis, 1967; Coleman, 1970). The northeastern part of the ridge displays ocean-floor basalts overlain by Upper Cretaceous and younger abyssal sediments (Coleman, 1970; van Deventer and Postuma, 1973; Hughes and Turner, 1977; Kroenke, 1972). These oceanic materials are imbricated and raised above a fossil trench at the northeast base of the ridge (fig. 151; Kroenke, 1972). (See also Johnson and others, 1974, and prior discussion of Ontong Java Plateau, in section on Mesozoic crust of the Pacific Ocean.) Serpentinite 

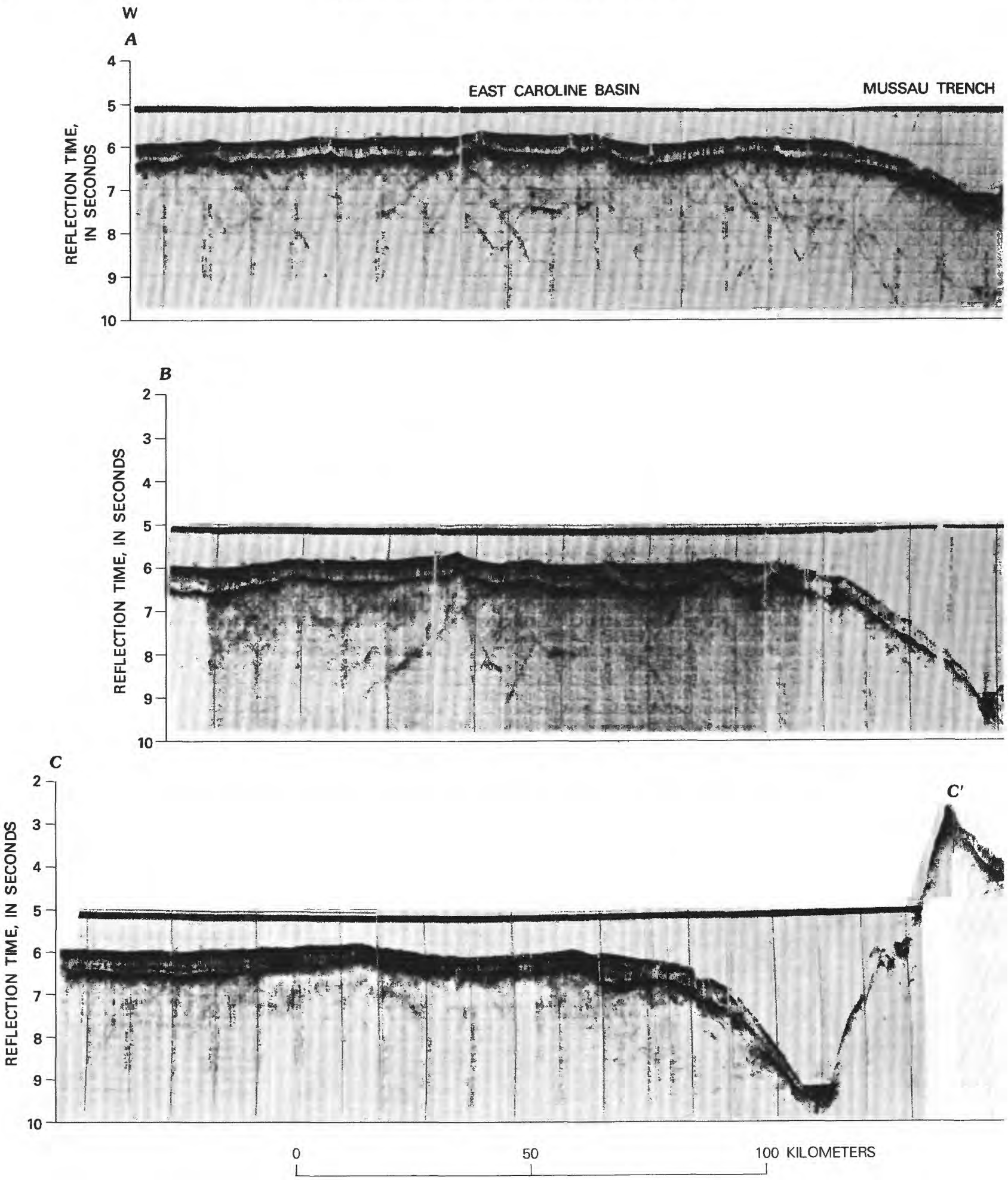

FIGURE 148 (above and facing page).-Seismic-reflection profiles across the Mussau terrain. Location of profiles shown on figure 145. From Erlandson (1975, figs. 4 and 6); reproduced by permission. 

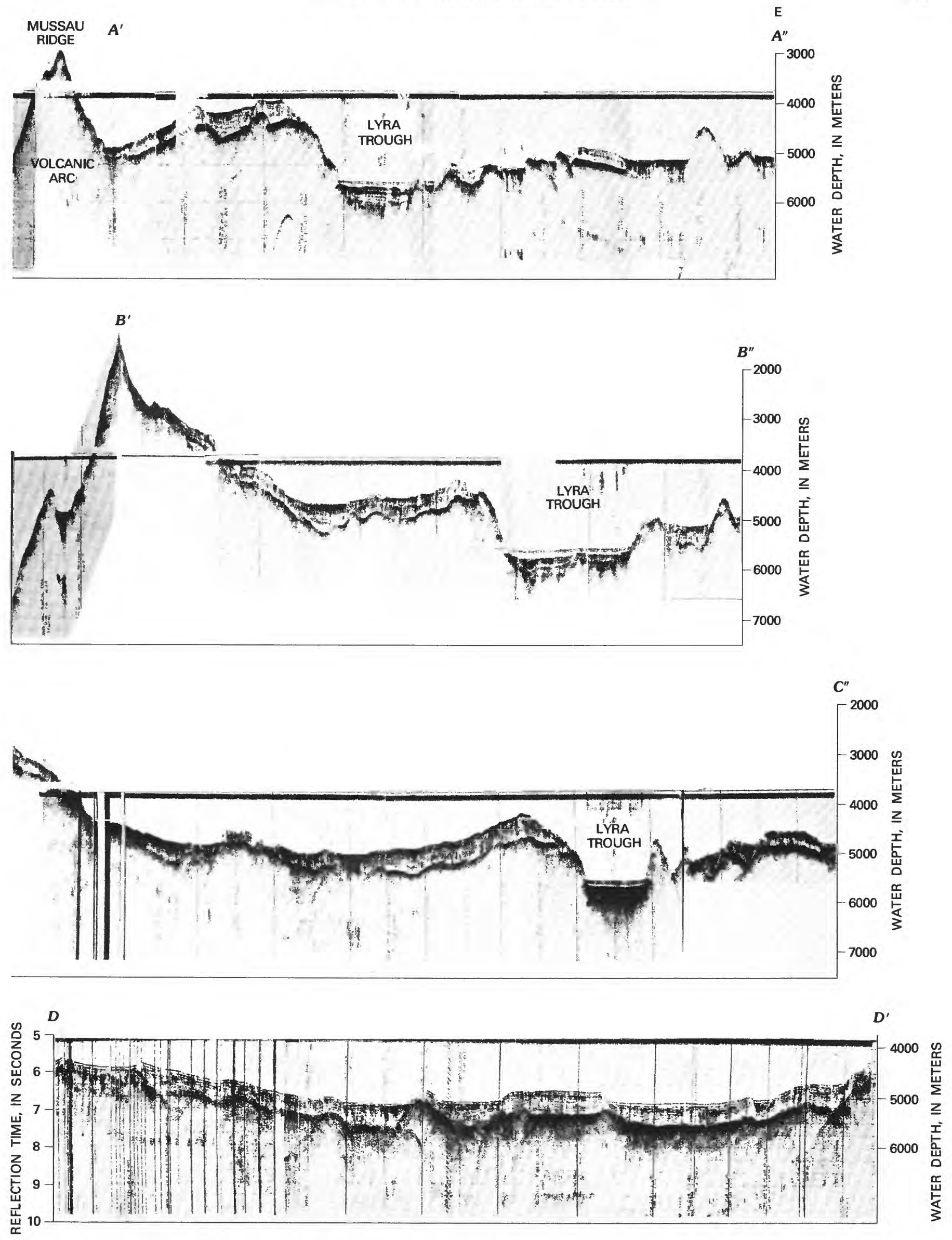


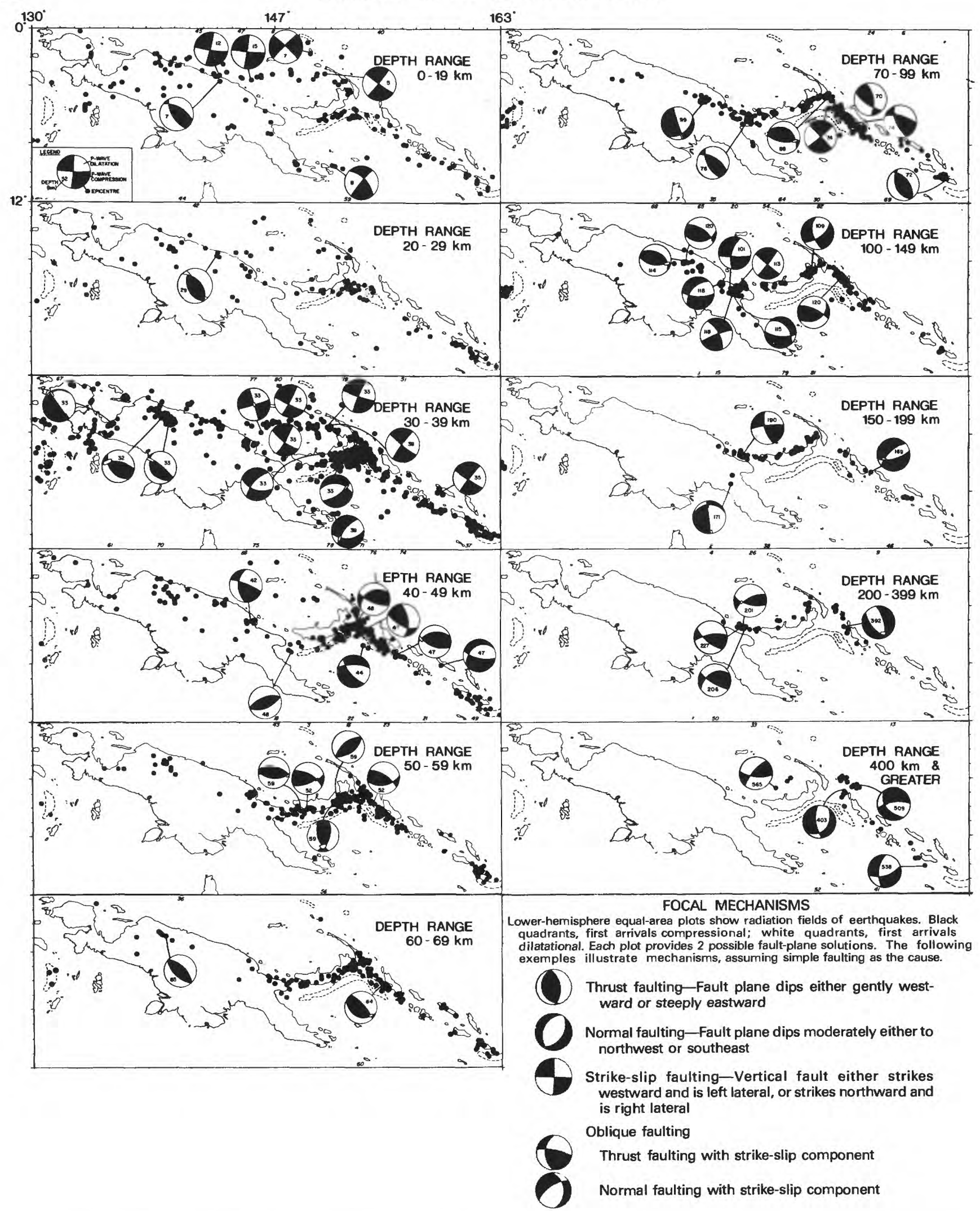

FIGURE 149.--Seismicity of the New Guinea-Solomon Sea region. Dots mark epicenters of earthquakes, recorded by 15 or more stations, from 1964 through 1972, within the specified depth ranges. Focal mechanisms determined by lan D. Ripper, Port Moresby Geophysical Observatory, who provided this figure and who published a similar one himself (Ripper, 1975a). 


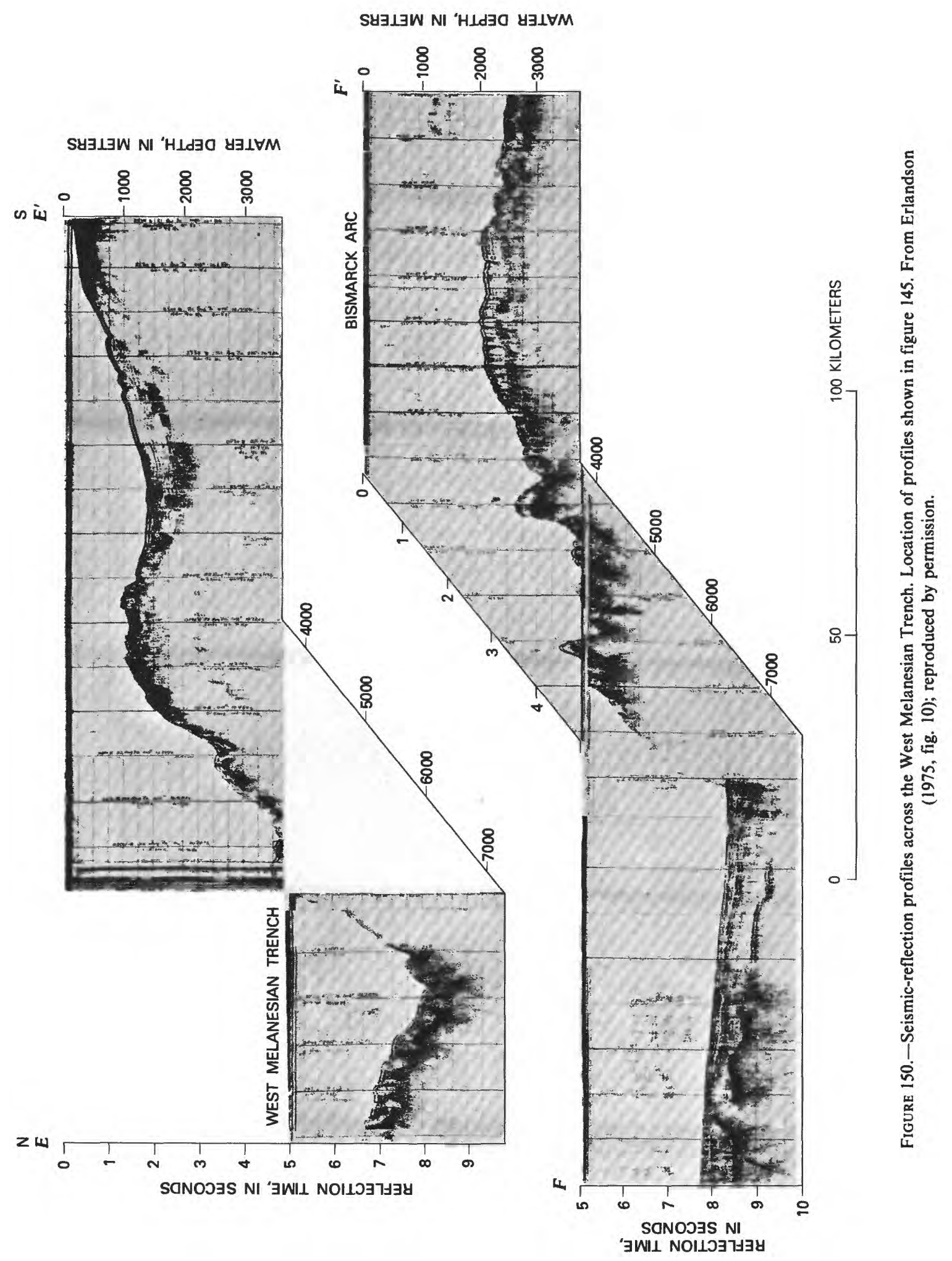


sheets partly separate medial and northeastern belts (Coleman, 1970).

The Solomon Islands now face southwestward across a subducting trench (fig. 146), but during earlier Tertiary time they faced northeastward, the arc polarity having since reversed (Karig, 1972; Karig and Mammerickx, 1972). Presumably the Eocene and Oligocene calc-alkalic magmatism correlates with southwestward subduction; geochemical studies, defining cross-strike gradients in potassium-silicon ratios of the volcanic rocks, would test this. The upper Neogene volcanic rocks correlate with northeast-dipping subduction. Widespread lower and middle Miocene shallow-water limestone records a nonvolcanic period.

\section{SOLOMON SEA AND WOODLARK BASINS}

A small triangular sea with curving sides is bounded on the northwest by the New Britain Arc, on the northeast by the Solomon Arc, and on the south by the Papuan Peninsula and Pocklington Rise (fig. 145). Within this sea, medial submarine Woodlark Rise separates the Solomon Sea Basin in the north from the Woodlark Basin in the south. The Solomon Sea Basin has moderately high heat flow (Macdonald and others, 1973) and presumably is of Tertiary age. Crust beneath part of the Solomon Sea is anomalously thick (Finlayson and others, 1977). The Woodlark Basin has a rough basement with an axial high, thin sediments that thicken away from the axis but are lacking near it, and high heat flow; it likely is a Neogene sphenochasm, opened by spreading that increases eastward (fig 146; Luyendyk and others, 1973). (See also Carey, 1958, Johnson and others, 1974, Krause, 1967, 1973, and Milsom, 1970.) The presently active spreading center, marked by a belt of shallow earthquakes (Curtis, 1973a), trends east-northeastward medially through the basin. The D'Entrecasteaux Islands, at the apex of the sphenochasm, carry Quaternary volcanoes that include alkalic basalt and peralkalic rhyolite (Johnson and others, 1973; I. E. Smith, 1976) - a rock assemblage that occurs typically in regions undergoing extension.

\section{WOODLARK AND POCKLINGTON RISES}

A bathymetric trough, here termed the Trobriand Trench, lies along the north base of the Papuan Peninsula and Woodlark Rise between long $148^{\circ} 45^{\prime}$ and $153^{\circ} 30^{\prime} \mathrm{E}$, (von der Borch, 1972; Rose and others, 1968). This feature is shown in the profiles of figures 152 and 153 to be a trench that is either active or only recently inactivated, with subduction southward at a gentle angle. The late Neogene magmatism of the Papuan Peninsula presumably is related to this subduction. No analogous trench is apparent where the northeast-trending part of the rise, farther east, is crossed by the profile of figure 152. There, the sharp-topped
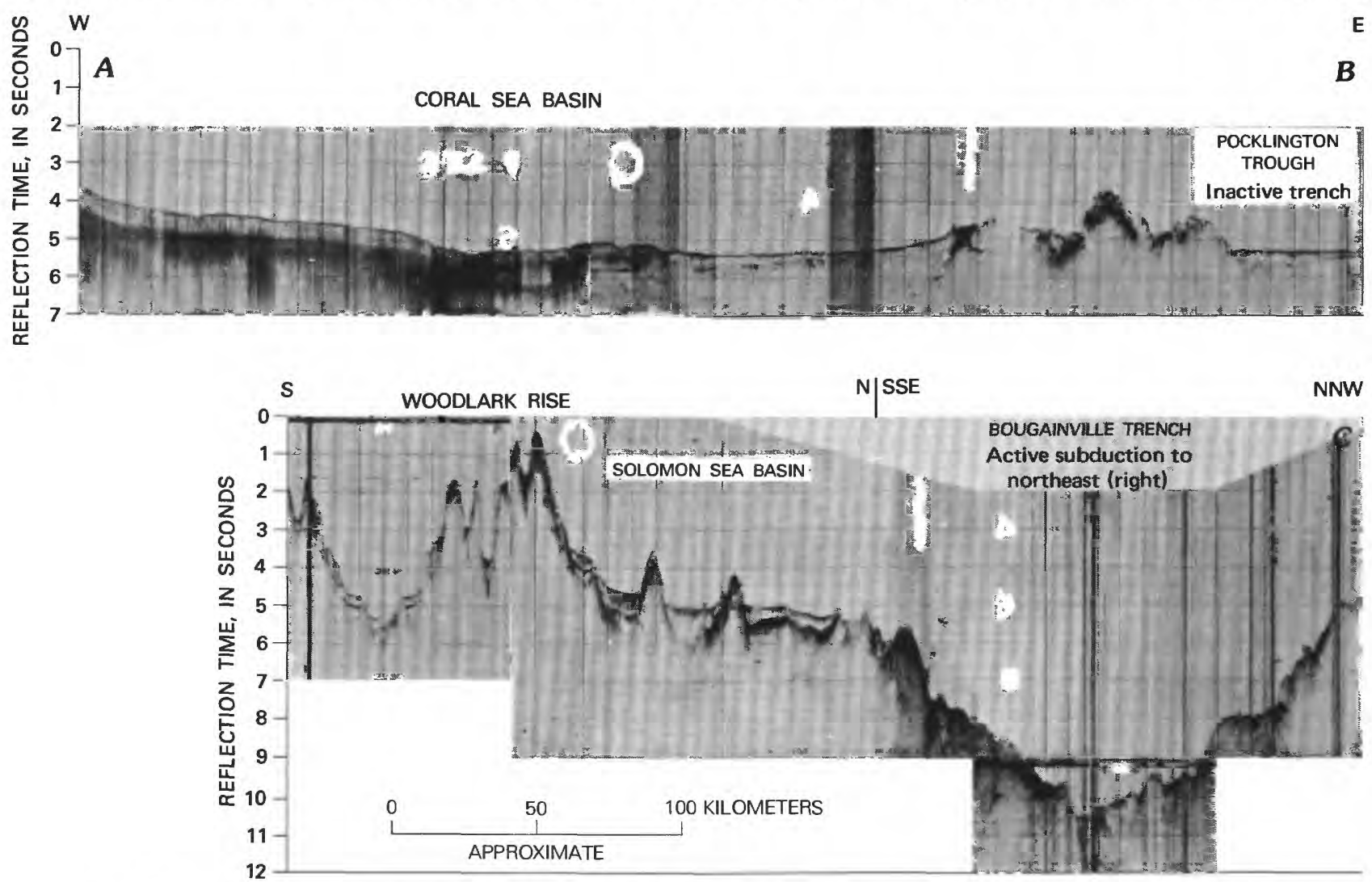

FIGURE 151.-Seismic-reflection profile from southeastern New Guinea to the Ontong Java Plateau. Vertical exaggeration about $18 \mathrm{x}$, but profile shown on figure 145. Profile made by U.S. Navy Ship Bartlett, August 1971, using sparker signal; 
seamounts of the rise have slopes of $15^{\circ}-30^{\circ}$ and appear to be volcanoes. Woodlark Island consists of andesite and basalt of early Miocene and older age (Trail, 1967), and much of the rise may be part of a middle Tertiary volcanic island arc.

The D'Entrecasteaux Islands, at the west end of the Pocklington Rise, have a complex basement of metamorphic and plutonic rocks: quartz-feldspar gneiss (typically approximating biotite granodiorite in composition), and minor schist, amphibolite, and calcareous gneiss, mostly metamorphosed in the amphibolite facies but partly in eclogite and granulite facies (Davies and Ives, 1965). These relatively silicic rocks are exposed within broad domes, around which masses of sheared serpentinite lie tectonically above the metamorphic rocks. The silicic character of the metamorphic rocks may indicate that they belong to a fragment of Mesozoic or other continental crust, presumably from Australia. Alternatively and more likely, quartzose, deep-water sediments of continental origin might here be mixed tectonically with oceanic crustal materials and owe their metamorphism to overriding by hot, young oceanic lithosphere, in the manner deduced by Woodcock and Robertson (1977). Basalt metamorphosed in blueschist facies occurs in the southern island of the D'Entrecasteaux group (figs. 120, 145; Davies and Smith, 1971). Both metamorphic and ultramafic rocks are intruded by upper Pliocene or lower Pleistocene granodiorite and quartz monzonite (Davies, 1973a). Pliocene andesite, dacite, rhyolite, and basalt, and Quaternary olivine basalt and subordinate silicic, alkalic rocks, are present also. Farther east on the Pocklington Rise, the Louisiade Archipelago contains undated low-grade metamorphic rocks cut by intrusive masses of intermediate composition (Bain and others, 1972). The Pocklington Trough, along the south side of the Pocklington Rise, may be a fossil trench (fig. 146; Karig, 1972; Recy and others, 1977). The Woodlark and Pocklington Rises might be the halves of a middle Tertiary volcanic island arc, which faced southward over the Pocklington trench, split apart by Neogene spreading of the Woodlark Basin. The Quaternary bimodal volcanic rocks of the D'Entrecasteaux Islands are of types commonly associated with crustal rifting, and may mark the landward extension of the spreading of the Woodlark Basin.

$$
\text { NEW BRITAIN - TROBRIAND COI.I.ISION ZONE }
$$

The New Britain and Trobriand Trenches converge westward (fig. 146): two arcs are here colliding, and the collision zone is lengthening eastward with time. The Solomon Sea floor is being subducted northward beneath New Britain from the New Britain Trench and either is or was until recently also being subducted southward beneath the Papuan Peninsula from the Trobriand Trench (fig. $153 E F)$. At the west end of the Solomon Sea, where the
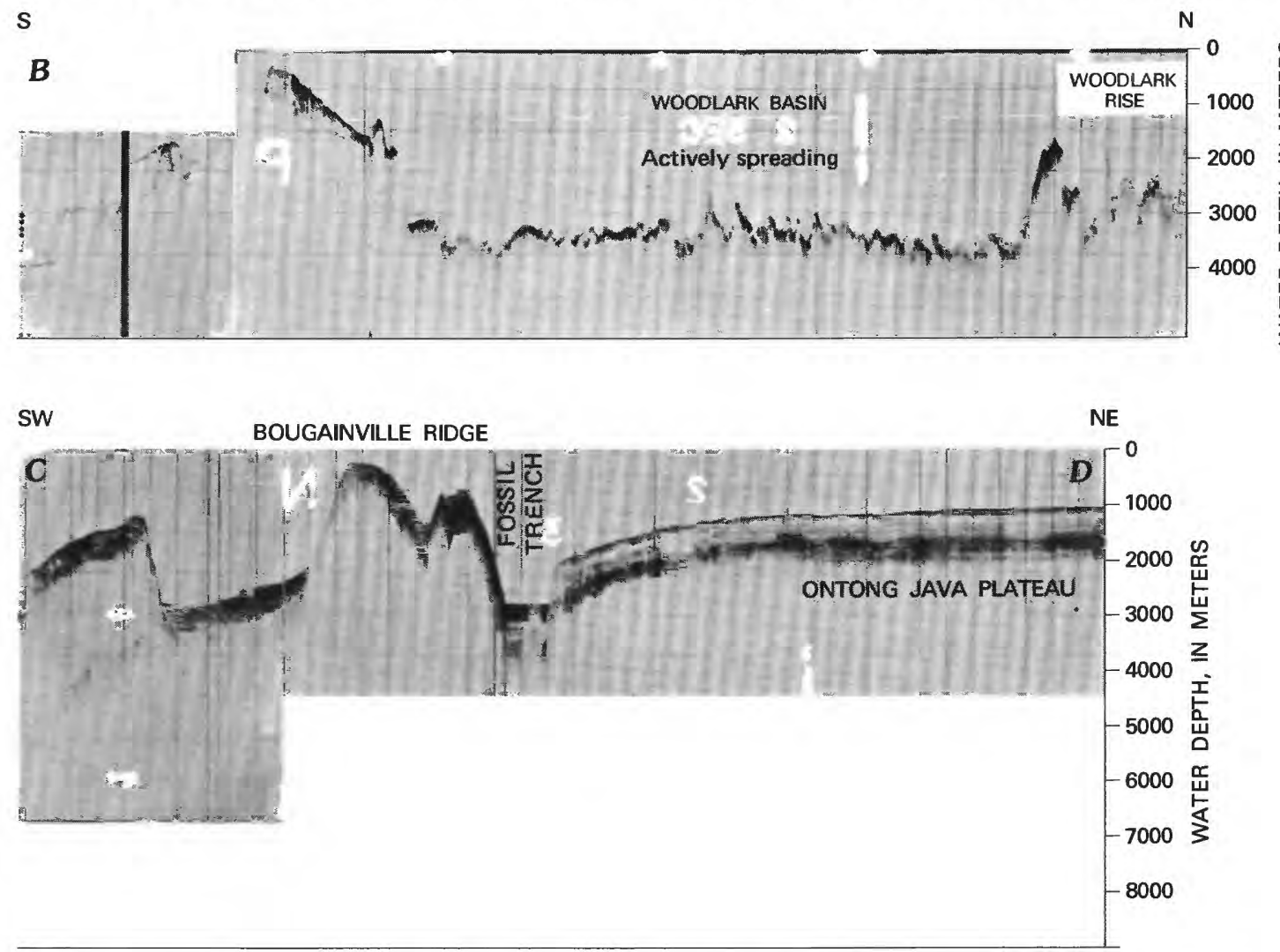

because of obliquity of course to strike of the Bougainville Trench the apparent exaggeration of that trench is only about $7 \mathrm{x}$. Location of published previously by Johnson, Egloff, and Hemler (1974, fig. 8) and reproduced by permission. 


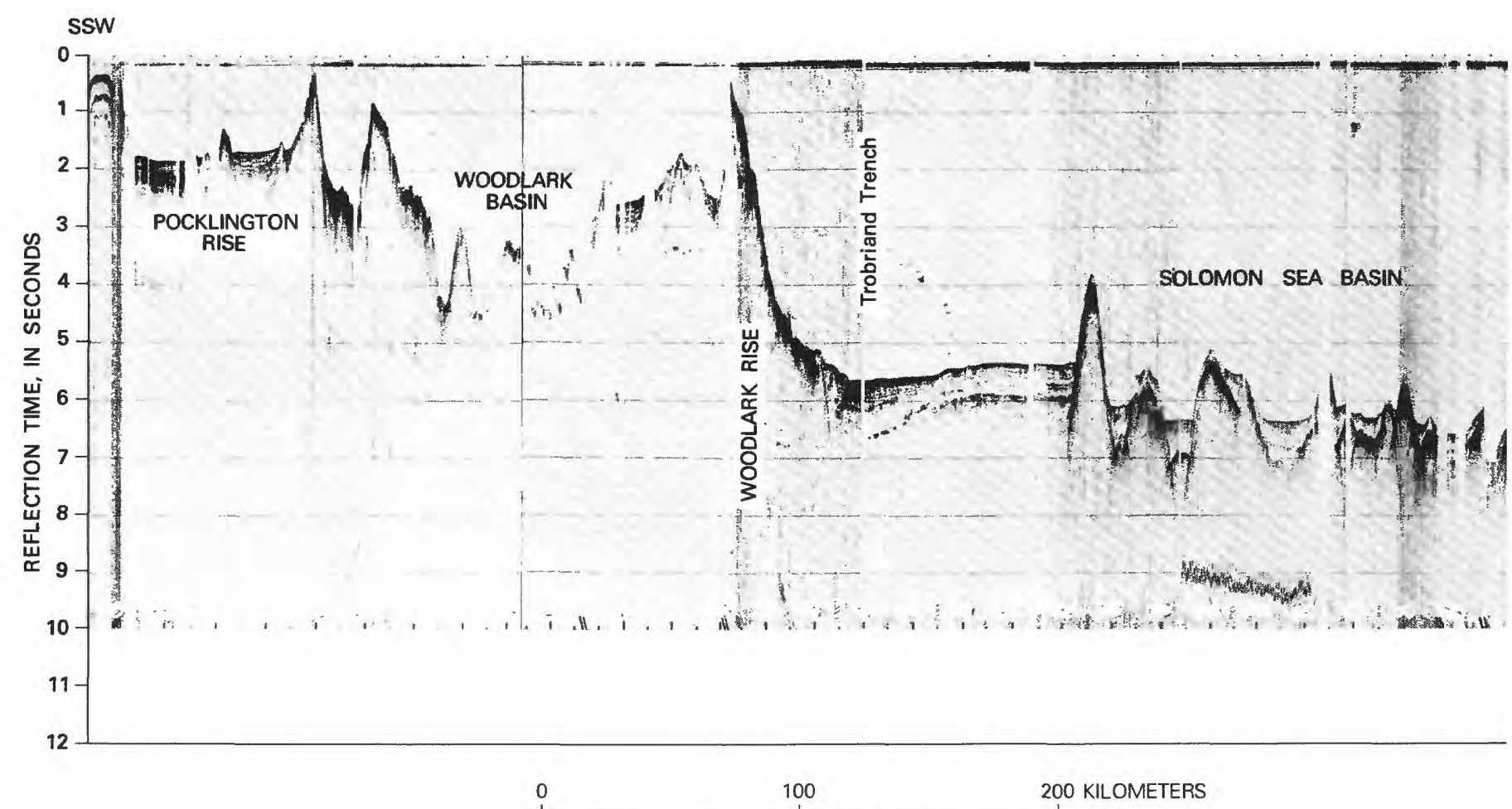

FIGURE 152 (above and facing page).-Seismic-reflection profile in the Solomon Sea region. Deep Bougainville Trench marks the trace of a subduction zone dipping northeastward. The basin on the slope up to Bougainville Island may be an outer-arc basin. A much shallower trench, with subduction southward, appears to be present at the north side of Woodlark Rise. Location shown on fig. 145. Profile from Lamont-Doherty Geological Observatory, R. V. Vema cruise 24.

opposed New Britain and Papuan Peninsula continental slopes have met, no trench is apparent on available reflection profiles (fig. $153 A B, B C$, and $D E$ ). Apparently the two arcs have collided in the west, and the collision zone is being covered with sediment as it undergoes further convergent, but minimally subductive, deformation. More profiles, preferably accorded multichannel processing, will be needed to define the geometry of the collision features, and the relation between the Trobriand, New Britain, Schouten, and New Guinea subduction systems in the Huon Gulf-Vityaz Strait-Schouten Islands region.

\section{FRAGMENTED ISLAND ARCS}

The ridges of the Bismarck-Solomon region-the Bismarck, New Britain, and Solomon Arcs, and the Woodlark and Pocklington Rises-appear to be parts of a system of island arcs active in early and middle Tertiary time. As subduction, spreading, and strike-slip faulting have been active since the early growth of these arcs, their present configuration must be quite different from their original distribution. The New Britain, Bismarck, and Solomon Arcs might all have been parts of a single north-facing island arc that extended far eastward from New Guinea in Oligocene time. The histories of these arcs are strikingly similar: Paleogene island-arc magmatism, at least partly above south-dipping Benioff zones; middle Miocene quiescence, with deposition of shallow-water limestone sheets; and renewed late Neogene island-arc magmatism, but this time mostly above north-dipping Benioff zones. The west end of the Bismarck Arc, somewhere west of Manus Island, may have formed adjacent to the east end of New Britain, the Bismarck arc having subsequently been transported past New Britain on left-lateral strike-slip faults. The west end of New Britain may have been in middle Tertiary time near the east end of the Papuan Peninsula-Pocklington Arc; or the arc that now comprises the Adelbert-Finisterre terrain of the northeastern New Guinea mainland, between long $145^{\circ}$ and $148^{\circ} \mathrm{E}$., may have been between these segments. This latter arc closely resembles New Britain in its middle Tertiary geology.

The Paleogene rocks of New Ireland presumably formed above a south-dipping Benioff zone, and the upper Neogene ones above a north-dipping zone. The triple junction defined by the intersection of the New Britain and Bougainville Trenches and the mid-Bismarck fault system has migrated southeastward relative to New Ireland, subduction having given way progressively to left-lateral strike-slip motion. The slightly active, highly alkalic volcanoes northeast of New Ireland may have formed above the deep part of the northeast-dipping subduction zone and thus represent slow magmatism continuing after major subduction has ceased. The trench that trends northwestward to the east of New 


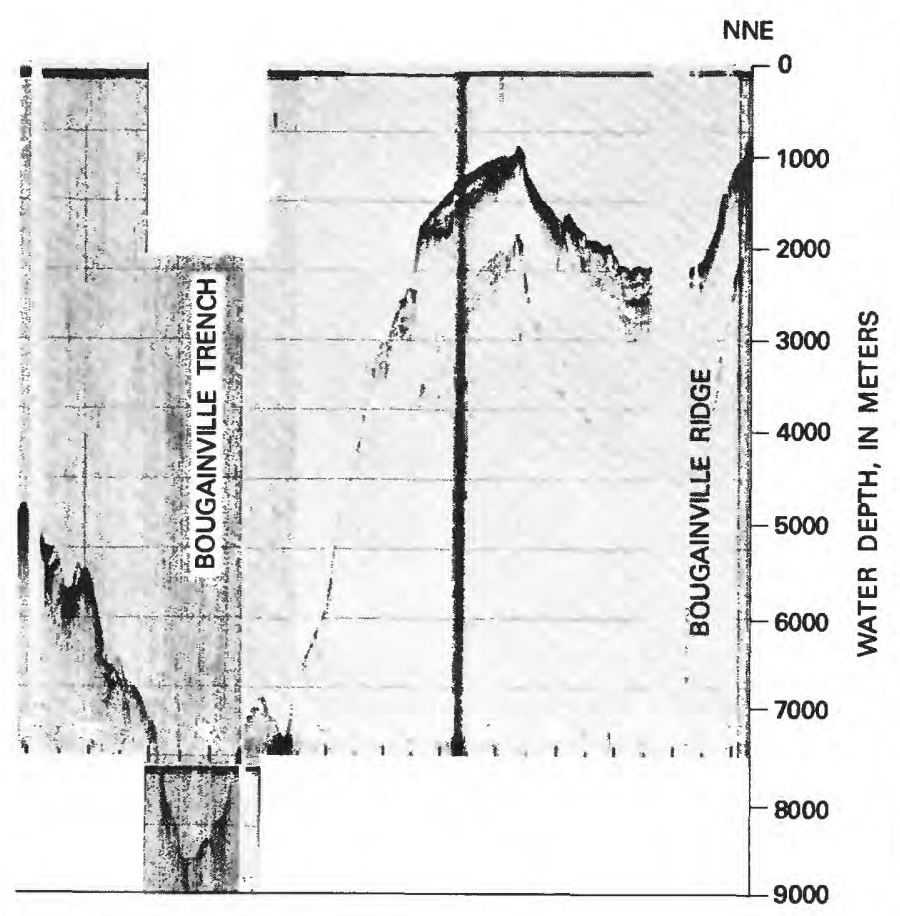

Ireland (fig. 146) could represent the fossil Paleogene trench, or a new trench at which southwestward subduction of the Pacific floor is beginning, or a Paleogene trench recently reactivated. North of Manus Island is the West Melanesian Trench, and the Quaternary volcanoes of Manus and its neighbors presumably reflect subduction southward from this trench.

The Paleogene array could alternatively have been a complex system of smaller arcs, each with a basin spreading behind it, which have since been scrambled by reversals of subduction polarity and by changing patterns dominated by the relatively westward motion of the Pacific megaplate to the north. The arc, or arcs, which collided with southern New Guinea and the Papuan Peninsula during Miocene time are among the other pieces to be accounted for. The New Britain Arc, now colliding with northern New Guinea, may have been transported far westward from the site it occupied at the time of the medial New Guinea collision with another fragment of the great system of arcs and may indeed have been continuous with the northern New Guinea Arc.

\section{PLATE MOTIONS}

The Bismarck-Solomon region displays one of the most active and complex plate-interaction complexes in the world. Curtis (1973b), Denham (1973), Johnson and Molnar (1972), and Krause (1973) are among those who have discussed plate motions in this complex. The rapidity of motions is reflected in the seismicity (fig. 149; Curtis, 1973a; Everingham, 1974). Intense subduction-zone seismicity characterizes the Solomon and New Britain Arcs; intense seismicity at shallow and intermediate depths underlies northern New Guinea; many earthquakes occur along the boundary that bisects the Bismarck Sea; and lesser seismicity is apparent on other structures. Three earthquakes of Richter magnitude 8.0 or greater have occurred in this century near the Solomon-New Britain-Bismarck triple junction, and three others have occurred in the Solomons and New Britain. The motion of the Pacific plate north of Melanesia, relative to Australia, is an oblique convergence, directed west-southwestward (Minster and others, 1974). As the motions of the small intervening plates of the Bismarck and Solomon complex represent relative rotations about nearby poles, the geometry of motions of these small plates must change rapidly (Krause, 1973). Oroclinal folding and intraplate deformation must be occurring also.

The net motion of the Pacific plate relative to the Australian plate increases from $11 \mathrm{~cm} / \mathrm{yr}$ across the southern Solomon Islands boundary to about $13 \mathrm{~cm} / \mathrm{yr}$ on the trajectory toward western New Guinea, and the azimuths of the motion vectors change from $260^{\circ}$ to $250^{\circ}$. (The vectors were calculated from the data of Minster and others, 1974, using a program written by Bruce $R$. Julian for the Hewlett-Packard ${ }^{16} 65$ calculator.) Approximate motion vectors for the intervening small plates can be deduced from the character of the boundaries and from earthquake slip directions. (See fig. 149, and Curtis, 1973b, Johnson and Molnar, 1972, and Ripper, 1975b, for earthquake first-motion solutions.) The Solomon Sea plate, north of the Woodlark spreading center, is moving northeast relative to the Solomon Islands, northwest relative to eastern New Britain, and north relative to western New Britain. Johnson and Molnar (1972) assumed this small Solomon Sea plate to be bounded against New Guinea by a northwest-trending left-lateral fault, within the Papuan Peninsula, for which I am aware of no evidence; I assume instead that the plate is pivoting counterclockwise relative to New Guinea. The curving, fast-moving strike-slip and extension boundary between the North and South Bismarck plates indicates the motion of the latter relative to the former to be eastward or east-southeastward in the west, but southeastward in the east to the trench-transform-trench triple junction. Slow convergence, with unproved direction, occurs across the West Melanesian Trench, and presumably across the Mussau Trench also. Motion unaccounted for on these various plate boundaries is taken up by deformation within and along northern New Guinea, on structures indicated by first-motion studies to be mostly left-lateral faults striking westward to northwestward and compressional structures striking northwestward.

Integration of these constraints with the known tectonic patterns and with some further assumptions regarding minor plate boundaries is attempted on figure 154 . The exercise is much more constrained than may at first appear: not only must vectors sum to zero around any closed

16Brand or manufacturers' names in this report are for information purposes only and do not constitute endorsement by the U.S. Geological Survey. 

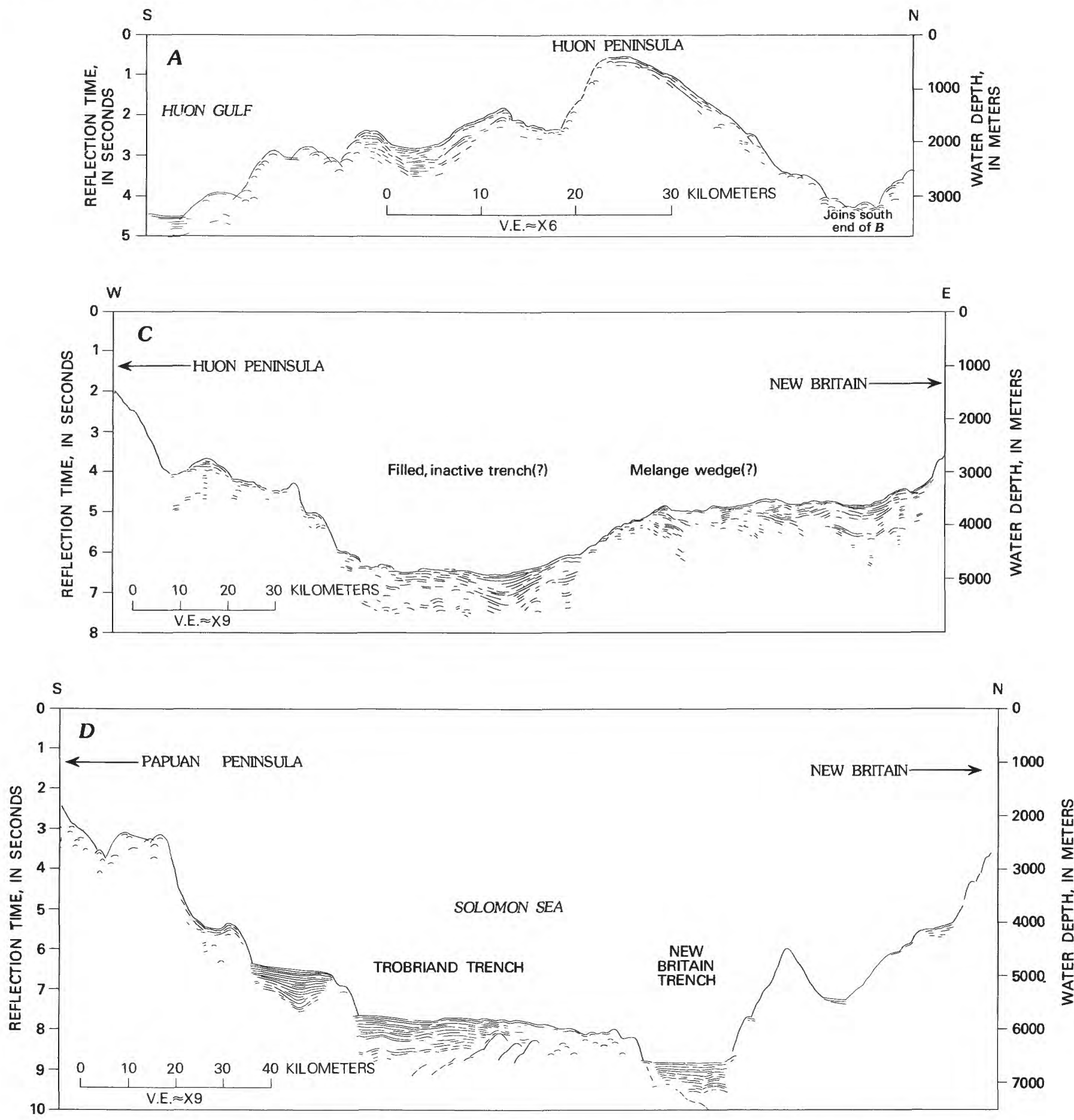

FIGURE 153 (above and facing page).-Seismic-reflection profiles in the western Solomon Sea. Trobriand and New Britain subduction systems face each other in $D$. The trough at the center of $C$, the compound trough shared by $A$ and $B$, and the trough at the south end of $A$ all may mark the collision of these arc systems. Location of profiles shown on figure 145. Line drawings of reflectors in single-channel-monitor profiles of records made for the Australia Bureau of Mineral Resources, Geology and Geophysics, by the Compagnie Generale de Geophysique.

circuit, but vectors across all parts of a boundary between two plates must define small-circle arcs, of constant arcuate lengths, to the same pole of relative rotation. Little freedom is allowed in the way the vectors can be drawn, and much trial-and-error experimentation is required to develop a coherent synthesis. 


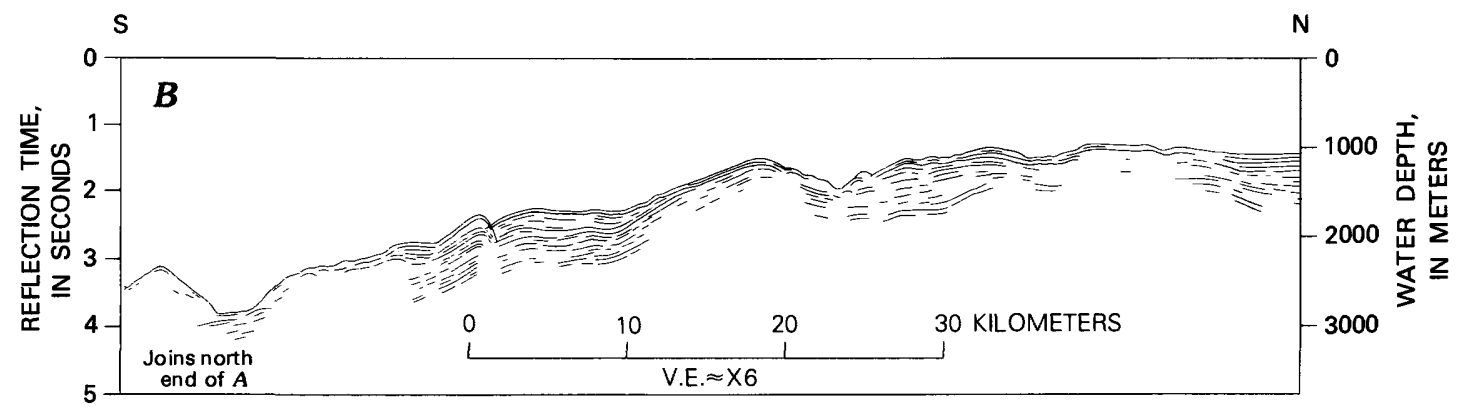

The integration assigns to the mid-Bismarck fault system the transforming of the major oblique convergence of the Pacific plate to New Guinea. The Mussau Trench is arbitrarily assigned a small convergence rate in a direction parallel to the Caroline Ridge rift zone at which the Mussau terrain ends (fig. 137). The West Melanesian Trench is assumed to record a simple relative rotation of the North Bismarck plate toward the Pacific plate, about a pivot at the east end of the trench, and is assigned arbitrarily a small angular velocity. Woodlark and Solomon Sea plates are assumed to record rotations about poles of rotation nearby in the Australian plate. These assumptions were derived in part from the trial-and-error process of experimenting with different local-boundary vectors and rotation poles.

From the chaotic patterns of relative motions across the local plate boundaries, a satisfyingly simple pattern emerges when all motions are put in the same framework, in this case relative to Australia. The boundaries between the Pacific, Caroline, and North Bismarck plates represent minor changes in direction and velocity of the general motion of the Pacific plate relatively west-southwestward toward the Australian plate. As the Australian plate is shown by paleomagnetic studies to be moving northward relative to the earth's spin axis, the dominant plate motions in this region are essentially east-west relative to the spin axis. The small, local-rotation South Bismarck, Solomon Sea, and Woodlark plates represent sharper discontinuities and perhaps can be viewed as being rolled between the oliquely converging megaplates. The trench along the southwest side of the Solomon Island Arc is not developed where the hottest, weakest part of the lithosphere produced at the Woodlark spreading axis is being subducted; active volcanoes are uniquely close to the front of the arc in the same section. (See Marshak and Karig, 1977), for discussion of possible analogs elsewhere.)

\section{MECHANISM}

Ocean floors spread, and the crust thereby created from the mantle at spreading axes returns into the mantle at subduction zones. The hinge-lines of those zones migrate into the subducting slabs, so new crust is formed behind the subduction zones also. Subduction can start or stop: An arc can reverse its polarity, subduction on one side ceasing as new subduction begins from the other side with opposite dip.
Arcs collide with each other and with continents. The results, as exemplified in Indonesia and surrounding regions can be chaotic: motions of very large plates continue for scores of millions of years, but the detailed interactions by which these motions are accommodated change rapidly and repeatedly.

\section{PLATE MOTIONS}

The many small plates between the converging Asian, Pacific, and Indian-Australian megaplates are moved by boundary interactions with the megaplates. Relative convergent motion between Asian and Pacific megaplates. north of lat $5^{\circ} \mathrm{N}$. is nearly perpendicular to a boundary zone of intervening plates, which absorb the convergence by subduction and minor rotations. The Indian-Australian and Pacific megaplates are converging obliquely; the small intervening Melanesian plates absorb the convergence in complex fashion with subduction accompanied by major rotations and transorms and by minor spreading. The eastern Indonesian zone of interaction between all three megaplates is still more complex. Much internal deformation of arc and continental crustal masses occurs in all of the convergence systems.

But what forces propel the megaplates? There are many conjectures, but no proofs.

Thermal convection was long the general process favored by a majority of geophysicists-Chapple and Tullis (1977), Elsasser (1971), Ichiye (1971), Kaula (1972), McKenzie, Roberts and Weiss (1973), Orowan (1965), Runcorn (1972), Turcotte and Oxburgh (1969), and many others. Details and mathematical elegance of the conjecture vary widely, but in general, mantle is pictured as rising where it is heated and diverging at or near the surface to form spreading ridges, and as sinking where it cools to form subduction systems. The moving plates are generally pictured as being carried along on the tops of the convection cells, which are illustrated by tidy two-dimensional cartoons. Variants of the theory push the plates away from a ridge that is formed by dike injection above a hot strip of mantle (for example, Lliboutry, 1969; but this possibility is not obviously consistent with the presence of open tension fractures along ridge crests) or pull the plates outward and downward away from the ridges toward the sites in which their cold portions are sinking gravitationally. A smaller number of geophysicists (including Jacoby, 1973, Jeffreys, 1974, Knopoff, 1967, and MacDonald, 1963) have argued that the physical properties 
of the mantle prohibit thermal convection of the type $/$ demonstrated process, further used such arguments to visualized by those who would use it to drive plates. (Jeffreys, MacDonald, and others, confusing evidence conclude mistakenly that continental drift is impossible.) Convective overturn in the mantle should, however, occur as against a hypothetical mechanism as evidence against a 1 a byproduct of plate motion, whatever the cause of that

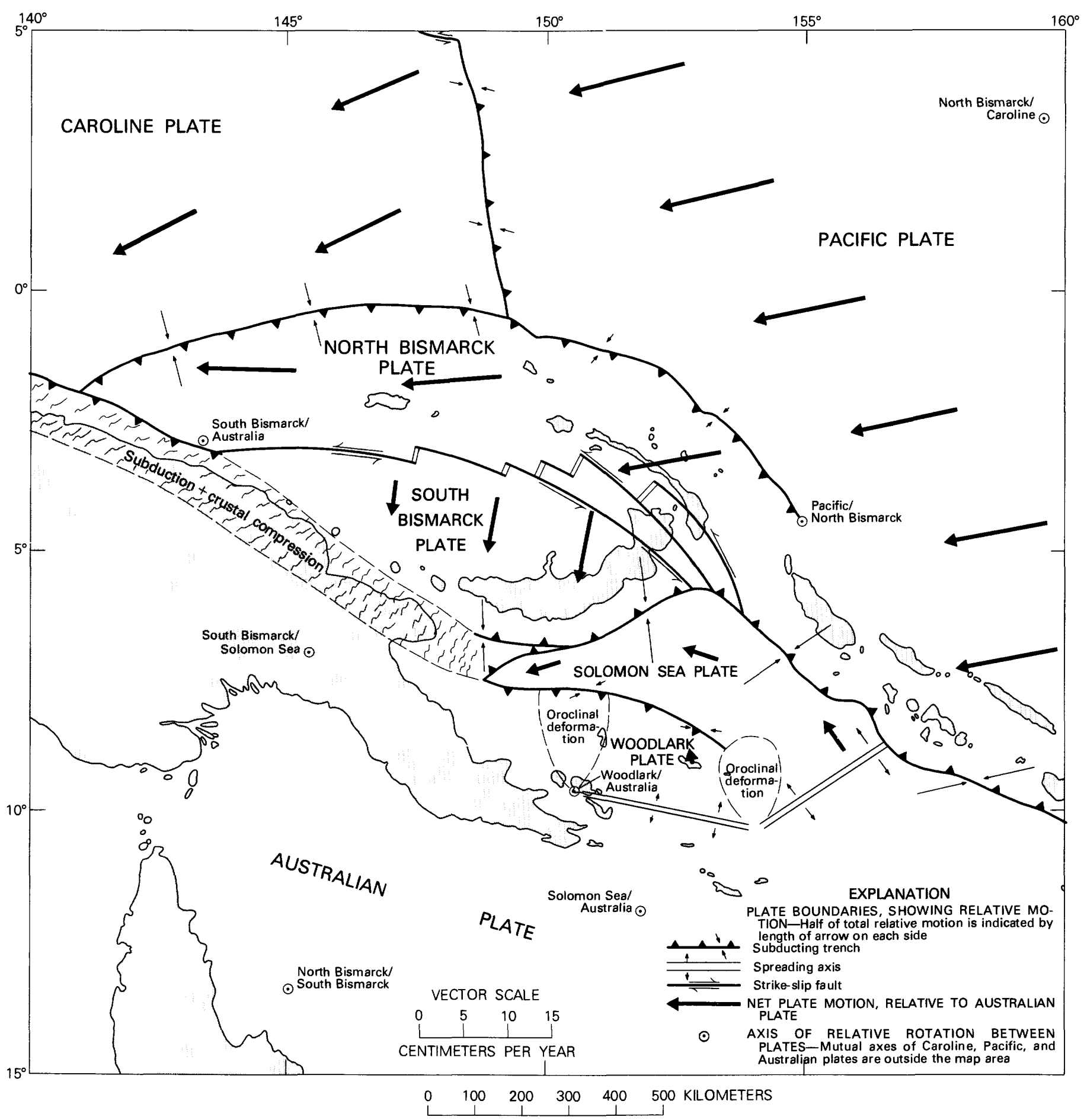

FIGURE 154.- Inferred present plate motions in the western Melanesian region. Plate boundaries are from figure 146. (See figure 145 for bathymetry.) Broad arrows indicate motion relative to the Australian plate; motion of the Pacific plate is calculated from the data of Minster, Jordan, Molnar, and Haines (1974), and that of the other plates is derived as discussed in text. 
motion, perhaps involves the entire mantle (Davies, 1977), and must respond to thermally generated density instabilities.

Other hypotheses for driving plates by thermal instabilities invoke "plumes," or "hot spots." A number of volcanic island chains show systematic age progressions which have been interpreted to indicate that lithosphere plates drift over long-lasting local heat sources in the mantle beneath the asthenosphere, and schemes to move plates by the action of mantle rising at such points have been devised by D. L. Anderson (1975), Burke and Dewey (1973b), Deffeyes (1972), Morgan (1973), Wilson (1973), and others. That "plumes" do not exist, and that the age progressions in volcanic chains are instead products of propagating cracks due to intraplate stresses, however, appears probable to me. (See Jackson and Shaw, 1975, Solomon and Sleep, 1974, Turcotte and Oxburgh, 1973, and Walcott, 1976.) Other conjectural thermal-instability mechanisms couple differential heat sources to shallow gravitational drives (for example, Lister, 1975, and Schuiling, 1973).

Another family of explanations, presently (1978) increasing in popularity, assigns gravity the primary role in producing plate motions: lithosphere slides gravitationally down the flanks of ridges, pushing plates, and sinks gravitationally in subduction systems, pulling plates (Forsyth and Uyeda, 1975; Gordon and others, 1978; Hales, 1969; Harper, 1975; Jacoby, 1973; and many others). Variants of this theme superimpose the effects of thermal convection and subduction pull (for example, Richter, 1973).

I do not believe that any of these proposed mechanisms can provide the major causes of plate motions, for the mechanisms cannot be reconciled with the geometry and behavior of actual plate boundaries. Thermal convection, in the sense of a drive of spreading ridges by upwelling above a linear heat source, is easily refuted. Spreading ridges migrate concentrically away from rifted margins, changing their lengths and curvatures in precisely the geometry required by the separating plates, moving all the while relative to other spreading ridges. The orthogonal geometry of ridge-and-transform systems indicates that spreading is produced by tensile forces in the plates (Oldenburg and Brune, 1972). Rifts jump from one site to another without change in spreading rates. Actively spreading ridges run into actively subducting trenches. The ridges that are migrating away from Africa and Antarctica around two-thirds of the perimeter of each are not compensated by any intervening subduction. Spreading in the Atlantic is compensated by subduction in the Pacific. All of this precludes hot-wire ridge drives. Upwelling of hot material into ridges is a product, not a cause, of plate separation.

Subduction must occur by gravitational sinking, as is elaborated subsequently, but it does not follow from this that sinking slabs pull plates halfway around the Earth. Gravitational-drive hypotheses seem little better than convection-current ones for accounting for observed plate behavior and geometry, and similarly are based primarily on two-dimensional cartoons of idealized spreading-and-subduction systems which cannot be related to actual global geometry. A number of specific aspects of actual subduction processes also are incompatible with subduction-pull rationales. Opposed island arcs collide; obviously the intervening plate cannot be pulled laterally beneath both arcs simultaneously. Continuous subduction around the $180^{\circ}$ bends of the Banda, Caribbean, and Scotia Arcs defies subduction-pull explanation. Arc reversals, either without or following collision with a continent or another arc, cannot easily be explained by subduction pull, for penetration of an old downgoing slab by a new one would be required.

Body forces, acting throughout the plates themselves, might produce the motions. The obvious candidates are gravity; tidal couples; and inertia, related to the Earth's rotation. The sinking of lithosphere slabs beneath arcs probably is due to the action of gravity on the cold, dense slabs, but this appears inadequate for consideration as the major global mover. The Earth-Moon gravitational tidal couple may perturb plate motions (Bostrom and others, 1974; Moore, 1973, 1975; Williams and Austin, 1973), but its effect likely is small (Jordan, 1974).

Torques generated by the Earth's spin might provide a major driving mechanism. Plate motions represent primarily slight differences in direction and velocity of rotation about the Earth's axis, and plate velocities are higher in low latitudes than in high ones, so the Earth's spin at least influences plate motions (Knopoff and Leeds, 1972; Solomon and others, 1975). Any shift of mass, horizontally or vertically, upon or within the Earth must produce compensatory gyroscopic shifts in other masses relative to the general axis of rotation (Gold 1955). Goldreich and Toomre (1969), Kane (1972), Knopoff and Leeds (1972), Liu (1974), Liu, Carpenter, and Agreen (1974), Pan(1975), Shaw (1973), and Whyte (1977) have presented variants of the concept that transfers of mass might, by changing the Earth's tensor vector, generate significant torques by gyroscopic effects.

\section{SUBDUC:TION}

The lithospheric slabs descending from subduction zones cause relatively little attenuation of seismic waves, hence must be colder than normal mantle at corresponding depth (Oliver and others, 1973). Computer modeling of temperature and other properties in downgoing slabs has been carried out by Neugebauer and Breitmayer (1975), Oxburgh and Turcotte, (1976), Smith and Toksöz (1972), Toksöz, Sleep, and Smith (1973), and others. The slab is dense because it is contracted thermally, because pressure-phase transormations, which are inhibited by increasing temperature, occur at relatively shallow depths within it (Ringwood, 1976), and likely also because its lowest-melting components are removed by partial melting beneath magmatic arcs. Earthquake locations and 
mechanisms indicate that the slabs are under tension at intermediate depths and compression at depths below about $300 \mathrm{~km}$ and apparently are sinking under their own weight (Billington and Isacks, 1975; Isacks and Molnar, 1969, 1971; Oliver and others, 1973). Portions of slabs possibly are detached and sink to depths of about 650 or $700 \mathrm{~km}$, but most descending slabs appear to be continuous (Barazangi and others, 1973; Oliver and others, 1973). Although it is generally assumed that the slabs do not penetrate the 650-700 km seismic-velocity discontinuity, Ringwood (1976) argued that likely they do sink through it. Deep earthquakes in descending slabs may be primarily results of density-phase transformations (McGarr, 1977).

Jischke (1975) suggested, on the basis of mathematical modeling, that the relative constancy of dip of individual Benioff zones, and their contrasts with one a nother, could be explained by hydrodynamic viscous shear forces that balance gravitational forces drawing the plates down. Solomon, Sleep, and Richardson (1975) deduced instead, by analysis of relative plate-motion velocities, that horizontal translation velocities of all subducting slabs are similar, near $1 \mathrm{~cm} / \mathrm{yr}$, and that different dips record different horizontal convergence rates of the plates.

Subduction takes place where plates converge and likely is controlled by gravity. But what are its mechanics? How much beam strength does the slab have: to what extent is it injected forward by the following plate, and how does this injection behavior change with increasing depth and temperature? How much of the dip of the Benioff-zone trajectory of a descending slab is due to forward injection, and how much to migration of the island arc or continental plate above a vertically sinking slab? (The 140-km depth limit on downdip compression inferred by Engdahl, Sleep, and Lin, 1977, from their first-motion studies may mark a transition from beam-injection to vertical-sinking behavior.) Where and how is the return flow, which must globally compensate subduction, accomplished? The concept of the advancing hingeline (De Fazio, 1974; Frank, 1968; Scholz and Page, 1970), discussed in this report in the section on the Mariana system, explains the spreading behind advancing arcs as merely the geometric consequence of the subduction of a plate that has a spherical curvature; how viable is this? How can these parameters be integrated into a global motion system? Many such questions cannot yet be answered.

The geometry of Indonesian subduction systems leads me to conclude that subducting slabs are primarily sinking vertically beneath advancing, overriding plates. The spoon-shaped Benioff zone of the Banda Arc is easily explained in these terms, whereas it defies explanation in terms of slab injection with a sizable horizontal component of motion. The collision of two arcs-well documented in the Molucca Sea region, and inferred from less complete data in the Schouten Islands region-by the complete subduction of an intervening oceanic plate beneath converging overriding plates also is easily visualized as due to vertical sinking of both sides of the subducting plate, but not as due to horizontal injection simultaneously outward in both directions.

The relationships between horizontal velocities of converging plates and the dips and lithosphere ages of subducting slabs obviously will tell much about the subduction process when they are defined. No published studies yet integrate all of these parameters. Lithosphere age controls density and thickness, hence the sinking velocities must vary with this age. The separate velocities of subducting and overriding plates must be considered. Overall convergence rates show only a very poor inverse correlation with dips of Benioff zones (Tovish and Schubert, 1978). In single, long island-arc systems, however, beneath which lithosphere of relatively uniform age is being subducted and along which the relative velocities of subducting and overriding plates vary only systematically, a much better inverse correlation prevails (Luyendyk, 1970). Along Chile, where convergence velocity is semiconstant, both the dip and the down-dip length of the seismic zone tend to increase with increasing age of the subducting lithosphere (Farrar and Lowe, 1978; see Woollard, 1977, for dips).

\section{RIFTING;}

Rifting is better understood than subduction because a larger proportion of its structural and lithologic products crop out on the surface of the lithosphere and can be ovserved directly, or are at only shallow depth and can be probed by drilling and by high-resolution geophysical methods. Continental rifts originate by attenuation of the lithosphere along zones controlled in substantial part by preexisting structural grains. Extension is accomplished at the surface primarily by block faulting and may proceed erratically and very slowly for tens of millions of years before the continental crust is ruptured (for example, Veevers and Cotterill, 1976, 1978), after which separation of plates commonly proceeds rapidly. The rifted continental margins subside, either with continuing block faulting or by gentle oceanward sagging, likely in either case representing gravitational spreading of the crust (Bott, 1971, 1973). At the now-oceanic rift axis, new crust is generated in a linear magma chamber (Cann, 1974; Rosendahl, 1976; Sleep, 1975), the melt for which is generated because of the pressure decrease on retrograde-flowing mantle beneath the rift. The "primitive" ocean-floor basalts formed by extrusion from the top of this chamber are actually highly evolved by massive fractionation of dunite and gabbro accumulated in the chamber (O'Hara, 1976). Concurrent metamorphism and off-axis magmatism complicate the products of rift magmatism (Christensen and Salisbury, 1975). Some of the geometric evidence that indicates rift zones to be products, not causes, of plate motions was noted previously.

\section{ARC: MAGMAGENESIS}

The magmas of the volcanic arcs of the Indonesian region are formed by processes related to the descent of lithosphere 
slabs. Volcanism is concentrated in belts that lie approximately above the $125-\mathrm{km}$ contours on the centers of the seismic Benioff zones that mark the descending plates (Hamilton, 1974b; pl. 1), so apparently magmas are formed at that depth, or at some other depth related systematically to the conditions in or above the slab at that part of its descent. Despite the assumption by many petrologists (for example, Eggler and Burnham, 1973; D.H. Green, 1973; and T.H. Green, 1972) that at least the basaltic lavas were generated directly at such slab depths and rose to the surface with little compositional change, it is unlikely that any such proto-magma ever reaches the surface without profound compositional modification. The fact that the surface magmas are generally equilibrated with low-pressure phenocrysts and lack superheat is prima facie evidence for such modification. High-pressure experimental work (O'Hara, 1965, 1970; Ringwood, 1977; Stern and others, 1975; Stern and Wyllie, 1973; and many others) indicates the same conclusion.

The occurrences of the lavas also require profound modification of the proto-magmas. The composition of magmas reaching the surface is controlled by the composition of the crust through which the magmas rise, as is shown strikingly along the continuous Sumatra-Java-Banda volcanic arc. The modern volcanic rocks are intermediate and silicic in Sumatra, which has old continental crust; intermediate and mafic in Java, but more silicic in the west (young crust, partly granitic) of Java than in the east (young crust formed by subduction); and mostly mafic from Flores around the Banda Arc (oceanic crust). Young oceanic arcs tend to be entirely basaltic, whereas long-active ones produce much intermediate magma also. Similar relationships characterize other active volcanic arcs around the Pacific (Dickinson, 1975; Miyashiro, 1974). Within single arcs, strontium and lead isotopes in magmatic rocks tend to become increasingly radiogenic as the preexisting crust becomes older and more silicic (Dickinson, 1975; Doe and Delevaux, 1973; Kistler and Peterman, 1972; Zartman, 1974; and for Indonesia in particular, B.R. Doe and R.E. Zartman, written commun., 1975, and Whitford, 1975) and are much too radiogenic to be produced by single-stage melting of mantle material (Armstrong, 1971).

It appears, then, that whatever the specific processes are by which primitive magmas are generated in or above the subducting slab, the magmas that finally reach the surface are products of long series of reactions of zone-refining type, whereby complete or partial equilibration of magma and wallrocks is reached at many successive depth levels, through the exothermic crystallization of the most refractory magmatic components and the endothermic solution of the least refractory wallrock components, the specific components changing as functions of pressure, temperature, and bulk compositions (O'Hara, 1965).

Within each magmatic belt, bulk compositions change as a function of the depth to the Benioff zone beneath. The ratio of potassium to silicon increases regularly across the relatively narrow main magmatic belt, and an erratic increase occurs behind that with increasing depth to the Benioff zone (Hatherton and Dickinson, 1969; Miyashiro, 1974; and many others). The K/Si ratio for a given depth to the Benioff zone also increases as a function of the thickness and degree of continentality of the crust through which the magmas have risen (Dickinson, 1975; Miyashiro, 1974). (C.S. Hutchison, 1975 and 1976, overlooked this relationship and went astray in his conclusions.) The largecation minor elements $\mathrm{Ba}, \mathrm{Cs}, \mathrm{Rb}$, and $\mathrm{Pb}$ show similar relationships (for example, Jakes and White, 1970), although reliable analytical data are not voluminous enough to permit quantitative comparison among many different arc systems. The isotopic compositions of $\mathrm{Sr}$ and $\mathrm{Pb}$ become more radiogenic with increasing continentality of intervening crust, as noted previously, and limited evidence suggests that $\mathrm{Sr}$ becomes more radiogenic also with increasing depth to the Benioff zone. (See, for example, Whitford, 1975.)

Numerous explanations have been suggested for the cross-strike variation in potassium contents of magmas. One major group of explanations postulates variable degrees of melting of potassium-bearing amphibole, mica, phlogopite, or sanidine in the mantle or descending slab (Beswick, 1976; Boettcher, 1973; Forbes and Flower, 1974; Jakes and White, 1970; Marsh and Carmichael, 1974), although Wyllie (1973) regarded high-pressure experimental data as minimizing the possible validity of such processes. Miyashiro (1974) appealed to the upward streaming of volatiles from the mantle beneath the subducting slab. Zone refining, invoked here previously to explain the variations in magmatic compositions that correlate with crustal compositions, must operate in the direction of the observed cross-strike variations also, and perhaps is primarily responsible for them. The greater the distance through which mantle magma rises, the greater is the volume of rock whose large, light cations it can ingest. A magmatic-streaming, zone-refining process would also operate to progressively differentiate the mantle and crust, depleting low levels, and enriching high ones, in the least refractory elements.

\section{THE FUTURE AND THE PAST}

The complex interactions between lithospheric plates, which have been the dominant topic of this report, are details superimposed on the broad convergence of megaplates. Australia continues to approach Asia at a velocity of something like $10 \mathrm{~cm} / \mathrm{yr}$, or $100 \mathrm{~km} / \mathrm{m}$.y. Projection of this convergence forward in time indicates that, barring a major reorganization of plate motions, the likely fate of Indonesian, Philippine, and western Melanesian complexes is to be squashed between Australia and Asia.

Eurasia is a composite of many small continents, separated by broad terrains of Paleozoic, Mesozoic and lower Cenozic magmatic and deformed rocks that include 
many Indonesian and Philippine analogs (Argand, 1924; Burke and others, 1977; Burret, 1974; Hamilton, 1970b). Kolyma, the Siberian Platform, Tarim, Tibet, North China-Korea-Japan (the latter before Tertiary opening of the Sea of Japan), South China, Indochina, India, Arabia, and many small masses from Afghanistan to France and Spain, are such continental pieces. The convergence and aggregation of these continental masses must in many cases have been accompanied by the long-continuing development of complex offshore arc systems and not have been limited to simple disappearance of oceans beneath continental margins of Andean type. This report, concerned primarily with a mere 100 million years of the history of one sector of a convergence zone, gives some notion of the complexities yet to be comprehended in the terrains now squashed between continental masses in composite continents.

\section{REFERENCES CITED}

[Surnames with prefixes such as van, 't, Von, Le, and De are alphabetized by the prefixes when those are capitalized, but by the surname proper when they are not. Many Indonesians have only one name. Chinese names are alphabetized by the family name, which is listed first as the names are normally used. Burmese and some other southeast Asian names are compound, and do not include a family name.]

Abbott, M. J., and Chamalaun, F. H., 1976, Geology and geochronology of Pliocene volcanics on Atauro and Oecusse, Timor: Internat. Geol. Cong., 25th Sydney, Australia, 1976, Abs., v. 1, p. 43.

Abendanon, E. C., 1916-18, Voyages géologiques et géographiques à travers la Célèbes centrale: Leiden, E. J. Brill, v. 1, p. 1-443, separate atlas, 1916 ; v. 2 , p. $445-969,1917$; v. 3, p. 970-1579, 1918.

Achalabhuti, Charan, 1974, Petroleum geology of the Gulf of Thailand: Thailand Dept. Mineral Resources, 53 p.

Adam, J. W. H., 1960, On the geology of the primary tin-ore deposits in the sedimentary formation of Billiton: Geologie en Mijnbouw, v. 39, p. 405-426.

Adams, C. G., 1970, A reconsideration of the East Indian letter classification of the Tertiary: British Mus. (Nat. History) Bull., Geology 19, no. 3, p. 87-137.

Adams, C. G., and Belford, D. J., 1974, Foraminiferal biostratigraphy of the Oligocene-Miocene limestones of Christmas Island (Indian Ocean): Falaeontology, v. 17, pt. 3, p. 475-506.

Adinegoro, A. R. U., 1973, Stratigraphic studies by the Indonesian Petroleum Institute (LEMIGAS): U. N. ECAFE, Comm. Co-ordination of Offshore Prospecting (CCOP) Tech. Bull. 7, p. 56-74.

Adinegoro, Udin. 1973, Reef-limestones in the Sukabumi area (S.W. Java); Indonesian Petroleum Assoc.. 2d Ann. Convention, Jakarta 1973, Proc., p. 109-120.

Adinegoro, Udin, and Hartoyo, Pramu, 1975, Paleogeography of north east Sumatra: Indonesian Petroleum Assoc., 3d Ann. Convention, Jakarta 1974, Proc., p. 45-61.

Adiwidjaja, P., and de Coster, G. L., 1973, Pre-Tertiary paleotopography and related sedimentation in South Sumatra: Indonesian Petroleum Assoc., 2d Ann. Convention, Jakarta 1973, Proc., p. 89-103.

Ahlburg, Johannes, 1913, Versuch einer geologischen Dartstellung der Insel Celebes: Geologische und palaeontologische Abhandlungen, v. 16, pt. 1, 172 p.

Ahmad, F., 1961, Palaeogeography of the Gondwana Period in Gondwanaland, with special reference to India and Australia, and its bearing on the theory of continental drift; India Geol. Survey, Mem. 90, 142 p.

Ahmad, F., and Ahmad, Z. S., 1977, Tectonic framework of the Gondwana basins of peninsular India: Internat. Gondwana Symposium, 4th, Calcutta, 1977, 29 p. bin Ahmad, Jaafar, 1976, The geology and mineral resources of the Karak and Temerloh areas, Pahang: Malaysia Geol. Survey Dist. Mem. 15, $138 \mathrm{p}$.

Aleva, G. J. J., 1960, The plutonic igneous rocks from Billiton, Indonesia: Geologie en Mijnbouw, v. 39, p. 427-436.

1973, Aspects of the historical and physical geology of the Sunda Shelf essential to the exploration of submarine tin placers: Geologie en Mijnbouw, v. 52, p. 79-91.

Alexander, J. B., 1968, The geology and mineral resources of the neighbourhood of Bentong, Pahang, and adjoining portions of Selangor and Negri Sembilan: West Malaysia Geol. Survey, Dist. Mem. 8, $250 \mathrm{p}$.

Allen, A. W., 1954, The geology of the Lundu district, West Sarawak: British Terr. Borneo Geol. Survey Dept. 1952 Ann. Rept., p. 41-85.

Allen, C. R., 1962, Circum-Pacific faulting in the Philippines-Taiwan region: Jour. Geophys. Research, v. 67, p. 4795-4812.

Allen, G. A., Pearce, L. G. G., and Gardner, W. E., 1978, A regional interpretation of the Browse Basin: Australian Petroleum Explor. Assoc. Jour., v. 18, pt. 1, p. 23-33.

Allen, P. M., and Stephens, E. A., 1971, Report on the geological survey of Hong Kong: Hong Kong Govt., Printer, 107 p.

Amos, B. J., 1968, The structure of the Paleozoic sediments of the Mossman and Cooktown areas, north Queensland: Geol. Soc. Australia Jour., v. 15 , p. $195-208$.

Andal, P. P., 1966, A report on the discovery of fusulinids in the Philippines: Philippine Geologist, v. 20, no. 1, p. 14-22.

van Andel, T. H., and Veevers, J. J., 1967, Morphology and sediments of the Timor Sea: Australia Bur. Mineral Resources, Geology and Geophysics, Bull. 83, 173 p.

Anderson, D. L., 1975, Chemical plumes in the mantle: Geol. Soc. America Bull, v. 86, p. 1593-1600.

Anderson, R. N., 1975, Heat flow in the Mariana marginal basin: Jour. Geophys. Research, v. 80, p. 4043-4048.

Andrews, D. J., and Sleep, N. H., 1974, Numerical modelling of tectonic flow behind island arcs: Royal Astron. Soc. Geophys. Jour., v. 38, p. 237-251.

Andrews, J. E., 1971, Gravitational subduction of a western Pacific crustal plate: Nature, Phys. Sci., v. 233, p. 81-83.

Andrews, J. E., Packham, Gordon, and others, 1975, Initial reports of the Deep Sea Drilling Project--Wellington, New Zealand, to Apra, Guam, v. 30: Washington, U.S. Govt. Printing Office, 753 p.

Anfiloff, W., Barlow, B. C., Murray, A., Denham, D., and Sandford, R., 1976, Compilation and production of the 1976 1:5,000,000 gravity map of Australia: Australia Bur. Mineral Resources, Geology and Geophysics, BMR Jour., v. I, p. 273-276.

Anikouchine, W. A., and Ling, Hsin-yi, 1967, Evidence for turbidite accumulation in trenches in the Indo-Pacific region: Marine Geology, v. 5 , p. $141-154$.

Anonymous, 1973, Called "Mission Impossible," Freeport's Ertsberg $\mathrm{Cu}$ project convinces skeptics: Mining Eng., v. 25, no. 1, p. 54-59.

Arculus, R. J., and Johnson, R. W., 1978, Criticism of generalized models for the magmatic evolution of arc-trench systems: Earth and Planetary Sci. Letters, v. 39, p. 118-126.

Argand, Emile, 1924, La tectonique de l'Asie: Internat. Geol. Cong., 13th, Belgium 1922, Comptes Rendus, pt. I, p. 171-372.

Armstrong, R. L., 1971, Isotopic and chemical constraints on models of magma genesis in volcanic arcs: Earth and Planetary Sci. Letters, v. 12, p. 137-142.

Armstrong, R. L., and Besancon, James, 1970, A Triassic time scale dilemma-K-Ar dating of Upper Triassic mafic igneous rocks, eastern U.S.A. and Canada, and post-Upper Triassic plutons, western ldaho, U.S.A.: Eclogae Geol. Helvetiae, v. 63, p. 15-28.

Audley-Charles, M. G., 1965a, A geochemical study of Cretaceous ferromanganiferous sedimentary rocks from Timor: Geochim. et Cosmochim. Acta, v. 29, p. 1153-1173. 
1965b, Permian palaeogeography of the northern Australia-Timor region: Palaeogeography, Palaeoclimatology, Palaeoecology, v. 1, p. 297-305.

$1965 \mathrm{c}$, A Miocene gravity slide deposit from eastern Timor: Geol. Mag., v. 102, p. 267-276.

1966a, Mesozoic palaeogeography of Australasia: Palaeogeography, Palaeoclimatology, Palaeoecology, v. 2, p. 1-25. 1966b, The age of the Timor Trough: Deep-Sea Research, v. 13, p. $761-763$.

1968, The geology of Portuguese Timor: Geol. Soc. London Mem. 4, 76 p.

1972, Cretaceous deep-sea manganese nodules in Timor-implications for tectonics and olistostrome development: Nature, Phys. Sci., v. 240, p. 137-139.

1973, Paleoenvironmental significance of chert in the Franciscan Formation of western California-discussion concerning the significance of chert in Timor: Geol. Soc. America Bull., v. 84, p. 363-368.

1974a, Banda arcs, in Spencer, A. M., ed., Mesozoic-Cenozoic orogenic belts: Geol. Soc. London Spec. Pub. 4, p. 349-363.

1974b, Sulawesi, in Spencer, A. M., ed., Mesozoic-Cenozoic orogenic belts: Geol. Soc. London Spec. Pub. 4, p. 365-378.

1975. The Sumba fracture-a major discontinuity between

eastern and western Indonesia: Tectonophysics, v. 26, p. 213-228.

1977, Mesozoic evolution of the margins of Tethys in Indonesia and the Philippines: Indonesian Petroleum Assoc., 5th Ann. Convention, Jakarta 1976, Proc., v. 2, p. 25-52.

Audley-Charles, M. G., and Carter, D. J., 1972, Palaeogeographical significance of some aspects of Palaeogene and early Neogene stratigraphy and tectonics of the Timor Sea region: Palaeogeography, Palaeoclimatology, Palaeoecology, v. 11, p. 247-264.

1974. Petroleum prospects of the southern part of the Banda arcs, eastern Indonesia: U.N. ECAFE, Comm. Co-ordination of Joint Prespecting for Mineral Resources in Asian Offshore Areas (CCOP), Tech. Bull. 8, p. 55-70

Audley-Charles, M.G., Carter, D. J., and Barber, A. J., 1975, Stratigraphic basis for tectonic interpretations of the outer Banda arc, eastern Indonesia: Indonesian Petroleum Assoc., 3d Ann. Convention, Jakarta 1974, Proc., p. 25-44.

Audley-Charles, M. G., Carter, D. J., and Milsom, J. S., 1972, Tectonic development of eastern Indonesia in relation to Gondwanaland dispersal: Nature, Phys. Sci., v. 239, p. 35-39.

Audley-Charles, M. G., and Hooijer, D. A., 1973, Relation of Pleistocene migration of pygmy stegodonts to island arc tectonics of eastern Indonesia: Nature, v. 241, p. 197-198.

Audley-Charles, M. G., and Milsom, J. S., 1974, Comment on "Plate convergence, transcurrent faults, and internal deformation adjacent to Southeast Asia and the western Pacific," by T. J. Fitch: Jour. Geophys. Research, v. 79 , no. 32 , p. $4980-4981$.

d'Audretsch, F. C., Kluiving, R. B., and Oudemans, W., 1966, Economic geological investigation of NE Vogelkop (western New Guinea): Koninkl. Nederlands Geol. Mijnbouw Genoot., Verh. Geol. Ser., v. 23, $151 \mathrm{p}$.

Australia Bureau of Mineral Resources, Geology and Geophysics, 1969 , Gravity, magnetic, and seismic profiles, maps C51-12, C52-5, C52-6, C52-7, C52-8, C52-9, D51-2, and D51-6.

1976a, Gravity map of Australia: scale 1:5,000,000.

1976b, Preliminary gravity map of Melanesia: scale 1:5,000,000.

Aw, P. C., 1974, Brief geology of the Sungai Aring area, southeast Kelantan: Malaysia Geol. Survey 1972 Ann. Rep., p. 127-131.

Bailey, E. H., and Blake, M. C., Jr., 1970, Late Mesozoic tectonic development of western California: Geotectonics, 1969, no. 3, p. 148-154, and no. 4, p. 225-230 [AGU translations].

Bailey, E. H., Blake, M. C., Jr., and Jones, D. L., 1970, On-land Mesozoic oceanic crust in California Coast Ranges, in Geological Survey research 1970: U.S. Geol. Survey Prof. Paper 700-C, p. C70-C8I.
Bailey, E. H., Irwin, W. P., and Jones, D. L., 1964, Franciscan and related rocks and their significance in the geology of California: California Div. Mines and Geology Bull. 183, 177 p.

Bain, J. H. C., 1973, A summary of the main structural elements of Papua New Guinea, in Coleman, P. J., ed., The western Pacific: Nedlands, Western Australia, Western Australia Univ. Press, p. 147-161.

Bain, J. H. C., Davies, H. L., Hohnen, P. D., Ryburn, R. J., Smith, I. E., Grainger, R. J., Tingey, M. R., and Moffat, M. R., 1972, Geology of Papua New Guinea: Australia Bur. Mineral Resources, Geology and Geophysics, scale 1:1,000,000.

Bain, J. H. C., and Mackenzie, D. E., 1974, Karimui, Papua New Guinea: Australia Bur. Mineral Resources, Geology and Geophysics, 1:250,000 Geol. Ser.-Explanatory notes, sheet SB/55-9, 39 p., map.

1975, Ramu, Papua New Guinea: Australia Bur. Mineral Resources, Geology and Geophysics, 1:250,000 Geol. Ser,-Explanatory notes, sheet SB/55-5, 40 p., map.

Bain, J. H. C., Mackenzie, D. E., and Ryburn, R. J., 1975, Geology of the Kubor anticline, Central Highlands of New Guinea: Australia Bur. Mineral Resources, Geology and Geophysics, Bull. 155, 106 p.

Baker, B. H., 1967. The Precambrian of the Seychelles Archipelago, in Rankama, Kalervo, ed., The Precambrian, v. 3: New York, Wiley-Interscience, p. 122-131.

Baker, George, 1955, Basement complex rocks in the Cycloop Ranges-Sentani Lake region of Dutch New Guinea: Nova Guinea (Leiden, E. J. Brill), Geology, v. 6, pt. 2, p. 308-328.

Balke, R., Page, C., Harrison, R. and Roussopoulos, G., 1973, Exploration in the Arafura Sea: Australian Petroleum Explor. Assoc. Jour., v. 13, pt. 1, p. 9-12.

Bally, A. W., Gordy, P. L., and Stewart, G. A., 1966, Structure, seismic data, and orogenic evolution of the southern Canadian Rocky Mountains: Canadian Petroleum Geology Bull., v. 14, p. 337-381.

Bamford, R. W., 1972, The Mount Fubilan (Ok Tedi) porphyry copper deposit, Territory of Papua and New Guinea: Econ. Geology, v. 67, p. 1019-1033.

Bandy, O. L.. 1962, Cenozoic planktonic foraminiferal zonation and basinal development for the Philippines: Philippine Geologist, v. 16, no. 3 , p. 12-34.

Bandyopadhyaya, S., Subramanyam, M. R., and Sharma, P. N., 1973, The geology and mineral resources of the Andaman and Nicobar Islands: India Geol. Survey Recs., v. 105, pt. 2, p. 25-68.

Bär, C. B., Cortel, H. J., and Escher, A. E., 1961, Geological results of the Star Mountains ("Sterrengebergte") Expedition: Nova Guinea (Leiden, E. J. Brill), Geology, no. 4, 99 p.

Barazangi, Muawia, and lsacks, B. L., 1971, Lateral variations of seismic-wave attenuation in the upper mantle above the inclined earthquake zone of the Tonga island arc-deep anomaly in the upper mantle: Jour. Geophys. Research, v. 76, p. 8493-8516.

Barazangi, Muawia, Isacks, B. L., Oliver, Jack, Dubois, Jacques, and Pascal, Georges, 1973, Descent of lithosphere beneath New Hebrides, Tonga-Fiji and New Zealand-evidence for detached slabs: Nature, v. 242, p. $98-101$.

Barber, A. J., and Audley-Charles, M. G., 1976, The significance of the metamorphic rocks of Timor in the development of the Banda arc, eastern Indonesia: Tectonophysics, v. 30, p. 119-128.

Barber, A. J., Audley-Charles, M. G., and Carter, D. J., 1977, Thrust tectonics of Timor: Geol. Soc. Australia Jour., v. 24, p. 51-62.

Barber, C. T., 1936, The Tertiary igneous rocks of the Pakokku District and the Salingyi Township of the Lower Chindwin District, Burma, with special reference to the determination of the felspars by the Fedoroff method: India Geol. Survey Mem. 68, pt. 2, p. 121-292.

Barnes, Harley, Jongco, C, P., Lazaga, G. C., Pilac, J. E., and Vokes, H. E., 1956, Geology and coal resources of the Argao-Dalaguette region, Cebu: Philippine Bur. Mines Spec. Projects Pub. 7, 52 p.

Barron, E. J., Harrison, C. G. A., and Hay, W. W., 1978, A revised reconstruction of the southern continents: EOS (Am. Geophys. Union Trans.), v. 59, p. 436-449. 
Baumann, Paul, de Genevraye, Patrick, Samuel, Luki, Mudjito, and Sajekti, Sri, 1973, Contribution to the geological knowledge of southwest Java: Indonesian Petroleum Assoc., 2d Ann. Convention, Jakarta 1973, Proc., p. 105-108.

Baumann, Paul, Oesterle, H., Suminta, and Wibisono, 1973, The Cenozoic of Java and Sumatra: Indonesian Petroleum Assoc., Ist Ann. Convention, Jakarta 1972, Proc., p. 31-42.

Bayliss, D, D., 1966, Foraminifera from the Bau Limestone Formation. Sarawak, Malaysia: Borneo Region Malaysia Geol. Survey, 1965 Ann. Rept., p. 173-175.

de Beaufort, L. F., 1922, On a collection of upper Cretaceous teeth and other vertebrate remains from a deep sea deposit on the island of Timor: Jaarboek Mijnwezen Nederlandsch Oost-Indië, Verh., v. 49, pt. 4 , p. $57-72$.

Beck, R. H., and Lehner, P., 1974, Oceans, new frontier in exploration: Am. Assoc. Petroleum Geologists Bull., v. 58, p. 376-395.

Beddoes, L. R., Jr., 1976, The Balabac sub-basin, southwestern, Sulu Sea, Philippines: South East Asia Petroleum Explor. Soc., Offshore Conf., Singapore, 1976, paper 15, $22 \mathrm{P}$.

Bell, Keith, and Powell, J. L., 1969, Strontium isotopic studies of alkalic rocks-the potassium-rich lavas of the Birunga and Toro-Ankole regions, East and Central Equatorial Africa: Jour. Petrology, v. I0, p. $536-572$.

Bell, R. M., and Jessop, R. G. C., 1974, Exploration and geology of the West Sulu Basin, Philippines: Australian Petroleum Explor. Assoc. Jour., v. 14, pt. 1, p. 21-28.

Beltz, E. W., 1944, Principal sedimentary basins in the East Indies: Am. Assoc. Petroleum Geologists Bull., v. 28, p. 1440-1454.

van Bemmelen, R. W., 1932, Geologische waarnemingen in de Gajolanden (N-Sumatra): Jaarboek Mijnwezen Nederlandsch-Indie, 1930, Verh., v. 59 , pt. 3, p. 71-94.

1933, Geologische kaart van Sumatra: Dienst Mijnbouw Nederlandsch-Indië, Toelichting bij blad 6 (Kroeï), scale 1:200,000. 1939a. The volcano-tectonic origin of Lake Toba (North Sumatra): De Ingenieur in Nederlandsch-Indië, v. 6, no. 9, pt. 4, p. 126-140.

1939b, De geologie van het Westerafdeeling van Borneo: Jaarboek Mijnwezen Nederlandsch-Indië, 1939, Verh., v. 68, p. 187-238.

1949, The geology of Indonesia, V. IA: The Hague, Govt. Printing Office, $732 \mathrm{p}$.

Ben-Avraham, Zvi, 1973, Structural framework of the Sunda Shelf and vicinity: Woods Hole Oceanographic Inst. Tech. Rept. 73-3, 269 p.

Ben-Avraham, Zvi, 1973, Structural framework of the Sunda Shelf and vicinity: Woods Hole Oceanographic Inst. Tech. Rept. 73-3, 269 p.

Ben-Avraham, Zvi, and Emery, K. O., 1973, Structural framework of Sunda Shelf: Am. Assoc. Petroleum Geologists Bull., v. 57, p. 2323-2366.

Ben-Avraham, Zvi, and Uyeda, Seiya, 1973, The evolution of the China Basin and the Mesozoic paleogeography of Borneo: Earth and Planetary Sci. Letters, v. 18, p. 365-376.

Berggren, W. A., 1969, Cenozoic chronostratigraphy, planktonic foraminiferal zonation and the radiometric time scale: Nature, v. 224, p. 1072-1075

Berggren, W. A., and van Couvering, J. A., 1974, The late Neogene: Palaeogeography, Palaeoclimatology, Palaeocology, v. 16, p. 1-216.

Berkland, J. O., 1972, Paleogene "frozen" subduction zone in the Coast Ranges of northern California: Internat. Geol. Cong., 24th, Montreal 1972, sec. 3, p. 99-105.

Bernoulli, Daniel, and Jenkyns, H. C., 1974, Alpine, Mediterranean, and central Atlantic Mesozoic facies in relation to the early evolution of the Tethys: Soc. Econ. Paleontologists and Mineralogists Spec. Pub. 19, p. $129-160$.

Berry, R. F., and Grady, A. E., 1977, Deformation styles and metamorphic conditions of the Aileu Formation, north coast, East Timor: Geol. Soc. Australia, Abstracts of 2d Australian Geol. Convention, p. 73.
Besang, Claus, von Braun, Eckert, Eberle, Walter, Harre, Wilhelm, Kreuzer, Han, Lenz, Heinz, Muller, Peter, and Wendt, Immo, 1975, Radiometric age determinations of granites in northern Thailand: U.N. Regional Offshore Prospecting in East Asia, Doc. R 034, p. 94-117.

Beswick, A. E., 1976, K and Rb relations in basalts and other mantle derived materials-Is phlogopite the key?: Geochim. et Cosmochim. Acta, v. 40 , p. $1167-1183$.

Bhandari, L. L., Fuloria, R. C., and Sastri, V. V., 1973, Stratigraphy of Assam Valley, India: Am. Assoc. Petroleum Geologists Bull., v. 57, p. 642-654.

Bignell, J. D., and Snelling, H. J., 1977, Geochronology of Malayan granites: Great Britain Inst. Geol. Sci., Overseas Geology and Mineral Resources no. 47, $72 \mathrm{p}$.

Billington, Selena, and Isacks, B. L., 1975, Identification of fault planes associated with deep earthquakes: Geophys. Research Letters, v. 2, p. 63-66.

Billman, H. G., and Kartaadiputra, L. W., 1975, Late Tertiary biostratigraphic zonation, Kutei Basin, offshore East Kalimantan, Indonesia: Indonesian Petroleum Assoc., 3d Ann. Convention, Jakarta 1974, Proc., p. 30I-310.

Binnekamp, J. G., 1973, Tertiary larger foraminifera from New Britain, PNG: Australia Bur. Mineral Resources, Geology and Geophysics Bull. 140, p. 1-26.

Biq, Chingchang, 1971, Comparison of melange tectonics in Taiwan and some other mountain belts: Petroleum Geology Taiwan, no. 9, p. 79-106.

1972a, Dual-trench structure in the Taiwan-Luzon region: Geol. Soc. China [Taiwan], Proc., no. 15, p. 65-75.

1972b, Western Taiwan thrusts, active or inactive?: Acta Geol. Taiwanica, no. 15 , p. 63-75.

1974. Metallogeny in Taiwan-a plate-tectonic approach: Taiwan Geol. Survey Bull. 24, p. 139-156.

Bird, J. M., and Dewey, J. F., 1970, Lithosphere plate-continental margin tectonics and the evolution of the Appalachian orogen: Geol. Soc. America Bull., v. 81, p. 1031-1059.

Bird, Peter, and Toksöz, M. N., 1977, Strong attenuation of Rayleigh waves in Tibet: Nature, v. 266, p. 161-163

Bird, Peter, Toksöz, M. N., and Sleep, N. H., 1975, Thermal and mechanical models of continent-continent convergence zones: Jour. Geophys. Research, v. 80, p. 4405-4416.

Blake, D. H., 1972, Regional and economic geology of the Herberton/ Mount Garnet area-Herberton tinfield, north Queensland: Australia Bur. Mineral Resources, Geology and Geophysics Bull. 124, 265 p.

Blake, D. H., and Ewart, A., 1974, Petrography and geochemistry of the Cape Hoskins volcanoes, New Britain, Papua New Guinea: Geol. Soc. Australia Jour., v. 21, p. 319-331.

Blake, D. H., and Miezitis, Y., 1967, Geology of Bougainville and Buka Islands, New Guinea: Australia Bur. Mineral Resources, Geology and Geophysics Bull. 93, 56 p.

Blake, M. C., Jr., and Jones, D. L., I974, Origin of Franciscan melanges in northern California: Soc. Econ. Geologists and Mineralogists Spec. Pub. 19, p. 345-357.

Boettcher, A. L., 1973, Volcanism and orogenic belts-the origin of andesite: Tectonophysics, v. 17, p. 223-240.

Boeuf, M. G., and Doust, H., 1975, Structure and development of the southern margin of Australia: Australian Petroleum Explor. Assoc. Jour., v. 15, pt. 1, p. 33-43.

van den Bold, W. A., and van der Sluis, J. P., 1942, On the rocks from the isle of Batam (Riouw Archipelago): Nederlandsche Akad. Wetensch, Proc., v. 45, p. 1003-1009.

Bolliger, W., and de Ruiter, P. A. C., 1976, Geology of the south central Java offshore area: Indonesian Petroleum Assoc., 4th Ann. Convention, Jakarta 1975, Proc., v. I, p. 67-81. 
Bonatti, Enrico, Honnorez, Jose, Kirst, Paul, and Radicati, Filipo, 1975, Metagabbros from the Mid-Atlantic Ridge at $06^{\circ} \mathrm{N}$-contact-hydrothermal-dynamic metamorphism beneath the axial valley: Jour. Geology, v. 83, p. 61-78.

Borax, Eugene, and Stewart, R. D., 1965, Notes on the Khorat Series of northeastern Thailand: U.N. ECAFE, Econ. Symposium Devel. Petroleum Resources of Asia and Far East, 3d Tokyo, 1965, 24 p.

von der Borch, C. C., 1972, Marine geology of the Huon Gulf region, New Guinea: Australia Bur. Mineral Resources, Geology and Geophysics Bull. 127, p. 1-36.

von der Borch, C. C., Sclater, J. G., and others, 1973, Initial reports of the Deep Sea Drilling Project, V. 22: Washington, U.S. Govt. Printing Office, 890 p.

Bostrom, R. C., Sherif, M. A., and Stockman, R. H., 1974, Deformation of earth's lithosphere with reference to tidal couples: Am. Assoc. Petroleum Geologists Mem. 23, p. 463-485.

Bothe', A. C. D., 1927, Voorloopige mededeeling betreffende de geologie van zuid-oost-Celebes: De Mijningenieur, v. 8, no. 6, p. 97-103.

1928, Geologische verkenningen in den Riouw-Lingga archipel en de eilandengroep der Poelau Toejoeh (Anambas- en Natoenaeilanden): Jaarbolk Mijnwezen Nederlandsch-Indië, 1925, Verh., v. 54 , pt. 2 , p. 101-152.

Bott, M. H. P., 1971, Evolution of young continental margins and formation of shelf basins: Tectonophysics, v. 11, p. 319-327. 1973, Shelf subsidence in relation to the evolution of young continental margins, in Tarling, D. H., and Runcorn, S. K. eds., Implications of continental drift to the earth sciences, v. 2: London, Academic Press, p. 675-683.

Bott, M. H. P., and Dean, D. S., 1972, Stress systems at young continental margins: Nature, Phys. Sci., v. 235, p. 23-25.

Bouquigny, R., Yusuf, J., Latreille, M., Negroni, P., and Oesterle, H., 1971, N.E. Sumatra basin: Jakarta, Geologi Pertamini-Lemigas, 95 p.

Bowin, Carl, 1973, Origin of the Ninety East Ridge near the equator: Jour. Geophys. Research., v. 78, p. 6029-6043.

Bowin, C. O., Purdy, G. M., Shor, G. G., Jr., Lawver, L., Hartono, H. M. S., Johnston, G., Chamalaun, F., and Sunderland, J., 1977, Geophysical study of the Banda Arc, Indonesia [abs.]: EOS (Am. Geophys. Union Trans.), v. 58, p. 509.

Bracey, D. R., 1975, Reconnaissance geophysical survey of the Caroline Basin: Geol. Soc. America Bull., v. 86, p. 775-784.

Bracey, D. R., and Andrews, J. E., 1974, Western Caroline Ridge-Relic island arc?: Marine Geophys. Researches, v. 2, p. 111-125.

Bracey, D. R., and Ogden, T. A., 1972, Southern Mariana arc-geophysical observations and hypothesis of evolution: Geol. Soc. America Bull., v. 83 , p. $1509-1522$.

Bradford, E. F., 1972, The geology and mineral resources of the Gunong Jerai area, Kedah: Malaysia Geol. Survey Dist. Mem. 13, 242 p.

Branch, C. D., 1969, Phanerozoic volcanic history of northern Queensland: Geol. Soc. Australia Spec. Pub. 2, p. 177-182.

Branson, J. C., 1975, Structures of the western margin of the Australian continent: Indonesian Petroleum Assoc., 3d Ann. Convention, Jakarta 1974, p. $171-187$.

de Broin, C. E., Aubertin, F., and Ravenne, C., 1977, Structure and history of the Solomon-New Ireland region: Internat. Symposium Geodynamics South-West Pacific, Noumea, 1976, Paris, Editions Technip, p. 37-50.

Brondijk, J. F., 1963, Sedimentological investigation in North Borneo and northern Sarawak: British Terr. Borneo Geol. Survey Dept. 1962 Ann. Rept., p. 61-74.

1964, The Danau Formation in northwest Borneo: Borneo Region Malaysia Geol. Survey, 1963 Ann. Rept., p. 167-178.

Brookfield, M. E., 1977, The emplacement of giant ophiolite nappes, 1. Mesozoic-Cenozoic examples: Tectonophysics, v. 37, p. 247-303.

Brooks, C., James, D. E., and Hart, S. R., 1976, Ancient lithosphere--Its role in young continental volcanism: Science, v. 193, p. 1086-1094.
Brouwer, H. A., 1915a, Bijdrage tot de geologie van Boven Kampar-en Rokan streken (Midden Sumatra): Jaarboek Mijnwezen Nederlandsch Oost-Indië, 1913, Verh., v. 42, p. 130-170.

19l5b, Gesteenten van het eiland Letti: Jaarboek Mijnwezen Nederlandsch Oost-Indie, 1914, Verh., v. 43, pt. 1; p. 89-160.

$1915 c$, On the granitic area of Rokan (middle-Sumatra) and on contact-phenomena in the surrounding schists: Koninkl Akad. Wetensch. Amsterdam Proc., v. 17, p. 1190-1202.

1918a, Gesteenten van het eiland Moa: Jaarboek Mijnwezen Nederlandsch Oost-Indië, 1916, Verh., v. 45, pt. 1, p. 11-36. 1918b, Geologie van een gedeelte van het eiland Moa: Jaarboek Mijnwezen Nederlandsch Oost-Indië, 1916, Verh., v. 45, pt. 1, p. 37-56. 1919, On the non-existence of active volcanoes between Pantar and Dammer (East Indian Archipelago), in connection with the tectonic movements in this region: Koninkl. Akad. Wetensch. Amsterdam Proc., v. 21 , p. 795-802.

1921a, Geologische onderzoekingen op de eilanden Loeange en Sermata: Jaarboek Mijnwezen Nederlandsch Oost-Indië, 1920, Verh., v. 49 , pt. 2, p. 207-222.

$1921 \mathrm{~b}$, Geologische onderzoekingen op de Soela-eilanden[Pt.] 1: Jaarboek Mijnwezen Nederlandsch Oost-Indië, 1920, Verh., v. 49 , pt. 2 , p. $69-158$.

$1921 \mathrm{c}$, Geologische onderzoekingen op de eilanden Ternate en Pisang: Jaarboek Mijnwezen Nederlandsche Oost-Indië, 1920, Verh. v. 49 , pt. 2, p. 3-68.

1922, Geologische onderzoekingen op het eiland Rotti: Jaarboek Mijnwezen Nederlandsch Oost-Indië, 1920, Verh., v. 49, pt. 3, p. 33-106.

1923a, Geologische onderzoekingen op de Tenimber eilanden: Jaarboek Mijnwezen Nederlandsch Oost-Indië, 1921, Verh., v. 50, pt. 2, p. 117-142.

1923b, Bijdrage tot de geologie van Groot-Kei en de kleine eilanden tusschen Ceram en de Kei eilanden: Jaarboek Mijnwezen Nederlandsch Oost-Indië, 1921, Verh., v. 50, pt. 2, p. 143-168.

1923c, Geologische onderzoekingen op het eiland Halmaheira: Jaarboek Mijnwezen Nederlandsch Oost-Indië, 1921, Verh., v. 50, pt. 2. p. 3-72.

1923d, Bijdrage tot de geologie van het eiland Batjan: Jaarboek Mijnwezen Nederlandsch Oost-Indië, 1921, Verh., v. 50, pt. 2, p. 73-106.

1924a. Bijdrage tot de geologie der Obi-eilanden: Jaarboek Mijnwezen Nederlandsch Oost-Indië, 1923, Verh., v. 52, p. 63-134.

1924b, Bijdrage tot de geologie der Radja Ampat eilanden-groep (Waigeoe, Salawati etc.): Jaarboek Mijnwezen Nederlandsch Oost-Indië, 1923, Verh., v. 52, p. 63-134.

1926, Geologische onderzoekingen op de Soela-eilanden-[Pt.] 2: Jaarboek Mijnwezen Nederlandsch Oost-Indië, 1925, Verh., v. 54, pt. 1, p. 3-14.

1928, Alkaline rocks of the volcano Merapi (Java) and the origin of these rocks: Koninkl. Akad. Wetensch. Amsterdam Proc., v. 31, p. 492-498.

1931, De stratigraphie van Nederlandsch Oost-Indië, [Chap.] 18-Paleozoic: Leidshe Geol. Meded., v. 5, p. 552-566.

1934, Geologische onderzoekingen op het eiland Celebes: Koloniën Nederland. Geol. Mijnbouw Genoot., Verh., Geol. Ser., v. 10, p. $39-218$.

1940, Geological and petrological investigations on alkali and calc-alkali rocks of the islands Adonara, Lomblen and Batoe Tara, in Brouwer, H. A., ed., Geological expedition of the University of Amsterdam to the Lesser Sunda Islands, V. 2: Amsterdam, North Holland Publishing Co., p. 1-94.

1942, Summary of the geological results of the expedition, in Brouwer, H. A., ed., Geological expedition of the University of Amsterdam to the Lesser Sunda Islands, V. 4: Amsterdam, North Holland Publishing Co., p. 345-401. 
1943, Leuciethoudende en leucietvrije gesteenten van den' Soromandi op het eiland Soembawa: Nederlandsche Akad. Wetensch. Verh., Afd. Natuurk., v. 52, p. 303-307.

1947, Geological explorations in Celebes-summary of the results, in Brouwer, H. A., ed., Geological explorations in the island of Celebes: Amsterdam, North Holland Publishing Co., p. 1-64.

Brown, C. M., 1974, Explanatory notes on the Yule geological sheet: Papua New Guinea Geol. Survey Rep. 74/27, 27 p., map.

1975. Definitions of stratigraphic names on the Yule 1:250,000 sheet: Papua New Guinea Geol. Survey Rep. 75/20, 26 p., map.

Brown, C. M., Pieters, P. E., and Robinson, G. P., 1975, Stratigraphic and structural development of the Aure Trough and adjacent shelf and slope areas: Australian Petroleum Explor. Assoc. Jour., v. 15, pt. 1, p. $61-71$.

Brown, D. A., Campbell, K. S. W., and Crook. K. A. W., 1968, The geological evolution of Australia and New Zealand: Oxford, Pergamon Press, 409 p.

Brown, G. F., Buravas, Saman, Charaljavanaphet, Jumchet, Jalichandra, Nitipat, Johnston, W. D., Jr., Sresthaputra, Vija, and Taylor, G. C., Jr., 1951, Geologic reconnaissance of the mineral deposits of Thailand: U.S. Geol. Survey Bull. 984, 183 p.

Bruce, C. H., 1973, Pressured shale and related sediment deformation-mechanism for development of regional contemporaneous faults: Am. Assoc. Petroleum Geologists Bull., v. 57, p. $878-886$.

ter Bruggen, Gerrit, 1935, De Eoceen fyllietformatie in Centraal-Borneo: Delft, Drukk. Waltman, 139 p. [English translation in British Terr., Borneo Geol. Survey Dept. Bull. 2, 1955, p. 39-124].

Brunei Shell Petroleum Co., Ltd., 1963, Status of micropaleontological studies: British Terr. Borneo Geol. Survey Dept. 1962 Ann. Rept., p. 70-74.

Brunnschweiler, R. O., 1966, On the geology of the Indoburman Ranges: Geol. Soc. Australia Jour., v. 13, p. 137-194.

1978, Notes on the geology of eastern Timor: Australia Bur. Mineral Resources, Geology and Geophysics, Bull. 192, p. 9-18.

de Bruyne, D. L., 1941, Sur la composition et la genese du bassin central de Timor, in Brouwer, H. A., ed., Geological expedition of the University of Amsterdam to the Lesser Sunda Islands, V. 3: Amsterdam, North Holland Publishing Co., p. 135-238.

Bryner, Leonid, 1969, Ore deposits of the Philippines-an introduction to their geology: Econ. Geology, v. 64, no. 6, p. 644-666.

Būcking, H., 1904a, Beiträge zur Geologie von Celebes: Reichs-Museums Leiden, Samml. Geol., v. 7, p. 29-207.

1904b, Zur Geologie des nordöstlichen Indischen Archipels: Reichs-Museums Leiden, Samml., Geol., v. 7, p. 231-253.

Bultitude, R. J., 1976, Flood basalts of probable Early Cambrian age in northern Australia, in Johnson, R. W., ed., Volcanism in Australasia: Amsterdam, Elsevier, p. 1-20.

Burckle, L. H., Saito, Tsunemasa, and Ewing, Maurice, 1967, A Cretaceous (Turonian) core from the Naturaliste Plateau, southeast Indian Ocean: Deep-Sea Research, v. 14, p. 421-426.

Burke, Kevin, and Dewey, J. F., 1973a, An outline of Precambrian plate development, in Tarling, D. H., and Runcorn, S. K., eds., Implications of continental drift to the earth sciences, v. 2: London, Academic Press, p. 1035-1045.

1973b, Plume-generated triple junctions-key indicators in applying plate tectonics to old rocks: Jour. Geology, v. 81, p. 406-433.

Burke, Kevin, Dewey, J. F., and Kidd, W. S. F., 1977, World distribution of sutures-the sites of former oceans: Tectonophysics, v. 40, p. 69-99.

Burma Geological Department, 1961, Geological map of Burma: scale 1 inch to 32 miles.

Burns, R. E., and Andrews, J. E., 1972, Glomar Challenger down under--Deep Sea Drilling Project Leg 21: GeoTimes, v. 17, no. 5, p. 14-16.

Burns, R. E., Andrews, J. E., and others, 1973, Initial reports of the Deep Sea Drilling Project, v. 21: Washington, U.S. Govt. Printing Office, 931 p.
Burrett, C. F., 1974, Plate tectonics and the fusion of Asia: Earth and Planetary Sci. Letters, v. 21, p. 181-189.

Burton, C. K., 1965, Wrench faulting in Malaya: Jour. Geology, v. 73, p. $781-798$.

1967, Graptolite tentaculite correlations and palaeogeography of the Silurian and Devonian in the Yunnan-Malaya geosyncline: Palaeont. Soc. Japan Trans. and Proc., v. 65, p. 27-46.

1969, The geological environment of tin mineralization in the Malay-Thai peninsula: Bangkok, Internat. Tin Council, 17 p. 1970a, The palaeotectonic status of the Malay Peninsula: Palaeogeography, Palaeoclimatology, Palaeoecology, v. 7, p. 51-60. $1970 \mathrm{~b}$, The geology and mineral resources of the Baling area, Kedah and Perak: Malaysia Geol. Survey Dist. Mem. 12, 150 p. 1972, Outline of the geological evolution of Malaya: Jour. Geology, v. 80, p. 293-309.

1974, Peninsular Thailand, in Spencer, A. M., ed., Mesozoic-Cenozoic orogenic belts: Geol. Soc. London Spec. Pub. 4, p. $301-315$.

Burton, C. K., and Bignell, J. D., 1969, Cretaceous-Tertiary events in southeast Asia: Geol. Soc. America Bull., v. 80, p. 681-688.

Caldwell, J. G., Haxby, W. F., Karig, D. E., and Turcotte, D. L., 1976, On the applicability of a universal elastic trench profile: Earth and Planetary Sci. Letters, v. 31, p. 239-246.

Cann, J. R., 1974, A model for oceanic crustal structure developed: Royal Astron. Soc. Geophys. Jour., v. 39, p. 169-187.

Capistrano, P. M., and Magpantay, A. L., 1958, Geology and mineral resources of the southern segment of the eastern range of Panay: Philippine Geologist, v. 13, p. 1-21.

Cardwell, R. K., and Isacks, B. L., 1978, Geometry of the subducted lithosphere beneath the Banda Sea in eastern Indonesia from seismicity and fault plane solutions: Jour. Geophys. Research, v. 83, p. 2825-2838.

Carey, S. W., 1958, A tectonic approach to continental drift, in Carey, S. W., ed., Continental drift-a symposium: Tasmania Univ., Hobart, Australia, p. 177-355.

1970, Australia, New Guinea, and Melanesia in the current revolution in concepts of evolution of the earth: Search, v. 1, p. 178-189.

Carter, D. J., Audley-Charles, M. G., and Barber, A. J., 1976, Stratigraphical analysis of island arc-continental margin collision in eastern Indonesia: Geol. Soc. London Jour., v. 132, p. 179-198.

Casasola, A. G., 1956, Geological reconnaissance of southern Palawan: Philippine Geologist, v. 10, p. 89-97.

Caudri, C. M. B., 1934, Tertiary deposits of Soemba: Amsterdam, H. J. Paris, 223 p.

Chai, B. H. T., 1972, Structure and tectonic evolution of Taiwan: Am. Jour. Sci., v. 272 , p. $389-422$.

Chamalaun, F. H., 1977a, Paleomagnetic evidence for the relative positions of Timor and Australia in the Permian: Earth and Planetary Sci. Letters, v. 34, p. 107-112.

1977b, Palaeomagnetic reconnaissance result from the Maubisse Formation, East Timor, and its tectonic implication: Tectonophysics, v. 42, p. T17-T26.

Chamalaun, F. H., and Grady, A. E., 1978, The tectonic development of Timor--a new model and its implications for petroleum exploration: Australian Petroleum Explor. Assoc. Jour., v. 18, pt. 1, p. 102-108.

Chamalaun, F. H., Lockwood, K., and White, Anthony, 1976, The Bouguer gravity field of eastern Timor: Tectonophysics, v. 30., p. 241-259.

Chandra, Umesh, 1975, Seismicity, earthquake mechanisms and tectonics of Burma, $20^{\circ} \mathrm{N}-28^{\circ} \mathrm{N}$ : Royal Astron. Soc. Geophys. Jour., v. 40, p. 367-381.

Chapman, R. E., 1974, Clay diapirism and overthrust faulting: Geol. Soc. America Bull., v. 85, p. 1597-1602.

Chappell, John, 1974, Geology of coral terraces, Huon Peninsula, New Guinea-a study of Quaternary tectonic movements and sea-level changes: Geol. Soc. America Bull., v. 85, p. 553-570. 
Chappell, John, and Veeh, H. H., 1978, Late Quaternary tectonic movements and sea-level changes at Timor and Atauro lsland: Geol. Soc. America Bull., v. 89, p. 356-368.

Chapple, W. M., and Tullis, T. E., 1977, Evaluation of the forces that drive the plates: Jour. Geophys. Research, v. 82, p. 1967-1984.

Chase, T. E., Karig, D. E., Newhouse, D. A., Taylor, I. L., and Menard, H. W., 1968, Bathymetry of the Southwest Pacific: California Univ., Scripps Inst. Oceanography, map.

Chase, T. E., and Menard, H. W., 1969, Bathymetric atlas of the northwestern Pacific Ocean: U.S. Naval Oceanog. Office, H.O. Pub. $1301,50 \mathrm{p}$.

Chase, T. E., Menard, H. W., and Mammerickx, J., 1968, Bathymetry of the North Pacific: California Univ., Scripps Inst. Oceanography, 10 sheets.

1971, Topography of the North Pacific: California Univ., San Diego, Inst. Marine Resources, Tech. Rept. 17, map.

Chatterji, A. K., 1964, The Tertiary fauna of Andamans: Internat. Geol. Cong., 22d, India 1964, Proc., pt. 8, p. 303-318 [1974].

Chin, A. P., 1971, Sungai Aring area, south Kelantan: Malaysia Geol. Survey 1969 Ann. Rept., p. 103-107.

Chong, F. S., 1970, Geology and mineral resources of the Melaka-Mersing area: Malaysia Geol. Survey 1968 Ann. Rept., p. 89-94.

Choubert, G., and Faure-Muret, A., 1968, Carte tectonique de l'Afrique: [Paris] UNESCO Assoc. African Geol. Surveys, scale 1:5,000,000.

Chowdhury, K. A., 1966, The Tertiary flora of Indian and probable disposition of continents: Palaeobotanist, v. 14, p. 172-184.

Christensen, N. I., and Salisbury, M. H., 1975, Structure and constitution of the lower oceanic crust: Rev. Geophysics and Space Physics, v. 13, p. 57-86.

Chung. S. K., 1973, Geological map of West Malaysia: Malaysia Geol. Survey, scale 1:500,000.

Clague, D. A., and Straley, P. F., 1977, Petrologic nature of the oceanic Moho: Geology, v. 5, p. 133-136.

Clegg, E. L. G., 1938, The geology of parts of the Minbu and Thayetmyo Districts, Burma: India Geol. Survey Mem 72, pt. 2, p. 137-317.

1941, The Cretaceous and associated rocks of Burma: India Geol. Survey Mem. 74, pt. 1, p. 1-101.

Clifford, T. N., 1970, The structural framework of Africa, in Clifford, T. N., and Gass, I. G., eds., African magmatism and tectonics: Darien, Conn., Hafner Publishing Co., p. 1-26.

Coats, R. R., 1962, Magma type and crustal structure in the Aleutian arc: Am. Geophys. Union Geophys. Mon. 6, p. 92-109.

Cole, W. S., Todd, Ruth, and Johnson, C. G., 1960. Conflicting age determinations suggested by Foraminifera on Yap, Caroline 1slands: Am. Paleontology Bull., v. 41, no. 186, p. 77-112.

Coleman, P. J., 1970, Geology of the Solomon and New Hebrides lslands, as part of the Melanesian re-entrant, southwest Pacific: Pacific Sci., v. 24 , p. 289-314.

Coleman, P. J., and Packham, G. H., 1976, The Melanesian borderlands and India-Pacific plates' boundary: Earth-Sci. Rev., v. 12, p. 197-233.

Coleman, R. G., and Lanphere, M. A., 1971, Distribution and age of high-grade blueschists, associated eclogites, and amphibolites trom Oregon and California: Geol. Soc. America Bull., v. 82, p. 2397-2412.

Collenette, Peter, 1958, The geology and mineral resources of the Jesselton-Kinabalu area, North Borneo: British Terr. Borneo Geol. Survey Dept. Mem. 6, 194 p.

1965, The geology and mineral resources of the Pensiangan and upper Kinabatangan area, Sabah, Malaysia: Borneo Region Malaysia Geol. Survey Mem. 12, 150 p.

1966. The Garinono Formation, Sabah, Malaysia: Borneo Region Malaysia, Geol. Survey 1965 Ann. Rept., p. 161-167.

Compston, W., and Arriens, P. A., 1968, The Precambrian geochronology of Australia: Canadian Jour. Earth Sci., v. 5, p. 561-583.

Condon, W. H., Pardyanto, L., and Ketner, K. B., 1975, Geologic map of the Banjarnegara and Pekalongan quadrangles, Java: Indonesia Geol. Survey, scale 1:100,000.
Coney, P. J., 1970, The geotectonic cycle and the new global tectonics: Geol. Soc. America Bull., v. 81, p. 739-747.

Connelly, J. B., 1974, A structural interpretation of magnetometer and seismic profiler records in the Bismarck Sea, Melanesian Archipelago: Geol. Soc. Australia Jour., v. 2., p. 459-469.

1976, Tectonic development of the Bismarck Sea based on gravity and magnetic modelling: Royal Astron. Soc. Geophys. Jour., v. 46 , p. $23-40$.

Conybeare, C. E. B., and Jessop, R. G. C., 1972, Exploration for oil-bearing sand trends in the Fly River area, western Papua: Australian Petroleum Explor. Assoc. Jour., v. 12, pt. 1, p. 69-73.

Cookson, I. C., 1947, Plant microfossils from the lignites of the Kerguelen Archipelago: British, Australian, New Zealand, Antarctic Research Exped., ser. A, v. 2, p. 128-142.

Cooper, J. A., Webb, A. W., and Whitaker, W. G., 1975, lsotopic measurements in the Cape York Peninsula area, Queensland: Geol. Soc. Australia Jour., v. 22, p. 285-310.

Corby, G. W., 1951, Geology and oil possibilities of the Philippines: Philippines Dept. Agriculture and Nat. Resources Tech. Bull. 21, 361 p.

de Coster, G. L., 1975, The geology of the central and south Sumatra basins: Indonesian Petroleum Assoc., 3d Ann. Convention, Jakarta 1974, Proc., p. 77-110.

Cotter, G. de P., 1938, The geology of the Minbu, Pakokku, and Lower Chindwin Districts, Burma: India Geol. Survey, Mem. 72, pt. 1, p. $1-136$.

Coulbourn, W. T., and Moberly, R., 1977, Structural evidence of the evolution of fore-arc basins off South America: Canadian Jour. Earth Sci., v. 14, p. 102-116.

Courtier, D. B., 1974, Geology and mineral resources of the neighbourhood of Kulim, Kedah: Malaysia Geol. Survey. Map Bull. 3, 50 p.

Cowan, D. S., 1974, Deformation and metamorphism of the Franciscan subduction zone complex northwest of Pacheco Pass, California: Geol. Soc. America Bull., v. 85, p. 1623-1634.

Craddock, Campbell, 1970, Radiometric age map of Antarctica: Am. Geog. Soc. Antarctic Map Folio Ser. 12, pl. 19.

1977. The evolution and fragmentation of Gondwanaland Internat. Gondwana Symposium, 4th, Calcutta, 1977, $17 \mathrm{p}$.

Crawford, A. R., 1969, India, Ceylon, and Pakistan-New age data and comparisons with Australia: Nature, v. 223, p. 380-384.

1972, A displaced Tibetan massif as a possible source of some Malayan rocks: Geol. Mag. v. 109, p. 483-489.

1974. The Indus suture line, the Himalaya, Tibet, and Gondwanaland: Geol. Mag., v. 11, p. 369-383.

Cree, Allan, 1972, Industry looks at Java Sea geology: Oil and Gas Jour., v. 70 , no. 27 , p. $72-74$.

Crostella, A. A., and Powell, D. E., 1976, Geology and hydrocarbon prospects of the Timor area: Indonesian Petroleum Assoc., 4th Ann. Convention, Jakarta 1975, Proc., v. 2, p. 149-171.

Cummings, R. H., 1961, Limestones of the Terbat Formation, west Sarawak: British Terr. Borneo Geol. Survey Dept. 1961 Ann. Rept., p. 36-48.

Curray, J. R., and Moore, D. G., 1971, Growth of the Bengal deep-sea fan and denudation of the Himalayas: Geol. Soc. America Bull., v. 82, p. 563-572.

1974, Sedimentary and tectonic processes in the Bengal deep-sea fan and geosyncline, in Burk, C. A., and Drake, C. L., eds., The geology of continental margins: New York, Springer-Verlag, p. 617-627.

Curray, J. R., Shor, G. G., Jr., Raitt, R. W., and Henry, Marilee, 1977, Seismic refraction and reflection studies of crustal structure of the eastern Sunda and western Banda Arcs: Jour. Geophys. Research, v. 82 , p. $2479-2489$.

Curtis, J. W., 1973a, The spatial seismicity of Papua New Guinea and the Solomon Islands: Geol. Soc. Australia Jour., v. 20, p. 1-20. 
1973b, Plate tectonics and the Papua-New Guinea-Solomon Islands region: Geol. Soc. Australia Jour., v. 20, p. 21-36.

D'Addario, G. W., Dow, D. B., and Swoboda, R., 1976, Geology of Papua New Guinea: Australia Bur. Mineral Resources, Geology and Geophysics, scale 1:2,500,000

D'Addario, G. W., Wilford, G. E., Fetherston, J. M., Cameron, R. L., and Wedgebrow, J. M., 1976 Geology of the Northern Territory: Australia Bur. Mineral Resources, Geology and Geophysics, scale 1:2,500,000.

Das, Shamita, and Filson, J. R., 1975, On the tectonics of Asia: Earth and Planetary Sci. Letters, v. 28, p. 241-253.

Dash, B. P., Shepstone, C. M., Dayal, S., Guru, S., Hains, B. L. A., King, G. A., and Ricketts, G. A., 1972, Seismic investigations on the northern part of the Sunda Shelf south and east of Great Natuna Island: U.N. ECAFE, Comm. Co-ordination of Offshore Prospecting (CCOP) Tech. Bull. 6, p. 179-196.

Davidson, D., 1973, Plate tectonics model for the Musgrave Block-Amadeus Basin complex of central Australia: Nature, Phys. Sci., v. 245 , p. 21-23.

Davies, G. F., 1977, Viscous mantle flow under moving lithospheric plates and under subduction zones: Royal Astron. Soc. Geophys. Jour., v. 49, p. $557-563$.

Davies, H. L., 1971a, Peridotite-gabbro-basalt complex of eastern Papua--an overthrust plate of oceanic mantle and crust: Australia Bur. Mineral Resources, Geology and Geophysics, Bull. 128, 48 p.

1971b, West Sepik party. T.P.N.G.: Australia Bur. Mineral Resources, Geology and Geophysics Rec. 71/103, p. 81-86.

1973a, Fergusson Island, Papua New Guinea: Australia Bur. Mineral Resources, Geology and Geophysics, 1:250,000 Geol. Ser.--Explanatory notes. sheet SC/56-5, 25 p., map.

1973b, Gazelle Peninsula, New Britain: Australia Bur. Mineral Resources, Geology and Geophysics, 1:250,000 Geol. Ser.-Explanatory notes, sheet SB 56/2, 24 p., map.

1976, Papua New Guinea ophiolites: Internat. Geol. Cong., 25th, Sydney, Australia, 1976, Excursion Guide 52A, 13 p.

Davies, H. L., and lves, D. J., 1965, The geology of Fergusson and Goodenough Islands, Papua: Australia Bur. Mineral Resources, Geology and Geophysics Rept. 82, 65 p.

Davies, H. L., and Smith, I. E. M., 1971, Geology of eastern Papua: Geol. Soc. America Bull., v. 82, p. 3299-3312.

1974. Tufi-Cape Nelson, Papua New Guinea: Australia Bur. Mineral Resources, Geology and Geophysics, 1:250,000 Geol. Ser.-- Explanatory notes, sheet SC/55-8,4, 34 p., map.

Davies, H. L.., and White, P. G., 1972, Base map compilation and geological interpretation of side-looking radar imagery, western Central Ranges, Papua New Guinea: Australia Bur. Mineral Resources, Geology and Geophysics Rec. 1972/62, 4 p.

Davis, T. A., Weser, O. E., Luyendyk, B. P., and Kidd, R. B., 1975, Unconformities in the sediments of the Indian Ocean: Nature, v. 253,p. 15-19.

Day, R. W., Murray, C. G., and Whitaker, W. G., 1978, The eastern part of the Tasman orogenic zone: Tectonophysics, v. 48, p. 327-364.

Deffeyes, K. S., 1972, Plume convection with an upper-mantle temperature inversion: Nature, v. 240, p. 539-544.

DeLong, S. E., and Fox, P. J., 1977, Geological consequences of ridge subduction: Am. Geophys. Union, Maurice Ewing Series, v. I, p. 221-228.

Den, N., Ludwig, W. J., Murauchi, S., Ewing, M., Hotta, H., Asanuma, T., Yoshii, T., Kubotera, A., and Hagiwara, K., 1971, Sediments and structure of the Eauripik-New Guinea Rise: Jour. Geophys. Research, v. 76, p. $4711-4723$.

Denham, David, 1969, Distribution of earthquakes in the New Guinea-Solomon Islands region: Jour. Geophys. Research, v. 74, p. 4290-4299.

1972. Earthquake focal mechanisms and continental drift: Australian Petroleum Explor. Assoc. Jour., v. 12, pt. 2, p. 81-85.
1973, Seismicity, focal mechanisms and boundaries of the Indian-Australian plate, in Coleman, P. J., ed., The western Pacific: Nedlands, Western Australia, Western Australia Univ. Press, p. 35-53.

Detrick, R. S., Sclater, J. G., and Thiede, J., 1977, The subsidence of aseismic ridges: Earth and Plantetary Sci. Letters, v. 34, p. 185-196.

van Deventer, J., and Postuma, J. A., 1973, Early Cenomanian to Pliocene deep-marine sediments from north Malaita, Solomon Islands: Geol. Soc. Australia Jour., v. 20, p. 145-150.

Dewey, J. F., 1977, Suture zone complexities-A review: Tectonophysics, v. 40 , p. $53-67$.

Dewey, J. F., and Bird, J. M., 1970, Mountain belts and the new global tectonics: Jour. Geophys. Research, v. 75, p. 2625-2647.

1971. Origin and emplacement of the ophiolite suite-Appalachian ophiolites in Newfoundland: Jour. Geophys. Research, v. 76, p. 3179-3206.

Dewey, J. F., and Burke, K. C. A., 1973, Tibetan, Variscan, and Precambrian basement reactivation-Products of continental collision: Jour. Geology, v. 81, p. 683-692.

De Wit, M. J., 1977, The evolution of the Scotia Arc as a key to the reconstruction of southwestern Gondwanaland: Tectonophysics, v. 37, p. 53-81.

Dickinson, W. R., 1969, Evolution of calc-alkaline rocks in the geosynclinal system of California and Oregon: Oregon Dept. Geology and Mineral Industries Bull. 65, p. 151-156.

1970, Relations of andesites, granites, and derivative sandstones to arc-trench tectonics: Rev. Geophys. and Space Physics, v. 8, p. $813-860$.

1973, Reconstruction of past arc-trench systems from petrotectonic assemblages in the island arcs of the western Pacific, in Coleman, P. J., ed., The Western Pacific: Nedlands, Western Australia, Western Australia Univ. Press, p. 569-601.

1975, Potash-depth $(K-h)$ relations in continental margin and intra-oceanic magmatic arcs: Geology, v. 3, p. 53-56.

Dieckmann. W., and Julius, M. W., 1925, Algemeene geologie en ertsafsettingen van Zuidoost-Selebes: Jaarboek Mijnwezen Nederlandsch-Indië, 1924, Verh., v. 53, p. 11-65.

Dietrich, V., Emmermann, R., Oberhänsli, and Puchelt, H., 1978, Geochemistry of basaltic and gabbroic rocks from the West Mariana Basin and the Mariana Trench: Earth and Planetary Sci. Letters, v. 39. 127-144.

Dietz, R. S., 1964, Commotion in the ocean-The growth of continents and ocean basins, in Yoshida, Kozo, ed., Studies in oceanography: Tokyo Univ. Press, p. 465-478.

Dietz, R. S., and Holden, J. C., 1971, Pre-Mesozoic oceanic crust in the eastern Indian Ocean (Wharton Basin)?: Nature, v. 229, p. 309-312.

Djuri, M., 1975, Geologic map of the Purwokerto and Tegal quadrangles, Java: Indonesia Geol. Survey, scale 1:100,000.

Djuri, M., and Sudjatmiko, 1974, Geologic map of the Majene and western part of the Palopo quadrangles, south Sulawesi:. Indonesia Geol. Survey, scale l:250,000.

Doe, B. R., and Delevaux, M. H., 1973, Variations in lead-isotopic composition in Mesozoic grantic rocks of California-a preliminary investigation: Geol. Soc. America Bull., v. 84, p. 3513-3526.

Dooley, J. C., 1976, Variation of crustal mass over the Australian region: Australia Bur. Mineral Resources, Geology and Geophysics, BMR Jour., v. 1, p. 291-296.

Douglas, R. G., and Moulade, Michel, 1972, Age of the basal sediments on the Shatsky Rise, western North Pacific Basin: Geol Soc. America Bull., v. 83, p. 1163-1168.

Doutch, H. F., 1976, The Karumba Basin, northeastern Australia and southern New Guinea: Australia Bur. Minerals Resources, Geology and Geophysics, BMR Jour., v. I, p. 131-140.

Dow, D. B., 1968, A geological reconnaissance in the Nassau Range, West New Guinea: Geologie en Mijnbouw, v. 47, p. 37-46.

1977, A geological synthesis of Papua New Guinea: Australia Bur. Mineral Resources, Geology and Geophysics Bull. 201, 41 p. 
Dow, D. B., and Davies, H. L., 1964, The geology of the Bowutu Mountains, New Guinea: Australia Bur. Mineral Resources, Geology and Geophysics Rept. 75, 31 p.

Dow, D. B., and Dekker, F. E., 1964, The geology of the Bismarck Mountains, New Guinea: Australia Bur. Mineral Resources, Geology and Geophysics Rept. 76, 45 p.

Dow, D. B., and Gemuts, I., 1969, Geology of the Kimberley region, Western Australia-the East Kimberley: Australia Bur. Mineral Resources, Geology and Geophysics Bull. 106, $135 \mathrm{p}$.

Dow, D. B., Smit, J. A. J., Bain, J. H. C., and Ryburn, R. J., 1972, The geology of the South Sepik region, New Guinea: Australia Bur. Mineral Resources, Geology and Geophysics Bull. 133, 88 p.

Dow, D. B., Smit, J. A. J., and Page, R. W., 1974, Wau, Papua New Guinea: Australia Bur. Mineral Resources, Geology and Geophysics. 1:250,000 Geol. Ser.-Explanatory notes, sheet SB/55-14, 33 p., map

Dow, John, 1976, Porphyry copper exploration in Block II, Sulawesi [abs.] Indonesia Geol. Survey Newsletter, v. 8, no. 33, p. 6.

Dozy, J. J., 1939, Geological results of the Carstensz Expedition.1936: Leidse Geol. Meded., v. 11, p. 68-95.

Duff, B. A., and Langworthy, A. P., 1974, Orogenic zones in central Australia -intraplate tectonics?: Nature, v. 249, p. 645-647.

van Dun, F. W. P., 1962, A survey of the Efar-Sidoas mountain ridge in northern Netherlands New Guinea: Geologie en Mijnbouw, v. 41, p. 391-395.

Dunn, P. R., and Brown, M. C., 1969, North Australian plateau volcanics: Geol. Soc. Australia Spec. Pub. 2, p. 117-122.

Dunn, P. R., Plumb, K. A., and Roberts, H. G., 1966, A proposal for time-stratigraphic subdivision of the Australian Precambrian: Geol. Soc. Australia Jour., v. 13, p. 593-608.

Dunning, F. W., 1966, Tectonic map of Great Britain and Northern Ireland: Great Britain lnst. Geol. Sci., scale 1:1,584,000.

Durham, J. W., 1940, Oeloe Aer fault zone, Sumatra: Am Assoc. Petroleum Geologists Bull., v. 24, p. 359-362.

Duyfjes, J., 1938, Toelichting bij blad 116 (Sidoärdjo). Geologische kaart van Java: Dienst Mijnbouw Nederlandsch-Indië, 79 p.

Edgerley, D. W., and Crist, R. P., 1974, Salt and diapiric anomalies in the southeast Bonaparte Gulf Basin: Australian Petroleum Explor. Assoc. Jour., v. 14, pt. 1, p. 85-94

Edwards, A. G., and Glaessner, M. F., 1953, Mesozoic and Tertiary sediments from the Wahgi Valley, New Guinea: Royal Soc. Victoria Proc., v. 64, p. 93-112.

Edwards, G., and McLaughlin, W. A., 1965, Age of granites from the tin province of Indonesia: Nature, v. 206, p. 814-816.

Effendi, A. C., 1974, Geologic map of the Bogor quadrangle, Java: Indonesia Geol. Survey, scale 1:100,000.

1976, Geologic map of the Manado quadrangle, North Sulawesi: Indonesia Geol. Survey, scale 1:250,000

Egeler, C. G., 1947, Contribution to the petrology of the metamorphic rocks of western Celebes, in Brouwer, H. A., ed., Geological explorations in the island of Celebes: Amsterdam, North Holland Publishing Co., p. 175-346.

Eggler, D. H., and Burnham, C. W., 1973, Crystallization and fractionation trends in the system andesite- $\mathrm{H}_{2} \mathrm{O}-\mathrm{CO}_{2}-\mathrm{O}_{2}$ at pressures to $10 \mathrm{~kb} ; \mathrm{Geol}$. Soc. America Bull., v. 84, p. 2517-2532.

Ehrat, H., 1928, Geologisch-mijnbouwkundige onderzoekingen op Flores, Jaarboek Mijnwezen Nederlandsch-Indië, 1925, Verh., v. 54, pt. 2, p. 221-315.

Eisbacher, G. H., 1974, Molasse-Alpine and Colombian: Geosci. Canada, v. 1 , no. 3 , p. 47-50.

Eittreim, S. L., and Ewing, John, 1972, Mid-plate tectonics in the Indian Ocean: Jour. Geophys. Research, v. 77, p. 6413-6421.

Elliott, David, 1976a, The motion of thrust sheets: Jour. Geophys. Research, v. 81, p. 949-963.

1976b, The energy balance and deformation mechanisms of thrust sheets: Royal Soc. London Philos. Trans., v. A-283, no. 1312, p. 289-312.
Ellis, D. J., 1975, A preliminary report on the petrography and mineralogy of the feldspathoid-bearing potassic lavas from the Tabar, Lihir, Tanga, and Feni lslands, off the coast of New Ireland, PNG: Australia Bur. Mineral Resources, Geology and Geophysics Rec. 1975/29, 22 p.

Elsasser, W. M., 1971, Sea-floor spreading as thermal convection: Jour. Geophys. Research, v. 76, p. I101-1112.

El Wakeel, S. K., and Riley, J. P., 1961. Chemical and mineralogical studies of fossil red clays from Timor: Geochim. et Cosmochim. Acta. v. 24, p. $260-265$

Embleton, B. J. J., 1973, The palaeolatitude of Australia through Phanerozoic time: Geol. Soc. Australia Jour., v. 19, p. 475-482.

Embleton, B. J. J., and Schmidt, P. W., 1977, Revised palaeomagnetic data for the Australian Mesozoic and a synthesis of late Palaeozoic-Mesozoic results for Gondwanaland: Tectonophysics, v. 38, p. 355-364.

Embleton, B. J. J., and Valencio, D. A., 1977, Palaeomagnetism and the reconstruction of Gondwanaland: Tectonophysics, v. 40, p. 1-12.

Emery, K. O., and Ben-Avraham, Zvi, 1972, Structure and stratigraphy of China Basin: Am. Assoc. Petroleum Geologists Bull., v. 56, p. 839-859.

Emery, K. O., Uchupi, Elazar, Sunderland, John, Uktolseja, H. L., and Young, E. M., 1972, Geological structure and some water characteristics of the Java Sea and adjacent continental shelf: U.N. ECAFE, Comm. Co-ordination of Offshore Prespecting (CCOP) Tech. Bull. 6, p. 197-223.

Engdahl, E. R., Sleep, N. H., and Lin, M.-T., 1977, Plate effects in North Pacific subduction zones: Tectonophysics, v. 37, p. 95-116.

England, R. N., and Davies, H. L., 1973, Mineralogy of ultramafic cumulates and tectonites from eastern Papua: Earth and Planetary Sci. Letters, v. 17, p. 416-425.

Eremenko, N. A., Negi, B. S., Kassianov, M. V., Sengupta, S. N., Talukdar, S. N., and Sastri, V. V., 1968, Tectonic map of India: India Oil and Nat. Gas Comm., scale 1:2,000,000, 4 sheets.

Erlandson, D. L., 1975, Geology and geophysics of the Lyra Basin: Hawaii Univ. M. S. thesis, 69 p.

Erlandson, D. L., Orwig, T. L., Kiilsgaard, Glenn, Mussells, J. H., and Kroenke, L. W., 1976, Tectonic interpretations of the East Caroline and Lyra Basins from reflection-profiling investigations: Geol. Soc. America Bull., v. 87, p. 453-462.

Ernst, W. G., 1970, Tectonic contact between the Franciscan mélange and the Great Valley sequence - crustal expression of a late Mesozoic Benioff zone: Jour. Geophys. Research, v. 75, p. 886-901.

van Es, L. J. C., 1926, Geologische overzichskaart van het Eiland Timor: Jaarboek Mijnwezen Nederlandsch-Indië, 1925, Verh., v. 54, pt. 2. scale $1: 250,000$.

Evans, P., 1964, The tectonic framework of Assam: Geol. Soc. India Jour., v. 5, p. $80-96$

Everingham. I. B., 1974, Large earthquakes in the New Guinea-Solomon Islands area, 1873-1972: Tectonophysics, v. 23, p. 323-338.

1975a, Faulting associated with the major north Solomon Sea earthquakes of 14 and 26 July 197I: Geol. Soc. Australia Jour., v. 22, p. 61-69.

1975b, Seismological report on the Madang earthquake of 31 October 1970 and aftershocks: Australia Bur. Mineral Resources, Geology and Geophysics Rept. 176, 45 p.

Ewing, J. 1., Houtz, R. E., and Ludwig, W. J., 1970, Sediment distribution in the Coral Sea: Jour. Geophys. Research, v. 75, p. 1963-1972.

Ewing. Maurice, Eittreim, Stephen, Trachen, Marek, and Ewing, J. I., 1969, Sediment distribution in the Indian Ocean: Deep-Sea Research, v. 16, p. 231-248.

Ewing, Maurice, Hawkins, L. V., and Ludwig, W. J., 1970, Crustal structure of the Coral Sea: Jour. Geophys. Research, v. 75, p. 1953-1962.

Ewing, Maurice, Houtz, Robert, and Hayes, D. E., 1972, The Kerguelen Plateau [abs.]: Internat. Geol. Cong., 24th Montreal, 1972, sec. 8, p. 63.

Ewing, Maurice, and Worzel, J. L., 1954, Gravity anomalies and structure of the West Indies, Pt. 1; Geol. Soc. America Bull., v. 65, p. 165-174. 
Facer, F. A., 1974, Apparent polar wander relative to Australia during the Precambrian: Earth and Planetary Sci. Letters, v. 22, p. 44-50.

Falvey, D. A., 1972, Sea-floor spreading in the Wharton Basin (northeast Indian Ocean) and the breakup of eastern Gondwanaland: Australian Petroleum Explor. Assoc. Jour., v. 12, pt. 2, p. 86-88.

Farrar, Edward, and Lowe, R. M., 1978, Age-length dependence of inclined seismic zones: Nature, v. 273, p. 292-293.

Faure, Claude, and Fontaine, Henri, 1969, Géochronologie du Viet-Nam méridional: Archives Géol. du Viêt-Nam, no. 12, p. 213-222.

Faure, Gunter, Bowman, J. R., Elliot, D. H., and Jones, L. M., 1974, Strontium isotope composition and petrogenesis of the Kirkpatrick Basalt, Queen Alexandra Range, Antarctica: Contr. Mineralogy and Petrology, v. 48, p. 153-169.

Faure, Gunter, and Powell, J. L., 1972. Strontium isotope geology: Berlin, Springer-Verlag, $108 \mathrm{p}$.

Ferguson, H. G., 1911, The geology and mineral resources of the Aroroy district, Masbate: Philippine Jour. Sci. v. 6-A, p. 397-425.

Findlay, A. L., 1974, The structure of the foothills south of the Kubor Range, Papua New Guinea: Australian Petroleum Explor. Assoc. Jour., v. 14, pt. 1, p. 14-20.

Finlayson, D. M., 1968, First arrival data from the Carpentaria Region Upper Mantle Project (CRUMP): Geol. Soc. Australia Jour., v. 15, p. 33-50.

Finlayson, D. M., and Cull, J. P., 1973a, Time-term analysis of New Britain-New Ireland island arc structures: Royal Astron. Soc. Geophys. Jour., v. 33, p. 265-280.

1973b, Structural profiles in the New Britain/New Ireland region: Geol. Soc. Australia Jour., v. 20, p. 37-48.

Finlayson, D. M., Cull, J. P., and Wiebenga, W. A., 1972, New Britain-New Ireland crustal seismic refraction investigations: Royal Astron. Soc., Geophys. Jour., v. 29, p. 245-253.

Finlayson, D. M., Drummond, B. J., Collins, C. D. N., and Connelly, J. B., 1976. Crustal structure under the Mount Lamington region of Papua New Guinea, in Johnson, R. W., ed., Volcanism in Australasia: Amsterdam. Elsevier, p. 259-274.

1977, Crustal structures in the region of the Papuan Ultramafic Belt: Physics Earth and Planetary Interiors, v. 14, p. 13-29.

Finlayson, D. M., Muirhead, K. J., Webb, J. P., Gibson, G., Furumoto, A. S., Cooke, R. J. S., and Russell, A. J., 1976, Seismic investigation of the Papuan ultramafic belt: Royal Astron. Soc. Geophys. Jour., v. 44 , p. $45-59$.

Fischer, A. G., and others, 1971, Initial reports of the Deep Sea Drilling Project, V. 6: Washington, U.S. Govt. Printing Office, 1329 p.

Fisher, N. H., 1957, Melanesia, Pt. 5 of Catalogue of the active volcanoes of the world including solfatara fields: Internat. Volcanol. Assoc., $105 \mathrm{p}$.

Fisher, R. L., 1975, Pacific-type continental margins, in Burk, C. A., and Drake, C. L., eds., The geology of continental margins: New York, Springer-Verlag, p. 25-41.

Fitch, F. H., 1952, The geology and mineral resources of the neighbourhood of Kuantan, Pahang: Federation of Malaya Geol. Survey Dept. Mem. $6,143 \mathrm{p}$.

1955, The geology and mineral resources of part of the Segama Valley and Darvel Bay area, Colony of North Borneo: British Terr. Borneo Geol. Survey Dept. Mem. 4, 142 p.

1958, The geology and mineral resources of the Sandakan area, North Borneo: British Terr. Borneo Geol. Survey Dept. Mem. 9, 202 p.

Fitch, T. J., 1970a, Earthquake mechanisms and island arc tectonics in the Indonesian-Philippine region: Seismol. Soc. America Bull., v. 60, p. 565-591.

1970b, Earthquake mechanisms in the Himalayan, Burmese, and Andaman regions and continental tectonics in central Asia: Jour. Geophys. Research, v. 75, p. 2698-2709.

1972, Plate convergence, transcurrent faults, and internal deformation adjacent to Southeast Asia and the Western Pacific: Jour. Geophys. Research, v. 77, p. 4432-4460.
Fitch, T. J., and Hamilton, Warren, 1974, Plate convergence, transcurrent faults, and internal deformation adjacent to Southeast Asia and the Western Pacific--Reply: Jour. Geophys. Research, v. 79, p. 4982-4985.

Fitch, T. J., and Molnar, Peter, 1970, Focal mechanisms along inclined earthquake zones in the Indonesia-Philippine region: Jour. Geophys. Research, v. 75 , p. 1431-1444.

Fjelstul, C. R., Tallis, N. C., and Erickson, J. O., 1969, Permit no. 30, Papua, marine seismic survey, 1966; Australia Bur. Mineral Resources, Geology and Geophysics, Petroleum Search Subsidy Pub. $84,27 \mathrm{p}$.

Fletcher, G. L., and Soeparjadi, R. A., 1976, Indonesia's Tertiary basinsthe land of plenty: South East Asia Petroleum Explor. Soc., Offshore Conf., Singapore, 1976, Paper 8, 54 p.

Flint, D. E., 1972, Geology of the Ertsberg copper deposit, Irian Barat, Indonesia: Geol. Soc. Malaysia Newsletter 34, abs. annex., p. 10-11.

Flint, D. E., Nelson, F. J., and Stuart, R. J., 1976, The Gunung Bijih copper deposit, Irian Jaya, Indonesia: Soc. Mining Engineers, Ann. Mtg., Las Vegas, Nevada, 1976, 9 p.

Fontaine, Henri, 1965, Remarque sur la géologie des districts de Van-Ninh et de Ninh-Hoa (Province de Nha-Trang): Archives Géol. du Viêt-Nam, no. 7, p. 5-6.

Fontaine, Henri, and Saurin, Edmond, 1965, Existence de granites et diorites post-Liasiques au Sud Viet Nam: Archives Géol. du Viêt-Nam, no. 7, p. 7-10.

Forbes, W. C., and Flower, M. J. F., 1974, Phase relations of titan-phlogopite, $\mathrm{K}_{2} \mathrm{Mg}_{4} \mathrm{TiAl}_{2} \mathrm{Si}_{6} \mathrm{O}_{20}(\mathrm{OH})_{4}-\mathrm{A}$ refractory phase in the upper mantle: Earth and Planetary Sci. Letters, v. 22, p. 60-66.

Ford, A. B., 1968, Fit of Gondwana continents-drift reconstruction from the Antarctic continental viewpoint; Internat. Geol. Cong., 24th, Prague, sec. 3, p. 113-121.

1975, Volcanic rocks of Naturaliste Plateau, eastern Indian Ocean, Site 264, DSDP Leg 28, in Hayes, D. E., and Frakes, L. A. Initial reports of the Deep Sea Drilling Project: Washington, U.S. Govt. Printing Office, v. 28, p. 821-833.

Forman, D. J., and Shaw, R. D., 1973, Deformation of the crust and mantle in central Australia: Australia Bur. Mineral Resources, Geology and Geophysics Bull. 144, 20 p.

Forsyth, Donald, and Uyeda, Seiya, 1975, On the relative importance of the driving forces of plate motion: Royal Astron. Soc. Geophys. Jour., v. 43, p. $163-200$.

Francis, T. J. G., and Raitt, R. W., 1967, Seismic refraction measurements in the southern Indian Ocean: Jour. Geophys. Research, v. 72, p. 3015-3041.

Frank, F. C., 1968, Curvature of island arcs: Nature, v. 220, p. 363.

French, D. J., 1966, The geology of southern New Ireland: Australia Bur. Mineral Resources, Geology and Geophysics Rec. 1966/179, 22 p.

Froidevaux, C. M., 1975, Geology of Misool lsland (Irian Jaya): Indonesian Petroleum Assoc., 3d Ann. Convention, Jakarta 1974, Proc., p. 189-196.

Fromaget, Jacques, 194I, L'Indochine Françáise-sa structure géologique, ses roches, ses mines et leurs relations avec la tectonique: Service Géol. de l'Indochine Bull. 26, pt. 2, 140 p.

1952, Carte géologique de l'Indochine: Service Géol. de l'Indochine, scale $1: 2,000,000,2$ sheets.

Furumoto, A. S., Webb, J. P., Odegard, M. E., and Hussong, D. M., 1976, Seismic studies on the Ontong Java Plateau, 1970: Tectonophysics, v. 34, p. 71-90.

Furumoto, A. S., Wiebenga, W. A., Webb, J. P., and Sutton, G. H., 1973, Crustal structure of the Hawaiian Archipelago, northern Melanesia, and the Central Pacific Basin by seismic refraction methods: Tectonophysics, v. 20, p. 153-164.

Gageonnet, Robert, and Lemoine, Marcel, 1958, Contribution à la connaissance de la géologie de la Province Portugaise de Timor: [Portugal] Junta Inv. Ultramar Estudos 48, 134 p.

Gansser, Augusto, 1966, The Indian Ocean and the Himalayas, a geological interpretation: Eclogae Geol. Helvetiae, v. 59, p. 831-848. 
Gardner, J. V., 1970, Submarine geology of the western Coral Sea: Geol. Soc. America Bull., v. 81, p. 2599-2614.

Garnett, R. A. P., 1975, Seismic reflection profiles across the Timor Trough: Australia Bur. Mineral Resources, Geology and Geophysics Rec. 1975/32, 4 p.

Garson, M. S., Amos, B. J., and Mitchell, A. H. G., 1976, The geology of the area around Neyaungga and Ye-ngan, Southern Shan States, Burma: Great Britain Inst. Geol. Sci., Overseas Mem. 2, 70 p.

Garson, M. S., and Mitchell, A. H. G., 1970, Transform faulting in the Thai Peninsula: Nature, v. 228, p. 45-47.

Garson, M. S., Young, B., and Mitchell, A. H. G., 1975, The geology of the tin belt in peninsular Thailand around Phuket, Phangnga and Takua Pa: Great Britain Inst. Geol. Sci., Overseas Mem. 1, 112 p.

Gatinskiy, Yu. G., Rasskazov, Yu. P., Isayev, Ye. N., Kamenetskiy, A. Ye., Le, B. K., Sukhov, V. I., and Chan, V. Ts., 1973, Strukturnyye elementy territorii Demokraticheskoy Respubliki V'yetnam: Sovetskaya Geologiya, 1973, no. 9, p. 95-110.

Gee, E. R., 1926. The geology of the Andaman and Nicobar Islands, with special reference to Middle Andaman lsland: India Geol. Survey Recs., v. 59, p. $208-232$.

Gellatly, D. C., 1971, Possible Archaean rocks of the Kimberley region, Western Australia: Geol. Soc. Australia Spec. Pub. 3, p. 93-101.

Gellatly, D. C., and Sofoulis, J., 1969, Drysdale and Londonderry, W.A.: Australia Bur. Mineral Resources, Geology and Geophysics, 1:250.000 Geol. Ser.-Explantory notes, sheets SD/52-5, 9. 19 p., map.

1975. Yampi. Western Australia: Australia Bur. Mineral Resources, Geology and Geophysics, 1:250,000 Geol. Ser.-Explanatory notes, sheet SE/51-3, 39 p., map.

de Genevraye, Patrick, and Samuel, Luki, 1973, Geology of the Kendeng zone (central and east Java): Indonesian Petroleum Assoc., Ist Ann. Convention, Jakarta 1972, Proc., p. 17-30.

Geological Society of London, 1964, Summary of the Phanerozoic time scale: Geol, Soc. London Quart. Jour., v. 120-S, p. 260-262.

Gerard, J., and Oesterle, H. G., 1973, Facies study of the offshore Mahakam area: Indonesian Petroleum Assoc., 2d Ann. Convention, Jakarta 1973, Proc., p. 187-194.

Germeraad, J. H., 1946, Geology of central Seran, No. 2, of Geological, petrographical and paleontological results of explorations, carried out from September 1917 till June 1919 in the island of Ceram, by L. Rutten and W. Hotz, in Geology, 3d Ser.: Amsterdam, J. H. de Bussy, $134 \mathrm{p}$

Gerth. H., 1926, Die Korallenfauna des Perm von Timor und die permische Vereisung: Leidshe Geol. Meded., v. 2, pt. 1, p. 7-14.

Gervasio, F. C., 1973, Geotectonic development of the Philippines, in Coleman, P. J., ed., The western Pacific: Nedlands, Western Australia, Western Australia Univ. Press, p. 307-324.

Ghosh, P. K., and Mitra, N. D., 1970, A review of recent progress in studies of the Gondwanas of India, in Haughton, S. H., ed., Gondwana Symposium, 2d, Pretoria, 1970, Proc. and Papers: Pretoria, Council Sci. Indust. Research, p. 29-36.

Gisolf, W. F., 1917, Beschrijving van een mikroscopisch onderzoek van gabbro's en amfibolieten, Herkomstig van Midden-Celebes: Rotterdam, Immig en Zoon, $141 \mathrm{p}$

1924, Microscopisch onderzoek van gesteenten van Noord-Nieuw-Guinea: Jaarboek Mijnwezen Nederlandsch Oost-Indië, 1921, Verh., v. 50, pt. 1, p. 133-161.

Glaessner, M. F., 1952, Geology of Port Moresby, Papua, in Sir Douglas Mawson Anniversary Volume: Australia, Adelaide Univ., p. 63-86.

1960, Upper Cretaceous larger Foraminifera from New Guinea: Tohoku Univ. Sci. Rept., ser. 2, spec. v. 4, p. 37-44.

Gobbett, D. J., 1968, The Permian system in Malaya: Geol. Soc. Malaysia Bull. 1, p. 17-22

1972, Geological map of the Malay Peninsula: Geol. Soc Malaysia, scale 1:1,000,000

1973, Carboniferous and Permian correlation in Southwest Asia: Geol. Soc. Malaysia Bull. 6, p. 131-142.
Gobbett, D. J., and Hutchison, C. S., eds., 1973, Geology of the Malay Peninsula: New York, Wiley-Interscience, $438 \mathrm{p}$.

Gogarten, E., 1918a, Geologie van Noord-Halmahera: Kolonien Nederland Geol. Mijnbouw Genoot., Verh., Geol. Ser., v. 2, p. 267-280.

1918b, Die Vulkane der nördlichen Molukken: Zeitschr. Vulkanologie, v. 4, p. 211-305.

Gold, T., 1955, Instability of the earth's axis of rotation: Nature, v. 175, p. 526-529.

Goldreich, Peter, and Toomre, Alar, 1969. Some remarks on polar wandering: Jour. Geophys Research, v. 74, p. 2555-2567.

Göllner. E. R. D., 1924. Verslag over de uitkomsten van mijnbouwkundig-geologische ondersoekingan op Poeloe Laoet: Jaarboek Mijnwezen Nederlandsch Oost-Indië, 1921, Verh., v. 50, pt. I, p. 4-52.

Good, Ronald, 1957, Some problems of southern floras with special reference to Australia: Australia Jour. Sci., v. 20, no. 2, p. 4I-44

1963, On the biological and physical relationships between New Guinea and Australia, in Gressitt, J. L., ed., Pacific Basin biogeography: Honolulu, Bishop Mus. Press, p. 301-309.

Gordon, R. G., Cox, Allan, and Harter, C. E., 1978, Absolute motion of an individual plate estimated from its ridge and trench boundaries: Nature, v. 274, p. 752-755

Grady, A. E., 1975, A reinvestigation of thrusting in Portuguese Timor: Geol. Soc. Australia Jour., v. 22, p. 223-227.

Grady, A. E., and Berry, R. F., 1977, Some Palaeozoic-Mesoroic stratigraphic-structural relationships in East Timor and their significance in the tectonics of Timor: Geol. Soc. Australia Jour. v. 24, p. 203-214

Grant, J. N., and Nielsen, R. L., 1975, Geology and geochronology of the Yandera porphyry copper deposit, Papua New Guinea: Econ. Geology, v. 70, p. 1157-1174.

Graves, R. R., and Weegar, A. A., 1973, Geology of the Arun gas field (North Sumatra): Indonesian Petroleum Assoc., 2d Ann. Convention, Jakarta 1973, p. 23-51.

Green, D. H., 1973, Contrasted melting relations in a pyrolite upper mantle under mid-oceanic ridge, stable crust and island arc environments: Tectonophysics, v. 17, p. 285-297.

Green. T. H., 1972, Crystallization of calc-alkaline andesite under controlled high-pressure hydrous conditions: Contr. Mineralogy and Petrology, v. 34, p. 150-166.

Greenwood, W. R., Hadley, D. G., Anderson, R. E., Fleck, R. J., and Schmidt, D. L., 1976, Late Proterozoic cratonization in southwestern Saudi Arabia: Royal Soc. London Philos. Trans., v. A-280, p. 517-527.

Grey, R. R., 1956, Eocene in the Philippines: Pacific Sci. Cong., 8th, Philippines 1953, Proc., v. 2, p. 503-510.

Gribi, E. A., Jr., 1973, Tectonics and oil prospects of the Moluccas, eastern Indonesia: Geol. Soc. Malaysia Bull. 6, p. 11-16.

Griffiths, J. R., 1971a, Reconstruction of the south-west Pacific margin of Gondwanaland: Nature, v. 234, p. 203-207.

1971b. Continental margin tectonics and the evolution of south east Australia: Australian Petroleum Explor. Assoc. Jour., v. I1, pt. I, p. 75-79.

Griffiths, J. R., and Burrett, Clive, 1973, Were South-east Asia and Indonesia parts of Gondwanaland": Nature, Phys. Sci., v. 245, p. 92-93.

Griscom, Andrew, 1973, Bouguer gravity map of California, Redding sheet: California Div. Mines and Geology, scale 1:250,000.

Grow, J. A., 1973a, Crustal and upper mantle structure of the central Aleutian arc: Geol. Soc. America Bull., v. 84, p. 2169-2192.

1973b, Implications of deep sea drilling. sites 186 and 187, on island arc structure, in Creager, J. S., and Scholl, D. W., Initial reports on the Deep Sea Drilling Project, v. 29: Washington, U.S. Govt. Printing Office, p. 799-803.

Grubb, P. L. C., 1968, Geology and bauxite deposits of the Pengerang area, southeast Johore: West Malaysia Geol. Survey Dist. Mem. 14, 125 p. 
Grunau, H. R., 1953, Geologie von Portugiesisch Osttimor: Eclogae Geol. Helvetiae, v. 46 , no. 1, p. 30-37.

1957, Neue Daten zur Geologie von portugiesisch Osttimor: Eclogae Geol. Helevetiae, v. 50, p. 69-98

Gubler, Jean, 1935, Études géologiques au Cambodge occidental: Service Géol. de l'Indochine Bull., v. 22, pt. 2, 176 p.

Gubler, Jean, and Saurin, Edmond, 1962, Notice sur la feuille de Pak Nam: Service Géog. Nat. Viet Nam, 22 p.

Gwinn, J. W., Helmig, H. M., and Kartaadipoetra, L. W., 1975, Geology of the Badak field, East Kalimantan, Indonesia: Indonesian Petroleum Assoc., 3d Ann. Convention, Jakarta 1974, Proc., p. 311-331.

Haak, R., and Postuma, J. A., 1975, The relation between the tropical planktonic foraminiferal zonation and the Tertiary Far East letter classification: Geologie en Mijnbouw, v. 54, p. 195-198.

de Haan, W., 1935, Gesteenten van Sumatra's Weskust: $\Gamma$ e Ingenieur Nederlandsch-Indiě, v. 2 , no. 10 , pt. 4 , p. 88-97.

Haile, N. S., 1954, The geology and mineral resources of the Strap Sadong Valleys, West Sarawak, including the Klingkang Range coal: British Terr. Borneo Geol. Survey Dept. Mem. 1, 150 p.

1957. The geology and mineral resources of the Lupar and Saribas valleys, west Sarawak: British Terr. Borneo Geol. Survey Dept. Mem. 7, 123 p.

1962. The geology and mineral resources of the Suai-Baram area, North Sarawak: British Terr. Borneo Geol. Survey Dept. Mem. 13 , 176 p.

1969. Geosynclinal theory and the organizational pattern of the North-west Borneo Geosyncline: Geol. Soc. London Quart. Jour., v. 124, p. 171-194.

1970, Notes on the geology of the Tambelan, Anambas and Bunguran (Natuna) Islands, Sunda Shelf, Indonesia, including radiometric age determinations: U. N. ECAFE, Comm. Co-ordination of Otfshore Prospecting (CCOP) Tech. Bull. 3, p. 55-89.

1973a, West Borneo microplate younger than supposed?: Nature, Phys. Sci. v. 242, p. 28-29.

1973b, The recognition of former subduction zones in Southeast Asia, in Tarling, D. H., and Runcorn, S. K., eds., Implications of continental drift to the earth sciences: London, Academic Press, v. 1, p. 885-892.

Haile, N. S., and Bignell. J. D., 1971, Late Cretaceous age based on K/Ar dates of granitic rock from the Tambelan and Bunguran Islands, Sunda Shelf, Indonesia: Geologie en Mijnbouw, v. 50, p. 687-690.

Haile, N. S., McElhinny, M. W., and McDougall, Ian, 1977, Palaeomagnetic data and radiometric ages from the Cretaceous of West Kalimantan (Borneo), and their significance in interpreting regional structure: Geol. Soc. London Quart. Jour., v. 133, p. 133-144.

Haile, N. S., and Tarling, D. H., 1975, Note on reconnaissance palaeomagnetic measurements on Jurassic redbeds from Thailand: Pacific Geology, no. 10, p. 101-103.

Haite, N. S., and Wong, N. P., 1965, The geology and mineral resources of Dent Peninsula, Sabah: Borneo Region Malaysia Geol Survey Mem. 16. $199 \mathrm{p}$.

Hales, A. L., 1969. Gravitational sliding and continental drift: Earth and Planetary Sci. Letters, v. 6, p. 31-34.

Halse, J. W., and Hayes, J. D., 1971, The geological and structural framework of the offshore Kimberley Block (Browse Basin) area, Western Australia: Australian Petroleum Explor. Assoc. Jour., v. II, pt. 1, p. 64-70.

Hamada, Takashi, 1969, Late Palaeozoic brachiopods from red beds in the Malayan Peninsula, in Kobayashi, T., and Toriyama, R., eds., Geology and Palaeontology of Southeast Asia, v. 6: Tokyo Univ. Press, p. 251-264.

Hamilton, Warren, 1963, Antarctic tectonics and continental drift: Soc. Econ. Paleontologists and Mineralogists Spec. Pub. 10, p. 74-93.

1969a. The volcanic central Andes - a modern model for the Cretaceous batholiths and tectonics of western North America: Oregon Dept. Geology and Mineral Industries Bull. 65, p. 175-184. 1969b, Meso7oic California and the underflow of Pacific mantle: Geol. Soc. America Bull, v. 80, no. 12, p. 2409-2430.

1970a. Tectonic map of Indonesia - a progress report: U.S. Geol. Survey open-file report, $29 \mathrm{p}$

$1970 \mathrm{~b}$. The Uralides and the motion of the Russian and Siberian Platforms: Geol. Soc. America Bull, v. 81, no. 9, p. 2553-2576.

1972, Preliminary tectonic map of the Indonesian region: U.S. Geol. Survey open-file report, scale 1:5,000,000, 3 sheets.

1973, Tectonics of the Indonesian region: Geol. Soc. Malaysia Bull. 6, p. 3-10.

1974a, Map of sedimentary basins of the Indonesian region: U.S. Geol. Survey Misc. Inv. Ser. Map 1-875-B [1975].

1974b. Earthquake map of the Indonesian region: U.S. Geol.

Survey Misc. Inv. Ser. Map I-875-C [1975].

1975, Subduction in the Indonesian region: South East Asia

Petroleum Explor. Soc. Proc., v. 2, p. 37-40.

1977a, Subduction in the Indonesian region: Am. Geophys.

Union, Maurice Ewing Series, v. 1, p. 15-31.

1977b, Plate tectonics and man: U.S. Geol. Survey Ann. Report Fiscal Year 1976, p. 39-53.

1978 . Tectonic map of the Indonesian region: L'.S. (ieol. Survey

Mis. Inı. Ser. Map 1-875-1).

1978b, Mesozoic tectonics of the western United States: Pacific

Sec. Soc. Econ. Paleontol. Mineral., Paleogeography Symp. 2, p. 33-70.

Hamilton, Warren, and Myers, W. B., 1967, The nature of batholiths: U.S. Geol. Survey Prof. Paper 554-C, 29 p.

Hantke, Gustav, 1976, Volcanological communications: Indonesia Geol. Survey Newsletter, v. 9, No. 1, p. 5-6.

Harding, R. R., 1969, Catalogue of age determinations of Australian rocks, 1962-1965: Australia Bur. Mineral Resources, Geology and Geophyics Rept. 117, 117 p.

Harloff, C. E. A., 1929a, Voorloopige mededeeling over de geologie van het Praetertiair van Loh Oelo in Midden-Java: De Mijningenieur, v. 10, no. 8, p. $172-177$.

1929b, Over radiolariënhoudende gesteenten in het Praetertiair van Loh Oelo (midden Java): De Mijningenieur, v. 10, no. 11, p. 240-243.

1933, Geologische kaart van Java: Toelichting bij blad 67 (Bandiarnegara), scale 1:1,000,000, Dienst Mijnbouw NederlandschIndië.

Harper, J. F., 1975, On the driving forces of plate tectonics: Royal Astron. Soc. Geophys. Jour., v. 40, p. 465-474.

Harrington, H. J., 1974, The Tasman geosylicline, in The Tasman geosyncline, A Symposium in honour of Professor Dorothy Hill: Geol. Soc. Australia, Queensland Div., p. 383-407.

Harrison, J. R., 1971, Bouguer gravity map of New Britain and New Ireland: Australia Bur. Mineral Resources, Geology and Geophysics Rec. 1971/131, pl. 50.

Harrison, John, 1969, A review of the sedimentary history of the island of New Guinea: Australian Petroleum Explor. Assoc. Jour., v. 9, pt. 2, p. 41-48.

Hart, S. R, Glassley, W. E., and Karig, D. E., 1972, Basalts and sea floor spreading behind the Mariana island are: Earth and Planetary Sci. Letters, v. 15, p. 12-18.

Harting, A., 1925, Bijdrage tot de geologie van Beraoe: Koloniën Nederland Geol. Mijnbouw Genoot., Verh., Geol. Ser., v. 8, p. 205-212.

Hashimoto, Wataru, and Sato, Tadashi, 1968, Contribution to the geology of Mindoro and neighboring islands, the Philippines, in Geology and palaeontology of southeast Asia, v. 5: Tokyo Univ. Press, p. 192-210.

1973, Geological structure of north Palawan, and its bearing on the geological history of the Philippines, in Geology and palaeontology of Southeast Asia, v. 13; Tokyo Univ. Press, p. 145-161.

Hatherton,'Trevor, and Dickinson, W. R., 1969, The relationship between andesitic volcanism and seismicity in Indonesia, the Lesser Antilles, and other island arcs: Jour. Geophys. Research, v. 74, p. 5301-5310. 
Hawkins, J. W., 1974, Geology of the Lau Basin, a marginal sea behind the Tonga arc, in Burk, C. A., and Drake, C. L., eds., The geology of continental margins: New York, Springer-Verlag, p. 505-520.

1976, Petrology and geochemistry of basaltic rocks from the Lau Basin: Earth and Planetary Sci. Letters, v. 28, p. 283-297.

Hawkins, J. W., and Batiza, Rodey, Metamorphic rocks of the Yap arc-trench system: Earth and Planetary Sci. Letters, v. 37, p. 216-229.

Hayes, D. E., and Frakes, L. A., 1973, Leg 28 deep-sea drilling in the southern ocean: GeoTimes, v. 18, no. 6, p. 19-24.

Hayes, D. E., and Ludwig, W. J., 1967. Gravity and magnetics measurements; [Pt.] 2 of The Manila Trench and West Luzon Trough: Deep-Sea Research, v. 14, p. 545-560.

Hayes, D. E., and Ringis, John, 1973, Seafloor spreading in the Tasman Sea: Nature, v. 243, p. 454-458.

Hedge, C. E., Watkins, N. D., Hildreth, R. A., and Doering, W. P., 1973, ${ }^{87} \mathrm{Sr} /{ }^{*} \mathrm{Sr}$ ratios in basalts from islands in the Indian Ocean: Earth and Planetary Sci. Letters, v. 21, p. 29-34.

Heezen, B. C., MacGregor, I. D., and others, 1972, Deep Sea Drilling Leg .20: GeoTimes, v. 17, no. 4, p. 10-14.

Heezen, B. C., MacGregor, 1. D., Foreman, H. P., Forristal, G., Hekel, H., Hesse, R., Hoskins, R. H., Jones, E. J. W., Kanpes, A., Krasheninnikov, V. A., Okada, H., and Ruef, M. H., 1973, Diachronous deposits - A kinematic interpretation of the post Jurassic sedimentary sequence on the Pacific Plate: Nature, v. 241, p. 25-32.

Heezen, B. C., and Tharp, Marie, 1965a, Physiographic diagram of the Indian Ocean: Geol. Soc. America.

1965b, Tectonic fabric of the Atlantic and Indian Oceans and continental drift: Royal Soc. London Philos. Trans., ser. A, v. 258, no. 1088, p. 90-106. 137-141.

1973, USNS Eltanin Cruise 55: Antarctic Jour. U.S., v. 8, p

Hehuwat, F., 1975, Radiometric age determinations in Indonesia--The state of the art: U.N. Regional Offshore Prospecting in East Asia, Doc. R 034, p. 128-145.

Heim, Arnold, 1939, Geological reconnaissance report on the Tanimbar, Kai, and Aroe Islands--N.E.I.: Indonesia Geol. Survey, unpub. rept. CI-1 (in libr.), $29 \mathrm{p}$.

1942, Lebende Diapire in den südöstlichen Molukken: Eclogae Geol. Helvetiae, v. 35, p. 225-233.

Heirtzler, J. R., Dickson, G. O., Herron, E. M., Pitman, W. C., 11I, and Le Pichon, Xavier, 1968, Marine magnetic anomalies, geomagnetic field reversals, and motions of the ocean floor and continents: Jour. Geophys. Research, v. 73, p. 2119-2136.

Heirtzler, J. R., Veevers, J. J., Bolli, H. M., Carter, A. N., Cook, P. J., Krasheninnikov, V. A., McKnight, B. K., Proto-Decima, Franca, Renz, G. W., Robinson, P. T., Rocker, Karl, Jr., and Thayer, P. A., 1973. Age of the floor of the eastern Indian Ocean: Science, v. 180, p. 952-954.

Heiskanen, W. A., and Vening Meinesz, F. A., 1958, The Earth and its gravity field: New York, McGraw-Hill, 470 p.

Hekinian, Roger, 1973, Petrology of igneous rocks from Leg 22 in the northeastern Indian Ocean, in von der Borch, C. C., Sclater, J. G., and others, Initial reports of the Deep Sea Drilling Project, v. 22: Washington, U.S. Govt. Printing Office, p. 413-447.

1974. Petrology of the Ninety East Ridge (Indian Ocean) compared to other aseismic ridges: Contr. Mineralogy and Petrology, v. 43, p. $125-147$.

Heming, R. F., 1974, Geology and petrology of Rabaul caldera, Papua New Guinea: Geol. Soc. America Bull., v. 85, p. 1253-1264.

1977, Mineralogy and proposed P-T paths of basaltic lavas from Rabaul Caldera, Papua New Guinea: Contr. Mineralogy and Petrology, v. 61, p. 15-33.

Hermes, J. J., 1968, The Papuan geosyncline and the concept of geosynclines: Geologie en Mijnbouw, v. 47, p. 81-97.

1974, West Irian, in Spencer, A. M., ed., Mesozoic-Cenozoic orogenic belts: Geol. Soc. London Spec. Paper 4, p. 475-490.
Hetzel, W. H., 1927, The geology of Kabaena-lsland: Indonesia Geol. Survey, 24 p., map, unpub. rept. (in libr.).

1930a, Over de Geologie der eilanden in de Flores-zee: De Mijningenieur, v. 11, no. 3, p. 53-56.

1930b, Over de Geologie der Toekang-Besi Eilanden: De Mijningenieur, v. 11, no. 3, p. 51-53.

1937, Geological description of the island of Boeton: Indonesia Geol. Survey unpub. rept. 20/dc (in libr.).

Higgins, G. E., and Saunders, J. B., 1974, Mud volcanoes--Their nature and origin: Naturforschenden Gesellschaft Basel, Verh., v. 84, p. $101-152$

Hilde, T. W. C., and Engel, C. G., 1967, Age, composition, and tectonic setting of the granite island, Hon Trung-Long, off the coast of South Viet Nam: Geol. Soc. America Bull, v. 78, p. 1289-1294.

Hilde, T. W. C., Uyeda, Seiya, and Kroenke, Loren, 1977, Evolution of the western Pacific and its margin: Tectonophysics, v. 38, p. 145-165.

't Hoen, C. W. A. P., 1930 Geologische overzichtskaart van den Nederlandsch-Indischen archipel: Toelichting.bij blad 16 (Midden-Java), scale 1:1,000,000, Jaarboek Mijnwezen Nederlandsch-Oost-Indië, 1929, Verh., v. 58, p. 1-72.

't Hoen, C. W. A. P., and Ziegler, K. G. J., 1917, Verslag over de resultaten van geologisch-mijnbouwkundige verkenningen en opsporingen in Zuidwest-Celebes: Jaarboek Mijnwezen Nederlandsch Oost-Indië, 1915, Verh., v. 44 , pt. 2 , p. $237-363$.

Hohnen, P. D., 1970, Geology of New Ireland: Australia Bur. Mineral Resources, Geology and Geophysics Rec. 1970/49, 38 p.

Holcombe, C. J., 1977, How rigid are the lithospheric plates? Fault and shear rotations in southeast Asia: Geol. Soc. London Jour., v. 134, p. 325-342.

Hon, Victor, 1975, Some analyses of the Serian Volcanics from the Kuap area: Malaysia Geol. Survey Annual Report 1975, p. 212- 220 [1978].

Horwitz, R. C., 1967, Provisional subdivisions of the Precambrian of Western Australia: Western Australia Dept. Mines 1966, Ann. Rept., p. 125.

Hosking, K. F. G., 1969, Aspects of the geology of the tin-fields of south-east Asia: Bangkok, Internat. Tin Coucil, 41 p.

1970, The primary tin deposits of south-east Asia: Minerals Sci. and Eng., v. 2, no. 4, p. 24-50.

1972, Primary tin mineralization of West Malaysia: Geol. Soc. Malaysia Newsletter 34, Annex, p. 24-28.

Houtz, R. E., Hayes, D. E., and Markl, R. G., 1977, Kerguelen Plateau bathymetry, sediment distribution and crustal structure: Marine Geol., v. 25, p. $95-130$.

Hsü, K. J., 1968, Principles of melanges and their bearing on the Franciscan-Knoxville paradox: Geol. Soc. America Bull., v. 79, p. 1063-1074.

Hsü, K. J., and Ohrbom, Richard, 1969, Melanges of San Francisco peninsula-geologic reinterpretation of type Franciscan: Am. Assoc. Petroleum Geologists Bull., v. 53, p. 1348-1367.

Hsu, M. T., I971, Seismicity of Taiwan and some related problems: Internat. Inst. Seismology and Earthquake Eng. Bull., v. 8, p. 41-160.

Hughes, G. W., and Turner, C. C., 1977, Upraised Pacific Ocean floor, southern Malaita, Solomon Islands: Geol. Soc. America Bull., v. 88, p. 412-424.

Hughes, l. G., and Bateson, J. H., 1968, Thailand: Great Britain Inst. Geol. Sci., 1967 Ann. Rept., p. 122-123.

Hutchison, C. S., 1973, Tectonic evolution of Sundaland-A Phanerozoic synthesis: Geol. Soc. Malaysia Bull. 6, p. 61-86.

1975, Correlation of Indonesian active volcanic geochemistry with Benioff zone depth: Geologie en Mihnbouw, v. 54, p. 157-168.

1976 , Indonesian active volcanic arc-K, $\mathrm{Sr}$, and $\mathrm{Rb}$ variation with depth to the Benioff zone: Geology, v. 4, p. 407-408.

Hutchison, C. S., and Dhonau, T. J., 1969, Deformation of an alpine ultramafic association in Darvel Bay, East Sabah, Malaysia: Geologie en Mijnbouw, v. 48, p. 481-494. 
1971, An alpine association of metbasites and ultrabasic rocks in Darvel Bay, east Sabah, Borneo: Great Britain Inst. Geol. Sci., Overseas Geol. and Mineral Resources, v. 10, no. 4, p. 289-308.

Hutchison. D. S., 1975, Basement geology of the North Sepik region, Papua New Guinea: Australia Bur. Mineral Resources, Geology and Geophysics, Rec. 1975/162, 53 p.

Hutchison, D. S., and Norvick, M., 1975a, Wewak: Papua New Guinea Geol. Survey, 1:250,000 Geol. Ser., sheet SA 54-16.

1975b, Vanimo: Papua New Guinea Geol. Survey, 1:250,000 Geol. Ser., sheet SA 54-11.

Ichiye, Takashi, 1971, Continental breakup by nonstationary mantle convection created with differential heating of the crust: Jour. Geophys. Research, v. 76, p. 1139-1153.

Indonesia Geological Survey, 1965, Geologic map of Indonesia: U.S. Geol. Survey Misc. Geol. Inv. Map 1-414, scale 1:2,000,000. sheets.

1970a, Geologic map of southeast Kalimantan: scale 1:500,000, 2

1970b, Peta geologi Kalimantan Barat dan Barat-Daja: scale 1:500,000, 4 sheets.

Ingle, J. C., Jr., and Karig, D. C., 1973, Leg 31, western Pacific floor: GeoTimes, v. 18 , no. 10 , p. $22-25$.

International Nickel Indonesia, 1972, Laterite deposits in the southeast arm Sulawesi [abs.]: Geol. Soc. Malaysia Newsletter 34, Annex, p. 32.

Irving, E. M., 1950, Review of Philippine basement geology and its problems: Philippine Jour. Sci., v. 79, p. 267-307.

1952, Geological history and petroleum possibilities of the Philippines: Am. Assoc. Petroleum Geologists Bull., v. 36, p. 437-476.

Isacks, Bryan, and Molnar, Peter, 1969, Mantle earthquake mechanisms and the sinking of the lithosphere: Nature, v. 223, p. 1121-1124.

1971, Distribution of stresses in the descending lithosphere from a global survey of focal-mechanism solutions of mantle earthquakes: Reviews Geophys. and Space Physics, v. 9, p. 103-174.

Isacks, Bryan, Oliver, Jack, and Sykes, L. R., 1968, Seismology and the new global tectonics: Jour. Geophys. Research, v. 73, p. 5855-5899.

Jackson, E. D., and Shaw, H. R., 1975, Stress fields in central portions of the Pacific plate--delineated in time by linear volcanic chains: Jour. Geophys. Research, v. 80, p. 1861-1874.

Jacob, K., 1954, The occurrence of radiolarian cherts in association with ultra-mafic intrusives in the Andaman lslands, and its significance in sedimentary tectonics: India Geol. Survey Recs., v. 83, pt. 2, p. $397-422$.

Jacobson, G., 1970, Gunong Kinabalu area, Sabah, Malaysia: Malaysia Geol. Survey Rept. 8, 111 p., [1972].

Jacoby, W. R., 1973, Gravitational instability and plate tectonics, in De Jong, K. A., and Scholten, Robert, eds., Gravity and tectonics: New York, John Wiley and Sons, p. 17-33.

Jahn, B.-M., Chen, P. Y., and Yen T. P., 1976, Rb-Sr ages on granitic rocks in southeastern China and their tectonic significance: Geol. Soc. America Bull, v. 86, p. 763-776.

Jakeš, P., and White, A. J. R., 1970, K/R b ratios of rocks from island arcs: Geochim. et Cosmochim. Acta, v. 34, p. 849-856.

James, D. E., Brooks, Christopher, and Cuyubamba, Arthur, 1976, Andean Cenozoic volcanism - magmagenesis in the light of strontium isotopic composition and trace-element geochemistry: Geol. Soc. America Bull., v. 87 , p. $592-600$.

Jaques, A. L., 1976a, High- $\mathrm{K}_{2} \mathrm{O}$ island-are volcanic rocks from the Finisterre and Adelbert Ranges, Papua New Guinea: Geol. Soc. America Bull., v. 87, no. 6, p. 861-867.

1976b, Explanatory notes on the Admiralty Islands geological map: Papua New Guinea Geol. Survey Rept. 76/15, 31 p.

Jaques, A. L., and Robinson, G. P., 1975, Bogia: Papua New Guinea Geol. Survey, 1:250,000 Geol. Ser., sheet SB 55-1.

1977, The continent/island arc collision in northern Papua New Guinea: Australia Bur. Mineral Resources, Geology and Geophysics, BMR Jour., v. 2, p. 289-303.
Jaques, A. L., and Webb, A. W., 1975, Geochronology of "porphyry copper" intrusives from Manus Island, Papua New Guinea: Papua New Guinea Geol. Survey Rept. 75/5, 8 p.

Javanaphet, J. C., 1969, Geological map of Thailand: Thailand Dept. Mineral Resources, scale 1:1,000,000, 2 sheets, [1971].

Jeffreys, Harold, 1974, Theoretical aspects of continental drift: Am. Assoc. Petroleum Geologists Mem. 23, p. 395-405.

Jenkins, D. A. L., 1974, Detachment tectonics in western Papua New Guinea: Geol. Soc. America Bull., v. 85, p. 533-548.

Jenkins, D. A. L., and Martin, A. J., 1969, Recent investigations into the geology of the Southern Highlands, Papua: U.N. ECAFE Symp. Devel. Petroleum Resources of Asia and Far East, 4th Canberra, Australia, 1969, 11 p.

Jischke, M. C., 1975, On the dynamics of descending lithospheric plates and slip zones: Jour. Geophys. Research, v. 80, p. 4809-4813.

John, T. U., 1963, Geology and mineral deposits of east-central Balabac Island, Palawan Province, Philippines: Econ. Geology, v. 58, p. 107-130.

Johnson, B. D., Powell, C. M., and Veevers, J. J., 1976, Spreading history of the eastern Indian Ocean and Greater India's northward flight from Antarctica and Australia: Geol. Soc. American Bull., v. 87, no. 11, p. 1560-1566.

Johnson, C. G., Alvis, R. J., and Hetzler, R. L., 1960, Military geology of Yap Islands, Caroline Islands: U. S. Army Engineers, Pacific, Intelligence Dossier Strategic Study Carolines, $164 \mathrm{p}$.

Johnson, G. L., Egloff, J., and Hemler, L. G., 1974, Geophysical observations between Hawaii and Australia: Pacific Sci., v. 28, no. 2, p. 191-205.

Johnson, R. W., 1970a, Seismicity in the Bismarck volcanic arc: Australia Bur. Mineral Resources, Geology and Geophysics Rec. 1970/35, 5 p.

1970b, Volcanoes of New Britain--A summary of preliminary petrological data: Australia Bur. Mineral Resources. Geology and Geophysics Rec. 1970/72, p. 2-5.

1975, Volcanology and ore genesis [abs.]: Australia Bur. Mineral Resources, Geology and Geophysics Rept. 189, p. 86-87.

1976a, Potassium variations across the New Britain island arc: Earth and Planetary Sci. Letters, v. 31, no. 1, p. 184-191.

1976b, Late Cainozoic volcanism and plate tectonics at the southern margin of the Bismarck Sea, Papua New Guinea, in Johnson, R. W., ed., Volca nism in Australasia: Amsterdam, Elsevier, p. 101-116.

Johnson, R. W., and Blake, D. H., 1972, The Cape Hoskins area, southern Willaumez Peninsula, the Witu Islands and associated volcanic centres, New Britain - volcanic geology with petrology: Australia Bur. Mineral Resources, Geology and Geophysics, Rec. 1972/133, 102 p.

Johnson, R. W., and Davies, R. A., 1972, Volcanic geology of the St. Andrew Strait islands, Bismarck Sea, Papua New Guinea: Terr. Papua New Guinea Geol. Survey, Note Inv. 72-002, 29 p.

Johnson, R. W., Mackenzie, D. E., and Smith, l. E. M., 1971, Seismicity and late Cenozoic volcanism in parts of Papua-New Guinea: Tectonophysics, v. 12, p. 15-22.

1978, Volcanic rock associations at convergent plate boundaries-reappraisal of the concept using case histories from Papua New Guinea: Geol. Soc. America Bull., v. 89, p. 96-106.

Johnson, R. W., Mackenzie, D. E., Smith, I. E. M., and Taylor, G. A M., 1973, distribution and petrology of late Cainozoic volcanoes in Papua New Guinea, in Coleman, P. J., ed., The western Pacific: Nedlands, Western Australia, Western Australia Univ. Press, p. 523-534.

Johnson, R. W., and Smith, I. E. M., 1974, Volcanoes and rocks of St. Andrew Strait, Papua New Guinea: Geol. Soc. Australia Jour., v. 21, p. 333-351.

Johnson, R. W., Smith, I. E. M., and Taylor S. R., 1978, Hot-spot volcanism in St. Andrew Strait, Papua New Guinea-geochemistry of a Quaternary bimodal rock suite: Australia Bur. Mineral Resources, Geology and Geophysics, BMR Jour., v. 3, p. 55-69. 
Johnson, R. W., Taylor, G. A. M., and Davies, R. A., 1972, Geology and petrology of Quaternary volcanic islands off the north coast of New Guinea: Australia Bur. Mineral Resources, Geology and Geophysics Rec. 1972/21, 127 p.

Johnson, R. W.. Wallace, D. A., and Ellis, D. J., 1976, Feldspathoid-bearing potassic rocks and associated types from volcanic islands off the coast of New Ireland, Papua New Guinea-a preliminary account of geology and petrology, in Johnson, R. W., ed., Volcanism in Australasia: Amsterdam, Elsevier, p. 297-3I6.

Johnson, Tracy, and Molnar, Peter, 1972, Focal mechanisms and plate tectonics of the southwest Pacific: Jour. Geophys. Research, v. 77, p. 5000-5032.

Johnston, J. C., and Walls, P. J., 1975, Geology of the Telupid area, Sabah: Malaysia Geol. Survey 1973 Ann. Rept. p. 213-220.

Jones, C. R., 1968, Lower Paleozoic rocks of Malay Peninsula: Am. Assoc. Petroleum Geologists Bull., v. 52, p. 1259-1278.

1970a, On a Lower Devonian fauna from Pahang. West Malaysia: Geol. Soc. Malaysia Bull. 3, p. 63-75.

1970b. The geology and mineral resources of the Grik area, upper Perak: West Malaysia Geol. Survey Dist. Mem. 11, 144 p.

1973. The Siluro-Devonian graptolite faunas of the Malay Peninsula: Great Britain Inst. Geol. Sci., Overseas Geol. and Mineral Reources, no. 44,28 p.

Jones, C. R., Gobbett, D. J., and Kobayashi. Teiichi, 1966, Summary of fossil record in Malaya and Singapore 1900-1965, in Kobayashi, T., and Toriyama, R., eds., Geology and palaeontology of Southeast Asia, v. 2: Tokyo Univ. Press, p. 309-359.

Jones, D. K., and Pearson, G. R., 1972, The tectonic elements of the Perth Basin: Australian Petroleum Explor. Assoc. Jour., v. 12, pt. 1, p. 17-22.

Jones, H. A., 1973, Marine geology of the northwest Australian continental shelf: Australia Bur. Mineral Resources, Geology and Geophysics Bull. 136, 102 p.

Jones, J. G., and Roots, W. D., 1974, Evolution of the Tasman Sea: Nature, v. 252 , p. $613-614$

Jones, M. R., Reed, B. L., Doe, B. R., and Lanphere, M. A., 1977, Age of tin mineralization and plumbotectonics, Belitung, Indonesia: Econ. Geology, v. 72, p. 745-752.

de Jongh, Munniks, 1915, Aantekiningen over de Tidoengsche Landen (Res. Z. en O. Afd. van Borneo): Jaarboek Mijnwezen Nederlandsch Oost-Indië, 1913, Verh., v. 42, p. 22-35.

Jongmans, W. J., 1937, The flora of the upper Carboniferous of Djambi (Sumatra, Netherl. India) and its possible bearing on the paleogeography of the Carboniferous: Cong. Av. des Études Stratigraphie Carbonifère, 2d, Heerlen, 1935, Comptes rendus, v. 1, p. 345-362

1940, Beiträge zur Kenntnis der Karbonflora von niederlandisch Neu-Guinea: Geologisch Bur. Mijngebied Heerlen, Mededeel. 1938-1939, p. 263-274.

Jongmans, W. J., and Gothan, W., 1935, Die paläobotanischen Ergebnisse der Djambi-Expedition 1925: Jaarboek Mijnwezen Nederlandsch-Indië, 1930, Verh., v. 59, pt. 2, p. 71-201.

Jongsma, Derk, 1974, Marine geology of the Arafura Sea: Australia Bur. Mineral Resources, Geology and Geophysics Bull. 157, 73 p.

Jongsma, Derk, and Petkovic, Peter, 1977, The structure of the Naturaliste Plateau and Trough: Australian Petroleum Explor. Assoc. Jour., v. 17, pt. 1, p. 3-12.

Jordan, T. H., 1974, Some comments on tidal drag as a mechanism for driving plate motions: Jour, Geophys. Research, v. 79, p. 2141-2142.

Kaharoeddin, F. A., Weaver, F. M., and Wise, S. W., Jr., 1973, Cretaceous and Paleogene cores from the Kerguelen Plateau, Southern Ocean: Antarctic Jour. U.S., v. 8, p. 297-298.

Kamili, Z. A., Kingston, J., Achmad, Z., Wahab, A., Sosromihardjo, S., and Crausaz, C. U., 1977, Contribution to the pre-Baong stratigraphy of North Sumatra: Indonesian Petroleum Assoc., 5th Ann. Convention, Jakarta 1976, Proc., v. 2., p. 91-99.
Kamili, Z. A., and Naim, A. M., 1973, Stratigraphy of lower and middle Miocene sediments in North Sumatra Basin: Indonesian Petroleum Assoc., 2d Ann. Convention, Jakarta 1973, Proc., p. 53-71.

Kane, M. F., 1972, Rotational inertia of continents-a proposed link between polar wandering and plate tectonics: Science, v. 175, p. 1355-1357.

Karig, D. E., 1970, Ridges and basins of the Tonga-Kermadec island arc system: Jour. Geophys. Research, v. 75, p. 239-254.

1971a, Origin and development of marginal basins in the western

Pacific: Jour. Geophys. Research, v. 76, p. 2542-2561.

$1971 \mathrm{~b}$, Structural history of the Mariana Island arc system:

Geol. Soc. America Bull., v. 82, p. 323-344.

1972, Remnant arcs: Geol. Soc. America Bull., v. 83, p. 1057-1068.

1973a, Plate convergence between the Philippines and the Ryukyu lslands: Marine Geology, v. 14, p. 153-168.

1973b, Comparison of island arc-marginal basin complexes of the north-west and south-west Pacific, in Coleman, P. J., ed., The Western Pacific: Nedlands, Western Australia, Western Australia Univ. Press, p. 355-364.

Karig. D. E., Anderson, R. N., and Bibee, L. D., 1978, Characteristics of back arc spreading in the Mariana Trough: Jour. Geophys. Research, v. 83, p. 1213-1226.

Karig, D. E., Ingle, J. C., Jr., and others, 1975, Initial reports of the Deep Sea Drilling Project, V. 31,: Washington, U. S. Govt. Printing Office, $927 \mathrm{p}$.

Karig, D. E., and Mammerickx, Jacqueline, 1972, Tectonic framework of the New Hebrides island arc: Marine Geology, v. 12, p. 187-205.

Karig, D. E., and Moore, G. F., 1975, Tectonic complexities in the Bonin arc system: Tectonophysics, v. 27, p. 97-118.

Karig. D. E., and others, 1973, Origin of the West Philippine Basin: Nature, v. 246, p. $458-461$

Karig, D. E., and Sharman, G. F., III, 1975, Subduction and accretion in trenches: Geol. Soc. America Bull., v. 86, p. 377-389.

Karunakaran, C., Pawde, M. B., Raina, V. K., Ray, K. K., and Saha, S. S., 1964, Geologoy of South Andaman lsland, India: Internat. Geol. Cong., 22d, Rept., 1964, Sec. 11, p. 79-100, [1969?].

Karunakaran, C., Roy, K. K., and Saha, S. S., 1968, Tertiary sedimentation in the Andaman-Nicobar geosyncline: Geol. Soc. India Jour., v. 9, no. 1, p. 32-39.

Kastowo, 1975, Geologic map of the Majenang quadrangle, Java: Indonesia Geol. Survey, scale 1:100,000.

Kastowo and Leo, G. W., 1973, Geologic map of the Padang quadrangle, Sumatra: Indonesia Geol. Survey, scale 1:250,000.

Katili, J. A., 1962, On the age of the granitic rocks in relation to the structural features of Sumatra: Am. Geophys. Union Geophys. Mon. 6, p. 116-121

1967, Structure and age of the Indonesian tin belt with special reference to Bangka: Tectonophysics, v. 4, p. 403-418.

1970a, Additional evidence of transcurrent faulting in Sumatra and Sulawesi: Bandung Natl. Inst. Geology and Mining Bull. 3, no. 3, p. 15-28.

1970b, Large transcurrent faults in Southeast Asia with special reference to Indonesia: Geol. Rundschau, v. 59, p. 581-600.

1973a, Plate tectonics and its significance in the search for mineral deposits in western Indonesia: U.N. ECAFE, Comm. Co-ordination Offshore Prospecting (CCOP) Tech. Bull. 7, p. 23-37.

1973b, Geochronology of west Indonesia and its implication on plate tectonics: Tectonophysics, v. 19, p. 195-212.

1974, Geological environment of the Indonesian mineral deposits: Indonesia Geol. Survey Econ. Geol. Ser. 7, 18 p.

1975, Volcanism and plate tectonics in the Indonesian island arcs: Tectonophysics, v. 26, p. 165-188.

Katili, J. A., and Hehuwat, 1967, On the occurrence of large transcurrent faults in Sumatra, Indonesia: Osaka City Univ. Jour. Geosciences, v. 10, p. $5-17$. 
Katsumata, Mamoru, and Sykes, L. R., 1969, Seismicity and tectonics of the western Pacific $\times$ lzu-Mariana-Caroline and Ryukyu-Taiwan regions: Jour. Geophys. Research, v. 74, p. 5923-5948.

Kaula, W. M., 1972, Global gravity and mantle convection: Tectonophysics, v. 13, p. 341-359.

Kaulback, J. A., and Veevers, J. J., 1969, Cambrian and Ordovician geology of the southern part of the Bonaparte Gulf Basin, Western Australia: Australia Bur. Mineral Resources, Geology and Geophysics Rep. 109, 80 p.

Kawai, Naoto, Nakajima, Tadashi, and Hirooka, Kimio, 1971, The evolution of the island arc of Japan and the formation of granites in the circum-Pacific belt: Jour. Geomagnetism and Geoelectricity, v. 23, p. 267-293.

Kaye, Peter, 1972, Untitled discussion: Australian Petroleum Explor. Assoc. Jour., v. 12, pt. 2, p. 53-54.

Kaye, Peter, Edmond, G. M., and Challinor, A., 1972, The Rankin Trend, northwest shelf, Western Australia: Australian Petroleum Explor. Assoc. Jour., v. 12, pt. 1, p. 3-8.

Keij, A. J., 1965, Late Cretaceous and Palaeogene arenaceous Foraminifera from flysch deposits in northwestern Borneo: Borneo Region Malaysia Geol. Survey, 1964 Ann. Rept., p. 155-158.

Kelleher, John, and McCann, William, 1976, Buoyant zones, great earthquakes, and unstable boundaries of subduction: Jour. Geophys. Research, v. 81, p. $4885-4896$.

Kemp, E. M., and Harris, W. K., 1975, The vegetation of Tertiary islands on the Ninetyeast Ridge: Nature, v. 258, p. 303-307.

Kennett, J. P., and Thunell, R. C., 1975, Global increase in Quaternary explosive volcanism: Science, v. 187, p. 497-503.

Kenyon, C. S., and Beddoes, L. R., Jr., 1977, Geothermal gradient map of Southeast Asia: South East Asia Petroleum Explor. Soc. and Indonesian Petroleum Assoc., $50 \mathrm{p}$.

Ketner, K. B., Kastowo, Modjo, Subroto, Naeser, C. W., Obradovich, J. D., Robinson, Keith, Suptandar, Tatan, and Wikarno, 1976, Pre-Eocene rocks of Java, Indonesia: U.S. Geol. Survey Jour. Research, v. 4, p. 605-614.

de Keyser, F., and Lucas, F. G., 1968, Geology of the Hodgkinson and Laura Basins, north Queensland: Australia Bur. Mineral Resources, Geology and Geophysics Bull. 84, 254 p.

Khoo, K. K., 1974, Brief geology of the Seremban area, sheet 103: Malaysia Geol. Survey 1972 Ann. Rept., p. 86-103.

1975, Geology of the Kuala Pilah area, sheet 104, Negeri Sembilan: Malaysia Geol. Survey 1974 Ann. Rept., p. 99-102.

Khoon, S. Y., 1971, The geology of new series map sheet 95 , Jelebu district, Negeri Sembelan: Malaysia Geol. Survey 1969 Ann. Rept., p. 72-8I.

Kicinski, F. M., and Belford, D. J., 1956, Notes on the Tertiary succession and foraminifera of Manus Island: Australia Bur. Mineral Resources, Geology and Geophysics Rept. 25, p. 71-75.

Kieft, C., 1952, Accessory transparent minerals in tin granites of North Banka, Indonesia: Koninkl. Nederlandsch Akad. Wetensch. Proc., ser. B, v. 55 , p. 140-149.

Kimpe, W. F. M., 1944, De eruptiva van het Siboemboen Gebergte en hun contactgesteenten (Padangsche Bovenlanden, Sumatra): Amsterdam Univ. Geol. Inst., Mededeling, no. 132, 141 p.

Kimura, Toshio, and Jones, C. R., 1966, Geologic structures in the northeastern and southern parts of the Langkawi Islands, northwest Malaya, in Kobayashi. Teiichi, and Toriyama, Ryuzo, eds., Geology and palaeontology of Southeast Asia, V. 3: Tokyo Univ. Press, p. 123-134.

King, P. B., 1969a, Tectonic map of North America: U.S. Geol. Survey, scale 1:5,000,000.

$1969 \mathrm{~b}$, The tectonics of North America-a discussion to accompany the tectonic map of North America, scale 1:5,000,000: U.S. Geol. Survey Prof. Paper 628, 95 p.

Kinkel, A. R., Santos-Yñigo, Luis, Francisco, F., and Samaniego, S., 1955, Preliminary report on the geology of the copper deposits east of Sipalay, Negros Occidental: Philippine Bur. Mines Rept. Inv. 13, 24 p.
Kintanar, E. R. L., 1966, Petroleum geology of the Philippines: Mineral Resources of the Philippines Geol. Convention, 2d, Manila, 1966, $59 \mathrm{p}$.

Kirk, H. J. C., 1957, The geology and mineral resources of the upper Rajang and adjacent areas: British Terr. Borneo Geol. Survey Dept., Mem. 8, $181 \mathrm{p}$.

1962, The geology and mineral resources of the Semporna Peninsula, North Borneo: British Terr. Borneo Geol. Survey Dept., Mem. 14, 178 p.

1968, The igneous rocks of Sarawak and Sabah: Borneo Region Malaysia Geol. Survey, Bull. 5, 210 p.

Kistler, R. W., and Peterman, Z. E., 1972, Variations in Sr, Rb, K, Na and initial $\mathrm{Sr}^{87} / \mathrm{Sr}^{86}$ in Mesozoic granitic rocks in California: Geol. Soc. America Abs. with Programs, v. 4, p. 562-563.

Klemme, H. D., 1975, Geothermal gradients, heat flow and hydrocarbon recovery, in Fischer, A. G., and Judson, Sheldon, eds., Petroleum and global tectonics: Princeton Univ. Press, p. 251-304.

Klompé, T. H. F., 1954, Geological map of Indonesia: Indonesia Geol. Survey, scale 1:5,000,000.

1956, The structural importance of the Sula Spur (Indonesia): Pacific Sci. Cong., 8th, Quezon City, Philippines, 1955, Proc., v. 2A, p. 869-889.

Klompé, T. H. F., Katili, J. A., Johannas, and Soekendar, 1961, Late Paleozoic-early Mesozoic volcanic activity in the Sunda Land area: Pacific Sci. Cong. 9th, Bangkok, 1957, Proc., v. 12, p. 204-216.

Knopoff, Leon, 1967, On convection in the upper mantle: Royal Astron. Soc Geophys. Jour., v. 14, p. 341-346.

Knopoff, Leon, and Leeds, A., 1972, Lithospheric moments and the deceleration of the earth: Nature, v. 237, p. 93-95.

Kobayashi, Teichi, Burton, C. K., and Tokyuama, A., 1966, The Daonella and Halobia facies of the Thai-Malay Peninsula compared with those of Japan, in Kobayashi, Teiichi, and Toriyama, Ryuzo, eds., Geology and palaeontology of Southeast Asia, V. 3: Tokyo Univ. Press, p. 98-122.

von Koenigswald, G. H. R., 1967, An upper Eocene mammal of the family Anthracotheriidae from the island of Timor, Indonesia: Koninkl. Nederlandse Aka. Wetensch. Proc., v. B-70, p. 528-533.

Koesoemadinata, R. P., 1969, Outline of geologic occurrence of oil in Tertiary basins of west Indonesia: Am. Assoc. Petroleum Geol. Bull., v. 53 , p. $2368-2376$.

Kogan, M. G., 1976, Gravity anomalies and main tectonic units of the southwest Pacific: Jour. Geophys. Research, v. 81, p. 5240-5248.

Koike, Toshio, Hashimoto, Wataru, and Sato, Tadashi, 1968, Fusulinid-bearing limestone pebbles found in the Agbahag conglomerate, Mansalay, Oriental Mindoro, in Kobayashi, Teiichi, and Toriyama, Ryuzo, eds., Geology and palaeontology of Southeast Asia, V. 4: Tokyo Univ. press, p. 198-210.

Koolhoven, W. C. B., 1930, Verslag over een verkenningstocht in den Oostarm van Celebes en den Banggai-Archipel: Jaarboek Mijnwezen Nederlandsch-Indië, 1929, Verh., v. 58, p. 187-228.

1932, De geologie van het Maliliterrein (Midden Celebes): Jaarboek Mijnwezen Nederlandsch-Indië, 1930, Verh., v. 59, pt. 3, p. 127-152.

1936, Het primaire voorkomen van den zuid-Borneo-diamant: Koloniën Nederland Geol.-Mijnbouw Genoot., Verh., Geol. Ser., v. 11 , p. 189-23I.

Koopmans, B. N., 1965, Structural evidence for a Palaeozoic orogeny in northwest Malaya: Geol. Mag., v. 102, no. 6, p. 501-520.

1966, A structural map of north and central Pahang: [Singapore] Jour. Tropical Geography, v. 22, p. 24-29.

1967. Deformation of the metamorphic rocks and the Chert-Spilite Formation in the southern part of the Darvel Bay area, Sabah: Borneo Region Malaysia Geol. Survey, Bull. 8, p. 14-24.

1968, The Tembeling Formation-a litho-stratigraphic description (West Malaysia): Geol. Soc. Malaysia Bull. 1, p. 23-43.

Koperberg, M., 1929, Bouwstoffen voor de geologie van de Residentie Manado: Jaarboek Mijnwezen Nederlandsch-Indië, 1928, Verh., v. 57, pt. 1, 397 p., pt. 2, 446 p., and atlas. 
Kraus, G. P., and Laws, R. A., 1974, Regional geology of Bonaparte Gulf-Timor Sea area, northwest Australia: Oil and Gas Jour., v. 72, no. 46, p. 98-101, and no. 47, p. 160-162.

Krause, D. C., 1965, Submarine geology north of New Guinea: Geol. Soc. America Bull., v. 76, p. 27-42.

1967, Bathymetry and geologic structure of the north-western Tasman Sea-Coral Sea-South Solomon Sea area of the south-western Pacific Ocean: New Zealand Oceanographic Inst. Mem. 41, 50 p.

1973, Crustal plates of the Bismarck and Solomon Seas, in Fraser, Ronald, compiler, Oceanography of the South Pacific 1972: New Zealand Natl. Comm. for UNESCO, Wellington, p. 271-280.

Kroenke, L. W., 1972, Geology of the Ontong Java Plateau: Hawaii Univ. Ph.D. thesis, $119 \mathrm{p}$.

1973. Crustal plates of the Bismarck and Solomon Seas, in Fraser, Ronald, compiler, Oceanography of the South Pacific 1972: Wellington, New Zealand Natl. Comm. for UNESCO, p. 271-280.

Kroenke, L. W., Moberly, Ralph, Jr., Winterer, E. L., and Heath, G. R., 1971. Lithologic interpretation of continuous reflection profiling, Deep Sea Drilling Project, Leg 7 in Winterer, E. L., and others, Initial reports of the Deep Sea Drilling Project, V. 7, pt. 2: Washington, U.S. Govt. Printing Office. p. 1161-1226.

Kroenke, L. W., and Scott, Robert, 1978, Old questions answered-and new ones asked: GeoTimes, v. 23, no. 7, p. 20-23.

Krol, L. H., 1920, Over de geologie van een gedeelte van der Zuider-en Oosterafdeeling van Borneo: Jaarboek Mijnwezen Nederlandsch Oost-Indië, 1981, Verh., v. 47, pt. 1, p. 281-367.

Krumbeck, Lothar, 1914, Obere Trias von Sumatra: Palaeontographica, supp. v. 4, pt. 2, p. 195-296.

Kudryavtsev, G. A., Agentov, V. B, Gatinskiy, Yu. G., and Mishina, A. V., 1971, Geologiya Yugo-vostochnoy Azii-Indokitay: Minist. Geol. SSSR, Nauchno-Issled. Lab. Geologil Zarubezhnykh Stran, Bypusk 19, Leningrad, Izdat. Nedra, 239 p.

Kuenen, P. H., 1942, Obilatoe, Kisar and Siboetoe: Geologie en Mijnbouw, v. 4 , no. $11-12$, p. $81-90$

1949. Ambon and Haroekoe: Koninkl. Nederlands Geol.Mijnbouw, Genoot., Verh., Geol. Ser., v. 15, p. 44-62. 1950, Marine geology: New York, John Wiley \& Sons, 568 p.

Kündig. E., 1956, Geology and ophiolite problems of East Celebes: Koninkl. Nederlandsch Geol.-Mijnbouw. Genoot., Verh., Geol. Ser. v. 16, p. 210-235.

Lacey, W. S., 1975, Some problems of 'mixed' floras in the Permian of Gondwanaland, in Campbell, K. S. W., ed., Gondwana geology: Canberra, Australian Natl. Univ. Press, p. 125-134.

Laird, M. G., Cooper, R. A., and Jago, J. B., 1977, New data on the lower Palaeozoic sequence of northern Victoria Land, Antarctica, and its significance for Australian-Antarctic relations in the Palaeozoic: Nature, v. 265, p. 107-110.

Lambert, R. St. J., 1971, The pre-Pleistocene Phanerozoic time-scale - a review: Geol. Soc. London Spec. Pub. 5, p. 9-31.

LaMoreaux, P. E., Charaljavanaphet, Jumchet, Jalichan, Nitipat, Chiengmai, P. P. N., Bunnag, Din, Thavisri, Adul, and Rakprathum, Chumphon, 1958, Reconnaissance of the geology and ground water of the Khorat Plateau, Thailand: U.S. Geol. Survey Water-Supply Paper $1429,62 \mathrm{p}$.

Lang, W. J., and Sun, R. J., 1966, Seismicity, V. 3, of Atlas of the Sino-Soviet bloc to support detection of underground nuclear testing [Atlas of Asia and eastern Europe to support detection of underground nuclear testing]: U.S. Geol. Survey.

Larson, E. E., Reynolds, R. L., Ozima, M., Aoki, Y., Kinoshita, H., Zasshu, S., Kawai, N., Nakajima, I., Hirooka, K., Merrill, R., and Levi, S., 1975. Paleomagnetism of Miocene volcanic rocks of Guam and the curvature of the southern Mariana island arc: Geol. Soc. America Bull., v. 86 , p. $346-350$.

Larson, R. L., 1975, Late Jurassic sea-floor spreading in the eastern Indian Ocean: Geology, v. 3, p. 69-71.

1977, Early Cretaceous breakup of Gondwanaland off western Australia: Geology, v. 5, p. 57-60.
Larson, R. L., Carpenter, G. B., and Diebold, J. B., 1978, A geophysical study of the Wharton Basin near the Investigator Fracture Zone: Jour. Geophys. Research, v. 83, p. 773-782.

Larson, R. L., and Chase, C. G., 1972, Late Mesozoic evolution of the western Pacific Ocean: Geol. Soc. America Bull., v. 83, p. 3627-3644.

Larson, R. L., Menard, H. W., and Smith, S. M., 1968, The Gulf of California: a result of ocean-floor spreading and transform faulting: Science, v. 161, p. 781-784.

Larson, R. L., and Moberly, Ralph, 1973, Leg 32, Deep Sea Drilling Project: GeoTimes, v. 18, no. 12, p. 14-17.

Laudon. T. S., 1968, Land gravity survey of the Solomon and Bismarck Islands: Am. Geophys. Union Geophys. Mon. 12, p. 279-295.

Laughton, A. S., Matthews, D. H., and Fisher, R. L., 1970, The structure of the Indian Ocean, in Maxwell, A. E., ed., The Sea, V. 4, Pt. 2: New York, Wiley-Interscience, p. 543-586.

Laws, M. J., 1971, The use of the seismic refraction method in Papua: Australian Petroleum Explor. Assoc. Jour., v. 11, pt. 1, p. 107-114.

Laws, R. A., and Kraus, G. P., 1974, The regional geology of the Bonaparte Gulf Timor Sea area: Australian Petroleum Explor. Assoc. Jour., v. 14 , pt. 1, p. 77-84.

Lawver, L. A., Curray, J. R., and Moore, D. G., 1975, Magnetics in the Andaman Sea and the effect of high sedimentation rates [abs.]: EOS (Am. Geophys. Union Trans.), v. 56, p. 1064.

Lawver, L. A., Curray, J. R., and Moore, D. G., 1975, Magnetics in the anomalies and crustal dilation in the Lau Basin: Earth and Planetary Sci. Letters, v. 33, p. 27-35.

Lee, D. T. C., 1968, Sandakan Peninsula, eastern Sabah: Borneo Region Malaysia Geol. Survey, 1967 Ann. Rept., p. 53-58.

Leeman, W. P., and Manton, W. I., 1971, Strontium isotopic composition of basaltic lavas from the Snake River Plain, southern Idaho: Earth and Planetary Sci. Letters, v. 11, p. 420-434.

Leitch, E. C., 1974, The geological development of the southern part of the New England fold belt: Geol. Soc. Australia Jour., v. 21, p. 133-156.

Lemoine, Marcel, 1959, Un example de tectonique chaotique-Timor: Rev. Géographie Phys. et Géologie Dynam., ser. 2, v. 2, pt. 4, p. 205-230.

Leong, K. M., 1971 a, Peridotite-gabbro problems, with special reference to the Segama Valley and Darvel Bay area, Sabah, East Malaysia: Geol. Soc. Malaysia Newsletter 28, p. 4-13.

197/b, Segama Valley-Darvel Bay area: Malaysia Geol. Survey, 1968 Ann. Rept., p. 120-124.

Le Pichon, Xavier, 1968, Sea-floor spreading and continental drift: Jour. Geophys. Research, v. 73, p. 3661-3697.

Le Pichon, Xavier, Francheteau, Jean, and Sharman, G. F., Jr., 1975, Rigid plate accretion in an inter-arc basin-Mariana Trough: Jour. Physics Earth, v. 23 , p. $251-256$.

Liechti, P., 1967, Über synsedimentäre Tektonic und ihre ölgeologische Bedeutung: Freiberger Forschungshefte, ser. C, no. 229, p. 31-63.

Liechti, P., Roe, F. W., and Haile, N. S., 1960, The geology of Sarawak, Brunei, and the western part of North Borneo: British Terr. Borneo Geol. Survey Dept., Bull. 3, 360 p., portfolio.

van der Linden, W. J. M., 1970, Morphology of the Tasman Sea floor: New Zealand Jour. Geology and Geophysics, v. 13, p. 282-291.

Lister, C. R. B., 1975, Gravitational drive in oceanic plates caused by thermal contraction: Nature, v. 257, p. 663-665.

Liu, H.-S., 1974, On the breakup of tectonic plates by polar wandering: Jour. Geophys. Research, v. 79, p. 2568-2572.

Liu, H.-S., Carpenter, L., and Agreen, R. W., 1974, Plate motion and the secular shift of the mean pole: Jour. Geophys. Research, v. 79, p. 4379-4382.

Lliboutry, L., 1969, Sea-floor spreading, continental drift and lithosphere sinking with an asthenosphere at melting point: Jour. Geophys. Research, v. 74, p. 6525-6540.

von Lóczy, L., 1934, Geologie van Noord Boengkoe en het Bongka-gebied tusschen de Golf van Tomini en de Golf van Tolo in Oost-Celebes. I. Geographie, geologie en tektonik: Koloniën Nederland Geol. Mijnbouw. Genoot. Verh., Geol. Ser., v. 10, p. 219-268. 
Lofting, M. J. W., Crostella, A., and Halse, J. W., 1975, Exploration results and future prospects in the northern Australasian region: World Petroleum Cong., 9th, Tokyo, 1975, Proc., v. 3, p. 65-81.

Loney, R. A., Himmelberg, G. R., and Coleman, R. G., 1971, Structure and petrology of the alpine-type peridotite at Burro Mountain, California, U.S.A.: Jour. Petrology, v. 12, p. 245-309.

Loth, J. E., and Zwierzycki, J., 1926, De kristallijne schisten op Java ouder dan Krijt: De Mijningenieur, v. 2, no. 2, p. 22-25.

Louden, K. E., 1976, Magnetic anomalies in the West Philippine Basin: Am. Geophys. Union Geophys. Mon. 19, p. 253-267.

1977, Paleomagnetism of DSDP sediments, phase shifting of magnetic anomalies, and rotations of the West Philippine Basin: Jour. Geophys. Research, v. 82, p. 2989-3002.

Luck, G. R., 1972, Palaeomagnetic results from Palaeozoic sediments of northern Australia: Royal Astron. Soc. Geophys. Jour., v. 28, p. 475-487.

Ludbrook, N. H., 1965, Tertiary fossils from Christmas Island, Indian Ocean: Geol. Soc. Australia Jour., v. 12, p. 285-294.

Ludwig, W. J., Hayes, D. E., and Ewing, J. I., 1967, The Manila Trench and West Luzon Trough-l. Bathymetry and sediment distribution: Deep-sea Research, v. 14, p. 533-544.

Luyendyk, B. P., 1970, Dips of downgoing lithospheric plates beneath island arcs: Geol. Soc. America Bull., v. 81, p. 3411-3416.

Luyendyk, B. P., and Davies, T. A., 1973, Across the southern Indian Ocean aboard Glomar Challenger: GeoTimes, v. 18, no. 3, p. 16-19.

Luyendyk, B. P., MacDonald, K. C., and Bryan, W. B., 1973, Rifting history of the Woodlark Basin in the southwest Pacific: Geol. Soc. America Bull., v. 84, p. 1125-1134.

MacDonald, G. J. F., 1963, The deep structure of continents: Rev. Geophysics, v. 1, p. 587-665.

Macdonald, K. C., Luyendyk, B. P., and Von Herzen, R. P., 1973, Heat flow and plate boundaries in Melanesia: Jour. Geophys. Research, v. 78, p. $2537-2546$.

MacDonald, S., 1967, The geology and mineral resources of north Kelantan and north Trengganu: West Malaysia Geol. Survey Dist. Mem. 10, 202 p.

Macke, A. F., 1924, Resultaten van een geologisch-mijnbouwkundig onderzoek in Z. O. Borneo: Jaarboek Mijnwezen Nederlandsch Oost-Indië, 1921, Verh., v. 50, pt. 1, p. 269-287.

Mackenzie, D. E., 1970, Pleistocene volcanoes of the New Guinea Highlands: Australia Bur. Mineral Resources, Geology anc Geophysics Rec. 1970/72, p. 5-10.

1976, Nature and origin of late Cainozoic volcanoes in western Papua New Guinea, in Johnson, R. W., ed., Volcanism in Australasia: Amsterdam, Elsevier, p. 221-238.

Mackenzie, D. E., and Chappell, B. W., 1972, Shoshonitic and calc-alkaline lavas from the highlands of Papua New Guinea: Contr. Mineralogy and Petrology, v. 35, p. 50-62.

Macnab, R. P., 1969, Geology of the Aroa-upper Dilava-Auga-middle Angabunga Rivers area, Papua: Australia Bur. Mineral Resources, Geology and Geophysics, Rec. 1969/126, 49 p.

Magaritz, M., Whitford, D. J., and James, D. E., 1978, Oxygen isotopes and the origin of high- ${ }^{87} \mathrm{Sr} /{ }^{86} \mathrm{Sr}$ andesites: Earth and Planetary Sci. Letters, v. 40, p. 220-230.

Magnier, Philippe, Oki, T., and Witoelar-Kartaadiputra, L., 1975, The Mahakam Delta, Kalimantan, Indonesia: World Petroleum Cong., 9th, Tokyo, 1975, Proc., v. 2, p. 239-250.

Malone, E. J., 1962, Pine Creek, N. T.: Australia Bur. Mineral Resources, Geology and Geophysics, 1:250,000 Geol. Ser., Explanatory Notes, sheet $\mathrm{SD} / 52-8,16 \mathrm{p}$., map.

Mammerickx, Jacqueline, 1978, Re-evaluation of some geophysical observations in the Caroline Basin: Geol. Soc. America Bull., v. 89, p. 192-196.

Mammerickx, Jacqueline, Chase, T. E., Smith, S. M., and Taylor. I. L., 1974, Bathymetry of the South Pacific: California Univ., San Diego, Inst., Marine Resources Tech. Rept. 44A, 21 sheets.
Marchant, Stephen, 1969, A photogeological assessment of the petroleum geology of the northern New Guinea basin, north of the Sepik River, Territory of New Guinea: Australia Bur. Mineral Resources, Geology and Geophysics, Rept. 130, 78 p.

Markl, R. G., 1974, Evidence for the breakup of eastern Gondwanaland by the early Cretaceous: Nature, v. 251, p. 196-200.

Marks, P., 1961, The succession of nappes in the western Miomalfo area of the island of Timor--a possible key to the structure of Timor: Pacific Sci. Cong. 9th, Bangkok, 1957, Proc., v. 12, p. 306-310.

Marsh, B. D., and Carmichael, I. S. E., 1974, Benioff zone magmatism: Jour. Geophys. Research, v. 79, p. 1196-1206.

Marshak, R. S., and Karig, D. E., 1977, Triple junctions as a cause for anomalously near-trench igneous activity between the trench and volcanic arc: Geology, v. 5, p. 233-236.

Martin, Salvador, 1976, A review of oil exploration and stratigraphy of sedimentary basins of the Philippines: United Nations Committee for Co-ordination of Joint Prospecting for Mineral Resources in Asian Offshore Areas (CCOP), Tech. Bull. 10, p. 55-102.

Martison, N. W., McDonald, D. R., and Kaye, Peter, 1972, Exploration on the continental shelf off north-west Australia: Australasian Oil and Gas Rev., Dec., p. 8-18.

Masatani, K., 1967, The petroleum geology of east Kalimantan: Japanese Assoc. Petroleum Technology Jour., v. 32, no. 4, p. 228-240 [in Japanese].

de Matharel, M., Klein, G., and Oki, T., 1977, Case history of the Bekapai Field: Indonesian Petroleum Assoc., Sth Ann. Convention, Jakarta, 1976, Proc., v. 1, p. 69-93.

Mathur, S. P., 1976, Relation of Bouguer anomalies to crustal structure in southwestern and central Australia: Australia Bur. Mineral Resources, Geology and Geophysics, BMR Jour., v. 1, p. 277-286.

Matrais, I. B., Pfeiffer, Dieter, Soekardi, Raden, and Stach, L. W., 1972, Hydrology of the island of Lombok (Indonesia): Geol. Landesämter Bundesrepublik Deutschland, Beihefte geol. Jahrb., v. 123, 23 p.

Matsuda, Jun-ichi, Zashu, Shigeo, and Ozima, Minoru, 1977, Sr isotopic studies of volcanic rocks from island arcs in the western Pacific: Tectonophysics, v. 37, p. 141-151.

Matthews, D. H., and Davies, D.. 1966, Geophysical studies of the Seychelles Bank: Royal Soc. London Philos. Trans., v. A-259, no. 1099, p. 227-239.

Maung Thein, 1973, A preliminary synthesis of the geological evolution of Burma with reference to the tectonic development of southeast Asia: Geol. Soc. Malaysia Bull. 6, p. 87-116.

Maxwell, J. C., 1974, Anatomy of an orogen: Geol. Soc. America Bull., v. 85, p. 1195-1204.

McCurry, Patricia, and Wright, J. B., 1977, Geochemistry of calc-alkaline volcanics in northwestern Nigeria, and a possible Pan-African suture zone: Earth and Planetary Sci. Letters, v. 37, p. 90-96.

McDougall, lan, Dunn, P. R., Compston, W., Webb, A. W., Richards, J. R., and Bofinger, V. M., 1965 , Isotopic age determinations on Precambrian rocks of the Carpentaria region, Northern Territory, Australia: Geol. Soc. Australia Jour., v. 12, p. 67-90.

McElhinny, M. W., 1970, Formation of the Indian Ocean: Nature, v. 228, p. 977-979.

1973a, Palaeomagnetic results from Eurasia, in Tarling, D. H., and Kuncorn, S.K., eds., Implications of continental drift to the earth sciences, v. I: London, Academic Press, p. 77-85.

1973b, Palaeomagnetism and plate tectonics: Cambridge Univ. Press, $358 \mathrm{p}$.

McElhinny, M. W., and Brock, A., 1975, A new palaeomagnetic result from East Africa and estimates of the Mesozoic palaeoradius: Earth and Planetary Sci. Letters, v. 27, p. 321-328.

McElhinny, M. W., and Embleton, B. J. J., 1974, Australian palaeomagnetism and the Phanerozoic plate tectonics of eastern Gondwanaland: Tectonophysics, v. 22, p. 1-29.

McElhinny, M. W., Embleton, B. J. J., Daly, Lucien, and Pozzi, J. P., 1976, Paleomagnetic evidence for the location of Madagascar in Gondwanaland: Geology, v. 4, p. 455-457. 
McElhinny, M. W., Embleton. B. J. J., and Wellman, P., 1974, A synthesis of Australian Cenozoic palaeomagnetic results: Royal Astron. Soc. Geophys. Jour., v. 36, p. 141-151.

McElhinny, M. W., Haile, N. S., and Crawford, A. R., 1974, Palaeomagnetic evidence shows Malay Peninsula was not a part of Gondwanaland: Nature, v. 252, p. 641-645.

McElhinny, M. W., and Luck, G. R., 1970a, The palaeomagnetism of the Antrim Plateau Volcanics of Northern Australia: Royal Astron. Soc. Geophys. Jour., v. 20, p. 191-205. 830-832

1970b, Paleomagnetism and Gondwanaland: Science, v. 168, p.

McElhinny, M. W., and McWilliams, M. O., 1977, Precambrian geodynamics--a palaeomagnetic view: Tectonophysics, v. 40, p. 137-159.

McGarr, A., 1977, Seismic moments of earthquakes beneath island arcs, phase changes, and subduction velocities: Jour. Geophys. Research, v. 82. p. $256-264$

McKenzie, D. P., and Morgan, W. J., 1969, Evolution of triple junctions: Nature, v. 224, p. 125-133.

McKenzie, D. P., and Parker, R. L., 1967, The North Pacific-an example of tectonics on a sphere: Nature, v. 216, p. 1276-1280.

McKenzie, D. P., Roberts, Jean, and Weiss, Nigel, 1973, Numerical models of convection in the earth's mantle: Tectonophysics, v. 19, p. 89-103.

McKenzie, D. P., and Sclater, J. G., 1971, The evolution of the Indian Ocean since the Late Cretaceous: Royal Astron. Soc. Geophys. Jour., v. 25, p. $437-528$.

Mc Manus, John, and Tate, R. B., 1976, Volcanic control of structures in north and west Borneo: South East Asia Petroleum Explor. Soc., 1976 Conference, Singapore, Paper 5, 13 p.

Meijer, Arend, 1976, $\mathrm{Pb}$ and $\mathrm{Sr}$ isotopic data bearing on the origin of the volcanic rocks from the Mariana island-arc system: Geol. Soc. America Bull., v. 87, p. 1358-1369.

Meiser, Paul, Pfeiffer, Dieter, Purbohadiwidjojo, Muljono, and Sukardi, 1965, Hydrogeological map of the isle of Sumba: Indonesia Geol. Survey, scale 1:250,000.

Melendres, M. M., Jr., and Barnes, Harley, 1957, Geology and coal resources of the Galatrava-Toboso region, Occidental Negros: Philippine Bur. Mines Spec. Projects Ser., Pub. 12, 50 p.

Melendres, M. M., Jr., and Comsti, Francisco, 1951, Reconnaissance geology of southeastern Davao: Philippine Geologist, v. 5, no. 2, p. $38-46$.

Meng, L. K., 1972, Upper Segama Valley-Darvel Bay area (Memoir 4 revised): Malaysia Geol. Survey 1969 Ann. Rept., p. 186-189

Merchant, F. E., 195I, General geology on parts of Mindanao: Philippines Dept. Agriculture and Nat. Resources, Tech. Bull. 2, p. 321-339.

Mertosono, S., and Nayoan, G. A. S., 1975, The Tertiary basinal area of central Sumatra: Indonesian Petroleum Assoc., 3d Ann. Convention. Jakarta 1974, Proc., p. 63-76.

Milsom, John, 1970, Woodlark Basin, a minor centre of sea-floor spreading in Melanesia: Jour. Geophys. Research, v. 75, p. 7335-7339.

1973, The gravity field of the Papuan peninsula: Geologie en Mijnbouw, v. 52, p. 13-20.

1975. Madang Province helicopter gravity survey: Papua New Guinea Geol. Survey Rept. 75/15, 18 p.

1977, Preliminary gravity map of Seram, eastern Indonesia: Geology, v. 5, p. 641-643.

Milsom, John, and Smith, I. E., 1975, Southeastern Papua-generation of thick crust in a tensional environment?: Geology, v. 3, p. 117-120.

Minster, J. B., Jordan, T. H., Molnar, Peter, and Haines, E. L., 1974, Numerical modelling of instantaneous plate tectonics: Royal Astron. Soc. Geophys. Jour., v. 36, p. 541-576.

Mitchell, A. H. G., and McKerrow, W. S., 1975, Analogous evolution of the Burma orogen and the Scottish Caledonides: Geol. Soc. America Bull. v. 86, p. $305-315$.

Miyashiro, Akiho, 1974, Volcanic rock series in island arcs and active continental margins: Am. Jour. Sci., v. 274, p. 321-355.
Moberly, Ralph, 1973, Origin of lithosphere behind island arcs, with reference to the western Pacific: Geol. Soc. America Mem. 132, p. 35-55.

Molengraaff, G. A. F., 1900, Geologische verkenningstochten in Centraal-Borneo 1893-94: Leiden, E. J. Brill, 529 p.

1910, On oceanic deep-sea deposits of Central-Borneo: Koninkl. Akad. Wetensch. Amsterdam, Proc., Sec. Sci., v. 22, p. 141-147.

1915a, On the occurrence of nodules of manganese in Mesozoic deep-sea deposits from Borneo, Timor, and Rotti, their significance and mode of formation: Koninkl. Akad. Wetensch. Amsterdam, Proc., Sec. Sci., v. 18, p. 415-430.

1915b, Geografische en geologische beschrijving: Jaarboek Mijnwezen Nederlandsch Oost-Indië, 1914, Verh., v. 43, pt. 1, p. I-87.

Molengraaff, G. A. F., and de Beaufort, L. F., 1921, On manganese nodules in Mesozoic deep-sea deposits of Dutch Timor: Koninkl. Akad. Wetensch. Amsterdam, Proc., v. 23, p. 997-1012.

Mollan, R. G., Craig, R. W., and Lofting, M. J. W., 1970, Geologic framework of the contincntal shelf off northwest Australia: Am. Assoc. Petroleum Geologists Bull., v. 54, p. 583-600.

Molnar, Peter, and Tapponnier, Paul, 1975, Cenozoic tectonics of Asia - effects of a continental collision: Science, v. 189, p. 419-426.

1977. Relation of the tectonics of eastern China to the India-Eurasia collision-application of slip-line field theory to large-scale continental tectonics: Geology, v. 5, p. 212-216.

Montecchi, P. A.. 1976, Some shallow tectonic consequences of "subduction" and their meaning to the hydrocarbon explorationist: Am. Assoc. Petroleum Geologists Mem. 25, p. 189-202.

Moore, G. F., and Karig, D. E., 1976, Development of sedimentary basins on the lower trench slope: Geology, v. 4, p. 693-697.

Moore, G. W., 1973, Westward tidal lag as the driving force of plate tectonics: Geology, v. 1, p. 99-100.

1975, Pump-like tidal driving of tectonic plates: Am. Assoc. Petroleum Geologists Bull., v. 59, p. 1020-1021.

Morante, E. M., and Allen, C. R., 1973, Displacement on the Philippine fault during the Ragay Gulf earthquake of 17 March 1973: Geol. Soc. America, Abs. with Programs, v. 5, p. 744-745.

Morgan, B. A., 1974, Chemistry and mineralogy of garnet pyroxenites from Sabah, Malaysia: Contr. Mineralogy and Petrology, v. 48, p. 301-314.

Morgan, C. M., 1972, Port Keats, Northern Territory: Australia Bur. Mineral Resources, Geology and Geophysics, 1:250,000 Geol. Ser., Explanatory notes, sheet SD/52-11, $18 \mathrm{p}$.

Morgan, W. J., 1968, Rises, trenches, great faults, and crustal blocks: Jour. Geophys. Research, v. 73, p. 1959-1982.

1973, Plate motions and deep mantle convection: Geol. Soc. America Mem. 132, p. 7-22.

Morgan, W. R., 1966, A note on the petrology of some lava types from east New Guinea: Geol. Soc. Australia Jour., v. 13, p. 583-591.

1968, The geology and petrology of Cainozoic basaltic rocks in the Cooktown area, north Queensland: Geol. Soc. Australia Jour., v. 15, p. $65-78$.

1974, A Carboniferous continental andesite-rhyolite association from the 'Nychum' area, north Queensland, Australia: Jour. Petrology, v. 15, p. 97-112.

Mudge, M. R., 1970, Origin of the disturbed belt in northwestern Montana: Geol. Soc. America Bull., v. 82, p. 377-392.

Mulhadiyono, 1973, Petroleum possibilities of the Banyumas area: Indonesian Petroleum Assoc., 2d Ann. Convention, Jakarta 1973, p. 121-129.

Muller, J., 1968, Palynology of the Pedawan and Plateau Sandstone Formations in Sarawak, Malaysia: Micropaleontology, v. 14, p. 1-37.

Murauchi, S., Ludwig. W. J., Den, N., Hotta, H., Asanuma, T., Yoshii, T., Kubotera, A., and Hagiwere, K., 1973, Structure of the Sulu Sea and Celebes Sea: Jour. Geophys. Research, v. 78, p. 3437-3447.

Murphy, R. W., 1973, The Manila Trench-west Taiwan foldbelt-a flipped subduction zone: Geol. Soc. Malaysia Bull, 6, p. 27-42. 
1975, Tertiary basins of Southeast Asia: South East Asia Petroleum Explor. Soc., Proc., v. 2, p 1-36.

Musper, K. A. F. R., 1928, Geologische waarnemingen in de Padangsche Bovenlanden, [Pt.] 1 - Over een voorkomen van Trias in de omgeving van Sawahloento: De Mijningenieur, v. 9, no. 7, p. 124-127.

1930. Beknopt verslag over de uitkomsten van nieuwe geologische onderzoekingen in de Padangsche Bovenlanden: Jaarboek Mijnwezen Nederlandsch Oost-Indiē, 1929, Verh., v. 58, p. 265-331.

1937, Geologische kaart van Sumatra: Toelichting bij blad 16 (Lahat), scale 1:200,000, Dienst Mijnbouw Nederlandsch-Indië, $110 \mathrm{p}$.

Mutter, J. C., 1975a, A structural analysis of the Gulf of Papua and northwest Coral Sea region: Australia Bur. Mineral Resources, Geology and Geophysics, Rept. 179, 52 p.

1975b, Queensland Plateau: Australia Bur. Mineral Resources, Geology and Geophysics, Rec. 1975/161, p. 81-83.

1977. The Queensland Plateau: Australia Bur. Mineral Resources, Geology and Geophysics, Bull. 179, 55 p.

Nagasaka, Koichi, Francheteau, Jean, and Kishii, Toshio, 1970, Terrestrial heat flow in the Celebes and Sulu Seas: Marine Geophys. Research, v. 1, p. 99-103.

Najoan, G. A. S., 1973, Correlation of Tertiary lithostratigraphic units in the Java Sea and adjacent areas: Indonesian Petroleum Assoc., 1st Ann. Convention, Jakarta 1972, p. 11-16.

Neugebauer, H. J., and Breitmayer, G., 1975, Dominant creep mechanism and the descending lithosphere: Royal Astron. Soc. Geophys. Jour., v. 43, p. 873-895.

Neumann van Padang, M., 1951, Indonesia, Pt. 1 of Catalogue of the active volcanoes of the world including solfatara fields: Internat. Volcanol. Assoc., $271 \mathrm{p}$.

1953, Philippine Islands and Cochin China, Pt. 2 of Catalogue of the active volcanoes of the world including solfatara fields: Internat. Volcanol. Assoc., 49 p.

Newton, H. J., 1964, Petroleum possibilities of the Gulf of Carpentaria: Australian Petroleum Explor. Assoc. Jour., v. 4, p. 32-37.

Newton-Smith, J., 1967, Bidu-Bidu Hills area, Sabah, East Malaysia: Borneo Region Malaysia Geol. Survey Rept. 4, 109 p.

bin Ngah, Khalid, 1974, The geology and mineral resources of the Ulu Sedili and Ulu Sedili Besar areas (sheets 126 and 127) of East Johore: Malaysia Geol. Survey 1972, Ann. Rept., p. 81-93.

Nguen Dinh Kat, 1970, Main tectonic features of North Vietnam: Geotectonics, 1969 , no. 4, p. 245-250.

Nicholls, 1. A., and Whitford, D. J., 1976, Primary magmas associated with Quaternary volcanism in the western Sunda arc, Indonesia, in Johnson, R. W., ed., Volcanism in Australasia: Amsterdam, Elsevier, p. 77-90.

Nicol, G. N., 1970, Exploration and geology of the Arafura Sea: Australian Petroleum Explor. Assoc. Jour., v. 10, pt. 2, p. 56-61.

Nikko Exploration and Development Co., Ltd., 1971, Report on geological survey of central Sulawesi, Indonesia, V. 1: Overseas Tech. Coop. Agency of Japan and Indonesia Geol. Survey (unpub. rept.).

1972, Report on geological survey of central Sulawesi, Indonesia, V. 4: Overseas Tech. Coop. Agency of Japan and Indonesia Geol. Survey (unpub. rept.).

Ninkovich, Dragoslav, 1976, Late Cenozoic clockwise rotation of Sumatra: Earth and Planetary Sci. Letters, v. 29, p. 269-275.

Ninkovich, Dragoslav, Hays, J. D., and Abdel-Monen, A. A., 1971, Late Cenozoic volcanism and tectonics of Sumatra: Geol. Soc. America Abs. with Programs, v. 3, p. 661.

Norvick, M. A., 1975, North Sepik project: Australia Bur. Mineral Resources, Geology and Geophysics Rept. 189, p. 85-86.

Nougier, Jacques, 1972a, Geochronology of the volcanic activity in lles Kerguelen, in Adie, R. J., ed., Antarctic geology and geophysics: Oslo, Universitetsforlaget, p. 803-808.

1972b, Volcanic associations in lles Kerguelen, in Adie, R. J., ed., Antarctic geology and geophysics: Oslo, Universitetsforlaget, p. 809-815.
O'Brien, C. A. E., Gray, K. W., and Gillespie, 1., 1961, The geological results of petroleum exploration in western Papua: Geol. Soc. Australia Jour., v. 8, p. 1-133.

Oca, G. R., and Gonzales, M. L., 1947, Notes on the sedimentary rocks of the Surigao gold district: Philippine Geologist, v. I, no. 4, p. 9-26.

O'Day, Michael, and Kramer, J. C., 1972, The "Coastal Belt" of the northern California Coast Ranges: Geol. Soc. Sacramento, 1972 Ann. Guidebook, p. 51-56.

Ohara, Jyonosuke, 1969, Heavy minerals of the Miocene Singit and Tarao Formations in Panay Island, the Philippines, in Kobayashi, Teiichi, and Toriyama, Ryuzo, eds., Geology and palaeontology of Southeast Asia, V. 7: Tokyo Univ. Press, p. 97-113.

O'Hara, M. J., 1965, Primary magmas and the origin of basalt: Scottish Jour. Geology, v. 1, p. 19-40.

1970, Upper mantle composition inferred from laboratory experiments and observation of volcanic products: Physics Earth and Planetary Interiors, v. 3, p. 236-245.

1976, Indentification of primary magmas from the mantle: Geol. Soc. America, Abs. with Programs, v. 8, p. 1034.

Oldenburg, D. W., and Brune, J. N., 1972, Ridge transform fault spreading pattern in freezing wax: Science, v. 178, p. 301-304.

Oliver, Jack, Isacks, Bryan, Barazangi, Muawai, and Mitronovas, Walter, 1973, Dynamics of the down-going lithosphere: Tectonophysics, v. 19. p. 133-147.

Oppel, T. W., 1970, Exploration of the southwest flank of the Papuan basin: Australian Petroleum Explor. Assoc. Jour., v. 10, pt. 2, p. 62-69.

Orowan, E., 1965, Convection in a non-Newtonian mantle, continental drift, and mountain building: Royal Soc. London Philos. Trans., v. A-258, no. 1088, p. 284-313.

Oversby, Brian, 1971, Palaeozoic plate tectonics in the southern Tasman geosyncline: Nature, Phys. Sci., v. 234, p. 45-47, 60.

Oxburgh, E. R., and Turcotte, D. L., 1976, The physico-chemical behaviour of the descending lithosphere: Tectonophysics, v. 32, p. 107-128.

van Oyen, F. H., 1972, Trough evidence along the southern foothills of the Prince Alexander Mountains (Sepik District-New Guinea): Australian Petroleum Explor. Assoc. Jour., v. 12, pt. 2, p. 74-78.

Ozima, M., Kaneoka, I., and Ujiie, H., $1977,{ }^{40} \mathrm{Ar}-{ }^{-39} \mathrm{Ar}$ age of rocks, and the development mode of the Philippine Sea: Nature, v. 267, p. 816-818.

Packham, G. H., 1973, A speculative Phanerozoic history of the south-west Pacific, in Coleman, P. J., ed., The western Pacific: Nedlands, Western Australia, Western Australia Univ. Press, p. 369-388.

Page, B. M., 1970, Sur-Nacimiento fault zone of California-continental margin tectonics: Geol. Soc. America Bull., v. 81, p. 667-689.

1972, Oceanic crust and mantle fragments in subduction complex near San Luis Obispo, California: Geol. Soc. America Bull., v. 83, p. $957-972$.

Page, R. W., 1975, Genchronology of late Tertiary and Quaternary mineralized intrusive porphyries in the Star Mountains of Papua New Guinea and Irian Jaya: Econ. Geology, v. 70, p. 928-936.

1976, Geochronology of igneous and metamorphic rocks in the New Guinea Highlands: Australia Bur. Mineral Resources, Geology and Geophysics Bull. 162, 177 p.

Page, R. W., and Johnson, R. W., 1974, Strontium isotope ratios of Quaternary volcanic rocks from Papua New Guinea: Lithos, v. 7, p. 91-100.

Page, R. W., and McDougall, Ian, 1970, Potassium-argon dating of the Tertiary $f_{1-2}$ stage in New Guinea and its bearing on the geological time-scale: Am. Jour. Sci., v. 269, p. 321-342.

1972, Ages of mineralization of gold and porphyry copper deposits in the New Guinea Highlands: Econ. Geology, v. 67, p. 1034-1048.

Page, R. W., and Ryburn, R. J., 1977, K-Ar ages and geological relations of intrusive rocks in New Britain: Pacific Geology, no. 12, p. 99-105.

Palfreyman, W. D., D'Addario, G. W., Swoboda, R. A., Bultitude, J. M., and Lamberts, 1. T., 1976, Geology of Australia: Australia Bur. Mineral Resources, Geology and Geophysics, scale 1:2,500,000. 
Pan, Cheh, 1975, Polar motion of a triaxial earth and dynamic plate tectonics: Tectonophysics, v. 25, p. 1-40.

Parke, M. L., Jr., Emery, K. O., Szymankiewicz, Raymond, and Reynolds, L. M., 1971, Structural framework of continental margin in South China Sea: Am. Assoc. Petroleum Geologists Bull., v. 55, p. 723-751.

Parsons, Barry, and Molnar, Peter, 1976, The origin of outer topographic rises associated with trenches: Royal Astron. Soc. Geophys. Jour., v. 45 , p. $707-712$.

Pascoe, E. H., 1959, A manual of the geology of India and Burma, V. 2: Calcutta, Govt. of India Press, p. 485-1343.

Paterson, S. J., and Perry, W. J., 1964, The geology of the upper Sepik-August River area, New Guinea: Geol. Soc. Australia Jour., v. 11 , p. 199-211.

Patmosukismo, Suyitno, and Yahya, Ibrahim, 1975, The basement configuration of the north west Java area: Indonesian Petroleum Assoc., 3d Ann. Convention, Jakarta 1974, Proc., p. 129-152.

Paul, D. D., and Lian, H. M., 1975, Offshore Tertiary basins of Southeast Asia, Bay of Bengal to South China Sea: World Petroleum Cong., 9th, Tokyo, 1975, Proc., v. 3, p. 107-121.

Pelton, P. J., 1975, Exploration of the South Barito Basin reef tract, Kalimantan, Indonesia: Indonesian Petroleum Assoc., 3d Ann. Convention, Jakarta 1974, Proc., p. 153-169.

Peter, George, Weeks, L. A., and Burns, R. E., 1966, A reconnaissance geophysical survey in the Andaman Sea and across the Andaman-Nicobar island arc: Jour. Geophys. Research, v. 71, p. 495-509.

Peterman, Z. E., and Heming, R. F., 1974, $\mathrm{Sr}^{87} / \mathrm{Sr}^{86}$ ratios of calc-alkalic lavas from the Rabaul caldera, Papua New Guinea: Geol. Soc. America Bull., v. 85, p. 1265-1268.

Peterman, Z. E., Lowder, G. G., and Carmichael, I. S. E., 1970, $\mathrm{Sr}^{87} / \mathrm{Sr}^{86}$ ratios of the Talasea Series, New Britain, Territory of New Guinea: Geol. Soc. America Bull., v. 81, p. 39-40.

Petkovic, Peter, 1975, Origin of the Naturaliste Plateau: Nature, v. 253, p. 30-33.

Pfeiffer, Dieter, and Meiser, Paul, 1968, Geologische, hydrogeologische and geoelecktrishe Untersuchungen auf der Insel Sumba (Indonesien): Geol. Landesämt. Bundesrepublik Deutschland, Geol. Jahrb., v. 86, p. 885-918.

Philippines Bureau of Mines, 1964, Geological map of the Philippines: scale $1: 1,000,000,9$ sheets.

Pierce, J. W., 1976, Assessing the reliability of DSDP paleolatitudes: Jour. Geophys. Research, v. 81, p. 4173-4186.

Pieters, P. E., 1974, Explanatory notes on the Port Moresby, Kalo and Aroa geological sheets: Papua New Guinea Geol. Survey Rept. 74/28, 25 p., 3 maps.

Pimm, A. C., 1965, Serian area, west Sarawak, Malaysia: Borneo Region Malaysia Geol. Survey, Rept. 3, 92 p.

1967, Triassic volcanic rocks in East and West Malaysia: Borneo Region Malaysia Geol. Survey, Bull. 8, p. 36-40.

Pimm, A. C., McGowran, Brian, and Gartner, Stefan, 1974, Early sinking history of Ninetyeast Ridge, northeastern Indian Ocean: Geol. Soc. America Bull., v. 85, p. 1219-1224.

Pinchin, J., 1974, A reinterpretation of seismic data in the Laura Basin, Queensland: Geol. Soc. Australia Jour., v. 21, p. 437-445.

Pinchin, J., and Hudspeth, J. W., 1975, The Queensland Trough-its petroleum potential based on some recent geophysical results: Australian Petroleum Explor. Assoc. Jour., v. 15, pt. 1, p. 21-31.

Pitman, W. C., III, Herron, E. M., and Heirtzler, J . R., 1968, Magnetic anomalies in the Pacific and sea floor spreading: Jour. Geophys. Research, v. 73, p. 2069-2085.

Plafker, George, 1969, Tectonics of the March 27, 1964, Alaska earthquake: U.S. Geol. Survey Prof. Paper 543-1, 74 p.

Plane, M. D., 1967, Stratigraphy and vertebrate fauna of the Otibanda Formation, New Guinea: Australia Bur. Mineral Resources, Geology and Geophysics Bull. 86, 64 p.

Plumb, K. A., Doutch, H. F., and Rickard, M. J., 1972, Tectonic map of A ustralia and New Guinea, 1971: Geol. Soc. Australia, scale 1:5,000,000 .
Plumb, K. A., and Gemuts, 1., 1976, Precambrian geology of the Kimberley region. Western Australia: Internat. Geol. Cong., 25th, Sydney, Australia, 1976, Excursion Guide 44C, $69 \mathrm{p}$.

Plumb, K. A., and Veevers, J. J., 1971, Cambridge Gulf, W. A.: Australia Bur. Mineral Resources, Geology and Geophysics, 1:250,000 Geol. Ser.-Explanatory notes, sheet SD/52-14, $30 \mathrm{p}$.

Pontifex, I. R., and Mendum, J. R., 1972, Fergusson River, Northern Territory: Australia Bur. Mineral Resources, Geology and Geophysics, 1:250,000 Geol. Ser.-Explanatory Notes, sheet SD52-12, 26 p.

Posavec, M., Taylor, D., van Leeuwen, Th., and Spector, A., 1973, Tectonic controls of volcanism and complex movements along the Sumatran fault system: Geol. Soc. Malaysia Bull. 6, p. 43-60.

Postel'nikov, Ye. S., 1964, Tektonicheskoye stroeniye i razvitiye Indokitaya: Akad. Nauk SSSR Geol. Inst., Trudy, v. 108, p. 28-93.

Powell, D. E., 1976, The geological evolution of the continental margin off Northwest Australia: Australian Petroleum Explor. Assoc. Jour., v. 16, pt. 1, p. 13-23.

Preest, D. S., 1963, A note on the dispersal characteristics of the seed of the New Zealand podocarps and beeches and their biogeographical significance, in Gressit, J. L., ed., Pacific Basin biogeography, see Good, 1963 reference, Honolulu, Bishop Mus. Press, p. 415-424.

Price, N. B., 1967, Some geochemical observations on manganese-iron oxide nodules from different depth environments: Marine Geology, v. 5, p. $511-538$.

Price, R. A., 1971, Gravitational sliding and the foreland thrust and fold belt of the North American Cordillera-discussion: Geol. Soc. America Bull., v. 82, p. 1133-1138.

Price, R. A., and Mountjoy, E. W., 1970, Geologic structure of the Canadian Rocky Mountains between Bow and Athabaska Rivers-A progress report: Geol. Assoc. Canada Spec. Paper 6, p. 7-25.

Priem, H. N. A., Boelrijk, N. A. I. M., Bon, E. H., Hebeda, E. H., Verdurmen, E. A T., and Verschure, R. H., 1975, Isotope geochronology in the Indonesian tin belt: Geologie en Mijnbouw, v. 54, p. $61-70$.

Pulunggono, A., 1974, Recent knowledge of hydrocarbon potentials in the sedimentary basins of Indonesia: Pertamina, Jakarta, Indonesia, $17 \mathrm{p}$.

Pupilli, M., 1973, Geological evolution of South China Sea area-tentative reconstruction from borderland geology and well data: Indonesian Petroleum Assoc., 2d Ann. Convention, Jakarta 1973, Proc., p. 223241.

Purdy, G. M., and Detrick, R. S., 1978, A seismic refraction experiment in the central Banda Sea; Jour. Geophys. Research, v. 83, p. 2247-2257.

Purdy, G. M., Detrick, R. S., and Shor, G. G., Jr., 1977, Crustal structure of the Banda Sea and Weber Deep [abs.]: EOS (Am. Geophys. Union Trans.), v. 58, p. 509.

Pushcharovskiy, Yu. M., and Udintsev, G. B., 1970, Tectonic map of the Pacific segment of the earth: Acad. Sci. USSR Inst. Geology and Inst. Oceanology, scale 1:10,000,000, 6 sheets.

Quilty, P. G., 1973, Cenomanian-Turonian and Neogene sediments from northeast of Kerguelen Ridge, Indian Ocean: Geol. Soc. Australia Jour., v. 20, p. 361-367.

Ragland, P. C., Stirewalt, G. L., and Newcomb, W. E., 1976, A chemical model for island arc volcansim, western Luzon, the Philippines: Geol. Soc. America Abs. with Programs, v. 8, p. 1056.

Raitt, R. W., 1967, Marine seismic studies of the Indonesian island are (abs.): Am. Geophys. Union Trans., v. 48, p. 217.

Rajah, S. S., 1970, Geology of the Gunong Blumat area: Malaysia Geol. Survey, 1968 Ann. Rept., p. 79-83.

Ranneft, T. S. M., Hopkins, R. M., Jr., Froelich, A. J., and Gwinn, J. W., 1960, Reconaissance geology and oil possibilities of Mindanao: Am. Assoc. Petroleum Geologists Bull., v. 44, p. 529-568.

Rastogi, B. K., Singh, J., and Verma, R. K., 1973, Earthquake mechanisms and tectonics in the Assam-Burma region: Tectonophysics, v. 18, p. 355-366.

Ratman, Nana, 1976, Geologic map of the Tolitoli quadrangle, North Sulawesi: Indonesia Geol. Survey, scale 1:250,000. 
Rau, S. S. R., 1933, The geology of the Mergui district: India Geol. Survey Mem. 55, p. 1-62.

Recy, J., Dubois, J., Daniel, J., Dupont, J., and Launay, J., I977, Fossil subduction zones-examples in the south-west Pacific: Internat. Symposium Geodynamics South-West Pacific. Noumea, 1976, Paris, Editions Technip, p. 345-355.

Redmond, J. L., and Koesoemadinata, R. P., 1976, Walio oil field and the Miocene carbonates of Salawati Basin, Irian Jaya, Indonesia: Indonesian Petrol. Assoc., 5th Ann. Convention, Jakarta 1976, Proc., v. 1, p. $41-57$.

Reid, H. F., 1913, Sudden earth-movements in Sumatra in 1892: Seismol. Soc. America Bull., v. 3, p. 72-79.

Reynolds, C. D., Havryluk, I., Bastaman, Saleh, and Atmowidjojo, Soepomo, 1973, The exploration of the nickel laterite deposits in Irian Barat, Indonesia: Geol. Soc. Malaysia Bull. 6, p. 309-323.

Richards, J. R., Berry, J., and Rhodes, J. M., 1966, Isotopic and lead-alpha ages of some Australian zircons: Geol. Soc. Australia Jour., v. 13, p. 69-96.

Richards, J. R., White, D. A., Webb, A. W., and Branch, C. D., 1966, Isotopic ages of acid igneous rocks in the Cairns Hinterland, north Queensland: Australia Bur. Mineral Resources, Geology and Geophysics Bull. 88, 41 p.

Richards, J. R., and Wilmott, W. F., 1970, K-Ar ages of biotites from Torres Strait: Australian Jour. Sci., v. 32, p. 369-370.

Richardson. J. A., 1939, The geology and mineral resources of the neighbourhood of Raub, Pahang, Federated Malay States, with an account of the geology of the Raub Australian Gold Mine: Federated Malay States Geol. Survey, Mem. 3, 166 p.

1950. The geology and mineral resources of the neighbourhood of Chegar, Perah and Merapoh, Pahang: Federation Malaya Geol. Survey Dept., Mem. 4, 162 p.

Richter, F. M., 1973, Dynamical models for sea floor spreading: Reviews Geophysics and Space Physics, v. 11, p. 223-287.

Rickwood, F. K., 1955, The geology of the western highlands of New Guinea: Geol. Soc. Australia Jour., v. 2, p. 63-82.

Ridd, M. F., 1971a, Faults in south-east Asia, and the Andaman rhombochasm: Nature, Phys. Sci., v. 229, p. 51-52.

1971b, South-East Asia as a part of Gondwanaland: Nature, v. 234, p. 531-533.

197 lc, The Phuket Group of peninsular Thailand: Geol. Mag., v. 108, no. 5, p. 445-446.

Ridley, W. I., Rhodes, J. M., Reid, A. M., Jakes, P., Shih, C. and Bass, M. N., 1974 Basalts from Leg 6 of the Deep-Sea Drilling Project: Jour. Petrology, v. 15 , no. 1 , p. 140-159.

Ringkasan, 1963, The geology and oil possibilities of northern West Java: [Indonesia] Bandung Inst. Technology, Contr. Dept. Geology, no. 53 , p. 1-32.

Ringwood, A. E., 1976, Phase transformations in descending plates and implications for mantle dynamics: Tectonophysics, v. 32, p. 129-143. 1977. Petrogenesis in island arc systems: Am. Geophys. Union. Maurice Ewing Ser., v. 1, p. 311-324.

Ripper, I. D., 1975a, Seismicity and earthquake focal mechanisms in the New Guinea Solomon Islands region: Australian Soc. Explor. Geophys. Bull., v. 6 , no. $2 / 3$, p. $80-81$.

$1975 \mathrm{~b}$, Some earthquake focal mechanisms in the New Guinea/Solomon Islands region, 1963-1968: Australia Bur. Mineral Resources, Geology and Geophysics, Rept. 178, 120 p.

1976. Some earthquake focal mechanisms in the New Guinea/Solomon Islands region, 1969-1971: Australia Bur. Mineral Resources, Geology and Geophysics Rept. 192.

Rishworth, D. E. H., 1974, The upper Mesozoic terrigenous Gagau Group of peninsular Malaysia: Malaysia Geol. Survey Spec. Paper 1, 78 p.

Rixon, L. K., 1978, Clay modelling of the Fitzroy Graben: Australia Bur. Mineral Resources, Geology and Geophysics, BMR Jour., v. 3, p. $71-76$

Robinson, G. P., 1974, Huoan-Sag Sag, Papua New Guinea: Papua New Guinea Geol. Survey, 1:250,000 Geol. Ser.--Explanatory notes, 22 p.
Robinson, G. P., and Jaques, A. L., 1974a, Explanatory notes on the Karkar geological sheet: Papua New Guinea, Geol. Survey Rept. 74/18, 13 p., scale 1:250,000 map.

1974b, Madang: Papua New Guinea Geol. Survey, 1:250,000 Geol. Ser., sheet SB SB 55-6.

Robinson, G. P., and Ratman, Nana, 1977, Explanatory notes on the Manokwari 1:250,000 geological sheet, Irian Jaya: Australia Bur. Mineral Resources, Geology and Geophysics, Record 1977/32, 25 p. 1978. The stratigraphic and tectonic development of the Manokwari Area, Irian Jaya: Australia Bur. Mineral Resources, Geology and Geophysics, BMR Jour., v. 3, p. 19-24.

Rod, Emile, 1966, Clues to ancient Australian geosutures: Eclogae Geol. Helvetiae, v. 59 , p. 849-883.

Rodolfo, K. S., 1969, Bathymetry and marine geology of the Andaman Basin, and tectonic implications for Southeast Asia: Geol. Soc. America Bull., v. 80, p. 1203-1230.

Roeder, Dietrich, 1977, Philippine arc system-collision or flipped subduction zones?: Geology, v. 5, p. 203-206.

de Roever, W. P., 1940a, Geological investigations in the southwestern Moetis region (Netherlands Timor), in Brouwer, H. A., ed., Geological expedition of the University of Amsterdam to the Lesser Sunda Islands, V. 2: Amsterdam, North Holland Publishing Co., p. 97-344. $1940 \mathrm{~b}$, Ueber Spilite und verwandte Gesteine von Timor: Koninkl. Nederlandsche Akad. Wetensch. Proc., v. 43, p. 630-634. 1941, Die permischen Alkaligesteine und die Ophiolithe des timorischen Faltengebirges: Nederlandsche Akad. Wetensch. Proc., v. 44, p. 993-995.

1942, Olivine-basalts and their alkaline differentiates in the Permian of Timor, in Brouwer, H. A., ed., Geological expedition of the University of Amsterdam to the Lesser Sunda Islands, v. 4: Amsterdam, North Holland Publishing Co., p. 209-289.

1947, Igneous and meta morphic rocks in eastern central Celebes, in Brouwer, H. A., ed., Geological explorations in the island of Celebes: Amsterdam, North Holland Publishing Co., p. 65-173.

1950, Preliminary notes on glaucophane-bearing and other crystalline schists from South East Celebes, and on the origin of glaucophane-bearing rocks; Koninkl. Nederlandsche Akad, Wetensch Proc., v. 53, p. 1455-1465.

1953, Tectonic conclusions from the distribution of the metamorphic facies in the island of Kabaena, near Celebes: Pacific Sci. Cong., 7th, New Zealand 1949, Proc., v. 2, p. 71-81.

1956, Some additional data on the crystalline schists of the Rumbia and Mendoke Mountains, south east Celebes: Koninkl. Nederlandsch Geol. Mijnbouw Genoot,, Verh., Geol. Ser., v. 16, p. 385-393.

Roggeveen, P. M., 1929, Jurassic in the island of Sumba: Koninkl. Akad. Wetensch. Amsterdam, Proc., v. 32, p. 512-514.

1932, Abyssische und hypabyssische Eruptivgesteine der Insel Soemba, Niederländisch Ost-Indien: Koninkl. Akad. Wetensch. Amsterdam, Proc., v. 35, p. 878-890.

Roothaan, H. P., 1928, Geologische en petrografische schets der Talaud en Nanoesa-eilanden: Jaarboek Mijnwezen Nederlandsch-Indië, 1925, Verh., v. 54 , pt. 2, p. $174-220$, pl. 8 in atlas.

Rose, J. C., Woollard, G. P., and Malahoff, Alexander, 1968, Marine gravity and magnetic studies of the Solomon Islands: Am. Geophys. Union Geophys. Mon. 12, p. 379-410.

Rosendahl, B. R., 1976, Constraints, implications, and inferences; [Pt.] 2 of Evolution of oceanic crust: Jour. Geophys. Research, v. 81, p. 5306-53i4

Rosidi, H. M. D., Tjokrosapoetro, S., and Pendowo, B., 19̄76, Geologic map of the Painan and northeastern part of the Muarasiberut quadrangles, Sumatra: Indonesia Geol. Survey, scale 1:250,000.

Rowlett, Hugh, and Kelleher, John, 1976, Evolving seismic and tectonic patterns along the western margin of the Philippine Sea plate: Jour. Geophys. Research, v. 81, p. 3518-3524.

Runcorn, S. K., 1972, Dynamical processes in the deeper mantle: Tectonophysics, v. 13, p. 623-637. 
Russell, K. L., Sutton, C., and Meyers, W. C., 1977, Organic geochemistry as an aid to exploration in the eastern Java Sea: Indonesian Petroleum Assoc., 5th Ann. Convention, Jakarta 1976, Proc., v. 2, p. 69-89.

Rutland, R. W. R., 1967, Preliminary report on the geology of the Laur-Dingalan fault zone, Luzon, Philippines: Philippine Bur. Mines Rept. Inv. 63, 58 p.

1973, Tectonic evolution of the continental crust of Australia, in Tarling, D. H., and Runcorn, S. K., eds., Implications of continental drift to the earth sciences, v. 2: London, Academic Press, p. 101 I-1033.

Rutland, R. W. R., and Walter, M. R., 1974, Philippine Archipelago, in Spencer, A. M., ed., Mesozoic-Cenozoic orogenic belts: Geol. Soc. London Spec. Paper 4, p. 491-500.

Rutten, L. M. R., 1917, Modifications of the facies in the Tertiary formation of East Kutei (Borneo): Koninkl. Akad. Wetensch. Amsterdam, Proc., v. 19, p. 728-736.

1919, De geologische expeditie naar Ceram, Pt. 9: Koninkl.

Nederlandsch Aardrijksk. Genoot. Tijdschr., v. 36, p. 559-579.

1920, De geologische expeditie naar Ceram, Pt. 10: Koninkl.

Nederlandsch Aardrijksk. Genoot. Tijdschr., v. 37, p. 17-32.

1925, Tertiary rocks from north-western British Borneo and from Berau (E. Borneo): Koninkl. Akad. Wetensch. Amsterdam, Proc., v. 28, p. 640-644.

1926, On the origin of the material of the Neogene rocks in Java: Koninkl. Akad. Wetensch. Amsterdam, Proc., v. 29, p. 15-33.

1927, Voordrachten over de geologie van Nederlandsch Oost-Indië: Groningen, J. B. Wolters, 839 p.

Rutten, M. G., 1940, On Devonian limestones with Clathrodictyon cf. spatiosum and Heliolites porosus from eastern Borneo: Nederlandsche Akad. Wetensch. Proc., v. 43, p. 1061-1064.

1947, De gesteenten der Midden Oost Borneo Expeditie 1925: Utrecht Univ. Geog. Geol. Mededeel., Physiog-Geol., ser. 2, no. 9, 50 p.

Ryburn, R. J., 1971, Geology [of New Britain and New lreland]: Australia Bur. Mineral Resources, Geology and Geophysics Rec. 1971/131, p. 15-19.

1975, Talasea-Gasmata, New Britain: Australia Bur. Mineral Resources, Geology and Geophysics, 1:250,000 Geol. Ser., sheet SB/56-5 and SB/56-9, Explanatory notes, $26 \mathrm{p}$.

1976, Cape Raoult-Arawe, Papua New Guinea: Australia Bur. Mineral Resources, Geology and Geophysics, 1:250,000 Geol. Ser. sheet SB/55-8 and SB 55/12, Explanatory Notes, $21 \mathrm{p}$.

1977. Irian Jaya project: Australia Bur. Mineral Resources, Geology and Geophysics, Record 1977/45, p. 187-191.

Saggerson, E. P., 1973, Metamorphic facies series in Africa, a contrast: Geol. Soc. South Africa Spec. Pub. 3, p. 227-234.

St. John, V. P., 1970, The gravity field and structure of Papua and New Guinea: Australian Petroleum Explor. Assoc. Jour., v. 10, p. 4I-55.

Samaniego, R. M., 1964, The occurrence of Globorotalia velascoensis in the Philippines: Philippine Geologist, v. 18, p. 65-74.

Samuel, Luki, and Muchsin, S., 1976, Stratigraphy and sedimentation in the Kutai Basin, Kalimantan: Indonesian Petroleum Assoc., Proc. 4th Ann. Convention, Jakarta 1975, v. 2, p. 27-61.

Santo, Tetsuo, 1969, Regional study on the characteristic seismicity of the world, Pt. 2-From Burma down to Java: Tokvo Univ. Earthquake Research Inst. Bull., v. 47, p. 1049-1061.

de los Santos, Victor, 1959, Preliminary report on the geology and mineral resources of central Palawan: Philippine Geologist, v. 13, p. 104-141.

Santos-Yñigo, Luis, 1949a, Geology and pyrite deposits of southern Antique, Panay: Philippine Geologist, v. 4, no. 1, p. 1-13.

1949b, Notes on the Jetafe copper deposits, Bohol: Philippine Geologist, v. 3, no. 2, p. 5-8.

1953, Geology of southern Zamboanga Province: Philippine Geologist, v. 7, no. 2, p. 45-64.

Santos-Yñigo, Luis, Vergara, Jose, Crispin. Oscar, and de los Santos, Victor, 1956, Geology and copper-pyrite deposits of the Lanuza district, Surigao: Philippine Geologist, v. I1, no. 1, p. 1-23.
Sastri, V. V., Raju, A. T. R., Sinha, R. N., and Venkatachala, B. S., 1974, Evolution of the Mesozoic sedimentary basins on the east coast of India: Australian Petroleum Ex plor. Assoc. Jour., v. 14, pt. 1, p. 29-41.

Sastri, V. V., Raju, A. T. R., Sinha, R. N., Venkatachala, B. S., and Banerji, R. K., 1977, Biostratigraphy and evolution of the Cauvery Basin, India: India Geol. Soc. Jour., v. 18, p. 355-377.

Sastri, V. V., Sinha, R. N., Singh, Gurcharan, and Murti, K. V. S., 1973, Stratigraphy and tectonics of sedimentary basins on east coast of peninsular India: Am. Assoc. Petroleum Geologists Bull., v. 57, no. 4, p. 655-678.

Sato, Tadashi, 1975, Marine Jurassic formations and faunas in southeast Asia and New Guinea, in Geology and palaeontology of Southeast Asia, v. 15: Tokyo Univ. Press, p. 151-189.

Saurin, Edmond, 1935, Études géologiques sur l'Indochine du Sud Est (Sud-Annam, Cochinchine, Cambodge oriental): Service Géol. de l'Indochine Bull. 22, pt. 1, 119 p.

1962, Notice sur la feuille de Saigon: Service Géog. Natl. Viet $\mathrm{Nam}, 79 \mathrm{p}$.

Savage, H. E. F., 1937, The geology of the neighbourhood of Sungei Siput, Perak, Federated Malay States, with an account of the mineral deposits: Federated Malay States Geol. Survey Dept., Mem. 1, 46 p.

Schaub, H. P., and Jackson, A., 1958, The northwestern oil basin of Borneo, in Weeks, L. G., ed., Habitat of oil: Am. Assoc. Petroleum Geologists, p. 1330-1336.

Scheibner, Erwin, 1973, A plate tectonic model of the Palaeozoic tectonic history of New South Wales: Geol. Soc. Australia Jour., v. 20, p. 405-426.

Scheidecker, W. R., and Taiclet, D. A., 1977, Ardjuna B-structure, a case history: Indonesian Petroleum Assoc., 5th Ann. Convention, Jakarta 1976, Proc., v. 1, p. 95-114.

Schmidt. P. W., 1976, The non-uniqueness of the Australian Mesozoic palaeomagnetic pole position: Royal Astron. Soc. Geophys. Jour., v. 47 , p. $285-300$.

Scholz, C. H., and Page, Robert, 1970, Buckling in island arcs (abs.): EOS (Am. Geophys. Union Trans.). v. 51, p. 429.

Schroeder ván der Kolk, J. L. C., 1902a, Mikroskopische Studien ueber Gesteine aus den Molukken, [Pt.] 2-Gesteine von Seran: Geol. Reichs-Museums Leiden, Samml., v. 6, p. 1-39.

1902b, Mikroskopische Studien ueber Gesteine aus den Molukken, [Pt.]3-Gesteine von Buru: Geol. Reichs-Museums Leiden, Samml., v. 6, p. 77-123.

Schuiling, R. D., 1973, Active role of continents in tectonic evolution-geothermal models, in De Jong, K. A., and Scholten, Robert, eds. Gra vity and tectonics: New York, John Wiley and Sons, p. 35-47.

Schürmann, H. M. E., 1929, Ofiolieten en abyssieten in Noord-Sumatra: De Mijningenieur, v. 10, no. 11, p. 235-237.

Schuster, R. M., 1976, Plate tectonics and its bearing on the geographical origin and dispersal of angiosperms, in Beck, C. B., ed., Origin and early evolution of angiosperms: Columbia Univ. Press, p. 48-138.

Schwartz, C. M., Laughbaum, G. H., Jr., Samsu, B. S., and Armstrong, J. D., 1973, Geology of the Attaka oil field, East Kalimantan, Indonesia: Indonesian Petroleum Assoc., 2d Ann. Convention, Jakarta 1973, Proc., p. 195-215.

Sclater, J. G., 1972, Heat flow and elevation of the marginal basins of the western Pacific: Jour. Geophys. Research, v. 77, p. 5705-5719.

Sclater, J. G., and Fisher, R. L., 1974, Evolution of the east central Indian Ocean, with emphasis on the tectonic setting of the Ninetyeast Ridge: Geol. Soc. America Bull., v. 85, p. 683-702.

Sclater, J. G., and Harrison, C. G. A., 197I, Elevation of mid-ocean ridges and the evolution of the south-west Indian ridge: Nature, v. 230, p. 175-177.

Sclater, J. G., Hawkins, J. W., Mammerick x, Jacqueline, and Chase, C. G., 1972, Crustal extension between the Tonga and Lau Ridges-petrologic and geophysical evidence: Geol. Soc. America Bull., v. 83, p. 505-518. 
Sclater, J. G., Karig, D. E., Lawver, L. A., and Louden, Keith, 1976, Heat flow, depth, and crustal thickness of the marginal basins of the south Philippine Sea: Jour. Geophys. Research, v. 81, p. 309-318.

Scrivenor, J. B., 1931, The geology of Malaya: London, Macmillan, 217 p. Scrutton, R. A., du Plessis, A., Barnaby, A. M., and Simpson, E. S. W., 1975. Contrasting structures and origins of the western and southeastern continental margins of southern Africa, in Campbell, $\mathbf{K}$. S. W., ed., Gondwana geology: Australian Univ. Press, p. 651-662.

Seekins, L. C., and Teng, Ta-liang, 1977, Lateral variations in the structure of the Philippine Sea plate: Jour. Geophys. Research, v. 82, p. 317-324.

Seely, D. R., Vail, P. R., and Walton, G. G., 1974, Trench slope model, in Burk, C. A., and Drake, C. L., eds., The geology of continental margins: New York, Springer-Verlag, p. 249-260.

Sein Myint, Hoke Maw, Tin Htut, and Tin Hlaing, 1972, Strike-slip faulting in upper Tenasserim [abs.]: Geol. Soc. Malaysia Newsletter 34, Annex, p. 52.

Semenenko, N. P., Scherbak, A. P., Vinogradov, A. P., Tougarinov, A. I., Eliseeva, G. D., Cotlovskay, F. I., and Demidenko, S. G., 1968, Geochronology of the Ukrainian Precambrian: Canadian Jour. Earth Sci., v. 5, p. 661-671.

Seno, Tetsuzo, 1977. The instantaneous rotation vector of the Philippine Sea plate relative to the Eurasian plate: Tectonophysics, v. 42, p. 209-226.

Shaw, H. R., 1973, Mantle convection and volcanic periodicity in the Pacific, evidence from Hawaii: Geol. Soc. America Bull., v. 84, p. $1505-1526$.

Sheldon, R. A., 1973, Stratigraphy and petroleum prospects of southwestern Cebu, Philippines: Am. Assoc. Petroleum Geologists Bull., v. 57, p. 1343-1347.

Shields, Oakley, 1977, A Gondwanaland reconstruction for the Indian Ocean: Jour. Geology, v. 85, p. 236-242.

Shih, T. C., 1976, Marine magnetic anomalies in the West Philippine Basin (abs.): Geol. Soc. America Abs. with Programs, v. 8, p. 1104.

Shiraki, Keiichi, 1971, Metamorphic basement rocks of Yap islands, western Pacific-possible oceanic crust beneath an island arc: Earth and Planetary Sci. Letters, v. 13, p. 167-174.

Shor, G. G., Jr., and Jacobson, R. S., 1977, Structure beneath the Timor-Tanimbar-Aru trough system [abs.]: EOS (Am. Geophys. Union Trans.), v. 58, p. 509.

Shor, G.G., Jr., Kirk, H. K., and Menard, H. W., 1971, Crustal structure of the Melanesian area: Jour. Geophys. Research, v. 76, p. 2562-2586.

Shor, G. G., Jr., Raitt,R. W., Henry, Marilee, Bentley, L. R., and Sutton, G. H., 1973, Anisotropy and crustal structure of the Cocos plate: Geofisica Internac, v. 13, p. 337-362.

Silitonga, P. H., and Kastowo, 1975, Geologic map of the Solok quadrangle, Sumatra: Indonesia Geol. Survey, scale 1:250,000.

Silver, E. A., Joyodiwiryo, Yoko, and McCaffrey, Robert, 1978, Gravity results and emplacement geometry of the Sulawesi ultramafic belt, Indonesia: Geology, v. 6, p. 527-531.

Silver, E. A., and Moore, J. C.. 1978, The Molucca Sea collision zone, Indonesia: Jour. Geophys. Research, v. 83, p. 1681-1691.

Simons, A. L., 1940, Geological investigations in N.E. Netherlands Timor, in Brouwer, H. A., ed., Geological expedition of the University of Amsterdam to the Lesser Sunda Islands, V. 1: Amsterdam, North Holland Publishing Co., p. 107-214.

Skwarko, S. K., 1966, Cretaceous stratigraphy and palaeontology of the Northern Territory: Australia Bur. Mineral Resources, Geology and Geophysics Bull. 73, 135 p.

1967, First Upper Triassic and ? Lower Jurassic marine mollusca from New Guinea: Australia Bur. Mineral Resources, Geology and Geophysics, Bull. 75 , p. 37-83.

1973a, Cretaceous stratigraphy of part of the Wiso Basin, Northern Territory: Australia Bur. Mineral Resources, Geology and Geophysics Bull. 140, p. 85-104.

1973b. First report of Domerian (Lower Jurassic) marine mollusca from New Guinea: Australia Bur. Mineral Resources, Geology and Geophysics Bull. 140, p. 105-112.
1976, Stratigraphic tables, Papua New Guinea: Australia Bur. Mineral Resources, Geology and Geophysics Rec. 1976/33, 75 p.

Skwarko, S. K., Nicoll, R. S., and Campbell, K. S. W., 1976, The Late Triassic molluses, conodonts, and brachiopods of the Kuta Formation, Papua New Guinea: Australia Bur. Mineral Resources, Geology and Geophysics, BMR Jour., v. 1, p. 219-230.

Sleep, N. H., 1975, Formation of oceanic crust-some thermal constraints: Jour. Geophys. Research, v. 80, p. 4037-4042.

Sleep, N. H., and Toksöz, M. N., 1971, Evolution of marginal basins: Nature, v. 233, p. 548-550.

van der Sluis, J. P., 1950, Geology of East Seran, No. 3, of Geological, petrographical and palaeontological results of explorations, carried out from September 1917 till June 1919 in the island of Ceram, by L. Rutten and W. Hotz, in Geology, 3d Ser.: Amsterdam, J. H. de Bussy, $66 \mathrm{p}$.

Smiley, C. J., 1970, Geologic considerations, Pt. I of Later Mesozoic flora from Maran, Pahang, West Malaysia: Geol. Soc. Malaysia Bull. 3, p. $77-88$.

Smith, A. G., 1976, Plate tectonics and orogeny, a review: Tectonophysics, v. 33 , p. $215-285$.

Smith, A. G., and Hallam, Anthony, 1970, The fit of the southern continents: Nature, v. 225, p. 139-144.

Smith, A. T., and Toksöz, M. N., 1972, Stress distribution beneath island arcs: Royal Astron. Soc. Geophys. Jour., v. 29, p. 289-318.

Smith, I. E. M., 1970, Late Cainozoic volcanism in eastern Papua: Australia Bur. Mineral Resources, Geology and Geophysics Rec. 1970/72, p. 10-17.

1976, Peralkaline rhyolites from the D'Entrecasteaux Islands. Papua New Guinea, in Johnson, R. W., ed., Volcanism in Australasia: Amsterdam, Elseveier, p. 275-285.

Smith, I. E. M., and Davies, H. L., 1976, Geology of the southeast Papuan mainland: Australia Bur. Mineral Resources, Geology and Geophysics, Bull. 165, 86 p.

Smith, J. G., 1968, Tectonics of the Fitzroy wrench trough, Western Australia: Am. Jour. Sci., v. 266, p. 766-776.

Smith, W. C., 1926, The volcanic rocks of Christmas Island (Indian Ocean): Geol. Soc. London Quart. Jour., v. 82, p. 44-66.

Soedarmo, D. P., 1973, Focal mechanisms and earthquake generating stress system in the Indonesian region: Indonesia Meteorological and Geophysical Inst., 15 p.

Soeparjadi, R. A., Nayoan, G. A. S., Beddoes, L. R., Jr., and James, W. V., 1975, Exploration play concepts in Indonesia: World Petroleum Cong., 9th, Tokyo, 1975, Proc., v. 3, p. 51-64.

Soeria Atmadja, Rubini, Golightly, J. P., and Wahju, B. N., 1974, Mafic and ultramafic rock associations in the East Arc of Sulawesi: [Indonesia] Bandung Inst. Technology, Proc., v. 8, no. 2, p. 67-85.

Soetantri, Bambang, Samuel, Luki, and Nayoan, G. A. S., 1973, The geology of the oilfields in North East Java: Indonesian Petroleum Assoc., 2d Ann. Convention, Jakarta 1973, Proc., p. 149-175.

Solomon, M., and Griffiths, J. R., 1972, Tectonic evolution of the Tasman orogenic zone, eastern Australia: Nature, Phys. Sci., v. 237, p. 3-6.

Solomon, S. C., Sleep, N. H., and Richardson, S. M., 1975, On the forces absolute plate motions: Jour. Geophys. Research, v. 79, p. 2557-2567.

Solomon, S. C., Sleep, N. H., and Richarson, S. M., 1975, On the forces driving plate tectonics-inferences from absolute plate velocities and intraplate stress: Royal Astron. Soc. Geophys. Jour., v. 42, p. 769-801.

South Africa Geological Survey, 1970, Geological map of the Republic of South Africa and Kingdoms of Lesotho and Swaziland: scale $1: 1,000,000,4$ sheets.

Spence, William, 1977, The Aleutian arc-tectonic blocks, episodic subduction, strain diffusion, and magma generation: Jour. Geophys. Research, v. 82, p. 213-230.

Spizharskiy, T. N., ed., 1966, Tectonic map of the USSR: Moscow, Minist. Geol. USSR, scale $1: 2,500,000,18$ sheets.

Spooner, E. T. C., and Fyfe, W. S., 1973, Sub-sea metamorphism, heat and mass transfer: Contr. Mineralogy and Petrology, v. 42, p. 287-304. 
Sproll, W. P., and Dietz, R. S., 1969, Morphological continental drift fit of Australia and Antarctica: Nature, v. 222, p. 345-348.

Srinivasan, M. S., and Sharma, V., 1973, Stratigraphy and microfauna of Car Nicobar island, Bay of Bengal: Geol. Soc. India Jour., v. 14, p. 1-11.

Stach, L. W., 1964, Petroleum potentialities of the continental shelf between Cape York and south-western Papua: Australian Petroleum Explor. Assoc. Jour., v. 4, p. 68-73.

Stagg, H. M. J., 1978, The geology and evolution of the Scott Plateau: Australian Petroleum Explor. Assoc. Jour., v. 18, pt. 1, p. 34-43.

Staritskiy, Yu. G., Maymin, Yu. S., and Trofimov, V. A., 1973, Tectonic development of North Vietnam: Internat. Geology Rev., v. 15, p. 1381-1390.

Stark, J. T., and Hay, R. L., 1963, Geology and petrography of volcanic rocks of the Truk Islands, East Caroline Islands: U.S. Geol. Survey Prof. Paper 409, $41^{\circ}$ p.

Stauffer, P. H., 1967, Studies in the Crocker formation, Sabah: Borneo Region Malaysia Geol. Survey Bull. 8, p. 1-13.

1974, Malaya and southeast Asia in the pattern of continental drift: Geol. Soc. Malaysia Bull. 7, p. 89-138.

Stauffer, P. H., and Gobbett, D. J., 1972, Southeast Asia a part of Gondwanaland?: Nature, Phys. Sci., v. 240, p. 139-140.

von Steiger, H. G., 1915, Petrografische beschrijving van eenige gesteenten uit de onderafdeeling Pangkadjene en het landschap tanette: Jaarboek Mijnwezen Nederlandsch Oost-Indië, 1913, Verh., v. 42, p. 171-227. 1922, Resultaten van geologisch-mijnbouwkundige verkenningen in een gedeelte van Midden-Sumatra: Jaarboek Mijnwezen Nederlandsch Oost-Indië, 1920, Verh., v. 49, pt. I, p. 87-200.

Stein, Seth, and Okal, E. A., 1978, Seismicity and tectonics of the Ninetyeast Ridge area-evidence for internal deformation of the Indian plate: Jour. Geophys. Research, v. 83, p. 2233-2245.

Stephens, E. A., 1956, The geology and mineral resources of the Kota Belud and Kudat area, North Borneo: British Terr. Borneo Geol. Survey Dept., Mem. 5, 137 p.

Stern, C. R., Huang, W.-L., and Wyllie, P. J., 1975, Basalt-andesiterhyolite- $\mathrm{H}_{2} \mathrm{O}$ - crystallization inter' $\mathrm{s}$ als with excess $\mathrm{H}_{2} \mathrm{O}$ and $\mathrm{H}_{2} \mathrm{O}$ undersaturated liquidus surfaces to 35 kilobars, with implications for magma genesis: Earth and Planetary Sci. Letters, v. 28, no. 2, p. 189-196.

Stern, C. R., and Wyllie, P. J., 1973, Melting relations of basalt-andesiterhyolite- $\mathrm{H}_{2} \mathrm{O}$ and a pelagic red clay at $30 \mathrm{~kb}$ : Contr. Mineralogy and Petrology, v. 42, p. 313-323.

Stewart, G. S., 1978, Implications for plate-tectonics of the Aug. 19, 1977 Indonesian decoupling normal-fault earthquake (abs.): EOS (Am. Geophys. Union Trans.), v. 59, p. 326.

Stille, Hans, 1945, Die tektonische Entwicklung der hinterindischen Festlands- und Inselgebiete: Geotektonische Forschungen, no. 7/8, p. 34-153, [1948].

Stockwell, C. H., ed., 1969, Tectonic map of Canada: Canada Geol. Survey Map 1251B, scale 1:5,000,000.

Stockwell, C. H., McGlynn, J. C., Emslie, R. F., Sanford, B. V., Norris, A. W., Donaldson, J. A., Fahrig, W. F., and Currie, K. L., 1970, Geology of the Canadian Shield: Canada Geol. Survey Econ. Geology Rept. I, [5th ed.] p. 44-150.

Stoiber, R. E., and Carr, M. J., 1971, Lithospheric plates, Benioff zones, and volcanoes: Geol Soc. America Bull., v. 82, p. 515-521.

Stoneley, Robert, 1974, Evolution of the continental margins bounding a former southern Tethys, in Burk, C. A., and Drake, C. L., eds., The geology of continental margins: New York, Springer-Verlag, p. $889-903$.

Sudiro, T. W., and others, 1973, The struciiral units of the Jawa Sea: Indonesian Petroleum Assoc., 2d Ann. Convention, Jakarta 1973, Proc., p. 177-185.

Sudradjat, A., 1975, Reconnaissance geologic map of Sumbawa, West Nusatenggara: Indonesia Geol. Survey, scale 1:250,000.

Sukamto, Rab, 1973a, Reconnaissance geologic map of Palu area, central Sulawesi: Indonesia Geol. Șurvey, scale 1:250,000. 1973b, Reconnaissance geologic map of Ujung Pandang area: Indonesia Geol. Survey Mapping Div., Open-File Map, scale 1:250,000.

1975a, Geologic map of Indonesia, Ujung Pandang: Indonesia Geol. Survey, scale $1: 1,000,000$, sheet 8 .

1975b, The structure of Sulawesi in the light of plate tectonics: Assoc. Indonesian Geologists, Regional Conf. on Geology and Mineral Resources of Southeast Asia, Jakarta 1975, 25 p.

1975c, Geologi daerah Kepulauan Banggai dan Sula: Geologi Indonesia, v. 2, no. 3, p. 23-28.

1976, Singkapan 'melange' di Pulau Karakelang: Indonesia Geol. Survey Newsletter, v. 8, no. 19, p. 5-6.

Sumartadipura, A. S., 1976, Geologic map of the Tewah quadrangle, central Kalimantan: Indonesia Geol. Survey, scale 1:250,000.

Suntharalingam, T., 1968, Upper Palaeozoic stratigraphy of the area west of Kampar, Perak: Geol. Soc. Malaysia Bull. 1, p. 1-15.

Suppe, John, 1973, Geology of the Leech Lake-Bull Mountain region, California: California Univ. Pubs. Geol. Sci., v. 107, 82 p.

Sutan Assin, N. A. D., and Tarunadjaja, A. N. S., 1973, "Djatibarang," the discovery and development of a new oilfield: Indonesian Petroleum Assoc. Ist Ann. Convention, Jakarta 1972, Proc., p. 125-137.

Sutton, John, and Watson, J. V., 1974, Tectonic evolution of continents in early Proterozoic time: Nature, v. 247, p. 433-435.

Sweet, I. P., 1977, The Precambrian geology of the Victoria River region. Northern Territory: Australia Bur. Mineral Resources, Geology and Geophysics Bull. 168, 73 p.

Sweet, I. P., Mendum, J. R., Morgan, C. M., and Pontifex, I. R., 1974, The geology of the northern Victoria River region, Northern Territory: Australia Bur. Mineral Resources, Geology and Geophysics Rept. 166, $117 \mathrm{p}$.

Sykes, L. R., 1970, Seismicity of the Indian Ocean, and a possible nascent island arc between Ceylon and Australia: Jour. Geophys. Research, v. 75 , p. $5041-5055$.

Symonds, P. A., and Cameron, P. J., 1977, The structure and stratigraphy of the Carnarvon Terrace and Wallaby Plateau: Australian Petroleum Explor. Assoc. Jour., v. 17, pt. 1, p. 30-41.

Symonds, P. A., and Willcox, J. B., 1976, The gravity field of offshore Australia: Australia Bur. Mineral Resources, Geology and Geophysics, BMR Jour., v. 1, p. 303-314.

Tallis, N. C., 1975, Development of the Tertiary offshore Papuan Basin: Australian Petroleum Explor. Assoc. Jour., v. 15, pt. 1, p. 55-60.

Tamesis, E. V., Mañalac, E. V., Reyes, C. A., and Ote, L. M., 1973, Late Tertiary geologic history of the continental shelf off northwestern Palawan, Philippines: Geol. Soc. Malaysia Bull. 6, p. 165-176.

Tamura, M., Hashimoto, W., Igo, H., Ishibashi, T., Iwai, J., Kobayashi, T., Koike, T., Pitakpaivan, K., Sato, T., and Yin, E. H., 1975. The Triassic System of Malaysia, Thailand, and some adjacent areas, in Geology and palaeontology of Southeast Asia, v. 15: Tokyo Univ. Press, p. 103-149.

Tan, N. K. (Denis), 1975a, Geology of the Engkilili area: Malaysia Geol. Survey 1973 Ann. Rept., p. 206-213.

1975b, Preliminary notes on the melange in the Lupar Valley, west Sarawak: Malaysia Geol. Survey, 1974 Ann. Rept., p. 219-227.

Tappenbeck, D., 1940, Geologie des Mollogebirges und einer benachbarter Gebiete (Niederlandisch Timor), in Brouwer, H. A., ed., Geological expedition of the University of Amsterdam to the Lesser Sunda Islands, V. 1: Amsterdam, North Holland Publishing Co., p. 1-105.

Tapponnier, Paul, and Molnar, Peter, 1976, Slip-line field theory and large-scale continental tectonics: Nature, v. 264, p. 319-324.

1977, Active faulting and tectonics in China: Jour. Geophys. Research, v. 82, p. 2905-2930.

Tarling, D. H., 1972, Another Gondwanaland: Nature, v. 238, p. 92-93.

Tarr, A. C., 1974, World seismicity map: U.S. Geol. Survey.

Taverne, N. J. M., 1924, Bijdrage tot de geologie van de Gajo-Lesten en aangrenzende gebieden: Jaarboek Mijnwezen Nederlandsch Oost-Indië, 1921, Verh., v. 50, pt. 1, p. 162-186. 
Tayama, Risaburo, 1935, Topography, geology, and coral reefs of the Yap lslands: Tohoku Univ. Inst. Geology and Paleontology Contr., 19, p. 1-43 [in Japanese].

Taylor, D. J., 1971, Foraminifera and the Cretaceous and Tertiary depositional history in the Otway Basin in Victoria, in Hopfner, H., and Douglas, J. G., eds., The Otway Basin of southeastern Australia: South Australia and Victoria Geol. Surveys Spec. Bull., p. 217-233.

Taylor, E. F., 1951, General reconnaissance survey of the geology of the Sulu archipelago: Philippines Dept. Agriculture and Nat. Resources, Tech. Bull. 21, p. 303-313.

Taylor, G. A. M., 1969, Post-Miocene volcanoes in Papua-New Guinea: Geol. Soc. Australia Spec. Pub. 2, p. 205-208.

Taylor, Lloyd, and Falvey, David, 1977, Queensland Plateau and Coral Sea Basin: stratigraphy, structure, and tectonics: Australian Petroleum Explor. Assoc. Jour., v. 17, pt. 1, p. 13-29.

Teichert, Curt, 1970, Marine fossil invertebrate faunas of the Gondwana region: Second Gondwana Symposium, Pretoria 1970, Proc. and Papers, South Africa Council for Sci. and Indus. Research, p. 125-138.

Terman, M. J., 1973, Tectonic map of China and Mongolia: Geol. Soc. America, scale 1:5,000,000.

Terpstra, H., 1932, Voorloopige mededeeling over een geologischen verkenningstocht op de eilanden Siberoet en Sipoera (Mentawi-eilanden; Sumatra's Westkust): De Mijningenieur, v. 13, no. 2, p. $16-20$.

Teves, J. S., 1953, The pre-Tertiary geology of southern Oriental Mindoro: Philippine Geologist, v. 8, no. 1, p. 1-36.

Thaden, R. E., Sumadirdja, Harli, and Richards, P. W., 1975, Geologic map of the Magelang and Semarang quadrangles, Java: Indonesia Geol. Survey, scale 1:100,000.

Thom, J. H., 1975, Kimberley region: Western Australia Geol. Survey Mem. 2, p. 160-193.

Thompson, G., Bryan, W. B., and Frey, F. A., 1973, Petrology and geochemistry of basalts and related rocks from DSDP Leg 22, Sites 214 and 216, Ninety-east Ridge, Indian Ocean: EOS (Am. Geophys. Union Trans.), v. 54, p. 1019-1021.

Tilbury, L. A., 1975, Geophysical results from the Gulf of Papua and Bismarck Sea: Australia Bur. Mineral Resources, Geology and Geophysics, Rec. 1975/115, 49 p.

Tingey, R. J., and Grainger, D. J., 1976, Markham, Papua New Guinea: Australia Bur. Mineral Resources, Geology and Geophysics, 1:250,000 Geol. Ser. sheet SB/55-10. Explanatory notes, $49 \mathrm{p}$.

Tipper, G. H., 1911, The geology of the Andaman Islands, with reference to the Nicobars: India Geol. Survey Mem. 35, p. 195-216.

Tjia, H. D., 1966, Structural analysis of the pre-Tertiary of the Lokulo area. central Java: [Indonesia] Bandung Inst. Technology Dept. Geology Contr. no. 63, $110 \mathrm{p}$.

1968. The Lembang fault, West Java: Geologie en Mijnbouw, v. 47 , p. $126-130$.

1973, 1rian fault zone and Sorong melange, Indonesia: Sains Malaysiana (Univ. Kebangsaan Malaysia), v. 2, p. 13-30.

Tjia, H. D., and Posavec, M. M., 1972, The Sumatra fault zone between Padangpandjang and Muaralabuh: Sains Malaysiana (Univ. Kebangsaan Malaysia), v. 1, p. 77-105.

Tjia, H. D., and Zakaria, T., 1974, Palu-Koro strike-slip fault zone, central Sulawesi, Indonesia: Sains Malaysiana (Univ. Kebangsaan Malaysia), v. 3, p. 65-86.

Tobler, A., 1923, Unsere palaontologische Kenntnis von Sumatra: Eclogae Geol. Helvetiae, v. 18, p. 313-342.

Todd, D. F., and Pulunggono, A., 1971, Wildcatters score in Indonesia: Oil and Gas Jour., v. 69, no. 24, p. 104-110.

du Toit, A. L., 1937, Our wandering continents: Edinburgh, Oliver and Boyd, 366 p.

Toksöz, M. N., Sleep, N. H., and Smith, A. T., 1973, Evolution of the downgoing lithosphere and the mechanism of deep focus earthquakes: Royal Astron. Soc. Geophys. Jour., v. 35, p. 285-310.
Tongeren, W. van, 1936, Mineralogical and chemical composition of the syenite-granite from Boekit Batoe near Palambang, Sumatra, Netherlands East Indies: Koninkl. Akad. Wetensch. Amsterdam, Proc., v. 39, p. 670-673.

Tovish, Aaron, and Schubert, Gerald, 1978, Island arc curvature, velocity of convergence and angle of subduction: Geophys. Research Letters, v. 5 , p. $329-332$.

Trail, D. S., 1967, Geology of Woodlark lsland, Papua: Australia Bur. Mineral Resources, Geology and Geophysics Rept. 115, 32 p.

Trend Exploration Technical Staff, 1973, Reef exploration in Irian Jaya, Indonesia: Indonesian Petroleum Assoc., 2d Ann. Convention, Jakarta 1973, Proc., p. 243-277.

Trueman, N. A., 1965, The phosphate, volcanic and carbonate rocks of Christmas Island (Indian Ocean): Geol. Soc. Australia Jour., v. 12, p. 26I-283.

Turcotte, D. L., and Oxburgh, E. R., 1969, Convection in a mantle with variable physical properties: Jour. Geophys. Research. v. 74, p. 1458-1474.

1973, Mid-plate tectonics: Nature, v. 244, p. 337-339.

Ubaghs, J. G. H., 1936, De geologie van een gebied in Noord Koetai (Oost Borneo) gekenmarkt door Spiroclypeus-houdend Eoceen: De Ingenieur in Nederlandsch-Indie, v. 3, no. 10, pt. 4, p. 183-195.

Udintsev, G. B., ed., 1975, Geological-geophysical atlas of the Indian Ocean: Akad. Nauk, SSSR Gl. Upr. Geol. Kartogr., 151 p.

Udintsev, G. B., Agapova, G. F., Beresnev, A. F., Verzhbitskiy, Ye. U., Suzyumov, A. Ye, and Filipas, S. F., 1972, Tectonics of the geosynclinal basin and framework of the Bismarck Sea: Acad. Sci. USSR Doklady, Earth Sci. Sec., v. 206, Sept.-Oct. 1972, p. 6-8 (AGl translation).

Udintsev, G. B., Dimitriyev, L. V., Sharas'kin, A. Ya., Agapova, G. V., Zenkovich, N. L., Bersenev, A. F., Kurentsova, N. A., and Suzyumov, A. Ye., 1974, New data on trench-faults in the southwestern Pacific: Geotectonics, 1974, no. 2, p. 65-69.

U.N. Economic Commission for Asia and the Far East, 1971, Geological map of Asia and the Far East [2d ed.]: U.N. Pub. 69-30632, scale 1:5,000,000, 4 sheets.

U.S. Army, 1956, Military geology of Palau Islands, Caroline Islands: U.S. Army Forces Far East, Intelligence Div., 285 p. (unclassified).

U.S. Geological Survey, 1974, Bathymetric map of the Indonesian region: U.S. Geol. Survey Misc. Inv. Ser. Map 1-875-A.

1975, Geological Survey research 1975, U.S. Geol. Survey Prof. Paper 975, 373 p. [1976].

Untung, M., 1974, Peta anomali Bouguer Jawa dan Madura: Indonesia Geol. Survey, Ser. Geofis. 4, scale 1:1,000,000.

Usna, L., 1977, Note on a seismic reflection profile across the Seram Trough: Indonesia Geol. Survey Newsletter, v. 9, no. 16, p. 193-194.

Utsu, Tokuji, 1971, Seismological evidence for anomalous structure of island arcs with special reference to the Japanese region: Rev. Geophysics, v. 9, p. 839-890.

Uyeda, Seiya, and Ben-Avraham, Zvi, 1972, Origin and development of the Philippine Sea: Nature, Phys. Sci., v. 240, p. 176-178.

Vacquier, V., and Taylor, P. T., 1966, Geothermal and magnetic survey off the coast of Sumatra: Japan Earthquake Research Inst. Bull, v. 4l, p. $531-540$.

Valk, W., 1945, Contributions to the geology of West Seran, No. 1, of Geological, petrographical and palaeontological results of explorations, carried out from September 1917 till June 1919 in the island of Ceram, by L. Rutten and W. Hotz, in Geology, 3d Ser.: Amsterdam, J. H. de Bussy, 104 p.

1962, Geology of West Amberbaken (New Guinea): Geologie en Mijnbouw, v. 41, p. $384-390$

Van Houten, F. B., 1974, Northern Alpine molasse and similar Cenozoic sequences of southern Europe: Soc. Econ. Paleont. Mineral., Spec. Pub. 19, p. 260-273.

van der Veen, A. L. W., 1914, Bijdrage tot de geologie van Nias: Geol. Reichs-Museums Leiden, Samml, v. 9, 225-243. 
Veevers, J. J., 1967, The Phanerozoic geological history of northwest Australia: Geol. Soc. Australia Jour., v. 14, p. 253-271.

1969a, Sedimentology of the Upper Devonian and Carboniferous platform sequence in the Bonaparte Gulf Basin: Australia Bur. Mineral Resources, Geology and Geophysics Bull. 109, 86 p.

1969b, Palaeogeography of the Timor Sea region: Palaeogeography, Palaeoclimatology, Palaeoecology, v. 6, p. 125-140. 1971a, Shallow stratigraphy and structure of the Australian continental margin beneath the Timor Sea: Marine Geology, v. 1I, p. 209-249.

1971b, Phanerozoic history of Western Australia related to continental drift: Geol. Soc. Australia Jour., v. 18, p. 87-96.

1974, Western continental margin of Australia, in Burk, C. A., and Drake, C. L., eds., The geology of continental margins: New York, Springer-Verlag, p. 605-616.

1976, Early Phanerozoic events on and alongside the Australasian-Antarctic platform: Geol. Soc. Australia Jour., v. 23, p. 183-206.

Veevers, J. J., and Cotterill, D., 1976, Western margin of Australia-a Mesozoic analog of the East African rift system: Geology, v. 4, p. 713-717.

1978, Western margin of Australia - evolution of a rifted arch system: Geol. Soc. America Bull., v. 89, p. 337-355.

Veevers, J. J., and Evans, P. R., 1975, Late Palaeozic and Mesozoic history of Australia, in Campbell, K. S. W., ed., Gondwana geology: Australian Natl. Univ. Press, p. 579-607.

Veevers, J. J., Falvey, D. A., Hawkins, L. V., and Ludwig, W. J., 1974, Seismic reflection measurements of northwest Australian margin and adjacent deeps: Am. Assoc. Petroleum Geologists Bull., v. 58, p. 1731-1750.

Veevers, J. J., and Heirtzler, J. R., 1973, Deep Sea Drilling Project, Leg 27 in the eastern Indian Ocean: GeoTimes, v. 18, no. 4, p. 16-17.

Veevers, J. J., Heirtzler, J. R., and others, 1974, Initial reports of the Deep Sea Drilling Project. V. 27: Washington, U.S. Govt. Printing Office $1060 \mathrm{p}$.

Veevers, J. J., Jones, J. G., and Talent, J. A., 1971, Indo-Australian stratigraphy and the configuration and dispersal of Gondwanaland: Nature, v. 229 , p. $383-388$.

Veevers, J. J., and McElhinny, M. W., 1976, The separation of Australia from other continents: Earth Sci. Rev., v. 12, p. 139-159.

Veevers, J. J., Powell, C. M., and Johnson, D. B., 1975, Greater India's place in Gondwanaland: Earth and Planetary Sci. Letters, v. 27, p. 383-387.

Veevers, J. J., and Roberts, J., 1968, Upper Palaeozoic rocks, Bonaparte Gulf Basin of northwestern Australia: Australia Bur. Mineral Resources, Geology and Geophysics, Bull. 97, 155 p.

Vening Meinesz, F. A., 1940, The Earth's crust deformation in the East Indies: Nederlandsche Akad. Wetensch. Proc., v. 43, p. 278-293.

1954, Indonesian Archipelago-a geophysical study: Geol. Soc. America Bull., v. 65, p. 143-164.

Verbeek, R. D. M., 1905, Geologische beschrijving van Ambon: Jaarboek Mijnwezen Nederlandsch Oost-Indië, Wetensch., v. 34, pt. 2, 308 p.

1908a, Rapport sur les Moluques: Jaarboek Mijnwezen Nederlandsch Oost-Indië, 1908, Verh., v. 37, p. 116-231, separate atlas [French ed.]

1908b, Molukken-Verslag: Jaarboek Mijnwezen Nederlandsch Oost-Indië, 1908, Wetensch., 1908, v. 37, 826 p., separate atlas.

Verhofstad, J., 1966, Glaucophanitic stone implements from West New Guinea (West Irian): Geologie en Mijnbouw, v. 45, p. 291-300.

Verstappen, H. T., 1960, Geomorphological observations on the north Moluccan-northern Vogelkop islands arcs: Nova Guinea (Leiden, E. J. Brill), Geology, no. 3, p. 13-37.

1973, A geomorphological reconnaissance of Sumatra and adjacent islands (Indonesia): Groningen, Netherlands, WoltersNoordhoff, $182 \mathrm{p}$.
Vincelette, R. R., and Soeparjadi, R. A., 1976, Oil-bearing reefs in Salwati [Salawati] Basin of Irian Jaya, Indonesia: Am. Assoc. Petroleum Geologists Bull., v. 60, p. 1448-1462.

Vind, E. W., and Harwood, C. R., 1965, Geophysical exploration in Torres Strait: Australian Petroleum Explor. Assoc. Jour., v. 5, p. 188-190.

Visser, W. A., and Hermes, J. J., 1962, Geological results of the exploration for oil in Netherlands New Guinea: Koninkl. Nederlands Geol. Mijnbouw Genoot., Verh., Geol. Ser., v. 20, spec. no., 265 p.

van der Vlerk, I. M., and Dozy, J. J., 1934, The Tertiary rocks of the Celebes-Expedition-1929: Koloniën Nederland Geol. Mijnbouw Genoot. Verh., Geol Ser., v. 10, p. 183-217.

Vogler, J., 1941, Ober-Jura und Kreide von Misol (Niederländisch-Ostindien): Palaeontographica, supp. v. 4, pt. 4, p. 245-292.

Vogt, P. R., 1973, Subduction and aseismic ridges: Nature, v. 241, p. 189-191.

Vogt, P. R., Lowrie, A., Bracey, D. R., and Hey, R. N., 1976, Subduction of aseismic oceanic ridges--effects on shape, seismicity, and other characteristics of consuming plate boundaries: Geol. Soc. America Spec. Paper 172, $59 \mathrm{p}$.

Von Huene, Roland, and Nasu, Noriyuki, 1978, Japan Trench transected: GeoTimes, v. 23, no. 4, p. 16-21.

de Waard, D., 1955, Tectonics of the Sonnebait overthrust unit near Nikiniki and Basleo: Indonesian Jour. Nat. Sci., v. 111, p. 144-151.

1956, Geology of a N-S section across western Timor: Indonesian Jour. Nat. Sci., v. 112, p. 101-115.

Walcott, R. 1., 1970, Flexure of the lithosphere at Hawaii: Tectonophysics, v. 9 , p. $435-446$.

1976, Lithospheric flexure, analysis of gravity anomalies. and the propagation of seamount chains: Am. Geophys. Union Geophys. Mon. 19. p. 431-438.

Walpole, B P., Dunn, P. R., and Randal, M. A., 1968, Geology of the Katherine-Darwin region, Northern Territory: Australia Bur. Mineral Resources, Geology and Geophysics, Bull. 82, v. 1, 170 p., v. 2, pls.

Wanner, J., 1910, Beiträge zur geologischen Kenntnis der Insel Misol (Niederländisch Ost-Indien): Koninkl. Nederlandsch Aardrijksk. Genoot. Tijdschr., ser. 2, v. 37, p. 469-529.

1913, Zur Geologie der Inseln Obimajora und Halmahera in den Molukken: Neues Jahrb, Mineralogie. Geologie, u. Paläontologie, supp. v. 36 , p. $560-585$.

1918, Beitrāge zur Geologie der Insel Buru: Palaeontographica, supp. v. 4, pt. 3, sex. 3, p. 59-112.

1941, Neue Beitrāge zur Kenntnis der permischen Echinodermen

von Timor, XV, Echinoidea: Palaeontographica. supp. v. 4, sec. 4, pt.

5., p. 295-314.

Ward, D. E., and Bunnag, Din, 1964, Stratigraphy of the Mesozoic Khorat Group in northeastern Thailand: Thailand Dept. Mineral Resources Rept. Inv. 6, 95 p.

Warris, B. J., 1973, Plate tectonics and the evolution of the Timor Sea, northwest Australia: Australian Petroleum Explor. Assoc. Jour., v. 13, pt. 1, p. 13-18.

Watanabe, Teruhiko, Epp, David, Uyeda, Seiya, Langseth, Marcus, and Yasui, Masashi, 1970, Heat flow in the Philippine Sea: Tectonophysics, v. 10, p. 205-224.

Waterhouse, J. B., 1972, The evolution, correlation, and paleogeographic significance of the Permian ammonoid family Cyclolobidae: Lethaia. v. 5 , p. $251-270$.

1973, Permian brachiopod correlations for South-east Asia: Geol. Soc. Malaysia Bull. 6, p. 197-210.

Waterhouse, J. B., and Piyasin, Sangat, 1970, Mid-Permian brachiopods from Khao Phrik, Thailand: Palaeontographica, v. A-135, no. 3, p. 83-197.

Waterschoot van der Gracht, W. A. J. M., 1915, Bijdrage tot de geologie van Centraal-Celebes: Jaarboek Mijnwezen Nederiandsch Oost-Indië, 1914, Verh., v. 34, pt. 2, p. 16-73.

Watkins, N. D., Gunn, B. M., Nougier, Jacques, and Baksi, A. K., 1974. Kerguelen-continental fragment or oceanic island?: Geol. Soc. America Bull., v. 85, p. 201-212. 
Watt, C. J., 1976, Geophysical results from the Timor Trough: Australia Bur. Mineral Resources, Geology and Geophysics, Rec. 1976/14, 15 p.

Watts, A. B., and Talwani, Manik, 1975, Gravity effect of downgoing lithospheric slabs beneath island arcs: Geol. Soc. America Bull., v. 86, p. 1-4.

Watts, A. B., and Weissel, J. K., 1975, Tectonic history of the Shikoku marginal basin: Earth and Planetary Sci. Letters, v. 25, p. 239-250.

Watts, A. B., Weissel, J. K., and Larson, R. L., 1977, Sea-floor spreading in marginal basins of the western Pacific: Tectonophysics, v. 37, p. $167-181$.

Webb, A. W., and McDougall, Ian, 1967, Isotopic dating evidence on the age of the Upper Permian and Middle Triassic: Earth and Planetary Sci. Letters, v. 2, p. 483-488.

1968. The geochronology of the igenous rocks of eastern Queensland: Geol. Soc. Australia Jour., v. 15, p. 313-346.

Weeda, Jan, 1958a, Oil basin of east Java, in Weeks, L. G., ed., Habitat of oil: Am. Assoc. Petroleum Geologists, p. 1359-1364.

1958b, Oil basin of east Borneo, in Weeks, L. G., ed., Habitat of oil: Am. Assoc. Petroleum Geologists, p. 1337-1346.

Weeks, L. A., Harrison, R. N., and Peter, G., 1967, lsland arc system in Andaman Sea: Am. Assoc. Petroleum Geologists Bull., v. 51, p. 1803-1815.

van der Wegen, C., 1966, Contribution of the Bureau of Mines to the geology of the Central Mountains of West New Guinea: Geologie en Mijnbouw, V. 45, p. 249-261.

Weissel, J. K., and Hayes, D. E., 1971, Asymmetric seafloor spreading south of Australia: Nature, v. 231, p. 518-522.

1977, Evolution of the Tasman Sea reappraised: Earth and Planetary Sci. Letters, v. 36, p. 77-84.

Wellman, H. W., 1971, Reference lines, fault classification, transform systems, and ocean-floor spreading: Tectonophysics, v. 12, p. 199-209.

Wellman, Peter, 1976a, The gravity field of the Australian basement: Australia Bur. Mineral Resources, Geology and Geophysics, BMR Jour., v. I, p. 287-290.

1976b, Regional variation of gravity, and isostatic equilibrium of the Australian crust: Australian Bur. Mineral Resources, Geology and Geophysics, BMR Jour., v. 1, p. 297-302.

Wellman, Peter, McElhinny, M. W., and McDougall, Ian, 1969, On the polar-wander path for Australia during the Cenozoic: Royal Astron. Soc. Geophys. Jour., v. 18, p. 371-395.

Wennekers, J. H. L., 1958, South Sumatra basinal area, in Weeks, L. G., ed., Habitat of oil: Am. Assoc. Petroleum Geologists, p. 1347-1358.

van West, F. P., 1941, Geological investigation in the Miomaffo region (Netherlands Timor), in Brouwer, H. A., ed., Geological expedition of the University of Amsterdam to the Lesser Sunda Islands, V. 3: Amsterdam, North Holland Publishing Co., p. 1-131.

Westbrook, G. K., 1975. The structure of the crust and upper mantle in the region of Barbados and the Lesser Antilles: Royal Astron. Soc. Geophys. Jour., v. 43, p. 201-242.

Westbrook, G. K., Bott, M. H. P., and Peacock, J. H., 1973, Lesser Antilles subduction zone in the vicinity of Barbados: Nature, Phys. Sci., v. 244, p. $118-120$.

Western Australia Geological Survey, 1974, Geological map of Western Australia: scale $1: 2,500,000$.

1975, The geology of Western Australia: Western Australia Geol. Survey Mem. 2, 541 p.

Westerveld, J., 1941, Three geological sections across South Sumatra: Nederlandsche Akad. Wetensch., Proc., v. 44, p. 1131-1139.

1942, Welded rhyolitic tuffs or "ignimbrites" in the Pasoemah region, West Palembang, South Sumatra: Leidsche Geol. Meded., v. 53, p. 202-217.

1949, Fasen van Gebergtevorming en Ertsprovincies in Nederlands Oost-Indië: De Ingenieur, v. 61, p. M 1-27. 1952, Quaternary volcanism in Sumatra: Geol. Soc. America Bull., v. 63, p. 561-594.
Whitaker, W. G., and Grimes, K. G., 1975, Queensland geology: Queensland Geol. Survey, scale 1:2,500,000.

Whitford, D. J., 1975, Strontium isotopic studies of the volcanic rocks of the Saunda [Sunda] arc, Indonesia, and their petrogenetic implications: Geochim. et. Cosmochim. Acta, v. 39, p. 1287-1302.

Whitford, D. J., Compston, W., Nicholls, I. A., and Abbott, M. J., 1977, Geochemistry of late Cenozoic lavas from eastern Indonesia - Role of subducted sediments in petrogenesis: Geology, v. 5, p. 571-575.

Whitford, D. J., and Nicholls, I. A., 1976, Potassium variations in lavas across the Sunda arc in Java and Bali, in Johnson, R. W., ed., Volcanism in Australasia: Amsterdam, Elsevier, p. 63-75.

Whyte, M. A., 1977, Turning points in Phanerozoic history: Nature, v. 267, p. $679-682$.

Wichmann, A., 1914, On some rocks of the island of Taliabu (Sula Islands): Koninkl. Akad. Wetensch. Amsterdam Proc., v. 17, p. 226-239.

Wiebenga, W. A., 1973, Crustal structure of the New Britain-New Ireland region, in Coleman, P. J., ed., The western Pacific: Nedlands, Western Australia, Western Australia Univ. Press, p. 163-177.

Wilcox, R. E., Harding, T. P., and Seely, D. R., 1973, Basic wrench tectonics: Am. Assoc. Petroleum Geologists Bull., v. 57, p. 74-96.

Wilford, G. E., 1955, The geology and mineral resources of the Kuching-Lunda area, west Sarawak, including the Bau mining district: British Terr. Borneo Geol. Survey Dept., Mem. 3, 254 p.

1961, The geology and mineral resources of Brunei and adjacent parts of Sarawak: British Terr. Borneo Geol. Survey Dept., Mem. 10, $319 \mathrm{p}$.

1967, Geological map of Sabah: Malaysia Geol. Survey, scale 1:500,000

Wilford, G. E., and Kho, C. H., 1965, Penrissen area, west Sarawak, Malaysia: Borneo Region Malaysia Geol. Survey, Rept. 2, 195 p.

Willbourn, E. S., 1934, The geology of that part of the Malayan gold-belt on the topographical map sheet $3 \mathrm{~B} / 4$ and on the southern part of $2 \mathrm{~N} / 16$ : Federated Malay States Geol. Survey Dept., 1933 Ann. Rept., p. 5-13.

Willcox, J. B., 1976, Structure of the Bismarck Sea: Australia Bur. Mineral Resources, Geology and Geophysics, Rec. 1976/59, 46 p.

Willcox, J. B., Exon, N., Petkovic, P., and Petkovic, J., 1975, The Exmouth Plateau: Australia Bur. Mineral Resources, Geology and Geophysics Rept. 190, p. 62-68.

Willems, H. W. V., 1937, Contribution to the petrology of the crystalline schists of western central Celebes: Amsterdam, J. F. Duwaer, 147 p.

Williams, G. E., and Austin, P. M., 1973, Global tectonics and the earth's rotation: Modern Geology, v. 4, p. 185-189.

Williams. 1. R., and Sofoulis, J., 197I, Prince Regent and Camden Sound, W. A.: Australia Bur. Mineral Resources, Geology and Geophysics, 1:250,000 Geol. Ser.-Explanatory notes, sheet SD/51-15, 16, 16 p.

Williams, L. W., Forman, D. J., and Hawkins, P. J., 1973, Sedimentary basins of the Sahul Shelf: Australasian Oil and Gas, v. 19, no. 13, p. 15-21.

Williams, P. W., McDougall, lan, and Powell, J. M., 1972, Aspects of the Quaternary geology of the Tari-Koroba area, Papua: Geol. Soc. Australia Jour., v. 18, p. 333-347.

Wilmott, W. F., 1972, Daru-Maer, Papua and Queensland: Australia Bur. Mineral Resources, Geology and Geophysics, 1:250,000 Geol. Ser. Explanatory notes, sheets SC/54-8 and SC/55-5, $15 \mathrm{p}$.

Wilmott, W. F., Whitaker, W. G., Palfreyman, W. D., and Trail, D. S., 1973, Igneous and metamorphic rocks of Cape York Peninsula and Torres Strait: Australia Bur. Mineral Resources, Geology and Geophysics, Bull. 135, 145 p.

Wilson, A. F., 1969, Granulite terrains and their tectonic setting and relationship to associated metamorphic rocks in Australia: Geol. Soc. Australia Spec. Pub. 2, p. 243-258.

Wilson, J. T., 1973, Mantle plumes and plate motions: Tectonophysics, v. 19, p. 149-164.

Wilson, R. A. M., 1961, The geology and mineral resources of the Banggi Island and Sugut River area, North Borneo: British Terr. Borneo Geol. Survey Dept. Mem. 15, 143 p. 
1963, The Chert-Spilite formation of North Borneo: British Terr. Borneo Geol. Survey Dept. Bull. 4, p. 61-78.

1968, Northwest Borneo geosyncline: Borneo Region Malaysia Geol. Survey 1967 Ann. Rept., p. 40-43.

Wilson, R. A. M., and Wong, N. P. Y., 1964, The geology and mineral resources of the Labuan and Padas Valley area, Sabah, Malaysia: Borneo Region Malaysia Geol. Survey, Mem. 17, 150 p.

Wing Easton, N., 1904, Geologie eines Teiles von West-Borneo: Jaarboek Minjwezen Nederlandsch Oost-Indië, 1904, Verh., v. 33, pt. 2, 542 p.

Win Swe, 1972, Strike-slip faulting in central belt of Burma (abs.): Geol. Soc. Malaysia Newsletter 34, Annex. p. 59.

Winterer, E. L., 1970, Submarine valley systems around the Coral Sea Basin (Australia): Marine Geology, v. 8, p. 229-244.

1973, Sedimentary facies and plate tectonics of equatorial Pacific: Am. Assoc. Petroleum Geologists Bull., v. 56, p. 265-282.

Winterer, E. L., and others, 1971, Initial reports of the Deep Sea Drilling Project, V. 7: Washington, U.S. Govt. Printing Office, pt. 1, p. 1-844, pt. 2, p. 845-1757.

Wiryosujono, S., 1977, Melange assemblage in Babar lsland: Indonesia Geol. Survey Newsletter, v. 9, no. 6, p. 71-75.

Wise, J. C., 1975, Petroleum potential of northern Australia: Australian Petroleum Explor. Assoc. Jour., v. 15, pt. 2, p. 80-85.

Wolfart, Reinhard, and Kursten, Martin, 1974, Stratigraphie und Paläogeographie des Kambriums in mittleren Süd-Asien (Iran bis Nord-Indien): Geol. Jahrb., ser. B, v. 8, p. 185-234.

Wolfenden, E. B., 1960, The geology and mineral resources of the lower Rajang valley and adjoining areas, Sarawak: British Terr. Borneo Geol. Survey Dept. Mem. 11, 167 p.

1965, Bau, Pt. I of Bau mining district, west Sarawak, Malaysia: Borneo Region Malaysia Geol. Survey Bull. 7, 147 p.

Wolfenden, E. B., and Haile, N. S., 1963, Sematan and Lundu area, west Sarawak: British Terr. Borneo Geol. Survey Dept. Rept. 1, 159 p.

Wongsosantiko, Abiratno, 1977, Lower Miocene Duri Formation sands, central Sumatra basin: Indonesian Petroleum Assoc., 5th Ann. Convention, Jakarta 1976, Proc., v. 1, p. 133-150.

Wood, B. L., 1971, Structure and relationships of late Mesozoic schists of NW California and SW Oregon: New Zealand Jour. Geology and Geophysics, v. 14, p. 219-239.

Woodcock, N. H., and Robertson, A. H. F., 1977, Origins of some ophiolite-related metamorphic rocks of the "Tethyan" belt: Geology, v. 5, p. $373-376$

Woollard, G. P., 1977, The status of geophysical research in Latin America: Canada Energy, Mines and Resources, Earth Physics Branch Pubs., v. 46 , no. 3 , p. $16-36$.

Workman, D. R., 1972a, Geology of Laos, Cambodia, South Vietnam and the eastern part of Thailand-a review: Great Britain Inst. Geol. Sci., Overseas Div. Rept. 19, 49 p.

$1972 \mathrm{~b}$, The tectonic setting of the Mesozoic granites of Korea: Geol. Soc. Korea Jour., v. 8, no. 2, p. 67-76.

1977, Geology of Laos, Cambodia, South Vietnam and the eastern part of Thailand: Great Britain Inst. Geol. Sci. Overseas Geology and Mineral Resources no. 50, $33 \mathrm{p}$.

Wright, W. S., Quicho, R. B., Salazar, Arsenio, and Manicaque, M. D., 1958, Iron-nickel-cobalt resources of Nonoc, Awasan and southern Dinagat Islands in Parcel 11 of the Surigao Mineral Reservation, Surigao, Minda nao: Philippine Bur. Mines Spec. Projects Pub. 16, 276 p.

Wunderlin, Wilhelm, 1914, Beiträge zur Kenntnis der Gesteine von Sudost-Celebes: Geol., Reichs-Museums Leiden, Samml., v. 9, p. 244-280.

Wyllie, P. J., 1973, Experimental eptrology and global tectonics-a preview: Tectonophysics, v. 17, p. 189-209.

Yancey, T. E., 1975, Evidence against Devonian unconformity and middle Paleozoic age of Langkawi folding phase in northwest Malaya: Am Assoc. Petroleum Geologists Bull., v. 59, p. 1015-1019.
Yanshin, A. L., 1966, Tectonic map of Eurasia: Acad. Sci. USSR Inst. Geol., scale 1:5,000,000, 12 sheets.

Yates, K. R., and de Ferranti, R. Z., 1967, Geology and mineral deposits Port Moresby/Kemp Welch area, Papua: Australia Bur. Mineral Resources, Geology and Geophysics, Rept. 105, 117 p.

Young, Brian, and Jantaranipa, Werapon, 1970, The discovery of upper Palaeozoic fossils in the 'Phuket Series' of peninsular Thailand: Geol. Soc. London, Proc., no. 1662, p. 5-7.

Zartman, R. E., 1974, Lead isotopic provinces in the Cordilleran region of the western United States and their geologic significance: Econ. Geology, v. 69, p. 792-805.

Zeijlmans van Emmichoven, C. P. A., 1935, Het Eoceen ten Z. van S. Kerijau in het $O$. deel van het Centrale Müllergebergte (Wester-afdeeling van Borneo): De Ingenieur in Nederlandsch-Indië, v. 2, no. 11, pt. 4, p. 102-105 [English translation in British Terr. Borneo Geol. Survey Dept., Bull. 2, p. 279-285, 1955].

1938, Korte schets van de geologie van Centraal-Borneo: De Ingenieur in Nederlandsch-Indië, v. 5, no. 9, pt. 4, p. 135-149.

1939. De geologie van het centrale en oostelijke deel van de Westerafdeeling van Borneo: Jaarboek Mijnwezen Nederlandsch-Indië, 1939, Verh., v. 68, p. 7-186 [English translation in British Terr. Borneo Geol. Survey Dept., Bull. 2, p. 159-272, 1955].

Zeijlmans van Emmichoven, C. P. A., and ter Bruggen, Gerrit, 1935 , Voorloopige mededeeling over het Tertiair ten W. van Merengebied in de Wester-afdeeling van Borneo: De Ingenieur in Nederlandsch-Indië, v. 2, no. 11, pt. 4, p. 99-102 [English translation in British Terr. Borneo Geol. Survey Dept., Bull. 2, p. 273-277, 1955].

Zeijlmans van Emmichoven, C. P. A., and Ubaghs, J. G. H., 1936, Bijdragen tot de geologie van Borneo, 3. Beschouwingen over den veronderstelden eoceenen ouderdom van de geheele "oude-leiformatie" in Centraal Borneo: De Ingenieur in Nederlandsch-Indië, v. 3 , no. 3, pt. 4, p. 37-45 [English translation in British Terr. Borneo Geol. Survey Dept., Bull. 2, p. 125-138, 1955].

Ziegler, A. M., Hansen K. S., Johnson, M. E., Kelly, M. A., Scotese, C. R., and Van der Voo, R., 1977, Silurian continental distributions, paleogeography, climatology, and biogeography: Tectonophysics, $v$. 40, p. 13-51.

Zillman, N. J., and Paten, R. J., 1975, Geology and petroleum prospects of Seram Island, eastern Indonesia: Australian Petroleum Explor. Assoc., Jour., v. 15, pt. 1, p. 73-80.

Zwartkruis, C. J., 1962, Orbicule-bearing blastopsammitic hornfelses from southern Bangka, Indonesia: Amsterdam Univ. Geol. Inst., Mededeling $269,94 \mathrm{p}$.

Zwierzijcki, J., 1922, Geologische overzichtskaart van den NederlandschOost-Indische Archipel, Toelichting bij blad 1 (Noord-Sumatra) Jaarboek Mijnwezen Nederlandsch Oost-Indië, 1919, Verh., v. 48, pt. 1, p. 11-71.

1924, Verslag over geologisch-mijnbouwkundige onderzoekingen en een gedeelte van Noord-Nieuw-Guinea: Jaarboek Mijnwezen Nederlandsch Oost-Indië, 1921, Verh., v. 50, pt. 1, p. $95-132$, pl. 3 in separate atlas.

1928, Geologische overzichtskaart van den NederlandschIndischen archipel, Toelichting bij de bladen 14 en 21 (Noord-en Zuid-Nieuw-Guinea): Jaarboek Mijnwezen Nederlandsch Oost-Indië, 1927 , Verh., v. 56, pt. 1, p. 248-308.

1930, Geologische oversichtskaart van den NederlandschIndischen archipel, Toelichtung bij blad 8 (Midden-Sumatra, Bangka, Riouw-eilanden): Jaarboek Mijnwezen Nederlandsch-Indië, 1929, Verh., v. 58 , p. $73-157$.

1932, Geologische overzichtskaart van den NederlandschIndischen archipel, Toelichting bij blad 12 (Vogelkop, West Nieuw Guinee) Jaarboek Mijnwezen Nederlandsch-Indië, 1930, Verh., v. 59 , pt. 3 , p. $1-55$.

1935, Die geologischen Ergebnisse der Paläobotanischen Djambi-Expedition 1925: Jaarboek Mijnwezen Nederlandsch-Indie, 1930, Verh., v. 59, pt. 2, p. 1-70. 



\section{INDEX}

[Page numbers of major references are in boldface; references to illustrations are in italic]

Page

Abyssal sediments. See Deep Sea Drilling Proj ect and individual ocean basins. See Melange and melange wedges and Ophiolite for abyssal sediments incorporated tectonically in land areas.

Accretionary wedges. See Melange and melange wedges.

Adelaideán Period (Australia), definition......

See also Precambrian and Precaunbrian(?) geology.

Adelbert Range, New Guinea ....... 232, 251, 252, 300 Admiralty Arc and Islands . . . . . . . . . . 232, 291 See also Bismarck Arc.

Africa ......................... 59, 63

Agusan-Davao Lowlands, Mindanao ..... 207, 209, 215

Aiduna River fault, New Guinea . . . . . . . 245, 247, 248

Alor .............................. 118, 124, 146, 156

Alor Trench $\ldots \ldots \ldots \ldots \ldots \ldots \ldots \ldots \ldots \ldots, 146,149,156$

Amblau $\ldots \ldots \ldots \ldots \ldots \ldots \ldots \ldots \ldots \ldots \ldots \ldots, 115,118$

Ambon ................ 115, 118, 134, 134, 135, 135

Anambas Islands ......................... 102, 109

Andaman-Nicobar arc system ....... 19, 60, 64, 65, 66, $67,79,80,81,82$

Andaman-Nicobar-Burma Trench ...... 19, 60, 65, 66, $66,79,80$

Andaman Sea $\ldots \ldots \ldots \ldots \ldots \ldots \ldots, 51,65,66,67,67,82$ Andesite. See Magmatic arcs.

Anomalies, gravity. See Gravity surveys and anomalies.

Anomalies, magnetic. See Magnetic anomalies. Antarctica ...................... 59, 60, 60,69 Antarctic lithosphere plate ...............

Anticlines, shale-cored or diapiric, Borneo.....

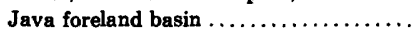

Malay Basin.

8

(240

Sarawak Basin .................. 104, 108, 109

Arabia .......................... 59, 63, 308

Arafura Basin, Australia ............. 221, 222, 225

Arafura Sea $\ldots \ldots \ldots \ldots \ldots \ldots \ldots \ldots \ldots \ldots, 222,225$

Arakan Yoma (Ranges), Burma $\ldots \ldots \ldots \ldots \ldots 65,79,80$

Arc-trench gap...

See also Outer-arc basin and Outer-arc ridge.

Archean, definition .................. 218

See also Precambrian and Precambrian(?) geology.

Argo Abyssal Plain, Indian Ocean ........21,56, 58, 59 Aria River fault, New Guinea .......... 245, 246, 248 Aru Basin ......................... 233, 245 Aru Islands . . . . . . . . . . . . . . . 115, 225, 233 Aru Trough. See Banda Trench.

Asia, Southeast . . . . . . . . . . . . . . . $67,69,82$ See also Burma, Indochina, and Malay Peninsula.

Asian (Eurasian) plate . . . . . . . . . . 8, 303, 307, 308 Assam syntaxis $\ldots \ldots \ldots \ldots \ldots \ldots \ldots \ldots .37,65,81,82$ Astrolabe Range, New Guinea ............. 232 Atauro (Kambing) . . . . . . . . . . . . . 115, 118 Aure Trough (Papuan Basin), New Guinea . 236, 239, 240 $264,269,270$

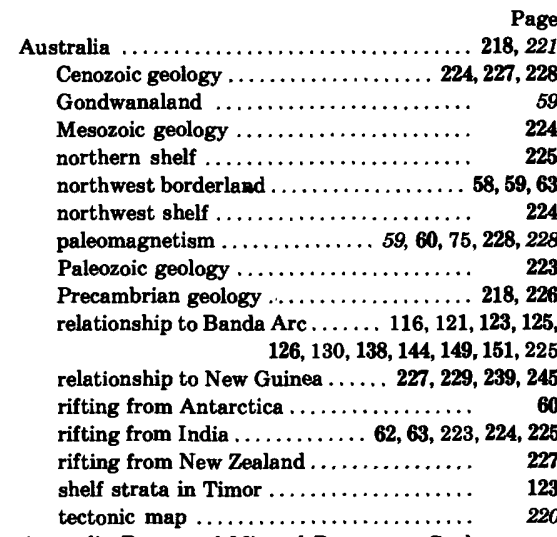

Australia Bureau of Mineral Resources, Geology and Geophysics, acknowledgments and credits .. 3, 7, 144, 145, 250, 256 , $258,258,259,265,266,288,302$

Australian-Indian lithosphere plate...... . 8, 290, 304

\section{B}

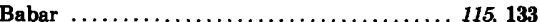

Babelthuap Island, Palau .............. 276, 277

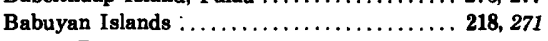
Bacan (Batjan) ...................... 190 Bagabag Island $\ldots \ldots \ldots \ldots \ldots \ldots \ldots .232,257,288,289$ Balabec Basin, Borneo ............... 85, 95 Balabec (Balabac) Island and Strait, Palawan Ridge .................103,111, 197 Bali ........................ 21, 114, 114, 118 Bali Basin $\ldots \ldots \ldots \ldots \ldots \ldots \ldots \ldots \ldots \ldots \ldots \ldots \ldots \ldots \ldots \ldots \ldots \ldots \ldots \ldots \ldots \ldots, 11,116$ Bancauan Basin, Borneo ................. 85,95 Banda Api $\ldots \ldots \ldots \ldots \ldots \ldots \ldots \ldots \ldots \ldots, 115,118,135$ Banda Arc ................ 114, 115, 117, 189, 305 Banda Sea ............. 114, 115, 117, 139, 140, 146, $149,150,151,155,189$

Banda Trench ...... 114, 115, 123, 136, 138, 138-147, 155 Banggai (Banggi, Banguey) Island, Palawan Ridge $\ldots \ldots \ldots \ldots \ldots \ldots \ldots \ldots$ 197, 199, 201 Banggai Islands, Banda Sea ........... 156, 157, 160, $172,181,183$

Banka. See Tin Islands

Barisan Mountains, Sumatra ......... 33, 35, 36, 38 Barito Basin, Borneo .............. 96, 101, 103, 113 Basalt, continental, non-arc

Australia, Cambrian ................ Cenozoic $\ldots \ldots \ldots \ldots \ldots \ldots \ldots \ldots \ldots, \quad 228$ Malay Peninsula, Cenozoic ............ 79

Torres Strait $\ldots \ldots \ldots \ldots \ldots \ldots \ldots \ldots \ldots, \quad \mathbf{2 2 8}$ Batan Islands ....................... 218, 271 Batanta Island $\ldots \ldots \ldots \ldots \ldots \ldots \ldots \ldots \ldots \ldots, 233,263$ Bathymetric base map .................. 7 Batjan (Bacan) . . . . . . . . . . . . . . . . 157, 190, 192 Batu Tara (Komba) . . . . . . . . . . . . . . 115, 118 Belitung. See Tin Islands.

Bengal, Bay of . $61,79,80,81,82$ Bengal Abyssal $f \circ \mathrm{n} . \ldots \ldots .19,21,44,45,50,51,51,52$, $54,59,60,66,66,69,79,80$
Page

Benioff seismic zones $\ldots \ldots \ldots \ldots \ldots \ldots \ldots, 7,9,11,14,17$ Banda Arc $\ldots \ldots \ldots \ldots \ldots \ldots \ldots \ldots \ldots, 116,156$ Burma ......................... $\quad 79$ Cotabato ......................... 207 Halmahera . . . . . . . . . . . . . . . . . . 191, 192, 193 Java ............................ $\quad 18$

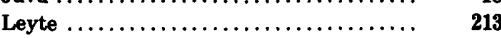
Manila .......................... 213, 218 Mariana . . . . . Mindanao .................... 196, 207, 216 Molucca Sea .................. 191, 192, 193, 196 Negros ......................... 210 New Britain-Schouten . . . . . . . . 256, 257, 289 New Guinea ............. 243, 254, 255, 256, 257 New Ireland ....................... 291 Panay $\ldots \ldots \ldots \ldots \ldots \ldots \ldots \ldots \ldots, \quad \mathbf{2 1 0}$ Philippines ........................ 213 Sangihe $\ldots \ldots \ldots \ldots \ldots \ldots \ldots 164,191,192,193,196,209$ Solomon Islands . . . . . . . . . . . . . . . . 298 Sulawesi $\ldots \ldots \ldots \ldots \ldots \ldots \ldots \ldots \ldots \ldots, \quad \mathbf{1 8 1}$

Sumatra ........................ 18 Bewani Mountains, New Guinea ......... 232, 252 Biak Island $\ldots \ldots \ldots \ldots \ldots \ldots \ldots \ldots \ldots \ldots \ldots \ldots \ldots \ldots \ldots, 233$ Billiton. See Tin Islands.

Biostratigraphy, Cenozoic . . . . . . . . . . . . $\quad 17$ Bismarck Arc $\ldots \ldots \ldots \ldots \ldots \ldots \ldots \ldots 232,237,289,290$, $291,292,297,300,301$

Bismarck fault zone, New Guinea . . . . . . . . 238 Bismarck Range, New Guinea ............. 232 Bismarck Sea . . . . . . . . . . . . . 232, 237, 259,

Bismarck Sea fault zone. See Mid-Bismarck $289,290,292,293$ fault system.

Bismarck Terrain, New Guinea ..... 236, 237, 249, 270 Blueschist. See Metamorphic rocks, highpressure.

Boeroe. See Buru.

Boeton. See Buton.

Bohol, Philippines ........... 210, 211, 212, 214, 217

Bomberai Peninsula, New Guinea .......... 233 Bonaparte Gulf Basin, Australia ........ 221, 223, 224 Bone, Gulf of . . . . . . . . . . . . . . 160, 166, 181, 188 Bonerate.......................... 160, 164 Bonin Trench . . . . . . . . . . . . . . . 271, 272, 279 Border Mountains, New Guinea ........ 292, 234, 237 Borneo . . . . . . . . . . . . . . . . . 64, 85, 109 east Borneo Cenozoic strata .......... 96, 98,99 interior Borneo Paleogene strata ....... 87, 91 magmatic-arc rocks $\ldots \ldots \ldots \ldots .86,87,92,93,94,95$ northeast Borneo Cenozoic strata ....... 94 northeast Borneo melange ........... 88 northwest Borneo melange . 88, 89-91, 112, 199, 201 oroclinal deformation $\ldots \ldots \ldots \ldots \ldots \ldots \ldots, 95,113$ paleomagnetism $\ldots \ldots \ldots \ldots \ldots \ldots \ldots \ldots, 86,113$ relationship to Java and Java Sea . . . . 100, 102 relationship to Java Sea and Burma ...... $\mathbf{8 0}$ relationship to Palawan ............. 199, 201 relationship to South China Sea and Asia .. 113 relationship to Sulu Arc ............ 205, 216 Sarawak, pre-Tertiary geology $\ldots \ldots \ldots \ldots \quad \mathbf{8 5}, \mathbf{8 7}$ southeast Borneo melange ............ 87 southwest Borneo, pre-Tertiary geology ... $\quad 86$ Bougainville Trench .... 289, 290, 293, 298, 300, 300, 303 Bowutu Mountains, New Guinea .......... 232 
Broken formation. See Melange and melange wedges.

Broken Ridge, Indian Ocean . . . . . . . . . . . . 59, 61, 62 Browse Basin, Australian shelf ......... 21, 220, 224 Brunei $. \ldots \ldots \ldots \ldots \ldots \ldots \ldots \ldots \ldots \ldots \ldots, \mathbf{8 4 , 8 5}$ See also Borneo.

Brunei-Saigon Basin

108

See also Sarawak Basin

Bunguran. See Natuna Islands.

Burma $\ldots \ldots \ldots \ldots \ldots \ldots \ldots \ldots .65,67,69,79,80,81,82$ Buru ............................ 115, 135, 135 Buru Mountains, New Guinea ........ 232, 245, 246, 248 Buton (Butung) . . . . . . . . . . . . . 160, 166, 172, 174

Cagayan Island, Cagayan de Sulu, and Cagayan Ridge ........157, 199, 200, 202, 214, 217 Calc-alkalic magmatic rocks. See Magmatic arcs. Cambodia. See Indochina.

Cambrian igneous rocks, Australia

Cambrian sedimentary rocks, Arabia and India Australia $\ldots \ldots \ldots \ldots \ldots \ldots \ldots \ldots \ldots \ldots, 223,224$ Malay Peninsula $\ldots \ldots \ldots \ldots \ldots \ldots \ldots \ldots, 6,68$ Camotes Islands, Philippines .............. 210 Canning River Basin, Australia ........... 220, 223 Cape York Peninsula, Australia ..... 221, 225, 226, 227, $232,234,236$

Carabao Island, Philippines ....... 197, 204, 210, 214 Carboniferous igneous rocks, Australia ...... 226, 227 Malay Peninsula ...................... 70 New Guinea $\ldots \ldots \ldots \ldots \ldots \ldots \ldots \ldots \ldots, 234,235$ Sumatra $\ldots \ldots \ldots \ldots \ldots \ldots \ldots \ldots \ldots \ldots, \quad 32$ Tin Islands . . . . . . . . . . . . . .

Carboniferous sedimentary rocks, Australia and shelves $\ldots \ldots \ldots \ldots \ldots, 224,225,226,227$

Borneo .......................... 86

Carabao, Philippines ................ 210

Malay Peninsula $\ldots \ldots \ldots \ldots \ldots \ldots \ldots \ldots \ldots, \quad \begin{array}{r}83 \\ \text { Indochina }\end{array}$

New Guinea $\ldots \ldots \ldots \ldots \ldots \ldots \ldots \ldots \ldots, 234$

Sumatra $\ldots \ldots \ldots \ldots \ldots \ldots \ldots \ldots \ldots \ldots, \quad 32$

Tin Islands . . . . . . .

Caribbean Arc ...................... 118, 305

Carnarvon Terrace, Indian Ocean ......... $\quad 59$

Caroline Plate . . . . . . . . . $287,288,290,303,304$

Caroline Ridge . . . . . . . . . . . . 271, 276, 278, 280, $281,285,287,288$

Carpentaria Basin and Gulf of Carpentaria . . 218, 220, $221,225,227$ Carpentarian Period (Australia), definition....
See also Precambrian and Precambrian(?) geology.

Catarman Island, Mindanao Sea . . . . . . . . . 209

Cebu, Philippines .............. 210, 211, 214, 217 Celebes. See Sulawesi.

Celebes (Sulawesi) Basin ............... 157

Celebes (Sulawesi) Sea . . . . . . . 157, 164, 175, 181, 182, $184,186,191,192,192,194,201,206$

Cenozoic geology, biostratigraphy ...........

Other aspects of Cenozoic geology are described throughout the book. Se series, areah and topical listings, and table of contents.

Central Basin, Andaman Sea ............ 65, 67 Central Cordillera, Mindanao .............. $\quad 207$ Central Highlands, New Guinea ........... 232 Central Range, New Guinea ............ 233, 250 Ceram. See Seram.

Chin Hills (or Ranges), Burma . . . . . . . . $65, \mathbf{7 9 , 8 0}$ China ..................69, 82, 83, 271, 272, 308 Christmas Island $\ldots \ldots \ldots \ldots \ldots \ldots, \ldots \ldots \ldots 20,44,57$ Cocos Islands . . . . . . . . . . . .

Collisions between continental masses. See Sutures.

Collisions of island arcs $\ldots \ldots \ldots \ldots \ldots \ldots \ldots 305,306$

Andaman-Nicobar Arc and Ninetyeast Ridge
Collisions of island arcs-Continued

Banda Arc and Australia-New Guinea .... 115, 117 ,

Mindanao $\ldots \ldots \ldots \ldots \ldots \ldots \ldots \ldots \ldots$ 209, 216, 217

New Britain-Schouten and New Guinea .. 256, 257,

259,260

New Britain-Trobriand ............ 299, 300, 302

North New Guinea and mainland New Guinea ... 229, 231, 236, 237, 239, 240, 244

$249,269,270$

Palawan and Manila Trenches .......... 214, 217

Palawan and Negros ................. 217, 218

Philippines ................... 157, 216, 217

Sangihe and Halmahera ....... 157, 158, 164, 181, $192,193,194,209,216,217$

Sulawesi and Buton $\ldots \ldots \ldots \ldots \ldots \ldots \ldots, 160,174$ Sulawesi and Sula-Banggai

Islands $\ldots \ldots \ldots \ldots \ldots \ldots 160,172,174,181$

Sulu Arc and Borneo................ 95, 201

Sulu Arc and Negros .... 157, 202, 210, 214, 216, 217

Taiwan and Asia .............69, 214, 218, 272

Con Son Swell, South China Sea .......... 103, 108

Convection .................................. 303

Copper ore $\ldots \ldots \ldots \ldots \ldots \ldots \ldots \ldots \ldots \ldots \ldots 164,210$

Coral Sea ............. 228, 228, 232, 237, 269, 289, 290

Coral Sea Basin . . . . . . . . . . . . 229, 230, 231, 289

Coral Sea (Queensland) Plateau ......... 221, 228, 228,

Correlation, Cenozoic .................... 229, 289

Cotabato Basin, Mindanao ............... 207

Cotabato Trench, Mindanao ......... 157, 182, 184, 192 207, 214, 216, 217

Cretaceous igneous rocks, Anambas Islands . 102, 103 Austraha $. . \ldots \ldots \ldots \ldots \ldots \ldots \ldots \ldots \ldots, 226,229$ Borneo $\ldots \ldots \ldots \ldots \ldots \ldots \ldots \ldots, 86,93,113$ Borneo........................... 86, 93, 113 China $\ldots \ldots \ldots \ldots \ldots \ldots \ldots \ldots \ldots \ldots \ldots \ldots$
Coral Sea Plateau $\ldots \ldots \ldots \ldots \ldots \ldots \ldots \ldots$

Indochina $\ldots \ldots \ldots \ldots \ldots \ldots \ldots \ldots \ldots \ldots, 83,113$

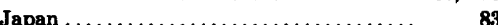

Java $\ldots \ldots \ldots \ldots \ldots \ldots \ldots \ldots \ldots \ldots, \quad 39$

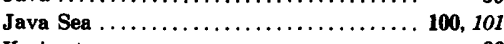

Karimata $\ldots \ldots \ldots \ldots \ldots \ldots \ldots \ldots \ldots, \quad \mathbf{8 6}$

Korea $\ldots \ldots \ldots \ldots \ldots \ldots \ldots \ldots \ldots \ldots \ldots, 8$

Malay Peninsula $\ldots \ldots \ldots \ldots \ldots \ldots \ldots \ldots \ldots, 72,76,80$

Mariana Arc System ............... $\quad \mathbf{2 7 0}$

Natuna $\ldots \ldots \ldots \ldots \ldots \ldots \ldots \ldots \ldots \ldots, \quad 102$

Naturaliste Plateau $\ldots \ldots \ldots \ldots \ldots \ldots \ldots, \quad 62$

Negros .......................... $\quad 210$

New Guinea ........... 237, 238, 239, 251, 252, 253

Ninetyeast Ridge .................. 52

Ontong Java Plateau ................. 289

Pacific Plate ....................... 285

South China Sea shelf $\ldots \ldots \ldots \ldots \ldots \ldots \ldots \ldots, 103,113$

Sumatra

Cretaceous sedimentary rocks. Occurrences in melanges are not listed.

Andaman and Nicobar Islands .......... 66

Australia and shelves ......... northwest shelf $\ldots \ldots \ldots \ldots \ldots \ldots \ldots, 60,63$

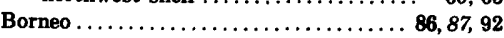

Broken Ridge .....................

Burma $\ldots \ldots \ldots \ldots \ldots \ldots \ldots \ldots \ldots \ldots \ldots \ldots \ldots \ldots, \quad 79$

Buru $\ldots \ldots \ldots \ldots \ldots \ldots \ldots \ldots \ldots \ldots \ldots, \quad 135$

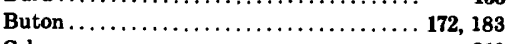

Cebu .......................... $\quad 210$

India, southeast shelf $\ldots \ldots \ldots \ldots \ldots \ldots \ldots$

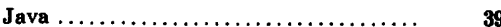

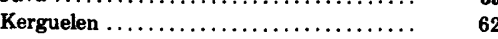

Leti........................... 133

Malay Peninsula $\ldots \ldots \ldots \ldots \ldots \ldots \ldots \ldots$ 71

Mariana Arc System . . . . . . .

Misool $\ldots \ldots \ldots \ldots \ldots \ldots \ldots \ldots \ldots \ldots \ldots \ldots, \quad \mathbf{2 4 5}$

Naturaliste Plateau ................. 62

Negros .......................... $\quad \mathbf{2 1 0}$ New Guinea ....... 181, 238, 239, 249, 251, 252, 268 Ninetyeast Ridge .................. Obi $\ldots \ldots \ldots \ldots \ldots \ldots \ldots \ldots \ldots \ldots \ldots, \quad 191$

Ontong Java Plateau ................. $\quad 283$

Pacific Plate ....................

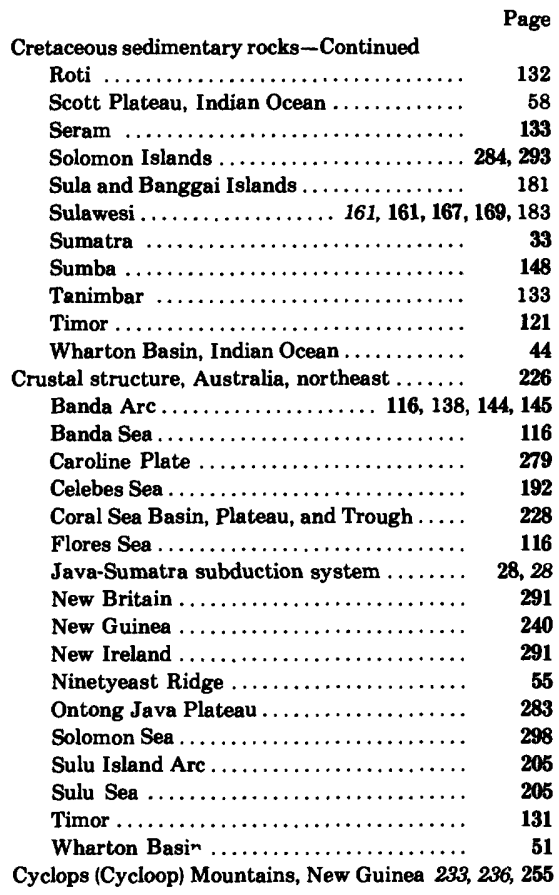

D

Daly River Basin, Australia ............. 221, 223 Damar Islands ..................... 114, 115

Dangerous Ground, South China Sea ........ 11

Davao Lowlands and Gulf, Mindanao ........ 207

Davao Peninsula, Mindanao........... 157, 196, 207

Deep Sea Drilling Project (DSDP), holes 53, 54 271, 273

holes 55-58 . . . . . . . . . . . . 271, 276, 282, 283

hole $59 . \ldots \ldots \ldots \ldots \ldots \ldots \ldots \ldots \ldots .271, \mathbf{2 8 4}, \mathbf{2 8 5}$

hole $60 \ldots \ldots \ldots \ldots \ldots \ldots \ldots \ldots \ldots \ldots .270,271$

hole $61 \ldots \ldots \ldots \ldots \ldots \ldots \ldots \ldots \ldots \ldots 271,284,285$

hole $62 \ldots \ldots \ldots \ldots \ldots \ldots \ldots \ldots \ldots . \mathbf{2 7 9}, \mathbf{2 8 0}, \mathbf{2 8 6}, \mathbf{2 8 9}$

hole $63 \ldots \ldots \ldots \ldots \ldots \ldots \ldots \ldots .271,280,286,289$

hole $64 \ldots \ldots \ldots \ldots \ldots \ldots \ldots \ldots \ldots 283,286,289$

holes $194-197 \ldots \ldots \ldots \ldots \ldots \ldots \ldots \ldots, 271$

holes $209,210 \ldots \ldots \ldots \ldots \ldots \ldots \ldots \ldots 228,229,289$

hole $211 \ldots \ldots \ldots \ldots \ldots \ldots \ldots 20,44,46,47,48,57,60$

hole $212 \ldots \ldots \ldots \ldots \ldots \ldots \ldots \ldots \ldots \ldots \ldots, 44,48$

hole $213 \ldots \ldots \ldots \ldots \ldots \ldots \ldots \ldots \ldots \ldots, 44,45,46,48$

hole $214 \ldots \ldots \ldots \ldots \ldots \ldots \ldots \ldots \ldots 44,48,52,53,55$

hole $215 \ldots \ldots \ldots \ldots \ldots \ldots \ldots \ldots \ldots, 45,48$

hole $216 \ldots \ldots \ldots \ldots \ldots \ldots \ldots \ldots \ldots \ldots \ldots \ldots \ldots \ldots \ldots, 48,52,55,56$

hole $217 \ldots \ldots \ldots \ldots \ldots \ldots \ldots \ldots \ldots, 45,48,52,65,66$

hole $218 \ldots \ldots \ldots \ldots \ldots \ldots \ldots \ldots \ldots \ldots, \quad 60$

hole $253 \ldots \ldots \ldots \ldots \ldots \ldots \ldots \ldots \ldots \ldots .48,52,56$

hole $254 \ldots \ldots \ldots \ldots \ldots \ldots \ldots \ldots \ldots \ldots, 48,52,53$

hole $256 \ldots \ldots \ldots \ldots \ldots \ldots \ldots \ldots \ldots, \quad 48$

hole $259 \ldots \ldots \ldots \ldots \ldots \ldots \ldots \ldots \ldots \ldots, \quad 49$

hole $260 \ldots \ldots \ldots \ldots \ldots \ldots \ldots \ldots \ldots 20,47,49,55$

hole $261 \ldots \ldots \ldots \ldots \ldots \ldots \ldots \ldots \ldots .21,47,49,57$

hole $262 \ldots \ldots \ldots \ldots \ldots \ldots \ldots \ldots \ldots \ldots . \ldots \ldots, 115,144$

hole $263 \ldots \ldots \ldots \ldots \ldots \ldots \ldots \ldots \ldots \ldots, \quad \mathbf{4 7 , 4 9}$

holes $265-267 \ldots \ldots \ldots \ldots \ldots \ldots \ldots \ldots, 60$

hole $287 \ldots \ldots \ldots \ldots \ldots \ldots \ldots \ldots \ldots \ldots 228,229,289$

holes $288,289 \ldots \ldots \ldots \ldots \ldots \ldots \ldots \ldots .283,286,289$

holes 290-294 . . . . . . . . . . . . . 271, 274, 276

holes 295-298 $\ldots \ldots \ldots \ldots \ldots \ldots \ldots \ldots .271,273,276$

hole $447 \ldots \ldots \ldots \ldots \ldots \ldots \ldots \ldots \ldots . \ldots, 27$

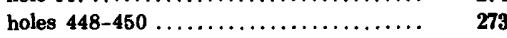

hole $451 \ldots \ldots \ldots \ldots \ldots \ldots \ldots \ldots \ldots \ldots, \quad 273$

Deep-sea terrace.

See also Outer-arc basin

Dent Peninsula, Borneo ......... 85, 94, 157, 206, 214

D'Entrecasteaux Islands .......... 228, 232, 237, 268,

Devonian igneous rocks, Australia ........ 226 


\section{Page}

Devonian sedimentary rocks, Australia ..... 224, 226 Borneo

Indochina

Malay Peninsula

88

New Guines $\ldots \ldots \ldots \ldots \ldots \ldots \ldots \ldots . .234$

Diapirs. See Anticlines, shale-cored or diapiric.

Djawa. See Java.

Earthquakes and seismicity $\ldots \ldots \ldots \ldots 9,10,12,17,30$

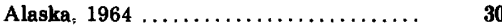
Banda Arc $\ldots \ldots \ldots \ldots \ldots \ldots \ldots \ldots \ldots \ldots \ldots, 116,154$ Bismarck Sea . . . . . . . . . . . . . 292, 296, 301 Cotabato Trench, Mindanao ........... 207 Luzon, $1973 \ldots \ldots \ldots \ldots \ldots \ldots \ldots . \ldots \ldots$ New Britain $\ldots \ldots \ldots \ldots \ldots \ldots \ldots \ldots \ldots \ldots .288, \mathbf{3 0 1}$ New Guinea, $1970 \ldots \ldots \ldots \ldots \ldots \ldots \ldots \ldots 256,296$ New Ireland $\ldots \ldots \ldots \ldots \ldots \ldots \ldots \ldots \ldots \ldots 291,301$ Solomon Islands $\ldots \ldots \ldots \ldots \ldots \ldots \ldots \ldots, 293,296,301$ Sulawesi $\ldots \ldots \ldots \ldots \ldots \ldots \ldots \ldots \ldots \ldots \ldots, \mathbf{1 7 5}, \mathbf{1 7 6}$ Sumatra $\ldots \ldots \ldots \ldots \ldots \ldots \ldots \ldots \ldots \ldots, \quad \mathbf{3 7}$ Sumba, $1977 \ldots \ldots \ldots \ldots \ldots \ldots \ldots \ldots \ldots . \quad 154$ Taiwan $\ldots \ldots \ldots \ldots \ldots \ldots \ldots \ldots \ldots, \quad 218$ Yap, $1911 \ldots \ldots \ldots \ldots \ldots \ldots \ldots \ldots \ldots \ldots$ See also Benioff seismic zones.

East Basin, Andaman Sea ............. 67 East Caroline Basin . 271, 276, 280, 281, 286, 287, 292, 294 East Malaysia (Sarawak and Sabah). See Borneo.

East Mariana Basin . . . . . . . . . . . .

East Sangihe Trench ....... 157, 158, 183, 185, 192, 194

Eastern Highlands, New Guinea ........... 232

Eauripik Rise (Eauripik-New Guinea Rise) ....271, 276, $279,286,289$

Eclogite . . . . . . . . . . 39, 79, 94, 161, 234, 249, 299 Emperor of China ..................... 115, 149

Enggano $\ldots \ldots \ldots \ldots \ldots \ldots \ldots \ldots \ldots \ldots \ldots, 21,34$

Eocene correlation ..................... 17

Eocene igneous rocks, Bismarck Arc ........ Borneo ......................... 89 Christmas Island $\ldots \ldots \ldots \ldots \ldots \ldots \ldots \ldots, \quad \mathbf{5 7}$ Coral Sea ......................... 229

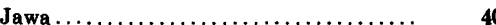

Mariana Arc System $\ldots \ldots \ldots \ldots \ldots \ldots \ldots \ldots, 270,273,274$

Mariana Trench ................... 270

New Britain Arc ..................

New Guinea .................... 251, 252

Ninetyeast $\ldots \ldots \ldots \ldots \ldots \ldots \ldots \ldots \ldots \ldots, \quad 52$

Palau .......................... 27

Eocene sedimentary rocks, Andaman and Nicobar Islands ....

Australia, northwest shelf $\ldots \ldots \ldots \ldots \ldots \ldots$

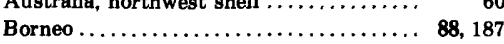

Burma ...................... 79, 80

Cebu ............................ 210

Christmas Island $\ldots \ldots \ldots \ldots \ldots \ldots \ldots \ldots, \quad 57$

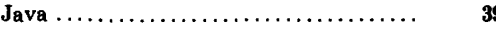

Java Sea $\ldots \ldots \ldots \ldots \ldots \ldots \ldots \ldots \ldots \ldots, 100,102$

Kai $\ldots \ldots \ldots \ldots \ldots \ldots \ldots \ldots \ldots \ldots \ldots, 133$

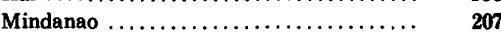

Misool $\ldots \ldots \ldots \ldots \ldots \ldots \ldots \ldots \ldots \ldots \ldots, \quad 245$

New Guinea . . . . . . . . . . . 239, 252, 261, 268

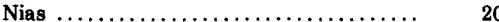

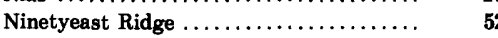

Pacific Plate ..................... $\quad \mathbf{2 8 5}$

Raijua $\ldots \ldots \ldots \ldots \ldots \ldots \ldots \ldots \ldots \ldots, \quad \mathbf{1 3 2}$

Roti $\ldots \ldots \ldots \ldots \ldots \ldots \ldots \ldots \ldots \ldots \ldots \ldots, 132$

Sarawak Basin $\ldots \ldots \ldots \ldots \ldots \ldots \ldots \ldots \ldots \ldots \ldots \ldots \ldots \ldots \ldots, 108$

Seram $\ldots \ldots \ldots \ldots \ldots \ldots \ldots \ldots \ldots \ldots \ldots, 138$

Sulawesi $\ldots \ldots \ldots \ldots \ldots \ldots \ldots \ldots \ldots, 162,169,172,187$

Sumatra $\ldots \ldots \ldots \ldots \ldots \ldots \ldots \ldots \ldots \ldots, \quad 35$

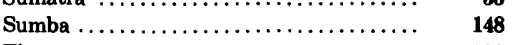

Timor .......................... 122

Ertsberg, New Guinea ............... 233, 254

Eugeosyncline $\ldots \ldots \ldots \ldots \ldots \ldots \ldots \ldots \ldots \ldots, 14$

Eurasian (Asian) plate $\ldots \ldots \ldots \ldots \ldots \ldots \ldots, 303,308$
Page

F

Falkland Plateau $\ldots \ldots \ldots \ldots \ldots \ldots \ldots \ldots \ldots, 59,63$ Faults, strike-slip (and transform) $\ldots \ldots \ldots \ldots, 7,8,9,17$ Andaman-Nicobar ..............6, 65, 66, 67 Australia ...................... 223 Banda Arc ...................... 116 Bismarck Sea . . 258, 290, 291, 292, 293, 300, 30 Burma $\ldots \ldots \ldots \ldots \ldots \ldots \ldots \ldots \ldots, 61$ China

65,81
81

Gulf of Thailand $\ldots \ldots \ldots \ldots \ldots \ldots \ldots, \mathbf{8 4}, 105$

Indian Ocean $\ldots \ldots \ldots \ldots \ldots \ldots \ldots, 50,51$

Indochina-Malaya-Sumatra region $\ldots \ldots \quad \mathbf{3 8 , 8 4}$

Investigator Ridge

Java

Java Sea

Malacca Strait .......... 38, 8

Malay Basin $\ldots \ldots \ldots \ldots \ldots \ldots \ldots \ldots$

Malay Peninsula $\ldots \ldots \ldots \ldots \ldots \ldots \ldots \quad \boldsymbol{7 7}, \mathbf{7}$

Mariana Trench .................. 27

Mergui Terrace .................. 78

New Britain ............... 160, 290, 291, 304

New Guinea .......... 116, 234, 238, 244, 245,

$246,248,253,261,264$

New Ireland $\ldots \ldots \ldots \ldots . .160,290,291,292,304$

Ninetyeast Ridge $\ldots \ldots \ldots \ldots \ldots \ldots \ldots, 50,51,64$

Philippines ................ 212, 213, 215

Sorol, Caroline Ridge ....... 272, 276, 283, 288

Sorong ................... 158, 181, 191

South China Sea ................ 113

Sula $\ldots \ldots \ldots \ldots \ldots \ldots \ldots \ldots \ldots \ldots$ 149, 158, 18

Sulawesi $\ldots \ldots \ldots \ldots \ldots \ldots \ldots \ldots 16,175$

Sumatra ................. 20, 37, 38, 84

thrust. For thrusting in accretionary

wedges, see Melange and melange wedges.

Borneo ...

88, 96

Java, foreland basin

New Guinea .......... 240, 241, 242, 243, 269

Sulawesi ............. 172, 172, 173, 174, 183

Sumatra, foreland basin ........... 36

Taiwan ....................... $\quad 218$

West Natuna Basin ............. 107

transform. See Faults, strike-slip.

Fergusson Island, New Guinea ........... 232 Finisterre Mountains, New Guinea ... 232, 251, 252, 300 Fitzroy Trough, Australia .............. 220, 223 Flores ................. 21, 114, 114, 118, 120, 189 Flores Basin ...................... 21, 114 Flores Sea ....... 115, 116, 121, 122, 123, 126, 156, 189 Flores Sea Trench ...............114, 122, 126, 156 Folding, Borneo, northwest $\ldots \ldots \ldots \ldots \ldots \ldots \ldots \quad 92,93$ Java, foreland basin ................ 43,44 Java Sea ........................ 100

New Guinea ...................... $\quad \mathbf{2 4 0}$ Sumatra, foreland basin .............. $35, \mathbf{3 6}$ Foreland basins, Java $\ldots \ldots \ldots \ldots \ldots \ldots 20,42,43,43$ Java Sea $\ldots \ldots \ldots \ldots \ldots \ldots \ldots \ldots \ldots, 20,100$ New Guinea . . . . . . . . . . . . 240, 241, 242, 243 Sulawesi $\ldots \ldots \ldots \ldots \ldots \ldots \ldots \ldots \ldots \ldots, 173,183$

Sumatra $\ldots \ldots \ldots \ldots \ldots \ldots \ldots \ldots \ldots \ldots, \quad 33$

Taiwan .......................... 218

Frieda fault, New Guinea .............. 236, 263

\section{G}

Gag .............................. $\quad 191$

Gagil Tomil, Yap Islands .............. 275, 276 Ganges-Brahmaputra delta $\ldots \ldots \ldots \ldots \ldots \ldots 6,6,8 \ldots, 81$ Gas, natural. See Petroleum and natural gas.

Gascoyne Abyssal Plain, Indian Ocean ....... 20,54 Gauttier Mountains, New Guinea ......... 233 Geelvink Bay, New Guinea .. 233, 234, 251, 253, 261, 262 Geographic names .................... 2,4 See also Index maps.

Geosynclines and geosynclinal cycle ......... 14 Geothermal gradients, Borneo ......... 92, 95, 96, 97 Gulf of Thailand .
Geothermal gradients-Continued

Java $\ldots \ldots \ldots \ldots \ldots \ldots \ldots \ldots \ldots \ldots, \quad 44$

Java Sea ...................... 102

Java-Sumatra outer-arc basin .......... 28

South China Sea ....................... 107, 109

See also Heat flow.

Glaucophane schist. See Metamorphic rocks, high-pressure.

Gondwanaland

Antarctica-Africa relationships ...........

Australia-Antarctica separation ...........

Australia-India separation ............. 62,63

Indian Ocean fragments . . . . . . . . . . . . 62

Mesozoic Gondwanaland .............. 59,60

paleobotany ........................ 254

paleoclimatology'. $\ldots \ldots \ldots \ldots \ldots \ldots \ldots \ldots \quad 62,254$

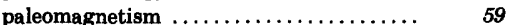

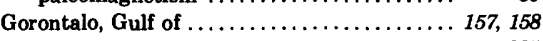

Gravitational plate drives ............... 305

Gravity surveys and anomalies, Australia .... 218

Banda Arc .............. 131, 132, 137, 148, 195

Bismarck Sea . . . . . . . . . . . .

Borneo ......................... 97

Java $\ldots \ldots \ldots \ldots \ldots \ldots \ldots \ldots \ldots \ldots \ldots, \quad 44$

Molucca Sea $\ldots \ldots \ldots \ldots \ldots \ldots \ldots \ldots \ldots \ldots, 192,195$

New Britain . . . . . . . . . . . . . $29 \ldots \ldots \ldots, \quad 29$

New Guinea . . . . . . . 232, 245, 249, 259, 262, 265

Seram $\ldots \ldots \ldots \ldots \ldots \ldots \ldots \ldots \ldots \ldots, \quad 137$

Solomon Sea . . . . . . .

Timor .......................... 131

Vening Meinesz' 'regional isostatic anomalies" .............. 31, 132, 148, 195

West Melanesian Trench ............. 292 Guam ........................ 270, 271, 276 Gumai Mountains, Sumatra ............. 33

Gunung Api $\ldots \ldots \ldots \ldots \ldots \ldots \ldots \ldots \ldots \ldots, 115,149$

Gureda Island $\ldots \ldots \ldots \ldots \ldots \ldots \ldots \ldots \ldots \ldots, \quad 195$

\section{H}

Hainan, China ......................

Halls Creek Mobile Zone, Australia . . ........ 219, 223

Halmahera island, and arc system ... 157, 183, 190, 191, $192,196,197,206$

Halmahera plate . ................... 193

Heat flow, Banda Sea .................. $\quad 149$

Celebes (Sulawesi Sea) . . . . . . . . . . . . 192

Coral Sea ........................ $\quad 229$

Eauripik Rise $\ldots \ldots \ldots \ldots \ldots \ldots \ldots \ldots \ldots, \quad 279$

Indian Ocean .................... $\quad 49$

Mariana Trough ..................... 273

North of Caroline Ridge .............. 283

Philippine Basin $\ldots \ldots \ldots \ldots \ldots \ldots \ldots \ldots, \quad \mathbf{2 7 7}$

Solomon Sea ....................... $\quad 298$

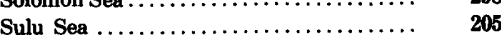

West Caroline Basin ................. $\quad \mathbf{2 7 9}$

Woodlark Basin .................. 298

See also Geothermal gradients.

Himalayas $\ldots \ldots \ldots \ldots \ldots \ldots \ldots \ldots \ldots \ldots, 8,64,81,82$

Holocene. See Quaternary entries.

Hot spots (plumes) . . . . . . . . . . . . . . . . $\quad 305$

Hunstein Range, New Guinea . . . . . . . . 232, 250

Hunstein terrain, New Guinea ...... 236, 249, 263, 270

Huon Gulf, New Guinea . . . . . . . . . 232, 262, 300, 302

Huon Peninsula, New Guinea ........... 232, 302

Iloilo Basin, Panay .................. 209, 216

Index maps, Andaman-Nicobar region ....... 65 Asia ...................... 65, 82, 103, 271 Australia ............................. 221 Banda Arc ..................... 21, 115 Borneo .......................... 85, 103 Coral Sea ........................ 228

Indian Ocean $\ldots \ldots \ldots \ldots \ldots \ldots \ldots \ldots \ldots, 20,45$

Indonesia ..... 


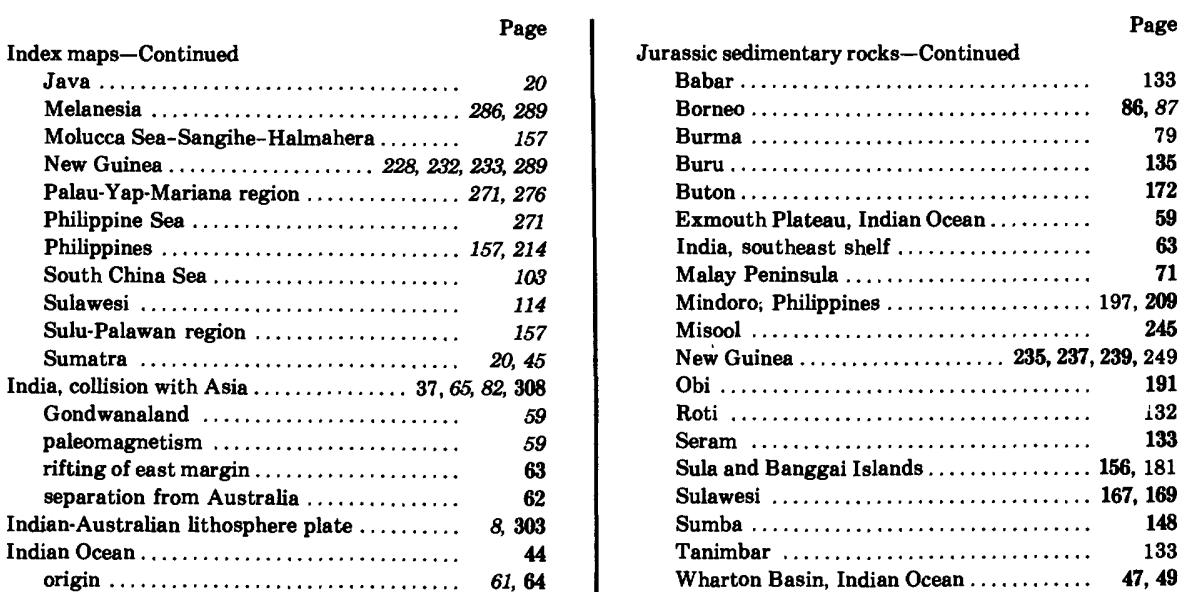

Kabaena $\ldots \ldots \ldots \ldots \ldots \ldots \ldots \ldots \ldots \ldots \ldots, 160,166$

Kai Islands . . . . . . . . . . . . . . . . . . 115, 133, 233

Kalao $\ldots \ldots \ldots \ldots \ldots \ldots \ldots \ldots \ldots \ldots \ldots, 160,164$

Kalimantan $\ldots \ldots \ldots \ldots \ldots \ldots \ldots \ldots \ldots \ldots, \quad \mathbf{8 4 , 8 5}$

See also Borneo.

Kambing (Atauro) . ........... 115, 118, 156

Kampuchea (Cambodia). See Indochina.

Kangean Island $\ldots \ldots \ldots \ldots \ldots \ldots \ldots \ldots 100,101,114$

Kapingamarangi Rise. See Ontong Java Pla-

.

See also New Guinea and Vogelkop.

Irrawaddy Delta and Lowlands, Burma ... 65, 79, 80, 81

Island arcs. See Magmatic arcs, Subduction systems, Trenches, and individual geographic listings.

Isopachs of sedimentary deposits

Isotopes. See Lead isotopes and Strontium isotopes.

\section{$J$}

Jadeite. See Metamorphic rocks, high pressure.

Japan ..................... 83, 271, 272, 308 Japan Trench $\ldots \ldots \ldots \ldots \ldots \ldots \ldots \ldots \ldots \ldots \ldots \ldots \ldots \ldots \ldots \ldots \ldots \ldots \ldots, 27,272,279$ Japen Island. See Yapen Island.

Java ................................ Cenozoic deformation $\ldots \ldots \ldots \ldots \ldots \ldots \ldots, \quad 43,43$ Cenozoic magmatism ................ 39, 42, 43 Cenozoic sedimentation and stratigraphy . 39 Crustal structure. See topical entries.

Melange, Upper Cretaceous and Paleogene 39, 40 Outer-arc basin. See topical entries.

Outer-arc ridge. See topical entries.

pre-Cenozoic rocks . . . . . . . . . . . . . . 39, 40, 101 relation to Sumatra .................. Trench. See topical entries.

Java Sea ......................... $\quad 100$ basement geology . . . . . . . . . . . . Cenozoic strata .................. 39, 43, 100 relationships between Java and Borneo ... 100, 102,

188, 189

relationships with Sulawesi $\ldots \ldots \ldots \ldots \ldots \ldots, 188,189$ subduction system $\ldots \ldots \ldots \ldots \ldots \ldots \ldots, 80,102,188$ Java-Sumatra Trench ........ 2, 5, 19, 20, 23, 24, 26, 28 ,

Jawa. See Java.

$29,34,45,50,55,58$

Jazirah Doberai. See Vogelkop.

Jimi terrain, New Guinea ... 236, 237, 238, 249, 263, 270

Jurassic igneous rocks, Borneo . . . . . . . . . . . 88

Buru .......................... 135

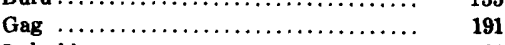

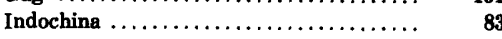

Malay Peninsula $\ldots \ldots \ldots \ldots \ldots \ldots \ldots \ldots, \quad \mathbf{7 2 , 8 0}$

New Guinea $\ldots \ldots \ldots \ldots \ldots \ldots \ldots \ldots \ldots \ldots \ldots, 237,251$

Palawan $\ldots \ldots \ldots \ldots \ldots \ldots \ldots \ldots \ldots \ldots, \quad 197$

Wharton Basin, Indian Ocean ........... 47

Jurassic sedimentary rocks, Australia and shelves ..................63, 224, 227 teau.
Karakelang $\ldots \ldots \ldots \ldots \ldots \ldots \ldots \ldots, 157,192,195,195$

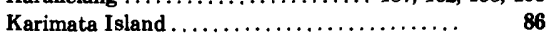

Karkar Island . . . . . . . . . . . 232, 256, 257, 288, 289

Kayuadi $\ldots \ldots \ldots \ldots \ldots \ldots \ldots \ldots \ldots \ldots \ldots .160,164$

Kerguelen Islands and Plateau .......... 59, 61, 62

Khlong (Klong) Marui fault, Thailand . . . . . . . 78

Khorat (Korat) Plateau, Thailand ......... 65, 69, 84

Khorat (Korat) Swell, South China Sea ....... 103, 108

Kimberley Basin or Block, Australia . . . . . 220, 220, 224

King Leopold Mobile Belt, Australia ....... 220, 222

Kisar ......................... 115, 132

Komba (Batu Tara) ................. 115, 118

Korat (Khorat) Plateau, Thailand ......... 65, 69, 84

Korat (Khorat) Swell, South China Sea ....... 103, 108

Korea $\ldots \ldots \ldots \ldots \ldots \ldots \ldots \ldots \ldots \ldots \ldots, \mathbf{8 3}, 272$

Kubor Range and anticline, New Guinea .. 232, 234, 235, $237,238,240,242,243,244$

Kutei (Kutai) Basin, Borneo . . . . . . . 85, 96, 98, 99, 188 Kyushu-Palau Ridge.......... 270, 271, 273, 274, 277

\section{$\mathbf{L}$}

Lamont-Doherty Geological Observatory of Columbia University (acknowledg $54,55,56,58,66,80,105,110,122$, $139,144,146,150,158,182,184,186$, $201,203,230,278,280,284,287,300$

Land Slip Range, New Guinea ............ 232

Lariang Basin, Sulawesi ................... 162

Laura Basin, Australia ............... 221, 227 Laut ......................... 85, 87, 96, 101 Lawanopo fault, Sulawesi . . . . . . . . 160, 166, 179, 181

Lead isotopes . . . . . . . . . California, granitic rocks .............. 73 Mariana Ridge ..................... 273 Tin Islands, granitic rocks ............ $\quad 38$

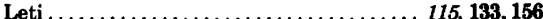
Leyte, Philippines ............ 210, 212, 213, 214, 215 Lithosphere plates ..................... 8 See also geographic entries.

Location of reflection profiles. See Index maps.

Lomblen $\ldots \ldots \ldots \ldots \ldots \ldots \ldots \ldots \ldots \ldots \ldots 115,118$ Lombok $\ldots \ldots \ldots \ldots \ldots \ldots \ldots \ldots \ldots \ldots \ldots, 21,114,118$

Lombok Basin . . . . . . . . . . . .

Long Island $\ldots \ldots \ldots \ldots \ldots \ldots \ldots, 232,256,257,288,289$
Kepala Burung. See Vogelkop. ments and credits) ......3,23, 24, 46, 50, 52
Lord Howe Rise .................... 227, 229, 270 Louisiade Archipelago . . . . . . . . . . . . . . . . 228, 289, 299

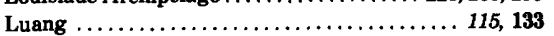
Luang $\ldots \ldots \ldots \ldots \ldots \ldots \ldots \ldots \ldots \ldots \ldots \ldots \ldots \ldots \ldots \ldots \ldots \ldots \ldots \ldots \ldots \ldots \ldots \ldots$
Luzon $\ldots \ldots \ldots \ldots \ldots \ldots, 214,217,218$ Lyra Basin . . . . . . . . . . . . . . . . 287, 289, 293 Lyra Plate ....................... 290 Lyra Trough . . . . . . . . . . . . 287, 287, 289, 293, 295

M

Madagascar $\ldots \ldots \ldots \ldots \ldots \ldots \ldots \ldots \ldots \ldots \ldots \quad 59,63$ Madura Basin ....................... 21, 43 Madura Strait .................... 21, 100, 101 Magmagenesis, granitic rocks ........... 72, 227 magmatic arcs $\ldots \ldots .9,37,42,43,118,188,306,307$ Magmatic arcs ................ 11, 14, 17, 29, 155 Andaman-Nicobar arc $\ldots \ldots \ldots \ldots \ldots \ldots 6,66,66,79$ Australia ....................... 226, 227 Banda $\ldots \ldots \ldots \ldots \ldots 114,115,118,119,120,122,124$, $139,140,146,155,156$

Bismarck $\ldots \ldots \ldots \ldots \ldots \ldots \ldots \ldots \ldots \ldots, \quad 291$ Bohol $\ldots \ldots \ldots \ldots \ldots \ldots \ldots \ldots \ldots \ldots, \quad 210$ Borneo $\ldots \ldots \ldots \ldots \ldots \ldots \ldots 6,69,86,87,92,93,94,95$ Burma .................... 65, 69, 79, 80 Cagayan (Palawan) ......... 157, 199, 200, 202, 217 Cebu ............................ $\quad 210$ China-Korea-Japan $\ldots \ldots \ldots \ldots \ldots \ldots \ldots 69,83,272$ Cotabato ....................... 217 Halmahera . . . . . . . . . . . . . . . . . . . 190, 192 Indochina $\ldots \ldots \ldots \ldots \ldots \ldots \ldots \ldots \ldots \ldots \ldots, 69, \mathbf{8 3}, \mathbf{8 4}$ Japan $\ldots \ldots \ldots \ldots \ldots \ldots \ldots \ldots \ldots \ldots, \quad 272$ Java $\ldots \ldots \ldots \ldots \ldots \ldots \ldots \ldots \ldots \ldots \ldots \ldots$ 39, 42, 102 Java Sea $\ldots \ldots \ldots \ldots \ldots \ldots \ldots \ldots \ldots, 69,100,101$ Leyte $\ldots \ldots \ldots \ldots \ldots \ldots \ldots \ldots \ldots \ldots, 211,213$ Luzon .............................. 213, 218 magmagenesis ..... 9, 37, 42, 43, 118, 188, 306, 307

Malay Peninsula $\ldots \ldots \ldots \ldots \ldots \ldots \ldots \ldots, 34,69,71$ Mariana ...................... 270, 273, 275 Mindanao $\ldots \ldots \ldots \ldots \ldots \ldots \ldots \ldots \ldots$ 192, 207, 208 Mussau ....................... 287, 287 Negros .................... 210, 211, 213, 217 New Britain-Schouten .............. 288 New Guinea ............. 241, 242, 243, 251, 269

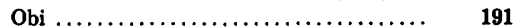
Philippines $\ldots \ldots \ldots \ldots \ldots \ldots \ldots \ldots \ldots, \quad 217$ potassium-silicon ratios $\ldots \ldots \ldots \ldots \ldots, 9,11,73,118$ Sangihe $\ldots \ldots \ldots \ldots \ldots \ldots \ldots$ 181, 182, 183, 185, 193 strontiuun isotopes. See Strontiuun isotopes. Sulawesi ...........160, 162, 175, 181, 188, 192

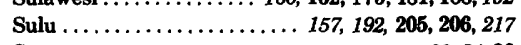
Sumatra $\ldots \ldots \ldots \ldots \ldots \ldots \ldots \ldots \ldots \ldots \ldots 29,34,36$

Togian $\ldots \ldots \ldots \ldots \ldots \ldots \ldots \ldots \ldots \ldots \ldots, \quad 181$ Zamboanga Peninsula, Mindanao........ 157, 207 Magnetic anomalies, ocean-floor spreading, Bismarck Sea ............... 292

Caroline Plate $\ldots \ldots \ldots \ldots \ldots \ldots, \quad 281$ Indian Ocean $\ldots \ldots \ldots \ldots \ldots \ldots \ldots \ldots, 48,49,60,60$ Philippine Basin ................... 274 Tasman Sea .................... 227, 229 Mahakam Delta, Borneo .... 85, 97, 98, 99, 114, 123, 188 Main Range, Malaya . . . . . . . . . . 68, 70, 71, 72, 76 Majau (Mayau Island) $\ldots \ldots \ldots \ldots \ldots \ldots \ldots \ldots 157,195$ Makassar Strait ............... 97, 114, 129, 160, 185 Malacca Strait . . . . . . . . . . . . . . . $\ldots \ldots \ldots \ldots, \mathbf{3 2 , 8 4}$ Malaita, Solomon Islands ................ 284 Malawali, Palawan Ridge ............... 199 Malay Basin ......................... 103, 103

Malay Peninsula $\ldots \ldots \ldots \ldots \ldots \ldots \ldots \ldots \ldots, \quad 68$ basement rocks ..................... 68 Cenozoic basalt .................... 79 granitic rocks $\ldots \ldots \ldots \ldots \ldots \ldots \ldots \ldots \ldots, 34,70,71$ paleomagnetism . . . . . . . . . . . . . 75, 113 Paleozoic and Mesozoic stratified rocks ... 68 strike-slip faults $\ldots \ldots \ldots \ldots \ldots \ldots \ldots \ldots, \quad \mathbf{7 7}, \mathbf{7 8}$ subduction history $\ldots \ldots \ldots \ldots \ldots \ldots \ldots, \quad 80$ suture in medial Malaya ............. 76, 77 $\begin{array}{ll}\text { western continental shelf } \ldots \ldots \ldots \ldots \ldots \ldots & 79 \\ & 68\end{array}$ See also Malay Peninsula. 
Malaysia. See Borneo and Malay Peninsula. Malaysia Barat (West Malaysia) ............. See also Malay Peninsula. Malaysia Timur (East Malaysia). See Borneo. Mangkalihat Peninsula, Borneo..........85, 97, 114, $123,160,188$

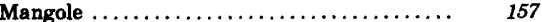
Manila Trench . . . . . . . . . . . 206, 213, 214, 217, 218 Manuk $\ldots \ldots \ldots \ldots \ldots \ldots \ldots \ldots \ldots \ldots \ldots 115,118$ Manus Island $\ldots \ldots \ldots \ldots \ldots \ldots \ldots \ldots \ldots \ldots \ldots \ldots, 236,289,291,300,301$ Map Island, Yap . . . . . . . . . . . . . . . 275, 276 Mariana Arc system . . . . . . . . . . . . . 189, 270 Mariana Ridge ......... 270, 271, 273, 274, 275, 276, 278 Mariana Trench . . . . . . . 270, 271, 272, 275, 276, 278 Mariana Trough $\ldots \ldots \ldots \ldots, 270,271,273,274,275,276$ Markham-Ramu fault zone, New Guinea . 236, 237, 262, 263,290

Masbate, Philippines . . . . . . . . . . 210, 213, 214 Matano fault, Sulawesi . . . . . . 160, 166, 175, 180, 181 Mayau (Majau) Island . . . . . . . . . . . . . 195 McArthur Basin, Australia .............. 221, 222 Meervlakte (Lake Flats) basin and lowlands, New Guinea ....... 233, 251, 260, 262, 263 Melange and melange wedges ......... 11, 13, 14, 17 , $26,28,29,130,204$

Andaman-Nicobar arc $\ldots \ldots \ldots \ldots \ldots \ldots \ldots \quad 66,80$ Banda Arc (exclusive of Timor and Seram) . $\quad 132$ Bohol ........................ $\quad \mathbf{2 1 0}$ Borneo ........... 85, 88, 89, 90, 93, 101, 185, 205 Burma ....................... 79, 80 Californis ....................... $\quad 11$ genesis $\ldots \ldots \ldots \ldots \ldots \ldots \ldots \ldots \ldots \ldots \ldots .28, \mathbf{2 9}, \mathbf{9 1}$ Halmahera .................... 190 Java, Upper Cretaceous and Paleogene. . 39, 40, 101 Jave Sea ............................... 100, 101 Java-Sumatra, offshore ....... 19, 23, 24, 26, 28,29 Leyte $\ldots \ldots \ldots \ldots \ldots \ldots \ldots \ldots \ldots \ldots, \quad 210$ Malay Peninsula $\ldots \ldots \ldots \ldots \ldots \ldots \ldots \ldots, \quad \mathbf{7 6 , 7 7}$ Mindanao $\ldots \ldots \ldots \ldots \ldots \ldots \ldots \ldots \ldots, \quad 207$ Mindoro $\ldots \ldots \ldots \ldots \ldots \ldots \ldots \ldots \ldots, \quad 209$ Molucca Sea $\ldots \ldots \ldots \ldots \ldots 157,158,159,183,185$, $192,193,195,195$ New Guinea . . . . . . 238, 249, 252, 255, 261, 265, 268 Nias ......................... 20, 24 Nicobar-Andaman arc $\ldots \ldots \ldots \ldots \ldots \ldots, \quad 66$ Obi $\ldots \ldots \ldots \ldots \ldots \ldots \ldots \ldots \ldots \ldots \ldots \ldots$ 159, 191 Palawan ......................... 197, 204 Panay $\ldots \ldots \ldots \ldots \ldots \ldots \ldots \ldots \ldots \ldots \ldots . \ldots \ldots, 209$ Samar $\ldots \ldots \ldots \ldots \ldots \ldots \ldots \ldots \ldots \ldots, 211$ Seram $\ldots \ldots \ldots \ldots \ldots \ldots \ldots \ldots 1 . \ldots \ldots, 134,136,136,139$ Sulawesi $\ldots \ldots 157,160,161,164,167,169,175,185,192$
Sulu $\ldots \ldots \ldots \ldots \ldots \ldots \ldots \ldots \ldots \ldots \ldots \ldots 205,206$ Sulu $\ldots \ldots \ldots \ldots \ldots \ldots \ldots \ldots \ldots \ldots \ldots \ldots$
Sumatra, pre-Tertiary $\ldots \ldots \ldots \ldots \ldots \ldots \ldots$ Talaud Ridge $. . \ldots \ldots \ldots \ldots \ldots \ldots \ldots, \quad 195$ Timor ......... 121, 125, 126, 127, 128, 129, 142, 149 Waigeo $\ldots \ldots \ldots \ldots \ldots \ldots$
See also Outer-arc ridge.

Melville Island, Australia ....

Mendoke Mountains, Sulawesi ............. 166

Mengkoka Mountains, Sulawesi .......... 166

Meratus Mountains, Borneo ... 85, 87, 96, 100, 101, 188

Mergui Terrace, Andaman Sea ........... 65, 78

Mesozoic geology. See listings for each system.

Metamorphic rocks, high-pressure $\ldots \ldots \ldots \ldots \quad 13,30$ Borneo ..................... 87, 88, 93, 94 Burma ............................ 79 California $\ldots \ldots \ldots \ldots \ldots \ldots \ldots \ldots \ldots \ldots, \quad 11$ D'Entrecasteaux Islands . . . . . . . . . . 299 Java $\ldots \ldots \ldots \ldots \ldots \ldots \ldots \ldots \ldots \ldots \ldots, \quad \mathbf{3 9}$ New Guinea ........... 238, 240, 249, 251, 255, 266

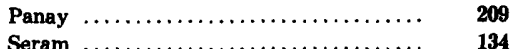
Seram $\ldots \ldots \ldots \ldots \ldots \ldots \ldots \ldots \ldots \ldots, 134$ Sulawesi $\ldots \ldots \ldots 160,161,164,166,167,168,175,188$ Timor $\ldots \ldots \ldots \ldots \ldots \ldots \ldots \ldots \ldots \ldots \ldots \ldots \ldots \ldots \ldots \ldots \ldots \ldots \ldots$
Wharton Basin $\ldots \ldots \ldots \ldots \ldots \ldots$ Metamorphism beneath ophiolite, D'Entrecasteaux Islands . . . . . . . . . . 268, 299 New Guinea $\ldots \ldots \ldots \ldots \ldots \ldots \ldots \ldots \ldots, 251$ Seram $\ldots \ldots \ldots \ldots \ldots \ldots \ldots \ldots \ldots \ldots \ldots \ldots \ldots \ldots \ldots \ldots \ldots \ldots, 135,154$
Metamorphism beneath ophiolite-Continued

Timor ......................... 127, 154 Mid-Bismarck fault system $\ldots \ldots \ldots \ldots 257,290,292,293$ Mid-slope basement high See also Outer-arc ridge.

Migration of island arcs ................ 306

Andaman-Nicobar $\ldots \ldots \ldots \ldots \ldots \ldots \ldots, \quad 6$

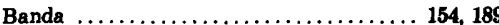

Bismarck $\ldots \ldots \ldots \ldots \ldots \ldots \ldots \ldots \ldots \ldots . \mathbf{3 0 0 ,} \mathbf{3 0 1}$

Borneo ......................... 96, 189

Mariana ...................... 274, 275, 283

New Britain $\ldots \ldots \ldots \ldots \ldots \ldots \ldots \ldots, 300,301$

North New Guinea $\ldots \ldots \ldots \ldots \ldots \ldots \ldots \ldots 253,254$

Palau ......................... 27

Palawan $\ldots \ldots \ldots \ldots \ldots \ldots \ldots \ldots \ldots \ldots, 204,218$

Papuan Peninsula . . . . . . . . . . . . . . 269, 270

Pocklington-Woodlark $\ldots \ldots \ldots \ldots \ldots \ldots \ldots, \quad \mathbf{2 9 9}$

Solomon $\ldots \ldots \ldots \ldots \ldots \ldots \ldots \ldots \ldots \ldots \ldots, \mathbf{3 0 0}$

Sulu .................... 204, 206, 216, 218

Sulu $\ldots \ldots \ldots \ldots \ldots \ldots \ldots \ldots \ldots, 204,206,216,218$

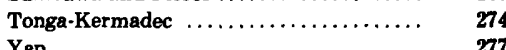

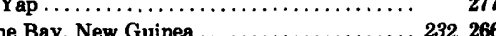

Milne Bay, New Guinea $\ldots \ldots \ldots \ldots \ldots \ldots \ldots 2.262,266$
Mindanao .......... 157, 192, 194, 196, 197, 206, 208, $213,214,215,216,217$

Mindanao Sea $157,202,209,214$

Mindanao Trench. See Philippine Trench.

Mindoro, Philippines ....... 204, 205, 209, 214, 216, 217 Miocene correlation ................... $\quad 17$

Miocene igneous rocks, Bali .............. 118 Banda Arc $\ldots \ldots \ldots \ldots \ldots \ldots \ldots \ldots \ldots, \quad 118$

Bismarck Arc ..................... 292

Borneo ................ 93, 94, 95, 96, 188, 206

Caroline Ridge ....................., 285

Flores ............................ 118

Indian Ocean sediments ................ 41,47

Java $\ldots \ldots \ldots \ldots \ldots \ldots \ldots \ldots \ldots \ldots, \quad 41, \mathbf{4 3}$

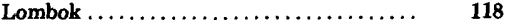

Mariana Arc System . . . . . . . . . . . 270, 273

New Britain Arc $\ldots \ldots \ldots \ldots \ldots \ldots \ldots \ldots, \quad 290$

New Guinea . . . . . . . 240, 251, 252, 253, 254, 269

Panay .......................... 209, 210

Sulawesi $\ldots \ldots \ldots \ldots \ldots \ldots \ldots \ldots \ldots \ldots \ldots \ldots, 162,188$

Sumatra $\ldots \ldots \ldots \ldots \ldots \ldots \ldots \ldots \ldots \ldots$

Sumba $\ldots \ldots \ldots \ldots \ldots \ldots \ldots \ldots \ldots \ldots \ldots, \quad 148$

Sumbawa $\ldots \ldots \ldots \ldots \ldots \ldots \ldots \ldots \ldots \ldots \ldots \ldots$

Timor .

Woodlark Rise ......

Zamboanga Peninsula, Philippines ....... 206

Miocene sedimentary rocks, Bengal Abyssal Fan $\ldots \ldots \ldots \ldots \ldots \ldots \ldots \ldots, \quad 60$

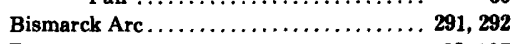

Borneo ......................... 92, 187

Burma $\ldots \ldots \ldots . \ldots .79$

Caroline Plate .................... 280

Caroline Ridge $\ldots \ldots \ldots \ldots \ldots \ldots \ldots \ldots \ldots \ldots, 282,285$

Christmas lsland $\ldots \ldots \ldots \ldots \ldots \ldots \ldots \ldots, \quad \mathbf{5 7}$

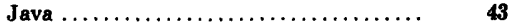

Java Sea $\ldots \ldots \ldots \ldots \ldots \ldots \ldots \ldots \ldots \ldots, 100,101$

Malay Basin .................... 104

Mariana Arc System ................ $\quad \mathbf{2 7 3}$

Misool $\ldots \ldots \ldots \ldots \ldots \ldots \ldots \ldots \ldots \ldots \ldots, 245,249$

Natuna $\ldots \ldots \ldots \ldots \ldots \ldots \ldots \ldots \ldots \ldots, 102$

Negros $\ldots \ldots \ldots \ldots \ldots \ldots \ldots \ldots \ldots \ldots \ldots, \quad \mathbf{2 1 0}$

New Britain . . . . . . . . . 291

New Guinea ....... 239, 252, 253, 259, 260, 261, 269

Nias $\ldots \ldots \ldots \ldots \ldots \ldots \ldots \ldots \ldots \ldots \ldots, \quad 21,24$

Palau $\ldots \ldots \ldots \ldots \ldots \ldots \ldots \ldots \ldots \ldots, \quad \mathbf{2 7 7}$

Panay $\ldots \ldots \ldots \ldots \ldots \ldots \ldots \ldots \ldots \ldots, \quad 210$

Sarawak Basin $\ldots \ldots \ldots \ldots \ldots \ldots \ldots \ldots \ldots, 108,109$

Solomon Islands ................... 298

Sulawesi $\ldots \ldots \ldots \ldots \ldots \ldots \ldots 162,169,172,187,188$

Sumatra $\ldots \ldots \ldots \ldots \ldots \ldots \ldots \ldots \ldots \ldots, \quad 35$

Sumba ............. $\quad 148$

Thai Basin $\ldots \ldots \ldots \ldots \ldots \ldots \ldots \ldots \ldots, \quad 106$

Timor ..................... 121, 129, 130, 130

Timor Trough $\ldots \ldots \ldots \ldots \ldots \ldots \ldots \ldots \ldots, \quad 144$

West Natuna Basin ................ 107

Yap $\ldots \ldots \ldots \ldots \ldots \ldots \ldots \ldots \ldots \ldots \ldots \ldots, 275,276,282$
Misool (Misol), New Guinea shelf . ........ 115,1 $233,245,249$

Mississippian. See Carboniferous entries

Moa .......................... 115, 133 Molucca Sea ...... 157, 158, 183, 185, 191, 192, 194, 216 Molucca Sea plate ................... 193 Money Shoals, Australian shelf $\ldots \ldots \ldots \ldots \ldots 221,225$ Mongolia

Mount Kinabalu, Borneo ............... 85, 95 Mount Lamington, New Guinea ............ 232, 255 Mud volcanoes $\ldots \ldots \ldots \ldots \ldots \ldots \ldots \ldots \ldots, 132,133,154$ Muna ............................. 160, 166, 173

Mussau Arc, Ridge, and Trench .... 271, 272, 283, 286, $287,288,289,290,292,294,301,303$

Naga Hills (or Ranges), Burma ..........6 65, 79, 80 Nankai Trench (Trough), Japan ........ 271. 272, 278 Nanuse Islands . . . . . . . . . . . . . . . . 157, 195 Nassau Range, New Guinea .............. 233 Natuna (Bunguran) Islands ..........34, 102, 103, 113 Naturaliste Plateau, Indian Ocean .... 59, 59, 60, 62, 220 Negros, Philippines ........ 157, 202, 210, 211, 214, 217 Negros Trench ...........157, 202, 210, 214, 216, 217

Neogene correlation................... 18 Neogene igneous rocks (major listings only).

Ambon......................... 134

Banda Arc $\ldots \ldots \ldots \ldots \ldots \ldots \ldots \ldots \ldots \ldots, 114,118$

Borneo ............................ 112

Burma $\ldots \ldots \ldots \ldots \ldots \ldots \ldots \ldots \ldots \ldots \ldots, \quad 79$

Buton ..........................

Indian Ocean sediments .............. $\quad 47$

Kerguelen $\ldots \ldots \ldots \ldots \ldots \ldots \ldots \ldots \ldots \ldots, \quad 62$

Malay Peninsula $\ldots \ldots \ldots \ldots \ldots \ldots \ldots \ldots, \quad \mathbf{7 9}$

Mindanao $\ldots \ldots \ldots \ldots \ldots \ldots \ldots \ldots \ldots, \quad \mathbf{2 0 7}$

Sumatra $\ldots \ldots \ldots \ldots \ldots \ldots \ldots \ldots \ldots \ldots, \quad \mathbf{3 7}$

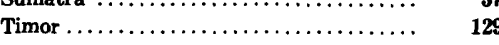

Yap ......................... 275, 277

See also Miocene igneous rocks, Pliocene igneous rocks, and Quaternary igneous rocks.

Neogene sedimentary rocks (major listings only).

Burma $\ldots \ldots \ldots \ldots \ldots \ldots \ldots \ldots \ldots \ldots \ldots$

Java

Kerguelen

Pacific Plate

Roti .

Sumatra

See also Miocene sedimentary rocks,

Pliocene sedimentary rocks, and Quaternary sedimentary rocks.

New Britain . . . . . . . . . 232, 237, 252, 256, 257, 259, $288,289,290,299,300$

New Britain Trench ............ 232, 237, 257, 259, $288,299,300,302$

New Guinea .......... 230, 232, 239, 236, 289, 290, 304 Cenozoic geology . . . . . . . . . . . . . . 238, 249 Mesozoic geology . . . . . . . . . . 235, 237, 239, 249 Misool ......................... 245, 249

Paleozoic geology ............ 233, 234, 237, 239 relationship to Australia . . . . 227, 229, 239, 245, 263 relationship to Banda Arc ... 116, 121, 133, 161, 249 New Guinea Trench . 232, 237, 256, 258, 258, 286, 289, 290 New Hanover . . . . . . . . . . . . 232, 237, 289, 290 New Ireland ...... 232, 237, 289, 290, 291, 292, 300, 301 New Ireland Trench . . . . . . . . . . 301 New Zealand $\ldots \ldots \ldots \ldots \ldots \ldots \ldots \ldots \ldots, 227,229,270$ Nias Island $\ldots \ldots \ldots \ldots \ldots \ldots \ldots \ldots \ldots \ldots, 20,24,34,45$ Nickel ore $\ldots \ldots \ldots \ldots \ldots \ldots \ldots \ldots \ldots \ldots \ldots, 174,174,191$ Nicobar-Andaman arc system $\ldots \ldots \ldots \ldots \ldots, 19,60,64$, $65,79,80,81$

Niewerkerk ........................ 115, 149 Nila $\ldots \ldots \ldots \ldots \ldots \ldots \ldots \ldots \ldots \ldots \ldots \ldots \ldots, 115,118$ Ninetyeast Ridge $\ldots \ldots .48,50,51,52,54,55,56,60,61,69$ basement rocks .................. $\quad \mathbf{5 2 , 5 5}$ origin $\ldots \ldots \ldots \ldots \ldots \ldots \ldots \ldots \ldots \ldots \ldots 55,61,64,81$ paleobotany $\ldots \ldots \ldots \ldots \ldots \ldots \ldots \ldots \ldots, \quad 53$ 
Ninetyeast Ridge-Continued sediments $\ldots \ldots \ldots \ldots \ldots \ldots \ldots, \quad \mathbf{5 2 , 5 5}$

Norfolk Island Ridge $\ldots \ldots \ldots \ldots \ldots \ldots \ldots \ldots \ldots, \quad 229$ North Banda Basin .................. 115, 150

291 North Bismarck Are ........

See also Bismarck Arc.

North Bismarck Plate ..... 290, 291, 292, 301, 303, 304 North Luzon Trough ................... 218 North Makassar Basin ................. 114, 123 North Solomon Trench ........... 290, 293, 299, 300 North Sulawesi Trench.. 157, 160, 175, 181, 184, 186, 194 Northern Divide Ranges, New Guinea .... 233, 251, 260 Northwest Borneo Trench ......... 103, 105, 111, 112 Nullaginian Period (Australia), definition ..... 219

See also Precambrian and Precambrian(?) geology.

$\mathbf{0}$

Obi Islands . . . . . . . . . . . . . . . . . 159, 191 Ocean-floor basalts and other rocks. See Ophiolite for occurrences on land, Deep Sea Drilling Project, and entries for individual oceanic basins.

Ocean-floor spreading. See Migration of island arcs and Spreading, ocean-floor.

Oenake Range, New Guinea ............ 232, 252

Oil. See Petroleum and natural gas.

Oligocene correlation ................. $\quad 17$

Oligocene igneous rocks, Bismarck Arc ...... 291

Borneo $\ldots \ldots \ldots \ldots \ldots \ldots \ldots \ldots .96,94,96,188,206$

Caroline Plate $\ldots \ldots \ldots \ldots \ldots \ldots \ldots \ldots \ldots \ldots, 279,280$

Caroline Ridge .................... 282, 283

Christmas Island $\ldots \ldots \ldots \ldots \ldots \ldots \ldots \ldots, \quad 57$

Java .......................... $\quad \mathbf{4 0 , 4 3}$

Mariana Arc System ................ 273, 274

New Britain Arc $\ldots \ldots \ldots \ldots \ldots \ldots \ldots \ldots, \quad 290$

New Guinea . $\ldots \ldots \ldots \ldots \ldots \ldots \ldots .251,252,253,269$

Ninetyeast Ridge .................. $\quad 52$

Panay .......................... $\quad \mathbf{2 1 0}$

Solomon Islands . . . . . . . . . . . . $\ldots \ldots, \quad 293$

Sulawesi $\ldots \ldots \ldots \ldots \ldots \ldots \ldots \ldots \ldots \ldots, \quad 162$

Sumatra $\ldots \ldots \ldots \ldots \ldots \ldots \ldots \ldots \ldots \ldots, \quad \mathbf{3 6}$

Oligocene sedimentary rocks, Andaman and Nicobar Islands .............. $\quad 66$

Bismarck Arc . . . . . . $\quad \mathbf{2 9 2}$

Borneo ........................ 89, 187

Burma $\ldots \ldots \ldots \ldots \ldots \ldots \ldots \ldots \ldots \ldots \ldots . \quad 79$

Buton $. \ldots \ldots \ldots \ldots \ldots \ldots \ldots \ldots \ldots \ldots, \quad 173$

Caroline Plate $\ldots \ldots \ldots \ldots \ldots \ldots \ldots \ldots \ldots \ldots, \mathbf{2 7 9}, \mathbf{2 8 0}$

Caroline Ridge ..................... $\quad 282$

Christmas Island $\ldots \ldots \ldots \ldots \ldots \ldots \ldots \ldots, \quad 57$

Coral Sea $. . \ldots \ldots \ldots \ldots \ldots \ldots \ldots \ldots \ldots, \quad \mathbf{2 2 9}$

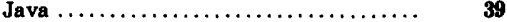

Java Sea $\ldots \ldots \ldots \ldots \ldots \ldots \ldots \ldots \ldots . \quad 100$

Mariana Arc System ................ $\quad \mathbf{2 7 3}$

Mindanao ......................... 207

Misool $\ldots \ldots \ldots \ldots \ldots \ldots \ldots \ldots \ldots \ldots \ldots, \quad \mathbf{2 4 9}$

New Guinea ................ 252, 253, 261, 269

Nias $\ldots \ldots \ldots \ldots \ldots \ldots \ldots \ldots \ldots \ldots, 24$

Ninetyeast Ridge $\ldots \ldots \ldots \ldots \ldots \ldots \ldots \ldots, \quad 52$

Panay ........................... 210

Sarawak Basin $\ldots \ldots \ldots \ldots \ldots \ldots \ldots \ldots \ldots, 108,109$

Sulawesi $\ldots \ldots \ldots \ldots \ldots \ldots \ldots \ldots \ldots 162,169,172,187$

Sumatra $\ldots \ldots \ldots \ldots \ldots \ldots \ldots \ldots \ldots \ldots, \quad 35$

Sumba ............................ 148

Thai Basin $\ldots \ldots \ldots \ldots \ldots \ldots \ldots \ldots \ldots \ldots, \quad 105$

Waigeo $\ldots \ldots \ldots \ldots \ldots \ldots \ldots \ldots \ldots \ldots, \quad 191$

Olistostromes $\ldots \ldots \ldots \ldots \ldots \ldots \ldots \ldots \ldots \ldots, 30,92,94$

Ontong Java Plateau ........ 174, 283, 284, 287, 289, 299

Ophiolite $\ldots \ldots \ldots \ldots \ldots \ldots \ldots \ldots \ldots \ldots \ldots \ldots \quad 13,17$

Andaman-Nicobar ................. 66

Borneo $\ldots \ldots \ldots \ldots \ldots \ldots \ldots \ldots \ldots, 85,87,88,93,96$

Burma $\ldots \ldots \ldots \ldots \ldots \ldots \ldots \ldots \ldots \ldots, \quad 79$

Buton $. \ldots \ldots \ldots \ldots \ldots \ldots \ldots \ldots \ldots \ldots \ldots, \quad 172$

California

D'Entrecasteaux Islands .............

Halınahera...$\ldots \ldots \ldots \ldots \ldots \ldots \ldots \ldots$

Indochina

Malaya

11
299
190
83
39,40
76

Ophiolite-Continued

Mindanao $\ldots \ldots \ldots \ldots \ldots \ldots \ldots \ldots \ldots \ldots, \quad 207$

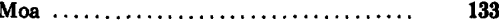

Natuna $\ldots \ldots \ldots \ldots \ldots \ldots \ldots \ldots \ldots \ldots, \quad 102$

New Guinea .... 236, 238, 249, 251, 252, 253, 255, 265

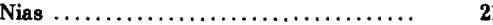

Obi $\ldots \ldots \ldots \ldots \ldots \ldots \ldots \ldots \ldots \ldots \ldots \ldots \ldots, \quad 191$

Palawan $\ldots \ldots \ldots \ldots \ldots \ldots \ldots \ldots \ldots, \quad 197$

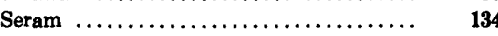

Solomon Islands . . . . . . . . . . . 283, 284, 293

Sulawesi ............... 161, 167, 169, 170, 172

Sumatra $\ldots \ldots \ldots \ldots \ldots \ldots \ldots \ldots \ldots \ldots, \quad 32,33$

Talaud $\ldots \ldots \ldots \ldots \ldots \ldots \ldots \ldots \ldots \ldots \ldots, 195$

Timor $\ldots \ldots \ldots \ldots \ldots \ldots \ldots 121,122,126,126,127$

Waigeo $\ldots \ldots \ldots \ldots \ldots \ldots \ldots \ldots \ldots, 191$

Yap ......................... $\quad 275$

Ordovician sedimentary rocks, Australia .... 223, 224

Malay Peninsula ...........................

Oroclinal folding and crustal rotation, Band Arc $\ldots \ldots \ldots \ldots \ldots \ldots \ldots \ldots \ldots 164,189$

Borneo ............... 86, 91, 93, 95, 113, 190

Burma $\ldots \ldots \ldots \ldots \ldots \ldots \ldots \ldots \ldots \ldots, \quad \mathbf{8 1}$

Flores $\ldots \ldots \ldots \ldots \ldots \ldots \ldots \ldots \ldots \ldots \ldots, \quad 189$

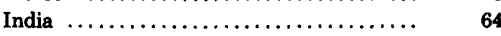

Malay Peninsula $\ldots \ldots \ldots \ldots \ldots \ldots \ldots \ldots, 76,81,113$

Mariana Ridge .................... 273, 274

Papuan Peninsula, New Guinea ....... 229, 269, 270

Philippines ................. 213, 214, 216, 218

Sulawesi $\ldots \ldots \ldots \ldots \ldots \ldots \ldots \ldots \ldots 164,181,188,197$

Sumatra $\ldots \ldots \ldots \ldots \ldots \ldots \ldots \ldots \ldots \ldots \ldots \ldots, \mathbf{3 7 , 7 6 , 8 1}$

Sumbawa ........................ 189

Vogelkop, New Guinea .......... 154, 254, 262, 263

Outer-arc basin $\ldots \ldots \ldots \ldots \ldots \ldots \ldots \ldots \ldots, \quad 9,29$

Andaman-Nicobar-Burma . . . . . . . 66, 66, 67, 80

Banda Arc ............ 114, 115, 139, 140, 144,

$146,147,154,157$

Bismarck ..................... 292, 297

Borneo, middle Tertiary $\ldots \ldots \ldots \ldots \ldots \ldots, 88,92,94$

$\begin{array}{rr}\text { Paleogene } \ldots \ldots \ldots \ldots \ldots \ldots \ldots \ldots \ldots & 92 \\ \text { urma } \ldots \ldots \ldots \ldots \ldots \ldots \ldots \ldots \ldots \ldots \ldots & 79\end{array}$

$\begin{array}{lr}\text { Burma } \ldots \ldots \ldots \ldots \ldots \ldots \ldots \ldots \ldots \ldots \ldots & 79 \\ \text { Java-Sumatra } \ldots . .19,20,21,23,24,25,26,28,29,122\end{array}$

Manila ........................., 213, 218

Mariana ................................. 270

Negros $\ldots \ldots \ldots \ldots \ldots \ldots \ldots \ldots \ldots \ldots \ldots \ldots \ldots \ldots \ldots \ldots \ldots \ldots \ldots \ldots \ldots \ldots, 210,217$

North Sulawesi . . . . . . . . . . . . . 181, 186

Palawan system ................. 157, 199, 217

Panay $\ldots \ldots \ldots \ldots \ldots \ldots \ldots \ldots \ldots \ldots \ldots . \ldots \ldots \ldots \ldots \ldots \ldots \ldots \ldots, 217$

Sarawak Basin .................. 108

Savu Basin ............... 114, 115, 144, 146, 154

Sulu ........................ 157, 200, 205

Weber Deep, Weber Basin ........... 115, 139, 140,

$142,147,154$

Outer-are ridge $\ldots \ldots \ldots \ldots \ldots \ldots \ldots \ldots \ldots \ldots \quad \mathbf{9 , 2 9}$

Andaman-Nicobar-Burma .......... 66, 66, 80

Banda $\ldots \ldots \ldots \ldots \ldots 114,115,121,139,140,142,146$,

See also Babar, Buru, Kai Islands, Leti

$147,151,155,189$ Roti, Savu, Seram, Tanimbar Islands, and Timor.

Bismarck ....................... 292, 297

Borneo, middle Tertiary $\ldots \ldots \ldots \ldots \ldots \ldots, \quad 92,94$

Paleogene $\ldots \ldots \ldots \ldots \ldots \ldots \ldots \ldots \ldots, \quad 91$

Burma $\ldots \ldots \ldots \ldots \ldots \ldots \ldots \ldots \ldots \ldots, \quad 79$

Java $\ldots \ldots \ldots \ldots \ldots \ldots \ldots \ldots \ldots \ldots \ldots \ldots \ldots \ldots, 23,24,26,58,122$

Manila .......................... 213, 218

Negros .......................... 202, 210

North Sulawesi ................... 181, 186

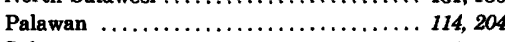

Sulu ........................ 157, 200, 217

Sumatra ................ 19, 23, 24, 29, 34, 50

Owen Stanley Range and terrain, New Guinea . 232, 237 ,

$238,251,264,266$

$\mathbf{P}$

Pacific Cordillera, Mindanao ......... 157, 196, 197 ,

207, 209, 216

Pacific plate ............ 8, 270, 275, 279, 285, 287, $287,290,301,303,304$

Pakistan syntaxis $\ldots \ldots \ldots \ldots \ldots \ldots \ldots \ldots \ldots 37,81,82$
Palau Islands and Ridge $\ldots \ldots \ldots \ldots \ldots 27,275,276,277$
Palau-Kyushu Ridge. See Palau Islands and Ridge and Kyushu-Palau Ridge.

Palau Trench $\ldots \ldots \ldots \ldots \ldots \ldots \ldots \ldots .271,274,276,277$

Palawan, island and ridge $\ldots \ldots \ldots . .85,103,112,114,157$, $197,198,206,209,214,216,217$

Palawan Trench .... 103, 110, 112, 201, 203, 204, 214, 217

Paleobotany, Cenozoic, New Guinea and Australia .

Cretaceous, Borneo

Cretaceous and Paleogene, Ninetyeast Ridge ....................

Permian, global .....................

Tertiary, Kerguelen ...................

Upper Paleozoic, New Guinea .......... 234, 235

Sumatra.......................

Paleocene correlation .................... 17

Paleocene igneous rocks, Cebu ............. $\quad 210$

Java ...........................

Java Sea .................... 100, 101, 190

New Guinea $. . \ldots \ldots \ldots \ldots \ldots \ldots \ldots \ldots \ldots, 252$

Ninetyeast Ridge $\ldots \ldots \ldots \ldots \ldots \ldots \ldots \ldots, \quad 52$

Sulawesi $\ldots \ldots \ldots \ldots \ldots \ldots \ldots \ldots \ldots \ldots, 162$

Paleocene sedimentary rocks, Andaman and Nicobar Islands ...............

Australia northwest shelf ................

Borneo $\ldots \ldots \ldots \ldots \ldots \ldots \ldots \ldots \ldots \ldots \ldots .88,89,92$

Java $\ldots \ldots \ldots \ldots \ldots \ldots \ldots \ldots \ldots \ldots \ldots, \quad 39$

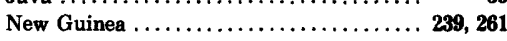

Ninetyeast Ridge $\ldots \ldots \ldots \ldots \ldots \ldots \ldots \ldots \ldots, \quad 52$

Pacific Plate ...................... $\quad \mathbf{2 8 5}$

Sulawesi $\ldots \ldots \ldots \ldots \ldots \ldots \ldots \ldots \ldots \ldots, \quad 162$

Paleoclimates, Australia ............... 125 Gondwanaland $\ldots \ldots \ldots \ldots \ldots \ldots, 62,125,235,254$

India $\ldots \ldots \ldots \ldots \ldots \ldots \ldots \ldots \ldots \ldots \ldots, \mathbf{8 1}, \mathbf{1 2 5}$

Malay Peninsula $\ldots \ldots \ldots \ldots \ldots \ldots \ldots \ldots \ldots, \mathbf{7 0}, 76,235$

New Guinea $\ldots \ldots \ldots \ldots \ldots \ldots \ldots \ldots \ldots \ldots .235,239$

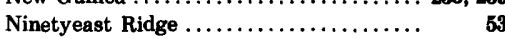

Southeast Asia $\ldots \ldots \ldots \ldots \ldots \ldots \ldots \ldots, \quad \mathbf{8 1}, \mathbf{2 3 5}$

Timor $\ldots \ldots \ldots \ldots \ldots \ldots \ldots \ldots \ldots \ldots \ldots, \quad 125$

Paleogene correlation ................... 18

Paleogene igneous rocks, Borneo ........... 92

Burma $\ldots \ldots \ldots \ldots \ldots \ldots \ldots \ldots \ldots, \ldots \ldots, \ldots \ldots$

Java $\ldots \ldots \ldots \ldots \ldots \ldots \ldots \ldots \ldots \ldots, \quad 41$

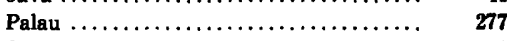

Sulawesi $\ldots \ldots \ldots \ldots \ldots \ldots \ldots \ldots \ldots \ldots, \quad 162$

Sumatra $\ldots \ldots \ldots \ldots \ldots \ldots \ldots \ldots \ldots \ldots, \quad \mathbf{3 6}$

Sumba $\ldots \ldots \ldots \ldots \ldots \ldots \ldots \ldots \ldots \ldots . \quad 148$

See also Eocene igneous rocks, Oligocene igneous rocks, and Paleocen igneous rocks.

Paleogene sedimentary rocks, Borneo ...... 86, 89, 89,

Burma $\ldots \ldots \ldots \ldots \ldots \ldots \ldots \ldots \ldots \ldots \ldots, \quad 79$

Buru $\ldots \ldots \ldots \ldots \ldots \ldots \ldots \ldots \ldots \ldots \ldots, \quad 135$

Malay Basin ....................... 104

Natuna $\ldots \ldots \ldots \ldots \ldots \ldots \ldots \ldots \ldots \ldots, \quad 102$

New Guinea .................. 238, 239, 249

Obi $\ldots \ldots \ldots \ldots \ldots \ldots \ldots \ldots \ldots \ldots \ldots, \quad 191$

Seram $. . . \ldots \ldots \ldots \ldots \ldots \ldots \ldots \ldots \ldots, 139$

Solomon Islands .................... 284

Sumba $\ldots \ldots \ldots \ldots \ldots \ldots \ldots \ldots \ldots, \quad 148$

Timor........................... 122

Waigeo ....................... 191

See also Eocene sedimentary rocks, Oligocene sedimentary rocks, and Paleocene sedimentary rocks.

Paleomagnetism, Africa ................ 59 Australia . . . . . . . . . . . . . . . 59, 60, 75, 228, 228 Borneo .......................... 86, 113 Gondwanaland $\ldots \ldots \ldots \ldots \ldots \ldots \ldots \ldots, 59,62,63$ Guam $\ldots \ldots \ldots \ldots \ldots \ldots \ldots \ldots \ldots \ldots, \quad 270$

India $\ldots \ldots \ldots \ldots \ldots \ldots \ldots \ldots \ldots \ldots \ldots \ldots \ldots, \quad 59$

Indian Ocean ...................... $\quad 49$

Malay Peninsula $\ldots \ldots \ldots \ldots \ldots \ldots \ldots \ldots \ldots, 75,81,113$

New Guinea $\ldots \ldots \ldots \ldots \ldots \ldots \ldots \ldots \ldots . \ldots, \quad 75$

Pacific Ocean ...................... $\quad 285$

Philippine Basin ................... 274

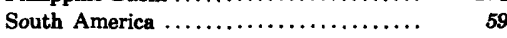

Thailand $\ldots \ldots \ldots \ldots \ldots \ldots \ldots \ldots \ldots \ldots \ldots, \quad \mathbf{7 6 , 8 4}$

Timor .......................... 125, 126

785
18
7
78
48
48


Paleontology, vertebrate, Timor and Florea, Cenozoic.................... 132, 189 Paleozoic geology. See listings for each system.

Paleozoic igneous rocks, Ambon $\ldots \ldots \ldots \ldots \ldots$ 134, 135

Batian (Bacan) . . . . . . . . . . . . . . . 191

Buru $\ldots \ldots \ldots \ldots \ldots \ldots \ldots \ldots \ldots \ldots \ldots, \mathbf{1 3 6}, \mathbf{1 3 7}$

Seram $\ldots \ldots \ldots \ldots \ldots \ldots \ldots \ldots \ldots \ldots, 134$

Sula and Banggai Islands . . . . . . . . . 156, 158

Palu fault, Sulawesi ........... 160, 175, 176, 177, 181

Panay, Philippines ..... 197, 202, 204, 209, 210, 211, 216

Pandai .

Pantar....

Papua, Gulf of $\ldots \ldots \ldots \ldots \ldots \ldots \ldots 228,229,239,240,255$ $265,266,267,269,289$

See also New Guinea and entries for other islands.

Papuan Basin, New Guinea. See Aure Trough.

Papuan Peninsula, New Guinea .... 228, 229, 230, 239, $240,252,255,263,264,266,267$

Papuan Plateau . . . . . . . . . . . . 266, 269, 270, 289 Parece Vela Basin .. 270, 271, 272, 273, 274, 276, 277, 280 Pelagic sediments, abyssal. See Ophiolite for occurrences on land, and entries for individual oceanic basins.

Peleng . 157,172

Pennsylvanian. See Carboniferous entries.

Penyu Basin, South China Seq ............. 103

Permian igneous rocks, Australia .......... 226, 227 Malay Peninsula $\ldots \ldots \ldots \ldots \ldots \ldots \ldots \ldots, \quad 70$ New Guinea .................. 234, 235, 237

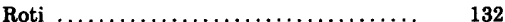

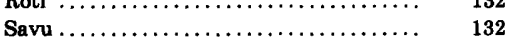
Sumatra $\ldots \ldots \ldots \ldots \ldots \ldots \ldots \ldots \ldots \ldots, \quad 32$ Timor $\ldots \ldots \ldots \ldots \ldots \ldots \ldots \ldots \ldots, 121,125,126,126$ Tin Islands . ......................... 38

Permian paleobiogeography, Asia ......... $\quad 235$ Australia ......................... 123, 125 Gondwanaland $\ldots \ldots \ldots \ldots \ldots \ldots \ldots \ldots, \mathbf{6 2 , 2 3 5}$

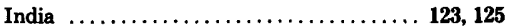
Malay Peninsula $\ldots \ldots \ldots \ldots \ldots \ldots \ldots \ldots, \quad \mathbf{7 6}$ Mindoro $\ldots \ldots \ldots \ldots \ldots \ldots \ldots \ldots \ldots \ldots, \quad 209$

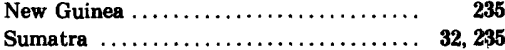

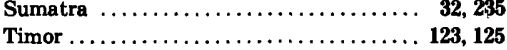
Timor $\ldots \ldots \ldots \ldots \ldots \ldots \ldots \ldots \ldots \ldots \ldots \ldots \ldots \ldots$. west and shelf $\ldots \ldots \ldots \ldots \ldots \ldots, 63,123,126$ Australia and shelves ............ 224, 225, 227 Babar ........................... 133 Borneo .......................... 86 Carabao, Philippines ................ 197, 210 India and shelf $\ldots \ldots \ldots \ldots \ldots \ldots \ldots \ldots \ldots, 63$ Indochina $\ldots \ldots \ldots \ldots \ldots \ldots \ldots \ldots \ldots, \ldots$ Leti ................................. 132 Luang ........................ 133

Malay Peninsula $\ldots \ldots \ldots \ldots \ldots \ldots \ldots \ldots, \quad 68,77$ New Guinea $\ldots \ldots \ldots \ldots \ldots \ldots \ldots \ldots \ldots .234,235$ Palawan $\ldots \ldots \ldots \ldots \ldots \ldots \ldots \ldots \ldots \ldots, \quad 197$ Roti $\ldots \ldots \ldots \ldots \ldots \ldots \ldots \ldots \ldots \ldots \ldots, 132$ Savu .......................... Sumatra $\ldots \ldots \ldots \ldots \ldots \ldots \ldots \ldots \ldots \ldots, \quad 32$ Timor $\ldots \ldots \ldots \ldots \ldots 121,122,123,125,126,128,129$ Tin Islands .

38

Petrogenesis. See Magmagenesis.

Petroleum and natural gas, Bangladesh...... 80 Borneo .................. 92, 93, 96, 97, 99, 99 Gulf of Thailand $\ldots \ldots \ldots \ldots \ldots \ldots \ldots \ldots, 105,106$ Java $\ldots \ldots \ldots \ldots \ldots \ldots \ldots \ldots \ldots \ldots \ldots$ Java outer-arc basin $\ldots \ldots \ldots \ldots \ldots \ldots \ldots, \quad 28$ Java Sea $\ldots \ldots \ldots \ldots \ldots \ldots \ldots \ldots \ldots \ldots \quad 101$

Malay Peninsula, western continental shelf . $\quad 79$ New Guinea $. . \ldots \ldots \ldots \ldots \ldots \ldots \ldots \ldots, \quad \mathbf{2 6 1}$

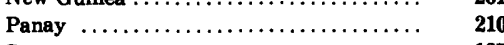
Seram $\ldots \ldots \ldots \ldots \ldots \ldots \ldots \ldots \ldots \ldots \ldots, \quad 137$ South China Sea . . . . . . . . . 105, 107, 108, 109 Sumatra $\ldots \ldots \ldots \ldots \ldots \ldots \ldots \ldots \ldots \ldots, \quad 36$

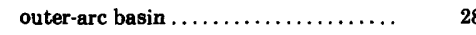
Philippine (West Philippine) Basin ...... 183, 270, 271, $272,274,276,277,284$
Philippine fault $\ldots \ldots \ldots \ldots \ldots \ldots \ldots \ldots \ldots, 213$
Philippine Islands . ................... See also entries for individual islands and topics.

Philippine Sea plate . . . . . . . . . \& \& 270, 272, 277 Philippine (Mindanao) Trench . . . . . 183, 189, 190, 194 $196,197,203,206,213,214,217,271,272,276$ Pine Creek Geosyncline, Australia . . . . 219, 220, 221, 222 Plate-motion mechanism ................ 303

Plate tectonics $\ldots \ldots \ldots \ldots \ldots \ldots \ldots \ldots \ldots \ldots, \mathbf{2 , 7 , 9 , 3 0 3}$

Pleistocene. See Quaternary entries.

Pliocene correlation ................... 17

Pliocene igneous rocks, Banda Arc .......... 118

Bismarck Arc .................... 291 Borneo $\ldots \ldots \ldots \ldots \ldots \ldots \ldots \ldots . .93,94,95,96,206$ Indian Ocean sediments ............... 47

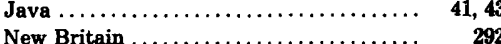

New Guinea $\ldots \ldots \ldots \ldots \ldots \ldots \ldots \ldots 24,254,255,269$

Panay $\ldots \ldots \ldots \ldots \ldots \ldots \ldots \ldots \ldots \ldots \ldots \ldots \ldots \ldots \ldots \ldots \ldots \ldots \ldots \ldots \ldots, 210$

Sulawesi $\ldots \ldots \ldots \ldots \ldots \ldots \ldots \ldots \ldots \ldots \ldots, 162,188$

Sumbr $\ldots \ldots \ldots \ldots \ldots \ldots \ldots \ldots \ldots$

Pliocene sedimentary rocks, Australia and shelves $\ldots \ldots \ldots \ldots \ldots \ldots \ldots \ldots \ldots, \quad 225$

Bismarck Arc . . . . . . $\ldots \ldots \ldots \ldots \ldots \ldots \ldots$

Borneo $\ldots \ldots \ldots \ldots \ldots \ldots \ldots \ldots \ldots \ldots \ldots, 93,96,97$

Caroline Plate $\ldots \ldots \ldots \ldots \ldots \ldots \ldots \ldots \ldots, \quad \mathbf{2 8 0}$

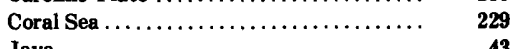

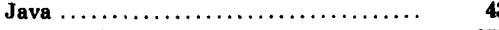

Mariana Arc System ................ $\quad 273$

Misool ......................... $\mathbf{2 4 9}$

New Guinea .......... 240, 253, 259, 260, 261, 269

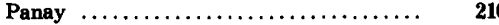

Sarawak Basin ................... 108, 109

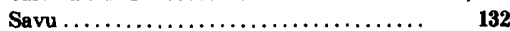

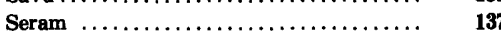

Sulawesi $\ldots \ldots \ldots \ldots \ldots \ldots \ldots \ldots \ldots \ldots, 162,172$

Sumba $\ldots \ldots \ldots \ldots \ldots \ldots \ldots \ldots \ldots \ldots$

Thai Basin $\ldots \ldots \ldots \ldots \ldots \ldots \ldots \ldots \ldots \ldots, \quad 106$

Timor $\ldots \ldots \ldots \ldots \ldots \ldots \ldots \ldots \ldots \ldots 129,130,130$

Timor Trough $\ldots \ldots \ldots \ldots \ldots \ldots \ldots \ldots \ldots, \quad 144$

West Natuna Basin ................ 107

Wharton Basin, Indian Ocean ...........

Plumes (hot spots) . . . . . . . . . . $305 \ldots \ldots \ldots \ldots, \ldots$

Pocklington Rise $\ldots \ldots \ldots \ldots \ldots \ldots \ldots, 228,299,300,300$

Pocklington Trough (Trench) . . . . . . 289, 290, 298, 299

Pompangeo Mountains, Sulawesi ......... 168

Port Moresby Trench ...... 236, 265, 266, 267, 270, 290

Precambrian and Precambrian.(?) geology, Ambon ................... 134, 136 Australia ........................ 218, 225, 226 Buru $\ldots \ldots \ldots \ldots \ldots \ldots \ldots \ldots \ldots \ldots \ldots 136,137$

Malay Peninsula ................... 68

New Guinea $\ldots \ldots \ldots \ldots \ldots \ldots \ldots \ldots \ldots, \quad 233$

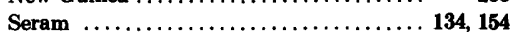

time scale $\ldots \ldots \ldots \ldots \ldots \ldots \ldots \ldots \ldots \ldots, \quad \mathbf{2 1 8}$

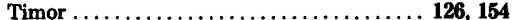

Prince Alexander Mountains, New Guinea .... 232, 252

Profiles, reflection, location. See Index maps.

Proterozoic...$\ldots \ldots \ldots \ldots \ldots \ldots \ldots \ldots$.

See also Precambrian and Precambrian(?) geology.

\section{Q}

Quaternary correlation .................

Quaternary igneous rocks, Andaman-Nicobar

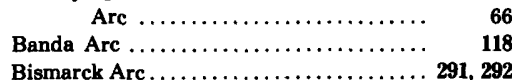
Bismarck Arc $\ldots \ldots \ldots \ldots \ldots \ldots \ldots \ldots \ldots, 291,292$ Borneo $\ldots \ldots \ldots \ldots \ldots \ldots \ldots \ldots \ldots .9 . \ldots, 95,96,206$ Burma $\ldots \ldots \ldots \ldots \ldots \ldots \ldots \ldots \ldots \ldots \ldots$
D'Entrecasteaux Islands $\ldots \ldots \ldots \ldots \ldots \ldots \ldots$ Halmahera ...................... 190

Indian Ocean sediments .............. $\quad 47$

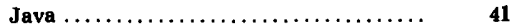

Malay Peninsula $\ldots \ldots \ldots \ldots \ldots \ldots \ldots \ldots, \quad 79$

Mindanao $\ldots \ldots \ldots \ldots \ldots \ldots \ldots \ldots \ldots \ldots, 207,209$

Negros ............................ $\quad 210$

New Britain ..................... 292
Quarternary igneous rocks-Continued

Page

New Guinea . . . . . . . . . . . . 243, 254, 255, 269

Sangihe $\ldots \ldots \ldots \ldots \ldots \ldots \ldots \ldots \ldots \ldots \ldots, 194$

Solomon Islands . . . . . . . . . . . . . . . . 293

Sulawesi $\ldots \ldots \ldots \ldots \ldots \ldots \ldots \ldots \ldots \ldots \ldots, 162,164,188$

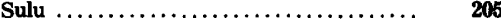

Sumatra $\ldots \ldots \ldots \ldots \ldots \ldots \ldots \ldots \ldots \ldots, \quad 35,37$

Quaternary sedimentary deposits, Australia and shelves $\ldots \ldots \ldots \ldots \ldots \ldots \ldots, \quad 225$

Borneo ..................... 95, 97

Caroline Plate $\ldots \ldots \ldots \ldots \ldots \ldots \ldots \ldots ., \quad \mathbf{2 8 0}$

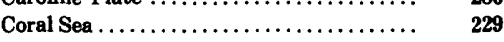

Java $\ldots \ldots \ldots \ldots \ldots \ldots \ldots \ldots \ldots \ldots, \quad 41$

Mariana Trough $\ldots \ldots \ldots \ldots \ldots \ldots \ldots \ldots \ldots, \quad \mathbf{2 7 3}$

Misool ........................ $\mathbf{2 4 9}$

New Guinea $\ldots \ldots \ldots \ldots \ldots \ldots \ldots \ldots \ldots \ldots, 240,253,259,260,261$

Sarawak Basin ...................... 108, 109

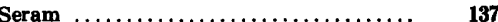

Sulawesi $\ldots \ldots \ldots \ldots \ldots \ldots \ldots \ldots \ldots \ldots \ldots, \quad 162$

Sumba $\ldots \ldots \ldots \ldots \ldots \ldots \ldots \ldots \ldots \ldots \ldots \ldots, \quad 148$

Thai Basin ...................... 106

Timor $\ldots \ldots \ldots \ldots \ldots \ldots \ldots \ldots \ldots \ldots, 128,130,131$

Timor Trough $\ldots \ldots \ldots \ldots \ldots \ldots \ldots \ldots \ldots, \quad 144$

West Natuna Basin ................ 107

Wharton Basin, Indian Ocean .......... 44

Queensland (Coral Sea) Plateau . . 221, 228, 229, 230, 289

Queensland Trough . . . . . . . . . . 221, 228, 228, 230

$\mathbf{R}$

Radiolaria, Cretaceous, Sulawesi (list) ....... $\quad 162$ Raijua (Raidjua) $\ldots \ldots \ldots \ldots \ldots \ldots \ldots \ldots \ldots \ldots, 115,133$

Ramu Basin, New Guinea .............. 259, 262

Ramu fault, New Guinea. See Markham-Ramu fault zone.

Ransiki fault, New Guinea .

Recent. See Quaternary entries.

Reed Bank, South China Sea ............. 103, 110

Renjuva. See Raijua.

Reversal of island-arc subduction polarity .... $\quad 305$

Alor $\ldots \ldots \ldots \ldots \ldots \ldots \ldots \ldots \ldots \ldots \ldots, 115,149,154$

Banda Arc $\ldots \ldots \ldots \ldots \ldots \ldots \ldots \ldots \ldots$ 121, 149, 156

Bismarck Arc . . . . . . . . . . . . $30 \ldots \ldots \ldots, \quad 300$

Flores ................... 114, 121, 149, 156

New Britain . . . . . . . . . . . . . . . . . 291, 300

New Guimea ................... 254, 269, 270

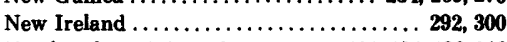

North Sulawesi-Sangihe ......... 181, 194, 196, 216

Philippine Islands . . . . . . . . . . . 206, 213, 272 Solomon Islands . . . . . . . . . . . . 284, 298, 299, 300 Sulu $\ldots \ldots \ldots \ldots \ldots \ldots \ldots \ldots \ldots \ldots . .96,201,204,206$ Taiwan ...................... 213, 218, 272

Rifting of continental masses ............. 306 Africa $. . \ldots \ldots \ldots \ldots \ldots \ldots \ldots \ldots \ldots, \quad 63$ Australia from Antarctica $\ldots \ldots \ldots \ldots \ldots \ldots, \quad 60$ Australia from India ........ 62, 63, 223, 224, 225 Batjan (Bacan) from New Guinea . . . . . . 191 Borneo and Southeast Asia .......... 113 Borneo from Sulawesi ....... 96, 114, 161, 162, 185 Buru from New Guinea ............... 137 Buton from New Guiner . . . . . . . . . . . 174, 183 Coral Sea Plateau from Australia ........ $\quad 229$ Flores from Java shelf and Sulawesi ....... $\quad 189$ Gondwanaland components .......... 59,60 Gulf of Thailand ................ 84, 105, 112

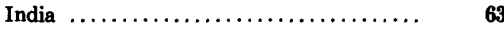
India and Southeast Asia .............. $\quad 81$ Indian Ocean continental fragments ...... 58,62 Malay Basin $\ldots \ldots \ldots \ldots \ldots \ldots, 105$ Malay Peninsula .................... $\quad 78$ Mergui Terrace $\ldots \ldots \ldots \ldots \ldots \ldots \ldots \ldots, \quad \mathbf{7 8}$ New Zealand from Australia ........... 227, 229 North Palawan from Asia .............. $\quad 197$ Papuan Peninsula from Australia . ....... 229 South China Sea $\ldots \ldots \ldots \ldots \ldots \ldots \ldots \ldots 112,197$ Sula-Banggai from New Guinea .. 158, 159, 174, 249 Sulawesi arms .................... 188 Sumatra from New Guinea . . . . . . 32, 33, 72, 75, 83, $159,227,235,238,239$

Sumba from Australia or Java Sea ....... 114, 148 Sumbawa from Java shelf and Sulawesi ... $\quad 189$ 
Rifting of continental masses-Continued Tibet from Malay Peninsula ......... 81, 235, 237

Vogelkop from Australia .............. Rifting of island arcs. See Migration of island arcs.

Roma $\ldots \ldots \ldots \ldots \ldots \ldots \ldots \ldots \ldots \ldots \ldots 115,118,156$ Roo Rise, Indian Ocean . . . . . . . . . . . . . . Rotational plate drives .................... 305 Roti (Rotti) . . . . . . . . . . . . . . . 114, 115, 132 Rouffaer Mountains, New Guinea .......... Rum Jungle complex, Australia ............ 218 Rumbia Mountains, Sulaweei .............. $\quad 166$ Rumong, Yap Islands ................. 275, 276 Ryukyu Island Arc ................. 214, 271, 272

\section{$\mathbf{S}$}

Sabah. $84,85,93$ See also Borneo.

Sadang fault, Sulawesi 160,175 Salawati Basin, New Guinea . . . . . . . . . . 260, 261 Salawati Island $\ldots \ldots \ldots \ldots \ldots \ldots \ldots \ldots \ldots \ldots, 233,263$ Salayar Island and Trench $\ldots \ldots \ldots \ldots 115,160,164,188$ Samar, Philippines ................. 211, 212, 213 Sandakan Basin, Borneo ................ 85, 95 Sangihe (Sangi, Sangir) Island Arc ...... 157, 160, 164, $181,182,183,185,192,192$ $194,206,207,214,217$

Sangihe plate 193

Sarawak ...... See also Borneo.

Sarawak Basin.

84,85

Savu ....

$103,104,108,108$ . Savu Basin .......... 21, 114, 115, 144, 146, 147, 155 Sawoe, Sawu. See Savu.

Scaly clay. See Melange and melange wedges.

Schouten Islands and arc . . . . $259,260,288,289,292,300$

Schrader Range, New Guinea ............. 232 Scotia Arc ......................... 118, 305 Scott Plateau, Indian Ocean .......... 21, 57, 58, 58 Sea-floor spreading. See Migration of island arcs and Spreading, ocean-floor.

Seismicity. See Earthquakes and seismicity.

Selayar (Salayar)

164

Semporna Peninsula, Borneo ...... 85, 94, 96, 157, 206

Sepik Basin and Lowlands, New Guinea . . 249, 250, 251 , $252,259,263$

Seram (Seran) . .........115, 133, 134, 135, 139, 141 Seram Trough (Trench). See Banda Trench.

Seribu Platform, Java Sea ............... 20 Sermata $\ldots \ldots \ldots \ldots \ldots \ldots \ldots \ldots \ldots \ldots \ldots \ldots 115,133$

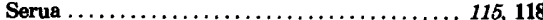

Seychelles Plateau, Indian Ocean $\ldots \ldots \ldots \ldots \ldots, 59,62,63$ Shan Plateau, Burma $\ldots \ldots \ldots \ldots \ldots \ldots \ldots \ldots, 65,79,81$

Siberut $\ldots \ldots \ldots \ldots \ldots \ldots \ldots \ldots \ldots \ldots \ldots \ldots, \quad 34$

Silurian igneous rocks, Australia .......... 226

Silurian sedimentary rocks, Australia and shelves $\ldots \ldots \ldots \ldots \ldots \ldots \ldots \ldots \ldots 225,226$

Borneo .......................... 88

Malay Peninsula $\ldots \ldots \ldots \ldots \ldots \ldots \ldots \ldots 68,76,77$

New Guinea $. . \ldots \ldots \ldots \ldots \ldots \ldots \ldots \ldots, \quad 234$

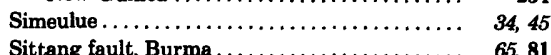

Sneeuw Mountains, New Guinea ........... 233, 234

Soemba. See Sumba.

Soepiori. See Supiori Island.

Solomon Islands and Arc....

$284,289,290$

$293,298,299,300$

Solomon Rise. See Ontong Java Plateau.

Solomon Sea ............. 237, 289, 298, 298, 300, 303

Solomon Sea Plate .................... 290, 304

Solor ......................................115, 118

Sorol Trough and fault system, Caroline Ridge 271, 276,

Sorong ar $\nrightarrow$ Sula-Sorong fault systems, Banda-

283, 288

Molucca region ..... 115, 137, 141, 157, 158

$158,159,174,181,183$

$185,191,192,253,261$
Sorong and Sula-Sorong fault systems-Continued

New Guinea .......... 234, 253, 260, 261, 262, 263 South Banda Basin ........ 115, 140, 149, 150, 151, 154

South Bismarck Arc. See New Britain.

South Bismarck Plate ......... 288, 290, 292, 301, 304

South China platform ................... 69

South China Sea ...............69, 82, 102, 103, 110 continental fragments, foundered .. $69,110,112,114$ islands between Borneo and Malay Penin-

$$
\text { sula } \ldots \ldots \ldots \ldots \ldots \ldots \ldots \ldots, \quad 102
$$

Northwest Borneo Trench ........... 111, 112, 190

origin $\ldots \ldots \ldots \ldots \ldots \ldots \ldots \ldots \ldots \ldots \ldots, \quad 113$

Palawan Trench .................... 110, 112

shelf basins . . . . . . . . . . . . . . . . . . 103, 112

South China Basin .................. 109, 190

tectonic correlations between Borneo and mainland Asia ............., 69, 113

South Makassar Basin . . . . . . . . . . . . 114, 122

South Solomon Trench .............. 290, 293, 303

Southeast Sulawesi Trench ........... 115, 149, 150

Southern Foothills, New Guinea ........... 232

Spreading, ocean-floor $\ldots \ldots \ldots \ldots \ldots \ldots, 7,8,306$

Andaman Sea ..................... 65, 66, 67

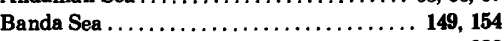

Bismarck Sea ..................... 292

Caroline Plate $\ldots \ldots \ldots \ldots \ldots \ldots \ldots \ldots, \quad 281$

Indian Ocean ..................... 49, 60, 61

Makassar Strait ............... 114, 160, 185, 188

Mariana Trough $\ldots \ldots \ldots \ldots \ldots \ldots \ldots \ldots, \mathbf{2 7 3}, \mathbf{2 7 4}$

Pacific Ocean ....................... $\quad \mathbf{2 8 3}$

Palau Ridge $\ldots \ldots \ldots \ldots \ldots \ldots \ldots \ldots \ldots, \quad \mathbf{2 7 7}$

Parece Vela Basin ................... 274, 277

Philippine Basin ................... 274, 277

South China Basin . . . . . . . . . . . 113

Southern Ocean .................... 60,61

Strike-slip faults. See Faults, strike-slip.

Strontium isotopes .................... $\quad 307$

Africa, volcanic rocks . . . . . . . . . . .

Ambon, volcanic rocks ............... $\quad 135$

Antarctica, Jurassic diabase .......... 73

Australia, granitic rocks . . . . . . . . . . . 72, 227

Bali, Cenozoic volcanic rocks ............

Banda Arc, volcanic rocks ............ 118

Banggai Islands, granitic rocks ......... 156

Bismarck Arc, volcanic rocks . . . . . . . . . 291, 292

California, granitic rocks ............. 73

Idaho, volcanic rocks ................ 73

Java, Cenozoic volcanic rocks ........... 43

Karimata Island, granitic rocks ......... $\quad 86$

Kerguelen, Cenozoic volcanic rocks ...... 62

Malay Peninsula, granitic rocks ........ 71, 74, 75

Mariana Ride. ............. 273

Mariana Trrugh, basalt ............... 273

New Britain A.rc, volcanic rocks ......... 291

New Guinea, volcanic rocks ............ $\quad 255$

Palau, volcanic rocks ............... 277

Sula Islands, granitic rocks . ........... 156

Sumatra, Cenozoic volcanic rocks ......... 37

Thailand, granitic rocks ............. 73

Tin Islands, granitic rocks ...........

Yap, greenschist . . . . . . . . $27 \ldots \ldots \ldots \ldots, \quad \mathbf{2 7 5}$

Structural stage $\ldots \ldots \ldots \ldots \ldots \ldots \ldots \ldots \ldots, \quad 15$

$\begin{array}{lr}\text { Sturt Block, Australia } \ldots \ldots \ldots \ldots \ldots \ldots \ldots \ldots \ldots & 224 \\ \text { Subduction processes } \ldots \ldots \ldots \ldots \ldots \ldots, 28,29,88,95,144 & \text {, }\end{array}$ $253,254,259,270,274,275,303$

See also Benioff seismic zones, Magmagenesis, and Melange and melange wedges.

Subduction systems $\ldots \ldots \ldots \ldots \ldots \ldots, 7,11,28,29,155$ Andaman-Nicobar-Burma $\ldots \ldots \ldots \ldots \ldots \ldots, \quad \mathbf{7 9}$ Australia ........................ $\quad 227$ Banda Arc $\ldots \ldots \ldots \ldots \ldots \ldots \ldots, 151,155,189,263$ Bismarck-West Melanesian .......... 292, 301 Borneo, Cenozoic ............. 88, 112, 188, 190 pre-Cenozoic $\ldots \ldots \ldots \ldots \ldots \ldots \ldots \ldots \ldots, 85,188$

Burma $\ldots \ldots \ldots \ldots \ldots \ldots \ldots \ldots \ldots \ldots, \quad 79$

California $\ldots \ldots \ldots \ldots \ldots \ldots \ldots \ldots \ldots \ldots, \quad 11$

Halmahera $\ldots \ldots \ldots \ldots \ldots \ldots \ldots \ldots \ldots \ldots \ldots, 191,196,216$
Subduction systems-Continued

Page

Java ......................... 18, 102, 190

Java Sea, Late Cretaceous and Paleogene . 100, 102,

188,190

Leyte $\ldots \ldots \ldots \ldots \ldots \ldots \ldots \ldots \ldots \ldots \ldots, \quad 213$

Malay Peninsula $\ldots \ldots \ldots \ldots \ldots \ldots \ldots \ldots, \quad 2$

Manila-Taiwan $\ldots \ldots \ldots \ldots \ldots \ldots \ldots \ldots \ldots \ldots \ldots \ldots \ldots \ldots \ldots, 209,216$

Mussau ............................ 287

Negros ...................... 204, 213, 216

New Britain-Schouten .............. 288

New Guinea ............. 229, 237, 253, 254, 269

Palawan $\ldots \ldots \ldots \ldots \ldots \ldots \ldots \ldots \ldots \ldots, 197,216$

Philippines ........................ 213, 216

Philippine Sea boundaries ............ 278, 279

Salayar $\ldots \ldots \ldots \ldots \ldots \ldots \ldots \ldots \ldots \ldots \ldots 164,188$

Sangihe $\ldots \ldots \ldots \ldots \ldots \ldots \ldots \ldots \ldots \ldots \ldots, 194,216$

Solomon . ....................... 293, 298

Sulawesi ............ 161, 164, 173, 174, 188, 189

Sulu $\ldots \ldots \ldots \ldots \ldots \ldots \ldots \ldots \ldots \ldots \ldots \ldots 205,216$

Sumatra $\ldots \ldots \ldots \ldots \ldots \ldots \ldots \ldots \ldots \ldots, \quad 18,150$

Trobriand

Sula Islands . . . . . . . . 115, 156, 157, 160, 172, 181, 183

Sula-Sorong faults. See Sorong and Sula-Sorong fault systems.

Sulabesi .................. 156, 157, 159, 159

Sulawesi (Celebes) . . . . . . 159, 160, 194, 196, 197, 284 Sulawesi Sea. See Celebes Sea.

Sulu Island Arc ........ 93, 157, 192, 204, 205, 216, 218

Sulu Sea ............... 85, 95, 96, 157, 197, 200, $202,203,205,206,214,217$

Sulu Trench and Island Arc ........ 85, 95, 200, 202, $205,214,217$

Sumatra (Sumatera) $\ldots \ldots \ldots \ldots \ldots \ldots \ldots \ldots, \quad 32$

Benioff zone ....................... 18

Cenozoic, geology $\ldots \ldots \ldots \ldots \ldots \ldots \ldots \ldots \ldots$

magmatic arc $\ldots \ldots \ldots \ldots \ldots \ldots \ldots, \quad 32,36$

stratigraphy and sedimentation......

tectonics $\ldots \ldots \ldots \ldots \ldots \ldots \ldots \ldots \ldots$.

granitic rocks $\ldots \ldots \ldots \ldots \ldots \ldots \ldots \ldots \ldots \ldots \ldots \ldots \ldots \ldots, 32,33,36$

motion relative to Malaya .............. 38

oil and gas . . . . . . .

Paleozoic and Mesozoic geology and paleontology .............. 32

pre-Cenozoic melange $\ldots \ldots \ldots \ldots \ldots \ldots \ldots, \quad 33,34$

rifting from New Guinea ............ 32, 33, 235

rotation $\ldots \ldots \ldots \ldots \ldots \ldots \ldots \ldots \ldots \ldots, \quad 37$

strike-slip faulting

$2,5,19,20,23,24,26$ $28,34,45,50,55,58$

Sumatran rift (Semangko fault), Sumatra .... 37, 38, 67 Sumba .............. 21, 114, 114, 117, 121, 148, 148 Sumbawa $\ldots \ldots \ldots \ldots \ldots \ldots \ldots, 21,114,114,118,119,189$

Sunda Basin, Java Sea $\ldots \ldots \ldots \ldots \ldots \ldots \ldots .20,101$

Sunda Shelf ......................... 103

Sunda Trench. See Andaman-Nicobar-Burma Trench, Banda Trench, and JavaSumatra Trench.

Supiori Island $\ldots \ldots \ldots \ldots \ldots \ldots \ldots \ldots \ldots, 233,253$ Sutures, Banda and Australia-New Guinea ... 151, 154 Borneo $. \ldots \ldots \ldots \ldots \ldots \ldots \ldots \ldots \ldots \ldots, \quad 94,95$ Burma $\ldots \ldots \ldots \ldots \ldots \ldots \ldots \ldots \ldots \ldots, \quad 81$ Burma-India $\ldots \ldots \ldots \ldots \ldots \ldots \ldots \ldots \ldots, \quad 65$ Eurasia $\ldots \ldots \ldots \ldots \ldots \ldots \ldots \ldots \ldots \ldots \ldots, 307,308$ Himalayas $\ldots \ldots \ldots \ldots \ldots \ldots \ldots \ldots \ldots \ldots, 64,81$ Indochina $\ldots \ldots \ldots \ldots \ldots \ldots \ldots, 32,65,69,83,84,235$ Indus $\ldots \ldots \ldots \ldots \ldots \ldots \ldots \ldots \ldots \ldots, \quad 64,65$ Malaya $\ldots \ldots \ldots \ldots \ldots \ldots \ldots \ldots \ldots \ldots \ldots \ldots \ldots \ldots \ldots \ldots \ldots \ldots \ldots, 76,7,84$ New Guinea . . . . . . . . . 236, 237, 238, 253, 254, $259,261,269,270,290$

Palawan-Panay . . . . . . . . . . $218 \ldots \ldots \ldots, \quad$ Sulawesi-Buton $\ldots \ldots \ldots \ldots \ldots \ldots \ldots 160,183,185$ Sulawesi-Sula-Banggai $\ldots \ldots \ldots \ldots \ldots, 160,181,183$ Sumatra $\ldots \ldots \ldots \ldots \ldots \ldots \ldots \ldots \ldots \ldots, \quad \mathbf{3 2 , 8 4}$

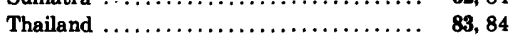
See also Collisions of island arcs.

Syntaxis, Assam . . . . . . . . . Pakistan $\ldots \ldots \ldots \ldots \ldots \ldots \ldots \ldots \ldots \ldots \ldots, 37,81$ Papua $\ldots \ldots \ldots \ldots \ldots \ldots \ldots \ldots \ldots \ldots, \quad \mathbf{2 6 9}$ 


\section{$\mathbf{T}$ \\ Page}

Taiwan ............... 83, 213, 214, 218, 271, 272 Talaud Ridge and Islands .......... 157, 183, 192, 192

$214,216,217$

Taliabu ............................ 156, 157 Tambelan Islands .................... 34, 102, 103 Tamrau Mountains, New Guinsa ........... 233, 253 Tanahjampea $\ldots \ldots \ldots \ldots \ldots \ldots \ldots \ldots \ldots \ldots \ldots, 160,164$ Tanimbar Islands ............ 115, 133, 138, 141, 233 Tarakan Basin, Borneo ................ 85, 97 Tarera fault zone, New Guinea ... 244, 245, 247, 248, 263 Tarim $\ldots \ldots \ldots \ldots \ldots \ldots \ldots \ldots \ldots \ldots . .235$ Tasman Orogenic Zone, Australia ............. 221 Tasman Sea .......................... 227, 229

Tectonic maps, Australia ................. 221

Banda Arc $\ldots \ldots \ldots \ldots \ldots \ldots \ldots \ldots \ldots, 115,152$ Borneo ........................... 69, 114, 157 Bismarck Sea region ................. 236

Burma ............................... 65

China $\ldots \ldots \ldots \ldots \ldots \ldots \ldots \ldots \ldots \ldots, \quad 82,214$ Indian Ocean ..................... 61, 83 Indonesia $\ldots \ldots \ldots \ldots 16,69,82,115,157,192$, plate 1 Melanesia ...................... 236, 290, 304 Moluccas ...................... 157, 192, 217 New Guinea .................... 236, 290, 394 Palau-Yap-southern Mariana region ..... 272

Philippine Sea-Mariana region.......... 272 Philippines $\ldots \ldots \ldots \ldots \ldots \ldots \ldots \ldots$ 82, 157, 214, 217 previous maps of other regions ........... Southeast Asia $\ldots \ldots \ldots \ldots \ldots \ldots \ldots \ldots \ldots 6,69,82$ Sulawesi $\ldots \ldots \ldots \ldots \ldots \ldots \ldots \ldots \ldots \ldots \ldots, 157,160,166$ Taiwan ....................... 214 Teluk Sarera, New Guinea. See Geelvink Bay.

Teon ............................. 115, 118

Tertiary, classification .......................... rocks. See listings for separate series and for Neogene and Paleogene.

Thai Basin ......................... 103, 105

Thailand. See Indochina and Malay Peninsula.

Thailand, Gulf of $\ldots \ldots \ldots \ldots \ldots \ldots \ldots 84,103,103,112$ Thermal gradients. See Heat flow and Geothermal gradients.

Tibet $\ldots \ldots \ldots \ldots \ldots \ldots \ldots \ldots \ldots \ldots, 64,73,82,235,308$ Tidal plate drives ..................... 305 Tifore Island ........................ 157, 195 Timor ............. 114, 115, 121, 142, 149, 155, 156 Timor Trough (Trench). See Banda Trench.

Tin $\ldots \ldots \ldots \ldots \ldots \ldots \ldots \ldots \ldots, 38,39,75,84,113,227$ Tin Islands ............ 32, 34, 38, 101, 112, 113, 159 Toba Caldera, Sumatra ................. 34,37 Tofure Island $\ldots \ldots \ldots \ldots \ldots \ldots \ldots \ldots \ldots \ldots, \quad 195$ Togian Islands . . . . . . . . . . . . . 167, 160, 181 Tolo, Gulf of ....................... 166, 169, 174 Tomini, Gulf of ............... 160, 167, 181, 188 Torres Strait . . . . . . . 221, 226, 227, 232, 234, 236, 239 Torricelli Mountains, New Guinea ....... 232, 251, 252 Transform faults. See Faults, strike-slip.

Trench outer rise ........................

Trench-slope break See also Outer-arc ridge.

Trenches $\ldots \ldots \ldots \ldots \ldots \ldots \ldots \ldots \ldots \ldots, 7,8,9,17,31$ Alor $\ldots \ldots \ldots \ldots \ldots \ldots \ldots \ldots \ldots \ldots, 149,150$ Andaman-Nicobar-Burma .. 19, 60, 66, 66, 67, 79, 80 Banda (Timor, Aru, and Seram Troughs) ... 114, 115,

123,138

Bonin ...................... 271, 272, 279 Bougainville ....... 289, 290, 293, 298, 300, 301, 303 Cotabato, Mindanao ......... 157, 184,192, 207, 216 East Sangihe .......... 158, 182, 183, 185, 192, 194 Flores Sea .................. 121, 122, 126, 156 Japan ....................... 271, 272, 279 Java-Sumatra ..... 2, 5, 19, 23, 24, 26, 28, 29, 55, 122 Manila (West Luzon) .......... 206, 213, 218, 272 Mariana ............ 270, 271, 272, 275, 276, 278
Trenches-Continued

Mussau ................ 283, 287, 287, 289, 290 , 292, 294, 301, 303

Nankai $\ldots \ldots \ldots \ldots \ldots \ldots \ldots \ldots \ldots$ 271, 272, 278

Negros $\ldots \ldots \ldots \ldots \ldots \ldots \ldots \ldots \ldots 157,202,210,216$

New Britain .............. 232, 237, 259, 288, 289, $290,299,300,302$

New Guinea ....... 237, 256, 258, 258, 286, 289, 290

New Ireland . . . . . . . . . . . . . . . 301

North Solomon ............... 290, 293, 299, 300

North Sulawesi .............. 157, 160, 175, 181,

184, 185, 186, 192, 194

Northwest Borneo ............. 103, 105, 111, 112 Palau ..................... 271, 272, 274, 277 Palawan .............. 103, 110, 112, 201, 203, 204 Philippines (Mindanao) ..... 183, 187, 189, 190, 192 , $194,196,197,203,206,213,214,271,272,286$ Pocklington Trough .............. 290, 298, 299 Port Moresby .............. 237, 265, 266, 267, 270 Ryukyu $\ldots \ldots \ldots \ldots \ldots \ldots \ldots \ldots \ldots \ldots, 271,272$ Salayar ......................... $\quad 164$ South Solomon ................. 290, 293, 299, 300 Sulawesi, southeast ............... 115, 149, 150 Sulu ................. 95, 192, 200, 202, 205

Sunda. See Andaman-Nicobar-Burma Trench, Banda Trench, and Java-Sumatra Trench.

Trobriand $\ldots \ldots \ldots \ldots$ 232, 237, 268, 269, 298, 300, 302 West Melanesian ............ 256, 258, 286, 289, $290,292,297,301,303$

West Sangihe ........157, 182, 192, 194, 207, 216 Yap .......... 270, 271, 272, 274, 275, 276, 277, 278

Triassic igneous rocks, Australia ............ 226 Borneo ........................... $\quad 86$ Indochina $\ldots \ldots \ldots \ldots \ldots \ldots \ldots \ldots \ldots \ldots, \quad \mathbf{8 3 , 8 4}$ Malay Peninsula .................... 70 New Guinea .................. 234, 235, 237 Sula and Banggai Islands .............. 156, 158

Triassic sedimentary rocks, Australia, northwest shelf.....

Australia and

Australia and shelves $\ldots \ldots \ldots \ldots \ldots \ldots \ldots, 224,225$
Babar $\ldots \ldots \ldots \ldots \ldots \ldots \ldots \ldots \ldots \ldots \ldots \ldots \ldots \ldots \ldots$

Borneo .................................... 86

Buton $\ldots \ldots \ldots \ldots \ldots \ldots \ldots \ldots \ldots, 172,183$

Buru .......................... $\quad 135$

Indochine $\ldots \ldots \ldots \ldots \ldots \ldots \ldots \ldots \ldots \ldots, \quad 84$

Leti $\ldots \ldots \ldots \ldots \ldots \ldots \ldots \ldots \ldots \ldots \ldots, 133$

Misool ................ 245

New Guinea ...................... 235, 237

Palawan $\ldots \ldots \ldots \ldots \ldots \ldots \ldots \ldots \ldots \ldots, \quad 197$

Roti $\ldots \ldots \ldots \ldots \ldots \ldots \ldots \ldots \ldots \ldots, \quad 132$

Savu $\ldots \ldots \ldots \ldots \ldots \ldots \ldots \ldots \ldots \ldots, \quad 132$

Seram $\ldots \ldots \ldots \ldots \ldots \ldots \ldots \ldots \ldots \ldots, \quad 133$

Sula and Banggai Islands .............. 181

Sulawesi ...................... 167, 169, 183

Sumatra $\ldots \ldots \ldots \ldots \ldots \ldots \ldots \ldots \ldots, \quad 32$

Tanimbar Islands .....................

Trobriand Islands $\ldots \ldots \ldots \ldots \ldots \ldots \ldots \ldots 282,289$ Trobriand Trench ............... 232, 237, 268, 269, $289,290,298,300,302$

Truk Islands ......................... $\quad 285$

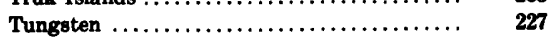

U

Umboi Island ........................ 282 Una-Una island $\ldots \ldots \ldots \ldots \ldots \ldots \ldots 157,160,164,181$ Uplift, Banda Arc .................. 131, 132, 156 Barisan Mountains, Sumatra ........ 33, 35, 36, 38 Bismarck Arc ..................... 291
Uplift-Continued $\quad$ Page

Buton...........................

Meratus Mountains, Borneo ................

Muna $\ldots \ldots \ldots \ldots \ldots \ldots \ldots \ldots \ldots . .173$

New Britain ...................... 291

New Guinea $\ldots \ldots \ldots \ldots \ldots \ldots \ldots \ldots \ldots .240,252$

Obi ............................. 191

Sulabesi............................... 159

Sulawesi $. . . \ldots \ldots \ldots \ldots \ldots \ldots \ldots \ldots, \quad 172$

$\mathbf{v}$

Van Rees Mountains, New Guinea......... 251

Victor Emanuel Range, New Guinea ......... 232

Victoria River Basin, Australia ........... 221, 222

Vietnam. See Indochina.

Vityaz Strait ..................... 232, 300

Vogelkop (northwest New Guinea) ......... 233

Cenozoic geology . . . . . . . 239, 244, 249, 253, 260 Mesozoic geology . . . . . . . . . . . . . 249. 239, Paleozoic geology ................... 233, 234 rotation $\ldots \ldots \ldots \ldots \ldots \ldots \ldots \ldots \ldots \ldots \ldots, \quad 154$

strike-slip faults ................... 158

Volcanic arcs. See Magmatic arcs.

Waigeo (Waigeu) . . . . . . . . . . . . . . 191, 233 Wallaby Plateau, Indian Ocean ........... 59 Wandamen Peninsula, New Guinea ......... 234, 251

Watubela Islands . . . . . . . . . . . . . . . . 115, 139 Weber Basin ......... 114, 115, 135, 139, 140, 144, 147 Weitin fault, New Ireland ........... 257, 290, 291 West Caroline Basin .... 271, 276, 279, 281, 281, 285, 286 West Java Basin .................20, 43, 101, 101 West Luzon Trench. See Manila Trench.

West Malaysia. See Malay Peninsula.

West Mariana Basin. See Perece Vela Basin.

West Mariana Ridge ........ 270, 271, 273, 274, 275, 276

West Melanesian Arc ................. 291 See also Bismarck Arc.

West Melanesian Trench ...... 256, 258, 286, 289, 290, $292,297,301,303$ West Natuna Basin ............... 103, 106; 106 West Philippine Basin. See Philippine Basin.

West Sangihe Trench . ...... 157, 182, 192, 194, 207, 216

Wetar ................... 114, 115, 118, 124, 156 Wharton Basin, Indian Ocean .......... 44, 45-59, 61 Australian borderland $\ldots \ldots \ldots \ldots \ldots \ldots \ldots \quad$ 68, 59 basement rocks . . . . . . . . . . . . . , 47, 49 crustal structure $\ldots \ldots \ldots \ldots \ldots \ldots \ldots \ldots, \quad 51$ heat flow $\ldots \ldots \ldots \ldots \ldots \ldots \ldots \ldots \ldots \ldots, \quad 49,51$ magnetic anomalies ................. 48, 49 ocean-floor spreading $\ldots \ldots \ldots \ldots \ldots \ldots, 48,49,61,64$ paleomagnetism ..................... 49 relation to continental drift $\ldots \ldots \ldots \ldots \ldots 47,58,60$ sediments $\ldots \ldots \ldots \ldots \ldots \ldots \ldots \ldots \ldots \ldots .44,47$

Wildflysch. See Melange and melange wedges.

Woodlark Basin ....... 228, 237, 289, 298, 299, 300, 303 Woodlark Island $\ldots \ldots \ldots \ldots \ldots \ldots \ldots \ldots \ldots \ldots 289, \mathbf{2 9 9}$ Woodlark Plate ......................... 304

Woodlark Rise . . . . . . . . 228, 289, 290, 298, 298, 300 Wowoni $\ldots \ldots \ldots \ldots \ldots \ldots \ldots \ldots \ldots \ldots \ldots, 166$

\section{$\mathbf{Y}, \mathbf{Z}$}

Yap 1slands and Ridge ........ 271, 275, 276, 280, 282 Yap Trench.$\ldots \ldots \ldots \ldots \ldots$ 270, 271, 272, 274, 275, 276, $277,278,280,281$

Yapen Island $\ldots \ldots \ldots \ldots \ldots \ldots \ldots \ldots, 238,253,281,262$

Zamboanga Peninsula, Mindanao .... 94, 157, 184, 204, $205,206,207,210,214,216,217$ 